Por lo demás cada hombre, hasta el más miserable, ocupa un lugar en el mundo y ahora se está viendo" (SENDER, RAMON J., El lugar de un hombre). "Por o demás cada hombre, hasta más miserable, mupa un lugar en el mundo y thora se está viendo" (SENDER, RAMQN J., El lugar de un hombre). "Por lo demás sada hombre, hasta

stá viendo" (SENDER, NAMON Uugar de un honúg bre, hasta el más miserable ocupa un lugar en el m do y ahora se está viendo: (SENDER, RAMON J., El lugre de un hombre). "Por lo más cada hombre, hasta el más miserable, ocupa un se está viendo" (SENDER, lugar an lugar de un hombre). "Por lo demás cad pombre, hasta el más miseLo demás cada hombre, hasla el más miserable, ocupa un lugar en el mundo y

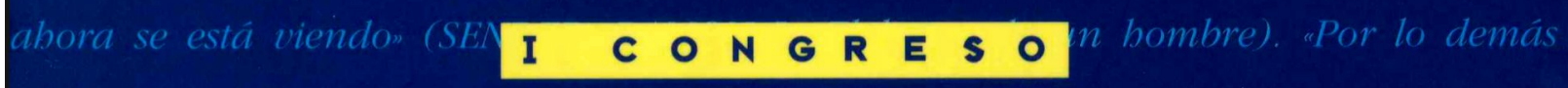
cada hombre, hasta el más miseole, apa está viendo" (SENDER, RAMON J., El lugar de un hombre). "Por lo demás cada hombre, hasta el más miserable, ocupa un lugar en el mundo y ahora se está viendo" (SENDER, RAMON J., El hugar de un hombre). "Por lo demás cada hombre, hasta el más miserable, ocupa un hugar en el mundo y ahora se está viendon (SENDER, RAMON J., El hugar de un hombre). "Por lo demás cada hombre, basta el más miserable ocuba un hear en el mundo v'ahora se está viendo" (SENDER. RAMON I.. EI 


\section{EL LUGAR DE SENDER}


Organización

INSTITUTO DE ESTUDIOS AltoARAGONESES

\section{Patrocinio}

Diputación Provincial de Huesca

Diputación General de Aragón

IBERCAJA

Colaboración

Ayuntamiento de Huesca

UNIVERSIDAD DE ZARAGOZA

INSTITUCIÓN FERNANDO EL CATÓliCO

Ayuntamiento de Alcolea de Cinca

Ayuntamiento de Chalamera

Cooperación

Dirección de Programas (MEC, Huesca)

Festival de Cine de Huesca

Central de Turismo Verde 


\title{
EL LUGAR DE SENDER
}

\section{ACTAS DEL I CONGRESO SOBRE RAMÓN J. SENDER}

(HUESCA, 3-7 DE ABRIL DE 1995)

\author{
Editadas por \\ Juan Carlos Ara TorralBa y Fermín Gil EnCABO
}

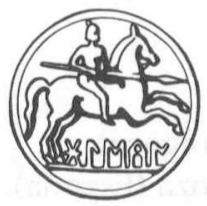

INSTITUTO DE ESTUDIOS ALTOARAGONESES (DIPUTACIÓN DE HUESCA)

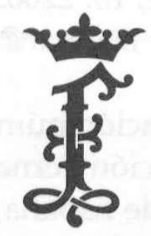

INSTITUCIÓN FERNANDO EL CATÓLICO (DIPUTACIÓN DE ZARAGOZA) 
Ficha catalográfica

CONGRESO SOBRE RAMÓN J. SENDER (1․ 1995. Huesca)

El lugar de Sender : Actas del I Congreso sobre Ramón J. Sender (Huesca, 3-7 de abril de 1995) / Editadas por Juan Carlos Ara Torralba y Fermín Gil Encabo. - Huesca : Instituto de Estudios Altoaragoneses : Zaragoza : Institución Fernando el Católico, 1997

761 p.: il.; $24 \mathrm{~cm}$

D. L. HU-44/97.- ISBN 84-8127-054-7

1. Sender, Ramón J.-Crítica e interpretación-Congresos y asambleas. I. Ara Torralba, Juan Carlos. II. Gil Encabo, Fermín. III. Título.

821.134.2 Sender, Ramón J. 1.06 (063)

\section{Editan}

Instituto de Estudios Altoaragoneses

Institución Fernando el Católico

Diseño: G. diZianni

Corrección: Teresa Sas Bernad

Cubierta: Camaleón

Preimpresión: Ebro Composición, S. L.

Imprime: Grafic RM Color, S. L.

ISBN: 84-8127-054-7

Depósito legal: HU-44/97

Instituto de Estudios Altoaragoneses (Diputación de Huesca),

Parque, 10. 22002 Huesca (España). Tel. 974-240180. Fax 974-231061.

e-mail: iealtoar@spicom.es

Publicación número 1.811 de la

Institución Fernando el Católico (Diputación de Zaragoza),

Plaza de España, 2. Palacio Provincial. 50004 Zaragoza (España).

Tel. 976288 878/79. Fax 976288869.

e-mail: ifc@mail.sendanet.es 


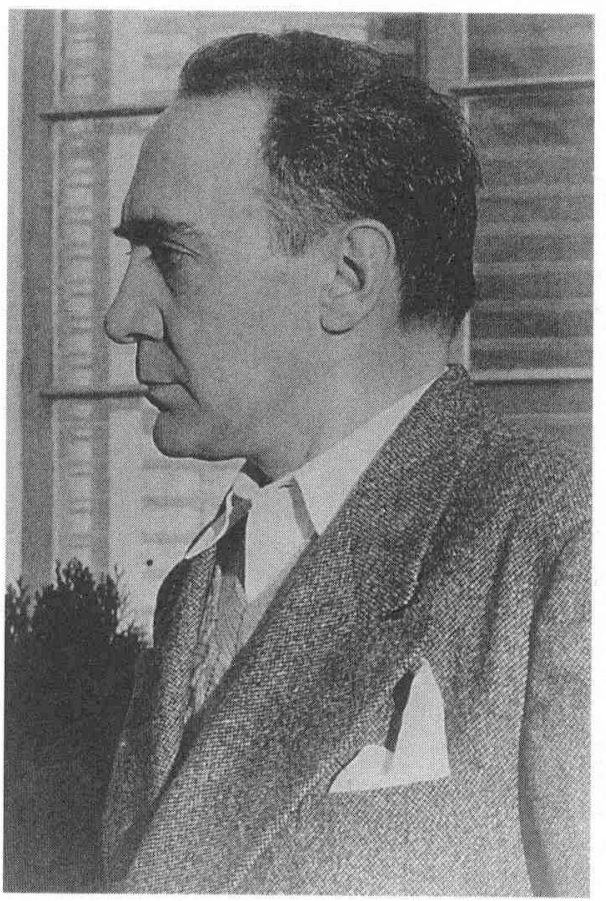

Ramón J. Sender en 1949. 
ni 


\title{
Comité de Honor
}

Excmo. Sr. Presidente de la Diputación General de Aragón

Ilmo. Sr. Presidente de la Diputación Provincial de Huesca

Excmo. Sr. Rector Magnífico de la Universidad de Zaragoza

Ilmo. Sr. Alcalde del Ayuntamiento de Huesca

Sr. Director del Instituto de Estudios Altoaragoneses

Sr. Presidente de IberCaja

Sr. D. Ramón Sender Barayón

\section{Comité Científico}

José-Carlos Mainer Baqué, Universidad de Zaragoza (Presidente)

Juan Carlos Ara Torralba, Universidad de Zaragoza (Secretario)

Francisco Carrasquer Launed, profesor emérito, Universidad de Leiden

Fermín Gil Encabo, Universidad de Zaragoza

\author{
Comité Ejecutivo \\ Luis Artero Canals \\ Enrique Chabier Compairé Angulo \\ José Domingo Dueñas Lorente \\ Luis A. Esteve Juárez \\ + Francisco García de Paso \\ Fermín Gil Encabo (Coordinador) \\ Luis Gómez Caldú \\ † Gemma Mañá Delgado \\ José Miguel Oltra Tomás \\ Jesús Vived Mairal
}

\section{Equipo Técnico}

Coordinador general: Fermín Gil Encabo

Secretaría técnica: Pilar Alcalde Arántegui y Ester Puyol Ibort

Prensa: Inmaculada Casasnovas

Mesas redondas

Agustín Sánchez Vidal ( «Sender y el cine»)

Ramón Gil Novales («Sender visto por los novelistas aragoneses de hoy»)

Cine: Luis Artero Canals

Extensión pedagógica ("El escritor en las aulas»)

Marta Puyol Ibort y Francisco Bolea Aguarón

Diseño y maquetación: Camaleón, G. diZianni, Blanca Otal,

José Miguel Pesqué, Charo Martín y Teresa Sas. 



\section{Índice}

Prólogo

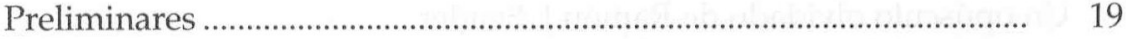

PONENCIAS

El héroe cansado: Sender en 1968-1970

José-Carlos Mainer ............................................................................ 27

Ramón J. Sender, periodista: el aprendizaje de la persuasión

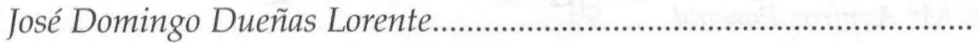

Ramón J. Sender, entre dos revoluciones (1932-1934)

Antonio Elorza.

El reto senderiano a los críticos literarios: consideraciones sobre el lugar de los bibliógrafos

Elizabeth Espadas.

La escritura simbólica de Ramón J. Sender en La mirada inmóvil Jean-Pierre Ressot

Tres calas en la biografía de Sender

Jesús Vived Mairal.

Sender en Albuquerque: la soledad de un corredor de fondo Francisco Caudet.

¿Escribir por pensar o pensar por escribir? La filosofía senderiana acude a los puntos de la pluma o al toque de las teclas Francisco Carrasquer Launed.

América como texto y contexto en la cuentística del exilio de Ramón J. Sender

Mary S. Vásquez.

Descripción y función del paisaje en Imán

Patrick Collard

El último Sender: una mitología nueva para «nuestros tiempos incongruentes»

Margaret E. W. Jones

La participación de Sender en la guerra de España: evidencias y dudas

Donatella Pini. 
Sender, Eros, don Juan y la revolución

Carlos Serrano.

Cómo narrar la aventura (Sobre El bandido adolescente)

Fernando Savater

COMUNICACIONES

«El puente imposible»: el lugar de Sender en la polémica sobre el exilio español de 1939

Manuel Aznar Soler

Un opúsculo olvidado de Ramón J. Sender

Javier Barreiro

Ramón J. Sender y la revolución española

Francis Lough

Manuel Sender y Mariano Carderera, dos alcaldes que regeneraron la actividad política en Huesca

José M ${ }^{\underline{a}}$ Azpíroz Pascual.

El expresionismo senderiano: a propósito de La noche de las cien cabezas

José Luis Calvo Carilla

Recuerdos para aplazar la tragedia (Los crímenes en Monte Odina) María Ángeles Naval López....

Dos visiones del «hombre natural perfecto»: Yank/Rómulo

+ Gemma Mañá Delgado

355

Ramón Sender y Dostoyevski: algunas coincidencias

Luis A. Esteve Juárez

Réquiem por un campesino español: summa narrativa de Ramón

J. Sender

Patricia McDermott

Réquiem por un campesino español o la lectura como resurrección de una guerra muerta: desarrollo de una experiencia de educación en valores en enseñanza secundaria

Manuel Hernández Martínez.....

Ramón J. Sender, crítico literario: el caso Valle-Inclán

Eliane Lavaud-Fage.

La lírica popular de Sender

Santiago Fortuño Llorens

401

Miguel de Molinos en la obra de Ramón J. Sender

Pilar Moreno Rodríguez

Una recepción privilegiada de la obra de Sender: la Inspección de Libros

Manuel L. Abellán 
La mirada equinoccial de Sender

Juan Emilio Estil.les Farré

En torno a «Historia de un día de la vida española»

José-María Salguero Rodríguez

El otro lado del muro en Los tontos de la Concepción

Gilberto Triviños

Autobiografismo en Las gallinas de Cervantes

Ángeles Pons Laplana

Literatura y novela histórica. Una lectura de Carolus Rex

Alberto Álvarez Sanagustín

Sender «en la mancebía»

$M^{\underline{a}}$ Teresa González de Garay.

Dos Hogueras en la noche (1923 y 1980) de Ramón J. Sender: de inclinaciones modernistas a estrategias posmodernistas Marshall J. Schneider.

Intertextualidad y proceso creativo en El extraño señor Photynos Josep Mengual Català

El lugar de El bandido adolescente en la mitología de Billy the Kid Juan Espadas

Una nueva lectura de El bandido adolescente de Ramón J. Sender Fermín Sierra Martínez.

De Siete domingos rojos a Las Tres Sorores: un proceso de reescritura José Miguel Oltra Tomás .....

Nueva lectura de «Aventura en Bethania»

Kathleen M. Glenn.

Monte Odina como síntesis de la narrativa senderiana

Clemente Alonso Crespo

Psicologías de autor y lógica de personajes femeninos:

Star, la adolescente anarquista; Amparo, la novia burguesa;

Milagritos, la fiel esposa cantonalista

Ma Pilar Martínez Latre.

El cantón de Cartagena en Sender y Galdós

Geoffrey Ribbans

Proyección biográfica de Sender en Ramiro Vallemediano y

Pepe Garcés: documentos y testimonios

Ramón Oteo Sans

El yo narrador y el otro

Ricardo Crespo

Notas lingüísticas sobre Solanar y lucernario aragonés José $M^{\underline{a}}$ Enguita Utrilla. 
El Don Juan de Sender Jean-Marie Lavaud............ 673

Problemática y sentido del encuentro con el otro en la novela de Ramón Sender

Eduardo Godoy G.

Ramón Sender y la literatura francesa

Dalia Á. Molina .

El imaginario literario de Sender en el norte de África

Vicente Moga Romero

705

El rey y la reina: ¿fábula, cuento, tragedia o novela?

Maryse Bertrand de Muñoz

Sir Peter Chalmers Mitchell, traductor al inglés de algunas obras de Sender

Luis Monferrer Catalán

De tal palo, tal astilla: biografía y creación literaria en los

Sender

Anthony Trippett

Apéndices 
Prólogo 

$\mathrm{E}_{1}$ lector tiene en sus manos el resultado científico del Primer Congreso sobre Ramón J. Sender, celebrado en Huesca del 3 al 7 de abril de 1995, con el que el Instituto de Estudios Altoaragoneses quiso contribuir a la puesta al día de los estudios sobre el escritor de Chalamera. La convocatoria respondía a la doble necesidad de revalidar el trabajo previo de recopilación sistematizada de materiales llevada a cabo por el «Proyecto Sender" y de propiciar un encuentro de expertos para fijar el estado de la cuestión y trazar las líneas de actuación futura.

Hasta la convocatoria de abril de 1995, en cinco años, el «Proyecto Sender» había conectado a los de una u otra forma relacionados con el escritor, había creado un estado de opinión crecientemente favorable hacia la vida y la obra de nuestro autor y su época y había logrado dotar a Huesca de unos fondos senderianos que han llegado a ser de consulta indispensable, en un proceso que ha ido quedando reflejado en el «Boletín Senderiano", sección especializada de Alazet, la revista de Filología del IEA. Igualmente, se abordó la recuperación textual crítica editando títulos como Imán, a cargo de Francisco Carrasquer, y Primeros escritos (19161924), preparado por Jesús Vived; se propició la publicación de estudios, como Ramón J. Sender (1924-1939). Periodismo y compromiso, de José Domingo Dueñas, y se estructuró un sistema de cursos y ediciones que mantuviesen vigente la actualidad de Sender todos los años. El vínculo entre senderianos se articuló en reuniones periódicas, en las que, llegado un momento, se hizo evidente la necesidad de realizar convocatorias de mayor alcance. La primera de ellas fraguó en este Primer Congreso cuyas actas ven ahora la luz. El «Proyecto Sender» iniciaba de esta manera una dinámica de consolidación como servicio de información y documentación, de investigación y divulgación que debía responder a las expectativas despertadas, entre las que, además, comenzaba a dibujarse la idea de configurarse como Fundación. 


\section{EL LUGAR DE SENDER}

Con el fin de que quedaran atendidos los aspectos medulares de Sender, el Comité Científico del Congreso acordó encargar una serie de ponencias a un grupo de especialistas que los cubriese con la debida solvencia. Así se pudo contar con la inexcusable recapitulación bibliográfica (Espadas), la revisión global de su biografía (Vived) y de hitos significativos como su participación en la guerra (Pini), el análisis de las etapas iniciales tanto de formación periodística (Dueñas) como de sus primeras novelas (Collard), el tan apasionante como controvertido Sender político (Elorza), la sustancial impronta del exilio en la cotidianeidad epistolar (Caudet) y en el tratamiento de los temas americanistas (Vásquez), la magnitud y riqueza de lo simbólico (Ressot), el peso y trascendencia de su peculiar mitología (Serrano), la interpretación de las épocas más recientes y menos atendidas de su labor creadora tanto en la evolución de su escritura (Jones) como de su pensamiento (Mainer), la reflexión sobre el oficio del escritor (Carrasquer) y las razones para la vigencia de un clásico (Savater).

De la respuesta a la convocatoria habla la cuarentena de comunicaciones que ensayó reinterpretaciones en variados asedios a obras particulares y contribuyó a iluminar los múltiples aspectos pendientes de estudio o revisión a propósito de géneros, técnicas, personajes, lengua y estilo, afinidades e influjos, ideario y rescate textual.

Las sesiones de ponencias y comunicaciones, en apretado programa, se sucedieron a lo largo de los cinco días y aún dejaron sitio para las actividades paralelas organizadas por los diferentes Comités del Congreso: proyecciones de cine basado en obras de Sender cerraban los actos diarios; sendas mesas redondas se ocuparon de estas adaptaciones cinematográficas (con la presencia de Agustín Sánchez Vidal, Alfredo Castellón, Antonio Páramo, Alfonso Ungría y Carlos Saura) y de la visión que del autor tienen los novelistas actuales (Ramón Gil Novales, IldefonsoManuel Gil, Ignacio Martínez de Pisón y la adhesión de Javier Tomeo), y el día 5 el Congreso se trasladó a Chalamera, donde se inauguró el busto del escritor realizado por Blanca Merchán, y a Alcolea de Cinca, donde se contó con la presencia de José Manuel Blecua, todo ello gracias a la colaboración de los respectivos Ayuntamientos. El Congreso sirvió, además, de marco para la presentación del guión cinematográfico de Carlos Saura ¡Esa luz! y de la edición de la correspondencia de Sender con Maurín preparada por Francisco Caudet. Una actividad especialmente pensada para los alumnos de enseñanzas medias fue el proyecto divulgativo e itinerante "Sender en las aulas", con el que el Congreso quiso acercar al escritor a su entorno social. De todo ello quedó constancia gráfica en un reportaje en vídeo, ilustrado musicalmente por Jesús Vived Mairal.

Estas actas, precedidas de las intervenciones que tuvieron lugar en la sesión inaugural, presentan las aportaciones al Congreso clasificadas en dos bloques, el primero de los cuales recoge, según su orden de exposi- 
ción, el texto de las catorce ponencias encargadas; engrosan el segundo las treinta y nueve comunicaciones que se acogieron a las bases de la convocatoria. Al final del volumen se transcriben las notas testimoniales de Ildefonso-Manuel Gil y de Javier Tomeo, así como la carta de adhesión de la hermana de Sender, Asunción, y las conmovedoras palabras de Ramón Sender Barayón, hijo del escritor, que clausuraron emotivamente el Congreso.

Queden estas páginas como tributo a Ramón J. Sender y acicate para los amantes y estudiosos de su obra, como agradecimiento a cuantos participaron en el Congreso y a las instituciones y personas que lo hicieron posible y como recuerdo entrañable de quienes, habiendo sido alma de todos estos afanes senderianos, ya no podrán leerlas: Gemma Mañá Delgado, Paco García de Paso y Antonio Durán Gudiol.

JUAN CARLOS ARA TORRALBA

Y FERMIN GIL ENCABO

Editores 
- 


\section{Preliminares}


w 


\section{todos: \\ Excelentísimas e ilustrísimas autoridades, señoras y señores, amigos}

Créanme que es para mí motivo de profunda y sincera satisfacción hallarme hoy aquí, entre todos ustedes, en el punto de arranque de este entrañable $y$, sin duda, trascendente I Congreso sobre la personalidad, la obra y la herencia e influencia del escritor altoaragonés Ramón José Sender Garcés.

Y esta sincera satisfacción se apoya, en primer lugar, en ver cómo, tras superar no pocas dificultades e invertir una gran dosis de tesón y de esperanza, los organizadores de este I Congreso han conseguido poner en pie este foro de trabajo y reflexión que, sin duda, marcará un hito, un punto de obligada referencia, en el conocimiento y difusión de la figura y la obra de uno de los mejores escritores aragoneses y españoles de todos los tiempos.

El segundo motivo de esta declarada satisfacción se apoya, lógicamente, en la indisimulada simpatía y respeto que a todo español $-\mathrm{y}$, más, a todo aragonés - progresista suscita tanto la apasionante biografía como la casi inabordable (por ingente y variada) labor literaria del autor de Réquiem por un campesino español, "quizás la más perfecta de las novelas cortas españolas de nuestro tiempo», en palabras del máximo responsable de este Congreso, el doctor don José-Carlos Mainer.

A trece largos años ya de su muerte en el exilio californiano y a casi un siglo de su nacimiento a orillas del Cinca, la biografía personal de Ramón José Sender continúa siendo un sólido punto de referencia y recuerdo para todos aquellos, vivos o ya desaparecidos, que lucharon con total entrega por la defensa de las libertades en un país tan espasmódico y agitado como el nuestro. Encarcelado por la Dictadura de Primo de Rivera, comandante del Ejército republicano sitiado en Madrid, exiliado en México y Estados Unidos, perseguido siempre por el recuerdo de la trágica muerte de su esposa, su hermano y tantos y tantos defensores de la República, Sender ejemplifica, como pocos de sus contemporáneos, la tragedia 
de la guerra y la fe inquebrantable en el valor supremo de las libertades y de la democracia.

Al margen de su obra ingente y caminante por todos los géneros -asunto que, sin duda, será tratado con todo rigor y precisión a lo largo y ancho de este I Congreso-- Aragón le debe a Sender, ante todo y sobre todo, uno de los mejores daguerrotipos, una de las mejores fotografías que acerca de sus paisajes, sus gentes, sus culturas y su temperamento se realizaron nunca. Me refiero, claro está, a su entrañable Crónica del alba, sin duda una de las más intensas, sinceras y veraces «biografías» que sobre el Aragón de las primeras décadas del presente siglo se han escrito. La tierra que vemos en José Antonio Labordeta "callada» y huérfana de ese Moncayo que ya no ampara se convierte en Sender en un inmenso cañamazo de ruidos, olores, sensaciones, colores y esperanzas, tímidamente enfrascados, por otra, en su inefable Solanar y lucernario aragonés o en su imponente Monte Odina.

Expertos y especialistas en la obra senderiana van a contribuir, sin duda, a través de este Congreso a un más intenso y pormenorizado conocimiento de la ingente obra senderiana. Sin embargo, me atrevería a suscribir - y aun a reivindicar, si ustedes me lo permiten aquí y ahora, las dos virtudes esenciales que, según don Francisco Carrasquer, subyacen en toda la obra senderiana: la naturalidad y la verdad, dos virtudes que, frente a los seguros defectos que nos afean como pueblo, caracterizan a los aragoneses en esa afortunada síntesis, no por tópica menos cierta, de la llamada nobleza o, mejor aún, franqueza.

Con esa franqueza, pues, quiero felicitar, felicitarnos todos, por el inicio definitivo de este I Congreso sobre la personalidad y la obra de un aragonés que nos fue dejando pistas y pautas en todas y cada una de sus novelas, de sus cuentos, de sus poemas y de sus dramas, incluido el suyo personal. De ahí la notable importancia de este Congreso que ahora comienza. De ahí el aplauso al propósito del Instituto de Estudios Altoaragoneses por hacer de Sender y su ingente obra la razón de ser de una futura Fundación y de un urgente centro de estudios senderianos. De ahí, en suma, la satisfacción de este responsable del Gobierno de Aragón al declarar inauguradas las sesiones de trabajo de este I Congreso, que, sin duda, va a contribuir de forma extraordinaria a poner a Ramón José Sender, parafraseando el lema de este evento, en el lugar que sin duda le corresponde.

Felicidades, pues, a los organizadores, a las entidades colaboradoras y a los congresistas, y a todos, muchas gracias. 
Es para mí un auténtico honor dirigirme a ustedes con motivo de este I Congreso sobre ese altoaragonés universal que fue nuestro Ramón J. Sender. No podía ser otro el lugar de Sender que este de su provincia natal, ni otra la sede natural para el homenaje que esta de la Diputación de Huesca.

Son tiempos, además, de congratulaciones, pues al inicio de la recuperación, ya hace algunos años, de Ramón Acín, Ángel Samblancat y Felipe Aláiz se ha sumado en los últimos meses la de Joaquín Maurín, el entrañable y honrado político que en su forzoso exilio tanto se relacionó con Sender. Fundó la Agencia Literaria Americana, plataforma benemérita que sirvió de lazo para todos los republicanos transterrados. Hoy, con los esfuerzos investigadores de Francisco Caudet y de Anabel Bonsón, conocemos al detalle el crudo día a día que vivieron Maurín y Sender en tierras americanas.

Sin embargo, de los citados, el beneficio de la universalidad lo ha disfrutado con diferencia el literato más puro, Sender. Si hemos de echar mano del conocido argumento de que un escritor pasa a la posteridad en el supuesto de que en los diez años posteriores a su muerte no ha dejado de hablarse de él ni de leerse, reconoceremos que Sender cumple, con creces, estas premisas para convertirse en un clásico. Si ya lo fue en vida, este Congreso ha de dar prueba de que lo será en lo venidero.

Sé que mucho se ha trabajado desde que hace cinco años el «Proyecto Sender» fue acogido en el seno del Instituto de Estudios Altoaragoneses, cuyo Patronato me honro en presidir, y sé de otras iniciativas que igualmente apoyará de forma decidida esta Diputación. Con denuedo, con el tesón que sólo otorga el entusiasmo, se ha conseguido que los fondos que alberga el Instituto lo hayan convertido en referencia ineludible para cualquier investigador de la figura y de la obra de Sender.

Faltaba, acaso, el lógico espaldarazo que consolidase la labor; y hoy, con orgullo, puedo y debo decir que tal acontecimiento ha llegado de la mano de la celebración de este Congreso que está a punto de comenzar. 


\section{EL LUGAR DE SENDER}

Nada mejor que la presencia de los más prestigiosos investigadores españoles y extranjeros para certificar la universalidad de Sender. A todos ellos, italianos, norteamericanos, franceses, belgas, canadienses, chilenos, holandeses, ingleses y españoles de más de una decena de autonomías, a todos ellos, repito, he de darles las gracias en mi nombre y en el nombre de la Diputación que presido.

De esta manera, el Altoaragón da la bienvenida a todos, familiares, estudiosos y amantes de la buena literatura, y les brinda la oportunidad de hermanar tan diversos lugares con las gentes de esta tierra, desde las estribaciones pirenaicas hasta los linderos monegrinos y cinqueños, donde dos localidades, Chalamera y Alcolea, tan entrañables y emblemáticas para la figura y la obra de «Pepe Garcés», representarán por derecho propio a todos los municipios de esta provincia.

Como el mismo Sender dijo: «Aragón es mi territorio y a él me atengo». Siguiendo la premisa, Huesca se ofrece como lugar de cita para rendir justo homenaje a quien sin desvincularse de sus orígenes supo trascenderlos mediante una singularísima obra literaria. La palabra de Sender, que ha llegado a tantos sitios calando de manera inolvidable en la mente y en el corazón de todos los que se han acercado a sus escritos, ha de resonar a partir de esta convocatoria con el aval de tan selecto y nutrido grupo de senderianos.

"Cada hombre ocupa un lugar en el mundo, y ahora se está viendo", dijo nuestro universal escritor de Chalamera. Durante estos días tendremos la oportunidad y el placer de comprobar cuál es el suyo.

Queda inaugurado el I Congreso sobre Ramón J. Sender. 


\section{PONENCIAS}




\title{
El héroe cansado: Sender en 1968-1970
}

\author{
José-Carlos Mainer \\ Universidad de Zaragoza
}

\begin{abstract}
Creo que el caos se acerca y que se va a armar la de D. es C. No sé si lo veremos. Yo no tengo gran interés porque sé de antemano lo que sucederá y para los viejos será bastante incómodo. En todo caso, habremos vivido un periodo histórico excepcional y los que vengan luego nos recordarán con simpatía - espero--. Aunque por mi parte se pueden ir todos al diablo y me da lo mismo que me recuerden o que me ignoren. (Carta del 30 de octubre de 1970 a Joaquín Maurín, en Correspondencia Ramón J. Sender - Joaquín Maurín [1952-1973], ed. Francisco Caudet, Madrid, Ediciones de la Torre, 1995)
\end{abstract}

\section{LA FORJA DE UNA SENSIBILIDAD}

Se discutirá mucho tiempo sobre si la de 1968 fue una crisis decisiva o un invento reciente de los medios informativos y de la nostalgia de los Peter Pan de turno. Pero cuando el río suena agua lleva... Como Frank Kermode ha señalado, la percepción de nuestra época está marcada por el signo de lo escatológico, por la premonición o la conciencia del final, y de ahí la importancia que entre nosotros cobran las nociones de transición, 
crisis, decadencia o renovación: «La idea de que nuestra época se encuentra en una relación extraordinaria con el futuro parece ser una condición relacionada con el ejercicio de pensar sobre el futuro que supongamos». ${ }^{1}$

Los años sesenta se nos ofrecen como el fin de una época y el comienzo de otra: en ellos dejaron de gobernar la mayoría de las figuras que habían dirigido la segunda guerra mundial y accedió a la vida pública una generación ya no tan decisivamente marcada por el pasado; en ellos se conoció una efimera ilusión de renovación ideológica y de esperanza (Jruschov, Kennedy, Juan XXIII) y la emergencia de luchas revolucionarias vinculadas al resurgir del Tercer Mundo (Cuba, Congo, Argelia). Aunque pronto no quedó nada de ello: Juan XXIII desapareció en febrero de 1963 y Kennedy murió en noviembre del mismo año; Jruschov cayó en el 64 y el Che murió en 1967, cuando ya empezaba a resquebrajarse el idilio de la revolución cubana con la intelectualidad progresista. A pesar de ello, la segunda mitad del decenio parecía tachonada de una constelación de utopías: la píldora anticonceptiva liberaba el ejercicio sexual del miedo ancestral al bíblico castigo del embarazo; el hippismo ofrecía una alternativa tribal a la aburrida relación interindividual y a la dependencia del consumismo; las nuevas drogas presentaban tentadores ámbitos de alucinación y el ácido lisérgico entraba en la mitología de la liberación, mucho más que la más doméstica marihuana; McLuhan proclamaba, con el fin de la Galaxia Gutenberg, una sociedad más fluida y universalizada, la «aldea global»; la carrera del hombre a la Luna ofrecía - al margen de su uso militar - una dimensión de sueño colectivo. El año de 1968 ofreció el paroxismo de esos signos contradictorios: por un lado, murieron a mano airada - abril y junio-Martin Luther King y Robert Kennedy mientras que la URSS interrumpió la primavera de Praga con la fuerza de sus tanques de agosto; pero, por otro, se iniciaron las conversaciones de paz sobre Vietnam y se vivió un movimiento juvenil que comenzó en Alemania -movilizaciones contra la prensa de Axel Springer-y tuvo su apogeo en París en los sucesos del 3 al 15 de mayo.

No era fácil decidir si uno se hallaba ante una aurora o un crepúsculo cuando se tenía cumplida la sesentena. Los escritores que frisaban en esta edad, como Sender, habían formado su sensibilidad - lo que Baroja llamaba el «fondo sentimental del escritor»- en los años treinta como herederos de una circunstancia histórica que abarca desde la guerra europea y su desmovilización hasta las vísperas del segundo holocausto mundial, en torno a algunas ideas muy claras: la desconfianza de la vanguardia respecto a la tradición anterior, la solidaridad con los desposeídos de cualquier orden - proletarios o seres marginales-, la hegemonía de lo afectivo, intuitivo e irracional sobre el intelectualismo, la esperanza en la revolución y la convicción de que la literatura podía tender un puente

\footnotetext{
${ }^{1}$ Franck KeRMODE, El sentido de un final. Estudios sobre teoría de la ficción, Barcelona, Gedisa, 1983, p. 96.
} 
hacia el futuro. Se creía resuelto todo si se acomodaba el individualismo innato del escritor a la vivencia solidaria de la revolución, a través de un acto de fe y una entrega heroica a la causa. Los textos senderianos de los años treinta son una fecunda mina al propósito ${ }^{2}$ pero su caso no es único. Hallaremos lo mismo en los escritores británicos de los años treinta que tuvieron su prueba de fuego en la guerra civil española. En ella murió - como John Cornford y Ralph Fox- Christopher Caudwell, autor en 1937 de un libro clave, Illusion and Reality. A Study of the Sources of the Poetry, en cuyo capítulo VIII, «The World and I», leemos: «In each man "truth" takes the form of perception - what is seizes of reality with his senses - and memory - what is active at any moment of former perception-, affecting his present perception. Because these human consciousnesses acquire tremendous power when their contents emerge organised by association, and become truth, they reflect back again with increasing penetration of the individual, whose memory and perception thus become more and more modified by being in society». De ese modo, el arte es, frente a la ciencia, «organised emotion attached to experience»y «the social ego that endures all and enjoys all and by its experience organises all, makes available for the individual a whole new universe of inner feeling and desire». ${ }^{3}$

Llaman la atención ese léxico posesivo, casi erótico, respecto a la incitación de la realidad y la confianza en la jubilosa interacción de lo individual y lo colectivo bajo el imperio de la buena fe. Caudwell se había interesado, como tempranamente lo haría Sender, por D. H. Lawrence, en quien vio un precursor de ese cambio: "La importancia de Lawrence como artista radica en que se dio cuenta de que el artista no puede existir hoy, de que el artista tiene que ser el hombre que odie las relaciones del dinero y el mercado, un hombre profundamente interesado en las relaciones entre personas [...]. Sentía que la Europa de hoy estaba moribunda; por eso se volvió a otras formas de existencia en México, Etruria y Sicilia, donde encontró, o creyó encontrar, sistemas de relaciones sociales en los que la vida fluía con mayor felicidad y más sentido». ${ }^{4}$ ¿Cómo no relacionar esta

2 Cfr. simplemente las excelentes apreciaciones sobre el tránsito del anarquismo al comunismo y sobre la función y retórica del periodista de combate en la reciente y fundamental monografía de José Domingo DuEÑAS, Ramón J. Sender (1924-1939). Periodismo y compromiso, Huesca, Instituto de Estudios Altoaragoneses, 1995.

3 Illusion and Reality. A Study of the Sources of the Poetry (1937), Londres, Lawrence and Wishart, 1975, p. 138.

${ }^{4}$ La agonía de la cultura burguesa, Barcelona, Anthropos, 1985, p. 35. La curiosidad de Sender por D. H. Lawrence es antigua. Anoto ya las primeras menciones en dos artículos sobre Canguro anteriores a la guerra civil (“Canguro y el individualismo», La Libertad, 27-9-1934, y "Sobre unas palabras de Gorki», La Libertad, 30-9-1934), aunque el interés proseguía en los primeros años del exilio ( $₫ \mathrm{D}$. H. Lawrence: The Fatalities of Light and Shadow», The New Leader, 31, 41 [1948]). En mi trabajo «Antropología del mito: El rey y la reina de Sender», Letras aragonesas. Siglos XIX y XX, Zaragoza, Oroel, 1989, pp. 209-229, apunto otras huellas y una posible relación de El amante de lady Chatterley con el relato citado. 
actitud con el dandy senderiano de su espléndido libro Proclamación de la sonrisa o con su búsqueda de los valores primigenios en su descubrimiento de México o del mundo rural aragonés en El lugar de un hombre?

Pero, a la altura de 1968, nada era tan fácil. Jean Paul Sartre, nacido en 1905, lo vio con claridad en una entrevista que en 1969 publicó New Left. Tras la experiencia de la resistencia y de la guerra, lo heroico era el esfuerzo de ser fiel a sí mismo en tiempo de normalidad: "Il fallait que le personnage d'avant la guerre, qui était une sorte d'individualiste égoïste, stendhalien, soit plongé malgré lui dans l'Histoire tout en gardant encore la possibilité de dire oui ou non, pour pouvoir ensuite affronter les problèmes inextricables de l'après-guerre comme un homme totalement conditionné par son existence sociale, mais cependant suffisament capable de décision pour réassumer ce conditionnement et en devenir responsable [...]. Je crois qu'un homme peut toujours faire quelque chose de ce qu'on a fait de lui». ${ }^{5}$ El escritor confesaba allí mismo que había tardado en reaccionar ante los sucesos de 1968, como -apostillaríamos nosotros- había tardado en hacerlo ante la drôle de guerre de 1939. Y es significativo que su esfuerzo de estos años se despliegue en dos direcciones aparentemente contradictorias: por un lado, el decidido servicio a los grupúsculos ultraizquierdistas -que incluyó la venta callejera del periódico $\mathrm{La}$ Cause du Peuple - y, por otro, una meditación sobre la condición intelectual, heredera del XIX, donde mezcla el masoquismo y la soberbia con las huellas intelectuales de Marx y Freud: tanto en la evocación de su propia infancia al escribir Les mots (1964) como en la trabajosa redacción de L'Idiot de la famille, reconstrucción de la vida de Flaubert cuyos dos primeros volúmenes aparecieron en 1971.

Pero otros escritores, quizá menos seguros de sí mismos, se encontraron con el turbio espejo de su envejecimiento y, en el fondo, de su defección. En 1967 la revista Remparts dio a conocer que la CIA había financiado las actividades del Congreso Internacional por la Libertad de la Cultura. Muchas revistas izquierdistas quedaron salpicadas: en Encounter dimitieron Spender y Kermode, en el mundo hispánico se asistió al hundimiento de los Cuadernos (que un día fueran del «Congreso por la Libertad de la Cultura») y se confirmó el apoyo de aquellos fondos a la «American Literary Agency», dirigida por el ex trotskista Maurín y para la que Sender entregó 663 artículos entre 1953 y 1975 («Los libros y los días»). Y lo cierto es que, desde 1939, el compromiso de Sender había evolucionado mucho. Primero, había sido el desencanto del comunismo, una etapa que fue común con otros grandes escritores de su tiempo (Gide, Steinbeck, Orwell, Dos Passos...) y que quizá algún día habrá que revisar sin el apa-

\footnotetext{
5 «Sartre par Sartre», Situations, IX.. Mélanges, París, Gallimard, 1972, p. 101. Cito por su traducción española en la antología Sartre: poder, violencia y revolución, introducción y selección de José Luis RoDRíGueZ, Madrid, Revolución, 1987, p. 175.
} 
sionamiento de estos años penúltimos: el rescate de Albert Camus - un escritor que Sender apreció enormemente- marca el camino de una revisión sin venganzas mezquinas. Más adelante, comprobamos la presencia en su narrativa de fuerzas oscuras que inevitablemente metaforizan esa decepción —el mal, la culpa, el destino-y que, muy a menudo, plasman por añadidura una oscura manía persecutoria respecto al comunismo - tan visible en La esfera, Los cinco libros de Ariadna, la última parte de Crónica del alba- que nunca será fácil determinar si correspondía a un temor real o a una voluntad de autojustificación.

Creo que -como le sucedió tempranamente a Robert Graves- la adopción de la novela histórica como género fue, por parte de Sender, una parábola de esa nueva reflexión sobre la realidad, donde juntaba el predominio de la fatalidad colectiva sobre la libertad individual y, a la vez, entonaba la elegía del héroe ya imposible en tiempos de escarnio y burocratización. La novela histórica fue para él una forma vicaria de la tragedia, en definitiva. Pero su mundo literario fue adoptando también otras direcciones muy significativas de ese proceso: el regreso a la infancia feliz como edad de inocencia (liturgia celebrada en torno a la invención de Pepe Garcés en Crónica del alba) y el exorcismo en forma de parábola del héroe autobiográfico (El verdugo afable y Los cinco libros de Ariadna, libros que son rapsodia de otros temas: lo folclórico, la alegoría, la guerra civil...). Y de ahí vino también el interés por autores con los que compartía -de un modo u otro- experiencias: con Louis Ferdinand Céline, la aversión por el convencionalismo burgués; con Albert Camus, el repudio de la violencia revolucionaria; con D. H. Lawrence, la búsqueda de la vitalidad espontánea; con Arthur Koestler, la precoz vivencia autobiográfica de la subversión. ${ }^{6}$

\section{EL REGRESO DE LOS FANTASMAS: LA VIDA EN LA OBRA}

En lo personal, los años 1968-1970 estuvieron para Sender marcados por su lenta reincorporación a la literatura española, algo que vio con una mezcla de recelo ( «sí, hay que andar con cuidado con España. Todo el mundo me quiere mucho al parecer, pero andan insultándose unos a otros con motivo de mi resurrección en España") ${ }^{7}$ y de entusiasmo renovado. Le otorgaron el Premio Ciudad de Barcelona de 1966 pero, a cambio, el direc-

\footnotetext{
6 Mencionaré los artículos «Camus and Panic», The New Leader, 31, 41 (1948); «Celine, again», The New Leader, 32, 40 (1949); «Lawrence, solitario animal de Dios», serie «Los libros y los días", abril de 1953; "A. Camus o la voz de Francia», id., febrero de 1954; "Sobre las memorias de Koestler», id., noviembre de 1954; "Camus y la difícil inocencia», id., noviembre de 1957, entre otras fichas que trae Charles F. KING, Ramón J. Sender: An Annotated Bibliography. 1928-1974, Metuchen, The Scarecrow Press, 1976.

7 Correspondencia Ramón J. Sender - Joaquín Maurín (1952-1973), ed. Francisco CAUDET, Madrid, Ediciones de la Torre, 1995, p. 618.
} 
tor del Heraldo de Aragón no contestaba la oferta de colaboración formulada por la American Literary Agency. Maurín le recomienda: «No te aconsejo que vayas a España de manera inmediata [...]. Y cuando vayas creo que ha de ser provisionalmente sin abandonar este país definitivamente. En España te respetarán más si no das la impresión de que regresas, como hizo torpemente Casona, entregándose de hecho. ¿No crees?». ${ }^{8}$ En julio de 1968 fracasó el proyecto de un primer viaje a España por la «dudosa y sospechosa conducta de la gente de la embajada española en Washington (que me llaman por teléfono una y otra vez para decirme que han enviado telegramas cifrados - no sé por qué cifrados- preguntando si pueden darme el visa político sin pasar por las vejatorias preguntas y cuestionarios de costumbre) y que ni obtienen respuesta de Madrid ni se atreven a actuar por su cuenta... Después de todas estas cosas he decidido que se vayan al diablo».9

En estas circunstancias, los acontecimientos de 1968 suscitaron, sin duda, un retoñar de antiguas situaciones. ¿Podía llamarse "revolucionario" lo que estaba viendo por el mero hecho de que existía un franco repudio de la hipocresía burguesa? ¿Alboreaba una nueva civilización destinada a enterrar el odio y el rencor de la guerra fría? "Sí —escribía a su amigo Maurín-, lo de Checoslovaquia es estupendo [...]. Albricias. Los rusos se van a enterar por fin de lo que es una revolución marxista con democracia funcional» ${ }^{10}$ Los ensayos que Sender publica en estas fechas son, pese a su tono divagatorio y hasta frívolo, muy reveladores: es cierto que en mayo del 68 - cuando surgían las barricadas del Barrio Latino- escribía ¡sobre la Atlántida!, pero lo cierto es que, en las semanas sucesivas, lo hace sobre el diario del Che y sobre las obras de Bertrand Russell, Solzhenitsin, Karen Blixen e incluso acerca de la música de los Beatles (con una primera alusión a la bossa nova que luego veremos reiterada); el 10 de enero discurria sobre Malraux y Cohn-Bendit, y en julio lo hacía sobre el LSD... ${ }^{11}$

Los términos de esta curiosidad se hacen más patentes si tomamos la colección de Ensayos del otro mundo (1970), impresa en España. El propio título patentiza la confirmación de su extrañamiento y el primer artículo, «Miserias y grandezas del viajar», metaforiza de cierto su condición de transeúnte indiscreto: si en 1935 Sender fue el dandy que escribía Proclamación de la sonrisa, ahora se contempla como el viajero ocasional que observa sin comprometerse. No deja de ser reveladora la insistencia en los recuerdos del espíritu de los años treinta, que afloran por inevitable comparación con un mundo que, de nuevo, advierte convulso e inseguro. La

\footnotetext{
${ }^{8}$ Ibid., p. 629.

${ }^{9}$ Ibid., p. 654.

10 Ibid., p. 649.

11 Referencia más completa de estos artículos puede verse en la citada bibliografía de Charles F. KING, pp. 196-205.
} 
hallamos, por ejemplo, en un artículo sobre Chaplin («Chaplin a propósito de Upton Sinclair») donde consigna: «Fue en aquellos tiempos de esplendor de Chaplin cuando se nos ocurrió pensar que la más alta sabiduría tenía cara de payaso. Una cara impávida y lunar de clown. ¿Se acuerdan ustedes de la cara de Einstein? ¿Y de Max Jacob? Y, sin ir más lejos, del nonagenario ilustre Bertrand Russell?».12 En aquella sazón, Russell era el activo presidente del Tribunal de su nombre y el ejemplo de un incómodo testigo que, desde principios de siglo, venía hostigando la buena conciencia del mundo occidental: «Tal vez hombres como él no sólo tienen derecho a decirlo todo, sino que están obligados a hacerlo. O por lo menos a intentarlo. Es un ejemplo para los demás mortales, un arquetipo y un modelo universal. Todo el mundo va a aprender algo con él».13 Pero no solamente son los hombres comprometidos quienes desgranan su lección. También están los tibios inquietos o los que huyeron del conflicto en busca de nuevos derroteros: así, se presenta una buida y emocionada evocación de Somerset Maugham, escritor vagabundo, y el recuerdo pertinaz de otro nómada, D. H. Lawrence («todo lo que dijo Lawrence a lo largo de su extensa obra fue que no debemos ser entidades morales, ni intelectuales, ni esteticistas, ni civiles, ni religiosas, ni políticas. Que debemos ser vitales. Con eso quería decir que antes que nada son los instintos y que nadie debe avergonzarse ni mucho menos defenderse de ellos»). ${ }^{14}$

Pero el ensayo más revelador del libro es «Los golfos de Buda y otros inocentes excesos», una reflexión personal sobre el hippismo californiano, al que ve - tan significativamente - como una caricatura de la protesta y la desazón que él conoció treinta años atrás: «Estos granujas del dharma - comenta - son hijos en España del Valle-Inclán de los esperpentos; en Inglaterra, de Hardy, de Lawrence, de Huxley; en los Estados Unidos, de Dos Passos, Faulkner, Dreiser, Steinbeck; en Francia, de todos los modernos, desde Zola a Gide, incluidos Anatole France, Malraux, Mauriac, Valéry. Todos estos autores habían encontrado una vía cómoda para explayar su talento: la negación [...]. Para dejar una obra como la de Cervantes, Bacon, Goethe, Balzac, serena, rica, profunda, y sin la afectación de la protesta por la protesta, hace falta genio. Nosotros, en nuestro tiempo, sólo tenemos talento y habilidad. Sobre todo, habilidad». ${ }^{15}$ Es indudable que el mal de la negatividad está también dentro de él mismo, pero lo que no acepta es ser reo de la "miserable superioridad» que afectan los hippies. Su mundo pudo ser confuso y equivocado pero fue heroico cuando menos. Por eso, cuando se oye llamar square por aquellos vagabundos, reacciona enarbolando el recuerdo de su juventud: «Square, ¿yo? ¿Cuántas

\footnotetext{
12 Ensayos del otro mundo, Barcelona, Destino, 1970, p. 54.

13 Ibid., p. 100.

14 Ibid., p. 204.

15 Ibid., p. 47.
} 
veces han estado ustedes en la cárcel por sostener ideas contrarias a las establecidas? ¿Cuántas noches han dormido al lado de una fila de muertos de guerra al aire libre creyendo que eran soldados vivos de su compañía? ¿Cuántas veces han arriesgado su vida en contiendas civiles para mantener y defender sus principios? ¿Ninguna? Pues yo, sí». ${ }^{16}$

De la misma fecha de 1970 es otra colección de narraciones de naturaleza autobiográfica que nunca ha llamado mucho la atención, pese al valor testimonial y artístico de los trabajos allegados. Me refiero a Relatos fronterizos, que, de nuevo, es un rótulo oportuno y expresivo, no sólo porque todos se refieran a ese territorio físico sino porque apuntan a una concepción liminar de la vida moral: la del que está a regañadientes en el ámbito de lo convencional pero también con un pie en el territorio de la utopía donde pueda armonizarse la conciencia y la biografía. Como dice al final de "Velada en Acapulco", tras oír la confesión de un tipógrafo mexicano que hizo la revolución y ha sido terriblemente desdichado en su vida personal: "-Pobre hombre. - ¿Por qué? -Porque estamos entrando en un tiempo en que ninguna de esas verdades tendrá sentido. -Pero siempre queda la conciencia de cada cual. El tribunal secreto». ${ }^{17}$ Esa necesidad de comprender los motivos del comportamiento humano preside todo el libro y sorprendentemente le acerca a dos significativas figuras de la vida marginal y violenta en las ciudades norteamericanas de los años sesenta. En "Adiós, pájaro negro", el protagonista es un muchacho negro que asalta su casa y que resulta ser un... respetuoso violador de mujeres blancas que acaba muerto por olvidar tirar la pistola al entregarse a la policía. En «Pantera negra» le visita un atracador que blasona de la ideología que traduce el título - la de los «black Panthers»- y que resulta ser un desdichado de vida errática y patética inocencia. "¿Pero ha entendido nunca nadie ninguna cosa realmente importante en nuestro universo, dorado de sol durante el día y negro de sombras por la noche?», se pregunta al cabo Sender, dejando consignada en esa deliberada secuencia negativa - «nunca nadie ninguna»- la obstinada cerrazón de un mundo pero que, sin embargo, contrasta implícitamente con el seguro y tranquilizador ritmo de la naturaleza. Pero ese contraste que aquí se esboza lo hemos de ver más adelante ampliarse hasta constituir un leit motiv sistemático del último Sender y, a la vez, un guiño de continuidad con el Sender de siempre.

Quizá la mejor joya del conjunto sea «Aventura de Texas», episodio narrado en una delatora primera persona, que recoge una historia -real o ficticia- de sus primeros días en Estados Unidos, donde - como se sabe- llegó en 1940 con un visado que avaló la propia Eleanor Roosevelt.

16 Ibid., p. 50. La dramática escena del soldado que duerme inadvertidamente junto a los cadáveres está narrada en Imán, ed. Francisco CARRAsquer, Huesca, Instituto de Estudios Altoaragoneses, 1994, p. 32.

17 Relatos fronterizos, México, Editores Mexicanos Unidos, 1970, p. 351. 
Nos cuenta que, viajando en un autobús por Texas, conoció a dos pasajeras, una anciana mexicana y su nieta, que padecía una fuerte fiebre, con las que estableció una superficial relación de afecto. En la parada de Pecos, decide acompañarlas a la compra de una aspirina y es testigo de la silenciosa negativa de la farmacéutica, a atender a los extraños: "Nunca había podido imaginar lo que era "no ser nadie" para alguien. No ser absolutamente nadie [...]. Yo no existía para aquella hembra, ni Yolanda ni su abuela, mexicanas. No habíamos nacido, no desplazábamos aire, ni ocupábamos lugar. Por eso ella no nos veía, se negaba a vernos». ${ }^{18}$ De nuevo, la insistencia estilística en la negación revela la profunda verdad que se busca: la insolidaridad como constante de la vida humana y, sin embargo, la obstinada necesidad de que haya "un lugar» para el ser humano, como postulaba el bellísimo título de 1939.

Otra vez, la autobiografía -y, por ende, el exorcismo del pasado de 1930-1940 - está presente en varios lugares del volumen. "Gaceta del acabamiento de Neuendorf», por ejemplo, es una evocación del antiguo traductor de Imán al alemán, que murió en el bombardeo de Dresde y cuya andadura anticipa algo el artificio de Nocturno de los 14, como veremos enseguida. En «Despedida en Bourg Madame», Sender acude de nuevo al lugar por donde salió de España en 1937 y encuentra ahora a unos campesinos que abandonan el país por otros motivos. "Yo también salí de España algunos años antes por el mismo lugar de la frontera [...]. Nos consideraban tipos siniestros. En mi caso y en el de cada fugitivo había sólo una callada desesperación. Digo, en 1939». ${ }^{19}$ Y perdió «el eco (era cuestión de un eco) de la risa de mis antiguas novias adolescentes, todas tan dulces y femeninas, por una razón u otra. El eco de los llantos de los niños recién nacidos que quedó vibrando en las paredes de mi hogar [...]. Perdería - había perdido ya - los reflejos del verde del Retiro en los cristales de la ventana de mi estudio. El gañido de los pavos reales de la Casa de Fieras [...]. Y también los rugidos de los leones hambrientos que oía desde la cama». ${ }^{20}$ Eso ha acabado por ser la guerra: el desgarrón. No hay otro sentimiento más solemne ahora que «nuestra patria va a ser pronto extendida y dilatada enormemente. Va a ser pronto el planeta entero, el planeta que sigue girando en su eje, bien ajeno y bien despreocupado de nosotros, sus hijos». ${ }^{21}$ Una suerte de vertiginoso zoom cinematográfico nos ha llevado desde la enumeración del pasado sentimental —on insistencia en un ámbito de animales que parecen aludir al paraíso terrenal perdido- a un porvenir de fría convivencia en un mundo feliz, quizá como el de Huxley,

\footnotetext{
18 Ibid., p. 13.

${ }^{19}$ Ibid., p. 114.

20 Ibid., p. 118.

21 Ibid., p. 117.
} 
concebido en términos cósmicos, casi newtonianos. Pero, mal que pese a la deshumanización de la última imagen, al autor no podrán arrancarle la dramática realidad de haber vivido la felicidad —como recuerda en Bourg Madame - o la injusticia, como proclamaba ante los hippies de California: tras la muerte de su mujer y de su hermano y la pérdida de sus hijos, «uno ha vivido realmente, desde entonces, en la frontera. No en la frontera geográfica, sino la otra, la que separa la vida de la muerte. Al borde del abismo». Y esa es una frontera "sin aduanas ni policías que busquen en las maletas mandíbulas con oro en los dientes. En esa frontera que todos cruzaremos un día. Tú también, lector amigo o enemigo, quién sabe». ${ }^{22}$

\section{EN LA VIDA DE IGNACIO MOREL $Y$ LA «FATIGA ANTICIPADA DE LA VIOLENCIA»}

Esa acusada sensación de extrañamiento se encarnó también en los protagonistas de las novelas de estos años. Tal fue el caso de En la vida de Ignacio Morel (1969), un relato al que la concesión del Premio Planeta enajenó la benevolente expectativa de los lectores progresistas y que fue unánimemente calificado de obra menor, cuando no de entrega sonrojante a los dictados de la comercialidad.

Bastantes años después, aparece, sin embargo, como uno de los libros más logrados de su última etapa. A primera vista, contiene elementos ya conocidos de sus obras anteriores. La introducción de un tono sarcástico - a modo de eco deformado de la acción principal- mediante la inserción de la comedieta Los cuatro enanitos parece tener que ver con la estructura de El rey y la reina, que, como se recordará, también incluye el recurso a los títeres (por otro lado, esa farsa del prepotente enano millonario enamorado de Güeny y engañado por ella tiene un vago parecido a la «aleluya erótica" Amor de don Perlimplín y Belisa en su jardín de Federico García Lorca). Es evidente que —como sucedía en la tensa novela-apólogo de 1947- la presencia de esa fábula escénica no hace sino evidenciar el cerco que lo brutal, lo esperpéntico, lo horrible cierran, partiendo de nuestros propios instintos, de nuestro propio interior, sobre la normalidad burguesa cotidiana. Y ese va a ser el argumento secreto de toda la obra...

Pero hay otros elementos en la obra que reiteran la misma función subversiva: así sucede con el argelino Darlbeida y su turbia amiga lesbiana. El argelino es, como ha visto Marshall J. Schneider, ${ }^{23}$ el "maestro" de Ignacio en el uso de los instintos y en la arbitrariedad de la relación entre la imaginación y la realidad. Pero también la presencia del niño hidrocéfalo y del

22 Ibid., p. 134.

23 «Life Parodying Art: Exemplarity and Verosimilitude in Ramón J. Sender's En la vida de Ignacio Morel", RHM, XLV (1992), pp. 60-71. 
«esclavo» annamita Thuan en la rígida casa burguesa de monsieur y madame Maissonave, en Argenteuil, significa otra apertura hacia los confines sórdidos de la vivencia humana. Como lo es la historia del judío al que sus verdugos hicieron elegir cuál de sus hijos ha de ir al campo de concentración y cuál permanecer para cuidarle, tras lo que deciden invertir los papeles asignados: el espantoso apólogo nos recuerda, por otra parte, la inevitable cercanía moral de los años del holocausto... Quizá no esté de más recordar que otro aragonés de 1900, Luis Buñuel, también debió de sentir en estos años el retorno del aroma subversivo de los años treinta $y$, con ellos, de lo más iconoclasta de su juventud: recordemos, por ejemplo, que rueda en 1967 Belle de jour sobre una tonta novela de Joseph Kessel y en 1972 Le charme discret de la bourgeoisie, dos filmes que son una carga de dinamita en los cimientos de la hipócrita burguesía francesa que en 1930 había rechazado la provocación de L'Âge d'Or.

$Y$ mucho de burlona complacencia en el derribo de la respetabilidad convencional tiene también nuestro libro. Por todo ello, la mescolanza de muerte y placer (de la clandestinidad del episodio y de la naturalidad del orgasmo que acaba por el óbito) que se produce en la relación central de Ignacio Morel con madame de Saint-Julien no nos coge de improviso: en una sociedad tan hipócrita y pautada, la subversión solamente puede anidar en la casualidad y la tragedia en la vulgaridad de la visita a un meublé. Pero tampoco es casual el hecho de que aquella muerte inopinada suscite la curiosidad erótica del resto de las mujeres del Liceo; también entre ellas el oscuro instinto del deseo se impone a la precaución o al temor, como en los deudos y en la policía la discreción y -en el fondo, la admiración-se superpone a la posible venganza. Resulta tentador preguntarse si Javier Marías conocía este relato senderiano al escribir Mañana en la batalla piensa en mi, donde, como se recordará, todo gira en torno a la perturbadora imagen de una muchacha casada muerta accidentalmente en brazos de su amante ocasional. Pudieron uno y otro escritor tomar ese elemento de la trama de una noticia periodística (como el propio Sender reconoció respecto a su novela) pero, tanto en un caso como en otro, lo que importaba artísticamente era rellenar de sentido el acontecimiento banal: en Sender, esa proclividad aciaga de la posesión física ya alentaba desde $E l$ rey y la reina y El verdugo afable, aunque aquí la asociación de erotismo e inmolación adquiera, a mi entender, un significado subversivo que faltaba antes; en el hermoso libro de Javier Marías, la peculiar implicación de amor y muerte, fatalidad y deseo, culpa e inocencia, provenía, sin duda, de la trama central de su novela anterior, Corazón tan blanco, e incluso de la aventura amorosa central de Todas las almas.

Como el Ramiro Vallemediano de la ya citada El verdugo afable, Ignacio Morel aparece bajo las especies de un hombre señalado por el destino. $Y$ eso se formula con una insistencia reveladora a lo largo de todo el libro: es hijo de exiliados españoles - los tristes parias de una sociedad alarma$\mathrm{da}-\mathrm{y}$ tiene desde su infancia lo que Sender llama, con sugestiva troque- 
lación léxica, la «fatiga anticipada de la violencia». Intenta hacerse una vida de rutina - lo que significa mantener las cosas y los riesgos a prudente distancia - pero su propósito será quebrantado por el acoso del absurdo. El que tenga cuidadosamente grabada en magnetófono su obra Los cuatro enanitos y que haya decorado su estudio con fotos ampliadas de sus amigas revelan esa voluntad de prevenirlo todo y de rodearse de un ámbito doméstico y autosuficiente. Pero algo de su propio aspecto físico le traiciona y revela la realidad interior de su naturaleza. En el capítulo titulado «Miércoles augural» le vemos «afeitado, con el pelo bien cortado y los zapatos limpios, podría ser secretario de un comité de filantropía, pero en realidad era un vagabundo "decente" $\gg .{ }^{24} \mathrm{Al}$ ver morir a Marcelle en el capítulo "Viernes venusto", "Ignacio pensaba: "Alguien me ha traído a la vida, y el que me ha traído es responsable. Yo no tenía interés alguno en venir". Pero comprendía que la vida estaba muy bien en sus fondos gozaderos». ${ }^{25}$ ¿Qué son esos "fondos"? Es palmario que Sender sitúa allá lo instintivo, el reino de la espontaneidad y, sin duda, de la transgresión, como la que le lleva a gozar de una mujer casada. Pero sin escándalo ni provocación, como una suerte de rebeldía discreta que, en un revelador momento, identifica con el ritmo de la bossa nova, otra vez: «le parecía un trasunto de lo que quería hacer en literatura: una melodía intelectualmente refinada con bajos fondos armónicos de jazz-band». ${ }^{26}$ Pero cien páginas después la mezcla de primitivismo salvaje y melancolía refinada vuelve a surgir como correlato de su propia vida: «la barbarie sorda y contenida de los timbales y los ruidos rítmicos removía la naturaleza desolada de Ignacio». ${ }^{27}$ Por todo eso, en Nocturno de los 14 define su melodía como «una combinación de jazz y de cuarteto de Haendel». ${ }^{28}$

Si la atractiva música brasileña es una muestra de la violencia contemporánea solapada en delicada armonía, todo se presenta por el mismo tenor de tensa dualidad moral... Nada es lo que a primera vista parece ser. Al ver sonreír al monstruoso hijo de madame Maisonnave, el protagonista comenta: «He aquí que los monstruos pueden sonreír —se decía Ignacio-. ¿De qué sonreirán? Tal vez todos somos monstruos y deberíamos sonreír a pesar de nuestra monstruosidad». ${ }^{29} \mathrm{El}$ argelino Darlbeida, contrafigura expiatoria de Ignacio y en cierto modo su maestro, como ya sabemos, es el que vive hasta las heces la contradicción y por ello cae en la abyección hasta convertirse en ex hombre: "Está bien - le dice a Ignacio- [...]. Estás orgulloso de ser hombre. Yo estoy sorprendido y perplejo de ser hombre

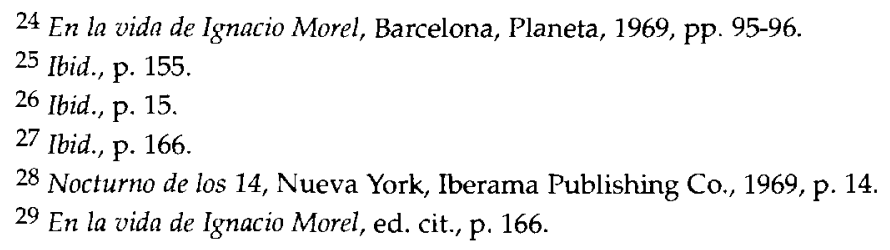


como lo estaría de ser un chacal sarnoso. Ni más ni menos [...]. Tú dices que yo juego con las cosas. No es que yo juegue. Es que la vida, el orbe, Dios creador de las galaxias y de las chinches, juega conmigo. Entonces yo estoy autorizado a jugar con todo lo demás». ${ }^{30}$ Obsérvese que, de nuevo, actúa lo que hemos llamado el efecto zoom, tan senderiano, que obliga a pasar de la sinrazón cósmica a la perplejidad microcósmica y viceversa en una vertiginosa mise en abîme. En la vida de Ignacio Morel viene a ser la novela de una nueva moral, como ha apuntado Schneider: «In a postmodernist manner, the pourposeful blurring of boundaries, as well as the ambiguity established by the textual play of the diegetic levels, significantly challenge the reader [...]. The rather complex exemplarity of Ignacio Morel permits the novel to interact meaningfully with the beholder's world, transforming it in some vivid way». ${ }^{31}$

\section{OTRAS PARÁBOLAS DEL EXTRAÑAMIENTO}

De 1969 fue también la publicación de Nocturno de los 14, una novela emborronada y confusa que tiene las peores características de la peculiar escritura automática senderiana pero que no carece totalmente de interés. De entrada, repite con paladina insistencia la idea de un protagonista -Pedro- marginado y perseguido (aquí por unos indios, tras haber librado junto con su hijo a un águila cautiva), unido a una mujer enigmática y arbitraria - a la que llama Mu-mú- que resulta ser viuda de un aviador suicida. Todo ello acontece en medio de escenas simbólicas, como la de los animales moribundos que buscan refugio en la casa, y las constantes referencias a la superioridad moral de las bestias sobre los hombres; si añadimos la historia del águila a la que he aludido (y que, por otra parte, solamente comparece ya más que mediado el relato) resulta indudable que ese singular zoológico senderiano apunta a una suerte de precursora ecología moralizante, quizá más franciscana que propia de nuestros días. El tono de todo el relato está siempre muy próximo a la revelación onírica: «Estoy solo en esta casa y mi sueño ha sido entreverado de espacios lúcidos».32 $Y$, por supuesto, vuelve a reiterarse el efecto de extrañamiento de los personajes, la necesidad de sentirse moralmente ajenos a un mundo injusto: "A veces he tenido la sospecha bastante fundada de estar asistiendo a la vida desde el margen. Pero de pronto alguien acudía a la puerta y me decía algo que la gente no suele oír con calma ni repetir sino en el mayor secreto». ${ }^{33}$

\footnotetext{
30 Ibid., pp. 230-231.

31 Marshall J. SCHNEIDER, art. cit., p. 66.

32 Nocturno de los 14 , ed. cit., p. 7.

33 Ibid., p. 10.
} 


\section{EL LUGAR DE SENDER}

Pero el lector no tiene tan hacedero llegar a estas conclusiones en medio del sistemático desorden de este relato que parece construirse a sí mismo en el marco de la más absoluta improvisación. Su estructura de fondo es marcadamente escénica ${ }^{34}$ y, si se me permite apurar la comparación, cercana a la tradición del auto sacramental: en una suerte de tierra de nadie - entre el sueño y la vigilia, entre lo propio y lo usurpado, entre la vida y la muerte - comparecen personajes ya muertos pero que, como en el Juicio Final, llegan cargados del fardo de sus vidas. Todos comparten parecido legado —el del fracaso y el de la voluntad de extrañamiento-y un mismo final, el suicidio: un tema que, como han demostrado muy bien Patrick Collard y Donatella Pini Moro, está obstinadamente presente a lo largo de toda la obra senderiana. En su trabajo recapitulador, Pini Moro ha escrito: «Suicidio, fuga, morte: tre modi per appagare l'ansia d'ausencia che s'impadronisce dell'uomo specie nelle avversitá». ${ }^{35}$ Sender lo expresa aquí con no menor contundencia: «El acto de humildad absoluta del hombre es el suicidio". ${ }^{36} \mathrm{Y}$ es que, sin duda, el autosacrificio se presenta como una manera de hacer propio el absurdo del mundo.

Todos los suicidas senderianos que pueden ser identificados en este Nocturno tienen como característica común la de haber vivido la misma experiencia histórica que su amigo y recreador: algunos tan estrechamente como el poeta y millonario costarricense Max Jiménez - -a quien conoció en Madrid-; el escritor alemán antifascista Ernst Töller, tan popular en la España de los años treinta; el periodista Fabián Vidal, que fue su director en El Sol; el inquieto profesor Ramón Iglesias Parga, al que presenta bajo sus siglas; el líder comunista Pepe Díaz, secretario general del Partido cuando Sender fue más activo "compañero de viaje»; la ministra laborista británica Helen Wilkinson, y el novelista Ernest Hemingway, de quien nos cuenta que le ofreció traducir Por quién doblan las campanas y no quiso aceptar... De todos se puede decir, al cabo, lo que escribe de Fabián Vidal: «Sabía que las parcas, las euménides, gemían en el aire crepuscular y que seguirían gimiendo en Madrid, París, Berlín, el Oriente Próximo o Lejano, ya para siempre [...]. Sabía que había comenzado la sombría fiesta de la sangre para no terminar ya nunca. Entre proclamas de paz y apelaciones al amor y la fraternidad». ${ }^{37}$ Pero lo cierto es que él, bajo la confusa

\footnotetext{
34 Algunas sugerencias y observaciones sobre la estructura escénica de la novela senderiana (que podría remitir al modelo dialógico del relato según la teoría bajtiniana) en mi trabajo «La narrativa de Ramón J. Sender: la tentación escénica», Letras aragonesas. Siglos XIX y XX, ed. cit., pp. 231-248.

35 «Variazioni sul suicidio», en Ramón J. Sender tra la guerra e l'esilio, Alessandria, Dell’Orso, 1994, p. 127; el artículo aludido de Patrick Collard es «Escribir para salvarse. Un tema en la obra de Ramón J. Sender", Revista de Literatura, 86 (1981), pp. 193-199.

36 Nocturno de los 14, ed. cit., p. 82.

37 Ibid., p. 116.
} 
identidad del hombre que salva un águila para su hijo y del amante de la mujer de un suicida, ha sobrevivido a la catástrofe y parece tener el propósito de seguir haciéndolo y de no suicidarse por tanto: este "nocturno" anda más emparentado con una dramática Walpurgisnacht que con la idea romántica y modernista, meditativa y autocomplaciente, de «notturno». Es, en fin, un descenso a los infiernos con viaje de regreso, como veremos que sucede también en la novela siguiente. En el definitivo reencuentro -que narran las últimas páginas- con el hijo perdido no sería ilícito advertir el eco de una circunstancia y una necesidad muy personales que seguramente afloraron en estos años difíciles; también en el relato inmediato, Tánit, podremos ver que el reconocimiento parcial de la condición de español por parte del protagonista y en el recuerdo de cómo la madre de Tánit abandonó un feto suyo (Nonatillo) en un banco de los Campos Elíseos parisinos constituyen fugaces destellos de autobiografía metafórica que densifican la compleja y enrevesada significación de este ciclo narrativo.

Tánit (1970) es una narración mucho más deshilachada pero no tanto como para que no se patenticen algunas de las obsesiones que rastreamos. Su estructura ceremonial básica es sustancialmente la misma de Nocturno de los 14: una fiesta de boda viene a ser pretexto para un desfile de personajes reales, una especie de teatro de la memoria contemporáneo similar a los que unos años después veremos en Monte Odina. ${ }^{38}$ Aquí los invitados son poetas y conviene, al propósito, no olvidar la importancia de la lírica como cifra intuitiva de lo humano en la obra de Sender; de ese modo y sin diferenciar entre escritores vivos o difuntos, desfilan por las páginas del relato Wallace Stevens («satánicamente trascendental»), Carl Sandburg ("parece un pastor de ovejas jubilado»), el delegado de Dylan Thomas («tan puro como puede considerarse un hombre en estos tiempos»), Roy Campbell ("un verdadero macho»), Juan Ramón Jiménez («la poesía de Juan Ramón es una especie de noche nupcial con novia sin nombre aún, que no tendrá nombre tal vez nunca») y hasta Rimbaud («un barco borracho bajo los soles más estupendos y las músicas más exóticas y las brisas más impropicias que se puedan imaginar»).

Pero, más que esto, nos importa que el protagonista vuelva a ser una identidad flotante y confusa en la nacionalidad - es un español naturalizado americano-, en su propio nombre -Enrique Lavedan es solamente "mi nombre legal de ciudadano"- y, lo que es más importante, en la condición clandestina de su profesión -es ejecutor (o verdugo, si queremos recordar a su próximo pariente, el Ramiro Vallemediano de El verdugo afable) y tiene la misión de matar a un dictador hispanoamericano---: "Yo no

38 Algunas notas sobre Monte Odina como «teatro de la memoria», en mi artículo «El territorio de la infancia y las fuentes de la autobiografía senderiana", en III Curso sobre Lengua y Literatura en Aragón (siglos XVIII-XX), ed. T. BUESA y J.-C. MAINER, Zaragoza, Institución Fernando el Católico, 1994, pp. 139-159. 
soy - nos explica en un rápido autorretrato que deja traslucir rasgos muy senderianos- un terrorista místico como los viejos nihilistas rusos que morían con su víctima, sino un hombre ordinario con convicciones arraigadas [...]. Es lo que hay que ser ahora: hombre ordinario con convicciones, las mías se diversifican y esparcen por la superficie de la realidad y van desde la Dama de Elche al afecto personal puramente amistoso con dimensiones retrospectivas». .39

Pero ya sabemos que esos seres acosados y complejos son agraciados (o perseguidos) por la lucidez y, de ese modo, pueden enlazar a su sabor con todos los misterios. El inevitable zoom cósmico no se limita en este caso a una amplificatio retórica, sino que adquiere aquí función de episodio del relato bajo la forma de unas extrañas pantallas que, manejadas por Schulten (un antiguo contable de los suicidios del ejército nazi), permiten a los espectadores el viaje en el tiempo hasta el origen de la Tierra: precisamente hasta la llegada del cometa Typhon, que fue el comienzo del mal. ¿Significaba esto la acuñación de un cierto maniqueísmo expreso, ya que - de forma latente- todo el mundo de Sender había aparecido siempre bajo los signos de la dualidad, de la contradicción (entre el bien y el mal, la vida y la muerte, la culpabilidad y la inocencia)? Lo cierto es que, en cualquier caso, esa creencia seudocientífica parece obsesionarle en estos años que también fueron los de continuada referencia a la Atlántida, otro mito oscuramente vinculado a la llegada del cometa: la primera comparecencia literaria de Typhon se registra en Las criaturas saturnianas (1967) y figura también en un capítulo de los ya citados Ensayos del otro mundo (1970). ${ }^{40}$

Provenga o no del misterioso astro, la corporeización del Mal enlaza, por otro lado, con la plasmación de la ambigüedad esencial del Bien, tal como se encarna en Tánit, la muchacha que da título a la novela. No debe olvidarse que Tánit es el nombre púnico de la diosa Astarté, matriz conceptual de las diosas-madres Hera y Juno en Grecia y Roma, pero además manifestación fundamental del mito de la gran diosa blanca originaria, según la conocida teoría de Robert Graves. El libro del solitario de Deià, The White Goddess. A Historical Grammar of Poetic Myth, se publicó en 1948 y es muy fácil que Sender, tan propenso a lo esotérico, lo leyera, como quizá leyó otros relatos de un escritor con el que ya hemos señalado más arriba algún parentesco: en todo caso, la argumentación de Graves guarda estrecha relación con las concepciones senderianas de lo femenino y de lo poético. Tánit es, a

39 Tánit, Barcelona, Planeta, 1970, p. 56.

40 Dice Cagliostro a la princesa Lizaveta: «La presencia histórica del Diablo viene de un cometa fabuloso hace cinco o seis mil años [...]. Un cometa que entró en la atmósfera de la tierra y transtornó mares, continentes, abrió océanos nuevos y hundió la famosa Atlántida [...]. El cometa después de chocar con la tierra saltó al espacio otra vez y quedó fijado como un planeta entre la Tierra y el Sol con el nombre de Lucifer. Era una serpiente, un ogro, un animal volante y cornudo, hijo de Dios (del Sol) que se rebeló contra él y fue condenado a caer a los abismos de la creación» (Las criaturas saturnianas, Barcelona, Destino, 1968, p. 269). 
fin de cuentas, enigmático (y moralmente ambiguo) principio de la vida y atractiva muchacha de nuestro tiempo, tal como la ve Sender. Un lado de Tánit revela la parte oscura y turbulenta de lo femenino (resulta ser la hija de una antigua relación de su pretendiente, es luego rival de su madre, es amante del hijo de un brutal tuareg que tiene el revelador nombre de Túbal —que fue el primer poblador mítico de España-...), mientras el otro perfil corresponde a la virgen inocente. Tánit se presenta como un ambiguo ideal femenino en torno al que el hombre edifica sus sueños y realiza sus trabajos como inútil pero constante ofrenda a una deidad a la vez propicia y veleidosa: una dimensión que ya apareció en la Niña Lucha de Epitalamio del Prieto Trinidad (pero también en las primeras e inolvidables partes de Crónica del alba, en torno a la numinosa figura de Valentina) y que supone una constante importante del pensamiento senderiano.

Lo que he llamado zoom cósmico y la necesidad senderiana de traer por testigo del absurdo a la totalidad del universo no acaba aquí, con las misteriosas pantallas del Dr. Lightning manejadas por Schulten. En este mismo año de 1970, Sender publicó una curiosa fábula - un aficionado a la retórica la hubiera llamado fabula morata - titulada $\mathrm{Zu}$, el ángel anfibio, seguramente escrita a partir de las numerosas noticias que se difundían sobre el lenguaje de los cetáceos y de la progresiva presencia de estas grandes bestias en los acuarios californianos. Lo que el autor busca, sin embargo, es utilizarlas como artilugio para ver al ser humano desde una óptica distinta. Porque esta novela trata de la triste aventura de una ballena macho - $\mathrm{Zu}-$, de su amante Zetania, del viejo y sentencioso Gau, del curioso delfín antropomorfo Xai (operado por sus cuidadores para poder comunicar con los humanos)..., pero, sobre todo, quiere tratar de los hombres -inmortales, poderosos pero crueles, absurdos y sentimentales-, tal como los ven los animales. Casi nada de este libro menor sobrepasa, sin embargo, la pretensión naîf algo empalagosa y los términos de una imaginación no muy brillante en este caso. La visión del santuario de los "ahogados verticales" - marineros muertos a los que sus asesinos ataron con cadenas al lastre que los fija al fondo marino- es quizá el capítulo más revelador y explícito de todo el libro, al lado, en todo caso, de la historia del Dr. Noel, que cometió suicidio porque su amigo el delfín le descubrió la verdad — la ambición de su hija, el adulterio de su mujer...- que él hubiera preferido ignorar. La suerte final de $\mathrm{Zu}$, traicionado por las aviesas orcas, muerto por un arponazo y luego descuartizado, subraya la imposibilidad de convivencia y la crueldad innata y destructiva del hombre: un ser que busca siempre la felicidad, tanto a través del bien como por medio del dolor infligido a otros. ${ }^{41}$

\footnotetext{
41 La presencia de los animales en la obra de Sender ha llamado la atención de Kessel ScHWARTZ en dos artículos, "Animal Symbolism in the Fictions of Ramón Sender», Hispania, 46 (1963), pp. 496-505, y su continuación «Fauna in selected Novels of Sender (1962-1968)", Homenaje a Ramón J. Sender, Newark, Del., Juan de la Cuesta, 1987, pp. 131-148, con numerosas citas de Zu, el ángel anfibio.
} 
Resulta patente que estas novelas - con la muy notable excepción de En la vida de Ignacio Morel - no son ni las mejores ni las más frecuentadas del autor, ni es fácil que hayan de serlo algún día. Alguna vez he escrito que Ramón J. Sender es escritor para leído a lo largo, como Baroja, y que triunfa por su insistencia dilatada mucho más que por los éxitos aislados, contrariamente a lo que quiere la opinión obstinada en hacerlo autor exclusivo de unos pocos títulos felices. No nos debe bastar la idea de un Sender de aciertos esporádicos y caídas inexplicables que también se ha aplicado a veces a don Pío. Muy a menudo, Sender repitió dos frases de Picasso - «yo no busco, encuentro» y la más enigmática «yo también pinto falsos Picassos»— ${ }^{42}$ que pueden aplicársele con fruto: si en su última época el pintor trabaja por series - palomas, bañistas, viejos, meninas...y por ámbitos — sexualidad, toros, vida doméstica...-, cuya luz de intención y de verdad adviene al espectador a través de la insistencia y de lo recurrente, incluso de la autoimitación, también los numerosos «encuentros» de Sender nacen de la dilatación de la «búsqueda» y de la obstinación cíclica de los temas.

Incluso en estas obras aparentemente menores se alberga un candente testimonio de sus días, tan cercanos y tan lejos a la vez de los nuestros, tal como lo veían los veteranos sobrevivientes de 1930 . En ellas suena indistinto un registro que, por razones obvias, no existió casi en la literatura española del momento, incluso si contamos al Cela de San Camilo 1936, al Torrente Ballester de La saga/fuga de J. B. y al Miguel Delibes de la Parábola del náufrago, que son lo más parecido a un testimonio español de la crisis histórica y civilizatoria del final de los sesenta. Treinta y tantos años después, los héroes estaban fatigados pero seguían siendo fieles a la pluma.

\footnotetext{
42 En «E1 hombre que compró un Picasso" leemos: «yo conocí a Picasso en 1939 y me dio la impresión de un pequeño gran hombre concentrado en una sola idea que había desarrollado en profundidad, agudo y con un completo dominio de su arte" (El extraño señor Photynos y otras novelas americanas, Barcelona, Aymá, 1968, p. 171). Las referencias al pintor son significativamente numerosas en toda la obra de Sender: me limitaré a citar lo que dice a su propósito en "Baroja y las contradicciones latentes", Examen de ingenios. Los noventayochos. Ensayos críticos, México, Aguilar, 1961, pp. 209-272; los cinco artículos que concluyen Ver o no ver. Reflexiones sobre la pintura española, Madrid, Heliodoro, 1980, pp. 178-258, y «Pablo, el malagueño", en Álbum de radiografías secretas, Barcelona, Destino, 1982, pp. 383-393.
} 


\title{
Ramón J. Sender, periodista: el aprendizaje de la persuasión
}

\author{
José Domingo Dueñas Lorente \\ I. E. S. Martínez Vargas, Barbastro (Huesca)
}

\begin{abstract}
C omo es bien sabido, en la historia de la literatura española reciente hay periodos de especial aproxirnación entre periodismo y literatura. No hay más que pensar en los años cincuenta, cuando la novela realista predominante asumió una función de denuncia o desvelamiento de la realidad social que en otros momentos de censura más relajada hubiera podido ser desempeñada por los medios de comunicación. Pero no sólo me refiero a una traslación de funciones sino también a una cierta superposición o confusión de pautas expresivas periodísticas y literarias. Así, un momento ciertamente paradigmático de las interrelaciones entre periodismo y literatura fue el primer tercio de nuestro siglo. De Ramón Sender, en concreto, cabe decir con toda propiedad que ejerció entonces tanto o más de periodista que de novelista. En estos años fue redactor y redactor-jefe de La Tierra de Huesca (1919-1923), formó parte de la plantilla de El Sol de Madrid (1924-1930), actuó como «redactor-corresponsal» del diario anarquista barcelonés Solidaridad Obrera (1930-1932), fue colaborador asiduo del periódico madrileño La Libertad (1930-1936), director durante un breve periodo del comunista La Lucha (1934), fundó y dirigió la revista quincenal de «Información literaria y orientación» Tensor (1935), figuró en el comité de redacción de la valenciana Nueva Cultura en su primera etapa
\end{abstract}


(1935-1936) y ya durante la guerra formó parte activa del comité del semanario republicano elaborado en París Voz de Madrid (1938). O, en fin, entre 1924 y 1939 firmó alrededor de mil textos para periódicos y revistas.

Este Sender anterior al exilio es el que nos va a ocupar aquí casi exclusivamente porque a partir de 1939 ya no puede decirse de él que ejerciera en sentido estricto como periodista, sino como un escritor que colaboraba, con bastante asiduidad por cierto, en la prensa, una vez declinado por circunstancias sobradamente conocidas el empeño movilizador, el afán de incidir de manera inmediata en el curso de la historia con que se había consagrado antes al quehacer periodístico. De forma muy ilustrativa en este sentido, el propio autor diría después que al salir de España dejó de escribir «una literatura de combate para escribir una literatura, por decirlo de un modo un poco absurdo, de iluminación». ${ }^{1}$

\section{LA ÉPOCA MÁS BRILLANTE DEL PERIODISMO ESPAÑOL}

Claro está que Sender no fue, ni mucho menos, un caso aislado. Otros muchos accedieron entonces como él a la literatura por el camino del periodismo o alternaron durante años y con parecida fidelidad el quehacer periodístico y el literario. Por algo los historiadores de la prensa localizan en aquel primer tercio del siglo «La época más brillante del periodismo español». ${ }^{2}$

Josep Lluís Gómez señala, por ejemplo, que en España la denominada «prensa de masas» inicia su «despegue» en los años de la primera guerra mundial y alcanza la «consolidación» durante la Segunda República, de manera - continúa-que "[e]n este periodo de unos veinte años se gestó la prensa moderna española». ${ }^{3}$ Enric Marín afirma que entre la primera guerra mundial y la segunda la industria informativa impresa no sólo se asentó definitivamente en España sino que logró superar carencias anteriores hasta poder homologarse con la de los demás países industrialmente avanzados. ${ }^{4}$

Una confluencia de factores hizo posible tal circunstancia: un apreciable incremento desde las últimas décadas del siglo XIX de la población urbana, acompañado por la transición desde un sistema de producción

\footnotetext{
1 Marcelino C. Peñuelas, Conversaciones con Ramón J. Sender, Madrid, Magisterio Español, 1969, p. 91.

2 Pedro Gómez. APARicio, "La época más brillante del periodismo español (1898-1921)", AEDE, 1 (junio de 1979), pp. 40-44. Para Enric Marín, «el periodo más brillante tuvo lugar, sin embargo, en los años de la Segunda República»; vid. Enric MARíN, "Estabilización y novedades en la prensa diaria", en Jesús Timoteo Álvarez y otros, Historia de los medios de comunicación en España, Barcelona, Ariel, 1989, p. 111.

3 «¿Existió en España prensa de masas? La prensa en tomo a 1900», en Jesús Timoteo ÁlvaREZ y otros, op. cit., p. 29.

4 Ibid., p. 104.
} 


\section{JOSÉ DOMINGO DUEÑAS LORENTE}

básicamente agrario a otro industrial, una ampliación notable de la tarea alfabetizadora en el periodo de entresiglos, la propia inestabilidad política del sistema de la Restauración, la instauración del sufragio universal -aunque con importantes restricciones- en 1890, el acceso a la prensa de las primeras promociones de intelectuales, el desarrollo tecnológico del sector periodístico impulsado por la acumulación de capital que supuso para la economía española la neutralidad en la guerra del 14 , etc. ${ }^{5}$

Al volcarse en el periodismo, los escritores no hacían, pues, en gran parte, sino atenerse a las condiciones que imponía la producción cultural del momento en España. El propio Menéndez Pidal registraba en 1925 que las colaboraciones periodísticas suponían para los literatos una fuente más nutrida y segura de ingresos que el libro. ${ }^{6} Y$ es que si el público empezaba a leer la prensa en número ostensible era aún muy reducido el que compraba y leía libros. ${ }^{7}$ Pero tal vez el testimonio más ilustrativo de todo este proceso reseñado aquí muy a grandes rasgos sea la justificación que en 1932 esbozaba el propio José Ortega y Gasset de su personal inclinación a escribir en los periódicos:

En nuestro país ni la cátedra ni el libro tenían eficiencia social. Nuestro pueblo no admite lo distanciado y solemne. Reina en él puramente lo cotidiano y vulgar [...]. He aquí por qué, dócil a la circunstancia, he hecho que mi obra brote en la plazuela intelectual que es el periódico [...]. El artículo de periódico es una forma imprescindible del espíritu, y quien pedantescamente lo desdeña no tiene la más remota idea de lo que está aconteciendo en los senos de la historia. ${ }^{8}$

\section{EL HACERSE DE UN ESCRITOR}

No cabe duda, pues, de que el periodismo tiñó con su impronta todo el proceso cultural y literario de la Edad de Plata. En lo que respecta a Sen-

\footnotetext{
5 Varias de estas razones y otras apunta Enric MARíN —ed. cit., pp. 110-111- como explicación de la excepcional coyuntura periodística que culminó en la Segunda República. Las bases de este proceso pueden apreciarse en Serge SALAÜN y Carlos SERRANO, eds., 1900 en España, Madrid, Espasa-Calpe, 1991 (vid. especialmente las aportaciones de Jean-Louis GuEREÑ $\Lambda$, «Las instituciones culturales: políticas educativas»; Carlos SERRANO, "Los "intelectuales" en 1900: ¿ensayo general?», y Brigitte MAGNIEN, "Cultura urbana»). También es ilustrativo el análisis de la función social de la prensa en España en aquellos años llevado a cabo por Jesús Timoteo en «Decadencia del sistema y movimientos regeneracionistas», en Jesús TIMOTEO y otros, op. cit., pp. 11-26.

${ }^{6}$ Discursos leidos ante la Real Academia Española en la recepción pública de don Eduardo Gómez de Baquero el dia 21 de junio de 1925, Madrid, Tipografía de la Revista Archivos, 1925, p. 51.

${ }^{7}$ Con una argumentación semejante explicaba GÓMEZ DE BAQUERO la espectacular profusión del ensayo a principios de siglo. Detectaba Andrenio - El renacimiento de la novela española en el siglo XIX, Madrid, Mundo Latino, 1924, p. 107-, entre otras cosas, "la formación de una clase media intelectual que acaso no puede leer tratados pero sí puede leer ensayos».

8 Obras completas VI, Madrid, Alianza Editorial, 1988, pp. 352-354.
} 
der, trataremos de apuntar algo acerca de cómo y en qué medida esta atmósfera periodística determinó su trayectoria en cuanto escritor. Para ello me parece especialmente relevante atender a las circunstancias en que el novelista se inició, siendo todavía adolescente, en ese mundo de la escritura que le envolvería ya como su segunda piel hasta la muerte.

En Zaragoza, con quince años, vio publicadas, y ya no sólo en revistas escolares, sus primeras creaciones literarias de que tenemos noticia. Según ha precisado Jesús Vived, Sender vivió en Zaragoza desde junio de 1914 a principios de 1918, es decir, desde los trece a los diecisiete años, aproximadamente. ${ }^{9}$ Antes había residido en Chalamera, Alcolea y Tauste y había estudiado como interno durante un curso en el Colegio de la Sagrada Familia de Reus, donde representó el papel de Segismundo en La vida es sueño, de Calderón, cuyo impacto - a la par que el famoso monólogoconservó el novelista de por vida. Su madre, según confirma también Jesús Vived, transmitió a este su primer hijo varón vivo la afición a la lectura; incluso ella misma en su primera juventud se había iniciado, si bien tímidamente, como escritora.

Pero no parece menos determinante en la dedicación precoz de nuestro autor la mencionada estancia en Zaragoza, a la sazón una ciudad que había superado ya los cien mil habitantes y que ofrecía, sin duda, a diferencia de los anteriores lugares de residencia, verdaderas condiciones para fomentar y avivar la fascinación por la letra de molde que recordaba insistentemente el propio Sender en Crónica del alba: ${ }^{10}$ «la letra impresa fuera de los libros de texto me parecía entonces ungida de divinidad». $Y$, de hecho, pronto intuyó que sus intereses estaban vinculados a la gran ciudad. Nada más terminado el bachillerato en Alcañiz, con diecisiete años, marchó a Madrid, donde se matriculó en la Universidad para cursar estudios de Letras, que hubiera podido realizar lo mismo en Zaragoza.

La vida literaria zaragozana de la segunda década del siglo ha sido estudiada detenidamente por José Luis Calvo Carilla. ${ }^{11}$ Por él sabemos que, si bien esta etapa no puede catalogarse de esplendorosa, no es menos cierto que confluyeron entonces suficientes condiciones materiales y espirituales como para comprobar que también en esta capital de provincias fue verdadero signo de época la fascinación juvenil por las bellas letras, así como la consiguiente precocidad en su cultivo. Algo especial había en aquella atmósfera de principios de siglo que empujaba a numerosos adolescentes y jóvenes a enviar en seguida sus escritos a la prensa o a fundar

\footnotetext{
9 Son imprescindibles para conocer estos avatares del primerísimo Sender las condensadas páginas de Jesús VIVED en "La vida de Ramón J. Sender al hilo de su obra», Alazet, 4 (1992), pp. 231-241, así como su estudio preliminar - «El primer Sender»- a Ramón J. SENDER, Primeros escritos (1916-1924), Huesca, Instituto de Estudios Altoaragoneses, 1993, pp. XVI-XXVI.

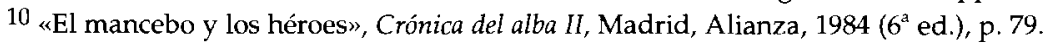

11 El modernismo literario en Aragón, Zaragoza, Institución Fernando el Católico, 1989. Para el periodo que aquí nos interesa, vid. sobre todo las páginas 151-196.
} 


\section{JOSÉ DOMINGO DUEÑAS LORENTE}

una revista literaria tras otra. Recordemos, si no, a aquellos hijos de la burguesía conservadora zaragozana, mauristas ellos mismos, que mientras estudiaban en la Universidad o se iniciaban en profesiones liberales sostuvieron publicaciones como Lealtad (1911-1913), Ambiente (1912), Paraninfo (1914-1916), en las que cultivaron un modernismo entre estetizante y casticista. $Y$, en no pocos casos, esta fascinación por el halo literario les llevó incluso a la práctica de una bohemia de tono menor, una bohemia «de veraneo donostiarra", según la ha calificado Calvo Carilla. ${ }^{12}$

Por las mismas fechas, la juventud progresista zaragozana frecuentó las páginas de semanarios como La Idea (1914-1915) o El Ideal de Aragón (1915-1920), órganos del Partido Republicano Autónomo de Aragón y defensores de un "modernismo germinalista» -según J. L. Calvo-, promotores de una veneración costista, casticista y de un regionalismo de izquierdas. Numerosos poetas «quinceañeros»-dice Calvo Carilla- y de vocación generalmente pasajera publicaron aquí sus primeros escritos: Avelino Casalé, José Lafuente, Saturnino Fustero, José Azcona, Jesús Vicente Pérez, etc. ${ }^{13}$

Las aspiraciones y referencias de otro quinceañero, Ramón Sender, no debían de andar por derroteros muy distintos. Nuestro autor no estaría muy lejos, por ejemplo, de las coordenadas en que se desenvolvía por entonces un Fernando Castán Palomar, bohemio pertinaz y tardío, tres años mayor que él y que con quince había comenzado a colaborar en el semanario Lealtad o con diecinueve contaba ya con dos novelas en la calle. ${ }^{14} \mathrm{Ni}$ siquiera sería muy diferente su caso al de Luis Franco, quien publicó su primer libro con dieciocho años y que con tal motivo era retratado por el prologuista, Gil Losilla, como «un soñador, encauzado siempre por el derrotero de lo bello, de lo artístico, de lo emocionante; espíritu inquieto, volandero, netamente Quijote, netamente español, bohemio elegante $[\ldots] » .{ }^{15} \mathrm{El}$ propio Sender recordaba que en su adolescencia zaragozana había adquirido «un sentido romántico de la literatura y un respeto -reiteraba - por la letra impresa que me han durado hasta hoy». ${ }^{16} \mathrm{Y}$ ya en su primer texto publicado en Zaragoza el narrador del relato se confiesa depositario de un «alma de artista». ${ }^{17}$

12 Ibid., p. 160. Entre estos jóvenes cabe mencionar a Ricardo Horno Alcorta, Alberto Marín Alcalde, Miguel Sancho Izquierdo, Agustín Aguilar Tejera, Diego Quílez, Julio Acha, Gil Berdejo, etc.

13 Ibid., p. 195.

14 Ibid., p. 175.

15 Apud José Luis Calvo Carilla, ibid., p. 170.

16 «El mancebo y los héroes», Crónica del alba II, ed. cit., pp. 119-120. Atribuía aquí Sender buena parte de su temprana inclinación a José María San Pío, joven amigo que "[q]uería hacerse editor profesional y promover talentos nuevos-decía gravemente-", ibid., p. 118.

17 «Recuerdos infantiles. Noche de ánimas», La Crónica de Aragón, 31 de agosto de 1916, p. 4. Recogido por Jesús VIVED en su antología del autor Primeros escritos (1916-1924), ed. cit., pp. 5-7. 
Si nos atenemos a los primeros escritos conocidos de nuestro autor, los que publicó cuando tenía quince años en el diario fundado y dirigido por José García Mercadal, La Crónica de Aragón, hemos de convenir en que no fue el periodismo y su capacidad de influencia lo que deslumbró e incitó al adolescente, sino la literatura o, lo que es lo mismo, la imagen del artista y del poeta que destiló el modernismo a revueltas de las conocidas pugnas entre la «gente vieja» y la «nueva». Hans Hinterhäuser percibió hace años la figura del artista en el periodo de entresiglos como una reacción idealista contra la plutocracia y el materialismo positivista de la época. ${ }^{18} \mathrm{Y}$ tal interpretación ha quedado sobradamente corroborada y desarrollada por María Pilar Celma basándose sobre todo en testimonios de la época. Constataba la estudiosa que, como antes para los simbolistas franceses - por citar los predecesores más inmediatos, en este sentido-, el arte fue para los modernistas un sacerdocio, un sustituto de la religión. ${ }^{19}$

Vate, adivino, sacerdote, profeta... son algunas de las palabras empleadas para recalcar la alta misión encomendada a los artistas [...]. El poeta es el intérprete de la divinidad, el que debe descubrir lo incognoscible y desentrañar el misterio que envuelve a toda la creación.

Para los jóvenes modernistas, el artista simboliza y resume, en buena medida, su propia y personal reacción contra lo establecido; la figura del artista es de alguna manera un modelo de héroe susceptible de canalizar la rebeldía juvenil del momento, el desacuerdo generacional incluso. Para aquellos adolescentes que entre los quince y los veintipocos años se empeñaban en escribir y publicar, ser artista o poeta significaba perseguir el ideal, desbordar los horizontes del mundo racionalista y materializado por el positivismo que habían heredado de sus mayores. De ahí aquella abundancia de vocaciones literarias precocísimas y de ahí aquella atmósfera propicia para el cultivo de las letras que respiró Sender en la Zaragoza tardomodernista.

El diario zaragozano La Crónica de Aragón había sido fundado en 1912 por J. García Mercadal, su director hasta mediados de noviembre de 1916, en que marchó a Madrid. Señala Carlos Forcadell que en el periodismo zaragozano de la segunda década del siglo cabe distinguir tres ideologías dominantes en pugna: el catolicismo social, representado por El Noticiero; un incipiente regionalismo político, encarnado en su vertiente conservadora por La Crónica de Aragón y en la progresista por Tierra Aragonesa y El

\footnotetext{
18 Fin de siglo. Figuras y mitos, Madrid, Taurus, 1980 (edición alemana de 1977), p. 136.

${ }^{19}$ La pluma ante el espejo (Visión autocritica del Fin de Siglo), Salamanca, Universidad, 1989, pp. 120-121. Puede verse también, en este sentido, Manuel AzNAR SOLER, «Modernismo y bohemia», en Pedro M. PiN̄ero y Rogelio ReYes, eds., Bohtemia y literatura. De Bécquer al Modernismo, Sevilla, Universidad, 1993, pp. 74-88, especialmente.
} 


\section{JOSÉ DOMINGO DUEÑAS LORENTE}

Ebro, y un republicanismo, contagiado también de regionalismo y plasmado en los semanarios La Idea o El Ideal de Aragón. ${ }^{20}$

Con ello, no deja de ser significativo que Sender empezara a publicar en un diario de inspiración regionalista, costista y regeneracionista, y de talante conservador. Su director, el todavía joven J. García Mercadal, era ya un antiguo promotor de publicaciones de índole aragonesista y cultural. En 1908 había fundado la Revista Aragonesa, en 1910 el diario La Correspondencia de Aragón, en 1912 el semanario Aragón y el diario La Crónica. ${ }^{21}$ Por otra parte, en 1910 había preparado una antología, Cuentistas aragoneses en prosa, que presentaba como el comienzo de «una campaña de propaganda en beneficio de las letras aragonesas, que en la actualidad se encuentran tan necesitadas de un renacimiento para el cual sobran elementos y falta expansión de publicidad».22

La Crónica de Aragón, en concreto, formaba también parte de esta estrategia difusora de su fundador. Era un periódico de claros «intereses culturales» que asignaba a la literatura —en opinión de Calvo Carilla- «un papel misional, en tanto en cuanto sirviera a sus proyectos de resurgimiento". ${ }^{23}$ En un principio, el diario había publicado un suplemento literario, "Los lunes de La Crónica», interrumpido en abril de 1913, y el 9 de diciembre de 1915 inició una nueva página literaria semanal titulada «Aragón literario y artístico», donde el 31 de agosto de 1916 apareció el primer cuento senderiano, «Recuerdos infantiles. Noche de ánimas», insertado entre poesías de marcada tonalidad modernista y de otros relatos impregnados de costumbrismo y casticismo.

Jesús Vived, quien ha rescatado del olvido y estudiado los primeros tanteos del autor, localizó cinco escritos senderianos en La Crónica de Aragón, aparecidos entre agosto y diciembre de $1916 .{ }^{24} \mathrm{El}$ primero presenta una sencilla estructura de cuento dentro del cuento, se localiza, en la línea de la mejor tradición romántica, en la «noche de ánimas» y ofrece ya una de las características que sería, a la postre, más definitoria de la literatura senderiana: la narración en primera persona, el sesgo autobiográfico, el

\footnotetext{
20 «La consolidación de la prensa durante la Restauración (1874-1931). Un marco general para la prensa aragonesa», en J. A. Dueñas LABARIAS y A. SERRANO DOLADER, eds., Historia del periodismo en Aragón, Zaragoza, Diputación de Zaragoza, 1990, p. 56.

21 Eloy Fernández Clemente y Carlos Forcadell Álvarez, Historia de la prensa aragonesa, Zaragoza, Guara, 1979, pp. 127-134; José Luis CALvo CARILLA, op. cit., pp. 141-144 y 183-186, especialmente.

22 Apud Juan Domínguez LASIERRA, "Notas para una historia del cuento aragonés», Cuentos, recontamientos y conceptillos aragoneses (Antología), Zaragoza, Librería General, 1981, p. 40.

23 Op. cit., p. 185.

24 «Recuerdos infantiles. Noche de ánimas», 31 de agosto de 1916, p. 4; «Domingo de pandereta», 12 de octubre de 1916, p. 3; «Lo puramente castizo», 14 de octubre de 1916, p. 1; «Del natural... no sería España», 7 de noviembre de 1916, p. 1, y «Ocurre a veces», 2 de diciembre de 1916, p. 4. Los tres primeros están recogidos en la antología de Jesús VIVED, op. cit., pp. 5-11.
} 
«yo» como inspiración, fundamento y tema literarios. Además, de acuerdo con la consabida obsesión modernista por los estados anímicos, por la indagación casi enfermiza en el propio "yo", el jovencísimo escritor intentaba dar cuenta sobre todo de cómo incide lo vivido en una conciencia, de cómo se plasma el mundo exterior en un «alma de artista»:

\footnotetext{
Mi alma de artista -concluía el relato-, embargada de una trágica emoción, sentía cosas sublimes, inexplicables, y ante mis alucinados ojos cruzaban hileras de esqueletos conduciendo en sus angulosos hombros la disforme silueta de un ataúd y un reloj de arena. 25
}

En general, los textos senderianos aparecidos en La Crónica redundan en una adjetivación cuidada que contribuye a desmenuzar la realidad, a convertirla en sutiles y matizadas interpretaciones. No obstante, dos de ellos — Lo puramente castizo» (14-10-1916) y «Del natural... no sería España» (7-11-1916)-, aun con una textura propiamente literaria, se acercan al artículo periodístico de opinión, ya que terciaban en un asunto de actualidad y pretendían sustentar y difundir una toma de postura, el rechazo de la fiesta taurina.

En cualquier caso, estos primeros escritos senderianos, no carentes de valor estético, fueron acogidos por el terreno abonado del regionalismo literario. $\mathrm{Y}$ el incipiente escritor no fue ajeno a esta atmósfera, como manifestaba sobre todo en "Lo puramente castizo», donde defendía que lo genuino y castizo aragonés era la jota y no las corridas de toros. El esteticismo casticista que apreció Calvo Carilla como predominante en el modernismo literario en Aragón ${ }^{26}$ es también el rasgo que mejor define estos tempranos textos de nuestro autor.

En los meses en que Sender colaboró en La Crónica, dos escritores firmaban ahí con especial asiduidad y los dos impresionaron particularmente a aquel joven estudiante de bachillerato, según sus posteriores testimonios. Me refiero a José García Mercadal y a Juan Moneva Puyol. La relación personal del oscense con ambos ha sido suficientemente puesta al descubierto por Jesús Vived ${ }^{27}$ y algo he apuntado yo mismo en otro lugar. ${ }^{28}$ García Mercadal cultivaba un periodismo literario y retórico, de clara raigambre decimonónica, aunque lleno de sugerencias y buen sentido. En cambio, el resorte, la referencia fundamental del periodismo de Juan Moneva, no era la literatura sino el didactismo. Moneva, catedrático de

\footnotetext{
25 «Recuerdos infantiles. Noche de ánimas», 31 de agosto de 1916, p. 4; en la antología de Jesús VIVED, op. cit., p. 7.

26 Op. cit., pp. 11-15, sobre todo.

27 «El primer Sender», introducción a Ramón J. SENDER, Primeros escritos (1916-1924), ed. cit., pp. 21-24 y nota 85 , especialmente.

28 Ramón J. Sender (1924-1939). Periodismo y compromiso, Huesca, Instituto de Estudios Altoaragoneses, 1995, en diversos momentos del capítulo «Redactor regional», pp. 59-89.
} 
Derecho Canónico de la Universidad de Zaragoza, era sobre todo un moralista, un educador, y su afán por incidir eficientemente en el lector, y en un lector de escasa preparación por lo general, le llevaba a cultivar un periodismo moderno, de estilo agilísimo. El Moneva columnista no daba un momento de tregua, conducía la atención lectora mediante una sintaxis simplicísima y saltarina, mediante una prosa resuelta en frases sentenciosas, y a ello añadía frecuentes cambios de perspectiva, un humor fino y otros recursos narrativos como la introducción de personajes, la transcripción de diálogos, etc. ${ }^{29}$

Jesús Vived ha hecho notar que Sender imitó entonces el cierre de los artículos de Moneva, que concluían con la fórmula «Ciudad» y la fecha del día. Pero parece evidente que no fue esto lo único que deslumbró a aquel quinceañero deseoso de aprender. Por entonces, publicaba Juan Moneva en La Crónica de Aragón una columna diaria titulada «Primores ciudadanos», cuya colección formaría años después un libro del mismo título que Sender pudo reseñar ya en las páginas de $E l$ Sol, en su calidad de "redactor regional» del diario madrileño, y ahí demostraba haber captado bastante de lo sustancial del buen hacer del profesor zaragozano:

El Sr. Moneva es partidario de la prosa donde se ofrece la levadura de las ideas sin fermentar. Gusta de despertar en los espíritus la actividad intelectual y de que cada cual se abra paso en la duda y la inquietud de esos fermentos, hasta hallar la luz de las ideas vírgenes. Quiere sembrar el placer de pensar por cuenta propia [...]. Sus primores son, pues, una doctrina de actividad. ${ }^{30}$

Si además atendemos a la manera periodística o a la disposición de la prosa en general del propio Sender, parece que sobran razones para considerar a Moneva como uno de los primeros maestros de nuestro autor.

\section{EN MADRID: DE LA NECESIDAD, VIRTUD}

Tras una breve y obligada estancia en Alcañiz mientras finalizaba el bachillerato, Ramón Sender se trasladó solo y con diecisiete años a Madrid. $Y$ tanto en Alcañiz como durante sus primeros momentos en la

\footnotetext{
29 Luis Horno LiRIA - En torno a D. Juan Moneva, Zaragoza, Institución Fernando el Católico, 1983, p. 17- escribió que «Los clásicos griegos y latinos, el Dante, el teatro español del XVII, Shakespeare, los grandes autores extranjeros y los novelistas españoles de su tiempo fueron por él leídos y estudiados y le crearon un estilo sentencioso, sincopado, lleno de vida, de fuerza y de jugo, que le hacen incomparable - por superior- a cualquier otro aragonés contemporáneo".

30 «Notas de la redacción. Primores ciudadanos», El Sol [Madrid], 30 de abril de 1925, p. 3. Eran notas anónimas de las que hablaremos después pero una confluencia de factores lleva a atribuirlas con toda seguridad a Sender; vid. al respecto José Domingo DuEÑAs LORENTE, Ramón J. Sender (1924-1938). Periodismo y compromiso, ed. cit., pp. 59-68.
} 
capital cultivó una poesía de marcado corte modernista, ${ }^{31}$ lo que nos confirma en que su aliento inicial no fue periodístico, a pesar de publicar frecuentemente en la prensa, sino literario. ${ }^{32}$

Diría luego el escritor que había ido a Madrid empujado por el deseo de ver las "grandes figuras, rey, jefes políticos, grandes responsables de lo bueno o lo malo». ${ }^{33}$ Pero si tenemos en cuenta su ya demostrada afición a las letras, así como la significación del Madrid del momento en el conjunto de la producción literaria española, parece probable que esa confesada curiosidad juvenil incluyera también el deseo de conocer la animada vida literaria de la capital. Manuel Aznar ha señalado, en referencia al periodo de entresiglos, un «crecimiento espectacular de jóvenes vocaciones literarias llegadas a Madrid desde los cuatro puntos cardinales de España». ${ }^{34}$ Y Alonso Zamora Vicente cree que entre nosotros la bohemia literaria como tal fue "un fenónemo exclusivamente madrileño», ya que, «[c]omo fruto del centralismo, todo confluye en Madrid, todo el mundo se lanza a la conquista de Madrid", "35 y añade que en España la llamada poetambre modernista, la bohemia "como estilo de vida y como función literaria», hay que darla por concluida «con la huelga general revolucionaria de $1917 » .36$

A los estertores de este mundo mágico llegó, pues, Sender, pero todavía con tiempo para vivir las estrecheces propias de los meritorios de la literatura, ya que pasó alguna temporada sin domicilio fijo, entre el parque del Retiro y el Ateneo y, al parecer, con los escasos recursos que le proporcionaban sus escritos, ${ }^{37}$ publicados en varios diarios de la capital, España Nueva, El País y La Tribuna. ${ }^{38}$

Es sabido que los periódicos fueron entonces el cauce más propicio y socorrido de los jóvenes pequeñoburgueses que en provincias o en Madrid pretendían hacerse un nombre en la literatura. En la capital, Sen-

31 Poemas recogidos por Jesús VIVED en Ramón J. SENDER, Primeros escritos (1916-1924), ed. cit., pp. 19-24.

32 Muchos años después (1957), en el prólogo a Los cinco libros de Ariadna, Barcelona, Destino, 1977, p. 7, escribía Sender: «Este libro de prosa está escrito, como otros míos, sub species poetica. [...] Ya pasada la juventud pero no el amor juvenil por la vida me gusta comprobar que mi acento natural era la poesía [...]».

33 Ramón J. SENDER, en respuesta a un «Cuestionario» que le propuso Francisco CARRASQuER en noviembre de 1966, Boletín Senderiano, 2, en Alazet, 3 (1991), p. 175.

34 Manuel AzNar SOLER, "Modernismo y bohemia", en Pedro M. PIÑERo y Rogelio RfYFs, eds., op. cit., p. 77.

35 «Nuevas precisiones sobre Luces de bohemia», en Pedro M. PIÑERO y Rogelio REYES, eds., op. cit., p. 11.

36 Ibid., p. 22.

37 Marcelino C. Peñuflas, Conversaciones con Ramón J. Sender, Madrid, Magisterio Español, 1969, pp. 75-77; Ramón J. SENDER, Crónica del alba III, ed. cit., pp. 57-61.

38 Jesús VIVED, «El primer Sender», introducción a Ramón J. SENDER, Primeros escritos (19161924), ed. cit., pp. XLI-LVI. 
der hizo de la necesidad virtud y se adaptó plena y velozmente a la pauta estilística e ideológica del periodismo en general y de los periódicos que eligió como cauce expresivo, en particular. De acuerdo con los rastreos de Jesús Vived, ${ }^{39}$ Sender, durante su temprana estancia madrileña, publicó en España Nueva bajo el pseudónimo de Lucas La Salle todos sus escritos periodísticos de entonces —once en total, aunque dos fueron tachados por la censura-, el primero el 25 de mayo de 1919 y el último el 10 de julio del mismo año, ${ }^{40}$ poco antes de que el joven literato fuera llevado por su padre a Huesca, donde vivía entonces el resto de la familia.

España Nueva, «Diario de la noche», había sido fundado por Rodrigo Soriano y se mostraba como defensor irreductible de un republicanismo de izquierdas, adobado con simpatías hacia el sindicalismo anarquista. Allí publicaba entonces el destacado dirigente de CNT Manuel Buenacasa o, los más asiduos, Ángel Samblancat y Gil Bel, aragoneses de tendencia libertaria, cultivadores de un periodismo moderno, ágil, de variados recursos. A diferencia de lo publicado poco antes en La Crónica, aquí Sender, bien adaptado a la línea ideológica del diario madrileño, puso en práctica un periodismo combativo, liberal, antimonárquico, defensor del movimiento sindical de Andalucía o Cataluña.

Sender irrumpió en el diario con una crónica, según la catalogación del propio autor, minuciosamente pensada para impactar, para hacer valer su texto. Así se ha de entender ya el propio título «Cuando caían las hojas. Leiba Bronstein», verdadero nombre de León Trotski. Se narraba aquí nada menos que un hipotético encuentro con el revolucionario ruso durante la reciente estancia de éste en España. La figura, las palabras, los gestos del político eran desgranados pormenorizadamente hasta apuntar incluso algunos rasgos psicológicos del personaje deducibles de su apariencia externa. Sin embargo, como ha puesto en evidencia Jesús Vived, tal encuentro no pudo ser real: cuando Trotski pasó por España entre noviembre de 1916 y enero de 1917 Sender era un adolescente de quince años que estudiaba bachillerato en Zaragoza. ${ }^{41}$

Sorprendemos, pues, al aspirante a escritor arbitrando sus propias estrategias para hacerse un hueco en el disputado mundo del periodismo.

\footnotetext{
39 Ibid., Pp. XLI-LIII.

40 “Cuando caían las hojas. Leiba Bronstein», 25 de mayo de 1919, p. 3; «Los limpiabotas», 1 de junio de 1919, p. 3; «El triunfo de Galileo», 4 de junio de 1919, p. 3; "Absurdos de la vida social I. Un soberano cacique», 11 de junio de 1919, p. 3; "Absurdos de la vida social II», 14 de junio de 1919, p. 2 (en blanco, por la censura); "Las fantasías de D. Ángel y el problema de Andalucía», 16 de junio de 1919, p. 2; "Absurdos de la vida social III. La censura", 23 de junio de 1919, p. 3; "Absurdos de la vida social IV», 26 de junio de 1919, p. 3 (censurado, en blanco); "Absurdos de la vida social V y último", 27 de junio de 1919, p. 3; “iRomanones, no!», 7 de julio de 1919, p. 3; «Una bacanal regia», 10 de julio de 1919, p. 4.

41 «Sender y Trotski», Artes y Letras, suplemento de Heraldo de Aragón [Zaragoza], 18 de abril de 1991, p. 1, y «El primer Sender», introducción a Ramón J. SENDER, Primeros escritos (19161924), ed. cit., pp. XLIV-XLV.
} 
Sender parecía ya muy consciente de que la virtualidad de un género como la crónica -o, en general, la de todo el periodismo de opinióndependía en buena medida de la propia condición del emisor, es decir, de la posición y características del «yo» opinante, y parece, en fin, que con diecisiete años entendía ya que el «yo» que hablaba en sus artículos no podía ser del todo él mismo.

$\mathrm{Si}$, como afirma - entre otros muchos- Josep Maria Casasús, la práctica periodística supone siempre un acto de persuasión, ya sea implícita en el caso de los géneros informativos- o explícita en los géneros argumentativos o interpretativos —,, 2 no es lo de menos en el logro de tal objetivo la proyección de una imagen del emisor persuasiva en sí misma. En este camino, Sender aprovechaba el sobreentendido realismo con que habitualmente se leía el género utilizado, la crónica, para reforzar su propia autoridad como emisor. ${ }^{43}$

El mismo procedimiento seguía en otro texto publicado poco después, «En casa de la marquesa de Urquijo. Una bacanal regia» (10-7-1919), o, en menor medida, en «Las fantasías de D. Ángel y el problema de Andalucía" (16 de junio de 1919). En el primero el narrador se autopresentaba como infiltrado en una fiesta aristocrática, a la que había acudido incluso el rey y de la que el periodista daba cumplida cuenta a sus lectores con bien expresa intención cáustica:

Asistí a ella como el más vulgar conde. Perdón, lector. Esta información creí que habría de justificar mi delito. ¿Que cómo entré? No te importe. Sabe que estuve toda la noche entre nuestra distinguida chusma. ${ }^{44}$

El narrador es, pues, un personaje de su propio relato, cómplice del lector, pero con la pátina de superioridad o prestigio que le otorgaba el haberse internado misteriosamente en el vedado campo del enemigo; un narrador que confesaba que, una vez en la fiesta, se había quitado el hambre atrasada sin contemplaciones o que se había limpiado con disimulo el brazo rozado por el rey al cruzarse con él. ${ }^{45}$

En el artículo dedicado días antes a condenar las iniciativas de Ángel Ossorio y Gallardo en contra del sindicalismo andaluz ( «Las fantasías de

\footnotetext{
42 Josep Maria CaSasús y Luis Núñez LADEvÉze, Estilo y géneros periodísticos, Barcelona, Ariel, 1991 , p. 97.

43 Ya en 1906, Rafael Mainar definía la crónica como «la información comentada» y «el comento c ':i, información", cit. por G. MARTín VIVALDI, Géneros periodisticos. Reportaje, crónica, articuic: Madrid, Paraninfo, 1987, $4^{\text {a }}$ ed.

44 "En casa de la marquesa de Urquijo. Una bacanal regia», España Nueva [Madrid], 10 de julio de 1919, en Jesús VIVED, ed., Ramón J. SEnder, Primeros escritos (1916-1924), ed. cit., p. 36. 45 Ibid., p. 39. Resulta paradigmático de este proceder el escrito que Valle-Inclán remitió a Alma Española en 1903, titulado "Autobiografía", en el que, como es bien sabido, confesaba, entre otras cosas, haber asesinado a sir Roberto Yones en el curso de una travesía marítima.
} 
D. Ángel y el problema de Andalucía»), 46 el "yo» figuraba como argumento de autoridad:

Yo he visto en Córdoba hace dos años, nada más que dos años, a un hombre viejo de setenta y ocho años (tuve la curiosidad de preguntarle) arrastrarse por los próximos caminos con un borriquillo recogiendo estiércol para una granja y ganando, a fuerza de sudor y de cansancio (era pleno septiembre), iiitreinta céntimos diarios!!!

El biógrafo del autor, Jesús Vived, muestra, por su parte, serias dudas acerca de la realización de tal viaje a Córdoba. ${ }^{47}$

\section{PERIODISMO, LITERATURA, PÚBLICO: INTERDEPENDENCIAS}

Con todo, cabe apreciar que tanto el periodismo inicial y de autoafirmación que Sender cultivó en su primerísima juventud como el patrón literario del modernismo, al que se acogió hasta bien entrados los años veinte, le indujeron a un tipo de escritura en que el "yo" se convertía, comúnmente, en el factor nuclear: en los textos de rango periodístico un «yo» confesional y testimonial, argumento de autoridad de lo dicho pero también instrumento de persuasión y, como tal, despegado del autor para transformarse en personaje de ficción; en los escritos de corte más literario, el «yo» aparece también como emisor, pero sobre todo como objeto de indagación y exploración de acuerdo con el extendido gusto del modernismo por la introspección y el autoanálisis (así en el citado «Recuerdos infantiles. Noche de ánimas» o en el cuento "Las brujas del Compromiso»). ${ }^{48}$

Tales pautas contribuyen, a mi entender, a explicar algo más acerca de la disposición autobiográfica de buena parte de la obra senderiana, y ello de acuerdo con la intuición que Roger Duvivier expuso hace ya bastantes años:

[...] estoy llegando a pensar que una aproximación correcta de la actitud autobiográfica de Ramón J. Sender obliga previamente a hacer un balance de las relaciones de la vida y la obra tal y como se observan en el primer periodo de actividad literaria del autor, extendido desde una edad muy temprana hasta el principio del exilio.

A lo largo de este periodo y desde sus primeros momentos, Sender como escritor es casi indisociable de individuo socialmente activo; el periodista asegura de alguna manera el acuerdo entre los dos personajes. ${ }^{49}$

\footnotetext{
46 Ibid., pp. 29-31.

47 Ibid., p. XLVI.

48 La Tribuna [Madrid], 6 de julio de 1919, pp. 6-7.

49 «Les prémisses de l'œuvre autobiographique dans la première époque de l'écrivain Ramón J. Sender», AA. VV., L'autobiographie en Espagne. Actes du II Colloque International de la
} 
Y piensa Duvivier que por este camino llegó Sender a la "fórmula» novelesca que inició con Imán (1930) y que mantendría en gran medida después, «una forma de novela que pone la historia propia al servicio de una causa", el mismo procedimiento que con "fines didácticos»-dice Duvivier - utilizaría Sender al hacer "pura y simplemente obra de periodista", como en los reportajes sobre la matanza de Casas Viejas (1933). .50

En mi opinión, Imán supuso, efectivamente, una primera culminación y confluencia de las dos modalidades de escritura que Sender venía practicando desde sus primerísimos tanteos: la manera de corte e intención periodísticos y la de pretensión y planteamiento literarios; dos procesos desarrollados de acuerdo con pautas distintas pero, claro está, con múltiples contaminaciones entre sí. ${ }^{11} \mathrm{Si}$ poco hay que decir de lo que en Imán recuerda la forma del reportaje periodístico, tal vez no esté de más insistir en lo que hay en la novela de propiamente literario e incluso de poético. Muy recientemente Jean-Pierre Ressot ha apuntado como rasgo sustancial de Imán "la poétisation du réel, qui va souvent jusqu'à la transposition fantastique», 52 y entiende la obra no tanto como un relato objetivista sino sobre todo como la historia de la destrucción de una conciencia, la de Viance. Con ello hay que pensar que Sender en 1930, a pesar de su incipiente compromiso, no se había desprendido del todo del ámbito temático más característico del modernismo, el del mundo interior, el del «yo», en el que desemboca, se plasma y se transforma la realidad exterior.

Poco después de que concluyera su aventura madrileña, Sender empezó a escribir en La Tierra de Huesca, semanario desde octubre de 1919 y diario desde la primavera de 1921, órgano de la Asociación de Labradores y Ganaderos del Alto Aragón, de la que el padre del escritor era gerente. La Asociación agrupaba a «una oligarquía rural naciente» cuyo ideario se asentaba «en los cuatro amores santos»: religión, familia, patria y propiedad, ${ }^{53}$ y cuyos intereses fueron ardientemente defendidos por el joven

Baume-les-Aix, Aix-en-Provence, Université de Provence, 1982; traducido en José-Carlos MAINER (ed.), Ramón J. Sender. In memoriam. Antología crítica, Zaragoza, Diputación General de Aragón et al., 1983, p. 137.

${ }^{50}$ Ibid., pp. 146-147.

51 Para una lectura de Imán como combinación de realismo acendrado y elementos poéticos, vid. Rafael Bosch, «La species poetica en Imán, de Sender», Hispanófila, 14 (1962), pp. 33-39. Recogido en José-Carlos MAINER, ed., Ramón J. Sender. In memoriam. Antología crítica, ed. cit., pp. 291-297.

52 "Présentation», Ramón J. SENDER, L'Aimant, presentación, traducción y notas de JeanPierre Ressot, París, Imprimerie Nationale, 1994, p. 28.

53 Roger DuvivieR, «Las mocedades de Ramón J. Sender en el periodismo altoaragonés: Índole e hitos de su actuación en La Tierra», Mary S. VÁsquez, ed., Homenaje a Ramón J. Sender, Newark, Juan de la Cuesta, 1987, pp. 27-29. 
periodista, que ejerció como director de hecho mientras la publicación fue semanal y como redactor-jefe desde que se convirtió en diario hasta principios de 1923, en que Sender marchó a Marruecos para cumplir el servicio militar. ${ }^{54}$

Del periodismo y la literatura que el escritor publicó en La Tierra - de muy difícil acceso para el investigador - ha recogido una amplia muestra Jesús Vived, en su recopilación y estudio de los Primeros escritos (19161924) del autor, ${ }^{55}$ y antes Roger Duvivier, una breve antología. ${ }^{56}$ Evidentemente, Sender debió de practicar en La Tierra un abundante y anónimo periodismo de información; en no pocas ocasiones se vería obligado a «hinchar» los escuetos telegramas ${ }^{57} \mathrm{o}$, por el contrario, a pulir, aligerar y dar forma periodística e informativa a textos ajenos o a poner por escrito lo que llegaba a la redacción por teléfono u otros cauces, según recordaba el propio Sender en el currículum que presentó a El Sol en $1924 .^{58}$

Pero al mismo tiempo frecuentó muy asiduamente un periodismo de opinión o interpretación en el que apreciamos voluntad de estilo, afán de convicción, construcción de una imagen seductora del "yo" opinante, adiestramiento y variación de la prosa de acuerdo con las intenciones comunicativas de cada caso. Sender sostuvo atrevidas polémicas que necesariamente debieron de acendrar sus recursos persuasivos y argumentativos, escribió artículos de opinión en los que, según Duvivier, osciló a menudo entre el adoctrinamiento costista y la ironía de Cavia, ${ }^{59}$ reseñó estrenos teatrales, firmó crónicas de viaje, reportajes, entrevistas, etc. Un periodismo de opinión e interpretación variado pero pasado una y otra vez por el tamiz de la literatura, según lo demuestra la cuidadísima selección léxica, la abundante adjetivación, las licencias del autor, etc. Aparte, publicó en La Tierra poemas y cuentos de marcado cariz modernista. Con todo, cabe distinguir las dos maneras que señalábamos antes

54 Ibid., pp. 25-46, y Jesús VIVED, «La vida de Ramón J. Sender al hilo de su obra», art. cit., pp. 239-241, especialmente, y «El primer Sender», introducción a Ramón J. SENDER, Primeros escritos (1916-1924), ed. cit., pp. LVII-CXII.

55 Ed. cit., pp. 49-207.

56 «Las mocedades de Ramón J. Sender en el periodismo altoaragonés: Índole e hitos de su actuación en La Tierra», en Mary S. VÁsquez (ed.), Homenaje a Ramón J. Sender, ed. cit., pp. 37-45.

57 Francisco AYALA recordaba - La retórica del periodismo y otras retóricas, Madrid, EspasaCalpe, 1985, p. 42 - que en su juventud como redactor de El Debate «me adiestré yo en aderezar - hinchar- los sucintos telegramas, y en darle vuelta -como se decía- a noticias obtenidas de segunda mano, sacadas de fuentes menos directas, para de ese modo disimular su origen".

58 ANÓNIMO, «¿Quién es? Ramón J. Sender», Arriba [Madrid], 21 de enero de 1969, p. 2.

59 Roger DuVIVIER, «Las mocedades de Ramón J. Sender en el periodismo altoaragonés: Índole e hitos de su actuación en La Tierra", Mary S. VÁsQuez (ed.), Homenaje a Ramón J. Sender, ed. cit., p. 34 . 
-la periodística y la literaria-, si bien, como ya apreció Roger Duvivier, las confusiones entre ambas son abundantes, de modo que en la mayoría de sus escritos asoma el «espíritu lúdico», el apunte subjetivo, la consideración banal, «el dilema entre la relevancia del mensaje y la voluntad de estilo». ${ }^{60}$

A pesar de tan considerable bagaje, el Sender maduro atribuía lo sustancial de su aprendizaje a su paso por El Sol, de Madrid, a cuya redacción perteneció durante seis años (1924-1930). Bien sabido es lo mucho que significó El Sol como modelo periodístico, confluencia de intelectuales y empeño reformista en la España de entonces, especialmente en los años en que estuvo presidido por Nicolás de Urgoiti y patrocinado intelectualmente por Ortega, es decir, entre 1917 y 1931.

Cuando Marcelino C. Peñuelas preguntaba a nuestro autor por su formación como escritor, respondía éste que en su caso «no hay misterio alguno. Trabajando en un periódico muy intelectual como El Sol, pues... se asimila eso de una vez para siempre». Y con respecto a las particularidades de su prosa, explicaba Sender:

¿Tú sabes lo que es estar, como te digo, seis u ocho años no sólo escribiendo cada día, sino corrigiendo materiales que te enviaban a la mesa; que tú debías limpiar de redundancias y repeticiones y dejarlos reducidos a la pura esencia informativa? Con lo cual llega un momento [en] que has asimilado por lo menos una virtud. La de discriminar y no decir sino cosas interesantes, ¿comprendes? Es decir, no ser aburrido. 61

Así pues, Sender venía a compendiar su proceso formativo como narrador en el hecho de haber aprendido a discernir lo realmente atractivo para el lector. $Y$ es que en España la amenidad fue verdadera obsesión en los novelistas que, como él, escribieron para las primeras generaciones masivamente alfabetizadas, provistas aún de muy escaso hábito lector. "[T]odo lo que es entretenido - declaraba Sender-, como dice Baroja en sus Memorias, es siempre bueno». ${ }^{62} \mathrm{La}$ misma preocupación manifestó insistentemente Josep Pla, por ejemplo, ${ }^{63}$ o el estudioso del periodismo Alfonso Ungría, quien proclamaba en 1930:

El estilo periodístico es claro, sintético, persuasivo, pedagógico [...]. Presupone en el lector escasa cultura y pocas ganas de leer. Ésta es la razón por la cual una de las más preciadas cualidades de estilo de un periodista es la amenidad. ${ }^{64}$

60 Ibid., pp. 35-36.

${ }^{61}$ Marcelino C. Peñuelas, Conversaciones con Ramón J. Sender, ed. cit., pp. 105-107.

62 Ibid., p. 107.

63 Josep Maria CaSAsús, Lliçons de periodisme en Josep Pla, Barcelona, Destino, 1986, pp. $214-215$.

${ }^{64}$ Grandeza y servidumbre de la prensa, Madrid, Editorial España, 1930, p. 60. 
Para ser leído había que adaptarse necesariamente a las condiciones de un público poco avezado, en general, y tal circunstancia parece la principal a la hora de explicar el predominio del llamado periodismo de opinión o ideológico en España cuando en otros países occidentales imperaba ya - a partir de la primera guerra mundial, aproximadamente- un periodismo informativo. ${ }^{65}$ En España, desde finales del XIX y durante todo el primer tercio del XX pugnaron ambas modalidades, la informativa y la ideológica, aunque todavía con mayor peso de esta segunda. ${ }^{66}$

En las primeras décadas de nuestro siglo, el tradicional afán educativo de la literatura española se manifestó también, y con especial intensidad, en el periodismo. Eran los momentos iniciales del sufragio universal, los años en que se configuró la llamada sociedad de masas, cuando la prensa resultó instrumento ineludible en la orientación del "nuevo soberano", las masas electoras, a las que se pretendía inducir y aconsejar lo más explícitamente posible.

A mi entender, esta coyuntura sociológica contribuye a dar cuenta - dentro de la tradición periodística española - de la abundancia de géneros híbridos, entre informativos e interpretativos, como la crónica, que, procedente de Francia, arraigó aquí con facilidad a finales del XIX. En esta misma tradición hay que insertar los más significativos reportajes senderianos: así, el publicado en El Sol en marzo de 1926 sobre el caso de "El muerto resucitado», conocido luego como «El crimen de Cuenca», o el que publicó ya en 1933 en las páginas de La Libertad sobre la matanza por parte de la Guardia de Asalto de veintiún campesinos en Casas Viejas (Cádiz), donde se había proclamado el comunismo libertario.

En el caso de «El crimen de Cuenca», Sender, «enviado especial» de $E l$ Sol, actuó no sólo como cronista de los hechos sino también como activo esclarecedor de los mismos. Antes de que se confirmaran las primeras informaciones viajó al lugar de los sucesos. Allí, en Tresjuncos y Osa de la Vega (Cuenca), paseó incluso al reaparecido José María Grimaldos, el presuntamente asesinado en agosto de 1910, con el fin de que sus convecinos aceptaran definitivamente que no se trataba de ningún fantasma -como llegaron a decir - ni de otra persona que el desaparecido años antes. Con las limitaciones que imponía la censura, Sender procuró en sus escritos -publicados en las portadas y contraportadas del diario madrileño entre el 6 y el 11 de marzo de 1926- subrayar la situación de las verdaderas víctimas del caso, los dos acusados, que por entonces habían pagado ya con más de diez años de cárcel, y para ello no dudaba en interpretar expresamente los hechos - de Grimaldos dijo en seguida que «parecía un anor-

\footnotetext{
65 Sigo la clasificación del periodismo en el mundo occidental que apunta, con otros, Ángel BENITO, Fundamentos de teoría general de la información, Madrid, Pirámide, 1982, pp. 74-75.

66 José Luis MARTínez AlBertos, Curso general de redacción periodística, Barcelona, Mitre, 1983, p. 277.
} 


\section{EL LUGAR DE SENDER}

mal, quizá un idiota»- o en servirse de recursos específicamente literarios, como el estilo indirecto libre o la recreación lírica de la realidad. ${ }^{67}$ Y, como bien se sabe, sobre la base de este reportaje escribió luego con sorprendente fidelidad una de sus mejores novelas, El lugar del hombre (1939), y su versión definitiva, El lugar de un hombre (1958).

Los sucesos de Casas Viejas de enero de 1933 conmovieron a la República. Poco después de llegar las primeras noticias a Madrid, Sender se desplazó a la población andaluza acompañado de otro periodista interesado en los hechos, Eduardo de Guzmán, redactor-jefe del diario anarquista La Tierra (Madrid). Desde el primer artículo estableció Sender un pacto narrativo con el lector: apuntaba la posibilidad de que el avión en que viajaba ganara tiempo al tiempo volando en dirección contraria al Sol algo más rápido que la Tierra en su giro sobre sí misma; de esta manera cabría "presenciar lo que ha sucedido ya» ${ }^{68}$ Finalmente, Sender contaba, en efecto, los hechos como un verdadero testigo presencial, acercaba los personajes al lector y relataba, en fin, la historia con parecidas licencias y perspectiva con que afrontaba sus novelas. Ahí radicó, a mi juicio, la diferencia más importante entre su reportaje y el de Eduardo de Guzmán, rico también en detalles e incluso en elevación lírica pero que no llegó a actualizar o a "novelar» la historia como su colega.

Y si nos atenemos a lo que dijeron los reseñistas del momento hay que convenir en que Sender acertó plenamente. Mundo Obrero calificaba el reportaje de nuestro autor como «el más veraz, el más real y emocionante de cuantos se han intentado hacer. Nada está vedado en él, todo está dicho de una manera clara, suficiente». ${ }^{69}$ Lázaro Somoza destacaba el «objetivismo» del relato, su «fuerza dramática», y anotaba que el episodio central del reportaje, el que informaba del asalto a la choza del cabecilla de la sublevación, "Seisdedos», parecía un "capítulo de novela que nos llena el alma de terror y la conciencia de gritos de protesta». ${ }^{70}$

Poco antes Sender había manifestado algo que ilustra bastante acerca de los supuestos teóricos en que fundaba tanto sus novelas como sus reportajes: «La historia contemporánea registra hechos que por sí solos poseen una categoría artística. No es necesaria la mano del poeta para dar-

\footnotetext{
67 Sobre este reportaje senderiano puede verse mi citado libro, Ramón J. Sender (1924-1939). Periodismo y compromiso, ed. cit., pp. 141-145, o también mi artículo "Ramón J. Sender en los años veinte: detalles de un aprendizaje", Alazet, 4 (1992), pp. 144-149.

68 «Tormenta en el sur. Primera jornada en el camino a Casas Viejas», La Libertad [Madrid], 19 de enero de 1933, p. 3. Sobre este reportaje vid. mi libro Ramón I. Sender (1924-1939). Periodismo y compromiso, ed. cit., pp. 270-285.

69 ANónIMO, «La horrible represión de Casas Viejas», Mundo Obrero [Madrid], 27 de enero de 1933, p. 4.

70 «Impresiones de lectura. Dos libros de Ramón J. Sender: Madrid-Moscú y Viaje a la aldea del crimen", La Libertad [Madrid], 1 de abril de 1934, pp. 7-8.
} 
les naturaleza literaria, porque ya son bastante elocuentes». ${ }^{11} \mathrm{Y}$, días antes de iniciar el reportaje sobre Casas Viejas, constataba el interés de los lectores por las «interpretaciones novelescas de lo que sucede». ${ }^{72}$ El uso de recursos considerados literarios en escritos de intención periodística se ha de explicar como una búsqueda de eficacia en el logro de los fines propuestos: captar, conmover y avivar el sentido de «protesta»—como decía Lázaro Somoza - en el lector, y en un lector no de tratados, ni siquiera de ensayos, sino de periódicos.

"Detrás de todo trabajo periodístico hay una excitación a obrar», escribía Alfonso Ungría en $1930 .{ }^{73}$ Y bien lo sabía Sender, que había publicado en $\mathrm{El}$ Sol entre enero de 1925 y mediados de 1930 alrededor de trescientos cincuenta breves editoriales - "Notas de la redacción» las denominaba el periódico-, en los que normalmente solicitaba ante las instancias administrativas competentes soluciones para los problemas que acuciaban al Aragón de aquellos años. Y para ello hilvanaba con frecuencia sus textos de acuerdo con recursos y procedimientos propios de la retórica clásica. Luego, entre septiembre de 1930 y julio de 1932, también había practicado un combativo periodismo de opinión y argumentación en las casi doscientas «Postales políticas» que envió al diario cenetista Solidaridad Obrera.

Si en los reportajes la pretensión persuasiva resultaba relegada o condicionada por las necesidades informativas, en el periodismo de opinión se convertía en explícita y prioritaria. Como textos diseñados para seducir y convencer, tales artículos primero habían de remover los esquemas y agarraderos en que el lector estaba cómodamente instalado, parecía preciso desestabilizarlo para conducirlo luego en el sentido deseado. Y aquí encaja la pertinaz tendencia senderiana a presentar la realidad de manera poco convencional. ${ }^{74}$

La literatura de nuestro autor guardó siempre bastante del afán — tan periodístico - por incitar al lector, por removerlo y transformarlo. Con ello, Sender seguía fiel a la ya aludida tradición educativa de la literatura española, especialmente acentuada cuando el aragonés nació al mundo de las letras: recuérdese el empeño quijotesco de Unamuno por remover las conciencias, el deseo de influencia de Ortega o el espectacular desarrollo del ensayismo durante el primer tercio del siglo.

Como ya dijimos, después de la guerra Sender dejó de ser periodista en sentido estricto, aunque siguió siendo un escritor que gustaba de cola-

71 «Teatro político de Piscator. El drama documental», La Libertad [Madrid], 31 de diciembre de 1930, p. 9 .

72 «Hechos y palabras. El realismo y la novela», La Libertad [Madrid], 6 de enero de 1933, p. 1.

73 Op. cit., p. 63.

${ }^{74}$ En este sentido, son interesantes las sugerencias de Rafael BosCH en «La species poetica en Imán, de Sender», art. cit., pp. 33-39, basándose en el concepto de «extrañamiento» de Shklovski. 
borar en periódicos. Charles King localizó más de ochocientos artículos suyos distribuidos por ALA - la agencia fundada y dirigida por Joaquín Maurín - desde el 3 de enero de 1953 hasta la muerte del novelista, veintinueve años después. ${ }^{75} \mathrm{Y}$ muchas de sus últimas obras presentan una peculiar mezcolanza genérica que parece deber bastante a la dedicación periodística de tantos años. Pienso en El fugitivo (1976), Ramú y los animales propicios (1980), Monte Odina (1980), Álbum de radiografías secretas (1982), etc., libros que combinan narración y comentario, que se sitúan entre la novela y el ensayo y en los que el «yo» es el principal - si no único- elemento vertebrador, como si de una larga columna periodística se tratara. Ya casi al final de su vida, en 1978, dedicó el autor un artículo al «quehacer periodístico» donde anotaba que la primera obligación del "periodista literario» —como decía él—o columnista es ayudar a los otros a ser humanos y «tratar de serlo nosotros mismos». ${ }^{76} \mathrm{Sin}$ duda, ésta fue la principal pretensión del Sender periodista.

75 "Sender's Column, "Los libros y los días", 1975-1982: An Annotated Bibiography", Mary S. VÁsquez (ed.), Homenaje a Ramón J. Sender, ed. cit., p. 201. Para conocer los entresijos y avatares de tal colaboración, vid. Francisco CAUDET, Correspondencia Ramón J. Sender - Joaquín Maurín (1952-1973), Madrid, Ediciones de la Torre, 1995.

76 Apud Charles L. KING, op. cit., p. 216. 


\title{
Ramón J. Sender, entre dos revoluciones
} (1932-1934)

\author{
Antonio Elorza \\ Universidad Complutense de Madrid
}

N'importe! Il se trouvera bien, dans l'avenir, quelques misérables pour ramasser cette ordure dans la boue et la rejeter contre moi, le jour où je serai désarmé par la défaite, la proscription —ou la mort. (Jules Vallès, L'insurgé)

En la última página de Madrid-Moscú Ramón J. Sender nos presenta la figura del viejo communard al que conoció en París, de paso para Moscú, quien asistía a todos los actos obreros para poder lanzar el grito de « Vive la Commune!». Así el viejo, comenta Sender, «vitoreaba a su propia juventud, encendida y poderosa». «Esa sinceridad —concluye— no es más que cierta lealtad biológica a sí mismo». Todos sabemos que Sender no guardó esa lealtad. El profundo anticomunismo derivado de su experiencia en la guerra se transformó en una abierta incomodidad, visible en las alteraciones introducidas en su obra capital del periodo revolucionario, Siete domingos rojos. «Una novela, como un poema, no está acabada mientras vive su autor", se justifica Sender en 1970 al presentar su mutilada segunda edición. El hecho es que desaparecen en ella tomas de posición que en el texto inicial permiten encontrar algunas claves de su paso al comunismo. En su conocida carta a Ínsula de diciembre de 1955 Sender se 
limita a reconocer la menor: «en mi juventud simpaticé con esa secta». Hoy ese trayecto del anarquismo al comunismo en Sender no supone novedad alguna. Si me atrevo a volver sobre la cuestión es por el hallazgo de un informe del delegado de la Internacional Comunista en España, Víctor Codovilla, donde se reseña puntualmente la postura, ya problemática, de Sender a su regreso de la peregrinación a la URSS. Creo que a través de ese texto se perciben mejor los elementos de continuidad en ese gran viraje y también, más allá de nuestro autor, el papel asignado a los intelectuales -y la persistente desconfianza ante los mismos- por parte del estalinismo, lo cual a su vez puede contribuir al entendimiento de la violenta confrontación posterior.

\section{EL ANARCOBOLCHEVIQUE}

En los primeros meses de 1932, la Confederación Nacional del Trabajo vive una doble crisis: la confrontación entre revolucionarios faístas y moderados o "treintistas» por el control de la organización, y el enfrentamiento con el Estado, con gran número de militantes deportados o en prisión. En enero, los sucesos del Alto Llobregat habían puesto en el orden del día la proclamación violenta del comunismo libertario. La insurrección anarcosindicalista no es ya una posibilidad sobre cuya pertinencia se discute, sino un hecho, aunque aún embrionario. Es un "ensayo», dentro de la estrategia de "gimnasia revolucionaria" que Juan Garcia Oliver, el cerebro del grupo-líder, el de Durruti y Ascaso, propugna para derribar rápidamente a la República e implantar la nueva sociedad. «No olviden los compañeros - advierte García Oliver a fines de marzo, desde la prisión celular de Barcelona, y en el semanario faísta Tierra y Libertad-que el gran problema de la reconstrucción económica y moral del mundo, sólo puede encontrar solución mediante la acción revolucionaria de las multitudes impulsadas por el afán de conquistar los medios de producción y enseñanza. Fuera de la revolución proletaria, todos los caminos están cerrados». Era una consideración apoyada en «la experiencia comunista libertaria del Alto Llobregat», tras la cual «nuestros pechos deben desbordar de entusiasmo" (Tierra y Libertad, 8 de abril de 1932).

Es el marco y la tendencia en que se inscribe el clima revolucionario descrito en Siete domingos rojos. Los dirigentes «treintistas», como Juan Peiró y Ángel Pestaña, partidarios de asentar por encima de todo el crecimiento de la CNT, sin lanzarse a insurrecciones prematuras, se encuentran atrapados por la presión faísta y por la escasa sensibilidad del Gobierno republicano-socialista respecto de las divisiones internas de la CNT. Si bien es cierto que Manuel Azaña nunca dijo lo de «tiros a la barriga» con relación a Casas Viejas, sí afirmó, con ocasión del alzamiento del Alto Llobregat, una línea de represión a ultranza, compartida por todos sus ministros, con la honrosa excepción de Fernando de los Ríos. «Mostré mi reso- 
lución de proceder con toda rapidez y con la mayor violencia a reprimir la rebelión -anota Azaña en su cuaderno sobre el Consejo de Ministros de 23 de enero de 1932 (O. C., IV, p. 311)-. Como Fernando me oyó decir que se fusilaría a quien se cogiese con las armas en la mano, quiso disentir; pero yo no le dejé, y con mucha brusquedad le repliqué que no estaba dispuesto a que se me comiesen la República». El 12 de febrero, Azaña rechaza las peticiones de Companys en favor de los deportados anarquistas del buque Buenos Aires. Las deportaciones traerán como consecuencia el terrorismo, advierte Companys. El 27 de febrero, quien le visita es el dirigente moderado Ángel Pestaña, pidiendo «clemencia» para los deportados. También sin efecto. "Casi no le he dejado hablar», consigna Azaña. En tales circunstancias, la imposición de los partidarios del anarquismo insurreccional era inevitable. Por otra parte, Sender tiene elegido su campo: el anarcosindicalismo como táctica de lucha para mejorar la condición económica de los trabajadores y, en todo caso, preparar a los sindicatos para una revolución a largo plazo no le suscita el menor entusiasmo. Su apuesta se sitúa en el campo de los revolucionarios.

Es lo que demuestran sus dos últimos artículos presentados como «Problemas interiores», publicados en Solidaridad Obrera en abril de 1932. Es el mes en que tiene lugar la conferencia regional de los sindicatos cenetistas en Sabadell, con un enfrentamiento áspero en que se imponen los faístas y los sindicatos locales se retiran de la reunión. Pero a Sender la polémica interna no le interesa. Encuentra inevitable la hegemonía de la FAI dentro de la Confederación:

\footnotetext{
Núcleos de militantes con un sentido político de organización y con el instinto de la ofensiva se creerán obligados a salir de una vez de los cauces demasiado estrechos de lo legal y a emprender la ofensiva por su cuenta. Como esa posición constituye para la C. N. del T. una necesidad biológica, es natural que la FAI u otra organización que tenga sus mismos estímulos, sea asimilada inmediatamente. («La C.N.T. y la ofensiva revolucionaria», Solidaridad Obrera, 2 de abril de 1932)
}

La posición de Sender se inserta en el vitalismo revolucionario, enfoque biologista que tenía muchos adeptos dentro de la propensión habitual en el anarquismo a justificar cada argumento desde una analogía con el campo de las ciencias naturales. El más famoso de los folletos que en 1932-1933 divulga las doctrinas del anarquismo hispano, El comunismo libertario. Sus posibilidades de realización en España, del médico Isaac Puente, se apoya también en la idea de que la llegada de la sociedad anarquista surge de una necesidad biológica, incubada en el interior del orden capitalista. Sender también coincide con Puente en la consideración de un doble sujeto de esa revolución, los sindicatos en el medio urbano y los municipios libres en el medio rural. Pero difieren claramente en el papel de la organización. Puente pone su programa al servicio de la espontaneidad. Sender juzga en cambio que la revolución sólo puede llegar como 
consecuencia de un esfuerzo de organización del que se deriven consignas muy claras que deberán asimilar los trabajadores. Es un anarcobolchevique, que no puede evitar la introducción de elementos tácticos procedentes del campo comunista en las propuestas revolucionarias dirigidas a la CNT y a la FAI. El propio empleo del término «consignas» es ilustrativo de esa captación.

La revolución es vista por Sender, no como un ensayo afortunado que arrastrará una serie de explosiones también revolucionarias por simpatía, sino como una confrontación militar entre los anarquistas revolucionarios y el Estado. El término «ofensiva» aparece en los artículos una y otra vez para aludir al comportamiento necesario de la CNT.

El principal obstáculo para esa actuación militar de la CNT-FAI surge a su juicio de la dimensión utópica que asume el anarquismo revolucionario. Las discusiones sobre el bien absoluto, la justicia, la organización de la sociedad tras la revolución, envuelven a los anarquistas y les sirven de coartada para evitar el planteamiento de los complejos problemas que entraña la adopción de una estrategia revolucionaria. La fe en el futuro libertario se traduce en 1932 en una preocupación creciente por las formas que ha de asumir ese orden social tras la revolución. Además, hay que fijar los rasgos del paraíso para competir con los comunistas, que lo tienen, y con rasgos mucho más verosímiles, merced a la imagen cada vez más consolidada de la Unión Soviética como un nuevo mundo en construcción. En CNT de Madrid, el 17 de noviembre de 1932, el anarcosindicalista gallego José Villaverde dejaba constancia de esa atención preferente que se prestaba a las cuestiones de la organización posrevolucionaria. «Hoy no hay tertulia, conversación o polémica —constata- que no tenga un rato para dedicarlo al estudio de las posibilidades de implantación del comunismo libertario». Era algo que Sender no podía soportar: «la línea de combate se puede establecer entre inteligencias firmes, no entre hombres que siempre discuten y siempre están de acuerdo". El recurso a la utopía constituye una cortina de humo que acaba actuando como obstáculo para la revolución. Genera un «sonambulismo revolucionario» en que se pierde la rebeldía difusa de los cenetistas.

A pesar de su determinación, la FAI no se libra del cerco que en torno al anarcosindicalismo trazan los dogmas estériles. Sender admite los dogmas, pero siempre que éstos enlacen con la praxis revolucionaria. De otro modo el dogma radical lo único que genera es el fanatismo y a partir de ahí se va hacia otra vía muerta en el difícil camino de la revolución. «Pero la FAI, como cualquier otro sector en su caso - advierte- tropezará con una insuficiencia orgánica de la CNT determinada por la rigidez de sus dogmas. Son indispensables éstos para aglutinar y agrupar. Pero es muy diferente el plano doctrinal en el que se han consagrado del de la acción" (Solidaridad Obrera, 2 de abril de 1932). Los dogmas han de articularse con la acción revolucionaria, pero los de la FAI quedan fijados en un orden sacralizado y desde ahí sólo pueden producir fanáticos. "Y un fanático 
-concluye- es la materia prima para un revolucionario, pero no es, ni mucho menos, un revolucionario».

La posición de Sender en 1932 puede definirse como un raciovitalismo revolucionario. Por supuesto, empleando raciovitalismo en un sentido muy diferente al de Ortega y Gasset. El núcleo es indudablemente el elemento vitalista, que se deriva de la mencionada concepción biológica del organismo social. El impulso de realización personal, estrictamente natural, constituye el agente que pone en movimiento los comportamientos de los individuos, la acción social. No existe componente religioso ni metafísico en esa acción. El amor es una cuestión de genitales derivada del sexo y Dios es una ficción a la que es preciso tomar en consideración exclusivamente por el impacto social que se deriva de la creencia. El individuo es el motor de la dinámica social, pero no se mueve en el vacío, sino dentro de una red de relaciones sociales, de modo que su acción carece de sentido si no intenta repercutir en una acción colectiva. Incluso la ficción de Dios ha de ser tenida en consideración por el hecho de que una multitud de creyentes la hacen real. Como define cuatro años más tarde en el artículo «El novelista y las masas», publicado en Leviatán en mayo de 1936:

\footnotetext{
El principio vital está en nosotros, pero sólo puede manifestarse en relación con las necesidades y las aspiraciones colectivas. Al hombre aislado no le sirve de nada. (Leviatán, mayo de 1936, p. 32)
}

Para a continuación insistir:

\footnotetext{
La naturaleza nos presenta el principio vital, no como hombres aislados, como creaciones perfectas, que tienen su fin en sí mismos, sino como cadenas de un eslabón, como elementos de la especie humana. [...] El principio vital es perfectamente social en todas sus manifestaciones. (ibid., p. 33)
}

De este modo, el fundamento anarquista se mantiene a partir del individuo o, mejor, del impulso individual, como motor de los comportamientos sociales. Pero esa centralidad del sujeto individual supone la inserción en un orden colectivo. El componente individual prevalece, pero requiere para su práctica la mediación social. No hay, pues, revolución individualista: la revolución es un proceso colectivo que arranca del individuo. La perspectiva es estrictamente materialista, lo cual explica el recurso al marxismo como instrumento de comprensión, pero dentro de una acepción biológica, casi darwiniana. La revolución surge de la necesidad de suprimir la sociedad burguesa y de sustituirla violentamente por un nuevo orden social regido por esa articulación de empuje individual y praxis colectiva. Es el «dobla» con que Sender encara la muerte de don Fidel o la visión determinista que acompaña el suicidio de la novia burguesa de Samar en Siete domingos rojos. No hay lugar para la compasión ni para el sentimiento, valores burgueses. La nueva sociedad surgirá de la violencia revolucionaria, administrada con total frialdad. $Y$ utilizando recursos racionales. De ahí la calificación de raciovitalismo o de vitalismo 
racionalista. El engarce del empuje individual con la acción colectiva no puede surgir del azar o de cualquier tipo de comportamiento. La razón entra en juego para designar los medios que deben emplearse en la actuación revolucionaria:

\footnotetext{
El mejor producto humano no es nunca un mito individualista, como es Dios, sino un hombre con su razón y sus instintos en armonía, capaz de muchas altas empresas, pero ninguna superior a la creación en común. (ibid., p. 33)
}

Es una perspectiva estrictamente anarcobolchevique. El énfasis puesto en los medios, la organización y la racionalización de la praxis, dentro de un contexto materialista, evocan el planteamiento comunista. Esta adhesión se ve reforzada por otra que pronto ha de explicitarse, la prestada al ejemplo soviético de construcción del socialismo. Pero no se consuma el paso hacia el comunismo político. Obviamente la instancia parlamentaria, pero también la forma partido, quedan fuera del enfoque revolucionario de Sender. Basta con esa vinculación entre lo individual y lo colectivo, mediante los procedimientos incorporados a partir del arsenal comunista. Por el momento, los agentes de la revolución coinciden aún con el anarcosindicalismo. Son el sindicato en la ciudad y el municipio libre en el campo. Sólo que ahormados por una concepción política de la revolución, bajo el doble signo de la organización y la disciplina de tipo militar.

Para cerrar el círculo, únicamente falta la afirmación de una homología existente entre las dos esferas de la acción. El individuo actúa de acuerdo con los resortes que se forjan en la vida social (el interés, la violencia, el amor) y por su parte la sociedad experimenta las peripecias propias de un organismo humano. Incluida la muerte. Por encima de todo la muerte. Las acciones individuales pueden ser así presentadas como otras tantas ilustraciones de los comportamientos propios de los grupos sociales y los acontecimientos asumen un valor simbólico, cuyos restos dependen del proceso social en su conjunto. El análisis del anarcobolchevique Sender rompe así necesariamente con el anarquismo de acción, con el cual comparte la centralidad de la praxis militar, pero del que le distancia su concepción materialista, contrapuesta al idealismo y a la fe en la espontaneidad revolucionaria, elevados además por los faístas como García Oliver o Durruti al rango del fanatismo. Las ideas de articulación y de impulso racionalizado son fundamentales para entender su concepción revolucionaria. Sin el resorte de la afirmación individual, orientada al cambio en la sociedad, no existe posibilidad de activar una dinámica revolucionaria. En este punto la lección anarcosindicalista es clara, por contraste con la deriva burguesa de los socialistas. Pero, una vez puesto en marcha, el impulso debe integrarse en una actuación que resulte de una práctica colectiva y el enlace entre ambas, la articulación, sólo puede venir de una concepción revolucionaria materialista. Es lo que Sender cree encontrar, con perfiles muy difusos, en el marxismo. 
La experiencia del salto adelante en la actuación de rebeldía social por parte de la CNT-FAI, con sus reiterados fracasos en los primeros meses de 1932, le parece a Sender una confirmación inequívoca de sus planteamientos. Los artículos teóricos de Solidaridad Obrera, en marzo-abril de dicho año, encontrarán un campo de aplicación a través de la ficción literaria de Siete domingos rojos, «la gran novela de la pre-revolución española», según la propaganda del momento. Es al mismo tiempo un elogio, un réquiem y un llamamiento. Un elogio de la personalidad de los anarquistas revolucionarios que no dudan en entregar la propia vida a la causa que defienden. Es la materia prima de la revolución social. Pero también se trata de un réquiem por el proyecto revolucionario anarquista basado en la instrumentalización de la CNT. Los planteamientos doctrinales, el fanatismo y la falta de organización eficaz son otros tantos factores de estrangulamiento. El faísmo es una vía muerta para la revolución. Y, en fin, es un llamamiento, a través de las elaboraciones teóricas y la ejemplaridad del protagonista Samar - trasunto del propio Sender-, para que esas energías se traduzcan en el necesario derrumbamiento del orden burgués. La combinatoria narrativa conjuga el reportaje, con la adaptación de episodios reales de la lucha social, y los movimientos biomecánicos de los personajes principales, que remiten mediante asociaciones elementales a su posición en el conflicto social. Al lado de Samar/Sender, la adolescente Star García lleva en su nombre el instrumento imprescindible de una revolución moderna, el arma de fuego, y a través de su frescura de adolescente luchadora es la encarnación del futuro revolucionario. Su complemento es la figura gris del anarcosindicalista Villacampa, del Sindicato Mercantil, que acaba convirtiéndose en el compañero de la huérfana Star y que también es portador en su nombre de los dos componentes del proceso revolucionario, el urbano y el rural. No menos cargados de simbolismo están los nombres de los tres obreros anarquistas muertos al iniciarse la narración: Progreso (la marcha de la historia), Espartaco (el nombre del grupo de Sender, la rebeldía organizada) y Germinal (el sacrificio de la lucha como anticipo del futuro). En la primera fila, el único protagonista burgués es la heroína desgraciada, Amparo, nombre que por una trágica coincidencia histórica es también el de la esposa de Sender, que en 1936 será fusilada por los franquistas. Amparo encarna en la ficción la imposibilidad radical para la burguesía de escapar a su extinción necesaria. La relación con el revolucionario Samar no puede salvarla, es más bien su sentencia de muerte. La revolución, entendida como extinción de la burguesía, es un hecho biológicamente necesario. Su ley inexorable se aplica al amor de Amparo hacia Samar y la lleva a la autodestrucción.

Pero una cosa son las peripecias individuales y otra el curso de la historia. La línea general de evolución de las sociedades puede encaminarse hacia la mutación revolucionaria, pero es preciso que los impulsos de ruptura encuentren la canalización adecuada. En este sentido, el mensaje de Siete domingos rojos no es sino el desarrollo a través de la ficción de las posi- 
ciones expresadas en la serie de artículos que bajo el denominador común de «Posiciones interiores» publica en Solidaridad Obrera, especialmente en los aparecidos el 22 y el 29 de marzo de 1932. A partir de una constatación del despilfarro de energías revolucionarias por parte de la CNT, Sender apunta al federalismo (es decir, a la ausencia de mecanismos centralizados de decisión) como causa de tales insuficiencias. «Ofrecemos nosotros frentes diversos en fuerza, con acción incongruente, consignas distintas y, naturalmente, con tal indecisión e inseguridad, que el fracaso lo prevé el militante menos experto» («El vicio federalista», Solidaridad Obrera, 29 de marzo de 1932). El federalismo puede servir como fórmula de actuación posrevolucionaria, pero «nada tiene que hacer en tiempos de lucha contra el capitalismo». Sender es partidario de la ofensiva revolucionaria, de modo que se distancia en este punto esencial de su estimado Juan Peiró, con quien comparte en cambio la perspectiva "industrialista", con el municipio rural como elemento de sustitución allí donde no hubiera sindicato de industria. Pero en la ofensiva citada para derribar el capitalismo lo esencial es lograr la articulación entre la CNT y la FAI. «Falta una "teoría de acción y de coordinación", una doctrina realista que sirva de vehículo y de lazo de unión entre la realidad material de la Confederación Nacional del Trabajo y su espíritu anarquista, que podría representar y representa, sin duda, la FAI» («Reflexiones sobre la crisis de la CNT», Solidaridad Obrera, 22 de marzo de 1932). Esa ausencia es la raíz del fracaso:

\footnotetext{
Como nos falta ese instrumento, se da constantemente el caso de que la fusión y el acoplamiento de esas dos corrientes es imposible a la hora de actuar. Y así, mientras la FAI divaga en la generosidad de lo heroico, del esfuerzo por sí mismo, de la revolución en abstracto, la CNT se adormece en la inercia de la gran masa, sin que acabe de prender en ella el impulso de una acción revolucionaria verdaderamente eficaz. Vienen como consecuencia las fluctuaciones, los contrasentidos, los levantamientos sin objeto, las revoluciones localizadas y sofocadas, un gasto, un derroche de energía que empobrece y que puede llegar a incapacitar definitivamente a la CNT como central sindical revolucionaria. (ibid.)
}

Con la exigencia consiguiente de una renovación doctrinal basada en la disciplina. Los sobresaltos insurreccionales del anarcosindicalismo son triunfos morales, pero logrados «a base de perder la sangre más viva y fecunda de la Confederación Nacional del Trabajo». Por eso, declara, «no los queremos». "Otros son los que se imponen ya - concluye- y otra la sangre que los ha de rubricar» (Solidaridad Obrera, 12 de marzo de 1932).

Siete domingos rojos arranca de un hecho emblemático: el tiroteo entre los anarquistas y la Guardia Civil tras un mitin saboteado. Quedan en tierra los cadáveres de tres obreros, Progreso, Espartaco y Germinal, otros tantos símbolos de "una realidad humana verdaderamente generosa", tal y como califica Sender en el prólogo el mundo del anarquismo revolucionario. Se convertirán en tres planetas nuevos que desde el firmamento presiden la agitación obrera y su fracaso. En un cuadro de lucha social acéfa- 
la, las intervenciones de Samar/Sender en los distintos comités apuntan siempre en la misma dirección. En la reunión de los delegados de grupos, reseñada en el capítulo XII, planea el deber para el comité revolucionario de «encauzar un movimiento hacia el triunfo y de articularlo constructivamente. "Si no queremos fracasar una vez más -explica-, hay que avanzar construyéndonos al mismo tiempo el camino", lo cual exige lanzar «las consignas netas, concretas e inmediatas para sustituir el poder burgués" (ed. de 1932, p. 216). El viejo anarquista ortodoxo se opone: hablar de sustituir un poder por otro es tanto como negar los supuestos de la acracia. Sender ridiculiza al oponente, que habla incluso de «mi ejecutoria de nobleza anarquista». Pero el hecho es que pierde la votación frente a los guardianes del comunismo libertario.

La segunda reunión reseñada, al abrirse el cuarto domingo, debe de corresponder al comité sindical, porque se menciona una comunicación del comité nacional, pero lo que cuenta es la consumación del fracaso de Samar en su intento de que la CNT adopte medidas revolucionarias, a favor de la situación de lucha. En cuanto despunta en su intervención el tema del poder, es interrumpido por otros asistentes. «Que es necesario - había dicho- comenzar a dar coherencia y cauce político a la energía revolucionaria que tan hondamente ha socavado el sistema y el poder burgués [...]». Ha de rectificar la expresión «cauce político», inaceptable para los oídos anarquistas. $Y$ tampoco admiten la perspectiva de «un poder revolucionario" que presidiera la formación de "consejos de soldados» y la abolición de todo contrato de propiedad (pp. 272-275). Lo que propone Samar es una revolución de tipo soviético, con la única cláusula de cautela de que el poder del comité revolucionario sería transitorio, hasta la celebración de un Congreso de la CNT. Un miembro anarquista del comité rechaza «la fórmula autoritaria y política en que plantea Samar el curso de la revolución». Y la propuesta negativa vence de nuevo.

Tras la derrota, "Samar movía la cabeza y volvía la mirada hacia los horizontes cada vez más claros" (p. 277), lo que supone un apartamiento definitivo de la actitud anarquista, puramente negativa, ante la revolución. Quedan como actores positivos el propio Samar, personificación de la inteligencia revolucionaria, y Star García, símbolo de una juventud sincera en su compromiso con la violencia antiburguesa. También el sindicalista Villacampa, que acaba la novela como compañero de Star y que está limpio de los resabios burgueses que en cambio afectan a los anarquistas doctrinarios: "La revolución tiene en Star y en él una dinámica fría y ascendente) (p. 281). Volvemos a la visión del proceso social como un enfrentamiento biomecánico entre el poder en declive, el de la burguesía, que, eso sí, cuenta con una organización defensiva adecuada, y el «ascendente» del proletariado, que solamente requiere una disciplina y una organización paralelas para triunfar, mediante el uso racional de la violencia.

Samar se lo explica a los destinatarios de su mensaje, Star y Villacampa, mientras los tres se dirigen en automóvil al asalto del cuartel: 


\begin{abstract}
Mi "después» no es tal que pretenda encauzar el porvenir. Se limita a enganchar los hechos y los números en racimo. A poner un poco de aire comprimido dentro de cada proyectil, un poco de veneno en las bayonetas, a atar el telémetro en el cañón de la ametralladora y a agrupar disparos y voces para que suenen y se oigan, y hieran donde queremos herir. A clavar la cuña bajo el régimen y facilitar el derrumbamiento buscando leyes físicas propicias. Eso nada más. (pp. 281-282)
\end{abstract}

La revolución necesita su ciencia, del mismo modo que ocurre con el mundo natural, que tampoco puede pensarse a sí mismo. «La física y la química son su conciencia, como Marx es la conciencia de la rebeldía", explica Samar, dejando clara una toma de posición que, como cabía esperar, el propio Sender elimina en su calidad de censor en la edición de 1970 (pp. 286-287 y 194, respectivamente). Tampoco incluye, lógicamente, los capítulos finales, donde Sender ofrece una sucesión de reflexiones, ensueños y pesadillas culminados por la noción metafísica de que la muerte es "la única libertad posible» (p. 473). En esa maraña de pensamientos, casi siempre interrumpidos antes de cerrar el relato o la argumentación, destaca la concreción del diálogo en la cárcel entre Samar y el comunista, donde este último desarrolla la idea de que España es un país que destaca por "el lujo libertario», carente de perspectivas y que será barrido por la República. «Bueno, contesta Samar. Aunque sea así, la revolución nada pierde. Las masas encontrarán su camino al fin» (p. 466).

A fines de 1932 la ruptura con el anarcosindicalismo es, pues, completa. No hace falta que llegue el alzamiento confederal de enero de 1933, el de Casas Viejas, para que Sender emita un diagnóstico en que la CNT y la FAI quedan irremisiblemente desahuciadas en cuanto sujetos revolucionarios. Está claro que no soporta la ideología anarquista que subyace a los planteamientos insurreccionales. Al comentar el libro del socialista Antonio Ramos Oliveira Nosotros los marxistas, Sender lógicamente deja fuera del combate al PSOE por «oportunista» y carente de toda técnica, pero coincide con él en diagnosticar

el espíritu anarquista de los revolucionarios españoles. De todos los campos. Yo estimo, además, que ese espíritu anarquista ha imposibilitado y dificultará mucho las soluciones revolucionarias. Pero ese temperamento anarquista - la libertad, la justicia, el bien, como sentimientos, no como conceptos-, que imposibilita la formación de un criterio revolucionario unánime (sic, subrayado A. E.) o lo suficientemente fuerte para imponerse: en la Confederación Nacional del Trabajo y en la UGT. A unos les lleva al sonambulismo y a otros al colaboracionismo sin condiciones. [...] Así no se ve muy claro el porvenir. (La Libertad, 1 de diciembre de 1932)

En este momento, la duda impera sin reservas en el pensamiento de Ramón Sender. Queda claro aquello que se rechaza, socialismo y anarquismo doctrinal, y también se confirma la preferencia por una movilización unitaria de «los revolucionarios», basada en un criterio de unanimidad. Por este lado la propensión hacia el comunismo parece evidente. Pero 
sólo hace unas semanas que se ha resuelto la crisis entre la Internacional Comunista y el grupo dirigente autóctono de Bullejos, por el momento retenido en Moscú mientras tiene lugar su expulsión. No era, pues, un panorama muy atractivo. Sender les aplica la misma valoración negativa que a otros componentes de la izquierda obrera:

\footnotetext{
Los comunistas están divididos por esa epidemia pequeñoburguesa de los personalismos y de las personalidades. No harán nada. Son en su mayor parte, los dirigentes - ¿hay dirigentes? - también anarquistas.
}

No obstante, en ese panorama de juicios negativos, había una excepción. Al disentir de la valoración de Ramos Oliveira sobre la relación entre Marx y Lenin, Sender apuntaba a un reconocimiento de la labor revolucionaria del segundo en Rusia, en unas condiciones abiertamente desfavorables por estar ausentes las precondiciones fijadas por Marx para la revolución social: industrialización, concentración del poder económico, proletarización. «Se están creando ahora - resume-, después de la revolución, bajo la política comunista del partido de Lenin».

\section{DE LA DUDA AL COMPROMISO}

Mientras Sender hace estas apreciaciones, la política de la Internacional Comunista experimenta un importante ajuste técnico. Los planteamientos generales no cambian por ello, sigue la táctica de "clase contra clase" y por consiguiente la consigna de preparar la revolución española a corto plazo, lo que por otra parte encajaba muy bien con las expectativas del novelista. El maximalismo se justificaba atendiendo a la lógica de una jugada de billar: "a través de la lucha contra la contrarrevolución republicana, aplastar la contrarrevolución monárquica» (Mundo Obrero, 25 de febrero de 1933). Las distintas fuerzas obreras, una vez destruida la influencia contrarrevolucionaria de "los jefes socialfascistas" y de «los dirigentes anarcorreformistas", confluirían en un frente único por la base, articulado mediante comités de fábrica y de taller, sucedáneos de soviets, que merced a la dirección revolucionaria del partido comunista encauzarían «las masas» hacia la revolución, siguiendo el ejemplo bolchevique de octubre de 1917.

No había, pues, variaciones sensibles con relación a cuanto se venía predicando desde abril de 1931. Es más, al consolidarse las relaciones de dependencia entre Moscú y Madrid, todo apunte de flexibilización tropezaría con la intransigencia del búlgaro Stepanov, un comunista de izquierda situado en la posición estratégica del secretario del Secretariado para los Países Latinos de la IC, desde donde podía fijar las consignas y esquemas revolucionarios, así como ejercer un control intransigente sobre su aplicación. No había muchos especialistas de la IC en el tema español. Por encima de Stepanov, Manuilski, hombre de confianza de Stalin y correa de 
transmisión del PCUS, había intervenido también decisivamente en los dos años posteriores para establecer las pautas de una estrategia revolucionaria, que a su juicio debía ser mimética de la de 1917, habida cuenta de las analogías que él creía descubrir entre la Rusia zarista y la España de la monarquía. Hasta el verano de 1932, la propensión a ejercer un control estricto sobre el PCE, por otra parte demasiado raquítico para encabezar cualquier tipo de revolución, tropezaba con una dirección autóctona encabezada por José Bullejos, tan radical como sus patrones de «la casa», pero inclinado a seguir sus propias apreciaciones y a rechazar los intentos de tutela por parte de los sucesivos delegados que le iban llegando de Moscú. En su libro La Comintern en España (México, 1972), Bullejos evoca la incompetencia de algunos delegados, que venían a España sin conocer la situación del país ni el idioma, como el alemán Stocker, que en 1931 les obliga a «discutar, discutar», incesantemente. «Hubo ocasiones -relata Bullejos- en que éstos [los desacuerdos] fueron de tal naturaleza que la ruptura entre el Bureau Político y la Comintern parecía inevitable» (op. cit., p. 159). La IC debía de temer el antecedente de otra ruptura, la efectuada con Joaquín Maurín en Cataluña, que supuso la pérdida de los pocos militantes que allí había, por lo que en agosto de 1932 envió a Madrid como delegado a un personaje que sí conocía el idioma y las maniobras políticas, el argentino Víctor Codovilla, procedente del comunismo de derecha pero dispuesto a aplicar cualquier directriz siempre que la gestión de la misma le abriera un margen de actuación. Mientras Bullejos y sus colaboradores están en Moscú, Codovilla se hace con el control definitivo del partido en Madrid y desde este momento hasta 1937 es el auténtico secretario general del PCE. El 2 de febrero de 1933, Codovilla explica a «la casa» las razones por las que ha elegido como secretario general del partido a José Díaz, «débil políticamente» pero con «calidades» que hacian augurar su futura conversión en «un verdadero secretario político del Partido» (Archivo del ex Instituto de Marxismo-leninismo, Moscú, 495-32-218). Mientras tiene lugar esa formación del príncipe, nunca completada, su tutor asumió todos los poderes. Así lo encuentra aún André Marty en los primeros meses de la guerra, hecho un "cacique" que lo decide todo e incluso redacta los editoriales de Mundo Obrero, sin dejar espacio alguno para la dirección formal, encabezada siempre por José Díaz. «El método de trabajo de Luis [Codovilla] —anota tras la caída en 1937 de Dolores Ibarruri- hacía inútiles las reuniones del Buró Político, privándolas de toda importancia» (Instituto de Marxismo-leninismo, 495-74-209). Además, desde 1933 cuenta con un enlace radiotelegráfico con Moscú, al estilo de «la orquesta roja», el cual, una vez que se alcanza un funcionamiento mínimamente correcto, incrementa aún más su poder por cuanto que esa red. de comunicación pasa indefectiblemente por él, tanto en la fase de emisión como en la de recepción.

No obstante, el poder personal de Codovilla ofrece algunas ventajas sobre la etapa Bullejos. Por lo menos, es un interlocutor autorizado, con 
todo el prestigio que en ese momento se atribuye a la URSS, y ello le permite desarrollar un haz de relaciones que en los primeros meses de 1933 tiene por resultado un discreto incremento de la fuerza del PCE, a pesar de que los planteamientos de fondo no varíen y se mantenga un discurso de guerra sin cuartel contra el Gobierno republicano-socialista. Entre otros contactos, los realizados con José Antonio Balbontín provocan la decisión del pequeño Partido Social Revolucionario de incorporarse al comunismo. Mientras este primer éxito se consolida, tiene lugar la aproximación al PCE de Ramón Sender, posiblemente convencido de que la confusión del periodo anterior, a que aún se refería en el artículo de La Libertad de 1 de diciembre, se estaba disipando y que, en consecuencia, cabía esperar un giro en el PCE congruente con lo que representaba el gran referente externo, la construcción del socialismo en la URSS.

Así, cuando Mundo Obrero elogia sus reportajes sobre Casas Viejas como obra de un escritor "anarquista", Sender se apresura a replicar con una carta, publicada el 30 de enero, donde rechaza de entrada tanto la calificación de anarquista que se le asigna como el propio encaje entre anarquismo y revolución. «He coincidido y coincido todavía hoy, con el apoliticismo de los anarquistas — añade-, sólo por entender que es muy secundaria la coyuntura de las elecciones democráticas y de los órganos de legislación burguesa, cuando es posible la lucha de masas». Sender apunta también otra idea que reitera en meses sucesivos y que enlaza con sus planteamientos revolucionarios de Solidaridad Obrera de abril de 1932: el papel que deben jugar los ayuntamientos rurales, una vez conquistados mediante las elecciones, en cuanto «órganos de gran capacidad revolucionaria». Son planteamientos heterodoxos que el periódico del PCE refuta escuetamente en días sucesivos, pero con una cordialidad que hace presagiar el acercamiento posterior.

El 7 de febrero de 1933, Mundo Obrero publica de nuevo «una carta del camarada Sender». Resulta plausible que los tratos fueran ya una realidad, porque las expresiones amistosas no eran lo habitual en el diario y menos cuando alguien se permitía algo tan insólito como mostrar desacuerdos sensibles respecto de la política de la Internacional Comunista y del PCE. Eso sí, Sender partía de una solemne declaración de proximidad a los comunistas: «si políticamente no estoy dentro de vuestros cuadros, prácticamente estoy a vuestro lado». Y doblaba el golpe con una rotunda profesión de fe marxista, acompañada por el rechazo no menos tajante de los planteamientos ideológicos del anarquismo:

Mi respeto y mi entusiasmo por la labor creadora de vuestro partido en la URSS no los he ocultado nunca. He intentado convencer siempre a los compañeros anarquistas de que la concepción marxista es la única que puede darles conciencia revolucionaria. [...] Creo que el espíritu libertario, llevado a la lucha de clases como orientador, es un veneno intelectual y sentimental burgués que embriaga a los obreros con la ilusión de lo absoluto e inaccesible para hacerles olvidar sus objetivos inmediatos de la lucha, sin los cuales será imposible seguir avanzando. (Mundo Obrero, 7 de febrero de 1933) 
Validez del marxismo como teoría revolucionaria versus negatividad radical de la aspiración anarquista a lo absoluto. Los obreros revolucionarios deben abandonar el idealismo, igual que los burgueses dejan fuera de sus consejos de administración otro idealismo, el cristiano, si aquéllos quieren alcanzar la revolución. Es de nuevo, como en Siete domingos rojos, una cuestión de vida o muerte. Sólo la dictadura del proletariado y lo que Sender considera la forma histórica del gobierno soviético, el gobierno obrero y campesino, pueden lograr la «desaparición y muerte» de la burguesía. Se trataba de encontrar un instrumento de ejecución eficaz y ése está trazado por el método de Marx y el modelo soviético.

Quedan, no obstante, las dudas. Ahora sobre cuestiones concretas, pero nada desdeñables. En primer término, está el papel, excesivo, que el PCE se autoasigna para hacer la revolución, en vez de limitarse a dirigirla. Pero sobre todo cuenta la sorprendente valoración de Rusia como «conservadora", aunque sea de la revolución propia, lo cual enlaza con la acusación inmediata de rigidez a la política aplicada a los diferentes partidos comunistas. No se explicita la dependencia, pero la vinculación entre ese supuesto conservadurismo ruso y la ausencia de matices en las políticas comunistas nacionales advierte sobre la localización del problema:

¿No hay motivos para pensar que en algún momento no se ajuste a la realidad revolucionaria española, por ejemplo, donde la posición tiene que ser activa y combatiente, ajustada a una línea capitalista y burguesa, que tiene sus entrantes y salientes propios, sus sinusoidales características?

Es un clase contra clase modulado según los rasgos y los comportamientos de las clases en conflicto. Y también por una curiosa supervivencia del comunalismo libertario, ya que si Sender acepta el antiparlamentarismo comunista piensa en cambio que el municipio ofrece una plataforma útil para la lucha de clases en el sector agrario. En lo fundamental, resume Sender, está al lado del PCE «y lucho contra el enemigo», la burguesía capitalista.

En las semanas que siguen, Mundo Obrero reproduce la serie de respuestas oficiales, muy posiblemente redactada por el propio Codovilla, donde se refutan lógicamente las objeciones de Sender, con abundante apoyo de citas sagradas. El tono sólo se eleva frente a la consideración de la URSS como conservadora, que el portavoz oficial juzga "un error completo, inadmisible» (Mundo Obrero, 23 de febrero de 1933). Lo que contaba era el valor simbólico del acercamiento de Sender, valorado como una muestra de la capacidad de atracción que ahora ejercía el partido. Dato complementario: Mundo Obrero anuncia la publicación como librito de los reportajes sobre Casas Viejas, la «Tormenta del Sur» que antes apareciera en La Libertad.

En realidad, el atractivo no lo ejercía el PCE, sino la construcción del socialismo en la URSS, que desde fines de los años 20 venía constituyendo un valor en alza para todo tipo de observadores extranjeros. Con «el socia- 
lismo en un solo país», la URSS superó la imagen inicial de amenaza para la seguridad del mundo burgués y asumió el carácter de un gigantesco experimento social, algunos de cuyos rasgos - los planes quinquenalesparecían incluso susceptibles de ser introducidos para la racionalización de un capitalismo en crisis. Fue disociándose de este modo la imagen de la URSS de las alborotadoras secciones nacionales, aunque a la larga aquélla acabase favoreciendo a las segundas. Además, la URSS aprendió el viejo ejemplo del príncipe Potemkin, para mostrar muy bien aquello que podía atraer a los extranjeros - burgueses o revolucionarios-, esconder lo que debía ser escondido y prometer correcciones en lo que no podía ocultarse. La fórmula, que se mantendrá hasta los años finales del «socialismo real», consistía en enseñar a los visitantes individuales aquello que convenía, de acuerdo con lo que el visitante representaba para la $\mathrm{IC}$, de modo que creyesen contemplar todo lo que deseaban, sin darse cuenta de lo que se hurtaba a su mirada. Fue toda una técnica de la invitación política, donde también contaba la complicidad inducida, con un trato excepcionalmente favorable que el visitante aceptaba, transfiriendo, sin pensárselo más, esas condiciones de vida positivas de que gozaba al conjunto de la población soviética. Uno de los más célebres viajeros españoles de los años 30, el socialista Julián Zugazagoitia, nos cuenta en su Rusia al día cómo el caviar no le faltó desde su paso por la embajada soviética en Berlín. Detrás del telón quedaba la hambruna del pueblo soviético, que ese año se cobraba cientos de miles de víctimas. «Éste es el único país donde los escritores no se mueren de hambre», proclamaba desde Moscú en diciembre de 1932 Rafael Alberti, en el primer paso de su larga trayectoria como viajero de la revolución (Mundo Obrero, 10 de febrero de 1933).

En el caso del viajero Sender, intentan transmitirle la impresión de que en la URSS existe una amplísimi libertad de debate. Ejemplo: ni más ni menos que las depuraciones del PCUS, presentadas como un ejercicio colectivo de autocrítica, donde no se libraría de una posible acusación ni el mismísimo Stalin. Hay también órganos encargados de limpiar el país de cualquier residuo burgués, siempre dentro de un derecho ilimitado de intervención para todo el mundo. Embelesado, Sender concluye: «Lealmente hablando, yo no puedo imaginar qué es lo que un obrero auténtico podría decir contra Stalin» (Madrid-Moscú, Madrid, 1934, p. 124). La URSS es, para Sender, un régimen de lo que después se llamará autogestión obrera. De este modo se concilian los viejos valores anarquistas con la nueva fidelidad. «Aquí el Estado es el mismo proletario», subraya (p. 129). No cuentan la administración burocrática ni el partido. Los órganos de poder son el cuartel, la fábrica y el koljós. «Obreros, soldados y campesinos están en una relación permanente». Los comunistas ganan menos que los sin partido: lo suyo es un sacrificio consciente. Es el imperio del trabajo. Por eso cree ver en la construcción del socialismo en la URSS un proceso en crecimiento constante, en la medida es que es endógeno su funcionamiento, por contraste implícito con el tipo de acción de un partido comunista 
que contempla en España, donde todo parece entregarse a la iniciativa del partido. El elogio desmesurado de Sender tiende en definitiva a bosquejar un modelo alternativo. Si los soviéticos le enseñan lo que ellos quieren, tambien él ve lo que quiere ver:

Es necesario ver personalmente todo esto para advertir hasta qué punto la construcción revolucionaria en Rusia no sólo no podrá ya nunca retroceder, sino ni siquiera estacionarse. El obrero, el soldado y el campesino tienen un instinto de creación formidable. Desde España parece que es la iniciativa del partido comunista quien lo hace todo. Aquí se ve con cierta sorpresa que el partido comunista no tiene otra misión que encarrilar la capacidad constructiva de las masas. El partido está en una posición que se podría llamar «de servidumbre». [...] No hay ya en el mundo - concluye- fuerzas capaces de oponerse a todo esto. La construcción soviética sigue adelante [...]. (p. 129)

$\mathrm{Al}$ abandonar la URSS, Sender dirige como despedida «a los camaradas de la Unión Internacional de Escritores Revolucionarios» la famosa carta de 4 de julio de 1933 que reproduce el $n^{\circ} 4-5$ de la revista Octubre:

\begin{abstract}
Ahora, después de mi estancia en la Unión Soviética, vuelvo con la mayor fe en el triunfo completo y definitivo. $Y$ no sólo definitivo, sino inquebrantable. Después de todo lo que aquí he visto, no hay razón para que un intelectual esté indeciso. En la trinchera hay un uniforme y un fusil más... Al llegar aquí era un intelectual. Hoy es un soldado del frente de lucha y de la edificación socialista el que os deja. (p. 6)
\end{abstract}

Puede añadirse que Sender llevaba en la mente la militarización de su propio pensamiento y lo que hace es encontrar el ejército que buscaba para enrolarse. Pero por debajo de la fascinación y del entusiasmo las diferencias de fondo se mantenían.

Tenemos noticia de ello por el informe sobre el viaje de Sender que el delegado-tutor Codovilla remite al Secretariado de los Países Latinos de la IC a principios de agosto de 1933 (recibido en Moscú y registrado el 22 de agosto). Al parecer, las crónicas de Sender sobre la URSS han tenido «una gran repercusión entre la masa trabajadora, y especialmente entre los obreros anarquistas» (Instituto de Marxismo-leninismo, 495-32-218). Pero le informan de que sus opiniones presentan "algo de extraño", por lo cual Codovilla llama a Vicente Uribe a fin de entrevistarse con Sender. Los resultados de la entrevista le permiten conocer las nuevas dudas o "cuestiones oscuras» que vuelven a perturbar el ánimo precomunista del escritor.

Lo peor es que Sender se ha dado perfecta cuenta de cómo funciona la Internacional Comunista y a partir de ahí formula sus críticas, no hacia el Partido Comunista de la URSS — «sobre el cual hacía nada más que alabanzas»—, pero sí hacia el PCE y la IC:

[...] No podía decir lo mismo en lo que respecta a la IC. Propiamente dicho - según él- la IC no tiene hombres capaces de dirigirla, y es un simple apéndice del Partido Ruso. Por consiguiente, la IC da órdenes — son sus 
propias palabras - inspiradas por el Partido bolchevique que piensa «en ruso" y por consiguiente no conoce la situación de los otros países, de allí, dijo, provienen los errores de táctica que cometen los partidos de los otros países.

Y por si las cosas no estaban claras, Sender pone como ejemplo el fracaso de la táctica de frente único "por querer aplicarla a la base», provocando la discordia y no la unión de los trabajadores.

Como consecuencia, los partidos nacionales, para Sender, debían gozar de autonomía. En el caso del PCE, «para que éste pudiera adaptar su táctica a la realidad nacional». España no era Rusia "y aquí la revolución podía seguir por cauces distintos a los de Rusia». El PCE, para terminar, debía ser más flexible y abandonar las acusaciones de socialfascistas a los jefes del PSOE y de traidores a los anarquistas.

Es decir, que, salvo en el elogio a la URSS, Sender discrepaba de todos y cada uno de los puntos que definían la estrategia política del PCE, y censuraba por añadidura su dependencia ciega respecto de la IC y de ésta en relación con el PCUS. Ante tal aluvión de discrepancias, Codovilla optó por repetir la táctica de febrero, refutando uno a uno «la falsedad» de los argumentos de Sender. Éste fue replegándose paso a paso. Y de ahí a las confesiones, relatando su estancia en París, con el incidente de su conversación con un ex dirigente del Komintern, alineado con la Izquierda Comunista. Es lo que describe de modo confuso en las dos últimas páginas de Madrid-Moscú. Treint le anuncia la próxima constitución de la IV Internacional y la llegada a Europa de Trotski para acelerar el proceso. «El hecho ocurrido con Sender - comenta Codovilla, futuro implicado en la preparación del asesinato de Trotski en México- demuestra cómo la canalla trotzquista está alerta y trata por todos los medios de hacer daño a la URSS y al movimiento comunista internacional». Pero sus sospechas van más lejos y piensa que tal vez el encuentro de París estaba ya preparado desde el interior de la URSS: era preciso, pues, revisar todos los contactos que Sender pudo tener en el país de la depuración autogestionada. El escritor no pudo imaginar que sus informaciones darían quizás la base para un acto de represión estaliniana.

A pesar de todo ello, Codovilla le juzga «utilizable». Puede servir ante todo, a su juicio, para formar un «movimiento puente» con los anarquistas.

\section{LA REVOLUCIÓN COMO ESQUEMA}

La ocasión no tardaría en llegar para esa utilización. En enero de 1934 comienza a publicarse en Madrid el diario La Lucha, con Sender como director (cargo que abandona el 24 de febrero, por razones desconocidas). Es un órgano de frente único, pero sobre todo es un periódico de combate que sufre constantes recogidas y procesos. En la colección incompleta que hemos manejado, de la Hemeroteca Municipal de Madrid, hay artículos 
de Sender, unos firmados y otros con el pseudónimo transparente de "Espartaco», que permiten estimar el alto grado de adecuación a las posiciones comunistas del momento. Sigue el «clase contra clase» y la fórmula del frente único por la base no ha cambiado, pero se intensifican los llamamientos a las demás fuerzas obreras. Es el aspecto en que van a insistir los artículos de Sender.

El más sugestivo es, obviamente, el menos programático. En la «Carta a los anarquistas presos», "Espartaco»/Sender hace el balance del último fracaso anarcosindicalista, el del levantamiento centrado en Aragón de diciembre de 1933. «Los anarquistas aparecéis organizados para el fracaso y sobre él», les amonesta. Lo único que consigue la CNT en su camino insurreccional bajo dirección anarquista es dar muestra de «una gran acometividad», pero ni siquiera constituyen una amenaza para la sociedad burguesa. La represión gubernamental contra los anarquistas suscitará la protesta social. Pero lo que Sender propone es la formación de un gran movimiento unitario de "todo el proletariado aliado con los campesinos". Es ese gran frente único el sujeto de la revolución y, por consiguiente, la posibilidad de que surja de la alianza entre comunistas y socialistas lo que sirve de amenaza contra la burguesía. "Saben que destruir todos los poderes es una utopía, mientras que conquistar el poder político y ejercerlo por la dictadura revolucionaria de una clase, con órganos democráticamente constituidos (sic) es una posibilidad que depende sólo de la unión de los trabajadores de todas las tendencias» (La Lucha, 30 de enero de 1934).

Los demás artículos sobre el frente único son ya carentes de originalidad. Cuentan con mejores palabras la consigna de Stepanov sobre la formación imprescindible de comités de fábrica, de taller, de cortijo, para agrupar a las masas de cara a la revolución. La confrontación entre estas fuerzas y las de la burguesía sigue siendo vista desde una perspectiva militar, como un juego de ataque y defensa. Siempre teniendo en cuenta la prioridad de la ofensiva, como en los artículos de 1932. La revolución comunalista aflora de cuando en cuando. Así, al valorar el papel de los comités locales de frente único («son los únicos capaces de transformarse en auténticos órganos de la lucha por el Poder, y finalmente, de ejercer el Poder mismo", La Lucha, 9 de febrero de 1934).

Los órganos de frente único son los auténticos sujetos revolucionarios, incluso desde una perspectiva general, según argumenta en un artículo de crítica a la concepción revolucionaria de Largo Caballero («Una revolución en voz baja y en puntillas", La Lucha, 30 de enero de 1934). La revolución no puede ser un golpe de Estado y, siempre desde la óptica militar de la confrontación de clase, serviría de pretexto para un golpe de Estado opuesto, de signo fascista. En definitiva, la revolución surge como resultado de una previa articulación de órganos de poder formados desde la sociedad. Es una revolución de tipo soviético, no de tipo bolchevique. «De ellos y únicamente de ellos - de los comités de frente único-, puede salir todavía, en periodo de lucha, el órgano de lucha capaz de sostener 
unificado y en avance constante el esfuerzo de las masas trabajadoras por su emancipación» ("Órganos del poder", La Lucha, 17 de febrero de 1934).

Del punto de partida revolucionario ligado al anarcosindicalismo sigue en pie la concepción militar de la lucha de clases, la prioridad otorgada a la ofensiva bien organizada, la preocupación por designar los órganos de poder, que obviamente ya no son ni el sindicato ni el municipio revolucionario, pero que en ningún momento, por lo menos en los artículos reseñados, es el Partido Comunista. Pervive el apoliticismo de fondo, frente a la institución republicana, al Parlamento y a la forma partido.

Como revolucionario en busca de organización, Sender había dado el paso espectacular desde la CNT en dirección al Partido Comunista, pero tampoco tiene lugar aquí un encaje satisfactorio, a pesar del deslumbramiento que le produce la Rusia soviética. El silencio cuenta a la hora de valorar las tomas de posición políticas y nada más elocuente a este respecto que el vacío que sigue a la experiencia militante de La Lucha.

\section{ANEXO DOCUMENTAL \\ INFORME DE CODOVILLA AL SECRETARIADO DEL KOMINTERN}

Sender: En estos días ha llegado Sender. Sus artículos sobre la URSS han tenido una gran repercusión entre la masa trabajadora, y especialmente entre los obreros anarquistas. Eso ha producido en torno a él una cierta aureola de popularidad. Los compañeros del Partido que se entrevistaron con él, encontraron sin embargo en sus conversaciones algo de extraño. Manifestaba una serie de reservas respecto de la línea política de nuestro Partido y de la IC. No así del Partido de la URS sobre el cual hacia nada más que alabanzas. Combiné una entrevista con él — con la presencia de Uribe - a objeto de conversar sobre sus proyectos futuros, y para atraerlo al trabajo del Partido.

Desde el comienzo de la entrevista asumió una actitud de "reserva», que luego se fue transformando en crítica a la línea del Partido español y de la IC. Planteó algunas cuestiones, que dijo ser obscuras para él, con el deseo de aclararlas. Las resumo: $1^{\circ}$ que en la URS había podido constatar el papel decisivo del Partido Bolchevique en lo que respecta a la construcción del socialismo, la capacidad de sus hombres dirigentes - que saben lo que quieren y dónde van - pero que no podía decir lo mismo en lo que respecta a la IC. Propiamente dicho - según él- la IC no tiene hombres capaces de dirigirla, y es un simple apéndice del Partido Ruso. Por consiguiente la IC da órdenes — son sus propias palabras- inspiradas por el Partido bolchevique que piensa "en ruso", y por consiguiente no conoce la situación de los otros países, de allí, dijo, provienen los errores de táctica que cometen los partidos de los otros países. La falta de flexibilidad y de iniciativas propias, de las secciones de la IC, han hecho que tácticas justas como la del frente único, por querer aplicarla a la base, hayan sido motivo de discordia y no de unión entre los trabajadores. Con eso -decía Sender-no quería afirmar que los trotzquistas tuviesen razón en sus críticas sobre la forma de aplicar el frente único en Alemania, pero que sin embargo era preciso reconocer que a causa del sectarismo de las secciones de la IC la táctica de frente único había fracasado. Segunda cuestión: que era preciso que la IC dejara más autonomía al Partido Comunista español para que éste pudiera adaptar su táctica a la realidad nacional. España -dijo Sender - no es Rusia, y aquí la revolución podría seguir por cauces distintos a los de Rusia. El Partido, para transformarse en una organización de masas, siguiendo el ejemplo de «Lenin», debía hacer concesiones a los adversarios y ser más flexibles con los principios si quería atraerse a los obreros anarquistas y socialistas. Dijo que eso de llamar a los jefes socialistas socialfascistas no era justo, menos aún lo de llamar traidores a los anarquistas. 


\section{EL LUGAR DE SENDER}

Rebatidos los argumentos y demostrada su falsedad, Sender fue abandonando poco a poco sus posiciones, y reconoció que sus acusaciones carecían de fundamento y en gran parte en contradicción con sus mismos artículos. Le demostramos que sus argumentos - posiblemente sin que él lo supiera -procedian del arsenal contrarrevolucionario del trotzquismo, y que de sostenerlos, los llevarían a una posición anticomunista. Así lo reconoció Sender y entonces nos hizo una confesión que es muy importante.

Nos dijo que llegado a París de vuelta de la URS fue a visitarlo un amigo suyo español, ex miembro del Partido Comunista Francés, un tal Latorre, el cual después de hablarle de varias cosas, lo felicitó por su viaje a la URS, diciendo que posiblemente lo que había relatado en sus artículos sobre la URS era lo que él había visto, pero que hay cosas que pasan en el Partido Comunista Ruso y en la IC, que él no había podido ver, y que era preciso que conociera para formarse un criterio más imparcial sobre la URS. Después de esa conversación le presentó un camarada francés, ex dirigente de la IC — dirigente actual de la «izquierda comunista»- que lo invitó a una reunión. (El ex «dirigente» de la IC, resultó ser Treint). En esa reunión de trotzquistas - y en una o dos más en que asistió- Sender dijo que se hicieron varios informes sobre la situación en la URS y sobre el movimiento comunista internacional. Respecto de la situación en la URS, en esa reunión se dijeron todas las canalladas y sandeces conocidas. $Y$ en lo que respecta al movimiento comunista internacional, dijo que Treint, después de haber declarado que las secciones de la IC están en plena descomposición, afirmó en tono patético que había llegado el momento de obrar, que era preciso liquidar las disidencias internas de los diversos grupos trotzquistas, para pasar a constituir "partidos comunistas leninistas» en cada país, primer paso hacia la constitución de la cuarta Internacional. La presencia de Trotzqui en Europa — según Treint- debía servir para acelerar ese proceso.

Sender dice que después de haber oído esas manifestaciones se retiró indignado de la reunión. Pero como se ve el veneno trotzquista ya había empezado a hacer mella en su mentalidad de intelectual.

El hecho ocurrido a Sender demuestra cómo la canalla trotzquista está alerta y trata por todos los medios de hacer daño a la URS y al movimiento comunista internacional. ¿Es que lo que Sender llama encuentro casual con Latorre, no será un encuentro organizado por alguien desde la URS? No estaría de más si ustedes hicieran una investigación allí para ver con qué clase de elementos ha tenido contacto Sender.

De todos modos creemos que Sender debe ser cultivado y que llegaremos a ganarlo completamente para el Partido. Después de nuestra conversación demostró haberse convencido plenamente de la justeza de la línea de nuestro partido y de la IC. Se puso a nuestra completa disposición para ser utilizado en el trabajo que se crea más necesario. Desde luego aceptó con entusiasmo la proposición de trabajar en los medios anarquistas, para crear un «movimiento puente» hacia el partido. 


\title{
El reto senderiano a los críticos literarios: consideraciones sobre el lugar de los bibliógrafos
}

\author{
Elizabeth Espadas \\ Wesley College, Dover (Delaware)
}

Un autor como Ramón J. Sender presenta un reto considerable a los críticos literarios por varios motivos, a mi modo de ver. El primero y quizá más insuperable es el tamaño de su obra: unas cincuenta y cinco novelas, nueve colecciones de cuentos, ocho obras dramáticas, trece libros de ensayo, tres tomos de poesía, cinco colecciones híbridas, además de unos dos mil artículos periodísticos. Es imposible abarcar la totalidad de una obra tan vasta en poco tiempo o adentrarse en un tema o género específico. No creo que sea aventurado afirmar que la obra de Sender no sólo merece sino que exige alguna orientación bibliográfica en la mayor parte de los casos.

¿Cuál es el lugar, pues, de los bibliógrafos en cuanto a facilitar la difusión y recepción de la obra de un autor? ¿Cuáles son los problemas metodológicos que más influyen en la presentación bibliográfica y, por tanto, en el acceso crítico? Vamos a examinar algunas de estas cuestiones mientras procuramos analizar el estado actual de esta tan extensa bibliografía.

\section{EL ORIGEN DE MIS TRABAJOS BIBLIOGRÁFICOS}

Mi interés en Sender como autor comenzó en el año 1974, cuando, al organizar un cursillo sobre la novela española para estudiantes de 
habla inglesa, descubrí que Sender, en aquel entonces, era uno de los pocos autores españoles contemporáneos traducido al inglés. Estudiamos en clase el Réquiem por un campesino español, edición bilingüe de Las Américas, y varios estudiantes eligieron otras obras suyas para su proyecto final, como El rey y la reina. Una tarde, llegaron dos estudiantes a mi despacho pidiéndome ayuda con la bibliografía, ya que desconocían las fuentes para el estudio de la literatura española. Asentí, en parte porque yo tampoco conocía mucho sobre este autor, aunque recordaba el entusiasmo por su obra que siempre había demostrado mi primer profesor de novela contemporánea, don José Ángeles, una década antes.

Entonces, por curiosidad personal, aparte de la petición, inicié la búsqueda de datos (en esa época, claro, sin la ayuda de ordenadores). Me encontré con una situación rarísima: en los manuales típicos de la profesión apenas existía el nombre de Ramón José Sender y en otros, sólo la información más mínima. Pero, gracias a los primeros esfuerzos bibliográficos de Julián Amo y Charmion Shelby (1950), de Dena Domenicali (1950) y de Charles L. King (1967, 1970), empecé a localizar información y crítica. Segura de que había mucho más, dada la extensión de su obra, me puse a «vaciar» las revistas especializadas y a hurgar en los diccionarios de literatura universal y en las notas y citas de todos los artículos encontrados. Pues bien, al final del semestre, no sólo había reunido más que suficiente para ayudar a mis estudiantes sino que ya había llenado la primera caja de fichas.

En uno de los artículos que descubrí, el prólogo de Rafael Conte a la antología Narraciones de la España desterrada (1970), leí algo sobre las reediciones de las obras senderianas en España, que habían comenzado con El bandido adolescente en 1965 (una obra inofensiva desde el punto de vista político) y que habían llegado a veinticinco entre 1965 y 1970. Entusiasmada por el «principio del final» de la censura franquista contra los exiliados, recuerdo que pensé: « $Y$ ahora que los españoles pueden conocer la obra de Sender, ¿no sería estupendo también dejarles saber algo de su recepción crítica, tanto en los Estados Unidos como en otras partes del mundo?». Y desde ese momento, en la primavera de 1974, decidí intentar cumplir ese propósito.

Revisé todas las revistas españolas que se recibían entonces en busca del vehículo adecuado y encontré que una de ellas, Papeles de Son Armadans, había publicado bibliografías anteriormente y también un artículo de crítica literaria sobre nuestro autor, el de nuestro compañero José-Carlos Mainer, «La culpa y su expiación: dos imágenes en las novelas de Ramón J. Sender» (1969). Así que decidí reunir y organizar todas las fichas en una bibliografía clasificada y anotada, con el objetivo principal de destacar el papel de Sender en la narrativa española del exilio y de animar a los investigadores a conocer más a fondo la extensa obra senderiana. 
Entre las personas que se pusieron en contacto conmigo después de la publicación estaba el profesor Francisco Carrasquer, de la Universidad de Leiden. En el momento de su jubilación, unos años después, y de la preparación de un tomo de ensayos sobre Sender, La verdad de Sender, me pidió una versión más actualizada de la bibliografía, a la que pude agregar varios centenares más de fichas. Se preparó la tercera versión para el volumen que publicó nuestra colega, Mary S. Vásquez, Homenaje a Ramón J. Sender, en 1987, ya con unas mil fichas. Recientemente, he terminado un «Suplemento 1985-1995, con Addendum», con unas seiscientas fichas más, que, sin repetir las anteriores, actualiza las bibliografías ya publicadas; éste será editado pronto en Huesca por el Instituto de Estudios Altoaragoneses.

No puedo dejar de mencionar aquí la labor de otro bibliógrafo senderiano, el profesor ya emérito Charles L. King, cuya Annotated Bibliography of Ramón J. Sender, 1928-1974, coincidió casi exactamente con mis primeros trabajos en Papeles de Son Armadans, pues se publicó en Estados Unidos en 1976. A pesar del tema común, hay varias diferencias notables en nuestro acercamiento. Primero, el profesor King siempre se ha interesado más por la relación de Sender con el mundo anglohablante, mientras que mi enfoque ha sido hacia España. Segundo, la obra de King se orienta fuertemente hacia su obra creativa y periodística (la mitad del libro), mientras que yo he trabajado hasta ahora primordialmente con la crítica sobre su obra. Finalmente, King se ha limitado en este estudio a la bibliografía en inglés y en español, mientras que yo siempre he procurado incluir todas las fichas de cualquier lengua, por mi interés en la recepción crítica (aunque no siempre he tenido mucho acceso a buenas fuentes bibliográficas para otras lenguas, especialmente en el caso de las no europeas).

En resumen, mi proyecto personal respecto a la obra de Sender ha sido crear una base de datos que facilite la investigación sin fronteras y ponerla en forma asequible para todos los investigadores.

OTROS TIPOS DE TRABAJOS BIBLIOGRÁFICOS: VENTAJAS Y DESVENTAJAS

Ya he explicado la larga evolución que ha llevado al tipo de bibliografía que decidí crear desde mis primeras incursiones bibliográficas. Pero claramente existen otras posibilidades que podrían considerarse para el futuro.

Siempre me ha parecido la menos útil una bibliografía organizada simplemente en orden alfabético por autor. Aunque sea muy completa ( $y$ a veces aún más por eso), es casi imposible encontrar materiales sobre un tema específico (o género u obra) sin dedicarle mucho tiempo al asunto. Muchas veces es difícil determinar el contenido de un estudio por el título solo. Por eso, personalmente descarto por completo este tipo desde el principio. 
Otro tipo sería una bibliografía ordenada por fecha de publicación. El orden cronológico puede ser, en efecto, un modo fructífero de estudiar la producción literaria o crítica, sobre todo si los intereses del investigador se orientan hacia la periodización, las generaciones literarias, problemas de cronología o de movimientos literarios. Por ejemplo, creo que sería muy útil para trazar la reintegración literaria de Sender a la literatura en España en la década 1965-1975.

Asimismo, se podría considerar una bibliografía dedicada a un solo género literario: la novela, el teatro, la poesía, el ensayo, el periodismo, etc. Para un escritor polifacético como Sender, podría tener gran utilidad para enjuiciar su exploración de los límites genéricos a través de su carrera. He incorporado algo de este enfoque en mi propio trabajo, en la parte dedicada a los estudios críticos sobre obras específicas, donde lo organizo primero según el género literario y luego por título de la obra, en orden cronológico. Este tipo de organización podría favorecer al investigador interesado en un solo género o en comparar distintos géneros.

A veces he pensado en otros tipos de presentación. Por ejemplo, podría resultar útil el separar la obra «americana» (que se podría definir en cuanto al lugar de publicación o a la temática de la obra) o las obras de tipo histórico o periodísticas en contraste con las de pura creación literaria. Está claro que estas bibliografías especializadas serían prácticas para ciertos tipos de investigación. Pero, por otra parte, se corre el riesgo de perder la visión del conjunto o de dejar de ver las relaciones entre una parte y otra de su obra.

En todo caso, siempre hay decisiones difíciles de tomar. Una de ellas es si la bibliografía debe pretender ser «completa» o «selecta», recordando, naturalmente, las palabras de Charles King de que toda bibliografía es por naturaleza incompleta e imperfecta (An Annotated Bibliography, XI). La extensión puede ser mejor, en el sentido de que le ofrece al lector/crítico más información, más posibilidades, pero también puede ser más difícil de manejar o aun imposible de publicar, por los gastos en que se incurre (por ser por naturaleza más costosa de preparar que los ensayos). Hoy, los gastos de publicación son un factor cada vez más decisivo. Y, como mencioné arriba, una lista sin anotaciones o algún tipo de clasificación es de poca utilidad, por lo tanto de poco valor en relación con esos gastos.

Se ha hablado mucho recientemente del impacto de los medios electrónicos, como el ordenador o el CD-ROM, pero no veo en este momento un impulso grande para este tipo de proyecto relativamente limitado. Para organizaciones con muchos recursos -como la Modern Language Association, con sus miles de socios y su bibliografía anual de miles de páginas- puede ser de gran eficacia en la relación extensión/precio, pero para lo que podría ser un suplemento, digamos anual, de menos de cincuenta páginas, no lo veo igualmente práctico. Pero sí se podría pensar en una "pizarra electrónica" en Internet y en la creación de una red de senderianos para intercambiar información sobre problemas de la investigación, 
las publicaciones, los congresos, etc. Y quizá para la bibliografía "completa" que espero reunir con motivo del centenario del nacimiento de nuestro escritor, allá por el año 2000, quizá algún medio electrónico sea el modo ideal para entonces.

\section{FUERZAS MOTRICES EN LA RECEPCIÓN CRÍTICA}

Antes de adentrarme en el análisis de la bibliografía misma, creo que es necesario abordar algunos de los factores decisivos en la crítica sobre nuestro autor, para poner en perspectiva ese repaso.

El primero de ellos es la experiencia periodística de Sender, que data de su adolescencia aquí en Huesca y que continúa en los años veinte en Madrid. Sus años periodísticos fueron decisivos en varios aspectos, a mi parecer: no sólo por el contacto con las preocupaciones y hechos históricos candentes de su día, que luego se fueron incorporando a la temática de su obra, sino también en la creación de un clima receptivo entre sus colegas en el periodismo hacia sus primeras obras (El problema religioso en Méjico, de 1928, y su novela Imán, de 1930). El servicio militar en el Rif, que le permitió formar sus propias ideas sobre el conflicto, le llevó a una postura antibélica y antimilitarista que le caracterizaría toda la vida esto en una época de gran expansión militar en España-. Otro factor, ligado con el anterior, es su preferencia por el arte comprometido, que iba en contra de la corriente del arte deshumanizado de la década. Como luego diría Laurent Boetsch, Sender llegó a ser el epítome de la «otra generación de 1927».

El éxito de sus primeras obras fue seguido por varias otras igualmente comprometidas, como O. P. (1931), El verbo se hizo sexo. Teresa de Jesús (1931), Siete domingos rojos (1932), Viaje a la aldea del crimen (1934) y La noche de las cien cabezas (1934), que a veces fueron desdeñadas por el llamado "público culto», precisamente por ese compromiso, a la vez que aceptadas fervorosamente por el público mayoritario. El Premio Nacional de Literatura en 1936 por su novela Mister Witt en el Cantón (del año anterior) consagró su carrera como escritor, aunque en realidad el principio de la guerra limitó tanto su momento de gloria como la reacción crítica a la obra. Durante la guerra publicó tres obras, Contraataque (1938), El lugar del hombre (1939) y Proverbio de la muerte (1939), las dos últimas ya en el extranjero.

Para mí, los asuntos de mayor importancia de este periodo (aparte del periodismo) que impactan en la recepción crítica son: $1^{\circ}$ ) la oposición senderiana al desarrollo del fascismo y del ejército, reflejada en Imán y en obras posteriores; $2^{\circ}$ ) su propia actividad política, su viaje a la Unión Soviética en 1933 y su acercamiento al Partido Comunista; $3^{\circ}$ ) su desilusión con los comunistas y $4^{\circ}$ ) su papel activo en la Asociación de Escritores Antifascistas y su labor humanitaria, como en las protestas contra 


\section{EL LUGAR DE SENDER}

el encarcelamiento de Miguel Hernández y de Leopoldo Alas (hijo), entre otros. Claro está que estos cuatro asuntos se relacionan, a veces entran en conflicto y todos pueden garantizarle amigos y enemigos. Así, podemos ver, por ejemplo, la controversia sobre la batalla de Seseña que ha estudiado nuestra compañera Donatella Pini Moro como producto de estas enemistades, rivalidades internas y diferencias ideológicas o personales en el lado republicano. Esta controversia, parece, se fraguó para destruir su imagen pública como persona, como escritor y como republicano. $Y$, en realidad, consiguieron en parte su propósito, creando una imagen desfavorable entre algunos grupos de exiliados e intelectuales, además de influir en la visión que luego tendría de él su hijo, Ramón Sender Barayón.

Tras la guerra civil, bajo la censura franquista, se prohibieron las obras senderianas hasta la primera "apertura» de mediados de la década de los sesenta. Durante ese periodo, el público general y hasta muchos de los especialistas en la materia desconocían las obras de diversos géneros que se irían publicando en el extranjero, con unas pocas excepciones. Entre los que se atrevieron a incluirle en los manuales de literatura contemporánea, deberíamos citar a Pérez-Minik en 1957, mucho antes de la gran obra de José Ramón Marra-López, publicada en España aunque producida en el extranjero, Narrativa española fuera de España (1963), que llegaría a ser una especie de «biblia» para los estudiosos del tema. Sólo puedo especular que este último libro tuviera alguna influencia en que se produjeran dos tesis doctorales en España sobre Sender en 1964: la de Rosario Losada Jávega, Algunos aspectos de la novela española en la emigración: Ramón J. Sender, leída en la Universidad de Barcelona, y la de Josefa Rivas, La senda de Sender, leída en la Universidad de Valencia y publicada más tarde en México bajo el título El escritor y su senda.

La autorización de El bandido adolescente en agosto de 1965 señala el principio de la reintegración literaria senderiana, de la misma manera que la obra de Marra-López señala el despertar crítico. Como podemos apreciar en mi reciente bibliografía de ediciones y traducciones, en el momento de la muerte de Franco quedaban ya muy pocas obras sin reeditarse en España. La primera visita de Sender en 1974 estaba supeditada precisamente a la reedición de varias obras importantes.

Si volvemos un momento a la situación de Sender como autor exiliado todavía fuera de España, encontramos también algunos factores importantes relacionados con la recepción literaria. Como señaló Rafael Conte en 1969, su producción literaria —extensa e irregular- era más conocida entre críticos extranjeros (ingleses, franceses y estadounidenses, en particular) que entre los españoles (La novela española del exilio, 31-32). En mi opinión, esto se debe a algo más que sólo a la mystique de ser un escritor español exiliado. Creo que su matrimonio con Florence Hall fue de singular importancia en establecer y consolidar su fama literaria. Sus contribuciones como traductora y editora todavía no se han 
reconocido lo suficiente, ni mucho menos analizado y enjuiciado, pero está claro que el acceso logrado a un público anglohablante no sólo fue beneficioso sino también distinto de los casos de otros muchos novelistas exiliados, como Francisco Ayala o Max Aub, hasta incluso Arturo Barea.

Una vez establecido como profesor de literatura española en la Universidad de Nuevo México, podemos ver que varias experiencias formativas influyeron en su carrera como escritor y en la recepción crítica de su obra. Su larga residencia en Albuquerque (creo que más extensa que ninguna otra en toda su vida), el contacto con estudiantes y colegas, su participación en varios proyectos de investigación (como el de los topónimos españoles en Nuevo México) le permitieron conocer a personas y lugares que luego se integrarían en su obra creativa. A su vez, estos nuevos materiales y actitudes iban a cambiar su obra en el léxico, la temática, los personajes, las costumbres, hasta en la aparición de elementos de la naturaleza. Ya no era el mismo escritor que el que había dejado España, como señala Glafyra Ennis («Silent Force...», 75 y 81).

Los años setenta en España - años de tantos cambios- estaban marcados por el deseo intenso de recuperar la cultura perdida y de reparar la escisión que había dividido a los españoles. Esta sed de reintegrar a la España peregrina, junto con las reediciones ya mencionadas y una ola constante de nuevas obras, hicieron de Sender uno de los autores más leídos y vendidos de la década, como documenta María Dolores de Asís en su Última hora de la novela en España $\left(1992,2^{a}\right.$ ed.). Sospecho, sin tener todos los datos necesarios para afirmarlo, que estas ventas y lecturas no fueron siempre las más provechosas por la calidad típica de las obras nuevas que salían entonces y la falta de orientación crítica adecuada.

El interés por la obra senderiana en su región natal aragonesa fue fomentado en parte por la prensa local, por amistades de la infancia y por la euforia democrática propia del tiempo. El primer viaje de Sender en 1974, tan anticipado, fue corto pero lleno de malentendidos y desilusiones, por ambas partes, aparentemente. Esta frustración fue captada magníficamente por Pozuelo en la revista Triunfo:

Superviviente de sí mismo. Es terrible haber cuajado la vida en torno a un momento, a unos años, y vivir después sobre esa involución. Es terrible el exilio larguísimo, injusto, y volver de él. Pero ¿se vuelve alguna vez del exilio? Vienen como Orfeo volvió de los infiernos: se les dice, se dicen así [sic] mismos, que es necesario no volver la vista atrás. La vuelven, y se desvanece para siempre la sombra querida de lo que amaron, de lo que vivieron. La sombra de ellos mismos. El exilio no es una condición exterior: termina calando los huesos, formando parte de su propia víctima. Forma una segunda naturaleza. Una manera de ser. Una manera de no ser. La patria no es solamente un espacio: es un tiempo. Lo peor que se ha hecho con los cientos de miles de españoles del exilio no ha sido sacarles de su espacio, negarles su espacio: ha sido negarles su tiempo, dejarles sin él. Suspendidos en una especie de vacío. (11) 
El balance bastante negativo de esta vuelta ha estado compensado en gran parte por otra manera de reintegrar la obra de Sender a la cultura española: a través del cine y la televisión. En este momento, Sender está en camino de ser uno de los autores españoles más filmados (después de Pérez Galdós) y algunas de sus obras más famosas han llegado a sectores sociales y políticos muy diversos, aunque Sender mismo no llegara a ver realizada ninguna de las películas comerciales.

\section{ESTADO ACTUAL DE LA BIBLIOGRAFÍA SENDERIANA}

La primera reacción que tuve al acercarme a este tema fue una pregunta: ¿Cómo podemos enjuiciar el estado actual de la bibliografía cuando no tenemos todavía una bibliografía completa con que trabajar? A pesar de los grandes pasos hacia ese fin que hemos conseguido en años recientes, con las contribuciones de King, del «Proyecto Sender» aquí en Huesca y de otros, me doy cuenta de que la extensión, tanto de la obra literaria senderiana como de los críticos de la misma, hace sumamente difícil esta tarea hasta que se logre una colaboración mucho más intensa de la que hemos conseguido hasta la fecha.

Primero, faltan fuentes sistematizadas para comunicar datos bibliográficos en el ámbito universal. Este verano, al preparar la bibliografía de ediciones y traducciones, me di cuenta más que nunca de lo difícil que es recoger datos de otras partes del mundo. Por ejemplo, al intentar localizar la traducción al chino de Imán mencionada por Charles L. King, aun con la ayuda de cuatro bibliotecarios especializados en esta región en las estupendas bibliotecas de la University of Pennsylvania y la University of California, Los Ángeles, no logré encontrar ni rastro de esta traducción. El magnífico Index Translationem de la UNESCO sale con ocho años de retraso. Otro día, cuando me puse a aprender el alfabeto cirílico para poder manejar los manuales rusos, pensé: « ¿Cuántas fichas se me estarán extraviando por no saber la lengua?», aunque di con más de una docena de traducciones, reseñas y artículos que antes no conocía. Estas lagunas no tienen fácil remedio, salvo el reconocer la urgencia de colaborar mucho más de lo que hemos hecho antes y aprovechar como nunca los nuevos medios comunicativos, como Internet.

En este breve repaso del estado actual de la bibliografía senderiana, propongo como esquema las siguientes grandes categorías: vida, periodismo, obra literaria creativa, obra literaria crítica, cine y arte pictórico.

Vida (biografía, personalia, entrevistas)

Lo primero que resalta es que todavía nos hace falta una biografía completa que procure resolver enigmas y dudas sobre hechos básicos (fecha de nacimiento, muerte de su esposa, otros matrimonios, hijos, evolución política, carrera periodística y educativa, etc.). Ya tenemos varios 
estudios importantes sobre diversos aspectos de su vida personal y profesional, notablemente los de Charles L. King, Marcelino C. Peñuelas, Luz Campana de Watts, Jesús Vived Mairal y Francisco Carrasquer. Este último ha publicado recientemente dos de los trabajos más sugerentes, para mí: «Sender por sí mismo», en el que traza la relación entre las ideas, experiencias y vida del escritor, y "Sintónico Sender", en el que analiza la actitud senderiana hacia el medio ambiente en el que se encontraba. Hay numerosas entrevistas (como las de Gutiérrez Gómez, Mainer, O'Brien, Peñuelas, Leiva, y de las revistas Blanco y Negro y Triunfo) que merecen coleccionarse y analizarse, especialmente las de tema filosófico o literario. Gran número de las fichas de esta categoría son simples notas bio-bibliográficas o necrologías. En la década de los ochenta, se observa que el caso de Sender, como el de otros muchos republicanos distinguidos, se ha vuelto a examinar y se ha hecho conocer de nuevo su actuación a favor de la causa republicana y las consecuencias de la pérdida de la guerra (véanse los estudios de Manuel Aznar Soler y Luis Mario Schneider, José Antonio Biescas, Burnett Bolloten, Antón Castro, Jean-Marie Ginesta y José-Carlos Mainer).

Lo más urgente, a mi parecer, es traer a un foro de debate las dudas, enigmas y acusaciones (como las de Enrique Líster, Juan Marsé, Normante y otros) y aclarar los datos controversiales de forma ecuánime, como está haciendo Donatella Pini Moro. Entonces se podrá escribir esa gran biografía de una vida compleja y llena de zozobra, como era la suya, para concederle plenamente su lugar en la historia.

\section{Periodismo}

Se divide esta categoría en dos partes: la producción periodística senderiana y la crítica sobre ella. Le agradecemos al profesor King la primera bibliografía ordenada de esa producción, el capítulo IV de su Annotated Bibliography, que recoge en total 1.135 fichas de narrativa, drama y poesía publicados en periódicos o revistas; artículos en La Libertad; artículos periodísticos dispersos y los de Los libros y los días. Esta bibliografía, que cuenta con la colaboración de Rafael Pérez Sandoval, incluye fichas hasta diciembre de 1974. Un suplemento posterior - Hispania, 66 (1983), 208216- cubre los años 1975-1982 pero no incluye publicaciones periodísticas salvo las recogidas en forma de libro. Vuelve al tema en Homenaje a Ramón J. Sender, editado por Mary S. Vásquez, en el trabajo «Sender's Column: Los libros y los días, 1975-1982», con 140 fichas anotadas adicionales. Por lo tanto, quizá valga la pena investigar estos últimos años en cuanto a su labor periodística. Ignoro hasta qué punto colaboró Sender con otras revistas o periódicos en esta última fase, aparte de Blanco y Negro.

El tema periodístico ha despertado el interés de varios investigadores recientes: primero Roger Duvivier y luego Jesús Vived, en Primeros escritos, 1916-1924, han trabajado sobre los años mozos en La Tierra; José Domingo Dueñas Lorente, sobre la obra periodística de juventud y pri- 
mera madurez, que llevó a su interesantísimo libro Literatura y periodismo en los años 20; Ricardo Crespo, sobre los artículos en El telegrama del Rif; Marcelo González Rodríguez, sobre su trabajo en La Libertad de 1931 a 1936; Rafael Osuna, sobre las revistas españolas entre dos dictaduras (1931-1939); Jesús Ruiz Gallego-Largo, sobre un artículo de Solidaridad Obrera, y Alicia Alted Vigil, sobre su colaboración en Ibérica en Nueva York. Castillo-Puche dedica varios capítulos al periodismo y a la relación vida/periodismo/literatura en Ramón J. Sender: El distanciamiento del exilio. Los esfuerzos de estos y otros investigadores no sólo han iniciado un nuevo análisis de este tema sino que también han ayudado a rescatar los textos mismos, muchos de ellos prácticamente inasequibles salvo en unas cuantas bibliotecas en microfilm. Esto debe llevar también a más exploración de conceptos fundamentales. Por ejemplo, que yo sepa, no se ha intentado trazar el impacto del periodismo en la totalidad de su producción literaria o comparar las fases española y estadounidense en el periodismo.

\section{Obra literaria creativa}

Primero, mirando su producción literaria creativa, es evidente que varias personas han contribuido a nuestras fuentes de información sobre la obra de Sender, con diferentes enfoques y limitaciones. Antes de la guerra civil, he encontrado muy pocos trabajos de tipo bibliográfico, aunque sí muestras de interés en la publicación de nuevas obras y en su recepción crítica nacional y en el extranjero. En la postguerra, en España prácticamente desaparece su nombre de las fuentes bibliográficas. Rafael Conte, por eso mismo, publica una lista de obras hasta Tánit en sus Narraciones de la España desterrada, que ayuda a divulgar estos datos. Pero aun con el silenciamiento y la censura, continúa su presencia a través de ciertos manuales, como el Manual del librero hispanoamericano (1948) de Palau y Dulcet, obra clásica en su género. José Manuel López de Abiada examina el tema de la inclusión/exclusión en «De escritores silenciados y manuales de literatura".

En el Nuevo Mundo también aparece Sender, en La obra impresa de los intelectuales españoles en América, 1936-1945 (1950), de Julián Amo y Charmion Shelby, y tanto Dena Domenicali (1950) como Charles L. King (1970) publican las primeras bibliografías sobre su obra (y crítica) en inglés. La principal fuente hasta ahora ha sido la primera parte de la Annotated Bibliography de King, en la que detalla los datos de publicación de las obras senderianas por género en orden cronológico, hasta 1974, que luego actualiza en el suplemento hasta 1982.

Se han mirado varios temas bibliográficos con respecto a la obra senderiana. Señalemos en particular los trabajos de María José Montes y de Maryse Bertrand de Muñoz sobre la guerra civil; de María Francisca Vilches de Frutos sobre el «primer Sender»; de Pablo Jauralde Pou, sobre las obras publicadas por la Editorial Guara; Iván E. Calimano, en su índice 
de cuentos en lengua española recogidos en antologías (1994), que incluye «La terraza», y Marshall J. Schneider, que varias veces nos ha llamado la atención sobre textos prácticamente perdidos, logrando su rescate permanente del olvido. Los estudios de Manuel Béjar, «Unidad y variedad en la narrativa de Sender», y de Jean-Pierre Ressot, "Les démons de Ramón J. Sender", nos han ayudado a ver el conjunto de su obra en cuanto a los temas u obsesiones más característicos. Quizá la contribución más original que he encontrado es el informe de Javier Goñi, en el que nos describe la presencia de obras senderianas en la colección de a bordo de la aerolínea Iberia, que se hizo en 1987 con motivo de sus sesenta años de servicio.

Mi reciente trabajo sobre las ediciones y traducciones es un intento de actualizar el trabajo de King y de incluir información sobre las traducciones a lenguas extranjeras, cosa que hasta ahora no se había recogido en forma ordenada, excepto para las traducciones al inglés. Las fichas de esta bibliografía suman aproximadamente 212 ediciones y 121 traducciones. Espero que se sigan examinando estos temas, especialmente las traducciones a lenguas eslavas y al japonés, y, consecuentemente, cuestiones de la recepción crítica en aquellos países, que merecen un estudio exhaustivo con respecto a todas las fases de su obra.

La crítica sobre la creación literaria senderiana es extensísima. Baso mi discusión aquí en las 2.600 fichas que tengo anotadas, entre la bibliografía de 1987 y el suplemento 1985-1995. Éstas incluyen libros, artículos y tesis sobre temas generales o sobre Sender mismo, a la vez que ensayos, prólogos, ponencias y reseñas sobre sus obras.

Lo primero que llama la atención es la gran desigualdad en el reparto de la crítica, como que un $85 \%$ esté dedicada a su novelística. José-Carlos Mainer, con sus excelentes consejos en «A los doctorandos del futuro», nos ha señalado este desequilibrio y la urgencia de atender a los otros géneros, como la poesía, el teatro y obras híbridas. Muchas de estas obras no han visto ni un solo artículo, simplemente reseñas cuando se publicaron. Concuerdo completamente con el análisis de Mainer y me alegro de ver precisamente la atención a las obras menos estudiadas entre las ponencias y comunicaciones de este Congreso.

El segundo rasgo observado es, en mi opinión, la falta de una visión contextual, es decir, de una visión de Sender como escritor español, europeo y también del Nuevo Mundo - a veces simultáneamente-. Para mí, el ensayo "Sender en la literatura española» de Leonardo Romero Tobar abrió nuevas vistas al señalar la importancia de la literatura medieval y áurea y nos ha animado a estudiar estas relaciones más profundamente. Laurent Boetsch ha acertado en relacionar a Sender con la «otra generación del 27», pero no se han agotado todas las posibilidades de identificar afinidades, buscar las influencias y contactos e indagar las relaciones generacionales en el panorama español. Y todavía no he visto un artículo que trate a Sender como escritor modernista (en el sentido europeo más que 
hispano) ni que nos dé una visión de las relaciones, influencias, amistades, afinidades $\mathrm{u}$ oposiciones con los escritores europeos de su tiempo. Claro que hay alusiones en muchos artículos, pero me refiero a un estudio a fondo de la cuestión. Parte de esta falta se podría remediar con un trabajo enfocado en los artículos periodísticos en los que se reflejan las lecturas de Sender a través de los años, para determinar sus preferencias y predilecciones, las fuentes de algunas de sus propias obras, afinidades filosóficas y literarias.

Hay otros aspectos que también merecen estudiarse de nuevo o por primera vez. Se podría intentar un análisis comprehensivo estilístico; estudiar el uso de la alegoría y el mito; el humor, en todas sus formas (ironía, parodia, lo grotesco, humor negro, lo ridículo, lo chistoso, etc.). Se podría atender a los personajes femeninos, actualizando la tesis de Elsa Delia Álvarez y fortaleciéndola con los más recientes conceptos teóricos, o aplicar otras de las últimas teorías críticas o intentar un análisis completo de la recepción crítica española e internacional.

Varios individuos han abarcado la crítica senderiana, en diversos contextos, y han llegado a una valoración de la misma: José-Carlos Mainer, "Resituación de Ramón J. Sender» (1983); L. Teresa Valdivieso, "La crítica suscitada en los Estados Unidos por la obra senderiana» (1987); Charles L. King, «Recent Research on Ramón Sender» (1988); Samuel Amell, «La crítica y el público frente a Ramón J. Sender» (1989), y Francisco Carrasquer, en «Sender para estudiantes» (1991). Mainer enfoca especialmente la dificultad de resituar a Sender bajo las circunstancias de un exilio tan prolongado, el desequilibrio en la proporción de críticos extranjeros frente a los españoles, la calidad desigual de la crítica y los altibajos de estima al reintroducirse en España. Valdivieso pasa revista a la crítica estadounidense (definida por el lugar de publicación, no por la nacionalidad de su autor), diferenciando la crítica lineal, que recoge y sistematiza, de la crítica creativa, que descubre. También resalta la tendencia de los críticos norteamericanos a examinar periodos específicos más que el conjunto.

Charles L. King aborda los trabajos publicados a partir de la muerte de Sender hasta 1987, que incluyen los dos homenajes (Mainer y Vásquez), el libro de Castillo-Puche, las tesis doctorales de Collard y de Samaniego y artículos en revistas de Duvivier, Vilches, Vásquez, Mainer, Iglesias Ovejero y Havard, además de un número de fnsula (1982). Desde su perspectiva, ha habido menos publicaciones en este periodo, pero de mayor calidad, lo cual le parece esperanzador en cuanto a la creación de una base sólida para el futuro.

Samuel Amell, un año después, toma una posición contraria y con un tono mucho más polémico. Para él, las publicaciones recientes demuestran una falta de interés por parte de la crítica española y además critica el carácter de homenaje que demuestran. Esto, junto con la disminución de tesis doctorales y la pérdida de interés del mercado español, le indican que 
el interés se va extinguiendo. Lamenta la serie de circunstancias que «haya tenido por resultado negar un reconocimiento de crítica y público en el grado que merece quien ha sido el autor de algunas de las mejores novelas escritas en castellano en el siglo veinte» (25).

Tales afirmaciones categóricas provocaron una reacción indignada por parte de Francisco Carrasquer, que, con un conocimiento mucho más profundo del estado de la crítica senderiana, protesta de los juicios hechos sin considerar todos los datos. Carrasquer, además, examina detalladamente toda la "carrera de obstáculos de la crítica senderiana", afirmando la necesidad de demostrar el arte completo de Sender, de insistir en que los estudiantes conozcan primero lo mejor y luego a continuación la diversidad ("Sender para estudiantes", 116 y 121).

Para mí, lo esencial es olvidarnos de una vez de las etiquetas, tanto en el caso del autor (que es español, europeo, norteamericano e internacional) como de los críticos, que como hispanistas dejan atrás su clasificación de nacionalidad. En otras palabras, los críticos somos tan heterogéneos como la obra misma de Sender y debemos aprovecharnos de esa cualidad. Ha habido buenos críticos y excelentes aportaciones en muchos países, pero ya es hora de que hagamos una investigación sin fronteras. Tenemos aquí una oportunidad de crear una red de investigadores de todos los países, de todas las edades y con diversos enfoques e intereses. Y Sender puede ser uno de los pocos escritores españoles que forme parte de la literatura universal.

\section{Obra literaria crítica}

Hay poco más que añadir a lo dicho arriba en cuanto al estado actual de su obra literaria. Contamos con fuentes básicas que explican las ediciones originales (y las más recientes, si las hay). No hay traducciones de ninguno de sus estudios críticos. Está claro que se ha trabajado muy poco el tema de Sender como crítico literario, aparte de las reseñas con motivo de la publicación de obras de crítica. Podemos señalar como excepciones los trabajos de Óscar A. Fasel sobre su ensayo «Unamuno, sombra fingida» y de Germán Gullón en El exilio español. Christopher Cobb dedica varias páginas en su importante libro La cultura y el pueblo (1980) a las ideas de Sender sobre el escritor y el pueblo desarrolladas en «El novelista y las masas», «La cultura española en la ilegalidad» $\mathrm{y}$ «Teatro de masas», entre otros temas. El estudio más profundo, aunque limitado al periodo 19291936, es el de María Francisca Vilches, «Ramón J. Sender, como crítico literario (1929-1936)». Más recientemente, Patrick Collard ha estudiado el realismo dialéctico senderiano a través de su crítica teatral y producción dramática en El teatro en España: entre la tradición y la vanguardia (19181939).

Está claro que hasta ahora no se ha visto un examen exhaustivo del crítico literario Sender, pero es un tema atrayente para cuya consideración ya contamos con algunos estudios parciales de calidad. 


\section{Cine}

Recientemente, robando un poco de tiempo a mis otras obligaciones, tuve la ocasión de investigar la relación de Sender con el cine en las filmotecas de Madrid, de la Generalitat de Catalunya y de Delmiro de Caralt en Barcelona. Así, pude reunir materiales para un primer intento de abordar el impacto de Sender en el cine con la primera base de datos sobre las películas relacionadas con su obra, tanto las que son recreaciones de cuentos o novelas como las que se inspiran en su obra literaria más indirectamente, como es el caso de El Dorado. Esta bibliografía, «De la literatura a la pantalla: Ramón J. Sender y el cine», acaba de aparecer en el número monográfico de Letras Peninsulares dedicado a la relación entre la literatura, el cine y las otras artes. Entre sus 350 fichas se incluyen reseñas, artículos, programas, libros, entrevistas, etc., además de la información básica sobre la película. Aunque no esté completa, espero que dé un impulso fuerte a la exploración de temas cinematográficos o comparativos relacionados con Sender y es mi deseo ampliarla con las futuras contribuciones de muchos de ustedes.

Al repasar la bibliografía existente, se perciben varias tendencias: primero, que predominan las reseñas y comentarios breves sobre pequeños incidentes o aspectos comerciales; segundo, que a partir del éxito de Valentina y de 1919. Crónica del alba hemos visto un incremento de atención crítica más detenida en estas películas, no sólo en España sino también en el extranjero, $y$, finalmente, una orientación interdisciplinaria en el análisis de los cambios efectuados al llevar las obras literarias a la pantalla.

Entre los estudios más importantes, se pueden nombrar los de Luis Quesada, La novela española y el cine; José María Caparrós Lera, El cine español de la democracia: De la muerte de Franco al 'cambio' socialista, 1975-1989; John Hopewell, El cine español después de Franco, 1973-1988; Frances R. Dorward, «Réquiem por un campesino español: Reflections after the Film»; JoséCarlos Mainer, «Réquiem por un campesino español: del filme y de la novela", en Andalán; Juan de Mata Moncho Aguirre, Cine y literatura: La adaptación literaria en el cine español; Marvin D'Lugo, The Films of Carlos Saura: The Practice of Seeing; Javier Hernández Ruiz y Pablo Pérez Rubio, Cineastas aragoneses; Agustín Sánchez Vidal, El cine de Carlos Saura y su reciente «Un Saura inédito», y Thomas G. Deveny, Cain on Screen: Contemporary Spanish Cinema. De particular interés para los estudiosos de la relación literatura/cine son los trabajos de Antonio Román Román, "Adaptación al cine de Crónica del alba» y «Un homenaje de Sender a Cervantes: Las gallinas de Cervantes".

Como se puede apreciar, queda mucho por explorar sobre este tema. Apenas se ha comenzado a analizar la relación obra literaria/película, ni mucho menos los valores artísticos y la riqueza simbólica y temática. 
Arte pictórico

En esta categoría se puede hablar de tres aspectos: la producción artística de Sender, la crítica sobre su producción artística y sus propias ideas sobre el arte pictórico (suyo y en general). Siendo un aspecto relativamente nuevo en el conjunto de su vida y obra, hay mucho menos que en las otras categorías ya discutidas.

Sobre su producción artística, lo principal que tenemos para orientarnos es el catálogo preparado por la Galería Multitud para la exposición de 1975 en Madrid. Con un total de 56 páginas, incluye el programa, un prólogo, comentarios sobre el novelista como pintor, su propia explicación de su pintura, una carta dirigida a la Galería Multitud y reproducciones de los cuadros y autorretratos, junto con fragmentos de sus obras literarias. La otra fuente que ahora tenemos son los artículos de Ángel Azpeitia Burgos y Juan Carlos Ara Torralba en el «Boletín senderiano» $n^{\circ} 5$.

Hasta la fecha, he localizado muy poca crítica sobre su obra artística. Francisco Prados de la Plaza hizo una reseña para la revista Bellas Artes, en la que alaba la riqueza simbólica y ambiental pero critica lo poco que dice técnicamente. Se reproducen tres cuadros, con una foto del interior de la galería. Lois R. Fishman, en "Recuerdos agridulces», habla de una exposición de arte de varios géneros sobre el exilio español que se hizo en México en 1984 y menciona a Sender como uno de los republicanos más célebres, pero no está claro si la exposición incluía alguna de sus obras.

Sender mismo describe la exposición en la Galería Multitud en un extracto de «Explicación de mi pintura» titulado «Ramón J. Sender, pintor de amuletos» y publicado en la revista Batik (1976). Pero también trató Sender el tema artístico otras muchas veces — quizá sorprenda cuántasen algunos de los ensayos de Los libros y los dias: «Más libros sobre Pablo Picasso» (1955), «La Dama de Elche, abuela de España» (1955), «Sobre el maestro Domenico» (1955), "Viladrich y las doncellas cimbreantes» (1956), «Un "Guernica" rapsódico» (1962), «El Greco y el "desnacer"» (1962), «Un sabio en las artes visuales» (1962), «Una mixtificación inspirada» (1962), "La vida fabulosa de Diego Rivera» (1963), "Cosas de Picasso" (1973), «Los Renoir y las artes visuales» (1975), «Tres siglos de desnudo» (1975), «Picasso y el dandysmo» (1977) y «Otra vez Picasso» (1980). Su libro Ver o no ver: Reflexiones sobre la pintura española (1980) vuelve sobre muchos de los mismos temas. Los nueve ensayos tratan principalmente sobre obras de Velázquez, El Greco, Goya y Picasso, este último no sólo el artista que más admira sino también amigo personal.

\section{EL «PROYECTO SENDER» Y LA BIBLIOGRAFIAA}

El inicio del «Proyecto Sender» hace pocos años y el establecimiento de los archivos sobre la vida y obra de Ramón J. Sender son de singular 
importancia en la bibliografía senderiana. Por fin tenemos un centro en el que podemos consultar materiales especializados, a veces raros o únicos, otras veces en vías de desaparecer; un lugar en que podemos conocernos; un lugar donde podemos investigar sin complicaciones o pérdidas de tiempo. Con la colaboración de todos a través de la donación de materiales, puede llegar a ser un depósito importantísimo sobre Sender y su época. Este Congreso demuestra que el interés crítico internacional por la obra de Sender sigue vivo y que este interés común por su obra puede ser motivo de grandes adelantos en el hispanismo.

\section{OBRAS CRÍTICAS CITADAS}

ALTED VIGIL, Alicia, «La cultura política del republicanismo español en el exilio. Un ensayo de caracterización a través de la revista Ibérica (1953-1974)", Journal of Interdisciplinary Literary Studies / Cuadernos Interdisciplinarios de Estudios Literarios, 1 (1988), pp. 237-264.

Álvarez, Elsa Delia, La obra de Ramón I. Sender: Un estudio de sus personajes femeninos, Tesis doctoral inédita, Michigan State University, 1970-1971 (directora: Julia Uceda).

AMELL, Samuel, “La crítica y el público frente a Ramón J. Sender», Cuadernos de ALDEEU, 5/2 (noviembre de 1989), pp. 199-205.

AMO, Julián, y Charmion SHELBY, La obra impresa de los intelectuales españoles en América, 19361945, Stanford, California, Stanford University Press, 1950, pp. 114-115.

ARA TORRALBA, Juan Carlos, "La galería personal de Ramón J. Sender», "Boletín senderiano", 5, en Alazet, 7 (1995), pp. 157-167.

Asis, María Dolores de, última hora de la novela en España, Madrid, Eudema, 1992 (2ª ed.).

AZNAR SOLER, Manuel, I Congreso Internacional de escritores para la defensa de la Cultura (París, 1935): 50 años después, I, Valencia, Generalitat Valenciana, 1987.

- y Luis Mario SCHNEIDER, eds., II Congreso Internacional de Escritores para la defensa de la Cultura (1937): Actas, ponencias, documentos y testimonios: 50 años después, Valencia, Generalitat Valenciana, 1987, $2^{\text {a }}$ ed., pp. 297-298.

AzPeITTA BuRGos, Ángel, «El escritor y la pintura. En torno a Ramón J. Sender», «Boletín senderiano", 5, en Alazet, 7 (1995), pp. 169-180.

BÉJAR HURTADO, Manuel, «Unidad y variedad en la narrativa de Sender», Revista de Occidente (mayo de 1982), pp. 117-123.

BertRAND DE MUNoz, Maryse, La Guerra Civil Española en la novela. Bibliografía comentada, Madrid, Ediciones José Porrúa Turanzas, 1982.

-_. «Bibliografía de la creación literaria sobre la guerra civil española», Anales de Literatura Española Contemporánea, 11/3 (1986), pp. 357-411; 12/3 (1987), pp. 369-417.

—- «Teoría y método narratológicos para el estudio de la novela política de la Guerra Civil Española», Hispania, 77/4 (diciembre de 1994), pp. 719-730.

BIESCAS, José Antonio, «El coste económico del exilio», en Destierros aragoneses, II: El exilio del siglo XIX y la guerra civil, Zaragoza, Institución Fernando el Católico, 1988, pp. 171-178.

BoEtsch, Laurent, José Díaz Fernández y la otra generación del 27, Madrid, Pliegos, 1987, pp. 144-150.

BOLLOTIEN, Burnett, La guerra civil española: Revolución y contrarrevolución, trad. de Belén URrutia, Madrid, Alianza Editorial, 1989.

Calimano, Iván E., Index to Spanish Language Short Stories in Anthologies, Albuquerque, SALALM Secretariat / General Library, University of New Mexico, 1994, p. 173.

Caparrós Lera, José María, El cine español de la democracia: De la muerte de Franco al 'cambio' socialista (1975-1989), Barcelona, Anthropos, 1992.

CARRAsquer, Francisco, «Sintónico Sender», Letras Peninsulares, 3/3 (otoño-invierno de 1990), pp. 417-422.

—, «Sender para estudiantes», Alazet, 3 (1991), pp. 115-123.

—, «Sender por sí mismo», Alazet, 4 (1992), pp. 69-122. 
CASTlLLO-PuCHE, José Luis, Ramón J. Sender, el distanciamiento del exilio, Barcelona, Destino, 1985.

CASTRO, Antón, "La patria interrumpida de Ramón J. Sender", en Aragoneses ilustres, ilustrados e iluminados, Zaragoza, Diputación General de Aragón, 1993, pp. 218-223.

Совв, Christopher, La cultura y el pueblo. España, 1930-1939, Barcelona, Laia, 1980.

Collard, Patrick, Ramón J. Sender en los años 1930-1936. Sus ideas sobre la relación entre literatura y sociedad, Gante, Universidad, 1980.

- "La crítica teatral de Ramón J. Sender en los años treinta», en Dru DougherTy y María Francisca VILCHEs, eds., El teatro en España: Entre la tradición y la vanguardia, 1918-1939. Madrid, CSIC / Fundación García Lorca / Tabacalera, S. A., 1992, pp. 189-192.

CONTE, Rafael, La novela española del exilio (Información librera), Barcelona, Javier Romaní Sopena, 1969.

—, «La novela española del exilio», Cuadernos para el Diálogo, 14 (extraordinario, mayo de 1969), pp. 27-38.

- Narraciones de la España desterrada, Barcelona, EDHASA, 1970.

CRESPO, Ricardo, «Sender en El Telegrama del Rif», Alazet, 1 (1989), pp. 7-28.

Deveny, Thomas G., Cain on Screen: Contemporary Spanish Cinema, Metuchen, N. J., y Londres, Scarecrow Press, 1993.

D'Lugo, Marvin, The Films of Carlos Saura: The Practice of Seeing, Princeton, Princeton University Press, 1991.

DOMENICALI, Dena, "A Bibliography of Works by and about Ramón J. Sender in the English Language", Bulletin of Bibliography, 20/3 (septiembre-diciembre de 1950), pp. 60-63; 20/4 (enero-abril de 1951), p. 93.

DORWARD, Frances R., «Réquiem por un campesino español: Reflections after the Film», en Jennifer Lowe y Philip Swanson, eds., Essays on Hispanic Themes in Honour of Edward C. Riley, Edinburgo, Departamento de Estudios Hispánicos de la Universidad de Edinburgo, 1989 , pp. 268-288.

DuEÑAS LORENTE, José Domingo, «Obra periodística de Ramón J. Sender», Alazet, 0 (1988), pp. 285-338.

-., «Periodismo y primera madurez», Rayuela. Suplemento de Cultura y Libros de «El Periódico de Aragón", 46 (5 de marzo de 1992), p. 5.

—, "Ramón J. Sender en los años veinte: Detalles de un aprendizaje», Alazet, 4 (1992), pp. $133-150$.

- Ramón J. Sender: Literatura y periodismo en los años 20. Antologia, Zaragoza, Edizions de l'Astral, 1992.

Duvivier, Roger, "Les prémisses de l'œuvre autobiographique dans la première époque de l'écrivain Ramón J. Sender", en L'Autobiographie en Espagne: Actes du Ile Colloque International de la Baume-les Aix, Aix-en-Provence, Université de Provence, 1982.

—, «Las mocedades de Ramón J. Sender en el periodismo altoaragonés: Índole e hitos de su actuación en La Tierra", en Mary S. VÁsQuEz, ed., Homenaje a Ramón J. Sender, Newark, Delaware, Juan de la Cuesta, 1987, pp. 25-46.

ENNIS, Glafyra, "Silent Force: Breadth of View of Sender Wrought by his Host Countries», Mid-Hudson Language Studies, 9 (1986), pp. 75-84.

ESPADAS, Elizabeth, «Ensayo de una bibliografía sobre la obra de Ramón J. Sender», Papeles de Son Armadans, en tres partes: I. Estudios sobre su obra en general, 220 (1974), pp. 91-104; II. Estudios sobre obras individuales, 221-222 (1974), pp. 233-262; III. Addendum, 233234 (1975), pp. 247-259.

- "Hacia una bibliografía sobre la obra de Ramón J. Sender», en Francisco Carrasquer, La verdad de Sender, Leiden, Cinca, 1982, pp. 125-177.

- "La visión crítica de la obra de Ramón J. Sender: Ensayo bibliográfico», en Mary S. VÁsquez, ed., Homenaje a Ramón J. Sender, Newark, Delaware, Juan de la Cuesta, 1987, pp. 227-287.

- «De la literatura a la pantalla: Ramón J. Sender y el cine (Bibliografía)», Letras Peninsulares, $7 / 1$ (primavera de 1994), pp. 221-238.

—, «Ramón J. Sender. Bibliografía de ediciones y traducciones», «Boletín senderiano», 5, en Alazet, 7 (1995), pp. 181-205. 


\section{EL LUGAR DE SENDER}

EsPADAS, Elizabeth, «La visión crítica de la obra de Ramón J. Sender: Ensayo bibliográfico. Suplemento (1985-1995) y Addendum» (en prensa).

FASEL, Óscar A., "Reminiscence and Interpretation: An Evaluation of Ramón J. Sender's Essay: "Unamuno, Sombra fingida"», Hispania, 42 (1959), pp. 161-169.

FiSHMAN, Lois R., "Recuerdos agridulces», Américas, 36/6 (noviembre-diciembre de 1984), pp. 30-35.

GINESTA, Jean-Marie, «La place des intellectuels espagnols dans la presse française pendant la guerre civile: tendances et limites», Imprévue, 2 (1986), pp. 47-56.

GoÑI, Javier, "Crónica literaria», en Letras españolas 1987, Madrid, Castalia / Ministerio de Cultura, 1988, p. 225.

GonZÁlez RodrígueZ, Marcelo, «Ramón J. Sender en La Libertad: 1931-1936», Cuadernos de Historia Moderna y Contemporánea, 6 (1985), pp. 313-322.

Gullón, Germán, «El ensayo y la crítica», en El exilio español, tomo IV, Madrid, Taurus, 1977, p. 272.

HAVARD, Robert G., "The Romance in Sender's Réquiem por un campesino español», Modern Language Review, 79/1 (enero de 1984), pp. 88-96.

GutiérRez GOMEZ, Juan de la Cruz, «Entrevista», Ya, 27 de junio de 1976.

Hernández RuIZ, Javier, y Pablo PÉREz Rubio, "Carlos Saura: El empeño de un cine de autor», en Cineastas aragoneses, Zaragoza, Ayuntamiento, 1992, pp. 129-151.

HOPEWELl, John, Out of the Past: Spanish Cinema after Franco, Londres, British Film Institute, 1986.

- El cine español después de Franco, 1973-1988, trad. de Carlos LaGuna, Madrid, Ediciones El Arquero, 1989.

IGLESIAS OVEJERO, Ángel, "Estructuras mítico-narrativas de Réquiem por un campesino español», Anales de Literatura Española Contemporánea, $7 / 2$ (1982), pp. 215-236.

Insula, 424 (marzo de 1982).

JAURALDE POU, Pablo, "La crítica literaria», en Letras españolas, 1976-1986, Madrid, Castalia / Ministerio de Cultura, 1987, p. 175.

KING, Charles L., «Una bibliografía senderiana española (1928-1967)», Hispania, 50 (1967), pp. 630-645.

- "A Senderian Bibliography in English, 1950-1968, with an Addendum", American Book Collector, 20 (1970), pp. 23-29.

- An Annotated Bibliography of Ramón J. Sender, 1928-1974, Serie bibliográfica, II, Metuchen, Nueva York, Scarecrow Press, 1976.

—, "A Partial Addendum (1975-1982) to Ramón J. Sender: An Annotated Bibliography (19281974)", Hispania, 66/2 (mayo de 1983), pp. 209-216.

_- "Sender's Column: Los libros y los días, 1975-1982», en Mary S. VÁsQuEZ, ed., Homenaje a Ramón J. Sender, Newark, Delaware, Juan de la Cuesta, 1987, pp. 201-225.

—, "Recent Research on Ramón Sender», España Contemporánea, 1/1 (1988), pp. 157-164.

Leiva, Ángel, "Ramón J. Sender: "Creo que hay un solo poema universal": "Yo no pertenezco a ninguna generación"» [Entrevista con Ramón J. Sender], Informaciones de las Artes y las Letras, suplemento 570 (28 de junio de 1979), pp. 1-2.

LISTER, Enrique, Nuestra guerra: Aportaciones para una historia de la Guerra Nacional Revolucionaria del Pueblo Español, París, Éditions de la Librairie du Globe, 1966.

LOPEZ DE ABIADA, José Manuel, «De escritores silenciados y manuales de literatura: En torno a los novelistas marginados de la generación del 27», en J. M. LÓPEZ DE ABIADA y Augusta LÓPEZ BERNASOCCHI, eds., De los romances-villancicos a la poesía de Claudio Rodríguez: 22 ensayos sobre las literaturas española e hispanoamericana en homenaje a Gustav Siebenmann, Madrid, José Esteban, 1984, pp. 213-251.

LOSADA JÁVEGA, Rosario, Algunos aspectos de la novela española en la emigración: Ramón J. Sender, Tesis doctoral inédita, Universidad de Barcelona, junio de 1964 (director: José M. Blecua).

MAINER, José-Carlos, «La culpa y la expiación: dos imágenes en las novelas de Ramón Sender», Papeles de Son Armadans, 161 (1969), pp. 117-132.

—, "Visita al Sender que nos visita», Camp de l'Arpa, 12 (1974), pp. 27-30.

- -, «El otro Sender», Andalán, 43 (15 de junio de 1974), pp. 8-9. 


\section{ELIZABETH ESPADAS}

MAINER, José-Carlos, «Resituación de Ramón J. Sender», en José-Carlos MAINER, ed., Ramón J. Sender. In memoriam. Antología crítica, Zaragoza, Diputación General de Aragón, Ayuntamiento de Zaragoza, Institución Fernando el Católico y Caja de Ahorros de Zaragoza, Aragón y Rioja, 1983.

- «Réquiem por un campesino español: del filme y de la novela. Sobre la insuficiencia de las buenas intenciones", Andalán, 435 (septiembre de 1986), pp. 24-26.

-, "A los doctorandos del futuro», Rayuela. Suplemento de Cultura y Libros de "El Periódico de Aragón", 46 (5 de marzo de 1992), p. 1.

Marra-López, José Ramón, Narrativa española fuera de España, 1939-1961, Madrid, Guadarrama, 1963, pp. 341-409.

MARSÉ, Juan, «Las manos limpias de Ramón J. Sender», en Confidencias de un chorizo, Barcelona, Planeta, 1977, pp. 167-170.

Moncho AguiRre, Juan de Mata, "Las novelas filmadas", en Cine y Literatura: La adaptación literaria en el cine español, Valencia, Generalitat, 1986, pp. 4-7.

MONTES, María José, La guerra española en la creación literaria. Ensayo bibliográfico, Anejos de Cuadernos Bibliográficos de la Guerra de España (1936-1939), II, Madrid, Universidad, 1970.

"NoRMANTE», "Los que se trajeron a Sender: Quién es quién», Andalán, 43 (15 de junio de 1974), pp. 8-9.

O'BRIEN, Mary E., «Interview with Ramón J. Sender», Hispania, 58 (1975), pp. 967-969.

OSunA, Rafael, Las revistas españolas entre dos dictaduras: 1931-1939, Valencia, Pre-texts, 1986.

PAt.AU Y Dutcet, Antonio, Manual del librero hispanoamericano, t. 20, Barcelona, Librería Palau, 1948 , p. 376.

Peñuelas, Marcelino C., Conversaciones con Ramón J. Sender, Madrid, Magisterio Español, 1970.

PÉREZ-MINIK, Domingo, Novelistas españoles de los siglos XIX y XX, Madrid, Guadarrama, 1957, pp. 302-306.

PINI Moro, Donatella, «¿Degradación de Sender en 1936?», Andalán, 459-460 (septiembreoctubre de 1986), pp. 29-31.

—, «Ramón J. Sender, víctima del estalinismo», Andalán, 466-467 (1987), p. 2.

—, «Degradazione di Ramón J. Sender durante la guerra civile spagnola? Una testimonianza inedita di Vittorio Vidali», Spagna Contemporanea, 19/3 (junio de 1988), pp. 477-502.

-., «La degradación de Sender: un montaje», Alazet, 2 (1990), pp. 145-149.

Pozuezo, "Cuando vuelven los rojos", Triunfo, 28.610 (8 de junio de 1974), p. 11.

Prados de la Plaza, Francisco, «Exposiciones en Madrid», Bellas Artes, $7 / 49$ (enero-febrero de 1976), pp. 60-62.

QuesadA, Luis, La novela española y el cine, Madrid, Ediciones J. C., 1986.

«Ramón J. Sender: Obra pictórica», Madrid, Galería Multitud, 1975.

"Regresar es morir un poco"» [Entrevista], Triunfo, 28.610 (8 de junio de 1974), pp. 18-20.

REssot, Jean-Pierre, "Les démons de Ramón J. Sender", Hispanística XX [Toulouse], 3 [Les Mythologies hispaniques dans la seconde moitié du XXe siècle. Actes du colloque international (Dijon, 22-23 novembre de 1985)] (1985), pp. 221-229.

Rivas, Josefa, La senda de Sender, Tesis doctoral, Universidad de Valencia, junio de 1964 (director: Francisco Sánchez-Castaner).

-, El escritor y su senda. Estudio crítico y literario sobre Ramón Sender, México, Mexicanos Unidos, 1967.

ROMÁN ROMÁN, Antonio, "Adaptación al cine de Crónica del alba», Cuadernos de ALDEEU, $5 / 2$ (noviembre de 1989), pp. 257-268.

-, «Un homenaje de Sender a Cervantes: Las gallinas de Cervantes», en Estudios en homenaje a Enrique Ruiz-Fornells, Erie, Pensilvania, ALdeEU, 1990, pp. 560-567.

ROMERO TOBAR, Leonardo, "Sender en la literatura española", Universidad, 9 (1982), pp. 23-24. Ampliado y recogido en José-Carlos MAINER, ed., Ramón J. Sender. In memoriam. Antología crítica, Zaragoza, Diputación General de Aragón, Ayuntamiento de Zaragoza, Institución Fernando el Católico y Caja de Ahorros de Zaragoza, Aragón y Rioja, 1983, pp. 241-250.

Ruiz Gallego-LaRgo, Jesús, "Artículos de Ramón J. Sender en el diario Solidaridad Obrera", Cuadernos de Historia Moderna y Contemporánea, 6 (1985), pp. 281-312. 


\section{EL LUGAR DE SENDER}

Samaniego, Fernando, Poética y textos en «Imán», de Sender, Tesis doctoral inédita, University of Washington, 1984 (director: Marcelino C. Peñuelas).

SÁnCHEz Vidal, Agustín, El cine de Carlos Saura, Zaragoza, Caja de Ahorros de la Inmaculada, 1988.

—, «Un Saura inédito», introd. a Carlos SAURA, ¡Esa luz! (Guión cinematográfico), Huesca, Instituto de Estudios Altoaragoneses, 1995, pp. IX-XXXVI.

SCHNEIDER, Marshall J., «Lost and Found: Some New Works of Ramón J. Sender: A Bibliographical Report and Update», Letras Peninsulares, 5/3 (invierno de 1992-1993), pp. 379-388.

"Sender: "Viviré definitivamente en Mallorca"» [Entrevista], Blanco y Negro, 3.343 (1976), pp. 54-55.

SEnder BARAyón, Ramón, A Death in Zamora, Albuquerque, University of New Mexico Press, 1989.

- Muerte en Zamora, trad. de Mercedes EsteBAn-MAEs KeMP, Esplugas de Llobregat, Plaza y Janés, 1990.

SENDER GARCÉS, Ramón J., «Ramón J. Sender, pintor de amuletos», Batik, 21/1 (1976), pp. 6-7.

VALDIVIESO, L. Teresa, "La crítica suscitada en los Estados Unidos por la obra senderiana», en Mary S. VÁsquez, ed., Homenaje a Ramón J. Sender, Newark, Delaware, Juan de la Cuesta, 1987, pp. 183-194.

VÁsquez, Mary S., "A Prison of Parallels: The Natural and Human Spheres in Imán», Hispanófila, 82 (septiembre de 1984), pp. 45-56.

—, ed., Homenaje a Ramón J. Sender, Newark, Delaware, Juan de la Cuesta, 1987.

Vilches DE Frutos, María Francisca, «Bibliografía crítica sobre el primer Sender», en Censo de escritores al servicio de los Austrias, Madrid, 1983, pp. 121-142.

—, "Ramón J. Sender, como crítico literario (1929-1936)», Revista de Literatura, 45/89 (1983), pp. 73-94.

- La generación del Nuevo Romanticismo. Estudio crítico y bibliográfico, Tesis doctoral, Universidad Complutense de Madrid, 1984.

—, «Las colaboraciones periodísticas de Ramón J. Sender durante los años 1929-1936: Incidencia en su producción literaria", en David A. Kossoff, José Amor Y VÁsquez, Ruth Kossoff y Geoffrey RibBans, eds., Actas del VIII Congreso de la Asociación Internacional de Hispanistas, t. II, Madrid, Istmo, 1986, pp. 687-695.

VIVed Mairal, Jesús, «El primer Sender», Artes y Letras. Suplemento de "Heraldo de Aragón», 16 de enero de 1992, p. 1.

—, "La vida de Sender al filo de su obra», Alazet, 4 (1992), pp. 231-270.

—, ed., Ramón J. SENDER, Primeros escritos (1916-1924), Huesca, Instituto de Estudios Altoaragoneses, 1993.

WatTs, Luz Campana de, Veintiún días con Sender en España, Barcelona, Destino, 1976.

—, Ramón J. Sender: Ensayo Biográfico-crítico, Buenos Aires, Ayala Palacio Ediciones Universitarias, 1989. 


\title{
La escritura simbólica de Ramón J. Sender en La mirada inmóvil
}

\author{
Jean-Pierre Ressot \\ Université de Paris-Sorbonne
}

La mirada inmóvil es una novela poco conocida. Tal vez porque, editada en 1979, ${ }^{1}$ no se ha vuelto a publicar, que sepamos. Sin embargo, se trata para mí de una obra de indudable interés e importancia, por presentar características muy típicas de la manera de escribir del autor y permitir echar las bases de una "gramática senderiana" (según la excelente formulación de Donatella Pini Moro). Los que llevamos años leyendo los relatos de Sender podremos incluso ver en la escritura de esta novela una como síntesis de los procedimientos que constituyen la marca personal de don Ramón y que hacen de una página suya algo inconfundible. Quizá sea este aspecto el que llegó a marginarla un tanto, porque su lectura supone un trato anterior y aun antiguo con la forma de expresión específicamente senderiana que se explaya en ella. Ya sabemos que esta expresión se caracteriza por su tendencia a la digresión o «divagación» ${ }^{2}$ y a los desarrollos aparentemente arbitrarios, de tal modo que el lector novato o perezoso pronto se desesperará ante un discurso narrativo que puede darle la sen-

\footnotetext{
1 Barcelona, Argos Vergara, 331 pp.

2 Según término propio de Sender.
} 
sación de perderse en los meandros de un relato aleatorio. Pero el analista verá en las mismas dificultades de la lectura las claves de una obra que bien podría considerarse como un testamento literario de Ramón Sender.

Para poner al alcance de todos, en la medida de lo posible, una novela inasequible tanto por su ausencia de las librerías como por la dificultad de su desciframiento, empezaremos con una breve descripción. El punto de partida de la ficción es la presencia en un hospital estadounidense de un personaje llamado Agamenón, ${ }^{3}$ por un cáncer de pronóstico fatal. Esta situación de desahuciado parece colocar al protagonista en un estado de lucidez propicio a una reflexión sobre el sentido de la vida, y en particular de la suya, cuyos episodios recordarán a menudo la vida del propio Ramón Sender. ${ }^{4}$ Poco importa que Agamenón se salve de la muerte milagrosamente ya en el $4^{\circ}$ capítulo (la novela comprende 21 ): de todos modos está puesto en marcha un proceso de autoanálisis que ocupa lo esencial de la obra, desplazando en segundo plano unos escasos elementos anecdóticos que son puros pretextos para una reflexión sobre el hombre en general. Esta especie de balance sobre el sentido de la Creación se hace mediante las relaciones que Agamenón mantiene con unos cuantos personajes de ficción. Entre ellos, Helena, su amante; Hilda y Rosa, que le alquilan el apartamento, y, sobre todo, tres seres muy raros que el protagonista llama sus coduencosmas y que son posibles dobles suyos. Como cada coduencosma representa supuestamente un momento de su vida, uno de ellos es motivo para una larga digresión sobre la experiencia marroquí atribuida al héroe. Los capítulos 10 a 15 se dedican en efecto a narrar la aventura que vive el «yo» desdoblado (algo parecido al Viance de Imán) en el desastre de Annual. Pero la verdad es que el material propiamente narrativo de la novela no es en ella lo más importante. Prueba de ello es el hecho de que el mismo título de la obra, La mirada inmóvil, se debe a un comentario de índole ensayística sobre un cuadro de Velázquez (El Bobo de Coria) que poco o nada tiene que ver con la vida del protagonista. Al fin y al cabo, este relato no cuenta propiamente hablando una historia, lo que no deja de tener relación con el desconcierto que suscita.

El interés de la novela no está, pues, en lo que cuenta sino en la manera de contarlo. Y precisamente ahí reside el carácter problemático de la obra, esa naturaleza desconcertante. La escritura de Sender presenta unos rasgos a los que tal vez nos hemos acostumbrado los analistas de su obra, pero que, por muy avezados que seamos, siguen causándonos alguna perplejidad. Comprender el porqué de semejante escritura quizá nos permita

\footnotetext{
${ }^{3}$ También burlescamente llamado "Aga".

${ }^{4} \mathrm{La}$ índole evidentemente autobiográfica del relato se ve sin embargo muy limitada por los datos anecdóticos, que son puro fruto de la imaginación del autor: en particular, al personaje se le evoca como un monstruoso traidor responsable del desastre de Annual. Además, se sabe que Sender no participó en el episodio histórico.
} 
superar la perplejidad y abrir perspectivas sobre el arte de narrar del ilustre aragonés.

Lo primero que llama la atención son los ya señalados fenómenos de digresión que suelen marcar la narrativa senderiana y que cobran particular importancia en La mirada inmóvil. En la novela, prolifera lo que el propio narrador llama "paréntesis llenos de reflexiones más o menos congruentes» (p. 91) y que hace que la construcción del discurso no parezca obedecer a un proyecto lógico, como en este ejemplo:

\footnotetext{
Todas esas reflexiones si no le divertían le entretenían. Y creía ver en la sala a los autores a quienes solía leer en relación con aquellas materias. Antes que nadie a M. Alvar y después a Hubschmid y a Rohlfs, estos últimos con un aire ofensivo de marionetas criptogermanas porque ¿a quién se le ocurre tener un nombre de cinco letras con una sola vocal? ¿O de nueve letras con sólo dos vocales?

Visigóticos del más bajo período feudal.

Tipos cerveceros y renales, es decir especialmente urinarios.

En el hospital donde había estado Aga los habrían clasificado con otro nombre cualquiera para evitar la orina.

Pero tenía que escribirle a Helena una carta de amor para que no se quisiera suicidar de nuevo. (p. 79)
}

Se habrá notado cómo el discurso narrativo progresa aquí por pura asociación de ideas (incluso a través del juego de palabras sobre renal / renano). Además, cuando la digresión se hace tan sistemática, multiplicándose en apartados cortos, provoca otro fenómeno, también característico de esta novela, a saber: la fragmentación del discurso narrativo. ${ }^{5}$ Un fenómeno que el mismo narrador asume, aludiendo varias veces a la índole divagatoria de su relato:

Se habla de los sueños, pero pocos caen en la cuenta de que despiertos y tumbados en la cama nuestra imaginación experta se divierte de un modo divagatorio y equinoccial, que es el mejor. ${ }^{6}$ (p. 28)

De ahí la advertencia de uno de sus dobles a Agamenón: «Déjate de ociosos corolarios» (p. 122). O la disculpa del narrador protagonista: «Y usted perdone, Hilda, si resulto prolijo" (p. 127). Un elemento discursivo recurrente es especialmente revelador de esta obsesión digresiva: se trata de los numerosos «como digo» o «como dije» ${ }^{7}$ y otras formas similares que intentan recuperar el hilo de un discurso que el escritor deja deshilvanarse muy a menudo.

\footnotetext{
5 Pueden considerarse las pp. 127 y siguientes o las pp. 149-150 como casos, entre otros muchos, de fragmentación máxima.

6 También en las pp. 69 («[...] recordando divagatoriamente [...]») y 75 («Helena [...] era divagatoriamente halagüeña»).

7 Por ejemplo, en las pp. $89,92,127,131,157$, etc.
} 


\section{EL LUGAR DE SENDER}

Semejante tendencia a la digresión, la divagación o la fragmentación trae consigo varias consecuencias. La primera de ellas es que, como aparece en el breve análisis que he dado al principio, La mirada inmóvil no es una novela fuertemente estructurada por una intriga. Pero hay más: el discurso narrativo carece muy a menudo de trascendencia, como se notará (un ejemplo entre muchísimos) en la anécdota en francés de la página 88. Lo intrascendente llega a veces a dominar tanto que el lector experimenta una frecuente sensación de escritura a la deriva:

Los [cuadros] de Miró me gustan, porque no son estructuras ni masas de color sino materia elemental bien combinada como barro y sangre, por ejemplo. No sangre menstrual sino sangre de palomita torcaz herida por el gavilán. En ella está la joroba y la trompetilla y el miserere del coduencosma y la brocha de albañil del coduenstraito. ${ }^{8}$ (p. 208)

Una deriva por supuesto voluntaria o a lo menos lo bastante consciente como para hacerle decir a Agamenón en el momento de un discurso típicamente divagatorio:

Tú dirás: ¿A santo de qué viene todo eso?

También yo me lo pregunto: ¿A santo de qué? (p. 83)

En algunos casos, la deriva viene a ser tal que se podrá percibir en ella un saborcillo a imagen surrealista:

El coduencosma creía que las superfluidades eran las mariposas con pechos de harpía que se posaban en el brazo extendido. (p. 287)

Y aún veremos a veces alguna manifestación de escritura automática, en particular en unos poemas intercalados en la narración:

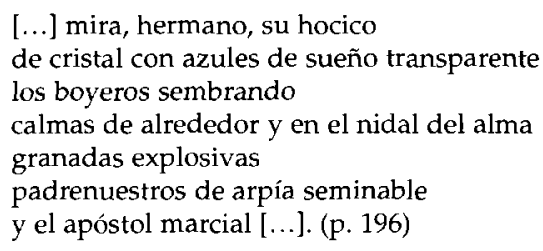

En esta misma tendencia de Ramón Sender a dejar correr el pensamiento y la escritura, negándose a imponerles las trabas de una organización convencional, se sitúa la afición al juego de palabras o juego con las palabras, del cual daremos este ejemplo de los más puros:

${ }^{8}$ El subrayado es mío. Las pp. 202-204 dan también excelentes ejemplos de escritura «derivante». 
Una táctica y una estrategia para sobrevivir y el deseo de gozar de una parte del calor solar que nosotros conservamos en lugares recónditos, genitivos, genitales, genéricos, genéticos, generadores o genitores ${ }^{9}$ con los que a veces sueñan las vírgenes. (p. 120)

\section{Y también éste:}

[La realidad] no existe realmente sino como incremento o excremento. Incremento es la esperanza en el mañana y lo otro el recuerdo incómodo y podrido del ayer. (p. 82)

Otros juegos, sobre «mortal» y «mortadela» (p. 38), «Micenas» y «mis cenas» (p. 189), «autopista» y «autopsia» (p. 274), «inflar el ego» e «inflar el higo» (pp. 84 y 278 ) resultan notablemente pesados. "Debilidades» evidentemente asumidas como tales por Sender, quien le hace decir a su narrador: «Y ustedes perdonen el torpe juego de vocablos» (p. 271). Una lucidez que no le impide reincidir poco después en el mismo vicio con una serie de retruécanos sobre "notarías / no te rías", "hojalaterías / ojalá te rías» y "paqueterías" / "para que te rías" (p. 313).

Parecida actitud lúdica con la escritura se manifiesta también en el conocido goce de don Ramón por inventar palabras. Ya hemos hablado de los "coduencosmas", trasuntos de Agamenón, desmultiplicación del personaje en "coduencosma por antonomasia", "coduenstraito" y "coduenscapro» respectivamente. La mirada inmóvil contiene una multitud de estos raros neologismos, ora completamente inventados, ora combinación de palabras preexistentes. Citamos algunos casos entre los más espectaculares:

somormujovitandopterigio (p. 26), falosophers y foliastrophers (p. 33), axileticia (pp. 36, 67, 198), comatontinsustanciales (p. 39), finiquitud y mortalera (p. 47), antimortiferario (p. 47), jacarandoscopia (p. 69), pornophotoestereóscopo (p. 72), logosnomía (pp. 99, 197), iberorromanovisigótimusulmanasantoficiosa (p. 216), líricogaseiformidabilísimas (p. 221), esquizoporcino ( $p$. 227), vaginouteroclitorial (p. 234), mayusculeóptero (p. 238), superproletarizarista (p. 239), líricogóticoerotiquísimas (p. 276).

A fin de cuentas, todas estas particularidades producen una impresión de escritura en libertad. Una escritura tan libre y autónoma que en contados casos llega a escapar al control del autor hasta incurrir éste en contradicciones. Valgan estas dos, muy claras, como ejemplos:

Cada cual cree que es sí mismo y no es verdad. (p. 12) / Cada cual es sí mismo aunque no lo sepa. (p. 105)

Uno se alegra de la muerte de un amigo cuando ha sucedido y no tiene remedio [...]. Una vez que ha muerto no puede menos de alegrarse un poco (como si se tratara de una fiesta) [...]. (p. 25) / Nunca he creído en Freud y menos cuando nos dice que nos alegramos de la muerte de una persona querida. (p. 199)

${ }^{9}$ El subrayado tipográfico (para señalar el radical común de las palabras) es de Sender. 


\section{EL LUGAR DE SENDER}

Pero bien es verdad que, por otra parte, aprendimos con Unamuno a no considerar ya la contradicción como un fracaso sino como la manifestación fecunda de un pensamiento paradójico. Ramón Sender también busca y cultiva la paradoja, que viene así a ser otro rasgo típico de su manera de escribir:

[...] Freud a quien admiraba y despreciaba al mismo tiempo. (p. 35)

[...] cuando voy a decir la verdad, toda la verdad, es cuando digo sin querer la más grande mentira. (p. 114)

No olvidaré mientras viva aquel hecho ignominioso. Repugnante y sin embargo con un fondo de justicia. Justo y con un trasfondo de barbarie. Bárbaro y sin embargo humanitario. Humanitario, pero con un reflejo de satanismo. (p. 146)

Es más pícara Yasmina, y al mismo tiempo más pura que las chicas de España. (p. 161)

El avanzar era retroceder o al contrario. (p. 190)

Ella entorna los ojos como adormecida y va diciendo cosas deliciosamente horrendas. Inocentemente criminales. ${ }^{10}$ (p. 263)

Yo amo apasionadamente mi falta de amor. (p. 268)

[...] cuanto más locos más sabios. (p. 271)

[Cristo] nunca ha existido y por eso puede darnos a todos la suprema lección desde la cruz. (pp. 317-318)

Con todas estas tendencias bastante relacionadas entre sí acaba por perfilarse para nosotros lo que, al fin y al cabo, quizá sea la característica mayor de la escritura senderiana: su naturaleza críptica o criptográfica (puesto que se trata de escritura), un «criptismo» que requiere de parte del lector un esfuerzo casi constante de desciframiento. El esfuerzo se ve generalmente frustrado, porque, como comprobaremos más adelante, el interés de este tipo de discurso narrativo no está en una posible «mise à plat» (resolución) del sentido, sino, al revés, en una interpretación razonada de la obsesión criptista del escritor. En particular, el lector nunca podrá resolver de modo satisfactorio la dificultad que ofrecen los fenómenos de desdoblamiento del personaje sujeto, que deben expresar, según el narrador, sus fuertes tendencias esquizoides. ${ }^{11}$ Ya hemos dicho que Agamenón se desdobla en tres «coduencosmas» (llamados también «trasuntos», «alteregos», "contrafiguras» o "fantasmas» del protagonista): el «coduencosma por antonomasia», el «coduenstraito» y el «coduenscapro», que corresponden en teoría a varios aspectos del personaje y a varias épocas de su vida. Pero al

${ }^{10}$ Es ésta una paradoja en forma de oxímoron.

11 «Me pregunto a veces si soy un esquizoide. Si lo soy, la escisión de mi persona, si la tengo, que lo dudo, o la de Aga, que tampoco la tiene, es increiblemente intensa o extensa. Y tal vez no acierto a resolverla contándoselo a la gente, que es como suelen hacerlo los esquizofrénicos» (p. 241). 
lado de estos borrosos trasuntos ${ }^{12}$ del protagonista aparece además un narrador principal, un "yo" sin identificación clara, «amigo" de Aga. De vez en cuando, este "yo" le deja la palabra a uno de los coduencosmas, pero de tal forma que no siempre podemos determinar quién «habla», quién es la voz narrativa: ${ }^{13}$

En estas páginas a veces habla él [Agamenón] y a veces yo y sólo se nota la diferencia cuando discrepamos y cultivamos la discrepancia. (p. 67)

Ahí se encuentra otro motivo de desconcierto para el lector, motivo tanto más importante cuanto que negarle así al sujeto de la narración una identidad estable es socavar el fundamento de cualquier novela. Un relato puede prescindir de un marco espaciotemporal explícito, pero no puede funcionar sin la relación sujeto/objeto, que es la base mínima sobre la cual suele asentarse. Si se suprime el sujeto, se pone en peligro la existencia misma de la narración, que puede venirse abajo. Aunque La mirada inmóvil empieza con unos cuantos capítulos de una funcionalidad clásica respecto a la construcción de una novela, la continuación da más la sensación de una descomposición que de una composición literaria, sensación en la cual participa de modo privilegiado esta fragmentación del "ego" narrativo que acabo de señalar.

Esta sensación se concreta en las numerosas frases que presentan la estructura de la explicación pero no explican nada, sino que, al revés, hacen las cosas más complejas. No sé si se puede, como lo hace el narrador, ${ }^{14}$ hablar de «sofismas», por ser la noción demasiado peyorativa, pero el caso es que ahí se halla lo esencial de lo que llamamos la índole «críptica» de esta novela. Pongamos como ejemplos estas frases:

[Sus tres coduencosmas le ofrecían] sus diferentes sentidos de la vida, que eran los siguientes: el axileticia del coduencosma primero que era el girar incesante alrededor de un eje magnético invisible que llamamos felicidad y que no sabemos realmente en qué consiste.

El inefabileño del coduenstraito representado por las dos manos pintadas de la hermosa cabileña enlazadas en forma de mariposa roja.

Y la logosmanía del coduenscapro que se basaba en el sistema sobrenatural de logos de Platón y Philón de Alejandría. (p. 36)

[...] el ángel es la idea, es decir el genii de Nínive que va y viene entre Dios y nosotros, y también el Logos de Platón y de Filón de Alejandría, ese

\footnotetext{
12 Los nombres de estos personajes significan obviamente algo, pero ¿qué? La raíz del nombre, coduencosma, puede evocar una mezcla de asociación y disociación de la personalidad en su relación con el mundo (la creación, el cosmos). Uno de ellos, el coduenstraito, remite al período marroquí de Agamenón: Sender imagina que este doble de Aga es responsable, por su traición, del desastre de Annual, y podríamos ver en la parte final del nombre algo que recordaría aquella cualidad fundamental de traidor. En cuanto al coduenscapro, podría interpretarse como el fondo primitivo e instintivo del protagonista de la novela.

13 Fenómeno especialmente visible en las pp. 139-141 o en la p. 259.

14 En la p. 96: «[... Aga] desistía con uno de sus sofismas».
} 
ángel que va y viene entre el cielo y la tierra y que según Aga es la idea creadora, base del universo al menos del universo perceptible para los hombres. (p. 77)

Había varias clases de coduencosmas (los de Aga eran los más humanos). Los había con carne de cerdo y otros con carne vegetal de hongos veraniegos, de esos que aparecen bajo los pinos después de las tormentas, aunque con tamaño y figura de hombres. (p. 92)

$\mathrm{Ni}$ las masas humanas ni los individuos se mueven en círculos sino, como dije, en rutas y vías helicoidales, es decir en espiral, y todos giramos alrededor de un eje que no está en nosotros sino en el espacio y que una vez más, y como todas las circunstancias originariamente vitales nuestras, ese eje es indefinible e imponderable. (p. 238)

Claro es que el coduencosma es toda una galaxia él solo y Aga y los tres juntos somos un trasunto del universo entero con sus misterios heliosísticos o litiales. (p. 259)

Etc.

El discurso narrativo es, formalmente, de tipo explicativo y aun analítico, pero resulta que no lo es en cuanto a la sustancia. A medida que el lector se adentra en la frase con la esperanza de que ésta le vaya a aclarar el sentido de las cosas, el misterio se hace más espeso. La escritura senderiana presenta la característica paradójica de que la imagen de la realidad se hace más oscura con el discurso aclaratorio. La aparente aclaración se hace en realidad complejificación, por motivos que nos tocará explicar más adelante.

Para introducir en su relato este lenguaje críptico, Sender suele usar de un procedimiento que consiste en darle la palabra a un personaje cuyo «perfil» le predispone a esta forma de expresión. Lo usa o, mejor dicho, lo reutiliza, ya que volvemos a encontrar en La mirada inmóvil la figura del viejo árabe ya presente, unos cincuenta años antes, en su primera novela, Imán. Esta vez, se llama Tarik-Ben-Tarik y aparece como un hombre dotado de un saber esotérico, lo que le permite formular misteriosas sentencias sobre la significación oculta del mundo que nos rodea:

Si hay eclipse solar al mediodía los animales vivos se acuestan y los muertos se levantan. (p. 159)

Hay en la tierra de los ciegos soles que nunca veremos nosotros. (ibid.)

Hay muchos universos y todos se nos muestran en el temblor de nuestra sombra sobre las aguas del estanque. (ibid.)

La ignorancia, como la enfermedad, son estados de merecimiento. (ibid.)

Comenta el personaje narrador:

La verdad, no sé lo que quería decir aquello [...]. A veces, creo que estaba un poco chalado, pero yo diría que a la manera sagrada, si la hay. (p. 159)

Este mismo Tarik, al final de uno de los capítulos que le están dedicados, propone una solución al problema de la cuadratura del círculo 
(pp. 190-191). Se trata de un texto críptico por excelencia, sobre todo con el comentario que lo acompaña:

\footnotetext{
Cuando voy a ver a Tarik él parece ponerse un poco impaciente y no contesta a veces mis preguntas sobre la cuadratura del círculo, pero tal vez un día lo entenderé como los antiguos dogones y entonces iré a España y con la cuadratura del círculo podré resolver, supongo, todos los problemas que yo he creado desde aquel día de Annual. (p. 191)
}

Otros elementos de la "criptomanía» senderiana serán aquellas nociones recurrentes que siempre conservan una parte de misterio, por más que intentemos captar su significación a través de las sugestiones del autor: lo "ganglionar", lo "equinoccial», la "logosmanía", la "constante de Nínive», etc. También quedan sin aclararse completamente los conceptos que remiten a realidades comprobables, como los tuaregs o los dogones, pero a los que Sender confiere un sentido simbólico no del todo comprensible. En cuanto a los coduencosmas, que desempeñan un papel tan importante en la novela, no resulta fácil determinar qué significan exactamente respecto al personaje de Agamenón y a la persona de Ramón Sender. En particular, suelen aparecer con atributos (respectivamente, una campana, una trompetilla o chuflaina y una brocha de pintar) ${ }^{15}$ cuya significación es completamente hermética, aunque es de suponer que habrá un simbolismo oculto en ellos. En algún momento, después de afirmar que «[Agamenón] sólo había logrado identificar total y absolutamente por entonces al coduenstraito" (p. 102), el narrador parece contradecirse en la misma página hablando de este doble como de un personaje «incalificable», «que no podía definir». Tampoco queda bien claro el porqué de los nombres de los dos personajes principales, Agamenón y Helena, que remiten obvia y aun explícitamente a la historia troyana, pero sin que la referencia llegue a cobrar un sentido preciso. En fin, Helena parece resumir las impresiones del lector cuando le reprocha a Agamenón: «Tú siempre dejas en el aire una lucecita equívoca que suele desorientarnos [...]» (p. 90).

Llegamos a la conclusión de que asistimos en esta novela a una perversión de un aspecto fundamental del texto narrativo: la perversión de su función hermenéutica, es decir, de su función de desciframiento del sentido de la realidad. En La mirada inmóvil, como en otras novelas de Sender, no se trata de descifrar sino de criptar este sentido. Lo que parece resumirse en una reflexión del personaje narrador: «Hablo y que entienda el que pueda entender» (p. 222).

Ahora, después de todas estas consideraciones sobre la índole críptica de la escritura senderiana en esta novela, conviene tratar de comprender el porqué de semejante manera de proceder. Primero, salta a la vista que

15 Páginas 20, 196, 262, etc. 
la ya aludida complejificación desemboca forzosamente en la idea de que existe otro sentido oculto detrás de las apariencias. Aunque el discurso narrativo de La mirada inmóvil se presenta a menudo como un discurso aparentemente intrascendente, no dejará, por supuesto, de tener su trascendencia. El problema está en determinar dónde se sitúa esta trascendencia y cuáles son sus características. Por otra parte, tan extraño modo de escribir relatos no puede sino señalarle indirectamente al lector otros rumbos, otras vías, otros caminos, los cuales participan evidentemente del símbolo. Digo «evidentemente», porque se trata de un fenómeno patente en cualquier novela, donde la escritura no vale tanto por lo que dice como por lo que sugiere más allá de su sentido literal y por lo que significa como postura ante la realidad y sus misterios. Pero lo que pasa es que en Ramón Sender se agudiza particularmente el proceso de simbolización de los medios expresivos, hasta llegar a los extremos que hemos señalado, hasta alcanzar un límite más allá del cual se pone en tela de juicio la viabilidad misma del relato. La mirada inmóvil, lo hemos dicho ya, es una composición narrativa que evoca al mismo tiempo un relato en descomposición, paradoja ésa que es el fundamento mismo sobre el cual se asienta la obra. Por eso yo la veo como una novela frágil, en equilibrio inestable, al borde de la delicuescencia, amenazada por una irremediable disgregación. Un caso límite, pues, que, precisamente porque es un caso límite, quizá nos permita entrever algo fundamental en la creación senderiana.

La significación, pues, hay que buscarla a otro nivel. $Y$, en la explicación de este "algo fundamental", puede servir de punto de partida un comentario de Sender acerca de «la gilipollez del pienso luego existo». ${ }^{16}$ Semejante juicio implica por supuesto un rotundo rechazo del cartesianismo y de la postura racionalista ante la realidad. Rechazo en cierto modo confirmado por el elogio a Bergson, ${ }^{17}$ abogado del intuicionismo como modo de conocimiento superior al de la razón. No hay duda de que procede de ahí la idea de una escritura que no se dejaría someter a una lógica narrativa estrecha:

[El coduencosma] es un narrador nativo, aunque como te decía es un tipo que habla de una manera razonable y por lo tanto un poco aburrida para nosotros. $^{18}$ (p. 216)

-Es que no hay sino soluciones irracionales - [proclama Agamenón] indignado y frenético. (p. 289)

Esta convicción de Sender la conocíamos todos, ya que él llevaba años afirmándola, pero en La mirada inmóvil la reafirma con una insistencia

\footnotetext{
16 Página 288: «Ni siquiera las cosas que vemos y tocamos existen. El que decía "yo pienso luego existo" creía decir algo, pero era una gilipollez cartesiana».

17 Página 33, p. 229.

18 El subrayado es mío.
} 
obsesiva. Para un escritor la postura racionalista significa una mutilación, un terrible empobrecimiento de nuestras capacidades de comprensión de la realidad, porque «nuestra razón no puede ir más lejos de aquello que hemos hecho con nuestra razón» (p. 293). La razón es una facultad que, en la experiencia vital humana, se ve muy pronto limitada:

Lo razonable ya establecido no requiere atención. Y todo lo que los hombres tenemos es esa capacidad de atención de la cual depende cualquier posible realidad, ya que es en esa atención donde las cosas con sus afinidades relativas nacen y toman forma. Lo explicable y razonable se extingue en la realización comprobada. ${ }^{19}$ (p. 228)

Así se afirma una vez más la idea ya común de que el conocimiento no está ahí donde uno se lo imagina. El acceso a las verdades no pasa por la razón positivista, sino que tiene forzosamente un carácter esotérico. Hablando de Tarik y de su ciencia, dice el narrador:

No siempre lo entendía por las palabras - decía cosas raras- pero sí por la intención que veía en la luz de sus ojos. Una luz que parecía venir de otros siglos lejanos, pasados y futuros. (p. 174)

En cuanto a lo que intentan comunicarle sus coduencosmas:

Lo que pasa es que formaban parte esas nociones de un repertorio privado y oculto que no está al alcance de todo el mundo [...]. (p. 198)

Al lado de estas plasmaciones novelescas que son Tarik-Ben-Tarik y los coduencosmas, Sender imagina otras, más generales y a priori menos literarias, unos seres privilegiados que, según el narrador, tendrían acceso a aquella forma de conocimiento libre de las trabas del racionalismo: los niños, los locos, los tontos.

[Los niños] lo saben todo en materia de afectos que es algo que nada tiene que ver con la inteligencia. Viven los niños del tesoro de su inconsciente sabio y no necesitan más. Los niños están en el centro de la sabiduria informulable. ${ }^{20}$

También se recordará la fascinación del autor ${ }^{21}$ por la creencia, entre los beréberes, de que a los locos se debe respetarlos porque gozan de una penetrante sabiduría:

Tal vez sólo a los locos les está permitido alcanzar esa difícil verdad que nos es inaccesible. ${ }^{22}$ (p. 211)

\footnotetext{
19 Ibid.

20 Ibid.

21 En Imán y en esta misma novela (p. 155, p. 211).

22 Lo que explica la paradoja ya señalada: "Cuanto más locos más sabios».
} 


\section{EL LUGAR DE SENDER}

Por lo que se refiere a los tontos, ahí está el ejemplo del personaje de Velázquez, el Bobo de Coria, cuya mirada encierra "la última y única verdad» (p. 317):

Ese Bobo de Coria conoce el secreto que todos buscamos, pero no puede decirlo desde la tela pintada. Es la única imagen que he visto en mi vida capaz de reflejar todo el saber del mundo. Un secreto que no podría decir, porque si lo dijera estallaría quizá el planeta. Ese enano tiene nuestro secreto. Todos los sabios del mundo lo buscan sin poder hallarlo, pero él lo tiene. (p. 295)

En su mirada de una tristeza y sabiduría indecibles están los últimos límites que el hombre puede alcanzar. (p. 290)

Como lo evoca esta última frase, el Bobo de Coria no debe solamente este privilegio a su condición de tonto. Es que también vive una situación límite, el límite de lo que puede soportar un ser humano:

El Bobo de Coria tiene el secreto porque ha descendido tan por debajo de toda posible dignidad humana que ha tocado ese fondo que sigue siendo inalcanzable para nosotros [...]. Muy por debajo de toda posible miseria entre las que conocemos y las que podríamos imaginar que son infinitas realmente, porque tienen sus raíces secretas en nuestro mundo inconsciente, tan insondable como el universo mismo. (p. 296)

Esto es precisamente lo que parece ocurrirle a Agamenón. Primero, cuando vive la situación extrema imaginada por el novelista (la de un desahuciado que muere por un cáncer), porque de esta manera se encuentra en una situación límite parecida a la que vive el idiota:

Llevo cincuenta años leyendo, pero no he aprendido nada de los libros. Todo lo que leo se me olvida. Entretanto, de esas profundidades oscuras e indeterminables donde me roe ahora la rata ${ }^{23}$ iluminada por los rayos $X$, salen nociones mudas [...]. (p. 30)

Le pasa algo parecido durante el episodio marroquí de su vida, cuando acaba de cometer la espantosa fechoría de la traición: ${ }^{24}$ como si esta experiencia de los límites del mal le hubiera puesto (idea varias veces expresada por Sender) en una situación privilegiada, "más allá del bien y del mal», para encontrar la sabiduría prohibida al hombre común.

Pero estos seres privilegiados (niños, locos, tontos, agonizantes, asesinos) no son capaces de comunicarnos este mundo prohibido al cual ellos acceden tan fácilmente. Sólo pueden expresar algo que no comprendemos:

¿No es ése el secreto de los idiotas y de los locos? La tristeza que vemos en los ojos de todos ellos es la amargura de poseer la verdad, de tener a cos-

\footnotetext{
23 Así se imagina su cáncer.

24 A partir de la p. 152, en el capítulo titulado «Un tiro en la cabeza, pero...».
} 
ta de una degradación sin nombre la posibilidad de decir esa verdad sin ser comprendidos. (p. 231)

Ahora bien, todas esas ideas que Sender nunca dejó de afirmar con constancia y obstinación en su obra determinan evidentemente su concepción de la literatura y, en particular, de la creación novelesca. Para un escritor, estas convicciones plantean ipso facto la cuestión de la manera de escribir. ¿Cómo, con un medio expresivo puramente textual, entrever aquella verdad última y única a la cual llegaron los idiotas y los locos?

Lo más obvio es que si cualquier conocimiento es esotérico, lo primero que puede hacer el novelista es practicar, él también, una escritura en cierto modo esotérica. $O$ por lo menos negarse a una forma de expresión demasiado racional y explicativa, rechazar el discurso referencial y analítico. Esto es lo que hace concretamente Ramón Sender, cultivando una escritura que vale no exactamente por lo que declara sino por lo que significa como permanente y desesperado esfuerzo por forzar intuitivamente los misterios del universo. La escritura de La mirada inmóvil es profundamente simbólica en eso de que detrás de su dudoso sentido literal se expresa crípticamente la posibilidad de una aproximación esotérica a la realidad. De tal forma que las perplejidades y el desconcierto que la lectura de la novela suscita en nosotros se deben al hecho de que, a pesar de ciertas apariencias, no aborda de frente la explicación de la Creación, sino de una manera sesgada, la cual, precisamente, no pretende nunca ser explicación sino posible intuición. La digresión, la divagación, la fragmentación, el juego con las palabras, la paradoja, el «criptismo» pueden explicarse y justificarse por la voluntad del artista de no permanecer nunca de frente, sino situarse oblicuamente para captar «esas zonas semidiscernibles de la realidad donde se fraguan los milagros» (p. 216).

Cuando el relato de Sender se pierde en ideaciones cientistas de muy discutible valor (especialmente en los capítulos que giran alrededor del personaje de Tarik), creo que nos encontramos con una actitud que ilustra ésta que acabo de evocar. Estas elucubraciones no deben tomarse al pie de la letra sino como expresión de otra tentativa para forzar la verdad por esa vía sesgada a la cual aludíamos. A ese respecto, merece particular atención lo que llamaré la "obsesión etimologista" de Sender. A lo largo de la novela (y como en muchas otras novelas suyas), el narrador se demora en explicaciones sobre el probable origen de ciertas palabras. No se trata de darle al lector una lección de lingüística sino de forzar el secreto de las palabras y de los nombres, atacándose a la misma materialidad del lenguaje, emprendiéndola con el significante lingüístico, retorciéndolo, triturándolo con el análisis etimológico para que suelte una migaja de secreto. Cuando Sender encuentra una palabra anterior al griego y al latín, ${ }^{25}$ la

25 Véanse los ejemplos de «mueso» (p. 168) o de «chivani» (p. 169). 
señala con fruición, como si esta palabra fuera una clave para penetrar el sentido profundo de las cosas:

[Huesca] venía del idioma osco anterior al viejo etrusco y al pelasgo, y desde luego al latín. ${ }^{26}$ (p. 79)

Y por eso a Sender le fascinan las lenguas antiguas, el indoeuropeo, el vascuence, el «shela» de Marruecos, porque imagina que estas lenguas son una posibilidad de entrever el origen del mundo. En este caso también, la escritura desempeñaría su cometido simbólico, abriendo una puerta sobre un saber oculto.

Dicho de otro modo, se trata de practicar una escritura que enfoca la realidad «al bies», con la esperanza de propiciar la visión fugitiva de aquellos intersticios o entresijos por donde se revela a veces la esencia de las cosas:

[Los coduencosmas] son como ángeles sin alas ni belleza alguna, los pobres, que Dios ha puesto a mi lado para refrescar los intersticios $18 \mathrm{de} \mathrm{mi}$ memoria y consolidarme a mí en las coyunturas. (p. 53)

En este caso, la aparente intrascendencia del discurso novelesco no sería un obstáculo para la «inteligencia» de las cosas, sino otro modo, quizá más eficaz, de alcanzarla. Fijémonos en esta frase que parece resumir con la mayor claridad la naturaleza de la escritura senderiana en esta novela:

\footnotetext{
Aunque [estas cartas de Agamenón] parecen no decir nada extraordinario dejan ver por los entresijos una perspectiva normalizante. (p. 201)
}

A fin de cuentas, lo que propone Sender no son respuestas ante los misterios de la realidad, sino una manera de abordarlos. Su escritura no pretende nunca agotar el sentido (de ahí su carácter críptico), sino solamente sugerir que el sentido de las cosas siempre estará donde no lo esperamos. De tal forma que si existe en esta novela una perversión de la función hermenéutica, como lo pretendo, es que la hermenéutica es el tema mismo del relato. La función hermenéutica está pervertida porque de lo que habla Ramón Sender es precisamente de hermenéutica. La problemática de la novela no es determinar lo que vemos, sino qué tipo de mirada debemos adoptar si pretendemos verlo. De ahí el símbolo de la mirada del Bobo de Coria, mirada inmóvil, mirada en apariencia vacía, pero cuya terrible vacuidad significa paradójicamente que el personaje posee los secretos del mundo.

Por eso surge varias veces la sugestión de que este discurso narrativo tan sorprendente, que se empeña en cultivar lo intrascendente hasta la casi

${ }^{26}$ Sobre estas calas etimológicas, véanse pp. 78-79, 130,151, 157, 168, 169, etc. 
insignificancia, bien pudiera ser, otra vez paradójicamente (y precisamente por su misma intrascendencia), la puerta de acceso a otro mundo, una puerta encontrada como por casualidad, gracias al ejercicio obstinado de una escritura más aleatoria que planificada. Al principio de la novela, Agamenón, al hacerse preguntas sobre su inesperada cura, emite la hipótesis:

\footnotetext{
O era un indicio con el cual alguien trataba de ponerle sobre aviso en relación con una segunda realidad que él ignoraba. (p. 32)
}

Y, más adelante, se imagina a sí mismo pasando por el centro de una vorágine:

[...] Ese centro oscuro que comunica con otro universo hacia el que apunto - vergüenza me da decirlo- en estas páginas. (p. 75)

Ahora bien, para alcanzar el centro, no hay que apuntar al blanco directamente, sino que hace falta adoptar una trayectoria oblicua, esta misma que supone la escritura senderiana en sus aspectos más desconcertantes. Esta escritura que se demora en la digresión, la divagación, la reiteración y el comentario intrascendente sería una manera de intentar alcanzar el centro por la periferia: como sin quererlo, esperando un azar favorable para encontrarse en el centro de la vorágine. Por eso, La mirada inmóvil da a menudo esa impresión de relato aleatorio, pero obstinado, en el cual el narrador estaría buscando su camino a puros tanteos y cambios de rumbo, probando cosas, abandonando otras. La misma novela en su totalidad no tiene otro propósito sino el de llevarnos desde la periferia de la vorágine hasta el centro donde está el punto de una posible revelación: la mirada del bufón Calabacillas, alias «Bobo de Coria», del cuadro de Velázquez.

Y hay más: instrumento para alcanzar el centro de la vorágine, la escritura, con las características que hemos apuntado, es ella misma vórtice. La propia novela también, tal como la concibió el autor, tiene algo que ver con una vorágine. Entonces es cuando La mirada inmóvil se nos aparece como ilustración de la gran idea de Sender, la que justifica toda su obra escrita y su manera tan personal de escribir literatura. Esta idea es la del poema único, en el cual la práctica pertinaz de la escritura cobra todo su sentido:

\footnotetext{
No dejaré de ser un explorador que abre vías hacia ese poema único que nadie ha escrito aún y que el mundo entero espera aunque todo el mundo sabe, también, que nadie lo va a escribir. (p. 75)
}

La mirada inmóvil, Sender lo afirma reiteradamente, participa del proyecto de llegar a escribir la «Evidencia Indecible» (p. 319), por lo menos simbólicamente:

Tenía que comenzar cuanto antes convocando a sus trasuntos como los había convocado en el hospital [...]. Sabía que ellos acabarían por devolver- 


\section{EL LUGAR DE SENDER}

le toda su salud. O de dictarle el poema único. De hecho habian comenzado ya. Pero habría que entenderlos, lo que no era del todo fácil. (p. 63)

[Los coduencosmas] Tienen en secreto algunos versos del poema total, es decir del centro del vórtice hacia el que va la Vía Láctea y sus miles de millones de soles. (p. 72)

Yo me salvaré contando un cuento. El cuento que todos esperan desde el comienzo de las edades.

Porque sólo hay un cuento. Ese cuento, yo lo escribiré. (p. 114)

En realidad, no es sólo La mirada inmóvil la que representa esa tentativa de escribir el cuento único. Son aquellos miles y miles de páginas, escritas a lo largo de su vida, páginas distintas todas pero que significan todas una misma voluntad reiterada de comprender los misterios del universo. Cada obra de Sender, a imagen de su Libro armilar de poesía, que, con este título, se designaba a sí mismo como figuración escrituraria del universo, es el poema único con que él soñó durante toda su vida. 


\title{
Tres calas en la biografía de Sender
}

\author{
Jesús Vived Mairal \\ Investigador
}

Larga e intensa fue la vida de Ramón J. Sender. Por eso, a la hora de referirnos a su biografía en el marco ajustado de una ponencia nos limitaremos a algunas etapas significativas. He elegido tres, que, como hilo conductor, tendrán la voluntad de un hombre que desde su infancia luchó por ser él mismo. Esa lucha, como principio de entidad e identidad, tendió a conseguir un objetivo: ser escritor. «Voluntad de ser» será la referencia de la primera etapa, "Voluntad de afirmación» la de la segunda y, finalmente, "Voluntad de subsistir» la de la tercera.

\section{VOLUNTAD DE SER}

Terminaba el siglo XIX y un matrimonio joven formado por José Sender Chavanel y Andrea Garcés Laspalas, naturales de Alcolea de Cinca y casados en la iglesia parroquial de esa villa, trasladaban su domicilio a Chalamera; él ejercería como secretario del ayuntamiento, y ella, como maestra. Les acompañaba el primer y único fruto de su unión, Concha, nacida en Alcolea el 14 de diciembre de 1897. Ya en Chalamera, el 6 de septiembre 
de 1899 vino al mundo su primer hijo varón, José Eugenio, fallecido a los seis meses de edad, y el 3 de febrero de 1901 a las cuatro de la mañana nacía nuestro escritor. Se le impusieron los nombres de Ramón, José, Antonio y Blas: Ramón, por una promesa familiar hecha a san Ramón Nonato, patrono de las parturientas, si el niño venía con bien; José, por llamarse así el padre; Antonio, por ser el nombre del padrino, y Blas, santo del día. Fueron padrinos de bautismo doña Rosenda Castillón Fumanal y su hijo, don Antonio Villas Castillón, naturales de Chalamera.

En relación con su primer apellido, el propio Sender advierte: «Como mis lectores saben me llamo Sender - la vocal tónica es la segunda-. Pero muchos me llaman Sénder. Es más cómodo poner el acento en la primera». ${ }^{1}$ También señala que «en casa me llamaban Pepe, porque era el nombre del jefe de la tribu y yo era el hijo mayor. Mi padre se llamaba José, y también mi abuelo y bisabuelo. Aunque mi nombre de bautismo es Ramón José, todos me llamaban dentro de casa Pepe y fuera de ella Ramón. Era como una invitación del destino para la esquizofrenia».2

En octubre de 1963 Ramón J. Sender escribía a don Antonio Villas Español, hijo de su padrino:

\begin{abstract}
Recuerdo muy bien a su padre don Antonio, mi padrino que cuando venía a Alcolea me llamaba a voces antes de llegar a casa y a quien yo salía a recibir alegre y sorprendido por su visita (era la mejor sorpresa para mí). Yo tendría entonces cinco o seis años. Lo recuerdo jovial y sonriente, siempre [...]. Aunque estoy muy lejos de Aragón sigo siendo el aragonés de siempre. Todavía recuerdo cuando ibamos a veces a las fiestas y estábamos uno o dos días en su casa. Desde una ventana en la cocina se veía la vega del río con un paisaje muy extenso. El hogar era ancho y profundo, con cadieras a los lados. Y en el cuarto donde yo dormía había una cómoda con conchas marinas y caracolas que llevándolas al oído daban un rumor misterioso... ${ }^{3}$
\end{abstract}

El matrimonio Sender-Garcés vivió en una casa propiedad de don Joaquín Castillón, hermano de la madrina del escritor. En el corral el pequeño Sender comenzó a dar sus primeros pasos de la mano de Adela Valero, una joven chalamerana que el 3 de septiembre de 1903 ingresó en la congregación de las Hermanas de la Caridad de Santa Ana. Treinta y tres años estuvo dedicada a los párvulos en el colegio de esas religiosas en Alagón, donde fue una institución, y para Ramón J. Sender, una especie de madre honoraria con un afecto y una ascendencia que le autorizaban a dar consejos y reprimendas, vía epistolar, a aquel ahijado ya maduro y famoso residente en Estados Unidos. Sor Adela leía a sus compañeras de congregación las cartas que le escribía Sender; las guardaba celosamente, según

\footnotetext{
1 Ramón J. SENDER, El futuro comenzó ayer (Lecturas mosaicas), Madrid, CVS Ediciones, 1975, p. 118.

2 Ramón J. SENDER, Monte Odina, Zaragoza, Guara, 1980, p. 100.

${ }^{3}$ Carta de Ramón J. Sender a don Antonio Villas Español fechada el 22 de octubre de 1969.
} 
me informó en Alagón sor María Galindo. ${ }^{4}$ En homenaje a su antigua niñera, Ramón J. Sender llamó Adela a la ardilla protagonista de su novela Adela y yo.

\section{Alcolea}

En 1903 el matrimonio Sender-Garcés regresó a su pueblo natal con sus hijos Concha y Ramón. El padre ejercería como secretario del ayuntamiento y la madre dejó la docencia para dedicarse a la familia, que se vio aumentada el 31 de diciembre de ese año con el nacimiento de una niña. Se instalaron en la casa número 2 de la Travesía de la Santa Cruz.

En la obra de nuestro escritor abundan las referencias a su infancia. Antes de entrar en ellas, les voy a leer unas líneas que, por mediación de María Garcés, prima hermana del escritor, me hizo llegar un coetáneo de Sender, don José Abenoza Suñé:

Recuerdo -dice- que los amigos le llamábamos Pepito; ibamos a la escuela de párvulos que llamábamos escuela de abajo. Era chico aplicado y serio, la maestra se llamaba doña Pilar; a veces jugábamos al juego llamado de los conejitos: se trataba de encontrar a quienes nos escondíamos, tocar a uno, que era el que volvía a buscar a los que se escondían; alguna que otra vez nos tirábamos piedras en los porches que están delante de la escuela y nos escondíamos detrás de los pilares de esos porches para librarnos de las pedradas. En esos mismos porches jugábamos a la rueda chicos y chicas ya que hasta los siete años íbamos juntos a dicha escuela; otras veces íbamos a las eras a jugar y ver unos pozos que llamábamos «los pocetes», desde donde mirábamos a un corral llamado "corral del carretero", donde había unos conejos. Cerca de allí había una cueva que llamábamos «la cachola de los murciélagos» y que estaba o está en la era llamada «de Carrasco». Otras veces íbamos a otra cueva llamada «casa la Roqueta». Y estos son a grandes rasgos los recuerdos que tengo de nuestra infancia. 5

Las cuevas... No sólo fueron para el niño Sender lugar de juegos y andanzas, sino también escenario de alguna vivencia profunda, como la que narra en Réquiem por un campesino español. En otros escritos nos habla de otras experiencias como monaguillo de quien entonces era párroco de Alcolea de Cinca, mosén Antonio Miralvés Santamaría, natural de Esplús (Huesca).

Ramón J. Sender nos cuenta asimismo la impresión que le causó el retorno del cometa Halley en 1910, el miedo que le producían las tormentas o la extrañeza que sentía cuando de madrugada en la cama oía cantar las "cuplillas»... Y, puestos en música, recuerda a un amiguito que recibía clases de violín de un italiano, «al menos le llamaban el italiano -escribe Sender-, que caminaba doce o quince kilómetros para venir a darle clases dos veces por semana». ${ }^{6}$ Aunque el escritor no da el nombre, yo creo que se refiere a don José Guioni Levetti, de origen italiano y nacido en 1880 en

\footnotetext{
4 Conversación del autor con sor María Galindo, 11 de agosto de 1990.

5 Carta de don José Abenoza al autor, 12 de abril de 1971.

6 Ramón J. SENDER, Crónica del alba, t. I, Barcelona, Destino, 1980, pp. 594-595.
} 
Ontiñena, localidad próxima a Alcolea, de la que Sender, por ejemplo, habla en El lugar de un hombre. Con el tiempo Guioni se instaló en Sariñena, donde siguió dando clases, y con el mismo fin se trasladaba a algunos pueblos vecinos. Yo lo conocí. Supongo que a él se refiere el ilustre profesor, hijo de Alcolea, don José Manuel Blecua cuando dice que de una localidad vecina iba a su pueblo natal un profesor de violín a enseñar música, pero que él no pasó del solfeo porque creía que se aprendía muy pronto a tocar y luego vio que no era así. ${ }^{7}$ El maestro Guioni murió en Sariñena en 1953.

Ramón J. Sender nos habla en algunos pasajes de su obra de travesuras, como colocar una esquila a un buitre, o de peleas, de las que guardaba alguna huella: "Tengo alguna cicatriz en mi cuerpo, consecuencia de agresiones. Entre ellas una en la frente, de una pedrada, siendo chico. No guardo el menor rencor contra los agresores, algunos de los cuales viven y pueden ser mis amigos». ${ }^{8}$ Nos habla también de las cigüeñas que se instalaban en la torre de la iglesia o de las campanas, sobre las que deja referencias en Monte Odina, Réquiem por un campesino español y, sobre todo, en El fugitivo. «Bárbara», «María», "Juana» y «Marta» eran sus nombres. Hoy solamente existen "Bárbara» y "María». Todas, especialmente "Bárbara», con su variado repertorio cumplian con funciones como dar las horas, anunciar las fiestas, convocar a los cultos o, en caso de siniestro, tocar a rebato. ${ }^{9}$

\section{De bandoleros y otros recuerdos}

Las guerras carlistas fueron germen de bandoleros, dado que muchos veteranos de la lucha se lanzaron al monte. Algunos alcanzaron una mítica aureola entre la gente sencilla por aquello de que robaban a los ricos para darlo a los pobres. Uno de éstos fue Mariano Gavín, apodado «Cucaracha», que, hasta ser muerto por la Guardia Civil en 1875 , se movió por los montes de Monegros y cercanías del Cinca. En junio de 1874 varios miembros de su banda fueron capturados en Alcolea de Cinca. ${ }^{10}$ Ramón J. Sender cuenta cómo su abuelo paterno tuvo alojado en su casa a un bandolero llamado "Ramonillo", que llegó una noche pidiendo auxilio. Al marcharse al día siguiente, se identificó y le dio las gracias. Era uno de aquellos bandidos con tirón popular por el referido altruismo con los necesitados. Ramón J. Sender recuerda haber hallado en los caminos alcoleanos, siempre en las encrucijadas, algún montón de guijarros sobre el lugar donde había sido enterrado un malhechor. Él arrojaba también el

\footnotetext{
${ }^{7}$ María Pilar PERLA, "José Manuel Blecua. Mis primeras lecturas fueron tebeos, Julio Verne y Salgari», Heraldo de Aragón, 2 de diciembre de 1922.

8 Ramón J. SENDER, Libro armilar de poesía y memorias bisiestas, México, Aguilar, 1974, p. 401.

${ }^{9} \mathrm{La}$ información sobre las campanas se la debo a don Pablo Mariñoso, párroco de Alcolea de Cinca.

10 Vid. Rafael ANDOLZ, El bandido Cucaracha y Puchamán de Loarre, Zaragoza, Librería General, 1982, pp. 9-55.
} 
suyo. ${ }^{11}$ No es extraño que cuando llegó a Albuquerque (Nuevo Méjico), tierra de algunas de las andanzas de "Billy el Niño», se sintiera predispuesto a escribir sobre este bandido. Así lo hizo en El bandido adolescente.

No faltan en la obra de Sender referencias a la leyenda sobre el origen del santo Cristo de los Milagros, devotamente adorado en Alcolea, ni a las famosas ripas - de las que ya se ocupó Braulio Foz en su Vida de Pedro Saputo- ni a otros lugares y costumbres alcoleanos. También dedicó abundantes páginas a la vida de su familia. Así, por él sabemos del amor que profesó a su madre, de la severidad de su padre, que le obligó - por reacción o autodefensa- a cimentar su personalidad, a fortalecer su voluntad en aras de una identidad que fue forjando contra viento y marea. En esos recuerdos aparece también la entrañable tía Ignacia —casada con don Antonio Laspalas Garcés, primo hermano de su madre-, que acudía a casa de los Sender a realizar faenas domésticas y a atender a los pequeños; éstos escuchaban embobados los cuentos de miedo que les contaba. Sin olvidarnos de la atención que nuestro escritor dedica en diversos lugares de su obra a su abuelo paterno, don José Sender Torres, muerto a los 92 años de edad el 8 de enero de 1922, a quien muestra como paradigma del hombre natural, curtido en la vida por la experiencia y la sabiduría emanadas del mundo rural. Alcolea... A la altura de sus setenta y siete años Ramón J. Sender escribía desde San Diego a la alcoleana doña María Peralta: «Creo que las ripas o la placeta del agua valen más que Zaragoza y más que Nueva York con todos sus rascacielos».12

\section{El niño Sender y la letra impresa}

Pero la atención de Ramón J. Sender no solamente se fija en Alcolea y Chalamera, sino que se extiende a los pueblos vecinos y a personas relacionadas con ellos. Así, en sus escritos aparecen Felipe Aláiz, natural de Belver de Cinca; Francisco Carrasquer, hijo de Albalate de Cinca, o el pintor catalán Viladrich, tan vinculado a Fraga, sin olvidarnos de Miguel Servet, nacido en Villanueva de Sijena, al que Sender dedica admiración y letras. Pero de la relación Sender-Servet quien mejor podría hablar es el aragonés, profesor en Nueva York, Ángel Alcalá, eminente servetólogo, de quien Sender en un artículo titulado «Miguel Servet, ayer y hoy" escribió que era "el más calificado y mejor comentarista e intérprete que Servet, quemado en Ginebra, ha tenido en la agitada y laboriosa historia del mundo de la fe y del pensamiento hispánicos». ${ }^{13}$

Costumbres, personajes, flora y fauna de esta tierra, que contribuyeron a cimentar la personalidad del pequeño Sender, quien con el tiempo seña-

11 Ramón J. SENDER, «El bandido sentimental», La Libertad, 3 de febrero de 1935, p. 1. Vid. también Ramón J. SENDER, "My grandfather was a Mountaineer», Harper's Magazine, 186/1114 (marzo de 1943), pp. 377-379.

12 Carta de Ramón J. Sender a María Peralta, 31 de mayo de 1978.

13 Ramón J. SENDER, «Miguel Servet, ayer y hoy», El Noticiero Universal, 12 de febrero de 1981, p. 11 . 
laría: «En el fondo soy un campesino aragonés - mi zona cultural-, es decir, un hombre de una sencillez natural que come pan, bebe vino y dice la verdad». ${ }^{14}$ No es de extrañar, por lo tanto, que escriba:

No hay gran novela, creo yo, sin un fondo rural. Al menos en los tiempos modernos. El campo es en arte literario un elemento natural de selección y depuración. En la ciudad una tontería puede ser aceptada si va envuelta en alguna forma de ingenio. Una trivialidad si va apoyada por la intención. En el campo, no. La trivialidad y la tontería no se salvan por la intención ni por el ingenio. Cada palabra campesina tiene su lugar (no se dicen entre los campesinos sino las que no pueden menos de ser dichas) e irradia, como los metales ionizados. 15

En aquel ambiente campesino Ramón J. Sender se familiarizó con la naturaleza y... con la letra impresa. Entre sus lecturas estaban los famosos cuentos de Calleja, de los que escribe: «Aquellos folletitos en dieciseisavo con cubierta en colores y una narración más o menos torpe en ocho o diez páginas, me abrieron horizontes nuevos. Me asombraron de que los niños fueran tratados en aquellas narraciones con respeto. Yo no podía distinguir la ficción de la realidad y el prestigio de la letra impresa era entonces enorme para mí». ${ }^{16}$

\section{Valentina}

En 1911 el matrimonio Sender-Garcés, ya con siete hijos, decidió buscar nuevos horizontes con la mirada puesta en el porvenir familiar. Don José Sender aceptó la oferta que se le hizo para ocupar la secretaría del ayuntamiento de Tauste (Zaragoza). Y a esta importante localidad de la comarca de las Cinco Villas se trasladó con su familia.

Sobre sus vivencias en esta histórica villa nos habla Sender a través de su trasunto Pepe Garcés en Crónica del alba. Solamente me referiré a uno de los personajes clave de esa narración: Valentina, su amor infantil. Una niña, escribiría, de «ojos rasgados, la boquita saliente y el óvulo perfecto, con un color de piel aceitunado y claro». Rodolfo Araus Ventura, uno de los hijos de Valentina, mantuvo correspondencia epistolar con Ramón J. Sender. En una de las cartas le escribía: «Siento mucho decirle que Valentina murió y que su vida distó mucho de ser feliz. En cambio hallo gran placer en poder manifestarle que fue una mujer extraordinaria y que éste es y será para los que la amamos nuestro mejor consuelo». ${ }^{17}$ En su contestación Sender señalaba:

No necesito decirle que lamento desde lo más profundo de mi alma que Valentina haya muerto, pero en fin hace muchos años era para mí sólo un ángel [...]. Si es usted tan amable y tiene tiempo le agradecería que me escribiera algo más diciéndome, por ejemplo, si sufrió Valentina en su enferme-

14 Ramón J. SENDER, Una virgen llama a tu puerta, Barcelona, Destino, 1973, p. 207.

15 Ramón J. SENDER, «Kazantzakis, novelista de Creta», Aragón/Exprés, 11 de abril de 1978, p. 20.

16 Ramón J. SENDER, Crónica del alba, t. II, ed. cit., pp. 534-535.

17 Carta de Rodolfo Araus Ventura a Ramón J. Sender, 18 de abril de 1966. 
dad (iqué habría hecho yo para evitarle la más pequeña molestia en su vida!) y si tuvo satisfacciones verdaderas, aunque supongo que sí, ya que, teniendo hijos, conoció las dulzuras de la maternidad. ${ }^{18}$

En otra carta Sender escribía a su corresponsal:

La figura de tu buena madre quedará en el conjunto de la obra (Crónica del alba) como la de una figura encantadora, con su halo espiritual que tiene ahora y que para mí ha tenido siempre. Sin materialidad alguna, casi... Si yo fuera un poeta como Dante el nombre de tu madre quedaría en la historia como el de Beatriz. Y tal vez en el futuro si alguien se acuerda de ese libro mío, citará el nombre de tu madre como se cita ahora el de Beatriz. Al menos la idea (atrevida y todo) me gusta. ${ }^{19}$

No menos entrañable resulta la figura del hermano lego de Hipogrifo violento. Ramón J. Sender fue llevado a Reus en octubre de 1913 para cursar el tercer curso de bachillerato en el colegio San Pedro Apóstol de los Hijos de la Sagrada Familia. Era rector de ese centro el padre Francisco Mascaró (Miró en la novela). Natural de Albelda (Huesca), fue compañero del padre de Sender en el seminario de Lérida. Éste abandonó los estudios eclesiásticos y el reverendo Mascaró ingresó en la orden de los Hijos de la Sagrada Familia.

En carta a Julio Guillén, fechada el 16 de julio de 1956, Sender escribe: «Todo en Hipogrifo es autobiográfico. Incluso el lego existió (murió pocos años después, en plena juventud), y era un tipo angélico, con santidad natural (esa impresión me daba a mí de chico, aunque confusamente, claro) [...]. El taller y sus pintorescas circunstancias existían también". Según mis indagaciones, el hermano lego se llamaba Alejandro Mateu Esparvé. Fue uno de los religiosos que formaron la primera comunidad del colegio San Pedro Apóstol de Reus. En su expediente personal y otras fuentes de la orden se habla de él como un santo varón. «Era un hombre muy sencillo y, aunque de pocas letras, llegó a identificarse plenamente con el espíritu del Instituto sufriendo y arriesgando por él», se dice del hermano Mateu, el lego inmortalizado por Ramón J. Sender. ${ }^{20}$

\section{VOLUNTAD DE AFIRMACIÓN}

Concluido el bachillerato, Ramón J. Sender quiso cumplir su deseo de ir a Madrid con el fin de «huir de la familia y ver de cerca las "grandes

\footnotetext{
18 Carta de Ramón J. Sender a Rodolfo Araus Ventura, 23 de abril de 1966.

19 Carta de Ramón J. Sender a Rodolfo Araus Ventura, 14 de octubre de 1966.

${ }^{20}$ La información sobre los religiosos Hijos de la Sagrada Familia se la debo al padre José María Blanquet, superior general e historiador de la orden.
} 
figuras", rey, jefes políticos, grandes responsables de lo bueno o lo malo».21 «No te preocupes - le dijo a su madre-, con un kilo de cuartillas y un litro de tinta sabré ganarme la vida en cualquier parte». Como se ve, su voluntad de llegar a la meta que su vocación le señalaba le estimuló a quemar etapas rápidamente.

En Madrid, diría Sender, recibió la primera impresión directa y honda de una realidad española completamente distinta de la que se imaginaba. "Leí desordenadamente, voracísimamente, $y$, naturalmente, también escribí. A esa edad es inevitable; pero como yo carecía de vanidad intelectualista, aquelos escritos tuvieron un aire sencillo y sentimental bastante tolerable».22

El joven Sender hizo del Ateneo madrileño su centro de lectura y escritura. Allí, además, pudo observar las idas y venidas de importantes personajes de la vida nacional. Dada su estrechez económica, recurrió a un menester con el que ya estaba familiarizado: mancebo de botica. Como tal trabajó en la de don Toribio Zúñiga Sánchez-Cerrudo, que, pasado un tiempo, lo despidió. Fue a la farmacia Francisco Cambó, líder de la Lliga Catalana y ex ministro de Alfonso XIII, a comprar un desinfectante de uso externo. Sender se confundió. Volvió Cambó con la sospecha de que se había producido una equivocación. Subsanado el error, el farmacéutico le dijo a Sender: « $\mathrm{jHa}$ estado usted a punto de matar al líder de la Lliga Catalana! ¡Habrían dicho que yo, como castellano, soy un anticatalanista!»». ${ }^{23} \mathrm{El}$ mancebo fue puesto en la calle. «Por entonces - escribe Sender- leía versos modernistas que me dejaban aturdido con sus efectos de sinestesia y aliteraciones y vaguedades órficas, pero dos días después me quedé lleno de versos y sin domicilio (no podía pagar mi cuarto). Además me sentía amenazado por fieras hambres». ${ }^{24}$

El doctor Zúñiga era un hombre con afición literaria. Natural de Béjar (Salamanca), publicaba una revista titulada Béjar en Madrid, en la que no faltaba un rincón literario, al que invitó a su joven ayudante. En esta publicación localicé dos poemas de Sender titulados "Paz" y "Diciembre». En el primero, publicado el 16 de noviembre de 1918, aparece por primera vez, que yo sepa, la firma «Ramón J. Sender». En anteriores escritos firmaba «R. José Sender» o con algún seudónimo. También el mancebo mostró en Béjar en Madrid sus habilidades para el dibujo, al ilustrar un cuento de su patrón, cuya afición a la literatura ha sido correspondida brillantemente por su hijo, el excelente escritor Juan Eduardo Zúñiga.

21 Del cuestionario que Francisco Carrasquer presentó a Ramón J. Sender, publicado en "Cuestionario", Alazet («Boletín Senderiano", 2), 3 (1991), p. 175.

22 José Luis Salado, «Los nuevos. Ramón J. Sender engordó cuatro kilos en la cárcel», Heraldo de Madrid, 15 de mayo de 1930, p. 8.

23 Ramón J. SENDER, Crónica del alba, t. II, ed. cit., p. 214. Vid. también Luz CaMPANa DE WaTTS, Ramón J. Sender. Ensayo Biográfico-Crítico, Buenos Aires, Ayala Palacio Ediciones Universitarias, 1989, p. 105.

24 Ramón J. SENDER, Crónica del alba, t. II, ed. cit., p. 214. 
Durante su estancia en Madrid Sender vivió en malas pensiones. En una de ellas tuvo que calmar a un muchacho de Huelva que, habiéndose enterado de que su novia había ido al cine con otro, dijo despechado: « $Y_{0}$ la mato!». "Nos costó mucho trabajo hacerlo desistir y quitarle el revólver que había comprado", añade Sender. ${ }^{25}$ Pero no siempre durmió a cubierto. A veces lo hizo en el parque del Retiro. Cuenta Luis Buñuel que un día lo encontró dormido - sentado y con el sombrero puesto- en un banco frente al Ministerio de la Guerra. Lo despertó y le dio dos pesetas para que fuera a desayunar. ${ }^{26}$ Buñuel, como es sabido, pertenecía a una familia acomodada.

El joven Sender quiso cursar en Madrid estudios universitarios, pero la estragadora gripe que azotó a España en los años 1918 y 1919 obligó a que se cerrara la universidad. Frustrado este proyecto, Sender se dedicó de por vida a formarse por su cuenta.

\section{Firma en la prensa}

Una muestra de su voluntad de afirmarse, de ser alguien en el mundo de las letras, fue su colaboración en varios diarios madrileños. Uno de ellos fue España Nueva, que se proclamaba «periódico escrito por republicanos y socialistas, defensor de las clases humildes y de los obreros». Fue durante algún tiempo medio de expresión de la CNT, cuya prensa estaba amordazada por el Gobierno. Tal vez llegó Ramón J. Sender a este diario de la mano de Gil Bel, un libertario aragonés instalado en Madrid en 1919 tras haber dirigido en Zaragoza el periódico republicano El Ideal de Aragón. Años más tarde las firmas de Sender y de Bel coincidirían en Solidaridad Obrera.

Nueve artículos de Ramón J. Sender -firmados con el seudónimo «Lucas La Salle»- localicé en España Nueva. De dos de ellos sólo apareció un recuadro en blanco, a causa de la censura. Su primera colaboración en ese diario se tituló «Leiba Bronstein» — verdadero nombre de Trotski-. Apareció el 25 de mayo de 1919. Habla en él de un imaginario encuentro en Madrid con el revolucionario ruso. En realidad, como veremos, Sender conoció personalmente a Trotski en 1940, en México D. F. En su último artículo en España Nueva - publicado el 27 de junio de 1919- Sender intercaló un soneto acróstico, que resultó ser una auténtica trampa para el censor. «Irás al patíbulo» es el resultado de la lectura de las letras iniciales de cada verso. Destinatario, el rey.

Años más tarde un soneto de esas características fue dirigido al general Primo de Rivera. El censor no se apercibió de que con las iniciales de cada verso se componía la frase «Primo es borracho». Publicado en el diario primorriverista La Nación, fue firmado por la "Señorita Valdecilla", seudónimo empleado en esa ocasión por José Antonio Balbontín.

\footnotetext{
25 Ramón J. SENDER, «Nancy», Blanco y Negro, 3429 (1978), p. 68.

26 Vid. Max Aub, Conversaciones con Buñuel, Madrid, Aguilar, 1985, p. 56.
} 
Otro de los diarios madrileños en los que colaboró el joven Sender fue El País, «remanso de literatos fracasados, albergue de ganapanes, más o menos ilustres; asilo de poetas beodos; ateneo de grandes figuras y mitin constante de republicanos íntegros", al decir de Arturo Mori, redactor que fue de ese diario. ${ }^{27}$ El 14 de junio de 1919, con motivo de cumplirse medio año de la muerte de Rosa Luxemburgo, El País publicó un poema de Ramón J. Sender en homenaje a esa luchadora espartaquista. Lo firmó con su seudónimo habitual de aquel tiempo en la prensa madrileña: el ya citado «Lucas La Salle».

Finalmente, el 6 de julio de 1919 Ramón J. Sender publicó en La Tribuna "Las brujas del Compromiso", un cuento cuya acción, como delata el título, se desarrolla en Caspe. La Tribuna era un diario conservador, militarista y taurófilo. Lo dirigía Salvador Cánovas Cervantes, que años más tarde recalaría en Solidaridad Obrera. Jean-Pierre Ressot, profesor de la universidad de París-Sorbonne, señala que «Las brujas del Compromiso" es un cuento fantástico, dado que presenta el esquema estructural común a este tipo de narración: equilibrio entre la realidad y lo imaginario. Añade que es un escrito claramente romántico. ${ }^{28}$ Similar punto de vista mantiene Patrick Collard, quien apunta que quizá no están muy lejos de ese cuento las Sonatas de Valle-Inclán y las Leyendas de Bécquer. ${ }^{29}$

En «Las brujas del Compromiso» hay alguna referencia biográfica del autor que bien puede ajustarse a la realidad. Escribe que llegó a Caspe por primera vez cuando agonizaba el año 1917 impelido por asuntos familiares. «Conmigo - añade- llevé algunas "contratas" literarias de Barcelona, dispuesto a trabajar, a trabajar de veras». En esa época residía la familia Sender en Caspe, de cuyo ayuntamiento era secretario el padre. Respecto de esas contratas, pudieron estar relacionadas con la revista Charlot, en la que el dibujante Rojo daba vida a "Cocoliche» y «Tragavientos», personajes que parodiaban a dos detectives. Sender en Crónica del alba habla de un escritor zaragozano apellidado Sánchez Bosqued, inventor de esa serie de aventuras. ${ }^{30}$ Por otra parte, Luis Buñuel cuenta que Ramón J. Sender escribió hacia 1918 para un editor de Barcelona unas tiras cómicas que se llamaban «Cocoliche» y «Tragavientos». 31

27 Arturo MORı, La prensa española de nuestro tiempo, México, Ediciones Mensaje, 1943, p. 51.

28 Jean-Pierre REssot, «Ramón J. Sender, escritor primerizo ("Las brujas del Compromiso")», Revista de la Universidad Complutense, 108 (abril-junio de 1977), pp. 250-261.

29 Patrick COLLARD, Ramón J. Sender en los años 1930-1936. Sus ideas sobre la relación entre literatura y sociedad, Gante, Rijksuniversiteit te Gent, 1980, p. 38.

30 Ramón J. SENDER, Crónica del alba, t. I, ed. cit., pp. 530-531.

31 Vid. Max Aub, Conversaciones con Buñuel, ed. cit., p. 96. 
Aunque en el vespertino madrileño La Correspondencia de España se daban a priori las condiciones más propicias para que el joven Sender colaborara allí, no fue así. Lo dirigía un zaragozano, Leopoldo Romeo, en torno al cual había varios excelentes periodistas aragoneses, entre quienes se encontraba José García Mercadal, que fue director en Zaragoza de La Voz de Aragón. En este periódico se asomó Ramón J. Sender por vez primera a las páginas de la prensa diaria. Era el año 1916. "Noche de ánimas", «Domingo de pandereta», "Lo puramente castizo», "No sería España» y «Ocurre a veces» son los títulos de los escritos del adolescente Sender aparecidos en $\mathrm{La}$ Voz de Aragón. Ahora bien, volviendo a La Correspondencia de España, ¿acaso Ramón J. Sender no quiso acercarse a este periódico y, concretamente, a García Mercadal, amigo de su padre, para resguardar así sus pasos en la Corte?

En cualquier caso, no deja de ser meritorio que un muchacho de provincias, sin raigambre en Madrid, colocara sus escritos no en uno sino en varios periódicos de la capital, donde permaneció hasta que un día, cuenta Sender, «estaba yo profundamente dormido en un sillón del Ateneo cuando alguien me tocó en el hombro. Abrí los ojos. Era mi padre. Yo dije: "¿Tú aquí?". Mi padre respondió secamente: "Vamos a casa"».32 Y a Huesca se fueron.

\section{VOLUNTAD DE SUBSISTIR}

A principios de marzo de 1939 Ramón J. Sender se embarcó en Francia con sus hijos Ramón y Andrea en el «U. S. Manhattan» con dirección a Estados Unidos. En este barco norteamericano - destruido por los alemanes- viajaba también Erich Remarque, autor de Sin novedad en el frente. Atrás quedaba París, Europa... Iba a comenzar una nueva vida en el exilio. La voluntad de subsistir allanaría dificultades y abriría puertas.

En Nueva York, Ramón Sender Barayón, de cuatro años y medio, y su hermana Andrea, de tres, quedaron al cuidado de Julia Davis, hija de John W. Davis, prestigioso abogado neoyorquino y aspirante a la presidencia norteamericana por el Partido Demócrata en las elecciones que en 1924 ganó el republicano Coalidge.

La buena disposición de esta dama tendía a facilitar libertad de acción al escritor recién llegado para que encontrara trabajo y acomodo. Que fue a buscar en Méjico, donde el conocimiento del idioma le haría más viables sus planes. Julia Davis insistió en que los pequeños se quedaran con ella hasta que Sender estabilizara su posición en tierra mejicana. Nadie podía imaginar entonces la gran vinculación que se iba a producir entre esta

\footnotetext{
32 Ramón J. SENDER, Crónica del alba, t. II, ed. cit., p. 219. Vid. también Marcelino C. Peñuelas, Conversaciones con Ramón J. Sender, Madrid, Magisterio Español, 1970, p. 77.
} 
dama y los hijos del escritor. "Los meses se convirtieron en años - ha escrito Sender Barayón- hasta que quedó tácitamente entendido que nos criaría como a sus propios hijos».33

En enero de 1955 Ramón J. Sender escribía a Joaquín Maurín:

La familia que tiene a mis niños es la de John W. Davis. Julia no puede tener hijos y tiene a los míos como si fueran suyos. Yo me resigné hace años por diversas consideraciones (la más importante es demasiado romántica para decirla y no la he dicho a nadie, aunque la tengo escrita en un largo documento donde cuento muchas cosas y encerrada en una caja de un banco en Wall Street, cuya llave - única- arrojé en 1940 al río Hudson). En ese documento digo por qué los rusófilos - por orden de Moscúse propusieron acabar con algunas personas, entre ellas yo. A las otras las mataron, después de la guerra. Conmigo no se atrevieron, pero podía ser que intentaran algo - me amenazaron dos veces concretamente-. En el caso de que ocurriera algo no quería que mis chicos sufrieran un nuevo shock después de haber conocido tantos en la guerra civil. [...]. No perdonaré nunca a los comunistas que me hayan privado de una de las satisfacciones más legítimas de la vida: vivir con mis hijos [...]. Los papeles que tengo en el banco deberán sacarse y ser publicados «el día que me pase algo", aunque creo que los comunistas han renunciado y se conforman con lo que ellos llaman la muerte civil, es decir, la persecución sistemática por la calumnia, etc. 34

Viene al caso recordar la declaración que Ramón Sender Barayón hizo al diario El Independiente:

Mi padre siempre creyó que los comunistas estaban en contra del Frente Popular y decía saber datos y acciones de los comunistas contra los republicanos. Tenía bastante información peligrosa para ellos y conocía lo que llamaba la "traición comunista». Él temía por su vida, incluso en Nueva York. En una ocasión fue llamado desde un barco español atracado en el puerto diciéndole que tenía un paquete. Allí intentaron secuestrarle para llevarlo a España y fusilarlo. 35

\section{Problemas varios}

Lo cierto es que, como cuenta el propio Sender, no más llegar a Méjico un comunista le retuvo en una oficina pública el pasaporte tras pedírselo con el fin de tramitar su naturalización mejicana. Cuando Sender volvió al día siguiente el pasaporte no apareció. Menos mal que Jaime Torres Bodet, escritor y alto funcionario de la Secretaría de Relaciones Exteriores de Méjico, intervino para que Ramón J. Sender pudiera contar con un nuevo pasaporte. Torres Bodet y el escritor aragonés se conocían de cuando aquél

\footnotetext{
33 Ramón Sender Barayó, Muerte en Zamora, Barcelona, Plaza \& Janés, 1990, p. 22.

34 Carta de Ramón J. Sender a Joaquín Maurín, 19 de enero de 1955.

35 Xabier MARTi, «Ramón Sender. Mi padre era un hombre bastante difícil y algo paranoico», El Independiente, 29 de marzo de 1990, p. 5.
} 


\section{JESÚS VIVED MAIRAL}

vivió en Madrid por los años veinte como secretario de la embajada de su país en España. ${ }^{36}$

Respecto de la relación de Ramón J. Sender con los comunistas —o afines- españoles exiliados en Méjico, es significativo lo ocurrido el día en que fue inaugurada la Casa de la Cultura Española en la capital mejicana en febrero de 1940. Al acto, entre otros, asistieron José Bergamín, Gallegos Rocafull, el doctor Márquez y el italiano Vittorio Vidali —alias comandante Carlos o Carlos Contreras-, uno de los creadores del $5^{\circ}$ Regimiento. Donatella Pini recoge el relato de Vidali en el que cuenta que Sender, también asistente al acto, manifestó que si Vidali se quedaba él se marcharía, como así ocurrió. ${ }^{37}$ Permanecía aún el rescoldo de viejos incidentes, como el relacionado con Seseña, sobre cuyo esclarecimiento la doctora Pini ha aportado importantes trabajos, u otro ocurrido en el frente de Madrid, al que se refiere Sender en una carta dirigida a Joaquín Maurín. "Vittorio Vidali -escribe- fue humillado en condiciones difíciles de olvidar (humillado por mí) en la Ciudad Universitaria de Madrid durante la guerra. Me demuestra que no lo olvida calumniándome en todos los niveles y sentidos». ${ }^{38}$

Ramón J. Sender tampoco mantuvo relación con el grupo creador de la revista Romance, publicación de letras, artes, filosofía y ciencias, cuyo primer número vio la luz el 1 de febrero de $1940 .{ }^{39}$ "Casi todos los redactores - me decía don Antonio Sánchez Barbudo- eran comunistas: Rejano, Herrera Petere, Valera. Yo no lo era. Lo cierto es que el grupo no quiso saber nada con Sender, ni éste con el grupo".40

En Méjico D. F. hablé con don Ricardo Mestre, veterano anarcosindicalista catalán. Conoció a Sender antes de la guerra, pero en la capital mejicana apenas lo vio. Como otros anarquistas, se quejó de que el escritor aragonés publicara Contraataque, donde no les deja bien parados, mientras, por el contrario, se deshace en elogios al $5^{\circ}$ Regimiento, creado y controlado por los comunistas. Sobre este libro Ramón J. Sender escribía a Margarita Nelken: «La edición española de Contraataque sale dentro de ocho días. Se hace una tirada abundante y naturalmente estoy muy satisfecho. Espero la edición vuestra». ${ }^{41}$ De todas formas, respecto a la actitud

\footnotetext{
36 Ramón J. SENDER, Obra completa, t. I, Barcelona, Destino, 1976, p. 10.

37 Carlos J. Contreras, "La degradación de Ramón J. Sender», texto traducido y publicado por Donatella PINI MORO en Andalán, 459-460 (segunda quincena de septiembre - primera de octubre de 1968), p. 31.

38 Carta de Ramón J. Sender a Joaquín Maurín, 13 de septiembre de 1962.

39 Sobre la revista Romance, vid. Francisco CAUDET, Romance (1940-1941). Una revista en el exilio, Madrid, Ediciones José Porrúa Toranzas, 1975.

40 Conversación del autor con el profesor Sánchez Barbudo, 11 de marzo de 1990.

41 Carta de Ramón J. Sender a Margarita Nelken, 26 de febrero de 1938. Aunque en la carta no aparece el apellido, todo indica que va dirigida a ella.
} 
de Sender con los anarquistas antes, en 1934, son significativas unas palabras introductorias suyas a la edición rusa de Siete domingos rojos, publicada en ese mismo año:

Pienso que ayudé mediante este libro al naciente comunismo español en su difícil lucha por liquidar el anarquismo pequeño burgués, que todavía sigue siendo una gran fuerza política entre los obreros y campesinos españoles. Pensé, por una parte, liquidar este fenómeno en mi conciencia y, por otra, que para influir positivamente en los círculos obreros españoles debía hablar su propio idioma, aprovechando de sus propios métodos sus expresiones emocionales. Políticamente este libro es un libro anarquista contra el anarquismo. Me parece que esto fue necesario para España. ${ }^{42}$

\section{Tertulias}

Descartados los ambientes comunistas y anarquistas, ¿en qué medios se desenvolvía Ramón J. Sender en Méjico D. F.? Era lógico que los exiliados, movidos por afinidades de índole política, profesional o de paisanaje, crearan sus propias tertulias. Entre las muchas que se formaron podemos citar la celebrada por los vinculados a la editorial "Séneca" -que dirigía Bergamín- o la del café «El Papagayo», perpetuada literariamente por Simón Otaola en su libro La librería de Arana.

Sender, por su parte, se reunía en un café de la calle Bolívar con Julián Gorkin, Lázaro Somoza Silva —viejo amigo de los tiempos de La Libertad- y Elfidio Alonso, diputado que fue por Unión Republicana y director de $A B C$ durante la guerra civil. Don Elfidio me contaba no hace mucho que Ramón J. Sender quería marcharse a Estados Unidos pero no lo decía. «Quienes pensaban trasladarse a ese país se lo tenían muy guardado con el fin de evitarse complicaciones... Sender se dedicaba íntegramente a la literatura, no hacía política ni frecuentaba grupos políticos. Nuestra tertulia duró unos tres meses. Un día apareció Benjamín Jarnés, quien, tras decir que "todos estamos como distraídos", se dirigió a Sender: "Tú, no; tú estás más centrado". Por cierto que Gorkin y yo queríamos editar un diario de tarde, que en Méjico D. F. no había. Le dijimos a Sender que contábamos con él, pero no veía claro el proyecto. En efecto, no lo conseguimos». 43

El propio Sender escribe que asistió a algunas tertulias celebradas en domicilios de personalidades del mundo intelectual o financiero, lo que le permitió conocer y mantener relación con emigrados españoles y extranjeros. Así, en casa de Michel Berveiller, director del Liceo Francés en Méjico entonces y más tarde profesor de la Sorbona, trató a Jules Romains, a André Maurois o Jacques Soustelle, y en el domicilio de Eduardo Villase-

\footnotetext{
42 Tomadas del texto mecanografiado en ruso que se conserva en el Archivo Literario Central Estatal de Literatura y Arte Ruso. Traducción de Eugueni Smirnov.

43 Conversación del autor con don Elfidio Alonso, 2 de agosto de 1994.
} 
ñor, director del Banco Nacional, a Víctor Serge, a la científica vienesa Marietta Blau o a Romain Rolland y se reencontró con viejos conocidos como Díez-Canedo o León Felipe, contertulios suyos en la Granja el Henar, con Valle-Inclán como protagonista. ${ }^{4}$

Ramón J. Sender se relacionó asimismo con Mr. Conway, uno de los principales directivos de la Canadiense de Electricidad. Conocía bien España. D. H. Lawrence le regaló las pruebas corregidas de La serpiente con plumas y Ramón J. Sender le dedicó su obra Hernán Cortés..$^{45}$ También trató a Pablo Neruda. "Mis relaciones con Neruda - escribe-- fueron francamente cordiales. En materia de ideas políticas no coincidíamos, aunque esa haya sido para mí sólo una razón secundaria, ya que no he pertenecido nunca a ningún partido. Pero tenía mi idea de las cosas y las personas, y él la suya, y estaban muy lejos de coincidir». ${ }^{46}$

En Méjico tuvo Sender un apasionado reencuentro con Elena CruzLópez, hija de un destacado directivo de El Sol. A Elena dirigió Sender su Carta de Moscú sobre el amor. (A una muchacha española) (1934). En 1963, tras divorciarse él y Florence Hall, cuando residía en Manhattan Beach pensó en llevar una mujer a casa. «Casado o no, pero quizá la lleve. Probablemente una antigua novia de los tiempos de España, que ahora está en Méjico y es viuda", le escribía a Joaquín Maurín. ${ }^{47}$ Yo creo que se refiere a Elena Cruz-López, que enviudó en 1957. Al final, Sender no adoptó esa solución.

Otro de los emigrados a Méjico fue el catalán Bartomeu Costa-Amic. Antiguo militante del POUM, es un hombre de larga e intensa dedicación al mundo editorial. Con el señor Costa-Amic he hablado en varias ocasiones, una de ellas en su casa de Méjico D. F. Según su testimonio,

Ramón J. Sender no estuvo integrado en ningún núcleo de la emigración. Era sumamente independiente. Allí todos estaban agrupados: la UGT, la CNT, los comunistas. Había un grupo, el nuestro, formado por viejos militantes del POUM. Él mantenía buena relación con nosotros, si bien no era la política lo que le movía. Le preocupaba lo intelectual, lo literario. Los comunistas, que gozaban de notoria ascendencia, lo tenían atravesado, y él no quería saber nada con ellos. Nosotros también sufrimos una terrible campaña. No hay que olvidar que habíamos contribuido a traer a Trotski a Méjico.

Con Trotski —esta vez, de verdad - se entrevistó Sender en la casafortín en la que aquél vivía en las afueras de Méjico D. F. La entrevista se celebró en francés. Encima de la mesa del despacho del viejo revoluciona-

\footnotetext{
${ }^{44}$ Vid. Ramón J. SENDER, Álbum de radiografias secretas, Barcelona, Destino, 1982, pp. 45-49 y 189. 45 Vid. Ramón J. SENDER, «Héroes aragoneses solitarios», Solanar y lucernario aragonés, Zaragoza, Ed. Heraldo de Aragón, 1978, pp. 204-205.

46 Ramón J. SENDER, Ramú y los animales secretos, Barcelona, Argos/Vergara, 1980, pp. 78-80.

47 Carta de Ramón J. Sender a Joaquín Maurín, 30 de noviembre de 1963.
} 


\section{EL LUGAR DE SENDER}

rio había un ejemplar de Mr. Witt en el Cantón de Ramón J. Sender, en versión rusa con prólogo del hispanista Fedor Kelyn, profesor de la universidad de Moscú. Trotski y Ramón J. Sender hablaron largo y tendido sobre la guerra civil española, sobre literatura, sobre la revolución rusa. Durante la entrevista Sender sacó la conclusión de que su interlocutor estaba encerrado en octubre de 1917 como en un fanal. A esta observación se unió la sospecha de que Trotski ya tenía en casa el verdugo que acabaría con él. No se equivocó. El 20 de agosto de 1940 la mano mercenaria del catalán Ramón Mercader acabó con el revolucionario ruso. ${ }^{48}$

Sender, editor

Ramón J. Sender creó una editorial que bautizó con el nombre de "Quetzal», apócope de "Quetzaltototl», dios del aire y de los fenómenos atmosféricos para los mejicanos de la época precolombina. Entre otros libros, editó los suyos Proverbio de la muerte, El lugar del hombre, Hernán Cortés y Mexicayotl. Pero sin colaboradores, sin ninguna clase de infraestructura y con el deseo creciente de abandonar Méjico, se avino a venderla a un grupo formado por Bartomeu Costa-Amic, Julián Gorkin, Eduardo Villaseñor, Michel Berveiller y ocho franceses pertenecientes al mundo de los negocios. Se trataba de un gran intento editorial de carácter bilingüe (español-francés), en el que Gorkin figuraba como responsable de la sección española. La editorial se convirtió en sociedad anónima. Bartomeu Costa-Amic ya contaba con alguna experiencia en este campo, como «Publicaciones Panamericanas», que se estrenó precisamente con la reedición de $O . P$. de Ramón J. Sender.

Este ambicioso proyecto sólo duró unos meses. Un día, cuando celebraban el éxito de la publicación de la novela Clochemerle, de Gabriel Chevalier, apareció la madre del tesorero de la editorial, una señora alta, flaca, vestida de negro, y comenzó a repartir paraguazos mientras decía a gritos que aquel libro era un insulto para Francia: « $i$ Para esto ponemos el dinero?». «Tras el incidente - me dijo Costa-Amic- sólo quedamos como miembros de Quetzal Eduardo Villaseñor, Julián Gorkin y yo. Entonces publicamos el libro de Gorkin Caníbales políticos (Hitler y Stalin en España) (1941). La editorial fue languideciendo, pero antes de desaparecer aún publicamos Epitalamio del prieto Trinidad (1943) de Ramón J. Sender». Liquidada, finalmente, Bartomeu Costa-Amic creó su propio negocio editorial con la firma «B. Costa-Amic, S. A.», de larga y sólida trayectoria, que publicó La Quinta Julieta (1957), Emen Hetan (1958) y El sosia y los delegados (1965), de Sender.

48 Ramón J. Sender ha hablado de su visita a Trotski en diversos pasajes de su obra. Por ejemplo, en Album de radiografias secretas, ed. cit., p. 112; en «El Trotski que yo conocí», Historia 16, 18 (octubre de 1977), pp. 129-133. Vid. también Jesús VIVED MAIRAL, «Sender y Trotski», Heraldo de Aragón, 18 de abril de 1991, p. 1. 
Ramón J. Sender ha escrito que en Méjico no tuvo ayuda ni protección de nadie. "No sólo no gané un real, sino que tuve que compartir magros royaltíes con refugiados políticos más pobres que yo». ${ }^{49}$ De hecho pidió ayuda al Servicio de Evacuación de los Republicanos Españoles (SERE), que no le fue concedida. El doctor Puche, director del Comité Técnico de Ayuda a los Refugiados Españoles, en carta fechada el 30 de abril de 1940 le escribía comunicándole la desestimación «por razones de carácter económico» de un crédito solicitado para «una plaza de trabajo». «Me complace comprobar por sus manifestaciones - añade Puche - que su desenvolvimiento en este país va desarrollándose cada día bajo los mejores auspicios y le deseo mucho éxito en sus trabajos». .50

En cualquier caso, de su estancia en Méjico Ramón J. Sender muchos años más tarde destacaba como hecho especialmente negativo la inquina que contra él mostraron los comunistas españoles. «Siempre me acordaré -manifestó- de la desgraciada persecución que sufrí en Méjico, ya exiliado, por parte de los comunistas españoles». ${ }^{51}$

\section{Escribir y más escribir}

«Por primera vez en mi vida no hago sino escribir. En este país bronco y generoso de Méjico, sobre una tierra quemada y bajo un cielo de maravilla escribir tiene la delicia de un juego infantil», dice Sender en la introducción a El lugar del hombre..$^{52}$ Fruto de ese juego, en un momento de intensa carga emocional, es su novela Proverbio de la muerte (1939), en la que bajo un sustrato biográfico discurre un contenido de alcance metafísico. Con este libro el escritor aragonés satisface, dice, ansiedades que «desequilibraron un poco mi acuerdo conmigo mismo desde hace tres años. Me siento inmortal, sé que lo soy y quiero decirlo a los demás porque puede servirles a ellos de reactivo para llegar a las mismas nociones». ${ }^{53}$ Más tarde reelaboró Proverbio de la muerte y le dio un título tan sugestivo como La esfera (1947).

El lugar del hombre (1939) es la segunda de las obras escritas por Ramón J. Sender en Méjico y la primera de su exilio en la que significativamente dirige su mirada a su infancia, a las tierras del Alcanadre y Cinca, aunque la trama argumental se basa en un suceso que él conoció bien como reportero del diario madrileño El Sol: el famoso crimen de Cuenca... que no se

\footnotetext{
${ }^{49}$ Ramón J. SENDER, Obra completa, t. I, ed. cit., p. 8.

50 Datos que obran en el Archivo del Instituto Nacional de Antropología e Historia de Méjico y que debo a la amabilidad del profesor Fernández Clemente.

51 Eduardo ALCALDE, “Una entrevista inédita con Ramón J. Sender», Diario 16, 24 de enero de 1982, p. IX.

52 Ramón J. Sender, El lugar del hombre, México, Ediciones Quetzal, 1939, p. 13.

53 Ramón J. SENDER, Proverbio de la muerte, México, Ediciones Quetzal, 1939, p. 13. Este libro está dedicado al norteamericano Jay Allen, corresponsal de guerra en la contienda española (1936-1939).
} 
cometió. Pasados unos años reelaboró la novela e hizo una modificación sustancial en el título: sustituyó un determinante - «el»- por otro - «un»-. El lugar de un hombre será el título definitivo, más sugerente y cálido, ciertamente. Este libro, en palabras de Ramón J. Sender, «es simplemente un alegato en favor del sentido universal de la presencia del hombre por el hecho de ser hombre, por el simple hecho de haber nacido". 54

A las pocas semanas de su estancia en Méjico Ramón J. Sender se encontró con un actor español amigo. Le prometió escribir una obra en la que hubiera algo de interpretación histórica en relación con España y Méjico. Y escribió Hernán Cortés (1940), «retablo en dos partes y once cuadros». Reelaborado, este retablo se transformó en Jubileo en el Zócalo (1964).

En la citada introducción a El lugar del hombre Ramón J. Sender dice que leía «todo lo que me faltaba leer sobre México y voy de sorpresa al asombro. Había leído entre las cosas fundamentales a Bernal Díaz del Castillo y a Sahagún, pero quedan todavía mil maravillas por conocer». ${ }^{55}$ No es de extrañar, pues, que saliera de su pluma un libro como Mexicayotl, de acento mejicano hasta la médula. Otro libro con resonancias mejicanas es Epitalamio del prieto Trinidad (1942), la obra "más importante de toda la obra narrativa de Sender ambientada en América", según Francisco Carrasquer. ${ }^{56}$

En 1942 vio también la luz en Méjico Crónica del alba, la primera de la serie de nueve narraciones que forman la obra que lleva ese título general. En este librito Pepe Garcés - trasunto literario de Sender- se mueve entre Alcolea de Cinca y Tauste. Mosén Joaquín, su profesor; Valentina, su amor infantil; la tía Ignacia... Todo un rosario de personajes aparece en un entramado autobiográfico que el autor maneja con criterio novelístico. Como en El lugar de un hombre Sender se agarra a su infancia, a su tierra natal...

En fin, con voluntad de subsistir compuso Sender en Méjico un mosaico literario que, ya entroncado con su obra anterior, es un avance de lo que será su producción posterior: atención a los temas históricos y a los hechos dramáticos que tuvo que sortear personalmente, una mirada a los temas americanos y un recuerdo de su infancia tratando de recuperar lo primitivo, lo natural, lo auténtico... Y todo ello como pretexto para profundizar en el devenir, en los derechos y la esencia del hombre... Ciertamente, llama la atención su inamovible apego a la tierra natal, raíz de lo primitivo individual que, como ha señalado José-Carlos Mainer, se complementa con la nostalgia del primitivismo social. «Para el escritor - añade- ese ámbito de libertad primigenia, de comunión espontánea con la tierra, lo

\footnotetext{
54 Marcelino C. PeÑuelas, Conversaciones con Ramón J. Sender, ed. cit., p. 119.

55 Ramón J. SENDER, El lugar del hombre, ed. cit., p. 13.

56 Francisco CARRASQUER, La integral de ambos mundos: Sender, Zaragoza, Prensas Universitarias, 1994, p. 47.
} 
mismo se da en Aragón y lo aragonés que se produce en su contacto con la América indígena o se puede rastrear en el acercamiento de su época revolucionaria al mundo del proletariado anarquista o al mucho más desconocido de las kabilas insurrectas del Rif». .57

En 1942 le fue concedida a Ramón J. Sender una beca de la «Fundación Guggenheim». Al parecer fue recomendado por sir Peter Chalmers Mitchell, que tenía una casa en Acapulco. ${ }^{58}$ Era el momento en que estaba gestionando la obtención del visado de entrada a Estados Unidos, para lo que contó con la recomendación de Eleonor Roosevelt. ${ }^{59} \mathrm{Al}$ final Ramón J. Sender consiguió su objetivo. Entretanto -y más adelante- era buscado en España por la policía. Así, en un escrito firmado por el inspector jefe de Policía de Madrid y dirigido al jefe superior de Policía el 10 de noviembre de 1942 se decía que «hasta el día de la fecha no se ha podido localizar al indicado individuo [Ramón J. Sender], de marcado matiz rojo, y escritor del Sindicalista (sic), suponiéndosele en el extranjero, huido de la liberación total de España». Fue el 12 de julio de 1945 cuando el gobernador civil de Madrid en un escrito dirigido al director general de Seguridad le comunicaba que «el señor Juez de Primera Instancia e Instrucción número 9 de esta capital, con fecha 2 del actual, participa a este gobierno haberse dictado auto de sobreseimiento en el expediente de responsabilidades políticas instruido contra Ramón J. Sender».60

Por otra parte —en relación con un punto que produciría confusiónSender perteneció a una escuadra denominada «Amanecer» en referencia a una revista socialista así titulada. ${ }^{61}$ El hecho de que existiera la «Escuadrilla del Amanecer», famosa por los numerosos registros, requisas y detenciones que realizó en Madrid en agosto de 1936, dio pie a que alguno relacionara a Ramón J. Sender con esta formación de triste memoria, ${ }^{62}$ que se llamaba del «amanecer» porque, como apunta Pedro de Répide,

\footnotetext{
57 José-Carlos MAINER, «El territorio de la infancia y las fuentes de la autobiografía senderiana", en AA. VV., III Curso sobre Lengua y Literatura en Aragón (siglos XVIII-XX), Zaragoza, Institución Fernando el Católico, 1994, p. 146.

58 Dato que debo a don Eduardo Talamantes, que me informó en su casa de San Diego (California) el 5 de mayo de 1989.

59 Vid. Ramón J. SENDER, Relatos fronterizos, México, Mexicanos Unidos, 1970, p. 19, y Nocturno de los 14, Barcelona, Destino, 1970, p. 196.

60 Del expediente policial de Ramón J. Sender, que se conserva en el Archivo Histórico Nacional. En relación con la colaboración de Ramón J. Sender en El Sindicalista, se redujo a un solo artículo. Vid. José Domingo DueÑas LoRente, Ramón J. Sender (1924-1939). Periodismo y compromiso, Huesca, Instituto de Estudios Altoaragoneses, 1994, p. 230.

61 Ramón J. Sender, “Correo del exilio: Carta de Pau. Héroes y rencor cancelado», CNT, 2 (noviembre de 1955), 5.

62 Vid. Emilio ROMERo, «Diario de un espectador. Una mala película y una buena bobada», Ya, 25 de septiembre de 1985, p. 11, y David JATO MIRANDA, Madrid, capital republicana, Barcelona, Acervo, 1976, p. 381.
} 
«operaba de madrugada».63 La escuadra o patrulla de Ramón J. Sender -que terminaría por integrarse como batallón en la $1^{\mathrm{a}}$ Brigada Mixtaactuó en los frentes de Guadarrama y del Tajo.

Tras este inciso, volvamos a Sender con un pie ya en Estados Unidos. Allí continuaría con su inveterada vocación de escritor hasta su muerte en enero de 1982. Su obra perdura; su recuerdo, también. Ese trascender tal vez se corresponda con el que el propio Sender apunta cuando escribe: «Todo es contingente en nosotros menos el misterio de la necesidad de trascender». ${ }^{64}$ Aunque, por el momento en que escribió estas líneas, el trascender posiblemente tenga un sentido --valga la redundancia - más «trascendental».

63 Pedro DE RÉPIDE, Memorias de un aparecido. Relato fiel del sangriento drama español (Madrid, 1936-1937), Madrid, Vassallo de Mumbert, 1977, p. 142.

64 Ramón J. SENDER, Libro armilar de poesía y memorias bisiestas, ed. cit., p. 403. 


\title{
Sender en Albuquerque: la soledad de un corredor de fondo
}

\author{
Francisco Caudet \\ Universidad Autónoma de Madrid
}

\begin{abstract}
Cuando recibí la amable invitación de los organizadores de este Congreso a presentar una ponencia, decidí, sin pensarlo dos veces, este título. Luego he comprendido que en esa decisión, un tanto impulsiva, había una cierta lógica. Porque en ese momento tenía en la memoria las cartas de Sender pertenecientes a los años de Albuquerque - acababa entonces de corregir pruebas del libro en el que recojo el epistolario de Sender con Maurín-, 1 que me habían causado una fuerte impresión.

La memoria de las cartas del largo periodo de Sender en Albuquerque —años 1947 a 1964 - debió de traerme a la memoria - por sinuosos pero explicables meandros- el libro de Alan Sillitoe The loneliness of the longdistance runner. ${ }^{2}$ Ahora, al ponerme a escribir esta ponencia, he buscado entre mis libros el ejemplar que creía — así ha sido- conservar en casa. Se trata de un librito en rústica que me compré en Nottingham (Inglaterra) en 1968.
\end{abstract}

1 Cfr. F. Caudet, Correspondencia Ramón J. Sender-Joaquín Maurín 1952-1973, Madrid, Ediciones de la Torre, 1995. En adelante, las referencias a cartas, de las que solamente doy la fecha, remiten a este libro.

2 A. SILliTOE, The loneliness of the long-distance runner, Londres, PAN Books, 1968, 11ªd. 
La portada de esta edición del libro de Alan Sillitoe reproduce en un primer plano el rostro, altanero y desafiante, del protagonista. Además, hay otras dos escenas. En una está Smith -así se llama el protagonista de la novela - con un compinche desvalijando una caja fuerte; en otra, le hace el amor a una joven en un descampado en el que destaca, al fondo, la silueta de unas naves industriales y unos postes eléctricos... Ese esbozo fabril recuerda el que describe Baroja en uno de los primeros capítulos de Camino de perfección. ${ }^{3}$

Los hilos sueltos que explican el título de mi ponencia son, por tanto: Sender exiliado en Albuquerque, el libro de Alan Sillitoe sobre un desecho social, mi propio deambular por el extranjero —salí en 1966 y regresé a España en 1982- y, no lo he mencionado aún, el libro de Peter Weiss Estética de la resistencia, ${ }^{4}$ título, sin duda —al menos, para mí-, emblemático.

Todos estos datos configuran el primer atisbo, borroso e inconexo, de una trama. $\mathrm{O}$, si se prefiere, los primeros pasos hacia la construcción de un discurso en el que se engarza el trabajo de investigación sobre un autor - en este caso Sender- con la búsqueda de explicaciones sobre unas experiencias personales. El investigador tiene motivaciones no siempre exclusivamente académicas cuando empieza un estudio. A menudo no resulta evidente si éstas despiertan el interés por un tema concreto o éste, el tema, alienta en el investigador la autorreflexión.

En mi trabajo de investigación sobre la correspondencia de Sender y Maurín, entraba de lleno mi obsesiva preocupación por los apátridas, por los marginados, por los desclasados, por quienes, en palabras de Shakespeare, forman parte del "seamy side of life». ${ }^{5}$ Esas situaciones, todas ellas límite, suelen ser un campo abonado para que al menos algunos desarrollen una inesperada capacidad de aguante, un sorprendente sentido de resistencia. La soledad, la impotencia, el dolor del desarraigo -uno de los dolores más insufribles - son campo abonado para poner a prueba la resistencia, la principal condición de todo corredor de fondo. Porque o se tira la toalla o se sigue en la brecha, corriendo, resistiendo. Se trata de comprobar quién puede más.

Sender, antes de abandonar España en 1937, había ya dado muestras de su capacidad de resistir, siempre en su caso con la pluma en la mano. Daré este ejemplo que se remonta a 1919, año en que escribió «Las brujas

\footnotetext{
3 Cfr. cap. II de P. Baroja, Camino de perfección, Madrid, Caro Raggio, 1974, p. 13.

4 P. Weiss, Estética de la resistencia, Barcelona, Versal, 1987. Cfr. también F. CAUdeT, «España: estética de la resistencia», en Las cenizas del Fénix. La cultura española en los años 30, Madrid, Ediciones de la Torre, 1993, pp. 407-435.

${ }^{5}$ ShaKespeare, Othelo, IV, 2. Cfr. B. W. WARdROPPER, «El trastorno de la moral en el Lazarillo», Nueva Revista Hispánica Moderna, XV (1961), p. 441: «The seamy side es el lado de un vestido que muestra las costuras [...]; la metáfora evoca una prenda vuelta al revés, que pone de manifiesto la parte basta, fea, impregnada por los sudores y olores del cuerpo, pero sin la cual no sería posible la nitidez y limpieza que se ven por fuera».
} 
del Compromiso». En esa narración describió la determinación que tomó cuando en 1917 tuvo que trasladarse temporalmente a Caspe con su familia. Entonces, como veintitantos años más tarde en el exilio de Albuquerque, decidió que había que poner buena cara al mal tiempo y se agarró a la pluma. En «Las brujas del Compromiso» recordaba con estas palabras la actitud que adoptó ante lo que para él, pasar un tiempo en Caspe, era una imposición nada satisfactoria:

Conmigo llevé algunas "contratas» literarias de Barcelona, dispuesto a trabajar, a trabajar de veras. La tranquilidad casi tétrica de la arcaica ciudad vieja y absurda habría de brindarme inspiración o, por lo menos, me encerraría en un dilema: o escribir, escribir mucho, abandonarme a una fecundísima misantropía, o morir de lipemanía vergonzante, como el más ridículo «melenudo vate decadente». De los dos términos, pese a mi innata indigencia, hube de optar por el primero y heme allí rodeado de pergaminos malolientes y de mis tres docenas de libros favoritos, de bruces sobre las cuartillas, sumergido en el silencio sepulcral de un caserío rancio. ${ }^{6}$

La correspondencia que intercambiaron Sender y Maurín de 1952 a 1973 recoge abundantes testimonios de que la condición de exiliados que compartían los dos acicateó de un modo decisivo la determinación de convertir el trabajo, uno como escritor y el otro como agente literario, ${ }^{7}$ en una forma de investir de relevancia la forzosa espera, aquella condena de aguardar la anhelada pero cada vez más hipotética reintegración a la patria.

En el caso de Sender, resulta muy revelador de que efectivamente le empujaron esos móviles el que escribiera una tan extensa obra en el exilio. Como reconoció en el prólogo a Los cinco libros de Ariadna, en Albuquerque consiguió trabajar «a distancia con los detritos acumulados o esparcidos de tantas ruinas». 8

Pero tuvo que superar muchas dificultades. Hay que tener presente que en la época de Sender - hoy han cambiado algo las cosas- ${ }^{9}$ un autor

\footnotetext{
${ }^{6}$ Cfr. Ramón J. SEnder, Primeros escritos (1916-1924), edición de Jesús Vived MaIRal, Huesca, Instituto de Estudios Altoaragoneses, 1993, p. 42.

7 Pero no fue ésa una dedicación exclusiva. Maurín además escribió regularmente, desde un primer momento, artículos con seudónimo para su agencia y para diversos periódicos y revistas.

${ }^{8}$ R. J. SENDER, prólogo a Los cinco libros de Ariadna, Barcelona, Destino, 1977, p. 7. Maurín, que se mostraba el 19 de abril de 1961 maravillado de la capacidad de trabajo de Sender, le comentaba, en esa carta, que había tenido la fortuna de haber podido recluirse, concentrarse, pensar y crear en una ciudad tranquila como Albuquerque: «En una ciudad como Nueva York, agitada, turbulenta, no te hubiese sido posible. Ni en México, con las grandezas y pequeñeces de la emigración política, tampoco. El hecho de que un escritor como tú tenga libros sin publicar es una manifestación del achatamiento espiritual de nuestro tiempo".

${ }^{9}$ De un reciente - pero tímido- cambio de esa situación, cfr. el artículo «Editoriales españolas se lanzan a la conquista de los lectores hispanos en Estados Unidos", El País, 24 de marzo de 1995, p. 31.
} 
que no escribía en inglés estaba condenado en Estados Unidos a prácticamente no tener lectores.

Desde luego, Sender fue traducido al inglés - también a otros idiomas- y era considerado, ya en los años cuarenta y cincuenta, un autor con prestigio en medios intelectuales norteamericanos. ${ }^{10}$ Pero su público natural era el que leía en español. De ahí que el contacto que estableció con Maurín en 1952 le permitió alcanzar, en Latinoamérica y solamente como periodista, ese objetivo.

Pero Sender era por encima de todo novelista. Y para sus novelas y narraciones no encontraba fácilmente ni editores ni público adecuados. Incluso tenía libros, en los años cuarenta y cincuenta -menos, en los sesenta-que a duras penas, después de mucho esperar y desesperar, conseguía publicar.

Durante los tres años que había pasado en México, publicó allí Proverbio de la muerte y El lugar del hombre, en 1939; Hernán Cortés y Mexicayotl, en 1940; Epitalamio del prieto Trinidad y la primera narración de Crónica del alba, en 1942. En este año se trasladó a los Estados Unidos ${ }^{11}$ y después de un tiempo de profesor y de traductor fue contratado en 1947 por la Universidad de Albuquerque.

Desde 1942, en que - repito- llegó a Estados Unidos, y 1952, que fue cuando entró en contacto con Maurín, había publicado: La esfera, Buenos Aires, 1947; El rey y la reina, México y Buenos Aires, 1949; El verdugo afable, Chile, 1952, y algunas narraciones, traducidas al inglés, en varias revistas norteamericanas. Además, había conseguido publicar en traducción a varios idiomas: Crónica del alba, la primera novela, que luego dio nombre a la serie completa de nueve, al inglés (Nueva York, 1944; Londres, 1945) y al italiano (1948); $;^{12}$ Epitalamio del prieto Trinidad,'como Dark Wedding, al inglés (Nueva York, 1943, y Londres, 1948), al portugués, 1948, y al francés, Noces rouges, 1948; La esfera, al inglés (Nueva York, 1949; Londres, 1950), y El rey y la reina, al inglés (Nueva York, 1948; Londres, 1949) y al holandés (1948).

En esos diez años sólo había publicado tres libros nuevos, La esfera, El rey y la reina y El verdugo afable, y si bien se habían traducido algunas de sus obras previamente publicadas en México esta década no fue, en cuanto a publicaciones, demasiado productiva. No me parece, por tanto, aven-

\footnotetext{
${ }^{10}$ A modo de ejemplo, $c f r$. la carta de Sender a Faulkner, hasta ahora inédita, que recojo al final.

11 En el prólogo a Obra completa, I, Barcelona, Destino, 1976, p. 8, insistía en la versión de que había sido víctima en México de la inquina comunista, motivo por el que se trasladó a Estados Unidos: «Salí de Méjico y de los feudos estalinistas en cuanto pude y me ayudó en eso una beca de la Fundación Guggenheim con la cual entré en los Estados Unidos».

12 La primera serie de tres libros de Crónica del alba se tituló en inglés Before Noon, Albuquerque, University Press, 1957. Esa misma traducción la publicó, en 1959, la editorial Gallancz de Londres.
} 
turado concluir que Sender había sentido la tremenda soledad del exiliado, las enormes dificultades de tener que escribir en un medio ajeno a su cultura y por cuestiones lingüísticas poco propicio a la recepción en español de su obra. Hay que hacer dos excepciones, Réquiem por un campesino español y Crónica del alba. ${ }^{13}$ Estas dos obras tuvieron muy buena acogida, pero en particular en los medios escolares y universitarios de los Estados Unidos.

El 15 de diciembre de 1952, mientras estaba en negociaciones con ALA, la agencia de Maurín, le comentaba a éste en un tono un poco ampuloso: «Yo publico algo en revistas hispánicas -y ahora, cada día más-. Por ejemplo, tengo tres largos ensayos para salir en Cuadernos A.[mericanos], en Las Españas y la Revista Iberoamericana - universitaria, que circula por todo el continente». Pero, en realidad, no eran motivos éstos como para echar las campanas al vuelo. Porque el ámbito de esas publicaciones estaba restringido a pequeños círculos académicos - Cuadernos Americanos y Revista Iberoamericana-o de exiliados, todavía más minoritarios — Las Españas.

En 1953, Germán Arciniegas estaba escribiendo un artículo sobre Sender, que luego tituló "No hay letras en España». Ese artículo debía servir de prólogo a una edición de Mosén Millán que finalmente no se publicó, como se tenía previsto, en Colombia. Como sea, el 16 de diciembre de 1953, Sender le pidió a Maurín — hacía éste de intermediario-que Arciniegas aludiera en su nota a sus «diez libros (novelas) publicados en inglés, en Londres y en Estados Unidos. Y a la popularidad de sus [sic] libros en Francia». Y añadía por último: «No es tanto vanidad como deseo de "situar" profesionalmente al autor, que por desgracia no es ya ningún niño. A los cincuenta años se me hace un poco deprimente ser "descubierto", en Colombia o en Australia". Se desprende de estas palabras que, en efecto, Sender, como escritor, se sentía en Albuquerque aislado y hasta acorralado.

ALA, por tanto, le ofreció, en el momento que más lo necesitaba, la oportunidad de hacer periodismo y, de ese modo, llegar al gran público. Así lo reconocía Sender unos años más tarde, en carta del 11 de enero de 1956, en la que le confesaba a Maurín:

En resumen de cuentas yo te agradezco que me hayas obligado a escribir esos artículos porque he dicho y trato de decir cosas que tal vez conviene que los escritores jóvenes lean por esos mundos hispánicos (donde hay tantos escritores en hierbas). Te agradezco también que ALA haya refrescado en la memoria de muchos mi pobre nombre de novelista.

13 Una edición en español de Crónica del alba se publicó en Estados Unidos (Nueva York, F. S. Crofts \& Co., 1946) con introducción, notas y vocabulario por Florence Hall, la esposa de Sender. 
Sender, a quien le solían llegar noticias por diversos conductos de que sus artículos, que fueron apareciendo regularmente desde 1952 en la prensa latinoamericana, habían alcanzado popularidad, le decía a Maurín el 13 de octubre de 1960: "Parece que ALA ha hecho de mí una figura pública, lo que no está mal... a distancia».

Maurín, por su parte, un poco antes, el 7 julio de 1958, ya le había hecho notar a Sender: «Ten en cuenta que tus artículos son leídos regularmente por más de un millón de lectores. ¿Te das cuenta de lo que esto representa?». 14

Sender era un trabajador infatigable. El 4 de junio de 1953 -todavía se hablaban de usted-, le decía de manera bien gráfica a Maurín: «Me hace usted escribir más que al Tostado, pero no importa. Me gusta y tengo que agradecerle el estímulo de esta obligación nueva y también de sus cartas y de sus atenciones».

El 2 de noviembre de 1956 le anunciaba a Maurín el envío de un artículo y en una posdata añadía este comentario: «Al terminar de escribir el artículo ha llegado un telegrama de Gorkin pidiéndome extraurgentemente otro sobre Baroja para Cuadernos. Reteniendo la blasfemia (porque soy ligeramente estoico y como dice uno de los héroes de La verbena de la Paloma el que no se reprime no es hombre) pongo otra vez manos a la obra». El 8 de enero de 1957 le decía: «Yo trabajo como una bestia (Universidad, mis cosas, etc.). Si no estallo un día será un milagro". Y el 16 de julio de 1970: "Y trabajo como si tuviera veinte años, lo que es ligeramente estúpido. Pero divertido».

Pero Sender tenía puestas, como es natural, todas sus miras y más arraigados empeños en su obra novelística. Y a esa labor, que hizo compatible con obligaciones académicas y quehaceres periodísticos, se entregó en cuerpo y alma.

El 30 de agosto de 1953 le anunciaba a Maurín que estaba terminando un ambicioso volumen, Novelas ejemplares de Cíbola, que pensaba ofrecer a la Editorial Sudamericana. Pero como encontraba resistencias para colocar este libro le pidió a Maurín que hiciera gestiones en esa editorial argentina.

El 22 de septiembre de 1953 estaba a punto de salir en México Hipogrifo violento, la segunda novela de Crónica del alba. El 2 de julio de 1953 le decía a Maurín que en Hollywood habían mostrado interés en llevar a la panta-

\footnotetext{
14 El 1 de mayo de 1953 había hecho Maurín esta predicción: «Me atrevo a augurarle que dentro de un par de años, será Ud. el periodista más leido en la prensa latinoamericana. Me sabría mal que pudiera pensar que le estoy dando "coba". ¿Qué necesidad tendría de ello?». Ese mismo año, el 18 de mayo, le decía Maurín que estaba al corriente de los manuscritos que Sender iba produciendo ininterrumpida, tenazmente: «Espero con interés las novelas que me anuncias. Eres un bárbaro escribiendo. La verdad es que te encuentras ahora en el apogeo de las facultades de creación».
} 
lla Dark Wedding (título en inglés de la novela Epitalamio del prieto Trinidad). ${ }^{15}$

De 1952 a 1964, año en que abandonó definitivamente Albuquerque, Sender, además de Novelas ejemplares de Cíbola, escribió: Mosén Millán, las dos primeras series de Crónica del alba, Los cinco libros de Ariadna, Bizancio, Las imágenes migratorias, La luna y los perros, Carolos rex, Las criaturas saturnianas y La aventura equinoccial de Lope de Aguirre, además de varios centenares de artículos en la prensa latinoamericana y en revistas de Estados Unidos, Francia y México.

En silencio, semiolvidado en una pequeña ciudad norteamericana, no había dejado de escribir. A veces, sin grandes esperanzas de ver un día publicados sus manuscritos. El 25 de enero de 1956, un tanto quejumbroso, le hacía a Maurín esta confidencia: «Tengo ahora mismo tres libros grandes de tamaño (sin contar Bizancio [novela histórica de 1.000 páginas que acababa de escribir]) listos para la imprenta. Y sin editor. Y sin embargo mis libros son los únicos en español (novelas, se entiende) que se venden». Y en esa misma carta añadía: «Es angustiosa la idea de que habiendo escrito a veces en quince días un libro (me refiero a La Quinta Julieta) luego tenga que esperar quince meses hasta publicarlo».

Cuatro años después, el 30 de julio de 1960, le hacía a Maurín estos comentarios, que saco a colación para insistir nuevamente en su capacidad de aguante, de resistencia frente a la adversidad o a las condiciones poco o nada propicias:

Te espantarás si te digo que tengo siete novelas inéditas (todas de venta segura y fácil y algunas de una cierta brillantez o de una gran brillantez y grandiosidad) y que ya no las ofrezco a nadie porque quiero evitarme el desaire. Es verdad que ninguna de esas novelas las he dado a leer a ningún editor. ¿Para qué?

Y el 14 de marzo de 1961 volvía con la misma cantilena:

Si no te desmayas y si no te burlas te diré que tengo una serie de 27 libros inéditos bajo el título general de El calendario armilar (memorias bisiestas). [...] Si estuviera en España, Aguilar haría un par de volúmenes de esos monumentales (2.000 páginas cada uno) que además se venderían bien. Ya veremos.

En 1957 - en carta sin fecha- hacía Sender estos comentarios: «Tú dirás que escribo mucho. Pero, chico, voy haciéndome viejo y el no poder volver a España y estar recluido aquí me lleva a buscar compensaciones. Y la vejez me hace apresurarme un poco (la amenaza de la vejez, se entiende)".

15 El 6 de enero de 1959 le anunciaba a Maurín que Ruth Ford había mostrado interés en estrenar en off-Broadway su obra de teatro Graziella y los cuervos. 
Pero entre escribir y publicar había, a menudo, un buen trecho. Y Sender no siempre guardaba la calma o la compostura.

El 19 de abril de 1954 albergaba la esperanza de que la editorial ZigZag de Chile iba a publicarle Novelas ejemplares de Cíbola —un libro en el que había puesto gran entusiasmo-. Ese libro, una colección de cuentos y novelas cortas, ya lo había intentado editar sin resultados, a pesar de la ayuda de Maurín, en Buenos Aires. Pero este nuevo intento tampoco cuajó. El 26 de julio de 1955 le escribía, contrariado e impotente, a Maurín: «Después de entretenerme ridículamente la editorial de Chile (Zig-Zag) salen a última hora con que no pueden hacer la edición de Novelas ejemplares de Cibola. Son cosas de Neruda y de los comunistas, que meten sus narices en todas partes".

Los comentarios anticomunistas - la coincidencia con Maurín en este punto era absoluta - los repetiría Sender continuamente desde que salió de España, tanto en esta correspondencia como en muchas de sus novelas y ensayos. Esa fobia fue acompañada en su caso de un obsesivo complejo de persecución. El 23 de agosto de 1953 le aseguraba a Maurín: «Sur, La Nación, Emecé (casa editorial) tienen veleidades intelectuales estalinoides y allí andan Alberti, de Torre y Mallea, la troica que corta el bacalao de la confusión peronista-comunista-aprista en Buenos Aires». El 27 de abril de 1954 le hablaba así de Los cinco libros de Ariadna, donde pretendió hacer sobre todo un alegato anticomunista: «Ariadna, un novelón de 900 páginas que mucho me temo que políticamente va a disgustar a todo el mundo aunque literariamente gustará también a todo el mundo -deo volente-. Espero publicarla en Méjico. El editor que la publique hará un buen negocio porque estoy seguro que se venderá como pan bendito".

Pero si la primera parte de Ariadna salió en México, en 1955, se interrumpió la publicación de las cuatro restantes partes de la novela porque, según Sender — carta del 16 de febrero de 1955-, se opusieron los comunistas. Finalmente se publicó, en 1957, en Nueva York. Culpó de la tardanza en aparecer - en seguida me detengo en ello- a los republicanos.

Ariadna, en su versión completa, se empezó a componer en Nueva York en 1956. Victoria Kent, que se comprometió a publicarla en la editorial de la revista Ibérica, ${ }^{16}$ que ella dirigía, no paraba de darle largas. Sender, que empezaba a estar molesto, ponía a Maurín al corriente de esa situación el 4 de diciembre de 1956:

La novela de Nueva York [Ariadna] va despacio. A razón de unas treinta páginas por semana la impresión va a durar más que un traje de pana y comienza a ser el «bonito y divertido juego del ay, qué coño». Pero en fin (y perdona la expresión realista) lo hacen con buena intención y con generosidad. No puedo quejarme sino de la lentitud. Lo que pasa es que a medida que uno se hace viejo querría hacerlo todo más rápido porque falta tiempo.

16 Cfr. carta de Sender del 6 de mayo de 1956. 
Así las cosas, hacia mediados de 1957 perdió Sender definitivamente la paciencia y montó en cólera contra Victoria Kent, a quien estuvo tentado de demandar judicialmente. Y cuando, por fin, en julio recibió un ejemplar de Los cinco libros de Ariadna, comprobó disgustado —carta del día 17 de ese mes-: «Hay erratas graves. Y líneas cambiadas. A pesar de los catorce meses que ha durado la impresión". ${ }^{17}$

Durante el largo proceso de la publicación de Los cinco libros de Ariad$n a$ en Nueva York, en la editorial Ibérica, Sender sacó a relucir un antirrepublicanismo casi tan virulento como su ya mencionado anticomunismo. También en este punto las coincidencias con Maurín fueron muy patentes. El 19 de junio de 1957 relacionaba lo que creía eran trabas para retrasar la aparición de esa novela con un viejo ajuste de cuentas:

Hay muchas razones para el odio secreto de algunos republicanos del corte de V.[ictoria] K.[ent]. Me consideran a mí el culpable de «su frustración política" por el escándalo de Casas Viejas. ¿Te acuerdas? Aquellas revelaciones le costaron el gobierno a Azaña y desde entonces la cosa fue de mal en peor. No me lo perdonan.

Sender ya el 30 de mayo de 1956 había acusado a los republicanos en el exilio de que, con su comportamiento, Franco se mantenía en el poder:

Los republicanos siguen dando muestras de la estulticia que nos costó a todos perder nuestro suelo patrio. Al menor atisbo de horizontes despejados comienza el alboroto en los gallineros respectivos: socialistas de derecha, de izqu.[ierda] o de centro, republicanos de centro, de izqu.[ierda] o de derecha, anarquistas puros, semipuros, impuros, bárbaros letrados o iletrados o semiletrados, ambiciosos de una laya u otra. Cada cual enseña la oreja de su tontería. Y a España que la parta un rayo.

En 1958 salían de nuevo a relucir comentarios contra los republicanos. Sender decía en carta del 8 de diciembre:

Lo de España va de mal en peor. Los republicanos esp.[añoles] en el exilio son los de siempre con los mismos defectos de 1935 aumentados y fermentados y empeorados por la vejez. En el fondo es cuestión de cultura. Todos ellos son unos zopencos.

17 El enfado se remontaba a los meses de marzo y abril y fue en aumento en junio y julio de 1957, es decir, hasta que salió Ariadna. Acabó con su paciencia que el primer ejemplar que le mandó Victoria Kent presentaba esos defectos. Pero a pesar de las dificultades que por esos años encontraba para publicar en español se resistía a tener agentes literarios. El 26 de febrero de 1958 le decía a Maurín: «Yo creo que no necesito agentes. La parte comercial de mi pequeña carrera nunca me ha proporcionado mucho. Algunos años me ha dado bastante dinero (para mis costumbres), otros poco. Pero no me siento capaz de atender la cosa como un negocio. Creo que vale más el placer que proporciona el escribir una buena página de vez en cuandos. 
Sender le insinuó a Maurín, en una de sus primeras cartas -me he referido a ello más arriba-, si podía ayudarle a colocar en Argentina Novelas ejemplares de Cíbola. Maurín se aprestó a escribir a un amigo que era accionista de la Editorial Sudamericana ${ }^{18}$ y ya entonces, en carta del 7 de septiembre de 1953, tuvo esta ocurrencia:

A propósito. ¿Usted no ha pensado nunca en la posibilidad de editar algo de lo suyo en España? Quizá la pregunta le sorprenda. A mi modo de ver, espiritualmente habria que ir entrando en España para ponerse en contacto con los buenos de España, que es la mayoría. [...] Le digo esto porque podría ver si algún editor [Janés] con el que yo estuve en contacto el año que estuve en libertad en España - hacía traducciones- podría interesarse por algo suyo. Usted verá, y podría ser algo a explorar, sin que me atreva a prever los resultados.

Esa idea tardó en fraguar todavía un par de años. Sender le pidió a Maurín finalmente en 1955 — carta del 13 de julio- que mandara a Janés los dos primeros libros de Crónica del alba y le indicó que el tercero, $\mathrm{La}$ Quinta Julieta - pensaba publicar los tres en un volumen bajo el título $L a$ Jornada-, se lo haría llegar en breve. ${ }^{19}$ El 29 de julio le anunció que ya había terminado La Quinta Julieta y en una nota a la carta del 13 de julio pronosticaba Sender: «El libro que podría hacer Janés puede tener un éxito comercial bárbaro. Vamos a ver». 20

Cuando Maurín recibió el manuscrito de La Quinta Julieta lo leyó y mientras lo hacía - otro dato para la pequeña historia de la edición española de Crónica del alba - puso "por aquí y por allá - así se lo decía en carta del 14 de agosto de 1955-, algún acento y alguna coma, que faltaban. Lo hago en los artículos. (Todos los escritores echáis en olvido, a veces, los acentos y las comas. Recuerdo que Unamuno tenía la guerra declarada a las comas.)».

\footnotetext{
18 Sender le ofreció entonces el 20\% de comisión, pero Maurín se negó, en carta del 5 de octubre de 1953, a recibir ningún tipo de compensación económica por su gestión: «De lo de la comisión, ni hablar. Se ha empeñado usted en hacerme un comisionista, y no quiero serlo de los amigos». En ese mismo año, aprovechó Maurín que Germán Arciniegas iba a pasar un tiempo en Colombia para, por mediación suya, editar en aquel país Mosén Millán. Arciniegas incluso escribió un prólogo - «No hay letras en España»- para esa edición que, después de una larga espera, no llegó a salir.

19 Maurín había traducido libros para Janés cuando salió en 1947 de la cárcel y mantenía desde Nueva York contactos con él. El 7 de junio de 1955 le decía Sender que le parecía mejor escribir La Quinta Julieta, el tercer volumen de Crónica del alba, que una novela histórica que tenía proyectada desde hacía algún tiempo (probablemente Bizancio — cfr. la nota 22-). La perspectiva de ofrecer a España esos tres volúmenes fue decisiva para completarlos sin mayor dilación.

20 A las pocas semanas hizo una escapada — carta del 16 de agosto de 1955- a San Diego "para probar si la diferencia de altitud influía en una forma u otra en mi "sinusitis con tendencia asmática"»"
} 
Maurín se encargó personalmente de gestionar y pagar el envío del manuscrito a Barcelona. Sender le mandó unos sellos para cubrir los gastos, pero Maurín se los devolvió. En carta del 16 de agosto de 1955 Sender, resignado, le decía: «Recibida la liquidación, el cheque, tu carta y... los sellos de correos. Está bien. Eres un caballero antes que un comerciante ( $u$ hombre de negocios). Pero haces todas esas diligencias gratis y... pones el hilo, además».21

Este primer acercamiento al mundo editorial español mantuvo a Sender durante varios meses en vilo. El 28 de diciembre de 1955 se mostraba desalentado: «Soy pesimista en relación con Janés y comienzo a preparar el campo para publicar eso en otra parte». Pero Maurín, que veía las ventajas de saber aguardar y ser paciente — dos cualidades que conformaban su personalidad-, intentaba el 29 de enero de 1956 convencerle con estos razonamientos de que merecía la pena, a pesar de la demora, no perder la calma y no darse por vencido:

Tú no sabes las dificultades en que se mueven los editores españoles: censura, papel, crédito, mercado de América, derechos de autor, etc. [...]

Creo que en tu caso interesa que Janés pueda publicar tu novela. Eso te abriría la puerta para la edición de otras. Por ejemplo, esa histórica, Bizancio, de que me hablas en tu última carta. ${ }^{22}$

La «industria» editorial en América (me refiero a la española) ha sido un fracaso, y poco a poco España vuelve a reganar las posiciones que habia perdido; mejor dicho, ya las ha ganado. Se trata, pues, de «entrar».

Sender aceptó los argumentos de su buen amigo Maurín, pero queriendo mostrarle los motivos de su intemperancia le contestaba el 1 de febrero de 1956:

Comprenderás que a veces pierde uno la paciencia con los conflictos de publicación. Ahora mismo tengo varias cosas que considero importantes y que van a salir quién sabe cómo y cuándo. Menos mal que para una de ellas - la más difícil [se refiere a Los cinco libros de Ariadna, que le iban a dar un montón de quebraderos de cabeza] - ya tengo editor.

Maurín, con todo, volvía el 19 de febrero de 1956 a insistir en que como los españoles habían vuelto a reconquistar la industria editorial:

te conviene "tocar tierra» en una editorial española y entonces tus novelas tendrán la difusión que conviene. Por eso he insistido en tener paciencia con Janés. Si la cosa marcha, verás cómo, a no tardar, las demandas de los editores serán superiores a tu producción posible y normal.

21 En esa carta hizo además unos interesantes comentarios sobre La Quinta Julieta.

22 El 25 de enero de 1956 le escribía a Maurín: «Estoy terminando una novela de cerca de mil páginas titulada Bizancio, de fondo histórico (1304-1309). Es sobre la expedición famosa de catalanes y aragoneses a Oriente». 
Pero entonces todavía no estaba España en condiciones de recuperar a uno de sus mejores novelistas y este primer intento de "tocar tierra" en una editorial española» fracasó.

Así las cosas, Sender pasó no pocos apuros para publicar los manuscritos que incansablemente iba produciendo en su casa-refugio de Albuquerque. Afortunadamente, muchas revistas norteamericanas y latinoamericanas iban publicando narraciones suyas; gracias a ALA estaba en contacto con un público amplísimo, y, a trancas y barrancas, algunos de sus libros salían en lengua española y aparecían, con mayor o menor facilidad, traducidos a otros idiomas.

Pero, con todo, era presa a menudo de la amargura, le embargaba por momentos un sentimiento de profunda frustración. No poder publicar en España era la razón principal de ese estado de ánimo. El 18 de mayo de 1955 le escribía a Maurín: «A veces se me ocurre (por las ganas de ser publicado en España) que podría escribir una novela de las que andan por mi mesa en nebulosa y en notas vagas y firmarla con un seudónimo. Se me ha ocurrido incluso el seudónimo: Norman Hall».

Pero el ejercicio de escribir, la entrega a su intensa y pertinaz pasión fabuladora, era la principal liberación de esas y otras insatisfacciones. Y es que tenía muy claro, como le comentó en una ocasión a Maurín - 31 de abril de 1958-, que «la novela u otra forma narrativa exige una dedicación completa (el caso de Balzac o modernamente Baroja). Sin hablar de Dostoiewski o de Turguenef".

El exilio, a pesar de todo, le ofrecía, cómodamente instalado en Albuquerque y con mucho tiempo a su disposición, esa posibilidad. Y no la desaprovechó. Pero la sala de espera empezó a resultarle insufrible y con el paso del tiempo le fue embargando una sensación de enclaustramiento y de impotencia, como si se hallara condenado a un cierto ostracismo. Albuquerque llegó a pesarle - tema sobre el que volveré más adelantecomo una losa. Sin embargo, el problema de fondo radicaba sobre todo en las continuas dificultades para encontrar editores y en que, cuando los encontraba - siempre acababa publicando en un lugar $\mathrm{u}$ otro sus novelas, sus cuentos, su teatro, su poesía-, le embargaba la decepcionante sensación de que cuanto escribía estaba condenado a no llegar a su público natural, el de España.

Fracasado en 1956 el intento de publicar Crónica del alba en Barcelona, fue nuevamente Maurín quien le alentó, el 3 de julio de 1964, a que volviera a probar fortuna. Maurín mantenía ahora relaciones con otro editor, Delos-Aymá, amigo de Víctor Alba. Después de que Sender se mostrara de acuerdo, mandó otra vez a Barcelona el manuscrito del primer tomo de Crónica del alba. El 12 de febrero de 1965 le daba Maurín la buena noticia de que su libro iba a ser finalmente publicado en España y le añadía en esa carta la siguiente apostilla: «La edición de tu novela será en España un acontecimiento literario, y tendrá favorables consecuencias. Alégrate, pues. Mi misión en este caso concreto ya ha termi- 
nado. Desde ahora en adelante tú te entenderás y te relacionarás con el editor».

En octubre de 1962 emprendió, después de muchas indecisiones, un viaje a Europa. Maurín le animó - Sender no paraba de darle vueltas al asunto- a que hiciera ese viaje e incluso a que fuera a España. Argumentaba - hacía gala a menudo el ex poumista Maurín de tener un sentido de la realidad pragmático y posibilista- que así entraría en contacto con editores españoles y con su público natural. Pero Sender se resistió entonces a cruzar los Pirineos. El 9 de septiembre de 1962 le decía Maurín:

Tú eres un escritor español - no americano-y tu pasado y tu porvenir literario está en España ante todo. Eres el novelista número uno de la presente generación, y tienes el deber de hacer valer tus derechos. Si te abandonas, si sigues estancado en Albuquerque, abandonas todo el potencial que hay de riqueza espiritual en tu obra. Tu presencia en España - breve, la primera vez- produciría sensación, y los editores harían cola esperando ser recibidos por ti. Casona, bien aconsejado, ha hecho lo que tú debieras hacer, y ha tenido un formidable éxito. García Lorca, según dice hoy el Times ha sido autorizado para que se represente teatralmente, y será asimismo de gran éxito. Por lo que se refiere a ti, tu presencia sería un estímulo político para la nueva generación, que es antifranquista y, además, te crearías un mercado para hoy y para mañana.

Las cartas que en octubre y noviembre mandó Sender desde Londres y París contienen interesantísimos comentarios. Por aquel entonces, le rondaba por la cabeza retirarse en el sur de Francia, pero había motivos de peso -expresados con un humor un tanto jactancioso-que le obligaron a desistir. Una vieja amante, con la que tuvo un hijo antes de salir de Francia en 1939 explicaba el 13 de septiembre de 1962-, estaba casada con el jefe de policía de Marsella y, claro, «un jefe de policía... si quiere puede molestar a cualquier extranjero que vive a su alcance». ${ }^{23}$

De vuelta a Estados Unidos, pasó el invierno de 1963 en Albuquerque. Pero ya había tomado la decisión de renunciar a su cátedra.

En septiembre de ese mismo año se instaló en Manhattan Beach, ciudad que está situada cerca de Los Ángeles, donde decía vivir por el momento - 4 de diciembre de 1963 - "como un fraile (de los castos, claro, porque los hay que iya, ya!)». ${ }^{24}$

23 Cfr. F. Carrasquer, «Un Edipo extemporáneo. A raíz de Muerte en Zamora, de Ramón Sender Barayón", Alazet, 4 (1992), p. 124.

24 Ese verano fue operado, según le contaba a Maurín el 14 de agosto de 1963, de vegetaciones - pólipos- en las fosas nasales. El 31 de agosto de 1963 le comentaba que acababa de ser distribuida la edición inglesa de El verdugo afable, muy bien recibida por la crítica norteamericana. En México estaba también entonces por salir Carolvs rex, del que decía Sender: «Es importante el libro para mí porque con ese rey resbaló España definitivamente al abismo». El 14 de noviembre de 1963 le comentaba que en Hollywood tenían interés en llevar a la pantalla sus novelas El rey y la reina y Epitalamio del prieto Trinidad. 
Maurín parecía ahora comprender la decisión que finalmente había tomado Sender de abandonar Albuquerque - tiempo atrás esa idea, que ya le rondaba por la cabeza a Sender, no le pareció acertada- 25 y, en carta del 6 de diciembre de 1963, instalado ya Sender en Manhattan Beach, le comentaba:

Me figuro que la estancia ahí, "en el mejor balcón del Pacífico", te será más agradable que Albuquerque. No sé por qué: pero tengo la impresión de que Albuquerque debe ser una especie de Huesca americana. Y Huesca está bien para pasar allí algún tiempo, pero no para convertirla en residencia definitiva.

Empezó entonces, en aquel espléndido «balcón del Pacífico», un periodo de cierto abandono y monotonía al que hacía alusión en carta del 31 de enero de 1964:

Nada nuevo por aquí. Sol, olas arena arriba, buen scotch, un poco de aburrimiento a veces, algunas amigas que vienen a veces de Los Ángeles y se quedan en casa (noche sin dormir, fatiga, vecinitas divertidamente escandalizadas) y más olas por la arena y más scotch y más sueño durante el día y vigilia nocturna. La verdad es que me había propuesto trabajar mucho y trabajo poco.

Sender inició en California, a partir de 1964, una nueva etapa de su vida. En lo que se refiere a sus relaciones epistolares con Maurín, en este nuevo periodo le mantuvo al corriente de su vida íntima, algo que ya había comenzado a hacer unos pocos años antes.

En el verano de 1961 fue contratado Sender como profesor visitante por la Inter American University, San Germán, Puerto Rico. En julio le mandó a Maurín varias cartas, muy interesantes todas ellas, con sus impresiones de la isla. Además, ese verano volvió a tocar el tema de las confidencias amorosas, que había comenzado el año anterior. El 19 de agosto de 1960 le anunciaba un viaje a Méjico y a la vez le confesaba los siguientes temores: "Como pasé año y medio de juventud turbulenta en aquella ciudad [México] dejé algunas novias (sic) entre las que no falta la casada cuyo marido me odia y las solteras que "se han pasado al enemigo" (por resentimiento), es decir, que andan con los "chinos"».

Pues bien, el 29 de julio de 1961 le comentaba la amenaza que estaba presentando para el regreso en barco de Puerto Rico el huracán Ana, amenaza que él sentía de una manera especial porque el nombre de Ana le

25 El 20 de octubre de 1959 se extrañaba Maurín de que Sender estuviera pensando dejar Albuquerque. Le decía en esa carta: «Creía que te encontrabas ahí como pez en el agua: tranquilidad, clima excelente, casa propia, muy querido por tus colegas, y con tiempo para poder trabajar y descansar. ¿A dónde podrás ir que estés mejor? Ahora bien, si te suben el sueldo cada vez que manifiestas deseos de marcharte plantea cada año tu propósito de irte... ¿No te parece?». 
había sido siempre funesto en materia de amoríos: «Y todavía hay por ahí una en México (alemana) y otra en París (francesa) que de vez en cuando me escriben cartas incómodas-apasionadas-insultantes-calumniosas-amenazadoras, etc., etc. Al saber el nombre de ese huracán [...] me puse a temblar $[\ldots] »$.

En septiembre de 1961 se hallaba Sender nuevamente en Albuquerque. Pero a los pocos meses la Universidad de California en Los Ángeles (UCLA) le invitó como profesor visitante y en enero de 1962 volvió a California. Por esas fechas le anunció a Maurín su próximo divorcio. El 13 de enero de 1962 le escribía:

\footnotetext{
Hay algo en el horizonte (digo, en el terreno afectivo) pero no es seguro que me vuelva a casar. Voy haciéndome viejo y acercándome al fin, quizá. Y a los animales del Alto Aragón nos gusta acabar solos y olvidados en el fondo más lejano del bosque. No creas que yo tengo ideas lúgubres o que me siento irremediablemente viejo. No, al revés. La vida clama por la vida. Estúpidamente pero implacablemente.
}

El 29 de enero de 1962 le comentaba en relación con su nueva situación: «Mi propósito es organizar la vida nueva alrededor de mi trabajo y hacer de él el motivo principal de mi pobre presencia en este mundo». Y el 7 de febrero de 1962 daba muestras una vez más de su peculiar sentido del humor: "Llevo aquí —en un apartamento, yo solo- cuatro días y ya he quemado tres cafeteras en el fuego. (Si sigo así tendré que casarme otra vez.)". Pero el 26 de febrero de 1962 se había producido - Sender tenía, sin duda, sentido del humor - un inesperado cambio: «Creo que no me casaré porque ya no he quemado más cafeteras. Todo se aprende». Y luego añadía:

No me casaré porque las que me gustan son muy jóvenes entre $14 \mathrm{y}$ 20 , signo de vejez en mí, jay!- y aquellas a quienes parece que les gusto por ahí son demasiado viejas. Así pues tomaré algo si me lo dan de vez en cuando mis amigas (no me hago ilusiones) más porque les guste algún libro mío que yo, y vigilaré la cafetera.

Sender le contó a Maurín numerosas anécdotas de esas sus primeras andanzas por Los Ángeles. El 13 de abril de 1962 le mandó unas curiosas impresiones en torno a la enorme urbe californiana y sus gentes y el 14 de mayo le decía a Maurín que unas monjitas fueron a buscarle en coche a su apartamento para llevarlo a un colegio donde dio una conferencia. Como había monjitas tan guapas, se le pasó por la cabeza - Maurín debía de divertirse lo suyo con estas confidencias - lo siguiente: «Si me hicieran capellán de un convento por ahí - pero sólo para ciertos deberes de confesor, etc., etc.- aceptaría aunque supongo que habría que hacerse cura y eso ya es más duro de pelar".

Esa estancia en Los Ángeles debió de causarle una impresión tal a Sender que reintegrarse a la vida provinciana de Albuquerque le tuvo que 
resultar insufrible. Era como pasar del desenfreno y el vértigo a la cordura insulsa. Optó por lo primero, pues era, entre otras cosas, como una última posibilidad de revivir - acaso demasiado tarde, lo cual sólo cuando le fallaba la salud parecía importarle- la juventud. El 29 de abril de 1962 escribía a su amigo y ahora ya confidente: «El mundo está loco y nosotros que registramos su locura tenemos derecho a divertirnos un poco, entretanto. Antes de ser su víctima, si eso ha de llegar». Ya el 14 de marzo de 1961 le había esbozado a Maurín esta descripción tan plástica de lo que se estaba plasmando en su interior: "Es verdad que no ando ya en la mocedad pero en fin, como decía el otro "voy acercándome a la edad de las pasiones" ".

Para terminar tocaré el tema del recuerdo de la tierra natal tanto en Sender como en Maurín. Éste, en un fragmento de sus memorias publicado en España Libre de Nueva York, en 1972, al tiempo que rememoraba su amistad con el pintor catalán Viladrich —que se había instalado en el Castillo de Urganda la Desconocida, en Fraga- y la visita que allí hizo Baroja en 1918, dedicaba a su terruño, ya para siempre perdido, estas emotivas palabras, entreveradas de nostalgia y pasión:

\footnotetext{
De las crestas y ventisqueros del Pirineo aragonés se despegan, abriéndose paso por profundas gargantas, el Ésera y el Cinca. Salvada la parte más escabrosa del recorrido, los dos ríos confluyen en las estribaciones de la cordillera. El Ésera pierde su nombre, y el Cinca, como si estuviera cansado de tanto saltar y correr, se apacigua al llegar a la tierra baja y, describiendo perezosos meandros, forma la ribera de su nombre.
}

El 19 de marzo de 1957 le anunciaba Sender que acababa de recibir de México ejemplares de su novela histórica Bizancio y le expresaba su enorme interés en que la leyera, porque «el tema te toca muy de cerca. La mayor parte de los tipos que forman la masa-fondo de la acción son los almogávares de Benasque, Benabarre, Aínsa, Sallent, etc. Tú eres uno de ellos, también. Yo soy sólo un ibero ilergete de los de más abajo, hacia el valle del Cinca. Pero también los del Cinca son gente templada». En otra ocasión, el 20 de agosto de 1959, le recordaba Maurín a Sender: «A propósito: el Cinca no nace, ni pasa por Benasque. Por Benasque pasa el Ésera, afluente principal del Cinca. El Cinca nace en Monte Perdido, región pirenaica de Boltaña».

A menudo, la nostalgia hacía viajar imaginariamente a Sender de Estados Unidos a España. Así, el 31 de marzo de 1964 escribía Sender a su amigo «neoyorquino»: "Ahí llega la primavera y supongo que hay lilas ya en los puestos de flores y de periódicos, como en Madrid. ¡Aquellas lilas húmedas de rocío que vendía una gitana joven y hermosa en la puerta de la Granja del Henar! Esa G.[ranja] del H.[enar] ya no existe. Al menos existen aún las lilas".

Pero esos viajes imaginarios a veces se trastocaban de repente en descabelladas tentaciones de llevarlos realmente, como fuera, a cabo. El 29 de 
mayo de 1959 hacía Sender esta confesión: «Leyendo estos días cosas de Galicia y de Santiago de Compostela tuve la tentación de ir con mi pasaporte americano (sin visa) un par de semanas a aquella ciudad a poner un ramo de flores en la tumba de Valle-Inclán. Pero no sé si sería prudente».

Pero la ribera del Cinca era la geografía a la que más gustosamente regresaban los dos. Esa ribera, que había configurado de manera decisiva sus personalidades, fue siempre, en los veintiún años de intercambios epistolares entre estos dos oscenses, un constante punto de referencia.

El 9 de marzo de 1972 le hacía Sender a Maurín estos lúcidos y a la vez lúgubres comentarios:

La vida de la infancia en una aldea española de 1909-1910 nos parece hoy el paraíso perdido. La infancia lo es siempre (ahora también), pero a medida que avanza la vida (adolescencia, juventud, madurez) el destino va mostrándonos sus dientes de tigre. $Y$ nos devora en condiciones casi siempre ominosas.

Pero mientras, alentado por la vocación de escritor y por la memoria de una infancia arcádica en la tierra ancestral, se entregó a su obra, a dar testimonio de que acaso una de las claves de la existencia sea resistir, en soledad, como un buen corredor de fondo.

\section{APÉNDICE} 1956:

Carta inédita de Ramón J. Sender a William Faulkner, fechada el 25 de septiembre de

September 25, 1956

Dear Mr. Faulkner:

Of course, I will join any organization trying to give a true picture of our country to other people.

But first we must accept the fact that the inside panorama of the literary world is somewhat depressing.

There are nuisances everywhere, especially the plague of literary agents and their business level. Some of these agents are pro-Communists, others have fascist tendencies (both interested in vilifying the American landscape). The neutrals look for the idealization of that landscape but in the direction, for example, of the Readers Digest and Hollywood. This idealization seems stupid outside America.

When America had Melvilles, Thoreaus, Walt Whitmans, etc., literary agents did not yet exist. Nor were there any in the Russia of Tolstoy, the England of Dickens or the France of Balzac and Stendhal.

If you can exert influence in the American literary atmosphere it would be a good thing to encourage inspired satire. When America satirizes herself bloodily (but with the comprehension given only by love, as is the case with Cervantes in Spain, Gogol in Russia, Dickens in England) the rest of the world will love America. Just as in the life of an individual, when he speaks discreetly ill of himself (with a sense of humor) he keeps others from doing so and awakens the most devoted friendships as well.

France is loved for Balzac's satires and not for the ultranationalistic writers who sing her glories. When a country tolerates the worst satires we take for granted that it is rich enough in virtues. Besides, in satire born of comprehension through love, the positive side is present. 


\section{EL LUGAR DE SENDER}

As for direct propaganda, I can only say what I do myself. Every week for four years I have been writing an essay on some American subject which is published in some forty newspapers (in Spanish). I have talked a lot about the American authors who have a great talent, from Melville to Faulkner. Poets, novelists, essayists, playwrights, etc. I am sure that the two million who read them understand and love America. This is a good work. I don't know if it will be able to continue, however, because the distributor of these articles (and others by Madariaga, Waldo Frank, etc.) is a spanish refugee who lives in New York and is threatened with deportation for having been a socialist (anti-communist) in his youth. If the modest, clean enterprise of this spanish refugee is suppressed, my two million readers will only read the cabled news reports from America on kidnappers, divorces, lynchings and millionaire widows who leave their money to their cats when they die.

Exclusively literary «little reviews» could be started (neither politically nor deliberately propagandist) in different languages and different places for "interstitial" influence. I had thought about starting one on my own in Juarez (Mexico) entitled Frontera, with influence throughout the entire continent. You could do another in French-English, in Canada. Maybe the literary skill of some other group of immigrants (Arabs, Chinese, Lebanese, Jews, Germans, Italians) can be utilized for doing some other similar in strategic places. Some of the materials of one review could be published in the others, well translated. It would not cost as much as the senators' trips through Europe. And it would be more effective.

It will also be a good thing to give prestige to the literary profession inside the country -the writers will feel more America. Literary prizes could be created as elsewhere, but decorous and worthy of America. The Pulitzer Prizes and the Library of Congress Poetry Prize are miserable. They should each be at least twenty-five thousand dollars (novel, poetry, theatre, ect.) and should never be given to best sellers but to original works, whose popularity is limited by their very originality.

If we want the writers to feel the maternal tutelage of America let Congress pass a law exempting from income tax novelists, poets, painters, etc., who earn less than fifteen thousand dollars annually. If there is a law permitting the importation of works of artistic value tax free (painting, sculpture, etc.), why not another to stimulate artistic production at home?

It would be well to avoid talking to high school students about contemporary literature. The teachers transmit their own conventional bad taste to them. It is better to train their taste with the intelligent criticism of authors of the past, Americans or foreigners.

Also prohibit the immoral censoring (by churches or special committees) of books, films, plays, since this marks a tendency toward the worst monopoly: the intellectual.

Cordially,

Ramón J. Sender

630 Girard Blvd. N. E.

Albuquerque, New Mexico

Mr. William Faulkner

c/o Miss Jean Ennis

Random House, Inc.

457 Madison Ave

New York, N. Y. 


\title{
¿Escribir por pensar o pensar por escribir? La filosofía senderiana acude a los puntos de la pluma o al toque de las teclas
}

\author{
Francisco Carrasquer Launed \\ Profesor emérito de la Universidad de Leiden
}

La verdad es que, con Sender, nunca se sabe si escribe para pensar o piensa para escribir. ¿Y si fueran las dos cosas a la vez? Un grafómano como él parece que ha de acabar su discurso interior escribiéndolo; pero también puede sentir la pulsión de escribir, como buen monomaníaco, y que al ir escribiendo se le abran los grifos del pensar por el estimulante insoslayable que representa la famosa hoja en blanco. Y aquí hemos hecho mención de dos verdades empíricas que tienen en común todos los escritores. Primera, que la experiencia nos dice que no hay escritor verdadero que no sea grafómano; y segunda, que la fascinación de la hoja en blanco es una realidad en todo escritor. Para el grafomaníaco, la hoja en blanco le pone en tensión, una tensión que para el poeta es la más alta y para el periodista apresurado que no hace periodismo literario la más baja. En todo caso, esa tensión reactiva enormemente las neuronas y en especial las de los lóbulos frontales con las de la memoria, porque se agolpan en el cerebro riadas de asociaciones (que combina el encéfalo anterior con las reservas del «disco duro»), prácticamente inagotables, alojadas en nuestro sistema nervioso central. Lo que llamamos inspiración no es más que el efecto de esa tensión que pone en actividad combinatoria los millones de 
posibilidades que ofrece nuestra lengua en el escritor (o de imágenes en el pintor, escultor, arquitecto, etc.; o de sonidos también a millones combinables en el músico). No hay creador que para crear no se ponga en trance, no se concentre, como dicen los deportistas, es igual. Pero he de hacer una aclaración: lo de la página en blanco es una metáfora, como los clásicos puntos de la pluma. Lo normal, en el creador, es que esa tensión ante un lienzo, ante un bloque de mármol o ante la pantalla de un ordenador se produzca al empezar a crear; tanto si se pone ante un piano y una partitura virgen como ante una tela por estrenar o ante la pantalla de un procesador de textos. Y es que la tensión viene preparándose de antes. Para atenernos al escritor, cuando se pone a escribir un artículo, un cuento, una novela o un poema hace tiempo que lo viene trabajando por dentro, hace horas o días o meses que le anda rondando la idea de escribir lo que quiere y la levadura, los fermentos de esa idea suben y suben y llega el momento en que el escritor se pone a hacer el pan por necesidad, porque la masa ya ha subido y el horno caldeadito ya espera.

Pues bien, conviene ahora analizar las necesidades de escribir en Sender, que es nuestra muestra por analizar. Fundamentalmente tendría Sender dos clases de necesidad escribidora: la de comunicar sus hallazgos sociopolíticos y filosóficos, pero más que nada descargar sus iras, fobias y filias de alcance societario en público, o sea, la necesidad de escribir artículos para la prensa; y la otra: crear para trascender la actualidad, con la insobornable intención de hacer arte, arte literario que rebase el aquí y ahora y devenga universal y eterno. La primera necesidad la ha podido satisfacer casi siempre, por fortuna. Prácticamente, a lo largo de su dilatada vida, siempre ha solido contar con algún medio periodístico con el que comunicarse directa y asiduamente. ¿Se ha hecho el cómputo de todos los artículos que ha escrito en El Sol, en La Libertad, en La Tierra, en la Soli y para la ALA, por no nombrar más que sus más importantes destinos de colaborador? Yo aventuraría que en los sesenta años hábiles de escritor habrá publicado unos 1.560 artículos y me temo que me quedo corto. Pero lo importante para mí ahora no es la cantidad, sino la disponibilidad con que contaba para pegar un grito contra una injusticia, llamar a capítulo a un grupo social, ponerle las peras a cuarto a un gerifalte, pronosticar bienios negros y revoluciones y echar su cuarto a espadas en la vida cultural, religiosa, política y literaria. Y en este ámbito se sintió, por lo tanto, a cubierto en ciencia y conciencia al ver corrientemente cumplida su obligación de hacer uso de la palabra ante la asamblea, como era su sentido compromiso. A veces, también resentido. Nadie es perfecto. Pero, por lo general, esos artículos los escribía en la Redacción, como quien dice, después de darle un repaso a la prensa o tras la lectura de un libro que le desvelara algún misterio, le informase sobre adelantos en la investigación susceptibles de ser debeladores de prejuicios o malentendidos, de manipulaciones sicosocietarias o monstruosidades resultantes de algún lavado de cerebro. Todo ese periodismo está al nivel del contenido de sus clases y de 
sus conversaciones o correspondencia con amigos; es decir, son reacciones directas a estímulos del exterior que han herido su sentido ético o estético, su corazoncito sensibilizado por la patria chica o dolido por la patria grande, cuando no enamorado de un talento, de un genio, de un héroe o de un santo.

Lo más curioso de Sender es que esas dos necesidades de escribir parezcan salir de dos compartimientos mentales/espirituales estancos. Ya es sabido que todo escritor, por grande que sea, no entona su estilo igual en un artículo para la prensa que en una novela y menos en un poema, pero en Sender no se trata tan sólo de tono, sino de timbre; no sólo de estilo, sino de peristilo (si puedo abusar de la aliteración), porque la naturaleza del son tiene otras fuentes instrumentales; $y$, así, las columnas del periodista Sender son pilastras de puente, mientras que las del novelistaensayista-dramaturgo-poeta Sender igual pueden ser dóricas sustentando un mausoleo, jónicas para un ateneo o gimnasio, corintias para un palacete neoclásico, góticas para una seo nunca ostentosa o salomónicas para palacios neobarrocos. Claro que hay tics mentales y estilísticos en Sender como en todo gran escritor (que no hace más que dar vueltas a la noria, como dice él mismo en un librito que vamos a hojear no poco). $Y$ esos iics se reproducen tanto en un compartimiento estanco como en otro, porque no dependen de un espacio limitado, sino de un tiempo inaugural que se ha grabado y remachado indeleblemente (a la letra). Una novela se sitúa en un episodio o sarta de episodios; un ensayo, en torno a un tema, como una comedia, y un poema, en torno a una intuición. Pero los reflejos estilísticos y automatismos mentales están antes de toda situación y saltan por encima de todo tema, así como por un resorte. Veamos con ayuda de algunos ejemplos lo que queremos decir.

La prosa de los artículos de Sender publicados en El Telegrama del Rif estando en Melilla no tiene nada que ver, pero en absoluto, vamos, con lo que va a escribir sobre Marruecos en Imán ni lo que escribe en El Sol con $O$. P., como lo que publica en la Soli con sus Siete domingos rojos, pero sobre todo está increíblemente divorciado lo que publicó en Tensor con su prodigiosa novela El rey y la reina. Para crear es como si cambiara de dimensión, Sender. Yo no he podido comprender jamás cómo un hombre tan comprometido con la tremenda actualidad de la guerra civil y tan baqueteado por sus propios camaradas del momento, y no digamos por sus ex compañeros, que lo tenían por tránsfuga, pudo abstraerse de tantas presiones del medio y neutralizar tantos acosos apuntando a su cabeza, tantas penas y quebrantos sentimentales íntimos, cómo consiguió abismarse en su compartimiento estanco creador para alumbrar ese prodigio de novela, probablemente la más «desafectada» ${ }^{1}$ de todas las que ha escrito, que no son pocas.

${ }^{1}$ Cfr. mi tesis «Imán» y la novela histórica de Sender (Londres, Tamesis Books, 1971), p. 262, en que hablo del estilo recio y desafectado de Sender. No digo desafecto en el sentido de 'opuesto' 


\section{EL LUGAR DE SENDER}

Podría ser este ejemplo la máxima prueba de mi segundo definidor del estilo senderiano, porque hay que tener una capacidad de abstracción extraordinaria para desentenderse hasta ese punto de lo concreto que pincha por todos los poros sin lograr alcanzar la sangre artística que circula incontaminable por esa mayestática alegoría de la realeza del hombre y la mujer. Diríase que esa desafectación roza el autismo o, por lo menos, que tiene no poco de esquizoide. Tal vez puedan calificarse de algo así esos momentos cuasi divinos del genio (un Hegel abismado en sus pensamientos que no oye los cañonazos de los ocupantes de su ciudad o un Van Gogh enajenado en su lienzo o un Beethoven encerrado con doble blindaje: su sordera y su música interior omnienvolvente).

\section{ESPIGANDO EN MEMORIAS BISIESTAS ${ }^{2}$}

Sobre el pensamiento de Sender ya hemos tratado en obras anteriores de una manera exclusiva o monográfica, si se prefiere. Quiero decir, tesis aparte (ya mencionada en nota 1), en mi ensayo «La parábola de La Esfera...» y en mi conferencia El pensamiento intimo de Sender. ${ }^{3}$ Por lo demás, en todos los libros de Sender se pueden hacer calas de su pulpa pensante hecha letra impresa, porque toda su obra está, más que salpicada, trufada de filosofía privativa y privada (a esto me refería con lo de pensamiento

o 'contrario', sino desafectado. Luego, en primer término, quiero significar lo contrapuesto a afectado, amanerado. Pero, si sólo fuera esto, ya iría implícita esta acepción en el primer calificativo. No, se trata de un efecto tal como que algo nos remueva el ánimo o modifique nuestra conducta (no hay tampoco alusión al sentido inglés de unconcerned, que viene a ser indiferente, ni mucho menos al francés désaffecté ni désaffectionnê). Hay, para mí, al menos, en desafectado una actitud voluntaria o, mejor, como una actitud preventiva a no ser víctima o juguete de nada ni de nadie, respectivamente. Como un empeño en mantenerse, pase lo que pase, sereno y lúcido, indiferente a todo compromiso en arte y, sobre todo, independiente, soberano... Soberano quiere decir aquí que Sender parte implacablemente de su realidad, una realidad interiorizada, cabalmente entrevista, y de sus prolongaciones, extrapolaciones y derivaciones de novelista siempre dispuesto a la combinatoria de un relato y a la estructuración de una novela. Pero quiero añadir un argumento cupular: Ramón José Sender Garcés es un ser cuadrado y encuadrado en esos cuatro nombres - padres y abuelos - pero con un marco elástico que igual cede por los lados como se rellena por los ladillos —como dicen los tipógrafos--; en vez de tener un cuadro con escapatorias imaginarias y un marco fijo y limitador, él es un cuadro fijo y estabilizado en un marco desestabilizador y libérrimo. De ahí que no se haya interesado nunca por las formas y mucho menos por las modas estilísticas. Cuando escribe, Sender no atiende al entomo, es como un autista. Bueno, un poco autista lo es todo creador. Cuántos artistas no se han autoculpado de esquizofrénicos, ¿verdad? Pero Sender no se ha sentido nunca culpable por eso. Ni por eso ni por nada.

${ }^{2}$ Ramón J. SENDER, Memorias bistestas (Bajo el signo de Sagitario), Barcelona, Destino, 1981.

${ }^{3}$ Cfr. el artículo de mi libro La verdad de Ramón J. Sender (Leiden-Tárrega, Ediciones Cinca, 1982, pp. 85-124), cuyo título completo es "La parábola de La esfera y la vocación de intelectual de Sender». Y en cuanto a mi conferencia - pronunciada en la Biblioteca Central de la Diputación General de Aragón (Zaragoza) el 27 de febrero de 1992-, está publicada en la revista de cultura aragonesa Rolde, 60 (abril-junio de 1992). 
íntimo de mi conferencia). Pero si en La Esfera, una de sus novelas más intrigantes, filosóficamente hablando, está su modo de pensar parabolizado y un mucho exasperado entre agudas y extremas contradicciones vivenciales, aquí en Memorias bisiestas no hay stream of thinking propiamente, sino una sucesión de charquitos que ha ido dejando la intermitente lluvia del pensar senderiano en un bloc de notas a mano que igual pueden reflejar una idea profunda como una ocurrencia cazada al vuelo o un mot d'esprit de cierto ingenio. Como hipótesis de trabajo queremos postular que el librito podrá ayudarnos a dilucidar, en lo posible, la aporía aparentemente dilemática que planteábamos al empezar.

Ya el título es la mar de raro y nos da que pensar. Porque eso de memorias, para empezar, no viene a cuento. No tiene este libro nada de memorias, salvo algunos esporádicos recuerdos de infancia o anécdotas que se cuentan para reforzar una idea o salirse del tiesto simili-docente. Hubiera podido titularlo con mayor aproximación a lo que es realmente: sentencias, filosofemas, epigramas y aforismos o desahogos reflexivo-líricos, porque en un texto de unas 192 páginas con que cuenta el libro, 48 páginas que he contado de poemas representan la cuarta parte, lo que es mucho para una obra que se espera y se anuncia de prosaria índole. Por lo general, los versos de este libro no tienen para nosotros gran interés como material filosófico, aunque sí para zanjar la cuestión de si Sender escribe para pensar o piensa para escribir. $\mathrm{O}$ hace lo uno y lo otro al unísono o alternativamente. Acabemos con la presentación de esta aportación lírica. La parte del león se la llevan los cinco largos poemas, por cierto en parte ya publicados en anteriores poemarios: los cuatro dedicados a los nombres de La Celestina, Don Quijote, Don Juan y los héroes de la picaresca (El Lazarillo de Tormes, El Buscón, Guzmán de Alfarache, Rinconete y Cortadillo y El Patio de Monipodio), sucesivamente. Más el poema a su hermano Manuel, que puede servirnos de muestra para sorprender cómo, al versificar, calza los coturnos y se le tensan las redes sinápticas de un golpe:

\footnotetext{
No sé qué me pasa. Pero cuando un hecho sacude profundamente mi vida, hay una especie de inhibición intelectual que hace difícil escribir sobre él. Por ejemplo, la muerte de mi hermano Manuel, que era y es en mi recuerdo el hombre más noble y puro que he conocido en mi vida. Sólo he podido escribir lo que sigue:

Los rifles lo miraban todos secos

- ocho bocas de hierro lo miraban-

y era el hijo de Dios, era mi hermano. [...] (p. 108)
}

$\mathrm{Y}$ así sucesivamente, durante cinco estancias de un total de 71 versos, para luego seguir nuevamente en prosa sobre el divinizado hermano, como se ha visto y puede verse aún más claro en este terceto de pie quebrado (fin de la cuarta estancia):

Que ha muerto Dios

lo mismo que mi hermano,

contra la tapia del fosal cercano. (pp. 109-110) 


\section{EL LUGAR DE SENDER}

Pero, ¿qué le pasa a Sender con el verso? Yo creo que no reacciona con la naturalidad con que lo hace al escribir prosa. Siempre he dicho que Sender se pone a escribir sin pararse a hacer ringorrangos con la pluma en el aire, como hacen muchos «fatos» o paletos al firmar, sino de rondón, como lanza su primer chorro un géiser que viene corriendo subterráneamente y casi hirviendo. Pero parece como si al encontrarse en la suerte de escribir poesía se cuadrara y se pusiera firmes, hasta que Erato no le ordene « $_{i}$ Descanso!». El hecho de que la musa le intimide tanto debe de tener una explicación sicoanalítica; quién sabe si de niño no impresionó con sus versos y en cambio sí que fue aplaudido por sus prosas. En todo caso, presiente los corsés del metro y de la rima y, sin dejar de acatarlos, se suelta el pelo como buen rebelde y versifica con la libertad, mejor: con el libertinaje y capricho de las asociaciones más superrealistas. $Y$ así no es extraño que se oigan crujidos y clics de huesos en esas estrofas senderianas. Porque en poesía no se pone a escribir por pensar, sino habiendo pensado que se va a poner entre la espada del arrojo traumatizado y la pared del canon insalvable. Claro que hay pensamiento en su poesía, ¿cómo podría escribir si no? Pero es un pensar en el verso de remedo y de remedio. Porque ha perdido lo que más le honra y le distingue en sus narraciones, ensayos y comedias: la naturalidad. Y, si no, que nos lo diga él mismo. En la página 114 del librito que nos entretiene, así, sin comerlo ni beberlo, nos espeta:

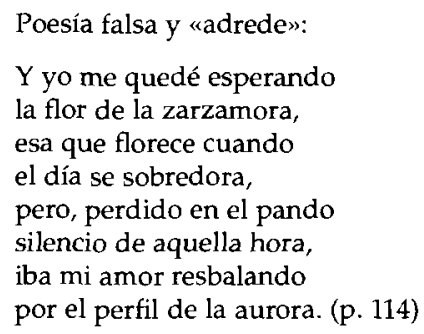

Sin comentarios. Pero así tantos versos, querido Ramón.

Maticemos un poco más nuestro análisis. Quien ha leído a Sender sabe muy bien que también en prosa rinde culto al superrealismo. ¿Y quién no? Todos los escritores desde Breton acá han tenido que pasar por el sarampión del superrealismo, un sarampión que se ha ido convirtiendo en un enriquecimiento prodigioso, que por algo el superrealismo nos abre nuevas dimensiones que sería tontería no hacer fructificar en obra literaria. Pero son, en Sender, siempre escapes de superrealismo que propicia el pensamiento, sea neoplatónico o hermético, mágico o mistagógico, panteísta, deísta o cristóforo, con sus derrames oníricos y hondos reflujos de mentalidad prelógica que no suelen faltar en cuanto se desboca el corcel del pensamiento primitivista senderiano. Y éstos son los momentos en que Sender escribe por (no para) pensar, mientras que cuando narra a ras de tierra y discurre sobre hechos o critica cosas y casos, personas y personajes, entonces no, entonces piensa por escribir. 
Tomemos algunos ejemplos. Yo he separado algunos trozos escogidos de Memorias bisiestas y los he clasificado en cinco categorías según el tema: a) ocurrencias más o menos ingeniosas, b) críticas políticas, c) sobre literatura y literatos, d) asuntos filosóficos (o filosofemas a lo Pompeyo Gener) y e) cuestiones religiosas.

a) De este primer apartado transcribimos:

El hombre no ha sido ni será nunca un objeto de demostración, dicen todos los filósofos. (Tampoco Dios, y eso nos ha dado grandes perplejidades secretas). (p. 32)

Pushkin fue asesinado por el amante de su esposa, Rimbaud muere en la ignominia, Baudelaire en la locura, García Lorca fusilado, Miguel Hernández abandonado en la cárcel, Dylan Thomas y Rubén Darío en la flor de su vida con el cerebro deshecho por el alcohol. Es como si los dioses tuvieran celos de los poetas. (p. 32)

No hay duda de que el paréntesis de la primera cita ha sido pensado antes que la primera frase. Luego puede decirse que aquí ha escrito por pensar. $\mathrm{Y}$ en la siguiente broma lo mismo:

No hay infierno para mí, ya que si me doy cuenta de que estoy algún día en el infierno por voluntad de Dios, el infierno será un paraíso. (p. 72)

Arte sofístico es o el bumerán de la lógica. Pero es verosímil que esta voltereta se deba más al escribir que al pensar previo.

Las citas del francés nos hacen parecer mundanos, las del inglés agudos, las del alemán sabios, las del latín falsos, las del griego perversos y las del sánscrito charlatanes. (p. 92)

Este catálogo de prejuicios contrasta con este antiprejuicio, en uno y otro caso sacando punta a algún principio obvio al que le sale el tiro por la culata:

\footnotetext{
La gente tiene miedo a los poderosos y desprecia a los que no son nada. Es un error. El poderoso es pusilánime y el que no tiene nada que perder es peligroso. Ojo, pues, con los miserables porque, además, y esto es lo más grave, tienen siempre razón. (p. 94)
}

He aquí, por cierto, una de esas verdades tan obvias que se pierden de vista pero que no por simples hay que despreciar ni olvidar, porque lo simple es siempre fundamental.

Ahora dos muestras de sendas observaciones que se remontan a verdades al arrancar la cortinilla del sagrario:

Los ángeles están un poco avergonzados de serlo en relación con nosotros, por sus ventajas. Algunas de ellas las comprendemos, pero eso de no tener que hacer pis es ya favoritismo. (p. 105) 
La Iglesia censura la obra de Dios poniéndole a Jesús Crucificado lenzuelos en las ingles. (p. 105)

Y por fin un mot d'esprit o juego conceptista que tanto gusta al émulo de Baltasar Gracián:

La vida es una aventura peligrosa de la que nadie sale vivo. (p. 117)

b) No hay mucha política en la obra de Sender, pero como en este libro se registran momentos de reflexión, por fuerza tenía que entrar la reflexión política, aunque sea muy de vez en cuando. En lo que no entra ni por casualidad es en politiquerías, como todo pensador que se respete. En la página 20 escribe:

Lo malo de las formas de política democrática o demagógica conocidas hasta hoy es que en ellas se cultiva y desarrolla un pragmatismo engañoso y también la licencia, el libertinaje, el escepticismo y una especie de estupor colectivo (que debíamos perseguir igual que el uso de las drogas estupefacientes), a través de los cuales todos los valores genuinos del llamado dasein de Heidegger bajan, y el sentido de lo religioso, esencial, ético, estético se pierde. (p. 20)

Parece un billet $d u$ jour del Le Monde de antaño, a cargo de un maestro de la crítica de la actualidad en cien palabras. Lástima que no esté de acuerdo, según parece, con la despenalización de la droga, sobre todo que lo diga del uso es lo que duele. En cuanto a nuestro dilema, es evidente que la idea ya estaba conceptuada antes de ser escrita, como es lo frecuente en todo tipo de escritura ensayística. Uno escribe un ensayo para lanzar y demostrar una idea o un complejo de ideas que puede definirse como teoría o doctrina.

En el siguiente fragmento, en cambio, la idea anunciada parece haberse sintetizado felizmente en un atajo muy fecundo de enseñanzas políticas, al escribirla:

Todos sabíamos hace tiempo que pensar es una forma de acción más impregnada de sentido y de consecuencias que cualquier clase de praxis. (p. 71)

Claro, pensar es lo que hace la democracia (jjamás la demagogia!), porque es lo que hace la crítica, la libertad.

A continuación un azote nihilistoide, seguido de una constatación histórica sublevante:

Para ser un buen político hay que ser fundamentalmente frívolo y tomar en serio los propios discursos y, sobre todo, esa utopía ridícula del bien general. (p. 116)

España sería un país modelo si tuviera alguna oportunidad en la historia, pero no le han permitido desde los tiempos de Gerión sino mantener a 
duras penas a su aristocracia. En cuanto trata de eludir ese vicioso hábito $\mathrm{y}$ hacer algo razonable, todo el mundo cae sobre ella. (p. 172)

c) Sobre literatura no se prodiga mucho en este librito. Otros hay más extensamente dedicados al tema, como Unamuno, Valle-Inclán, Baroja y Santayana o Examen de ingenios. Los noventayochos, así como también en algunos capitulillos de Ensayos del otro mundo y en Solanar y lucernario aragonés, y después de su estupendo Monte Odina, en su Segundo Solanar y lucernario, pero sobre todo, quizá, en ese magnífico libro titulado Álbum de radiografias secretas.

Pues bien, veamos qué nos da esta temática para nuestro objeto:

En tiempos de nuestros padres no se podía imprimir la palabra puta. Ahora, sí. Tal vez mañana estarán permitidas otras palabras más procaces, pero de pronto vemos que esas palabras, cuya libertad nos sorprende, las imprimían ya el Arcipreste, Cervantes, Quevedo y otros autores, y que lo que la gente llama avanzar en literatura es dar vueltas a la noria. (p. 20)

Idea intuida y perseguida que se rinde a la expresión recta. Yo mismo la he enunciado y repetido: que no hay progreso en arte, hay momentos estelares $y$, como ha habido siempre estrellas y es de esperar que titilen mientras haya humanidad, siempre ha habido, hay y habrá obras literarias (poquitas, eso sí) que nos alumbren con su luz propia desde cualquier tiempo.

En este loar indirecto a su admirado maestro (sería interesante averiguar por qué somos tantos los aragoneses que admiramos a don Ramón) hay juego de revelación:

Todavía no se ha enterado la gente de que la mejor y tal vez la única novela de veras original y merecedora de consideración entre todas las de los autores del 98 es Flor de Santidad de Valle Inclán. (p. 41)

Por el contrario, aquí se descubre una de sus fobias moderada por la ironía de contagio a costa de un valor con alguna sombra de duda:

\footnotetext{
Se habla del existencialismo de Unamuno y del de Ortega. Es verdad que el primero era un existencialista seudo religioso y el segundo seudo ateo. Por esa condición de seudos no entran en la capilla de los meros meros, como dirían en México. (p. 83)
}

Contra los mismos, pero ahora sin ironía. La primera flecha, de su aljaba trágica extraída, quiere ser un correctivo al Filósofo Ibero; y la segunda un pinchazo al sapo hinchado vascongado:

Si me hubieran matado los fascistas, como a Lorca, ahora yo estaría más vivo de lo que estoy. (Para argüir contra el vitalismo de Ortega). (p. 85)

La tontería de la época de nuestros padres se define de una vez leyendo Del sentimiento trágico de la vida y pensando que por ese libro le dieron a Una- 
muno fama de místico y de sabio, cuando es sólo un mediocre vulgarizador de Spinoza. (p. 85)

Y, por último, dos consejos de refracción, más que de reflexión:

Con menos talento hay escritores que tendrían éxito. Esa evidencia va destruyendo a algunos poco a poco. (p. 112)

Lo malo de los escritores jóvenes es que creen que el universo depende de una buena frase. No es verdad. Depende de una buena revelación - de una idea justa-, más o menos secreta hasta entonces, en la cual el estilo cuenta poco o nada. (p. 113)

En la primera cita veo claramente una alusión a Felipe Aláiz, de quien ha dicho en otra parte que lo que le pierde es su talento. $Y$ es verdad, si no fuera porque, además, le tenía al éxito, precisamente, un miedo cerval. Pero, si nos fijamos bien, las dos citas abundan en lo mismo y compendian toda la poética senderiana: cargar el acento sobre la idea original, por secreta, sin preocuparse del estilo. Y de paso podemos inferir que, si la idea nuclear de una obra de Sender va envuelta en misterio, en desenvolverlo consiste su discurso, ya sea narrativo, retórico o poético. Luego por pensar es por lo que escribe, si el discurso es la acción y el resultado de discurrir.

d) y e) En estas dos últimas partes que nos quedan por espigar, se ha de encontrar lo más interesante, puesto que nos las habremos con los legados más ricos de Sender en su obra: el filosófico y el religioso. Y el hecho de que éste sea uno de sus últimos libros entre rememorativos y recolectores, medio memoriales, medio testamentarios (jah! y con sus codicilos, que podrían ser la razón suprema de su publicación, algo así como lo que decíamos: unos a modo de apéndices, pues, o de apostillas), le da a Memorias bisiestas una categoría de última palabra. librito:

He aquí lo que reflotamos del pensamiento filosófico de Sender en este

El filósofo es el único que ve en la verdad de lo que es. Pero no necesariamente el filósofo profesional, sino ese que nunca escribe y que considera la expresión escrita, y sobre todo impresa, como una especie de lujo innecesario. (p. 8)

La incongruencia de vivir puede ser comparada sólo con la incongruencia de morir. Las dos juntas son una gran fuente de poesía. (p. 8)

La primera sentencia ha debido de pasar por la experiencia del trato con labriegos aragoneses, lo más probable, pero puede haber sido también con otros: un diálogo con uno de esos hombres graves y taciturnos que viven la tierra y le sacan a la naturaleza, entre todo lo que poseen, su sabiduría, no tiene apenas que envidiar a un diálogo de Platón, belleza de expresión aparte. 
Y la segunda cita es algo privativo de Sender: jugar con las incongruencias para hacer o al menos sugerir poesía. Advirtiendo que esas incongruencias no las elabora en seco sino al correr de la pluma (o del teclado).

\footnotetext{
Toda filosofía comienza con el estremecimiento ante el misterio, lo mismo que la religión y la poesía. (p. 16)
}

¿Nota existencialista? Sí, pero no; del Dasein más que de la Existenz heideggeriana. Ya no es el asombro clásico ni todavía la inquietud nuestra. Participa de todos modos del existenciario sentir, ese pensar que surte el escribir.

Y, ya que nos sale Heidegger, un salvavidas para el Martin de Messkirch:

Lo único bueno del fascista nazi Heidegger es que todas sus intuiciones de ateo se rinden frente a la obra de un poeta místico: Hölderlin. (pp. 37-38)

Ahora una broma sangrante a expensas de Sartre (hay otras en que también pagan el pato los franceses por «reductores» del hombre):

\footnotetext{
El hombre es una pasión fútil —dice Jean-Paul-, y eso sería verdad si fuera capaz ese filósofo de morir como otros en la hoguera defendiendo sus puntos de vista. (Lo que sería una síntesis admirable del en soi y del pour soi). (p. 63)
}

Lo más seguro es que tuviera in mente a nuestro Servet. ¡Lástima que no lo haya nombrado!

\footnotetext{
Lo que entiendo por real absoluto lo he escrito mejor o peor, y podría ser una de las bases — un punto de partida - para una escuela filosófica española. Lo digo sencilla y sinceramente. (Pero impúdicamente, es verdad). (p. 73)
}

Sender distingue entre real absoluto y Absoluto Real (así, con mayúsculas). Lo primero sería como una invitación de Dios. Lo segundo es el silencio del universo y el lenguaje de ese silencio que está detrás de cada palabra y que sería el lenguaje de Dios. Sender parte del convencimiento de que las palabras no lo pueden decir todo y la zona del entendimiento que escapa o rebasa la palabra es la región del real absoluto. También la ciencia trata de explorar esa zona inefable, sobre todo con la idea de la luz, pero es la mística, la poesía mística, la que trabaja en ese campo ignoto, en ese horizonte de misterio que, de lo real absoluto, hace lo Absoluto Real. En resumen, lo real absoluto sería para Sender la realidad esencialista que revestida de abstracción tiende a las intuiciones universales y eternas. Por poner dos ejemplos, lo Absoluto Real se presiente/intuye en la invención de Jesús dándose en su carne y sangre divinas al hombre y en la poesía de 


\section{EL LUGAR DE SENDER}

san Juan de la Cruz. La idea del Logos y del Verbo no es otra cosa. Es el supremo «infringimiento» dirigido a lo real absoluto. ${ }^{4}$

Quiero que vengan ahora tres frases que se anticipan a mi tesis de que Servet es un precursor hispano del nieto de iberos, el holandés Baruch Spinoza:

\footnotetext{
A los filósofos les va mal en la vida. Sócrates, Séneca, Miguel Servet, Giordano Bruno, y tantos otros fueron condenados a morir. El más angélico de ellos, Spinoza, no pudo publicar en su vida nada importante y fue perseguido, agredido en la calle, se escapó de ser asesinado por casualidad. Todo esto en la liberal Holanda, país de gente seria, aunque no tanto como los calvinistas suizos. (p. 82)

Si hay un pensamiento genuinamente español —no serio sino angélico-, es el de Spinoza. Los serios más peligrosos están en Suiza y en Holanda y en algunas partes del middle east americano. Es decir, en el limbo. (p. 82)

Un hereje español, Miguel Servet, ha conocido la suerte de los genuinos y grandes profetas, y en España se le ignora o poco menos. Fue quemado vivo en Suiza, y, después, bajo su inspiración, se fundó la iglesia cristiana más liberal del mundo: la iglesia unitaria de los Estados Unidos. (p. 82)
}

Como que Sender es genuinamente español, no es de extrañar que haya abrevado muy a gusto en las fuentes del gran filósofo de Amsterdam, hijo de padre nacido en Portugal y nieto de abuelo nacido en Espinosa de los Monteros. En el repaso que hago de las posibles influencias filosóficas en Sender (véase el citado La verdad de Ramón J. Sender) me extiendo, naturalmente, sobre la de Spinoza. Todo lector de la obra senderiana ha tenido por fuerza que rastrear primeros planos y fondos panteístas. Baste una frase del comentario mío en esa obra para aclarar mi apunte: «La corrección senderiana respecto a Spinoza se perfila a partir del momento en que el renegado de la Sinagoga sigue (aun queriendo sacudírsela) la influencia del unilateral racionalismo (Descartes, Leibniz) y no llega a exteriorizar los fundamentos más profundos que podrían explicar esa actitud de hombre-no-sólo-de-razón [...] Por ejemplo, el conocimiento intuitivo y directo de Spinoza se prolonga en Sender hasta el límite de un conocimiento innato y total, y la acción de contemplar directa e intuitivamente como acción de conocer del Espinosa holandizado se hace un saberlo todo primigenio en el maño californizado. Pero más importante quizá sea la idea de realidad positiva del autor de Ética, que en el autor de La Esfera es un leitmotiv fundamental, porque desde Imán descubrimos en Sender creencias panteístas perfectamente conciliables con esa sealidad plena, positiva, perfecta de Spinoza que abarca a cuerpo y alma, espíritu y materia». 5

\footnotetext{
4 De Ensayos sobre el infringimiento cristiano, México, D. F., Editores Mexicanos Unidos, 1967, pp. 180-184.

5 La verdad de Ramón J. Sender, ed. cit., pp. 94-95.
} 
Salidos a la descubierta de un modo de escribir pensando en Sender, podrían ustedes haberse preguntado: ¿para qué?, ¿qué puede importarnos si ha de escribir para pensar o ha de pensar para escribir? Pues, por ejemplo, para determinar en este mismo caso en que rebasa al maestro si lo rebasa por inspiración grafógena o por reflexión peripatética, pongamos more aristotélico. Y yo creo que es lo primero y que, a la lectura luego reposada de lo escrito, más de una vez debió de quedarse Sender más que perplejo, como cuando uno ve que ha saltado ocho metros en un aprieto de vida o muerte, sintiéndose normalmente incapaz de saltar cuatro.

Es, pues, como se ve, toda una enseñanza. Por lo menos este caso nos enseña que la actividad de escribir puede ser, no sólo creadora, sino recreadora. $Y$ ahora prosigamos el curso del pensamiento senderiano de espejuelo en espejuelo:

No sé qué sucede, pero yo pienso con Husserl que no hay relativismo posible en cuanto a la verdad. Hay una esencia de la verdad que se refleja en todas las verdades particulares, y yo estoy de lleno en esa verdad sin la cual el universo no podría existir. Ni yo ser parte de él. (p. 102)

Y esto lo escribe un admirador del inventor de la relatividad ( $\mathrm{a}$ ah!, por cierto, ¿quién le había acusado a Sender de antisemita? Siendo un fan como fue siempre de Einstein y de tantos genios judíos, entre los que destaca su Simone Weil, poco menos que su mentora y ninfa Egeria, semejante calumnia no puede salir más que de la más negra envidia o a lo mejor de fobias políticas que aún son peores). Pues bien, para Sender, la ley de la relatividad es también una verdad absoluta, porque, literalmente, no podría existir sin ella el universo.

Acabaremos con estas tres espigas filosóficas, la tercera de las cuales es un breve tributo a un maestro al que le ha dedicado no pocas páginas de glosa admirable y admirativa:

La filosofía no es una profesión de hombres superiores, sino una actividad natural de todos, como la respiración y el soñar. (p. 135)

En cuanto un filósofo más o menos académico (en realidad, los filósofos han prosperado siempre fuera de las universidades) trata de crear alguna clase de mandarinismo, ya no es sino un charlatán. (p. 135)

A los noventa años, el admirable Bertrand Russell va al frente de una manifestación pública y se sienta en el suelo para permanecer así varias horas frente al edificio del gobierno en protesta contra la bomba atómica. ¿Habría sido capaz Ortega y Gasset - a quien, por otra parte, también admiro- de una cosa así? (p. 135)

Con estas tres frases queda, pues, para Sender bien claro que la filosofía no tiene nada de profesional y menos de oficial, que es como tirar a la barra: hay quienes llegan más lejos que los demás y no por eso son premiados, que en este deporte rural no hay tinglados de torneos ni campeonatos con metálicos galardones escandalosos. 


\section{EL LUGAR DE SENDER}

Y hemos llegado a la temática más desconcertante de Sender: la religiosa. Ensayos sobre el infringimiento cristiano es, sin duda alguna, el libro en que más se extiende y profundiza sobre materia religiosa. Pero tratar a nuestra satisfacción ese ensayo nos llevaría un libro entero. Vamos a seguir sirviéndonos del libro que nos guía: Memorias bisiestas, no sin antes transcribirles una frase que resume el mentado ensayo sobre el infringimiento. Dice así:

Pero el núcleo del sagrado fuego se salva siempre. Se salvan Jesús y su doctrina. Jesús más vivo que nunca por no haber existido: ahí está la cifra de su inmortalidad y su doctrina más atractiva y sublime por ser impracticable $e$ imposible. (ed. cit., p. 256) [Subrayo yo y ya se ve por qué.]

Retengamos esta frase de 1967 y volvamos a 1981. Primera cita:

La obsesión de la razón pura nos ha llevado al dualismo de Descartes (pensamiento y extensión), al de Kant (razón teórica y práctica), al de Nietzsche (Apolo y Dionysos), al de Sartre (esencia y existencia). Eso hace pensar que no hay ontología posible sin un trascender religioso. (p. 8)

¿A ver, a ver! ¿Acaso esos dualismos los identifica Sender con tesis y antítesis de las que ha de desprenderse una síntesis a la manera dialéctica hegeliana? No estamos en sistemas antitéticos o contradictorios ni conflictivos y de esos dualismos no tiene por qué desprenderse nada. $¿ \mathrm{O}$ es que el trascender religioso es lo único que puede resolver, disolviéndolos, esos dualismos? Y, aun así... La ontología es la parte de la filosofía que trata de estudiar la noción del Ser. Si para ese trascender necesitamos que nos explique el Ser la religión, nos quedaremos con esa explicación que por explicarlo todo no nos explica nada: Dios. Si al menos nos valiéramos de la fórmula spinoziana Deus sive Natura, con la naturaleza tendríamos las puertas abiertas para explicárnosla nosotros mismos y a partir de los mismos «nosotros»...

Segunda cita:

El hombre es -creo que ha dicho Gabriel Marcel-capax Dei. Y sólo en esa dimensión se puede considerar infinito. (p. 16)

Porque en él cabe Dios, es infinito el hombre, si damos la infinitud como primer atributo de la divinidad, naturalmente. Digamos que es una infinitud poética o un sofisma ingenioso dar por cierto que se es lo que se piensa ser, no, peor: lo que se piensa que es otro... impensable. La famosa inmortalidad en carne y hueso de Unamuno sólo es de recibo en poesía. Como el no menos famoso momento eterno del amor (o del orgasmo, más concretamente).

Tercera cita:

Dios se ha tomado tanto trabajo haciendo todo esto, que sin duda tiene alguna intención. Nadie sabe cuál. A veces yo creo que la sé, esa intención, y si no la digo es porque tengo miedo. (p. 30) 
Tiene gracia y parece salida de un rápido del río-discurso senderiano. Pero, ¿miedo a qué?, ¿por qué?, ¿de qué? Todo hace creer que se trata de una escapatoria retórica, porque no queremos creer que sea supersticiosa.

Cuarta cita:

Definición de Dios por exclusiones: Dios es todo aquello que nosotros no somos ni podemos ser (además de ser nosotros mismos). (p. 35)

Razonable, ¿no? Podía haberlo dicho antes y nos habría evitado romper tantas cañas.

Quinta cita:

\footnotetext{
Hemos necesitado veinte siglos de idea y sentimiento de Dios para que el hombre comience a percibir religiosamente qué es la libertad. (p. 59)
}

He aquí una idea genial, si la entendemos bien. Y traduzco: si percibir es dar paso a la sensación o al estímulo externo hasta el cerebro, o sea, tener conciencia de algo, y si percibir religiosamente es tener conciencia trascendente de lo que nos pasa, la libertad se sitúa en lo más alto como faro, si no ya como estrella polar, guía de navegantes. Comenzar a entender religiosamente la libertad será, como quería Spinoza, la prueba de nuestra dignidad de hombres y el vehículo más idóneo para vivir en sociedad. Luego ese adverbio religiosamente hay que entenderlo en su versión panteísta, que no daña ni compromete a nadie.

Como sexta cita, una frase que ha repetido muchas veces:

La idea de Dios es la idea más práctica que conozco. (p. 62)

¿Hay que acoger esto como un rasgo de cinismo senderiano? Quiero decir si hay que tomar eso de práctico como lo entienden los curas y los maquiavelos de tres al cuarto que dicen: si no hubiera religión habría que inventarla. Estoy seguro de que no es ése el plano en que se expresa Sender, sino que sitúa el concepto práctico en el real absoluto de que hemos hablado, desde el momento en que Dios es, para Sender: libertad, amor y trascendencia del arte y de la vida existencial del hombre y la mujer. Y, si quieren ustedes más claro, el agua de esta otra frase (séptima cita):

\footnotetext{
Definir a Dios como a un ser esencial sin principio ni fin es renunciar a definirlo, y eso es lo mejor de la definición. (p. 64)
}

Deslumbrante claridad... si Dios no se atribuyese el don de la eternidad, y si es eterno no puede tener principio ni fin, en efecto. Pero la broma está en que la mejor definición de Dios se encierra en renunciar a definirlo. Todo está ahí implicado, como hay Dios.

Otra charada por el estilo es la octava cita: 


\section{EL LUGAR DE SENDER}

Un viajero ruso del espacio dice que «no ha visto a Dios por allá arriba». Ésa es una prueba de que lo hay. Si el viajero lo hubiera visto, ya no lo habría. (pp. 87-88)

\section{Novena cita:}

Benavente decía: Dios es el autor aplaudido de una obra silbada. Es verdad, pero ahora vamos sabiendo que es precisamente detrás de esos tremendos círculos viciosos donde Dios se esconde de nosotros. (p. 97)

La frase de Benavente tiene miga, por algo es uno de nuestros repentistas más ingeniosos, pero el dribbling de Sender tampoco tiene desperdicio. Círculos viciosos son encerronas lógicas, pero ¿por qué se habría de encerrar Dios y menos aún esconderse de nosotros? Porque si aún dijese que se esconde para nosotros... Sería entonces como lo que ha dicho Sender tantas veces, aquello de que las grandes verdades se nos enuncian como paradojas, pero paradoja es más bien lo que formula Benavente y no círculo vicioso. Dios es Dios y no hay más que decir, sino aplaudir, pero ese trágico ¿dramaturgo, comediógrafo, sainetero, bufo?, por intocable que sea y engloriado que esté, puede crear obras aburridas, absurdas, patosas...

Viene la décima cita a enfrentar contabilidad con lo real absoluto:

Hay que decirlo de una vez. La muerte es lo que nos salva, porque gracias a ella somos acreedores de la Providencia. De otro modo, estaríamos siempre en deuda con ella. (p. 106)

El undécimo no estorbar, dicen. $\mathrm{Y}$ a fe que las dos frases de esta doble undécima cita vienen a estorbarlo todo como dos jarros de agua fría. Primer jarro:

Si Jesús tuvo plena conciencia de que con su muerte salvaba a la humanidad, su sacrificio es menos meritorio que el de millares y millares de pobres judíos que morían en las cámaras de gas sin saber por qué. ( $Y$ cientos de miles de españoles estuvieron en el mismo caso). (p. 173)

Segundo jarro:

No hay que hacerse ilusiones. Al fin nacemos, hacemos el amor y morimos como los perros. (p. 173)

\section{ZANJANDO CON DOS CONCLUSIONES OBLIGADAS}

Quiero dejar en claro dos cosas: una formal de investigación estilística y otra de gran calado con mar de fondo. La primera sería saber con qué nos quedamos ante aquel dilema que planteábamos al principio sobre si Sender piensa por escribir o escribe por pensar. $Y$ la segunda, qué hay de 
todo lo muchísimo que ha escrito sobre Dios y la religión, ¿es rollazo, como diría un estudiante de hoy, o es confesión tan de fiar como las de san Agustín, Rousseau o Amiel?

I. La primera pregunta nos la hemos hecho a propósito del librito de 1981 Memorias bisiestas. Pero podíamos habérnosla hecho a propósito de muchas obras de Sender, si no ya de todas. Es bien sabido que desde muy niño le traía loco a Sender la letra impresa. Siempre fue un grafoextravertido, tenía que decirlo todo, a ser posible por escrito. Eso no quiere decir que no fuese hablador, porque también nos consta que era muy amigo de sus amigos y que gustaba como nadie de una buena charla con café, copa y puro entre amigos, iy no digamos entre amigas! Pero no le gustaba escribir para presumir publicando, sino porque necesitaba comunicarse (este se es muy importante, porque significa más a sí mismo que comunicar a o con los demás). Y la primera y principal muestra que nos lo sugiere es el simple hecho de que escriba como escribe: directo, natural y llano. El que presume de escritor se adorna con las mejores plumas, dicho sea literalmente y por extensión al adornarse con plumas ajenas. Sin embargo, una vez en el ajo, sobre la marcha, le gusta que el lector pique y le pique su literario condimento.

Son muy frecuentes las pequeñas trampas al lector como cebos de pescador y aún son más frecuentes los finales que escuecen o los paréntesis que alampan o requeman el paladar del lector ingenuo o exquisito. Éstas son las franquezas que se permite Sender llevado por su afán de hacerse con el que le leyere. O para ganárselo o para apabullarlo.

Yo no le hago a Sender un hombre morosamente reflexivo. No es de los contemplativos buceadores del pensamiento. Me lo figuro más elaborando su pensamiento al correr de la pluma (o del teclado) que parado ante la ventana o deambulando por los bosques. En este deambular lo veo observando, reteniendo imágenes y estados, comparando situaciones a la vista y sus prolongaciones, extrapolaciones y derivaciones de novelista siempre dispuesto a la combinatoria de un relato y a la estructuración de una novela. Pero aparte de nuestras apostillas a las citas, en que hemos tenido ocasión de dar muchas pistas, quiero añadir un argumento cupular.

Más de una vez nos ha revelado que su manera de novelar no obedece a montajes previamente ideados ni a planos u órdenes de operaciones propios de arquitectos y generales. Siempre nos ha confesado que su estilo es de estructuras y que empieza una novela sin tener ni siquiera un guión o chuleta de lo que va a ser, sino simple y sencillamente una revelación más o menos nebulosa, una idea que quiere someter a la prueba literaria o un vago argumento del que, a lo mejor, no tiene más que un esquema vacilante con una meta apenas visible. $Y$ otra confidencia que nos importa mucho aquí es la de que construye sus novelas en virtud de una memoria selectiva. Con este término quiere decir que las secuencias de sus novelas manan de los datos que va seleccionando según una polarización pensada y sentida por el novelista, deseçhando lo innecesario y aun estor- 
bante y subrayando o poniendo de relleno lo más importante y lo más verosímil para su historia, respectivamente Pero esto está dicho hablando en términos generales. Claro que se seleccionan los datos de la memoria, pero para cada dato en particular habríamos de entrar en otra clasificación, muy cara a Proust, por cierto: la de memoria voluntaria y memoria involuntaria...

La primera es la que proviene de la memoria selectiva, pero no la segunda, que corresponde enteramente a la memoria imprevista, automática de asociación, con sus datos-sorpresa y, sobre todo, con sus corolarios, alusiones y llamadas a la antítesis, a la paráfrasis, a la parábola y a la analogía. Ésta es la primera responsable del estilo senderiano y, por ende, de la manera de desarrollar Sender su corriente pensante en la escritura.

$\mathrm{Ni}$ que decir tiene que estas cosas que decimos de Sender no creemos ni por un segundo que sean nada exclusivo de nuestro autor. Lo único que pretendemos es demostrar que en Sender estos fenómenos de naturalidad en el estilo, de memoria involuntaria y de asociaciones preferentemente chocantes, paradójicas o ambiguas se dan con más fuerza y frecuencia que en el común de los escritores. Porque, por ejemplo, de la memoria y el olvido incontrolables ya nos habla el gran Pascal en sus Pensées:

\footnotetext{
Los pensamientos vienen y se van de forma caprichosa. No existe ningún sistema para contenerlos ni para poseerlos. Se ha escapado un pensamiento que yo estaba tratando de escribir; entonces escribo que se me ha escapado... Cuando escribo mis pensamientos a veces se me escapan, pero esto me hace recordar mi propia debilidad, que olvido continuamente y me enseña tanto como mi pensamiento olvidado, pues sólo lucho por reconocer mi propia insignificancia. ${ }^{6}$
}

En esta transcripción nos llama poderosamente la atención cuánto se parece esa manera pascaliana de escribir a la del mismo Sender. Sobre todo la segunda frase. Podíamos haberla atribuido tranquilamente a nuestro Ramón, siendo como es tan típica de aquel del punto redondo (porque «lo dijo Blas»...: ¿cómo el azar ha asociado aquí al refranero español con el genio francés, el menos francés de los franceses genios, por cierto?).

II. Otro azar que parece providencial: que Pascal nos cierre la primera conclusión y nos abra la segunda. Porque nos toca ahora abordar la más seria aporía del universo senderiano: su religiosidad. Pues bien, Sender se ha referido a Pascal y a su famoso pari ya en su libro de ensayos Examen de ingenios. Los noventayochos ${ }^{7}$ y en el librito que nos ocupa escribe:

Mi negocio, sin embargo, no es como el de Pascal. Yo me digo: si hay Dios, será bueno conmigo, y entonces todo habrá valido la pena. Si no lo hay, nadie me pedirá cuentas y la vida habrá sido una broma monstruosamente divertida. $[\ldots]$ (p. 59)

${ }^{6}$ Apologie de la religion chrétienne. Pensées, París, 1670.

7 Nueva York, Las Américas Publishing Co., 1961, p. 176. 


\begin{abstract}
Se dice que la existencia de Dios es una imposibilidad lógica y ontológica, pero olvidamos que la divinidad no puede tener la misma estructura ontológica que nosotros. (p. 59)
\end{abstract}

La misma estructura ontológica quizá no, pero sí lógica, porque lógicas sólo hay una. $Y$ hasta aquí queríamos llegar. ¿Puede el Logos ir contra el Verbo? ¿O puede la Razón ser negada por lo numinoso de Rudolph Otto, que tantas concomitancias guarda con el pensamiento senderiano más heterodoxo? Ni las Iglesias ni las ciencias admiten esas etiquetas numinóticas de lo misterioso y tremendo a la vez, de lo perverso y a un tiempo majestuoso, de lo venerable y fascinante, de lo realista y mágico, de lo sublime y desaforado, de lo solemne y absoluto. Las Iglesias, porque, aun sin invocar a la déesse Raison, no se fían y temen a ese magma del Das Heilige ottoniano como amenaza en sus propios y comunes dominios de la espiritualidad. Y las ciencias porque se deben sobre todo $\mathrm{y}$ ante todo al dictado racional con resultados universalmente observables, experimentables y controlables.

Si vamos directamente al grano y al fondo, la religiosidad de Sender arranca del convencimiento de un hecho exegético que le lleva a una admiración veneranda al interpretar dos mitos de las Sagradas Escrituras: el amor al prójimo, incluso al enemigo, como a uno mismo; y la Eucaristía como prueba de la necesidad de Dios de amar al Hijo del Hombre hasta la muerte para darle vida. La necesidad es algo impensable para la divinidad, pero no lo es menos la muerte para el Ser eterno. Pues bien, para Sender,

\footnotetext{
El solo hecho de que la humanidad haya sido capaz de concebir esas dos formas casi divinas de amar, la acerca al Creador tanto que la salva de la nada. La plenitud y la aniquilación son dos fines igualmente apasionantes. Entre el uno y el otro hay un camino desierto. Es decir: nada. El amor mismo va a lo uno o a lo otro.
}

Antes de esta frase tan senderiana íbamos a decir: pues, ¿por qué no ves ya a la Humanidad como Dios? Pero ante esa dilemática alternativa de un amor que igual puede tender a aniquilarse como a henchirse eufórico, no sabemos con qué carta quedarnos. En cualquier caso, Dios no puede ser más que plenitud, jamás aniquilación. Y si lo fue por invención del hombre, en esa invención entra la omnipotencia para ser aniquilado como hombre y resucitable como eterno. Por debajo de la muerte del Hijo de Dios estaba la vida eterna de Dios-Hijo. Una transubstanciación a la inversa. Pero no deja de ser una invención, por cuasi perfecta que sea. Mas, a lo que íbamos: ese acierto de invención sublime, ¿es suficiente para mover a un sentimiento religioso? Sobre todo si se empieza por decir que Jesucristo no ha existido, por mucho que se juegue con paradojas como esa de que precisamente por no haber existido es más Dios, de hecho todo confluye al hombre y Dios no tiene arte ni parte. Pero hay más: ¿ha tenido en cuenta Sender que ya en el episodio bíblico de Jonás, cuando Dios le manda a redimir a los «pecadores» de Nínive, se da pie a una idea sorprendente y 
original, sobre todo si se tiene en cuenta la época en que tuvo lugar: siglo VIII a. C., la era de Heráclito? $Y$ entonces le dice Dios que los pecadores o paganos, y hasta sus ganados, son igualmente de Dios, como los hebreos y sus animales domésticos. Que hay que amar hasta a los enemigos, porque son tan hijos de Dios como los amigos. En fin, que si la justicia existe se ha de hacer justicia para todos, sin excluir a nadie; de lo contrario, no la hay.

$Y$, aun así, ¿no ha tergiversado Sender el término religión? Religare es atar, atarse, sujetar, anclar, anudar, enyugarse, enyuntar, casarse y, en términos eclesiásticos, reunirse, congregarse, comulgar, orar en comunidad... Mientras que religio significó escrúpulo, ser concienzudo y consciente, tener conciencia moral, etc., más sus acepciones de carácter sagrado: enterrar religiosamente, ceremonias sacras, devociones religiosas, etc. $Y$ bien, ¿hay alguna de esas acepciones que se avengan a la susodicha religiosidad de Sender? Si ha entrado en alguna religión, no habrá sido por ningún escrúpulo de conciencia, tampoco por consciencia ni conciencia y menos por querer atarse a nada ni a nadie. Lo único que le acerca a religión es el sentido de lo sagrado. Pero de lo sagrado sin sagrarios ni sacramentos. La prueba suprema es que cuando murió no dispuso que se le enterrara en sagrado, sino que se esparcieran sus cenizas sobre el más ancho océano (el Pacífico, por más señas, para descansar en paz).

Nos plantea, por tanto, un peliagudo problema la religiosidad de Sender. Ya hablábamos a este respecto de aporía. Desde luego, iy tamaña! ¿Estamos en un atolladero? Para el crítico no hay atolladeros. Crítico viene del latín crisis y éste del griego xrisis, decisión; luego tiempo de crisis es tiempo de decisiones ante conflictos o de soluciones de problemas; y el verbo griego xrisein puede significar separar, decidir o juzgar. Lo primero prepara el terreno, porque antes de decidir o juzgar hay que triar, separar la paja del grano; hay que analizar cada elemento, factor, parte o componente por separado. Y una vez que se ha visto claro por dónde hay que cortar y cuáles son las alternativas de cura o solución, llega la hora de decidir, de zanjar, de emitir juicio o sentencia, porque sin fallo no hay crítica que lo valga. Nuestro idioma nos hace una jugarreta con este término, porque una crisis puede provocarla un fallo y por un fallo ser superada. Pues bien, fallemos (y no fallemos). Esto le habría gustado a Sender. Pero para el crítico queda así indicado el riesgo que corre al fallar: ¡fallar!

Vamos allá, pues. Ni por su «complexión» mental ni por sus querencias ideográmicas ni por sus reacciones temperamentales ni por sus estructuras caracterológicas puede llamársele con razón a Sender un tipo humano religioso. Y menos practicante. Es un espíritu demasiado autosuficiente, demasiado fuerte y de demasiada prestancia para necesitar comulgar con otras gentes, congregarse en la oración y unir su voz a cualquier comunidad por una misma fe. Lo gregario y lo adocenado le repugnaban. No digamos ya la obediencia al Dios que fuese o a sus ministros. Sender no quería atarse, sujetarse a nada ni a nadie. Por consiguiente, sin capacidad de religari no se puede ser religioso. 
No, lo que le va a Sender es lo numinoso, como ya apuntábamos más arriba, o religioso, por lo que encierra el término de sagrado. Eso también. Esa necesidad de contar con un ultrahorizonte suprarrealista, de romper los límites de la racionalidad y de la lógica y sobre todo los moldes de la costumbre y de la moral de curso corriente y moliente, es privativamente senderiana. En ese sentido se le puede llamar a Sender críptico, mistagógico, hermético, esotérico, feérico, gnóstico y agnóstico alternativamente, como, no menos alternativamente, estoico/hedonista (¿la doble condición de los ribereños del Cinca: capaces de grandes esfuerzos y sacrificios y a la vez de fenomenales juergas y orgías eutrapélicas, aunque parezca esto contradictorio?), naturalista y sobrenaturalista, realista y superrealista, en fin, eidético y mágico como un niño. Que no sea un tipo humano religioso stricto sensu no le impide a Sender ser un hombre de fe, como siempre y con gran ahínco se ha proclamado. Lo único que cabe cuestionarse, conociéndolo, es si cree o quiere creer. Desde la afirmación aquella tan citada de que «Uno sólo se entiende con los hombres de fe» habrá reiterado docenas de veces esa profesión de fe que nos hace en el prólogo de Los cinco libros de Ariadna. ${ }^{8}$ Pero, ¿de qué fe? Fe de notario, sí, y mucha y muy bien dada; pero esta fe no se tiene sino que se da: el notario en sus actas y el novelista en sus obras trasuntando la realidad. ¿Fe de carbonero? Imposible. Sólo fe en el hombre, empezando por él mismo; fe en el espíritu del hombre, en su pensamiento, más raudo que la luz, demasiado rápido para seguirlo con la pluma ni con el tecleo por muy buen mecanógrafo que se sea; fe en la verdad trascendente, fe en la belleza natural y artificial (del arte), fe en el amor

Estas tres cosas: verdad, belleza y amor, llama Sender Dios. Y así es como llega a la conclusión de que cree en Dios. Pero, ¿para qué le hace falta esa creencia? ¿No hace, así, double emploi? ¿O es que dice «Dios» como los que dicen «alma» sin creer en ella? Más cerca todavía: como el mismo Sender que cree en Jesucristo «porque no existe». Y aquí queríamos llegar: a concluir que Sender quiere creer en Dios porque no lo hay. En lo que cree de verdad, aun sin querer, si se me apura, es en la trascendencia del hombre. Siendo un autor esencialista como es, no puede quedarse en superficies ni en espumas de apariencia. No soportaría vivir frívolamente y necesita como el comer creer en él y en sus congéneres en marcha hacia un futuro cada vez más pleno. Luego también necesita la esperanza. Y no digamos la caridad entendida etimológicamente: como amor. Por ahí se le podría llamar religioso, porque necesita de las tres virtudes teologales, pero no de las apócrifas que se inventan las Iglesias, sino de las verdaderas, las que ha descubierto él mismo desde sus ganglios hasta el mito eucarístico.

Palabras finales. Tratando de indagar en lo posible un fenómeno de estilo en Sender, nos hemos paseado, con ayuda de uno de sus últimos libritos un tanto resumidor, por la galería de sus imágenes e ideas más recu-

${ }^{8}$ Ramón J. SENDER, Los cinco libros de Ariadna, Nueva York, Ibérica, 1957, p. XI. 
rrentes. Y esto era lo importante, como habrán adivinado los que me conocen. Lo de si piensa escribiendo o escribe lo pensado es lo de menos. Creemos haber mostrado, no obstante, que Sender tendía a perderse en la escritura para encontrarse a sus anchas pensando. Tal vez podamos sacar de ahí una pequeña enseñanza: que apegarse al estilo encorsetadamente puede frenar, cuando no esterilizar, incluso, la divina actividad del pensar. Y que, por consiguiente, tal vez sea mejor no tener estilo (como Sender asegura no tenerlo) y poseer, en cambio, riqueza y esencialidad de pensamiento, que es, a fin de cuentas, lo más importante de todo escritor.

Corolario. Cuanto más libremente, más a rienda suelta, si no ya desbocadamente, se escriba, mayor probabilidad de cosechar opimamente pienso (intelectual y numinoso) para el lector. 


\title{
América como texto y contexto en la cuentística del exilio de Ramón J. Sender
}

\author{
Mary S. Vásquez \\ Davidson College (North Carolina)
}

\begin{abstract}
Una vez en Seattle, bella ciudad del estado de Washington en el occidente extremado de Estados Unidos, se encontraba sentado don Ramón Sender en una casa particular, la de un doctorando en letras hispánicas, rodeado de un grupo de estudiantes graduados que le hacíamos preguntas de toda índole -de los años de la preguerra, de sus tiempos como simpatizante de los anarquistas, de la guerra misma, de aspectos específicos de sus obras, de sus relaciones con otros escritores-y le pedíamos observaciones y anécdotas. Era el verano del 68 . Había venido Sender a Seattle desde San Diego de California a pasar unas ocho semanas dictando dos cursos. Cuando tuvo lugar la velada que cuento, su temporada en Seattle - temporada durante la que Marcelino Peñuelas le grabó las entrevistas que se convertirían muy pronto en el libro Conversaciones con Ramón J. Sender- llegaba a su final. Había sido enormemente provechosa para los que tuvimos la inmensa suerte de estudiar con él selecciones de la novelística de la postguerra y hacer otro recorrido por la literatura peninsular del siglo XX. Sender parecía pasarlo bien y esa noche también daba la impresión de estar muy a gusto. La conversación viró hacia sus primeras experiencias del exilio, esos primeros años de comer el pan del otro, de respirar su aire, de buscar entre otros seres convivencias y el modo de seguir, lejos de su tierra. Sender hablaba entonces lentamente, reflexivo, nostálgico, rememorando temporadas que, a la fuerza, habrían sido para él durí-
\end{abstract}


simas. «¿Y México?», le preguntó uno de los compañeros de promoción. «México - repitió don Ramón-, México». Le notábamos un gesto de ternura. «Todos los españoles amamos a México». Repetiría la frase durante una de las entrevistas realizadas por Peñuelas (Conversaciones, p. 141).

Por muchas que fueran las dificultades políticas que enfrentó Sender en México, y por vivo que fuera el deseo que llegó a tener de trasladarse a Estados Unidos, sintió el calor humano del ámbito mexicano. Efectivamente, fue México el país que tal vez con más generosidad acogió al exiliado del 39, abriéndole el hogar, las puertas de la oportunidad, el corazón colectivo. El exiliado, por su parte, llegaba llevando a cuestas toda la carga amarga de la guerra por España, todo el peso de la derrota. Hubo quien vivió y murió en la penuria -Joaquín Arderius-y quien prosperó. Y fueron muchos los que, como Max Aub y Ramón Sender, llegaron a manifestar un profundo agradecimiento, una deuda permanente debida a México. El libro de Patricia Fagen Exiles and Citizens: Spanish Republicans in Mexico (1973) trata precisamente este tema. Un artículo de Jesús Vived Mairal, «Sender y América», publicado en la revista Turia en el 94, destaca el interés senderiano por las Américas antes del exilio, interés patentizado en el libro del primer Sender El problema religioso en Méjico; católicos y cristianos (1928).

La temporada que pasó don Ramón en México fue relativamente breve, ya que se trasladó en el 42 a Estados Unidos, donde pasaría 16 años de docencia universitaria en Albuquerque, Nuevo México, a partir del 46 y otros muchos en la Universidad de California del Sur. Sin embargo, ya en el 39 publica Sender la novela filosófica Proverbio de la muerte, que en su edición posterior sería La esfera y que Peñuelas califica de «expresión de un intenso estado de angustia que sufría Sender a resultas de la catástrofe de la guerra» (La obra narrativa de Ramón J. Sender, p. 27, n. 10), y la novela $E l$ lugar del hombre, titulada posteriormente El lugar de un hombre, obra que sintetiza la postura social de Sender y cuya importancia dentro de su trayectoria literaria se destaca en el título dado a este excelente Congreso, «El lugar de Sender». $\mathrm{Al}$ año publica Sender un libro de cuentos bajo el título general de Mexicayotl; son nueve relatos de trasfondo mexicano que se valen de la mitología de las civilizaciones indígenas del país, primordialmente la tolteca y la azteca. El ambiente mexicano informará también un libro muy poco posterior, la novela Epitalamio del prieto Trinidad, de 1942, cuya acción se ubica en las islas Marías.

Mi tesis es que en los cuentos de Mexicayotl la ambientación geográfica y mitológica mexicana sirve principalmente de trasfondo para retomar preocupaciones temáticas del Sender de la preguerra, y sirve también el ambiente ajeno, distante tanto temporal como vivencialmente, como vehículo de expresión, neutralizada precisamente por estos factores de distanciamiento, del horror de la guerra fratricida tan reciente todavía. Será en el Sudoeste estadounidense donde sabrá Sender integrar plenamente los mitos regionales y valerse de ellos para alimentar su imaginación literaria. 
Antes, en Mexicayotl, lo míticamente mexicano e indígena es más bien un revestimiento, un discurso que permite la expresión de aquellos temas que el tiempo, la distancia, la reflexión calmada, pasada la inmediatez de la guerra, posibilitarán, para que se aborden directamente. Ejemplo de ello es la novela Los cinco libros de Ariadna, de 1957, obra corrosivamente satírica, de denuncia política y humana, por una parte, junto con el tratamiento de la experiencia bélica en los tomos posteriores de la serie de Crónica del alba, iniciada ya en México, y la vertiente nostálgica de los primeros tomos de esta serie en que Sender vuelve la mirada hacia atrás, a esta tierra oscense tan profundamente querida.

Ya para las Novelas ejemplares de Cíbola de 1961 asume don Ramón plenamente el destierro. Al choque del desarraigo, que en él se hizo por etapas -Francia en el 37, Francia en el 38, México y, por fin, Nuevo México-, le sigue el encuentro de resonancias, convivencias. Tal vez la presencia que de lo español se siente en el Sudoeste estadounidense y, más que en ninguna otra parte, en Nuevo México y sobre todo en el norte de este estado, donde se encuentra Albuquerque, le facilitó a Sender el difícil proceso de la integración, el nuevo arraigo, sin que perdiera nunca las raíces ni renegara de ellas. Esos vínculos le permitieron no sólo continuar sino asumir la ardua tarea de la revaloración de la guerra, revivida en la contemplación, lo que le llevó no sólo a la denuncia - Ariadna - sino también a la profunda reflexión adolorida. La familiaridad le habrá permitido también seguir retomando hilos de escritos pasados. Ahora, transcurrido el tiempo y sentidas las convivencias, es cuando Sender demuestra una asimilación de lo americano, una incorporación integral de lo americano a sus líneas constantes, a su perfil de escritor.

El exilio habrá sido para Sender igualmente difícil de asumir como para otros exiliados. Ha habido muchas evocaciones, ficticias y poéticas aún más que directas, de esta encrucijada problemática. El personaje L. F. Sotomayor del relato de Carme Riera «Sí, me llamo Helena», epistolar en su versión castellana, quizá sea representativo de esta experiencia vivencial. Republicano derrotado que llega también al Sudoeste estadounidense, Sotomayor observa respecto a un personaje femenino a quien conoció en el trayecto a América y a quien llegó a amar:

Conocí a Helena a bordo del Independent dos días después de haber salido de Le Havre. Nadie nos presentó. No importaba. Los dos sabíamos por qué estábamos allí y esto era suficiente. El estigma de la derrota de tantos ideales levantados con años de esfuerzo y lucha estaba patente en nuestros rostros. Nada nos hubiera acercado tanto.

Luego unas palabras pronunciadas en nuestra lengua nos devolvieron, inmersos en la nostalgia, a la ciudad donde habíamos nacido y en donde un día también nos hubiéramos encontrado, sin duda, si un destino hostil no nos hubiera arrebatado la victoria.

-No, no es justo lo que han hecho con nosotros. Nos han condenado a la impotencia de la rabia y la añoranza. ¿Cómo podremos olvidar tanto odio? («Sí, me llamo Helena”, Palabra de mujer, pp. 69-70) 
Para Sender, la amarga decepción había empezado bastante antes, durante la guerra, como demuestra en su Contraataque, publicado en francés y en inglés en el 37 y en España en el 38. Hemos estudiado en otro momento la presencia en esta obra supuestamente propagandística de fuerzas encontradas de celebración y subversión, la presencia de la denuncia intercalada con la exhortación, la denuncia que combatía con la exhortación, que en cierto sentido salía de ella, como para Sender la II $^{a}$ República misma se subvertía no sólo desde fuera sino también desde dentro. ${ }^{1}$ La autosubversión venía en la falta de atención al peligro y a las advertencias acerca de su existencia, la presencia de una quinta columna en los ministerios y en el ejército mismo, errores tácticos. El investigador senderiano Francisco Carrasquer en su artículo «El raro impacto de Sender en la crítica literaria española» nos sugiere otra razón de la decepción senderiana para con la II ${ }^{\mathrm{a}}$ República en el comportamiento del general Líster, ahora recién fallecido, en los frentes del norte. El conflicto entre ambos se esboza en la obra de Líster Nuestra guerra y en el inquietante libro de Ramón Sender Barayón, libro de búsqueda de la madre desconocida y añorada y de denuncia del padre ausente y tal vez, en todos los niveles, igualmente desconocido.

La desilusión agrega al destierro otra ruptura más para Sender, una ruptura anticipada no sólo con el compromiso literal con la contienda sino del sentido de pertenencia. Una especie de pre-exilio reflejado en su estancia en el sur de Francia en el 37 y su partida definitiva en el 38 y en el pre-exilio interno que suponen estos actos y las circunstancias que los informan.

Este pre-exilio, este cruce de fuerzas encontradas dentro de la filiación con una causa, son elementos de distanciamiento que tal vez ayudaron a propiciar la asunción, a primera vista sorprendente, de una nueva mitología, tan divergente, presente en un libro publicado en diciembre del 40, un año escaso después de la llegada de Sender a tierras mexicanas. En el prólogo a la edición de Quetzal, editorial que había fundado él mismo, afirma Sender que "Mexicayotl" [...] en lengua mexicana quiere decir "canción de Méjico". Esa canción he tardado un año en aprenderla» (Mexicayotl, p. 9). Por supuesto que la canción de México, si por tal término entendemos mito vital, compenetración, no se aprende en un año. No se adquieren en

1 Véanse Mary S. VÁsquez, "Narrative Voice and the Toll of War in Ramón Sender's Contraataque», en Frieda S. BROWN, Malcolm A. COMPITELLO et al., eds., Rewriting the Good Fight: Critical Essays on the Literature of the Spanish Civil War, East Lansing, Michigan State University Press, 1989, pp. 111-124; «Estrategias de guerra y texto en Contraataque de Ramón J. Sender», Alazet. Revista de Filología del Instituto de Estudios Altoaragoneses, 4 [ $\mathrm{n}^{\circ}$ monográfico sobre Sender] (1992), pp. 215-230, versión más extensa del artículo anterior, traducida al castellano por Francisco CARRASQUER; «Ramón Sender and Wartime Defenses: Contraataque as Fictive Autobiography", en Luis T. GONZÁlez DEL VAlLE y Julio BAENA, eds., Critical Essays on the Literatures of Spanish and Spanish America, Boulder, Colorado, Society of Spanish and Spanish-American Studies, 1992, pp. 225-233. 
tan poco tiempo convivencias íntimas ni una profunda interacción con todo un sustrato mítico que es a la vez reflejo y perpetuación de convivencias de antaño. Lo que sí se puede adquirir es el conocimiento de una serie de signos y de símbolos que son la manifestación externa, la proyección hacia fuera, de este sustrato mítico. Los elementos visibles de un nuevo discurso que sin embargo servirá primordialmente para la reinscripción de preocupaciones senderianas de la preguerra y de la guerra misma, revestidas de una ambientación y de un código discursivo externo americanos. O sea, una apropiación a nivel léxico y semántico de esencias que luego se apropiará de modo más completo, asimilando el contenido de mito vivido, en los cuentos de Cíbola, El extraño señor Photynos y otras novelas americanas (1968), en los Relatos fronterizos (1972), en El Mechudo y La Llorona (1977) y, en menor grado, en El bandido adolescente de 1965. Una inscripción de lo americano facilitada en parte por los paralelos, las resonancias compartidas, la supervivencia de lo peninsular en formas reinscritas, retextualizadas.

Mexicayotl consta de nueve narraciones acompañadas de hermosas ilustraciones en color hechas por Darío Carmona. Cinco de los relatos giran en torno a figuras mitológicas de la época precolombina: «Tototl o el valle», «Xocoyotl o el desierto», «Nanyotl o la montaña» y «Navalatl o el volcán». Los cuatro cuentos restantes son relatos prosopopéyicos sobre animales, protagonizado cada uno de ellos por el animal epónimo: «El puma», «El águila», «Los peces» y «El zopilote». Entre cada dos cuentos de la primera serie va intercalado un relato de la segunda. Funcionan las narraciones del segundo grupo como un contrapunto irónico a las del primero, que retratan al ser humano en toda su fragilidad, ceguera y violencia. Los animales de la segunda serie, en cambio, observan y reflexionan sobre la pobreza de visión del hombre. Son moralmente superiores y dotados de una capacidad de juicio patentemente superior a la de la humanidad. Contemplan al hombre desde arriba (el águila y el zopilote, que se denomina el buitre en la versión posterior y abreviada de este relato en Novelas ejemplares de Cíbola), desde abajo (el pez) o a su propio nivel (el puma), y llegan a la misma conclusión de patetismo y lástima. Al final, en el último cuento de esta serie, devora uno de ellos el cadáver del ser humano matado por el prójimo en ese afán de auto-destrucción que demasiadas veces nos caracteriza. Cuando el mundo animal no encierra un comentario irónico sobre la supuesta superioridad del ser humano, ofrece paralelos que confirman la universalidad en el mundo animal y humano de impulsos de odio y destrucción. En los cuentos de Mexicayotl, en la llamada «canción de Méjico», tal vez haya pasado que la letra amarga de la guerra de España encontrara otro acento, otra tonada.

Mexicayotl presenta temas de problemas morales, genéricos, exploraciones de la situación humana, dilemas morales, cuestiones de guerra, impulsos cainitas. Cada uno de estos cuentos prosopopéyicos es una alegoría. La denuncia alegórica acusa el recurso a técnicas de distanciamien- 
to que posibilitaran o facilitaran el comentario sobre determinados temas, además de que la proporciona el hecho del pre-exilio interior. Mi análisis se ceñirá, por razones de espacio, a cuatro de estas narraciones mexicanas: «Navalatl o el volcán», «Nanyotl o la montaña», «Los peces» y «Ecatl o el lago".

El relato «Navalatl o el volcán» recoge una de las leyendas del Popocateptl, volcán situado entre Ciudad de México y Puebla y unido míticamente a Ixtaccihuatl, La Mujer Durmiente, que en la versión senderiana no es aludida. La narración contrapone el maniqueísmo al círculo, el ciclo de continuidad muchas veces representado en el arte precolombino mexicano por la imagen de la serpiente que se muerde la cola. Recoge el ritual antiguo de la renovación del fuego. La ceremonia de apagar el fuego y encender un fuego nuevo simbolizaba la renovación del ciclo de la vida. En el calendario azteca, el ciclo vital acababa cada 52 años. Al cabo de este tiempo, comenzaba otro ciclo nuevo. El ritual del fuego sintetizaba este ciclo vital simbólico. En el cuento, se celebra cada cuatro años.

Navalatl se encara con los sacerdotes y guerreros de México que han subido al volcán en busca de la renovación del fuego. El cabeza es el Cariamarillo, que junto con los demás desprecia a Navalatl por su sencillez y su falta de arrogancia. Navalatl responde: hombres.

-Tus pies no salen de México donde vive el acuerdo estéril entre los

-Soy el Sumo Sacerdote - -dijo el Cariamarillo.

- ¿Qué quiere decir eso? - preguntó ingenuamente Navalatl.

- Soy el depositario del fuego, el que dice la palabra del fuego y he venido a buscar madera de yuca porque se han cumplido los cuatro años. Hemos matado al fuego viejo y ahora hay que sacar el nuevo para los hogares del imperio.

Navalatl no comprendía.

- ¿Cómo dices? ¿Para sacar fuego nuevo hay que matar al anterior? Eso es imposible, porque el fuego no muere nunca. (Mexicayotl, p. 228)

Más tarde reitera su acusación de esterilidad: «-Sacerdote de los convenios estériles. Cara de ceniza. Boca de golondrina. Vuelve a México y guarda las gallinas enfermas» (p. 228).

El cuento contrapone la divinidad a la falsa y ciega religiosidad del ser humano, tan intensamente involucrado en la adoración de falsos ídolos y dioses que rehúsa reconocer a la divinidad auténtica e incluso procura destruirla. Es significativo que sea precisamente cuando el Sumo Sacerdote y sus súbditos tienen constancia de los poderes sobrenaturales de Navalatl, de cuyo cuerpo se desprende fuego y que quema por su boca, su tacto, cuando se enemistan con más ahínco aún con él. Es entonces cuando comienzan a intrigar para inmolarlo.

El relato está construido alrededor de un eje de ironías entretejidas. No ven los sacerdotes la suprema ironía de que no se puede quemar el fuego porque siempre se está quemando, que si lograran matarlo no habría fue- 
go nuevo, ya que han apagado ellos todos los fuegos propios y es él la fuente de todo fuego original, es el fuego originario, la boca del fuego. Matándolo, se matarían. Es el dios del fuego en forma humana, antropomórfica. Además, él es superior a ellos, como hijo del volcán. Sin embargo, él, capaz de destruirlos a todos como destruye al primer Sumo Sacerdote, el Cariamarillo, y a sus hombres en la primera sección del relato, es objeto de sus planes de destrucción y asesinato. Según la lógica interna de sus creencias, debieran rendirle culto, adorarlo, en vez de procurar destruirlo. Él es la verdad auténtica detrás de los ídolos y los rituales. Existe eternamente pero ellos no saben verlo. ¿O será que, intuyéndolo a través de las múltiples pruebas que él les proporciona, tiene que morir, a sus ojos, por esa superioridad misma? Creyéndolo por fin muerto por inmolación, lo han devuelto a lo suyo, a su padre, a su origen, refortaleciendo así su ser. Él se venga; el volcán entra en erupción, cubriendo de lava casi toda la ciudad y haciendo perecer a todos los que lo despreciaban y pretendieron quitarle la vida. En vez de reconocer su superioridad y acatar su autoridad, lo desprecian según categorías humanas, poniéndole el apodo despreciativo de campesino. Su tranquilidad, su sencillez les han hecho suponer que no puede ser igual a ellos. El paralelo cristero queda patente.

Navaltl los enjuicia al cabo de su actuación mal encaminada:

-Venís al Popocatepetl ensuciando el camino con vuestros pies para hablarme a mí del fuego nuevo. No hay fuego nuevo ni fuego viejo. No hay más que el fuego sin origen que vive en el Popocateptl y que los dioses han puesto en el corazón de los hombres. (Mexicayotl, p. 229)

-Ahora, que no tienen el fuego del convenio estéril, va naciendo en todos ellos el fuego verdadero. (Mexicayotl, p. 243)

La leyenda explica la erupción periódica del volcán como resultado de la incomprensión, de la ceguera de los hombres. El fuego cobra un sentido metafórico y paradójico: da vida, sin él la vida perece, y representa también la ira fundada en la soberbia. Herido el amor propio, éste y la soberbia, que es su acompañante, se convierten en odio y, como el volcán mismo, en violencia y destrucción. Con el tiempo, el ciclo se repite en una inversión del ciclo del fuego, que muere y renace para volver a dar vida. El odio renace para quitar la misma vida a cuyo nombre se batalla. El ciclo vital no sólo se convierte en ciclo mortal recorrido en su nombre, no sólo se invierte, convirtiéndose en su contrario, sino que encierra dentro de sí mismo tal inversión. Su aspecto cíclico evoca la duplicación por el ser humano de los mismos errores, cualidad que encuentra una de sus representaciones artísticas en Hispanoamérica en las novelas de dictadura que sirvieron de modelo a Valle-Inclán, figura profundamente admirada por Sender, en la creación de su Tirano Banderas. El ciclo mortal es una réplica irónica del vital. Este concepto unitario de que cada cosa es ella misma y su contrario informa profundamente los mitos precolombinos mexicanos, por ejemplo el de Huitzilopochtli. 
La narración «Nanyotl o la montaña» gira en torno a este Huitzilopochtli, dios de la primavera, de la regeneración, de la fertilidad (y de la guerra). Una madre viuda de linaje noble tiene tres hijos: uno, tierno y artístico, pacífico, de nombre Axacayatl — «es tierno y sensual como su padre", piensa la madre--; otro, Ahuitzotl, es observador, callado - "es astuto y sagaz como su padre", reflexiona la madre-; el tercero es agresivo y burlón - Chimalpopoca «es violento y arbitrario como su padre"(p. 131). Representan los tres aspectos del ser humano, sus tres capacidades.

En una casa de niebla en la cima del monte nace un hijo de Nanyotl y del espíritu del padre difunto. Este hijo vence a los tres hermanos, que procuran vengar y castigar el supuesto deshonor de su madre. Al final llega una tormenta, que crea arroyos:

\footnotetext{
rados

[...] Saliendo de la tierra, el agua producía un rumor de besos apresu-

Los cinco arroyos se unían después en el valle y formaban un nuevo y grande río que produjo desde entonces gran abundancia de maíz y toda clase de frutas para las tribus del valle.

$Y$ el hijo se llamó Huitzilopochtli y con ese nombre lo conocen y recuerdan las generaciones. (Mexicayotl, p. 161)
}

Esta última oración es la clausura del relato. Sender no nos explica la naturaleza múltiple de Huitzilopochtli, pero es imposible que en sus lecturas durante el año en que aprendía la canción de México no encontrara referencias a ella. Se trata de un dios cruzado, hecho de fuerzas encontradas, como el ser humano mismo.

El cuento «Los peces» sigue directamente a "Nanyotl o la montaña» y vuelve a tomar el hilo de la multiplicidad del ser humano. «Los peces» sigue el patrón alegórico establecido en la primera serie de narraciones, las que se centran en figuras mitológicas humanizoides.

Si la tragedia del ser humano estriba en el hecho de que, siendo capaz de crear belleza y de cometer actos generosos y nobles, elija con tanta frecuencia destruirnos atentanto contra el prójimo y nuestro planeta, Sender recoge en «Los peces» esta tragedia humana, agregando a nuestra aspiración a la belleza y la bondad por una parte y al impulso contrario de la estúpida y ciega violencia un tercer componente que facilita el triunfo temporal del segundo impulso sobre el primero: la lenta parálisis de la inacción. Cuenta «Los peces» una historia de observación más que de movimiento; la trama es casi inexistente. El Buen Leñador de la selva de Culua se siente morir y pasa a vivir su muerte bajo las aguas, mineralizándose gradualmente entre los corales rojos hasta convertirse él también en coral. Así lo han hecho sus antepasados y cumplirá él el mismo destino asignado. El Buen Leñador aparece en otro cuento de la colección como representante de la modesta y decente bondad contrastada con fuerzas más egoístas de aprovechamiento y ambición. Aunque ha dejado de ser 
actante sigue siendo un ser pensante. Le molesta sobremanera la misma interrogante tonta y vacía del pez Pico de Pato: «¿Por qué?».

Había también otros peces de tamaño más que mediano cuya torpeza le irritaba. Eran toscos, rígidos. Sus movimientos eran los de un tarugo de madera que a veces despertara y se animara. Crecían deprisa y su cabeza era alargada con una boca en forma de pico de pato armada de finas serratas. Cuando miraba parecía preguntar estúpidamente:

- ¿Por qué?

A pesar de esa pregunta nada en el pez Pico de Pato revelaba curiosidad. Aquella pregunta era lo único que sabía expresar y, orgulloso de poderlo hacer, preguntaba todo el día. (Mexicayotl, p. 166)

Se le contrapone al Pico de Pato otro pez más pequeño, fino y bonito y más genuinamente interrogante. A cada instante, viendo las maniobras del Pico de Pato, le pregunta al Buen Leñador: «¿No te extraña?». Por fin es devorado por el pez inferior aunque de mayor fuerza física. A la pregunta final de la presa responde el Buen Leñador:

-No me extraña, no. [...] Tú me has reconocido a mí, lindo pez mariposa. Tú sabes que soy un hombre y esperabas mi ayuda. Pico de Pato, en cambio, no me reconoce. Sabías demasiado, lindo pez.

Y añadía, viéndolo desaparecer entre las mandíbulas abiertas, estúpidamente abiertas e inmóviles:

-Habías alcanzado la perfección. (Mexicayotl, p. 174)

Ante la constante amenaza que acaba por cumplirse, el leñador no puede más que observar y comprender. "[E]l hombre seguía durmiendo indiferente su sueño mineral con los ojos abiertos» (p. 172). Pierde inexorablemente no sólo la capacidad de actuar sino también la voluntad. «El Buen Leñador contemplaba aquello lo mismo fuera que dentro de su cerebro y de sus sueños y nada podía hacer» (p. 173). El relato recoge una constante senderiana: la doble naturaleza del ser humano, minando y consumiendo una faceta lo que ha creado la otra, acompañada de la indiferencia, la incapacidad existencial y anímica de actuar para impedir la carrera de la tragedia que se avecina. Esta constante se ve ligeramente revestida de una ambientación americana. Posiblemente encontrara Sender en estos elementos míticos el vehículo para comentar alegóricamente, así, desde una distancia mitigadora, aunque fuera en menor grado, del dolor, experiencias suyas. En las conversaciones con Peñuelas, comenta don Ramón respecto a la convulsión nacional que lo llevó fuera de España:

[...] Durante la guerra civil todos éramos culpables de lo que estaba pasando. Unos por acción, otros por omisión. Mi culpabilidad era por omisión. Yo no disparé la pistola una sola vez en toda la guerra, y no permití que cerca de mí se matara a nadie. Pero podría haber protestado más de lo que protesté. Me habrían echado del país o me habrían fusilado, pero debía haber protestado más, porque yo sabía que sucedían cosas terribles. Entonces, al 
final de la guerra me sentía culpable y sigo sintiéndome culpable. Supongo que a cada español con conciencia le pasa lo mismo, en un lado y en el otro. (Conversaciones, 121-122)

Digno es de notar que el leñador no puede actuar, ya que su progresiva mineralización se lo impide. Hay también una mineralización moral, quizás retratada metafóricamente aquí. En El verdugo afable, obra del pleno exilio senderiano estudiada tan provechosamente por Marshall Schneider y otros senderianos, dará el autor un paso más, haciendo que un solo hombre asuma la violencia y destrucción colectivas, invitando al desprecio del prójimo por cometer los actos, ya oficialmente y en nombre del Estado, que la humanidad no ha dejado nunca de cometer ni dentro ni fuera de la oficialidad. Actante carente de voluntad de actuar, actúa a pesar de su pasividad y desde dentro de ella.

En el relato «Ecatl o el lago» se retrata a otro protagonista que va por la vida llevado por fuerzas que no comprende, que responde a resortes desconocidos. Ecatl nos recuerda a Viance, de Imán, y anticipa a Ramiro Vallemediano de El verdugo afable. El cuento podría llevar el subtítulo «La necesaria muerte innecesaria de Ecatl». El joven, tras una búsqueda y una serie de pruebas que constituyen los clásicos pasos ritualizados de la transición a la vida adulta y los de la forja del héroe en su odisea, es sacrificado según los rituales precolombinos de los toltecas, los mayas ya conquistados por ellos y los aztecas. Cuando Ecatl pregunta por qué se tiene que morir, la voz del Buen Auspicio, que le ha aconsejado a través de su trayectoria, le contesta que su muerte es necesaria. Esta misma voz le ha susurrado antes: «-Renuncia y te salvarás» (Mexicayotl, p. 205). Ecatl ya ha renunciado a todas las tentaciones, pero no a la última, la de dejarse adorar, de no seguir el consejo anterior de la voz del Buen Auspicio: «-Sigue adelante, haz el encanto del mundo, pero no retengas a nadie cautivo por la belleza de tu alma» (p. 196). Cuando los sacerdotes le sacan el corazón, "[u]na voz salía de entre la sangre. - Has retenido a los hombres cautivos por la belleza de tu alma. No has sabido renunciar» (p. 208). De haber hablado a tiempo, de haberse resistido a la reificación, hubiera podido Ecatl evitar la muerte.

El punto de arranque del trayecto de Ecatl es su encuentro violento en el bosque de noche con un fantasma denominado el Tezcatlipoca, que le ha interrumpido el sueño con un ruido molesto. Al agredirle y lograr asirle de la camisa, Ecatl ve que «[e]ra un hombre con la cabeza cortada. Tenía en el pecho dos ventanas con las puertas de madera que se unían en el centro y se abrían y cerraban con el viento, golpeando sin cesar y produciendo así el ruido de cortar madera» (p. 180). Ecatl le quita el corazón -acto que luego se repetirá irónicamente en el sacrificio de Ecatl- y descubre al día siguiente que es una esmeralda de sumo esplendor. La clave del paradójico triunfo/derrota de Ecatl yace en el diálogo entre el joven y un poste que se encuentra delante de su puerta.

Habla primero el poste: 


\section{MARY S. VÁSQUEZ}

- Si el fantasma te ha dado una gema verde debes dejar el bosque $y$ marcharte a vivir al lago.

Ecatl decía:

- ¿Qué me espera? ¿Grandes riquezas, venturas de guerra, de amor?

-Te esperan la sabiduría y la calma. (Mexicayotl, p. 181)

En definitiva, no halla Ecatl ni la una ni la otra, aunque le llegue a parecer que sí. Pero en realidad no buscaba estas dos cosas sino que esta meta le fue sugerida, tal vez impuesta, por la voz del poste.

$\mathrm{Al}$ iniciar su viaje al lago y la travesía del mismo, para llegar después a seis lagos más, Ecatl se ve tentado por todas las apelaciones al placer de los sentidos: colores brillantes, aromas deliciosos, luces seductoras, texturas aterciopeladas. La hipérbole del bombardeo sensorial cede a estímulos y tentaciones más sutiles para luego resolverse en otra tentación, la de formas inacabadas de mujer que lo invitan a la cópula para completarse. Siguen las tentaciones del silencio y posteriormente de la paz interior y del poder. No es accidental que coincidan. Durante toda su trayectoria, guían a Ecatl las palabras de la voz del Buen Auspicio, que resulta ser el primer Tezcatlipoca visto ya en forma de hombre viejo, contraponiéndose esta voz a la del Mal Auspicio. La tirantez entre las dos voces es, por supuesto, la lucha entre el bien y el mal dentro del ser humano, aquí exteriorizada según el patrón mitológico. Creyendo Ecatl acercarse cada vez más a la renuncia, y a la sabiduría y la calma consiguientes, se aferra en realidad a las fuerzas de la debilidad. Es reveladora la proximidad de dos citas contradictorias de Ecatl:

"Ya sé - se decía-, ya sé lo que es la armonía. Yo seré también poderoso y perfecto y sacaré de esta fuerza una nueva luz para alumbrar el mundo». (Mexicayotl, p. 188)

Y un poco más adelante:

$-[\ldots]$ Seré dueño del mundo. [...]

- Las tribus lejanas no estarán nunca tan lejos que no llegue mi mano o la sombra de mi cabello. Vendréis voluntariamente a darme servidumbre. Soy el más fuerte de los hombres y el poder que vendrá a mis brazos es un poder que no había sido creado antes de mí. (Mexicayotl, p. 189)

El eje de ambas citas es el deseo del poder. Instado por la voz del Buen Auspicio a renunciar al poder, Ecatl cree haberlo logrado. A la gente que lo veía pasar le sorprendía siempre que una persona tan joven hubiera llegado a dominarse hasta tal punto que supiera renunciar. Pero al último placer no renunció y en esta falta estriba su fallo trágico, que lo llevará a la muerte. Su tragedia es que precisamente en su triunfo a los ojos del mundo yaciera su derrota. Pertenece Ecatl al linaje de Ramiro Vallemediano por las ambigüedades que caracterizan su visión y experiencia del mundo, su paso por la vida difícil de descifrar o el dejarse llevar por sugerencias de otros. Pero a diferencia de Ramiro, que resuelve su incertidum- 
bre asumiendo la culpabilidad colectiva e invitando así al desprecio del mismo pueblo en cuyo nombre actúa, Ecatl se deja buscar la adulación popular y es ésta su flaqueza y su ruina. Cuando Ecatl se siente inseguro, cuando está tanteando, vacila, toma un camino y recapacita, va bien. Acaba por no errar. Es cuando se siente confiado, cuando se deja seducir por sus propios logros, su propia bondad, cuando cae en la trampa de la certeza, que lo pierde.

Esta narración también es circular. Comienza Ecatl dormido, es decir, en un estado de quietud, para luego convertirse en actante, adoptando una postura activa y agresiva. Imponiéndosele al fantasma, le arranca el corazón, punto culminante este acto del sacrificio ritual tolteca y azteca. Progresivamente, va volviendo Ecatl a una postura de quietud. Es objeto de la adoración de la multitud y de los sacerdotes mismos. Ahora se actúa sobre él. Cuando se le arranca el corazón en el sacrificio, se invierten los papeles y se cierra el círculo, efectuándose la clausura tanto del relato como de la vida de Ecatl.

En esta narración sobre la problemática del individuo en su entorno social y en su circunstancia espiritual y moral particular -énfasis consagrado en Sender- existe un doble proceso integrante y disgregante. Su situación de actante poderoso ofrece una visión integrada. A medida que vaya progresando por los seis lagos, se expone a la disgregación. Cada lago es distinto y distan mucho unos de otros. Es significativo que el lago de las mujeres se caracterice precisamente por la presencia en sus aguas de miembros disgregados. Por fin llega Ecatl al séptimo lago, que reúne todos los estímulos sensoriales. Pero esta integración se ve subvertida por una disgregación subyacente: atravesando este lago, Ecatl se siente confiado. Ya no le atormenta la duda. "Sabe» que puede resistir las tentaciones y dominarse. Ha alcanzado su meta - que nunca lo fue de verdad-y es justamente en este momento de máxima integración cuando Ecatl se condena a su contrario. Confunde la sabiduría con la autocomplacencia, la calma con la pasividad. Hay una vocecilla interna que le acucia, una inquietud, pero Ecatl le hace caso omiso. Esta vocecilla -la incertidumbre - podía ser su salvación.

La doble naturaleza del proceso narrativo en el cuento «Ecatl o el lago» nos sugiere la índole doblada de la metáfora misma, reflexión tal vez útil ante el fenómeno del uso senderiano de metáforas ajenas que resultaron ser, en el fondo, también caseras y su recurso en las narraciones de Mexicayotl a la alegoría, es decir, a un sistema sostenido de metáforas interrelacionadas. La metáfora es simultáneamente distanciadora e intensificadora. Distanciadora, y expresión de distancias, por ser figurada, intensificadora por su condensación de realidades, por sintetizadora. En esta tensión inherente yace la vida, la fuerza de la metáfora. Es a la vez inmediatez y distancia, aproximación y alejamiento, unión y separación. Los mitos precolombinos mexicanos quizás le hayan servido a Sender, en su conversión en las metáforas alegorizadas aquí tratadas, como una 
manera de eludir el horror tan inmediato aún y, a la vez, comentarlo durante esta primera temporada suya del exilio.

Las Novelas ejemplares de Cíbola, fruto ya de la segunda, son una colección de doce narraciones, seis de las cuales se originaron en Mexicayotl, aunque en forma modificada, en algunos casos profundamente. «Nanyotl o la montaña", de casi treinta y tres páginas en Mexicayotl, se condensa en siete páginas en Cíbola, con el título «La montaña». «Ecatl o el lago» pasa por un proceso semejante, reduciéndose de las casi treinta páginas que tiene en el primer libro a las siete páginas y media de "El lago» de la colección de Cíbola. Al cuento "Xocoyotl o el desierto", que no hemos podido analizar en estas páginas debido a consideraciones de espacio, le ocurre lo mismo, como también a «Navalatl o el volcán», que se transforma en "Cariamarillo" en Cíbola, protagonizándolo ahora el Sumo Sacerdote en vez de Navalatl, un cambio fundamental. «Tototl o el valle», de cuarenta y cinco páginas - la narración más larga de Mexicayotl—, se convierte en «El cetro», de trece. Conserva Sender en Cíbola sólo una de las historias de animales, «El zopilote» de Mexicayotl y «El buitre» en el libro de Cíbola, y es el relato que más se aferra al cuento original, el único que sigue de cerca al primero. «El buitre» gana en calidad lo poco que pierde en extensión; la depuración incrementa su belleza estética y refuerza su impacto temático. La colección contiene otros seis relatos totalmente nuevos: «La terraza», hábilmente estudiado por Elizabeth Espadas en dos artículos; ${ }^{2}$ el magistral «El padre Zozobra», basado en una tradición religioso-cultural neomexicana de Santa $\mathrm{Fe}$ - sede del Gobierno español del territorio y hoy capital del estado de Nuevo México--, honda exploración de las debilidades del alma humana en su proyección teológica y universal, del pecado y de la expiación; «La madurez del profesor St. John», indagación en las oscuras fuerzas primitivas que mueven al ser humano, sabiamente analizada, junto con otros cuentos de la colección, por Patrick Collard; ${ }^{3}$ más "Aventura en Bethania», «Los invitados del desierto» y "Delgadina». De este último y de los dos primeros me ocupo en la continuación del presente estudio, ahora en preparación. Por el momento, a modo de clausura de este análisis, quisiera plantear una interrogante: ¿en qué consiste el trasfondo neomexicano y del Sudoeste de estas narraciones de Cíbola?

El Sudoeste de Estados Unidos, en su manifestación literaria y cultural tanto como en la experiencia vivida de sus habitantes, ofrece a sus con-

\footnotetext{
2 Véanse Elizabeth EsPADAS, «Una novela ejemplar del mundo moderno: La terraza de Ramón J. Sender», Cuadernos Americanos, 25/6 (noviembre-diciembre de 1976), pp. 206-221, y “Cíbola en las obras americanas de Ramón J. Sender», Cuadernos de ALDEEU, $5 / 2$ [In memoriam. Ramón J. Sender, monográfico sobre Sender] (1983), pp. 227-239, artículo que aborda el tema del uso senderiano de motivos del Sudoeste: nombres toponímicos, incorporación de figuras y rituales de la legendaria de la región, adaptación de elementos religiosos.

3 Patrick Collard, "En torno a las Novelas ejemplares de Cíbola», en Mary S. VÁsQUEZ, ed., Homenaje a Ramón J. Sender, Newark, Delaware, Juan de la Cuesta, 1987, pp. 111-130.
} 
templadores una serie de ambivalencias entretejidas. Para los exploradores españoles que atravesaron los desiertos y las sierras del Sudoeste durante aquellos trayectos tempranos, la promesa infinita se unía a la posibilidad del sacrificio supremo. Perecieron muchos de sed y agotamiento. Las siete ciudades de Cíbola - fábula que parece remontar a las novelas de caballerías y que vieron confirmada los españoles en referencias míticas indígenas $-{ }^{4}$ resultaron ser, cuando mucho, pueblos pequeños y pobres de viviendas hechas de barro. El rigor de la vida serrana de los pueblos que establecieron los españoles en el norte de lo que es ahora Nuevo México era tal -frío extremado en el invierno, aislamiento durante el año entero- que el gobernador de Santa Fe prohibía como una de las condiciones básicas de su concesión de tierras que los pobladores dejaran su pueblo sin el permiso formal otorgado por él; temía éste que no volvieran jamás. Esta tierra de extremos es una región donde no se aplican siempre las definiciones normales, donde los componentes de la realidad pueden ser a la vez una cosa y su contrario en una especie de juego de espejos que crea una realidad ambigua o contradicha. Los pueblos de adobe de la Cíbola fabulada tal vez parecieran ser dorados desde cierto ángulo del sol, como hoy el calor extremado de agosto crea espejismos en el asfalto o la arena, produciendo la ilusión del agua, tan necesaria como escasa. Y el sol que admira y deleita al turista es el mismo que le quema la espalda al labrador migrante.

Decía Azorín que los paisajes levantinos de su niñez y juventud servían de estímulo a su sentido plástico; prácticamente carentes de vegetación, se revelaban a su ojo de pintor con todo su escueto drama. La riqueza del juego de luz y sombra suplía, y compensaba, la pobreza de vegetación. También en el Sudoeste el drama de extremos y absolutos tiene lugar sobre un escenario de pocos adornos creado precisamente por esa parquedad. En la continua e intensificada lucha por la vida a la que obliga el desierto, los términos de esta lucha se vuelven más nítidos, más angulosos y se toca el deseo de supervivencia en toda su fuerza instintiva.

Llegó a conocer bien don Ramón el norte de Nuevo México y los pueblos de la sierra —Española, Trampas, Las Truchas, Chimayó-, donde por el mismo aislamiento que temía el gobernador de Santa Fe la gente mayor habla todavía un español cervantino y donde en las noches en que arrecia la lluvia — son pocas - la gente afirma haber visto cabalgar por la sierra a don Quijote, montado en Rocinante, pero sin su fiel acompañante Sancho Panza. En la misma medida en que los contrastes y contradiccio-

\footnotetext{
4 John Chávez, en su The Lost Land: The Chicano Image of the Southwest (Albuquerque, University of New Mexico Press, 1984), traza la fusión de la leyenda europea de la existencia de siete fabulosas ciudades de plata con el mito hispano-indígena de las Siete Ciudades de Cíbola y la riqueza de Quivira, siendo un ímpetu importante el informe de parte del esclavo Esteban a fray Marcos de Niza de que la expedición (de 1539) llegaba a una ciudad llamada «Cíbola» $\mathrm{O}$ «bisonte», la primera de las siete ciudades fabuladas (pp. 8, 15).
} 
nes, la apelación del desierto al instinto de la supervivencia, informan los cuentos de Cíbola, la presencia hispana, los paisajes tan afines a los de su Aragón, las cadencias de la lengua castellana y de los giros antiguos que aún se oyen hoy, le habrán ofrecido a Sender el consuelo de lo conocido y familiar. La asimilación de lo americano se pudo efectuar desde la base de unas convivencias reconocidas y compartidas.

Todos los estudiosos de Sender hemos notado desde siempre el doble fenómeno de la presencia de una línea constante junto con la enérgica capacidad de tomar elementos de fuentes diversas. Los cuentos de Mexicayot - novedad y continuidad, novedad como revestimiento de la continuidad-y los de Cíbola — otra vez novedad y continuidad, novedad que es a la vez renovación de convivencias ya conocidas, combinadas con otras netamente nuevas- son una muestra más de ello.

\section{BIBLIOGRAFÍA}

CARRASQUeR, Francisco, «El raro impacto de Sender en la crítica literaria española», en Mary S. VÁsqueZ, ed., Homenaje a Ramón J. Sender, Newark, Delaware, Juan de la Cuesta, 1987, pp. 149-182.

Collard, Patrick, «En torno a las Nozelas ejemplares de Cibola», en Mary S. VÁsquez, ed., Homenaje a Ramón J. Sender, Newark, Delaware, Juan de la Cuesta, 1987, pp. 111-130.

CHÁvez, John, The Lost Land: The Chicano Image of the Southwest, Albuquerque, University of New Mexico Press, 1984.

ESPADAS, Elizabeth, "Cibola en las obras americanas de Ramón J. Sender», Cuadernos de ALDEEU, 5/2 [In memoriam. Ramón J. Sender, monográfico sobre Sender] (1983), pp. 227-239.

-_- "Una novela ejemplar del mundo moderno: La terraza de Ramón J. Sender», Cuadernos Americanos, $25 / 6$ (noviembre-diciembre de 1976), pp. 206-221.

FAGF, Patricia W., Exiles and Citizens: Spanish Republicans in Mexico, Austin, Texas y Londres, University of Texas Press, 1973.

Peñuelas, Marcelino C., Conversaciones con Ramón J. Sender, Madrid, Magisterio Español, 1970.

- La obra narrativa de Ramón J. Sender, Madrid, Gredos, 1971.

RIERA, Carme, "Sí, me llamo Helena», en Palabra de mujer, Barcelona, Laia, 1980, pp. 63-77.

SENDER, Ramón J., Contraataque, Salamanca, Almar, 1978.

- - Imán, ed. de Francisco Carrasquer, Huesca, Instituto de Estudios Altoaragoneses, 1992.

- El lugar de un hombre, México, CNI, 1958.

- Mexicayotl, México, Ediciones Quetzal, 1940.

—- Novelas ejemplares de Cibola, Nueva York, Las Américas, 1961.

VIVEd MAIRAL, Jesús, "Sender y América», Turia, 27 (marzo de 1994), pp. 147-155. 


\title{
Descripción y función del paisaje en Imán
}

\author{
Patrick Collard \\ Universiteit Antwerpen / Rijksuniversiteit Gent
}

\begin{abstract}
Hace muchos años, en un libro mío, ${ }^{1}$ tuve ocasión de comentar -después de que lo hubiera hecho ya, entre otros, Marcelino C. Peñuelas -2 la curiosa (y falsa) modestia de las palabras introductorias de Sender a la primera edición de Imán (1930); sobre ellas vuelve también JeanPierre Ressot en la interesantísima "Présentation" de su excelente traducción de Imán al francés. ${ }^{3}$ Recordemos que el joven Sender presenta ${ }^{4}$ su primera y magistral novela, que fue, en palabras de Jean-Pierre Ressot, un «livre de référence pour toute une génération d'Espagnols, au moment où les convulsions de l'histoire ébranlaient les bases de leur sociétén, 5
\end{abstract}

\footnotetext{
${ }^{1}$ Ramón J. Sender en los años 1930-1936. Sus ideas sobre la relación entre literatura y sociedad, Gante, Rijksuniversiteit, «Werken uitgegeven door de Faculteit van de Letteren en Wijsbegeerte», 1980, pp. 158-159.

2 La obra narratioa de Ramón J. Sender (carta prólogo de Ramón J. Sender), Madrid, Gredos, 1971, p. 100.

${ }^{3}$ Ramón J. SENDER, L'aimant, presentación, traducción y notas de Jean-Pierre RESSOT, Imprimerie Nationale, Éditions, 1994, p. 24.

4 «Nota a la primera edición del año 1930», p. 7 en la edición preparada e introducida por Marcelino C. Peñuelas, Barcelona, Destino («Áncora y Delfín»), $2^{2}$ ed., 1976. Todas las referencias de los fragmentos que citaré remiten a esta edición.

5 L'aimant, ed. cit., p. 7.
} 
como simples «notas [...] apenas ordenadas [...]» y que el «libro no tiene intenciones estéticas ni prejuicios literarios». Éstas y otras afirmaciones del epígrafe han de tomarse cum grano salis $\mathrm{y}$, sobre todo, han de relacionarse con una intención testimonial y documental en conformidad con cierto concepto del realismo que Sender fue desarrollando en textos ensayísticos desde finales de los años veinte hasta la guerra civil. ${ }^{6}$

Pero si aquí se trae a colación el epígrafe de Imán es sobre todo por sus palabras finales, que no parecen haber despertado mucho interés entre los estudiosos y que mediante una expresión con sinestesia remiten en tono discretamente emotivo al recuerdo del marco geográfico de la novela. Sus "notas", dedicadas a los soldados que con él compartieron la experiencia de la guerra de Marruecos, fueron "escritas con la voz del paisaje africano en los oídos", concluye Sender. Pues bien, estimulado por estas palabras, me gustaría examinar una serie de aspectos - estilísticos, temáticos, narratológicos- referentes a la evocación del paisaje en Imán, puntualizando de antemano que el texto estudiado lleva necesariamente a una extensión del objeto de estudio hacia la naturaleza ${ }^{7}$ en su conjunto.

¿Qué se nos dice explícita y concretamente del paisaje en Imán?, ¿cuáles son su grado de presencia y sus funciones?, ¿es palpable el efecto de una mirada que vuelve subjetivo el paisaje interpretándolo?, ¿cómo se distribuyen diegéticamente los fragmentos que se dedican a su descripción?, ¿se relacionan más o menos directamente con determinados aspectos del ideario de Sender en aquel período?... Son éstas las preguntas (artificiales en la medida en que, al menos parcialmente, surgen, por así decir, post factum, a partir del resultado de una lectura de Imán por quien las hace) a las que se tratará de contestar a continuación.

\section{EXTENSIÓN, DISTRIBUCIÓN Y CONTENIDO REFERENCIAL DE LAS DESCRIPCIONES}

La crítica ha subrayado ya varias características y cualidades de la prosa descriptiva del Sender de Imán, entre otras su dimensión poética (comentada en un notable artículo de Rafael Bosch), ${ }^{8}$ y por otra parte su «verismo indiscutible $[. .$.$] con algún apunte impresionista y visos expre-$

\footnotetext{
6 Véanse P. COLLARD, «Las primeras reflexiones de Ramón Sender sobre el realismo», en Alan M. GoRdon y Evelyn RuG., eds., Actas del sexto Congreso Internacional de Hispanistas, Department of Spanish and Portuguese, University of Toronto, 1980, pp. 179-182; María Francisca VILCHES de FRUTOS, "Ramón J. Sender, como crítico literario», Revista de Literatura, XLV/89 (enero-junio de 1983), pp. 73-94.

7 Uso la palabra según la tercera acepción ofrecida por el Diccionario de uso del español de María MOLIner (Madrid, Editorial Gredos, reimp. 1971): «Universo físico, o sea, ajeno a la intervención espiritual del hombre».

8 «La "species poetica" en Imán, de Sender» [1962], en Josê-Carlos MAINER, ed, Ramón J. Sender. In memoriam. Antología crítica, Zaragoza, Diputación General de Aragón, Ayuntamiento de Zaragoza, Institución Fernando el Católico, Caja de Ahorros de Zaragoza, Aragón y Rio-
} 
sionistas», según Francisco Carrasquer. ${ }^{9}$ Aparte de aludir a la función que las descripciones del paisaje desempeñan en la definición de estados de ánimo de los personajes (aspecto sobre el cual, por supuesto, volveré), Marcelino C. Peñuelas hace observar que las descripciones «son de una concisión extrema. Las de la naturaleza, del paisaje, se suelen reducir a breves frases intercaladas esporádicamente en la narración [...]». ${ }^{10} \mathrm{Y}$, en efecto, la brevedad llama la atención ya que, si entre los trozos puramente descriptivos algunos pocos llegan a constituir un párrafo de unas ciento veinte palabras o más (por ejemplo pp. 39-40), otros forman un bloque textual dentro del párrafo, por ejemplo introduciéndolo (como al final de la p. 204) y muchos se limitan a unas pocas palabras; más adelante se comentará la función de una importante excepción: los tres párrafos dedicados a la descripción de San Juan de las Minas (pp. 173-174). Es notable además la frecuencia con que Sender acude a los enunciados sin núcleo verbal, ${ }^{11}$ que recuerdan las acotaciones teatrales o, más exactamente, quizás las frases tan típicas del Valle-Inclán de Tirano Banderas. ${ }^{12}$ Dicho de otro modo: formalmente ya lo descriptivo en Imán se resiste a cumplir con su tendencia clásica a aparecer como una amplificatio, una digresión. Luego se verá que también su contenido, por su carácter funcional, ofrece la misma resistencia.

Se debe sin embargo completar estas observaciones con un dato cuantitativo que no carece de interés para el estudio de la creación ambiental y que matiza el adverbio usado por Marcelino C. Peñuelas cuando habla de «frases intercaladas esporádicamente» (el subrayado es mío): aunque generalmente breves, las referencias al paisaje son relativamente numerosas (unas cincuenta) y se reparten a lo largo de la novela; son más frecuentes sin embargo en la parte central, «Annual - La catástrofe», que en la pri-

ja, 1983, pp. 291-297. Véanse también la ya citada «Présentation» de J.-P. REssOT, op. cit., p. 28, quien habla de la "poétisation du réel», y los apartados "Sentido lírico", en M. C. PEÑUELAS, La obra narrativa..., cit., pp. 257-260, y "Notas poéticas», en Francisco CARRASQUER, "Imán y la novela histórica de Sender (con Prólogo de Ramón J. Sender), Londres, Tamesis Books Limited, 1970 , pp. 37-48.

9 Ibid., p. 37.

${ }^{10}$ La obra narrativa..., cit., p. 238.

11 Por ejemplo: «Llanuras pardas, grises» (p. 38); «Cráteres de los cercos de tiendas desmoronadas" (p. 49); "Las colinas, limpias; el cielo fresco y diáfano» (p. 133); "La tierra, blanca; los arbustos, escasos y secos; llanura cruzada por mil caminos invisibles de desolación" p. 153).

12 «Luna clara, nocturnos horizontes profundos de susurros y ecos», "Santa Fe de Tierra Firme - arenales, pitas, manglares, chumberas- en las cartas antiguas, Punta de las Serpientes», etc. (pp. 9 y 15 en la $7^{\text {a }}$ edición de la colección "Austral», 1968). Como se sabe, la referencia a Tirano Banderas no es nada arbitraria: Sender se había quedado deslumbrado por la lectura de esta novela cuyas cualidades se elogian en «El novelista y las masas» (Leviatán, 24 [mayo de 1936], pp. 1-21) y más tarde en "Valle-Inclán y la dificultad de la tragedia», Examen de ingenios. Los "noventayochos», Nueva York, Las Americas Publishing Co., 1961. 
mera, «El campamento - El relevo», y la tercera, «Salvación - La guerra Licenciamiento - La paz de los muertos». Y en la segunda parte es donde se narra lo esencial (y lo más espeluznante) de la tremenda experiencia de Viance en su alucinante itinerario de más de cien kilómetros entre Igueriben ( $« R . »$ en la novela) ${ }^{13}$ y Melilla, caracterizados por horribles sufrimientos. Además, como el contenido de las notas descriptivas tiende necesariamente a la repetición, el paisaje que marcó hasta la obsesión los recuerdos de Viance, Antonio y, desde luego, Sender, está pues muy presente y marca necesaria e insistentemente los recuerdos del lector.

En la mayoría de los casos la motivación de la descripción paisajística es la mirada y el punto de vista que el narrador delega en Viance $u$, ocasionalmente, en otro personaje; los ejemplos siguientes muestran cómo varias veces la motivación tiende a subrayarse de manera explícita (mirada o movimiento del protagonista $\rightarrow$ trozo descriptivo que muestra un paisaje enfocado desde la posición de Viance o, episódicamente, de otro personaje o del mismo narrador):

Viance se impacienta en el puesto. Tarda el relevo. Ve el barranco [...]; la carretera blanca [...]. Azulean las lomas hacia el río [...]. A la izquierda, las cumbres [...]. (p. 39)

Luego [el comandante] se acerca al parapeto y mira con los gemelos insistentemente, sin distraerse un instante.

El color blanco de las lomas [...]. (p. 95)

[Viance] Se asoma, subiendo por una rampa, afuera. Una llanura gris, [...]. (p. 152)

Al doblar la loma aparece, en la lejanía, Dar Drius. La llanura [...]. (p. 159)

Al doblar el recodo de la colina, cara a la gris llanura [...]. (p. 189)

Al pie de la extensa colina que ocupamos se extiende una planicie cerrada $[\ldots]$. (p. 275)

Por fin, a solas en el vagón de un tren secundario que le conducía a la estación de término, mirando la estepa seca y oscura, [...]. (p. 294)

"Llanura (desértica)» sería el pantónimo ${ }^{14}$ que aparece desde las primeras líneas y que a lo largo de la novela se recuerda, se amplifica, se configura — se declina, como diría Ph. Hamon-: combas, colinas, algún barranco, algunas matas, matices de colores, etc. Mención aparte merecen las evocaciones de lo que se podría llamar el paisaje "militarizado»: fragmentos en los que la descripción por un vocabulario tiende a convertirse

\footnotetext{
13 Véase J.-P. RESSOT, «Présentation», p. 26.

14 Traduzco la palabra pantonyme de la terminología de Ph. HAMON, Du descriptif, París, Hachette Livres ("Hachette Université, Recherches Littéraires»), p. 127: «Déclinaison (actualisation) de paradigmes latents, un système descritif (S. D.) est un jeu d'équivalences hiérarchisées: équivalence entre une dénomination (un mot) et une expansion [...]; la dénomination [...] assure la permanence et la continuité de l'ensemble, servant [...] de pantonyme à la description [...]; le pantonyme est donc, en quelque sorte, le 'nom propre' de la description".
} 
en topografía militar, a veces caracterizada por un léxico especializado; dos de los ejemplos más largos y más aislables como entidad textual donde el paisaje natural enmarca la topografía militar se encuentran en el quinto capítulo de la novela, pp. 88-89 y 94.

«Primera estampa. Síntesis de la narración», así titula Marcelino C. Peñuelas ${ }^{15}$ su comentario al primer párrafo de Imán; la palabra «síntesis» también es aplicable al tema aquí tratado:

\begin{abstract}
Cuatro carros de asalto entran a media tarde en el campamento. Ruido inseguro de chatarra en la solidez del silencio. Traen la sequedad calcárea de los desiertos que rodean la posición y cierran las perspectivas sin un árbol, sin un pájaro. (p. 33)
\end{abstract}

El primer párrafo, sobre el que se volverá tanto al final de esta parte como en la segunda, impresiona por su fuerza de evocación ambiental condensada en tan sólo cuarenta y una palabras (nótese la presencia del enunciado sin núcleo verbal). La tercera oración evoca el marco natural, de una manera que podría calificarse de oblicua pero sumamente significativa: son los carros de asalto los que, por su procedencia, el polvo que levantan y el que los recubre, «traen» el desierto —es decir, su ambiente- al campamento; de entrada, pues, el paisaje está fundido con lo bélico. Unas páginas más lejos, surge la primera referencia a la llanura, que ha de convertirse en verdadero leitmotiv: "Las llanuras amarillas onduladas a trechos [...]", pp. 36-37; «Llanuras pardas grises», p. 38; «Los llanos de Drius se enrojecen», p. 39; «Ladran perros en el corazón de la noche sobre la llanura desolada», p. 49; "Una llanura gris, desierta», p. 152; "La llanura pertenece a un planeta que no es el nuestro», p. 153; «La llanura sigue hacia Drius [...]», p. 158; «La llanura poblada de arbustos se alza lejos [...]», p. 159; «La llanura sigue muerta y viva con raros contrastes", p. 161; “ $i$ la llanura? Quedan diseminadas las mismas sombras largas [...]», p. 163; «La llanura, con su honda y dilatada lobreguez [...]», p. 172; «ha perdido de vista Tistutin y se enfrenta con la llanura, cuyos reflejos [...]», p. 175; «La llanura sigue desierta», p. 175; "La llanura es ahora blanca, pelada, lisa», p. 176; "La llanura amenaza por todas partes», p. 176; «Despierta la llanura y con ella comienzan a agitarse bajo el sol los moros [...]», p. 177; «Viance quiere salir, pero la luz de la llanura es como [...] ], p. 180; «cara a la gris llanura», p. 189; "[...] llega a la llanura de Monte Arruit», p. 191; "La llanura duerme arriba. [...] La llanura, hasta Monte Arruit, no es tan blanca, [...]», p. 205; «sin el agobio de las llanuras calcáreas», p. 231; «se extiende una planicie cerrada a la izquierda [...]», p. 275; "mirando la estepa seca y oscura [...]», p. 294.

Sender distribuye estratégicamente sus pinceladas descriptivas, con gran economía de medios pero con evidente insistencia. Esa inacabable llanura obsesivamente presente, teatro de la dramática experiencia de Viance y reflejo físico de sufrimientos que parecen tan interminables

15 «Introducción», op. cit., p. 13. 
como la misma llanura, queda grabada en la retina del lector como indisociable de la historia del protagonista. Pero se trata de un efecto que el arte descriptivo no puede lograr con la repetición y la distribución sólo. Lo que pasa es que el escritor se dedicó en Imán a un acertado experimento artístico de evocación paisajística de tendencia impresionista; ${ }^{16} \mathrm{y}$, dicho sea de paso, aunque el adjetivo "artístico" contradiga ciertas afirmaciones explícitas del epígrafe, es evidente que el simple hecho de declarar allí que las páginas de Imán fueron escritas «con la voz del paisaje africano en los oídos» no sólo anuncia un determinado grado de protagonismo de este paisaje sino que revela también, de antemano, la voluntad de estilo que determina su representación. En primer lugar cabe poner de relieve que la constante poetización ${ }^{17}$ de la realidad, uno de los rasgos más llamativos de Imán, origina en algunos fragmentos descriptivos imágenes de una gran belleza, como ésta por ejemplo: «A la izquierda, las cumbres de dromedario de Tizzi Asa buscan la luna con la joroba; pero es inútil» (pp. 39-40).

En segundo lugar se debe mencionar la gran variedad que Sender introduce en sus evocaciones del paisaje. Pues esas llanuras bastante uniformes, con unas suaves lomas o cráteres de granadas como únicos accidentes del terreno, esas llanuras secas, desoladas y desérticas a las que el texto alude tantas veces, Sender las muestra al lector como una realidad cuya apariencia varía según el momento del día, el lugar del itinerario de Viance y la posición de éste. Destaca la especial atención que Sender dedicó a captar los colores y sus matices: la tierra que se ofrece a los ojos del narrador y de Viance, generalmente inhóspita y mutilada por la guerra, es, dependiendo del momento y del lugar, amarilla, parda, pardusca, gris, gris plomizo, lóbrega («la llanura, con su honda y dilatada lobreguez», p. 172), lívida, blanca o «no tan blanca $[. .$.$] como la de [...]», p. 205; higue-$ ras y setos conforman una «lejanía verdeoscura» (p. 158), etc. La guerra aporta su siniestra contribución a los colores de la tierra, transformando a los muertos en simples manchas trágicamente incorporadas al paisaje: el gris plomizo de la llanura está «salpicado del blanco o del amarillo tumefacto de los cadáveres desnudos» (p. 189). Mediante el uso de verbos derivados de nombres de color, el detalle contemplado cobra más vida; se sugieren los efectos de la luz y un sutil juego de matices y transiciones: «Azulean las lomas» (p. 39), «amarillean las lomas» (p. 154); o se evoca con eficacia, conjuntamente, el color y un movimiento serpenteante: «Negrea la tierra entre rocas» (p. 159). Los tonos dominantes en Imán

\footnotetext{
16 Sobre las tendencias impresionista y expresionista en la prosa senderiana, véanse Josefa Rrvas, El escritor y su senda. Estudio crítico-literario sobre Ramón J. Sender, México, Editores Mexicanos Unidos, $2^{a}$ ed., 1967, pp. 234 y ss.; F. CARRAsqler, op. cit., pp. 49-58, y M. C. PeÑUELAS, La obra narrativa..., cit., pp. 249-250.

17 Otra vez remito, para más detalles sobre este tema, a R. BOSCH « La "species poetica" en Imán, de Sender», art. cit.
} 
(gris, pardo, amarillo) sin duda son los que efectivamente corresponden a la realidad del marco geográfico descrito en la novela; pero es de subrayar, como por cierto lo hace Marcelino C. Peñuelas, ${ }^{18}$ que también se trata de los tonos predilectos de Sender, «que ha sentido toda su vida una cierta atracción hacia la pintura como medio de expresión y como tema de estudio». ${ }^{19}$ Transcribo un pasaje de las conversaciones que mantuvieron Sender y Peñuelas:

$[P]-.[\ldots]$ Parece que has tenido siempre una sensibilidad especial para el color. [S.] - Más que para el sonido. Sobre todo, tonos fríos y tonos menores. Matices de gris, matices de blanco, matices de amarillo bajo. La púrpura de los cardenales, de los emperadores, no me gusta. es un color «barato». [P.] — ¿Utilizas conscientemente el color para matizar? [S.] - Casi siempre para rebajar un poco los colores fuertes. Porque prefiero, como he dicho, los tonos fríos y bajos. [...] Como ambientación. Me gusta mucho en el ambiente el gris, porque en el gris destaca cualquier forma de énfasis natural, aunque sea muy poco acusado. $Y$ entre mis defectos tengo también alguna forma de fuego interior que no puedo evitar. El esfuerzo mío cuando escribo consiste más en atenuar el fuego que en atizarlo, ¿comprendes? Entonces hago lo más tenue posible ese fuego interior en la expresión y procuro que resalte sobre un fondo neutro y gris. 20

Es evidente que se debe andar con prudencia y cuidado al cotejar el primer texto novelesco de un escritor de unos veintinueve años con las reflexiones del novelista que, en la vejez, contempla el conjunto de las obras publicadas a lo largo de cuarenta años: lo que dice éste no se aplica necesariamente a aquél; pero, hecha la salvedad, en este caso merece la pena resaltar la coincidencia entre los juegos de tonos y matices en Imán y las citadas declaraciones de Sender. Me imagino que los casi dos años ${ }^{21} \mathrm{de}$ servicio militar en Marruecos marcaron profundamente al joven escritor. ${ }^{22}$ ¿Sería sorprendente que esas preferencias hubieran sido por lo menos acentuadas, si no reveladas, por la experiencia marroquí?, ¿o fue simplemente la contemplación y la vida en medio de un marco natural, con cuyos tintes se sentía en sintonía, las que incitaron a Sender a evocarlos con cierta insistencia? Las preguntas quedan abiertas.

\footnotetext{
18 La obra narrativa..., cit., pp. 245-250.

19 Ibid., P. 245.

20 M. C. Peñuelas, Conversaciones con Ramón I. Sender, Madrid, Magisterio Español, 1970, pp. 230-231.

${ }^{21}$ De fines de febrero de 1922 hasta el 31 de enero de 1924, según la imprescindible y ejemplar fuente de información sobre el "primer Sender», la muy documentada "Introducción» de Jesús Vived Malral (ed.) a Ramón J. SEnder, Primeros escritos (1916-1924), Huesca, Instituto de Estudios Altoaragoneses, 1993, p. XCVII.

22 Es sabido sin embargo que Imán no es el primer texto literario de Sender cuya historia transcurre en Marruecos. Recordemos un dato señalado por José Domingo DuFÑAs LoRENTE (en la «Introducción» de su edición de Ramón J. SENDER, Literatura y periodismo en los años 20. Antologia, Zaragoza, Edizions de l'Astral [«Cuadernos de Cultura Aragonesa», 12], 1992, p. 25): el soldado Sender desembarcó en Melilla muy preparado al descubrimiento del país; su
} 
Como comenta Ph. Hamon 23 en su capítulo sobre el enunciado descriptivo y su construcción teórica, la descripción siempre tiene algo que ver con un horizonte de expectativas preexistentes, o sea, con un código, una norma (un ser humano tiene una cabeza, dos brazos, etc.; el diccionario enciclopédico dice de qué piezas básicas consta tal o cual máquina). De ahí que una descripción pueda modalizarse: la modalización es un procedimiento frecuente que consiste en describir evaluando lo descrito con referencia a un horizonte de expectativas y señalando, por ejemplo, ausencias, carencias. Uno de los ejemplos más conocidos en poesía castellana moderna quizás sean estos amargos y crueles versos, con su quíntuple repetición de las palabras privativas «ni» o «sin», del famoso «A orillas del Duero», de los Campos de Castilla:
¡Oh, tierra triste y noble,
la de los altos llanos y yermos y roquedas, de campos sin arados, regatos ni arboledas; decrépitas ciudades, caminos sin mesones, y atónitos palurdos sin danzas ni canciones que aún van, abandonando el mortecino hogar, como tus largos ríos, Castilla, hacia la mar! ${ }^{24}$

También en Imán se encuentra el procedimiento, desde el mismo principio del texto, y para concluir la primera parte de este trabajo quisiera dedicar un comentario al final del primer párrafo, donde se insiste en lo que no hay en el paisaje. Recordemos la tercera y última oración del primer párrafo de la novela:

[cuatro carros de asalto] Traen la sequedad de los desiertos que rodean la posición y cierran las perspectivas sin un árbol, sin un pájaro. (p. 33)

Ya queda dicho que de entrada, desde la primerísima estampa, aparece un paisaje desértico, fundido con lo bélico. De entrada también el desierto se define no sólo por lo que es (un espacio de «sequedad») sino por lo que no es (un espacio sin árboles ni pájaros). Pero esto ya tiene que ver con la focalización en Imán por cuanto - y que se me perdone la aparente perogrullada- el lector se entera, a través de la modalización «sin..., sin...», de que el punto de vista adoptado es el de hombres para quienes árboles y pájaros constituyen lo normal en un paisaje o espontáneamente

primera novela corta, «Una hoguera en la noche», publicada en 1923 en los números 26 (julio) y 27 (agosto) de la revista barcelonesa Lecturas, se ambienta en Marruecos, pero «los conocimientos sobre Marruecos y sobre la propia guerra colonial que exhibe Sender en "Una hoguera en la noche" proceden no de la vivencia directa sino de sus ya abundantes lecturas y curiosidades». J. D. Dueñas Lorente remite a una cita de Crónica del alba, Madrid, Alianza Editorial, 1971, III, p. 125: «Cuando fui a Marruecos había leído tanto sobre aquel sombrío y árido país y sobre las condiciones de la vida militar en las colonias que no me sorprendió nada en absoluto".

23 Du descriptif, cit., pp. 118 y ss.

24 Antonio Machado, Poesías completas, prólogo de Manuel Aivar, $12^{\mathrm{a}}$ edición, Madrid, Espasa Calpe, 1987, p. 138. 
se asocian con lo ameno en un paisaje y de todas formas contrastan con «la sequedad calcárea»: además de los mismos lectores, el narrador Antonio, Viance y los otros militares españoles que sufren en Marruecos. Porque la lectura confirmará que esas últimas palabras del primer párrafo remiten indirectamente a España, reflejan la nostalgia de los que extrañan su tierra y sus hogares y anuncian la expresión de esta nostalgia:

La tarde es ahora color de miel y en el olvido momentáneo de todo - un olvido tan suave, tan fácil, hundido en la armonía del cielo, del aire, de la propia conciencia virgen - se desean oír las esquilas de la campiña española. (p. 96)

Los que se salven llegarán por milagro a las alambradas de Annual. Y todo bajo la indiferencia del cielo estrellado, tan lejos, ausentes hasta del recuerdo de las personas queridas [...]. (p. 105)

Viance no puede dormir. Los pequeños rumores de la posición le recuerdan, por referencias, ruidos de agua. Al pensar en su casa de la aldea envidia aquella miseria con el cantaral rezumante y la tinaja donde al extraer una jarra de agua cantaban las gotas resbalando. No concibe por qué se marchó estando como estaba el pueblo tan bien abastecido de manantiales. Y luego aquellas nevadas que en el deshielo llenaban los caminos, las calles de charcos. (pp. 114-115)

La noche, cuando se ocultaba la luna, era negra como las entrañas de un volcán, mucho más negra que en España. (p. 135)

De los fragmentos que se acaban de citar, el más significativo, respecto del tema aquí tratado, es por supuesto el tercero, que es una muestra del desarrollo de uno de los leitmotiv más acentuados, el de la sed: en la visión de Viance (que tuvo que beber orina), la obsesión por el agua transforma la aldea aragonesa, donde el protagonista y su familia conocieron una negra miseria, en una suerte de locus amœnus identificado como tal únicamente a base de lo que en la tragedia de Marruecos les falta a los soldados españoles del ejército en derrota.

Se ve que, en términos cuantitativos, las alusiones a la nostalgia de España son bastante discretas. Pero preparan eficazmente el reencuentro decepcionante de Viance con España en el último capítulo, a cuyo principio el protagonista medita sobre su experiencia marroquí, a partir de la contemplación de los paisajes españoles a través de la ventanilla del tren. Pero este fragmento se considerará en el apartado siguiente.

\section{EL PAISAJE COMO SIGNO}

Mieke Bal, ${ }^{25}$ al principio de su capítulo «Descriptions», en el que lleva a cabo un penetrante análisis de la descripción de Rouen en Madame Bovary, cita esta significativa declaración de Flaubert: "ll n'y a point dans mon livre

25 Narratologie. Les instances du récit, París, Éditions Klincksieck, 1977, p. 92. 
une description isolée, gratuite; toutes servent à mes personnages et ont une influence lointaine ou immédiate sur l'action». Los trabajos contemporáneos de teoría literaria que tratan del texto narrativo suelen insistir en las relaciones entre las descripciones y la macroestructura del texto y en la función de los marcos escénicos «como expresiones metonímicas o metafóricas del personaje» ${ }^{26}$ o como «signo» ${ }^{27}$ del personaje. En las páginas anteriores han sido considerados los modos y grados de presencia de la descripción paisajística en Imán y se ha visto así que ésta participa con gran eficacia en la recreación ambiental de las campañas del Rif; con razón habla Francisco Carrasquer de descripciones «de situaciones muy bien enmarcadas en el paisaje geográfico y humano». ${ }^{28}$ A continuación se analizan esas mismas descripciones, pero desde el punto de vista del papel que desempeñan, más allá de lo puramente ambiental, en la economía del relato y como «signo» del personaje.

Raras veces el paisaje es inocente en Imán. Cualquier lector medianamente atento debe descubrir pronto que, por descripción directa o a través de símiles o metáforas, el paisaje y la naturaleza entera se asocian estrechamente con el drama, los tormentos físicos y las angustias psicológicas y metafísicas de los hombres, contribuyendo «a definir la acción y el clima humano del momento». ${ }^{29}$ Soledad, sufrimiento, muerte, desesperanza: eso es lo que dice el paisaje. Por tres razones: es de tipo desértico; es, dicho en términos militares, teatro de operaciones; se proyectan en él los sentimientos humanos. Y esto desde el primer párrafo, a cuyo final una vez más debemos volver:

[cuatro carros de asalto] Traen la sequedad calcárea de los desiertos que rodean la posición y cierran las perspectivas sin un árbol, sin un pájaro. (p. 33)

Mis subrayados señalan el principio de la interpretación subjetiva del paisaje, su lectura por el narrador, en este caso, o por Viance ${ }^{30}$ en otros. Confieso que me quedo con alguna duda en cuanto al sujeto de "cierran": ¿los carros de asalto o los desiertos? Gramaticalmente la oración es ambigua; opto por «los desiertos». Éstos «rodean» —como si se tratara de un asedio- el campamento y la acción de cerrar «las perspectivas» sugiere entonces la idea de trampa sin salida en que han caído los hombres. Se ve cómo Sender juega con los significados literal y figurado de la voz «perspectiva»: lo que se ofrece a la vista y el aspecto con que nos representamos cosas de un futuro más o menos lejano. «En esta primera estampa —escri-

\footnotetext{
26 René Wellek y Austin Warren, Teoría literaria [1948], prólogo de Dámaso A tonso, versión española de José $\mathrm{M}^{a}$ Gimeno, Madrid, Gredos ("Biblioteca Románica Hispánica»), $4^{d}$ ed., p. 265.

27 Antonio Garrido DOMíngurz, El texto narratioo, Madrid, Síntesis («Teoría de la Literatura y Literatura Comparada»), 1993, pp. 216 y ss.

28 «Imán" y la novela histórica..., cit., p. 37.

${ }^{29}$ M. C. PeÑuelas, «Introducción» a Imân, ed. cit., p. 21.

30 Para las distintas focalizaciones en Imán e incluso cierta ambigüedad o confusión (¿voluntaria?) en cuanto a ellas, véase M. C. PEÑueLAS, «Introducción» a Imán, ed. cit., pp. 17-20.
} 
be Marcelino $C$. Peñuelas — 31 puede vislumbrarse también, plasmado en esquemático compendio, el sentido trascendente de la novela que apunta hacia la absurdez final del sufrimiento, del esfuerzo humano, en una vida vacía de sentido».

Unas tres páginas después del párrafo inicial, se lee esta oración, en la que la morfología del terreno - la realidad, digamos - inspira un símil que mediante un adjetivo ("tormentoso") remite al drama del que las llanuras son el escenario y se hace como anunciador de la palabra final, «sangre»:

Las llanuras amarillas, onduladas a trechos como un mar tormentoso, van a curvarse unánimemente sobre el río, y el convoy pone en ellas un trazo rojo de sangre. (pp. 36-37)

O sea, que la primera definición del paisaje es la de un elemento hostil: forma parte de un marco geográfico que en rigor pertenece al enemigo vencedor y de donde surge el enemigo vencedor. A lo largo de la novela aparecen variaciones sobre este aspecto del paisaje; ante la imposibilidad de comentar cada caso, me limitaré a citar una serie de ejemplos representativos, dedicándoles luego un comentario de conjunto:

El color blanco de las lomas lejanas va dorándose. Hay una soledad y un silencio extraños. ¿Quizá por la comba de esas llanuras corre el aliento helado de la muerte, que se desencadenará con silbidos y mugidos de cierzo en cuanto salgan! (p. 95)

La dulzura del paisaje es una apariencia hipócrita, porque hacia la izquierda se puebla el horizonte de sombras azulencas, y en la inmensidad desierta y desolada las granadas sondean el silencio y averiguan hasta qué dramáticos infinitos llega. (p. 100)

$\mathrm{Al}$ amanecer las caras tienen una palidez de cera, acentuada por la sombra troglodítica de la barba. Apenas se alza el sol da en lo alto de una tienda. Siguen todos en el parapeto. Las colinas, limpias; el cielo, fresco y diáfano. La naturaleza ha dormido y aparece con la cara lavada. (p. 133)

La llanura pertenece a un planeta que no es el nuestro. Un planeta muerto, aniquilado por las furias de un apocalipsis. [...] La tierra, blanca; los arbustos, escasos y secos; llanura cruzada por mil caminos invisibles de desolación. (p. 153)

Al doblar la loma aparece, en la lejanía, Dar Drius. La llanura poblada de arbustos se alza lejos, en un gran escalón [.... I. Su [= de Viance] ansiedad se señala ya un objeto, y su miseria una meta. ¡Qué dulce ver hechos materia viva los sueños! Pero la llanura, tan lívida bajo este sol filtrado, no se abarca bien. Hay demasiado matorral. (p. 159)

La llanura sigue viva y muerta con raros contrastres, algo de cementerio y el bullicio y la animación de los zocos. (p. 161)

La llanura es ahora blanca, pelada, lisa. Hay otra vez muertos recientes. Y un grupo lejano de soldados atolondrados, perseguidos y cazados a golpes

31 «Introducción» a Imán, ed. cit., p. 15. 


\section{EL LUGAR DE SENDER}

de alfanje por unos cincuenta jinetes moros. La llanura amenaza por todas partes. (p. 176)

Viance quiere salir, pero la luz de la llanura es como una inmensa cuchillada de verdugo que le segará la cabeza en cuanto aparezca fuera. (p. 180)

Al doblar el recodo de la colina, cara a la gris llanura - gris plomizo salpicado del blanco o del amarillo tumefacto de los cadáveres desnudos-, la soledad le sale al paso y lo rodea, prolonga las perspectivas en una dimensión nueva, llena de asechanzas, de misterios, de peligros, de hados y duendes. (p. 189)

[Viance] Corre bajo la mole irregular del Gurugú que a veces parece gravitar sobre su cabeza, amenazando con aplastarle, y que corta el cielo de improviso como una nube tormentosa. (p. 231)

Estos fragmentos, a los que se suman los dos anteriormente comentados y varios otros que luego veremos, se citan según su orden de aparición en el texto, lo que permite apreciar que lo pautan con bastante regularidad. Hagamos un inventario de los procedimientos, temas y aspectos lexicológicos más destacados. La presencia efectiva, por la situación bélica, de la violencia y la muerte se transfiere al paisaje, como contaminándolo e invalidando lo que podría tener de ameno: su «dulzura es una apariencia hipócrita», su luminosidad «como cuchillada de verdugo», por él «corre el aliento helado de la muerte», la llanura es "planeta muerto», a su cromatismo contribuyen los cadáveres; llega a estar "lívida», es decir, del color asociado con muerte, enfermedad y herida. El paisaje es activamente agresivo frente al invasor: la llanura lo "amenaza» e igual hace el Gurugú. Imán no sólo es una novela pacifista, sino que tiene también sus dimensiones antiimperialistas y anticoloniales, 32 lo cual repercute en el tratamiento del paisaje: en determinado momento, la llanura, ambiguamente, está a la vez «viva y muerta», «cementerio» para los unos, zoco animado y bullicioso para los otros. Pero uno de los fragmentos que mejor representa el antagonismo entre el paisaje y los soldados españoles es el que evoca (p. 133) la "palidez de cera" de las caras, "acentuada por la sombra troglodítica de la barba», o sea, seres de apariencia entre primitiva y fantasmal, marcados ya por el sello de la muerte, frente al tranquilo y triunfante desafío de una naturaleza descansada, reluciente, aseada, que pertenece al enemigo. Observemos por último, en cuanto a la serie de fragmentos aquí comentados, un cierto grado de personificación en las descripciones: al paisaje se le atribuyen acciones, funciones y aspectos propios del ser humano, como dormir y lavarse la cara, amenazar, la "apariencia hipócrita», la lividez, la mortífera cuchillada del verdugo; en la

\footnotetext{
32 Véanse fragmentos como éstos: «Viance añadió: - iCabo, somos fuertes y tenemos buenas armas! ¿Por qué nos han de poder esos piojosos? Yo sí que lo sé. Porque ellos tienen la razón y eso pesa mucho» (p. 212); «El cabo, de espaldas, está curando con su paquete individual al viejo árabe. Después de verterle el yodo en las dos heridas le envuelve cuidadosamente la garganta con gasa. Luego le da una palmada en el hombro y le dice gritando epilépticamente: - ¡Vosotros tenéis razón!» (p. 282).
} 


\section{PATRICK COLLARD}

penúltima cita, la soledad que "sale al paso" es como un ser vivo, engendrado por la "gris llanura".

En otra serie de segmentos la función de la descripción ya no se relaciona con la situación bélica y su drama humano en lo material, físico, sicológico y social, sino con la dimensión que podríamos llamar trascendental o metafísica de la novela: los "dos mil años de injusticia» (p. 96) y la trágica absurdez de la guerra lanzan gritos y miradas interrogatorias hacia un cielo indiferente, insondable o vacío: ${ }^{33}$

\footnotetext{
$Y$ todo bajo la indiferencia del cielo estrellado, tan lejos, ausentes hasta del recuerdo de las personas queridas. (p. 105)

El parapeto ha subido poco a poco, y está ahora hacia arriba, horizontal bajo el cielo impenetrable. (p. 123)

La indiferencia del sol convierte la tragedia en una cosa tonta y vulgar, sin sentido. (p. 145)
}

La realidad geográfica de abajo, esa desértica llanura, descrita alguna vez como "rincón deshabitado» que tiene «algo de paisaje lunar» (p. 49), no es única: tiene su equivalente arriba del que parece funcionar como réplica y signo. El mundo creado por Sender en Imán tiene cierto aire de parentesco, aunque sea lejano, con el mundo que, años después, aparecerá en varios relatos de Jorge Luis Borges: un caos laberíntico que su creador, avergonzado quizás, ha abandonado o del que se ha olvidado; en todo caso, un mundo en que brilla por su ausencia cualquier idea de Providencia. El primer momento en que el texto define la soledad en relación directa con el paisaje se sitúa muy al principio, como era de esperar (p. 38, sexta página de la novela en la edición de Destino), y la formulación hace intuir ya que esa soledad trasciende lo meramente circunstancial e individual, haciendo referencia a la radical soledad del ser humano en un universo cuyo significado escapa a la comprensión o es inexistente:

La soledad del centinela es desabrida, áspera. La reflexión agrava esa soledad. Llanuras pardas, grises. A la de uno se suma la total soledad del campo y del cielo, más ancho y frío en estos desiertos. (p. 38)

Nótese que la frase sin núcleo verbal, que señala o recuerda el marco escénico («Llanuras pardas, grises»), está colocada, literalmente, en el centro mismo de la reflexión del narrador sobre la soledad, como si ésta saliera, en ondas expansivas, del paisaje. Una impresión análoga se desprende

\footnotetext{
33 El cielo es ambivalente; ocurre que su contemplación produce una sensación de paz en medio del estruendo de las armas y subraya de ese modo lo absurdo de la guerra: «Otros callan, mirando el cielo azul limpio y hondo, sin un pájaro. Con los ojos llenos de ese suave azul fresco y tonificador, los tiros del parapeto no se conciben, no se sabe a cuento de qué disparan» (p. 91); "El cielo, de un negro abismático, está poblado de inquietas luminarias que lo hacen mucho más hondo. Hay una paz sedante, con aliento de eternidad» (p. 189).
} 
de las oraciones citadas a continuación, que además ponen de relieve explícitamente una dimensión metafísica:

El trueno es débil y lejano, pero ahonda la soledad y descubre la gran desolación de esos campos sobre los cuales llega. El miedo es ya un miedo metafísico, bajo el cual desaparece el hambre, la sed, el dolor físico de las heridas [...]. (p. 167)

Otro momento característico de la estrechísima compenetración textual y temática entre la descripción del paisaje y la reflexión en torno a esa terrible soledad de alcance ya mítico, que pesa sobre el mundo como un pecado original o una maldición eterna, se encuentra en un espléndido párrafo, estratégicamente colocado al final de la primera parte del octavo de los dieciséis capítulos de Imán, o sea, casi exactamente en la mitad del libro, lo cual, me imagino, no es casual. Lo cito por completo:

La llanura pertenece a un planeta que no es el nuestro. Un planeta muerto, aniquilado por las furias de un apocalipsis. Silencio y muerte infinitos, sin horizontes, prolongados en el tiempo y en el espacio hasta el origen y el fin más remotos. La tierra, blanca; los arbustos, escasos y secos; llanura cruzada por mil caminos invisibles de desolación. Moros muertos, españoles despedazados. La soledad grita al sol en mil destellos sin eco: «Tú irás por Occidente; yo por Oriente, y al final nos encontraremos en un lugar de desventura». Sin un rumor de brisa, sin un pájaro, en el silencio que ahonda la mañana hasta la lividez de la última mañana del universo. (p. 153)

La lectura del párrafo ya viene a ser en gran parte un reencuentro con rasgos señalados y comentados a propósito de citas anteriores: un contexto de guerra y muerte, reflejado también en el léxico aplicado a circunstancias naturales, como, por ejemplo, la lividez de la mañana; una situación de radical enajenación («un planeta que no es el nuestro"); mención de lo que no hay, de lo que falta («Sin..., sin...»); enunciados sin núcleos verbales, que describen en breve la realidad del paisaje y forman como el corazón del párrafo; en esa realidad se apoyan la personificación e hipotiposis de una soledad y una desolación cósmicas. Por supuesto, si en las palabras de introducción a este fragmento se habla de "alcance mítico" es porque el contenido nos arranca al tiempo histórico lineal y nos proyecta en un espacio - el mítico- atemporal, el de los grandes acontecimientos ejemplares siempre repetidos. Es evidente que en un fragmento como éste, la campaña del Rif, con sus matanzas de Annual y Monte Arruit, momentáneamente aparecen como pretextos o, mejor dicho, como base referencial a partir de la cual el texto despega emprendiendo su vuelo poético hacia niveles de realidades esenciales y superiores. Bien se aplican al párrafo comentado estas palabras de Rafael Bosch: «He aquí la razón de la existencia de la poesía toda de Imán: el dolor absoluto de la experiencia interior del destino humano no puede ser vivido espiritualmente en la forma de la comunicación por palabras sino en el espacio abierto y superior donde la acechada realidad humana se salva de todas sus heridas mortales 
acudiendo a la confluencia con la metafísica». ${ }^{34}$ Los lectores de Imán sabemos dónde y cómo Viance consigue hallar un cierto alivio frente a ese «dolor absoluto» y la acechanza de la muerte: en una especie de regreso al útero, refugiándose en el vientre de un caballo muerto, donde no sólo escapa al enemigo, sino que se siente "momentáneamente reconciliado con la materia» (p. 179), intuyendo que la vida es un «accidente» de «sencilla grandeza», "que nos equipara a algo tan sereno y milagroso como las piedras y los árboles» (ibid.). Una escena aquélla en que lo humano, lo animal, lo vegetal y lo mineral forman un todo. La podemos considerar como un anticipo de las reflexiones sobre los conceptos afines, tan senderianos, de la «hombría» y del «hombre ganglionar», 35 esbozados en Imán y en «El realismo y la novela», ${ }^{36}$ desarrollados en «El novelista y las masas» (1936, art. cit.) y en La noche de las cien cabezas (1934), elevados al rango de piedra angular de un ambicioso conjunto especulativo en La Esfera (1947).

Termino este trabajo con el examen de dos fragmentos descriptivos de particular importancia para el contenido ideológico de la novela y que corresponden a sendos momentos decisivos: el primero, la contemplación de San Juan de las Minas y el segundo, la vista de los paisajes españoles, al final de la novela. En ambos casos, la mirada directa es la de Viance pero la interpretación política y los términos precisos que traducen ésta son, evidentemente, de Antonio, el narrador - alter ego de Sender, quien por cierto destaca de vez en cuando su propio papel de portavoz privilegiado subrayando los límites de la posibilidad interpretativa de Viance:

Estas reflexiones no las resuelve Viance; pero las plantea oscuramente y quedan iniciadas en la subconsciencia, otra vez alerta. (p. 177)

Sus intuiciones son muy vagas. [...] Por ignorarlo, se pierde su razón en laberintos. (pp. 294-295)

El principio del capítulo nueve relata la llegada del protagonista a las instalaciones de San Juan de las Minas, destruidas, abandonadas y sembradas de cadáveres de obreros españoles; de los cinco párrafos del episodio, transcribo los dos finales:

Viance llega a sentir cierta satisfacción maligna y vengativa. Se ha sentado en una piedra. Preside el paisaje la cresta de San Juan de las Minas. San Juan Bautista debe ser. Ahí está el anacoreta de los millones, el místico de la industria pregonando la virtud, la abstinencia, el ayuno y bautizando al indigena con el polvo rojizo del mineral. Bautismo de esclavitud, de vasallaje. Prostitución del trabajo impuesto y mal pagado. Nada de jornadas estableci-

\footnotetext{
34 «La "species poetica" en Imán...», art. cit., p. 296.

35 Véase «Realismo y hombría» en mi libro Ramón J. Sender en los años..., cit., pp. 122-125.

36 En La Libertad, 6 de enero de 1933, pp. 1-2.
} 
das ni jornales mínimos. La procesión de encapuchados, cubiertos de polvo rojizo y de piedra manchada por la entraña sangrante de la montaña, hormigueaba de la mina al tren, del tren a la mina, silenciosa, aguardando la caída del sol y los seis reales.

Civilización de Occidente, trenes mineros, sociología de piedad cristiana y, detrás, el ejército, la vida joven y poderosa con tres palabras vacilantes en los labios: patria, heroísmo, sacrificio. Más abajo de la cresta minera, rocas blancas enhiestas, agrupadas, superpuestas: el hueso mondo de la montaña. Todavía más abajo, blancas losas calcáreas, donde la lluvia, la erosión constante, ha dibujado columnas y encasillados de arriba abajo. Una tabla de cotizaciones de Bolsa. $\mathrm{Y}$ al pie... Al pie se han refugiado algunos para morir. En este sector, la gran losa calcárea es un área feroz y primitiva. (p. 174)

Se trata de uno de los momentos de denuncia más explícita y socialmente totalizadora en Imán; el hondo dramatismo de la situación descrita se transmite a través de un tono sobre todo sarcástico, alegórico y panfletario que hace pensar en ciertos dibujos satíricos de la prensa política de izquierdas de aquellos años. O en el Sender de La noche de las cien cabezas. El contenido de los párrafos desarrolla y amplifica gráficamente la respuesta dada en el capítulo seis a la pregunta «Oye, tú, muchacho: ¿Sabes qué es la Patria?»:

Ah, rediós; la Patria no es más que las acciones del accionista. Se lo han dicho el otro día unos obreros catalanes que están en la segunda compañía, y con razones bien claras. (p. 121)

La cresta y las rocas del centro minero forman como una pirámide, descrita desde arriba hasta abajo: la pirámide social cuya organización, tal como aquí la representa Sender, se basa en la explotación de las clases populares españolas e indígenas por el capitalismo y el imperialismo, con la colaboración de la Iglesia y bajo la protección del ejército. La misma composición del nombre del sitio, que une lo religioso con lo económico, es todo un símbolo del que el texto se aprovecha: «anacoreta de los millones", "místico de la industria», "Bautismo de esclavitud, de vasallaje», «procesión de encapuchados». Al pie del edificio están sus víctimas: Viance rodeado de cadáveres; el párrafo que comienza con las palabras «Civilización de Occidente» termina con las palabras "área feroz y primitiva», como si éstas fueran una definición de aquéllas. Viance, soldado raso, uno de los de abajo, contempla, desde abajo, aquel conjunto de instalaciones y rocas. $\mathrm{Y}$ lo contempla con "cierta satisfacción maligna y vengativa» porque comprende de manera más o menos precisa que se encuentra delante de la causa verdadera de su presencia en Marruecos, de tantos sufrimientos, de tantas muertes. El paisaje desempeña, aquí también, su papel de signo. En otros momentos de la novela se puede hablar de un paisaje militarizado y mutilado por la guerra. Esta vez se trata de un paisaje colonizado, castigado e instrumentalizado con fines industriales; un paisaje literalmente dominado: «Preside el paisaje la cresta de [...]». Igual que la guerra u otras formas de explotación del ser humano, la explotación mine- 
ra -que transforma a los obreros en esclavos- es presentada como una actividad violenta, que hace sangrar la montaña vaciando sus entrañas y dejando al aire su esqueleto - «el hueso mondo»- como la actividad paralela, la bélica, siembra de esqueletos las llanuras. En su metamorfosis final, el producto de la montaña es "tabla de cotizaciones de Bolsa», altar de una divinidad "feroz y primitiva» que exige sacrificios humanos.

Cuando Viance, casi vaciado de su sustancia humana, finalmente regresa a España, el primer contacto con su patria es distante y hostil. Dos oraciones sin núcleo verbal encabezan el último capítulo de Imán:

Cuatro días y tres noches de viaje. El paisaje frío, concreto e inexpresivo, y por la noche una negra y abstracta España irresponsable en la sombra de la ventanilla. (p. 294)

En estas dos frases, que no se refieren de manera explícita al protagonista, la presencia de un Viance que se ha vuelto extranjero en su país se perfila como en una filigrana a través de los adjetivos que definen y dan aire subjetivo al paisaje. Si cinco de los seis de la segunda frase, «frío», "concreto", "inexpresivo", "negra", "abstracta", apuntan hacia la distancia temporal, geográfica y emocional que se ha creado entre el personaje y su tierra, el sexto, «irresponsable», nos traslada a otro nivel, el ideológico, el de la denuncia y de la crítica política. La España «irresponsable» es la que no ha sabido o no ha querido evitar la tragedia narrada en la novela. En el último tramo del viaje que lo debería llevar a su pueblo aragonés (aún no sabe que Urbiés fue sumergido a raíz de la construcción del embalse),

[...] mirando la estepa seca y oscura, recobró la conciencia de sí mismo» (p. 294),

se encuentra con paisajes y gentes singularmente parecidos a los de Marruecos:

Ha recorrido España de punta a cabo. Ha visto llanuras, montañas, como en África, y, labradores altivos y taciturnos, como los moros. (p. 294)

El campo, el paisaje, no son lo que se figuraba en Marruecos. No hay tanta diferencia entre aquel campo y éste. Matas, tomillo, tierra parda, blanca y alguna vez rojiza. Cuervos, lo mismo que allá. Esperaba que esta tierra le hablara al corazón. (pp. 297-298)

Pero, como si Viance se agarrara a sus últimas ilusiones, a medida que se aproxima a lo que cree ser su lugar de destino, sigue apelando a sus recuerdos para recrear el paisaje de su infancia, el que se está preparando a ver de manera inminente. Hasta entonces nada corresponde a los sueños nostálgicos, evocados algunas veces en la novela, de los soldados con su tierra. Lo más amargo de la trayectoria de Viance reside en el hecho de que mientras a él lo deshumanizaban en la guerra de África al mismo tiempo 
le robaban su pueblo y este espacio de su pasado queda relegado para siempre al estado de recuerdo y de sueño de soldado en las lejanas llanuras de Marruecos. Cuando el lector atento se entera de que el pueblo de Viance ha desaparecido bajo el agua quizás atribuya retrospectivamente cierta dosis de ironía a la evocación (capítulo seis, p. 114), citada en la primera parte de este trabajo, de los pensamientos de Viance, quien, torturado por la sed, tiene de su aldea ante todo la imagen de un lugar donde por todas partes y en todo tiempo abunda el agua...

Se ha visto pues que Viance ve en España paisajes muy parecidos a los que formaban el telón de fondo de su terrible experiencia. ¿Por qué? En parte, sin duda y sencillamente, por verosimilitud geográfica: ciertas zonas de España - recorrida, no lo olvidemos, de «punta a cabo» por Viance- efectivamente pueden hacer pensar en otras del norte de África; esto lo sabe cualquiera. La verosimilitud incluso puede ser, en este caso, psicológica: para Viance, totalmente impregnado del paisaje africano, los parecidos reales pueden resaltar todavía más (¿no se ha dicho que Viance recobra «la conciencia de sí mismo» «mirando la estepa seca y oscura»?). Pero está claro que la razón profunda por la que el texto insiste en ellos es ideológica: la proyección del paisaje africano en las geografías españolas enmarca, otra vez, una reflexión de tipo político e histórico. Viance regresa a España con un esbozo de conciencia de clase y de sentimiento antiimperialista y anticolonial; a la comprobación del parentesco geográfico y humano sigue la pregunta, que todavía puede pertenecer al personaje:

Pero, ¿por qué los de aquí son tan sumisos? ¿Basta el estrecho de Gibraltar, una "manga de agua", para hacerlos cambiar de esa manera? Sus intuiciones son muy vagas. (p. 294)

Las últimas palabras señalan que el narrador, intelectualmente superior a Viance, toma el relevo y proporciona elementos de respuesta:

Lucha histórica del godo contra el africano. La aristocracia del Norte, confabulada con los judíos en un amasijo de catolicismo, contra el hermano de África, gemelo del español primitivo y hermano mayor del auténtico español moderno. El caso de España es el mismo que el de Marruecos. La aristocracia goda "corre los moros" y busca títulos de grandeza, y en España corre a los españoles y busca títulos de la Deuda de acuerdo con los auténticos bárbaros del Norte. (pp. 294-295)

Los que conocen los textos periodísticos y ensayísticos publicados por Sender en los años treinta saben que la idea básica enunciada en este segmento (no exento quizás de cierto relente antisemita) de la novela de 1930 se desarrollará cinco años después en un texto de clara inspiración marxista, «La cultura española en la ilegalidad», que Sender publica en Tensor. ${ }^{37}$ La idea es que desde el tiempo de los árabes hasta el momento actual

37 Tensor, 1-2 (agosto de 1935), pp. 1-21. 
(= la Segunda República), la historia de España es la de la lucha inconclusa entre las clases populares y el poder feudal; los árabes, pretende Sender, pudieron invadir fácilmente la península porque «libraban al pueblo de la opresión de la Iglesia y del naciente feudalismo». También en Viaje a la aldea del crimen (Documental de Casas Viejas) se habla de esa lucha entre el Norte, de donde vinieron «el estado, la ley y la Iglesia», y el ámbito del Mediterráneo, de donde vino "el hermano de África». ${ }^{38}$ En Imán el motivo del paisaje, que pauta toda la novela, termina poniéndose al servicio de esa tesis histórica y política.

Las páginas de este trabajo son de alcance limitado y en principio sólo aspiran a contestar de manera sistemática e interpretativa a la invitación, contenida implícitamente en el epígrafe de Imán, a leer la primera novela de Ramón J. Sender como un texto escrito «con la voz del paisaje africano en los oídos». Pero aunque sólo examinan ese paisaje sin contemplar siquiera las otras descripciones (de personajes, lugares, costumbres...) no quieren ocultar su ilusión de que contengan propuestas y puntos de partida para trabajos más amplios y constituyan así una modesta contribución al estudio de lo descriptivo y su función en las primeras obras literarias de un autor que ocupó un lugar tan destacado en los años inmediatamente anteriores a la guerra civil.

38 Madrid, Pueyo, 1934, p. 178. 


\title{
El último Sender: una mitología nueva para «nuestros tiempos incongruentes»
}

\author{
Margaret E. W. Jones \\ University of Kentucky
}

\begin{abstract}
Cada año en la producción de un escritor tan prolífico como Sender ofrece nueva evidencia para comprobar -0 desmentir- su inicial promesa de talento. Cuanto más vive y escribe, ranto más se expone al riesgo de ser medido no sólo contra otros sino contra sí mismo. La carrera de Ramón Sender es un destacado ejemplo de esta rueda de la fortuna literaria. Abarca más de medio siglo, tiempo suficiente para dar a varias generaciones de críticos y aficionados la oportunidad de juzgar su obra, considerándola según la moda crítica imperante.

Nunca ha faltado el interés crítico en Sender. Sólo hay que consultar la magnífica obra bibliográfica de Elizabeth Espadas para ver el crecido número de estudios dedicados a varios aspectos de su literatura, vida e ideología. Con razón, estos estudios se concentran en las obras "clásicas» como Réquiem por un campesino español, que, hasta la fecha, tiene dedicados más de treinta y cuatro estudios sin contar ni la materia en los libros más generales ni las guías de lectura.

El aspecto menos estudiado durante los trece años transcurridos después de su muerte es la obra senderiana escrita entre 1970 y 1982. Las razones de tal negligencia son diversas. Los lectores que esperaban encontrar en estos escritos tardíos la recreación del mundo familiar de Crónica del alba, por ejemplo, y el estilo sencillo que lo estructuraba quedaron decepciona-
\end{abstract}


dos ante una nueva modalidad. En algunas reseñas había alusiones negativas a la explotación literaria, al reciclaje de materia ya presentada -rasgo (hay que constatar) no limitado a este periodo- ${ }^{1}$ y, sobre todo, una sorpresa desagradable ante materia tan diferente de la época "clásica». ${ }^{2}$

A primera vista, la ficción de Sender después de 1970 parece unida sólo por su falta de unidad. Las novelas se desarrollan en lugares tan diversos como Brasil, Perú, California, Madrid, México, las islas Canarias, Marruecos, las islas Malvinas, el fondo del mar y el interior de un avión en vuelo. El reparto de personajes generalmente incluye a un narrador maduro -factor comprensible dado el carácter autobiográfico de la obra- y una mezcla de personajes reales y ficticios, figuras mitológicas y toda la gama del mundo animal — ballenas, ardillas, gorilas, pingüinos-, que representan un papel influyente en la trama.

Sin embargo, a pesar de tanta aparente variedad, se nota la recurrencia de temas que corroboran la unidad de la visión literaria de Sender: su obsesión con la muerte y la nada, la presentación de la experiencia humana en términos binarios (vida/muerte, diablo/ángel, inocencia/culpa, fantasía/realidad, etc.) y el esfuerzo para reconciliar éstos en la búsqueda de trascender el misterio del universo.

La crítica ya ha señalado la práctica de reelaborar materia e ideas en el corpus senderiano. ${ }^{3}$ Así, el que conozca su obra anterior reconocerá los temas mencionados. Sin embargo, es provechoso examinar las modificaciones que sufre la materia, destacando las repeticiones obsesivas de ciertas proposiciones en este último periodo. Sin duda, la más importante y predilecta es la oposición entre la cultura y la naturaleza. A partir de los setenta, Sender cambia el enfoque para revelar que la civilización contemporánea - la suya - peca, por un lado, de una especie de hubris actual por su ilusión de control y su orgullo tecnológico y, por otro, del deterioro de ideales y la mala fe entre la gente.

\footnotetext{
1 Véase el artículo por Carole ADAM, «The Re-Use of Identical Plot Material in Some of the Novels of Ramón Sender", Hispania, XLIII/3 (septiembre de 1960), pp. 347-352.

2 Marcelino C. Peñuelas, en “Sender o la polémica», pp. 196-197, describe así la última obra de Sender: «El propio Sender complicó el problema al final de su vida al escribir descuidadamente una excesiva serie de narraciones de baja calidad que no debía haber dado a la luz. [...] Escribía probablemente por inercia, por hábito, por una especie de necesidad [...] y publicaba lo que salía de su máquina sin reescribir, sin pulir, primeros borradores que con razón desorientaban y decepcionaban a los lectores [...]". Un ejemplo más directo en cuanto a la calidad del escritor se ve en una reseña de LARIOS VENDRELL: «Ramón J. Sender [...] probably wrote two or three worthwhile novels a long time ago. In the last twenty years, however, the literary quality of his production has left much to be desired. Poorly written and boring as his books are, one cannot but wonder how they ever get published" (p. 260). Sin embargo, José-Carlos MAINER ofrece otra perspectiva — «una explicación exculpatoria»- en su «Resituación de Ramón J. Sender».

3 "In a sense, as have other great authors, Sender has written only one novel but he has written it thus far in thirty-two or more versions, each revealing a different angle on reality” (KING, P. 292).
} 
Con creciente intensidad, el Sender de los años setenta se hace el cronista de esta cultura decadente, inventando una forma personal que se aproxima a la novela-ensayo. Prepondera la narración en primera persona $\mathrm{o}$ a veces en tercera persona omnisciente, con digresiones, aclaraciones y comentarios personales que sitúan al escritor dentro y fuera del universo que interpreta, dejándole simultáneamente expresar su solidaridad con la condición humana y mantener la objetividad extradiegética para juzgar.

Abundan las historias intercaladas y los apartes (incluso notas al pie de la página [Arlene]), característicos de un género híbrido que se distingue por el disminuido énfasis en la linealidad de la trama, el creciente interés por el ensayo personal, el tono de conversación, el suministro de un sinfín de datos y explicaciones objetivos, enciclopédicos, experienciales o costumbristas. ${ }^{4}$ La tendencia abiertamente alegórica añade otra dimensión, como en La antesala, con el doble sentido del título - la antesala real y la metafórica de la muerte-, o en $\mathrm{Zu}$, el ángel anfibio, en la cual las aventuras de una ballena revelan hondas verdades de la cultura contemporánea.

En esta última fase, la tarea del escritor, dotado de la capacidad de ver más allá de lo cotidiano, es interpretar para el lector las señales secretas de un mundo degradado y desprovisto de héroes y de materia heroica. Su misión de artista ahora será encontrar la clave que unirá otra vez los términos binarios en una resolución armónica. Para imponer el orden por medio del arte, Sender forja una nueva mitología para contrarrestar el caos circundante. $^{5}$

Huelga decir que las características mencionadas no aparecen en igual medida en los veintiséis libros de ficción publicados después de 1970. Sin embargo, la visión artística es lo bastante consistente para dar coherencia al corpus y el escritor la encauza en dos tipos de ficción: primero, las "crónicas» de la vida contemporánea, en las cuales el protagonista, generalmente un hombre maduro, narra sus experiencias -o las de un amigo suyo - contra un fondo de múltiples episodios que iluminan el estado del mundo contemporáneo (inter alia, Adela y yo, Arlene y la gaya ciencia, Una virgen llama a tu puerta); ${ }^{6} \mathrm{y}$, segundo, las obras de trasfondo alegórico que aluden a los dilemas de la vida moderna (El fugitivo, Orestíada de los pingüinos, Zu, el ángel anfibio, etc.). Algunas novelas hábilmente manipulan las

\footnotetext{
${ }^{4}$ Reconoce esto José Domingo, que caracteriza su narrativa de los últimos años como «novelas de tipo ensayístico, en las que el autor nos muestra los conocimientos sobre todo lo humano y divino acopiados a lo largo de su vida.

5 La intromisión en muchos libros de frases de índole profética, de tono lírico y oracular (Orestiada; Arlene, p. 48) dota al narrador de cierta autoridad presciente. No deja de ser significante que cuando el protagonista de El fugitivo, novela de implicaciones alegóricas, sube al campanario, donde piensa esconderse por un crimen nunca nombrado, lleva consigo un libro titulado El fin del miundo moderno. El sentido apocalíptico no puede ser más claro.

6 Aunque Hughes y el once negro no ofrece esta perspectiva narrativa, tiene bastantes características para merecer su inclusión en esta división.
} 
dos tendencias, insertando episodios obviamente simbólicos dentro de un contexto cotidiano (La antesala, La mirada inmóvil).

El ambiente que rodea a los protagonistas es caótico, incomprensible. Uno de los protagonistas confiesa: «era una de sus ideas fundamentales en la vida, que sólo existe [...] lo inesperado adverso [...]» (Arlene, p. 161). A veces «lo inesperado adverso» cobra formas específicas, como «catástrofes políticas, y sobre todo [...] amenazas atómicas» (Adela, p. 104). Otras veces, esta adversidad se revela en formas intangibles: "[...] odio sin motivo, un odio activo y malevolente que nos infectaría mortalmente el núcleo del ser si no estallara. La perfidia inicua, esa que nadie se atreve a autorizar con su nombre» (Arlene, 48). Esta cita forma parte de una larga lista que detalla la maldad del hombre; es una sección que se destaca tanto por el contenido cada vez más surrealista como por un recargado estilo que contrasta fuerte y deliberadamente con la sencillez del resto de la narración.

Los protagonistas se quedan perplejos ante un mundo cuyas leyes parecen ser regidas por fuerzas o suertes malignas, ya no de estirpe clásica, sino totalmente nuevas. ${ }^{7}$ Una gran diferencia entre los otros periodos históricos y éste es que la radix malorum ya no es el destino implacable sino algo más peligroso e inmediato: la ciencia y la tecnología llevadas a un estado fuera de nuestro control. En las novelas de esta fase, la cantidad de alusiones científicas sugiere la fascinación que los logros tecnológicos tenían para Sender. Abundan las referencias a datos reales y ficticios: entre los auténticos, el hoyo negro y los quásars (Arlene, p. 180); el Cobalt 50 (Virgen); los neutrones (Mirada, p. 100); los electrones, la ionización, las naves espaciales (Alarido, p. 39); entre los imaginarios, la invención de una máquina que permite ver escenas de tiempos pasados (Tánit, p. 181). En Hughes y el once negro, el protagonista está deslumbrado por una computadora que se perfecciona a sí misma de una manera automática (p. 67), ofrece opiniones e incluso sirve de oráculo. ${ }^{8}$

Sender insinúa que la humanidad está amenazada por los mismos adelantos científicos, contrarrestando su admiración por la ciencia con abundantes ejemplos de los riesgos que conllevan los "triunfos": reactores nucleares, peligrosas basuras nucleares (Hughes, pp. 71-72) o experimentos de explosiones atómicas que pueden destruir el universo (Adela, p. 189). La amenaza del holocausto nuclear parecía preocupar a Sender, si se juzga por el número de referencias en estos libros. La posibilidad del error que pueda iniciar la catástrofe es otra variación sobre el tema: «[Con las máquinas de la defensa nacional] la equivocación del hombre inteligente puede acabar con la vida orgánica en el planeta [...]. Nosotros podemos

\footnotetext{
7 Estilísticamente, el uso y abuso de la coincidencia y la fragmentación narrativa subrayan la naturaleza ilógica de la vida.

8 En otro libro, el narrador pronuncia un discurso erudito sobre la astronomía, con referencias a la química y la física (Virgen, pp. 182-184).
} 
cometer un error y la máquina desarrollarlo hasta la destrucción de la Tierra e incluso del universo" (Hughes, pp. 56-57). En efecto, es el hombre responsable a la larga de un futuro «en la orilla del apocalipsis» (Hughes, p. 59).

De menos peligro inmediato, otras invenciones tocan los límites a que puede llegar la ciencia. Un profesor inventa un sistema para estimular el placer mecánicamente por medio de electrodos en el cerebro (Mesa, pp. 194-195). Con su supuesta sabiduría tecnológica, el hombre puede convertirse en un Pigmalión moderno por medio de una computadora: «El pecador inteligente puede fabricar muñecas parlantes, suspirantes y erotizantes [...] y hacerlas hablar con el silicón-carbono. Un negocio económico, moral, intelectual y metafísico" (Hughes, p. 81). Pero, a fin de cuentas, las consecuencias no saldrán según el plan: «El éxito de aquella atrevida empresa representaría la más alta aspiración de la humanidad: acabar consigo misma a fuerza de imaginación. Aquellas multitudes muñequiles serían sexualmente apetecibles, pero no quedarían fecundadas ni tendrían generación» (Hughes, p. 92).

El peligro está en la misma perfección y coherencia de la máquina: «A mí no me gustan las computadoras ni las conductas estólidamente rectilíneas e inalterables. El error aceptado es fuente de evidencias nuevas, elaboradas a través de un sentido relativo de todas las cosas que es el mismo de la naturaleza y tal vez la base suprema del orden universal» (Hughes, p. 54). En efecto, este camino puede llevar al «final de la especie humana ( $\tan$ objecionable) por el uso de facultades mentales y de victorias económicas y técnicas capaces de hacer el milagro» (Hughes, p. 128). Esta nueva interpretación del binomio civilización/naturaleza implica que la razón (es decir, la tecnología) desvía el fluir natural y errabundo de la vida al tratar de separar, cuantificar y así controlar los componentes.

Además de los problemas tecnológicos, una serie de conspiraciones y complots logran añadir a las tramas de esta etapa otro sentido subyacente de amenaza y peligro constantes: la malevolencia, las intrigas, las vendettas personales y el asesinato de carácter llenan las páginas de Arlene. Otros ejemplos son la subversión del mando y la lucha por el poder (entre las bandas de pingüinos en Orestíada), la conspiración para asesinar a un tirano (Tánit) o una sociedad secreta llamada Thanatos, que piensa usar la bomba atómica para una especie de chantaje mundial (Virgen, p. 43).

Para realzar la impresión de inquietud que late en estas obras, Sender regala al lector con un retrato del comportamiento contemporáneo excesivo y vergonzoso: el uso y abuso de drogas, barbitúricos y alcohol (Arlene, Tánit, Virgen) o la gráfica descripción de episodios de crueldad inhumanamente sádica de la segunda guerra mundial (Mesa). Hay toques grotescos y chocantes - un aborto es metido en una caja de sombrero y dejado en el banco de un parque (Tánit, p. 152), una mujer hace que unos asesinos capen y luego empalen a su marido (Cronus), un cadáver colocado en un ascensor baja y sube, apareciendo cada vez que se abren las puertas, como 
en una pesadilla—, 9 horribles detalles escogidos para revelar la cara inferior de la civilización. ${ }^{10}$

La creciente inversión de valores tipifica esta sociedad. Un personaje de Tánit comenta que «A pesar de los prodigios que hacen los hombres con la tecnología, la ciencia nuclear, los gloriosos viajes a la luna", vemos el desprestigio de los pantalones, en el sentido de que «los llevan las mujeres» (p. 272). Una psiquiatra famosa está de acuerdo: "Vamos hacia una estructura social de hombres femeninos y mujeres masculinas... no sólo aquí sino en todo el planeta..." » (pp. 272-273). Aunque Sender nos ofrece estas ideas en una vena medio humorística, el contraste entre el progreso y la decadencia realza el lado más grave.

La creación de protagonistas se modifica según los nuevos criterios que se propone el autor. Los protagonistas principales viven casi desligados, real y metafóricamente, del mundo que habitan. Son exilados en toda la extensión de la palabra - los expatriados nacionales y espirituales-, que muchas veces viven distanciados del prójimo. Los más obvios son los españoles radicados en América, generalmente en California (Adela, Mirada, Virgen). También se puede incluir al yugoslavo que se escapa al Perú (Yauri); a Cronus, el brasileño que vive en Chicago, o al príncipe desterrado de El oso malayo. Es un estado que afecta a todos: "¿quién en nuestros tiempos, no ha sido un exiliado obligado o voluntario? ¿Quién no ha dejado en casa una Penélope?» (Tánit, p. 248). Más grave es el caso de otros cuya separación del mundo se debe a algún accidente terrible: el hombre desfigurado de La efemérides; el esquizofrénico Mitchell, víctima psicológica de la crueldad de la guerra (Mesa), o el protagonista de El superviviente, cuya experiencia con la muerte causa un cambio de personalidad y la consecuente separación espiritual del mundo.

La introducción de personas conocidas problematiza la división convencional entre el mundo de la novela y el del lector, promoviendo una deliberada confusión entre la ficción y la realidad histórica. A veces basta la mención del nombre: Charlie Chaplin, Edith Sitwell, Dylan Thomas, el novelista inglés G. K. Chesterton. Otros personajes aparecen brevemente en el nivel diegético, como los poetas Carl Sandburg, Wallace Stevens, Herbert Read o Roy Campbell, poeta y autor de investigaciones sobre Lorca (Tánit). En la mayor parte, estos iconos del mundo moderno ofrecen ejemplos del estado decadente del hombre, con su actuación o por medio de sus comentarios analíticos.

\footnotetext{
${ }^{9}$ Este episodio está prefigurado en El rey y la reina cuando Rómulo mata al soldado y mete el cadáver en el ascensor.

10 Será provechoso medir el desarrollo de las ideas senderianas comparando estos casos con un episodio igualmente grotesco de Crónica del alba, en el cual un campesino hierve un cadáver para vender el esqueleto. La diferencia radica en la inocencia básica del campesino de la primera novela y la sofisticación malvada de los otros.
} 
La novela Hughes y el once negro presenta el curioso ejemplo de la transformación de un personaje histórico en protagonista ficticio: el célebre multimillonario Howard Hughes. Esta obra seudobiográfica describe el triste caso de un hombre que lo tiene todo pero que vive guiado por el dinero y desconfiando de los otros. Se compra el amor, vive apartado de los demás e, irónicamente, muere de desnutrición. Ofrece otra variación sobre el héroe degradado, apto modelo del ocaso de nuestra edad.

La mala fe entre las personas es evidente. En una larga disquisición sobre el antagonismo entre el «tú» y el «yo», el narrador de Adela ofrece como prueba de su teoría los más de tres mil adjetivos denigrantes para aplicar al "tú", o sea, al "otro» (p. 185). Estos libros ofrecen abundantes ejemplos de traición, abuso de poder, violencia física y emocional. De este modo, el hombre se siente amenazado no sólo por la tecnología, la sociedad y otras fuerzas menos tangibles, sino por el "otro» —o la "otra".

En este periodo novelístico senderiano, la mujer cobra más importancia real y simbólica. Personajes femeninos de todas las edades aparecen en estas páginas. Hay dos casos de muchachas jóvenes (de nueve y de trece años) que visitan y charlan con frecuencia con el narrador maduro. Su presencia puede recordar a otra joven arquetípica, la Valentina de Crónica del alba. Pero estas niñas parecen contaminadas a su pesar por los problemas de los adultos. No poseen la ingenuidad de Valentina; su inocencia y falta de experiencia están matizadas por una precocidad en cuanto al conocimiento de los "secretos" de los adultos, sobre todo los problemas sexuales o matrimoniales de sus padres.

Se puede medir este cambio de énfasis en las novelas tardías, ofreciendo como punto de comparación las referencias al cuerpo encontradas en Crónica del alba. Cuando Pepe mira a Valentina, ve a una persona delicada e inocente, cuyo cuerpo está desprovisto de implicaciones sexuales: «A veces, jugando con Valentina yo veía una parte de sus muslos, [...] tropezaba mi mirada con una prenda íntima blanca que tenía pequeñitos encajes y recibía la impresión de que las partes de su cuerpo que no se veían no eran de carne sino de una materia preciosa e inanimada. [...] me gustaba pensar que eran de ámbar» (I, pp. 29-30). Treinta y un años más tarde, el narrador mira a una foto de la joven Sandra y ve mucho más: "Tenía ya los senos formados, las caderas dulcemente henchidas [...]" (Virgen, p. 26), y más tarde comenta: «[...] ella me había seducido a mí sin darse cuenta y era yo quien tenía miedo de ella, $[. .$.$] de su inocencia. Una$ voz ronca y salvaje decía dentro de mí: "El estupro no debía ser un delito" $\gg$ (p. 31). Indudablemente, el joven Pepe no tiene la misma experiencia que el narrador ya maduro, pero es el énfasis, la dimensión erótica y la unión de la sexualidad con la inocencia lo que sugiere que ya no quedan recintos puros en el mundo.

Las mujeres adultas adquieren dimensiones a la vez amenazantes $y$ eróticas, separando aún más la mujer buena y pura (lo ideal) de la mujer mala, devoradora. En La mirada inmóvil, las parientes de Agamenón, el 
protagonista enfermo, ni siquiera esperan verificar su muerte para vender sus posesiones. Cuando sale Agamenón del hospital, vuelve a un cuarto completamente vacío. Hasta su amante, con el igualmente mítico nombre de Helena, se ha llevado una pintura valiosa (pp. 245-246). También hay una serie de madres espantosas que no vacilan en sacrificar el bienestar y la seguridad de sus hijas y que llegan al extremo de serles rivales en el amor (Adela, Arlene, Tánit).

El sexo representa la insuperable distancia y la falta de comunicación entre el hombre y la mujer, relación análoga al estado fragmentado del mundo contemporáneo. Y, si de un lado el protagonista añora un amor idealizado, de otro parece intuir que será imposible conseguirlo, intuición comprobada repetidas veces. Aprovechando la ausencia de la amante de Abel (el protagonista de Arlene y la gaya ciencia), una vecina hace el amor con él y le explica: "Soy muy puta, pero no yo sola, sino todas las mujeres" [...] "Las mujeres nacemos ya así"» (p. 143). Este libro contrasta el idealismo del amor cortés (especialidad académica de Abel) con el desengaño en cuanto a la realidad actual, simbolizado por la "equívoca conducta» de Abel con Esther: "Cuando algo tan fundamental y básico en la vida de un hombre se cumple en condiciones viciosamente anormales -el amor sin amor y tal vez, incluso el amor con odio- la inseguridad invade la conciencia valiéndose de mil pequeños monstruos sin nombre conocido todavía. Recelos, sospechas, inquietudes innominadas» (p. 47). Los análisis académicos de la mystique, la codificación y las manifestaciones poéticas del amor cortés llenan las páginas de esta novela, ofreciendo un contrapunto poco halagador para las relaciones modernas.

Sobre el tema obsesivo del amor, las novelas ofrecen detalles del acto sexual abierta y explícitamente. Hay referencias a varias prácticas heterosexuales, la homosexualidad, la masturbación, la fellatio (Arlene), la bestialidad (Mirada), la pornografía insinuada en fotografías de una joven desnuda (Virgen), el intercambio de esposas y una noche de bodas filmada por cámaras secretas, sin saberlo la novia (Cronus).

Gran parte de las novelas describen un ambiente erótico saturado de traición e intrigas. El adulterio es prevalente; y, de parte de las esposas, no faltan sueños de matar o de deshacerse del marido (Alarido, Mirada, Virgen). En su parloteo, una joven amiga revela inocentemente al narrador una situación sórdida: tiene que salir de casa cada día y dejarla libre para los amores adúlteros de su madre (Adela, pp. 59, 124). En otro caso, la esposa del decano compara al marido y al amante de Arlene: «El amante era a sus ojos más simpático que el esposo. Ella también tenía su amante [...]» (Arlene, p. 200). Hay casos más barrocos: la mujer casada que practica un doble adulterio, traicionando a su amante con otro hombre (Adela, p. 52; Mirada, p. 50), o el extraño cuadrángulo de complejas relaciones equívocas entre el narrador, su padre, su amante Pat y la madre de ésta, todo con insinuaciones incestuosas (Adela). La calculadora esposa de El alarido de 
Yaurí ofrece un excelente ejemplo de cómo el egoísmo y la lujuria pueden desencadenar una tragedia de proporciones clásicas.

Los espacios cobran un sentido simbólico para subrayar estos problemas. Los sitios urbanos trascienden su valor funcional. Hollywood, por ejemplo, representa la degradación y el exceso: "Hollywood [...] era desde hacía muchos años símbolo de vulgaridad y de mezquindad, de mal gusto y de indigencia intelectual» (Arlene, p. 105). Los rascacielos significan encierro vertical, con sus ascensores que suben y bajan, y algunas comodidades, como el montacargas, pueden resultar a la vez útiles y peligrosas.

En una nota al pie de la página —estrategia narrativa para comunicar más directamente con el lector- el narrador explica: «Nosotros pensamos sólo con la cabeza. Es nuestra gloria y nuestra miseria. Con sólo nuestra cabeza organizamos una realidad lógica (lo que es absurdo en un mundo ilógico e irracional) y construimos aviones que nos llevan a París a ver a nuestra novia o a bombardear la casa de nuestra novia y que nos han llevado recientemente a la formulita famosa que puede acabar mañana con la vida entera del planeta. Ésas son nuestras ideas arquetípicas" (Arlene, p. 95). La palabra clave — «arquetípicas»- sugiere que estos principios ya están inculcados en los códigos de la conducta moderna.

El orgullo del hombre llega al punto de pervertir las leyes naturales para su propia diversión: amaestra ballenas y delfines, haciéndolas actuar en circos acuáticos, enseña a hablar a estos últimos $(Z u)$ y, por medio de una operación, los gorilas pueden hablar y comportarse como humanos (Virgen, p. 162). Estos contactos entre el hombre y el mundo natural ofrecen los más nocivos ejemplos de los "avances» de la humanidad, que ahora estropean el orden natural. Tales cambios pueden producir resultados inesperados y catastróficos. Los gorilas «amaestrados", que son - en las palabras de uno de los protagonistas - «tan hábiles y tan humanos como nosotros» (Virgen, p. 196), se sublevan y roban una bomba atómica con la cual piensan tomar el mundo como rehén (Virgen, pp. 196-203).

Sender parece muy preocupado por la idea del orden en el universo y recurre a un vocabulario de palabras como simetría, orden, armonía, normal, etc. para subrayar la necesidad de un equilibrio cósmico. "No hay duda - se dijo [Abel]- de que el universo ama la simetría"» (Arlene, p. 170), sentimiento que elabora Agamenón: «Porque al universo le gusta la simetría y ésta suele lograrse frecuentemente por la compensación de opuestos semejantes" (Mirada, p. 121). Sin embargo, hay destacadas pruebas de las desequilibradas relaciones entre el hombre y la naturaleza. La más sobresaliente ocurre en un parque acuático. «El hecho de que el poderoso Leviatán baile con música de escarabajos [el grupo los "Beatles"], bajo la batuta del hombre y la risa de los infantuelos, parece un signo de nuestros tiempos incongruentes» $(\mathrm{Zu}$, p. 36).

Semejante incongruencia explica la enajenación que sufre el hombre contemporáneo en general y la pérdida de contacto con sus raíces natura- 
les: «[...] el existencial vivir del hombre [...] ya no es la naturaleza misma sino la naturaleza cultivada, la naturaleza intelectualizada, la naturaleza estilizada [...] entre el hombre natural y el ciudadano había un abismo y [...] ese abismo se hacía mayor cada día. En todas partes» (Tánit, p. 178). Esta situación impele a Sender a exponer y denunciar a la sociedad actual por su olvido de los principios casi sagrados que exigen el respeto por y la responsabilidad hacia la vida. Al mismo tiempo, el autor también busca un nuevo alineamiento del hombre y su mundo. Para conseguirlo, Sender fabrica una mitología nueva para contrarrestar la creciente degradación y asimetría con el fin de reconciliar - una vez más - la cultura y la naturaleza. En este periodo, la realización literaria de este propósito aparecerá en dos formas: en el nivel concreto de la trama, es decir, el vivir cotidiano del hombre en relación con su circunstancia, y en el nivel artístico, en el cual varias estrategias literarias directa o indirectamente insinuarán la armazón mítica y cósmica que consagrará los principios que propone.

Es evidente que el escritor se sentía atraído por la mitología: muchas de sus obras contienen modelos míticos, clásicos arquetipos, etc. En 1977, escribió un artículo dedicado al asunto, en el que amplía la definición del mito: «Las cosas y los seres de la historia se convierten en mitos cuando se hacen símbolos de una virtud, un vicio o una costumbre memorable» («Mitos», p. 11). ${ }^{11}$ El narrador de Una virgen llama a tu puerta interpreta la fuerza directiva del mito: «Todo lo que hacen las artes, las religiones, las teorías políticas y la vida misma, la vida espontánea, es propiciar el mito y cuando éste se ha logrado la humanidad entera sigue detrás. [...] La historia de la humanidad está señalada por hitos o términos míticos: Buda, Sócrates, Platón, Cristo» (Virgen, pp. 179-180). ${ }^{12}$

En el nivel narrativo, Sender fabrica un subtexto referencial para invocar o confirmar el nivel mítico latente en su universo novelesco. Con un sinfín de citas o paráfrasis de fuentes clásicas y antiguas reconoce abiertamente su deuda en cuanto a materia novelesca-mítica: inter alia, menciona a Platón y su teoría de la Atlántida (Tánit, pp. 189 y ss.), Plinio (Tánit, pp. 222 y ss.), Homero (Tánit, p. 249), Orígenes ( $\mathrm{Zu}$, p. 36), Eurípides (Orestíada), Plutarco y Plinio. Estos datos muchas veces aparecen en forma de largas compilaciones que, por su sabor académico-erudito, encajan de manera algo forzada dentro de la materia ficticia. Sin embargo, el recurso a las

1.1 La crítica reconoció este interés. En un excelente artículo sobre «Les Démons de Ramón J. Sender», Jean-Pierre RESSOT analiza la «mitificación» de dos temas importantes: la guerra civil y el exilio. Otros, por ejemplo PINI MORO, reconocen que su esfuerzo para crear una nueva mitología puede implicar una reestructuración del mundo. «Aparece una mitología de la locura, en Sender, así como hay el mito del niño, del poeta, de la virgen..." (p. 43).

12 Después de estas palabras, que preceden a la meta de «poner un nuevo mito en pie» (p. 179), todos entran en una sala que obviamente simboliza un espacio mítico: su forma recuerda las características de las estructuras monumentales (el gimnasio helénico, la catedral) y dentro hay estatuas que sugieren un dios del Olimpo o un emperador (p. 180). 
«grandes» autoridades sugiere que Sender pone por escrito la base epistemológica de la tradición antes de actualizarla para su interpretación personal.

El vocabulario del mito se encuentra a cada paso. Se desarrolla una rica intertextualidad a base de personajes míticos: harpías, furias, «ninfas, minotauros, narcisos [...], driadas, grifos", etc. (Hughes, p. 47). Un recurrente trío de mujeres simboliza a las parcas (las tres muñecas del campanario de El fugitivo, las tres mujeres de La mesa de las tres moiras) y abundan los nombres o conexiones míticos: el pingüino Orestes, que revive la tragedia de Eurípides; Agamenón, protagonista de La mirada inmóvil, o el personaje principal de la novela Cronus y la señora con rabo. El príncipe de El oso malayo monta en el caballo Pegaso y lucha con la Quimera. Tampoco faltan referencias a los mitos del mundo nórdico, amerindio, fenicio, artúrico-caballeresco y cristiano. La teoría de la Atlántida, que se asocia con la destrucción de la civilización, es el tema de las investigaciones del narrador de Tánit. Cuando el investigador establece un nexo entre el país legendario y varios lugares representativos de la civilización contemporánea (París [p. 284], América [p. 123]), confirma el mensaje apocalíptico de la obra. Las alusiones de esta índole establecen un ambiente propicio para las ideas trascendentales que estructuran el nivel simbólico de las ficciones senderianas de la última época.

Sender superimpone factores mitológicos de otras épocas sobre la edad contemporánea: describe a unas porteras como "arpías encantadoras» (Adela, p. 195); se refiere a una persona real -la rica Nancy Cunardcomo la ninfa Egeria (Tánit, pp. 68 y ss.); Tánit, el nombre de una protagonista, es el nombre de una diosa fenicia «de la remotísima antigüedad» (p. 29). ${ }^{13}$ Estas referencias dejan ver la coincidencia entre el mundo moderno y el antiguo, realzándola por medio del mito.

Las obras de base alegórica (Orestíada, Zu) se abren fácilmente a un armazón mítico, porque el sentido metafórico sitúa la acción en un plano ideal. Pero aun en las novelas de ambiente actual se emplean elementos oníricos e incluso sobrenaturales que socavan la base realista: fantasmas, sombras, arpías y varios santos muertos pueblan una sección onírica de Una virgen llama a tu puerta; las escenas resucitadas del pasado por una máquina añaden una dimensión fantástica a Tánit. Esta técnica rompe la adhesión tenaz a una realidad lógica y valida la incorporación de la mitología como una presencia natural.

El escritor está dotado de la capacidad de reconocer estas ocultas conexiones y tiene un lugar privilegiado para interpretarlas: «[...] el poeta genuino es un hombre normal que ha aprendido a hipnotizarse a sí mis-

${ }^{13}$ En esta misma obra, se añade una dimensión cósmica al vincular el cometa Typhon al mito del mal y también a un tirano contemporáneo con el legendario nombre de Sagitario (Tánit, p. 187). 
mo [...] y que [...] entra en un mundo que no es exactamente el del mito y tampoco el del sueño, sino el mundo que podríamos llamar de lo real absoluto. Esa realidad absoluta está en lo más genuino, puro, secreto y original del hombre. [...] Si se logra comunicar [la realidad absoluta] a los otros con las menos palabras posibles (y por alusiones oblicuas) es posible que nazca un mito bautizado con un nombre propio. (Una especie de sueño colectivo con un protagonista.)» (Tánit, p. 315). Al asumir el doble papel de profeta y guía, el narrador puede facilitar la reincorporación al mundo de la mitología y explicar la transformación de fenómenos reales en materia mítica: «La gente de la antigüedad no solía inventar nada, sino interpretar a su manera los hechos históricos que no les parecían racionales» (Tánit, p. 181).

Si la historia puede convertirse en códigos míticos, el tiempo sufrirá la misma transformación. ${ }^{14}$ La invocación al mito conlleva la esperada negación del tiempo lineal, histórico, y deja abierta una brecha para vislumbrar el sentido sincrónico de la vida. Sender reconoce las analogías entre el mito y el tiempo sincrónico: «Los mitos [...] no se conducen linealmente, sino cíclicamente [...]» («Mitos», p. 15). El recurso a las imágenes de la espiral y las formas helicoidales ofrece el paralelo visual de esta teoría: su forma abierta, sin clausura, simboliza un continuo fluir y doblarse que desafía la lógica. Este tema elabora una idea que el novelista estableció hace años cuando habló del alma: «órbitas circulares y campos esferoidales - helicoidales - donde cada valor se completa en su contrario sin cerrarse nunca» («Notas», p. 73). Parece que Sender sentía una especial fascinación por esta curva geométrica; el crecido número de referencias lo prueba. ${ }^{15}$

Si las primeras novelas dejaban vislumbrar un mundo cada vez más caótico, sin valores, las últimas obras llevan la creciente degradación del hombre civilizado a su conclusión lógica, con una visión pesimista, casi apocalíptica, de una sociedad que no aprende de sus errores, que se repiten eternamente: «La historia igual que el planeta, el sistema solar y la galaxia es redonda y rueda sobre sí misma. [...] Y lo que sucedió ayer vuelve a suceder mañana, no en círculo ni en elipse sino en espiral helicoide» (Orestíada, p. 58).

Si se puede caracterizar la ficción de este periodo por su pesimismo, también se puede señalar un movimiento desde el caos hacia el orden por medio de una armazón mítica. Para arreglar el inestable binarismo naturaleza/cultura, Sender busca un posible modelo en el mundo de los ani-

\footnotetext{
14 «Pour Sender, le recours au mythe signifie clairement une réaction contre l’Histoire» (RESSOT, p. 226).

15 Se incorporan estas formas en muchos libros, a veces sólo mencionándolas, otras veces analizando largamente su simbolismo vital y cósmico: Adela y yo, Orestíada, etc.
} 
males. ${ }^{16}$ El mundo natural, con su simplicidad eterna y su tiempo cíclico e inmensurable, puede restaurar el equilibrio entre la humanidad y su circunstancia para configurar un nuevo «lugar del hombre». El narrador de Adela y yo hace hincapié en la plenitud que promete esta vuelta: "[...] he sentido tantas horas felices en el abandono a la naturaleza primaria y en la comunión con las leyes más simples de la convivencia desinteresada» (p. 12). Palabras de esta cita como primaria, simples y convivencia desinteresada subrayan el implícito contraste con la vida falsa fuera de lo natural. En esta nueva mitología, el hombre reverencia y aprende de la naturaleza; si hay «héroes», pertenecen al mundo animal, por su falta de egoísmo y malicia.

Si el espacio urbano simboliza los peligros de la vida moderna, el antídoto se encuentra en los parques, pequeños recintos verdes abiertos a todo. Allí aparecen los todavía no corrompidos por el roce con la sociedad: las jóvenes y los animales. La descripción de la naturaleza circundante es lírica, a veces sensorial, y el narrador se recrea en las posibilidades demográficas de este lugar acogedor y propicio a la comunicación y el desahogo (Arlene, Mesa, Virgen [pp. 9-12]). Aún más fuerte es la oposición espacial entre la naturaleza limpia y franca de las montañas y la impersonal ciudad de Lima en El alarido de Yaurí. Aquí el espacio cobra dimensiones simbólicas por medio de los que habitan estos lugares: la traicionera esposa pensaba que «la naturaleza era un estado inferior del que debían redimirse las "personas decentes"» (p. 73); su imperdonable comportamiento adúltero contrasta fuertemente con la fidelidad de una pareja de palomas torcaces (pp. 94-95). Zu, el ángel anfibio ofrece otros puntos de comparación en la vida sencilla de las ballenas en el fondo del mar y la sofisticada e igualmente desgraciada de los hombres. Estos lugares naturales tienen algo de sagrado, donde el hombre puede renacer espiritualmente según las nuevas doctrinas.

El rito de la reintegración consagra el orden natural y reconcilia el sistema binario civilización/naturaleza. En Tánit, este rito se efectúa espacialmente por un movimiento que rechaza la confusión urbana: el narrador y la protagonista Tánit pasan algún tiempo en las montañas Adirondaks, en Nueva York. Su vivienda está cerca de lo más dramático del escenario natural: un enorme macizo de rocas, un bosque espeso, una vasta cañada, un río espumoso. La fauna incluye «irisadas truchas», osos, venados y serpientes que "siguen honrándonos con su ausencia» (pp. 43-

\footnotetext{
16 El profesor Kessel Schwartz, que demostró con numerosos ejemplos el interés de Sender por los animales, nota que las últimas novelas enfatizan la importancia de la fauna para el hombre: «In keeping with a broader allegorical, philosophical bent, Sender seems to imply that human culture depends on animal origins and mythology without which man would be seriously traumatized. Man is dependent on natural phenomena and animals; without them life itself loses meaning» («Fauna», p. 132).
} 
44). Este espacio es «apacible y arcádico» (p. 44), "un lugar paradisíaco» (p. 47) que crea una situación feliz y atemporal en fuerte contraste con el caos que precedía y que va a seguir. Otra novela es aún más explícita: cuando el narrador de Adela se hace amigo de una ardilla, "[a]sí se cumplían dos leyes importantes de las que rigen el orden natural. La unidad del mundo de los vertebrados - por el amor-y la tendencia al círculo o a la esfera en todos los movimientos físicos o circunstancias morales e intelectuales" (Adela, p. 13). En estos y otros casos, la "comunión" con la naturaleza trasciende el hecho en sí: es el rechazo simbólico de las normas actuales - una especie de bautismo que permite la entrada en una dimensión de atemporales valores míticos.

Incluso los libros que no tratan directamente de la relación hombrenaturaleza tienen comentarios sobre la superioridad de los animales. Hablando de la guerra, el protagonista Mitchell recuerda: «He visto que sólo son honrados los animales porque no tienen inteligencia y que todos los demás usamos la nuestra para mentir y engañar aunque sea a costa de las vidas inocentes de las mariposas y las gaviotas» (Mesa, pp. 136-137). En una larga y acerba comparación, que por los detalles no deja de ser irónica, Agamenón acusa al hombre, usando la naturaleza como medida de comparación:

[...] queremos exterminarlas [a las ratas] fabricando venenos como ese que llaman «la última cena" en latas con la pintura de Leonardo en la tapa. Los insectos fecundan las flores, las abejas fabrican la miel. Y nadie nos ataca ni trata de destruirnos. Son seres inteligentes, más que nosotros, ya que sabiendo tejer (las arañas) y hacer diques (los topos ingenieros) y las aves todas construyendo nidos adecuados a sus necesidades no quieren ir más lejos ni entrar en esas matemáticas destructoras ni poner a Dios a su servicio [...]. No han tratado de hacer sagrada la familia para que resulte más sabroso el adulterio ni se reúnen en trusts para almacenar víveres y hacer morir de hambre a los que no los tienen. No invaden los territorios de los otros y nos dan lecciones de sensatez que no queremos aprender. [...] Nosotros hemos llegado a tal degradación que ya no sabemos vivir de acuerdo con la naturaleza. (Mirada, p. 203)

Adela y yo (1978) ilustra esta filosofía. En esta novela, el narrador -un hombre maduro que vive en California- se hace amigo de una ardilla en el parque. Adela - el nombre con que la bautiza el narrador- representa lo mejor de la naturaleza: la dignidad, la fidelidad de la amistad y la simbólica unión del hombre con su identidad natural ( $«$ Mi amistad con Adela me parecía una integración en la que todo era plausible» [p. 14]).

Interpretada desde esta perspectiva, Adela y yo no es la historia rara de la relación entre un hombre y una ardilla, sino la fuerte acusación del comportamiento humano (simbolizado aquí en complicadas, malévolas y posiblemente incestuosas relaciones entre dos generaciones de parejas), cuyas aventuras paralelas a las «naturales» de Adela se revelan como sórdidas e incongruentes. 
La naturaleza puede redimir al hombre por medio de una asociación trascendente: «La emoción de la naturaleza ha sido siempre una emoción religiosa» (Mirada, p. 194). El narrador reconoce que su relación con la ardilla es como un rito de purificación en medio de una vida ímproba: «Pero yo tengo algo puro y sin mácula. Digno de la alta idea que a veces me formo de mí mismo: mi amor por Adela y el amor de Adela por mí» (Adela, p. 166). Cuando el narrador la lleva a su apartamento, la ardilla rehúsa quedarse y vuelve a su árbol, es decir, al orden natural, acción metafórica que subraya las consecuencias de los esfuerzos del hombre para dominar el mundo natural.

$\mathrm{Zu}$, el ángel anfibio (1970), escrito al principio del periodo que consideramos, ilustra estas ideas de modo más alegórico; al mismo tiempo ofrece evidencia de la constante preocupación de parte de Sender por la relación hombre-naturaleza. Se puede ver esto desde las primeras páginas, que describen al hombre desde un punto de vista literalmente cósmico: el prólogo ofrece la vista del planeta desde la perspectiva de los astronautas. La descripción de las ballenas también se vale de una perspectiva extraordinaria al presentar al animal como ser mítico y trascendental, definido en tiempos antiguos como dragón o ángel anfibio (Orígenes, Celso), como el leviatán de la Biblia o trasformado en mito moderno en la novela Moby Dick.

Esta introducción prepara al lector para el nivel alegórico, en el cual la ballena $\mathrm{Zu}$ sigue el modelo del mítico viaje del héroe. Se rebela contra la religión de las ballenas, que predica la divinidad del hombre. Reconoce la fuerza «mágica» de la tecnología, creyendo en los poderes magnéticos de un cable telegráfico que causa la muerte de su novia cuando queda enredada en él. Sus aventuras, conversaciones y esfuerzos para comprender el mundo de los hombres hacen destacar una sencillez e ingenuidad que recuerdan a los jóvenes protagonistas de los primeros libros de Sender, sugiriendo que el reino animal todavía retiene la inocencia y franqueza que faltan en los tiempos actuales.

Sender contrasta esta figura mítica con una visión del mundo contemporáneo, simbolizado por un hotel-club debajo del agua, maravilla de la ingeniería. Las paredes de cristal trasparente permiten que $\mathrm{Zu}$ contemple maravillado los logros del hombre: casi cree en la inmortalidad de los humanos cuando ve a una actriz «morir»y «resucitarse» en varios ensayos del rodaje de una escena; se contempla en la pantalla de una televisión. cuando la cámara le filma. Sin embargo, el resultado es caótico e incomprensible para $\mathrm{Zu}$, sobre todo por las conclusiones erróneas que saca de lo que ve.

El símbolo más representativo del descuidado poder del hombre es Marineland, obra maestra de su habilidad para moldear la naturaleza a su medida. Zu oye varios ejemplos de los malogros de la ciencia, que, en vez de poner orden en la vida, hace todo lo contrario. En sus experimentos, un famoso investigador enseña a un delfín a hablar y a articular teorías abstractas. Con esta capacidad, el animal revela la perfidia de la familia del 
investigador, con el resultado de que el doctor se suicida, reconociendo que es «una víctima de la ciencia» $(\mathrm{Zu}, \mathrm{p} .195)$.

En efecto, todo el libro es una extensa comparación entre el comportamiento animal y el humano, comparación en la que pierde el hombre. Xai, el sabio delfín y guía de Zu en su aprendizaje, habla de esta diferencia:

\begin{abstract}
En todas las funciones orgánicas su cuerpo [del hombre] se conduce como el nuestro, ni más ni menos. Nacen y mueren como nosotros, gozan y sufren como nosotros. En lo que se diferencian [...] es en su poder destructivo. También los animales destruyen, claro, pero de ese poder destructivo saca el hombre su aptitud creadora. Sus grandes inventos humanitarios los han sacado de las guerras, es decir, que en ellas los han aprendido. ( $Z u, p .166)$
\end{abstract}

Puesto que todo ser viviente parte de la misma base vital, lo que separa a las supuestas especies más altas es su refinamiento de los instintos básicos al servicio del mal.

Al final del libro, Zu muere a traición —un destino simbólico después de su viaje de iniciación por el mundo del hombre-. Una lucha épica por su cuerpo entre los tiburones y las ballenas recuerda la lucha entre los ángeles y los demonios por el alma. Pero, en vez de ser enterrado con honores, su cuerpo es despedazado con enormes cuchillos por los marineros del ballenero. El libro termina con una frase escueta, de una sencillez y sequedad poco común en el último Sender: "Así acabó Zu, lo que en definitiva era una manera natural de acabar, supongo» $(Z u, p .230)$.

Una virgen llama a tu puerta es un compendio aún más directo de estas preocupaciones: los abusos de la tecnología y la experimentación, con el consiguiente desvío de las leyes naturales, las relaciones incómodas entre las personas, el deseo y el abuso del poder. Como otros libros, trata de examinar estos factores dentro del contexto que coloca al hombre en su lugar de «ciudadano del universo»:

«[...] a través de nuestro frágil organismo millones de rayos de todas clases,
incluidos los rayos cósmicos, pasan cada día sin dejar otra huella aparente
que la de estimular nuestra imaginación para usarla como estamos hacien-
do en este momento». [...] "[...] Las fronteras de la nada están a nuestro
lado. Hay que salvar la parte de la creación que nos es accesible y que está
en peligro. Las fronteras de la nada están en nuestra casa, en la del vecino,
en la calle, en el vacío del bulbo eléctrico donde se hace la luz, en nuestro
mundo físico y moral, en la brizna de hierba, en la gota de lluvia y en nues-
tro espíritu e intelecto. [...] Hoy el objetivo que llevará esa tarea a la pleni-
tud es la unidad del planeta, digo en el orden táctico. En el orden estratégi-
co es el acercamiento a un conocimiento más vasto del universo y al
conocimiento más profundo también de nuestro mundo interior. [...]». (Vir-
gen, pp. 184-186)

Esta cita es típica de una serie de discusiones que imbuyen las palabras «destrucción» y «nada» con un sentido polisémico que paradójicamente reúne lo cósmico con lo personal. 
La presencia abrumadora de la muerte y la nada llena las páginas de todas las ficciones de esta época: muertes, asesinatos, suicidios, enfermedades graves. Tal vez una explicación del carácter ensayístico de estos libros, que asume la forma de interminables discusiones sobre esta materia, es la oportunidad para un hombre en la última etapa de su vida de desahogarse por medio de sus personajes - técnica que recuerda no poco a Unamuno-. Sender trata de airear sus ideas sobre este triste destino en un nivel personal (la muerte y la nada), en un nivel humano (encarnado en la búsqueda y fracaso del amor) y en el problemático abuso de las leyes naturales (la ciencia y la tecnología incontroladas e incontrolables).

Es interesante notar que en movimiento característicamente circular -o espiraloide- Sender recoge unos principios introducidos en La esfera, novela escrita en 1947, en la cual el protagonista lucha por afirmar su identidad y logra superar el aparente antagonismo de la vida por medio de una filosofía monadista y esferoidal que define la esencial unidad de lo binario. El interés en esta filosofía seguía intacto hasta el final, a juzgar por las numerosas veces que aparece la palabra esfera, en contextos como: «para el devenir es necesaria la idea esferoidal de todas las cosas en el movimiento (intelectual o físico)» (Mirada, p. 238). Sin embargo, la unidad esferoidal se ve amenazada por el caos actual, que causa la asimetría del universo.

Uno de los temas que más fascina a Sender es el binarismo razónintuición. No es de extrañar que lo racional se alinee con el desmesurado hubris tecnológico de la civilización y lo intuitivo con la naturaleza simbolizada por el mundo animal. En vísperas de su propia destrucción, el hombre se ve forzado a ceder su potencial como héroe a los animales dentro de la naturaleza, cuyo esquema mitológico consagra la integración del hombre con un mundo primario, franco, inocente y casi maternal (hay que recordar que la ardilla Adela es tocaya de una muchacha que "fue mi niñera cuando yo tenía un año o dos de edad. [...] Ella era una especie de madre honoraria mía en la aldea donde nací» [Adela, p. 13]).

A lo largo de una vida de gran productividad, Sender seguía desarrollando una serie de temas básicos que parecían obsesionarle de una manera personal y literaria. No es sorprendente que continuara explorando y elaborando estas ideas en el último periodo. La oposición cultura-naturaleza de un lado pone el énfasis en los pecados, excesos y el consiguiente peligro del comportamiento y avances actuales; la redención, si la hay, podrá ocurrir mediante el ejemplo de la naturaleza. ${ }^{17}$ Además del ambiente y lenguaje míticos en que presenta estos ejemplos, el contexto totalizador de muchas referencias ensancha el enfoque para abarcar un juicio $s u b$

17 Podemos comprender el sentido religioso de la integración con la naturaleza cuando dice: «No es sólo en la literatura o en la historia política de los pueblos donde el mito ejercita su inmensa eficacia, sino [...] en los niveles religiosos» («Mitos», p. 12). 


\section{EL LUGAR DE SENDER}

specie æternitatis. "Todo se conduce en esfera, y en la esfera todo es infinito, digo, los caminos. No acaban nunca. [...] Y así debe ser en un planeta esférico que forma parte de un sistema esferoidal que a su vez forma parte de una galaxia y de un universo esférico» (Mesa, pp. 31-32). El vocabulario astronómico subraya la dimensión cósmica-mitológica de este periodo, que constituye la más amplia de las múltiples e ingeniosas estrategias empleadas por Sender en su espiraloide búsqueda para el lugar del hombre en «nuestros tiempos incongruentes».

\section{OBRAS CITADAS}

Dominco, José, «Dos novelas de Ramón J. Sender», Ínsula, 304 (marzo de 1972), p. 5.

KING, Charles L., «Ramón Sender's Literary Evolution Re-examined», en Charles L. NELSON, ed., Studies in Language and Literature: Proceedings of the 23rd Mountain Interstate Foreign Language Conference, Richmond, Kentucky, Eastern Kentucky University, 1976, pp. 289-293.

LARIOS VENDRFLL, L., Teseña de Álbum de radiografias secretas y El jinete y la yegua nocturna, World Literature Today, 57 (primavera de 1983), p. 260.

MAINER, José-Carlos, «Resituación de Ramón J. Sender», en José-Carlos MalNer, ed., Ramón J. Sender. In memoriam. Antología poética, Zaragoza, Diputación General de Aragón, Ayuntamiento de Zaragoza, Institución Fernando el Católico y Caja de Ahorros de Zaragoza, Aragón y Rioja, 1983, pp. 7-23.

Peñuelas, Marcelino C., «Sender o la polémica», en Mary S. VÁsquez, ed., Homenaje a Ramôn J. Sender, Newark, Delaware, Juan de la Cuesta, 1987, pp. 195-197.

PINI MORO, Donatella, "Sender y el suicidio", Quimera, 21-22 (julio-agosto de 1982), pp. 42-43. Rfssor, Jean-Pierre, «Les Démons de Ramón J. Sender», Hispanistica, XX/3 (1985), pp. 221-229. SCHWARTZ, Kessel, "Fauna in Selected Novels of Sender (1962-1978)", en Mary S. VÁsQuEZ, ed., Homenaje a Ramón J. Sender, Newark, Delaware, Juan de la Cuesta, 1987, pp. 131-148.

SeNDER, Ramón J., Adela y yo, Barcelona, Destino, 1978. [Adela]

-, El alarido de Yauri, Barcelona, Destino, 1977. [Alarido]

- La antesala, Barcelona, Destino, 1971.

-- Arlene o la gaya ciencia, Barcelona, Destino, 1976. [Arlene]

- Crónica del alba, vol. I, Barcelona, Destino, 1973.

- Cronus y la señora con rabo, Barcelona, Destino, 1980. [Cronus]

- La efemérides, Barcelona, Destino, 1981.

—, El fugitivo, Barcelona, Destino, 1976.

-, Hughes y el once negro, Barcelona, Destino, 1987. [Hughes]

—, La mesa de las tres moiras, Barcelona, Planeta, 1974. [Mesa]

—, La mirada inmóvil, Barcelona, Argos Vergara, 1979. [Mirada]

—, «Notas sobre lo real absoluto», Cuadernos, 94 (marzo de 1965), pp. 67-74. [«Notas»]

-, Orestíada de los pingüinos, Barcelona, Destino, 1981. [Orestíada]

-, El oso malayo, Barcelona, Destino, 1981.

—, «Sobre los mitos», Urogallo, 7 (enero-febrero de 1977), pp. 11-15. [«Mitos»]

—, El superviziente, Barcelona, Destino, 1978.

- Tánit, Barcelona, Planeta, 1970.

- Una virgen llama a tu puerta, Barcelona, Destino, 1973. [Virgen]

—, Zu, el ángel anfibio, Barcelona, Planeta, 1970. [Zu] 


\title{
La participación de Sender en la guerra de España: evidencias y dudas
}

\author{
Donatella Pini \\ Istituto di Lingue e Letterature Romanze, Padova
}

La participación en la guerra de España es, quizá, el nudo más enredado de la turbulenta biografía de Sender; su complicación aumenta cuando, con el intento de desenredarlo, se aborda el tema - realmente muy complejo, arriesgado y difícil de indagar- de la conducta de Sender para con sus familiares. En este ámbito, por un lado debemos agradecerle a su hijo Ramón Sender Barayón el valor con que se metió «en medio de la refriega ${ }^{1}$ terciando con determinación en la turbamulta de los defensores y detractores de su padre. Su intervención - en sentido único, aunque a su modo generosa- puede leerse en clave mítica, como la acometida de un Edipo moderno contra el Teseo con quien Sender y los «fantasmas de $s u$ intimidad $»^{2}$ se identificaron en Los cinco libros de Ariadna. De hecho, Muerte en Zamora ${ }^{3}$ tiene un alcance mítico y aun titánico que tiene algo de la

\footnotetext{
${ }^{1}$ Expresión usada por Sender en el «Prólogo» a Los cinco libros de Ariadna, Barcelona, Destino, 1977, p. 9 (prólogo que, según M. ANDÚJAR, Las revistas culturales y literarias del exilio en Hispanoamérica, en J. L. ABellán [dir.], El exilio español, Madrid, Taurus, III, 1976, p. 64, había salido por primera vez en la revista Las Españas, 26 y 28 [1956]).

2 Ibid., p. 7.

3 Ramón Sender BARAYón, Muerte en Zamora, Esplugues de Llobregat (Barcelona), Plaza y Janés, 1990 [1ª ed.: A Death in Zamora, Albuquerque, University of New Mexico Press, 1989].
} 
obra paterna. Por lo demás, de la arremetida de Sender hijo contra Sender padre (secundaria respecto al objetivo principal, que era reconstruir la circunstancia en que se produjo el asesinato de su madre) no parece que hayan surgido elementos nuevos que puedan incrementar la comprensión del tema que aquí interesa. Antes bien, el hijo parece conceder demasiado terreno a su deseo de reducir la imagen de su padre sin ser capaz, siempre, de eludir los escollos tremendos constituidos por acontecimientos arduos de captar para un sujeto crecido en un contexto tan distinto del español como es el de los Estados Unidos.

Quiero aclarar de antemano que mi dedicación a este argumento no procedió de un burdo y estéril deseo de hurgar en las vicisitudes particulares del escritor (vicisitudes que, por cierto, han asumido un aspecto turbio en las memorias de algunos protagonistas de la guerra de España), sino que fue estimulada ante todo por la voluntad de contribuir, en el cincuentenario de la guerra civil española, a delinear el panorama en que se realizó la participación de los intelectuales: el caso muy especial de Sender se presentaba como un útil punto de observación sobre el horizonte colectivo. Sobre todo, tal dedicación surgió de la necesidad de sentar algún punto firme en el terreno de la relación entre literatura y vida - siempre lábil y escurridizo aun cuando se trata de un militante- al sondear cómo esta se perfila en el caso de Sender. También quiero decir que mis indagaciones en el asunto son verdaderas incursiones en campo ajeno, pues no soy historiador o periodista profesional; simplemente, dimanan de la voluntad de aproximarme a la «vivencia» en que se forjaron los primeros libros senderianos del exilio y en concreto El lugar de un hombre.

He intentado desempeñar esta tarea de una manera muy sencilla y, bien mirado, pedestre: $1^{\circ}$ poniendo en orden los datos disponibles, $2^{\circ}$ tratando de distinguir por conjeturas a base de puro buen sentido lo verdadero de lo falso, lo verosímil de las "vulgatas" difundidas con fines de mixtificación, y $3^{\circ}$ buscando cada vez pruebas objetivas que confirmasen o rectificasen las hipótesis que había ido adelantando.

Si algún resultado he conseguido en mis estudios, ${ }^{4}$ creo que esto se debe en primer lugar a la distancia temporal y espacial, que ha permitido que mi investigación se realizara lejos de influjos o prejuicios, por así decir, ambientales.

\footnotetext{
Seguramente hay que reconocerle el mérito de haber señalado la existencia de una interesantísima correspondencia que acaba de salir a la prensa: Correspondencia Ramón J. SenderJoaquín Maurín (1952-1973), edición, introducción y notas de Francisco CALDET, Madrid, Ediciones de la Torre, 1995; y también del libro de Julia Davis, The Sun Climbs Slow, Nueva York, E. P. Dutton \& Co., Inc., 1942, donde se narra bajo falso nombre el desembarque de Sender en Nueva York en marzo de 1939 y se evoca la muerte de Amparo Barayón según la versión suavizada y fabulada que se adoptó para los hijos cuando niños.

${ }^{4}$ Ahora recogidos en el libro Ramón José Sender tra la guerra e l'esilio, Alessandria, Edizioni dell'Orso, 1994, donde se encuentran divididos en dos partes tituladas «Il vissuto" e «Il narrato».
} 
En segundo lugar, lo que me animó a seguir ahondando en el asunto fue el darme cuenta de que el tema de la culpa, tan acertadamente destacado como central en la obra de Sender por un pionero estudio de JoséCarlos Mainer, ${ }^{5}$ tenía segura centralidad en las pesadillas vivenciales de Sender; y que quedaba por reflexionar más detenidamente sobre las modalidades de su afloración en la escritura, tanto de los textos autobiográficos como de los de ficción: me refiero sobre todo a las figuras de la expulsión y la fuga, del suicidio y el homicidio, y a las isotopías del chivo expiatorio recurrentes en toda la obra.

En esta investigación he tenido la suerte enorme de encontrar el apoyo tan caluroso como generoso de Eloy Fernández Clemente y José-Carlos Mainer y la discreta benevolencia de dos hermanas del escritor, Carmen y Asunción. La mayor recompensa a mis esfuerzos fueron las páginas que Suni Sender tuvo a bien añadir a las mías como apéndice en Alazet, 2 (1990). ${ }^{6}$

En la actividad desarrollada por Sender durante la guerra de España, se destacan netamente dos focos que podemos denominar, según el paradigma cervantino tan amado por Sender, las «armas» y las «letras». La dedicación de Sender en los dos ámbitos fue intensísima: basta con hojear su libro Contraataque, compaginando esta lectura con la de la prensa de guerra, para darse cuenta de cómo fue alternando cada día la actuación militar con la emisión de discursos, tanto directos como radiofónicos, y la redacción de textos (artículos periodísticos, folletos, dramas, opúsculos, libros). Pero, igual que a su gran modelo, a Sender no le fue concedido prosperar en las «armas», a pesar de que, como se percibe con bastante claridad, durante el conflicto fue más ambiciosa la actividad desarrollada en el plano militar que la realizada por medio de la palabra. Difícil, en efecto, esperar algo distinto de un sujeto que había abrigado una confianza tan grande en sí mismo. La misma esperanza optimista de poder influir en las vicisitudes políticas de su país que había demostrado en período de paz va inspirando ahora su actuación en la guerra. El compromiso político realizado en el periodismo había sido tan pugnaz en los años de la República como lo es ahora su deseo de determinar en el frente el destino del pueblo español. Sender tiene treinta y cinco años; sus acciones se han

\footnotetext{
5 José-Carlos MAINER, "La culpa y su expiación: dos imágenes en las novelas de Ramón Sender», Papeles de Son Armadans, 161 (agosto de 1969), pp. 116-132; reproducido en José-Carlos MAINER (ed.), Ramón J. Sender. In memoriam. Antología crítica, Zaragoza, Diputación General de Aragón, Ayuntamiento de Zaragoza, Institución Fernando el Católico, Caja de Ahorros de Zaragoza, Aragón y Rioja, 1983, pp. 127-135.

6 Asunción SENDFR, «Apéndice» a Donatella PINI MORO, «La degradación de Sender, un montaje», Alazet, 2 (1990), pp. 145-153. Mi trabajo, traducido al italiano, ahora está también en Ramón José Sender..., cit., pp. 97-101.
} 


\section{EL LUGAR DE SENDER}

desarrollado hasta ahora bajo el signo del protagonismo y de la identificación con las aspiraciones colectivas.

Al lado de estas evidencias está otro hecho universalmente conocido: que, en la posguerra, tanto su crónico inconformismo como cierto tipo de propaganda le causaron a Sender una total marginación del grupo del cual hubiera debido formar parte naturalmente, el grupo de los escritores, artistas e intelectuales que habían luchado en pro de la República, el famoso «batallón del talento». Como digo, no sólo esto no ocurrió, sino que su imagen sufrió un proceso tan fuerte y sistemático de descalificación que en muchos países se dejó de hablar de su participación en la guerra para no tener que mencionar episodios mezquinos donde la cobardía y la deserción habían tenido al parecer un papel determinante. En Italia, por ejemplo, después del homenaje tributado a Sender por Aldo Garosci, se produjo un silencio sospechoso. ${ }^{7}$ Entre los acusadores de Sender descuella Enrique Líster, cuya denuncia (una denuncia gravísima de traición), después de una capilar difusión oral de la cual verosímilmente no había sido el único responsable, salió a la prensa en sus libros de memorias de 1966 y $1977 .{ }^{8}$

El contraste entre las dos indicaciones sobre la conducta de Sender (dedicación, valor e integración, por un lado; cobardía, traición y marginación, por el otro) resulta violento. La opinión general antifascista, fatalmente, aceptó durante años la segunda versión patrocinada por todo un Partido Comunista Español: demasiada diferencia de crédito y prestigio entre un escritor que en el exilio tuvo un destino de soledad y un jefe militar, un «héroe», cuyo valor ya no pertenecía a la historia sino que había pasado a la leyenda, por lo menos en la historiografía de marca comunista sobre la guerra civil. ${ }^{9}$

Pero cincuenta años no pasan en vano: cincuenta años durante los cuales por una parte sale a plena luz la cara atroz del estalinismo y por otra los estudiosos profesionales ya no pueden conformarse con opiniones predeterminadas.

\footnotetext{
7 Aldo Garosci, Gli intellettuali e la guerra di Spagna, Milán, Einaudi, 1959 (en particular las pp. 160-178). El libro fue reseñado por Darío PuCcINI, Società, XVI (1, enero-febrero de 1960), pp. 160-167. Después de estas intervenciones se produjo un silencio que sólo podemos tratar de explicar a la luz de informaciones negativas sobre la figura de Sender como la que Puccini recibió de parte de Vittorio Vidali después de traducir dos fragmentos de Contraataque para Vie Nuove (27-XI-1949) y para El Paese (cfr. PIN], Ramón J. Sender..., cit., p. 14n).

8 Enrique LÍster, Nuestra guerra: Aportaciones para una Historia de la Guerra Nacional Revolucionaria del Pueblo Español, 1936-1939, París, Ebro, 1966; y, del mismo, Memorias de un luchador, Madrid, G. del Toro, 1977.

9 Sobre la leyenda de Enrique Líster, «cuidadosamente avivada por el Partido Comunista", José Domingo DueNas LoRENTE acaba de orientarnos con acierto al citar el testimonio de Enrique Castro Delgado en Ramón J. Sender (1924-1939). Periodismo y compromiso, Huesca, Instituto de Estudios Altoaragoneses («Colección de Estudios Altoaragoneses», 40), 1995 , p. 376
} 
En el caso de Sender empiezan los estudios sistemáticos sobre su actividad de periodista, ${ }^{10}$ la colección de referencias documentales para su biografía, ${ }^{11}$ etc.

En mis modestas indagaciones, dio un primer resultado el simple hecho de ir ordenando y compaginando datos por secuencias cronológicas: ${ }^{12}$ por ejemplo, los que afectan a la relación que se estableció en el frente entre Sender y sus soldados. Habiendo tenido noticias indirectas sobre la intratabilidad o, mejor dicho, insociabilidad de Sender (la noción quedaría confirmada por el testimonio del hijo en Muerte en Zamora) y habiendo leído en Líster de su frialdad para con los milicianos, no hubiera creído poder encontrar en una fuente próxima a los acontecimientos -Milicia Popular, el periódico del $5^{\circ}$ Regimiento- la evidencia de que Sender estuvo unido a sus soldados por un vínculo entrañable de solidaridad, un compañerismo que podríamos calificar de feliz a pesar de la trágica coyuntura. Esta identificación plena con sus soldados, atestiguada sobre todo por Milicia Popular ${ }^{13}$ pero también por otros periódicos (cfr. El Sol, 3X-1936, p. 3), había sido consagrada por su nombramiento de capitán a consecuencia de la democrática elección por parte de su compañía. ${ }^{14}$ Esta

\footnotetext{
10 Jesús Ruiz Gallego-LARGo, "Artículos de R. J. Sender en el diario Solidaridad Obrera», Cuadernos de Historia Moderna y Contemporánea, 6 (1985), pp. 281-312; Marcelo GONZÁLEZ RodríGUEZ, «R. J. Sender en La Libertad: 1931-1936», Cuadernos de Historia Moderna y Contemporánea, 6 (1985), pp. 313-329; José Domingo DuEÑAS LORENTE, «La obra periodística de Ramón J. Sender», Argensola, 100 (1986), pp. 5-58 (después Alazet, 0 [1988], pp. 285-338); Ramón José SENDER, Literatura y periodismo en los años 20 (Antología), ed. de J. D. DueÑas LoRENTE, Zaragoza, Edizions de l'Astral ("Cuadernos de Cultura Aragonesa», 12), 1992; José Domingo DuEÑAS LORENTE, «Ramón J. Sender en los años veinte: detalles de un aprendizaje», Alazet, 4 (1992), pp. 133-153, y ahora, del mismo DUEÑAS LORENTE, el magnífico libro Ramón J. Sender (19241939). Periodismo y compromiso, citado en la n. 9: una contribución sistemática que se presenta como concluyente en este campo de investigación.

11 Charles L. King, Ramón J. Sender, Nueva York, Twaine Publishers, 1974; Jesús VIVEd MAIRAL, «La vida de Ramón J. Sender al hilo de su obra», Alazet, 4 (1992), pp. 231-270. Del mismo, cfr. la monumental biografía en preparación.

12 Pini, Ramón José Sender..., cit., pp. 37-69.

13 Cfr. Contraataque, Madrid-Barcelona, Nuestro Pueblo, 1938, pp. 162-210 y particularmente p. 175: «[...] si algún trabajo me ha gustado es el de capitán. La ligazón con los soldados es directa e inmediata y está llena de responsabilidades de un tipo casi familiar. Evitaba los peligros innecesarios cuidadosamente - un brazo de un miliciano era una prolongación de mi brazo- [...]». Milicia Popular, 3-X-1936, p. 4 (Sector del Tajo), atestigua el vínculo amistoso y fraternal que une a Sender con el comandante León, gracias al cual la resistencia en el sector mejora notablemente. Milicia Popular, 15-X-1936, p. 5 (Relevos del Batallón Amanecer): «[...] los mandos de estas unidades han sido elegidos democráticamente a través de la capacitación y las experiencias demostradas en el terreno de la lucha. La identificación de los oficiales con los milicianos es absoluta, y la camaradería y la cordial fraternidad de todos facilitan al [sic] trabajo de la campaña [...]".

14 Sender, Contraataque, p. 162; Milicia Popular, 1-X-1936, p. 5: «Nuestro gran amigo el escritor Ramón J. Sender forma parte del $5^{\circ}$ Regimiento, y con el grado de capitán lucha con nuestras fuerzas en el sector del Tajo. - El autor de Imán no sólo escribe de la guerra, sino que toma también parte en ella luchando contra el fascismo. - Nos sentimos orgullosos de contar entre nosotros a Ramón J. Sender, el gran escritor y buen combatiente».
} 
información, que podría ofrecer duda al encontrarse alegada sólo por Sender en Contraataque (1937 y 1938), cobra veracidad al resultar referida en las columnas de un periódico de 1936, fuente más antigua y además autorizada por el Partido Comunista, e insinúa en cambio la sospecha de la superchería en los testimonios a posteriori (de Líster, 1966, 1977) hasta entonces tenidos por fidedignos. ${ }^{15}$

Vamos ahora al centro de las acusaciones que se apuntaron contra Sender durante el exilio: es decir, esencialmente, al episodio de la supuesta degradación, que, alegado siempre por Líster, destruyó la imagen del aragonés (entonces jefe de Estado Mayor en Valdemoro) sin que pudiesen servirle de exculpación sus negativas al respecto. En este caso, a la compaginación de los testimonios que ya se conocían, pude añadir un documento inédito de Vittorio Vidali, alias Carlos Contreras, ex comisario político y jefe del $5^{\circ}$ Regimiento. ${ }^{16}$ Se trataba de un «informe» sobre La degradación de Ramón Sender, redactado verosímilmente después de 1940 y antes de 1966, en el cual Vidali notificaba haber sido él quien degradó a Sender el día después de la batalla de Seseña (29 de octubre de 1936) en la comandancia del $5^{\circ}$ Regimiento. El análisis comparativo de este escrito a la luz de los dos de Líster ya citados, de Contraataque y de una carta que el mismo Vidali me envió en fecha 27-I-1983 respondiendo a unas cuantas preguntas mías, me permitió formular una hipótesis que después quedaría confirmada por un texto que encontré en época posterior en la Hemeroteca Municipal de Madrid (un artículo de alabanza a Sender aparecido en el Boletín de la $1^{a}$ Brigada Mixta del 31-XII-1936): la hipótesis era que, simplemente, la degradación de Sender no tuvo lugar, ni en la fecha que aducen Líster y Vidali (30 de octubre de 1936) ni en fecha posterior ( 7 de noviembre), ${ }_{17}$ según indicaba una carta anónima dirigida a Sender Barayón en 1982 y publicada en El País. ${ }^{18}$ Esta conclusión, al desmentir las noticias que habían circu-

\footnotetext{
15 «Ya en el período de formación de la Brigada [Sender] mostró su desconocimiento en cuestiones de organización y su falta de calor, de humanidad, de compañerismo hacia los hombres que lo rodeaban» (Nuestra guerra..., cit., p. 97; Memorias de un luchador..., cit., p. 166). La elección desde lo bajo debió de percibirse como una amenaza de desestabilización: un principio de legitimación referible a métodos anarquistas (vid. H. E. KAMINSKI, Quelli di Barcellona [título original: Ceux de Barcelone], Milán, Il Saggiatore, 1966, p. 208) seguramente peligroso en una unidad militar basada en un código parecido al de una unidad legionaria.

16 PINI, Ramón José Sender..., cit., pp. 73-95: es ampliación de PINI, «¿Degradación de Sender en 1936?», Andalán, 459-460 ( $2^{a}$ quincena de septiembre - $1^{a}$ quincena de octubre de 1986), pp. 29-31.

17 PINI, «La degradación de Sender, un montaje», Alazet, 2 (1990), pp. 145-149; ahora en PINI, Ramón José Sender.., cit., pp. 97-112.

18 R. SENDER BARAYÓN, Muerte en Zamora, cit., pp. 205-206, acepta como posible la versión del anónimo.
} 
lado hasta entonces sobre la conducta de Sender durante la guerra, venía a confirmar lo que el mismo Sender había declarado tajantemente en un paratexto muy importante: el "Prólogo" a Los cinco libros de Ariadna ${ }^{19}$ (1956): «Ni me degradó nadie, ni tuve altercados con nadie y menos de la naturaleza que se me atribuyen».

El cotejo de los textos había permitido detectar, al lado de las constantes relativas a la degradación, algunas variantes o, mejor, desmalladuras significativas (posiblemente debidas a fallos de memoria o a instancias personales de venganza), ${ }^{20}$ de las que surgieron principalmente tres consideraciones:

1) de las dos fechas ( 30 de octubre, 7 de noviembre) sólo una puede ser verdadera, y la otra, falsa; o las dos se anulan recíprocamente; y de hecho

2) ambas quedan desvalorizadas por la coincidencia de testimonios -de Sender en Contraataque y de varias firmas en los números de noviembre y diciembre de 1936 de Milicia Popular - que revelan cómo Sender siguió colaborando con los defensores de la República no sólo en tareas de persuasión y propaganda sino también en actividades militares, y con funciones de mando, en el mismo frente de Madrid; más aún,

3) ambas quedan anuladas por la evidencia de la presentación de Sender a los soldados como ejemplo de valor en una fecha en que, según sus acusadores, Sender habría sido descubierto como traidor, degradado y alejado del frente para siempre.

Estas deducciones, tan obvias como necesarias, permitieron descubrir el fraude en una operación de descrédito que ahora, a todas luces, se patentiza como un montaje; y revelaron cómo la denigración tiene su propia retórica, con sus tópicos atroces y triviales a la vez: pertenece a su técnica la presentación del sujeto al que se quiere desacreditar en tanto ambicioso, presuntuoso y cobarde. $Y$ he ahí la descripción estereotipada, recurrente en las versiones de sus detractores, de Sender exhibiendo un elegante uniforme nuevo, ${ }^{21}$ claramente sugerida por la similitud con el pavo real con que Eisenstein tildó la vanidad de Kerenskij en la película Octubre. He ahí la denuncia de aquella inoportuna supervaloración de sí

${ }^{19}$ Cfr. Los cinco libros..., cit., p. 14.

20 Afectan al tiempo (Líster y Vidali la refieren al 30 de octubre, el anónimo la hace remontar al 7 de noviembre) y a la presencia (en la versión de Líster) vs. ausencia (en Vidali y en el anónimo) del episodio de la exhibición de las insignias de comandante por parte de Sender el día después de la batalla de Seseña, al creer que Líster había muerto, aduciendo que él mismo se las había «dado antes de morir» (Memorias..., cit., p. 166).

${ }^{21}$ Líster: «[... Estaba enfundado en un flamante "mono" hecho en tela de gabardina, con un no menos flamante correaje y una pistola colgada de la cintura dentro de una brillante funda: parecía el anuncio de una sastrería de uniformes militares» (Memorias..., cit., p. 166). Vidali: «[...] vidi davanti a me Ramón J. Sender, con la sua brillante divisa di capitano ben stirata, gli stivali lucidissimi, il berretto in testa». Anónimo: «Llegó su padre a las nueve de la noche con su flamante uniforme nuevo de comandante [...]" (Muerte en Zamora, cit., p. 205). 
mismo que habría inducido a un simple "escritor», como era Sender, a enfrentarse y competir con el mismo comandante-jefe del $5^{\circ}$ Regimiento: supervaloración que yo había creído posible, suponiendo, en este orden de reflexiones, una hipertrofización del super ego senderiano a raíz de aquella doble marginación que el exilio significó para él. En cambio, también a este respecto, salen de la prensa de guerra contrapruebas objetivas: por ejemplo, del periódico Ejército Popular, I, 6 del 29-X-1936, pp. 4 y 5, que nos presenta al "capitán» Sender trabajando en los preparativos de la ofensiva de Seseña a las órdenes del "comandante» Enrique Líster, sí, pero en un plan de colaboración factual que resulta innegable:

En un pueblecito de los alrededores de la capital se trabaja en este sentido, estando encomendadas las funciones de organización al valiente batallador comandante Enrique Líster, que ve sus esfuerzos realizados por la ayuda competente del capitán Ramón J. Sender, actuando ambos jefes, en la organización de la brigada mixta, de acuerdo con el Ministerio de la Guerra. $^{22}$

He ahí la concordancia de todos los «testimonios» en alegar la cobardía $^{23}$ destinada a explicar el repentino alejamiento del frente por parte de Sender, a su vez inmediatamente identificado con una deserción en plena regla y, por lo tanto, ejemplarmente castigado con la degradación.

Pero en este tipo de análisis, expresamente dedicados a distinguir lo verdadero de lo falso y a delinear posibles procesos de derivación entre los textos, las variantes tienen más valor que las invariantes: en este caso se revelan como grietas que permiten detectar la manipulación. Aunque es verdad que un célebre refrán italiano - «Calunniate, calunniate, qualche cosa resterà „- muestra cuánta fuerza tiene en los espíritus la calumnia, sobre todo si es reiterada, también es verdad que el resorte funciona hasta cuando no se lo someta a una detenida observación, que en este caso ha permitido descubrir una maquinación urdida efectivamente en los mismos términos que Sender señalaba en 1956 con palabras que no se pueden parafrasear:

22 En PINI, Ramón José Sender..., cit., pp. 43-45, se ofrece una serie de posibles deducciones a partir de la entrevista incluida en este importante artículo.

23 Líster: «[...] fue, sobre todo, al entrar la Brigada en fuego cuando puso plenamente de relieve su falta de condiciones y que sus nervios no estaban hechos para resistir los tiros y las bombas» (Memorias..., cit., p. 166). Vidali: «Tu sei scappato davanti al nemico; hai abbandonato la tua brigata, tradito la fiducia dei compagni... Sei un disertore...". Anónimo: "Su padre no quiere contarles nada porque (y es triste decírselo a usted) en aquellos momentos se portó como un cobarde, tenía un miedo espantoso a morir, y vencido por el terror, aquella noche desapareció y nos quedamos sin comandante" (recogido en Muerte en Zamora, cit., pp. 205-206). A esto hay que añadir el testimonio de Santiago Álvarez aportado por Jesús VIVfo MAIRAL, "La vida de Ramón J. Sender al hilo de su obra», Alazet, 4 (1992), p. 252. 
No soy yo solo a merecer este privilegio aunque conmigo han ido demasiado lejos y quiero recordarles que eso de que la mayor mentira sea la más fácilmente creída no da resultado siempre y que hay en el orden natural de las relaciones humanas una secreta ley de compensaciones. A fuerza de acumular injurias sobre una persona no es raro verla aparecer de pronto aureo$\operatorname{lada}^{24}$ de una pureza angélica. En las resistencias secretas del escritor y del artista hay defensas de una calidad que ignorarán eternamente los del alboroto y todavía en los momentos más críticos nos flanquean los duendes custodios de lo indiscernible. ${ }^{25}$

Al lado de la evidencia de que a Sender no se le degradó ni en octubre ni en noviembre, y tampoco antes del 31 de diciembre de 1936, sigue en pie la duda alrededor de aquel abandono del frente el día de la batalla de Seseña, que, alegado por Líster y por Vidali, dio pie a la acusación de deserción.

Posiblemente tuvo lugar algún acto de indisciplina, que luego daría pie a tacharle de irresponsable, ${ }^{26}$ pero no nos es dado establecer su gravedad. Del cotejo de los testimonios Jesús Vived ${ }^{27}$ saca la conclusión de que efectivamente «en el transcurso del ataque, Sender dejó su puesto y se marchó a Madrid». Eso declara S. Álvarez, ${ }^{28}$ jefe que fue del $4^{\circ}$ Batallón de la Primera Brigada Mixta y, en cierto modo, eso había admitido el mismo Sender:

Esa historia de mi degradación viene del hecho de que habiéndome obligado a trabajar en una oficina, cosa que había logrado evitar a lo largo de toda mi vida por no creerme con aptitudes, me quité las insignias militares y las metí en un cajón como silenciosa protesta y también como lección. Los que debieron entenderla la entendieron. («Prólogo» a Los cinco libros..., cit., p. 14)

\footnotetext{
${ }^{24}$ La aureola, según enseña René GIRARD, La violence et le sacré, París, Éditions Bernard Grassé, 1972, es un signo de chivo expiatorio.

25 «Prólogo» citado, p. 8.

26 José-Carlos MAINER, «Antropología de un mito: El rey y la reina, de Ramón J. Sender», en Homenaje a J. M. Blecua, Madrid, Gredos, 1983, p. 390. También téngase en cuenta que, dado su carácter de voluntariedad y su estado inicial de desorganización, la costumbre de alejarse del frente sin autorización estaba, en las brigadas mixtas, más difundida de lo que podríamos suponer. A esto añádase lo que DuEÑAs, a raíz de lo denunciado por Mijail Kolisov (Diario de la guerra española, Madrid, Akal, 1978, p. 182), subraya a propósito de la frecuencia con que los oficiales abandonaban sus puestos de combate (Ramón J. Sender [1924-1939]. Periodismo y compromiso, cit., p. 377).

27 VIVED, «La vida... », cit., p. 252.

28 Santiago Áivarf.7, Memorias II, Sada-A Coruña, Ediciós do Castro, 1986, p. 76 (agradezco a J. Vived la generosidad con que me ha facilitado este texto que desconocía). De todas maneras, la modalidad de la escritura comunica la impresión de que Álvarez, aunque sinceramente convencido de conocer los términos exactos de la cuestión, no tuvo conocimiento directo del acontecimiento referido a Sender, sino que, al acabar de llegar al puesto de mando de la brigada, aceptó sin más la versión concordada por Contreras y Líster.
} 
Al mismo tiempo, resulta elocuente lo que Sender escribió en una carta publicada en $A B C$ el 20-XI-1974, p. 35, también recogida por Vived:

Yo fui Jefe de Estado Mayor de la Primera Brigada Mixta con él [Líster] entre Pinto y Valdemoro (que no deja de tener gracia). Menos gracia tenía que quisiera fusilar a los mejores de mis amigos oficiales cuando la culpa del fracaso de la operación era de él. Yo salvé entonces sus vidas (alguno fue fusilado por él, más tarde, en lo de Belchite). Viendo la clase de sujeto que era, me di de baja con otros jefes y regresé a Madrid, dejando las posiciones como estaban antes del fallido ataque y una avanzadilla en Seseña.

Declaración que lleva a establecer una relación estrecha entre la acusación de deserción lanzada contra Sender (con la consecuente "vulgata" de la degradación) y la voluntad de ocultar las responsabilidades de los errores cometidos en Seseña por parte de los jefes del $5^{\circ}$ Regimiento. Errores que el aragonés había denunciado en Contraataque, ante todo considerando lo que Seseña hubiera podido ser y no fue: «Para que la experiencia nos depure, algún día habrá que recordar aquella jornada, que pudo ser el comienzo de una ofensiva nuestra arrolladora» (p. 232), y luego describiendo su estado de ánimo cuando, al escuchar los rumores de la batalla desde lejos, donde Líster le había obligado a quedarse, tuvo la evidencia del error cometido por su comandante:

Yo sentí desmoronarse todo el plan del ataque. Una sensación de ingravidez y de honda y callada impotencia me agobiaba. Aquel pueblo [Torrejón $]^{29}$ no había que atacarlo hasta la segunda fase de la ofensiva. (p. 241)

No se olvide que, después de haber efectuado juntos los preparativos de la operación la mañana de la batalla, Líster le había impedido a Sender que tomara su puesto en las líneas ${ }^{30}$ verosímilmente pensando coger él solo el fruto victorioso que todos esperaban de la primera intervención concreta de los soviéticos al lado de la República española. ${ }^{31}$ Lo cual hace

\footnotetext{
29 Lugar adonde Líster había conducido sus fuerzas erróneamente.

30 Sender escribe sin polémica en Contraataque, p. 232: «El jefe [...] Como vio que su decisión me disgustaba, me propuso que, a partir del mediodía, iría yo a las líneas y se quedaría él en mi puesto. [...] Y me quedé en el Estado Mayor, deduciendo, por los ruidos del campo, la marcha de la operación. El martilleo de los cañones, el crepitar de las ametralladoras y los fusiles, las explosiones de los motores de los camiones y motos se fundían en un solo rumor inmenso: -Está cociéndose la victoria». Pero manifiesta abiertamente su estado de decepción e inquietud: «No podía dejar aquel lugar al lado del teléfono, cerca de los hospitales, del depósito de gasolina, de las municiones. Pero trataba de averiguar, por indicios, lo que sucedía. De vez en cuando enviaba un motorista a un punto de observación, sin otro fin que estar quince minutos mirando para que, al volver, me contara lo que veía. Como sabía la situación de las fuerzas, deducía la marcha de la operación por los vagos informes de los motoristas. Yo seguía en aquel puesto atendiendo a mil pequeñeces que podía resolver mi ayudante, pero no quería desobedecer a mi jefe».

31 SENDER, Contraataque, p. 232: «Yo pensaba que mi amigo y jefe buscaba el éxito personal, lo que me parecía noble y muy comprensible. [...] Quería lograr que los hechos anduvieran al compás de su entusiasmo. Y aquel día todo parecía anunciar la victoria”.
} 
suponer también una rivalidad personal y estratégico-militar cuyos posibles afloramientos directos e indirectos he rastreado ${ }^{32}$ a lo largo tanto de los escritos testimoniales ${ }^{33}$ como de las obras senderianas de ficción (en particular de Los cinco libros de Ariadna).

Mis dudas crecen al tratar de enfocar un hecho que, por otra parte, es posible que no haya ocurrido nunca: otra supuesta fuga del frente, llevada a cabo por Sender con el fin de poner en salvo a sus hijos. Hasta ahora, esta peripecia había quedado aún más nebulosa pues no disponíamos de ninguna referencia objetiva.

Ramón Sender Barayón, en Muerte en Zamora, había dado por descontado que su padre había huido de España inmediatamente después de lo de Seseña, quizá inducido por una interpretación demasiado literal de algunos textos en que su padre aludía a su fuga a Francia con objeto de recuperar a sus hijos como al episodio que le salvó de la persecución comunista.

Yo, por mi parte, considerando la continuidad con que Sender resulta activo en el $5^{\circ}$ Regimiento hasta diciembre, el testimonio de sir Peter Chalmers Mitchell en My House in Málaga ${ }^{34}$ y el encomio publicado el 31 de diciembre de 1936, había supuesto que la recuperación de los niños Sender debía remontarse a una fecha posterior a esta última. Para precisarla había solicitado la ayuda de Florianne Truninger, "Chargée de recherches, Doctrine, Droit et Relations avec le Mouvement» del Comité International de la Croix-Rouge, pero sin resultado, pues la Cruz Roja, como es comprensible, no suele conceder ni documentación ni noticias sino a los directos interesados. ${ }^{35}$

Acabo de tener noticia en estos días de que Ramón Sender Barayón pudo conseguir de la Cruz Roja la noticia de que las fechas de la recuperación suya y de su hermana por parte de su padre en Bayona se sitúan

32 PINI, Ramón José Sender..., cit., pp. 41-112, pero, sobre todo, pp. 97-101.

33 Ramón Sender Barayón acepta sin discusión el hecho de que «su padre llevó a cabo el imprudente intento de tomar el mando de la brigada de Lister» (Muerte en Zamora..., cit., p. 206). En cambio José Luis CAstrllo PUCHE afirma mucho más verosímilmente que Sender, "cuando llegó a jefe de Estado Mayor», disputó «si no el mando, sí la orientación de los planes de operaciones al mismo Líster" (Ramón J. Sender: el distanciamiento del exilio, Barcelona, Destino, 1985, p. 42).

34 Londres, Faber \& Faber, 1938.

35 Florianne Truninger respondió muy amablemente a mis cartas del 11-IV-1989 y del 2-VI1989 en las fechas 25-V-1989, 26-VI-1989 y 3-X-1989, informándome que la Agencia central de investigaciones del CICR no comunica nunca las informaciones personales que tiene sobre las víctimas de la guerra sino a los mismos interesados o a sus familiares. Sin embargo, al poco tiempo, me notificó que las investigaciones que se acababan de realizar a instancia mía sobre la recuperación de los niños Sender durante el invierno 1936-1937 habían tenido resultado negativo. 
efectivamente en el mes de enero de 1937, respectivamente el 12 y el $18 .{ }^{36}$ Lo cual, si por una parte concuerda con mis hipótesis en cuanto a la fecha de recuperación de los niños y viene a confirmar que no hubo fuga ninguna en noviembre ni en diciembre con motivo de estas gestiones, por otra parte no impide que tal huida se haya producido en enero de 1937; aunque mi impresión es que la hipótesis de la fuga haya surgido al tratar de establecer una relación entre lo que se creyó que ocurriera en Seseña y el viaje a Francia.

Por la obra de Sender se encuentran pasajes manifiestamente autobiográficos donde el escritor aragonés declara abiertamente su fuga con un tono de honda amargura, explicándola sí con la necesidad inmediata de poner a salvo a sus hijos pero, esencialmente, con el fin de evitar insidias mortales que se le iban preparando dentro de sus mismas filas; y declara esto no para justificarse sino más bien para despreciarse. Quizá el pasaje más explícito se encuentre en Libro armilar de poesía y memorias bisiestas: ${ }^{37}$

[...] desde que murió mi hermano tan noblemente como un campesino y como un infante de Aragón y yo salí huyendo por los caminos del sobrevivir con el pretexto de salvar a mis hijos, desde entonces yo tengo el derecho a despreciarme.

La coyuntura en que se encuentra en 1937, con el problema no sólo de proporcionar a sus hijos el indispensable auxilio, sino de garantizarles aquella incolumidad que, estando él en peligro, también se encontraba amenazada, ${ }^{38}$ y la consecuente intención de asentar en Francia una nueva familia, con una mujer que confía pueda ser una segunda madre para ellos, le ve padre por tercera vez en el mes de noviembre. ${ }^{39}$ Esto le debió de alejar irremediablemente de los lugares de guerra causándole un agobiante sentido de culpabilidad que posiblemente arraigaba, más que en una conducta verdaderamente reprochable, en una comparación humillante, para un hombre de acción, entre su destino de superviviente y el de los que estaban muriendo por la causa. Hay que evitar creer de manera sistemática que a un sentido de culpabilidad deba necesariamente siempre corresponderle una culpa. Novelas como El fugitivo muestran precisamente que la conciencia culpable es un castigo que puede prescindir completamente del delito.

\footnotetext{
${ }^{36} \mathrm{Cfr}$. el extracto documental de la Cruz Roja, fechado en Burgos el 21-I-1937, encontrado en los archivos por Lix Simonius, "Chef du Secteur Europe Occidentale et Amérique du Nord de l'Agence Centrale de Recherches" del Comité International de la Croix-Rouge, y transmitido en copia a Ramón Sender Barayón con carta fechada en Ginebra el 13-IV-1983.

37 México, Aguilar, 1974, p. 412.

38 Sender alude a esto en el paratexto Cuarenta años después, introducción a Contraataque, edición de J. A. Pérez BowIE, Salamanca, Almar, 1978, p. 13.

39 PINI, Ramón José Sender.., cit., p. 59.
} 
Por otra parte Sender nos informa de que, después de terminar la redacción de Contraataque, no permaneció continuamente en Francia durante el año 1937, sino que volvió a Barcelona (probablemente más de una vez) y pidió que le asignaran al frente aragonés, pero los comunistas, que le consideraban como un enemigo, no se lo concedieron. ${ }^{40}$ Sobre su presencia en Barcelona durante los sucesos de mayo no tengo documentación; su obra de ficción hace suponer su implicación en ellos, sin que podamos afirmar a ciencia cierta si Sender los experimentó directamente o en cambio los conoció a posteriori, después de la guerra, gracias a sus amigos anarquistas y del POUM. ${ }^{41}$ Por fin, es evidente que Sender no hizo ningún misterio alrededor de su permanencia en Francia si el 17 de julio intervino con una ponencia, en calidad de delegado español, en la sesión parisiense de clausura del II Congreso Internacional de Escritores Antifascistas. Así que, para mí, sigue siendo dudoso que al desplazamiento de Sender de España a Francia se le pueda efectivamente calificar de fuga. ${ }^{42}$

Otro tema que queda por aclarar es el del doble, o triple, intento de volver al frente. Sender habló a Carrasquer tan sólo de un intento, ocurrido en 1937, que fracasó al recibir la negativa de los mandos comunistas.

Jesús Vived habla de un segundo intento de volver al frente al regresar de Estados Unidos, en junio de 1938: «[...] quiso volver al frente pero se le nombró miembro del comité de redacción de Voz de Madrid [...]».43

Peñuelas, en cambio, habla de un intento que Sender hizo a primeros de noviembre, pero dice que poco después renunció al ver que los rusos querían el control absoluto de la situación mediante la eliminación de los disidentes. ${ }^{44}$ Michiko Nonoyama ${ }^{45}$ acoge lo referido por Peñuelas. La estudiosa japonesa no tiene la menor duda sobre eso y escribe sobre la actividad desarrollada por Sender inmediatamente después del trabajo en la redacción de la Voz de Madrid:

\footnotetext{
40 Marcelino C. Peñutelas, Conversaciones con Ramón J. Sender, Madrid, Magisterio Español, 1970, pp. 58-59; PeÑuelas, La obra narrativa de Ramón J. Sender, Madrid, Gredos, 1971, p. 36. Sender había contestado en 1966 a un cuestionario de Francisco CARRAsQuER: después de haber actuado como "Jefe de Estado Mayor de la 1“ Brigada Mixta (defensa de Madrid)", "salí a buscar a mis hijos en Francia, volví con ellos a Barcelona (1937) y los comunistas se negaron a que tuviera mando en las líneas» (cita sacada de Alazet, 3 [1991], p. 176).

41 Dueñas (Ramón J. Sender [1924-1939]. Periodismo y compromiso, cit., p. 382) habla del «aislamiento en que [Sender] vivió buena parte de 1937».

42 Sobre la visibilidad de las actuaciones de Sender en Francia en 1937, resultan concluyentes las aportaciones de la indagación francesa ahora referidas por DUENAS (Ramón J. Sender [1924-1939]. Periodismo y compromiso, cit., pp. 383-384).

43 «La vida de Ramón J. Sender...», cit., p. 256.

44 Peñuelas, La obra narrativa..., cit., 1971, p. 26.

45 Michiko Nonovama, El anarquismo en las obras de R. J. Sender, Madrid, Nova-Scholar, 1979.
} 


\begin{abstract}
Después de volver a Madrid, trabajó cerca de los estalinistas rusos y entró en graves conflictos con ellos cuyo proceso es descrito en Los cinco libros de Ariadna (1957). Al ver que las discrepancias entre diferentes partidos no tenían ninguna solución constructiva, salió definitivamente de España [...]. (p. 13)
\end{abstract}

Pero la falta de referencias documentales, junto a la dificultad de rastrear en Los cinco libros de Ariadna (y también en los últimos tres de Crónica del alba) alusiones que puedan referirse con seguridad a hechos ocurridos en 1938 (y no en 1937), dificultan enormemente, a mi manera de ver, la posibilidad de aceptar tranquilamente una nueva participación en el conflicto a finales del tercer año de guerra: una participación sobre la cual Sender no proporcionó a Carrasquer la menor noticia.

A la discontinuidad de la actividad militar se opone una patente continuidad en la dedicación intelectual en favor de la República española y del Frente Popular.

En el ajetreado segundo semestre de 1936, el incesante compromiso militar no le impide aprovechar constantemente los ratos libres para redactar artículos destinados a la prensa de guerra y pronunciar discursos, ya directos a las tropas, ya radiofónicos a la población de la zona republicana. ${ }^{46}$ En la segunda mitad de agosto, durante una licencia de diez días, lleva a cabo una misión de propaganda en Córdoba junto con los compañeros de la organización Cultura Popular. ${ }^{47}$

Termina en septiembre de 1936 Crónica del pueblo en armas (Historia para niños) y en diciembre $1^{\mathrm{a}}$ de acero, opúsculo destinado a integrarse con refundiciones en el libro Contraataque.

Trabaja para el «teatro de urgencia». ${ }^{48}$ Ilustra el cine soviético en varios lugares del frente con el fin de despertar la conciencia de clase e inflamar el espíritu bélico en los milicianos.

Remonta a los primeros meses de 1937 la redacción de Contraataque, ${ }^{49}$ libro importantísimo en defensa de la causa frentepopulista, destinado principalmente, aunque no exclusivamente, ${ }^{50}$ al público extranjero con

\footnotetext{
46 PINI, Ramón José Sender, cit., pp. 39-56.

47 Cfr. «En Villafranca de Córdoba», Milicia Popular, 23-VIII-1936, p. 6. Sobre Cultura Popular cfr. Milicia Popular, 16-IX-1936, p. 2; 10-X-1936, p. 2; Contraataque, pp. 98, 101, 103, 162-163.

48 Redacta y pone en escena actos únicos como La llave, El secreto, El sumario, El Cristo, El duelo. En París, el 1-XI-1938, pondrá en escena el Don Juan Tenorio de Zorrilla.

49 Le encargó el libro la editorial inglesa Faber \& Faber, que lo publicó con el título The War in Spain, en la traducción de Peter Chalmers Mitchell. Publicado en el mismo año también en Estados Unidos (Counterattack in Spain, Boston, Houghton Mifflin, 1937) y en Francia (Contre-Attaque en Espagne, trad. de Georges BÉNICHOU, París, Éditions Sociales Internationales, 1937), Contraataque salió a la prensa en España sólo en 1938.

${ }^{50}$ Distintos puntos de vista nos ofrecen al respecto Jean-Pierre RESSOT ( De Sender à Malraux", Mélanges offerts à Charles Vincent Aubrun, París, 1975, II, pp. 195-203; incluido en versión española en José-Carlos MAINER [ed.], Ramón J. Sender..., cit., pp. 333-341) y Mary S. VÁsquez («Estrategias de guerra y texto en Contraataque de Ramón J. Sender», Alazet, 4 [1992], pp. 215-230).
} 
vistas a abrir una brecha en la política de la no intervención. Según testimonios recogidos por su hijo Sender, empieza a escribir El lugar del hombre en $1937 .{ }^{51}$ Es del 17 de julio del mismo año la citada ponencia en el II Congreso de Escritores Antifascistas, pronunciada por Sender en París con el papel oficial de «delegado español».

En mayo-junio de 1938, forma parte de una importante misión de propaganda expresamente definida por la prensa «delegación del gobierno de Madrid»,52 que le ve, junto con José Bergamín, Ogier Preteceille, secretario de prensa de la UGT, y Carmen Meana, operadora social representante de las mujeres de Madrid, pronunciando una serie de conferencias por Estados Unidos. Objeto principal de la misión es convencer a la opinión americana de la necesidad de quitar el embargo al envío de ayudas militares a España. El 9 de junio, en la ceremonia de conclusión, los tres hablan frente a un público de 20.000 personas en el Madison Square Garden de Nueva York, presente el embajador español Fernando de los Ríos, después de una alocución radiofónica del jefe del gobierno Juan Negrín transmitida en directo desde Barcelona.

A esto sigue, entre julio y noviembre de 1938, en París, el intenso trabajo, probablemente con funciones directivas, para la redacción de Voz de Madrid, semanario de información y orientación de la ayuda a la democracia española. Un análisis detallado, ${ }^{53}$ comparado con el que ya Rafael Osuna habia realizado anteriormente, ${ }^{54}$ me ha permitido descubrir una contribución de Sender hasta entonces escondida bajo un pseudónimo ( $« \mathrm{~F}$. Saila») destinado a clarificarse después de la publicación de Proverbio de la muerte ${ }^{55} \mathrm{y}$, sobre todo, ha permitido enfocar la tendencia del periódico, plenamente en línea con la política del Partido Comunista Español.

He querido subrayar claramente esta función ideológica predominante de la escritura senderiana de guerra para que quede claro que todos los aspectos de inconformidad hacia la política y la conducción militar llevada a cabo por el Partido Comunista que aquella indudablemente tiene, y que yo misma he contribuido a evidenciar, son aspectos secundarios que denotan la postura difícil, y para muchos incomprensible, mantenida por Sender durante todo el conflicto: la postura de un indómito «compañero de viaje» que, dentro de una sustancial lealtad al PCE y al Frente Popular, quiso mantener celosamente y expresar francamente su libertad e inde-

\footnotetext{
51 Muerte en Zamora, cit., p. 210.

52 New York Times, 10-VI-1938, p. L 13.

53 PiNI, Ramón José Sender..., cit., pp. 61-66.

54 Rafael OSUNA, «El periódico La Voz de Madrid, 1938-1939», Quaderni Iberoamericani, 51-52 (junio-diciembre de 1978 - 1979), XIII, VII, pp. 190-193.

55 Es la «narración inédita» «El piloto arrestado», Voz de Madrid, 17-IX-1938, p. 4. Cfr. PiNI, Ramón José Sender.., cit., pp. 63-64 y 103-112.
} 
pendencia de juicio. ${ }^{56}$ Lo cual queda ahora sumamente reforzado por los elementos aducidos por Antonio Elorza en este mismo Congreso.

Esta actitud de Sender ha dado pie a juicios muy diferentes, según los puntos de vista y las épocas de su emisión: algunos han hablado de traición, otros de irresponsabilidad y alucinación quijotesca, otros de heroica defensa de la dignidad dentro de la indignidad general. ${ }^{57}$ En cualquier caso, hay que reconocer que nunca escondió aquellos repentinos virajes políticos que le vieron pasar del anarquismo al comunismo (1933) para alejarse al poco tiempo también de este (1936); ni su carácter orgulloso le ayudó a ganarse una solidaridad o una comprensión que nunca había buscado. 58

Como se ve, en la participación de Sender en la guerra de España las «letras» acabaron por prevalecer sobre las «armas», aunque ciertamente no por su voluntad. Esto constituyó, en el exilio, uno de sus más graves motivos de amargura. En efecto, resultaba evidente, ya en Contraataque, ya en su periodismo de guerra, que en los primeros meses del conflicto se había entregado en alma y cuerpo, tanto en el plano de la organización como en el de la actuación bélica, a aprovechar, afinar, perfeccionar la experiencia estratégica y táctica madurada durante el servicio militar prestado en Marruecos. La inteligencia prodigada en octubre en el batallón «Amanecer», frente del Centro, sector del Tajo, la admiración por la competencia del teniente coronel Mena en predisponer y efectuar las maniobras, la cohesión con el comandante León, a cuyas órdenes alterna el trabajo de jefe de Estado Mayor con el de capitán, la estupenda camaradería con sus soldados, cuya democrática elección había legitimado sobremanera su nombramiento de capitán, tal como se encuentran relatadas en Contraataque ${ }^{59}$ y en Milicia Popular, no sólo atestiguan una participación entusiasta y vital sino que son el signo de un fuerte y entrañable compromiso en la guerra, sentida ahora como el único instrumento de que el pueblo español dispone para apoderarse de su propio destino y determinar su rumbo. No pararse un momento para apreciar la identificación con la

\footnotetext{
56 Julia UCEDA, «Ramón J. Sender: el lugar de un hombre», El Independiente, 12-IV-1990, p. 4, se expresa en estos términos: «Sender caminaba por el arriesgado filo de reconocer la eficacia de los comunistas y admirar el idealismo anarquista».

57 Enrique CAStro Delgado, Hombres made in Moscú, Barcelona, Luis de Caralt, 1963, p. 175 : «Posiblemente el único intelectual que mejor comprendió al Partido, que no se dejó engañar por el Partido, al que no envilecieron los halagos, el que no sacrificó su libertad de pensamiento, el que fue la dignidad frente a la indignidad, fue: Ramón ]. Sender» (apud VIVED, «La vida de Ramón J. Sender...”, cit., p. 255).

58 Véase al respecto lo que escribe su hermana Asunción SENDER GARCÉS en el «Apéndice» citado, Alazet, 2 (1990), pp. 151-153.

59 Páginas 162-210.
} 
masa que anima estas páginas, evocando la análoga identificación auspiciada hace poco, aunque en tiempo de paz, para el novelista, ${ }^{60}$ sería como querer permanecer sordos ante un estado anímico y psíquico de gran arrebato y generosidad. ${ }^{61}$

Algo parecido hay que admitir a propósito del empeño prodigado por Sender en los preparativos de Seseña, aunque en condiciones muy distintas deducibles, ya de Contraataque, ya de la paralela prensa de guerra. ${ }^{62} \mathrm{El}$ empeño de Sender en las "armas» fue, por lo menos en su manera de percibirlo, terminante y sin reservas: de sus páginas rezuma un fuerte pero positivo y generoso deseo de afirmación personal basado en la conciencia de estar realizando en un momento crucial para España algo decisivo para su destino.

Le esperaba, igual que a Cervantes, la hora amarga de la decepción y el desengaño, en la cual encontraría, sí, pero sólo en parte, compensación en las «letras»: una producción novelesca destinada a alcanzar altas cotas entre los años 40 y los 60, aunque marcada al fuego de un fracaso que, como para el Cervantes de Las gallinas..., 63 quedaría localizado en su memoria entre Pinto, Valdemoro y Seseña.

60 «El novelista y las masas», Leviatán, 24 (1 de mayo de 1936), pp. 31-41. Sobre el significado mítico atribuido por Sender a los significantes "masa" y «pueblo" véanse las eficaces puntualizaciones de RESSOr en «Les Espagnols face à leur guerre: la solution negativiste de Ramón J. Sender», Imprévue, 2 (1986), pp. 87-98. DueÑas (Ramón J. Sender [1924-1939]. Periodismo y compromiso, cit., pp. 359-360) enfoca con acierto la compleja red cultural que contribuyó a formar el concepto senderiano de "masa».

61 "Generosidad» es el título de un artículo que aparecerá en Voz de Madrid, I, 15, 22-X-1938, p. 2, donde se repiten conceptos ya expuestos dos años antes en «La voz nueva», artículo publicado en la revista Ayuda (VIVED, "La vida de Ramón J. Sender...», cit., p. 256).

62 PiNi, Ramón José Sender..., cit., pp. 42-49.

63 Cfr. SENDER, Las gallinas de Cervantes, en Novelas del otro jueves, Barcelona, Destino, 1985, pp. 85, 92. El cuento había aparecido anteriormente en Las gallinas de Cervantes y otras narraciones parabólicas, México, Mexicanos Unidos, 1967. 
ni 


\title{
Sender, Eros, don Juan y la revolución
}

\author{
Carlos Serrano \\ Université de Paris-Sorbonne (Paris IV)
}

\section{UNA LITERATURA DEL EROTISMO}

En 1968, Ramón Sender publicó en México una curiosa y relativamente poco conocida obra de teatro, Don Juan en la mancebia (México, Editores Mexicanos Unidos, 1968, 128 pp.), edición plagada de erratas, que se subsanaron en la segunda edición de la obra, ya en España (Barcelona, Destino, 1972, 173 pp.), que incluía a su vez 25 páginas de un prólogo nuevo, titulado "Consideraciones sobre don Juan" y fechado en 1971. Tras tantísimos otros autores, Sender se lanzaba, pues, de este modo por la arriesgada senda de una reelaboración personal del mito de don Juan. Un año después de que apareciera por primera vez el drama, salió por otra parte a la venta en España otro curioso librillo suyo, al que puso por título Tres ejemplos de amor y una teoria. ${ }^{1}$ Se trataba de «un ensayo un poco irregular», según él mismo dice, «sobre algo que podríamos llamar la guerra de los sexos» (op. cit., p. 20) y cuyos "episodios centrales son como tres grandes batallas de la intimidad apasionada", dedicados respectivamente a Balzac en sus relaciones con madame Hanska, al Tolstoï de La sonata a Kreutzer y, por fin, al Goethe de Werther. El libro, sin embargo, concluye con un séptimo y último capítulo, «Los instintos, la reintegración y el suicidio. Con-

${ }^{1}$ Madrid, Alianza, 1969, $286 \mathrm{pp}$. 
clusión», en el que Sender procura formular algo así como la teoría de sus observaciones anteriores, pero alimentándola por añadidura, y no sin varias coqueterías, con la (re)edición de ese "pequeño ensayo sobre el amor" en que consiste la extraña "carta» - real o supuestamente - remitida desde Rusia unos treinta y tantos años antes por el joven Ramón a una «novia virgen» que le «exigía el matrimonio» (op. cit., p. 244). En una forma algo más extensa, este texto se había publicado por primera vez en 1934 (Madrid, Pueyo), ${ }^{2}$ pero, pese a su antigüedad, es necesario evocar la «carta» aquí puesto que el propio autor afirmaba, a la hora de reeditarla, que, a pesar de «alguna inmadurez», seguía representando su sentir en las materias por él abordadas.

En definitiva, en 1968-1969 y con prolongaciones hasta por lo menos en 1971, Sender parece prestarle una renovada atención a una temática erótica que, si bien nunca fue ajena a su obra, cobra aquí una dimensión nueva por la propia proyección teórico-literaria de que es objeto en tan poco tiempo a través de sendos libros. Es, pues, grande la tentación de leer uno a la luz del otro, tanto más cuanto que en ambos es cuestión de don Juan, como mito literario, por supuesto, pero sobre todo como figuración de cierta exaltación vitalista de la sexualidad.

\section{EL LUGAR DE LA MUJER}

Desde un primer momento las cosas quedan bien claras: Sender va a hablar del amor, pero pretende evitar deliberadamente "perder[se] en los confusos y brillantes laberintos de la mística y de la poesía»; su propósito es exclusivamente "el amor entre hombre y mujer» (Tres ejemplos de amor, cit., p. 7), que, de entrada, queda definido a través de su teoría, «un poco chocante pero tan legítima como cualquier otra», que resume en los siguientes términos:

\footnotetext{
Nadie ignora que un día fuimos entidades bisexuales en el mar o cuando nuestros remotísimos abuelos probaban a salir de él como algunos moluscos ahora, que son hermafroditas todavía. Nosotros tenemos aún restos de feminidad en los pechos y las hembras reminiscencias masculinas del pene. Un día fuimos todos al mismo tiempo hembras y varones, muchísimos siglos después de aparecer las células primarias. (ibid., pp. 7-8)
}

Pero la historia de la humanidad no comienza realmente sino después de esa fase de indiferenciación, con una ruptura esencial, por tanto, que para Sender determina la esencia misma del deseo:

\footnotetext{
${ }^{2}$ Charles L. KING, Ramón J. Sender: An annotated bibliography, 1928-1974, Metuchen, N. J., The Scarecrow Press, 1976; Luz CamPANA DE WATTS, Ramón J. Sender. Ensayo biográfico-crítico, Buenos Aires, Ayala Palacio, 1989.
} 
Un día [...] sucedió un hecho estupendo sobre el que los naturalistas no tienen duda alguna: la mujer se nos separó. [...] Desde el día que la mujer se nos separó [...], el hombre busca a la hembra para reintegrarse en su unidad de origen y la hembra busca al hombre con el mismo fin. El hombre quiere entrar a toda costa y riesgo por el lugar por donde salió, y sólo habiendo entrado alcanza por un instante el gozo de esa reintegración. La mujer penetrada, también. (ibid., p. 8)

Tras el aparente equilibrio de la funciones masculinas y femeninas que parece darse en la anterior cita, hay, de hecho, en esta peregrina interpretación filogenética del deseo y del impulso sexual no poco de lo que los adalides del gender criticism podrían calificar sin duda como sexismo conceptual o literario. $Y$ es que es recurrente en Sender la atribución de un papel segundario, esto es, derivado, a la mujer, enfocada aquí desde ese punto de vista masculino-centrista que tan a las claras manifiesta ese «la mujer se nos separó» de la cita anterior. En otro lugar, las mencionadas "Consideraciones sobre don Juan», Sender, para explicar el éxito del que define como el «campeón» del amor, es más explícito en lo referente a la idea que se hace de las mujeres, que - escribe-- se dejan seducir porque, "con su mentalidad de niños de trece años, caen en esa especie de gregarismo suscitado por los campeones. Campeones de no importa qué» (op. cit., p. 17). Como quiera que sea, el deseo, tanto del hombre como de la mujer, no sería entonces más que la traducción orgánica de algo así como una querencia, del ansia de retorno a los orígenes felices de la especie: «Para los dos, esa ambición de la reintegración definitiva en un solo ser es indispensable y para los dos es imposible» (ibid.). «No pocos dramas y tragedias nos recuerdan cada día [...] esa necesidad y esa imposibilidad", sigue comentando a continuación Sender. La busca amorosa es, pues, según la línea directora de la «teoría» senderiana, la persecución de esa unidad perdida, «físicamente imposible y moralmente necesaria», de que tan sólo intuimos la perfección a través de la "generosa promesa y la corta experiencia del orgasmo" (ibid., p. 10). No obstante, no queda tan clara aquí tampoco la simetría entre hombre y mujer que aparenta querer mantener Sender, puesto que el deseo, repentinamente, parece remitir a una naturaleza sustancialmente diferenciada: «Si el amor lo hubieran inventado las mujeres, sería con un fin lascivo», prosigue Sender en las "Consideraciones sobre don Juan", antes de concluir: "Ellas son maestras en ardides y lo que buscan es ser fecundadas» (ibid., p. 18). Escritas en 1971, estas palabras no hacen sino reiterar lo que ya afirmaba el Sender de 1934, en su "Carta», cuando, dirigiéndose a su «novia» y tras haberle expuesto los supuestos estragos de una sexualidad masculina reprimida, le comentaba:

En vosotras, en las mujeres, la cuestión es diferente. Más grave en un aspecto y menos en otro. Tenéis menos libertad. Pero la desviación del instinto sexual a lo largo de una represión sostenida se rectifica más fácilmente con la maternidad. (op. cit., p. 264) 
La igualdad y el paralelismo entre hombre y mujer eran, pues, fingidos y esta última se ve aquí súbitamente devuelta a una supuesta naturaleza, la maternidad como destino, que niega toda autonomía a una sexualidad tan tradicionalmente reducida por el «revolucionario» Sender a su mera función reproductora: «El hombre busca a la mujer como un fin. La mujer normal busca en el hombre, sin saberlo, al hijo» (ibid.).

Las modernas feministas apreciarán el valor exquisito de ese adjetivo: «la mujer normal». Como quiera que sea, éstas son las premisas, reiteradas al cabo de treinta años, de un pensamiento que acaso culmina en los Tres ejemplos de amor ya evocados, libro en cuyo tercer capítulo, por ejemplo, dedicado a comentar las relaciones de madame Hanska y de Balzac, se encuentran peregrinos comentarios de la supuesta dieta de la primera ( En las costumbres alimenticias de Evelina figuraba cada día la carne, el vino, el café y los licores de sobremesa. En una naturaleza como la suya los excitantes debían producir efectos devastadores», op. cit., p. 59; el subrayado es mío, C. S.) que derivan fácilmente hacia los tópicos del más añejo machismo:

\footnotetext{
$Y$ la mujer tiene que admirar en el macho alguna cualidad positiva, algo que le dé una impresión de manifiesta superioridad, si no en otros niveles, en el de la fuerza bruta. En la posesión de una mujer por un hombre tiene que haber algo de violación (física, moral, intelectual, espiritual). La mujer ama ser violada y las circunstancias de la violación no le importan mucho. (op. cit., p. 61)
}

Lo que acaso salve estas por otro lado del todo improcedentes teorizaciones senderianas es, en definitiva, su tan discreta cuan declarada arbitrariedad: "voy a decir lo que pienso en esta materia con una gratuidad y autoridad naturales», confiesa en efecto Sender, que justifica su propósito aduciendo el hecho de que «todos los hombres vivos pueden hablar de su vida y construir síntesis propias y proyectarlas sobre la vida de los otros»; lo que, en otros términos, equivale a decir que cada individuo pueda "convertir su vida en la vida» (op. cit., p. 12). Es, pues, del todo inútil buscar a qué verdad responden o dejan de responder las antes referidas especulaciones erótico-literarias del autor aragonés: su único criterio, como él mismo lo reconoce, es el de su propia gratuidad. No hay, pues, lugar a discutir unas opiniones que no pretenden ser más que eso, opiniones de un individuo en el uso de su derecho a formular -bien es cierto que a veces en un tono de cierto amaneramiento- y dar por generalmente buenas sus más singulares opciones. Sólo cabe, entonces, intentar entender cuál es su lógica y cómo ésta incide en su producción literaria. Sin embargo ha de notarse que Sender no por arbitrario dejaba de pretender respaldarse en las más recientes teorizaciones al respecto. Tras haber afirmado que "los especialistas y los filósofos rechazan la generalización del psicoanálisis», afirmaba sin embargo que la «psicología erótica» moderna debía partir del «instinto y desconocer al espíri- 
tu o, en todo caso, tratarlo como una consecuencia accidental y a veces morbosa de lo biológico». A pesar de su aparente rechazo de Freud, todo o casi todo proviene de la infancia para el Sender de la «Carta» de Rusia, que piensa que la «influencia de los demás se ha enderezado contra nuestros instintos" (op. cit., p. 251). La religión, en particular, se le antoja ser un sistema de represión de los impulsos naturales y más precisamente de los instintos sexuales (op. cit., pp. 252-253): «la discrepancia del espíritu y de los instintos es una causa de neurosis", explica entonces Sender.

Esta verdadera alienación provocada por la pervertida educación que en España se daba a los niños bajo el influjo mayormente de la Iglesia, le parecía al todavía joven autor de Imán el producto a su vez de una organización social inadecuada, esto es, más concretamente, de los conflictos de clases que en ella se producían: «lo espiritual ha sido hasta ahora el gran truco de tu clase social, en alianza estrecha con los tabúes tradicionales», le explica a su novia (op. cit., p. 273); y ese «ambiente pequeño-burgués" en que ella vive es el que le ha imbuido de sus erróneos sentimientos de oposición entre «la armonía de [su] cuerpo y de [sus] sentimientos» (op. cit., p. 247). Contra esa degeneración provocada por un "seudoespiritualismo propiciado por una deficiente educación religiosa», Sender, desde Moscú, cree discernir alguna alternativa. Frente a «los intelectuales, los hombres de la clase media y gran parte de la alta burguesía», entre los cuales domina «el amor enervante, el amor-nirvana», existe un pueblo, humilde pero puro, que por su humildad misma vive ajeno a las perversiones y a las supersticiones de las clases altas. En el horizonte intelectual del Sender de la "Carta", Marx releído por el Buen Salvaje sugieren entonces estas líneas impregnadas de un naturalismo ingenuo:

\footnotetext{
Tú podrás preguntarme después de todo esto si, a mi juicio, hay en España otros sectores sociales tan netos y deslindados como el pequeño-burgués, donde se pueda generalizar en sentido contrario. Ese sector existe. Por no haberse asomado a la vieja cultura - son por lo general obreros y campesinos, algunos analfabetos- muchos hombres viven en la verdad armoniosa de los instintos, unidos a mujeres de iguales condiciones, mujeres sin ensueños ociosos y sin supersticiones. (op. cit., pp. 265-266)
}

Parodiando un conocido título de Antonio Machado, puede decirse que Sender vaticina sobre un amor comunista que pudiera venir de Rusia y que éste es precisamente el fundamento de su «Carta»: sugerir que, frente al "amor» tal y como se daba en la España del momento, existía otro posible «amor», un «amor» más natural, conforme con los instintos, liberado diríase hoy, y que acompañaría la liberación toda de la sociedad. «¿El amor entre los esquimales o los cosacos o los kalmucos? Existe, desde luego", le sigue escribiendo a su novia, que le preguntaba qué era el amor en Rusia (op. cit., p. 250); y le añade estas consideraciones optimistas: 


\section{EL LUGAR DE SENDER}

La libertad amorosa de los períodos revolucionarios se presentó con caracteres muy parecidos a los que en su pánico le atribuye la burguesía, pero los instintos en libertad hallaron el buen camino y hoy parece que el sexo como problema lo es menos cada día. (op. cit., p. 269)

Esta concepción general del amor, en el que la sexualidad desempeña un papel tan central para Sender, no podía menos de conducirlo entonces, tarde o temprano, a reflexionar sobre el símbolo mismo del erotismo ibérico, esto es, sobre la figura de don Juan.

\section{TEORÍA DE DON JUAN}

La gran diferencia entre don Juan y los demás hombres, opina al respecto Sender, es que aquél es ajeno a la fundamental ilusión del amor, la que lleva a los amantes a querer «sentir el objeto de su amor como una parte de su propio ser, por lo menos en el mundo moral: una sola conciencia, una sola imaginación, un solo deseo, un pensamiento común para los dos». Como esto no sucede, prosigue el autor, «después de la saciedad de la carne [...] viene la fatiga, la decepción y con frecuencia el odio» (Tres ejemplos de amor, cit., p. 9). Pero para don Juan no hay tal decepción, porque no hay tal ilusión: es el «hombre sabio» que ha renunciado a «la identificación con el objeto deseado" y que por lo mismo más cercano se halla a las verdades inmediatas del ser:

De acuerdo con las leyes de la especie, don Juan busca la hembra, la posee y la abandona para buscar otra. La frecuencia del coito es tal vez la única manera de acercarse lo más posible a la reintegración física, y en cuanto a la otra, la moral, le tiene sin cuidado. (ibid., p. 9)

Para el Sender de los Tres ejemplos de amor, don Juan, en efecto, destruye «la hipocresía y la moralidad y el idealismo retórico del amor (novela pastoril, y Garcilaso y la caterva de las encantadoras Belisas y Filis)», recordando a todo el mundo que el amor es "un placer carnal y que éste es legítimo" (op. cit., p. 89). El triunfo de don Juan, que para Sender es "universal, límpido y sin sombras», sólo se explica, en efecto, porque «representa los derechos de nuestra carne a un placer desnudo de retórica y de falso idealismo». Este particular acercamiento al tema donjuanesco le permite entonces a Sender lograr alguna de sus más acertadas formulaciones, resumiendo el resorte principal de la intriga del clásico Burlador de Sevilla en esta frase: "Comienza don Juan por donde el enamorado idealista termina. Don Juan comienza todos sus amores por la noche de bodas» (op. cit., p. 89).

El autor ya maduro de estas líneas se mostraba fiel así a sus posturas juveniles, aquellas por lo menos que se había esforzado por exponer en su «Carta» de 1934 y por las cuales urgía a su novia a que aceptara «la necesi- 
dad física y la delicia de los sentidos para luego ver lo que hay detrás». «El amor cumple en sí mismo, en la necesidad y la delicia, su propio fin», seguía explicando desde Moscú el joven revolucionario, que añadía entonces:

\begin{abstract}
Pero tanto has soñado tú, tanto has leído en líneas largas y cortas, con música o sin ella, tantos símbolos religiosos, imágenes artísticas se han proyectado sobre vuestros sentimientos, reprimidos por la educación, por la intolerancia, por el miedo metafísico y la vergüenza de la carne, que la necesidad física y la delicia os parecen corruptoras y no las aceptáis como base de discusión. (op. cit., p. 249)
\end{abstract}

"Habéis creado en torno a todo esto", le sigue reprochando Sender a su novia, "una zona cuyos límites desconocéis y tampoco nosotros conocemos. Esa zona pretende enlazar algo tan concreto como el sexo con algo tan vago como el espíritu» (op. cit., p. 250). Y prosigue su lección: «como ves, [...] entre los instintos y lo que tú llamas "lo espiritual", hay espacio para que cada cual trace y construya sus laberintos» (ibid.). Casi cuarenta años más tarde, en 1971, Sender se ratifica en el planteamiento básico de su doctrina amorosa, escribiendo rotundamente, en las "Consideraciones sobre don Juan» de la edición española de su obra teatral: «El sexo conduce al amor y no el amor al sexo"; y, siguiendo en esto por lo menos al por otra parte aborrecido Unamuno, añade: «La existencia es antes que la esencia y don Juan es todo existencia [...]) (Don Juan en la mancebia, ed. cit., p. 18). Y es que la "gran peripecia» del mito de don Juan, sigue exponiendo Sender aquí, «se basa en los instintos desnudos» (ibid., p. 19).

Hay, pues, a lo largo de toda la vida y de la obra de Sender una constante y rotunda reiteración doctrinaria: el amor tiene su origen y su legitimidad en el sexo y todo lo demás es hipocresía, tapujos vergonzantes o disimulaciones malsanas. $Y$ don Juan, mito inasequible en la realidad, no hace más que reafirmar simbólicamente esta anterioridad, mostrando el deseo en actos y deshaciendo los espejismos ilusorios del sentimentalismo, como don Quijote deshacía entuertos. Y es que don Juan, para Sender, apunta a lo más inmediatamente orgánico en el ser humano, designa en él su radical inscripción en el universo natural de las verdades biológicas. De ahí que el autor aragonés discrepara con las teorías, que tanta boga tuvieron en su momento, en las que Gregorio Marañón afirmaba que el donjuanismo era algo así como una inmadurez, una indefinición sexual que asemejaba al seductor y sus víctimas: los éxitos femeninos, opinaba el autor en las "Notas para la biología de don Juan", ${ }^{3}$ se debían a su propio afeminamiento. "Nada menos cierto», responde Sender, que no obstante concede que en el trato con las mujeres don Juan puede adquirir «cierta dulzura equívoca»: "adamados decían antes. Amariconados, dicen ahora», comenta entonces, con la radicalidad lexical que para estos casos suele

${ }^{3}$ Revista de Occidente, III/15 (1924). 


\section{EL LUGAR DE SENDER}

usar el escritor aragonés (Tres ejemplos de amor, cit., p. 87), que, acto seguido, reitera sin embargo su absoluta fe en el sexo de don Juan. Esto es lo que en el seductor busca toda mujer, afirma crudamente Sender con el apólogo siguiente:

[Don Juan] Es sólo un sexo. Es la verdad del amor, desnuda de retórica, de idealismo y de disfraces inefables. El sexo es una virtud, como el amor. Es la primera virtud del amor, el sexo. «Para lo que yo quiero a mi amante plebeyo - dice una dama noble a su hermano que le reprocha esa plebeyez-, sabe tanta filosofía o más que Socrates y Platón juntos". Ésa es la cuestión con don Juan. (Tres ejemplos de amor, cit., p. 92)

Don Juan es, pues, el símbolo de una verdad biológica y natural que hace que, contra todo lo que opinaba Marañón, se halle en el polo opuesto a todas las desviaciones que el Sender de 1934 creía reconocer tanto en los que «sucumbe[n] desenfrenadamente a los sentidos» y para quienes «la perversión ha llegado a la homosexualidad y a otras aberraciones más frecuentes - sadismo, masoquismo, exhibicionismo", como los otros, "espiritualistas exacerbados" en que afloran los signos del erotismo o del «autoerotismo» (Tres ejemplos de amor, cit., pp. 256-258). Cerca de un tercio de siglo más tarde, todas estas teorías, complejas y a veces confusas, seguían teniendo la suficiente vigencia para que su autor acudiese a las mismas para escribir entonces ese "drama litúrgico en cuatro actos» que es, según reza el subtítulo, el Don Juan en la mancebía.

\section{DON JUAN EN LA MANCEBÍA}

A pesar de que figure en la monumental bibliografía donjuanesca de Armand E. Singer, 4 esta nueva versión teatral del mito ha sido escasamente estudiada. Charles L. King, en su ya mencionada bibliografía, complementada en $1983,{ }^{5}$ tan sólo recoge alguna fugitiva recensión periodística del drama en el momento de su edición española. 6 Tampoco la bibliografía actualizada del MLA para los años 1981-1994 o el volumenhomenaje, dirigido por José-Carlos Mainer en $1983{ }^{7}$ proporcionan infor-

\footnotetext{
4 The Don Juan theme: An Amotated Bibliography of Versions, Analogues, Uses and Adaptations, Morgatown, West Virginia University Press, 1993.

5 "A partial addendum (1975-1982) to Ramon J. Sender, an annotated bibliography, 1928-1974", Hispania, 66/2 (mayo de 1983), pp. 209-216.

6 Pere Gimferrer, Destino, 1.822 (2-IX-1972), pp. 32-33, que, sin embargo, no he podido localizar en dicho número; José Mendiola, El Diario Vasco [San Sebastián], 17-IX-1972; Ricard SALVAT, Tele-eXpress [Barcelona], 26-IX-1972; Hoja del Lunes [Barcelona], 12-IX-1972; La Vanguardia española, 27-VII-1972; WILLIAMSEN, Vern G., Books Abroad, 47 (1973), p. 334.

7 Ramón J. Sender. In memoriam. Antología crítica, Zaragoza, Diputación General de Aragón, Ayuntamiento de Zaragoza, Institución Fernando el Católico, Caja de Ahorros de Zaragoza, Aragón y Rioja, 1983.
} 
mación alguna sobre esta obra. Elizabeth Espadas, por su parte, ${ }^{8}$ tan sólo remite a los trabajos entonces inéditos de Gladys Crescioni Neggers - posteriormente editado con el título de Don Juan (hoy). Innovación y tradición en el teatro y el ensayo del siglo XX en España (prólogo de F. Umbral; epílogo, E. Giménez Caballero), Madrid, Turner- y de María Canteli Dominicis. ${ }^{9}$ Salvando, pues, alguna escasa excepción, puede decirse que este Don Juan moderno ha sido ampliamente ignorado por la crítica. Creo por lo tanto que no es improcedente volver un instante al mismo, aunque no sea más que para apuntar algunas de sus características esenciales.

En sus «Consideraciones sobre don Juan», que, como se ha dicho, sirven de prólogo a la edición española del drama, Ramón Sender parte de una definición, etimológica por así decirlo, del personaje: «Don Juan es el calavera máximo", escribe, en efecto, antes de explicar que en la España musulmana las mujeres recluidas en los serrallos tan sólo estaban autorizadas a salir una vez a la semana, permitiéndoseles entonces acudir al cementerio, «que era un parque florido y casi alegre en las afueras de las ciudades" donde disfrutaban de amplia libertad. Siguiendo en esto las indicaciones proporcionadas por el historiador francés Lévi-Provençal (recogidas en su España musulmana -quinto tomo de la Historia de España dirigida por Ramón Menéndez Pidal, Madrid, Espasa Calpe, 1957, pp. 284-285-) y el español Emilio García Gómez, Sender remite en efecto (op. cit., p. 7) a Ibn Hazm —en cuyo Collar de la paloma (siglo XI) se narra un encuentro amoroso en ocasión de la visita de la bella Khalva al cementerio del Arrabal de Córdoba (Ibn Hazm, Le collier de la colombe, Argel, Carbonel, 1949, pp. 57-58)-y, sobre todo, al Tratado en que Ibn 'Abdun, ya en el siglo XII, reclamaba que las autoridades sevillanas restablecieran la disciplina en los cementerios, donde «se permit[ía] que encima de las tumbas se instal[asen] individuos a beber vino o, incluso, en ocasiones, a cometer deshonestidades"; y el moralista árabe pedía mano dura contra tales desmanes en los siguientes términos:

No [...] se consentirá que los días de fiesta se estacionen los mozos en los caminos entre los sepulcros a acechar el paso de las mujeres. [...] También deberá prohibir el gobierno que algunos individuos permanezcan en los espacios que separan las tumbas con intento de seducir a las mujeres [...]. Se ordenará así mismo [...] que registren los cercados circulares [...] que a veces se convierten en lupanares, sobre todo en verano, cuando los caminos están desiertos a la hora de la siesta. (E. GARCía Gómez y E. Lévi-ProvençAl, Sevilla a comienzos del siglo XII. El Tratado de Ibn 'Abdun, Sevilla, Ayuntamiento [«Biblioteca de Temas Sevillanos»], 1981, pp. 94-96)

\footnotetext{
8 «La visión crítica de la obra de Ramón J. Sender: ensayo bibliográfico», en Mary S. VÁsQuez, ed., Homenaje a Ramón J. Sender, Newark, Delaware, Juan de la Cuesta, 1987.

${ }^{9}$ Don Juan en el teatro español del siglo XX, tesis doctoral inédita, New York University, 1974, $258 \mathrm{pp}$.
} 
Como puede verse, al lado de los datos recabados por Víctor Said Armesto en su obra clásica sobre La leyenda de don Juan, Sender pretendía, pues, asentar uno de los orígenes del personaje de don Juan en una tradición islámica que comentaba afirmando que semejantes costumbres se habían mantenido «en los territorios sojuzgados por los árabes» y que "los asiduos de los martelos funerario-galantes eran llamados calaveras porque no salían de los cementerios» ("Consideraciones sobre don Juan», cit., p. 7).

No sé si la explicación es del todo acertada. El caso es, sin embargo, que el Diccionario crítico-etimológico de Corominas-Pascual (Madrid, Gredos, 1984) no recoge literalmente este origen de la curiosa acepción castellana del término calavera con el sentido de tronera, pero también la relaciona con alguna probable influencia árabe, siendo así que lo interpreta como «uno de tantos calcos semánticos» de esa lengua, inspirado en la palabra qahûf, plural de qihf, con significado de 'vil', según explican los autores del mencionado Diccionario, dando por razón de todo ello lo habituales que son «esas metáforas [...] en las lenguas orientales», que tanto chocan «en las de Occidente», que es casi como no decir nada. Más convincente parece por tanto un Sender encandilado que, apoyándose en los ejemplos literarios antes aducidos, afirma por su parte:

\footnotetext{
En el cementerio musulmán se hacía el amor entre las tumbas. Ningún otro pueblo ha llegado a ejemplos de asimilación de contrarios tan extremos. La exaltación de la carne y de sus apetitos desenfrenados comienza con el temblor metafísico ante un misterio nunca descifrado. (ibid., pp. 7-8)
}

Don Juan, calavera en el que se confunden muerte y sexo: independientemente de lo que tenga o deje de tener de cierta la explicación etimológica propuesta, esta conjunción de datos tenía que fascinar a un Sender siempre propenso, como se ha visto, a asentar los orígenes el amor en esos «temblores de la carne» que se evocan aquí. Sin embargo, su aproximación teatral al tema se hace dentro de los parámetros de una tradición más inmediata, en la que desempeña un papel primordial el precedente de Zorrilla. Bien lo demuestra el propio elenco de personajes, en que aparecen por supuesto una doña Inés — «dieciocho años, espíritu virginal»-; el comendador, «en forma de estatua, 50 años», e incluso - verdadera autentificación de la referencia al Don Juan Tenorio- un «Ciuti», aunque ahora presentado como un "hombre tosco» de 65 años, cuyo envejecimiento corresponde al de su amo, ya que el don Juan senderiano, que se sitúa en una tradición bien arraigada a partir de los años veinte de este siglo, es a su vez un hombre envejecido con sus «setenta años», aunque «todavía gallardos".

Si en este aspecto del dramatis personæ Sender se muestra bastante fiel a Zorrilla, no ocurre así con la acción del drama, que se desarrolla «en Sevilla a mediados del siglo XVII", iniciándose en "la tarde del día de las ánimas en 1635", y no, como en el Don Juan Tenorio, bajo el reinado de 
Carlos Quinto. Pero este desplazamiento en el tiempo tiene su razón de ser: y es que al lado de don Juan, o frente a él si se prefiere, no aparece ya un cualquier don Luis Mejía de ficción como en el drama romántico, sino el hijo del propio Miguel de Mañara, "disoluto" y borracho - esc. IV, p. 21-, en claro contraste con un don Juan de quien se elogia todavía la elegancia.

Es bien sabido que, desde Mérimée hasta Dumas y de Dumas hasta Zorrilla, se han ido entrelazando la vida histórica de Mañara y la vida legendaria de Tenorio. Pero en cierto modo Sender da un significado nuevo a esta pareja entre historia y leyenda: el disoluto y arrepentido Mañara (o ese doble suyo que es aquí su hijo) se convierte, de algún modo, en el réprobo, puesto que su final de remordimiento, tan exaltado por la tradición de moralismo religioso y que tan espectacular materialización halla en el hospital de la Caridad de Sevilla, simboliza el rechazo de la legitimidad del amor carnal de la concepción senderiana y por tanto el triunfo de la religión represora. Mañara es, frente a la moral del sexo donjuanesca, la encarnación de la hipocresía represiva: no por nada aparece aquí, en el burdel de Sevilla, acompañado por un familiar de la Inquisición, «enlutado, grave e hipócrita, 50 años», según reza la lista de personajes. Frente a lo que significa, pues, el nombre de Mañara como signo del sexo reprimido, el don Juan senderiano debe reiterar su identidad, increpando entonces a la estatua del comendador en estos términos:

\footnotetext{
Yo busqué la carne y la encontré. Hasta que yo vine a la vida todo era en el mundo hipocresía, retórica y... teología. Teología también. A la hembra se la llamaba el ángel del hogar, un ángel a quien había que pervertir gozosa y secretamente. Ángeles. Diablos y ángeles. Pero la verdad es más simple: hombres. Hombres y mujeres. Tú eres quien blasfema. Yo con mi cuerpo que es todo lo que tengo he cantado la vida. Tú desde tu mausoleo presides la fornicación y la penitencia de los llamados hombres de bien (ríe irónico) en las sacramentales. (Don Juan en la mancebia, ed. cit., p. 35)
}

Conquista de la carne, victoria del sexo, triunfo del cuerpo: tales parecen ser los blasones de don Juan, contra las sombras y contra las teologías; o, lo que viene a ser lo mismo y como escribe el propio Sender en sus «Consideraciones sobre don Juan»: «reapreciación moral del erotismo» (op. cit., p. 9). Y estas verdades son las que le aseguran sus victorias puesto que ellas son también las que mueven en sus similares verdades íntimas a todos los demás personajes y, en particular, a las mujeres. En clara alusión al Burlador de Sevilla, se evoca así una duquesa napolitana -extrañamente llamada ahora «Octavia» en vez de «Isabela»- que una noche le abrió las puertas «al marqués de Tenorio» (1, III, p. 16), no ya para descubrir luego, horrorizada, que se había entregado a un hombre desconocido (el «hombre sin nombre» de la primera escena de la comedia clásica), sino muy a sabiendas de lo que hacía, como en diferentes ocasiones (p. 16, p. 17, p. 22) hace más que sugerirlo su antigua sirviente: «Le abrió la puerta 
al marqués de Tenorio aquella noche sabiendo muy bien quién era. Luego se hizo de nuevas, pero a mí... (Ríe)» (1, III).

Es más, la propia Inés, la heredera de la virginal doña Inés zorrillesca, es presentada aquí desde la perspectiva del erotismo positivo y del deseo inacabable. Muerta, como requiere el caso, surge en el cementerio y en medio de las demás estatuas como figura fantástica que se queja de la brevedad de sus amores y se muestra deseosa de volver a gozar una vez en brazos del seductor:

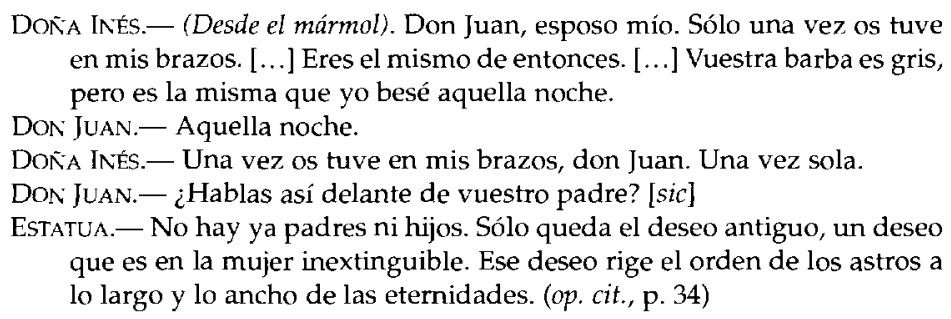

Revisitada por Sender, la famosa escena del sofá no parece haberse limitado al mero disfrute del aire fresco y a la contemplación de las orillas del Guadalquivir: ha sido ocasión de amor, de unos amores de los que ha nacido una hija, esa Beatriz, "hermosa, entre ingenua y pícara, 24 años", que descubre don Juan en casa de Camila, a cuya mancebía ha acudido él al reclamo de un misterioso mensaje y en la que llega a prendarse de su gallarda figura. Pero este nuevo deseo no es sino el de la doña Inés de las sombras, que, en una especie de comunión de los santos heterodoxa y blasfema en la que el alma difunta haría algo como reencarnarse en el cuerpo de su hija viva, trata de (re)conquistar un instante al seductor de antaño, demasiado fugazmente gozado: «Estoy en mi hija esta noche. Por ella te oigo y te hablo», le dice la sombra de Inés a don Juan. Y, de hecho, Beatriz conduce a don Juan hasta el cementerio - en clara referencia al tema erótico-mortuorio del calavera-, donde le revela ser nieta del comendador e hija de esa doña Inés de quien le precisa a don Juan, sin todavía conocerlo, que «fue la mujer más desgraciada del mundo» porque, añade precisamente entre pícara e inocente: «¿No es una desgracia gozar sólo una vez?» (op. cit., p. 26). Ella, como se desprende del diálogo que sigue, no odia a ese padre a quien no conoce; más bien parece admirar a ese «hombre tremendo», como lo califica, usando el adjetivo que en otra ocasión utiliza el propio Sender para caracterizar al tipo donjuanesco (Tres ejemplos de amor, cit., p. 87).

A fuerza de querer demostrarlo todo, es probable que la obra pierda fuerza y sobre todo claridad; $y$, en todo caso, hay momentos en que cae en anacronismos: pese a que la acción se desarrolla a mediados del siglo XVII, uno de los principales malos de la obra, el Chepas, es un supuesto discípulo del condenado por herejía Miguel de Molinos (op. cit., II, VIII, p. 59), cuya Guía espiritual no llegó a publicarse hasta 1675 y sólo fue condenada 
en Roma en 1687. No obstante, perseguido por la Inquisición, este personaje se libra entregando a Beatriz y a su nuevo amante, el escultor Hermenegildo, que esculpe estatuas funerarias con un arte que linda tan de cerca con la magia que parecen quejarse como alma en pena en los cementerios. Pero tanto hereje da pie a que intervenga la Inquisición en el drama, siendo así que se asiste a la riña que opone al familiar, al juez y a su escribano por saber de quién deben ser los condenados y, principalmente, su dinero. Amén de estas referencias confusas a unos complejos trasfondos histórico-teológicos, la trama del drama complica por demás sus peripecias: no contentándose con dotar a don Juan de una hija hipotética amante suya, llega a incluir entre las mujeres seducidas por aquél la propia esposa de Mañara ( «el hijo de Mañara a cuya madre tuviste también en tus brazos", se le dice en algún momento, op. cit., p. 32), de manera que don Juan se ve acosado, en palabras de la estatua, por «una hija que quiere ser [s]u manceba y un adalid de [s]us enemigos». «Ella te desconoce. Él te odia y te busca», concluye entonces, fúnebre, el comendador de marras (op. cit., p. 32).

\section{¿HACIA UN MATERIALISMO AMOROSO?}

Mucho me temo que, en el momento de escribir este nuevo Don Juan, efectivamente Sender se "haya metido en camisa de once varas mezclando lo divino con lo humano", como él mismo dice hablando de su drama en las «Consideraciones sobre don Juan» (op. cit., p. 14). Arcaísmos estilísticos ("yo los vide», p. 13) mezclados con algún díptico valleinclanesco ("¿un ánima o un bellaco?»: la pregunta en el cementerio - p. 85- recuerda aquella de Romance de lobos: «¿sois almas en pena o sois hijos de puta?»); drama entrecruzado con farsa (el san Pedro burlesco como guarda de comisaría que juzga a un don Juan alborotador y su acción, una «labor sediciosa», p. 93; el simulacro de Catálogo de conquistas: «veintinueve páginas a tres columnas», en la categoría de "pecado de Adán», p. 91); cierta opacidad deliberada (doña Inés habla por imágenes oscuras, comentando: «mi idioma, [...] es el idioma de después. Todos éstos hablan el de antes», p. 108) acompañada por un estilo llano y a veces rayano en la vulgaridad: todo esto, y todo lo demás, es sin duda excesivo y hace que la obra carezca de una indispensable unidad, de forma que ahí donde su admirado Valle-Inclán hubiera desarrollado un esperpento Sender no pasa a menudo de truculento. Queda entonces un proyecto, sintomático: el de reivindicar a don Juan, contra don Juan de algún modo, puesto que éste no es ya aquí ningún burlador sino, muy por lo contrario, algo así como la propia Verdad, esa verdad de la carne y del instinto que proclama Sender contra la mentira de opresiones y represiones. Su única ambición es "afirmar su presencia y decir a los demás: aquí estoy» (op. cit., p. 94), en "un simple y sostenido acto de presencia» (op. cit., p. 95), en cuyo fondo 
late algo como una «voluntad» que tiene no poco que ver con el Schopenhauer de El mundo como voluntad y representación al que en sus «Consideraciones sobre don Juan" remite explícitamente Sender (op. cit., p. 26). En la perspectiva senderiana, de lo que se trata es de afirmar la dimensión natural del amor, física por no decir fisiológica: ¿como primer paso hacia lo que pudiera ser una concepción materialista del amor? No cabe duda de que en sus tiempos juveniles de la «Carta», allá por el año 1934, ésta era la ambición de Sender: elaborar una teoría materialista del amor. Pero han corrido luego los años, con ellos la historia y con ésta han ido evolucionando las posturas de Sender, que sin embargo apostilla el libro Tres ejemplos de amor con esta última frase dirigida «al lector o lectora: Dios te depare buena suerte en tu camino. En tu amoroso camino hacia el amor» (op. cit., p. 286). Pero algo ha cambiado, de tal forma que a la hora de presentar en el mencionado volumen la famosa "Carta» de 1934 le pone ahora un -leve- reparo, escribiendo: «He recordado esa "carta de Moscú sobre el amor", aunque revela alguna inmadurez. Ésta consiste en la radical aversión al idealismo metafísico" (Tres ejemplos de amor y una teoría, cit., p. 279).

En efecto, la ingenua perspectiva de un materialismo erótico de los años treinta, que se proponía combatir y denunciar el espíritu, «esa "superestructura" fluida», como la designaba en la "Carta» (op. cit., p. 255), en nombre de los instintos, ha dejado lugar a una suerte de nuevo «idealismo metafísico» - por decirlo en las propias palabras de Sender-. Por supuesto, permanece vigente su adhesión a una filosofía de la existencia en la que domina una fuerza inmediata, principio - en todos los sentidos de la palabra- vital e impulso primordial que encuentra su plasmación en la imagen biológica: es lo que podría llamarse su concepción ganglionar de la existencia. Tras haber concluido Werther, Goethe "conservaba la fe ganglionar en el amor y no la perdió a lo largo de su vida», escribe el Sender maduro (Tres ejemplos de amor, cit., p. 19), que evoca al mismo tiempo «las leyes oscuras y poderosas del inconsciente ganglionar» (ibid., p. 19) o proclama la «función glandular» de la especie que late en el fondo del mito de don Juan (ibid., p. 89). Pero su Don Juan en la mancebía revela algo más que ese elementalismo de las glándulas y que tiene sin duda que ver con unas nuevas convicciones, de carácter religioso aunque siempre supuestamente articuladas sobre verdades científicas. El «drama litúrgico»-y el adjetivo es aquí sintomático del registro religioso en que busca situarse ahora Sender- oscila entre la reiteración del ganglionarismo de antaño y una nueva dimensión espiritual. De ahí viene que la obra esté constantemente oscilando entre un universo fantástico-religioso y su contrapunto realista. Las estatuas se quejan como almas en pena, pero por destreza del escultor; y si los muertos aparecen es en las pantallas de un hipotético cine, según rezan las didascalias, de forma que no se sepa si esas apariciones son ilusiones de la técnica o verdades de ultratumba.

Y posiblemente son ambas cosas a la vez. Porque, en torno a 1970, el pensamiento de Sender ha evolucionado ya hacia posturas más religiosas, 


\section{CARLOS SERRANO}

que no anulan sin embargo su anterior fe en la ciencia: «mi fe religiosa deb[e] ir acompañada de alguna clase de convicción lógica. De otro modo no pasaría de ser una emoción lírica, como otras", escribe en una de sus últimas obras, el curiosísimo libro titulado Ensayos sobre el infringimiento cristiano, que se publicó en $1967 .{ }^{10}$ En esta obra expone su nuevo sentido religioso y los objetivos, entre espirituales y materiales, que se asigna en esa fecha, entre los que domina la consecución del Absoluto Real (op. cit., p. 282), en el que confluyen religión, esoterismo, ciencias... y cuyo fundamento parece ser ese "infringimiento [...] de la verdad total anterior que ignoramos o la ley establecida que no conocemos y a la que tratamos de acercarnos tanteando como los ciegos», como explica el autor en su prólogo, añadiendo a modo de comentario: «ese infringimiento a priori es el primer peldaño inevitable para seguir adelante» (op. cit., p. 13). En este nuevo contexto, el don Juan senderiano, que hasta entonces sólo había sido el símbolo de las verdades ganglionares, cobra un nuevo significado, transformándose de héroe del sexo en paladín del Infringimiento y del Absoluto.

10 México, Mexicanos Unidos; reeditada en 1975 en Madrid, Editora Nacional («Biblioteca de Heterodoxos y Marginados»), que es la que uso aquí, p. 11. 
ni 


\title{
Cómo narrar la aventura (Sobre El bandido adolescente)
}

\author{
Fernando Savater \\ Universidad del País Vasco
}

La narración por excelencia, que precede a todas las demás, las posibilita y las subyace, que asoma entre las otras de vez en cuando como un gran mamífero marino emerge de repente para respirar en medio de un cardumen centelleante y viscoso de peces menores, es la narración de la aventura. Porque es la aventura lo digno por antonomasia de ser contado y es ese cuento el que despierta la atención que luego tantos otros relatos de diverso corte sabrán aprovechar. Llamo aventura a la gesta del héroe aventurero: una saga de peripecias en las que un mortal desafía la rutina de la mortalidad y vive por un breve o largo momento - siempre sólo un momento, empero, porque en la aventura no cabe instalarse- sin ceder al miedo, a la renuncia o al lamento. Los demás, los que vivimos asustados, renunciando y quejándonos, queremos escuchar la crónica de ese hermano insólito para estimularnos con su triunfo aun si culmina en el desastre de la muerte, pues la muerte del aventurero parece rescatada por lo que la precedió. Tanto esa muerte como esa vida pertenecen al ámbito del coraje, en el que nada resulta totalmente fallido y hasta la más ciega necesidad se alza en destino.

Pueden no ser individualistas todos los aventureros, pero al menos son declarada y notoriamente individuos, por mucho que se agrupen. La 
aventura es siempre personal o no es aventura, sino incidente o accidente. Meterse en aventuras supone individualizarse, fraguarse una personalidad, salir del rebaño. Uno puede salirse del rebaño solo o acompañado de otros cien mil, porque lo propio del rebaño no es el número - hay rebaños de uno y muchos de dos- sino la mentalidad: friolera, ahorrativa, resguardada. Los aventureros se van siempre del rebaño, se oponen a él: son inevitablemente egregios. Hay muchas formas de llegar a la aventura. Los unos la buscan por curiosidad o por la inquietud rebelde de su carácter, otros la asumen bajo presión de una vida inclemente, implacable, pero que siempre es vida y por tanto estímulo genial para quien sabe aprovecharla (los jóvenes protagonistas de $A$ través del desierto de Sienkiewicz, por ejemplo, o el capitán de quince años cuya crónica maravillosa escribió Julio Verne). Lo único que sabemos de cierto es que el protagonista debe aceptar inequívocamente su aventura, sea sonriendo ilusionado o refunfuñando. Uno puede ser aventurero por cualquier motivo menos por inercia o por descuido. En cambio es muy posible verse arrastrado por una aventura menor a otras mayores: cada aventura asumida predispone a otras, las atrae, las desencadena. Es arte difícil ser moderadamente aventurero...

Hay aventureros moralmente inocuos, que ni desafían ni defienden los valores de la comunidad a la que pertenecen: son los que se miden ante todo con el obstáculo por excelencia, la naturaleza, y viajan, exploran, escalan, cazan, navegan, bucean, arrostrando de mil maneras lo inhóspito y agresivo de nuestra madrastra. En otras ocasiones, el aventurero es un paladín de su grupo (familiar, tribal o nacional, incluso de la humanidad entera) y lucha contra los enemigos externos o internos que lo amenazan. Este tipo de aventurero llega a convertirse en héroe y quizá alcance finalmente la dignidad de jefe, por lo que a su evidente utilidad une no menos evidentes peligros: una muerte gloriosa y temprana le es siempre favorable, según dejaron hermosamente dicho poetas épicos griegos como Homero o Simónides. Pero se dan también aventureros de otro modelo, aventureros del lado de sombra de las sociedades, perturbadores, dañinos, destructores, que transgreden sin titubear las leyes e introducen el desorden de su entropía audaz en el cosmos pacífico al que se acoge la mayoría. No me refiero, claro está, al fuera de la ley que se enfrenta con un orden injusto para reivindicar los derechos de los suyos, como Espartaco, ni al bandido generoso estilo Dick Turpin que remedia con lo que roba a los ricos la menesterosidad de los pobres, ni al justiciero enmascarado - hay muchos en las crónicas, demasiados- que castiga sin remilgos jurídicos la prepotencia astuta de los enemigos de los débiles.

No, hablo de auténticos ladrones por interés propio como el Raffles de Hoffnung, incluso de asesinos como el Ripley de Patricia Highsmith o de seductores sin escrúpulos como el don Juan de Tirso, de Molière y de Zorrilla. $\mathrm{O}$ de pistoleros como Billy the Kid. Son aventureros que hacen pupa y que dejan tras de sí un reguero de víctimas que deberían despertar en los lectores más simpatía que ellos pero que sin embargo rara vez lo 
logran. Se prefiere en cambio la energía de esos diablos, su capacidad perversa de pasar por encima de convencionalismos cuyo beneficio aceptamos sin embargo como indudable. No quisiéramos tropezar con ellos pero nos alegramos de que existan de vez en cuando. Es como si para soportar mejor nuestra domesticidad necesitásemos también sentir cierta complicidad puntual, estética, con los indomables. Ellos nos muestran los riesgos pero también la osadía que hemos sacrificado para obtener la continuidad normativa en la que prosperan los negocios y crecen nuestros hijos. Como nos enseñó Aristóteles respecto a los protagonistas trágicos, profesamos hacia estos aventureros aciagos una mezcla de piedad y de temor; piedad porque derrochan con obstinada generosidad el ímpetu sobrante de la sociedad que les excluye, temor porque en el fondo nos gustan aunque su desplante sería fatal para nosotros, los que solemos pastar en rebaño.

Contar la historia de estos aventureros transgresores presenta literariamente dificultades especiales. Es preciso conservar sin idealizaciones ni excusas oportunistas la dimensión asocial e incluso brutal del personaje pero con la habilidad de no hacerle tan repelente como para que el lector rechace cualquier identificación simpática con él y su destino. Si nada nos une emocionalmente al protagonista de la aventura (ni siquiera la admiración por su coraje o su destreza) seguiremos sus peripecias con más impaciencia que interés; desearemos el desenlace en lugar de temerlo, que es el más inequívoco síntoma de fracaso en un relato de este género. Por otra parte, el cronista debe superar la tentación moralizante de pretender edificar a los lectores por medio de las desventuras o castigo final del aventurero, no digamos ya de su arrepentimiento postrero (aunque es lícito que utilice la coartada del ejemplo moral a contrario para despistar a la censura en épocas intolerantes o serenar irónicamente la conciencia de los hipócritas, como suelen hacer Sade y otros autores pornográficos). Ninguno de los comentarios edificantemente vengativos de las amantes burladas por don Giovanni que cierran el libreto de Da Ponte para la ópera mozartiana pueden borrar de nuestros oídos el fiero «iSuelta, viejo fatuo!» con que el burlador repudia in extremis la mano del comendador que puede salvarle del infierno si acepta arrepentirse. Pero también debe el narrador evitar convertir a su protagonista en una especie de santo de la inmoralidad, entendiendo ésta como una serie de valores más auténticos que los comúnmente admitidos o denunciando las lacras nunca escasas de la sociedad que le condena. El personaje asocial tendrá inevitablemente su propio código, pues sin código mejor o peor nadie puede vivir ni sobre todo actuar de forma mínimamente relevante; pero si ese código sin otra sanción que la individual se propone como preferible al vigente o al menos como una alternativa plausible, la idiosincrasia luciferina y trágica del aventurero queda neutralizada para convertirlo en un reformador de las costumbres aún lamentablemente incomprendido o en un crítico del sistema vigente. Sus radiantes fechorías se degradarán en arengas y perderá el estado de gracia del rebelde, que no consiste en apuntar nuevas 
convenciones sino en desobedecer en su provecho las reinantes. Quien cuente la aventura de uno de tales diablos debe saber conservarle juntamente fatal y atractivo, comprensible aunque no justificable, enemigo de la mayoría y amigo de pocos pero sobre todo de sí mismo, lo cual le emparenta por cierto con la índole secreta de todos los demás y le vincula sin avasallarle con la razón última del orden establecido.

Ramón J. Sender es el gran narrador español de la posguerra, el más puro y sólido, el más sobrio, el más intenso, el más dramático también, entendiendo el drama ante todo como conflicto ético en determinadas circunstancias históricas. Su prosa no gorjea ni se entretiene con lo juguetón o con esa subespecie de lo juguetón, el lirismo de oficinista que cuela metáforas domingueras entre fieles transcripciones de exabruptos callejeros para inflar así lo que alguno tomará por estilo actualísimo de alto coturno. Al menos en dos ocasiones eligió Sender como tema narrativo la crónica verídica de las andanzas de un aventurero del género aciago que antes se ha descrito, en La aventura equinoccial de Lope de Aguirre y en El bandido adolescente. Es la lectura de esta última la que motiva las reflexiones de la presente ponencia.

El bandido adolescente cuenta la vida y andanzas de un personaje real que se apoderó de la imaginación popular, Billy the Kid o Billy el Niño, como solemos llamarle por aquí. La novela pertenece a un género también eminentemente popular, el del oeste y sus pistoleros, que ha tenido cultivadores de gran éxito público y poca aceptación entre los críticos literarios menos condescendientes: los que fuimos muchachos hace más de treinta años no olvidamos las historias de aquel minucioso dentista de Nueva York, Zane Grey, o de José Mallorquí y Marcial Lafuente Estefanía entre los autores de nuestro país. Las novelas de género tienen una serie de rituales y convenciones que el aficionado exige sin remilgos pero que mecanizan un tanto el relato, encorsetando al escritor aunque quizá de manera no más grave que el metro y la rima del soneto encauzan al poeta que lo elige como forma para sus versos. Por eso hay que mirar con cierta desconfianza las incursiones de los novelistas considerados «serios» por la crítica, los de primera $\mathrm{A}$, en el ámbito deliciosamente claustrofóbico de la literatura policíaca, del oeste o de terror. Cabe temer que se sientan por encima de su tarea y que pretendan hacer «mucho más» que una simple novela de género (lo que para el lector aficionado suele ser en realidad «bastante menos») o que se plieguen a sus normas implícitas de forma obsequiosa pero falta de soltura. En general es difícil que se resignen a no incluir algún morceau de bravoure que ofrezca muestra fehaciente de la amplitud de sus facultades, transitoriamente constreñidas por los requisitos formales del género elegido. El malentendido cultural que supone al premio Nobel más capaz de escribir una buena novela policíaca que a Conan Doyle o Patricia Highsmith (quienes nunca podrían ganar dicho galardón precisamente por su aptitud para escribir novelas policíacas) es pariente próximo del error que supone al superdotado Plácido Domingo 
mejor intérprete de corridos que Jorge Negrete o mejor cantor de tangos que Gardel, incluso primo lejano del que busca los más suculentos bocadillos de calamares en restaurantes de cinco tenedores en lugar de en bares modestos pero especializados.

La incursión de Ramón J. Sender en la novela del oeste es modélica por su forma de lograr a través de una sabia modestia de estilo la máxima agilidad eficaz en la narración. El bandido adolescente supera en efecto a la mayoría de las obras del género pero no desentona nunca pedantemente con él. Puede satisfacer por igual a un entusiasta de Zane Grey y también a cualquiera de los más exigentes lectores del propio Sender.

El encanto de este libro proviene a mi juicio de que sabe ser juntamente veloz y detallista. Está contado con una prosa rapidísima, impresionista, que no se enmaraña en largas descripciones pero que va surtiendo su efecto en el lector por la superposición de breves impactos que cercan el suceso que se pretende contar en lugar de remansarse en él directamente. La muerte de un personaje importante sólo se menciona en tres palabras, pero viene acompañada de frases secas y leves que aluden a lo polvoriento del camino en que murió o al comentario alarmado de un transeúnte que presenció la refriega. Se consigue así una visión más intensa y desolada del suceso, así como la sensación del vértigo de lo irremediable que todo lo arrastra como un viento tenaz. El propio personaje de Billy está descrito del mismo modo, con simples avisos tajantes que a veces apuntan a lo esencial de su carácter y otras a una circunstancia menor pero relevante en un momento concreto de la historia. Se hace hincapié a trechos en la condición perpetuamente juvenil del pistolero, en su personalidad de puer æternus, por utilizar la terminología jungiana. Al principio se nos advierte que «usaba el Kid su revólver como un juguete rápido y eficaz»; más adelante, aprendemos que Billy "tenía la misma afición que tienen ahora los niños de todas partes a jugar a los indios, con la sola diferencia de que los revólveres despedían plomo caliente y en aquellos juegos los muertos no volvían a levantarse»; más tarde su acelerado tiempo se va cumpliendo y entra «en una clase curiosa de vejez: la vejez de su adolescencia»; cuando la bala traicionera de Pat Garrett le hiere justo encima del corazón, partiéndole la aorta, «Billy cayó al suelo y se le oyó respirar y toser unos segundos como un niño que se ha atragantado bebiendo leche. Luego el silencio para siempre».

Marcado así por el signo de la perpetua inmadurez, Billy se caracteriza por otros dos rasgos que determinan su impacto en la imaginación de quienes le conocieron: su coraje y su jovialidad, siendo esta última algo así como la manifestación gozosa de aquel. «Bebía y reía — cuenta de él su enemigo y ajusticiador Pat Garrett-, cabalgaba y reía, hablaba y reía [...] mataba y reía también. No eran risas insolentes ni carcajadas histéricas, sino expansiones casi infantiles y pequeños gorjeos de alegría. Aquellos gorjeos de Billy eran a veces el último rumor que oían sus víctimas, sin embargo». En cuanto al coraje, Billy fue un valiente pero no un valentón, 
que quizá sea lo opuesto. Había más cordura que romanticismo en su coraje: pensaba con razón que valiente es quien dice la última palabra, no la primera, pues ésta suele pronunciarla casi siempre el tonto. «Nunca sacó Billy el revólver en vano - dice Sender- aunque siempre mató de frente». Sin embargo, después sabremos que al menos en una ocasión el Kid mató por la espalda y que ese reproche le ha de perseguir más que sus otros crímenes. Es un buen detalle narrativo de Sender esta contradicción, como si en las primeras páginas de la novela se nos contase lo que Billy siempre quiso ser y luego el relato nos decepcionara un poco, al modo en que suele portarse la vida. Aunque su valor no tiene nada de suicida, la veta caballeresca de Billy se mantiene viva gracias a su culto a la lealtad, que «era una de las normas de Billy que se podía considerar innata en él. Y no esperaba forma alguna de reciprocidad ya que se pagaba a sí mismo que había aprendido tal vez de su madre cuando ella le hablaba de los caballeros de la Tabla Redonda». Esta fidelidad a los amigos es el eje de su relación ambigua y humanísima con su antiguo compañero Jesse Evans, su "amigo mortal" (en parejo sentido a cuando se habla de "enemigos mortales»), que podría haber sido su víctima o su verdugo pero finalmente será su vengador. El Kid se crió sin padre, aún peor: con padrastro, envuelto en los soñadores cuentos irlandeses de su madre como por las alas débiles pero mágicas de un hada. Su carrera de pistolero comienza de muy niño, ajustándole las cuentas a uno que le ha faltado a su madre; después culminará su trayectoria castigando a los responsables del asesinato de otro inglés, Tunstall, que por la amplitud de su cultura pero sobre todo por su madurez humana se había convertido en una especie de sustituto ideal del padre. Aunque Sender señala que «tenía Billy un sentido de solidaridad que no era de familia ni de clan sino de especie humana, excluidos los indios", lo cierto es que mostró ante todo fiero apego por los suyos, por los ancestros europeos caballerosos, inquisitivos y científicos de los que quiso descender por vía materna y paterna, lo cual no le impide sino todo lo contrario experimentar constante simpatía por la gente hispánica con la que se codea en sus vagabundeos por Texas y Nuevo México, herederos algo maltrechos de aquellos terribles aventureros del siglo xvi que intimidaban a sus enemigos rugiendo: "Me vais a soñar, hijos de puta".

No hubiera estado de acuerdo Billy con el título que Sender pone a su crónica: El bandido adolescente. Protestaba el Niño diciendo que él no era ningún ladrón pues «el que pone limpiamente su vida en la aventura ese no es ladrón, sino guerrillero o conquistador». Sin embargo, el narrador no edulcora a su personaje, que además de aventurero es también ladrón, asesino y no siempre simpático. Sender recuerda al lector desde la primera página que el joven pistolero vivió en una época y en un país donde apenas existía el derecho; en cierto modo, él mismo fue «ese brazo del instinto social que precede históricamente en todos los pueblos al establecimiento de algún orden jurídico. El rifle entonces hacía la ley y a veces la ley era casi razonable». Pero no es ese discutible carácter precursor de una 
legalidad más civilizada lo que convirtió a Billy el Niño en leyenda, como sabe muy bien el cronista de sus correrías. Otras dos cualidades suyas apuntalan su pedestal en la memoria de los que le conocieron y de quienes hemos leído sobre él: primero, su firmeza voluntariosa, indispensable a todo tipo de aventureros, que el mismo Billy subrayó diciendo que «en la vida todo lo hace la voluntad»; en segundo lugar, su coraje ante la ronda perpetua y apremiante de la muerte. «Es verdad - comenta sobriamente el narrador - que en todas partes se admira a los que desprecian la vida y tal vez eso quiere decir que frente a los grandes problemas (vida o muerte) nuestra razón no es más que un juego de infantes y hay valores más importantes que la muerte y la vida». Páginas atrás había dado con una clave aún más sucinta de este tema esencial: «El problema no está en evitar la muerte, lo que es imposible, tarde o temprano, sino en evitar el miedo a la muerte». No hay fórmula más condensada ni más exacta para comunicar la entraña de nuestra sempiterna admiración por aventuras y aventureros. Malo o bueno, sociable o fuera de la ley, el héroe de la aventura triunfa sobre el miedo a la muerte. Y el impacto de esa victoria, la más alta y quizá la única verdadera que los hombres pueden alcanzar, se refuerza cuando el aventurero rinde pronto su tributo necesario a la muerte misma, subrayando así la veracidad de su desplante. La muerte, a fin de cuentas, nunca es la conclusión, porque la noticia que trae el narrador no es la del imperio de la muerte que todos conocemos sino la buena nueva de que es posible desafiarla sin temblar.

En diversas poblaciones de Nuevo México — cuenta Sender- se exhiben calaveras que pretenden ser la auténtica de Billy el Niño, robada por nadie sabe quién de su tumba prematura. En cada uno de esos cráneos y en sus órbitas deshabitadas buscan algo los fetichistas. ¿Qué buscan? ¿Qué buscamos los lectores del relato de aventuras? Probablemente, el secreto simple pero huidizo de la intrepidez, tal como un gran hombre de antaño - el duque de La Rochefoucauld - la describió en su día: «La intrepidez es una energía extraordinaria del alma que la eleva por encima de las turbaciones, de los desórdenes y de las emociones que la visión de los grandes peligros podría despertar en ella, y gracias a esa fuerza los héroes se mantienen en un estado sereno y conservan el libre uso de su razón en medio de los sucesos más sorprendentes y más terribles». Ahora nos parece oír a lo lejos el gorjeo de la risa de Billy, como un reto o una convocatoria. 
, 
COMUNICACIONES 
$-1$ 


\title{
«El puente imposible»: el lugar de Sender en la polémica sobre el exilio español de 1939
}

\author{
Manuel Aznar Soler \\ Universitat Autònoma de Barcelona
}

El hispanista norteamericano Robert G. Mead, Jr., profesor de la Universidad de Connecticut, publicó en la revista Books Abroad, editada por la Universidad de Oklahoma, un artículo titulado «Dictatorship and Literature in the Spanish World ${ }^{1}$ que, a partir de 1951, iba a desencadenar una larga e interesante polémica sobre las relaciones entre literatura, historia y política, es decir, sobre la situación intelectual de España bajo la dictadura franquista y sobre el lugar del exilio español de 1939 en nuestra cultura. En esta polémica intervinieron tanto intelectuales españoles que vivían en la España franquista (Julián Marías, José Luis L. Aranguren) como algunos hispanistas norteamericanos (Dwight L. Bolinger, Elías L. Rivers) y diversos intelectuales exiliados, entre los cuales destaquemos a Arturo Barea, Guillermo de Torre, un grupo de escritores españoles exiliados en Argentina, Jerónimo Mallo o Ramón J. Sender, cuyo artículo titulado "El puente imposible» constituye el objeto fundamental de nuestro análisis.

1 Robert G. MEAD, Jr., «Dictatorship and Literature in the Spanish World», Books Abroad — An International Literary Quaterly»-, 25/3 (verano de 1951), pp. 223-226. 


\title{
EL LUGAR DE SENDER
}

\section{BREVE HISTORIA DE UNA LARGA POLÉMICA}

\author{
El propio Mead, que volverá a intervenir en esta polémica al menos \\ dos veces más, resumirá en 1954 el sentido de su primer artículo en estos \\ términos:
}

Al redactar mi "Dictatorship and Literature in the Spanish World» mi propósito fue bien sencillo: resumir lo que me parecía la verdad acerca del actual mundo intelectual español. Lejos estaba de la intención de provocar polémicas ni mucho menos de ganarme la reputación de hispanófobo. ${ }^{2} \mathrm{Me}$ dirigía principalmente a los lectores de Books Abroad, personas, lamentable es registrarlo, que en su mayoría ignoran mucho de lo que pasa en España e Hispanoamérica. Mis alegatos capitales, y me limito aquí a bosquejarlos, eran que el régimen de Franco, mediante la censura y otros recursos represivos, había deformado el normal desenvolvimiento intelectual del país, dejándolo trunco o poco desarrollado en varios sentidos. Señalé la magna pérdida en todos los ramos del arte y del pensamiento que había sufrido España como resultado de la emigración forzada o voluntaria de tantos de sus hijos. ( $Y$ no olvidemos que, junto con estos intelectuales y artistas, se expatrió una multitud de personas más humildes, obreros y labradores, que también representan una merma sensible para la nación). Recordé la complicidad de muchas casas editoras en la campaña oficial de eliminar de los libros los nombres de aquellos escritores y críticos que fueron republicanos. Apunté el hecho de que una gran parte de la producción de los historiadores, ensayistas y eruditos peninsulares después de la Revolución se canalizara en el desarrollo de temas patrióticos o religiosos, con su énfasis reiterado y frecuentemente hueco sobre la hispanidad, o en trabajos de filología o lingüística, etc. Noté que no eran numerosas las referencias que se hacían a figuras o sucesos contemporáneos, y que las pocas referencias de esta índole que sí se hacían tendían a ser denigrantes, ambiguas o inocuas. Me creía autorizado a colegir que, bajo estas circunstancias, el florecimiento intelectual de España (y conste que nunca negué que existiera tal florecimiento) no presentaba un aspecto robusto y variado. En cambio, me parecía que la constelación de los españoles peregrinos, dispersos en varios países de América pero principalmente en México, la Argentina y Estados Unidos, ofrecía un aspecto bien distinto. Éstos, a pesar del trauma que sufrieron al dejar patria y hogar, pronto reaccionaron en la mayoría de los casos y, trabajando en una libertad de pensamiento y expresión inusitada, con el transcurso de los años lograron producir una obra intelectual y artística de tal variedad y mérito que a la vez honra a España y representa una valiosísima aportación a la cultura de las naciones donde residen. De todo esto no pude menos que deducir que la emigración representaba una pérdida inestimable para España y un beneficio de semejante magnitud para los países hispanoamericanos. Continuando la misma cavilación, llegué a la conclusión de que mientras continuasen imperando las varias limitaciones a la libertad de expresión que ha impuesto el actual régimen, negras en verdad eran las perspectivas para el futuro desarrollo intelectual de España. Me parecía, dadas las circunstancias, que una prolongación indefinida del régimen significaría la pérdida

2 Elías L. Rivers había calificado el primer artículo de Mead, a mi modo de ver injustamente, como ejemplo del "ataque tendencioso de una tradicional hispanofobia yanqui» en su "Carta de Norteamérica. Temas hispánicos a través de las revistas», Insula, 94 (15 de octubre de 1953), p. 8 
para siempre por parte de España de cualquier preeminencia que ella hubiera tenido en la orientación intelectual del mundo de habla española. ${ }^{3}$

Julián Marías replicó al primer artículo de Mead con otro titulado «Spain is in Europe», que publicó la propia Books Abroad $d^{4}$ y que, en una versión ampliada, apareció también ese mismo año de 1952 en la revista peruana Mar del Sur. No nos interesa ahora analizar todos los elementos de esta polémica sino, ante todo, los que tengan una relación directa con «El puente imposible» de Sender. Por tanto, de la réplica de Marías sobre un tema que él mismo califica como «interesante y peliagudo", 5 destaquemos cuatro aspectos: en primer lugar, «que la emigración intelectual española es de un volumen, un valor y una importancia histórica superiores a lo que el Sr. Mead haría pensar. Y, ni que decir tiene, representa un problema intelectual, político, moral e histórico - no se salte el lector ningún adjetivo- - de primera magnitud y que merece atención grave y suficiente; y, cuando ésta no sea posible, respetuoso silencio». 6 Pero si Marías nos ha proporcionado una de cal, ahora viene en segundo lugar la de arena cuando, contra Mead, agrega sorprendentemente - confundiendo acaso su deseo con la realidad - que «lo que no se puede decir, en cambio, es que estos intelectuales estén totalmente perdidos para España; su relación con ella es considerable; leen a los escritores que viven en España, son leídos por ellos y por los españoles que no escriben; la gran mayoría de los libros españoles valiosos publicados en América se encuentran en las bibliotecas y librerías españolas», y añade además para mayor perplejidad que «en las historias de la literatura española no se olvida a los escritores emigrados. $Y$ en las revistas se habla con toda frecuencia de ellos». ${ }^{7}$ Consecuente con esa tan idílica como, a mi modo de ver, irreal situación de libertad de la cultura española bajo la dictadura franquista, Marías afirma por tanto, en tercer lugar, «que en España existen grupos considerables que cultivan

\footnotetext{
${ }^{3}$ Robert G. MEAD, Jr., "Meditación sobre la libertad intelectual en el mundo hispánico", Cuadernos Americanos, 2 (marzo-abril de 1954), pp. 48-49. El propio autor reproduce este artículo en las páginas iniciales de su libro Temas hispanoamericanos, México, Ediciones de Andrea («Colección Studium»), 1959, pp. 5-12.

4 Julián MARías, «Spain is in Europe», Books Abroad, 26/3 (verano de 1952), pp. 233-236.

5 Julián MARÍAS, «España está en Europa», Mar del Sur. Revista peruana de cultura, año IV, 23 (septiembre-octubre de 1952), p. 65. De una manera muy simplificadora, soberbia y despectiva se refiere el propio Marías a este artículo de Mead en otro posterior suyo, donde escribe que «tampoco un profesor americano ha sentido escrúpulo en afirmar que en España no hay más intelectuales que media docena de ancianos; aunque en este caso hay que advertir que la revista en que tal afirmación fue publicada se apresuró a imprimir un artículo mío en que se mostraba la grotesca falsedad de aquella tesis». Este nuevo artículo de Marías se titula "El problema de la libertad intelectual» y fue reproducido por el Suplemento de Ínsula, 86 (15 de febrero de 1953), p. 2.

6 Ibid., p. 67.

7 Ibid., p. 67.
} 
intensamente todas las disciplinas intelectuales» y «que su número -como podía anticiparse a priori- es enormemente mayor que el de los radicados en el extranjero». ${ }^{8}$ La fundación en 1948 por parte de Ortega y Gasset del Instituto de Humanidades viene a probar, a su juicio, la calidad intelectual de esos "grupos" sin advertir que, en todo caso, ese Instituto sería la excepción que vendría a confirmar la regla. Pero vayamos al cuarto y último aspecto, sin duda el más interesante. Porque Marías, contra la «progresiva implantación de la mediocridad en todas las esferas del pensamiento" defendida por Mead, acierta a poner el dedo en la llaga cuando plantea «el impacto producido por la guerra civil y sus consecuencias, enorme traumatismo histórico del que España no está todavía curada, y ése es precisamente el problema", ${ }^{9}$ un problema que, sin embargo, soluciona en estos términos:

El supuesto básico del Sr. Mead, el que vicia e inutiliza su artículo entero, es lo que podríamos llamar su politicismo. Quiero decir su creencia de que lo primero, decisivo y más importante, es la política. [...] Como si no fuese la política un fenómeno relativamente superficial y epidérmico, cuya acción, por perturbadora que sea, es transitoria y deja además intactos los estratos más profundos de una sociedad. [...] Con pretexto del régimen español, se trata de la eliminación, y para siempre, de España. Lo cual, de ser cierto, implicaría una sobreestimación del régimen político, el cual habría sido capaz, en doce años, de esterilizar un país entero para todo el resto de la historia. [...] Todo lo cual muestra que era acertado el diagnóstico de Ortega cuando hablaba hace poco de la «sorprendente, casi indecente salud» de España. Su vitalidad histórica es tal, que puede permitirse hasta el error. No hay duda de que la emigración representa una tremenda mutilación de la vida intelectual española - aunque no se puede predecir si será negativo el balance que pueda hacerse de ella y de sus consecuencias dentro de un par de siglos-. Pero lo asombroso es que, a pesar de tanta pérdida o casi pérdida - ya hemos visto que no es tan total como se dice-, todavía queda vida intelectual en España, en un volumen, como es lógico, aún mucho mayor. $\mathrm{Ha}$ habido una dolorosa, penosa, perturbadora escisión, que plantea un problema siempre vivo, cada vez más agudo; existe una floreciente y fecunda España extra muros. (Extra muros, sí; pero no exageremos, porque ¿quién pone puertas al campo?) $\mathrm{Y}$ a pesar de ello, como podía preverse, España está en Europa. ${ }^{10}$

Mucha mayor repercusión tuvo un artículo de José Luis L. Aranguren sobre «La evolución espiritual de los intelectuales españoles en la emigra-

\footnotetext{
8 Ibid., p. 69.

${ }^{9}$ Ibid., p. 71.

10 Ibid., pp. 71-73. Mead replicó a estas afirmaciones de Marías en una carta abierta - publicada también por Books Abroad, 27/1 (invierno de 1953), p. 97-, donde señalaba que la diferencia crucial entre ambos se refería precisamente a la relación entre política y vida intelectual. En el $\mathrm{n}^{\circ} 2$ de la propia revista Books Abroad, correspondiente a la primavera de 1953, aparecieron dos artículos que significaban nuevas intervenciones en esta polémica: "A Quarter Century of Spanish Writing», de Arturo BAREA, y "... And Should Thereby Be Judged", de Dwight L. BOLINGER, pp. 117-128 y 129-132, respectivamente.
} 
ción", que quería ser "comienzo de diálogo", ${ }^{11}$ voluntad de diálogo que se precisaba con estas palabras: «queremos hablar con nuestros compatriotas los intelectuales emigrados; pero queremos, al par, hablar precisamente de los emigrados». ${ }^{12}$ El artículo de Aranguren, de un tono mesurado y reflexivo que quería evitar cualquier atisbo de polémica, ${ }^{13}$ pretendía constituir una invitación sincera a un diálogo intelectual más amplio y ponderado sobre el tema, tanto entre los intelectuales españoles exiliados como entre los que vivían bajo la dictadura. Resulta curioso y significativo que Aranguren no quiera hablar de política y que, sin embargo, se apresure a precisar que «si en algún punto nos vemos forzados a hacerlo, lo haremos desde un punto de vista descriptivo, no polémico». ${ }^{14}$ Desde el inicio Aranguren nos confiesa que «todo el presente artículo tiende a mostrar cómo el sentido de la evolución de los intelectuales emigrados ha consistido en un entrañamiento, cada vez más profundo, en su constitutivo ser hispánico» ${ }^{15}$ y para ello analiza el exilio como una «situación» y un «talante»: por una parte, «la situación de desterrado imprimiendo carácter a la obra intelectual»; 16 por otra, si «a la situación de desterrado corresponde normalmente un "talante" determinado que se halla en función de aquélla», 17 Aranguren afirma que, con excepciones como la de Cernuda, entre los intelectuales españoles exiliados predomina un talante de nostalgia $y$, sobre todo, de melancolía. ${ }^{18} \mathrm{El}$ propio Aranguren venía a resumir el sentido de su trabajo con estas palabras:

Hemos perseguido la evolución espiritual de los intelectuales emigrados en el tránsito desde su posición anterior, más bien europeizante, a la apasionada nostalgia de la patria y, de la mano de Unamuno, a su entrañamiento en su ser de españoles; y consiguientemente, en el esfuerzo por levantarse

\footnotetext{
11 José Luis L. ARANGUREN, "La evolución espiritual de los intelectuales españoles en la emigración», Cuadernos Hispanoamericanos, 38 (febrero de 1953), p. 125. El propio Aranguren aludía a la necesidad política del régimen franquista de contrarrestar la influencia de los exiliados españoles en América latina con un ejemplo contundente que afecta a la propia revista: «¿No está pregonando su título que fue proyectada y fundada como réplica a los Cuadernos Americanos de Méjico, a los que tan vinculados estaban y están los emigrados?» (art. cit., p. 126).

12 J. L. L. Aranguren, ibid., p. 128.

13 «Como este estudio quiere ser cualquier cosa menos polémico», afirma ARANGUREN en ibid., p. 137.

14 Ibid., p. 126.

15 Ibid., p. 127.

16 Ibid., p. 129.

17 Ibid., p. 132. Sobre los conceptos de "situación» y «talante» afirma el autor «que en realidad no son sino las dos caras -histórico-social y anímica o, dicho con más rigor, antropológica- de una misma realidad" (ibid., p. 132, n. 18).

18 «Este talante, superadas por el tiempo y la nobleza de alma las reacciones casi instintivas de carácter negativo —odio, resentimiento, etc.-, suele estar tejido, en su forma más apacible, de melancolía» (ibid., pp. 132-133).
} 


\section{EL LUGAR DE SENDER}

desde una concepción partidista a una comprensión total, si bien partida y por ende trágica, de España y de su historia. ${ }^{19}$

Y si para los republicanos españoles la "situación" de destierro fue determinada por su derrota en la guerra civil, Aranguren analiza, justo antes de concluir su trabajo, la actitud que en 1953 mantienen los intelectuales exiliados respecto a la misma para acabar defendiendo abiertamente en su «Final» la necesidad de construir un puente de diálogo con la España peregrina:

Es hora ya de terminar. Al principio de este estudio nos trazamos dos objetivos: hablar de los intelectuales emigrados y hablar con ellos. De ellos hemos hablado haciendo ver cuán decisivamente ha pesado en su vida espiritual, y en qué sentido, la amarga experiencia del destierro. ¿Hemos hablado también con ellos? Yo diría que apenas hemos hecho sino empezar a hablar. Hemos transmitido, espero que con fidelidad y un cierto orden, lo que de ellos hemos escuchado. Creo que toca ahora a otros compatriotas, aquí o allá, proseguir el diálogo. 20

En 1969 - el año en que Max Aub regresaba a España sin vuelta posible para ir anotando sus impresiones de viaje en ese «diario español» que acabó por llamarse La gallina ciega $a^{21}$ y el mismo año en que Sender ganaba el premio Planeta con su novela En la vida de Ignacio Morel-, Aranguren publicó sus Memorias y esperanzas españolas, donde afirma con indisimulada complacencia la recepción positiva que su artículo de 1953 había tenido entre los intelectuales españoles exiliados:

Mi viaje -imaginario entonces - por América tenía la intención, muy diferente, de visitar a los intelectuales españoles exiliados y oírles expresar su nostalgia de España; la de, como dije al final del artículo, "hablar con ellos». Lo conseguí, cosa no frecuente aún en aquella época, pese a que el artículo contenía reservas impuestas por la situación del momento. Conservo cartas muy hermosas de Juan Ramón Jiménez, del doctor Pittaluga, de Montesinos, de otros también, aparte respuesta colectiva publicada en Cuadernos Americanos de Méjico. Don Américo Castro, don Claudio Sánchez-Albornoz, mi anti-

19 Ibid., p. 149.

20 Ibid., p. 157. Una prueba de la repercusión de este artículo entre los intelectuales españoles exiliados nos la proporciona Jerónimo MALLO, quien afirma que «esta cordial invitación a los exilados para que reanuden las relaciones con los escritores que residen en España [...] no sólo refleja el modo de pensar de su autor, José Luis L. Aranguren, sino los deseos de muchos intelectuales, que consideran necesario para el bien de la cultura hispánica establecer una intercomunicación a manera de puente por encima del Atlántico y de las discrepancias políticas. Es posible que este artículo tenga, no tardando, importantes consecuencias» ("Sobre la "libertad intelectual" en la España de hoy", Cuadernos del Congreso por la Libertad de la Cultura, 13 [julio-agosto de 1955], p. 88). Una "consecuencia" más de este artículo se constata en la n. 22.

21 Max AuB, La gallina ciega, México, Joaquín Mortiz, 1971 (reedición española: Barcelona, Alba Editorial, 1995, edición, estudio introductorio y notas de M. AZNAR SOLER). 
guo maestro José Gaos, García Bacca, Serrano Poncela, me dieron asimismo muestras de cordial atención. Y, a partir de aquel artículo, anudé o estreché una relación de muy afectuosa amistad con José Ferrater Mora, Juan Marichal, Antonio Sánchez Barbudo, Francisco Ayala, Max Aub, María Zambrano, Guillermo de Torre, Claudio Guillén. Creo, en fin, que en otro plano mucho más profundo y verdadero que el de la oficializada «Cultura Hispánica», contribuí a reconstruir «el puente» entre España e Hispanoamérica, precisamente, como tenía que ser, por la mediación de nuestros compatriotas exiliados. $^{22}$

Doble puente, por tanto, el señalado por Aranguren: el puente entre los intelectuales españoles —entre los antifranquistas de España y los exiliados- y el puente entre España e Hispanoamérica.

Guillermo de Torre fue cronológicamente el primero en contestar desde Buenos Aires a esa invitación de Aranguren a construir un puente de diálogo con un artículo, titulado «Hacia una reconquista de la libertad intelectual", que empezaba por elogiar el talante de los textos de Marías y Aranguren, pues «por vez primera —desde España y con maneras antes desacostumbradas, con altura de tono y limpieza de intenciones- se tiende a esclarecer una cuestión que era usual soslayar o confundir: la cuestión de la emigración intelectual española». ${ }^{23}$ Por la índole intelectual y moral de esas voces valía la pena, a juicio de De Torre, aceptar el diálogo desde la España peregrina e intentar superar por ambos bandos lo que él denomina «anacronismos», ${ }^{24}$ unos anacronismos producidos por el cisma de la guerra civil que acaso en 1953 pueden superarse desde la convicción de que es conveniente y necesaria para todos la construcción de un puente de diálogo hacia la mutua comprensión:

Son muchos (somos más de los que se cree -estoy seguro-) en cualquier sector, quienes, una vez pasado el turbión de la guerra, recobraron la serenidad y volvieron a tender mentalmente puentes de acceso hacia la com-

\footnotetext{
22 José Luis L. ARANGURen, Memorias y esperanzas españolas, Madrid, Taurus Ediciones, 1969, pp. 69-70. Aranguren alude a la «Respuesta de intelectuales españoles en la emigración a José Luis L. Aranguren», Cuadernos Americanos, 4 (julio-agosto de 1954), pp. 79-85, que firman Clemente Cimorra, Alejandro Casona, Eduardo Zamacois, Claudio Sánchez Albornoz, Francisco Vera, Valentín de Pedro, Gumersindo Sánchez Guisande, José Rovira Armengol, Gori Muñoz, Gerardo Ribas, Eduardo Blanco Amor y Juan Cuatrecasas, todos ellos residentes por entonces en Argentina. He reproducido este documento en mi libro Materiales para una historia del exilio literario español de 1939: textos, manifiestos, polémicas y documentos, Sant Cugat del Vallès, Cop d'Idees - Grupo de Estudios del Exilio Literario (GEXEL), en prensa.

23 Guillermo DE TORRE, «Hacia una reconquista de la libertad intelectual», La Torre, 3 (julioseptiembre de 1953), pp. 107-108. El autor cree que esta nueva actitud «implica un cambio de óptica, inaugura el camino de una inteligencia, cuya primera estación se llama concordia y cuya última meta es libertad» (ibid., p. 109).

24 «Anacronismo - no hay por qué ocultarlo- se llama la figura en que suelen incurrir ciertos desterrados intelectuales, imaginándose que en España todo está igual que cuando la dejaron, que son todavía válidos los gestos, los reactivos emocionales que llevaban al pasar la frontera» (ibid., p. 110).
} 
prensión y la convivencia, con desinterés y altura de miras, con angustia y emoción a la par: con esperanza. ${ }^{25}$

De Torre, por tanto, resalta el valor del artículo de Marías, "de intención tan clara y recta, de tono tan noble y generoso", ${ }^{26}$ pero no deja de poner los puntos correspondientes sobre determinadas íes cuando, para empezar, afirma:

La verdadera clave del hecho diferencial entre una y otra porción de la intelectualidad española, entre la literatura de dentro y fuera de España, no es una cuestión de cantidad o calidad: es una cuestión de libertad. ${ }^{27}$

Por ello denuncia que la censura impuesta por la dictadura militar, aunque no haya logrado hacer desaparecer la vida intelectual en España como afirmaba Mead, sí ha conseguido, contra la opinión de Marías, su aislamiento. Porque esa censura $-y$ no olvidemos que no sólo política sino, debido al nacional-catolicismo del régimen y al monopolio consiguiente de la educación por parte de la Iglesia católica, también morales la raíz de la autocensura dominante entre los intelectuales que viven en España, pero también de «la desconfianza automática que todas las publicaciones sometidas a ella suscitan irreprimiblemente fuera de España, y no sólo en los medios intelectuales, sino en todos, aun en los más burgueses, diríamos». ${ }^{28}$ Para De Torre «el mal de la censura no es cuestión de grados, sino de principio» ${ }^{29}$ por lo que, a su juicio, tiene razón Mead cuando afirma "una declinación de la influencia cultural de España» ${ }^{30}$ y carece de ella Marías cuando escribe, por ejemplo, que «la gran mayoría de los libros españoles valiosos publicados en América se encuentran en las librerías y bibliotecas españolas», palabras que «sólo un olvido momentáneo de esta triste realidad» ha podido dictar. ${ }^{31} \mathrm{Y}$ nos acercamos ya a la relación entre literatura, historia y política, un tema candente que Guillermo de Torre, contra Marías, acierta a precisar en términos tan exactos como rotundos:

Abomino quizá en mayor grado que Julián Marías de lo político y del politicismo. Pero no puedo coincidir con él en creer que el artículo de Mead,

25 Ibid.

26 Ibid.

27 Ibid., p. 112.

28 Ibid., p. 115.

29 Ibid., p. 116.

$30 \mathrm{Ibid}$., p. 115. Para el autor, tanto Mead («España ha perdido para siempre cualquier preeminencia que haya tenido alguna vez en esta esfera") como Marias ("Con pretexto del régimen español, se trata de la eliminación, y para siempre, de España") se han excedido al realizar, respectivamente, afirmaciones categóricas y «deducciones veloces» (ibid., pp. 120-121).

31 Ibid., p. 116. De Torre transcribe una frase escuchada por él en un café madrileño: «Sí; aquí no nos privamos de nada. También vivimos detrás de un telón de acero. Mejor dicho, el nuestro es un telón de a cero cincuenta..." (ibid., p. 122). 
y cuantos se han escrito en estos años sobre el mismo tema, estén dictados sustancialmente por el politicismo, sino por sus consecuencias en lo cultural -cosa muy distinta.

Para Julián Marías lo político tiene muy poca importancia. Sustancialmente estoy de acuerdo con él en que «lo primero, decisivo y más importante" no es la política y quisiera que nada viniera a contradecirnos. Pero, ¿acaso no sucede - contra nuestra voluntad- que mi vida, tanto como la vida de Julián Marías y la de muchos otros que aplicaron sus potencias fundamentales a cosas muy distintas de la política, han sido, desde hace más de tres lustros, influidas, deformadas, zarandeadas por esa nefanda política, por la extensión insoslayable de sus efectos? [...] Lo político, en sus dimensiones corrientes, en sus proyecciones normales, suele y puede dejar «intactos los estratos más profundos de una sociedad»; pero, ¿cómo juzgar así la influencia de lo político cuando pretende volver del revés un país, aislarlo del resto del mundo, cuando intenta partirlo en dos trozos y hacer que una de sus mitades prevalezca violentamente sobre la otra mitad, en vez de buscar una conciliación armoniosa y equilibrada entre ambas? ¿Podrá en este caso sostenerse que lo político es superficial y epidérmico? No; sino un fenómeno muy profundo y trastornador, de gravísimas consecuencias. ${ }^{32}$

De Torre recuerda a Marías que la vida intelectual en Europa, a diferencia de la de España bajo la dictadura, goza de libertad y le critica que en su trabajo de Ínsula sobre «El problema de la libertad intelectual» dicho problema sea «examinado aisladamente, sin relacionar la libertad intelectual con otra que es previa e imprescindible: la libertad política general». ${ }^{33}$ Y si Marías defiende que España está en Europa, De Torre, pese a que el reciente ingreso de España en la UNESCO deba implicar «un compromiso de reintegración europea», 34 manifiesta que la realidad actual es muy otra, pues "iel tiempo presente suscita tantos desmentidos!». ${ }^{35} \mathrm{Y}$, sin embargo, a pesar de «la precaria libertad intelectual» en la España franquista, lo estimulante y alentador para Guillermo de Torre es que voces como las de Aranguren o Marías inviten a construir un puente de diálogo entre los intelectuales al que el propio autor se suma al final de su trabajo:

Más evidente que la «evolución» del sentimiento de lo español advertida por José Luis L. Aranguren en la obra de los escritores españoles desterrados [...] nos parece la "evolución" de los allí residentes en su manera de considerar la obra de los colegas extrafronterizos, en su óptica para encarar la reconquista de la libertad intelectual. Y buena muestra de ello es el propio ensayo de Aranguren, tan abierto y mesurado, delatando una curiosidad comprensiva, un afán de inteligencia con los distantes, en suma, un noble afán de diálogo al que seguramente sus afines, los «no energúmenos", habrán de corresponder.

\footnotetext{
32 Ibid., pp. 117-118.

33 Ibid., p. 118.

34 Ibid., p. 125.

35 Ibid., p. 123.
} 
[...] Durante muchos, demasiados años, sólo se han escuchado en este vital dramático pleito, voces sectarias. Hora es ya de que acallando ecos partidistas, resonancias agrias, se oigan voces limpias, criterios independientes. $^{36}$

En la misma revista portorriqueña La Torre correspondió a Aranguren el turno en esta construcción de un puente de diálogo entre «los intelectuales españoles de dentro y fuera de España - que nos necesitamos mutuamente-».37 A partir de su convicción metafísica y "teológica» -fundada sobre la de Francisco Ayala en La cabeza del cordero- de que la guerra civil fue «un acontecimiento ineluctable», 38 Aranguren, en su réplica a De Torre, hace alarde de su catolicismo, crítico con el régimen dictatorial pero compatible o, cuanto menos, comprensivo con algunas de sus manifestaciones. Véase, por ejemplo, este párrafo moralista sobre la censura:

\begin{abstract}
Guillermo de Torre deja de lado, discretamente, la censura «estrictamente política». Personalmente mantendría también, sin dudarlo un momento, la censura para las publicaciones que insultasen nuestras creencias y para las publicaciones simplemente pornográficas, pero es claro que ni unas ni otras tienen nada que ver con la libertad intelectual. Ésta, en mi opinión no debería ser coartada. No soy político y por consiguiente no me incumbe decidir si la supresión debiera hacerse de golpe o bien gradual, pero decididamente. ${ }^{39}$
\end{abstract}

Aranguren, como Marías, acepta la realidad de la censura y, por idealismo ingenuo, por posibilismo pragmático o por espíritu de inercia acomodaticia con el régimen, desvincula también libertad política y libertad intelectual, como si ésta fuese posible sin aquélla. Aranguren trata de minimizar y desdramatizar la existencia de la censura — «creo que la existencia o la inexistencia de la libertad no puede pender de la supresión o el mantenimiento de la censura»- ${ }^{40}$ para defender que «la libertad es la inacabada tarea de cada día. Y tiene poco que ver con la Censura, porque consiste en una actitud ética». ${ }^{41}$ En rigor, al igual que hacía Marías con los cursos de filosofía de Ortega en el madrileño Insti-

36 Ibid., pp. 125-126.

37 José Luis L. ARANGUREN, «La condición de la vida intelectual en la España de hoy», La Torre, 4 (octubre-diciembre de 1953), p. 84.

38 Ibid., p. 85. Y poco después agrega: «Al comenzar el verano de 1936 la guerra se presentaba en el horizonte bajo la forma, como diría Ferrater Mora, de un fenómeno "geológico", que sería totalmente vano pretender detener; era el efecto físico y tremendamente sangriento determinado unívocamente por los errores de todos» (ibid., p. 85).

39 Ibid., p. 91.

40 Ibid., p. 93.

41 Ibid. 
tuto de Humanidades, Aranguren magnifica la transcendencia de los cursos de filosofía de Xavier Zubiri y la significación de «algunos prometedores intentos de renovación católica», 42 aun cuando precisa con exactitud «un par de reservas» respecto a revistas católicas republicanas como Cruz y Raya, dirigida por Bergamín: "A mi entender, su desvinculación del catolicismo real - bueno o malo- de los españoles, fue un error. Hay que partir siempre de la realidad, aun cuando sea para transformarla. Y, en segundo lugar, no es posible vivir católicamente de espaldas a la Jerarquía eclesiástica. Con la Iglesia hay que estar siempre, aun cuando a veces no nos comprenda». ${ }^{43}$ Iglesia o Estado, las limitaciones en 1953 del pensamiento de Aranguren, como las del de Marías, son tan obvias como reveladoras y su posibilismo iba a resultar discutible y hasta cierto punto irritante para muchos intelectuales exiliados, por ejemplo Sender.

\section{«EL PUENTE IMPOSIBLE» DE SENDER}

Sender interviene en esta polémica con un artículo tan interesante como rotundo que tituló "El puente imposible» y que se publicó en Cuadernos del Congreso por la Libertad de la Cultura, una revista editada en París que, en el contexto de la "guerra fría», estaba financiada por la CIA al servicio de la propaganda anticomunista y en defensa de una libertad de la cultura a la medida de sus intereses políticos democratistas. Sender, residente por entonces en Estados Unidos, comienza por considerar la división de los escritores españoles durante la guerra civil en «leales» y «facciosos»:

\footnotetext{
Los escritores españoles han salido bastante bien de la experiencia del despotismo. No ha habido sorpresas en la conducta de nadie. Tampoco traiciones. Lo que algunos consideran villanía y bellaquería - los casos de Eugenio d'Ors, Baroja, Benavente- no es más que senectud. Y entre estos tres autores Baroja no ha defendido nunca el régimen, que yo sepa. [...] De los otros dos, Benavente es sólo un eco atrasado de Oscar Wilde, a cuya escuela literaria y a cuyo falansterio moral pertenece, con todas las consecuencias. D'Ors, que mostró en los comienzos de su vida de escritor un talento original, es el único de los tres que quema el incienso voluntaria y alegremente a los pies del verdugo. Ni Benavente ni d'Ors bastan, como es natural, para dar a la dictadura fascista una apariencia civilizada. Pero como no tienen otra cosa, los generales los tratan con una bondad paternal. ${ }^{44}$
}

\footnotetext{
42 Ibid., p. 94.

43 Ibid., p. 95.

44 Ramón J. SENDER, «El puente imposible», Cuadernos del Congreso por la Libertad de la Cultura, 4 (enero-febrero de 1954), p. 65.
} 
Tras elogiar a Valle-Inclán, ${ }^{45}$ resaltar el antifascismo final de Unamuno, ${ }^{46}$ criticar la condición de paniaguado vergonzante de Benavente ${ }^{47}$ y defender a Baroja, ${ }^{48}$ considera los casos de dos intelectuales que han regresado a la España de Franco: Menéndez Pidal y Ortega y Gasset. ${ }^{49}$ Se muestra comprensivo con el regreso de Jarnés, "un espíritu débil», ${ }^{50}$ y resalta, a la inversa, el exilio voluntario de Antonio Espina. ${ }^{51} \mathrm{Y}$ es que para Sender el panorama de la literatura española franquista entre 1939 y 1954 ues desolador y ellos mismos lo confiesan velis nolis. No hay nadie", 52 salvo honrosas excepciones novelísticas como, a su juicio, Nada, de Carmen Laforet, o La familia de Pascual Duarte, de Cela. Y si «lo que la llamada "cultura" de la nueva era produce en España es moralina y baja retórica», por

45 Sender, al elogiar la calidad literaria de los esperpentos, critica la saña con que Pío Baroja se refiere al escritor y resalta la lucidez política de Valle-Inclán al advertir «del peligro que representaba ese tipo vulgar, ambicioso y sin escrúpulos» (ibid., p. 65), en referencia al general Franco. Las relaciones entre Sender y Valle-Inclán merecen un estudio monográfico aún por realizar. No se olvide que Sender es autor de un polémico libro titulado Valle-Inclán y la dificultad de la tragedia, Madrid, Gredos («Colección Campo Abierto»), 1965, reproducido en Examen de ingenios. Los noventayochos. Ensayos críticos, México, Aguilar, 1971, 2 ed. corregida y aumentada, pp. 89-207.

46 «En cuanto a Unamuno ya sabemos cómo vivió desde el momento de la sublevación. Y cuáles eran sus sentimientos en los días que precedieron a su muerte. [...] A pesar de esas y otras cosas los fascistas se lo quieren hoy asimilar. [...] A Unamuno quieren hacerlo suyo los fascistas porque no lo han leído tampoco o porque habiéndolo leído quizás incurren en lo que Unamuno consideraba el mayor de los crímenes: la resistencia a entender» (ibid., p. 66). Sobre el escritor puede leerse "Unamuno, sombra fingida», un "ensayo crítico" recopilado en Examen de ingenios. Los noventayochos, cit., pp. 15-88.

47 "Hay escritores que han sido siempre casi fascistas, casi antisemitas, casi republicanos, casi socialistas según el viento que soplaba. Ésos siguen en España comiendo el pan de la vergüenza mientras confían -o "casi" confian- en hallar alguna forma de impunidad en el futuro. Jacinto Benavente es de ésos" (ibid., p. 67).

48 A propósito de las Memorias de Pío Baroja, escribe Sender: «Por supuesto no habla bien de nadie. Tampoco francamente mal, con la excepción de Valle-Inclán, Unamuno y el pintor Solana. [...] Baroja si no habla bien de sus contemporáneos tampoco elogia a Franco. Algo es algo" (ibid., p. 67). Sobre el escritor puede leerse un "ensayo crítico» titulado «Baroja y las contradicciones latentes", en Examen de ingenios..., cit., pp. 209-272.

49 «Los dos tienen una formación liberal - ¿es que hay otra formación humanística?-》 (ibid., p. 67). Sin embargo, respecto a Ortega precisa: «Queda por aclarar si la presencia de un profesor como él en el Madrid de Franco representa una adhesión al régimen" (ibid., p. 67). Y poco después agrega que "Ortega es un emigrado "amateur", no profesional, un disidente condicionado" (ibid., p. 70).

50 «En cuanto a Jarnés - un escritor exiliado que volvió a España- se sentía en Méjico solo, pobre, viejo y enfermo. Cualquiera de esas circunstancias se puede sobrellevar sin las otras, pero todas juntas, añadiendo además el destierro, son demasiadas para un espíritu débil» (ibid., p. 68). Jarnés regresó a Madrid en 1948, un año después de que Juan Gil-Albert hiciera lo propio para instalarse en el «exilio interior» de Valencia.

51 «Contra el regreso de Jarnés tenemos varios casos de escritores que han logrado evadirse y salir a compartir nuestro exilio, entre ellos el de Antonio Espina» (ibid., p. 68).

52 Ibid. 
contra la superioridad intelectual y literaria de la España exiliada es un hecho incuestionable, ya que, según Sender, «para encontrar hoy un digno descendiente de San Juan de la Cruz hay que buscarlo en los círculos de la emigración liberal, en Jorge Guillén, por ejemplo, o en Juan Ramón Jiménez. La poesía española está fuera de España, también».53 Sender, a propósito de la atención dispensada por la revista Ínsula a la literatura exiliada, afronta directamente el tema del «puente» posible para afirmar con rotundidad su inexistencia e imposibilidad:

Un grupo interesante es el que representa la revista Ínsula, que suele despreocuparse en lo posible de las motivaciones políticas y ha dedicado un número homenaje a Guillén, otro a Juan Ramón Jiménez y encomiásticos artículos a algunos exiliados como Pedro Salinas, recientemente fallecido. Observando estos hechos y los elogios ocasionales en la radio o en los periódicos a algún escritor de los que estamos en el exilio, no faltan quienes hablan de la existencia práctica de un puente o al menos de una zona indefinida por la que se mantiene alguna forma de contacto. Esa zona existe, pero no como la imaginan algunos. No pocos escritores amordazados, entre los jóvenes, callan y esperan pensando en nosotros. $Y$ coinciden con nosotros en el secreto de su angustia cada vez que recuerdan a los mártires que han caído y a los héroes que caen cada día. Ellos y nosotros nos encontramos en esa devoción por el héroe, mejor que en las estructuras intelectuales y en los intereses de la literatura. Ellos saben muy bien que el puente no existe ni existirá en las condiciones presentes, aunque traten algumos de crearlo dirigiéndose a aquellos escritores que resienten más la emigración, y entre éstos a los que sistemáticamente el grupo moscovita calumnia y ofende. ${ }^{54}$

La convicción senderiana de que «el puente no existe ni existirá en las condiciones presentes» significaba una descalificación tanto de las actitudes posibilistas de Marías y Aranguren como de la de Guillermo de Torre. Para Sender, «el escritor que se ha quedado en España y tácita o expresamente se hace cómplice de lo que pasa ${ }^{55}$ va perdiendo la autoestima y experimenta un sentimiento de culpabilidad que, en su caso, no le provoca, sin embargo, ninguna clase de compasión: «Esos escritores podrían salir si quisieran. Tampoco los envidiamos. Nosotros podríamos ir, si quisiéramos. Los recordamos con la sensación de una amistad frustrada. $\mathrm{Ni}$

\footnotetext{
53 Ibid. Esa superioridad intelectual le hace escribir con orgullo poco después que «los españoles que fuimos echados de España en 1939 éramos gente que leía» (op. cit., p. 70).

54 Ibid., p. 68. Cuadernos del Congreso por la Libertad de la Cultura era una "revista trimestral», dirigida por Julián Gorkin, dirigente del POUM, cuyo primer número apareció en marzomayo de 1953. A partir del n 69 (febrero de 1963), consta Germán Arciniegas como nuevo director. Sobre el anticomunismo senderiano puede consultarse, por ejemplo, el estudio de Peter TURTON sobre "Los cinco libros de Ariadna: la puntilla al minotauro comunista», en AA. VV., Ramón J. Sender. In memoriam. Antología crítica, ed. al cuidado de José-Carlos MAINER, Zaragoza, Diputación General de Aragón, Ayuntamiento de Zaragoza, Institución Fernando el Católico, Caja de Ahorros de Zaragoza, Aragón y Rioja, 1983, pp. 445-463.

55 Ibid., p. 69.
} 
ellos ni nosotros tenemos toda la culpa». ${ }^{56}$ Los españoles exiliados son fieles al pueblo por su convicción de que «la aristocracia española está en el pueblo», ${ }^{57}$ pero son fieles también a la patria, a la memoria y a la esperanza ${ }^{58}$ y, por tanto - añade Sender-, «no podemos sentirnos culpables. Además, todos eran gente pura y con las manos limpias de sangre, como la inmensa mayoría de los emigrados". ${ }^{59}$ A pesar de ese patriotismo, de ese amor «territorial» y de esa nostalgia de España que experimenta el escritor exiliado, ese puente para Sender es sencillamente imposible:

Sin embargo, no hay puente. Ni de plata ni de piedra. No puede haberlo. Es decir, hay un puente de niebla o de rayos de luna por decirlo de un modo ligeramente cursi. Porque [...] nosotros podríamos decir que la emigración nos ha hecho sentimentales. A veces patrióticamente cursis. Una cursilería, al menos, sin himnos ni efemérides. No es nuestro amor -repito- un amor de nación sino de territorio. No es de alegorías ni escudos y ni siquiera de estadísticas, sino de colinas, amaneceres, arroyos y campanarios. 60

Esa imposibilidad del puente se concreta para Sender en la imposibilidad moral del regreso del escritor exiliado a una España sin libertad ni democracia:

Hubo un puente para salir y no fue de plata sino de sangre, de duelo y de odio. Cualesquiera que sean los esfuerzos de los colegas que en Madrid, en Barcelona, quisieran facilitar nuestra vuelta a la casa paterna, no volveremos nunca sino con la seguridad de que una vez allí no tendremos que reajustar nuestra imaginación ni desestimarnos, ni avergonzarnos ni odiarnos. Sin el riesgo de que nuestra ilusión (lo único que nos queda) se disuelva en una realidad sórdida. Defendemos nuestro sueño a falta de otra cosa. $Y$ no somos ilusos sino realistas. Realistas a la española, es decir a la manera de don Quijote y de Segismundo y del Calixto de La Celestina, y de tantos otros héroes de ficción o de historia que sabían que el sueño determina a menudo la realidad y la conforma. Somos españoles no rojos ni verdes sino del color de nuestra tierra. No nos interesa Rusia, donde cualquier forma de honradez intelectual es imposible. Tampoco nos interesa una España en la que es imposible la convivencia sin caer en alguna forma de siniestra complicidad. ${ }^{61}$

56 lbid., p. 69.

57 Ibid., p. 70.

58 «La diferencia entre ellos y nosotros está en que nosotros conservamos nuestra patria entera y viva en nuestra memoria y en nuestra esperanza. [...] Nuestra patria está viva y entera en nosotros. Nosotros amamos a España. [...] Amamos la España territorial con su pueblo y su estado llano y es más nuestra que de ellos, porque nos la hemos ganado con la sangre, con la esperanza, con el recuerdo y con esta renuncia a ella por el amor que da sentido a nuestros actos hasta a los más mínimos» (ibid., pp. 70-71).

59 Ibid., p. 71.

60 Ibid.

61 Ibid., pp. 71-72. 
Con la memoria histórica del viejo Imperio español, los vencedores de la guerra civil, con la ayuda del fascismo internacional, han construido para Sender no un puente sino un Nuevo Orden, el franquismo, "ese imperio que no ha conquistado sino cementerios de aldea, sacristías y escuelas dominicales. Eso sí, a sangre y fuego. Y cantando himnos. Y señalando efemérides. $Y$ poniendo delante a los moros y detrás a los italianos y encima, en el aire, a los alemanes». ${ }^{62}$ Ese franquismo, ese españolismo «de nación», ese nacionalismo españolista, «ese imperio nos envilece a todos, incluso a nosotros, los españoles "de territorio" $\gg, 63$ porque -piensa el autor-, al envilecer la dignidad y la vida colectiva del pueblo español, se destruye cualquier posibilidad de construcción del puente:

Los de Franco siguen envileciendo la nación y nosotros honrando el territorio que va con nosotros y que nadie nos puede robar. Y si algún espíritu fraterno habla de un puente que restablezca la convivialidad, debemos decirle que también nosotros soñamos con volver y sentarnos a la vieja mesa solariega. Pero a esa mesa y no a otras que aún huelen a baba y pezuña de imperios de hordas que fueron los enemigos de nuestra alma natural. Sin miedo y sin odio como ayer cuando hacíamos la guerra, y como ahora cuando andamos por el mundo entre el ejemplo de los que mueren antes que aceptar la complicidad y los que viven para seguir denunciándola. Si alguno dentro de España piensa en nosotros, más vale que piense así, justamente y sin malentendidos. 64

Si el puente del diálogo, aunque difícil sin libertad, es acaso posible sin eufemismos ni malentendidos, el puente del regreso es sencillamente imposible para Sender en 1954 sin libertad ni democracia porque sería mera claudicación y pura indignidad.

\section{LA SIGNIFICACIÓN DE LA POLÉMICA}

Esta polémica iniciada por Robert G. Mead, Jr., en 1951 no es, sin duda, una polémica más entre los intelectuales de la España franquista y los intelectuales exiliados. El propio Mead acierta a valorar su novedad, ya que, a su modo de ver, no se trata de «otro capítulo en la larga historia de polémicas, comparaciones odiosas, prejuicios y partidismo cuando no de silencio o abstención obligatoria entre los españoles peregrinos y los peninsulares», sino de un capítulo inédito que ha servido para iniciar la construcción de un puente de diálogo entre los intelectuales españoles que viven dentro de España (Aranguren, Marías) y los exiliados (De Torre, Sender). Puente de diálogo, sí, pero por el momento sólo de diálogo, pues

\footnotetext{
62 Ibid., p. 72.

63 Ibid.

64 Ibid.
} 
ni 


\title{
Un opúsculo olvidado de Ramón J. Sender
}

\author{
Javier Barreiro \\ I. E. S. José Manuel Blecua, Zaragoza
}

La Tipografía «Cosmos», sita en el número 42 de la barcelonesa calle de Urgel, sacaba de sus prensas en 1932 un opúsculo de Ramón José Sender con 64 páginas en octavo, titulado La República y la cuestión religiosa. El volumen venía auspiciado por Ediciones Cultura Libertaria, que publicaba también una revista con ese título, y se vendía al módico precio de 40 céntimos.

No he visto relacionada esta obra en ninguna de las bibliografías ${ }^{1}$ de Sender ni en los libros a él dedicados que tocan especialmente esa época. ${ }^{2}$ Sí que la citan José Domingo Dueñas Lorente ${ }^{3}$ y Jesús Vived Mairal. ${ }^{4}$ Dice

${ }^{1}$ Vid. Elizabeth EsPaDAS, «Hacia una bibliografía sobre la obra de Ramón J. Sender», publicada como artículo final en el libro de Francisco CARRASQUER, La verdad de Sender, Leiden, Ediciones Cinca, 1982, pp. 125-177. Existen otras bibliografías más antiguas como la de Charles L. KING que se cita en la nota 7 y la de María Francisca VILCHES DE Frutos, «Bibliografía crítica sobre el primer Sender", en Censo de escritores al servicio de los Austrias y otros Estudios Bibliográficos, Madrid, Instituto Miguel de Cervantes (CSIC), 1983, pp. 121-142.

2 Especialmente, Patrick Collard, Ramón J. Sender en los años 1930-1936. Sus ideas sobre la relación entre literatura y sociedad, Gante, Rijksuniversiteit te Gent, 1980.

3 José Domingo Dueñas LoRENTE, "Obra periodística de Ramón J. Sender (1924-1936)», Argensola, 100 (1986), pp. 5-58.

4 Jesús Vived Mairal, «La vida de Ramón J. Sender al hilo de su obra», Alazet, 4 (1992), pp. 231-270. 
el primero de ellos en su trabajo hablando de los artículos de Sender en $\mathrm{La}$ Libertad:

\begin{abstract}
Las cinco reflexiones sobre "la cuestión religiosa», que se publican entre enero, febrero y marzo de 1932, quedan poco después reunidas en un folleto de 64 páginas, que el 18 de marzo de ese mismo año era anunciado en la revista barcelonesa "Cultura Libertaria» del siguiente modo:

«Nuestras ediciones. Ha sido puesto a la venta el folleto La República y la cuestión religiosa del camarada Ramón J. Sender. Los grupos de Cultura, de Educación sindical, etc., deben poner al alcance de los trabajadores este magnífico instrumento de propaganda".

El folleto costaba cuarenta céntimos; no debieron de resultar muy exitosas su venta y distribución, puesto que vuelve a ser recomendado por la misma revista el 23 de setiembre. ${ }^{5}$
\end{abstract}

Por su parte Vived Mairal anota en su artículo:

Bajo el epígrafe «La cuestión religiosa» vieron la luz asimismo en ese periódico [La Libertad] cinco artículos a lo largo de los meses de enero, febrero y marzo de 1932; con ellos formó el folleto titulado La República y la cuestión religiosa (1932). ${ }^{6}$

De cualquier modo, el primero que había citado alguno de los artículos en cuestión, que no el opúsculo, había sido Charles L. King, ${ }^{7}$ que en las páginas 63-64 de su libro relaciona cuatro de ellos: «Impopularidad de la Iglesia», «¿Dónde está la fe?», «Presencia y coacción de la Iglesia» y «Posición anticlerical de la república», aparecidos respectivamente los días 29 de enero, 4 y 16 de febrero y 1 de marzo de 1932. En realidad, el orden de publicación de los artículos y sus títulos fueron los siguientes:

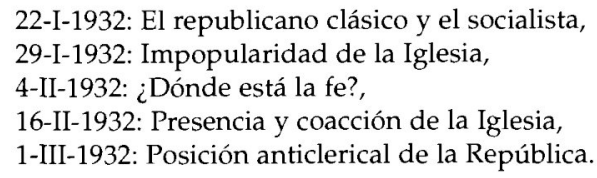

Como vemos, tenía razón Jesús Vived y los artículos fueron cinco pero el libro, en cambio, reúne doce artículos, lo que significa que Sender lo redondeó para darle una unidad y entidad mayores. Los capítulos del pequeño volumen son:

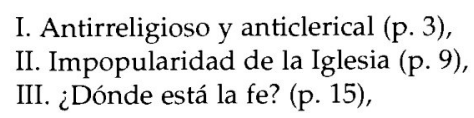

5 J. D. DUEÑAS, art. cit., p. 40.

6 J. VIVED, art. cit., pp. 245-246.

${ }^{7}$ Charles L. KING, Ramón J. Sender: An annotated Bibliography, 1928-1974, Metuchen, N. J., The Scarecrow Press, 1976. 
IV. Desconcierto de los católicos (p. 20),

V. Presión del superestado católico (p. 25),

VI. Labor anticlerical de la República (p. 31),

VII. La disolución de los jesuitas (p. 37),

VIII. La Iglesia con armas legales y con dinero (p. 42),

IX. El voto femenino y la Iglesia (p. 48),

$X$. La Iglesia y las medidas gubernativas (p. 52),

XI. Roma y la República anticlerical (p. 56),

XII. El Nuncio: límites supersticiosos del porvenir (p. 60).

No aparece, pues, en La Libertad el capítulo IV ni tampoco los que van del séptimo al duodécimo. El capítulo $V$ aunque cambia de título es el que en La Libertad aparece titulado como "Presencia y coacción de la Iglesia». Significa esto, pues, que estamos ante una obra con material inédito al menos en su mitad, independientemente de que en los capítulos reproducidos tampoco se produce una transcripción literal sino que Sender modifica frecuentemente la redacción y el estilo.

A la sazón, Sender ya había publicado tres novelas, Imán (1930), O. P. (1931), El verbo se hizo sexo (1931) y otros tres libros de artículos o ensayos: El problema religioso en Méjico (1928), América antes de Colón (1930) y Teatro de masas (1932). Nótese que los elementos en torno a lo religioso tenían un lugar preeminente en dos de ellos: en su primer libro, en el que estaba asimismo presente su preocupación por lo americano que el destino se encargaría de asentar, y en El verbo se hizo sexo, con santa Teresa como protagonista, novela escrita bajo la presión de las circunstancias pero que no por ello deja de mostrar cuáles eran algunas de las obsesiones de este Sender treintañero que, por cierto, reaparecieron una y otra vez a lo largo de su trayectoria narrativa.

Las tesis de Sender en este libro, firme y lúcidamente argumentadas, se alinean con la conocida posición de los sindicalistas en cuanto a la imposibilidad de la República para afrontar un cambio que no fuera puramente formal y la necesidad de presión por parte de las organizaciones obreras para obligarla a intentar una revolución verdadera. Obviamente hay que situar esta publicación entre la numerosísima literatura que produce la contrapropaganda anarquista respecto a la religión y la Iglesia. Téngase en cuenta que la edición de 1917 de Doce pruebas de la inexistencia de Dios de Sebastián Faure llegó a la increíble cifra de 600.000 ejemplares y libros como Las ruinas de Palmira de Volney y La religión al alcance de todos de Ibarreta fueron lecturas constantes y comunes para todos los militantes. ${ }^{9}$

Es, precisamente, esta época la de mayor conexión y militancia de Sender con la Confederación Nacional del Trabajo, con la que había entrado

\footnotetext{
8 Vid. a este respecto el reciente libro de Francisco CARRASQUER, La integral de ambos numdos: Sender, Zaragoza, Prensas Universitarias, 1994.

$9 \mathrm{Vid}$, por ejemplo, el reciente testimonio de un veterano militante como Inocencio Ruiz Lasala en El Bosque, 9 (septiembre-diciembre de 1994), p. 30.
} 
en relación directa durante 1929, integrando el grupo «Espartaco» y colaborando habitualmente en su periódico oficial, Solidaridad Obrera. Como resalta Jesús Vived, ${ }^{10}$ mientras en el diario anarquista escribía preferentemente sobre cuestiones sociopolíticas y relacionadas con la organización sindical, en La Libertad, periódico izquierdista y republicano, firmaba artículos más ambiciosos y elaborados literariamente.

En la obra que comentamos, Sender acomete en primer lugar una reflexión histórica de la que concluye que el republicanismo español desde las Cortes de Cádiz había clamado contra dos géneros de latifundios: el agrario, de orden económico, y el latifundio cultural, de orden religioso, sin darse cuenta de que eran simples expresiones de un problema más hondo. Sobraba pasión y faltaba sistema, con lo que no había un análisis profundo y sagaz. Así, Joaquín Costa, el símbolo histórico de la lucha por la reforma agraria, "sería hoy fascista» y José Nakens, el más eximio representante del laicismo republicano, se quedó en mero anticlerical, siendo tildado, para colmo, por sus correligionarios de «santo laico». Ni anticlericalismo ni antilatifundismo eran suficientes para señalar una posición revolucionaria ya que los partidos burgueses podían afrontar esas cuestiones con la separación de la Iglesia y el Estado o la expropiación retribuida. Eso no entrañaba para la Iglesia ninguna preocupación seria.

Continúa Sender aduciendo que la estrecha ligazón de la religión en España con el Poder produjo que la Iglesia nunca fuera popular. Se la temía y respetaba pero sin aceptar la religión como una filosofía de la vida. ${ }^{11}$ La Iglesia fracasó en su intento de llegar al corazón del pueblo a pesar de su habilidad en cristianizar ritos y arquetipos y en asociar a lo religioso los estados compactos de opinión. Para el escritor aragonés el pueblo español es irreligioso y sólo en un sector importante de la clase media es posible encontrar la fe religiosa por inclinación a las formas y hábitos de la alta burguesía y la aristocracia:

Comiendo como el proletario (el miembro de la clase media), piensa y siente como el aristócrata. De esa paradoja surge, a través de la lucha por la vida y por la estimación social que no consigue, porque sólo la alcanza el dinero, una sensación de subordinación a los que tienen el poder y la consideración social. Hacen de esa subordinación un fin, un objetivo y su posición falsa determina un complejo de inferioridad -empleemos los términos de la psicopatología- dentro del cual la fe religiosa encuentra el mejor campo.

Todas las religiones están construidas a base de ese complejo. Incapacidad del hombre frente a la naturaleza que le rodea y a las mismas leyes de

10 J. VIVED, art. cit., p. 245.

11 De una opinión muy similar es el padre Peiró, autor de uno de los rarísimos libros de la época sobre sociología política. Para él, en 1935, la clase trabajadora había apostatado de la religión y en las demás clases la afección se conservaba únicamente por razones de interés. Francisco PEIRO, El problema religioso-social de España, Madrid, 1935, apud Juan María LABOA, La Iglesia y la Il República, Madrid, Cuadernos de Historia 16, $\mathrm{n}^{\circ} 220$. 
su propio organismo. No puede el hombre de mentalidad prostituida por la civilización burguesa incorporarse a la naturaleza, no puede el hombre débil defender y realizar sus impulsos biológicos, sus aspiraciones morales, y de esa sensación de impotencia surge la posición indecisa que les hace acercarse a todo lo firme y sólido con un anhelo de protección. De ahí surge la corriente católica y burguesa de la clase media. (p. 16)

El carácter compacto de esta masa religiosa, tan víctima del proletariado como del capitalismo, que ahora habrá de sostener a la Iglesia, antes costeada por el Estado, será utilizada por el capitalismo democrático de la República y para ello se ha aprobado el voto femenino y será guardada en reserva como elemento contrarrevolucionario.

Como vemos, no faltaba razón a Sender ni tampoco cuando se refería al desconcierto de los católicos que consideraban a la Iglesia intangible y atribuían sinceramente cualquier contratiempo a la conjura de las fuerzas del mal. La no intervención de las fuerzas de orden público en los episodios de quema de conventos del 11 de mayo de $1931^{12}$ tiró por tierra la convicción de que detrás de cualquier uniforme estaba la defensa del orden divino. Sin embargo, no creía nuestro escritor en la independencia de la República sino en su voluntad de utilizar los radicalismos de ambos signos para consolidar su posición. Sólo que uno de ellos tenía el poder económico y, si la República había solventado la omnipresencia de la Iglesia padecida por el ciudadano siempre que tenía que establecer contacto con el Estado, no había movido ni pensaba hacerlo uno solo de los resortes de su poder económico. En resumen, el anticlericalismo fue utilizado por la República para contener al pueblo.

Fuera de la solidez de la argumentación, otros puntos interesantes podemos encontrar en esta obra pese a que Sender se ciñe continuamente a la idea fundamental y no se permite ninguno de los excursos anecdóticos que caracterizarán gran parte de su prosa posterior. Por ejemplo, cuando caracteriza a esa clase media que acude a lo religioso con un anhelo de protección, se refiere también a una parte de ella que busca una «engañosa sensación de autoridad y dominio y de ahí la tendencia que se da a menudo en ese sector hacia el comunismo estatal, tendencia de un decadentismo peligroso, ya que aporta a las corrientes ideológicas puras la escoria mental burguesa y tiene de los fenómenos sociales una visión frívola y feminoide" (p. 17).

La CNT también recibe su ración de cal y arena, aunque la conclusión sea positiva: «El exceso de vitalidad revolucionaria de la CNT, uni-

12 Originados por sucesos anteriores, como el enfrentamiento entre miembros del Círculo Monárquico Independiente y el pueblo madrileño o la represión de la Guardia Civil ante el intento de asalto al $\mathrm{ABC}$, en la que murieron un adolescente y un portero, todavía no conocemos perfectamente los entresijos de estos incidentes no reivindicados por organización alguna. Es cierto que fueron incendiados unos cien edificios, aunque no hubo víctimas. El Gobierno declaró finalmente el estado de guerra. 
do a su falta de disciplina orgánica, hizo posible que se produjeran levantamientos aislados y esporádicos en distintos lugares. El instinto de conservación de la central revolucionaria y otro más trascendental instinto, el de su misión histórica para un porvenir próximo, determinaron un repliegue de energías, y los movimientos se resolvieron sin gran desgaste, y, desde luego, con experiencias positivas para el mañana» (pp. 38-39).

Como se vio más arriba, los anarquistas siempre habían considerado a la Iglesia como el enemigo por antonomasia no sólo por su alineamiento descarado con cualquier clase de Poder sino por el sentimiento libertario de proclamar una nueva moral y una nueva cultura. Sender, como se comprueba tanto en estas palabras como en algunas de sus obras y artículos contemporáneos, tenía un sentido más táctico de la lucha social.

En el capítulo $X$, «La Iglesia y las medidas gubernativas», Sender denuncia la diferencia entre las represiones a sangre y fuego en contra de los trabajadores y las medidas, siempre llenas de garantías legales, respecto al clero, que, en la fecha de publicación de la obra, todavía no había sufrido siquiera una sola prisión gubernativa. Era notoria, por ejemplo, la actividad conspirativa del primado de España en estrecho contacto con el cardenal Pacelli, futuro Pío XII y, entonces, secretario de Estado del Vaticano, ${ }^{13}$ que llegó a apoyar a Acción Nacional, fuerza que, en el artículo $1^{\circ}$ de sus estatutos, proclamaba «la propaganda y acción política bajo el lema de Religión, Familia, Orden, Trabajo y Propiedad». Igualmente se intentó la salida del capital eclesiástico mediante Deuda Pública de países extranjeros. Sender defiende, además de que las comunidades religiosas tengan el mismo régimen que cualquier otra asociación, la eliminación de las señales exteriores de religiosidad y la prohibición de la educación religiosa para los niños hasta que tengan capacidad de discernimiento. El hecho de poner la cuestión religiosa bajo la ley es una garantía para la supervivencia de la Iglesia, que la tiene a su lado para defenderse de la opinión de la calle. Aun siendo antirreligiosa, la ley resulta inocua mientras el pueblo debe afrontar, cuando quiere defenderse, la represión sangrienta.

Sender tampoco cree suficiente la separación de la Iglesia y el Estado proclamada por la Constitución y viene a considerar demagógica la disolución de la Compañía de Jesús. «¿Es que acepta el Estado que unas Órdenes son peligrosas y otras no?», se pregunta, para dictaminar finalmente que ese anticlericalismo «ha decepcionado a los republicanos clásicos y ha desconcertado al mismo clero que, inerme y delincuente, esperaba un ataque a fondo" (p. 36).

13 Vid. Manuel TuÑón DE LARA, La Segunda República, pp. 125-126, en Historia de España, tomo IX, Barcelona, Labor, 1981. 
En el capítulo VII, dedicado específicamente a la disolución de los jesuitas, confirma su percepción de que la misma fue una concesión demagógica propiciada por la vitalidad revolucionaria de la CNT y que, de no ser por ella, no se hubiera producido. Sender ironiza sobre la ausencia de presión que Carlos III e Isabel II tuvieron para dictar tal medida, mientras la República necesitó la rebelión popular desatada de múltiples focos. $\mathrm{La}$ medida iba, evidentemente, destinada al desanclaje de la estructura educativa de la Compañía, aparte de que la pragmática sanción de Carlos III no había sido nunca derogada, con lo que, según el propio ministro de Justicia, Álvaro de Albornoz, vivía al margen de la ley. La Enseñanza no podía partir de presupuestos que contrariaban el propio régimen que se había dado el país, pero los jesuitas constituían un número - cercano a los 3.000 - irrelevante frente a la cantidad total de frailes, que excedía los 80.000 individuos, sin contar al clero secular, con lo que continuaba, en palabras de Sender, «la monstruosa organización conventual» y su intocado poder económico.

No hay tampoco más nombres propios de los citados, salvo alguna mención irónica al cardenal Segura: ${ }^{14}$ «uno de los pocos altos funcionarios de la Iglesia que creen en Dios", que, después de la sublevación de Jaca, quería asperjar los cuarteles con agua bendita como mejor solución para matar el germen. O a Alfonso XIII, germanófilo durante la guerra, lo mismo que el clero y la aristocracia. En cualquier caso, llamaría la atención, de no conocer la ya brillante trayectoria periodística anterior de Sender, lo compacto de sus argumentos, la abundancia de datos y la riqueza de su información, junto a su habitual desparpajo estilístico.

Este opúsculo no carece, pues, de interés y debiera situarse, como colección de artículos, entre las obras de Sender, tal como se incluye América antes de Colón ${ }^{15}$ otro volumen de las mismas características, tamaño y paginación. La cuestión religiosa en el periodo de la II República no tiene una larga tradición investigadora pese a su relevancia fundamental, aunque en los últimos diez años empieza a ser atendida. ${ }^{16}$ Ojalá esos estudios

\footnotetext{
14 Cardenal primado al advenimiento de la República, el Primero de Mayo de 1931 propagó una pastoral defendiendo la monarquía y su estrecha unión con la Iglesia.

15 Así lo hace Elizabeth Esr'ADAs, op. cit., p. 124, que, en cambio, como se vio, no menciona la obra objeto de este comentario.

16 Algunas publicaciones interesantes que pueden consultarse son: Víctor Manuel ARBELOA, La Semana Trágica de la Iglesia en España (octubre 1931), Barcelona, Galba, 1976. ArCHIVo VIDAL Y BARRAQUER, Església i Estat durant la segona república espanyola (ed. M. BATLLORI y V. M. ARBELOA) (6 vols.), Monasterio de El Escorial (1971-1988). Francisco AsTARLoA, Región y Religión en las Constituyentes de 1931, Valencia, 1976. Manuel AzAÑa, Obras completas (4 vols.), México, 1966-1968. Domingo BENAVIDEs GOMEZ, El fracaso social del catolicismo español, Barcelona, Nova Terra, 1973. Alfonso Botri, Cielo y dinero. El nacionalcatolicismo en España (1881-1975), Madrid, Alianza, 1992. Vicente CÁRCEL ORTÍ, La persecución religiosa en España durante la Segunda República (1931-1939), Madrid, Rialp, 1990. Raymond CARR, ed., Estudios sobre la República y la Guerra Civil española, Barcelona, Ariel, 1973. Miguel Ángel GonzÁlez MuÑIz,
} 


\section{EL LUGAR DE SENDER}

sociales sirvan para seguir sobre la pista de esa España tan jaleada y estudiada, pero no siempre comprendida, del primer tercio de siglo.

Problemas de la Segunda República, Madrid, Júcar, 1974. Mariano GRANADOs, La cuestión religiosa en España, México, Las Españas, 1959. Juan María LABOA, La Iglesia y la II República, Madrid, Cuadernos de Historia 16, $\mathrm{n}^{\circ} 220$. Frances LANnON, Privilegio, persecución y profecía. La Iglesia Católica en España, 1875-1975, Madrid, Alianza, 1987. Josep M. Llorens, La Iglesia contra la República española, Vieux, Grupo de Amigos del Padre Llorens en el exilio, 1968. F. DE MEFR, La cuestión religiosa en las Cortes Constituyentes de la II República española, Pamplona, Eunsa, 1975. A. Melquíades y V. CACHO VIU, Aproximación a la historia social de la Iglesia española contemporánea, Madrid, Real Monasterio de El Escorial, 1978. Stanley G. PAYNE, El catolicismo español, Barcelona, Planeta, 1984. Mariano Pérez GaLÁN, La enseñanza en la II República Española, Madrid, 1975. Manuel RAmírez JiméNEZ, Los grupos de presión durante la II República, Madrid, Tecnos, 1989. Javier Tusell, Historia de la Democracia Cristiana en España (2 vols.), Madrid, Sarpe, 1986. VV. AA., Estudios históricos sobre la Iglesia Española contemporânea, Madrid, Real Monasterio de El Escorial («Ediciones Escurialenses»), 1979. VV. AA., La cuestión social en la Iglesia española contemporánea, Madrid, Real Monasterio de El Escorial («Ediciones Escurialenses»), 1981. 


\title{
Ramón J. Sender y la revolución española
}

\author{
Francis Lough \\ University of Kent
}

\begin{abstract}
Como ocurrió con muchos escritores del exilio español, la guerra civil y la infancia en el mundo de la preguerra llegaron a ser temas predilectos en la narrativa de Ramón Sender después de 1939. Pero a Sender le interesó durante toda su vida, no solamente la guerra en sí y sus consecuencias, sino la vida y la pasión de los que quisieron crear otro mundo en la España de los años treinta. La importancia para Sender de la temática de sus primeras novelas, y de las experiencias vitales en que se basan, se nota en la necesidad que sintió durante toda su vida de volver a interpretarla: O. P., La noche de las cien cabezas y el reportaje Viaje a la aldea del crimen toman nueva forma en El verdugo afable —novela editada más de una vez- en los años cincuenta; Siete domingos rojos se publica en tres nuevas versiones antes de aparecer bajo el título Las tres sorores en los años setenta. A diferencia de las muchas novelas en que Sender repite anécdotas o la misma materia narrativa, en estos casos se trata de obras enteras refundidas una y otra vez, quizás sin lograr nunca su forma definitiva. Lo único cierto es que el tema de la revolución no dejó de preocuparle al autor durante toda su vida. Dadas las fechas de las novelas mencionadas, este tema ofrece un buen punto de partida para estudiar aspectos del cambio y de la continuidad en las obras de Sender.

En 1970, en conversación con Marcelino Peñuelas, Sender definió el cambio de enfoque en sus novelas después de la guerra civil de la siguien-
\end{abstract}


te manera: «Dejé de escribir una literatura de combate inmediato para escribir una literatura, por decirlo de un modo un poco absurdo, de iluminación» (Peñuelas, 1970, 91). Para muchos esta definición correspondía a la imagen que tenían de Sender, la de un novelista comprometido que abandonó su interés en cuestiones políticas durante sus años de exilio. Huelga destacar ahora que esta imagen no se basaba en muchos casos en una lectura de las novelas de los años treinta, por ser éstas difíciles, si no imposibles, de localizar. Hoy no deja de sorprender la falta de reediciones de algunas de las novelas más «comprometidas» del autor de aquellos años y, especialmente, de Siete domingos rojos, que sí ha vuelto a publicarse en inglés. ${ }^{1}$ Pero, gracias a los muchos estudios que se han hecho de las primeras novelas de Sender, se ha podido desmentir esta imagen y forjar otra nueva y más exacta. Se ha demostrado claramente que la involucración de Sender en la política de los años veinte y treinta no basta para que se le considere mero novelista político. Además se ha señalado en varias ocasiones que hay un importante elemento de continuidad en las obras de Sender que presta a su obra completa una coherencia y unidad a pesar de los cambios efectuados después del trauma de la guerra civil y sus consecuencias. Pero, si es así, es legítimo preguntar hasta qué punto sus primeras novelas representan «una literatura de combate inmediato». $O$, por decirlo de otra manera, ¿qué sentido tiene definir así unas novelas cuyo valor último no es político? O hay que abandonar esta etiqueta o buscar una forma de entender el concepto de una «literatura de combate» sin limitarlo al mundo reducido de la política.

Cuando se habla de continuidad en las obras de Sender es casi imprescindible empezar con Imán ya que, como señaló Peñuelas, esta novela resume, «en germen, todos los diversos rumbos que su obra ha seguido con el tiempo» (Peñuelas, 1971, 99-100). El episodio central de Imán lo forma la huida de Viance de un universo que se desmorona. Hace falta, por lo tanto, otro concepto del mundo para llenar el vacío dejado por la destrucción del antiguo. Cuando Viance se siente renacer en el vientre del caballo muerto, sus intuiciones le llevan hacia otra manera de entender el lugar del hombre en la tierra. Una de sus intuiciones más importantes se relaciona con la idea de la unidad de toda la materia. La base de esta unidad la entiende como una forma de amor cósmico que justifica el amor entre los hombres: Viance siente «el deseo de hacer el bien y de encontrarlo todo dulce y bueno» (152); por consiguiente, «no odia a nadie: ni a los moros ni a los españoles causantes de esta catástrofe» (172-173). De esta forma, Sender une lo metafísico con lo ético para luego aplicar sus ideas a una situación política. Pero esta intuición sólo le da a Viance la mitad de

1 Seven Red Sundays (trad. del español de sir Peter Chalmers MrTCHELL), Chicago, Elephant Paperbacks, 1990. Es una nueva edición de la traducción que se publicó por primera vez en 1936. 
un todo. Sólo sienta la base de una ética en términos de la relación del individuo con otros individuos. No le dice nada sobre la experiencia de su propia individualidad. Quizás una intuición aún más importante es la siguiente:

La vida de un ser vale menos que el vapor de una gota del mar evaporada bajo el sol. $\mathrm{Y}$, sin embargo, se considera el centro y el eje del universo y cree que las estrellas sólo existen para que él pueda orientarse y saber qué hora es. Si no hay luna es porque así él se encubre mejor en las sombras. (162)

Hay aquí una paradoja importante: el hombre es a la vez centro del universo y elemento tan insignificante como cualquier gota de agua. ${ }^{2} \mathrm{El}$ amor que siente Viance y que fácilmente se asocia con una actitud altruista sólo puede existir si el individuo es capaz de superar sus inclinaciones egoístas, que son igualmente naturales. Encontramos entonces en esta primera obra de Sender la base de la visión del mundo y las relaciones humanas que más tarde expresa el autor en términos de hombría y persona.

Otro episodio importante en Imán que hay que destacar es el del viejo a quien Viance conoce en el desierto. Visto con la óptica de la paradoja de la vida, este viejo enigmático representa una actitud egoísta extrema. ${ }^{3}$ Él mismo, en el contexto de la relación con su mujer, resume su ética de esta manera:

Yo inventé un pacto que nos hizo a los dos felices. Ése es el único pacto que en la vida se puede hacer con los demás. No lo olvides. Con las mujeres, con los hombres, con las sociedades. Rendirlos, destruirlos, aniquilarlos cuando se tiene la suficiente voluntad para serles después fieles toda la vida... (161)

Pero ¿se puede saber si su mujer es feliz o no? El egoísmo del viejo se revela en el yo con el que introduce su tema. La conclusión lógica de una actitud basada sobre la destrucción de todo menos el yo del sujeto es el fin de toda la civilización. La existencia misma de este viejo aislado y solitario, que vive de los escombros de los campos de batalla, revela la insensatez de su ética si se mira desde el punto de vista de la sociedad y las relaciones humanas. Por consiguiente, este episodio contrasta con el del

\footnotetext{
${ }^{2}$ Estas ideas pueden basarse en las de Schopenhauer, quien habla de una contradicción en la naturaleza según el punto de vista del que se mira, el del individuo o el de la naturaleza en sí: "Nature flatly contradicts herself, according as she speaks from the universal or the particular, from inside or outside, from the centre or the periphery" (Arthur SCHOPENHALER, The World as Will and Representation, Nueva York, Dover Publications, 1966, trad. del alemán de E. F. J. PAYNE). Analizo de manera extensa la relación entre las ideas de Schopenhauer y Sender en mi libro Politics and Philosophy in the Early Novels of Ramón J. Sender, 1930-1936. The Impossible Revolution, The Edwin Mellen Press, 1996.

${ }^{3}$ Casi todo lo que dice el viejo puede interpretarse en términos de la filosofía de Schopenhauer. Vid. la nota anterior.
} 
caballo. Pero, al mismo tiempo, corresponde a su complemento necesario. Viance, con su metafísica de la unidad de la materia, y el viejo egoísta corresponden a los dos polos de la paradoja existencial de la vida del individuo. Pero, mientras el viejo aparece en la novela defendiendo su tesis y llevándola a cabo, la de Viance no se ve en la práctica. En Imán, la defensa del altruismo como piedra angular de la convivencia social no pasa de ser una vaga intuición. El intento de ponerla en práctica es el tema principal de las obras «revolucionarias» de Sender, las que enfocan las acciones de los revolucionarios españoles de los años veinte y treinta.

En Siete domingos rojos, el anarquismo y el comunismo se observan a través de la óptica de la visión ética establecida en Imán. A pesar de la declaración del autor en su prólogo, que no busca una verdad social, moral ni política, está claro que en Siete domingos rojos las ideas de estas índoles son de una importancia central. Lo que quería decir Sender quizás es que no buscaba una verdad única, porque no creía en una solución tan sencilla para la problemática de la existencia humana.

No se puede negar que Sender sentía una gran atracción hacia los anarquistas y que, en los primeros años de la segunda República, valoraba positivamente la capacidad de organización de los comunistas. Sin embargo, esto no quiere decir que no observara a ambos grupos desde una perspectiva crítica. Por algo dice en el prólogo de Siete domingos rojos que "desde el punto de vista político o social este libro no satisfará a nadie» (5). Aunque los anarquistas y los comunistas buscan el mismo fin, se distinguen por su manera de llegar a él: los anarquistas defienden la autonomía del individuo motivado por su generosidad, mientras que los comunistas prefieren abandonar todo concepto del individuo para buscar fuerza en la unidad de las masas. Sin embargo, a pesar de sus ideales, ambos grupos caen víctimas de la paradoja de la existencia intuida por Viance.

La lucha contra la sociedad burguesa se presenta en Siete domingos rojos como lucha contra una actitud egoísta. Villacampa, por ejemplo, dice que los burgueses "tienen las cabezas planchadas de egoísmo" (168). Y la crítica más radical que hace Samar de los anarquistas es que son burgueses, lo cual indica que él ve en sus compañeros la misma actitud individualista que caracteriza a la sociedad burguesa contra la que luchan. Cuando un grupo de anarquistas rechaza su plan, por ser demasiado autoritario, Samar piensa: «¿Cómo se va a conseguir esto con hombres como ese que en un mitin se quemó la mano con una cerilla para demostrar lo que vale la voluntad revelando una vanidad exhibicionista desenfrenada?» (276). En otra reunión, cuando Samar muestra su satisfacción al descubrir que está de acuerdo con él un anarquista viejo, éste modifica lo que acaba de expresar "para decir algo que no haya dicho Samar, algo original» (73). En otra ocasión, la crítica se hace aún más severa cuando se llega a cuestionar los motivos fundamentales de otros dos anarquistas:

Discutían por discutir, iban evolucionando hasta cambiarse recíprocamente las tesis y había tal suficiencia y tal satisfacción en perderse en el labe- 
rinto pequeño intelectual que se veía que ninguno de los dos esperaba la revolución. (277)

No es extraño entonces que al final de la novela los anarquistas aparezcan en el sueño de Samar desnudos, pero con claras características burguesas (464).

El caso de Samar como representante de la alternativa comunista es diferente y sólo se entiende bien si se nota la distancia cada vez mayor que existe entre Samar y el narrador después de la muerte de Amparo. ${ }^{4}$ Samar sólo puede dedicarse exclusivamente a la revolución cuando, al morir Amparo, muere su «espíritu burgués». El problema para Samar, sin embargo, es que, con la pérdida de Amparo, él deja de ser en cierto modo humano. El narrador resume su experiencia en pocas palabras:

En ella moría su propio espíritu. Pero Samar se quedaba mortalmente vacío. Sin espíritu capaz de consagrar la fe, de transformar la fe de los sentidos en fórmulas morales y de elevar éstos a una categoría sobrehumana no podría vivir. (390)

El narrador, que destaca aquí la importancia del tema moral, también informa al lector del valor humano del espíritu que acaba de morir en Samar, esto es, el espíritu burgués asociado con el individualismo: «El espíritu tiene esa misión de rodearnos de infinito. Pero Samar ya no sentía lo imposible» (395). Aunque Samar se recupera un poco sólo es para identificarse con las máquinas simbolizadas en la imagen de la locomotora. Al final de la novela, Star recoge la descripción de Samar que ofrece el narrador. Es Villacampa quien comunica las palabras de Star al lector:

\footnotetext{
En la alameda me dio la lata con eso de que Samar está muerto. Pasemos por ello aunque yo no lo veo claro. Ella dice que no podrá dar nunca Samar a ninguna mujer sentimientos verdaderos porque ya no sentirá ni la pasión, ni la alegría ni la pena. Que será efectivamente como una máquina... (454)
}

Samar ha llegado a representar un extremo de altruismo en que se ha negado del todo el último vestigio de individualidad. En este sentido ha dejado de ser humano y queda metafóricamente muerto.

$\mathrm{Ni}$ los anarquistas ni Samar consiguen resolver la paradoja existencial de Imán. El hombre no puede dejar de ser, al mismo tiempo, individuo y parte insignificante del cosmos. Cada individuo se siente centro del universo, pero es también capaz de reconocer lo que tiene en común con los otros, con la Naturaleza, en fin. En términos de la praxis revolucionaria, los ideales altruistas tienen que conseguirse a través de las acciones de individuos capaces de armonizar sus ideas y acciones buscando, al mismo

${ }^{4}$ Discrepo de los que ven en Samar la voz de Sender (Nonoyama, 103; Burs, 120). 
tiempo, una armonía entre los dos aspectos de su condición humana. Como dice Sender en su prólogo, no hay que dar el máximum, que es lo que intenta Samar:

No puede un hombre acercarse a los demás dando el máximum y exigiendo el máximum también. Las sociedades se forman no acumulando las virtudes individuales sino administrando los defectos con un sistema que limita el área de expansión de cada cual. (8)

Ningún hombre puede ser perfecto ni perfectamente altruista. Necesita defender, hasta cierto punto, su propia individualidad. Por otro lado, también podría decirse que no es posible la sociedad si el hombre sólo da el mínimum, que es el caso del viejo en Imán. ${ }^{5}$ Para llevar a cabo una revolución social el amor tiene que triunfar sobre el individualismo, hombría sobre persona, altruismo sobre egoísmo, pero sin negar del todo el segundo de los términos en cada caso. Los anarquistas, a pesar de sus ideales y metas altruistas, sufren las consecuencias de su excesivo individualismo a la hora de organizarse, mientras a Samar, al final, no le queda ningún vestigio de individualidad y, por consiguiente, de humanidad. Se halla implícita en todo esto la aceptación de la necesidad de un equilibro entre los dos aspectos del hombre, una idea que sólo desarrolla plenamente Sender, como se verá, después de la guerra civil, una vez apartado del ambiente tenso de la segunda República.

Después del idealismo del sueño quevedesco que representa La noche de las cien cabezas, Sender vuelve, en Mister Witt en el Cantón, a la problemática en el mundo real de la relación entre egoísmo y altruismo en un contexto revolucionario. En este caso, su intención queda más clara que en Siete domingos rojos. Por una parte, ha evitado meterse en la política del movimiento cantonalista, lo que permite una más fácil identificación entre los acontecimientos narrados en la novela y los de 1935, cuando se escribió. Por otra parte, la reunión de mister Witt con Antonete al principio de la novela sirve para establecer de forma explícita en la narrativa los valores éticos que la gobiernan. Estos dos personajes representan dos extremos, como se ve en el análisis de sus papeles que hace el inglés antes de la reunión:

¿Qué interés personal podía tener el señor Gálvez? Los aventureros le interesaban, pero un profeta es todo lo contrario de un aventurero. El profeta actúa de día, a plena luz. Podría decirse que lleva las entrañas al aire y que necesita que los demás las vean. Carece de individualidad y trata de diluirse en los sueños o las angustias de su pueblo y de su época. En cambio, el aventurero [...] va robando a la vida, en la sombra, con insinuaciones, con pasos cautelosos, con habilidades, audacias, y si es preciso con esa difícil flor negra del cinismo en el ojal, va robándole a la vida sus mejores frutos, sus más cos-

\footnotetext{
${ }^{5}$ El viejo no rechaza a Viance de inmediato, pero sólo acepta el contacto social con él durante poco tiempo. Su filosofía de la vida le impediría establecer una relación más permanente.
} 
tosas galas, y adorna y alimenta con ellas su individualidad. «Todo el mundo para mí», dice el aventurero. "Yo para todo el mundo", dice el profeta. $Y$ Gálvez le parecía a míster Witt eso: un profeta. (pp. 78-79)

Estas dos frases que emplea mister Witt para definir las actitudes vitales asociadas con los dos personajes - «todo el mundo para mí», «yo para todo el mundo»- apuntan hacia el conflicto moral que existe en el fondo de la novela. Lo importante en cuanto a la revolución, sin embargo, es que el mismo conflicto se reproduce hasta cierto punto entre los rebeldes de Cartagena.

Mientras Antonete, encarnación de la revolución en Míster Witt en el Cantón, aparece idealizado como el altruista perfecto, muchos de los otros cantonalistas se muestran incapaces de tal perfección (una excepción aquí es la figura de Colau). Antonete se decepciona cuando tiene que llegar a una conclusión que le parece absurda: «la de separar en cierto modo la idea cantonal del pueblo» (167). O sea, cuando se da cuenta de que hay una distancia importante entre su idealismo y la realidad. En otra ocasión, acepta que los jefes como él y el pueblo tienen cualidades distintas: «es una fuerza el sentir del pueblo, el pensar de sus jefes» (101). El pueblo representa el mundo instintivo pero, como repara mister Witt desde su balcón, no todo lo instintivo es bueno: «Todo lo que sucedía en la calle era primario e instintivo como ella [Milagritos]: hambre, sed, odio, amor, irreflexión, ceguera» (54). Por eso Antonete hace el papel importante de guía moral del pueblo y tiene que recordarles, cuando quieren saquear las casas de los ricos, que hay que controlar sus instintos: «¿Qué queréis? ¿Ensuciar vuestros ideales con el asesinato y el robo?» (176). O, como le dice a Hozé poco antes: "con la crueldad no se consigue nada... Nosotros no somos el odio sino el amor» (175). ${ }^{6}$

Al final, los rebeldes de Cartagena tienen que rendirse. Por una parte, no puede ser de otra manera, ya que la historia dicta tal final. Pero, como he intentado demostrar en otra ocasión, el que en la novela el responsable del hundimiento del Tetuán sea mister Witt y que este acontecimiento se presente como el símbolo del final del cantón parece indicar que Sender quería destacar no sólo el fracaso militar, sino también cierto fracaso moral entre los rebeldes que les habría impedido construir la sociedad soñada por Antonete. ${ }^{7}$

Francisco Carrasquer ha notado en el Sender de los años treinta cierto pesimismo que sorprendería en un escritor políticamente comprometido (1992, CLIV). No pretendo con lo dicho haber llegado al fondo de este tema, pero sí creo que sus novelas «revolucionarias» de estos años no ins-

\footnotetext{
${ }^{6}$ Es interesante notar aquí que según Schopenhauer la turba violenta es la expresión del grado más alto de egoísmo en el hombre (I, 333).

7 Vid. mi artículo «History and Fiction in Mister Witt en el Cantón», Anales de la Literatura Española Contemporánea, 16 (1991), pp. 275-289.
} 
piran mucho optimismo en cuanto a la posibilidad de una revolución española por entonces. No se puede negar el entusiasmo de Sender, en distinta medida, por los anarquistas y los comunistas, pero tampoco hay que descartar su actitud crítica para con ellos. Es importante subrayar aquí que hablo solamente de las novelas de Sender y no de su periodismo, ya que, como también ha señalado Carrasquer, son dos formas de escritura distintas y con diferentes fines (1992, CLX). Sender entendía que la revolución de masas dependía al final de las acciones de los individuos que componían esas masas. Ya en su primera novela empezó a indagar en la naturaleza metafísica y ética del individuo porque rechazaba una solución política al problema de la paradoja de la existencia. Como advierte Samar en Siete domingos rojos: «Tratamos de resolver con fórmulas políticas muy limitadas esta angustia de vivir que nos oprime y que nos oprimirá siempre» (414).

¿En qué sentido, pues, se puede decir que estas primeras novelas de Sender son representativas de "una literatura de combate inmediato»? Está claro que fueron escritas desde el punto de vista revolucionario de un novelista que rechazaba totalmente, y quería destruir, la sociedad burguesa. Para sustituirla sólo existía la visión todavía imprecisa y vaga de una utopía social. Sin embargo, esta visión sólo puede quedar como promesa para un futuro todavía distante, ya que en la realidad de los años treinta, según Sender, los revolucionarios no poseían las cualidades morales necesarias para hacer de su sueño una realidad. Lo que no queda claro, ni siquiera para Sender, es cómo la sociedad puede cambiar dada la problemática metafísica asociada con la vida de cada individuo. Antes de la revolución social tiene que haber millones de revoluciones individuales, millones de casos parecidos, pero no iguales, al de Samar. Habrá casos excepcionales de individuos, como Antonete, que han realizado su revolución individual. El problema es cómo hacer que este proceso individual se transmita a todos los individuos que componen las masas que van a efectuar la revolución social. Sender no ofrece ninguna solución a este problema, a lo mejor porque no la hay. Sin embargo, se podría decir que, aparte de su crítica a la sociedad burguesa, uno de los fines de sus novelas fue el hacer más conscientes a sus lectores revolucionarios de la dificultad de realizar un cambio social radical. Pero lo más interesante aquí es que no se puede hablar del valor revolucionario de las novelas sin pasar a considerar su calidad de «literatura de iluminación», lo cual no debería sorprender dado el punto de partida en las intuiciones metafísicas de Viance en Imán.

Desde su primera novela, lo que le interesa a Sender es el lugar del hombre. Lo que cambia con los años es el enfoque específico sobre el mismo problema y éste viene dictado por las circunstancias vitales del autor mismo. Durante los años de gran tensión política de la segunda República Sender observa el mundo político a su alrededor y habla de la realidad de ese mundo. Después de la guerra, al autor le sigue preocu- 
pando el lugar del hombre pero la distancia -geográfica, temporal y emocional-que le separa de su mundo hace que sea más fácil, y quizás más necesario, ver lo español en un contexto más amplio. No deja de escribir sobre el movimiento revolucionario de la España de los años treinta. Como se sabe, vuelve a interpretar los mismos hechos de sus primeras novelas en varios momentos de su vida. Pero con la pérdida de la inmediatez de las experiencias, junto con la decepción del fracaso final al terminar la guerra civil, el elemento humano ocupa cada vez más el primer plano en sus novelas. En vez de buscar en lo humano una forma de entender a los revolucionarios españoles de los años treinta, Sender empieza a ver en éstos un ejemplo más de unos principios generales que definen su forma de concebir el hombre. Este cambio de enfoque se nota claramente en la forma en que Sender ha incorporado en El verdugo afable sus tres obras O. P., La noche de las cien cabezas y Viaje a la aldea del crimen, y en la nueva versión de Siete domingos rojos que publicó hacia el final de su vida, Las tres sorores. En todos los casos, los acontecimientos son iguales pero se despolitizan para traer al primer plano las preocupaciones de orden ético y metafísico.

En El verdugo afable, el protagonista, Ramiro, quiere entender lo que es el mal y cómo actuar frente a él (Trippett, 24). La diferencia primordial entre Ramiro y los protagonistas de las primeras novelas de Sender es que aquél no identifica el mal con la sociedad burguesa. Aunque Ramiro vive los mismos acontecimientos revolucionarios que los protagonistas de algunas de las primeras novelas, rechaza de una forma aún más contundente que el Samar de Siete domingos rojos toda acción política. Se hace amigo de los anarquistas por su generosidad de espíritu, pero no le interesan sus doctrinas (112). Si les ayuda es porque son sus amigos. Sin embargo no lo hace con mucha convicción. Cuando se muda de casa, no les dice nada y ellos tienen que buscarlo a él: a los anarquistas Ramiro les es útil porque tiene un piso no fichado por la policía (219). Además casi no cumple su promesa de ir a Benalup porque prefiere quedarse con su amante argentina. Cuando al final decide ir es porque «le gustaba sentirse forzado por alguna forma de urgencia» (229). Es una forma de evitar la responsabilidad de sus acciones. No sería difícil poner más ejemplos de la falta de interés de Ramiro por la política. De más importancia es la actitud del protagonista hacia el fin que quieren conseguir los anarquistas. Después del sueño que resume los acontecimientos de La noche de las cien cabezas, Ramiro duda de la posibilidad del éxito de la revolución cuando se pregunta: “¿Pero será todo eso posible? ¿No es demasiado fantástico y utópico?" (204). Cuando vuelve a soñar con "el hombre indecible» que, en la primera novela, representaba el nuevo hombre capaz de construir una nueva sociedad, descubre que se ha alejado. Le dice un anarquista: «Está en un lugar adonde nadie llegará nunca. Pero eso no importa» (264). El idealismo de los anarquistas se mantiene vivo, pero no lo comparte Ramiro, como se ve cuando racionaliza su rechazo de la violencia: 


\section{EL LUGAR DE SENDER}

[...] a reces llegaba a sentirse uno de ellos. En un momento dado podría matar como el Cojo y morir como Graco, pero ¿y qué? ¿Cambiaría eso el orden del mundo? ¿Haría mejores las relaciones humanas? ¿Y quién era él para proclamar una forma de justicia y aplicarla a otros hombres? Si él tenía ese derecho, todos los hombres lo tenían también y ejercerlo sería un llamamiento al caos. (162-163)

La posibilidad, por tenue que fuera, de una revolución española implícita en las novelas de los años treinta aquí se sustituye con una visión del hombre que hace imposible la revolución en sí. La referencia al caos indica que Ramiro no comparte la noción anarquista de que el hombre es intrínsecamente bueno, sino que piensa que es demasiado egoísta.

Esta imagen de los anarquistas cobra más importancia años después en Las tres sorores. Aunque el retrato de los anarquistas en sí no se diferencia del original presentado en Siete domingos rojos, el marco en que se encuadra manifiesta el cambio de actitud en el autor hacia los revolucionarios y sus ideales. Esta nueva novela se estructura alrededor de la tesis de Samar de que la historia está gobernada por una «ley pendular», 8 según la cual se alternan siempre períodos de anarquía con períodos de absolutismo: "La monarquía absoluta conducía tarde o temprano a la anarquía y ésta, en plano más o menos cercano, a la teocracia [...]. Desde los primeros tiempos que registra la historia documentalmente había sido así» (9). Esta tesis la expone Samar en las primeras páginas de la novela para que se entere el lector desde el principio de la narrativa de cómo hay que entender a los anarquistas. La acción revolucionaria de los anarquistas, pues, se presenta, no como algo nuevo, sino como una manifestación más de un momento histórico que se ha repetido muchas veces y que seguirá repitiéndose.

En Las tres sorores hay tres acciones paralelas: las actividades políticas de los anarquistas, la vida de Espartaco y el relato de las actividades sexuales de unas monjas en la época de Felipe II. Las tres acciones tienen el mismo valor ideológico, según se nota en las definiciones que de ellas ofrecen Samar y el narrador: las monjas son «anarquistas del siglo XVI [...] sin saberlo» (171); el deseo de luchar de los anarquistas lo interpreta Samar como «la orgía de la libertad» (125); «estas orgías, al revés que la de las bernardinas, son colectivas y públicas. Como fueron las de Espartaco y sus seis mil adictos" (63-64). "Orgía» y "anarquía" se relacionan con la natural inclinación egoísta de los niños: «Los niños lo primero que aprenden es a ser egoístas. Más tarde comienzan a pensar en los otros y se hacen un poco altruistas para conseguir alguna armonía con lo que les rodea. Ahí

8 Ocurre a veces en las novelas de Sender que una imagen que aparece en una novela se transforma en motivo central de otra. En este caso, la imagen de la ley pendular de la historia la utiliza el autor con anterioridad en El verdugo afable (128). 
comienzan a ser conscientes. Si no lo logran caen en formas de degeneración» (295).

Lo que hay que hacer es buscar algún tipo de equilibrio entre los dos extremos de absolutismo y egoísmo. Hay que encontrar el centro, aunque Samar reconoce que no es fácil de conseguir: «La dificultad de armonizarlos era lo que hacía generalmente al hombre agresivo, sanguinario, destructor y francamente irresponsable» (14-15); « ¿y el centro? No hay manera de determinarlo» (128).

La diferencia ideológica entre Siete domingos rojos y Las tres sorores es importante, pero se basa en un cambio de enfoque y no en un cambio radical en la forma de concebir lo humano. El individualismo de los anarquistas en la primera novela se asociaba con la contaminación del espíritu por la ideología burguesa. Los anarquistas fracasaban por su excesivo individualismo, pero siempre parecía existir la posibilidad, aunque remota, de que en un futuro lejano podrían cambiar. En la segunda, esta posibilidad deja de existir. El individualismo ya no se percibe como resultado de la corrupción de una ideología burguesa, sino como el instinto más natural del hombre. En Siete domingos rojos los revolucionarios españoles no estaban todavía preparados para realizar sus ambiciones. En Las tres sorores, la historia se entiende solamente desde la perspectiva de una alteración continua entre caos y absolutismo. Ya no existe la posibilidad de la organización de la sociedad sobre principios altruistas. El fracaso de los anarquistas en esta segunda novela viene a ser un ejemplo más del fracaso de la humanidad; la revolución en España ya no es posible porque la revolución en sí es una meta inalcanzable.

Samar sólo puede llegar a esta conclusión porque vive «al margen» de los acontecimientos. La distancia temporal del autor del ambiente muy político de los años treinta ha creado una distancia psicológica entre él y los acontecimientos. Esta distancia, que le permite profundizar en los sucesos, contribuye al proceso de «iluminación» de la naturaleza humana que definió Sender como una de las características de su narrativa después de la guerra civil. Pero hay que subrayar que es una conclusión que casi se podría sacar de una lectura de las novelas que escribió antes de la guerra, ya que se basa en un análisis más detenido de las consecuencias de las premisas iniciales presentadas en Imán. El hombre se siente a la vez centro y nada más que una parte más del universo, dos puntos de vista que dan lugar respectivamente al egoísmo y al altruismo. Siete domingos rojos revela la imposibilidad de la convivencia humana basada en cualquiera de estos extremos, de lo cual se puede deducir la necesidad de un punto de equilibrio entre ambos. Sin embargo, en el momento de vivir la política revolucionaria de los años trienta, el idealismo del joven Sender quizás mantenía alguna fe en la posibilidad de un punto que se acercaba más al extremo altruista. Por lo tanto le interesaba más la promesa del combate que la necesidad de la iluminación, aunque de esto también había en sus novelas. Después de la guerra civil (y también de la segunda guerra mun- 
dial) Sender perdió esta fe al mismo tiempo que abandonó su idealismo. El Samar de Las tres sorores, como Sender mismo, llegó a pensar que la propaganda política no es más que «pamplinas» (48), aunque al mismo tiempo necesaria porque hay que seguir luchando. La sociedad no puede ser perfecta, no puede transformarse radicalmente, pero puede mejorarse. Así que sigue siendo importante combatir, pero más aún entender o «iluminar». Durante toda su vida, Sender siempre combatió y siempre iluminó, pero en distinto grado en épocas diferentes. El Samar de Las tres sorores ha dejado de ser un extremista de la izquierda para convertirse en lo que él denomina un "extremista del centro" (233), autodefinición paradójica mediante la cual Sender, al final de su vida, supo responder a la paradoja existencial de la vida humana que reveló por primera vez en Imán.

\section{OBRAS CITADAS}

BUYS, Anne, «Siete domingos rojos (1932) de Ramón J. Sender: un compromiso político y social y un conflicto existencial», Iberoromania, 10 (1979), pp. 112-127.

CARRASQUer LAUNFD, Francisco, «Introducción» a Ramón J. SENDER, Imán, Huesca, Instituto de Estudios Altoaragoneses, 1992.

Lough, Francis, "History and Fiction in Mister Witt en el Cantón», Anales de la Literatura Española Contemporánea, 16 (1991), pp. 275-289.

- Politics and Philosophy in the Early Novels of Ramón J. Sender, 1930-1936. The Impossible Revolution, Lewiston, The Edwin Mellen Press, 1996.

NONOYAMA, Michiko, El anarquismo en las obras de R. J. Sender, Madrid, Playor, 1979.

PeÑLelas, Marcelino C., Conversaciones con Ramón J. Sender, Madrid, Magisterio Español, 1970.

- La obra narrativa de Ramón J. Sender, Madrid, Gredos, 1971

SCHOPENHAUER, Arthur, The World as Will and Representation, Nueva York, Dover Publications, 1966.

SENDER, Ramón J., Imán, Madrid, Cenit, 1930.

— O. P. (Orden Público), Madrid, Cenit, 1931.

—- Siete domingos rojos, Barcelona, Balagué, 1932; Buenos Aires, Proyección, 1970; Buenos Aires, Proyección, 1973; Seven Red Sundays (trad. de sir Peter Chalmers Mrtchel..), Londres, Faber, 1936; Harmondsworth, Penguin, 1938; Chicago, Elephant Paperbacks, 1990.

- La noche de las cien cabezas, Madrid, Pueyo, 1934.

—, Mister Witt en el cantón, Madrid, Espasa-Calpe, 1936; Madrid, Alianza, 1968.

-..., El verdugo afable [1952], Barcelona, Destino, 1981.

- Tres novelas teresianas, Barcelona, Destino, 1967.

- Las tres sorores, Barcelona, Destino, 1974.

TRIPPETT, Anthony M., Adjusting to Reality: Philosophical and Psychological Ideas in the Post-Civil War Novels of Ramón J. Sender, Londres, Tamesis, 1986. 


\title{
Manuel Sender y Mariano Carderera, dos alcaldes que regeneraron la actividad política en Huesca
}

\author{
José Ma Azpíroz Pascual \\ I. E. S. Ramón y Cajal, Huesca
}

\begin{abstract}
Al igual que en otras capitales de provincia, el 14 de abril y los días siguientes fueron de euforia y de auténtica fiesta popular. ${ }^{1}$ En la proclamación de la República en Huesca tuvo un papel protagonista el joven abogado Manuel Sender Garcés, que encabezando una multitudinaria manifestación, una vez en el Gobierno Civil, dirigió desde uno de los balcones estas palabras a los oscenses: «Por voluntad popular queda proclamada la República en Huesca. ¡Viva la República!».

Más tarde, en la Agrupación Republicana de Huesca, Sender volvió a hacer uso de la palabra, manifestando que «por fin el pueblo de Huesca ve plasmados sus ideales republicanos, ansío que la justicia sea una realidad y que los caciques que durante cincuenta años nos han gobernado sean proscritos para que el pueblo se gobierne por sí mismo». ${ }^{2}$ A continuación,

1 La afirmación de Santos Juliá «Madrid es una fiesta" se generalizó en todos los pueblos y ciudades españoles y Huesca no fue ajena al sentimiento popular republicano (Santos Julí, Madrid, 1931-1934. De la Fiesta a la lucha de clases, Madrid, Siglo XXI, 1984, Pp. 9-21).

2 El Diario de Huesca, 16-IV-1931.
\end{abstract}


él mismo convirtió la Junta Directiva de la Agrupación Republicana en Gobierno permanente de la provincia para tomar las medidas más convenientes hasta que el gobernador civil monárquico, Pérez Viondi, anunciara la renuncia al trono de Alfonso XIII y la formación de un Gobierno Provisional presidido por Alcalá Zamora.

En esta capital el regeneracionismo en las instituciones estuvo representado ostensiblemente por los partidos de Acción Republicana y el Partido Republicano Radical Socialista. No obstante, al proclamarse la II República buena parte del republicanismo histórico estaba encarnado en el Partido Republicano Radical dirigido por Alejandro Lerroux. Muchos de sus militantes, incluso los más veteranos, confiaban en que el Partido Radical podía desde actitudes centristas regenerar los vicios heredados del viejo caciquismo que campeó a sus anchas durante la Restauración borbónica. En este partido pronto se produjeron desavenencias entre quienes entendían que no se regeneraría la actividad política si no se republicanizaban las instituciones y quienes opinaban que el nuevo régimen republicano debía asentarse en un compromiso histórico que salvaguardara el orden y evitara rupturas bruscas con el pasado.

Esta forma de valorar el presente se tradujo en que unos veían la oportunidad de exigir responsabilidades a los políticos y altos funcionarios de las instituciones, por sus comportamientos corruptos durante los años de la Dictadura, y otros desearon traspapelar los expedientes e incluso admitir en el seno del Partido Radical a conspicuos políticos y personajes monárquicos de la época histórica anterior. ${ }^{3}$

Entre los que pusieron más empeño por regenerar la política, republicanizando las instituciones provinciales, con el objetivo de hacer de la República un régimen democrático más justo y de contenido eminentemente social, se hallaban Manuel Sender Garcés y Mariano Carderera Riva, integrados a partir de abril de 1934 en Izquierda Republicana, partido liderado por Manuel Azaña. Ambos dirigieron desde las instituciones locales - Ayuntamiento y Diputación Provincial - a un grupo de destacados militantes y políticos republicanos. Manuel Sender fue alcalde de Huesca de mayo de 1932 a octubre de 1934 (depurado como consecuencia de la revolución de Asturias); posteriormente fue repuesto como alcalde el 21 de febrero de 1936 y lo fue hasta abril de ese mismo año, al ser designado miembro de la Comisión provincial que debía evaluar las tierras expropiables al aplicarse en la provincia la ley de Reforma Agraria. Por otro lado, Mariano Carderera fue alcalde desde abril de 1931 hasta noviembre de ese año; más tarde ejerció el mismo cargo desde abril de 1936 hasta el 20 de julio de 1936, en que fue detenido en el mismo Ayun-

\footnotetext{
3 José $\mathrm{M}^{a}$ Azpíroz Pascual analiza estos enfrentamientos en el seno del Partido Republicano Radical en el epígrafe titulado «El asunto Diputación y la quiebra del Partido Radical», pp. 65 a 77 de Poder político y conflictividad social en Huesca durante la II República, Huesca, Ayuntamiento (Col. «Crónica»), 1993.
} 
tamiento. Durante el corto periodo del Frente Popular fue también gestor provincial de la Diputación.

Este grupo de dirigentes locales era profundamente anticlerical, especialmente en materia educativa, donde pretendieron imponer las ideas del viejo krausismo y de la Institución Libre de Enseñanza. Su labor en las instituciones, durante el Bienio Reformista (1931-1933) y durante el Gobierno del Frente Popular (1936), para la creación de escuelas fue intensa e imaginativa. Eran partidarios de la escuela única y laica y aplicaron con rigor la política educativa que se aprobó en el Parlamento. También fueron mucho más lejos de los postulados del liberalismo económico: deseosos de profundas reformas políticas y económicas, querían transformar la sociedad para evitar que ésta sucumbiese ante una eclosión revolucionaria. No estaban interesados por la lucha de clases, sí por la solidaridad entre ellas; admiraban el espíritu solidario de León Bourgeois y Henry George, defensores de propiciar frente a los monopolios un mayor igualitarismo a base de pequeños y medianos propietarios y de políticas fiscales más justas que hicieran contribuir al que más tuviera con objeto de redistribuir mejor la riqueza. Apoyaron asimismo la intervención del Estado como moderador y árbitro de los desajustes producidos por las iniciativas privadas; para ellos, el aparato del Estado debía estar controlado por republicanos auténticos y no por prófugos de la Monarquía. Este grupo, en su mayoría jóvenes republicanos, defendió, en palabras del historiador Juan Avilés Farré, «un liberalismo menos respetuoso hacia los formalismos legales y más agresivo contra los privilegios de unas minorías, sin cuya destrucción una democracia efectiva se reputaba imposible». 4

Aunque la actuación política de Sender y Carderera quedó enmarcada dentro de las directrices señaladas por los diferentes partidos en los que militaban, destacaron sobre el resto de los ediles y gestores provinciales por su capacidad de iniciativa y por su compromiso y entrega bien significados. Su tenacidad para mejorar la ciudad fue grande a pesar de los inconvenientes del momento que tuvieron que sortear.

La crisis económica internacional incidió negativamente en el nuevo régimen republicano porque gran parte del capital nacional se resistió a invertir debidamente; la burguesía industrial protestó y se resistió a que la legislación laboral favoreciera tanto a los trabajadores. Por otro lado, la capitalización de las instituciones locales era todavía débil y se sufragaban a base de impuestos personales (cédulas personales y contribuciones especiales), que se recaudaban lentamente y mal. Algunos presupuestos extraordinarios se conseguían, de cuando en cuando, del Estado, preferentemente del Ministerio de Obras Públicas y de los Fondos contra el Paro (creados en la República). Además los Ayuntamientos republicanos

\footnotetext{
4 Juan Avilés FARRé, La izquierda burguesa en la II República, Madrid, Espasa Calpe, 1985, pp. 316 y 319.
} 
de Huesca debieron enfrentarse al empréstito obtenido en 1928 del Banco Local de España por valor de 2.500 .000 pesetas para acometer reformas urbanas, con lo que la hacienda municipal quedó hipotecada durante varios años. A pesar de ello Manuel Sender y Mariano Carderera emprendieron una tarea encomiable por los frentes que abordaron con objeto de transformar esta pequeña capital de provincia que entre 1931-1936 osciló entre los 15.000 y 16.000 habitantes.

El principal inconveniente que tuvieron que sortear fue el elevado número de parados, que, según el Censo municipal que se elaboró en 1931, ascendía a 200 obreros. Reunieron en reiteradas ocasiones a los representantes de la patronal oscense, de la banca, de los sindicatos obreros y de las instituciones para establecer compromisos y fórmulas que ayudasen a resolver este problema. Los viajes a Madrid presidiendo comisiones para conseguir fondos públicos de los diferentes ministerios y de la banca fueron muy frecuentes. El objetivo era crear empleo dinamizando el arreglo y trazado de nuevos caminos vecinales, el desarrollo de carreteras provinciales, la construcción de escuelas, la pavimentación de calles importantes, el desarrollo de infraestructuras de saneamiento, etc.

Nada más proclamarse la República emprendieron, en consonancia con el Gobierno Provisional y con la Constitución de 1931, la secularización de la vida pública con riesgo y valentía, dado el arraigo de la tradición católica en provincias eminentemente rurales y en capitales pequeñas como Huesca. Medidas como la secularización del cementerio municipal y la retirada de todos los símbolos religiosos de los centros públicos originaron una fuerte controversia y animadversión entre los estamentos y clases sociales más conservadores. La tensión se agudizó al conformar el Ayuntamiento oscense la no obligación de asistir como concejales a las ceremonias religiosas y dejar de salir con los danzantes en la procesión del día de San Lorenzo. También originó controversia la separación del personal religioso de los centros de beneficencia dependientes de la Diputación o del Ayuntamiento oscense (había maestros-sacerdotes en la residencia de niños, monjas-enfermeras en el manicomio provincial y en el hospital provincial). La implantación de nuevas festividades (el 14 de diciembre, en conmemoración de la sublevación de Jaca, y el 14 de abril) en sustitución de otras religiosas enraizadas en la tradición popular y el cambio de nombre de algunas calles y plazas originaron agudos enfrentamientos en el concejo oscense con las minorías derechistas. ${ }^{5}$

\footnotetext{
5 Actas del Pleno del Ayuntamiento, sesión del 25-IV-1931. Fuerte controversia por no haber ido el Ayuntamiento en la procesión del día de San Jorge. A propuesta de Manuel Sender se votó y acordó que en lo sucesivo el Ayuntamiento de Huesca se abstendría de concurrir a los actos o festividades religiosas con el voto favorable de los concejales Aínsa (PSOE), Arenas, Asún, Bescós, Bonet, Coll, Delplán, Ferrer Gracia, Ferrer Susín, Galindo, Santamaría, Sender y el alcalde Carderera. Sesión del 25-IV-1931. Sender propuso y se aprobó el cambio de denominación del Coso Alto y Coso Bajo por Coso de Fermín Galán y García Hernández, respectivamente. Días más tarde la plaza de San Victorián se denominó de Concepción Arenal; la
} 
Otro aspecto importante del regeneracionismo republicano se cimentó en la transformación y dignificación de la enseñanza a través de la figura del maestro y con la creación de escuelas (llevando a la práctica uno de los postulados base del altoaragonés Joaquín Costa). Según el Censo de población de 1930 el porcentaje provincial de analfabetos, un $38,51 \%$ de la población, era extraordinariamente elevado. De 243.000 habitantes que tenía la provincia, 83.579 no sabían leer ni escribir. Los partidos judiciales de Fraga, con el 50,67\% de analfabetos; de Tamarite, con el 43,29\%, y el de Sariñena, con el $41,69 \%$, presentaban las tasas más elevadas de analfabetismo (y coincidían con la mayor presencia del latifundio y de la conflictividad social). ${ }^{6}$ Los alcaldes Sender y Carderera retomaron con energía este tema nada más proclamarse la República. El censo escolar de Huesca el 1 de enero de 1931 era de 2.886 niños y el número de matriculados en escuelas nacionales y privadas ascendía a 1.993; no recibían enseñanza, por tanto, 953 niños y niñas. Con la creación de uno o dos centros escolares, si se ponía en funcionamiento el colegio de San Vicente, con la ampliación del número de secciones en el colegio de Sancho Ramírez y con la apertura de las escuelas anejas a la Normal de Magisterio, quedaba prácticamente resuelto el tema de la escolarización en Huesca.

El problema se agravó con la ley sobre Confesiones y Congregaciones Religiosas de 1933. En Huesca por dicha ley tenían que dejar de impartir enseñanza la orden salesiana y las congregaciones de San Viator, Santa Rosa, Santa Ana y el asilo de San José; ${ }^{7}$ el edificio que los jesuitas habían regentado (hasta su reciente expropiación) en la plaza de Luis López Allué, capaz para 24 ó 25 grados escolares, pensaba destinarse a graduada escolar, al sustituirse la enseñanza religiosa por la escuela única y laica.

Durante el mismo periodo (1931-1933) se propició desde el Ayuntamiento la creación de colonias escolares de verano en el Pirineo para cien-

plaza de Santo Domingo, de Manuel Abad, y la calle del Ángel, de Pablo Iglesias. Actas de las sesiones de la Comisión Gestora, 12-V-1931 y 8-II-1932. Dado que los gestores provinciales, presididos por Sixto Coll, estuvieron más empeñados en depurar y expedientar a los altos funcionarios de las dependencias de la Diputación, las sustituciones del personal religioso fueron más numerosas durante el periodo del Frente Popular (Actas de las sesiones del 21-III-1936, 1-IV-1936 y 17-IV-1936). En el Ayuntamiento, el 16-VII-1931 hubo un intenso debate en torno a si el Ayuntamiento debía asistir a la procesión del día de San Lorenzo; de nuevo se retomó el asunto en la sesión del día 23-VII-1931. En las sesiones del 30-XII-1931 y 16-III-1932, hubo acalorada discusión con las minorías de derecha en torno a la secularización del cementerio municipal. El 2-III-1932, el concejal M. Carderera propuso que se solicitara del Presidente del Patronato encargado de administrar los bienes nacionalizados con motivo de la disolución de la Compañía de Jesús, la cesión al Ayuntamiento de Huesca de la Residencia de los Jesuitas situada en la plaza de Luis López Allué. En la sesión del 5-VIII1932, Sender propuso se fijasen como días festivos locales los del 14 de abril, el 23 de abril, 10 de agosto y 14 de diciembre.

6 José $\mathrm{M}^{\mathrm{a}}$ AzPíroz PASCuAL proporciona más información en el artículo titulado «La Escuela en la II República», publicado en el Diario del Altoaragón del 10 de agosto de 1993.

7 Actas del Pleno del Ayuntamiento, sesiones del 16-VI-1933 y 14-VII-1933. 
tos de niños, así como la puesta en marcha de comedores escolares gratuitos para niños de familias necesitadas (en Huesca asistieron normalmente más de 100 escolares a estos comedores).

La planificación y el diseño urbanístico de la ciudad centraron también el interés de los ediles republicanos; para su ejecución recabaron en Madrid, de manera continuada, fondos del Estado y restablecieron — dado el fuerte endeudamiento del Ayuntamiento- las contribuciones especiales. Por este procedimiento se pavimentaron las calles y arterias más importantes de Huesca: los Cosos, la calle de Vega Armijo (actual Porches de Galicia), la plaza de la República, el paseo de Ramón y Cajal y las calles de Alcoraz y de Zaragoza. Para proporcionar empleo se procedió al saneamiento de aquellas fincas urbanas en alquiler que no tuvieran baño ni agua corriente, se remozaron fachadas y se alinearon calles (expropiando, incluso, algunos solares) con objeto de mejorar el aspecto de la ciudad, se proyectó una gran estación depuradora de aguas, etc. ${ }^{8}$

Para resolver la situación crítica de la hacienda municipal, el concejal Mariano Santamaría defendió en una sesión del Pleno la emisión de deuda amortizable por valor de cinco millones de pesetas, al 5,5\% de interés y libre de impuestos. ${ }^{9}$ Con este capital se pretendía amortizar el préstamo del Banco de Crédito Local de España, pagar las pavimentaciones de las calles señaladas, costear la construcción de escuelas y hacer reformas en el mercado municipal y en el matadero. Se planificó también la construcción de piscinas y baños públicos, se acordó emprender la obra de un nuevo depósito de agua en Loporzano y de otro para regular la distribución de aguas en la parte alta de Huesca. La instalación del alumbrado eléctrico en el parque de Miguel Servet y la construcción de la biblioteca de Luis López Allué serían otras obras que se decidió ejecutar.

No obstante, el proyecto de mayor envergadura consistió en la urbanización y diseño del denominado ensanche oeste (en los terrenos comprendidos entre la carretera de Zaragoza y la de Jaca). La urbanización comenzó a efectuarse mediante la expropiación de las huertas colindantes ${ }^{10}$ con el objeto de prolongar la avenida de la Libertad (calle del Parque) hasta la carretera de Jaca, a base de viviendas unifamiliares ajardinadas;

\footnotetext{
8 Las contribuciones especiales para las reformas urbanas fueron aprobadas en el Pleno del Ayuntamiento del 16-III-1932. El debate sobre la construcción de la estación depuradora se llevó a efecto en las sesiones de los plenos del 22-VIII-1931 y 12-IX-1931; su ejecución debía prolongarse durante 4 ó 5 meses y daría trabajo a 50 obreros.

${ }^{9}$ Dicha moción fue presentada en la Sesión del Pleno del 9-XII-1932. Se emitieron títulos de deuda amortizable por valor de $5.000,500$ y 250 pesetas nominales; la fecha de emisión de los mismos tendría lugar dentro del primer trimestre de 1933; se empezarían a amortizar el 1-I-1936 y el plazo de amortización se prolongaría durante 25 años.

${ }^{10}$ El plan se valoró en la Sesión del Pleno del Ayuntamiento del 21-II-1936, en la que Mariano Carderera propuso que los arquitectos presentaran varios planes urbanísticos a concurso a lo largo de la primavera de 1936.
} 
algunas ya se habían levantado con el dinero del segundo premio de la lotería navideña de 1932, que gratificó a algunas familias de la burguesía oscense. Al oeste de esta divisoria se configurarían los siguientes elementos urbanísticos: una grandiosa plaza rodeada de edificios nobles de estilo racionalista como el Gobierno Civil y edificios administrativos; la plaza pensaba decorarse con un monumento conmemorativo impresionante dedicado a la Libertad y centrado en las figuras de Fermín Galán y García Hernández, configurado por el destacado artista oscense Ramón Acín. ${ }^{11}$ En este ensanche se emplazaría además un Instituto de Bachillerato, escuelas públicas y casas ajardinadas individuales y adosadas junto a la construcción de casas baratas para obreros y trabajadores del Ayuntamiento.

Todo ello exigía la expropiación de huertas que debían parcelarse para ser subastadas; con las ganancias de la reventa el Ayuntamiento urbanizaría dicho ensanche. El inicio de estos proyectos originó serias confrontaciones entre varios propietarios con el Ayuntamiento, que no llegaron a resolverse ante el estallido del alzamiento militar. ${ }^{12}$

Además, la Diputación Provincial y el Ayuntamiento oscense continuaron la trayectoria iniciada con el siglo de construir edificios públicos y hospitalarios imponentes para mejorar los servicios y dotar de mejores infraestructuras sanitarias a la ciudad. Así, se emprendió la ampliación del manicomio de Quicena y la construcción del nuevo Hospital Provincial -obra que no avanzó al ritmo debido por falta de numerario-; se con-

11 El Diario de Huesca, 17-IV-1934. La maqueta y los planos de este monumento cubista estuvieron expuestos en la Escuela Normal de Maestros, donde era profesor Ramón Acín. Estaba constituido por un prisma hexagonal de $16 \mathrm{~m}$ de altura por $4 \mathrm{~m}$ de radio; las aristas estaban rematadas por otros tantos prismas hexagonales menores. En los intersticios, unas puertas comunicarían con el interior y las paredes estarían decoradas con motivos alegóricos en relieve. Todo el conjunto descansaría sobre una escalinata igualmente hexagonal, formada por nueve escalones. El monumento se emplazaría en el centro de una amplia plaza, circundada por tres edificios que guardarían la simetría y uniformidad del conjunto, los cuales, por estar más en armonía con el motivo, deberían destinarse a museos, bibliotecas y otros centros culturales o científicos. En los tres rincones que se formarían al construirse dichos edificios, se colocarían tres artísticas fuentes con alegorías dedicadas a los tres genios más destacados de nuestra provincia, Miguel Servet, el conde de Aranda y Joaquín Costa, formando todo un conjunto admirable y severo. Los materiales serían de ladrillo rojo y hormigón, que eran los más usados en aquella época. El monumento se costearía por suscripción popular. El conjunto sería sencillo y sobrio y su característica más esencial la constituiría la magnificencia de la línea, la estilización del conjunto y el sentido alegórico que encerraba todo el espíritu magistral de la obra.

12 La cooperativa para la construcción de casas baratas, la Unión Municipal Oscense, mediante instancia al Ayuntamiento pidió que éste solicitase al Ministerio de Trabajo y a la Junta Nacional contra el paro una subvención por el importe del $20 \%$ del coste total del proyecto, que alcanzaba la cantidad de 500.000 pesetas. Libro de actas del Pleno del Ayuntamiento, sesión del 14-V-1936: los ediles decidieron no ceder a los excesos especulativos de algunos propietarios de huertas que aspiraban a obtener mayores beneficios que cuando se urbanizó el parque Miguel Servet. 


\section{EL LUGAR DE SENDER}

cluyó durante el periodo republicano el centro antituberculoso; el Ayuntamiento cedió los terrenos para el inicio de la construcción de la Audiencia Provincial y de los nuevos Juzgados. Los planteamientos innovadores de los diputados provinciales después de las elecciones frentepopulistas de febrero de 1936 condujeron a una nueva remodelación de la residencia de niños a base de nuevas y mejores instalaciones: biblioteca, sala de estudios, ampliación y mejora de las instalaciones deportivas y construcción de una escuela de artes y oficios para una mejor formación profesional de los internos asilados. ${ }^{13}$

Desde el Ayuntamiento y la Diputación Provincial se propició la activación de las obras de Riegos del Alto Aragón y una mayor autonomía de éstos frente a la Confederación Hidrográfica del Ebro. Los alcaldes demandaron la construcción urgente del canal de la derecha del pantano de Santa María de Belsué, así como la subasta y rápida construcción del último tramo de la carretera de Huesca a la estación férrea de Sabiñánigo, del trozo de Castilsabás a Nocito (de la carretera de Huesca-Monzón a Aineto) y de la carretera de La Peña a Bailo. ${ }^{14}$

Reiteradamente se solicitó del Ministerio de Obras Públicas la modificación por la Compañía del Norte de los servicios de trenes para que «quede en el lugar que corresponde Huesca como cabeza de la línea Huesca a Francia por Canfranc»;, 15 se exigió asimismo a la Compañía mejores combinaciones horarias para poder acceder, sin tantos inconvenientes, a Zaragoza, Madrid y Barcelona.

Sin embargo, dada la limitación temporal de la República - poco más de cinco años- y que a raíz de la "revolución de octubre» en Asturias los concejales de partidos de izquierda fueron apartados en todo el país de los Ayuntamientos, al ser acusados de colaborar con los revolucionarios, una parte de los proyectos señalados se hizo realidad pero otra quedó en proyecto simplemente. Si se ejecutaron, fue bastante después de la guerra civil y con un criterio y enfoque distintos a como se configuraron previamente.

Y con los progenitores de estos proyectos, ¿qué sucedió? Exceptuando a la minoría derechista que configuró, en parte, el primer Ayuntamiento franquista después del 18 de julio y a los concejales radicales que apenas fueron importunados, el resto de los ediles y gestores provinciales fueron detenidos y juzgados, algunos, y fusilados sin juicio ni sumario, otros. Tanto Manuel Sender (joven abogado de 31 años, que fue elegido compromisario por Izquierda Republicana en 1936 para elegir al presidente de

\footnotetext{
13 Actas del Pleno de la Comisión Gestora Provincial, sesión del 3-IV-1936: el presidente, José M ${ }^{a}$ Viu, y Mariano Carderera (como alcalde y gestor) obtuvieron en Madrid más de 400.000 pesetas para el nuevo hospital provincial y 150.000 pesetas para la Audiencia Provincial y los nuevos juzgados. Todo lo referente a la residencia de niños se aprobó en la sesión del pleno del 17-IV-1936 (Actas de la Comisión Gestora Provincial).

14 Actas del Pleno del Ayuntamiento, sesión del 9-IX-1933.

15 Actas del Pleno del Ayuntamiento, sesiones del 10-II-1933 y 29-IX-1933.
} 
la República) como Mariano Carderera (de 42 años, médico titular del Instituto Provincial de Higiene) fueron detenidos el 22 de julio y fusilados en una triste y desgraciada madrugada del 13 de agosto de $1936 .{ }^{16}$

La muerte de Manuel Sender y las circunstancias que la rodearon estuvieron presentes en la memoria y obra de su hermano Ramón J. Sender. Como nos recuerda Jesús Vived: “[...] La propia policía le había sugerido que abandonara Huesca; él contestó que no esperaba nada malo, dado que no se consideraba responsable de cargo alguno. Se equivocó. Unos fascistas, sin juicio ni sumario, lo llevaron al paredón. [...]».17

Ramón J. Sender rememora este triste acontecimiento con insistencia y amargura en El fugitivo; ${ }^{18}$ en Monte Odina escribe unos versos alusivos a la muerte de su hermano; ${ }^{19}$ en el Libro armilar de poesía y memorias bisiestas, dice el autor: «[...] No sé qué me pasa, pero cuando un hecho sacude profundamente mi vida, hay una especie de inhibición intelectual que hace difícil escribir sobre él. Por ejemplo, la muerte de mi hermano Manuel, que era y es en mi recuerdo el hombre más noble y puro que he conocido en mi vida», ${ }^{20}$

En El rey y la reina, Ramón J: Sender le dedica el libro fervorosamente y en el prólogo recuerda esta conversación:

En el invierno de 193[5] mi hermano Manuel y yo estábamos cazando jabalíes en la Sierra de Guara (Aragón). Íbamos a caballo y hablábamos de política. «Si los fascistas se sublevan y triunfan -me dijo-, me fusilarán a mí antes que a ti». Lo dijo sonriendo, como se suelen decir las cosas demasiado serias.

Poco después la guerra civil comenzó y los fascistas se apoderaron de la ciudad de Huesca, donde mi hermano era alcalde. [...]

Tenía el coche lleno de gasolina en la puerta de su casa, la frontera francesa a cincuenta millas y al otro lado de la frontera un hogar confortable donde Francis Jammes, el viejo poeta, le hablaba a veces a él y a su joven esposa de las dulzuras de la paz cristiana. Mi hermano creyó que era más noble quedarse y dar la cara al peligro con su tranquila sonrisa de hombre honrado. $[\ldots]^{21}$

En Contraataque vuelve de nuevo a evocar algo que en él es ya una obsesión: «El día antes de detenerlo le avisaron amigos oficiosos, que lo eran también de los rebeldes: "Márchate a Francia con tu mujer". Pero mi

\footnotetext{
16 Julián CASANOVA et al., El pasado oculto: fascismo y violencia en Aragón (1936-1939), Madrid, Siglo XXI, 1992, p. 598.

17 Jesús Vived MAIRAL, «La vida de Ramón J. Sender al hilo de su obra», Alazet, 4 (1992), p. 251.

18 Ramón J. SENDER, El fugitivo, Barcelona, Planeta, 1972, p. 38.

19 Ramón J. Sender, Monte Odina, Zaragoza, Guara Editorial, 1980, pp. 207-208.

20 Ramón J. SENDER, Libro armilar de poesía y memorias bisiestas, Madrid, Aguilar, 1974, pp. 369372. Después de estas palabras le dedica un extenso poema de 72 versos, repartido en cinco estrofas de once versos y otras cinco de tres versos, excepto la última, que es de cuatro.

21 Ramón J. SENDER, El rey y la reina, Buenos Aires, Ed. Jackson de Ediciones Selectas, 1949, p. 1
} 


\section{EL LUGAR DE SENDER}

hermano - un muchacho fuerte y sano, de 29 años, cuya inteligencia y cuya honradez herían a las viejas cornejas de la política provincial, a quienes les resultaban cualidades insolentes y ofensivas- se negó"..22

Marcelino C. Peñuelas ${ }^{23}$ no obtiene, al respecto, más información; sin embargo, Gemma Mañá y Luis A. Esteve ${ }^{24}$ van más lejos estrechando conexiones y buscando paralelismos - en ningún modo fortuitos-- entre Paco, el del Molino, protagonista de Réquiem por un campesino español, y el propio Manuel Sender. Ambos mueren fusilados, en agosto de 1936, a los 29 años de edad (aunque Manuel Sender murió realmente a los 31 años, Ramón le da en Contraataque, curiosamente, los mismos años que a Paco). Los dos hacía poco tiempo que habían contraído matrimonio, en el Libro armilar... le atribuye a Manuel una muerte tan noble como la de un campesino (Paco $)^{25}$ y en El verdugo afable una persona calva y vieja recita esta extraña letanía: «A mi hermano lo mataron. Antes de disparar contra él le dieron un pañuelo para vendarse los ojos. Él, con el pañuelo, se secó el sudor porque era verano. Después lo arrojó, pero en lugar de caer el pañuelo subió flotando en el aire y se perdió en el horizonte». ${ }^{26}$ Mosén Millán aún guarda el pañuelo de Paco que no se ha atrevido a devolver a su viuda.

El artículo titulado «Flores para una tumba», publicado en Aragón/Exprés con motivo de la muerte de Ramón J. Sender, ${ }^{27}$ testimonia la honda significación que en el escritor tuvo la muerte de su hermano:

[...] Cuarenta años después, todavía bajo la jefatura del General Franco, cuando el escritor hizo su primer viaje a España, alguien con manifiesta inoportunidad propuso que pronunciara una conferencia en Huesca, capital de su provincia natal.

La noche de la víspera Ramón llamó a nuestro director para decirle que él no podía volver a Huesca, si antes no se ponían flores frescas en la tumba de su hermano.

Desde Aragón/Exprés hicimos diversas gestiones con los intelectuales organizadores de la conferencia, para que llevaran las flores. Todos se excusaron. [...] desde nuestro periódico telefoneamos a León Buil Giral, miembro del jurado del Premio Sender, [...] quien aceptó el encargo, y cuando Sender llegó a Huesca para pronunciar su conferencia, un ramo de flores había sido colocado en la tumba de su hermano.

«Estas flores - nos comentó Sender- pueden ser un Jordán para un pueblo. Muchas gracias por tan noble gesto».

22 Ramón J. SENDER, Contraataque, Salamanca, Almar, 1978, p. 387.

23 Marcelino C. Peñlelas, Conversaciones con Ramón J. Sender, Madrid, Magisterio Español, 1970, pp. 57, 59, 88-91 y 129; y La obra narrativa de Ramón J. Sender, Madrid, Gredos, 1971, pp. 25-26.

24 Gemma MaÑá Delgado y Luis A. Esteve JuÁRez, «Nueva aproximación a Réquiem por un campesino español", Alazet, 4 (1992), pp. 163-179.

25 Ramón J. SENDER, Libro armilar..., cit., p. 412.

26 Ramón J. SENDER, El verdugo afable, México, Aguilar, 1970, p. 45.

27 "Flores para una tumba», Aragón/Exprés, 19-I-1982, pp. 18-19. 


\title{
El expresionismo senderiano: a propósito de La noche de las cien cabezas
}

\author{
José Luis Calvo Carilla \\ Universidad de Zaragoza
}

El marco interpretativo para la presente indagación va a ser el expresionismo, tanto el que pudiera llamarse "primitivo" o "histórico», gestado en plena agonía del Imperio Austro-Húngaro, como el posterior, derivado de aquel y admitido por la mayor parte de los estudiosos como «expresionismo internacional». ${ }^{1}$ Demostrar cómo La noche de las cien cabezas ${ }^{2}$ se sitúa en la estela de esta vanguardia literaria es el objeto inmediato de las páginas que siguen, cuyas sugerencias, al menos como hipótesis de trabajo, pretenden apuntar en última instancia a una lectura en clave expresionista de lo más granado de la novelística senderiana.

\section{LA NOCHE DE LAS CIEN CABEZAS}

No es difícil establecer unos ajustados paralelismos entre la agonía del Imperio Austro-Húngaro en la primera década del presente siglo y los

\footnotetext{
${ }^{1}$ Remito, entre otros, al estudio de Sherrill E. GraCE, Regression and Apocalypse. Studies in North American Literary Expressionism, Toronto, University of Toronto Press, 1989, con una selecta bibliografía.

2 Ramón J. SENDER, La noche de las cien cabezas. Novela del tiempo en delirio, Madrid, Imprenta de Juan Pueyo, 1934. Utilizo la segunda edición, con portada de la primera (Madrid, Ed. Yagües), que amablemente me ha facilitado don Vicente Martínez Tejero.
} 
contestados estertores del ocaso de la Restauración, con el represor colofón de la Dictadura primorriverista. Por otra parte, la Gran Guerra había tenido una fuerte repercusión en España, donde había generado un reflejo de apasionamiento ideológico condicionado, visible no sólo en las diferentes actitudes germanófilas y aliadófilas en que se alinearon los intelectuales del momento. También - al menos parcialmente- está en el origen de estéticas de la exasperación como la esperpéntica o en pervivencias aparentemente trasnochadas, contagiadas de violencia y sangre, como en el caso del naturalismo tardío de López Pinillos. Finalmente, el último momento genuinamente expresionista, el del espartaquismo alemán, tiene una estricta correspondencia, incluso en el nombre, con los grupos libertarios en los que se movió Sender. En este sentido, una revisión de la denominada "novela de avanzada» llevaría a descubrir una vanguardia narrativa que, a diferencia de la deshumanización anterior, se propone la vuelta a «lo humano" y a lo «social» desde los postulados estéticos de la Rusia posrevolucionaria y del expresionismo germano.

No faltan, por lo tanto, razones de peso para justificar esta lectura expresionista de la novelística senderiana y, de modo especial, de La noche de las cien cabezas, subtitulada precisamente "Novela del tiempo en delirio", singular y extraña creación que se ha visto inexplicablemente postergada, tanto en los honores de una reedición actual como en el favor de la crítica especializada. ${ }^{3}$

Uno de los presupuestos básicos del expresionismo es el de la renovación formal. Aunque sin romper completamente con la tradición de los géneros literarios, el expresionismo representa una concepción vanguardista del arte y en la sustancia medular de sus preocupaciones estéticas está la revolución formal o, lo que es lo mismo, la pretensión de que el mesianismo social de que quiere hacerse portador vaya indisolublemente asociado a una utopía artística.

Esa utopía se materializa en La noche de las cien cabezas en una volatilización del concepto de novela tradicional, repudiada tanto por los prosistas españoles de vanguardia como, ya antes, por expresionistas como Döblin, quien, en sus Apuntes sobre la novela, de 1918, la rechazaba como simplificadora, debido a que el interés se fundaba únicamente en la progresión de la intriga. ${ }^{4}$ Coherentemente con esta radicalidad constructiva, La noche de las cien cabezas está concebida como una serie de aguafuertes goyescos, cada uno de los cuales posee un valor autónomo en sí mismo, a la vez que se integra en una unidad significativa mayor de carácter simbólico. La sintaxis que relaciona entre sí estos cuadros visionarios es la derivada de una estética del grito, como fórmula amplificadora de una

\footnotetext{
3 Debe citarse como honrosa excepción el artículo de Manuel BÉJAR, «Estructura y temática de La noche de las cien cabezas", en José-Carlos MAINER, ed., Ramón J. Sender. In memoriam. Antologia crítica, Zaragoza, Diputación General de Aragón et al., 1983, pp. 299-322.

4 Jean Michel GuiksoHn, L'expressionisme littéraire, Paris, PUF, 1990, p. 98.
} 


\section{JOSÉ LUIS CALVO CARILLA}

visión apocalíptica de la sociedad contemporánea, distorsionada y aireada a los cuatro puntos cardinales del planeta.

Lo aconsejaba ya Leonhard como programa literario general: «No se puede hacer poesía más que en hipérboles, porque la actividad poética sólo comienza en lo superlativo». ${ }^{5}$ En este sentido, la macabra lluvia de cabezas cortadas sobre el cementerio - dosificada en racimos a lo largo de diecinueve capítulos - le sirve al novelista para construir una fábula cuyo significado último no escapa al lector: la necesidad de destruir la sociedad y de construir una utopía libertaria (no se olvide que la fábula, como la parábola, son recursos retóricos de amplificación persuasiva del discurso).

La novela comienza con la presentación de la miserable existencia del Rano - tan arrastrada como las ratas y culebras que caza y con las que convive-, su encuentro con el obrero metalúrgico y la muerte de ambos abrazados en un nicho, desde donde se convertirán en espectadores del espectral desfile de cabezas.

Basándose en la aparente autonomía de estos tres primeros capítulos, Manuel Béjar ha llegado a poner en cuestión la unidad de esta novela, la cual, en su opinión, habría sido el resultado de una de las reelaboraciones que, en algún momento posterior a su gestación, pudo llevar a cabo el novelista de Chalamera. ${ }^{6}$ Sin embargo, desde una perspectiva expresionista, La noche de las cien cabezas adquiere una trabada unidad interna en la significación simbólica del aparentemente disperso conjunto de visiones fragmentarias. Cabe volver de nuevo a Gliksohn para recordar que el grito expresionista - y no cabe duda de que esta novela lo es- se sustenta sobre una poética de lo inarticulado, lo que implica una intención privilegiadora de efectos elementales y paroxísticos como el sufrimiento o el horror. No ofrece lugar a dudas el grito apocalíptico, estridente y descarnado, de la obra senderiana, la cual reúne los rasgos esenciales de la estética expresionista: el gusto por lo patético y la ambición de autenticidad.

La evidencia más auténtica -y, como en las Danzas medievales, la más igualitaria - es la de la muerte, tema expresionista por excelencia y objeto, en la novela que nos ocupa, de esa voluntad senderiana de universalizar y de conferir intemporalidad a un mensaje artístico libertario, propio de quien, pese a ser un comunista accidental, no dejó de ser nunca libertario en espíritu. ${ }^{7}$ Los mismos contenidos destructores animan las producciones expresionistas más representativas. Para Modern, los expresionistas se ahogan en el aire que respiran, se ven rodeados por todas partes de falsedad y sinsentido y muestran una complacencia secreta por la aniquilación y el nihilismo y por la exhibición de lo corrupto y ruinoso. En la

${ }^{5}$ Ibid., p. 90.

${ }^{6}$ Cfr. la discusión en Manuel BÉJAR, art. cit., p. 303.

${ }^{7}$ Cfr., entre otros, el prólogo de Francisco Carrasquer a su edición de Imán (Huesca, Instituto de Estudios Altoaragoneses, 1992), Peter TurToN, «Los cinco libros de Ariadna: la puntilla 
génesis misma del expresionismo está el reconocimiento de que la humanidad se ha precipitado al caos por lo que, a partir de un irracionalismo exacerbado y exclusivo, intentan intuir de forma inmediata y sin rodeos el ser de las cosas, su verdad propia y auténtica, para lo que cargan las palabras de un énfasis y de una intencionalidad emocional excepcionales. ${ }^{8}$

Con otras palabras, Kasimir Edschmid venía a aconsejar lo mismo a los jóvenes artistas, cuando les exhortaba a buscar en el fondo de ellos mismos una imagen del mundo no falsificada por las percepciones exteriores y, a la vez, sencilla y auténtica. La obra de arte así concebida debería constituir una explosión, plasmada en visiones: la explosión de ese hallazgo interior intuido en el alma primitiva e ingenua del creador, una vez despegado de la realidad concreta que le rodea. ${ }^{9}$ Es indudable que a esta concepción unitaria de raíz expresionista responde la escritura de La noche de las cien cabe$z a s$, cuyo carácter voluntariamente fragmentario es coherente con ese grito exterminador que emana simbólicamente del conjunto de la fábula.

Pero ese sucederse de las visiones está fuertemente impregnado de espectacularidad teatral, nueva razón de unidad constructiva que aglutina lo aparentemente descoyuntado de la estructura de la novela. Y es que, ante los ojos del Rano y del obrero metalúrgico como espectadores de excepción, se representa un macabro auto sacramental protagonizado por ridículos títeres descabezados, a quienes el autor desenmascara con trazos despiadados e implacables.

No eran nuevas estas técnicas entre los primeros expresionistas, quienes se sirvieron para sus propios fines artísticos tanto de la organización paratáctica de la obra en Stationendrama como de la deshumanización genérica lindando el costumbrismo - Kafka se apoyaría en gran parte en este recurso-, de la reducción de los personajes al absurdo o a la caricatura o de la utilización de marionetas de estereotipado parloteo como víctimas de la degradación e instrumentos de la propaganda o el militarismo. Sin embargo, va a ser el teatro esperpéntico de Valle-Inclán el que inspire de forma inmediata y moderna la concepción expresionista de La noche de las cien cabezas.

\section{EL DISCÍPULO DE UN VALLE EXPRESIONISTA}

Como se lee en un sugerente ensayo del escritor de Chalamera, "La época anterior a la guerra civil española era la de Valle Inclán. [...] Todo

al minotauro comunista» (en José-Carlos Mainer, ed., Ramón J. Sender..., cit., pp. 445-463) y, de modo especial, José Domingo Dueñas Lorente, Ramón J. Sender (1924-1936). Periodismo y compromiso (Huesca, Instituto de Estudios Altoaragoneses, 1994).

8 Rodolfo E. MODERN, El expresionismo literario, Buenos Aires, Editorial Universitaria, 1972, $2^{\mathrm{a}}$ ed., pp. 15 y ss.

${ }^{9}$ En Jean Michel GliksoHn, L'expressionisme..., cit., pp. 43-44. 
era grotesco entonces en España. [...] Hasta el crimen tenía, como los esperpentos, un tono de inocencia macabra. [...] Detrás de esa actitud [esperpéntica] de Valle Inclán sólo podía haber dos cosas: una sorda desesperanza y un resentimiento amargo contra la providencia». ${ }^{10}$ Es precisamente esta actitud vital de "resentimiento, odio y sarcasmo", coincidente con la de los expresionistas, la que le inspira el esperpento.

Pocas dudas caben acerca del expresionismo de Valle-Inclán -estudiado por Carlos Jerez-Farrán- ${ }^{11}$ y sobre su raíz goyesca, la misma de donde crece el árbol más frondoso del expresionismo europeo. Además de la confesión del propio Valle («El esperpento lo ha inventado Goya»), este extremo era objeto de frecuentes conversaciones con Ramón Sender, cuando éste, con la admiración de un discípulo hacia el maestro, le acompañaba a casa de regreso de la tertulia y aprovechaba para dialogar sobre su obra y para recibir el tesoro de sus confidencias.

El contexto estético más inmediato de La noche de las cien cabezas es el Centenario de Goya, acontecimiento que aviva el interés de Sender por el esperpento valleinclanesco:

Por entonces se celebraba el centenario de la muerte de Goya y después de explicarle a mi manera en qué consistía aquella plasticidad y de ligarla con la de algunas páginas de la picaresca y con los Caprichos, le dije que para mí la magia de sus esperpentos consistía en la obtención de lo inefable lírico por acumulación de lo grotesco, lo feo y lo procaz. ${ }^{12}$

Como ha señalado Agustín Sánchez Vidal, la figura de Goya neutraliza a la desideologizada de Góngora - a tal efecto se adelanta en un año la conmemoración - y sirve de catalizadora de las diversas tendencias surrealistas y expresionistas que convocan Valle-Inclán y, al menos en parte, Gómez de la Serna, además de la emblemática figura de Quevedo, y que tienen como consecuencia un brusco giro humano y comprometido en la producción literaria de los años posteriores. ${ }^{13}$

Se ha apuntado la presencia de Quevedo y de Goya en La noche de las cien cabezas, pero el eslabón más activo de esa tradición sombría y grotesca es el Valle de los esperpentos. A este respecto, se puede generalizar a toda la obra senderiana el ideal literario que el entusiasta discípulo ve en su maestro: el de ese realismo que "se obtiene por una cadena de alusiones a formas que a su vez apelan a lo real absoluto». ${ }^{14}$ Este realismo de lo absoluto o realismo de esencias no siempre logró plasmarlo en sus novelas,

\footnotetext{
10 Ramón J. SENDER, Valle-Inclán o la dificultad de la tragedia, Madrid, Gredos, 1965, p. 137.

11 El expresionismo en Valle Inclán: una reinterpretación de su visión esperpéntica, A Coruña, Ediciós do Castro, 1989.

12 Ramón J. SENDER, Valle Inclán o..., cit., p. 10.

13 «Góngora, Buñuel, the Spanish avant-garde and the centenary of Goya's death», en Derek HARrIS, ed., The Spanish avant-garde, Manchester University Press, 1995, pp. 110-122.

14 Ramón J. SENDER, Valle Inclán o..., cit., p. 139.
} 
pero sí en un buen número de ellas, inspiradas en sus tormentosas vivencias políticas y existenciales de los años treinta y cuarenta.

En el caso más concreto que ahora nos ocupa, La noche de las cien cabezas parece apuntalada por aquellos fundamentos estéticos desde los que precisamente consideraba las tragedias valleinclanescas como aquejadas de una entidad novelesca que las hacía irrepresentables. La misma yuxtaposición de masas de color inmóviles y sin profundidad y los mismos títeres grotescos, genéricos y sin relieve como caracteres son los que se encuentran en este que he llamado «auto sacramental grotesco» y que apunta inequívocamente a la inmersión del novelista en los secretos de la vanguardia teatral del esperpento.

Debe recordarse como corolario que esta dimensión teatral constituye uno de los rasgos distintivos de la novela expresionista europea, proclive a resolver en forma dialogada muchos momentos decisivos del relato, especialmente en monólogos que, a diferencia del monólogo interior -que explora el proceso del pensamiento-, van dirigidos, no tanto a un receptor o interlocutor concreto dentro del texto, como a sí mismos, al cosmos o al Hombre como receptor universal. ${ }^{15}$ La noche de las cien cabezas es, a este respecto, representativa de la utilización del monólogo y del diálogo expresionistas, como fórmula descarnadamente presentadora de un friso de tipos a lo Grosz, ejemplos grotescos de la sociedad burguesa contemporánea.

En su artículo «La narrativa de Ramón J. Sender: la tentación escénica", José-Carlos Mainer ha explorado este rasgo estructural recurrente en la novela senderiana, a saber, "la utilización de una forma explícitamente dramática —es decir, algo más que dialogal- como culminación de la sintaxis novelesca y, en algún caso, como formalización íntegra del material narrativo». ${ }^{16}$ Considera dicha "tentación escénica» como vanguardista y, entre las razones con que la justifica, señala el deseo de "obtener una mayor inmediatez del efecto artístico, a expensas de las convenciones genéricas». ${ }^{17}$ Pues bien, esta inmediatez no es otra que la del grito expresionista.

Hasta aquí he venido caracterizando La noche de las cien cabezas como una novela expresionista, en esa intuición de la realidad como un conjunto de delirantes visiones yuxtapuestas, las de unas grotescas cabezas parlantes, cuya fábula moral remite a la realidad simbólica de un urgente y necesario apocalipsis.

Pero también su exasperada prosa, especialmente en los momentos narrativos y descriptivos, adquiere la rabiosa sustancialidad de los expresionistas. Dos broncos contrastes cromáticos —el de la oscuridad de la noche en el cementerio, con un silencio mortal que permite distinguir las

\footnotetext{
15 Sherrill E. GRACE, op. cit., p. 64.

16 Bulletin Hispanique, LXXXV/3-4 (1983), p. 326.

17 Ibid., p. 328.
} 
voces de las sombras, sobre el rojo violento del crepitar de la ciudad en llamas, al que le sucede la derrota final del Dios blanco de las personas por el Dios negro de los instintos-enmarcan la significación y la violencia visual de toda la serie de capítulos a modo de aguafuertes, en una escritura nervuda, racheada y de nudosa elementalidad (la primitiva y tan vanguardista desnudez del nombre y el verbo, el adjetivo imprescindible, el latigazo de fulgurante irracionalidad). Ejemplo representativo es la visión inicial de esa tromba de agua de huracán teñida en sangre, que «alentaba entre el cielo y la tierra como un monstruo fatigado de su propia furia». ${ }^{18}$

Esta hipnótica visión de la ciudad en llamas la pudo haber visto Sender en la serie de «incendios» de August Stramm o en Yo y la ciudad o La ciudad en llamas de Ludwig Meidner, cuadro este último donde los muertos-vivientes, ante la inexorable inminencia del incendio, gritan su desesperación por toda una vida de banalidad y de inconsciencia. Porque, en última instancia, la visión de la noche y la muerte está asociada a la ciu$\mathrm{dad}$, tal como aparece en la pintura y en algunas novelas expresionistas (como verdadero inframundo de avenidas kafkianas, cárceles, cuarteles, sótanos o ríos de inmundicia y de sangre). La misma contemplación urbana inspira la poesía, como sucedía ya en Les villes tentaculaires de Émile Verhaeren (1895) y como se refleja, por ejemplo, en la de Tralk, donde de la ciudad no se retiene más que el hospital, la morgue y el cementerio y cuyos habitantes son leprosos, ciegos o esqueletos. ${ }^{19}$

Completar este perfil me lleva a mencionar otros elementos comunes con los expresionistas, como la noche, marco de tantas obras expresionistas - una noche que recubre con su manto semántico tan esperpéntico desfile mortuorio-, la ya apuntada ambientación en el cementerio o el mismo centenar de cabezas que figura en el título a modo de simbólico numeral de calamidad bíblica. Pero quiero detenerme en dos temas genuinamente expresionistas de La noche de las cien cabezas, por ser especialmente caros a la narrativa senderiana posterior.

\section{EL TEMA DE LA HOMBRÍA}

El primero es el tema de la hombría. Esclarecer esta obsesión temática de nuestro novelista exige acudir de nuevo a claves expresionistas y, muy en concreto, al dramaturgo alemán Ernst Toller.

En Nocturno de los 14, Sender reconstruye la figura de un Toller «héroe de la revolución alemana, héroe transitorio y provisional del famoso movimiento espartaquista y también novelista y autor de teatro, gran viajero $y$, en cierto modo — sólo en las formas expresionistas-, antecedente y maes-

\footnotetext{
18 Cap. V: «Primeros efectos de la tromba», pp. 35-39.

19 Francis Courtade y Henry Veyrier, Cinéma expressionniste, París, Veyrier, 1984, p. 49.
} 
tro de Berthold Bretch [sic]. [...] En la primera guerra fue herido. En el movimiento espartaquista arriesgó otra vez la vida y salió con cinco años de prisión y con una cierta simpatía natural por el anarcosindicalismo. $[\ldots] \gg .^{20}$

Sender conoció a Toller en Madrid durante el año 1933. En agosto de ese mismo año había huido a Inglaterra después de que sus obras hubieran sido quemadas, prohibidas sus representaciones y desposeído él de su nacionalidad alemana por Goebbels, a quien le había enviado una carta de protesta. Cuenta Sender que «En España solía andar por los locales de los sindicatos de la CNT y era curioso verle discutir en español con los obreros y con los intelectuales que iban por allí. Discutía los problemas de España como un español. [...] Toller quería influir en la CNT. A veces teníamos largas discusiones. [...]". ${ }^{21}$ Nuestro novelista alude incluso a una fluida correspondencia con el dramaturgo alemán, la cual no llegó a conservar, pero demuestra la continuidad de estas relaciones personales desde aquellos años en que estaba escribiendo La noche de las cien cabezas.

En 1939 volvieron a encontrarse en Nueva York. Sender abrigaba la íntima sospecha de que Toller se iba a suicidar, lo que así sucedió ese mismo año en su hotel de Manhattan, «donde habíamos estado tantas veces bebiendo y charlando".22

La herida que Toller recibió en la guerra había destrozado sus órganos genitales y este drama íntimo lo trasladó a su tragedia Hinkemann, traducida y publicada en 1931 dentro del círculo de relaciones de Ramón Sender, donde se había rechazado ya una mala traducción, anterior a la definitiva de Rodolfo Halffter. ${ }^{23}$

En Hinkemann, Toller encarna su propia tragedia en el personaje de Eugenio Hink, alter ego que da título a la obra (ya que en alemán Hinkemann significa 'mutilado'). Desde la primera escena aflora esta obsesión por la hombría, proyectada simbólicamente en un pájaro ciego o en un perro sarnoso. «iLloras - le dice a su esposa Grete- porque yo [...] porque los hombres me señalarían con el dedo, como a un payaso, si supiesen..., porque el tiro heroico de aquella criatura maldita me convirtió en un mutilado miserable, en un hazmerreír?».24

Hink llegará a murmurar para sí que «hay ocasiones en que es más fácil ser un dios que un hombre". Se lo recuerda inconscientemente su amigo Pablo, al verle pensativo: «-Pórtate como yo, ¡como un hombre!, y serás un amo».

\footnotetext{
20 Ramón J. SEnder, Nocturno de los 14, Barcelona, Destinolibro, 1983, p. 103.

21 Ibid., pp. 110 y 113.

22 Ibid, p. 106. Cfr. también Monte Odina, pp. 377-378.

23 Ernst Toller, Hinkemann (Tragedia). Los destructores de máquinas (Drama), trad. del alemán por Rodolfo HalfFter, Madrid, Cenit, 1931.

${ }^{24}$ Hinkemann, p. 18.
} 


\section{JOSÉ LUIS CALVO CARILLA}

La tragedia de Hink trasciende la intimidad del ámbito del hogar cuando Grete se entrega a Pablo, porque: "-Mi Eugenio... Mi Eugenio... Mi Eugenio no es... No es un hombre». A lo que le responde Pablo, besándola y tratando de apartar los remordimientos que le asedian: «-Mala serías, para ti misma, si guardaras fidelidad a un hombre que no es hombre».

La hombría se convierte en el motivo recurrente de casi todos los diálogos de la obra. En el segundo acto, Hink, desesperado ya de no encontrar empleo, se presenta ante el propietario de una barraca de feria, a quien lee el anuncio que le ha llevado allí: «Para número sensacional, necesito hombre fuerte. Buena retribución. Sólo admitiré material humano de primera calidad».

De labios del propietario escucha en qué va a consistir su trabajo: "Aquí, una jaula con ratas. Aquí, otra con ratones [...] Su número: atravesar de un mordisco la garganta de una rata y un ratón. Dar dos buenas chupadas de sangre. Algunos gestos. ¡Eso en todas las funciones! El público se retorcerá de risa». Las fanfarrias le anunciarán como «Homunkulus, el hombre-oso alemán».

Conocedor de la infidelidad de su esposa Grete, penetra en la taberna $y$, bajo los efectos del alcohol, se ve impulsado a referir su tragedia, aunque encarnada en un amigo. Es el momento en que entra en la taberna Pablo, borracho y despechado por el abandono de Grete: "-Presumir de ser el hombre más fuerte de la tierra... ¿Y no ser siquiera un hombre?». Y, ante los parroquianos espartaquistas de la taberna, que estallarán en carcajadas: “-Reparé en el individuo en cuestión... Le conocí... Y no pude por menos que reírme a carcajadas... El hombre más fuerte del mundo es un conocido mío, que no tiene... En la guerra... ¡Pif, paf!... Le dejaron sin... iEs un pobre eunuco!».

Al margen de la significación de denuncia de la culpabilidad colectiva que se deriva de esta tragedia individual, me interesa destacar que, como para Sender, para Toller el concepto de la hombría es un concepto animal o, si se quiere, testicular o ganglionar —que vienen a resultar sinónimos-, en representativa sinécdoque del mundo de los instintos, verdadero objeto de preocupación de los expresionistas. Es ésta, por lo tanto, la clave comprensiva de la grandiosa y apocalíptica visión del de otro modo desconcertante capítulo XXII de La noche de las cien cabezas, titulado "Proclamación de la hombría. La colina de fuego», en el que varios grupos de hombres desnudos erigen un primitivo dolmen al Hombre liberado de la hipertrofiada personalidad que le ha impuesto la sociedad, la religión y la cultura. Este primitivo monumento fálico, sobre el que el joven desnudo levanta su voz «viendo a los caballos blancos del amanecer trotar por el segundo horizonte", tiene su correspondencia en el tercer acto de Hinkemann, donde Hink empeña su reloj para llevarse a su casa una estatuilla de Príapo que ha visto en un escaparate. Ante ella hace arrodillarse y rezar a su mujer y, como en alucinada elegía a su naturaleza mutilada, monologa entrecortadamente: 


\begin{abstract}
Porque la naturaleza viva de los hombres es más fuerte que su inteligencia... La inteligencia no es sino un medio para engañarnos a nosotros mismos... Tú estás sana... Un enfermo, como yo, no tiene nada que hacer en este Mundo... Al menos, mientras la sociedad esté organizada como lo está hoy... 25
\end{abstract}

Esta situación límite - que lleva a Grete a arrojarse al patio- es el desenlace de una doble tragedia de la hombría, en la paradójica formulación de un Hink que no encuentra a su alrededor más que marionetas, caricaturas de hombres desalmados que han obedecido las consignas de los grandes asesinos del mundo. Pero, «si nuestra época no tiene alma..., yo no tengo órganos sexuales", confesará apesadumbrado. Es su propia tragedia de ser hombre, la de la mutilación de su esencia instintiva.

La hombría depende en última instancia de esa condición desnudamente primitiva del hombre que le hace semejante al mundo animal en la libertad de sus instintos. En este sentido, la vida del Rano de La noche de las cien cabezas - icontrafigura de El cazador de renacuajos del expresionista Alexander Döblin? - se diferencia poco de la de las ratas y culebras que caza, mientras que, al final de la tromba, sobre los rescoldos se alza apoteósicamente el Dios exterminador del Dios de los cristianos, que no es otro que el Dios de la verdad negra de los instintos.

\title{
EL OSCURO ÁMBITO DEL INSTINTO
}

La segunda obsesión senderiana, íntimamente vinculada con la hombría, es la importancia concedida al mundo animal, otro de los grandes temas de los expresionistas, como también lo será del surrealismo.

En principio, los animales están relacionados con el culto a lo primitivo, lo que ya es motivo suficiente para su consideración. Sin embargo, sus asociaciones con los impulsos irracionales eran nuevas en unos años, los veinte y los treinta, en los que las teorías de Freud y de Jung eran seguidas con avidez en los círculos intelectuales europeos. En la cuenta de este vivo interés por el mundo animal hay que sumar libros como los de Maurice Maeterlinck, Jean Henri Fabre, Edward Step o Michelet, los cuales ahondan en la vida social de los animales, especialmente los insectos, y en las relaciones instintivas que la rigen.

Uno de los aspectos más ambiguos y seductores del expresionismo alemán es su concepción de la sociedad entre lo espiritual y lo bestial. El hombre es dueño de una carga potencial de sexualidad y de energía destructiva semejante a la de los animales y es precisamente esa riqueza de primitivismo instintivo la que puede aniquilar el mundo burgués, poblado por "personas" socialmente aceptadas, cuya hombría ha sido amputa-

${ }^{25}$ Ibid., p. 95. 
da por el poder, la riqueza o las ideologías alienantes. Por lo tanto, no es el azar el que explica la aparición de numerosos animales a lo largo y ancho de toda la narrativa senderiana y Kessel Schwartz, aunque ha acertado a fijarse en la importancia del fenómeno, no ha llegado a profundizar en las implicaciones últimas de su inventario. ${ }^{26}$

Estas implicaciones, de filiación expresionista, iluminan también el segundo momento «incomprensible» de La noche de las cien cabezas: el último capítulo del libro, en el que el cementerio ha sido convertido en una idílica y laboriosa "cooperativa apícola número 8".

Agustín Sánchez Vidal ha señalado la decisiva influencia que libros como La vida de los insectos de Fabre, las Maravillas de la vida de los insectos de Step, Los insectos de Michelet o La vida de las abejas de Maeterlinck ejercieron sobre los surrealistas y, concretamente, en el cine de Luis Buñuel. En lectura paralela a la de los expresionistas, el surrealismo vio en el mundo de la colmena o de la termitera la réplica a una sociedad regida por oscuros componentes irracionales e instintivos. ${ }^{27}$ No obstante, no siempre es fácil separar expresionismo y surrealismo, dada la común distorsión formal que presentan, originada en gran parte desde la erupción de los subterráneos del mundo consciente bajo la especie de imágenes y estructuras inconexas. En este sentido, quizás cabe señalar, como distinción de la delicada y dudosa frontera que los separa, que el arte expresionista no sólo busca plasmar cosmovisiones angustiosas o desesperadas, individuales o colectivas, sino que, a partir de ellas, desea también la transformación del mundo, a pesar de lo idealistas y contradictorias que suelen ser sus metas. ${ }^{28}$ Tiene, por lo tanto, una significación o inteligibilidad última que no se encuentra en el surrealismo.

Esta significación es la que asume Ramón Sender en La noche de las cien cabezas. La reducción de la sociedad a cenizas y a cráneos vacíos deja paso a la construción de una sociedad armónica de hombres libres -también en sus instintos- regidos por la utopía libertaria.

\section{EXPRESIONISMO Y FÁBULAS EXPIATORIAS}

Los resultados de este análisis sirven de base para pensar que Ramón Sender asimiló profundamente la estética expresionista desde sus prime-

\footnotetext{
26 «Animal Symbolism in the Fiction of Ramón J. Sender», Hispania, 46/3 (1963), pp. 496-505. Recogido en Kessel SchwaRTz, ed., The Meaning of Existence in Contemporary Hispanic Literature, Coral Gables, Florida, University of Miami Press, 1969, pp. 99-111.

27 El mundo de Luis Buñuel, Zaragoza, Caja de Ahorros de la Inmaculada, 1993, especialmente pp. 100 y ss.

28 Más elementos para esta distinción -no todos ellos convincentes- se encuentran en Sherrill E. GRACE, op. cit., pp. 29-30.
} 
ros años como novelista. Su propia respuesta ante las circunstancias políticas y sociales exigía ese grito: el de la militancia y la rebeldía y, con posterioridad a la guerra, el no menos expresionista de unas fábulas expiatorias de una culpabilidad colectiva, en pugna con la inocencia individual. ${ }^{29}$

Por otra parte, en estos años y en los inmediatamente posteriores a la guerra civil mantuvo relaciones personales con escritores expresionistas. Además de la estrecha con Ernst Toller, la más fugaz con Franz Werfel, autor con respecto al que el de Chalamera dice experimentar repugnancia como persona, aunque silencia cualquier valoración literaria sobre su obra.

Pero fue Eugene $\mathrm{O}^{\prime}$ Neill — premio Nobel en 1936 y nombre vinculado a la recepción de los expresionistas alemanes- ${ }^{30}$ el objeto de una intensa y prolongada amistad ${ }^{31} \mathrm{y}$, posiblemente, el inspirador de esa adorada e inaccesible figura de la reina a los ojos del jardinero Rómulo, tan alejada e inaccesible como ve el fogonero Yank a la hija del multimillonario en The Hairy Ape.

El rey y la reina es quizá el mejor y más logrado ejemplo de novela expresionista y cumple esos rasgos distintivos que Sokel y Arnol reconocen en el género, tal como lo cultivaron Kafka, Döblin o Robert Walser: un desarrollo no racional de la ficción en un ambiente casi onírico y unos personajes movidos por los resortes del instinto y convertidos en figuras, en excéntricas abstracciones de la realidad y en casi alegóricas imágenes de la España en guerra. ${ }^{32}$ La hombría es, de nuevo, la motivación irracional que obsesiona a Rómulo y le impulsa a subir una y otra vez al torreón, en medio de los horrores de la guerra.

La contienda está captada en visiones de un expresionismo sonoro y plástico: el chorro de luz en la oscuridad, los fogonazos y las bengalas, los cuerpos mutilados, los escombros, los cañonazos, amplificados en el silencio de la noche... Lo mismo sucede con el castillo, especie de campana neumática asfixiante, con la representación de las marionetas o con ese submundo de los sótanos y de las calderas de la calefacción, reino tenebroso del enano y de las ratas, motivos ambos frecuentados por el expresionismo alemán.

Sender trasciende la realidad concreta de la guerra civil en una fábula de significación supraindividual, del mismo modo que en La esfera —con el recuerdo del conflicto como fondo- extiende a una significación colectiva la encerrona existencial del alucinado Federico Saila.

\footnotetext{
${ }^{29}$ Cfr. José-Carlos MAINER, «La culpa y su expiación: dos imágenes en las novelas de Ramón J. Sender", Papeles de Son Armadans, 161 (1969), pp. 116-132. Recogido en J.-C. MAINER, ed., Ramón J. Sender..., cit., pp. 127-135.

30 Sherrill E. GRACE, op. cit., p. 24.

31 Reflejada en Álbum de radiografías secretas y Monte Odina.

32 Citado por Grace, pp. 60 y ss.
} 
La esfera presenta en Saila la figura de un héroe típicamente expresionista, caracterizado por una «impotencia emocional y psíquica» que lo lleva a la tragedia del desgarramiento íntimo en un proceso de desfondamiento y regresión aniquiladora.

Como en las dos novelas anteriormente citadas, se ofrece en La esfera una construcción en apariencia incongruente, donde la parataxis de un conjunto de visiones alucinantes (desde el autobús de los locos sorteando a los francotiradores camino de la frontera, hasta la contemplación del velero blanco o el naufragio y la muerte del Jebuseo) se articula en una interpretación amplificada de la existencia humana, simbolizada por ese Viscount Gall desnortado, sin provisiones y a merced del azar y de la fatalidad, y por la geometría de la esfera, coincidente con la afición expresionista por el simbolismo de lo circular como expresión del callejón cerrado de la existencia.

Sería prolijo mencionar otros rasgos expresionistas comunes, como las amplificaciones fundadas en repeticiones y recurrencias de temas y motivos o la función del diálogo y, especialmente, de los monólogos. Baste señalar la importancia de la meditación sobre lo ganglionar, que ha venido siendo una obsesiva constante en ese infatigable cuestionamiento sobre «el lugar del hombre» (por cierto, título de otra novela de similar inspiración y significación, por encima de lo anecdótico que pueda tener la recreación de un error judicial).

En conclusión, creo que, a la vista de lo anteriormente expuesto, se puede hablar de un Sender expresionista, no sólo en La noche de las cien cabezas sino en buena parte de las grandes novelas senderianas de los años cuarenta. Sender encontró en el expresionismo alemán la fórmula idónea para encauzar su propio grito rebelde y apocalíptico de los años treinta (Imán, $O$. $P$., Siete domingos rojos, La noche de las cien cabezas). Posteriormente, siguió reencontrándose con él en su época norteamericana, cuando el expresionismo literario y artístico había cruzado ya el Atlántico -impulsado principalmente por su amigo $\mathrm{O}^{\prime}$ Neill y favorecido por el descubrimiento del cine alemán en los Estados Unidos de los años treinta- y allí había arraigado como una planta híbrida, que combinaba los rasgos originales del modelo alemán con los materiales autóctonos de la vida americana. Ese ambiente —el mismo de Djuna Barnes, Malcom Lowry, el primer Faulkner o el propio $\mathrm{O}^{\prime} \mathrm{Neill}-\mathrm{es}$ el de sus grandes novelas de la purgación exculpatoria del conflicto vivido y de la meditación sobre la condición humana.

Por otra parte, es más verosímil que el Sender americano de los años cuarenta se decantase hacia el expresionismo que hacia el surrealismo, dado que, por razones de pura supervivencia, no tendría especial interés en profesar una estética que le situase totalmente a contracorriente de los planteamientos políticos oficiales. ${ }^{33}$

33 Cfr. Peter TURTON, "Los cinco libros de Ariadna: la puntilla al minotauro comunista», art. cit., pp. 445-464. Sobre la importancia de Nueva York como capital vanguardista en la segunda 


\section{EL LUGAR DE SENDER}

Cabe precisar, finalmente, que en esta segunda fase, y como en el caso de autores como los arriba citados, no se trataba de un expresionismo «histórico" o puro (si es que alguna vez llegó a serlo). Las actitudes expresionistas se funden con las nuevas tendencias del existencialismo europeo, si bien en el fiel mediador de esta simbiosis se encuentra la proteica sombra de Kafka. ${ }^{34}$

posguerra mundial, una Nueva York donde críticos y capitalistas rechazaron el surrealismo en nombre de la reaccionaria acuñación del concepto de "posmodernismo» (que, de hecho, exorcizaba a aquel y a la ideología comunista que le era inherente en favor de una recuperación apolítica de las vanguardias históricas), cfr. Serge Glilbalt, How New York Stole the Idea of Modern Art: Abstract Expressionism, Freedom, an the Cold War, University of Chicago Press, 1983. También Sherrill E. GRACE, op. cit, especialmente en sus conclusiones (pp. 229-246).

${ }^{34}$ En este último aspecto, remito a los trabajos de José-Carlos MAINFR, «La culpa y su expiación...", cit., y Shermann H. EOFF, "El desafío de lo absurdo», en José-Carlos MAINER, ed., Ramón J. Sender..., cit., pp. 95-111 y 127-135. 


\title{
Recuerdos para aplazar la tragedia (Los crímenes en Monte Odina $)^{1}$
}

\author{
María Ángeles Naval López \\ Universidad de Zaragoza
}

La muerte, el crimen, la culpa, la justicia o la expiación son constantes temáticas en la obra de Sender, aun cuando éste frecuenta, como en Monte Odina, los espacios autobiográficos de la infancia. En esta novela Sender plantea una reflexión sobre lo trágico en la vida humana, en el mundo natural e incluso en el cosmos, pero soslaya, en cambio, el relato de tragedias relacionadas con el espacio rural de Monte Odina y que le saltan aquí y allá al hilo de sus recuerdos. Por eso la presencia de crímenes rurales es importante en Monte Odina, sin que el relato de ninguno de ellos constituya la base argumental de la novela.

El texto proteico y extenso de Monte Odina está dedicado, entre otras cosas, a reflexionar acerca del teatro anglo-americano y español del siglo $X X$, sobre todo en la primera mitad de la obra. ${ }^{2}$ La referencia a las piezas

\footnotetext{
1 Este artículo es un homenaje a tres vidas inscritas en la tierra del Somontano y marcadas por la guerra civil: a Lorenzo Naval Lasierra y a sus hijos Jesús y José Naval Coll.

2 Monte Odina fue publicada en la colección "Nueva Biblioteca de Escritores Aragoneses» de Guara Editorial en 1980. De esa edición se han extraído las citas textuales del presente texto, por lo que únicamente se consignará al final de cada cita el número de página en que se encuentra.
} 
dramáticas sirve como hilo conductor. La lectura de libros de teatro o su disposición en los estantes de la biblioteca que el narrador dice estar construyendo para la casona de la titular finca somontanesa ejecuta una técnica similar a la de "relato marco». En esa guía se van ensartando reflexiones y relatos sobre la vida de los escritores, la propia vida de Sender, las obras de unos y otro, los grandes temas de la humanidad y de la historia. En el entramado ensayístico-narrativo que se compone con estos elementos básicos ocupan un papel destacado las reflexiones sobre la historia de Aragón y sobre la existencia del drama en la naturaleza, lo que lleva a concebir el mundo como teatro, en manifiesto contrapunto calderoniano, pues habla Sender del «pequeño teatro del mundo».

Monte Odina acaba convirtiéndose en una autobiografía intelectual, en un libro de memorias dispersas entreveradas de juicios literarios, de evocaciones de personajes históricos, y por último en una preparación para la muerte. Muerte que en los primeros capítulos se anuncia trágica, vinculada a los crímenes de la tierra y de la guerra civil y acaba dibujándose como un destino brillante, inocente y cósmico que aguarda desde la infancia en el prolongado año solar del cometa Halley. El final de todo se dibuja en la liberación de Austral, un albatros antinaturalmente criado en la biblioteca de Monte Odina y que representa el enfrentamiento del escritor con el mundo real. ${ }^{3}$ Es un acto de antigua belleza moral la liberación de ese pájaro, que en tierra resulta objeto ridículo y risible, y la dolorosa separación es una apuesta por la verdad del orden natural de las cosas y por el futuro. El alejamiento del albatros al final de la novela constituye una síntesis de todas las separaciones, incluida la definitiva. Además viene a indicar un rechazo de éticas decadentes y literaturizadas que ya había quedado expuesto al principio de la novela:

Lo que le pasa a Beckett y le pasaba a nuestro también irlandés James Joyce es que su fe en las cosas, en los hombres, y ocasionalmente en sí mismos era una fe literaria. Desde Óscar Wilde a Beckett los irlandeses se han dedicado a mostrar que el único interés de la realidad está en la literatura. Ésa es una actitud decadente difícil de asumir para un español. (p. 42)

Y unas líneas antes había asegurado que los autores dramáticos españoles contemporáneos tienen además de las virtudes de estos autores irlandeses «la fe en el hombre y en el mañana del hombre (y naturalmente la fe en sí mismo)» (p. 42). Esta fe se supone que infiere un propósito moral a la literatura que para Sender sólo puede existir en el «mundo de las estructuras religiosas» (p. 42).

\footnotetext{
3 José-Carlos MAINER, en «El territorio de la infancia y las fuentes de la autobiografía senderiana", III Curso sobre lengua y literatura en Aragón (siglos XVIII-XX), Zaragoza, Institución Fernando el Católico, 1994, pp. 139-159, ya señaló el significado y procedencia de este pájaro, quimera baudeleriana.
} 
A pesar de lo dicho sobre el arranque y el final de Monte Odina, el título de la obra apunta al relato de las peripecias de unas tierras unidas al crimen y a la injusta reparación de la culpa. ${ }^{4}$ Todavía hoy se recuerda un crimen acontecido antes de la guerra civil, el de Andrés Cambra. El cadáver del propietario rural fue hallado en las Casas de Odina y un guarda jurado, juzgado culpable, cumplió doce años de cárcel, de la que salió porque su culpabilidad no resultó probada suficientemente. Este crimen es aludido varias veces en Monte Odina y sirve para poblar de cierto misterio los alrededores de la finca y el pueblo abandonado que visita Sender y que es la aldea del crimen a la que me acabo de referir. El lector de El lugar de un hombre o de Viaje a la aldea del crimen o de Mosén Millán espera un relato semejante a los citados y una reflexión sobre el crimen y el castigo en agreste versión rural y española. La lectura de las dos primeras páginas de Monte Odina sugiere que se va a leer el relato de un crimen trágico. Los comentarios de Sender sobre la elección del título de su obra imprimen en el lector una especial evocación de historias trágicas:

Para que la sugestión de Monte Odina tenga una dimensión metafísica de acuerdo con los tiempos azarosos en los que nos ha tocado vivir, el recuerdo del buen don Francisco, igual que el de tantos otros amigos, está manchado por la violencia: cayó en Monzón frente a una escuadra de ejecución formada por milicias incontroladas. (p. 32)

Sender utiliza como telón de fondo esos referentes que tiene el lector de Sender y por contra le escamotea constantemente el relato del crimen, pese a lo cual las referencias a muertes, aludidas como tragedias o dramas, acontecidas en el entorno rural de Monte Odina constituyen uno de los hilos conductores de la obra. Cifra la tragedia en el asesinato del que fuera propietario de la finca en 1936 (don Francisco Laguna) y por extensión en todos los crímenes de la guerra civil. Entre tanto aplaza para próxima ocasión el relato de tragedias, crímenes, etc. que le salen al paso en su relato. Menudean frases como las siguientes: «En su familia hubo una tragedia que algún día contaré» (p. 42); "Pues bien, en aquella aldea hicieron una muerte de un forastero. $Y$ en otra aldea de un heredero de casa rica. Pariente de los Palacio de quienes hablés (p. 85).

Mientras se difiere el relato de lo que parecía ser la justificación del título de la novela -0 de ese texto que el autor presenta como unas verdaderas memorias apócrifas (p. 17) - el espacio geográfico de Monte Odina se transforma en un microcosmos, como ya comentaba José-Carlos Mainer

\footnotetext{
${ }^{4}$ La importancia de este tema en la novelística de Sender fue señalada por José-Carlos MAINER en "La culpa y su expiación: Dos imágenes en las novelas de Ramón J. Sender», Papeles de Son Armadans, 161 (1969), pp. 236-256, recogido en José-Carlos MAINER, ed., Ramón J. Sender. In menoriam. Antología crítica, Zaragoza, Diputación General de Aragón, Ayuntamiento de Zaragoza, Institución Fernando el Católico y Caja de Ahorros de Zaragoza, Aragón y Rioja, 1983, pp. $127-135$.
} 
en su artículo de 1994 antes citado. En su biblioteca, que a veces parece sala monacal, y en la naturaleza que puede verse desde la terraza se encuentra abreviado el universo entero. Hace Sender una bonita recreación del viejo tema con ese estilo aforístico, meditativo y fragmentario que caracteriza su prosa memoriográfica y que se acentúa en Monte Odina. El ojo, la mirada panorámica (en el sentido etimológico) como microcosmos: «yo creo que todo es pequeño si cabe dentro de nuestros ojos, incluido el universo" (p. 42). La elección de este paraje como reducto del universo de Sender se amplía en ocasiones a toda la geografía aragonesa circundante. Por ejemplo las tormentas de Alcolea de Cinca superan a las de cualquier lugar tropical o con más tradición tormentosa o tempestuosa:

\footnotetext{
La tormenta, sin embargo, no fue gran cosa.

Las había conocido yo mucho más espectaculares y memorables. Las más dramáticamente hermosas que he visto en mi vida son las de Alcolea de Cinca. Ni las de las turbulentas Antillas, ni las del frígido Canadá, ni las de los Estados Unidos o Méjico o Perú pueden compararse. (p. 87)
}

Las reflexiones históricas y antropológicas que le llevan a unir lo fragatino con lo bereber y lo andino tienen el mismo sentido: potencian la microcosmia de Monte Odina y al mismo tiempo dibujan la Historia como marco del devenir universal, con la historia literaria en primer plano. La conciencia de la Historia — que ha inquietado a muchos personajes de la novela moderna y por tanto a sus creadores, ya desde don Quijoteimpone a Sender la referencia a la guerra civil como pasado inmediato y la necesaria atención a España. Monte Odina con las muertes acaecidas en sus alrededores al filo de 1936 es también España: «Uno está en España y en Monte Odina y el drama, si lo hay, es el de la naturaleza. El gran teatro del mundo. O el pequeño, según» (p. 42). Esta frase sigue a las anteriores que he citado sobre los escritores irlandeses y los españoles («Ésa es una actitud decadente difícil de asumir para un español") y pone de manifiesto cómo Monte Odina es una España en pequeño y cómo Sender pasa de la historia de la literatura a la historia de España. Monte Odina con su biblioteca es a la vez España y la historia de la literatura universal.

\section{EL DRAMA DE LA NATURALEZA}

Sender merodea por las posibilidades de la biblioteca y del teatro como síntesis cósmicas. Así comienza a hablar de «el pequeño teatro del mundo», "el teatro de la naturaleza que no necesitaba autores ni libretos» (p. 89) y aun otro teatro que tiene menos repercusión en las reflexiones del autor: «Hay otro, el de las costumbres y las efemérides que tampoco está escrito, pero no es por eso menos impresionante y eficaz» (p. 89). También la idea de museo ronda la cabeza de Sender unida a la memoria de Picasso. El museo como modo de perfección es la muerte; la única forma de 
entender algo como perfecto, es decir, terminado, es contemplándolo muerto. Ésta puede ser una interesante observación de poética aplicable a la propia construcción de esta novela. Nuestro autor prefiere frente al mundo ordenado y perfecto el «museo de Dios», es decir, la naturaleza. Del mismo modo va a elegir la naturaleza como el espacio para su tragedia o quizá simplemente drama. Este espacio es denominado «pequeño teatro del mundo" y como en El gran teatro del mundo de Calderón los personajes actúan bajo los dictados de una ley, que no es la ley de la gracia, como en el auto sacramental, sino la "ley natural».5 En el pequeño teatro del mundo y bajo el dictado natural se representa el drama de la naturaleza.

Hay un determinismo no impuesto por razones sociológicas sino más bien religiosas, de una religión también natural, en la formulación de esa ley:

A veces es hermosa la vida. Vamos a la hembra encelados y falsos y ellas nos reciben como si fuéramos ángeles. Tal vez las dos cosas son verdad y los dos tenemos razón. Entonces el prodigio no está en ellas ni en nosotros, sino en la naturaleza en la que estamos integrados y cuyas leyes seguimos, sin saberlo. (p. 75)

La ley natural no siempre propicia esta representación placentera, preside también la comisión del crimen: el odio y la codicia forman parte de sus prescripciones:

El pequeño teatro del mundo está lleno de tragedias naturales, es decir, de muertes artificiales. El artificio suele ser el revólver o el puñal, herramientas bellacas del odio o de la codicia. ${ }^{6}$ (p. 85)

La tragedia alberga una forma de reconciliación del hombre y la naturaleza e incluso puede pasar a formar parte de esta última: « ¿Se han fijado ustedes en que toda genuina obra de arte añade algo importante a la tarea

${ }^{5}$ J.-C. MAINER, en el artículo de 1994, comenta la importancia del Segismundo calderoniano como mito personal de Sender, más allá del título de la novela Hipogrifo violento. En Monte Odina creo que se produce un contrapunto con Calderón cuyo significado debería precisarse en el ámbito de las ideas religiosas de Sender.

6 Sender distingue entre muerte natural y muerte artificial. En el capítulo VI ensaya una reflexión sobre el primer tipo de muerte. Es un capítulo que puede considerarse variante de un importante tema contemporáneo, La mort des artistes. Merece la pena transcribir el siguiente párrafo: «En la biblioteca están las obras de Benavente, muerto a los ochenta y siete. La noticia de su muerte recordó a muchos que estaba vivo, todavía. Porque como autor había muerto mucho antes. Rilke, el poeta alemán, se negó a que los médicos le ayudaran a morir, diciendo que no quería que le escamotearan su muerte natural, que quería su muerte genuina y legítima, y no la de los médicos. Bernard Shaw murió diciendo que se negaba a seguir viviendo, que la vida ya no tenía interés para él. Benavente murió discretamente, como vivió. Como solían morir sus personajes madrileños en un aura liberal católica y en la atmósfera de bienestar entre culpable y resignado de la gran burguesía o de la aristocracia. Y murió su muerte natural» (p. 105). 
de la unidad de la creación? Sí, de la entera creación. A la unidad de la entera creación de Dios» (p. 109). Citando a Eugene O'Neill dice Sender: "La tragedia del hombre es quizá el único aspecto significativo de su presencia y su realidad". Es cierto. Y la única perfección accesible, la muerte». Todas estas reflexiones nos devuelven de nuevo al pequeño teatro del mundo:

Pero como he dicho antes, ninguna tragedia de Sófocles, del inefable don Jacinto o del sombrio O'Neill se acercan a la sublime perfección inacabada de las tragedias naturales, es decir, esas tragedias por las que se deshabita y abandona un pueblo, uno de esos que yo veo o creo que veo, o digo que creo que veo, desde la terraza. ${ }^{7}$ (p. 112)

\section{LA LEY DE LA NATURALEZA VERSUS LA SELECCIÓN NATURAL}

Monte Odina resulta un texto difícil de clasificar en un tipo de novelas. Tiene un componente claramente autodescriptivo pero la reflexión sobre la literatura y el teatro y la tragedia, así como la referencia al crimen, al asesinato - los de la guerra $\mathrm{u}$ otros-, hace que nos situemos ante una narración que oscila entre el relato social, el tremendista o incluso ante la ordenación novelística de los componentes de un drama rural.

Los crímenes que constituyen los fondos del paisaje moral de Monte Odina, así como el punto de referencia histórico que proporciona la guerra civil, hacen que estas memorias establezcan un diálogo y sirvan de contraste con otro tipo de novela senderiana bien distinta: la que representan textos como El lugar de un hombre, Mosén Millán o Viaje a la aldea del crimen. Estas obras son herederas de una tradición que arranca del naturalismo y que llevó a los escritores de las primeras décadas del siglo XX a la constitución de un género peculiar de novela social. Este modelo narrativo presenta ambientación rural o regionalista y en él la preocupación por la España negra es un punto de referencia importante. Es antecedente de la novela social de los años treinta. El tremendismo, del que se viene hablando a propósito del Pascual Duarte de Cela, tampoco es ajeno a esta tradición. Jarrapellejos de Felipe Trigo o Doña Mesalina de J. López Pinillos ejemplifican este estatuto narrativo que aporta contenidos ideológicos de radicalización política a los modelos decimonónicos. Éstos son novelistas

7 La utilización de esa secuencia de oraciones progresivamente disyuntivas forma parte de las estratagemas de inspiración cervantina que de cuando en cuando usa Sender para hacernos notar que el texto que leemos es una ficción. No significan estas frases un guiño metalingüístico, panacea del ingenio retórico moderno, sino la constatación del carácter literario, pese a su autobiografismo, del proceso de reconstrucción de la propia vida. Constatación melancólica, si no dolorosa. En el prólogo de Los cinco libros de Ariadna (Barcelona, Destino, 1977), texto que tiene mucho que ver con Monte Odina, tras una apasionada reconstrucción de sus raíces ilergetes, escribe: «Ese aliento, repito, viene de lejos. O creo que viene de lejos. O digo que creo que viene de lejos" (p. 13). 
de la generación anterior a la de Sender con los cuales el aragonés compartió formas de subsistencia y arribada al mundo literario: Madrid y el periodismo. También la utilización de las crónicas periodísticas como material novelesco es recurso compartido por Sender con estos escritores. ${ }^{8}$ Nuestro aragonés en su etapa de formación hubo de tener contacto directo con la producción de éstos. En diciembre de 1919, año en que Sender consolida su carrera de escritor-periodista, se estrenó en Madrid La red de López Pinillos, drama rural cuyo argumento ya fue puesto en relación con el de El lugar de un hombre por J.-C. Mainer. ${ }^{9}$ En Monte Odina parece haber una reminiscencia del drama La tierra (1921), del mismo autor. López Pinillos plantea la huida de todas las gentes de un lugar como consecuencia del asesinato represivo de varios campesinos huelguistas. La suposición de que tras un pueblo abandonado hay una historia trágica de crímenes es una idea recurrente en esta última novela de Sender.

Con estos antecedentes la mención de la ley natural como razón de los hechos relatados puede llevar a pensar que Sender nos aboca al relato de unas conductas criminales de explicación naturalista, es decir, con un fuerte componente de determinismo sociológico, tal como podemos encontrar, por poner un ejemplo aragonés, en El Pedroso y el Ternplao de José $\mathrm{M}^{\mathrm{a}} \mathrm{Ma}$ theu. ${ }^{10}$ En esta novela se reflexiona sobre el cainismo, la instintiva e inexplicable comisión del crimen. Más cerca se encuentra Sender de esta actitud que de otras propias del drama rural. Debo señalar que del drama rural Sender rechaza lo melodramático. Dice de La Malquerida de Benavente: «Yo tampoco he podido entender el éxito de ese drama rural lleno de torpezas melodramáticas» (p. 107).

En la incorporación de algunos elementos de este género dramático soslaya Sender el sentido del honor, que en última instancia remite a planteamientos dramáticos del Siglo de Oro y que es la parte más conservadora de estas obras.

Para nuestro autor la ley natural que preside los crímenes tiene un contenido simbólico, enigmático y poco racional. Está más próxima, en

8 J.-C. MAlNer, en su prólogo a Doña Mesalina, Barcelona, Turner, 1975, pp. 7-20, comenta el significado de este proceso en López Pinillos (pp. 10-12).

9 "José López Pinillos en sus dramas rurales», Literatura y pequeña burguesía en España (Notas, 1890-1950), Madrid, Cuadernos para el Diálogo, 1972, pp. 110-111.

${ }^{10}$ José $\mathrm{M}^{\mathrm{a}}$ Matheu hace un ensayo de explicación de la conducta criminal del Pedroso por las condiciones del medio social y de una educación deficiente. El crimen, por otra parte, se enquista en el medio social y transmite la desgracia de padres a hijos. Asistimos a una especie de formulación contemporánea del fatum trágico, sometido ahora a dimensiones humanas e históricas. En la novela de Matheu hay poca penetración en el mundo rural. Sus protagonistas son albañiles, es decir, obreros no del campo, aunque ubicados en un medio rural. La articulación de la novela en capítulos refleja el deseo de Matheu de ofrecer un cuadro analítico y racional de los componentes que llevan a la tragedia. Véanse los títulos de algunos de los seis capítulos de la novela: «I. Dos tipos y varios pormenores», «IV. Influencia del medio», «V. Las consecuencias». Esta novela fue publicada en 1905 en Zaragoza por Mariano Escar. Previamente había podido leerse en la Revista de Aragón. 
todo caso, y contemplando el conjunto de la narrativa senderiana, a ser una abstracción sobre esencias nacionales. En ese orden de cosas la tragedia rural en Monte Odina parece algo noventayochista. Quizá pueda tener sentido recordar unas frases de Antonio Machado en sus prosas de «La tierra de Alvar González»: «En las pequeñas ciudades las gentes se apasionan del juego y de la política como en las grandes del arte y de la pornografía -ocios de mercaderes-, pero en los campos sólo interesan las labores que reclaman la tierra y los crímenes de los hombres». ${ }^{11}$

En Monte Odina Sender cuenta tres crímenes trágicos y en dos de ellos se trata de crímenes de familia. El cainismo está de alguna forma también presente en estas muertes como lo estaba en el texto aludido de Matheu o en el de Machado: "Mucha sangre de Caín tiene la gente labradora».12

La presencia del crimen inexplicable es un componente fundamental de cierta novela social que cultivó Sender y otros contemporáneos. Se impone mencionar La familia de Pascual Duarte, aunque yo me sumo a las consideraciones que hizo Max Aub en 1945 sobre el escaso contenido sociopolítico del texto de Cela. ${ }^{13}$ Fernando Morán, haciendo consideraciones sociológicas, también observó que el tremendismo, por lo que tiene de irracional, es una vía para obviar la crítica y la denuncia. ${ }^{14}$ Esta novela de 1942 tiene un planteamiento adecuado para un relato determinista, de análisis social de la pobreza y sus secuelas materiales y morales; sin embargo esta realidad acaba sublimada en un oscuro sentimiento del odio. A veces, como en el capítulo doce, resultan excesivamente líricas las consideraciones para puestas en el magín del protagonista; en otras se adivina una experiencia irracional del propio autor, que significativamente dedica esta novela a sus enemigos. Pueden entresacarse algunas citas de ese capítulo a propósito del odio, el crimen y la culpa, la abolición de la culpa, sumida en la ceguera del abismo interior, como en Monte Odina:

\footnotetext{
11 Antonio Machado, Poesías completas, ed. de Manuel Alvar, Madrid, Espasa-Calpe («Selecciones Austral»), 1975, p. 160.

12 Ibid., p. 162.

13 «El dia de mañana puede ser un novelista. Hoy debe su éxito al apoliticismo de su literatura, todavía en fárfara. Buscándose cae en El nuevo Lazarillo, en el pastiche clasicoide, donde lo único que tiene sabor es cierto regusto gallego y valleinclanesco de brujas y mendigos». Max Aub, Discurso de la novela española contemporánea, en la serie Jornadas, $n^{\circ} 5$, El Colegio de México, Centro de Estudios Sociales, 1945, pp. 101-102.

${ }^{14}$ Fernando MORÁN, Novela y semidesarrollo. Una interpretación de la novela hispanoamericana y española, pp. 317 y ss. Se habla de tremendismo sin que esta palabra tenga una definición precisa en su uso literario. Peñuelas, en la p. 255 de La obra narrativa de Ramón J. Sender, Madrid, Gredos, 1979, dice algo tan general como lo siguiente: «Al tratar del tipo de realismo que insiste detalladamente en los aspectos horrendos de la realidad se ha hablado mucho de "tremendismo", aplicándose el término a alguna novela española de la postguerra, concretamente a La familia de Pascual Duarte. Pero se suele olvidar que este llamado tremendismo no era nada nuevo cuando Cela publicó dicha novela en 1942. Además de que en el mismo año salió, en México, Epitalamio del prieto Trinidad, ya en Imán, doce años antes, aparecen multitud de escenas llenas de ese realismo de lo horripilante".
} 


\section{MARÍA ÁNGELES NAVAL LÓPEZ}

La conciencia sólo remuerde de las injusticias cometidas: de apalear un niño, de derribar una golondrina... Pero de aquellos actos a los que nos conduce el odio, a los que vamos como adormecidos por una idea que nos obsesiona, no tenemos que arrepentirnos jamás, jamás nos remuerde la conciencia.

La presencia de los crímenes en Monte Odina contiene una reflexión literaria sobre cuestiones que venían de antiguo en nuestra literatura: el drama rural, el drama social, la novela de tipo naturalista que analiza las conductas según la herencia y el medio y la novela social. En conclusión, el fondo de referencias literarias para una novela de crímenes rurales está formado por un amplio espectro de piezas que van desde los dramas de Feliu y Codina y López Pinillos hasta La casa de Bernarda Alba de Lorca o Los hijos de la piedra y El labrador de más aire de Miguel Hernández.

En el texto de Sender las tragedias, la sangre derramada, impulsan la devastación y el abandono de la tierra, como en la leyenda machadiana y como en La tierra de López Pinillos:

Esas aldeas abandonadas que vemos a veces al pasar - dice Sender-... han conocido tragedias. A veces imposibles de trasladar al teatro, de tal modo ofenden nuestra sensibilidad. (p. 132)

Hacía tiempo que quería visitar ese otro pueblo donde los habitantes han emigrado y no sólo para buscar el pan en Francia o en Alemania, sino por una especie de repugnancia moral ante hechos como el que voy a contar. (p. 352)

Sender ensaya una explicación sociológica para la primera de estas historias rurales y homicidas, que nos relata en el capítulo siete de su novela, el crimen de Tomaso. Si bien la abstracción explicativa va precedida de una frase distanciadora: ${ }^{15}$

Ahora que estoy entrando en la vejez soy amigo de síntesis generalizadoras. Y estoy convencido de que la llamada proletarización del campesino ha hecho mucho daño en las aldeas. [...]

$\mathrm{Al}$ pasar un campesino a ser considerado en la ciudad industrial como proletario, es envilecido por esa misma expresión. Proletario quiere decir esclavo irredento. [...]

Lo peor es que el hortelano que va a la ciudad y se proletariza pierde frecuentemente sus virtudes humanas. [...]

Degenera un poco. Al menos en algunos aspectos. Y no tiene él la culpa, sino el sistema social. (pp. 132-133)

\footnotetext{
15 Conviene notar que es una actitud muy distinta a la que puede observarse, por ejemplo, en Mosén Millán, de cuyo componente de racionalidad histórica se ha podido escribir, vr. gr.: «Presenta, en síntesis, los elementos básicos del problema rural español, en sus raíces más hondas y al mismo tiempo más visibles» (M. C. PEÑUELAs, op. cit., p. 139). Las explicaciones de carácter histórico están deliberadamente abolidas en Monte Odina. De los crímenes que tienen importancia en esta obra ocurrieron realmente, además de los de la guerra civil, el de Andrés Cambra, de las casas de Odina, y el de la familia Palacio, de Berbegal.
} 
Las tragedias en realidad no tienen otra explicación que la ley o la fatalidad natural y hay que aceptarlas con sobrecogimiento:

\footnotetext{
Pensando en eso me decía yo que entre la primera palabra del Tomaso al regresar al pueblo y el último golpe de Miguel cuando su enemigo estaba ya muerto, en aquel espacio aparentemente corto, cabían todas las tragedias escritas y también las no escritas todavía. En aquel breve periodo estaban implícitas todas las miserias de la historia de la humanidad, distribuidas en los millones de células del sistema nervioso del Tomaso, de Miguel, de su madre y del campesino herido.

Esas cosas pasan en la tierra y se escriben o no. (p. 137)
}

Otras tragedias tienen como protagonistas personajes de extracción pequeño-burguesa y ahorra Sender explicaciones como las anteriormente transcritas. La primera de éstas se menciona ya en la página 44. Probablemente los escrúpulos o el respeto a los vivos hace que no se relate el crimen trágico. Pero ahí está aludido y para los conocedores de la comarca este crimen no dejaría de tener también curiosa explicación sociológica. El autor de esta tragedia podría haber dado pie a Sender para reconstruir el estadio histórico inmediatamente anterior al representado por la proletarización de Tomaso. El personaje ejecutor de la tragedia, junto con don Lorenzo Naval, médico de Peralta de Alcofea, habían impulsado proyectos de modernización en la zona construyendo una central eléctrica y una harinera entre Berbegal y Peralta. Ambos modernizadores tuvieron un final sangriento, uno muerto en la tragedia familiar a la que alude Sender y el otro, el médico de Peralta, en la no menos fratricida guerra civil. Bien representa el desastrado fin de ambos el agotamiento de los impulsos regeneracionistas en la zona cerealística monegrina. Este sucedido, que tiene los componentes fundamentales que interesan a Sender (odio, parricidio e incluso la guerra civil al final), no se cuenta ni se analiza pero se sabe. Como se sabe también el crimen de las casas de Odina: "Yo indagué y me enteré pronto de algo que sabía todo el mundo. "Aquello" sucedió en esa aldea hoy abandonada» (p. 355).

En realidad Sender pretende reducir la fábula narrativa a la historia. Que la historia sea el hilo conductor de su obra o la cadena que preexiste al relato y que permite que éste sea inconexo. Ocurre que, como la historia y sus análisis son también algo conocido, la novela puede reducirse a apuntes, reflexiones, sugerencias, despuntes de argumentos dramáticos eludidos y que el lector ubica en ese microcosmos que es Monte Odina como lugar físico y también la novela de ese mismo título. ${ }^{16}$

El tercer episodio se nos narra de forma más explícita: es el de Santiago, el segundón que quiso ser el heredero (pp. 355-357). Se trata del crimen

\footnotetext{
16 Progresivamente la Historia se convierte para Sender en algo no del todo racionalizable, que se justifica por oscuras razones de la ley natural. MAINER habló de «su visión de la Historia como un caos que acierta a enmascarar las hondas realidades del Hombre" («Prólogo", Ramón J. Sender. In memoriam. Antologia crítica, cit., 1983, pp. 7-23).
} 
por avaricia que al final trae la devastación de la vida y de la hacienda, la misma devastación de los pueblos abandonados. En esta historia podría haberse traído a colación uno de los temas del derecho aragonés más espinoso y que más desgracias y desavenencias ha ocasionado por estas tierras: los derechos exclusivos del hijo mayor a la herencia paterna. En la omisión de las interpretaciones sociológicas en estas últimas historias Sender manifiesta un cierto respeto por el estrato de los propietarios rurales más o menos acaudalados. Nuestro escritor en sus memorias se muestra siempre bastante adepto de estas clases sociales a las que perteneció durante los primeros años de su vida. La visión del mundo rural que nos presenta el autor altoaragonés está bastante relacionada con lo que acabo de decir. Pero de eso me ocuparé luego.

Al comienzo de la parte VIII el autor recapitula tras haber relatado el crimen de Tomaso. De forma no explícita se iguala ese crimen con los de la guerra civil. Es Monte Odina, el espacio, lo que facilita esta homologación:

La pequeña tragedia del pueblo abandonado, que he contado antes, parece sólo un incidente sangriento sin importancia. Pero olvidamos que no hay tragedias pequeñas ni grandes. La tragedia se define en sí misma con esa sola denominación y no sufre alteración por sus accidentes. Me refiero a la tragedia natural. ¿Es que podemos calificar de un modo adjetivo la que tuvo por protagonista a mi viejo amigo don Francisco Laguna, dueño de Monte Odina? Lo asesinaron en Monzón al comienzo de la guerra civil. ¿Qué más se puede decir en favor de la víctima sacrificada injustamente o en contra de sus asesinos? El hecho se califica solo. (p. 143)

La asociación de Monte Odina a la guerra civil es una forma de identificarla con España. Toda esta reflexión sobre la tragedia que venimos refiriendo no es más que un intento de quintaesenciar el conflicto de la guerra civil, el acontecimiento axial de la vida de Sender. Monte Odina, la guerra del treinta y seis y España están unidas por la tragedia. Y la tragedia como impulso arcano y universal es la misma, tenga por protagonistas a los dioses, los héroes, los artistas o los hombres más vulgares. Escribe Sender a propósito de la exaltación del amor exclusivamente carnal que lleva a cabo don Juan Tenorio: «De ahí la tragedia a lo divino implícita en todas las cosas, desde Prometeo atado a la roca y devorado por los buitres hasta Lorca asesinado en Granada». A renglón seguido vuelve a reflexionar sobre la bochornosa tragedia intrascendente de Tomaso. Hemos recorrido el camino al revés, desde lo universal a lo particular, de lo mítico a lo sórdido.

La tragedia de la guerra civil, es decir, los crímenes cometidos, quedan igualados a tantos otros crímenes que los mismos lugares albergaron antes de la contienda. Y el impulso que lleva a matar, como ya hemos visto, forma parte de esa peculiar ley natural que rige el universo. En esta homologación y en esta sublimación hay una exculpación de la propia conciencia del autor. 
De todos modos la tragedia es una necesidad también para el fabulador; en la página 194 comenta que no se puede escribir sobre las vidas honradas ni sobre las naciones felices: «¿Para qué hablar? Lo que está bien hace la vida ejemplar y merecedora de amistad y de amor. Las personas honradas como las naciones felices (Suiza, por ejemplo) no tienen historia» (p. 194). En suma la novela, Monte Odina, tiene que girar en torno a lo trágico porque «[e]l interés de este pequeño teatro del mundo comienza con la irregularidad» (p. 194).

\section{LO QUE QUEDA DE LA ESPAÑA DECOROSA}

Si Monte Odina es a veces España y sus tragedias son las de la guerra civil, otras es Aragón, es "la tribu» y es lo que el exiliado puede salvar de su país y a la vez lo único en el mundo entero capaz de dignificar y de enraizar al exiliado. El prólogo a Los cinco libros de Ariadna es muy explícito en este sentido:

\footnotetext{
Como cada español yo he tenido mis aventuras. Los riesgos han sido muchos, pero me ha ayudado hasta hoy el repertorio de los valores más simples y primarios de la gente de mi tierra. No del español de la urbe (repito que una de las cosas que no puedo ser es un burgués y no lo siento), sino tal vez del campesino de las tribus del norte del Ebro en la parte alta de Aragón. ${ }^{17}$
}

Claramente la guerra civil sesga la vida de Sender y su obra, como tantas veces han señalado la crítica y el propio escritor. El mencionado episodio nacional atraviesa las páginas de estas peculiares memorias en unos términos que son comparables al trasfondo histórico que suele contextualizar los relatos de ambiente rural y de tema trágico y enmarcar y fundamentar buena parte de la novela contemporánea. La guerra civil tiene una trayectoria literaria en el siglo XX semejante a la de las guerras carlistas o a la de la revolución de 1868 en el XIX. No procede ampliar aquí esta aseveración. Recordemos alguna novela ya mencionada, como La familia de Pascual Duarte, u otras de ambientación aragonesa, El santo patrono de Matheu o Capuletos y Montescos de López Allué. Esta última, centrada en el caciquismo y en el sistema del turno de partidos, muestra en uno de sus personajes principales, el maestro don Cándido, a un antiguo partidario de la Gloriosa convertido al sistema canovista. Sender con su propia biografía y a través de sus obras representa o presenta un tipo muy característico de la evolución de una parcela de la historia de España: anarquista, comunista español y por último algo que podríamos resumir como la reconciliación con la tradición liberal. De todos modos Sender intenta

17 R. J. SENDER, Los cinco libros de Ariadna, ed. cit., p. 11. El texto va firmado en Albuquerque en 1956. 
zafarse de todo esto al hablar de Monte Odina y al construir una mítica historia de Aragón. Así pues, en lugar de estar ante una novela en la que la fábula sirve para ilustrar la Historia, asistimos al intento de transformar el propio pasado personal y colectivo enmarañando los acontecimientos y haciéndolos pasar a formar parte de una trama cósmica, universal, pantemporal, entre poética y religiosa.

Por eso en Monte Odina nos encontramos con la imposibilidad de relatar la tragedia rural, de ahí el aplazamiento del relato de las sangrientas historias a las que simplemente alude. Porque Sender recurre a Monte Odina buscando esos rasgos antropológicos que lo dignifican como español, a este o al otro lado del Atlántico. Por eso en esta novela hay un fuerte componente de idealización de algunas virtudes del campesino, aunque sería más correcto decir labrador, como en las comedias del siglo XVII. No está muy lejos de este tipo literario la dignidad que Sender proclama en don Francisco Laguna y su familia y que a veces generaliza al mundo rural.

Me interesa hacer notar que Sender destaca unos aspectos que son muy característicos de un tipo de campesino oscense, donde hay un buen número de pequeños o medianos propietarios que no pueden llamarse terratenientes o latifundistas ni son jornaleros ni asalariados. No son rasgos o virtudes burgueses los que comenta con placer nuestro autor, pero tampoco son proletarios. Responden quizá a una peculiar sociología de la zona, a una clase media rural en extinción. Se trata en el fondo de las mismas clases sociales a las que quiso redimir Costa, enriqueciendo y transformando la base eminentemente rural y agraria de ese mundo admirable para ambos, para Costa y para el autor de Monte Odina. En Crónica del alba pueden encontrarse algunos pasajes en los que el protagonista siente impulsos de tipo regeneracionista. En El mancebo y los héroes, concretamente, donde yo creo que hay más pasión e identificación en las escenas campestres de caza que en las de subversión anarquista, no puede evitar el protagonista sugerir un arbitrio al contemplar unas tierras improductivas:

\footnotetext{
Íbamos entre la carretera y el río por una ancha faja de más de un kilómetro, donde poco a poco los plantíos se hacían raros hasta desaparecer y convertirse todo en retama y mata baja.

-Esta tierra - habló el mayordomo - rezuma agua salobre.

-No es salobre - dijo otro-, pero aunque sea agua dulce se aguachinan los plantíos y todo se malmete.

Yo dije, al azar, recordando el álbum del pigmeo donde había leído nociones de agricultura:

- Tal vez sería buena esta tierra para arroz.

Me miraron extrañados porque nadie cultivaba arroz en la región y no tenían la menor idea de lo que aquello podía ser. Pero la verdad es que unos años después los campesinos plantaron arroz en aquellos terrenos y algunos se hicieron ricos. ${ }^{18}$
}

18 Madrid, Alianza, 1984 ( $1^{\mathrm{a}}$ ed., 1971), p. 54. 
Costa, como Sender, tienen sus raíces en el mundo rural, aunque ambos con pocas posibilidades de futuro en ese medio. Ambos soñaron la redención - ya fuera económica, moral, histórica, legendaria o de otro tipo- de su tierra, lo que en el fondo era para ambos y con todas las distancias una forma de redención personal o, dicho de otra forma, la posibilidad de un futuro brillante en el lugar propio.

En El mancebo y los héroes aparece un propietario rural amigo del padre del protagonista, don Hermógenes, con el que el joven José Garcés siente una identificación más decidida que con el quiosquero anarquista del paseo de la Independencia, Ángel Checa. Incluso parece que don Hermógenes representa la figura del padre que Sender no acabó de admirar en el suyo propio. Pero éste es otro tema. Don Hermógenes, mesurado y hospitalario, generoso, resulta para José Garcés una persona profundamente respetable:

\begin{abstract}
Era un hombre grande, de voz y de gestos generosos. El más frecuente de éstos consistía en alzar los brazos y alzar los hombros para disculparse de algo. Yo no podía entenderlo, porque estoy seguro de que aquel hombre tenía siempre razón. Luego comprendí que se disculpaba de eso, de tenerla.
\end{abstract}

No me parece del todo ocioso recordar que don Hermógenes es el propietario de la finca a la que José Garcés y su padre han sido invitados para una cacería, porque son las virtudes de esos generosos y austeros, aunque más o menos ricos, propietarios rurales, a veces incluso cultos, las que recupera Sender al volver sus ojos a España y a su pasado en Monte Odina. Junto a don Hermógenes, don Francisco Laguna o el propio abuelo del escritor $y$, entre las mujeres, su madre y la de Valentina, son personajes representativos de este mundo que Sender respeta. El campo y el campesino aragonés están investidos de una dignidad especial:

\footnotetext{
Lo bueno de los campesinos españoles, especialmente los de Aragón, es que no se sienten nunca fuera de lugar ni tratan los mayores de discriminar a los inferiores. (p. 122)

En Loarre se siente uno satisfecho de ser aragonés y orgulloso de un pueblo que haría honor a los pueblos más nobles de Europa.

Nobles en el sentido moral, no en el de los blasones. (p. 158)
}

Los héroes aragoneses también merecen especial respeto a nuestro autor: "Nunca ha sido una región de aventureros menores y cuando ha habido alguno se ha llamado Durruti o Ascaso o Escartín y han sido generosos en la vida y en la muerte» (p. 358).

Hay páginas en Monte Odina que revelan una identificación sentimental con el mundo rural - una visión de la vida del campo y de las tareas agrícolas que no está lejos de Costa - y acercan a Sender - sólo en estoal ámbito del casticismo. No cabe duda de que hay en el siguiente texto un impulso idílico de fe en el progreso del campo y en el orden social allí establecido: 


\begin{abstract}
Mi vida en Monte Odina transcurre más bien entre la biblioteca y la terraza. Ocasionalmente me reúno con los sobrinos de don Francisco cuando están aquí. Son personas amables, un matrimonio en plena madurez, una niña adolescente muy linda y graciosa interesada también en cuestiones de alta cultura y varios empleados que según la época del año manejan con destreza profesional la maquinaria agrícola más moderna. (p. 150)
\end{abstract}

También hay una afirmación ennoblecedora del campo oscense en el siguiente párrafo:

De mí deben pensar que soy un viejo con la manía de los libros, pero esa manía ha sido siempre respetable en el campo aragonés y especialmente en la familia de mi antiguo protector y cómplice de rebeldías en mi vida de hijo discrepante y pugnaz. Quiero decir del hidalgo mártir don Francisco Laguna, a quien tantas veces me he referido. (p. 150)

Uno de los episodios más significativos a este respecto es el de la doncellica de Alquézar, personaje en el que se nos presenta la belleza aunada con la sencillez, la honradez, la dignidad y, en fin, un conjunto de conductas que pueden resumirse en esa virtud de la discreción expuesta en nuestra literatura áurea. Esta discreción es el logro depurado de muchos siglos de historia: "Lo decía sin arrogancia y sin mostrar ofensa ni tratar de ofendernos. Yo seguía deslumbrado. Todo era perfecto en ella. Treinta y cinco siglos llevaba aquella familia prodigiosa tal vez aprendiendo $y$ practicando la discreción» (p. 322).

La búsqueda de un resquicio de dignidad y de la exculpación es lo que lleva a volver los ojos hacia un mundo rural inevitablemente lejano para nuestro autor: "Yo, con la valva de los milagros abierta bajo la luz cenital, yo solo, en este lugar silencioso y noble, recuerdo a veces cosas de prestigio. Es decir cosas ligeramente ennoblecedoras para mí. A veces es torpemente inevitable» (p. 419). Sender se siente, al incorporar determinados episodios y observaciones a su texto, como un escritor de los llamados costumbristas:

No sé por qué cuento estas cosas evidentemente triviales en la biblioteca de mi viejo amigo don Francisco, muerto hace tantos años, pero tengo la impresión de regresar a mi infancia y muchas de esas viñetas de la vida rural tendrán pronto algún interés en un mundo que cambia tan deprisa. (pp. 318-319)

Monte Odina se confunde con los espacios de la infancia en general; todos son concitados allí: Chalamera, Alcolea, Fraga y los castillos de Sancho Abarca y de Loarre. Y como telón de fondo la guerra civil. Monte Odina no está alejado de otros espacios geográficos recreados por novelistas mucho más jóvenes. Pienso en Mágina de Antonio Muñoz Molina o en Ainielle de Julio Llamazares más que en Región de Benet. En La lluvia amarilla (1988) el joven de origen rural leonés trasplanta su inundado Vegamián al abandonado Ainielle del Pirineo oscense y lo transforma en un 


\section{EL LUGAR DE SENDER}

punto en el que fulguran las ignominias infligidas por la Historia y por los vecinos. El pueblo abandonado que visita Sender desde Monte Odina es también un pueblo fantasmal, desolado a causa de los crímenes allí cometidos. Es el lugar simbólico del reencuentro con los amigos y compañeros de letras caídos en sangre. La reconciliación con su recuerdo vendrá dedicándoles un lugar destacado en la biblioteca de don Francisco:

En la ermita tuve de pronto una extraña revelación. [...]

-En aquella noche, mientras tú dormías, acudieron al hogar y se sentaron en la cadiera de enfrente tus amigos y compañeros de letras que murieron de muerte violenta por mano ajena o por mano propia. Y con ellos Froilán. $[\ldots]$

Me propuse entonces buscar los libros de aquellos amigos y ponerlos en lugar preferente (una estantería aparte) en la biblioteca de don Francisco. (p. 376)

Quizá se parezca más Monte Odina a Mágina y sobre a todo a la de $E l$ jinete polaco (1991) antes que a la de Beatus Ille (1986). Mágina es también un lugar en el que el pasado familiar e incluso el espacio de la población giran en torno de la guerra civil. Es el lugar del reencuentro con lo que verdaderamente es el protagonista después del exilio de unos y de los viajes de otros. Ahora bien, el texto de Sender se acerca descaradamente a las memorias dejando de lado las convenciones de una fábula novelesca tradicional. En el fondo Sender pretende crear un interés más humano que novelesco, más natural según sus palabras: «Escribir en primera persona estimula la curiosidad del lector de una manera que podríamos llamar natural y no artificiosa» (p. 189).

En suma, la tragedia resulta inevitable, pues forma parte de la ley natural, pero Monte Odina, ese pequeño teatro del mundo que es Aragón y es lo que puede salvarse de España después de la guerra civil, ofrece una síntesis moralmente aceptable de todos esos elementos:

Pero los mayores milagros, como todos sabemos, los hace la naturaleza, incluyendo en ella los designios de Dios. Lo digo porque en este "pequeño teatro del mundo" en el cual la tragedia lo preside todo aunque tratemos de ignorarla o atenuarla con las buenas relaciones humanas, la sencillez y honestidad de la vida campestre en los lugares donde hemos nacido nosotros y nuestros amigos de la infancia, en este pequeño teatro del mundo, como digo, se nos ofrecen constantes ejemplos de adversidad que hay que observar. (p. 351) 


\title{
Dos visiones del «hombre natural perfecto»: Yank/Rómulo
}

\author{
† Gemma Mañá Delgado \\ Investigadora
}

\begin{abstract}
Es indiscutible que las lecturas realizadas por un escritor en sus años de formación ejercen una influencia imborrable. Tal es el caso de Sender con los dramas de Eugene O'Neill. Así, en Monte Odina dedica varias páginas ${ }^{1}$ a hablarnos de su persona y de su teatro, basándose sobre todo en los seis artículos que escribió sobre el gran dramaturgo norteamericano para "Los libros y los días» ${ }^{2}$ y también en sus recuerdos personales. Confiesa Sender que la temprana lectura del Emperador Jones y Antes del desayuno fue para él una revelación. Con los años no decayó su interés por O’Neill y una de las obras que cita expresamente es The Hairy Ape (El mono peludo o el gorila), ${ }^{3}$ una de las que le causaron mayor impacto. En este brevísimo

\footnotetext{
1 Ramón J. SENDER, Monte Odina, Zaragoza, Guara Editorial («Nueva Biblioteca de Autores Aragoneses»), 1980, pp. 108-118.

2 Charles L. KING, Ramtón J. Sender: An annotated bibliography, 1928-1974, Metuchen (N. J.), The Scarecrow Press, 1976; entradas 123, 142, 154, 163, 167, 176.

3 Eugene O'NEII. I. The Hairy Ape \& all God's chillun got wings, Calcuta, Royal National Theatre \& Nick Hern Books, 1993, XXVI + 85 pp. Introduction, biographical sketch and list of produced plays by Christine Dymkowski. Se trata de la edición más reciente en su lengua original, por la que citaremos dada la dificultad de consultar la versión española, agotada hace muchos años.
} 
trabajo vamos a ocuparnos de cómo creemos que influyó el protagonista de ese drama de $\mathrm{O}^{\prime} \mathrm{Neill}$ en la concepción del personaje principal de El rey y la reina.

El antecedente de esta pieza de O'Neill se halla en una de sus narraciones breves fechada en 1917, inspirada en Driscoll, personaje real amigo del dramaturgo. Driscoll, fogonero en el "Philadelphia", representaba para O'Neill la encarnación de la fuerza bruta y la más grande vitalidad. Pero un buen día de 1915 se suicidó arrojándose por la borda. Eugene O'Neill trató de comprender este suicidio; de ahí que tanto el cuento como el drama sean intentos de respuesta a las preguntas que le asediaban de por qué Driscoll, orgulloso de su superioridad animal y en completa armonía con su limitada concepción del universo, se mató.

The Hairy Ape se estrenó en el Playwrights' Theatre de Nueva York el 9 de marzo de 1922 con gran éxito. No tardó en tener versiones en el continente europeo (París, Moscú), que acentuaron su componente expresionista, ${ }^{4}$ contando asimismo con actores de físico y carácter impresionantes para interpretar al protagonista, Yank. ${ }^{5}$

En la primera escena nos descubre el autor un Yank satisfecho de sî mismo y de «su lugar» alimentando de carbón la caldera que hará alcanzar al barco su velocidad de crucero. $\mathrm{O}^{\prime}$ Neill insiste en presentar a los rudos fogoneros como animales en una jaula, aunque advirtiendo que de ningún modo debe caerse en una ambientación o interpretación naturalista. ${ }^{6}$ En ese mismo barco viaja Mildred, la hija del rey del acero, que siente curiosidad por ver las condiciones en que trabajan los fogoneros. Su descenso al cuarto de calderas le provocará un shock. Después de sentir la mirada horrorizada de la muchacha Yank no volverá a ser el mismo de antes y ya no recobrará la seguridad en sí mismo. La frágil apariencia de Mildred (potenciada por sus blancas vestiduras) le causa tal impacto que cree que es un fantasma o un ser irreal, del que se enamora. Consciente de la distancia que los separa, Yank intenta acercarse a los ricos, de los que sólo recibirá ignorancia o desprecio y que harán que acabe en la cárcel. A pesar de que se ha trasladado a la Quinta Avenida para verlos en su verdadero ambiente, Yank cree que los ricos tampoco pertenecen allí, no tienen su lugar, acaso porque su sofisticación es negación de lo vital. Así los describe O'Neill:

A procession of gaudy marionettes, yet with something of the relentless horror of Frankensteins in their detached, mechanical unawareness. (29)

\footnotetext{
${ }^{4}$ Juan Guerrero Zamora, Historia del teatro contemporáneo, vols. 2 y 4, Barcelona, Juan Flors Editor, 1961 y 1967. Vol. 2, pp. 85-89; vol. 4, ils. n $^{\circ}$ 59-60.

5 Sculley BRADLEY, Richmond C. BEATTY y E. Hudson LONG, The American tradition in literature, vol. 2, Nueva York, W. W. Norton, Grosset \& Dunlap, 1967, $3^{\mathrm{a}}$ ed., p. 1212.

${ }^{6}$ En la acotación que abre la primera escena, leemos: «The treatment of this scene, or of any other scene in the play, should by no means be naturalistic" (O'NEILL, op. cit., p. 5).
} 
Entonces su reacción es acudir al Sindicato de fogoneros dispuesto a la acción directa (colocar bombas), cosa que escandaliza a los mandos sindicales. En última instancia, Yank acude al Zoo y allí, en la jaula del gorila, parece encontrar por fin compañía. Desesperado, monologa: "I ain't on oith and I ain't in Heaven, get me? I'm in de middle tryin' to separate 'em, takin' all de woist punches from bot' of 'em. Maybe dat's what dey call Hell, uh?» (43). Al fin muere entre los brazos del gorila y el autor apostilla: "And, perhaps, the Hairy Ape at last belongs" (44).

Uno de los leitmotiv de esta pieza teatral es la obsesión del fogonero por indagar cuál es el lugar exacto que ocupa en la sociedad y, sobre todo, con respecto a los «ricos». Esta indagación, que se expresa en inglés con el verbo «to belong», que significa, en primera acepción, "pertenecer a» y que connota «adecuación», se repite cinco veces en la primera escena y es el tema central del monólogo de Yank en la última.

Otro de los motivos es la duda que atenaza al protagonista sobre las palabras exactas de Mildred al verle en el cuarto de calderas. La joven exclama, con asco y horror: «Oh, the filthy beast!», justo antes de desmayarse. En acotación dice O'Neill: «Rage and bewildered fury rush back on YANK. He feels himself insulted in some unknown fashion in the very heart of his pride" (20). Y lanza su pala salvajemente contra la puerta, que, por suerte, se acaba de cerrar tras los oficiales con el cuerpo inanimado de Mildred. En la escena siguiente, la cuarta, Yank expresa al viejo marinero Paddy sus dudas acerca de lo que pudo o no oír y al fin decide quedarse con el comentario del viejo: «Sure, 'twas as if she'd seen a great hairy ape escaped from the Zoo!» (23).

Yank intenta desesperadamente volver a sentirse como al principio, pero no puede; lleva clavada en el pecho la mirada de asco y desprecio de Mildred, que lo denigra y le recuerda todo el despotismo e injusticia social que pesa sobre sus espaldas: para encontrar su lugar deberá morir, ofrecer su cabeza.

Eugene O'Neill subtituló The Hairy Ape «A Comedy of Ancient and Modern Life» (drama de la vida antigua y moderna), que podemos interpretar como de la vida primitiva y la civilizada. Si Yank es un símbolo y el dramaturgo así lo reconocía en carta a Robert Sisk, en la que describe The Hairy Ape como "a modern Morality Play", 7 desde luego simboliza lo más primitivo e instintivo que hay en el hombre. De ahí que, de acuerdo con las acotaciones de $\mathrm{O}^{\prime}$ Neill, el dormitorio de los fogoneros en el barco se asemeje a una jaula. Además aún hay otra jaula para Yank, la celda de la cárcel, y finalmente la de verdad, la del gorila en el zoológico. Es la JAULA, con mayúscula, que la civilización pone al instinto. Yank, que parece que está más cerca de la selva que de la modernidad, acude a morir a manos del gorila, encontrando así su, quizá, verdadero lugar.

7 Carta de 15 de marzo de 1935, recogida en Travis BoGARD y Jackson R. BREYER, eds., Selected letters of Eugene O'Neill, New Haven - Londres, Yale University Press, 1988, p. 445. 


\section{EL LUGAR DE SENDER}

The Hairy Ape es, pues, una pieza relativamente breve que trata de los esfuerzos del fogonero Yank "por encontrar su lugar». ${ }^{8}$ Yank es un coloso humano, infatigable trabajador, en perfecto acuerdo con su naturaleza instintiva, a quien sus compañeros del cuarto de calderas de un gran trasatlántico temen y respetan.

Quizá sea el momento de reflexionar sobre la posible relación que puede haber entre un drama expresionista y una novela como El rey y la reina. A este propósito cabe recordar la clasificación de Peñuelas, que la incluye dentro de las alegórico-realistas ${ }^{9}$ pero con la consideración de que el nivel alegórico es en Sender más bien una forma de "expresionismo poético". También Palley la clasifica con las que ofrecen un contenido simbólico. ${ }^{10}$ Además, si O'Neill atribuía a su drama cierta analogía con la representación de un "misterio" medieval, no estará de más recordar que D. Pérez Minik dijo de El rey y la reina que era un relato digno de figurar entre los apólogos del infante don Juan Manuel. ${ }^{11}$ Quizá Pérez Minik responda a la sugestión producida por el título del libro de cabecera de la duquesa: Libro de los esiemplos de las monarquías. ${ }^{12} \mathrm{El}$ mismo Sender la califica reiteradamente años después de novela "gótica» ${ }^{13}$ confirmando la alusión que desliza en la escena final:

Rómulo miraba con estúpida atención uno de los dibujos de nácar incrustado en las maderas de la mesilla, que representaba un rey y una reina con una leyenda gótica al pie. (177)

Por otra parte, cabe considerar algunas afinidades entre ambos autores debidas a la extracción social de su entorno familiar (rural) y su educación y ambiente cultural, marcados por el catolicismo.

El rey y la reina ${ }^{14}$ es una de las novelas que Sender escribió sumido en las negativas consecuencias que tuvo para él la guerra civil española, conflicto que magnifica en sus obras posteriores a 1939 debido a dos terri-

\footnotetext{
${ }^{8}$ La biografía del propio $\mathrm{O}^{\prime}$ Neill tiene mucho que ver con ese sentirse desplazado, fuera de lugar. Su nacimiento, no deseado, fue la causa de la adicción a la morfina de su madre; la profesión de su padre (actor) le hizo vivir su infancia de hotel en hotel, etc.

9 Marcelino C. Peñuelas, La obra narrativa de Ramón J. Sender, Madrid, Gredos («Biblioteca Románica Hispánica»; II, «Estudios y Ensayos», 153), 1971, pp. 62 y 72-74.

${ }^{10}$ Julián PALLEY, El laberinto y la esfera. Estudios sobre novela moderna, Madrid, Ínsula, 1978, pp. 81-82.

11 Domingo PÉreZ MinIK, Novelistas españoles de los siglos XIX y XX, Madrid, Guadarrama («Crítica y Ensayo", 3), 1957, pp. 302-303.

12 El título del libro aparece un mínimo de nueve veces entre las pp. 82 y 146. Ello sin contar con las referencias temáticas al mismo y que constituyen uno de los motivos centrales de la fábula: el rey y la reina.

13 Marcelino C. Peñuelas, Conversaciones con Ramón J. Sender, Madrid, Magisterio Español («Novelas y Cuentos», 59), 1982, pp. 135 y 165.

14 Por la dificultad de localizar la primera edición (Buenos Aires, Jackson, 1949) citaremos por la más asequible de Barcelona, Destino («Áncora y Delfín», 341), 1970.
} 
bles acontecimientos familiares: los fusilamientos de su hermano Manuel en Huesca y de su esposa en Zamora en los primeros meses de la contienda. Este impacto tan negativo provoca en el escritor una reacción existencial que queda reflejada en La esfer $a^{15}$ mediante la teoría de "los ganglios" de Federico Saila, de raíz schopenhaueriana. ${ }^{16}$ Por otra parte, educado dentro de la órbita del catolicismo ortodoxo, no es de extrañar que el novelista en ese momento de crisis acentúe su alejamiento de aquél, acercándose por un lado a heterodoxos como Miguel de Molinos ${ }^{17}$ y por otro a filósofos como Spinoza, que reduce la libertad del hombre a su adecuación al orden natural. ${ }^{18}$

El protagonista de El rey y la reina es el portero-jardinero Rómulo, campesino cordobés de unos cuarenta años que Sender describe como dotado de una gran fuerza - transporta el «frigidaire» (sic) (50), carga con el cadáver del capitán Ordóñez (109) - y presencia física — «cabeza romana» (13), «ancho pecho" (80), "reposada dignidad» (50)—; además se ocupa de las calderas que dan calefacción y agua caliente al torreón del palacio ducal $(25,31)$. Es el último en la jerarquizada escala de la servidumbre del palacio de los duques de Arlanza y, cuando se inicia la novela, está sumido en la mayor conformidad, tanto en lo individual como en lo social. La novela se abre con la espléndida escena de la sala de armas, en cuya piscina Rómulo contempla a su señora nadando completamente desnuda. Desde el punto de vista de la reacción y evolución del jardinero, esta escena cumple la misma función que la visita de la frágil Mildred al cuarto de calderas del trasatlántico en The Hairy Ape, pues la duquesa, ante la advertencia de su doncella, se pregunta si Rómulo es un hombre. Tal es el estupor del protagonista que, al igual que Yank no acertaba a recordar las palabras exactas de la joven respecto a su persona, también

\footnotetext{
15 Ramón J. SENDER, La esfera, Madrid, Aguilar («Novela Nueva»), 1969. Las referencias a «los ganglios» aparecen a lo largo de toda la novela, pero tienen especial relevancia en las pp. 4647, 67 y 97. Quizá resulte más clara la exposición básica en la primera versión de esta obra: Ramón J. SENDER, Proverbio de la muerte, México, Quetzal, 1939, cap. II, "Los ganglios en el tedio iluminado», pp. 39-64, especialmente pp. 49-51 y 55-60.

16 Charles L. KING, "Sender's 'spherical' philosophy", Publications of the Modern Language Association, 69/5 (diciembre de 1954), Pp. 993-999. También Sherman H. EoFf, El pensamiento moderno y la novela española, Barcelona, Seix Barral ("Biblioteca Breve. Ensayo», 206), 1965, pp. 243-246.

17 Gemma Mañá y Luis A. ESTEve,. «Un desterrado, Ramón J. Sender; Miguel de Molinos, un perseguido", en Destierros aragoneses, II. El exilio del siglo XIX y la Guerra Civil, Zaragoza, Institución Fernando el Católico, 1988, pp. 197-206.

18 Francisco CARRASQUER, «La parábola de La esfera y la vocación intelectual de Sender», Norte, XIV./2-4 (1973), pp. 67-93. Puede verse ahora en Ramón J. Sender. In memoriam. Antología crítica, edición al cuidado de José-Carlos MAINER, Zaragoza, Diputación General de Aragón et al., 1983, pp. 399-424. V. especialmente las pp. 404-407. Para una referencia rápida a Spinoza, Nicolás AbBagnano, Historia de la Filosofía 2, Barcelona, Hora, 1985, cap. V, pp. 232 y ss., y José Ferrater Mora, Diccionario de Filosofía, Buenos Aires, Sudamericana, 1975 (5a ed., $3^{\mathrm{a}}$ reimp.), vol. II, s. v. «Spinoza», pp. 713-716.
} 


\section{EL LUGAR DE SENDER}

se debatirá ante el dilema de si la duquesa quiso referirse a su nombre o a su hombría:

Rómulo avanzó en las sombras hasta el mismo lugar donde había estado el día del incidente y dijo en voz alta:

- ¿Rómulo un hombre?

Luego en el mismo tono añadió:

- ¿Rómulo un nombre?

$Y$ comprobó que sonaban las dos frases exactamente igual. Las repitió situándose en otros ángulos de la sala. A veces había eco y cuando lo había la confusión le parecía mayor. Estaba completamente seguro de que lo que había dicho la duquesa era «un nombre» y no "un hombre». (60-61)

Desde aquel momento, el jardinero se siente «otro». Ese «otro» Rómulo $(14,21,23)$ que descubre intacto en su interior y le hace sentirse «en el centro de sí mismo" (59) es el de los veinte años (121 y 122), cuando "oía otra vez las voces de su juventud" $\mathrm{y}$ "aquellas ideas locas tenían valor porque no nacían en la cabeza sino en la sangre» (97). En ese «otro» se reconoce el protagonista en plena posesión de su naturaleza, de sus instintos, de su hombria; es su YO IDEAL que ha quedado oculto tras muchos años de sometimiento al despotismo y la injusticia social y al que ya no quiere renunciar desde que se le revelara al contemplar el magnífico cuerpo desnudo de la de Arlanza en la piscina. ${ }^{19}$ El shock que ha sentido al ser mirado como un animal o un mueble (27-28) remueve las entrañas y la conciencia del jardinero. $\mathrm{Y}$ el personaje irá evolucionando hacia ese «otro" Rómulo en el que perviven los instintos más elementales: la lucha por la hembra, el de supervivencia, etc. Al mismo tiempo - coadyuvando las circunstancias bélicas-, para superar la humillación sufrida, que le ha dado la medida de su inferioridad social, decide abandonar su inercia, su pasividad y tomar partido:

Había en el aire el sentimiento de una fuerza ante la cual Rómulo no quería ceder, no quería replegarse. No le quedaba otro recurso ante aquella fuerza enemiga que ser «un rojo». (70)

Y en esto se ayuda de una circunstancia aleatoria como es que, por casualidad, posee el carnet de un sindicato (22). Si bien por esa circunstancia los milicianos le confían las llaves del palacio, no pueden dejar de reírse de él e incluso considerarlo algo ridículo $(48,100,138)$ por su extraña actitud. Pero Rómulo no es exactamente un "desclasado", como apunta José-Carlos Mainer, ${ }^{20}$ sino algo mucho más radical y profundo:

19 Para este aspecto véase el reciente trabajo de Eduardo GODOY GALLARDO, "El rey y la reina, de Ramón Sender, y el encuentro con "el otro"”, Revista Chilena de Literatura, 46 (1995), pp. 21-33.

20 José-Carlos MAINER, "Antropología del mito: El rey y la reina, de Ramón J. Sender», en Homenaje a José Manuel Blecua, Madrid, Gredos, 1983, p. 399. No coincidimos tampoco con 
como Sabino en El lugar de un hombre, no cuenta para nadie, no es ni siquiera un hombre. ${ }^{21}$ Así llega a identificar su reacción y su violencia con la del pueblo en armas:

He estado cuarenta años empeñado en entender todas las cosas que pasaban fuera de mí y en conducirme razonablemente. Cada día decía diez veces que sí, cuando pensaba quizá que no. Ésa ha sido la gran tontería mía. O el gran crimen mío. (96)

No sé lo que habrá sido la vida de todos ésos, pero por lo que hacen ahora se puede calcular. Se ve que están rescatando su falsa conformidad de muchos años, y es tanto lo que hay que rescatar, que tienen que hacerlo así: a fuerza de cañones, a fuerza de cuchillos; a sangre y fuego. (97)

Rómulo se siente "absolutamente feliz» (76) cuando se da cuenta de que la duquesa le necesita para seguir escondida y sobrevivir. Por eso no duda en entregar al duque a la justicia popular, aunque tampoco tiene escrúpulos a la hora de engañar a los milicianos para proteger a su señora. Está decidido a todo porque ahora sabe cuál es su destino, ha encontrado $\longrightarrow$ cree haber encontrado-su verdadero lugar:

\footnotetext{
-Ahí fuera, ahí, suceden cosas que uno no quiere ni puede comprender. ¿Qué me importa a mí lo que sucede? La vida, ¿qué es eso? La guerra, la sangre, ¿qué es eso? No quiero decir que no sea lamentable, pero por encima de todo eso yo tengo mi camino. Un camino nuevo, señora. (96; el subrayado es nuestro)
}

Tal como Mildred constituye un ideal para Yank, la duquesa de Arlanza desempeña ese mismo papel, "promesa grandiosa a plazo fijo" (171), para nuestro jardinero. ${ }^{22} \mathrm{Si}$ la blancura o palidez de Mildred dejan alucinado a Yank, Rómulo asocia el cuerpo desnudo de su señora con la PUREZA. Y así lo expresa en diferentes ocasiones: «El desnudo de la mujer se le aparecía a Rómulo en el recuerdo de la duquesa como algo de una gran pureza» (59); «Los pétalos, encerrados todavía dentro del cáliz verde, debían tener la pureza de la piel del vientre de la duquesa» (85); o bien de su cuerpo y de sus ojos «sale la luz que lo hace todo más hermoso aquí que en los otros mundos" (119); para acabar cerrando la novela con este leit-

Luis LOPEZ ÁlVAREZ en su reseña de la edición francesa de la novela, Cuadernos [París], 17 (1956), pp. 122-123, quien dice que Rómulo no siente el odio de clases, a pesar de haber sido humillado.

21 Ramón J. SENDER, El lugar de un hombre, México, CNT, 1958, 2ª ed. revisada, pp. 55-57, 5960 y 163. Para la consideración de Sabino desde un punto de vista existencial, Shermann E. EOFF, op. cit., pp. 251 y 254.

22 Se ha querido ver en la duquesa el símbolo de la España tradicional y en Rómulo al pueblo español. Aunque no vamos a analizar este nivel simbólico, hay que hacer constar que el propio Sender alentó estas identificaciones. V. Marcelino C. PEŃUELAS, Conversaciones con Ramón J. Sender, Madrid, Magisterio Español («Novelas y Cuentos», 59), 1982, p. 165. 
motiv: «Rómulo miraba aquel cuerpo. ¡Qué pureza en el misterio de su boca entreabierta!» (179). ${ }^{23}$ Y lo que en Rómulo es expresión de lo sentido adquiere otra dimensión en la "idea poética» con que comienzan los Esiemplos de las monarquias y que a nuestro parecer es capital para cualquier acercamiento a la novela desde su mismo título:

\begin{abstract}
El universo es una inmensa monarquía. Los pobladores del universo estamos sometidos fatalmente a ella y somos a nuestra vez reyes de la realidad que nos rodea. Todo lo que el hombre ha soñado, ambicionado, creado, lo ha sido por esta monarquía del hombre - rey-y la ilusión, su propia ilusión - reina-. El hombre y la ambición ideal que lleva consigo son el rey y la reina del universo. (143)
\end{abstract}

Para alcanzar ese ideal, el mismo que representa Christel para Saila en La esfera, ${ }^{24}$ es necesario que Rómulo llegue a ser en la consideración de la de Arlanza un hombre. Sólo al final de la novela lo conseguirá y oirá exclamar a la duquesa: «Rómulo, tú... Tú eres el primer hombre que he conocido en mi vida» (177), pero para ello habrá tenido que jugarse la vida tanto en el palacio como en el frente, delatar al duque y hacerse cómplice de la duquesa y su amante al hacer desaparecer en la caldera encendida el cadáver del capitán Ordóñez. ${ }^{25}$

Lo que definitivamente acercará a Rómulo y a la duquesa será compartir la culpabilidad. ${ }^{26}$ La duquesa piensa que Rómulo es un criminal pero hay en él cierta inocencia; y se preguntará de dónde viene el crimen. Ella se siente también culpable de la muerte del duque, especialmente cuando por las noches recibe a su amante, Esteban, "el diablo": "iOh, Dios! Oyendo a Esteban y aceptando sin protesta lo que decía, yo no hacía sino someterme también a la miseria universal y a la tontería universal» (99).

El sentimiento de culpa acerca a ambos especialmente tras la muerte de Balbina, la mujer de Rómulo, en un bombardeo sobre el palacio, atraídos los aviones por un foco de luz que manipuló Esteban. A pesar de todo, el jardinero cree que existe posibilidad de salvación: "Sin embargo, en estos tiempos me voy dando cuenta de que detrás de lo más horrible, hay siempre algo amoroso, más fuerte y más alto que nos salva" (116). El tema de la posibilidad de salvación en medio de los crímenes más horrendos

\footnotetext{
23 No entramos a analizar las fijaciones freudianas como la adoración de Rómulo por los pies de la duquesa, "carnosos como los de un niño".

24 Shermann E. EOFf, op. cit., p. 247, donde además señala expresamente la relación temática entre ambas obras.

25 También el Jebuseo, fogonero del «Viscount Gall», hace desaparecer al jefe de máquinas en las calderas del barco (La esfera, ed. cit., p. 165). De él dice Saila, el protagonista: «Tiene una inocencia de gorila» (p. 128). Estos dos indicios conforman otro personaje que, sin forzar excesivamente la analogía, podemos relacionar con el Yank de O’ Neill.

26 José-Carlos MAINER, loc. cit., p. 399.
} 
nos remite a una novela clave de Sender, El verdugo afable, de la que hemos tratado con cierta extensión en otro lugar. ${ }^{27}$

Conforme se va haciendo palpable el dramático desenlace de la novela, Rómulo se enfrenta a la superación de las divisiones sociales y a la duquesa alzándose al plano de lo genérico (Hombre-Mujer, Rey y Reina) $o$ arquetípico (Adán y Eva):

Viendo en la duquesa todavía un género nuevo de armonía, lleno de perfidia, una fuerza que - en un rincón de aquel alto plano- a él le era inaccesible, la admiraba. (163-164)

Quizás en aquel alto plano se podía estar cómodamente, confortablemente y hasta virtuosamente, por encima de la sangre y el fuego. También él estaba por encima, pero su plano era otro. Y nada se podía hacer ya. Nada más que bajar la cabeza y ofrecerla. (165)

Oía llorar a la duquesa. "Quizás ella se duele de todo, se duele de mi suerte también y la acepta con menos resignación que yo mismo». Esta reflexión le conmovió más todavía y cuando entró en el ascensor se sintió por primera vez un verdadero hombre --en el mismo plano de la duquesa -, afrontando un destino verdaderamente sobrehumano. (165-166; el subrayado es nuestro)

Estos dos planos han sido sugestivamente comparados por Edwin Honig ${ }^{28}$ con los que dividen El entierro del conde de Orgaz de El Greco. El «bajo» es el que nos cuenta la historia del jardinero y la duquesa recluida en su palacio durante las primeras semanas de la guerra civil. El interés del lector, sin embargo, lo va llevando al otro nivel, el "alto", en el que se expone alegóricamente, poéticamente, el tema de la novela: la transformación de la servidumbre y pasividad de Rómulo en la hombría y «realeza» de sus aspiraciones al descubrir paulatinamente su propia dignidad.

Evidentemente hay en el personaje de la duquesa también un proceso de transformación paralelo. Pero, cuanto más cerca se siente Rómulo de la de Arlanza, más lejos está ella, inconsciente, delirando, en el umbral de la muerte. De ahí la frustración de Rómulo, que el jardinero expresa invocando la «antigua ley»:

¿Qué ley es ésa? ¿Es que las leyes de Dios sólo las entienden los muertos? (178)

27 Gemma Maña y Luis A. Esteve, «Vida de Pedro Saputo, de Braulio Foz, y la construcción de El verdugo afable, de Ramón J. Sender», en Homenaje a José Manuel Blecua, Huesca, IEA, 1986, pp. 93-120.

28 Edwin HoniG, reseña a la edición inglesa en New Mexico Quarterly Review, 18 (1948), pp. 352-354. Maryse BERTRAND DE MUÑoz los distingue tambiên, añadiendo un tercer plano, el de lo infrahumano o animal en el sótano. V. «Los símbolos en El rey y la reina de Ramón J. Sender", Papeles de Son Armadans, 220 (1974), pp. 37-55. Margaret E. W. JONE5 se ocupa de otros simbolismos en "Psychological and Alchemical Motifs in Sender's El rey y la reina», Revista Canadiense de Estudios Hispánicos, XIV/1 (otoño de 1989), pp. 79-95. 
Se puede aplicar aquí lo que Sender dice al calificar The Hairy Ape como «el más horrendo drama de frustración que haya podido imaginar un ser humano. El idilio imposible entre el fogonero de un barco de lujo y la linda hija de un gran financiero americano". ${ }^{29}$ La frustración de Yank es total, ya que no encuentra su lugar más que con la muerte; Rómulo llega a encontrar su lugar en el alto plano en el que sitúa a la duquesa, pero entonces todo se frustra y no la consigue, pues ella es la que muere.

$\mathrm{El}$ interés de Sender por los personajes más insignificantes y oscuros ${ }^{30}$ es una constante desde su primera novela, Imán (1930). Por otra parte también se ha venido indicando repetidamente ${ }^{31}$ la íntima relación de El rey y la reina con otras novelas, como La esfera, El lugar de un hombre o El verdugo afable, escritas entre 1939 y 1952, primer periodo del exilio de nuestro autor. Ya hemos visto cómo en esos años inmediatamente posteriores a la guerra civil se abre para Sender una gran crisis de tipo existencial que le hace reaccionar contra un cierto concepto de Dios - considerado un Ser misterioso e incognoscible — ${ }^{32}$ y la existencia del mal, así como contra una sociedad organizada diz que «racionalmente» pero en la que no está claro qué lugar ocupa el individuo.

Al comprobar que el intelecto, la capacidad racional, no evita el pecado ni el crimen, Sender deriva la responsabilidad del hombre hacia el acuerdo con sus instintos, su "naturaleza» más profunda, ya que es la que parece estar libre de los errores de una existencia intelectualizada y convencional. ${ }^{33}$ De ahí su interés por crear personajes que respondan al tipo del «hombre natural perfecto», como califica «el Cojo» a Ramiro Vallemediano, el verdugo:

\footnotetext{
- ¿Sabes qué te digo? Que tú eres el hombre natural perfecto. No toleras ninguna doctrina, no haces sino lo que tu naturaleza te inspira en cada instante.

— ¡Bah!, todo el mundo es más o menos como yo.

-No. Todo el mundo está pervertido por las influencias de alguna forma de cultura: religiosa, moral, política, social, etc. Pero tú eres el hombre natural tan limpio de influencias como el día que naciste. ${ }^{34}$
}

Por eso se fija en personajes literarios como Yank, tanto por lo que encarna como por el leitmotiv de su preocupación por «encontrar su

\footnotetext{
29 Monte Odina, ed. cit., pp. 118-119.

30 Shermann E. EOFF, op. cit., p. 240.

31 José-Carlos MAINER, art. cit., pp. 389-390.

32 Shermann E. EOFF, op. cit., p. 240.

33 Es lo que, según EOFF, intenta Saila, pero desde luego su postura nos parece algo «tramposa». Nótese que Eoff dice: «A pesar de que está siempre reflexionando, se crea una ilusión de relajación completa, imaginándose libre de la responsabilidad de pensar con su capacidad racional» (op. cit., p. 244).

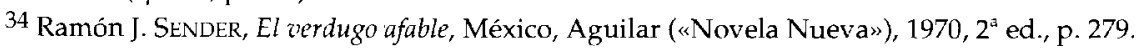


lugar». La distancia entre un moderno «morality Play» y una fábula o alegoría como El rey y la reina no es tanta, como ya ha quedado apuntado.

Hemos venido señalando con certeza las coincidencias estructurales (escena inicial), las de los protagonistas y motivos literarios (la duda; la búsqueda de un lugar en el mundo, en la sociedad y como individuo) entre The Hairy Ape y El rey y la reina. Y es que Sender nos ha ido dando pistas desde el «fogonero loco» de La esfera hasta ese pobre Sabino que anda a cuatro patas y gruñe como "un mono peludo" cuando lo encuentran en el monte, ${ }^{35}$ en la novela cuyo título y sugerente cita devino lema de este Congreso.

35 En el texto no se dice literalmente, sino que se insinúa gradualmente. Así, Tomaser, uno de los cazadores, sugiere que pudiera ser un orangután; la primera visión es la de «algo entre gris y amarillo, cubierto de pelos», y la descripción de Sabino una vez capturado recuerda talmente la de un simio. V. Ramón J. SENDER, El lugar de un hombre, cd. cit., pp. 21, 32 y 38 respectivamente. 


\title{
Ramón Sender y Dostoyevski: algunas coincidencias
}

\author{
Luis A. Esteve Juárez \\ I. E. S. Infanta Isabel de Aragón, Barcelona
} - ¿Te gusta más Stendhal que Dostoyevski?
-Sí, está más cerca de mí. Dostoyevski era un enfermo genial, pero un
enfermo. Stendhal era de una gran salud mental. ${ }^{1}$

\begin{abstract}
Afirmaba Sender a Marcelino Peñuelas. Y si menciona al novelista ruso otras veces - sea en libros misceláneos ${ }^{2}$ o en alguno de sus artículos- ${ }^{3}$ es como de pasada dentro de un repertorio de grandes novelistas o a propósito de otro tema, pero rara vez por interés directo. Por todo ello resulta más sorprendente un texto como la Parábola de Jesús y el Inquisidor,
\end{abstract}

\footnotetext{
${ }^{1}$ Marcelino C. Peñuelas, Conversaciones con Ramón J. Sender, Madrid, Magisterio Español («Novelas y Cuentos», 59), 1982, $2^{\text {a }}$ ed., p. 226.

2 Ramón J. SENDER, Álbum de radiografias secretas, Barcelona, Destino («Áncora y Delfín», 558), 1982, p. 275. O Tres ejemplos de amor y una teoría, Madrid, Alianza («Libro de Bolsillo», 171), 1969, p. 182.

${ }^{3}$ A título de ejemplo, puede consultarse Charles L. KrNG, Ramón I. Sender: An annotated bibliography, 1928-1970, Metuchen (N. J.), The Scarecrow Press, 1976, donde se reseñan cinco artículos $\left(\mathrm{n}^{\circ} 539,618,789,828,982\right)$ en los que se menciona a Dostoyevski.

4 Ramón J. SENJer, Las gallinas de Cervantes y otras narraciones parabólicas, México, Ed. Mexicanos Unidos, 1967, pp. 87-117. Citamos por esta edición. También se incluye en Novelas del
} 
donde dice: «Dostoyevski nos lo cuenta y comenzaré por parafrasear y extractar ese capítulo de Los hermanos Karamázov que falta en algunas ediciones antiguas españolas» (87). La historia ocupa el capítulo $\mathrm{V}$ del libro $\mathrm{V}$ de la parte II. El texto debía de faltar en algunas ediciones españolas, pero no en la que usó Sender: la de su amigo, contertulio y amistoso crítico Rafael Cansinos Assens. ${ }^{5}$ Una simple lectura superficial de ambas lo confirma de inmediato - selección de léxico, sintagmas, etc.- a pesar de que en muchos casos extracta efectivamente el texto original; para muestra, reproducimos dos breves fragmentos:

Pasarán todavía siglos de desordenada y libre razón, de sus ciencias y su antropofagia, porque al proponerse edificar su torre de Babel sin nosotros acabarán en la antropofagia. Pero entonces se llegará a nosotros la Bestia y se pondrá a lamernos los pies y nos los regará con lágrimas de sangre que verterán sus ojos. $\mathrm{Y}$ montaremos sobre la bestia y alzaremos un cáliz, y en él estará escrito: «Misterio!». Pero entonces, sólo entonces llegará para los hombres el reinado de la paz y la dicha. (213a)

[...] pasarán todavía siglos de desordenada y libre razón, de predominio de sus falsas apariencias y de su... antropofagia, porque al proponerse edificar ellos solos su torre de Babel —es decir, sin nosotros-, acabarán en el canibalismo. Entonces la humanidad será una grande Bestia y se acercará y se pondrá a lamernos los pies y nos los bañará con lágrimas de sangre. Y montaremos nosotros en la bestia y alzaremos un cáliz y en él estará escrito: misterio. Pero entonces, sólo entonces, llegará para los hombres el reinado de la paz y de la dicha. (95-96)

El relato es una fábula que Iván Karamázov confiesa haber escrito y que, previa justificación de su valor como parábola, narra de viva voz a su hermano Aliosha. En ella se cuenta el retorno a la tierra de Cristo y su encuentro con el Gran Inquisidor de Sevilla, para quien la felicidad del cristiano reside en seguir ciegamente los preceptos de la Iglesia abdicando de su libertad. Según el Inquisidor, Cristo se equivocó al predicar su evangelio, pues los hombres prefieren la seguridad y el pan cotidiano al ejercicio de la libertad, los placeres de la sociedad a los ensueños, la autoridad a la libre iniciativa, y se siente cautivado por el milagro y el misterio como alimentos de la imaginación. «Esta visión del paraíso artificial es premonitoria de cierto tipo de sociedades contemporáneas totalitarias, y en tal sentido -así como en otros más- Dostoyevski puede ser considerado como un profeta», escribía Serrano Poncela. ${ }^{6}$ Sin embargo, Sender, frente

otro jueves, México, Aguilar, 1969. El texto había aparecido por primera vez como colaboración en Política, Caracas, 1966.

5 Fiodor M. Dostoyevski, Obras Completas, 3 vols., Madrid, Aguilar, 1964, $8^{\mathrm{a}}$ ed. Los hermanos Karamasovi (sic), en vol. III, pp. 7-596. Las citas se harán por esta edición, indicando entre paréntesis página y columna. Por razón de límites nos ceñiremos sólo a esta novela. Para contrastar la exactitud de la traducción de Cansinos, puede consultarse la de Augusto Vidal, Barcelona, Bruguera («Libro Amigo»), 1979.

6 S. SerRano Poncela, La literatura occidental, Caracas, Universidad Central de Venezuela («Ed. de la Biblioteca», 40), 1971, pp. 537-538. Es curioso señalar la coincidencia con el artí- 


\section{LUIS A. ESTEVE JUÁREZ}

al beso de Jesús al Inquisidor por toda respuesta, escribe un discurso de réplica, creación propia donde se perciben ecos de la Meditación sobre Cristo, ${ }^{7}$ y altera levemente el final.

Esta historia provoca la siguiente reacción del pequeño de los Karamázov: «no puede haber un personaje tan fantástico como tu inquisidor. ¿Qué es eso de tomar sobre sí los pecados de los hombres? ¿Quiénes son esos guardadores de secretos que cargan con esa maldición por la felicidad de las gentes? ¿Cuándo se ha visto eso? Conoces a los jesuitas, de ellos se habla mal, pero ¿son ésos a los que tú te refieres?» (215 a). Lo que nos recuerda de inmediato lo que espeta Ramiro Vallemediano — «lo único respetable es ese pobre hombre de las manos espantosas que nada pide a cambio de recibir y acumular sobre su conciencia las claudicaciones, los terrores nocturnos, los crímenes de todos»- al jesuita padre Anglada en El verdugo afable. ${ }^{8}$ En esta conversación - clave a nuestro juicio para la comprensión de la obra- Ramiro censura la violencia e hipocresía de una sociedad que necesita del verdugo para mantener su orden, al tiempo que lo desprecia; mientras que el sacerdote le presenta el mal como algo inevitable e inherente a la naturaleza humana. Tanto los argumentos del padre Anglada como los de Ramiro los hallaremos en la Parábola de Jesús y el Inquisidor de Sender, por lo que -excepción hecha de los añadidos senderianos- podemos afirmar que ya están contenidos en El gran Inquisidor de Dostoyevski.

Antes de pasar adelante en cuestiones temáticas, me detendré brevemente en este personaje: el padre Anglada S. J. Se trata de un sacerdote anciano, con fama de santo y sabio, que vive en la residencia que tienen los jesuitas en Chamartín de la Rosa, en las afueras de Madrid según la novela, y que apenas recibe en su celda a unos pocos a causa de su enfermedad. El paralelismo con el stárets Zósima - guía espiritual de Alexei Karamázov- está servido: anciano y enfermo sacerdote de vida retirada con fama de santo y sabio. Pero hay aún otros detalles que llaman la atención. El primero es la actitud de Zósima ante Dimitri Karamázov y la bendición del padre Anglada a Ramiro. Y cuando Alexei Karamázov inicia el relato de la vida de Zósima y escribe: «Nací en un remoto gobierno del norte, en la ciudad de V[...]» (234a), recuerda el inicio del relato de Ramiro, el verdugo: «dijo que había nacido en una provincia del norte [...]» (30). Por otro lado, según señalaba Rubia Barcia, ${ }^{9}$ parece ser que el padre

\footnotetext{
culo de Sender «Las profecías de Dostoyevski», de la serie Los libros y los días, 5 de febrero de 1962. Y en Tres ejemplos de amor y una teoria, cit., en n. 2 dice: «es sorprendente la agudeza con que vio en el Diario de un escritor el futuro próximo de su patria, incluida la revolución de 1917 r.

7 Fiodor M. DosToYEvski, Meditación sobre Cristo, en Obras Completas HI, cit., pp. 1628-1630.

8 Ramón J. SENDER, El verdugo afable, México, Aguilar ("Novela Nueva»), 1970, p. 290.

9 José RUBIA BARCIA, «Réquiem por Ramón J. Sender», en Destierros aragoneses, II. El exilio del siglo XIX y la Guerra Civil, Zaragoza, Institución Fernando el Católico, 1988, p. 127.
} 
Anglada tiene un remoto antecedente histórico: el padre Pedro S. de Anglada, agustino del siglo XVII, coetáneo de Miguel de Molinos y que entre otros cargos llegó a desempeñar el de Calificador del Consejo de la Suprema Inquisición. Si añadimos que hacia el final de El verdugo afable Ramiro dice a nuestro novelista que el padre Anglada «Tiene más de noventa años» (369) y que el Inquisidor era «un anciano de cerca de noventa años", nos hallaremos ante un número significativo de elementos que confluyen en la creación del personaje, suficientes si tenemos en cuenta los procedimientos constructivos de Sender, que aprovecha y sincretiza toda clase de materiales (biográficos, históricos, lecturas, etc.) haciendo uso de lo que él llama la «memoria selectiva». ${ }^{10}$

La presencia de Dostoyevski penetra toda la novela ya que se basa - como hemos apuntado antes- en una semejante consideración del problema de la culpa y de la expiación, que son tema constante e irrenunciable del atormentado novelista ruso. Así, las palabras del padre Anglada «Quizá Dios le había enviado a Ramiro para turbarle y confundirle antes de su muerte, para mostrarle a un hombre inocente en medio de sus crímenes, de unos crímenes que no eran suyos y que, sin embargo, hacía suyos y quería expiar» (296) nos retrotraen a la actitud del stárets Zósima al postrarse ante Dimitri Karamázov, el cual mucho más adelante le dirá a Aliosha: «¿Por qué yo tuve en aquella ocasión aquel sueño de la criaturita? ¿Por qué es pobre la criatura? ¡Ésta fue para mí una profecía en aquel momento! ¡Por la criatura iré! ¡Porque todos somos culpables para con todos! ¡Para con todas las criaturitas, porque hay niños pequeños y niños grandes! ¡Todos... criaturas! Por todos iré allá, porque es preciso que alguno vaya allá por todos» (459b), repitiendo y resumiendo lo expresado en pasajes anteriores, ${ }^{11}$ lo que, por otra parte, resuena en las palabras de Jesús al Inquisidor en la Parábola senderiana: «tú amas a los hombres y por eso aceptas sobre tu conciencia sus pecados y sus crímenes» (107).

Por su parte Ramiro se indigna ante la propuesta del padre Anglada de quedarse en el convento porque le parece «un buen negocio en condiciones fraudulentas. Como si me dijera: "no seas tonto, yo conozco un truco magnífico. Sálvate como me he salvado yo"» (287). Y añade: «La felicidad terrena y, si es posible, la otra, la celestial. Por de pronto, la inmediata, que no falla. Hay en ustedes [...] una satisfacción de sí mismos demasiado sospechosa» (288), palabras que transmiten una reprobación semejante a la del cínico y borracho Fiodor Karamázov: «Ustedes se refugian aquí a comer coles y se creen justos. Gobios comen, un gobio diario, y piensan con gobios comprar a Dios» (75b). Y añade un poco más adelante: «Padres frailes, ¿por qué ayunan ustedes? ¿Porque esperan por ello una recom-

\footnotetext{
10 Marcelino Peñuelas, Conversaciones..., cit., p. 104.

11 Nos referimos especialmente a pasajes de la parte II, libro VIII, cap. VI, y libro IX, cap. VIII (el sueño de Mitia).
} 
pensa en los cielos? ¡Porque por semejante recompensa también ayunaría yo! No, santo monje, condúcete bien en la vida, sé útil a la sociedad en vez de encerrarte en un monasterio, donde tienes el pan seguro, y sin aguardar recompensa allá arriba... Eso ya es más difícil» (87a).

Si volvemos a la Parábola, hallaremos que Jesús en su respuesta al Inquisidor explicita y define la idea de la esfera como concepto metafísico y moral, lo que nos remonta de inmediato a una de las obras consideradas clave en el desarrollo del pensamiento senderiano, La esfera. Las recurrencias sobre la dicotomía temática «Culpa/Inocencia» son muy abundantes y podrían buscarse nuevos paralelismos al respecto. Pero prefiero señalar un pequeño detalle que, por más concreto, apunta más directamente a los Karamázov. Se trata de un pasaje del capítulo II de Proverbio de la muerte ${ }^{12}$ suprimido en las versiones posteriores. En él, Federico Saila, partiendo de esta afirmación: «Nuestros ganglios son capaces de aprobar la antropofagia sin escándalo...» (56), construye un discurso en el que parece querer responder al planteamiento de Iván Karamázov de que «la inmoralidad absoluta es el resultado ineluctable de la ausencia de la fe religiosa tradicional", según Palley. ${ }^{13}$ Si hemos señalado el punto de partida del discurso de Saila, es porque se trata del momento álgido de la retórica de Iván: «si hay y hubo antes de ahora amor en la tierra, no es debido a ninguna ley natural, sino tan sólo a que los hombres creen en la otra vida. [...] hasta el punto de que si extirpáis al género humano su fe en la inmortalidad, [...], todo estará permitido, hasta la antropofagia». En síntesis, "No hay buenas acciones si no hay inmortalidad» (71b-72a). Porque, como afirma Palley, "un vago sentimiento de culpa y el complejo expiatorio de Dostoyevski, son veneros que corren a lo largo de las páginas a veces oscuras de La esfera» (92), a lo que suma un cierto paralelismo entre el viaje expiatorio de Dimitri Karamázov y Grushenka con la escena final de la novela, en la que Saila y Christel se alejan hacia el bosque.

Ese mismo venero que recorre La esfera por entero subyace también como uno de los componentes ideológicos de El rey y la reina ${ }^{14}$ transferidos a sus personajes centrales. Así, mientras escucha a Rómulo, la duquesa reflexiona: "Es un criminal, pero hay en él cierta inocencia. Soy yo tan culpable como él de la muerte del duque. Y, sin embargo, soy al mismo tiempo inocente también. Pero si todos somos inocentes, ¿de dónde viene el crimen? ¿Quién lo fragua y dónde y para qué?» (97; el subrayado es nuestro), donde

\footnotetext{
12 Ramón J. SENDER, Proverbio de la muerte, México, Quetzal, 1939. Reelaborada considerablemente, se reedita ya como La esfera, Buenos Aires, Siglo Veinte, 1947. Y con nuevos retoques, Madrid, Aguilar, 1969.

13 Julián PALLey, El laberinto y la esfera, Madrid, Insula, 1978, cap. IV: "Vuelta a La esfera, de Sender", p. 91. Trad. de F. CARRASQUER.

14 Ramón J. SENDER, El rey y la reina, Buenos Aires, Jackson, 1949. Cito por Barcelona, Destino («Áncora y Delfín», 341), 1994, $4^{\text {a }}$ ed.
} 
se plantea que nadie puede juzgar a otro sin ser consciente de que quizá es más culpable por ese mismo crimen. ${ }^{15}$

Sin embargo, no se agotan las posibilidades de relación en el tratamiento de la dicotomía Culpa/Inocencia ni en el complejo expiatorio. Ramiro Vallemediano, como consecuencia de su trato con los anarquistas, reflexiona así:

\footnotetext{
En cuanto a las doctrinas anarquistas, le parecian hermanas de las de Jesús, con la diferencia de que los cristianos tenían una filosofía más completa, una verdadera metafísica, y los anarquistas eran en cambio más generosos porque no esperaban premio alguno en la otra vida. Las dos doctrinas habían proclamado la fraternidad universal y habían sembrado el camino de su fraternidad de víctimas inocentes. (166)
}

La idea de la semejanza entre el anarquismo y el cristianismo también la hallamos en la anécdota que cuenta Miúsov a propósito de lo que le confió un policía político parisino: no temen a los socialistas ni a los anarquistas, pero hay entre ellos «unos cuantos individuos particulares. Éstos creen en Dios y son cristianos y, al mismo tiempo, socialistas. Pues ésos son los que más temor nos inspiran: ¡son una gente terrible! El socialista cristiano es más tremendo que el socialista ateo» (69b). Esto, que parecería reforzar el pensamiento de Ramiro, es, sin embargo, contundentemente rebatido por Iván Karamázov: «el liberalismo europeo y hasta nuestro diletantismo liberal ruso, con frecuencia y desde hace ya tiempo, viene confundiendo los fines concretos del socialismo con los del cristianismo. Esta extravagante conclusión es, sin duda, un rasgo característico. Por lo demás, socialismo y cristianismo los confunden, por lo visto, no sólo los liberales y los dilettanti, sino también los gendarmes" (71a). Aquel pensamiento de Ramiro nace de su paso por los ambientes anarquistas de Madrid, los mismos que se recrean en Siete domingos rojos, ${ }^{16}$ donde también hallamos alguna referencia a la relación anarquismo/religión. ${ }^{17}$ Pero es que hacia el final de la novela acompañamos a Samar en una amarga reflexión sobre la libertad. Ésta sólo es accesible a quien, resueltas las incógnitas de lo eterno, es un esclavo alienado y carente de responsabilidad. Si además le proporcionan el alimento y lo embriagan de ilusión y de esperanza de vida eterna, es el único que puede sentirse libre porque ya no padece angustia. $Y$ añade: «Es admirable la actitud de los arzobispos, de los cardenales, de los papas que sostienen la fe y que, naturalmente, no creen en Dios. [...] Y la

15 Fiodor M. Dostorevski, Los hermanos Karamásovi, en Obras Completas III, cit., parte II, libro VI, cap. III: «De la plática y doctrina del stárets Zósima», p. $260 \mathrm{~b}$.

16 Ramón J. SENDER, Siete domingos rojos, Barcelona, Balagué, 1932. Cito por esta edición y no por la $2^{a}$ ed., corregida, Buenos Aires, Proyección, 1970, en cuyo «Prólogo» ya dice el autor que «si alguien quiere acordarse de mí en el futuro, sean estas últimas ediciones las que tome en consideración. Pero si no es así, estará en su derecho y a mí no me importa gran cosa".

17 Pueden verse algunos comentarios en las pp. 135, 162 y 167. 
alta Iglesia que no cree en Dios da la felicidad en el nombre de Dios a millones de seres libres, auténticamente libres» (412-413). Cuando Samar dice que no creen en Dios, no hace sino repetir el juicio de Alexei Karamázov sobre El gran Inquisidor: «iTu inquisidor no cree en Dios: ése es todo su secreto!» (215b). Lo que no es de extrañar, porque en esas páginas Sender ya resume uno de los temas centrales del cuento dostoyevskiano y nos anticipa un embrión de lo que será muchos años más tarde la segunda parte de la Parábola de Jesús y el Inquisidor: la irrelevancia del hecho histórico del Gólgota, pues se puede levantar una doctrina tomando como base cualquier otro sacrificio. Y más adelante en una secuencia onírica Lucas Samar se dirigirá a unas masas amorfas para decir: «Os odio a todos. Os odio y os desprecio. Por la imbecilidad de vuestra mirada, por la insuficiencia de vuestras pasiones, por vuestras dudas y por vuestras convicciones. Pero sabría haceros felices como nadie, imbéciles» (468). Por otra parte el discurso discontinuo de Lucas Samar acerca de la libertad como sentimiento y no como idea viene a coincidir también en sus grandes líneas con el discurso dostoyevskiano de Iván Karamázov, al señalar que no es concebible fuera de los credos religiosos: «La religión me da la libertad al decirme que nada hay perfecto en el ser humano, [...] Dios, la perfección suma y la suma clemencia, ha de juzgarme no con su rigor sino con su sabiduría y dar la libertad y la felicidad eterna a mi alma. Y los que me lo dicen y me convencen no creen en Dios» (414). Como el Inquisidor que, sin creer en Dios, absuelve a su rebaño y le da libertad y normas para conducirse y, si peca, le perdona en nombre de un Dios en el que no cree. Las coincidencias podemos rastrearlas en Siete domingos rojos también referidas a temas como el asesinato: «el que mata ya ha perdido el reposo, el equilibrio interior. Irá muriendo también en las sombras y el asco de sí mismo le cerrará, al final los ojos» (407-408), como pierde el equilibrio y se consume «El visitante misterioso» (245-253) que visita al stárets Zósima y que muere consumido por la contemplación de su propio crimen. $Y$ aún podríamos añadir la relación con el Raskolnikov de Crimen y castigo, como sugería Cansinos Assens en la serie de artículos que dedicó a la «novela social» con motivo de la aparición de Siete domingos rojos. ${ }^{18}$

Tras esta enumeración de coincidencias tomando como base una sola obra de Dostoyevski y sólo unas pocas de Sender, creemos poder afirmar que la presencia de aquél en el pensamiento literario senderiano es un hecho digno de consideración tanto por la importancia de los temas como por la persistencia temporal de la misma (de 1932, Siete domingos rojos, a 1966, Parábola de Jesús y el Inquisidor). No es mi pretensión en tan breve espacio abordar esta cuestión en toda su amplitud y profundidad, sino

\footnotetext{
18 Rafael Cansinos Assens, «Ramón J. Sender y la novela social», en Ramón J. Sender In memoriam. Antología crítica, Zaragoza, Diputación General de Aragón et al., 1983, pp. 37-56. Se trata de una serie de seis artículos aparecidos en La Libertad en enero-febrero de 1933, de muy interesante lectura.
} 
plantear la necesidad de una más detenida revisión de la influencia de Dostoyevski en Sender, aspecto que hasta ahora — según mi información- no se ha tratado más que tangencialmente. El hecho de que Sender hable de Dostoyevski de pasada y hasta con cierta ligereza no es indicio de nada, pues parece ser hábito arraigado en nuestro escritor el juego de despistar a lectores y críticos en torno a preferencias, afinidades y fuentes, llegando en algunos casos a negar graciosamente la evidencia, ${ }^{19}$ en una especie de ocultación gracianesca, o quizá responda a la resolución que se daba en las tertulias de los años treinta al problema de la originalidad y que tan donosamente recogía Eduardo Dieste: «El robo en literatura no es delito si va seguido de asesinato". ${ }^{20}$

Por otro lado al tratarse de dos escritores con profundas preocupaciones morales, metafísicas y religiosas, las coincidencias temáticas y el aprovechamiento de otros elementos por parte de Sender no debe sorprender en absoluto. Este estudio se convertiría a su vez en una nueva vía de asedio a algunos problemas centrales de nuestro escritor, comenzando por la dicotomía temática ya reseñada -culpa/inocencia-, que se extiende a lo largo y ancho de su producción como se extiende también a toda la obra de Dostoyevski. Pero hay también otros, como el problema de la libertad. O la temática religiosa abordada desde una doble vertiente: la religión como vivencia y lo que representa la Iglesia en relación con la sociedad humana. Sin olvidar el aprovechamiento de elementos constructivos.

Pero además se trata de una componente que contribuye a situar a Sender dentro de las corrientes del "pensamiento literario» de su época, más concretamente dentro de lo que Albérès denomina la novela de la "condición humana", donde la fórmula permanece "dostoyevskiana"; puesto que no hay ningún cambio en la estructura más superficial de la novela, sino un profundo cambio en la visión del hombre, concebido sobre todo como un animal metafísico, ${ }^{21}$ que es lo que hallamos en La esfera, novela existencial de raíz schopenhaueriana. 22

Para terminar quisiera dejar claro que la búsqueda de las fuentes y el establecimiento de coincidencias temáticas y formales es un intento de clarificar cuáles son las vías del pensamiento y del arte literario seguidas por Sender al abordar idénticos temas y problemas, lo cual en su caso des-

19 Es característica en este sentido la negación del uso de Vida de Pedro Saputo como falsilla inicial en la construcción de El verdugo afable. V. Gemma MAÑá y Luis A. EsTEve, "Vida de Pedro Saputo, de Braulio Foz, y la construcción de El verdugo afable, de R. J. Sender", en Homenaje a José Manuel Blecua, Huesca, IEA, 1986, pp. 93-120.

20 Eduardo Dieste, Obra selecta. Cuentos, Teatro y Teoría estética, Barcelona, Anthropos («Memoria Rota», 10), 1987, p. 119. Prólogos de C. GurméndeZ y Rafael Dieste.

21 R.-M. AlBÉrès, Historia de la novela moderna, México, UTEHA («Biblioteca de Síntesis Histórica», 143), 1966, trad. y apéndice «La novela hispanoamericana» por Fernando ALEGRÍA, p. 203. 22 V. Shermann E. EOFF, El pensamiento modemo y la novela española, Barcelona, Seix Barral («Biblioteca Breve», 206), 1965, p. 249. 
pierta un mayor interés por esa socarrona actitud de ocultamiento antes comentada. Cuando, sin embargo, afirmaba sin ambages: «Yo tengo, eso sí, una memoria selectiva bastante buena. Cuando tú me oyes contar alguna cosa del día anterior, o hace un año, o en la infancia, ¿verdad?... cuando hablamos, ¿no?, tú verás que la cuento con gran eficacia [...]. Una memoria selectiva un poco más fuerte de lo ordinario que organiza los materiales de la experiencia vital de uno, y los organiza de un modo instintivo, pero con una intención muy concreta y frecuentemente negativa». ${ }^{23}$ Pero al enfrentarnos con su obra nos inclinamos a pensar que esa «experiencia vital» no son sólo acontecimientos externos, sino que sus lecturas se incorporan a esa experiencia vital como lo cuenta en Crónica del alba: «Otra cosa extraña hice en la cárcel: leí teología mística y teosofía. En la biblioteca había toda clase de libros menos los de Marx o Bakunin. La teología y la teosofía me dieron la impresión de ser algo así como la anarquía de lo absoluto. Era más que divertido. Era orgiástico, especialmente los días de viento en el alero». ${ }^{24}$ Sus lecturas no son simple formación intelectual académica o autodidacta, sino una gozosa experiencia vital que como muchas otras, algunas muy dolorosas, se incorpora a ese acervo del que irá extrayendo parte de su materia prima novelesca.

23 Marcelino C. Peñuflas, Conversaciones..., pp. 104-105.

24 Ramón J. Sender, Crónica del alba, III. Los términos del presagio, Barcelona, Delos-Aymá («Biblioteca Literaria»), 1966, p. 121. 


\title{
Réquiem por un campesino español: summa narrativa de Ramón J. Sender
}

\author{
Patricia McDermott \\ University of Leeds
}

\begin{abstract}
Ortega y Gasset, en su análisis de la impopularidad y antipopularidad del nuevo estilo vanguardista, resume las tendencias del arte del siglo XX - un juego puramente formal, esencialmente irónico, intrascendentebajo el título célebre de La deshumanización del arte (1927). ${ }^{1}$ En su conclusión, pronuncia la imposibilidad de volver hacia atrás y desafía al objetante a que insinúe cotro camino para el arte que no sea éste deshumanizador ni reitere las vías usadas y abusadas» (1011). Ya había rechazado la óptica de un arte que propusiera una doble mirada combinando «la preocupación de la realidad viva y la percepción de la forma artística" como «un arte bizco», ejemplificado por el arte del siglo XIX, condenado como «tal vez la máxima anomalía en la historia del gusto», según su proposición central: «Todas las grandes épocas del arte han evitado que la obra tenga en lo humano su centro de gravedad» (994).

La respuesta antielitista al reto orteguiano por parte de Ramón Sender se encuentra en su práctica y teoría de la novela antes de la guerra civil. Su propuesta de un realismo dialéctico al servicio de la revolución social

1 Obras de José Ortega y Gasset, $2^{a}$ ed. corregida y aumentada, Madrid, Espasa-Calpe, 1936, I, pp. 981-1011 (referencias entre paréntesis en el texto).
\end{abstract}


logra su máxima formulación en el artículo que salió en la revista socialista Leviatán el 1 de mayo (día del Trabajo) de 1936, cuyo título, «El novelista y las masas», establece claramente su relación dialéctica con el autor de La rebelión de las masas:

El problema es ése: se identifica con las masas, no el que quiere, sino el que puede. $Y$ descubre la esencia activa, el principio vital de la confianza de los hombres sencillos entre sí, el que tiene la razón acondicionada para ese análisis y esa interpretación. Uniendo nosotros ganglionarmente nuestra confianza a la de los demás hombres, ingresamos en la masa y somos parte de ella. La razón nos permitirá encontrar la esencia de esa confianza y abstraernos para traducirla en palabras. Las masas sabrán entender esas palabras como nadie, mejor que las academias, mejor que los cenáculos y los críticos de la burguesía. Ésa será nuestra gloria. Una gloria de solidaridad y utilidad. $^{2}$

La gloria de don Ramón se realiza en la época de postguerra cuando, separado de las masas compatriotas, se reúne con ellas en espíritu en la composición de su Réquiem por un campesino español, pequeña obra maestra que consigue ese equilibrio entre forma y experiencia preconizado por el poeta Yeats en su búsqueda modernista de un arte integral: «blood, imagination, intellect, running together». ${ }^{3}$ En Réquiem por un campesino español técnicas modernistas se ponen al servicio de una fe humanista que sobrevive a la derrota, afirmando la trascendencia de la obra de arte en el sentido doble identificado por Ortega con respecto a la novela decimonónica: «[...] por su tema, que solía consistir en los más graves problemas, y [...] por sí mismo, como potencia humana que prestaba justificación y dignidad a la especie» (1009).

En el exilio Sender restaura el patetismo en la novela y resucita su misión salvadora de la especie en un momento crítico para la España franquista durante la guerra fría, mostrando por medio del texto que hay dos maneras de entender, desde el punto de vista de las dos Españas, la definición existencialista hecha por Ortega a raíz de la gran guerra mundial:

Yo soy yo y mi circunstancia, y si no la salvo a ella no me salvo yo. Benefac loco illi quo natus es, leemos en la Biblia. Y en la escuela platónica se nos da como empresa de toda cultura, ésta: «salvar las apariencias», los fenómenos. Es decir, buscar el sentido de lo que nos rodea. ${ }^{4}$

2 Para la teoría de preguerra véase P. COLLARD, Ramón I. Sender en los años 1930-1936. Sus ideas sobre la relación entre literatura y sociedad, Gante, Rijksuniversiteit te Gent, 1980.

3 «Personality and the Intellectual Essences» (1906), ensayo citado por P. FAULKNER, Modernism, Londres, Methuen and Co., 1977, p. 11.

4 Meditaciones del Quijote, en Obras de José Ortega y Gasset, ed. cit., I, p. 13 (referencias entre paréntesis en el texto). En su «Meditación primera (Breve tratado de la novela)» ORTEGA declara: «De uno u otro modo, es siempre el hombre el tema esencial del arte. $\mathrm{Y}$ los géneros entendidos como temas estéticos irreductibles entre sí, igualmente necesarios y últimos, son amplias vistas que se toman sobre los vertientes cardinales de lo humano» (52). 
Desde la perspectiva de la España errante, el Ortega de las Meditaciones del Quijote (1914) y su «crítica como patriotismo» resultan más simpáticos, como lo habían sido antes para Antonio Machado:

\begin{abstract}
¿No es un cruel sarcasmo que luego de tres siglos y medio de descarriado vagar se nos proponga seguir la tradición nacional? ¿La tradición! La realidad tradicional de España ha consistido precisamente en el aniquilamiento progresivo de la posibilidad España. No, no podemos seguir la tradición. Español signïfica para mí una altísima promesa que sólo en casos de extrema rareza ha sido cumplida. No, no podemos seguir la tradición; todo lo contrario: tenemos que ir contra la tradición, más allá de la tradición. De entre los escombros tradicionales, nos urge salvar la primaria substancia de la raza, el módulo hispánico, aquel simple temblor español ante el caos. Lo que suele llamarse España no es eso, sino justamente el fracaso de eso. En un grande, doloroso incendio habríamos de quemar la inerte apariencia tradicional, la España que ha sido, y luego, entre las cenizas bien cribadas, hallaremos como una gema iridiscente la España que pudo ser.

Para ello será necesario que nos libertemos de la superstición del pasado, que no nos dejemos seducir por él como si España estuviese inscrita en su pretérito. Los marinos mediterráneos averiguaron que sólo un medio había para salvarse del canto mortal que hacen las sirenas, y era cantarlo del revés. Así, los que amen hoy las posibilidades españolas tienen que cantar a la inversa la leyenda de la historia de España, a fin de llegar a su través hasta aquella media docena de lugares donde la pobre víscera cordial de nuestra raza da sus puros e intensos latidos. (49)
\end{abstract}

Réquiem por un campesino español es un cantar a la inversa la leyenda de la historia de la España de los vencedores para vindicar la intrahistoria de la España de los vencidos. La summa histórica de la España castrense desde las guerras púnicas hasta la nueva cruzada se condensa en los nombres de los pudientes Valeriano, Gumersindo y Cástulo y del cura mosén Millán, con su siniestra reminiscencia del general Millán Astray - «iMuera la inteligencia!»- en su enfrentamiento en 1936 con Unamuno - «Venceréis pero no convenceréis"-; mientras el nombre familiar de Paco refleja la condición de la España colonial y de una España ilustrada que pudo ser - Cabarrús y Goya- y un cristianismo primitivo que opta por los pobres - san Francisco de Asís- en oposición a los valores nacionalcatólicos del caudillismo triunfante.

La presentación de Paco como héroe trágico vuelve al revés el proceso del desarrollo genérico trazado por Ortega en las Meditaciones del Quijote, que va desde la épica, poesía mítica del pasado heroico, hasta la novela, poesía realista del presente vulgar, género cómico que marca, según Ortega, la caída del mito y el «desmoronamiento de una poesía» (70). Sender da marcha atrás en su novela poemática, que señala el proceso de la mitificación de lo cotidiano del pasado inmediato en una narración que, como la gran novela modernista que es el Ulises de Joyce, inscribe la dialéctica de los conceptos mimético-realista y poético-irrealista del arte en un contexto referencial que pasa revista a toda la tradi- 


\section{EL LUGAR DE SENDER}

ción del discurso literario de Occidente. Rasgos del cuadro de costumbres, el cuento folclórico-mágico, la fábula, la parábola, la lírica, el romance épico, el rito litúrgico y el mito se suman aquí con la economía de la novela corta, forma narrativa ideal del modo trágico, equiparable, en su efecto doble de expansión por la intensificación, con la tragedia antigua.

Mientras Joyce, como Valle-Inclán, ironiza la posibilidad de una visión mítica para el hombre moderno, Sender la afirma. En Réquiem por un campesino español el concepto de un mundo ideal, esencial, ausente, aparece por alusión y símbolo con referencia a los tres grandes sistemas míticos de la cultura occidental: el clásico, el cristiano y el romántico o natural. Sin embargo, en el juego de luces y sombras referenciales hay una irónica transvaluación de valores ortodoxos en la oposición binaria que se establece entre la tradición demótica (la fe viva de los muertos / Paco) y el tradicionalismo oficial (la fe muerta de los vivos / mosén Millán). ${ }^{5}$ La inercia de ese tradicionalismo se concretiza en el detalle realista de la mancha grasienta hecha por la cabeza del hombre de Dios en la pared de la sacristía, mientras la fuerza viva del espíritu del hombre del pueblo se encarna en el potro, animal solar, que corre libre por el pueblo y que misteriosa y sacrílegamente se introduce en la iglesia desierta.

El doble proceso de la creación y la destrucción de mitos nacionales, la sacralización de los valores naturales del héroe laico (el revolucionario como figura de Cristo) frente a la desacralización de los valores teológicos del antihéroe sacerdotal (la Iglesia como el Anti-Cristo), se subraya por el proceso dialéctico de las memorias voluntarias e involuntarias involucradas en la narración múltiple. La corriente de conciencia (en el doble sentido estético-ético de stream of consciousness / stream of conscience) del cura que se dramatiza en el primer plano se interrumpe por las idas y venidas del monaguillo y su recitación del romance. Paradójicamente, se utiliza una técnica modernista para revelar la crisis interna eclesiástica, mientras la vox populi utiliza la forma tradicional, que en sus orígenes divulgaba la ideología de la casta guerrera, para cantar su versión subversiva antimilitar. $^{6}$ El contrapunto llama la atención sobre la composición musical del

\footnotetext{
5 Para la oposición de la cultura eclesiástica y la ancestral, véase L. BONET, «Ramón J. Sender, la neblina y el paisaje sangriento: Una lectura de Mosén Millán», Ínsula, CDXXIV (1982), pp. 1, 10-11. En El tema de nuestro tiempo, de 1923 (Obras de José Ortega y Gasset, ed. cit., II, p. 866), ORTEGA pregunta: « ¿No es tema digno de una generación que asiste a la crisis más radical de la historia moderna hacer un ensayo opuesto a la tradición de ésta y ver qué pasa si en lugar de decir "la vida para la cultura" decimos "la cultura para la vida"?". Sender y Ortega comparten una postura que intenta armonizar lo vital y lo racional, el realismo y el idealismo.

6 En M. C. PeÑuelas, Conversaciones con Ramón J. Sender, Madrid, Magisterio Español («Novelas y Cuentos»), 1970, p. 221, Sender habla del nacimiento de la épica "para hacer la barbarie verosímil. Luego, romances para hacer los relatos épicos accessibles a la gente que no quiere oír si no es con música». Antes, pp. 110-111, considera el romance y otras manifestaciones de la cultura popular como una defensa del pueblo contra la violencia histórica.
} 


\section{PATRICIA MCDERMOTT}

relato a la vez que sobre la importancia del perspectivismo (muy orteguiano) en la recordación/relación de la historia.

El relativismo narrativo hace presente al lector la distorsión/estilización que tiene lugar cuando la memoria selectiva, personal o colectiva, representa la historia / la vida real en el espejo de la mente o del arte: la licencia o la convención poética, la censura externa o interna pueden interferir en la expresión vocalizada o mental. El monaguillo se da cuenta del uso de la palabra ejecutado (la perspectiva de los vencedores) en vez de asesinado (la perspectiva dẻ los vencidos) y el cura le manda fuera para no escuchar su propio nombramiento en el romance de Paco. La epifanía, en el sentido joyceano de revelación de significado, el descubrimiento del Cristo mítico en Paco y de Judas en mosén Millán, se queda para la comprensión del lector en esa cuarta dimensión del texto señalada por Sender, el espacio entre líneas donde la visión del autor se encuentra vitalmente con la del lector para operar una transferencia mental que puede alterar la visión de éste en su enfrentamiento con las mitologías de las ideologías imperantes en su vivencia histórica fuera del mundo ficticio del libro.

Los trozos del romance que sugieren desde el principio de una manera elíptica la analogía Paco-Cristo y que anuncian de una manera proléptica su pasión y muerte apuntan a la reconstrucción analéptica de su vida en la crónica narrativa en prosa. ${ }^{7} \mathrm{~A}$ la vez que insinúan como intertexto implícito el Evangelio, las interrupciones en verso tienen el efecto de separar los episodios de la vida y muerte del héroe y de presentarlos morosamente como una serie de cuadros para concentrar la meditación sobre el significado de la vida a la luz del fin como en los Misterios del Rosario y las Estaciones de la Cruz.

Crucial para la interpretación del significado de la muerte final, en un montaje narrativo dominado por el motivo de los últimos sacramentos y la misa de réquiem, y para la relación vida-arte es el episodio de llevar la extremaunción al pobre anciano que se muere en las cuevas sin los elementos necesarios para vivir. La parábola central de la España negra del subdesarrollo da lugar en el texto a la epifanía, el momento de iluminación. en las sombras, que cambia el rumbo de la vida del héroe de la ficción, Paquito, como el episodio de la vivencia real en que se basa inspiró la acción en la vida y el arte del niño Ramón Sender. ${ }^{8}$ La experiencia personal del autor, objetivada en la escena del mundo de la novelita, ilustra per-

\footnotetext{
7 Véase I. CRIADO MiGUEL, «Mito y desmitificación de la guerra en dos novelas de posguerra», Estudios sobre literatura y arte dedicados al profesor Emilio Orozco Díaz, A. GALLEGo MORELL, A. SORIA y N. MARÍN (eds.), Granada, Universidad, 1971, I, pp. 333-356. Es imprescindible la lectura de R. G. HAVARD, "The "Romance" in Sender's Réquiem por un campesino español», Modern Language Review, LXXIX/1 (1984), pp. 88-96.

8 PeÑuelas, op. cit., p. 200: «Creo que condicionó toda mi vida. Yo tenía entonces siete años y no lo he podido olvidar. [...] fui desde entonces un ciudadano discrepante y una especie de escritor a contrapelo".
} 


\section{EL LUGAR DE SENDER}

fectamente el diálogo convergente-divergente que el texto del Réquiem por un campesino español entabla con la tradición filosófica-literaria de Occidente desde el mito de la caverna de la Républica de Platón, pasando por la hagiografía de los místicos y el esperpento de Valle-Inclán, para dar el mentís a la tesis de la deshumanización del arte de Ortega y Gasset.

En «Unas gotas de fenomenología» (La deshumanización del arte) Ortega ejemplifica su explicación del perspectivismo y de la autenticidad con una composición de lugar:

\footnotetext{
Un hombre ilustre agoniza. Su mujer está junto al lecho. Un médico cuenta las pulsaciones del moribundo. En el fondo de la habitación hay otras dos personas: un periodista, que asiste a la escena obitual por razón de su oficio, y un pintor que el azar ha conducido allí. Esposa, médico, periodista y pintor presencian un mismo hecho. Sin embargo, este único y mismo hecho - la agonía de un hombre-- se ofrece a cada uno de ellos con aspecto distinto. Tan distintos son estos aspectos que apenas si tienen un núcleo común. La diferencia entre lo que es para la mujer transida de dolor y para el pintor que, impasible, mira la escena, es tanta, que casi fuera más exacto decir: la esposa y el pintor presencian dos hechos completamente distintos. (988)
}

Según Ortega, «El medio más claro de diferenciar los puntos de vista de esas cuatro personas que asisten a la escena mortal consiste en medir una de sus dimensiones: la distancia espiritual a que cada uno se halla del hecho común, de la agonía». Pasa a evaluar una escala de distancias espirituales que va desde la realidad vivida/humana hasta la realidad contemplada/inhumana: desde la mujer que vive dolorosamente la escena, pasando por el médico, que la vive profesionalmente, y el periodista, que la contempla y luego finge haberla vivido para conmover a sus lectores, hasta llegar al pintor: «Su actitud es puramente contemplativa, y aun cabe decir que no lo contempla en su integridad; el doloroso sentido interno del hecho queda fuera de su percepción. Sólo atiende a lo exterior, a las luces y las sombras, a los valores cromáticos. En el pintor hemos llegado al máximum de distancia y al mínimum de intervención sentimental» (989).

En Réquiem por un campesino español el reportero-pintor que es el novelista Ramón Sender revive el doloroso sentido interno suscitado en el niño que descubre la inhumanidad de la vida por la atención que presta su mirada a lo exterior en la escena de muerte de un hombre de los bajos fondos: «la silueta del enfermo - que tenía el pecho muy levantado y la cabeza muy baja - se proyectaba en el muro, y el más pequeño movimiento del cirio hacía moverse la sombra». ${ }^{9}$ Para el moralizador humanista lo que importa en la contemplación del juego de luces y sombras de la vida y la muerte proyectado en las paredes de la cueva, real o ficticia, es la praxis que puede producir el patetismo de la escena. Incluso el esperpento es una estética ética.

${ }^{9}$ Barcelona, Destino («Destinolibro»), 1980, $6^{\text {a }}$ ed., p. 36. 


\section{PATRICIA MCDERMOTT}

La anciana, coagonizante en el espectáculo de la muerte - «le temblaba a veces la barba, y en aquel temblor se percibía el hueso de la mandíbula»-, calla, en resignación fatalista, como el sacerdote, quien profesionalmente guarda las apariencias pero ejerce su oficio con desgana, evitando la responsabilidad personal ante los designios misteriosos de un Dios silencioso. Es el ojo inocente del niño el que registra los detalles de una escena goyesca - «No se veían por allí más muebles que una silla desnivelada apoyada contra el muro» (37) - y establece la comparación entre los pies del agonizante y $y^{\prime}$ los de los crucifijos abandonados en el desván de la iglesia. El espectáculo de la miseria ajena despierta la piedad en el niño, su sentido de la justicia, y le encamina a una vida de acción social. Como en el caso del encuentro de Max Estrella y el anarquista en las sombras de la cárcel en Luces de Bohemia, es una conversión paulina al revés; cuando el niño mira las estrellas fuera de las cuevas no ve la luz divina sino una iluminación humana: su idealismo es de este mundo y camina por una tierra desigual.

En el siglo XVI el monaguillo Juan de Yepes descubrió en la iglesia del convento de la Magdalena y en el hospital de la Concepción una vocación religiosa que le llevaría como fray Juan de la Cruz a una misión activa en la reforma carmelita y a la vida contemplativa de la ermita. La hagiografía del santo místico, modelo espiritual del Régimen, encuentra eco en Réquiem por un campesino español, que va por otro camino de perfección en el siglo XX: el monaguillo Paco opta por la vida activa en la reforma de la sociedad secular, separándose de la vocación religiosa, que se retira a la soledad de las ruinas de una abadía. ${ }^{10}$ En Réquiem por un campesino español el monaguillo que fue Ramón Sender, en su vida activa de contemplativo artístico, ofrece el ejemplo de las dos vías para la contemplación/elección de los lectores de su novela ejemplar. Como narrador cuyo centro de gravedad es siempre lo humano, cumple con la prescripción del partidismo, objetivo de la estética de Engels, a la vez que con la prescripción del perspectivismo según Ortega en El tema de nuestro tiempo: «La verdad integral sólo se obtiene articulando lo que el prójimo ve con lo que yo veo, y así sucesivamente» $(880)$.

\footnotetext{
10 «Veríamos cómo lo que antes se entendía por virtuoso y noble - el misticismo- es todo lo contrario: egoísta, y de un grado de perversión antisocial enorme» («El novelista y las masas», p. 36).
} 


\title{
Réquiem por un campesino español o la lectura como resurrección de una guerra muerta: desarrollo de una experiencia de educación en valores en enseñanza secundaria
}

\author{
Manuel Hernández Martínez \\ I. E. S. Cinco Villas, Ejea de los Caballeros (Zaragoza)
}

\begin{abstract}
Nuestra comunicación parte de la premisa de potenciar el estudio de la literatura en las aulas de una forma humanística y, a la vez, diversa. Parte también de la certeza de las posibilidades de este texto para su trabajo en el aula, intentando mostrar a través de él nuevas formas de recepción y comprensión del fenómeno literario. Por ello nos parece interesante aportar esta experiencia ya que una de las secciones de las comunicaciones del Congreso incide en «La recepción del escritor» y esta novela ha sido, sin duda, una de las más leídas por diferentes generaciones de lectores en el bachillerato. Con la configuración del nuevo sistema educativo se puede pretender llegar a nuevas lecturas y trabajos que potencien una especial recepción de la obra literaria, a pesar de las deficiencias y los inconvenientes que el currículo del área de Lengua Española ha impuesto, restringiendo notablemente los contenidos literarios. La elección de esta obra es oportuna, como se podrá comprobar, y comentar la experiencia ampliará el abanico de posibilidades de la recepción e interpretación de este escritor, tanto para un público juvenil como para el adulto. En Réquiem podemos encontrar un ejemplo preclaro de
\end{abstract}


cómo la lectura es una de las mejores formas de educar el pensamiento y de que ello puede llevarse a cabo con textos que contengan una gran dosis de creación.

\section{DESARROLLO DE LA EXPERIENCIA}

Es de todos conocido que trabajar con Réquiem por un campesino español, de Ramón J. Sender, en el aula es ejercicio acostumbrado por la facilidad de lectura del que quizá sea el más importante relato corto de un autor aragonés. La sencillez estructural, que no simplicidad; la amenidad de la anécdota, que gana en tensión y crudeza, desde una historia infantil hasta una situación trágica de la historia española; la brevedad, en fin, hacen que el ejercicio de lectura en el aula, muchas veces relectura, no sea un recurso para que «lean», sino un verdadero aprovechamiento en el arte de la lectura por el cual el libro deja de ser papel y se convierte en arte. Nuestro deseo de experimentar nuevas posibilidades para enriquecer la lectura del alumnado nos hizo arriesgarnos y plantear unos trabajos un tanto «especiales» a partir de la lectura del texto.

Estos trabajos quedaban especificados en seis formas diferentes de acercarse al texto:

a) Análisis estilístico de la obra literaria.

b) Análisis pormenorizado de los personajes o protagonistas del enunciado.

c) Estudio de contextos histórico-políticos.

d) Recreación de la historia desde el punto de vista de un protagonista distinto del que el autor escogió.

e) Exposición de situaciones y argumentos similares cercanos a los estudiantes.

f) Creación de posibles continuaciones de la historia.

Los trabajos de los tipos a) y b) pertenecen al terreno clásico del «trabajo de literatura y lengua" y, con los del tipo c), formarán el bloque de estudios destinados al análisis del texto. Los trabajos de los tipos d), e) y f) proporcionan una mayor creatividad para la expresión; parten de una lectura muy especial del texto a la búsqueda de posibles modelos que se recrean. Son ejercicios propiamente retóricos.

Ya que era imposible que un solo estudiante tratase varias perspectivas a la vez, se les propuso aquel tipo de trabajo que podía adecuarse mejor a las capacidades que en el aula se evaluaban y que mejor correspondiese al proceso de aprendizaje de cada alumno. Esto, como decíamos arriba, no dejaba de ser arriesgado. Sin duda muchos alumnos y alumnas creativos no pudieron trabajar en ese momento de esta forma especial el lenguaje. De igual modo, estudiantes reflexivos y analíticos tampoco pudieron demostrar entonces sus habilidades y tuvieron que introducirse en el incómodo mundo de la inventio, dispositio y elocutio de su propio texto. 
El primer grupo de trabajos recibió una serie de preguntas-guía que concretaban la tarea de análisis que cada estudiante debía ejecutar al volver a leer el Réquiem por un campesino español. Algunos trabajaron la estructura del relato, otros catalogaron y clasificaron los sustantivos, adjetivos o verbos. También se dedicaron especialmente algunos al estudio de los escenarios, «del tratamiento del tiempo y del espacio». Especialmente difícil resultó el estudio de los narradores, confundiendo el concepto de narrador y "protagonista de enunciación», que fue la perspectiva que adoptaron más cómodamente los alumnos y alumnas. A pesar de esto llegaron a interesantes disquisiciones sobre los personajes del «monaguillo» y «la Jerónima», que contagian su voz al «narrador implícito» del texto.

La novela que nos ocupaba da "fácil juego" para que el "lector interesado» que es el estudiante rastree las características de un personaje a lo largo de todo el relato, con lo que la lectura analítica e intensa de la obra abarca todo el texto. El alumnado, enseñado a citar, en ocasiones reducía su exposición a una presentación de textos en los que aparecía el personaje, sin llegar al verdadero análisis del «tratamiento» del mismo. No obstante, quizá imbuidos por el lenguaje periodístico o simplemente de las revistas más comunes, encontramos títulos como Jerónima. Todo sobre ella o Cómo era Paco.

En los trabajos del tipo c), los estudiantes intentaron introducirse en el difícil mundo del análisis y la bibliografía sobre la historia, a fin de comprender mejor lo que se cuenta en el Réquiem. El anarquismo, Las consecuencias de la guerra civil, Contexto histórico, El anarquismo en Aragón, Las cárceles y los fusilamientos - un trabajo especialmente documentado en su apartado fotográfico- configuraron sin duda una nueva perspectiva para que la «verosimilitud» de esta obra literaria quedase perfectamente demostrada.

Los protagonistas de la novela, con mayor o menor cantidad de pinceladas-detalles, aparecen tan jugosamente retratados por Ramón J. Sender que no era aventurado pedir a los estudiantes un ejercicio de creación un tanto especial. Era evidente que el autor recurría a un protagonista muy implicado en la historia, mosén Millán — tan implicado que dio el primer título a la obra-, para contarnos la vida de Paco, el del Molino. Pero hay una serie de protagonistas que no dejan de vivirla con igual intensidad y de los cuales se podía conocer más, ya que el autor, por las exigencias de la obra de arte escrita dedicada a una trama central y concisa, no daba explicaciones. Reinventar los sucesos desde el punto de vista de otro personaje e intentar contarlos con su propio lenguaje ofrecía la posibilidad de «crear literatura» con una base sólida, lo que ya conocemos por las magistrales, numerosas o escasas, pinceladas de Sender. Águeda, el zapatero, el padre de Paco, don Valeriano... son personajes que dan su voz para contarnos la vida de Paco, desde sus sentimientos y perspectiva, en muchos de estos trabajos. Algunos no se han arriesgado a tanto y prefieren tomar sólo la perspectiva de dichos personajes, pero no inventan 
la autobiografía. Son especialmente destacables los relatos contados desde «la Jerónima» o el monaguillo, al que quizá por la cerçanía de edad se asimilan mejor los estudiantes y recrean novelas muy creíbles contadas desde la infancia y adolescencia. Incluso resulta interesante ver contada la historia de su vida por un Paco, encerrado en la cárcel antes de ser fusilado, a un reo compañero de la última noche; o leer el testamento de Paco, recreando a un "Pascual Duarte». No podemos olvidar el punto de vista de un hipotético hijo de Paco que revive en el pueblo la experiencia y fama de su padre, texto que lleva una mayor carga creativa que los anteriores, ya que, por supuesto, es un personaje inventado totalmente. No sólo en la biografía que Sender no nos llega a ofrecer, también en los otros personajes, los alumnos han tenido que inventar para desplegar su imaginación sobre los momentos desconocidos en los que esos personajes tomaban contacto con Paco y podían así hablar de su historia.

Pero antes de pasar a los trabajos puramente literarios vamos a resenar aquellos en los que los estudiantes ejercitaron su capacidad para recoger por escrito situaciones y biografías similares en el mismo contexto que nos presenta Sender. Algunos trabajos presentan elaboraciones literarias y otros transcriben los acontecimientos tal y como les han sido contados. La perspectiva es múltiple en este apartado, algo que no era previsible. En algún caso, un personaje de avanzada edad dialoga con un nieto o niño, al que acaba contando un hecho sucedido en la guerra civil española. En otros, el estudiante actúa como narrador de un hecho en tercera persona, un hecho verídico. Dentro de esta posibilidad está la variante del autorentrevistador que nos describe su propia situación personal y la de la persona que le va a dar cuenta de la historia del pasado, una historia y un presente perfectamente reales. También se atreven a adoptar, para contar una historia real, una postura autobiográfica, haciendo vivir el suceso que en casa les han contado. Con esta variante se llega también a una mayor posibilidad creativa.

Cabe decir que, exceptuando aquellos trabajos-relatos en los que el estudiante adopta un punto de vista de narrador omnisciente, que cuenta la historia como si se hubiese documentado o como si ésta fuese perfectamente conocida, todos los demás (abuelo o padre que cuenta la historia, autobiografía en el presente o en el pasado, entrevistador que busca un protagonista de la guerra) están enmarcados en un contexto que literaturiza la recepción de la información con una presentación literaria del momento en que se establece el diálogo.

Si bien el objetivo de los trabajos del tipo e) no estaba pensado para que los estudiantes desarrollasen sus potencialidades creativas, los alumnos y alumnas, quizá imitando el relato de mosén Millán y su perspectiva, han enmarcado e incluso filtrado la anécdota o el hecho trágico de la guerra en una visión claramente literaria próxima a lo que se les requería a los estudiantes seleccionados para desarrollar los trabajos del tipo f), puramente creativos: continuación de la historia. 
La característica o nexo común de estos últimos trabajos - al entrar en creación literaria, en potenciar la «imaginación» y la "fantasía», se pierde la posibilidad de lograr univocidad de criterios- es un tratamiento de la lectura creativa que algunas editoriales de libros han comercializado: continuar la historia que se cuenta en capítulos previos eligiendo la continuación a partir de una premisa.

Además de lectura intensa - previa en todos los trabajos del segundo grupo: tipos d), e) y f)-, superamos este concepto hacia la escritura creativa, continuación de la historia desde la libertad imaginativa a partir de lo leído, esquema tradicional de retórica literaria, que hemos trasladado a una obra moderna.

Una continuación fantástica es la planteada en alguno de los trabajos en que Paco «resucita»; es decir, se transforma el final de la historia para que Paco pueda reaparecer en el pueblo, haciendo comprender su presencia el triunfo de unos valores frente a los de los que lo intentaron asesinar. Interesa sobre todo no el contenido, tan fantasioso, sino la forma que ofrece el texto, que continúa el mismo tratamiento de tiempo y espacio, idéntico grado de verosimilitud, una sintonía emocional en el retrato de los personajes propuesto por Sender y una anagnórisis literaria. También es una forma de "resurrección» el final y continuación propuestos en otro de los trabajos, donde mosén Millán se arrepiente de forma efectiva y fantásticamente "rescata» de la cárcel a Paco antes de que le apliquen la «ley de fugas». Han captado con su fantasía la cara oculta de mosén Millán, su lado valiente, que queda oculto por las circunstancias políticas; han captado la honda tristeza del sacerdote, que se debate entre la amistad y el "deber», y han optado por la primera, cuando Sender optó por la segunda para dar un mayor dramatismo - y verosimilitud - al texto.

Otro de los trabajos desarrolla en estilo y contenido la sensación de tristeza y arrepentimiento que el personaje narrador de mosén Millán nos ofrece a lo largo de la novela de Sender. Tristeza, soledad, pesimismo y cierta dosis de estoicismo continúan, ahora sin recuerdos que retengan esa angustia como en la obra senderiana, la profundización psicológica del biógrafo mental de Paco, el del Molino...

Finalmente nos encontramos con otra posibilidad - muy literaria, unamuniana- de «resurrección» en la continuación de la historia con el protagonista: Paco, hijo de Paco, el del Molino. No es un narrador que nos cuenta desde su perspectiva la vida del padre, como los trabajos del tipo d), sino una narración en tercera persona de un adolescente que va haciendo de alter ego de su padre.

\section{CONCLUSIONES \\ LA LITERATURA, LECTURA Y APRENDIZAJE DE VALORES}

Es en los últimos trabajos analizados donde se ofrece la posibilidad de acercarnos a la literatura con los alumnos y alumnas de una forma que se 
ha perdido en los estudios humanísticos: aprehender valores de personajes literarios. No es el momento para comentar ahora cómo los escritores -sobre todo de literatura «realista" y, más aún, "social»- proponen en su escritura una forma de revivir la realidad, para que los lectores realicen, conscientemente, una lectura comprometida de esa realidad, reviviéndola y asumiendo los valores que aquéllos han filtrado.

Los estudiantes que han trabajado el Réquiem por un campesino español han llegado sin duda, quizá inconscientemente, a una lectura de valores que quizá no han podido asimilar totalmente, ya que los «contenidos» -conceptuales - educativos que deben asimilar inexcusablemente suponen la mayor parte de su dedicación. Pero, sin duda, algo queda. Así, podemos analizar estos últimos trabajos como reflejo de una propuesta de optimismo frente a la visión pesimista del escritor.

Las «resurrecciones» de Paco, ya sea por una licencia literaria, por la salvación, a lo Saulo, en la cárcel, o por la permanencia en el hijo demuestran bien a las claras el anhelo de supervivencia de la persona «buena» frente a los personajes marcados negativamente, aunque sin ninguna profundización psicológica, sino simplemente funcional - los señoritos...-. Observamos en definitiva una propuesta de futuro, un deseo de mantener las personas que ejemplifican los valores positivos morales y de convivencia.

No estaría mal dedicar un breve apartado de nuestras lecturas guiadas a poder evaluar y analizar, junto a los valores artísticos, históricos, lingüísticos..., los éticos y morales que propone el autor, directa o indirectamente en sus personajes, que suelen aparecer como «tipos» que representan problemas. Incluso, como en los relatos que continúan la angustia de Millán, podemos observar la reflexión sobre unos valores morales más difíciles de analizar y asumir, pero sin duda, en su ambigüedad, más interesantes. No estaría mal "perder» un poco de nuestro precioso tiempo pedagógico, dedicado a contenidos científicos, en los contenidos morales que, como soluciones o interrogantes, nos plantean las obras literarias. 


\title{
Ramón J. Sender, crítico literario: el caso Valle-Inclán
}

\author{
Eliane Lavaud-Fage \\ Université de Bourgogne
}

$E_{n} 1965$, es decir, un año antes de que se celebre el centenario del nacimiento de Valle-Inclán, Ramón J. Sender publica un largo ensayo sobre la obra del autor gallego titulado: Valle-Inclán y la dificultad de la tragedia. ${ }^{1}$ Según reza al final del libro, éste fue escrito el mismo año de su publicación en la «University of Southern California». En el marco de esta comunicación sólo quisiera destacar unos cuantos puntos del ensayo senderiano interesantes tanto en relación con Valle-Inclán como con el propio crítico: la precocidad del ensayo de Sender sobre el gran gallego y el interés de sus recuerdos, la teoría de las masas de color, el sentido del pecado y el caso esencial de Flor de santidad, así como cierto concepto recurrente.

Notemos en seguida que, aunque es el trabajo más extenso de Sender sobre Valle, no es el único ni es el primero. Ya había publicado unos artículos sueltos en diarios y revistas americanos y latinoamericanos, ${ }^{2}$ unos

\footnotetext{
1 Ramón J. SENDER, Valle-Inclán y la dificultad de la tragedia, Madrid, Gredos, 1965, 150 pp.

2 «La gestación literaria en Valle-Inclán», Cuadernos Americanos [México], XI/2 (1952), pp. 270-281. "Algo más sobre Valle-Inclán", Cuadernos Americanos, XII/2 (1953), pp. 275-283. "Cómo murió el Marqués de Bradomín", El Diario de Hoy [El Salvador], 10-V-1953. «Hablemos otra vez de Valle-Inclán», El Diario de Hoy, 27-III-1955. «Los libros y los días. Las fuentes galaicas de Valle-Inclán", El Diario de Nueva York, 13-V-1955.
} 
ensayos cortos a modo de prefacio a ediciones americanas de la obra valleinclanian ${ }^{3} \mathrm{y}$ un breve avance del volumen que hoy nos interesa, con el mismo título, en un tomo de los Cuadernos Americanos de $1952^{4}$ primero y luego en un volumen de ensayos críticos. ${ }^{5} \mathrm{Y}$ destacaré en seguida el interés de este ensayo senderiano por ser una de las primeras críticas de conjunto de la obra de Valle-Inclán. Con anterioridad sólo conocemos la primera versión del trabajo de Melchor Fernández Almagro, Vida y literatura de Valle-Inclán, ${ }^{6}$ la presentación carente de todo rigor científico de Francisco Madrid, La vida altiva de Valle-Inclán, ${ }^{7}$ la tan preciosa como fantasiosa biografía escrita por Gómez de la Serna ${ }^{8}$ y el trabajo —éste, sí, serio y documentado - de Rubia Barcia sobre bibliografía e iconografía de ValleInclán. ${ }^{9}$ Es coetáneo de las reflexiones de Guillermo Díaz Plaja sobre Las estéticas de Valle-Inclán, también publicado por Gredos en 1965 y anterior en un año a la obra de Antonio Risco, La estética de Valle-Inclán en los esperpentos y en "El ruedo ibérico", que asimismo ofrece Gredos en 1966. Más adelante, a raíz de la celebración del centenario de Valle-Inclán en 1966, se publicarán más estudios de conjunto, pero, en 1965, comparte Sender con Guillermo Díaz Plaja el honor de ser uno de los dos primeros críticos en reflexionar sobre la obra de Valle-Inclán y es, de hecho, uno de los pioneros de la crítica valleinclaniana en América. Esto ya merece destacarse.

El ensayo de Ramón Sender, que se presenta de un tirón, sin capítulos ni blancos tipográficos, parte de una presentación crítica de la edición de las Obras completas de Valle-Inclán realizada por la editorial madrileña Plenitud, la única que existía entonces y la única que existe hoy todavía. ${ }^{10}$ Señala los descuidos de la edición: es discutible el orden de presentación de las obras en cada tomo, ya que no tiene nada que ver con el de la publicación en librería, y no está precisada la fecha de la primera edición de cada obra; carece de biografía documentada y de bibliografía y no consta de referencia de variantes de textos, reproche este último que revela un conocimiento de los textos de Valle-Inclán y unas exigencias críticas muy por encima de la media en aquel momento. Este punto de partida concre-

\footnotetext{
3 «Escolios al margen de las Sonatas», Ramón DEL VALLE-INCLÁN, Sonatas, Nueva York, Las Américas, 1961, pp. VII-XLI.

4 «Valle-Inclán y la dificultad de la tragedia», Cuadernos Americanos [México], XI/5 (1952), pp. 241-254.

5 Unamuno, Valle-Inclán, Baroja y Santayana. Ensayos críticos, México, Ed. de Andrea, 1955, pp. 45-94.

6 Madrid, Nacional, 1943. Se publicó una segunda edición ampliada en 1966 (Madrid, Taurus, $247 \mathrm{pp}$.).

7 Buenos Aires, Poseidón, 1943, 388 pp.

8 Don Ramón María del Valle-Inclán, Buenos Aires, Espasa-Calpe, 1944, 216 pp.

${ }^{9}$ A bibliography and iconography of Valle-Inclän (1866-1936), Berkeley - Los Ángeles, University of California Press, 1960, $101 \mathrm{pp}$.

10 Ramón del VAlLe-INCLÁn, Obras completas, 2 vols., Madrid, Rivadeneyra, 1944; $2^{\mathrm{a}}$ y $3^{\mathrm{a}}$ ed., Ed. Plenitud, 1952 y 1954. Volúmenes, por supuesto, inencontrables hoy.
} 
to le da pie a Sender para denunciar la deficiente atención que se le presta a Valle-Inclán en España, donde apenas se ha hecho hincapié más que en lo pintoresco de su atuendo y en las anécdotas de su vida sin meterse de lleno en la obra, y sabemos que Sender lleva toda la razón. Ya en 1965, e incluso en el avance de 1955, Sender equipara a Valle-Inclán con Rojas, Cervantes o Quevedo, valoración que las décadas siguientes justificaron plenamente.

De entrada recuerda Sender cómo, siendo él un joven, conoció a Valle-Inclán. Se conocieron en 1925, seguramente en el Ateneo y en la tertulia de La Granja del Henar, y Sender evoca las charlas, tan gratas para él, que versaban sobre literatura, en el Ateneo, en casa de Valle o en la calle. Estas primeras charlas las sitúa en 1925, «cuando [Valle-Inclán] escribía Tirano Banderas», en su avance de 1955. En el estudio publicado diez años más tarde, la fecha no se da con tanta precisión: "por entonces se celebraba el centenario de la muerte de Goya"," lo que nos llevaría al año 1928. Ramón Sender es entonces un joven de 27 años, si nos situamos en 1928, ya conocido como periodista en la capital, concretamente en El Sol, autor de un ensayo sobre uno de los temas latinoamericanos - El problema religioso en Méjico le vale un prólogo firmado por Valle-Inclán-12 que le preocupaban mucho, un joven que escribe poesía, cuentos y ya alguna que otra novela mientras está buscando su vía ideológica y políticamente. En cuanto a Valle-Inclán, en 1928, se puede decir que ya lleva toda su obra publicada; en 1926 aparece Tirano Banderas y el 23 de octubre de 1928 sale el segundo y último tomo en vida de su autor de El ruedo ibérico, su gran fresco histórico. Lo único nuevo que se publicará de él en adelante son unos libritos ${ }^{13}$-cortos y en ediciones populares- que entrarán a formar parte de la obra póstuma: Baza de espadas. ${ }^{14}$ Así se entiende la admiración constante que le tributa el joven Sender al maes-

\footnotetext{
11 Ramón J. SENDER, Valle-Inclán y la dificultad de la tragedia, cit, p. 10. En Unamuno, ValleInclán..., de 1955, las sitúa de manera más precisa: «La primera vez que me habló de sus nebulosas de colores fue en 1925, cuando escribía Tirano Banderas", p. 54.

12 El problema religioso en Méjico, católicos y cristianos, Madrid, Cenit, 1928, 230 pp., con prólogo de Valle-Inclán (pp. 11-16) o, por lo menos, firmado por Valle, ya que su paternidad parece problemática en la medida en que unos pretenden que le corresponde a Giménez Siles y otros la atribuyen a Juan Andrade y los dos la reivindican (véase Jesús VIVED MAIRAL, «La vida de Ramón J. Sender al hilo de su obra", Alazet. Revista de Filología, Monográfico dedicado a Ramón J. Sender, 4 [1992], p. 247). El propio Sender, en una carta, le confiesa a Robert Lima: «El prólogo de don Ramón a mi libro [...] no fue escrito por don Ramón sino que fue escrito por la misma casa editorial y firmado benévolamente por don Ramón como un deseo para ayudar con el eco de su prestigioso nombre a una empresa de amigos suyos" (véase Robert LIMA, An annotated bibliography of Ramón del Valle-Inclán, University Park, Pa., Pennsylvania State University Libraries, 1972, P. 64).

13 Otra castiza de Samaria (estampas isabelinas), Madrid, Cía. Ibero-americana de publicaciones, Ed. Atlántida (Col. «La novela de hoy», VIII, n³92), 1929. Visperas de la gloriosa, Madrid, Cía. ibero-americana de publicaciones, Ed. Atlántida (Col. "La novela de hoy», IX, $\mathrm{n}^{\circ} 418$ ), 1930.

${ }^{14}$ El ruedo ibérico. Primera serie. Tomo III. Baza de espadas, Barcelona, Ed. AHR, 1958.
} 
tro, una admiración que él mismo pone de realce en su ensayo publicado casi cuarenta años más tarde.

La primera parte del ensayo la dedica Sender a unas reflexiones generales sobre el Valle-Inclán que conoció y sobre unos enfoques teóricos de su obra, mientras que luego analiza una a una las obras valleinclanianas que más le llamaron la atención o que se atienen más al concepto senderiano de tragedia frustrada. En esta primera parte, Sender ofrece un rico abanico de evocaciones, a veces inesperadas, del autor gallego. Quisiéramos recordar aquí unas cuantas particularidades del hombre Valle-Inclán visto por Sender: la soledad, la sencillez, la modestia y el sentido práctico. La soledad de Valle-Inclán, soledad del hombre de genio en medio de la tropa de los aduladores, no es ningún dato sorprendente. De su sencillez y su modestia hablaron muchos de sus amigos. En cambio, nadie, ni siquiera hoy, se hubiera atrevido a calificarle de hombre práctico y sin embargo la demostración hecha por Sender no deja de ser convincente. Luego, y antes de entrar en detalles sobre la creación literaria de ValleInclán, rememora Sender el tipo de temas que había que descartar de las confidencias con Valle y, en cambio, los que suscitaban su interés y algunos de aquellos recuerdos son de sumo interés tanto para los valleinclanistas como para los senderianos. "Había que eliminar de ellas [las confidencias] todo doctrinarismo político, sociológico o científico. Entre otras razones porque don Ramón odiaba las certidumbres sistemáticas. Evitaba hablar de economía política, de marxismo o de problemas suscitados por la estadística u otros elementos de sociología. Adoraba las medias verdades imaginadas con una base aparente en la realidad y una proyección mágica. Yo, también. Y yo estimaba su confianza más que nada en el mundo». ${ }^{15}$ Este concepto de medias verdades con base aparentemente real y proyección mágica no tiene desperdicio a la hora de analizar la obra valleinclaniana y pone de manifiesto en Sender una lucidez digna de los mejores elogios. Paralelamente uno puede imaginar fácilmente el incentivo que podía representar para el espíritu del joven Sender el interés que le manifestaba Valle-Inclán.

A la hora de reflexionar sobre el arte de Valle-Inclán y sobre su creación literaria en general, Ramón Sender alude, apelando otra vez a su memoria, a la teoría valleinclaniana de las masas de color: "Me repitió algo que me había dicho ya otras veces: que sus novelas y comedias nacían de un deseo casi físico, confuso y brillante y que cuando ese deseo era más vivo comenzaba a darles forma por combinaciones de masas de color». ${ }^{16}$ Confusas y nebulosas en su origen, poco a poco aquellas masas de color iban adquiriendo contornos en la imaginación del escritor, teniendo en cuenta que siempre el color precedía a la línea, para hablar en tér-

15 Op. cit., p. 16.

16 Ibid., p. 23. 
minos pictóricos que no desmentirían ni El Greco ni los modernos impresionistas. Recalca así Sender el aspecto sensual de la imaginación de ValleInclán, haciendo hincapié en la supremacía del color sobre el sonido: primero estaba el color y luego la musicalidad de las palabras se ponían al servicio del color deseado. Se conoce la teoría de las vocales coloreadas desde Rimbaud, René Ghil y Vigié-Lecoq hasta Pío Baroja, que escribió también un ensayo sobre el tema. Ahora, y aquí sí que aparece el punto flaco de esta teoría - y cierta ingenuidad en el ensayo senderiano-, se trata de atribuir su color a las respectivas vocales. Tomemos sólo el caso de la $a$. Es, para Sender, «la vocal más luminosa» y «si es la más luminosa será también una vocal blanca ya que es ese color el que refracta más la luz, mientras que el negro, el rojo, el verde oscuro la absorben». ${ }^{17} \mathrm{Sin}$ embargo, no podemos dejar de recordar que, para Rimbaud, la $a$ es negra y, para Vigié-Lecoq, es roja, color de llamas. De donde un enorme subjetivismo a la hora de la recepción del texto... Sender se da cuenta de ello: "No siempre esta asociación de colores y sonidos es la misma en todos nosotros» y, no obstante, mantiene la idea de una coincidencia mínima: «pero, al menos coincidimos en la blancura - candidez - de la a y en la oscuridad - lobreguez- de la $o$. Desde la infancia. Con el alba - dos aes- llega el hada -otras dos-y con la noche hosca y oscura llega el coco de los niños. Los ejemplos podrían ser infinitos». ${ }^{18}$ Uno se pregunta si también serían coherentes... El propio Valle-Inclán discrepa atribuyendo a la $a$ el valor rojo que le otorga Vigié-Lecoq: " $\grave{A}$ claironne vainqueur en rouge flamboiement»... ${ }^{19}$ Seguramente estas confidencias de Valle-Inclán sobre su concepción pictórica de la creación literaria habían de interesar sobremanera al Sender pintor. Ya se sabe que, aunque la pintura fuera para él un hobby, llegó a exponer sus cuadros en Madrid y en Zaragoza. ${ }^{20}$ Asimismo la teoría de las vocales coloreadas tampoco podía dejar indiferente a un escritor que, por lo menos en ciertos años de su vida, vio en Baroja a uno de sus modelos.

Para Sender, la estructura en Valle-Inclán equivale pues a la organización de aquellas masas de color y el resultado es una estructura inmóvil que informa todas sus obras (con excepción de algunas páginas de El ruedo ibérico), inmovilidad que el crítico aragonés considera como inadecuada para el teatro. A esta inmovilidad espacial se añade la temporal, teñidas ambas de quietismo, ya que para Sender «el presente lo es todo en el esperpento de Valle-Inclán».21 Aparte de esto, Sender tiene una extraña teoría sobre las posibilidades de representación. Afirma efectivamente que

\footnotetext{
17 Ibid., p. 25.

18 Ibid., p. 107.

19 En el artículo «Modernismo», La Ilustración Española y Americana, 22/II (1902), aunque erróneamente atribuye a René Ghil el verso de Vigié-Lecoq.

20 Respectivamente en la «Galería Multitud» en 1975 y en la “Galería Berdusán» en 1976.

21 Op. cit., p. 132.
} 
no es un teatro para la escena en tanto en cuanto lo que acepta un lector solo frente a su libro no lo tolera un grupo humano, que, cuando se encuentra reunido frente a unas tablas, siente despertarse un sentimiento de solidaridad, unos intereses de conservación y un repertorio de pudores que no tiene el individuo aislado. Así que el crítico aragonés, que demostró tener tanta lucidez en el caso de otras obras valleinclanianas, no llegó a adelantarse a su época en el tema del teatro de Valle-Inclán.

Empieza Sender su estudio de las obras de Valle-Inclán con las Sonatas, pero se ve claramente que no las volvió a leer para redactarlo. ${ }^{22}$ Está claro que, por lo menos en muchos casos, habla de recuerdos de lectura y digamos de entrada que varias veces le falla la memoria, lo que provoca sobresaltos en el lector asiduo de Valle-Inclán. Ahora, esto mismo también es interesante en oposición con la minuciosa y precisa atención que dedica a Flor de santidad, obra que desde luego ocupa en su mente y su corazón un lugar mucho más alto que las Sonatas. De entrada, precisa que las leyó al amparo de otras lecturas anteriores - las Comedias bárbaras y unos esperpentos- y, de haber sido de otra manera, confiesa que «no es seguro que [su] entusiasmo fuera tan rendido e incondicional». ${ }^{23}$ Lo que es preciso recalcar en las páginas que el Sender de 1965 dedica a las Sonatas es la insistencia sobre la idea de pecado. Por supuesto, ya se sabe que el mito de don Juan que informa las cuatro Sonatas tiene por fundamento un conflicto entre Dios y el hombre y la historia literaria demostró el papel provocador de las Sonatas en la sociedad burguesa de principios de siglo, llegando a verse en Sonata de otoño una especie de manifiesto del modernismo. Pero no deja de sorprender que, después de unas breves alusiones a «las galas del estilo» ${ }^{24}$ que sin embargo, según Sender, son las que sustentan y explican la importancia de las Sonatas, el crítico aragonés sólo se interese por el concepto de pecado en las cuatro obras. «Es el marqués un pecador que recaba para sí las luces que el pecado tiene en la tradición del cristianismo, especialmente del catolicismo. No es el pecado en definitiva sino enfermedad que requiere cuidado y conmiseración, es fuente de remordimiento y en último extremo primera triste y fatal circunstancia de la gracia. Nuestra vida animal - parece pensar el marqués-es igual que la de otros vertebrados con una desventaja: nosotros somos libres y los animales no. Los animales están esclavizados a los instintos y no son libres; tampoco son responsables. [...] Cierto es que después del pecado nos queda la redención por el arrepentimiento y por la gracia. Pero el marqués piensa algo más. Piensa que el privilegio del hombre no es necesariamente la gracia sino el pecado calificado por cuatro adjetivos seguidos:

\footnotetext{
22 En el ensayo de 1955 no aparecía ningún estudio detallado ni de las Sonatas ni de Flor de santidad.

23 Op. cit., p. 52.

24 Ibid., p. 42.
} 
consciente, deleitante, prestigioso y suntuoso. A veces le gusta regresar un momento a ese reino prohibido de la irresponsabilidad animal y las promiscuidades». ${ }^{25} \mathrm{El}$ héroe valleinclaniano siente «la conciencia del pecado y su clara noción metafísica y el gozo semiteológico de esa noción».26 Bien es verdad que se pueden leer las Sonatas como el relato gozoso de una culpa deleitable referido bajo la forma de memorias que permiten que se duplique el tiempo mezclándose constantemente el pasado de la acción y el presente de la escritura. Ahora no parece tan evidente que el marqués valleinclaniano considere el pecado como una enfermedad que exige cuidado y conmiseración ni asimile al hombre con los otros vertebrados. No se puede decir que sea un sentimiento de culpabilidad con la consiguiente necesidad de expiación lo que estructura la serie de relatos narrados por el marqués de Bradomín. Está claro que la recepción que de las cuatro Sonatas hace el Sender de los años sesenta tiene mucho que ver con la forma en que él mismo estructura ciertas de sus novelas por los años cincuenta y sesenta. Aquel tipo de estructura senderiana la recalca acertadamente José-Carlos Mainer mediante dos conceptos: «la culpa y su expiación". ${ }^{27}$

En cuanto a las páginas dedicadas a Flor de santidad, son, a mi parecer, modélicas. Sender precisa que leyó la Historia milenaria en 1924 y a medida que el crítico maduró y envejeció la obra fue creciendo en su recuerdo, privilegio éste de las obras maestras. Para él es la «única obra maestra narrativa que se puede comparar con las obras monumentales de la arquitectura románica de la baja Edad Media». ${ }^{28}$ En ella ve algo así como una crónica del año mil con aquella tendencia de los personajes a la quietud y al éxtasis propia de los seres primitivos, personajes que están hundidos en una desgracia indiferente de orden pánida o panteísta, una masa regida por fuerzas ocultas que asimila e: misterio y lo resuelve dentro de las posibilidades y limitaciones de lo humano, una masa de la que sobresale una individualidad "maldita». Sender compara la Historia milenaria con «un gran fresco mural al aire libre», añadiendo paradójica pero acertadamente que tiene «al mismo tiempo la calidad delicada y preciosa de una miniatura». ${ }^{29}$ Presenta la obra de Valle-Inclán como «una antiepopeya que acaba no en un episodio cortado ni en la interrupción de una historia, sino en la disolución de la anécdota como el contenido de un frasco de fuerte perfume en la intemperie de una tarde tormentosa». ${ }^{30}$ Abierta, ambivalente,

\footnotetext{
25 Ibid., p. 58.

26 Ibid., p. 60.

27 «La culpa y su expiación: dos imágenes en las novelas de Ramón J. Sender», Ramón J. Sender In memoriam. Antología crítica, Zaragoza, Diputación General de Aragón et al., 1983, pp. 127-135.

28 Op. cit., p. 101.

29 Ibid., p. 116.

30 Ibid., p. 124.
} 
contradictoria, lindando toda con el prodigio, para el crítico aragonés Flor de santidad es la obra de Valle-Inclán que más se acerca a la tragedia. Para Sender, la clave de esta tragedia frustrada, de esta imposibilidad de la tragedia, como reza el título del ensayo, reside en el hecho de que no podemos identificarnos con los personajes valleinclanianos: sin identificación la tragedia no es posible. Tal imposibilidad de la tragedia en el autor gallego es emblemática de lo que ocurre a nivel nacional: la tragedia no se da en el teatro español por los mismos motivos que en Valle-Inclán.

Al leer el ensayo de Sender llama la atención la recurrencia de un concepto expresado mediante las voces "rapsoda» y sobre todo el adjetivo "rapsódico". Aquí van unos ejemplos: los esperpentos están "concebidos de una manera colorista y rapsódica", 31 en Flor de santidad aparece un tiempo "rapsódico», 32 el habla de los caminantes recuerda a «los rapsodas religiosos del remoto oriente de los vedas". ${ }^{33}$ Ahora bien, este concepto no se suele aplicar a la obra de Valle-Inclán y probablemente sea Sender el único en atribuírselo. Esto equivale a hacer del escritor un rapsoda, es decir, alguien que improvisa un texto con ritmo y coherencia sobre un esquema de fórmulas e historias conocidas de su auditorio. El rapsoda efectivamente es la memoria religiosa e histórica de su pueblo. Como él, Valle-Inclán fue cosiendo juntos trozos de la historia desde el tiempo mítico de los orígenes con Flor de santidad hasta las horas más candentes de la actualidad española en los esperpentos, jugando con el misterio de estas medias verdades, que también apuntó Sender, con una base aparente en la realidad y una proyección mágica.

Para concluir esta breve comunicación, primero conviene recalcar lo asombroso que resulta el silencio prácticamente absoluto que observa Sender a propósito de unas obras valleinclanianas como son Tirano Banderas y El ruedo ibérico, en las que la relación literatura/sociedad hubiera tenido que llamar poderosamente la atención del crítico aragonés. Luego, aparte de la precocidad y la constancia del interés senderiano hacia Valle-Inclán, hay que hacer hincapié en la recepción que hace el Sender de los años sesenta y cinco de las Sonatas y de Flor de santidad. No se sabe cómo recibió estas obras valleinclanianas cuando las leyó por los años 25-30, pero el testimonio que da en 1965 deja traslucir las inquietudes del crítico en la década de los sesenta y nos enseña tanto sobre Sender como sobre ValleInclán. Y cabe recordar el propio itinerario biográfico e ideológico de Sender. José-Carlos Mainer lo resume en unas frases breves: «Partiendo de una ideología libertaria - la adhesión, más bien, al vago humanitarismo de un partido concreto-, la guerra civil y el exilio consecuente obligan al escritor a una reconsideración de su propio ideario: crítica violenta del

\footnotetext{
31 Ibid., p. 133.

32 Ibid., p. 115.

33 Ibid., p. 109.
} 
comunismo, acendrada defensa de los derechos del individuo, elogio de un universo arcaico y primitivo y hasta un confuso tinte religioso». ${ }^{34}$ En 1965, o sea, el año mismo en que se publica Valle-Inclán y la dificultad de la tragedia, el crítico Sherman $\mathrm{H}$. Eoff apunta en su ensayo sobre la ideología de Sender cómo el escritor «está preocupado por los aspectos mágicos primitivos- de la religiosidad, no entendiendo ésta como una explicación de lo absurdo cósmico sino como un humano intento de jerarquización de lo desconocido», cómo "hace gala de un vigoroso primitivismo». ${ }^{35}$

34 Art. cit., p. 128 .

35 El pensamiento moderno y la novela española, Barcelona, 1965, p. 237 et passim. 


\title{
La lírica popular de Sender ${ }^{1}$
}

\author{
Santiago Fortuño Llorens \\ Universitat Jaume I, Castelló
}

En 1960, en la editorial mejicana Atenea, se publica el libro de poemas de Ramón J. Sender Las imágenes migratorias: las imágenes se suceden e interfieren. La realidad queda trasmutada en virtud de la imaginación y la fantasía. Nos encontramos ante una poesía telúrica en la que el hombre se ve incorporado y fusionado con los poderes de la naturaleza, lo que ocasiona desconcierto y maravilla. Catorce años después, su Libro armilar de poesía y memorias bisiestas, ${ }^{2}$ compuesto de ciento setenta y siete poemas, amplía la creación lírica de Sender con un «Prólogo del autor», fechado en Los Ángeles, California, en 1968, que constituye una explícita poética a la par que justificación hermenéutica de su lírica.

Pero yo tampoco soy feliz [...l, y más que mostrar a los otros la aptitud gozadera de ese idiota [identificado, en griego] disgregado de la comunidad que soy yo o que me muestro en estas páginas, lo que trato de hacer es mostrarles uno de los muchos caminos de la ilusión reciente o antigua, apenas señalado por las luces verdes de la luciérnaga española, que se encienden o

\footnotetext{
${ }^{1}$ Este trabajo ha sido financiado por la Dirección General de Investigación Científica y Técnica (DGICYT) en el Proyecto de Investigación n ${ }^{\circ}$ PB94-0862-C03-02, correspondiente al año 1995.

2 México, Aguilar, 1974.
} 


\section{EL LUGAR DE SENDER}

se apagan sin contar con la voluntad expresa de uno y mucho menos con la del vecino. Y que sacan la luz de donde pueden. (p. 23)

A diferencia de otros aspectos de su obra - novelística, primordialmente-, esta vertiente literaria ha sido y es desconocida, no habiendo merecido casi ningún estudio específico.

De la producción poética de Sender, he seleccionado para su análisis la vertiente popular, que comprendería, en los libros arriba señalados, doce poemas de extensión media: los cinco primeros alusivos al cromatismoverde, amarillo, malva, tornasol y azul-, "Las horas interiores", seguidos de otros referentes a los cinco sentidos, «Glosa de los sentidos», con la coda de dos últimos denominados «Villanelas». ${ }^{3}$

En ellos lo popular, que viene dado por el estribillo, con ecos de la canción tradicional en algunas ocasiones, queda entreverado por el irracionalismo y el ambiente imaginativo envolventes: «Además se trata de liberar la imaginación del lector, frecuentemente esclava de lo convencional" (p. 18), repite Sender en el precitado prólogo y lo consigue. Es una poesía sugerente, alusiva, repleta de asociaciones, brillante de sensualidad, con un claro intento de desvelar los lados ocultos de la realidad: "Yo no digo que la mía sea poesía grande o pequeña, y me basta con creer que hay en ella una apelación a la belleza secreta de las cosas» (p. 18). En sintonía con las tesis de Kant, de los románticos y del modernismo, al que tanto se asemeja esta poesía por su brillantez, rehúye cualquier finalidad práctica alejándose de la poesía social y realista, aun siendo primordialmente comunicativa:

Si en este libro hay a veces sensación gozosa de plenitud, no es la de los hombres sino la de los lagartos más bien. $\mathrm{O}$ de las plantas viciosas (no aprovechables) cerca de los manantiales, la de las rocas cubiertas de liquen o de sal marina, la de algunas aves (no grandes ni heráldicas, sino así como gorriones o mirlos silbadores de arpegios). [...] Sin embargo, el acento de este Libro armilar y lírico y mi felicidad de lagarto o de planta ociosa o de rata del desierto o de ser humano es una parte del orden de la realidad. (pp. 19-20)

Esta veta lírica no está desligada de su restante producción literaria. En Réquiem por un campesino español o La tesis de Nancy nos encontramos con textos poéticos imbricados en su prosa. En Crónica del alba nos topamos con «El poema que sigue se refiere tal vez a aquel otoño en la Quinta Julieta y se titula "Las horas amarillas" ", 5 que corresponde al segundo de «Las horas interiores» de la edición que seguimos.

\footnotetext{
3 En lo que respecta al presente trabajo, sigo la edición de 1960 (Las imágenes migratorias, México, Atenea), modificada en algunos aspectos textuales en la segunda, de 1974. La paginación indicada entre paréntesis se refiere a la ed. de 1960, en las poesías, o a la de 1974, en las citas del «Prólogo del autor» (Libro armilar...).

4 Crónica del alba, I, Barcelona, Destino, 1973, p. 398 y ss.

5 Página 36.
} 


\section{VARIANTES}

Algunos de los estribillos de estas canciones de tipo tradicional traen ecos de la antigua lírica hispánica.

1. Nadie diga / que lo vio / hasta que saliera el sol. (p. 24)

Allá se me ponga el sol / donde tengo el amor. $(65 \mathrm{~B})^{6}$

Que si crece el sol que sale, / volveráse la niña, dirá que es tarde. (1088)

2. ¿ ¿Dónde tienes / tus raíces / violeta de la noche? (p. 50)

Alta estava la peña, / naçe la malva en ella / y el trébol florido. (71)

En este último poema introduce los ababoles (amapolas): «En alentar de tu sueño / se callan los ababoles", que, según Vicente Beltrán, son una de las flores de la canción tradicional «que los enamorados cogen, otro símbolo de sus relaciones». ${ }^{7}$

3. Qué olor / el del rosale / y el del sol de los mares. (p. 117)

Olorosas son las rrosas / y suave el açaar, / y vos no para olvidar. (104)

4. De los viveros, madre, / cuida tú por nosotros / y del aire. (p. 290)

De nuestras huertas, madre, / cuida tú por nosotros / y del aire. (p. 305)

De los álamos vengo, madre, / de ver cómo los menea el aire. (309 A) ¡Ayres, ola!, / ique me abraso en amores toda! (269)

\section{TEMAS}

El amor, en maridaje con la muerte, la evocación y la nostalgia de la tierra lejana, la desazón del exilio, la inquietud existencial, el erotismo, la voluptuosidad son los temas de esta lírica tradicional senderiana, todo ello con «un impulso mágico que vive en la transmutación constante de todos los seres y de todas las cosas». ${ }^{8}$

Amor: «En mi soñar de emigrante / se desnudan las terrazas / y quedan soles prendidos / en tu delantal de gala / oh, virgen la de mi celo / como en las doradas parvas / amarilla te recuerdo / de oro y trigo en la ventana / aunque tu cabello negro / —casi azul— te coronaba» (pp. 38-39).

Y muerte: "El mundo se me aparece / como un enorme desierto / cubierto de losas blancas / y de cunas y de lechos. [...] / y el olor llena los mundos / de un rosal de cementerio» (p. 65).

La nostalgia de la patria, sentimiento que viene imbricado con el amor: «Te miro tal como eres / viva en el centro de España / mírame tal como

\footnotetext{
${ }^{6}$ Margit FRENK, Corpus de la antigua lírica popular hispánica (siglos XV a XVII), Madrid, Castalia, 1987. A esta edición hacen referencia los números de las canciones.

${ }^{7}$ La canción tradicional. Aproximación y Antología, Tarragona, Tarraco, 1976, p. 62.

8 Rafael BosCH, «Ramón J. Sender: Las imágenes migratorias», Cuadernos del Congreso por la libertad de la Cultura [París], 64 (1962), p. 94.
} 
soy / muerto en las tierras lejanas» (p. 36); «Entre todos los sabores / prefería el del espliego / de Castilla cuando había / reverdecido en tu huerto» (pp. 196-197).

La inquietud existencial: Quien «en 1934 (mucho antes de la novela existencialista francesa) escribía: "Salimos de las sombras, vivimos sobre las sombras, vamos a las sombras" $\gg \gg^{9}$ plasma también esa preocupación en su lírica: «las aguas de los arroyos / nunca se muestran conformes / murmuran por el azul / de sus glaciares rectores / pero en recatados huecos / de los troncos de los robles / malva orquídea sonando / la ley nazarena imponen. [...] / En dorso de la fontana / veo la sombra del hombre / malva luz la determina / contra el fondo azul del orbe» (pp. 51-52).

Erotismo: «Todo es rosa / cuando llego / al vértice de tu seno» (p. 63); «Mis tactos van prisioneros / en las cadenas natales / las doncellas me retienen / entre sus muslos fragantes / las abispas [sic] de mi tacto / van y vienen en enjambre» (p. 218); «hasta que oí -como el denso / fragor de la llamarada, / la voz sin verbo del sexo, / dentro de mi joven alma» (p. 106).

\section{ESTILO}

El «Prólogo del autor», aludido al principio, constituye un tratado de poética de la obra senderiana inscribible en la escuela de la Estética de la Recepción: «Un poeta nunca escribe para el público extenso sino para el que podríamos llamar intenso y profundo» (p. 16).

La poesía de Sender no es fácil de comprender intelectualmente sino que está conformada de irracionalismo y poder mágico verbales. No tanto de modernismo en lo que se refiere a su musicalidad y el empleo de términos brillantes e inusuales, que también encontramos con profusión, cuanto de simbolismo por su capacidad de sugerir, como propugnaba Mallarmé:

En todo lo que hacemos y vemos y decimos y oímos hay elementos de racionalidad y los hay también al mismo tiempo de misterio y de vaguedad, [...] La lírica en el poema abarca otros niveles y el de la musicalidad o el color son los menos importantes. Queda toda una gama de alusiones y sugestiones del todo inefables, es decir, inexpresables, a pesar de lo cual no están menos presentes. (p. 13)

De ahí la invitación a la recreación fantástica y a un mundo adánico, «a la región donde nada se olvida» de Aleixandre: «Mírame ahora en la fábula" (p. 119); "Volvamos a la aurora / de nuestra vida / y en ella cultivemos / la maravilla» (p. 306), admitiendo la falta de sentido y comprensión del mundo: «si nazco ahora tampoco / faltan los signos

${ }^{9}$ Ibid. 
astrales / bajo los que pasan cosas / a veces inexplicables» (p. 216). «En ese futuro indefinible yo me considero el autor excepcional de un libro maravilloso que no escribiré nunca» se propone abiertamente Sender (p. 23).

Establece asimismo un deslinde claro de la poesía con la prosa. La finalidad de ambas delimita su función y también su forma. También las diferencia la sinrazón y la belleza de la primera, ajena a modas: «La razón tú sabes que no nos sirve sino para obtener un alza de salario y llegar a tiempo a una cita de negocios. En todo lo demás es la sinrazón poética la que decide» (p. 17).

La poesía de Sender es una poesía de sensualidad, de encantamiento y fruición ante lo natural y la vida: «En todo caso, si hay felicidad, es una felicidad de pobre bicho de esos que vemos a veces en los prados con su luz verde en la barriga. [...] No hay humildad en mi poesía, sino codicia de gozador secreto" (pp. 19-20).

La gracia y frescura de la lírica popular, oscurecida su primitiva sencillez, quedan entreveradas de elementos de modernidad literaria, así como por su plurisignificacionalidad. El léxico es inusual, culto, en un intento claramente manifestado por evitar el término coloquial: «Las palabras más ricas de sentido (suelen ser también las más antiguas) se formaron así, es decir, poéticamente» (pp. 14-15); «En mi caso, lo que domina es la voluptuosidad de la palabra de la cual no me atrevo a abusar en la prosa por recelo del decadentismo y porque en la prosa mis efectos líricos se obtienen por una acción lo más desnuda posible. (Lo más desnuda posible de palabras.)» (p. 21).

Emplea asimismo un estilo brillante, repleto de imaginación y fantasía: «trataré de ayudarte a liberar tu imaginación, si lo necesitas. Yo tardé muchos años en liberar la mía» (p. 21). «Además se trata de liberar la imaginación del lector, frecuentemente esclava de lo convencional» (p. 18), apostilla Sender.

Sus versos son sugerentes, henchidos de sensualidad, cultura y mezcla de elementos heterogéneos, con un único objetivo de invitar al lector a la búsqueda de los «sentidos directos, indirectos, poderes de evocación, de sugestión, de proyección, de elusión y de hipnosis, de confusión lírica deliberada, de musicalidad y de colorido" (p. 12).

Claramente Sender se sitúa en una estética de vanguardia literaria, desdeñando el tono popular y la consigna social contemporáneos: «No hay poesía de falda corta ni de falda larga. La moda de estos días es prosaica con el pretexto del antiformalismo y de la protesta social» (p. 18), reivindicando la huella de lo popular en este tipo de poesía: "y sin acento popular esa seudoprotesta resulta frustrada como poesía y además afectada y decadente. ¿Por qué escribir poesía prosaica existiendo la prosa?» (p. 18); aunque no deja de recalar en el carácter cívico y social, típico de gran parte de su narrativa: "tú sentirás las tres cosas / que dan calidad humana, / la piedad por los humildes / que se acercan a tu casa, / la ambición 
de la justicia / - aun sin llegar a alcanzarla / y el deseo creador / de formas por las palabras» (pp. 104-105).

\section{ELEMENTOS IRRACIONALISTAS}

Una serie de técnicas de índole visionaria o irracionalista conforma esta poesía popular de Sender, lo que provoca su aparente desconcierto. En primer lugar observamos que los doce poemas analizados no guardan un hilo argumental y descriptivo sino que en un mismo poema existen elementos que entorpecen su claridad o unidad significativa. Esta disociación produce desorden. Su carácter fragmentario coadyuva aún más a su ininteligibilidad. Es el poema en su conjunto el que nos proporciona una determinada emoción sensitiva, pues la sensación juega un papel destacadísimo en el mismo.

Las imágenes visionarias, las visiones y sinestesias, el desplazamiento calificativo, las superposiciones ${ }^{10}$ nos dan un tipo de poesía moderna en la que prima la sugerencia y alusión sobre la inteligencia y el detalle concreto: "El vidrio de la agonía / guarda la canción menor / de sus aguas en la arena / seca de la extremaunción» («Las horas interiores. Verdes», p. 25). El primer verso, «El vidrio de la agonía», de resonancias lorquianas, una imagen visionaria en complemento preposicional, iguala dos realidades de naturaleza distinta (concreta / abstracta) en virtud de una serie de elementos de carácter preconsciente, irracional, tales como «cortante», «fría», atribuibles a ambas, lo que produce análoga emoción subjetiva.

Las visiones se suceden en estos versos: «Soledades de la menta / en los ardientes rincones / de la infancia [...]» («Las horas interiores. Malva», p. 51). O, del mismo poema: «duelo malva la define / a la luz de los ibones» (p. 52). En ambos casos, tanto en el complemento preposicional en el primero como en el modificador directo en el segundo, se aplican elementos irracionales a realidades que provocan estados de ánimo de amargura y velatorio, respectivamente. En « $Y$ las horas son azules / en la linterna del ábside» ("Las horas interiores. Azul», p. 77) el color presta, por el contrario, una sensación de placidez y sosiego con arraigo en la tradición modernista.

Uno de los rasgos que caracteriza esta poesía es la visión sinestésica. Las irisaciones sensoriales se entrelazan e intercambian en "una apelación a la belleza secreta de las cosas. Digo, a la que no ha sido develada aún» (p. 18).

10 En cuanto a la terminología empleada, sigo los ya clásicos estudios de Carlos Bousoño desde Teoría de la expresión poética, Madrid, Gredos, 1952, a Superrealismo poético y simbolización, Madrid, Gredos, 1979. 


\section{SANTIAGO FORTUÑO LLORENS}

el silencio es amarillo / en mitad de la mañana / [...] / vienen los aires perdidos / amarillos de venganza (p. 37)

Color del llanto de oriente / y del lirio de los montes (p. 51)

Azules fríos / de la segur venerable / frios azules (p. 78)

¡Qué sabor / el del cierzo / en el ancho desierto! / [...] / oh, nobles horas del labio / mojado y el blando eco (pp. 196-197)

Los desplazamientos calificativos colaboran en la creación de esta atmósfera de realismo mágico, en la que las cualidades se atribuyen a los objetos y cosas por causa de la impresión subjetiva, lo que, en un primer momento, deriva en desconcierto racional pero consigue la «confusión lírica deliberada, de musicalidad y de colorido, el cual, según la palabra anterior o la que sigue, cambia y se modifica igual que pasa con las mezclas de colores» (p. 12): «Por el reguero verde / de los bancales / la rosada y el cierzo / son mayorales» (p. 306); "Los espejos / se entreabren / por espacios de la tarde» (p. 77), donde en el declinar de la tarde surgen sus destellos, que son vistos como espejos. Poesía de sugerencia y alusión, en la que la connotación y el símbolo importan más que la referencia directa.

\section{CONSTRUCCIÓN POEMÁTICA}

Junto a esa vertiente irracional de la poesía de Ramón J. Sender, destaca el empleo de técnicas recurrentes que prestan elaboración artificiosa a la par que intensificación poética. La junctura verborum, asociando sentimientos o sensaciones, colabora en la creación de este ambiente de confusión e irracionalismo. Unas veces, será el quiasmo, técnica artificiosa: «Verdes las horas / [...] / las horas verdes» (p. 25); «Ave de amores / [...] / de amores ave» (p. 64); «Sueño del mar / [...] / mar del sueño» (p. 79); «Todo cubierto de bocas / de lenguas todo cubierto» (p. 197). Y, otras, el hipérbaton: «y del atrio de los orbes / sale el tiempo con la dalle» (p. 77). O esta hipérbasis enrevesada para aludir al juego de la seducción: «caricia muda del labio / y la mano persuadiendo / para en palma del dominio / autorizar rendimiento» (p. 64).

\section{MÉTRICA}

Los poemas que constituyen «Las horas interiores» $\mathrm{y}$ «Glosa de los sentidos" poseen, en general, una construcción estrófica homogénea: un estribillo de tres versos, tetrasílabos los dos primeros, rimados y en hemistiquio, y octosílabo el último, de rimas variadas (abb, predominante), precedido de otros tres versos polisilábicos en rima uniforme con el romance que los configura. 
Los dos poemas "Villanelas» quedan conformados en estrofas de cuatro versos tetrasílabos y heptasílabos, asonantados los pares, engarzados con el estribillo de tres versos de rima alterna $(7 \mathrm{a} 7 \mathrm{~b} 4 \mathrm{a})$. Quien utiliza con profusión el molde rígido del soneto se inscribe en esta poesía en fórmulas métricas de raigambre popular, de las que se sirve para expresar "que la vida es un milagro maravilloso del cual muchos de nosotros no somos merecedores».11

11 "La muerte del autor de Crónica del alba», EI País, 19 de enero de 1982, p. 34. 


\title{
Miguel de Molinos en la obra de Ramón J. Sender
}

\author{
Pilar Moreno Rodríguez \\ Escuela Universitaria de Magisterio de Huesca
}

\begin{abstract}
-El hombre, padre del hombre, es el principio de todas las cosas. Y el fin. Como las cosas no tienen principio ni fin, el hombre sin nombre es infinito. Proclamemos la hombría dueña del espacio, dueña del tiempo, fundida con la sustancia misma de lo eterno. El hombre que talla una piedra, canta una canción, conduce un tranvía, construye un avión, somete al infinito y le presta una medida. Pero sólo mientras conserva la hombría en puridad sin la corrupción de la vieja personalidad adquirida y postiza. Sin la infantil locura de la diferenciación. ${ }^{1}$
\end{abstract}

Establecer el alcance que la doctrina de Miguel de Molinos pueda tener en el dilatado y profundo pensamiento de Ramón J. Sender constituiría tarea tan necesaria como compleja, objetivo éste que exigiría, sin duda, un más detenido estudio. La presente investigación no pretende otra cosa que fijar un primer contacto formal con el tema propuesto en el título de esta comunicación: «Miguel de Molinos en la obra de Ramón J. Sender», y ello circunscrito al ámbito específico de la novela El verdugo afable.

${ }^{1}$ Ramón J. SENDER, El verdugo afable, México, Aguilar, 1970, p. 205. 
Lo primero que sorprende en la lectura de la novela El verdugo afable de Ramón J. Sender es el peso que la doctrina de Miguel de Molinos parece adquirir en el contexto general de la misma. Resulta cuando menos destacable el volumen de citas dedicadas al autor de la Guía espiritual. Sin embargo, abordar el posible influjo de la doctrina de Miguel de Molinos en la obra de Sender nos obliga de antemano a plantear una cuestión en absoluto menor dentro del pensamiento senderiano: el tema de la mística en Ramón J. Sender.

\section{EL MISTICISMO EN RAMÓN J. SENDER. POSIBLES CLAVES DE APROXIMACIÓN}

La temática esotérica y mística no constituye nueva aportación de $E l$ verdugo afable. Voces autorizadas han tratado la cuestión. ${ }^{2}$ Sin embargo, cabría plantear la necesidad de un rastreo detenido y estructural sobre el reiterado interés de Ramón J. Sender hacia el misticismo. Acaso hoy, cuando una nueva sensibilidad hacia la mística parece resurgir, el discurso liberador y realista que nuestro autor vierte sobre el tema aportaría una no desdeñable luz no sólo sobre el pensamiento senderiano sino tal vez en torno a la propia visión del misticismo, contemplado por Sender en proximidad al anarquismo.

Mair José Bernadete reproduce un texto de Sender que no me resisto a transcribir y en el que, como en otros pasajes de la producción senderiana, queda de manifiesto la admiración de nuestro autor hacia la mística y los místicos:

\footnotetext{
Se pierde nuestra alma en brazos de Azrael. Y se disuelve. Pero no es una disolución en la nada sino en el todo. No es muerte sino vida. Todavía vida, o más vida que nunca. Para entender eso hay que ser religiosamente enemigo de los dogmas de las iglesias. Esa especie de anarquistas de lo absoluto que eran los misticos castellanos y su hijo aragonés Miguel de Molinos. ${ }^{3}$
}

El texto resulta clarificador. En él encontramos algunas pistas de interés para el tema que nos ocupa. Así, el tema central de la nada, preñado de positividad para Molinos y que, como veremos, se presenta más próximo a la negatividad en la obra de Sender. Igualmente destaca en el fragmento la caracterización de los místicos como «anarquistas de lo absoluto» o la necesidad de ser «religiosamente enemigo de los dogmas y las

${ }^{2}$ Cfr. Francisco Carrasquer, La verdad de Ramón J. Sender, Leiden-Tárrega, Ediciones Cinca, 1982; Julio Rodríguez PuérTolas, "Ramón J. Sender y Santa Teresa», en Santa Teresa y la literatura mística hispánica. Actas del I Congreso Internacional sobre Santa Teresa y la mística hispánica, Madrid, Edi-6, 1984, pp. 785-792; Elsa L. Di SANTO, "Santa Teresa de Jesús en la novela de Ramón J. Sender», Letras [Universidad Católica de Argentina], 15-16 (1986), pp. 36-41.

3 Los subrayados que aparecen en las citas de la presente comunicación son míos. 
iglesias", que tan adecuadamente conviene a la visión senderiana de la mística. Como puede verse en El verdugo afable, Sender aproxima la pureza del anarquista al místico. Sorprende asimismo, en el texto, la naturalidad con que nuestro autor apunta la filiación de Miguel de Molinos con Teresa de Ávila y Juan de la Cruz.

José Domingo Dueñas, en su excelente trabajo Ramón J. Sender (19241939). Periodismo y compromiso, ${ }^{4}$ señala el hecho de que «las invocaciones a "lo eterno", la apelación a la "especie" o el abandonarse por completo a la naturaleza que predicaba [Sender] en "Materialismo y misticismo en el pinar" (19-7-1934) denota[ría]n desaliento ante las posibilidades revolucionarias, pérdida de confianza en la capacidad para la transformación social [...] y parecen anunciar ya una cierta atracción hacia el quietismo de Miguel de Molinos, presente en "El verdugo afable" (1952)». La interpretación de Dueñas no deja de presentar un perfil atrayente y lógico, contemplada desde la dimensión senderiana de radical compromiso social. Sin embargo, precisamente debido a esa radicalidad, puede resultar un tanto sorprendente la supuesta claudicación en la mística. Máxime cuando, en el mismo artículo citado por José Domingo Dueñas، Sender, al igual que en otras ocasiones, subraya el realismo místico, esta vez como causa de la condena de nuestros grandes espirituales y místicos. Así, nombrando entre otros a Servet, Miguel de Molinos, Juan de Ávila, Arias Montano, fray Luis de León o Bartolomé de las Casas, concluye: «Se les condenaba, como a Santa Teresa y a San Juan de la Cruz, por su realismo siquiera fuera una simple expresión realista a "lo divino". Todos ellos conocieron la persecución. Los poetas se tragaban sus versos y los filósofos desviaban su pensamiento bajo el terror, hasta por ejemplo el quietismo suicida de Miguel de Molinos». ${ }^{5}$

Francisco Carrasquer, ${ }^{6}$ quien ha señalado un tenue quietismo moderno en la obra de Ramón J. Sender, escribe en la «Introducción» a Imán: «El derrumbe de la causa del pueblo español desencadena en Sender el propio derrumbe [...]. De ahí que, a partir de 1939, la obra de Sender cambie de nivel. Él mismo le dice a Peñuelas: "Dejé de escribir una literatura de combate inmediato para escribir una literatura, por decirlo de un modo un poco absurdo, de iluminación"». Sin embargo, el mismo Carrasquer concluye a continuación: «Es una manera de salir del paso en la necesaria

\footnotetext{
4 José Domingo Dueñas LoRente, Ramón J. Sender (1924-1939). Periodismo y compromiso, Huesca, IEA, 1994, p. 335.

5 Ramón J. SENDER, «La cultura española en la ilegalidad», Tensor [Madrid], 1-2 (agosto de 1935), p. 22.

6 Francisco CARRASQUER, «Imán» y la novela histórica de Ramón J. Sender. Primera incursión en el realisno mágico senderiano [Universidad de Amsterdam, 1968], Londres, Tamesis Books Limited, 1970, apud Julia UCEDA, «Realismo y esencias en Ramón J. Sender», Revista de Occidente, 82 (1980), PP. 39-53.

7 Francisco CaRrasquer, «Sender entero ya en Imán», «Introducción» a Ramón J. SENDER, Imán, Huesca, IEA, 1992, pp. XXVIII-XXIX.
} 


\section{EL LUGAR DE SENDER}

improvisación de una charla, eso de "iluminación". Semejante expresión puede querer significar lo que un día bauticé como "realismo mágico" [...] el abandono de lealtades contingentes para abrazar la esencialidad». Para el lector apenas iniciado en Sender la interrogante resulta inevitable: ¿qué papel juega realmente la mística, no sólo en la novela, sino en el núcleo del pensamiento de Ramón J. Sender, cuando se descubre la recurrente inquietud del autor hacia el misticismo? La cuestión no parece trivial.

El joven autor de El verbo se hizo sexo publica en 1947 La esfera, cuyo propósito «es más iluminativo que constructivo Icon palabras del propio autor, siempre fiel a su vocación educadora] y trata de sugerir planos místi$c o s$ en los que el lector pueda edificar sus propias estructuras». ${ }^{8}$ Apenas transcurridos cinco años Sender escribe El verdugo afable, cuyo gozne central queda constituido por una especie de dramático intento de integración entre lo caótico y lo místico que definen al hombre. Intento, por otra parte, decisivo en el pensamiento senderiano.

Crónica del alba, Don Juan en la mancebía, la Aventura equinoccial de Lope de Aguirre, Imán..., podría afirmarse que la producción toda de Ramón J. Sender presenta de forma más o menos explícita el hilván violeta de la búsqueda mística. Búsqueda mística que contiene claros indicios de un quietismo aniquilador que deviene en casualidad fatalmente progresiva, en general más próxima al fatum estoico que a la quietud y recogimiento molinosianos. En Ensayos sobre el infringimiento cristiano descubre nuestro pensador y novelista su fe, su profunda religiosidad. Religiosidad «a lo místico»; aquella religiosidad "que lleva en sus entrañas la fraternidad universal y ese hacerse los hombres a imagen y semejanza de Dios por el único camino que hoy tenemos como seguro: la libertad y el amor. "Dios es Amor y Dios=Libertad" ». ${ }^{9} \mathrm{O}$ utilizando otra fórmula de Sender: "Libertad, amor, Cristo y Dios son una misma formulación con signos distintos". ${ }^{10}$

Treinta y seis años después de escribir El verbo se hizo sexo, Sender retoma el tema de Teresa de Jesús en Tres novelas teresianas (1967). «Siendo la pasión y la libertad las cualidades que más admira [Sender], es entusiasta admirador de Teresa de Jesús y de Juan de Yepes», escribe Mair José Bernadete. ${ }^{11}$ Ángel Alcalá, defendiendo una peculiar forma de ser heterodoxo aragonés, ve a Sender, en su religiosidad sedienta de absoluto, heredero de Servet y de Molinos: "Esa veta de interpretación poética de la vivencia religiosa que entiende la religión, más que como dogma y sacra-

\footnotetext{
8 Ramón J. SENDER, La esfera, Barcelona, Destino, 1985, p. 7.

9 Ramón RuFAT, «El sentimiento religioso en Ramón J. Sender», Alazet [Huesca], 4 (1992), pp. 181-186; p. 186.

10 Ramón J. SENDER, Ensayos sobre el infringimiento cristiano, Madrid, Editora Nacional, 1975, p. 265.

11 Mair José BERNADETE, "Ramón J. Sender, cronista y soñador de una nueva España», en Réquiem por un campesino español, México, Editores Mexicanos Unidos, 1971, p. 116.
} 


\section{PILAR MORENO RODRIGGEZ}

mento, como símbolo y búsqueda de lo absoluto, y que se observa en algunas de las mejores novelas de Sender, sobre todo en La esfera, de 1968, tan incomprendida, como era de prever, por buena parte de críticos, tiene, a mi modesto entender, su ilustre ascendencia en Servet y en Molinos [...]. En el fondo, es un ansia de libertad individual. Es una racial característica aragonesa».12

Francisco Carrasquer ha escrito que el anarquizante Sender se acerca a santa Teresa a través de ese "vivo sin vivir en mí", que indica "una vida derramada hacia Dios y hacia el mundo, y por eso es plena, porque no se acaba en nada ni en nadie, empezando por ella misma». ${ }^{13}$ Como reza aquel conocido poema de Agustín García Calvo, el destacado ácrata zamorano, «libre te quiero [...] ni de Dios, ni de nadie ni tuya siquiera».

Pero Sender no sólo perseguiría la definitiva y absoluta Libertad libertaria. "La ecuación actual libertad=Dios es la esencia misma de nuestro tiempo", afirma en Ensayo sobre el infringimiento cristiano. Nos encontraríamos ante aquella libertad que, unida al amor, conduce, quiérase o no, "a la intuición asombrosa de lo real absoluto», según las propias palabras de Sender. ${ }^{14}$ Sin embargo, según entiendo desde esta somera aproximación al tema, el eje para enmarcar la tendencia de Ramón J. Sender hacia el pensamiento místico lo constituiría el tema central del realismo, clave en la obra senderiana. Esta primordial cuestión nos situaría de inmediato en el ya mencionado realismo místico, por el que nuestro pensador se siente tan atraído. Desde esta perspectiva, Sender caló en el quid de la mística de manera más atinada y profunda que muchos teólogos. Veamos brevemente la cuestión.

Dos líneas de interpretación, en absoluto lejanas, encontramos respecto del realismo senderiano. La lectura de Julia Uceda ${ }^{15}$ nos sitúa ante un "realismo de esencias». Por otro lado, la visión acaso más cálida y cordial de Francisco Carrasquer ${ }^{16}$ se halla proclive a subrayar los aspectos místico-simbólicos en lo que denomina «realismo mágico» de Sender. Patrick Collard, en «Las primeras reflexiones de Ramón J. Sender sobre el realismo», ${ }^{17}$ nos muestra a un novelista "realista» desde muy joven.

\footnotetext{
12 Ángel AlCaLÁ, «Sender y sus novelas, y su Aragón”, en José-Carlos MAINER, ed., Ramón J. Sender. In memoriam. Antología crítica, Zaragoza, Diputación General de Aragón et al., 1983, p. 181.

13 Francisco CARRASQUeR, «Imán» y la novela histórica de Sender, cit., p. 220, apud Julio RodRiGUez PuÉRTolas, «Ramón J. Sender y Santa Teresa», art. cit., p. 792.

14 Ramón J. SENDER, «Física del infringimiento último», Ensayos sobre el infringimiento cristiano, cit., p. 266.

15 Julia UCEDA, «Realismo y esencias en Ramón J. Sender», en José-Carlos MAINER, ed., Ramón J. Sender. In memoriam, cit., pp. 113-125.

16 Francisco CARRASQUER, "Sender entero ya en Imán», introd. cit., pp. XI-CLXXXVI; "Sender por sí mismo", Alazet, 4 (1992), pp. 69-122.

17 Patrick COLLARD, «Las primeras reflexiones de Ramón J. Sender sobre el realismo», en JoséCarlos MAINER, ed., Ramón J. Sender. In memoriam, cit., pp. 87-94.
} 
El realismo senderiano presenta características bien definidas ya desde su origen. Características que, por otra parte, mantiene y profundiza a lo largo de su producción. Destacaré dos notas que considero decisivas a la hora de enmarcar el carácter filo-místico del pensamiento de Ramón J. Sender, que entiendo permanecen a lo largo del pensamiento del escritor.

a) En primer lugar, lo que podríamos denominar un realismo antropológico. El realismo de Sender va indisolublemente unido a su concepto del hombre, primordialmente a través de la idea de hombría. ¿Qué aportaría esta fundamental noción senderiana al tema de la mística que nos ocupa? Una concepción integral del hombre, en la que lo orgánico y lo biológico, lo psíquico y lo espiritual se conjugan en perfecta unidad y armonía; en perfecta solidaridad. Frente al naturalismo y frente al espiritualismo, el hombre integral e integrado en el todo del cosmos.

Perfecta unidad y armonía solidarias que nos recuerdan esa pureza original a la que pretenden transportar al ser humano todas las místicas que en el mundo han sido. Esta actitud preludia las bases de un realismo filo-místico. Se podría definir la hombría, partiendo de «El novelista y las masas», diciendo que es el hombre «en plena puridad sin la corrupción de la vieja personalidad adquirida y pegadiza». ${ }^{18} \mathrm{O}$ también como "el hombre con su razón y sus instintos en armonía", concepción ésta que recuerda de inmediato la «razón poética», ese hermanar las entrañas y la luz, de María Zambrano. ${ }^{19}$

Como expresa en El verdugo afable, estableciendo neta diferencia con los conceptos de «persona» $y$ «personalidad»:

La hipertrofia de la personalidad que segrega sustancia metafísica tortura a los hombres. Y esa "personalidad" es lo que muere. [...].

- Oídme los tristes y los fuertes, los débiles y los vencedores. Oíd los contaminados y los puros. El hombre, hijo del hombre, está sobre la tierra, en la tierra y debajo de la tierra. En el aire, en el suelo, en el mar. Vive en la materia única y con ella domina el espacio y el tiempo. Está en la luz y en la sombra, que son accidentes de la materia indiferenciable. ${ }^{20}$

Lo «ganglionar» configuraría junto con la «hombría» la concepción antropológica de Sender. Los ganglios vendrían a ser el último centro biológico-espiritual del hombre. "Los "ganglios" — ha escrito Carrasquer-_21 entroncan con la interpretación de los mitos de Lévy-Strauss y con la oleada de retorno al chamanismo y a la religiosidad antiobjetiva de la contracultura. En última instancia, los ganglios de Sender son como los fundamentos en que arraigar y hacer fructificar un renuevo de entendimiento y

\footnotetext{
18 lbid., p. 90.

${ }^{19}$ La posible relación de Sender con María Zambrano sería una cuestión por estudiar.

20 Ramón J. SENDER, El verdugo afable, ed. cit., Pp. 204-205.

21 Francisco CARRASQUER, «Sender por sí mismo», art. cit., p. 90.
} 
comportamiento humanos de la mayor profundidad ontogénica y filogénicamente». Con palabras de Sender:

Amemos nuestros ganglios que saben más de nosotros mismos que nuestra razón. El hombre sabe mucho más que lo que cree saber y esa sabiduría inexpresada está en lo ganglionar.

Para nuestros ganglios, la digestión de las religiones, con sus símbolos y sus mitos (pero no con sus credos), es fácil y estimulante. ${ }^{22}$

La apreciación antropológica de mi admirado Carrasquer es oportunísima. A ella habría que sumar, sin embargo, otras dos posibles dimensiones: la junguiana, «divinizadora» de las fuerzas inconscientes, de lo abisal humano, más o menos explícita en la obra senderiana; y otra, acaso más novedosa, la que el propio Sender añade desde la física cuántica, entre otros, en el último capítulo de Ensayos sobre el infringimiento cristiano. ${ }^{23}$ Como tuve ocasión de mostrar en "Mística y ciencia hoy", ${ }^{24}$ las consecuencias metafísicas y antropológicas de esta nueva física podrían alcanzar hasta el propio misticismo. Pero dejemos esta cuestión para más adelante y continuemos con el realismo místico senderiano. El diálogo vivificante entre lo "ganglionar", los mitos y la insistente búsqueda de "lo real absoluto", clave de La esfera, nos ofrece una fórmula antropológica revolucionaria, explosiva. Preñada de misticismo de la mejor calidad. Pues un hombre así integrado y uno - aspiración definitiva de Sender; aspiración universal de la sabiduría mística - deviene solidaridad y compromiso sumos; con lo social, con la naturaleza, consigo mismo y con lo absoluto que todo ello concita. Desde el cómic zen de los diez bueyes y el mito platónico de la caverna, a la contemplación-acción de nuestros místicos españoles - de Lulio a Teresa de Jesús, Juan de la Cruz y Miguel de Molinos-, destaca en profundidad y en extensión la gran coherencia interior y el esencial compromiso que entraña ese realismo místico. Realismo místico que nuestro autor supo percibir, descubriendo la ética radical de la nopropiedad; del total desasimiento hacia la libertad y el compromiso supremos. La unidad solidaria con todo lo existente, desde las entrañas - como diría María Zambrano, con quien tantos paralelismos presenta nuestro autor-; o desde lo "ganglionar», como dice Sender. Por aquí, entiendo, encontraríamos una singular clave para la búsqueda de esta dimensión filo-mística del pensamiento de Ramón J. Sender. Sin duda, nuestro pensador y novelista vio con claridad el compromiso radical que la vida mística - aquella que en verdad lo es- implica. Intuyó en profundidad «Esa

\footnotetext{
22 Textos ambos de La esfera, citados por CARRASQUER, "Sender por sí mismo", art. cit., pp. 91-92.

23 Ramón J. SENDER, «Física del infringimiento último», Ensayos..., cit., pp. 263-286.

24 Pilar Moreno Rodríguez, El pensamiento de Miguel de Molinos, Madrid, Fundación Universitaria Española, 1992, pp. 65-89.
} 


\section{EL LUGAR DE SENDER}

especie de anarquistas de lo absoluto que eran los místicos castellanos y su hijo aragonés Miguel de Molinos».

b) La segunda clave en esta posible hermenéutica mística arrancaría de la identificación histórica española con la tradición heterodoxa del pensamiento místico hispano. Tal es la propuesta de Sender en "La cultura española en la ilegalidad». Lo cierto es que por aquí desenvocamos nuevamente en el realismo. Radical realismo español, que ha subrayado de manera admirable la insigne filósofa malagueña María Zambrano, ${ }^{25}$ a quien aludíamos anteriormente. Realismo místico de nuevo, reivindicador de lo concreto, de la vivencia; "el predominio de lo espontáneo, de lo inmediato», que dice la autora de Claros del bosque. Realismo antropológico de nuevo, simbolizado en el desharrapado de los Fusilamientos de la Moncloa, de Goya, lectura que me atrevo a recomendar al lector. No me resisto a transcribir algún fragmento de la descripción efectuada por María Zambrano, que tan vivamente recuerda el pensamiento de Sender:

Es el hombre íntegro, en carne y hueso, en alma y espíritu; su arrolladora presencia que penetra así en la muerte. El hombre entero, verdadero. [...] El universo entero está en él. Él solo nos da idea de la infinitud del mundo y de su cohesión, de su dureza y de su fuego. Es la imagen de un hombre que a nada ha renunciado, que de nada se ha desprendido. Es como una piedra recién salida de la creación. [...] Tan virginal e íntegro es, que ni ante el terror de la muerte inmediata muestra un solo rastro de experiencia. [...] Sabe ya todo lo que puede saber y ninguna ciencia puede modificarle. Está hecho de una vez para siempre. [...] esta criatura se nos aparece como el elemento permanente que presta a un pueblo su imperecedera juventud; el "ser», en toda su arisca independencia. ${ }^{26}$

De este realismo antropológico zambraniano, integrador a pleno pulmón de lo popular, se desprendería la peculiar manera de concebir y relacionarse el español con la naturaleza. Manera y concepto que igualmente parecen coincidir con el pensamiento senderiano. Coincidencia que vuelve a aparecer en la relación hombre-naturaleza. En la relación hombrenaturaleza que concibe la filósofa malagueña, el término clave es «Materialismo", así entre comillas. Materialismo que

es la consagración de la materia, su exaltación, su apoteosis [...] materia sagrada, es decir, materia cargada de energía creadora. Materia que se reparte en todo y todo lo identifica, que todo lo funde y transfunde, que es el vehículo y la unión: la comunión asequible y concentrada por la cual todo va a todos. [... ] Dentro del catolicismo, este materialismo toma caracteres de mística sensualidad, de una transfusión de cielo y tierra, en que a la tierra han

25 María ZAMBRANO, «El realismo español», «El realismo español como forma de conocimiento» y «Materialismo español», en Obras reunidas. Primera Entrega, Madrid, 1971, pp. 273-284.

26 lbid., pp. 278-280. 


\section{PILAR MORENO RODRÍGUEZ}

sido transpuestos todos los valores celestiales y al cielo han ascendido todos los valores terrenos. ${ }^{27}$

Y unas líneas más adelante esencializa este realismo «materialista» en las cosas mismas, en su más cotidiana concreción. Así, ejemplificando en la novela española por antonomasia, El Quijote, escribe María Zambrano:

En una obra como el Quijote, donde la figura señera del héroe alcanza tan inmensas proporciones, queda, sin embargo, intacta debajo de su sombra una novela castellana, donde los protagonistas son los caminos, las ventas, los árboles, los arroyos y los prados, los pellejos de vino y aceite, los trabajos de todas clases, en suma: las cosas y la naturaleza. [...] La magnificencia de las cosas más humildes, de las criaturas más vulgares a las que el tema trágico no ha podido anular. [...] Entonces quedan las cosas solas, entonces se muestra que con cosas, con nada más que cosas, brilla un universo en el que hay la huella del hombre, huella que es posible por esa cercanía o entrañamiento en que el hombre ha vivido con ellas.

Las similitudes con el pensamiento de Ramón J. Sender no pueden ser mayores.

Julia Uceda ${ }^{28}$ ha destacado la esencialización de los objetos y elementos sensoriales en las novelas de Ramón J. Sender. "Sender suele utilizar cosas menudas - a veces objetos, colores, movimientos, observaciones inesperadas-, y sin importancia aparente, pero que al fin contienen la clave de una realidad esencial». ${ }^{29}$ La mística española, frente a la mística alemana, se enraíza y nutre en este realismo sensual y transfigurado de las cosas y la naturaleza; en lo humano divino de esa unidad que tanto recuerda la mística islámica. Por aquí, entiendo, podría situarse el realismo de Ramón J. Sender, que tantos ecos muestra de esta línea de pensamiento, que contempla la filosofía española desde la cordial vivencia mística. Filosofía vivencial e intuitiva, de un pensamiento autóctono que se situaría en las antípodas filosóficas del frío y formalista racionalismo europeo. ${ }^{30}$ Igualmente desde estos parámetros cabría interpretar la teoría senderiana de «los filtros», que Francisco Carrasquer recoge de La esfera:

Esos filtros que actúan en todas las formas de nuestra sensibilidad (ojosoídos) nos protegen constantemente contra el ataque de la luz, el sonido, las

\footnotetext{
27 lbid., pp. 284-285.

28 Julia UCEDA, “Realismo y esencias en Ramón J. Sender», en José-Carlos MAINER, ed., Ramón J. Sender. In memoriam, cit., pp. 113-124.

29 Francisco CARRASQUer, "Sender por sí mismo", art. cit., p. 78, cita un texto de Los cinco libros de Ariadna en el que el propio Ramón J. Sender expresa esta idea: «La tendencia a perfilar el detalle no es barroquismo, sino una inclinación dramática y amorosa por las cosas pequeñas y transitorias en las que me gusta bucear y destacar lo más genuino y permanente".

30 Cfr. Pilar Moreno Rodrícuez, «Mística y filosofía española. Hacia una recuperación del pensamiento español», en El pensamiento de Miguel de Molinos, cit., pp. 91-127.
} 


\section{EL LUGAR DE SENDER}

formas. Pero el mayor de esos filtros es la inteligencia. La tenemos no para comprender, sino sobre todo para "no comprender demasiado". ${ }^{31}$

Aún podrían plantearse otras posibles vías de acceso al pensamiento místico de Sender. Apuntaré tres cuestiones más.

1) Si en la aproximación al realismo místico de Sender la perspectiva diacrónica nos situaba en esa tradición heterodoxa de la «cultura española en la ilegalidad», desde una perspectiva sincrónica otra clave en la lectura del supuesto Sender "místico" podría arrancar de la profunda antropología hermenéutica junguiana que parece deslizarse en el pensamiento senderiano. Los conceptos de Self, individuación y sincronicidad desarrollados por Jung podrían constituir herramienta singular en el esclarecimiento del pensamiento místico de Ramón J. Sender. ${ }^{32}$

2) Como he indicado al hablar del realismo antropológico senderiano, la física cuántica y la relatividad einsteniana preocupan, y no en menor grado, al pensador aragonés, quien incorpora las revolucionarias cuestiones de la física al ámbito de su antropología trascendente, acaso la verdadera preocupación senderiana.

En el citado último capítulo de Ensayo sobre el infringimiento cristiano, en el que plantea Sender el infringimiento de la ciencia junto al religioso, nuestro autor escribe lo siguiente:

La fe religiosa nos establece en lo absoluto a través del trabajo creador de nuestra imaginación y del pensamiento "más rápido que la luz". Pero, además, todos los movimientos de nuestra sensibilidad, de nuestro afecto, de nuestra necesidad de presencia capaces de producir alguna clase de esencialidad nos sitúan mil veces cada día en el umbral de la eternidad. ¿Quién sabe si somos productores de esencialidad — cualquier clase de abstracción inefable-, con la cual enriquecemos de algún modo la de Dios mismo, querámoslo o no y sepámoslo o no?

Y unas líneas más adelante:

La realidad física comienza con una conjetura (la indeterminación de la conducta de los electrones en la teoría de los quantas) y nada de extraño tiene que acabe (según nuestra manera de entender lo que empieza y acaba) con otra conjetura silenciosa: la de lo eterno al otro lado de la barrera de la luz donde el tiempo ya no rige. Entre una conjetura y la otra, todo el repertorio barroco de nuestro mundo moral no expresado aún y tal vez no expresable del todo porque no tiene fin. Y detrás de cada palabra todo el silencio del universo. Ese silencio que es el lenguaje no de lo real absoluto sino de lo Absoluto Real. ${ }^{33}$

\footnotetext{
31 Francisco CARRASQUER, "La parábola de La esfera y la vocación intelectual de Sender», en José-Carlos MAINER, ed., Ramón J. Sender. In memoriam, cit., p. 415.

32 Javier BARREIRO, en «Bajo el signo de la perplejidad: El verdugo afable», Alazet, 4 (1992), pp. 59-68, apunta alguna nota interpretativa en la línea junguiana.

33 Ramón J. SENDER, «Física del infringimiento último», Ensayos..., cit., pp. 280-281.
} 
El capítulo por sí solo bien merecería un detenido comentario. Nuestro objetivo, sin embargo, no es otro que la breve indicación de una pista que apunta hacia el tema que nos ocupa. Ramón J. Sender firma el final del Ensayo en «San Diego, California, 1975». Curiosamente en ese mismo año el físico Fritjof Capra, profesor en la universidad de Berkeley, publicaba The Tao of Physics, donde plantea una exploración de los paralelismos existentes entre física moderna y misticismo oriental.

3) Por último, no quiero dejar de aludir a la profunda y riquísima personalidad que muestra el pensador de Chalamera en sus escritos: ${ }^{34}$ podría constituir una no desdeñable vía de aproximación al tema que nos ocupa.

Así, podrían destacarse entre otras las siguientes notas:

-En primer lugar, habría que destacar esa especial sensibilidad que muestra nuestro escritor hacia la trascendencia. Podría hablarse de la búsqueda de la trascendencia como una constante senderiana.

Como señala Jesús Vived ${ }^{35}$ refiriéndose a la muerte de Sender: "Queda su obra y en un rincón de ésta una frase con una de sus palabras preferidas: "Todo es contingente menos el misterio de la necesidad de trascender"». Queda su obra, sí; impregnada de trascendencia por los cuatro costados. Desde los más concretos niveles materiales y sociales, hasta las más elevadas inquietudes metafísicas y religiosas; desde la reiterada admiración de figuras como Simone Weil, ${ }^{36}$ hasta la consagración cuasi divina de lo pequeño y cotidiano.

-El amor a la libertad por encima de todo, traducido en su inestimable admiración por el anarquismo plasmado en esa «fórmula apolítica» que aclara su posición personal ante el anarcosindicalismo español: «los seres demasiado ricos de humanidad sueñan con la libertad, el bien, la justicia, dándoles un alcance sentimental e individualista». El anarcosindicalismo es visto por Sender como fruto de supervitalidad de los individuos y las masas, fruto de «la generosidad y exceso de sí mismos»; exceso de sí mismos que en Sender empuja inequívocamente hacia la trascendencia de lo humano.

- La decidida solidaridad y vocación educadora, manifiesta a lo largo de los escritos de Sender, hacia ese hombre esencial, ganglionar y «divino", trascendido desde la materia-madre.

- Su carácter decididamente integrador y holístico. Carácter que se manifiesta en ese intento casi obsesivo de conciliar los opuestos, empujando sin tregua hacia la unidad inmanente, tantas veces defendida.

-Pero acaso todo lo anterior se resuma en la descripción que Francisco Carrasquer ${ }^{37}$ nos ofrece de Sender como ese «hombre eminentemente

\footnotetext{
34 Francisco CARrasquer, "Sender por sí mismo", art. cit., pp. 69-122.

35 Jesús Vived MAIRAL, «La vida de Ramón J. Sender al hilo de su obra», Alazet, 4 (1992), p. 270.

36 Cfr. Ramón J. SENDER, Álbum de radiografías secretas, Barcelona, Destino, 1982, pp. 52-71. Sender cita generosamente a Simone Weil en Ensayo sobre el infringimiento cristiano.

${ }^{37}$ Francisco CARRASQUER, «Sender entero ya en Imán», introd. cit., p. XXXV.
} 


\section{EL LUGAR DE SENDER}

cordial en el sentido pascaliano que fue Sender: "la logique du cœur"». Personalidad profundamente intuitiva, vivencial y divergente, que tan bien se adecua con la sensibilidad mística.

Para concluir este primer apartado acerca del misticismo en el pensamiento de Ramón J. Sender, no resisto la tentación de reproducir aquí unos textos que espero ilustren esta inquietud interior senderiana. Los dos primeros pertenecen a Los cinco libros de Ariadna: ${ }^{38}$

1. Un defecto que podría ser menor [y se refiere a sí mismo y su obra] es la tendencia a usar voluptuosamente del color. No es una voluptuosidad tan acusada como en otros españoles a quienes aplaudo y admiro (no tanto como en Valle-Inclán o en Miró) pero así y todo, esa tendencia contradice al silencio interior que quisiera expresarse en formas más ascéticas. En todo caso, uno es como lo han hecho y esa voluptuosidad es legítima. Si se reflexiona un poco, se verá que no es tanto el gozo del color, como el de la luz. Me gusta abusar de la luz sobre superficies frías y colores «pasivos». El amor es el deseo de la forma. El universo está trabajando en esa dirección desde sus orígenes. La música es la forma del silencio y el color la forma de la luz. El pensamiento es la forma de la muerte cuando es certidumbre, y de la inmortalidad - del «devenir» - cuando es fe no comprobada con la realidad y tal vez no comprobable.

2. Todos estamos obligados a dar forma al silencio y a la luz, esos dos puntos de partida que Dios nos ofrece para que con ellos le ayudemos a poblar la nada y a redimimos y a redimirle a él en cierto modo del horrendo caos de los orígenes. Esta creencia es religiosa. Religión y poesía son una misma cosa. Novalis ha dicho que la religión es poesía práctica y para un español la sangre derramada (primer rito de las religiones) y la canción que la sucede son el resumen de la historia de toda la humanidad. Sangre, religión y poesía (pasión, ensueño y canción) son cosas de las que el español entiende. Nuestra religión es el hombre. Y sus virtudes aquellas en las que todos los hombres podrían coincidir. Algunas de esas virtudes para muchos serán objecionables. En su derecho están.

Acaso el autor de El verdugo afable intuyó y sintió esa nostalgia. De ahí el leitmotiv de sus inquietudes hacia esa religiosidad radical que es la mística; su preocupación por la quietud y la aniquilación. De ahí tal vez arrancara lo que podría ser un posible intento de «individuación» junguiana, más o menos explícita en la novela El verdugo afable, al llegar a la mitad de la vida.

De José-Carlos Mainer ${ }^{39}$ han sido tomados los dos siguientes fragmentos, que hablan igualmente de esa búsqueda interior. El primero de ellos nos muestra, igualmente, el pensamiento del Sender pintor; el segundo constituye uno de los aforismos senderianos de Memorias bisiestas. En ambos destaca Mainer la raíz senequista del ser moral de Sender.

38 Francisco CARRASQUeR, «Sender por sí mismo», art. cit., p. 79.

${ }^{39}$ José-Carlos MAINER, «Resituación de Ramón J. Sender», en José-Carlos MAINER, ed., Ramón J. Sender. In memoriam, cit., p. 19. 


\section{PILAR MORENO RODRÍGUEZ}

Ambos pudieran arrojar luz sobre el tema de la búsqueda de lo profundo en Sender:

1. Yo hace algunos años que pinto para mí mismo porque encuentro en la pintura elementos de expresión que completan los de la novela, la poesía, el teatro o el ensayo [...]. Se trata de establecer formas de armonía estable con cada una de las cuales creamos un fortín de defensa contra el vacio agresor. ¿Es perfecto este fortín? Es eficaz y nos basta. Nada hay en lo perfecto sino la muerte, y a ella nos empuja la agresión de ese vacio. A la muerte interior que suele anteceder a la otra.

2. El pasado, el futuro y el presente son circunstancias del ser interior y podemos gozar de ellas cuando queremos. En realidad estos gozos nos recompensan poéticamente de la crudeza de nuestra lucha contra la nada.

¿A qué se refiere Sender con la expresión «armonía estable»? ¿Qué significan «el vacío agresor» y «la muerte interior», previa a la muerte física? Y, sobre todo, ¿acaso no resultaría pertinente interrogarse acerca del tema de la nada en los textos y contextos senderianos? Entiendo que ésta sería una clave importante en la aproximación al tema del pensamiento místico de Sender.

Pero pasemos al tema central de la presente comunicación, Miguel de Molinos en la novela El verdugo afable.

\section{EL PENSAMIENTO DE MIGUEL DE MOLINOS EN EL VERDUGO AFABLE}

La literatura generada en torno a la novela El verdugo afable ocupa un lugar intermedio, equiparable a la suscitada por obras como Epitalamio del prieto Trinidad, Mr. Witt en el cantón, La esfera o La aventura equinoccial de Lope de Aguirre, si bien en el caso de El verdugo abundan más las reseñas. ${ }^{40}$ $\mathrm{Al}$ repertorio bibliográfico de E. Espadas ${ }^{41}$ habría que sumar las publica-

\footnotetext{
40 El 4 de junio de 1954 Sender escribía a Maurín comunicándole, entre otras cosas, el envío de su novela $E l$ verdugo afable en inglés. "Si lo lee tu señora me gustaría que me dijeras su impresión». En carta de 28 de junio, contestaba Maurín al respecto: «A mi mujer la lectura del verdugo afable le gustó mucho. Te resumo lo que ella me dijo sin que yo le dijera que podría comunicarte: el comienzo es impresionante, magistral, insuperable; muy interesante la descripción de lo ocurrido en un pueblo de Andalucía y el relato de la guerra civil. El ritmo de la novela en la segunda parte no va en ascenso. No es que decaiga, pero el lector tiene la impresión de que la primera parte es mucho más consistente. Al final, el protagonista deja una impresión un poco difusa: es un personaje complejo al que uno no sabe si querer o detestar. En conjunto, bien. Con una gran variedad de problemas, y con una técnica de exposición magnífica» (Francisco CAUDET, Correspondencia Ramón J. Sender - Joaquín Maurín [195219731, Madrid, Ediciones de la Torre, 1995, pp. 163 y 167.

${ }^{41}$ Cfr. Elizabeth ESPADAS, «Hacia una bibliografía sobre la obra de Ramón J. Sender», en Francisco CARRASQuer, La verdad de Ramón J. Sender, cit., pp. 125-167. A ella habría que sumar, entre otros, el artículo «El verdugo afable de Ramón J. Sender y el "crimen del expreso de Andalucía" ", de Jesús VIVED MAIRAL, publicado en Rolde (Revista de Cultura Aragonesa), 63-64 (1993), pp. 20-21.
} 
ciones posteriores de Jesús Vived, ${ }^{42}$ Ricardo Senabre, ${ }^{43}$ Javier Barreiro ${ }^{44}$ y Gemma Mañá y Luis Esteve. ${ }^{45}$ Si Ramón J. Sender parece haber calado el quid de la mística, no queda tan claro que llegara a penetrar con igual fortuna el pensamiento de Miguel de Molinos. Sender cita explícitamente el nombre de Miguel de Molinos en dieciséis ocasiones a lo largo de la novela: seis en el capítulo X; una en el XI, tres en el XII, dos en el XV y cuatro en el capítulo XVII. Los términos "quietud», "quietismo", "aniquilación", "pasividad" referidos a la doctrina molinosiana van hilvanando el entramado de El verdugo afable, desde la página diecisiete, en que el narrador Sender señala su presencia en las ejecuciones indicando que «la ciudad sólo me exigía una actitud pasiva», hasta la transformante quietud que lleva a Ramiro Vallemediano a convertirse en verdugo. El cauce por el que discurre la narración filo-notarial de la novela se situaría entre dos claras orillas: por un lado, la fatalidad, ensartada en el principio de «culpabilidad inocente" que encarna Ramiro Vallemediano; por otro, el posible asidero y salida de la paradoja existencial, a través de la quietud y la aniquilación molinosianas. La lectura de la novela El verdugo afable parece descubrir una expresa voluntad del autor en divulgar la doctrina quietista de Molinos.

La primera cuestión que cabría preguntar sería ¿de dónde arranca el interés de Ramón J. Sender por Molinos? Es éste un extremo que deberá ser analizado más detenidamente. ${ }^{46}$ De momento quede planteada la posibilidad de que el novelista aragonés se interesara por el pensamiento de Miguel de Molinos a través de Luis Bello, cuyos artículos «Miguel de Molinos. Para otro centenario» y «Más sobre Miguel de Molinos» fueron publicados en 1927 en el Heraldo de Aragón, cuando ambos colaboraban en el citado periódico aragonés.

En aquel momento la obra reciente sobre Molinos es el estudio citado por Sender del jesuita Dudon, publicado seis años antes. Ocho años más tarde, en 1935, aparecerían dos reediciones de la Guía espiritual: la de Ovejero y Maury, publicada en Madrid en la Biblioteca de Filósofos Españoles, y la de Entrambasaguas, que aparece en la Biblioteca de Cultura Española. Hasta entonces, la primera reedición disponible era la de Urbano, de 1911.

\footnotetext{
42 Jesús Vived MaIRAL, "El verdugo afable de Ramón J. Sender y el "crimen del expreso de Andalucía" ", art. cit.

43 Ricardo SENABRE, "Una novela-resumen de Ramón J. Sender: El verdugo afable», La Literatura en Aragón, Zaragoza, CAZAR, 1984, pp. 153-162.

44 Javier BARREIRO, art. cit., pp. 59-68.

45 Gemma MañÁ y Luis ESTEve, «Un desterrado, Ramón J. Sender; Miguel de Molinos, un perseguido", separata del Simposio sobre destierros aragoneses, Zaragoza, Institución Femando el Católico, 1988, pp. 197-206.

46 Javier BARREIRO, art. cit., p. 61, plantea la posibilidad de que Sender conociera la obra del jesuita Dudon a través de Valle-Inclán. En El pensamiento de Miguel de Molinos, apunté el influjo del quietista aragonés en La lámpara maravillosa.
} 
Interesa, sin embargo, ver cómo queda planteada la doctrina molinosista en la novela $E l$ verdugo afable. ¿Cómo interpreta Sender la doctrina de Molinos?

La primera cuestión para responder a esta interrogante nos lleva inevitablemente a la fuente de acceso a la doctrina utilizada por nuestro autor. Si aceptamos la información que nos da el propio Sender en la novela - «Ojeando la cartera vio Ramiro que había un libro titulado Le quietiste espagnol Miguel de Molinos»-, ${ }^{47}$ fácilmente sabemos que la obra citada es el estudio del jesuita P. Dudon, Le quiet iste spagnol Michel Molinos, publicada en París en 1921.

La información vertida por Sender sobre Molinos, su doctrina y la condena de aquél parece provenir de esta única fuente. Resulta obvio señalar que, pese a tratarse de una obra claramente antimolinosista, la visión de Ramón J. Sender no sólo no queda en absoluto contaminada, sino todo lo contrario: la relectura de los textos de la Guía transcritos por el jesuita francés — «Ramiro releyó algunos capítulos en los que el escritor copiaba lo más sustancial de la famosa Guía espiritual"_48 llevaron al autor del Réquiem a una penetración crítica y liberada de los textos. Todo parece confirmar, dentro del marco de la novela, que nuestro autor no debió conocer directamente la Guía espiritual. De haber sido así no habría pasado inadvertido a Sender el potencial de positividad encerrado en el concepto de nada expresado por Molinos en su obra. Igualmente, cuesta aceptar que no haya una sola alusión al lenguaje de la Guía. Resulta sospechoso que, dada la sensibilidad estilística de Sender, no aparezca algún tipo de alusión a la forma, al lenguaje de la Guía. Igualmente el propio concepto de quietismo, excesivamente vinculado al fatalismo iluminista, resulta más propio de la antimolinosista obra de Dudon, en la que Sender bebiera el pensamiento del maestro espiritual aragonés.

Pero volvamos a retomar la pregunta inicial: ¿cómo aparece la doctrina de Miguel de Molinos en la novela El verdugo afable? Apuntaré brevemente tres temas fundamentales: el tema del quietismo, el tema de la aniquilación y el tema de la nada.

\section{a) Quietismo y aniquilación}

Como acabo de apuntar es aquí donde aparecería más claramente el sesgo iluminista de la fuente utilizada por Sender en su aproximación a la doctrina de Miguel de Molinos. El fatalismo - leitmotiv, por otra parte, de la obra senderiana- nos daría la clave para la interpretación de este núcleo temático central que es el quietismo en la novela El verdugo afable. ${ }^{49}$

\footnotetext{
47 Ramón J. SENDER, El verdugo afable, ed. cit., p. 174.

48 rbid., p. 178.

49 Debo advertir que, siendo enorme la variedad y extensión de los textos que acerca del quietismo aparecen en la novela, la selección aquí realizada ha de resultar necesariamente incompleta.
} 
«Lo que convierte en víctima a los personajes de Sender —escribe Julia Uceda- ${ }^{50}$ es, con frecuencia, una casualidad fatalmente progresiva: [... así,] los crimenes de Ramiro». Continuando unas líneas más adelante: «Esta compleja red de hechos fortuitos toman el lugar del antagonista al que el hombre no puede vencer. Se trata de un destino o de un Dios que lo determina y que no tiene consideración con nosotros ante el cual nuestro único acto de libertad es el de colaborar con él en nuestra destrucción».

Como ha expresado la profesora Uceda en «Criaturas senderianas», 51 los personajes centrales de las novelas de Sender sufren en alguna etapa de su desarrollo un "alejamiento de toda apetencia», que en definitiva sería «un dejar hacer al destino, a la vida, abandonando toda oposición ante el mal y el horror. Incluso justificándolos y recibiéndolos pasivamente». Sitúa Uceda la fuente remota de esta actitud en Miguel de Molinos y sus razones tendrá para ello. Sin embargo, la cuestión exige un análisis detenido. La mencionada actitud de pasividad aniquiladora y fatalista se hallaría más próxima a la denuncia de "quietismo nihilista» formulada por el jesuita francés y por nuestro insigne políglota Menéndez Pelayo que a la esencial doctrina del supuesto heresiarca. La historia viene de antiguo. Molinos, ya publicada la Guía espiritual, tuvo que salir al paso de esta acusación formulada por algunos destacados jesuitas de Roma, como queda patante en la Defensa de la contemplación. La literatura antimolinosista posterior a la condena también abunda sobre el tema, según puede verse en «Miguel de Molinos», en la obra inédita de Francisco A. Montalvo Historia de los quietistas. ${ }^{52}$ Hoy, las investigaciones, entre otros, de Eulogio Pacho distinguiendo el «quietismo epocal» del quietismo iluminista han esclarecido suficientemente esta antigua cuestión.

La doctrina de la aniquilación fatalista bien podría haberla bebido Sender en alguna de sus fuentes filosóficas favoritas. ${ }^{53}$ Me refiero al autor de El mundo como voluntad y representación, Schopenhauer, quien introdujo en Occidente una visión del budismo aniquiladora y fatalista. Tampoco habría que obviar la posible veta estoica.

Como he expuesto en «Quietud y Antropología», 54 el concepto de pasividad y quietud de la doctrina de Molinos evita el fatal escollo del subjetivismo y el antinomianismo. ¿Qué tiene que ver el pensamiento de Molinos con esta doctrina iluminista? Más bien poco. Intuyo que la profesora Uceda, al apuntar la fuente remota del fatalismo senderiano, ha podido caer en la trampa - muy común, por otro lado- de aceptar sin más la doctrina vertida en la condena, aproximándose a Miguel de Molinos no

\footnotetext{
50 Julia UCEDA, «Consideraciones para una estilística de las obras de Ramón J. Sender», en Réquiem por un campesino español, ed. cit., pp. 21-22.

51 Julia UCFDA, «Criaturas senderianas», Alazet, 4 (1992), p. 204.

52 J. Ignacio TellecheA, Molinosiana, Madrid, FUE, 1987, pp. 109-192.

53 Cfr. Francisco Carrasquer, La verdad de Ramón J. Sender, cit., p. 97.

54 Pilar Moreno Rodríguez, op. cit., pp. 505-516.
} 
directamente, sino a través de las famosas proposiciones condenadas en la «Bula Colestis Pastor». En el capítulo XXI de la Defensa de la contemplación, que ella cita, ${ }^{55}$ nuestro autor ya sale al paso de tan antigua acusación.

Mas veamos el tema en la novela. Acaso los textos más explicativos en su conjunto sean los expresados en el capítulo $X$, al que hemos aludido supra. Aunque extensos, transcribimos los dos siguientes fragmentos:

1. - ¿En qué consistía esa doctrina molinista? ${ }^{56}$ Ipregunta Ramiro al duque] $[\ldots]$

- Me lo explicó una vez el canónigo Astorga, pero no me acuerdo. Desde luego, es algo satánico. ${ }^{57}$

[...] Esa doctrina [descubre Ramiro Vallemediano en los documentos entregados por el duque] aconsejaba la no resistencia interior al mal, el tranquilo envilecimiento por la aceptación de todas las miserias que de fuera llegan al alma hasta sentirse situado en una «soledad irrespirable» en la cual el alma rendida va aniquilándose. «Cuando ese aniquilamiento es casi completo se produce -dice Molinos- una paz interior muy profunda en la cual quizá Dios misericordioso desciende a nosotros con su gracia». La expresión "quietismo" se refería, pues, a una atonia de la voluntad moral que aislaba al hombre hasta encerrarlo en el castillo de su propia miseria. Una vez allí se quedaba inmóvil, sin voluntad de virtud, esperando la ayuda de Dios. Consciente el hombre de su propia insignificancia, de su bestialidad natural y de su criminalidad, con el alma sorda y muda, con el espíritu inerte como una roca, esperaba a Dios si quería venir.

2. La evidencia de la miseria cegaba en el quietismo todas las potencias del alma menos las que atienden al infinito del propio no ser (porque en la teología el pecado no existe sino en la forma del «no ser», de la negación del ser) y no valer y no poder nada ante los otros ni ante sí mismo más que renunciar incluso a la idea de reconocerse en su propia vergüenza. Cuando se alcanza ese estado a través de un largo y delicado proceso, la palabra "virtud" está tan desprovista de sentido como la otra: «vicio». El desprecio de sí mismo podía llevar al hombre a contemplar el propio crimen como un hecho natural. Nada de lo que hacia el cuerpo tenía el menor sentido. Pero en esa quietud Dios, para quien la materia y el acto volitivo que nace de sus necesidades y preferencias son sólo miserias, descendía a auxiliar el alma y a salvarla iluminándola tal vez con su presencia. Para eso la primera condición era no buscar ni desear nada, ni siquiera a Él.

Como puede comprobarse a través de ambos fragmentos, la complejidad del tema es enorme. Se exigiría un análisis detallado, no sólo de éstos, sino de un considerable número de alusiones y referencias, directas e indi-

55 Julia UCEDA, «Criaturas senderianas», art. cit., p. 204.

56 Queremos llamar aquí la atención sobre el término utilizado. Sender identifica el término «molinista», que alude a la doctrina del libre albedrío y de la predestinación de Luis de Molina, con el «molinosismo», doctrina del quietismo y la aniquilación de Miguel de Molinos, identificación que resulta pertinente a lo largo de la narración si tenemos en cuenta el intento de superación de fatalismo y libertad a partir de una actitud quietista.

57 Con esta caracterización de la doctrina de Molinos como «algo satánico», puesta en boca del duque, Sender parece hacerse eco de la tradición antimolinosista, definitivamente consolidada por Menéndez Pelayo en la Historia de los heterodoxos españoles. 
rectas, a la supuesta doctrina de Molinos. Doctrina que, como he indicado supra, se halla más cercana al quietismo iluminista que al pensamiento que Miguel de Molinos expresa en la Guía. La razón es clara: en la Guía espiritual que desembaraza al alma y la conduce por el interior camino para alcanzar la perfecta contemplación y el rico tesoro de la interior paz —así reza el título completo-, el fatalismo, tan cacareado por el jesuita francés Dudon y por el polígrafo español Menéndez Pelayo en relación con el místico aragonés, apenas tiene cabida. Al «rico tesoro de la interior paz» y a la "perfecta contemplación" - aquella que deviene no sólo plenitud sino compromiso sumos- no se accede por un fatalista y pesimista quis et otium estoico, como he mostrado en la obra El pensamiento de Miguel de Molinos.

La nada y la radical aniquilación molinosianas, lejos de situarnos ante "el quietismo suicida de Miguel de Molinos», que dijera Sender, aparecen cargadas de un potencial transformador, deificador, que, paradójicamente, afirma y plenifica la vida. ${ }^{58}$ En el tema de Molinos en la novela El verdugo afable, el problema viene planteado por la interpretación dada por Sender a la doctrina molinosista; interpretación que entendemos puede residir, por una parte, en la fuente utilizada y, por otra, en el posible influjo ejercido en nuestro autor por autores como Schopenhauer. De haber leído - gustado- la fuente directa de ese pequeño gran libro que es la Guía espiritual, el resultado habría sido diferente. Toda la Guía es un mapa, una carta de ruta y un método encaminados a liberar al psiquismo de los bloqueos y embarazos que tienen encadenado y oculto al verdadero ser del hombre. La quietud y la aniquilación, preñadas de positividad, son el puente que enlaza y posibilita el tránsito a una nueva realidad óntica, que sólo se hace presente en la nada. Acaso el diálogo directo y vivificador con Molinos desde la Guía habría dado contestación a la angustiosa interrogante que Ramiro Vallemediano se hace en un momento de confusión interior:

La verdad es que no sabiendo qué clase de naturaleza moral es la mia, nunca sé cómo voy a obrar ante un hecho determinado. Lo mejor sería la quietud de Miguel de Molinos alcanzada en plena conciencia. Pero... ¿cómo conseguirla si tengo la imaginación llena de visiones? ${ }^{59}$

\section{b) El tema de la nada}

Constituiría este tema la piedra de toque del supuesto molinosismo senderiano. La hipótesis propuesta supra acerca de la - me atrevería a afirmar que única- fuente utilizada por Ramón J. Sender en su aproximación a la doctrina de Molinos fue la antimolinosista obra de Dudon. El

\footnotetext{
58 Cfr. Pilar MORENO RoDRíGuez, «La nada, clave filosófica de la Guía espiritual», en op. cit., pp. 333-376.

59 Ramón J. SENDER, El verdugo afable, ed. cit., p. 208.
} 
tema de la nada en el contexto molinosiano de la novela aparece explicitado al final del capítulo XV y a comienzo del XVI a lo largo de la central entrevista mantenida entre Ramiro y el padre Anglada. El concepto de nada expuesto en el capítulo XV quedaría identificado a través del siguiente texto:

- Todos estamos expuestos a cada paso a caer en el mal, es decir, en la negación de las cosas que nos conducen a Dios. Porque el mal en sí mismo no existe sino como negación del ser. Ser malo no es lo contrario de ser bueno, sino lo contrario de ser. Cuando tenemos la voluntad del mal no es que queremos hacer algo malo sino que queremos «hacer nada». Hacer la nada. Lo mismo que Dios dice: "sine Me nihil potestis facere», podríamos decir aunque con impropiedad gramatical: «Sine Me potestis facere nihil». Es decir, sin la gracia caeremos en la constante circunstancia de hacer la nada, de negar la inmensa y creciente creación de la divinidad. Cualquier forma de la realidad nos lleva a Él. ${ }^{60}$

Plantea Sender aquí un concepto de nada metafísica de corte platónico, como negación del ser. Mal y nada se identificarían equiparándose al no-ser. Este concepto de nada no aparece en la Guía espiritual de Molinos; sin embargo Sender ha podido encontrarla en las disquisiciones teológicas del padre Dudon. En el capítulo XVI, siempre a través del personaje del jesuita Anglada, el concepto metafísico de la nada se amplía desde la imagen del "círculo vicioso», dando un salto a la infinitud en los siguientes términos:

-El círculo vicioso es la esfera de la ley divina. Estamos encerrados en ella como en la esfera del planeta, del sistema solar y del universo. Nunca saldremos de ellas. El ser y el no ser dependiendo el uno del otro.

Y unas líneas más abajo continúa Sender:

\footnotetext{
— ¿No se da cuenta —añadió el sacerdote- de que el círculo vicioso es el reducto donde Dios se nos oculta? [...]

-Pero nos queda su presencia en el hecho divino de esa ocultación. Esa ausencia y ese gran silencio son Dios mismo. ${ }^{61}$
}

La idea de nada aquí vertida pretende salvar el fatalismo y la paradoja del mal desde la identificación de ser y no-ser, donde se oculta lo divino. El salto ontológico fundamental se daría con la equiparación entre "ausencia»y "gran silencio» con Dios mismo.

En "La metafísica de Sender en la esfera», 62 al hilo de la comparación de nuestro autor con Antonio Machado, con quien comparte la inquietud

60 Ibid., p. 285.
61 Ibid., p. 292.
62 Francisco CARRASQUer, La verdad de Ramón J. Sender, cit., p. 102. 
por el tema de la nada, escribe Francisco Carrasquer: «Para Sender es la Nada la razón de ser del Ser, su campo de batalla y enemigo a la vez, su "complementario" antagónico». La nada molinosiana poco tiene que ver con esta concepción metafísica senderiana.

Aún encontramos la nada y la aniquilación en otro pasaje de $E l$ verdugo afable, esta vez aparentemente fuera del contexto molinosista. Nos encontramos finalizando el capítulo II. En la densa y simbólica letanía onírica oficiada por la imagen de su doble, figurado en un anciano calvo (¿imagen arquetípica para nuestro autor?), Sender escribe:

\footnotetext{
Ayer tuve que romper cada uno de los infinitos diques que me separaban de mí.

Salir del horror negando la vida entera tal como la disfrutaba. [...]

Lo iba negando todo e iba rompiendo el dique de piedra y el de acero y el de diamante, pero el más difícil era el de la niebla.

Al fin me he encerrado en mí mismo definitivamente, con todas las luces apagadas.

Hundido en mis sombras interiores ya no espero nada ni a nadie.

Pero una corriente nueva comienza a llevarme, una corriente más poderosa que la vida. [...]

De esa corriente en la que me encuentro sin saber cómo, se desprende una fuerza no antes conocida.

Esa fuerza se confunde con mi abandono y me hace poderoso.

Realmente todopoderoso, tal como me siento desde el fondo de mi humildad. ${ }^{63}$
}

Curiosamente, en este contexto aparentemente lejano a las citas expresas de Molinos y de la supuesta doctrina molinosiana - no «molinista», que dice Sender-, nuestro autor parece aproximarse más al concepto de nada y aniquilación propuesto en la Guía espiritual. La nada ascética, la nada radical aniquilación del de Muniesa, deviene pura disponibilidad, receptáculo vacío, paradójicamente, preñado de fuerza, de fuerza positiva transformante, deificadora. ${ }^{64}$

No obstante, el planteamiento general que sobre el central tema de la nada parece mantener Ramón J. Sender convendría más con la visión filosófica tradicional que arranca de Parménides que con el planteamiento radicalmente positivizador heideggeriano, más cercano, sin duda, a las filosofías orientales que a la tradición occidental. Podrían aquí convocarse innumerables citas que a lo largo de la obra del universal aragonés corroborarían la idea. Las palabras del propio Sender citadas supra aludiendo a la temporalidad como recompensa poética «de la crudeza de nuestra lucha contra la nada» o la afirmación de Los cinco libros de Ariadna: "Todos estamos obligados a dar forma al silencio y a la luz, esos dos puntos de parti-

63 Ibid., p. 44

64 Cfr. Pilar Morevo Rodríguez, «La nada, clave filosófica de la Guía espiritual», en op. cit., pp. 333-376. 
da que Dios nos ofrece para que con ellos le ayudemos a poblar la nada y a redimirnos y a redimirle a él en cierto modo del horrendo caos de los orígenes». Un planteamiento similar puede encontrarse en Don Juan en la mancebía, donde Sender identifica la locura con la nada. ${ }^{65}$

Podría, por tanto, concluir este apartado afirmando que Sender, al igual que sus intérpretes, se ha quedado con una imagen sesgada de Miguel de Molinos; aquella imagen deformada que arranca de la infame condena del maestro espiritual aragonés. De haber escuchado directamente al de Muniesa, de haber saboreado la Guía espiritual, el resultado hubiera sido muy distinto.

Para finalizar podríamos plantear las siguientes cuestiones:

a) ¿Qué papel jugaría la reiterada alusión al supuesto heterodoxo aragonés, alusión que llega a convertirse no sólo en hilo conductor sino en verdadera clave argumental de esta calificada como biográfica «novelaresumen" de Sender cumplida la mitad de la vida?

"Sender escribe "El verdugo afable" al cumplir el medio siglo de vida. Novela-resumen, es también reportaje testimonial, como muchas otras producciones del autor, sólo que en este caso vuelto hacia dentro, hacia la explicación de los propios sentimientos, en un intento de aclarar, mediante la biografía de un personaje no enteramente ficticio, su claudicación final, su caída en el conformismo, su complicidad - por omisión- en una gigantesca culpa colectiva». "Late en el fondo de El verdugo afable una desoladora confesión de culpabilidad». Con estas palabras concluye Ricardo Senabre su artículo «Una novela resumen de Ramón J. Sender: El verdugo afable».66

El profesor Senabre, quien a lo largo de su trabajo pone de relieve la "densidad considerable" de la novela, subraya en el texto citado dos ideas sólo en apariencia secundarias. En primer lugar, la nota cronológica. No ha de pasar desapercibido el hecho: Sender escribe este libro en la mitad de la vida. En segundo lugar, la interiorización, que lleva al autor a utilizar la literatura no sólo como descarga del peso de la conciencia sino como necesaria clarificación.

Partiendo de ambas premisas, concluyo esta primera aproximación al tema propuesto, dejando en el aire las siguientes interrogantes antropológicas:

b) A través de la insistente - casi obsesiva- recurrencia a la doctrina del quietismo y la aniquilación de Miguel de Molinos, ¿persigue Sender una nueva -y tal vez definitiva - aproximación a la conciencia mística como salida —o soporte - necesaria a la paradójica existencia humana?

c) La última cuestión se orientaría de manera más concreta y ceñida al Sender existencial y la enunciaríamos de la siguiente forma: ¿expresa o,

\footnotetext{
65 Ramón J. SENDER, Don Juan en la mancebía, Barcelona, Destino, 1972, pp. 16-17.

66 Ricardo SENABRE, “Una novela-resumen de Ramón J. Sender: El verdugo afable», art. cit., pp. $153-161$.
} 
mejor, proyecta Ramón J. Sender en El verdugo afable una posible necesidad hacia el proceso de individuación junguiano, a través del modelo quietista $y$ aniquilador molinosiano?

En modo alguno debe pasarnos desapercibida la afirmación que Sender pone en boca de Ramiro Vallemediano, en su decisivo encuentro con el padre Anclada:

$$
\begin{aligned}
& \text { - ¿Cuál es su ambición, si tiene alguna? } \\
& \text { - Tengo la ambición de comprender. }
\end{aligned}
$$

Acaso, Ramón J. Sender sintió con fuerza, allá en el hondón ganglionar de su existencia dramática y difícil, aquella afirmación enigmática de La esfera: "Soy un águila verdadera, sólo que tengo vértigo».

67 Ramón J. SENDER, El verdugo afable, ed. cit., p. 285. 


\title{
Una recepción privilegiada de la obra de Sender: la Inspección de Libros
}

\author{
Manuel L. Abellán \\ Universiteit van Amsterdam
}

\begin{abstract}
No ha tenido la literatura española — tanto la del interior como la del exilio e indistintamente del idiona peninsular en que fuera escrita- lectores tan atentos como aquellos que leyeron e informaron por encargo de los responsables del aparato censorio. Éste, auténtico ente camaleónico, entre 1938 y el otoño de 1976, sin jamás renunciar a su primordial objetivo -la represión cultural y literaria-, fue transustanciándose con el paso del tiempo de un improvisado Departamento de Ediciones época un tanto púdicamente velada por P. Laín Entralgo- en una Sección de Ordenación Editorial - época final-, habiendo adoptado entre ambos cabos una variopinta gama de denominaciones y organigramas de engorroso rastreo, al son de los cambios del personal político que tuvo a su frente.

Cuando el editor Saturnino Calleja, en noviembre de 1950, eleva una instancia en solicitud de autorización para imprimir una tirada de mil ejemplares de La esfera, ignora que algunos días antes el avieso lector de turno de la denominada Sección de Inspección de Libros -dependiente del Ministerio de Educación Nacional, por aquellos años- ya había dictaminado que el libro de Ramón J. Sender, «esta novela de un emigrado español, no podrá ser autorizada, a nuestro juicio, por encontrarse en ella párrafos de tendencia dudosa, como los señalados en la página 57 , relativos a la gue-
\end{abstract}


rra civil». ${ }^{1}$ Sin duda, el incontrovertible hecho de que el editor estuviera en posesión de algún ejemplar aceleró la puesta en marcha de los resortes coercitivos apropiados a las circunstancias. Algunos días después ya había sido cursada la orden de intervenir todos los ejemplares que estuvieran en circulación en el territorio nacional. ${ }^{2}$ En el caso de haberlos, dichos ejemplares debían ponerse a disposición del Instituto Nacional del Libro en conformidad con las «instrucciones reglamentarias». Para mayor seguridad se pedía a las delegaciones provinciales de Educación Popular - la organización territorial de la que dependía el control de la prensa y la propagandaverificasen si la novela había circulado o si circulaba todavía. Nada se sabe del resultado de estas gestiones. Sin embargo, a tenor de la increible precisión informativa observada y recogida sobre otros casos, ${ }^{3}$ hay que suponer que los efectos de la orden cursada fueron contundentes, máxime si se tiene en cuenta el extraordinario rigor censorio imperante en 1950.

El caso de La esfera - -según nuestra información- puede servir de ejemplo para poner de relieve una de las modalidades más corrientes de la actuación censoria y algunos de sus efectos a corto y a largo plazo. Ante un libro de importación - pensado, escrito, impreso y distribuido en otras latitudes - primariamente destinado a un público de habla castellana no peninsular, la actitud de la censura puede antojarse absurda y/o paradójica. La denegación decretada para su distribución en el territorio nacional, basada en una esporádica mención a la guerra civil, mención sin importancia, ha inducido a no pocos a tildar al aparato censorio en su conjunto de cavernícola, carpetovetónico, incompetente y arbitrario. Mientras ésa fue la imagen prodigada por censura entre sus víctimas - autores y lectores - la reacción de éstas estribó en quitarle fuego al hierro y remitir, éste y otros numerosos casos, al mundo de las estupideces humanas dignas de conmiseración: el lobo no era tan feroz como lo pintaban. ${ }^{4}$ Sin embargo, mediaba

\footnotetext{
${ }^{1}$ La supuesta gravedad del irreparable pasaje arroja bastante luz acerca de la susceptibilidad de quienes estaban acostumbrados a imponer su voluntad a los demás. Véase: «Preguntó a Saila si sabía jugar al ajedrez y al decir Saila que sí se le iluminó el rostro. Tell miraba a Saila y al viejo como si estuviera ante dos idiotas. Mr. What comenzó a hablar de la guerra de España. Él era amigo de algunas de las personas complicadas en los trámites diplomáticos que habían dado el triunfo a los fascistas. Ese triunfo era cosa decidida desde hacía más de dos años».

2 Hay dos instancias del editor Saturnino Calleja con idéntica fecha (13-XI-1950) e idéntico número de expediente (5872-50); en una se solicita la impresión de mil ejemplares y en la otra la importación de un número indeterminado de ejemplares.

3 Sobre la información acerca de los títulos de obras de importación puede verse a propósito de Paradiso de Lezama Lima mi artículo «La censura franquista y los escritores latinoamericanos", Letras Peninsulares, 5/1 (1992), pp. 11-21.

${ }^{4}$ Creo que ha sido éste uno de los efectos de mayor alcance de las intervenciones censorias durante el régimen franquista. A ello habrá contribuido no poco la naturaleza de la transición política, la desidia investigadora de los especialistas en literatura contemporánea y un pseudo-periodismo de investigación, pero de talante sensacionalista, que ha convertido en lectura «inefable» - por entregas - la documentación censoria.
} 
un verdadero abismo entre las medidas tomadas —orden de intervención de los ejemplares, más prohibición de importación y venta- y la objeción hecha contra algunos párrafos de tendencia dudosa como el mencionado. Señalar la obvia imposibilidad de enmienda en una página concreta de ese libro de importación eludía exponer mayores considerandos y la cuestión quedaba zanjada. El lobo cerraba sus fauces porque no iba a haber cordero, mientras el público se regocijaba en la inveterada estulticia censoria.

Dieciocho años más tarde, en el momento álgido de remozamiento aperturístico de puertas hacia fuera, cuando la obra de Sender se editaba ya pródigamente, salen a relucir las innumerables objeciones que en 1950 habían quedado reducidas a unas líneas de página. El personaje principal era un español republicano, huido tras la derrota del Ebro. El argumento de la obra, aunque sencillo a los ojos de los distintos censores, tenía un cariz simbólico raro, futurista casi, de temática religioso-parabólica de difícil interpretación según unos lectores, mientras según otros Sender pretendía decir que "la religión constituye una necesidad vital, aunque esté adulterada. Pero las religiones son creaciones humanas y el hombre es un lobo para el hombre. La curiosa teología de Sender está diluida en todo el libro». Teología privativa o alegoría profética, las propuestas de dichos lectores señalan numerosos párrafos suprimibles: llamadas a la violencia, justificación del suicidio, calificativo de fascista a los vencedores de la guerra civil, mención a los masones e ideas sobre la religión y la sexualidad. Al decretar la prohibición de venta e importación le habían ahorrado al virtual lector de La esfera, en 1950, toda clase de esfuerzos hermenéuticos. ${ }^{5}$ Pero tanto en 1950 como en 1968 a los atentos censores del servicio les había guiado el criterio de cortar de cuajo cuanto en La esfera rezumaba ideas o juicios en discordia con la cultura que debía imperar en la sociedad del franquismo.

El segundo intento de Ramón Sender, o del editor José Janés, por publicar en España Crónica del alba, Hipogrifo violento y La quinta Julieta se inició al comienzo del verano de 1955. La obra fue autorizada formalmente sin que hubiera ni siquiera una tachadura. El lector especialista y asesor

5 Los censores señalaron numerosos párrafos suprimibles. Las páginas 25, 27, 28, 29 y 33 , donde se aplica el calificativo de "fascistas" a los "nacionales»; referencias a masones en la página 114: «a los curas les irrita ver el espíritu religioso (la piedad y la solidaridad humana de los francmasones, por ejemplo) fuera de la iglesia"; numerosas otras páginas referentes a temas religiosos y sexuales, como las $121,129,134,135,144,149,154$ y 156 de las galeradas. La tachadura en esta última era: "falta en el calendario católico una fiesta: la del exterminio y renovación de los curas lascivos». En la página 194, la afirmación de que «los milagros los hace la humildad y él [el papa] es demasiado ostentoso y suntuarion. Agradezco a Claudia Ulferts buena parte de la documentación que utilizo en este artículo. Sus horas de búsqueda en los Archivos de la Administración Civil de Alcalá de Henares se concretizaron en una excelente tesina de final de carrera presentada en la Universidad de Hamburgo en 1990, titulada: Die Literaturzensur unter Franco und ihre Auswirkungen auf den Versuch der Veröffentlichung spanischer Exilromane zwischen 1950 und 1975. 
religioso fray José Cuervo López dictaminó parcamente: «tiene páginas fuertes, pero puede permitirse su publicación». El día 7 de junio se firmó la tan codiciada tarjeta de circulación según la cual «vistos el informe del Lectorado, las disposiciones vigentes comunicadas por la Superioridad, esta Sección estima que la obra a que se refiere este expediente puede ser autorizada». Lo que sucede entre esta fecha y finales de abril del año siguiente es un enigma. La obra de Sender, debidamente autorizada, no se publica o no se distribuye, si acaso fue impresa. No hay rastro de ello. Tampoco se ha conservado correspondencia o documentación alguna. Lo cierto es que el editor vuelve a presentar con fecha 3 de abril de 1956 una instancia en solicitud de autorización para imprimir la obra. Nuevamente es autorizada a propuesta del jefe del Lectorado por el jefe de la Sección de Inspección de Libros, Joaquín Úbeda. El informe del lector rezaba así: «Un relato autobiográfico de la adolescencia del autor. La primera obra [sic] su vida pueblerina y sus amores infantiles con Valentina. Ante éstos sus padres deciden su internado. En el segundo tomo, su vida de colegial con todas las peripecias consiguientes. El tercero le lleva otra vez con su familia a la ciudad. Ahora cuenta su choque con ella, el progreso de sus amores. Son unas expansiones poetizadas de un capitán del ejército rojo que murió en un campo de concentración francés en el mismo año de la derrota. Pero no es un resentido. No hace ninguna alusión política de ninguna clase. El relato es totalmente limpio. Procede su autorización». Como puede observarse, este informe se refiere a los tres volúmenes. No se trata sólo de lo que años más tarde se convertirá en Crónica del alba I. Una nueva tarjeta de circulación será expedida con fecha 5 de mayo de 1956 hasta que el día 22 del mismo mes Florentino Pérez Embid, Director General, decida denegar rotundamente - son sus palabras - la autorización propuesta por razones de carácter político. Además, en una nota de su propio puño y letra, escribe: «Ramón Sender, a quien he conocido en persona, era un comunista fino, procedente del izquierdismo pequeño burgués, es decir, del sector masonería-vegetarianismo-fraternidad. Por los años de la República tuvo bastante difusión una novela suya que se llamaba Siete domingos rojos o algo así. Tuvo bastante popularidad entre el sector "chíbiri" y hoy está olvidado casi por completo. Actualizar ahora su recuerdo con una novela autobiográfica, es echar los cimientos de un nuevo "caso Miguel Hernández". Políticamente me parece descabellado autorizar esa obra, aunque, al parecer, el lector, desconociendo los antecedentes a que aludo, haya informado correctamente [...]». La referencia a Miguel Hernández resulta a todas luces enigmática y sin parangón posible, salvo que, desde su rancio opusdeísmo, fuera meta política importante evitar a toda costa la actualización de cualquier escritor «rojo» en vida o a título póstumo. ${ }^{6}$ Parece lógico que así sea ya que son los antecedentes políticos -su

6 Seguramente debido a la acumulación de experiencias, los censores, al comienzo de los
años sesenta, iban con pies de plomo a la hora de dictaminar sobre las obras de los exiliados. 
actuación durante la guerra civil- y su condición de escritor exiliado - un desconocido para las nuevas generaciones - lo que impele a intervenir tan rotundamente.

Si La esfera había dado lugar a muy pocos trámites internos en 1950 por tratarse de un libro de importación y, como era de esperar, los problemas surgieron al editarse en España en 1968, con Crónica del alba iba a ocurrir todo lo contrario. Salvo el prólogo de Luis de Capdevila ${ }^{7}$ —que sería suprimido- el texto sale indemne de la prueba, lo cual viene a confirmar que los llamados antecedentes habían sido el dique de contención contra la intrusión de la literatura del exilio en 1950. Pero, una vez sólidamente consolidado el franquismo y habiendo ya generado una generación de leales servidores, el espantajo del exilio era superable. Los escritores de inoculada rojez, prestos a execrar la ruindad vengativa de los nacionales, podían ser editados. ${ }^{8}$ Así dio comienzo en la década de los sesenta una diplomática campaña de guante blanco hacia este tipo de escritor de la que Ramón Sender se benefició sin duda. La campaña sobre los "veinticinco años de paz», es decir, de consolidación e irreversibilidad del régimen, fue

De Max Aub había sido denegada la importación de ejemplares de Sala de espera (1951), Yo vivo y No (1953) aunque se autorizara la de dos ejemplares de su obra teatral San Juan (1951). La importación de Las buenas intenciones - autorizada en 1968- había sido prohibida en 1954. En 1959 se prohibía La calle de Valverde _editada en Méjico, en 1961 - pero se autorizaba en 1967, el mismo año en que se vetaba Campo de sangre. Cuando en 1960 la Editorial Aguilar intenta dar a la luz pública unas Novelas completas de Francisco Ayala, el jefe del Lectorado anota: «jFrancisco Ayala es un exiliado!». Dichas Novelas completas acabarán publicándose en Méjico en 1969. El gran obstáculo era entonces La cabeza del cordero, obstáculo que persistió en 1974 hasta que en plena transición hubo una edición íntegra en Cátedra (1978).

7 «Lo que no cabe duda, es que de la lectura del prólogo se nota un matiz tendencioso contrario al régimen. Los personajes que resultan loados o con los que hay corriente de simpatía son notorios desafectos al régimen como Arturo Barea, Pablo Casals, etc. Los conceptos que se vierten son desintegradores respecto al orden político con una condenación expresa del hombre en cuanto "político". Se nota la exaltación de los vencidos en la contienda, a los que idealiza como hombres de temple, hombres plenos de dignidad, etc. Se crea un confusionismo para el lector no avezado en el juicio de estas cuestiones. Parece ser que no es preciso ser vate, para adivinar que la referencia de la pág. 5 a Federico, es a García Lorca AsEsINADO. En resumen, tiene una intencionalidad política contraria a la situación actual el conjunto del texto, que dice BASTANTE MÁs de lo que en imprenta se expresa".

8 Podían ser editados, siempre sub conditione, como se desprende de los numerosos comentarios que afloran en los informes censorios: «La parcialidad antifranquista y en definitiva antinacional --escribía uno de los lectores a propósito de Campo de sangre-- potenciada por las excepcionales facultades literarias de un artista como Max Aub resulta [...] peligrosa". $\mathrm{O}$ aquel otro sobre El rey y la reina de Sender: «Con el carácter tendencioso de la mayoría de las obras de Sender, esta novela no es una excepción en la lista general». Consideraciones de este tipo se exponen con regularidad en notas personales para orientación del ministro. Así, en abril de 1964, sobre La cabeza del cordero: «nos presenta unos cuadros de nuestra última guerra, de sus antecedentes y de sus secuelas, cargados de sentido polémico antinacional y de fervor frentepopular. Aun suponiendo que las dos facciones contendientes pudiesen reprocharse mutuamente demasías e injustas represalias, siempre sería maliciosa, y descaradamente parcial la versión novelesca de Francisco Ayala». 


\section{EL LUGAR DE SENDER}

precedida, coincidió y se prolongó mediante una cautelosa política de guiños a los escritores del exilio, por un lado, y por otro mediante una feroz represión contra los díscolos del interior -escritores, sindicalistas, obreros, estudiantes, clérigos-, que aguaban los faustos de la efemérides. Sin embargo, como pronto se vio, el regreso de la obra antigua o nueva de los escritores del exilio quedaría supeditado al criterio político de la Superioridad. Crónica del alba I y Crónica del alba II no sufrirán ninguna contrariedad ya que el período que abordaban era relativamente lejano en el tiempo al contexto histórico, social y político de los orígenes del franquismo, lo cual no obstó para que alguno de los lectores de la Inspección de Libros se aviniera a señalar que «no falta[ban] algunas irreverencias religiosas, alusiones anticlericales y páginas de fuerte erotismo al relatar los amores del protagonista con la aldeana y sensual Isabelita en Alcañiz».

En 1965, la Editorial Delos-Aymá obtiene el visto bueno para el primer volumen de Crónica del alba y anuncia para 1966 el resto de la trilogía. Con una diferencia de meses aparece también en ese mismo año, publicada por Destino, El bandido adolescente.$^{9}$ La prensa especializada, las revistas ya casi de antiguo dadas al aperturismo literario - Insula, Indice-, se hacen eco del fenómeno, ${ }^{10}$ así como la Estafeta Literaria, vocero oficial del Ministerio de Información y Turismo. Eduardo Toda, cónsul general en Los Ángeles, trata de relacionarse lo más posible con Ramón J. Sender, sin dejar de informar puntualmente a su querido ministro y amigo, Manuel Fraga: "agradezco mucho tu comprensión y buen interés en el asunto Ramón J. Sender - le escribe en junio de 1966-, conforme a tu carta de 4 del pasado mayo. Puedo añadir ahora que el domingo 19 de los corrientes estuvo cenando en casa - a la que venía por primera vez- en compañía de la poetisa panameña Elvira Álvarez y de mi mujer, pasando más de cuatro horas en muy amigable compañía, sin el menor incidente de ninguna clase. $\mathrm{Al}$ contrario, nos regaló el primer volumen de Crónica del alba, dedicado, recién publicado, como sabes, en España. Creo, pues, que las gestiones van bien encaminadas y espero que los otros dos volúmenes de su interesante obra puedan también aparecer en nuestro país. Recibí el ejemplar de

9 «Cuenta las andanzas de un "desesperado" — con aires de leyenda. Billy, protector de los mejicanos y morenos frente a los anglosajones. Al relato prolijo de sus aventuras une reflexiones y argumentos de la moral del ambiente de los apartados de la sociedad, envueltos en diálogos, pero por el volumen de páginas entendemos va dirigida a mayores. Recoge canciones y folklore de la época y expresiones que por cierto pone en inglés muchas veces». Hay un segundo informe, también positivo: "Prolijo relato de los numerosos crímenes de "Billy the Kid", célebre pistolero, defensor de los mejicanos, que comenzó dando muerte, cuando era niño, al hombre que ofendió a su madre y terminó asesinado por un traidor que consiguió confiarle como un amigo».

${ }^{10}$ Una primera aproximación cuantitativa a la presencia de los autores del exilio en las páginas de las revistas del interior puede verse en mi artículo «Los diez primeros años de Ínsula (1946-1956);, Sistema, 66 (1985), pp. 105-114. 
la Estafeta Literaria con la crítica muy favorable a su novela El bandido adolescente que le mandé y le agradó mucho».11

Aunque el jurado del Premio «Ciudad de Barcelona» otorgara unánimemente el galardón a los dos primeros volúmenes de Crónica del alba, una cosa era la diplomacia del guante blanco y otra que pudiera difundirse el tercer volumen, donde el autor ofrecía «una visión personal como actuante ocasional en la zona nacional —el sector de Aragón, tierra del escritory en la zona roja, a la que se pasó con un aviador que, desde Francia, se proponía salir para América». ${ }^{12}$ Las imágenes que desfilaban por la Crónica III podían antojárseles repelentes, amargas, innobles, turbias o indeseables a los lectores de la Inspección de Libros, para quienes la obra era un claro exponente de la «España que volvió la espalda al orden, a la auténtica libertad, a la verdadera democracia y al progreso». Desde esa perspectiva, no careció ni de coraje ni de coherencia el lector anónimo que defendía la publicación de la obra —con las debidas supresiones y modificaciones - ya que el panorama esbozado por Sender era «la visión que todo el mundo [debía] conocer para evitar que jamás volviera».

Fue, sin embargo, la lectura del censor militar la que puso todo el peso en el platillo de la balanza. Tras afirmar el personal anarquismo de Sender, su caracterial indisciplina, sus ataques al comunismo, a la Iglesia, al Ejército, a la Monarquía y a la misma República, el lector especialista establece diáfanamente lo que sigue: «Ante todo es ofensa para el militar, llegando a suponer que todos son ladrones $\mathrm{y}$ ofende a sus viudas como libidinosas en general, se burla del honor militar. Expone la traición con naturalidad prácticamente aprobatoria [...] bromea a propósito del fune-

11 Esta política de "atracción" del exiliado ha dado lugar a curiosos contactos, interesante correspondencia y escritos de diversa índole. Si Sender establece contactos con el cónsul de Los Ángeles Eduardo Toda y en Madrid con José L. Ponce de León, Francisco Ayala, en 1963, se dará cita en un restaurante madrileño con Manuel Fraga, encuentro al que se referirá en Recuerdos y olvidos, Madrid, Alianza Editorial, pp. 501-502, haciendo mención al juicio de Fraga "es un gran escritor pero no es buena persona" en su Memoria breve de una vida politica. Un año más tarde, tras algún escrito mediador de José Ortega, desde Nueva York se dirige a Fraga, en carta con fecha del 30-III-1964, preguntándole «si no habrá llegado el momento de que una casa editorial [...] publique mis narraciones coleccionadas en un solo volumen para ponerlas al alcance de los lectores a quienes ese tipo de literatura interesa. Tal edición no tendría sentido para mí a menos que pueda hacerse sin supresiones, que por lo demás — seguro estoy- ni usted ni el Sr. Robles Piquer considerarán indispensables, pero que en cambio algún subordinado de menos amplio criterio pudiera creerse obligado a proponer". La respuesta de Fraga del 8-IV-1964, a vuelta de correo, es: «en esto como en otras materias es muy conveniente proceder con cuidado si queremos evitar errores que tan perjudiciales han sido a nuestro país en los tiempos contemporáneos".

12 «Ramón Sender parece querer colocarse en el terreno de la pura objetividad, de la pura especulación, por encima de uno y otro bando, apoyándose en la eterna condición humana y sus contradicciones. Sin embargo, como alude, si no enjuicia, al Ejército y a la Guerra Civil española aunque sea a través de algún Coronel y episodios de la retaguardia - conforme puede verse en las páginas 122, 135, 141, 194, 196, 197, 392, 401-409, 585, consideramos aconsejable que este libro sea examinado por algún lector militar». 
ral de Calvo Sotelo y nivela la represión y ensañamiento en zona nacional y roja, explica el Alzamiento como defensa de privilegios [...] no aparece ni un oficial honrado ni una viuda de militar decente, se burla del honor militar, del patriotismo y se justifica la traición por amor [...]». No menos de setenta son las páginas que incurren en delitos tipificados por el Código Penal y los preceptos de la vigente ley de Prensa e Imprenta. A todo ello se añaden los repetidos ultrajes a la religión católica, a la divinidad de Cristo, a los evangelios, a los eclesiásticos. En esas condiciones la obra era absolutamente impublicable y, en caso de hacerlo por el método del depósito legal, el editor se exponía a la denuncia de oficio con todas las consecuencias económicas y penales. Azorado, el editor recurrió ante el Director General exponiéndole que estaba abocado a una obligada suspensión de pagos. Estaba dispuesto a aceptar ciertas supresiones pero desconocía si el autor llegaría a aceptarlas también. Ramón J. Sender debió aceptar todas las tachaduras y modificaciones impuestas a su Crónica III. ${ }^{13}$ En mayo de 1967 se presentaron las galeradas y fueron halladas conforme. Las modificaciones y supresiones afectaron a cuarenta y un pasajes en total.

Mucho es de temer que el texto original del manuscrito de Sender no ha sido restituido en las sucesivas reediciones, quedándose así rematado el triunfo final del aparato censorio sobre la cultura literaria: los vencedores siempre ganan. De eso se trataba, de impedir la difusión de una creación literaria opuesta o en disonancia con aquella acariciada por el franquismo, como se expresaba en la parodia senderiana del sermón patriótico-religioso de la página 396, señalada por el censor militar, presumible parodia del Cara al sol: «Señoras y señores, la patria llama al cumplimiento de nuestro deber de españoles y al sacrificio de nuestras vidas y haciendas. Así que ya ven. Por la fe al lucero. El centinela vigila en el imperio. Caigamos al sol. La sangre de los héroes y el sudor de los santos corren por las venas de los españoles de mañana. Digo, del pasado glorioso. $Y$ el corazón nos revienta debajo de la camisa por un estado, un caudillo, un ideal y una Santísima Trinidad».

\footnotetext{
13 «[...] se me comunica que la difusión del tercer tomo de Crónica del Alba, de Ramón Sender, caso de ser editada, sería impugnada de acuerdo con la vigente Ley de Prensa e Imprenta. Debo confesar a V. I. que el contenido de dicho escrito me ha sorprendido y consternado en grado sumo. Teniendo en cuenta que de C. D. A. se han publicado ya los dos primeros tomos y que, a juicio del que suscribe, en los tres tomos (nueve novelas) que constituyen la obra, su autor demuestra un gran espíritu de comprensión y manifiesta voluntad de diálogo, no esperaba obstáculo alguno para la puesta en venta del tomo tercero y último. Además, y éste es para mí el aspecto más doloroso y trascendental de la cuestión, tengo que manifestarle que la no publicación del tercer tomo no sólo me causa un grave perjuicio económico por el mucho dinero invertido en el mismo [...] sino que al quedar truncada por tal motivo la serie, el daño adquiere tal importancia que --siento tener que exponerlo tan crudamente-puede significar para esta editorial, tan modesta hoy, la ruina y quizá una obligada suspensión de pagos $[\ldots]$ ».
} 
La difusión de la obra narrativa de los autores del exilio en la España del franquismo fue intermitente pero posible en la medida en que esa producción literaria no pusiera en entredicho los cimientos del régimen. $Y$, aun cuando así fuere, había dentro de éste personajes con patente de corso para alardear de ficticias polémicas, en tonos y sobre temas en parte vetados al común de los mortales. Un buen ejemplo de ello fueron los comentarios de Juan Fernández Figueroa en Índice, en 1951, en torno a otra obra del exilio - Campo abierto de Max Aub-, ${ }^{14}$ o las devotas alusiones a la poesía de León Felipe. ${ }^{15}$

Max Aub, Francisco Ayala y Ramón J. Sender, como máximos exponentes de la narrativa todavía sobreviviente en el exilio, trataron de capear como bien pudieron el toro de la censura. Con supresiones o sin ellas lograron editar o reeditar algunas de sus obras. Max Aub tuvo que esperar 12 años para que Las buenas intenciones (México, 1954) apareciera, censurada, en España. ${ }^{16}$ La calle de Valverde fue presentada en España a censura en 1959, antes de que tuviera que salir a la luz en México, produciendo un interminable trasiego de informes entre los lectores del montón al de los especialistas; todo ello dio lugar a su prohibición. ${ }^{17}$ En

14 «Max Aub ha abierto con Campo abierto un capítulo, en el que se oyen con frecuencia, a través de la sangre, latidos de verdad. Hay que dejar aparte ese capítulo, escribir otro igualmente extremoso e injusto y fundir ambos. Lo que salga puede no ser una novela, sin duda no será una novela; pero sólo con los materiales de lo que salga puede conseguirse algo que se aproxime a la verdad que todos en el fondo de nuestra conciencia reconoceremos como única verdad. He querido corresponder a la muestra de confianza de Max Aub enviándome su libro con estas precipitadas reflexiones y en las que nadie puede ver el menor ánimo de discurso. A su hora estuve en la trinchera en que creí mi deber estar. Cincuenta metros por medio, disparando, los amigos de Max Aub. Puedo jurar que no sentía, ni he sentido nunca, el menor odio contra ellos; contra nosotros, pues desde un plano superior de vista, desde la hondura de la sangre y el espíritu, ellos y nosotros somos uno, somos los mismos, salvo la porción de mentira que nos diferencie, desuna y separe -según la cual, en definitiva, cada uno recibe su merecido" (Índice, 53 [1951], pp. 1 y 16). Huelga decir que, en 1951, escasísimos debieron de ser los lectores del libro de Max Aub y menos todavía quienes pudieron permitirse el lujo de un comentario en la prensa de aquellos años.

15 Para un exhaustivo análisis y estudio de las relaciones entre política y literatura bajo el franquismo a través de esta revista puede verse Jereon OsKam, La revista «índice» durante los años 1951-1976 (tesis), Amsterdam, Universiteit van Amsterdam, 1992, 318 pp.

16 «A pesar de las conocidas tendencias políticas del autor [...] la obra carece de toda agresividad contra el actual Régimen español. Aún más, en conjunto, la República aparece desfavorecida en las pocas y breves alusiones que se hacen en ella». Otro de los lectores señalaba que como políticamente «Max Aub es anarquista, su odio principal es el comunismo», con lo cual la novela era publicable con las supresiones indicadas que en nada restaban calidad literaria. $\mathrm{Y}$ así se hizo.

17 El sacerdote M. de la Pinta Llorente, asesor religioso, escribe: «Hay referencias sobre personalidades, cuyas familias naturalmente viven, y dejar pasar por censura algunas de esas referencias, podrían derivar en trastornos y realidades más o menos escandalosas en la vida social de ahora, perjudicando gravemente a la censura». Aconseja tachaduras en más de sesenta páginas. Ocho años más tarde un lector anónimo dictamina todavía: «naturalmente la obra, y a pesar del tiempo transcurrido, no es publicable en su totalidad». 
1967, se autorizó con tachaduras aunque reconociendo que "puede que haya habido un exceso de rigor en algunas supresiones $[. .$.$] pero hay cosas$ que a pesar de no ser estrictamente antijurídicas suenan todavía muy fuerte en los oídos del público español». Muchos años deberá esperar el indefenso - aunque protegido - público español para leer la serie del Laberinto mágico sin que le dolieran los oídos. Salvo la doble edición de Campo del moro (Andorra y Barcelona en 1969 y 1970 respectivamente), con supresiones y correcciones, ${ }^{18}$ deberá esperarse hasta final de la década de los setenta y comienzos de los ochenta, a caballo entre la transición y la consolidación democrática, para gozar de la lectura de una obra publicada treinta y cinco años antes como Campo cerrado, treinta y tres como Campo de sangre, veintisiete como Campo abierto, catorce como Campo francés o bien tres años como Campo de almendros.

A Francisco Ayala tampoco le sirvió de nada ni el contacto directo con el ministro de Información y Turismo ni la mediación de determinadas personas para sacar adelante su primer proyecto de Novelas completas, a cargo de la Editorial Aguilar, en 1960, ni tampoco, más tarde, el de Obras completas y cuatro cuentos más. ${ }^{19}$ Tanto Los usurpadores como La cabeza del cordero y Cazador en el alba salían en exceso malparados de las lecturas realizadas por la Inspección de Libros, razón por la cual tardarán más de diez años en verse impresos en España, con las debidas enmiendas y supresiones. ${ }^{20}$ Sin embargo, La cabeza del cordero es un caso aparte ya que será auto-

\footnotetext{
18 Si Campo de sangre había sido juzgada impublicable por antinacional y por parcialidad antifranquista en 1967, dos años más tarde, en 1969, se autoriza Campo del moro aduciendo que "tiene gran categoría literaria, histórica y humana, muy superior a novelas como, por ejemplo, la de Lera sobre el mismo tema [...] hay detalles de gran emotividad, ternura e ironía. La España nacional es juzgada naturalmente como enemiga pero sin nada peyorativo. Al contrario se vuelca sobre la propia España republicana, desunida y abocada a la derrota inevitable». Como argumento final se señala también «la importancia de que pueda decirse que precisamente esta novela se ha publicado íntegramente en España».

19 Esas Obras completas y cuatro cuentos más incluían los siguientes relatos autorizables integralmente: Boxeador y un ángel, Cazador en el alba, Historia de macacos, Medusa artificial, A las puertas del Edén, Una lección ejemplar y Los usurpadores. Ofrecian graves problemas El as de bastos (páginas $27,28,39,40,41,42,59,61$ a 73 y 80) y La cabeza del cordero, con tachaduras propuestas de la página 9 a la 23, la 25, de la 65 a la 91 y de la 178 a la 187, además de numerosas otras páginas donde se hablaba de pillajes, horrores y atrocidades cometidas por los nacionales.

20 En algún que otro caso las recomendaciones y apoyos surtieron el deseado resultado. Así ocurrió con el volumen de cuentos titulado El rapto, violaciones y otros inconvenientes, a pesar del dictamen extremadamente negativo de los lectores. Jorge Cela Trulock, en carta a Faustino G. Sánchez Marín, jefe de Orientación Bibliográfica, en defensa de la publicación de la obra, le argumentaba: «[...] como te decía, Paco Ayala es una reconquista, en primer lugar de Camilo José con su revista Papeles, y después de Alfaguara. Reconquista es. Ayala de espaldas a España quiere publicar, pero publicar aquí, y creo que esos trozos no convenientes, al ser únicamente algo fuertes, no más que otros muchos a los que no se les ha puesto reparos, quizá no deberían ser quitados. Es agradable ver que ese tipo de personas vuelvan a lo suyo de nuevo. Sería una pena, por tan poca cosa, no ayudar a su vuelta».
} 


\section{MANUEL L. ABELLÁN}

rizada en versión censurada sólo para la exportación en 1972, hasta que salga a la luz la versión íntegra de Cátedra, ya en 1978.

Para Ramón J. Sender, una vez pasado el cabo difícil de 1966, el horizonte quedará despejado y colocará en el mercado editorial peninsular una cantidad impresionante de obras: Jubileo en el zócalo, La aventura equinoccial de Lope de Aguirre, La llave y otras narraciones, Tres novelas teresianas, El rey y la reina, La esfera, Las criaturas saturnianas, Mister Witt en el cantón, Tres ejemplos de amor y una teoría, En la vida de Ignacio Morel, La luna de los perros, La antesala, El fugitivo, Páginas escogidas, Relatos fronterizos y, por fin, Réquiem por un campesino español en 1974 e Imán en 1976, ya en la línea de llegada a la transición.

Entre 1966 y 1976 sólo fueron vetadas -es un decir- tres obras de Sender: El verdugo afable, El lugar de un hombre y Los noventayochos. Examen de ingenios. En la primera - cuya edición era de 1952, Chile- se achacan el mal gusto, la chabacanería, la incitación a la violencia, la mofa de la religión, de los obispos y del papa, pero también «exagerado está, por ejemplo, que Ramiro, disfrazado de mujer, ingrese tan fácilmente en el convento y posea a dos novicias, dejando embarazada a una. Exagerado está el episodio de su amor por la sirena. O por la prostituta Canamón. Idealizados todos los tipos anarquistas, que jamás presentan ningún rasgo negativo». Pero tanto en ésta como en El lugar de un hombre la censura no está dispuesta a admitir distorsiones y falseamientos históricos contra la Guardia Civil, atribuyéndole salvajadas.

Si de este azaroso decurso seguido por la obra de Ramón J. Sender -así como de otros relevantes escritores del exilio- se pudieran extraer algunas conclusiones, éstas podrían resumirse en dos: 1) al habérsele ocultado al lector de a pie, al consumidor de lecturas, las innumerables manipulaciones que han precedido la publicación de una obra de un escritor del exilio, el lector o el crítico ha tendido, bien a sobrevalorar la amplitud de miras del aparato represivo, bien a considerar como fenómeno ineluctable - por falta de racionalidad - la práctica censoria llevada a cabo, y 2), en los casos de máxima permisividad, apertura y benevolencia, esta actitud siempre ha estado supeditada al reconocimiento de la legitimidad fundacional del régimen. En la medida en que el acceso de la literatura del exilio fortalecía dicha legitimidad, su difusión en la España de aquellos años era reconquista, el último estertor de la batalla contra los empecinados en no reconocer la victoria. 


\title{
La mirada equinoccial de Sender ${ }^{1}$
}

\author{
Juan Emilio Estil.les Farré \\ Universidad de Zaragoza
}

\section{EL ACCESO A LA DESCRIPCIÓN LITERARIA}

La metodología con que suele abordarse la descripción, derivada todavía del mundo de la Retórica, polariza sus apreciaciones en dos alternativas teóricas que, a mi juicio, empobrecen su naturaleza estética: o bien sitúan la descripción en el análisis del estilo, la caracterización y el funcionamiento del relato, o bien abandonan toda perspectiva al aislar excesivamente la descripción en el arte del retrato y el paisaje.

Inmersos en estos presupuestos, vemos en la descripción un conjunto de recursos estilísticos, una figura, un adorno, un constituyente del espacio o el personaje, un tipo de texto, una función lógica, uno de los sucesivos niveles que supuestamente intervienen en la construcción

\footnotetext{
1 Empleo la edición de Magisterio Español (col. «Novelas y Cuentos»), 1968. Como señala VIVED Mairal (1992, p. 264), "Avanzado 1963, Sender se compró una casa en Manhattan Beach y allí comenzó su vida al margen de la docencia. Puso su empeño en la escritura de $L a$ aventura equinoccial de Lope de Aguirre, editado en 1964 en Nueva York por Las Américas. Hacía años que le rondaba la idea de escribir sobre un tema que ya conoció cuando leyó en la década de los veinte La expedición de Ursúa al Dorado y la rebelión de Lope de Aguirre, del oscense Emiliano Jos. Sobre este libro redactó una crítica en El Sol». Sender señala el uso de esta fuente en el cap. VIII, entre otros, de la novela.
} 
narrativa ${ }^{2} \mathrm{u}$ otra clase de principio cerrado ${ }^{3}$ cuya esencia se diluye, en ocasiones, en un criterio tan pedestre como el de su extensión. ${ }^{4}$

Esta concepción, perpetuada por el Formalismo, ha contribuido a que consideremos la descripción como un fenómeno esencialmente curioso cuya aparición hay que, por tanto, justificar. Es una sensación que domina en la narrativa de Sender, como veremos.

La descripción se nos aparece así como un elemento sin entidad propia y ante cuya ausencia y limitaciones no sabemos muy bien qué decir porque sólo tenemos ojos para su presencia. Y considero que precisamente desde ahí debería plantearse una reflexión estética sobre la descripción, en la investigación sobre sus negaciones: por qué se omite históricamente la descripción y de qué modo se ha pretendido superar lo indescriptible. ${ }^{5}$

Los esfuerzos de la teoría han optado, sin embargo, por señalar cómo es, dónde está y para qué sirve: 6 han partido, pues, de lo fenomenológico, en una premura por atender las manifestaciones de superficie que bloquea el establecimiento de su verdadera naturaleza. $Y$ el máximo resultado obtenido por este camino lo constituye la oposición ya fosilizada entre descripción y narración?

${ }^{2}$ El mismo Sender, en una particular visión de tales niveles, sitúa en uno de ellos la descripción: «[en Crónica del alba] está lo idílico, lo siniestro; hay amor y odio; hay desesperación y esperanza; hay voluptuosidad más o menos cínica; hay tonos líricos; tonos narrativos de realismo directo; hay sátira; hay un humor sostenido, a veces muy agrio; hay los cinco niveles usuales de la expresión: lo sensual muy fuerte, quiero decir la descripción física (como decían los que traducen mis libros al braille para los ciegos. Decían que los lectores ciegos querian todos mis libros porque veían en ellos la realidad física mejor que en otros. A mí me gusta mucho eso). De modo que está lo sensual muy concreto, está lo afectivo, lo intelectual -que yo creo es lo que domina-, lo espiritual y lo onírico» (Conversaciones, p. 159).

3 El origen de este panorama se halla, bien es cierto, en un rasgo que en la descripción es inherente: la facilidad con que puede ser localizada y aislada; pero que ha sido sobrevalorado por el reduccionismo textual propio del Formalismo.

${ }^{4}$ De hecho, y desde la retórica clásica, gran parte de la reflexión que ha suscitado el fenómeno descriptivo se nutre teóricamente en el análisis de la digressio o parékbasis.

5 Estas dos negaciones constituyen la naturaleza estética de la descripción y la convierten en un caso único, pues sólo en la descripción esa debilidad teleológica se convierte en rasgo constituyente. El fracaso de la voz del descriptor es esencial: muchos géneros narrativos no describen y muchos autores asumen lo indescriptible; pero es algo más que un problema lingứístico, retórico o gnoseológico, es un atributo estético de la descripción literaria. Adoptando este enfoque pretendo llevar a la práctica las propuestas de BAjחíN (1924) sobre El problema del contenido, el material y la forma en la creación literaria.

${ }^{6}$ Esta reducción narratológica a que se ha visto sometida la descripción lleva implícito que no se conciba sino marginalmente la posibilidad de un género descriptivo, tanto en la teoría como en la práctica literarias.

${ }^{7}$ La sintonía que tradicionalmente ha existido entre la teoría y la práctica de la descripción - superior a la que se da en otros fenómenos- nos llena de interrogantes. La literatura, presa de la teoría, ha permanecido tantos siglos describiendo sin observar - sin intención de describir por tanto- que la descripción ha tenido que dotarse a sí misma de sentido; pero no es fácil advertir si no pudo ser de otro modo a raíz de una supuesta esencia de los relatos o ha sido la teoría literaria la causante de tal situación. 
Es este aislamiento lo que ocasiona que nuestros comentarios sobre las descripciones sean habitualmente valoraciones impresionistas o poco ceñidas al caso del que se parte y sean, de hecho, extrapolables a obras de la más variada índole.

\section{FUNDAMENTACIÓN DE LA DESCRIPCIÓN EN SENDER}

Los estudios sobre la descripción senderiana se ven afectados por estas carencias. Y suelen, cómo no, hacer referencia al estilo, a su posición - su función - en el relato y su extensión textual. Peñuelas (1971, p. 238) justifica la brevedad invocando la relación del argumento con el personaje y el espacio: ${ }^{8}$

En su recia prosa las descripciones, nunca ornamentales, además de ser breves van siempre fundidas a la acción, orientadas a la creación de un ambiente que es en sí, más que un marco, parte esencial de los elementos vivos de la fábula. Por eso la ambientación descriptiva nunca es puramente física y estática sino vital y dinámicamente inmersa lo mismo en la peripecia exterior que en las actitudes secretas y en el estado de ánimo de los personajes. Es decir, que describe lacónicamente lo significativo, lo humanamente significativo; la proyección de las cosas o de la naturaleza en los personajes y su mutua relación.

Estas afirmaciones, siendo correctas, no terminan de explicar la desconfianza que siente ante la descripción nuestro autor, en mi opinión consciente a su manera de lo que acabamos de formular, afectado de una cierta aprensión frente a todo lo que pueda parecer falso en el plano de la verosimilitud y en el del estilo:

La gente confunde el estilo con la afectación retórica. El estilo es una proyección inmediata y directa de la estructura. Es decir, que todas las literaturas de fondo colonial y atrasado ponen un énfasis excesivo en el llamado "estilo", pero confunden el estilo con el manerismo [sic] y el amaneramiento. En realidad, el estilo surge espontáneamente del fondo del ser y, naturalmente, el mejor estilo es el que no se percibe. Cuando se percibe el estilo es que hay algo que interfiere entre el pensamiento del que escribe y la sensibilidad del que lee. (Conversaciones, p. 223)

\footnotetext{
$8 \mathrm{O}$ bien refiriéndose sólo al argumento: «El ritmo de la narración -relacionado con lo que se podría llamar la "subestructura", que conforma la sutil secuencia del desarrollo internoes tranquilo, sereno, reposado. La cadencia está perfectamente adecuada al tono general, frío y distante, a media voz, dentro del cual los hechos destacan con independiente y objetiva corporeidad. Por eso no hay comentarios explicativos, ni párrafos descriptivos de los objetos, de la naturaleza o del ambiente. Las sobrias descripciones expuestas en breves frases, a veces sobre pequeños detalles aparentemente insignificantes, contribuyen a fijar los hechos, a concretar su significado, y se encuentran integradas en el cuerpo de la narración, nunca independientes. $\mathrm{El}$ ambiente físico y humano surge solo, por inferencia, sin necesidad de glosa directa" (ibid., pp. 147-148).
} 
Por eso llega a afirmar que

La palabra debe ser terriblemente funcional sin ayuda de subrayados, de adjetivos acumulados o solos, y mucho menos de aumentativos o diminutivos. La palabra en sí misma debe ir cargada de intención de tal forma que cualquier ampulosidad, aunque sea simplemente la expresión «todos», o "ninguno», o «muchos», o «pocos», la suprimo si no es indispensable, porque me parecen formas enfáticas innecesarias que quitan serenidad y don de matización. [...] Y en cuanto al barroquismo, prefiero el de estructura al del estilo. (Ibid., p. 231)

La descripción es, pues, para Sender algo que hay que fundamentar sometiéndola a una duda cartesiana de la que saldrá dotada de sentido estético y hallada digna de confianza.

Este sentido lo reconquistará en las hondas preocupaciones que articulan su obra: de otro modo declinaría el intento. El uso de la descripción en Sender se apoya, en mi opinión, en tres instancias: en las ramificaciones del problema de la ficción - lo que él denomina verosimilitud-, en el problema del género y, sobre todo, en la pasión por la mirada.

He escogido para esta exposición La aventura equinoccial de Lope de Aguirre porque considero se trata de uno de esos relatos que tanto interesaron a Sender por su carácter inverosímil y que, a la vez, por su historicidad, plantean interesantes problemas de género. La obra presenta además, como ya se ha observado, ${ }^{9}$ amplias zonas en las que la descripción desaparece.

Espero poder aclarar cómo es, precisamente, la mirada expresada sólo en ocasiones mediante la descripción-, la instancia que unifica y pone en juego todas estas cuestiones. Quizá de este modo logremos situar en alguna medida a la descripción en el problema general de la ficción iniciando así la resolución de su estética. En cualquier caso, probablemente sea un camino válido por el que llegar al lugar creativo de Sender.

\section{UNA ESTÉTICA PARA LO INVEROSÍMIL}

Sender se siente atraído ante el vértigo de lo inverosímil. Se trata, es cierto, de una atracción fundada en las estrategias que establecerá para su expresión, como él mismo ha manifestado:

Sólo el arte fija, establece en qué consiste la realidad común a todos y la hace verosímil. Íntegramente verosímil en todos los niveles. Y el deseo de escribir en algunos de nosotros viene de eso. Hay que hacer verosímil la realidad. [... J la gran tarea es la de los artistas, porque sabemos cómo poner en

\footnotetext{
9 Penuelas (1971, p. 240) ya ha llamado la atención sobre la ausencia de descripciones en el segundo tramo de la novela.
} 


\section{JUAN EMILIO ESTIL·LES FARRÉ}

orden las ideas y cómo escoger las palabras para decir lo posible o lo imposible de un modo convincente. ${ }^{10}$ (Conversaciones, pp. 220-221)

Pero, sobre todo, esta atracción por lo real inverosímil se dirige a la entraña moral que frecuentemente la sustenta:

[...] hay dos maneras de afrontar la realidad para un novelista: una, hacer verosímil la realidad, que no lo es casi nunca [...], y otra, hacerla inverosímil cuando la conciencia no puede aceptar los hechos por su brutalidad o por su maldad natural [...]. Cuando la realidad choca con todos nuestros conceptos apriorísticos y valores morales, entonces nos salvamos haciéndola irreal, sin dejar de conservar su naturaleza. Que es entonces meramente una naturaleza estética. U onírica.

-Que es lo que ocurre en la vida también. Es el escape de la locura. (Conversaciones, pp. 160-161)

La versión barojiana del tema de Lope de Aguirre es significativamente contraria a esta intención. En el breve capítulo que le dedica en Shanti Andía, Pío Baroja se interesa también, como se sabe, por la inverosimilitud de aquellos hechos, pero no intenta conjugarla con la historicidad. Más bien se complace en el absurdo:

De muchos capitanes, marinos, aventureros y frailes se ocupaba el libro de la familia; pero, entre todas aquellas historias, la más extraordinaria, la más absurda, dentro de su realidad, era la de Lope de Aguirre, el loco, llamado también Lope de Aguirre, el traidor.

Varias veces leí las aventuras asombrosas de este hombre, que en el manuscrito se contaban con todos sus detalles. (pp. 63-64)

\section{La comprensión del personaje y por el personaje, que tanto preocupa a Sender, es en Baroja mero juego:}

El leer aquellas aventuras de Aguirre me producia un poco la impresión que produce a los niños Guignol cuando apalea al gendarme y cuelga al juez. A pesar de sus crímenes y de sus atrocidades, Aguirre, el loco, me era casi simpático. ${ }^{11}$ (p. 67)

${ }^{10}$ Un caso de mera técnica es la escena central de El pelagatos y la flor de la nieve:

A partir de aquel momento lo que sucedió era difícil de precisar. La confusión en la sala fue tremenda y el mismo profesor no podía poner en orden --ahora en el aeródromo- sus impresiones. $[\ldots]$

En el laboratorio de historia natural sucedía lo que nadie habría podido sospechar. El gato estaba vivo. El cloroformo no había conseguido matarlo, sino sólo anestesiarlo.

Estaba vivo, y se ponía de pie, y soplaba. Sus resoplidos eran secos y mecánicos como escapes de una cámara de aire comprimido.

Pero lo peor era -igual que antes- el efecto visual. Era algo increíble, inverosímil, no necesariamente repugnante, sino espantoso y apocalíptico.

Sin orejas, con las cómeas globulares saledizas; toda su anatomía interior roja, rosa, color ladrillo, color naranja (varios matices de encarnado y blanco), el animal soplaba y maullaba, y se veían sus pulmones hincharse y la pleura brillar, roja y malva. (pp. 183-184)

11 Por eso gusta de exagerar las situaciones escandalizando al lector:

A la cabeza de sus hombres, subyugados por el terror (ahorcó a ocho que no le parecían bas- 


\section{EL LUGAR DE SENDER}

Y de ahí, quizá, la crítica que le merece a nuestro autor:

No es realista Baroja. Está preso en todas las convenciones de su tiempo. Todas las convenciones de una sociedad falsamente idealista. Y el salto no lo da nunca. Eso es lo que nos defrauda en él, a quien por otra parte admiro. (Conversaciones, p. 235)

Sender también ha visto en Lope un enigma fascinante, pero en su caso nos urge a una reflexión sobre las raíces del mal moral. Una de las manifestaciones de esa preocupación aparece reseñada en el personaje Pedrarias, una de las figuras más cuidadas de la novela:

-Vive Dios que esta es una ejecución cuyo sentido y razón no entiendo.

Lope, sin alzar tampoco la voz, dijo:

- Lo comprenderéis cuando os diga que lo he hecho para probar a Paco el Piloto. Después de lo que ha visto si vuelve al real con nosotros es porque no fue ayer traidor ni es ahora espía. ¿Comprendéis?

- Creo que sí - dijo Pedrarias.

Una de las tareas que más ocupado traían a Pedrarias era la de explicarse las cosas que veía a su alrededor. La vida no había comenzado a ser verosímil todavía para él y en eso le sucedía lo mismo que a los indios del Amazonas rodeados por el prodigio de una naturaleza que los excedía por todas partes.

- Nada de lo que veo me espanta —añadió Pedrarias-, que como decís más muertes y crueldades hace en una semana Felipe II, y la violencia es necesaria para la conquista y el gobierno, pero quisiera comprender lo que pasa en vuestra alma, si pasa algo cada vez que suprimís una vida humana. (p. 364)

Esa preocupación, constante en la narrativa senderiana, por abarcar -comprehender - al personaje le lleva a comprenderlo en el sentido moral:

[...] yo debo confesar mi tendencia a ennoblecer siempre al hombre, cualquiera que sea. He tratado, a veces, en mis libros, tipos abominables. En Siete domingos rojos hay un confidente de la policía que se llama Fau, y que es la suma de la abyección. Algunos lectores me han dicho que, a pesar de todo, cuando Fau cae asesinado por obreros revolucionarios, sienten dolor y tris-

tante fieles), bajó por el Amazonas y recorrió, después de meses y meses, la inmensidad del curso de este enorme río y se lanzó al Atlántico.

No contaba Lope más que con barcas apenas útiles para la navegación fluvial; pero él no reconocía obstáculos y se internó en el océano. Lope de Aguirre era todo un hombre. (p. 65)

El fraile de la flotilla se permitió aconsejar, suplicar a su capitán que no fuera tan cruel. Aguirre le escuchó atentamente, y atentamente lo mandó ahorcar. (p. 65) cabeza.

- ¡Mal tiro! —exclamó Lope al primer disparo, al notar que la bala pasaba por encima de su

Y cuando sintió, al segundo disparo, que la bala penetraba en su pecho y le quitaba la vida, gritó, saludando su matador con una feroz alegría:

- Este tiro ya es bueno.

Realmente Lope de Aguirre era todo un hombre. (pp. 66-67) 
teza. No me extraña, porque a Fau, a quien yo no podía ennoblecer, lo he presentado tratando de explicar en cada caso las razones de su abyección. Resulta un malvado, pero también, y quizá en mayor proporción, un estúpido irresponsable, que no tiene la menor culpa de serlo. ${ }^{12}$ (Proclamación de la sonrisa, pp. 5-6)

\section{De esa misma capacidad de comprensión hace gala Lope, precisamen- te ante su hija:}

Veían los españoles todo aquello indiferentes y pensando que ninguna mujer tenía atractivos y que sólo alguna niña entre los nueve y los diez años podía ser apetecible antes de ser tatuada y deformada. Esa edad equivalía allí a los quince años de las mozas de Castilla.

Lope acudió a la fiesta seguido de Elvira y de la Torralba, pero se quedaron poco tiempo, y volviendo luego a casa decía Elvira:

-Esos indios son peores que los motilones, padre.

-Posiblemente.

- Son gente muy baja y tirada esos indios.

-Pero tienen sus méritos, como cada cual. Siempre hay un lado por el que merecen consideración estas gentes, por bajas que sean. (p. 175)

\section{COMPRENSIÓN Y MIRADA}

Pero esos intentos de comprensión no pasan por la caracterización directa del personaje, más bien la rechazan. Si lo que se pretende hacer verosímil es la realidad, de poco sirve sólo describirla, pues sabemos desde Aristóteles que verosimilitud no es lo mismo que realismo. Y si el empeño radica en comprender moralmente al personaje, su mera descripción es más ineficaz todavía. El paisaje, el retrato, no proyectan al objeto hacia la credibilidad, no sobrepasan los límites del absurdo, se afianzan en él cuando este se produce.

La técnica que emplea Sender para dar razón de los objetos, las situaciones $\mathrm{y}$, sobre todo, de los personajes consiste en sumergirlos en el mundo de la mirada. En La aventura hay cientos de miradas. Es un modo

12 Apud AbUelata (1992, p. 14), quien añade: «Para nuestro escritor, la novela es un cajón de sastre donde cabe todo, especialmente el pequeño hecho verdadero, muchos personajillos - algunos tomados de la realidad-, el protagonista que, a veces, tiende a desaparecer dejando lucir a los personajes pequeños. El personaje se presenta directamente mediante sus cualidades. Además, hay otros rasgos característicos de su forma de novelar que, enseguida, se hacen notar: novelas de capítulos breves, el acusado sentido del tiempo vivido, la abundancia de notas líricas y otras autobiográficas. Sus prototipos humanos son sistemáticos: buenos, honrados y nobles, o malos, antipáticos y envilecidos; trabajadores y luchadores o burgueses y ambiciosos. Pero todos han tenido un momento para reflexionar equilibradamente sobre qué es lo que han hecho con su vida. Hasta el más vil de sus personajes rezuma humanidad. Y es que Sender no trata de ennoblecer a las personas ni trata la tragedia - en sus obrascomo metáfora, sino que transcribe la tragedia fiel y objetivamente como algo vital e inevitable, de ahí que se realce la metáfora de la vida real». 
de establecer lazos entre el personaje y la realidad, un sistema de expresar la interacción estética: el único lugar donde la verosimilitud se localiza y sustenta. ${ }^{13}$ Por eso casi nunca se describe a los personajes en sí mismos, no se dice casi nunca cómo son: se nos enuncia más bien cómo miran. ${ }^{14}$ No los vemos, pero miramos con ellos. Es algo más que un truco o una técnica que aparece formulada teóricamente desde Goethe pero que está presente en Platón, en Longino, en Cervantes, en los grandes pensadores de la literatura que lo han sido manteniéndose al margen de la retórica.

Este modo de acceder a la mirada, obsesivo en La aventura, es inaugurado ya en Imán de forma clarividente: ${ }^{15}$

Cuando detrás de los ojos no hay una aspiración al panorama ideal que corresponde a cada paisaje, la mirada aparece vacía. Así miran siempre los idiotas. Los locos sólo ven lo imaginado y tienen una mirada demasiado lejana, demasiado expresiva de lo inmaterial. Viance mira de ambas maneras. La idiotez y la locura se dan la mano sobre una realidad muerta. (p. 213)

$Y$ casi todos una mirada deslustrada, que en Viance es una lejana y gris mirada de estupefacción. Se adivina, más que el asombro de lo que nos rodea, la sorpresa del estado a que uno mismo ha llegado y una angustia anhelante de que pueda haber desaparecido para siempre aquella vida que se comenzó a vivir. (p. 12)

13 Siempre se ha dicho, por ejemplo, que la descripción detallista es más verosímil; pero lo es porque la suponemos sustentada en una mirada.

14 Otro sistema de caracterización paralelo lo constituye la palabra del personaje:

Ella le decía con el acento bobo de la luna de miel: - Eres el jefe de la expedición, el que manda en todos. Pero no en mí. No eres mi jefe, sino mi amante. (p. 67)

Esta obsesión [por la sífilis que padece] parecía agravarse con los años y ni siquiera las miserias de aquellos dos meses de lucha con la muerte se la hicieron olvidar, pues cuando Ursúa abrazó al gran arcabucero y le preguntó cómo le iba dijo García de Arce: - Sudando la ponzoña de dentro y vigilando la de fuera. Porque alli los indios usaban flechas envenenadas. (p. 78)

Vargas bromeaba según su estilo. Era un madrileño parco en palabras. (p. 62) (p. 153)

Le extrañó a Lope que Martín Pérez hablara tanto, porque era hombre de muy pocas palabras.

-Ustedes los viejos - le dijo Zalduendo, como siempre inoportuno- no deben tener mucho interés por la vida. (p. 98)

Recordaba Lope que Pedrarias, refiriéndose a aquellos animales, había dicho el perrerío. ¡Qué maneras raras de hablar! Y a Lope le gustaba aquello. Su niña copiaba las rarezas de palabra de Pedrarias. Dijo una o dos veces aquello del perrerío, gozando de la palabra, la niña. (p. 59)

Etc.

15 El mismo Sender parece tener una sensibilidad especial hacia la mirada. «Cuando doy conferencias públicas, siempre hay en la última fila cinco o seis burócratas que van a tratar de confundirme. Hablan entre sí, me miran y sonríen, ríen a carcajadas.. La primera vez me impresionó un poco. Pero después ya sé lo que pasa y no me inmuta. Es un truco femenino del cual ya habla el Arcipreste de Talavera en el Corbacho... Que hagan ahora burócratas del partido comunista lo mismo que hacían las mujeres en tiempos del Arcipreste de Talavera no es muy revolucionario que digamos. Pero así es todo. Espero que un día me dejen en paz. Las cosas hoy van cambiando" (Conversaciones, p. 97). 


\section{JUAN EMILIO ESTIL·LES FARRÉ}

En Lope de Aguirre todos los personajes, y son abundantes, poseen una mirada peculiar:

Veía el negro Bemba las maniobras de la pesca, del descabezamiento y destripamiento del pez y de su preparación para el fuego -envuelto en hojas verdes de un árbol cuyo nombre ignoraba-, sabiendo que no iba a probarlo, a no ser que pescaran muchos más y sobrara, y recordando que no se conservaría más de tres o cuatro horas con aquel calor.

Había calculado el negro que hacía falta para que todo aquello sucediera que pescaran más de diez piracucús. Y estaba atento a la pesca y contando los ejemplares de aquel hermoso animal a medida que los sacaban. Cuando vio que había seis y que no sacaban ninguno más se marchó despacio, mirando sus propios pies. (p. 198)

El soldado que se había reído del rollo de la nueva ciudad fundada era un tal Serrato, un poco simple, aunque hombre de valor como soldado. Tenía una particularidad de carácter aquel hombre, y era que no podía mirar al cielo ni tampoco a las lejanías del río (allí donde el río parecía mar y el azul de abajo se confundía con el de arriba), porque sentía vértigo.

El padre Portillo, que murió de aprensión en aquel lugar, solía decirle a Serrato que tenía miedo del infinito y que hacía bien en tener miedo, porque en el fondo del infinito estaba Dios. En todo caso, Serrato, desde el incidente del rollo, miraba con recelo a Aguirre y procuraba evitar su presencia, que le producía una sensación parecida al vértigo, también. (p. 248)

Los marañones que estaban en el bergantín miraban impasibles. El caudillo vasco miraba también atentamente a las aguas como si esperara algo. Vio a Guevara debatirse un momento y desaparecer dejando arriba una mancha roja de sangre. Un indio de los que estaban en la balsa inmediata llamó la atención de Lope y le dijo:

-Mira al agua y verás algo que no has visto nunca. (p. 255)

El comendador Guevara era hombre que necesitaba pasear. Cuando estaban navegando en el río y no podía pasear se ponía impaciente, sacaba su cabeza a la brisa, haciendo flotar en ella sus barbas de capuchino, y miraba al agua, porque con la sensación física del movimiento del barco se calmaba un poco.

Cuando bajaba a tierra, lo primero que hacía, después de elegir su vivienda si la había o el lugar de la playa donde dormir, era ponerse a pasear con las manos a la espalda y la mirada en el suelo. (p. 126)

Ahora bien, si la mirada es tan omnipresente y si el narrador declina su responsabilidad comunicativa frente a las cosas, la descripción se verá necesariamente afectada: la realidad sólo aparece en el personaje y estos carecen habitualmente de una mirada estética. No abundan, de este modo, las descripciones literarias del trópico. A Sender le interesa tan poco la exótica realidad equinoccial como la historia de su conquista. Lo que más le cautiva es lo que pueda suceder en el interior de la persona.

En algunas ocasiones, sin embargo, la descripción de lo exterior sí puede convertirse en un modo de acceder por esta vía al interior del individuo; precisamente cuando este tiene algo que observar: cuando su mirada lo justifica. En este sentido, la única descripción que corre a cargo del pun- 
to de vista de Lope es toda una manifestación del único afecto que parece adornar su desaforada personalidad:

Aquella noche, algunos soldados se aventuraron hasta la entrada de la selva. Hacía luna clara. Eran los árboles tan espesos que parecía imposible penetrar, y Lope, que era curioso de novedades más por las preguntas que le hacia su hija que por sí mismo, se propuso volver al día siguiente con la luz del sol.

$Y$ así lo hizo.

La vegetación era todavía más espesa de lo que prometía la noche anterior.

Había muchas clases de palmeras, y a simple vista, y sin ser experto, se podían distinguir hasta cinco o seis, unas de altísimo tallo recto, con una tufa de palmas como las de la pascua florida. Otras iguales de tallo, pero con palmas de abanico en lo alto; otras, aun en las cuales las palmas se desplegaban desde el suelo alrededor del tronco y más variedades todavía, combinando diferentes formas y hasta colores porque había una palmera color marfil, casi blanca, en lugares donde no entraba nunca el sol.

La abundancia de palmeras por todas partes -árbol que en Europa sólo tenía carácter suntuario- daba a la selva un aspecto de gran parque señorial. Acercándose un poco se veía que los señores de aquel parque, cuyos confines no se podían imaginar, eran los monos, los jaguares, los pumas, los tapires, las onzas y mil especies y subespecies y familias. (p. 86)

\section{Pero esto no es lo habitual.}

\section{LA MIRADA DE LOPE DE AGUIRRE}

En este contexto es lógico que la percepción visual de Lope de Aguirre adquiera en la pluma de Sender una categoría y un tratamiento especiales. Su forma de observar la realidad define su posición a lo largo de la novela. En los primeros compases, el protagonista observa recelosamente las situaciones y a sus protagonistas procurando que su actitud no sea advertida:

Todos iban apercibidos viendo que Ursúa mostraba mal talante y andaba en interrogatorios y apercibimientos y amenazas. Lope lo miraba desde lejos, y recordando a Montoya [...]. (p. 88)

Al oscurecer, cuando la gente parecía más retraída, salían los negros que solían formar rancho aparte y comenzaban, como los animales nocturnos, a alegrarse. [...] Los miraba desde lejos Lope de Aguirre [...]. (p. 89)

Recordaba Lope que el día anterior había visto a Vargas es decir, había estado mirándolo casi una hora - sin que él se diera cuenta. No hubo entre ellos cambio de miradas, y menos de palabras. No sabía Vargas que era observado porque Lope estaba en la cubierta inferior y lo veía desde abajo por la abertura de un mamparo. (p. 81)

Con la frecuentación de doña Inés, La Bandera iba cambiando de hábitos, ni más ni menos que Ursúa, aunque por un estilo diferente. A menudo se quedaba inmóvil con la vista perdida en el aire y Lope lo veía desde lejos, se golpeaba con la fusta la pierna coja y reía por lo bajo [...]. (p. 156) 


\section{JUAN EMILIO ESTIL·LES FARRÉ}

Más adelante, cuando ya ha comenzado a tomar posiciones de poder, su obsesión por la mirada se revuelve contra él:

Es cierto que Lope tampoco podía sostener la mirada de Alcaraz y que sabiéndolo evitaba mirarlo de frente. Cuando no tenía más remedio que mirarlo, los ojos se le desenfocaban ligeramente y se veía un pequeño y momentáneo estrabismo. (p. 281)

No miraba Lope a Caxo porque era difícil cruzar los ojos con una persona a quien había anunciado la muerte inmediata. (p. 206)

La verdad era que aquel hombre grande, rubio, de ojos huraños y de gesto torcido le parecía a Lope de Aguirre una acusación constante y no podía respirar a gusto si lo miraba dos veces. (p. 253)

Esa obsesión le lleva, más adelante, a pretender controlar la percepción ajena impidiendo su despliegue:

Mandó que los sacaran de la prisión alta, donde tenían ventanas con rejas desde las cuales se veía el mar, y los bajaron a los sótanos de la fortaleza. Los presos, habiendo visto a lo lejos el barco del provincial, concibieron otra vez esperanzas [...]. (p. 313)

u obligando a ejercerla:

La población en masa fue obligada por Lope de Aguirre a presenciar la ejecución. (p. 305)

En los últimos instantes de su destino ya no soporta que nadie escape a su campo visual:

De vez en cuando ordenaba que saliera una tropa de incondicionales bien armada a afrontar a los escuadrones de Bravo de Molina, que era el que más provocaba, pero llegó un momento en que no sabía Lope de Aguirre con quiénes podía contar y con quiénes no. Desde la defección de Tirado veía traidores a su alrededor y a todas horas. (p. 411)

Luego les obligó a todos a volver y a quedarse a la vista del resto de la fuerza. (p. 393)

Sender ha sabido de este modo presentarnos cabalmente la cuestión que más le interesó en Lope, la evolución de su locura, y nos hace asistir a ese desarrollo desde donde esta se produce.

\section{DESCRIPCIÓN Y GÉNERO}

Pero si la mirada, en aras de la verosimilitud, anda ocupada en revelarnos el interior, ¿qué espacio queda para la descripción? La descripción ocupa el único resquicio dogmático que Sender no ha advertido: el género, el género en el que se desenvuelve. 
La descripción aparece en todo aquello que no es la historia personal del loco Aguirre, en todo aquello que escapa al mundo oculto de los personajes: en la novela histórica, ${ }^{16}$ en la novela de aventuras, en el viaje maravilloso, en la crónica de descubridor, en el relato humanista: está auspiciada, en definitiva, por los subgéneros que se entrecruzan en su obra. Sólo estas cinco instituciones literarias posibilitan que la mirada de algunos personajes se detenga en la realidad física e interponga una contemplación descriptiva.

Si antes hemos tenido que hablar de cómo observan los personajes ahora habría que atender a qué es lo que perciben, a cuál es el contenido de su mirada. Pero para ello Sender debe hacer una cierta violencia a su arquitectura narrativa y dejarse llevar del género. Anteponiendo a las descripciones la figura del guía, la referencia al cronista, al explorador ilusionado, al buscador de oro, al descubridor o, sencillamente, la mirada colectiva de unos españoles que eran todo eso a la vez, consigue, que no es poco, dar coherencia a su trabajo. Esta es la vía de entrada en la novela de algunos elementos que se le presentan inexcusables: el color local, las descripciones de la selva, las costumbres de los indios, las curiosidades del Amazonas, etc.

\section{LA MIRADA EQUINOCCIAL DE SENDER}

Entre todas ellas destaca, con voz propia, la mirada de Pedrarias, un hombre sin fe (p. 379), un "hombre maduro, sentimental y solitario" (p. 58), «un soldado con manías de humanista que quería enterarse de todo" (p. 37), un aprendiz de investigador ocupado en anotar y describir la vida de los indígenas (pp. 242-243). Pedrarias es, en definitiva, un punto de vista creado para comprender y describir con naturalidad y que nos confirma que Sender no quiere hacerlo en tanto que narrador:

\footnotetext{
Había días - decía Pedrarias- que el calor hacía enloquecer a la gente, y por eso repetía a veces que todo el mundo debía descontar en la intemperancia y en la irritabilidad de los demás lo que correspondía a la fatiga nerviosa de aquellos calores, a la que Pedrarias llamaba el paroxismo ecuatorial, y otros, la tarumba del equinoccio. Se suponía que en aquellas latitudes cada cual tenía derecho a una cierta incongruencia y a una cierta irresponsabilidad. (pp. 217-218)
}

Habría mucho más que decir de tan interesante personaje, pero conformémonos con señalar que no se comporta como un mero foco observador. Como ya hemos visto, en todo momento su interés se vuelca en dar

\footnotetext{
16 Sender se ha confesado admirador de Walter Scott en alguna ocasión, cfr. PEÑUelas (1971,
} p. 257) 
sentido a lo que ve, en hacer verosímil la realidad desde una posición neutral, desde una mirada estética:

Era la vida del Amazonas aparentemente miserable y penosa, pero mirando las cosas despacio se llegaba pronto a comprender que dentro de la fatalidad en la que los hombres todos vivimos no era aquélla una vida tan ardua como la de algunos pueblos civilizados.

La vida de aquellas gentes desde que nacían era una especie de deslumbramiento del que no acababan de salir en todo el tiempo de su existencia. Es decir, que llegaban al día de su muerte sin haber comenzado siquiera a comprender nada. Cuando nacían veían caudales inmensos de agua que tomaba distintos colores, entre los que predominaba el amarillo dorado. Veían al lado una selva poderosa y llena de misterio, con rumores siniestros durante el día y una algarabía infernal e inextricable durante la noche. El dios implacable de la vida y la muerte era visible y perceptible - volcanes lejanos que hablaban por el estruendo de sus erupciones y por los terremotos-. Las tormentas diarias desde Navidad hasta avanzado agosto con rayos y truenos, lluvias torrenciales y un sol aplastante mantenía en un estado de asombro a los hombres.

Nadie llegaba nunca a acostumbrarse ni a familiarizarse con todo aquello. Los grandes placeres físicos compensaban la incomodidad del hambre ocasional o del peligro de las guerras de tribus. Y cada día la sorpresa era mayor. Cuando no podían más sorbían por la nariz el polvo del paricá o mascaban la coca. Así conseguían una calma interior perfecta.

Llegaban a la mayor edad y morían a los treinta o cuarenta años sin haber salido de su asombro y sin ocasión para comenzar a reflexionar. Ahí estaba el peligro de los otros, de los españoles y los blancos. En la reflexión sin soluciones ni conclusiones. La vida de aquellos seres del Amazonas, con todas sus dificultades, era mejor que la vida gris y sórdida de los pobres en los países del viejo continente. La gente pobre de Europa vivía sesenta años o más abrumada por el hábito de reflexionar y de comprender demasiado sin poder resolver nada en definitiva. Y esto sucedía a veces también con los ricos.

Pensando así, Pedrarias mostraba a Elvira las cosas de la naturaleza. (pp. 231-232)

Y, pensando así, Pedrarias — que no es otro que Sender-, desde el lugar más extraño e inhabitable de la tierra, desde ese lugar neutral donde los días se igualan a las noches, nos invita a compartir, como él hace con sus personajes, esa mirada equinoccial suya - ponderada y toleranteque tanto puede aportarnos.

\section{BIBLIOGRAFÍA}

Abuelata, M., «Aspectos técnicos en la narrativa de Ramón J. Sender (1930-1936)», Alazet, 4 (1992), pp. 11-57.

Bajtí, M., «El problema del contenido, el material y la forma en la creación literaria», en Teoría y estética de la novela, Madrid, Taurus, 1989 ( $1^{\text {a }}$ ed., 1924).

Baroja, P., Las inquietudes de Shanti Andía, Madrid, Cátedra, 1980 (1ª ed., 1911).

Peñuelas, M. C., Conversaciones con Ramón J. Sender, Madrid, Magisterio Español (col. «Novelas y Cuentos»), 1969. 


\section{EL LUGAR DE SENDER}

PENUelas, M. C., La obra narrativa de Ramón J. Sender, Madrid, Gredos, 1971.

SENDER, R. J., Imán, Huesca, Instituto de Estudios Altoaragoneses, 1992 (1ª ed., 1930).

- Proclamación de la sonrisa, Madrid, Pueyo, 1934.

- «El pelagatos y la flor de la nieve», en La llave y otras narraciones, Madrid, Magisterio Español (col. "Novelas y Cuentos»), 1967.

Vived Mairal, J., «La vida de Ramón J. Sender al hilo de su obra», Alazet, 4 (1992), pp. 231270. 


\title{
En torno a \\ «Historia de un día de la vida española»
}

\author{
José-María Salguero Rodríguez \\ I. E. S. Cuatro Caminos, Don Benito (Badajoz)
}

En 1935 se dedicó Sender con especial intensidad a las revistas literarias, consagrándose por entero a una empresa casi particular con la edición de Tensor. De esta revista aparecieron tres números dobles: el 1 y 2 , el 3 y 4 y el 5 y 6 . En el número primero aparecían dos artículos: uno de Sender, «La cultura española en la ilegalidad», y otro sobre Paul Nizan, de André Gide, autor que gozaba de las simpatías senderianas por haberse acercado a posiciones comunistas desde un punto de partida de intelectual humanista y cristiano. En el siguiente número se publicaron otros dos ensayos: uno de César Falcón sobre Barbusse - de nuevo un autor digno de las simpatías de Sender-y el otro, del ruso Dinamov sobre literatura capitalista, tema obsesivo en el Sender del momento; además este último artículo está traducido por «R. S.», iniciales inequívocas. El último número de Tensor es aún más «senderiano» que los dos precedentes, como intentaré mostrar más adelante.

Hasta ahora las evidencias no dejan lugar a dudas sobre el práctico monopolio de la revista por parte de nuestro autor, monopolio presumiblemente no deseado, sino obligado por una probable falta de colaboración, quizá limitada a César Arconada. En una nota de Levia- 
tán $n^{1}$ anunciando el segundo cuaderno de Tensor se dice que Ramón J. Sender era el director de la publicación, aunque tal cargo no aparece en los ejemplares de la revista, que pretendía ser una obra colectiva. Lo que sí aparece en la contraportada del último número es la propaganda de los libros de Sender, frente a los de Arconada y otros, que se anuncian en la contratapa.

Este último número está íntegramente ocupado por un trabajo pretendidamente anónimo y colectivo, "Historia de un día de la vida española»," quizá el experimento más interesante de toda esta faceta senderiana, y, ante él, se nos presenta como primer problema la determinación de qué tipo o género de texto sea. En principio, por estar publicado en un número regular de una revista periódica, que en otros números había publicado artículos variados y reseñas, se nos podría ofrecer como artículo o trabajo colectivo, distinto de lo que normalmente consideramos libro u obra literaria. En ese sentido primaría el tipo del canal de difusión sobre el de la obra. Collard lo califica de "verdadero mosaico literario» ${ }^{3}$ y efectivamente eso es lo que nos encontramos, impresión acentuada por la conciencia de anonimia colectiva que la introducción deja por sentada. En ese «mosaico» hallamos textos de índoles muy distintas, descripciones rurales, urbanas, narraciones sobre personajes concretos o situaciones ambientales, recortes de prensa..., hasta el parte meteorológico o las carteleras de cine.

Hay varias constantes que se repiten a menudo encadenando los textos en un macrotexto con coherencia intencional: el día 27 de septiembre - tema de la obra- es un día cualquiera, "un día gris», en el que no ocurren acontecimientos relevantes para la historia oficial; sin embargo para el pueblo llano, las masas trabajadoras, todos son acontecimientos significativos del estado de explotación, represión y lucha en que se encuentran. Se establece pues la oposición entre historia oficial e «intrahistoria» que Unamuno, entre otros, había desarrollado en su día. Ese estado se ejemplifica en casos concretos de personas con nombres y apellidos en situaciones de lo más diverso. La repetición insistente de estas constantes, así como de ciertos pasajes "familiares", que luego comentaremos, lleva inexcusablemente a sospechar que el autor de los textos es una sola y única persona, cuya identidad podría corresponder al propio Sender.

Ello estaría abonado en primer lugar por citas de distintas procedencias. Partimos de la constatación de que, aunque la revista no lo aclare, el papel de Sender, como ya hemos visto, en la publicación de Tensor fue

\footnotetext{
1 «Tensor. Revista quincenal de información literaria y orientación», Leviatán, 18 (octubre-noviembre de 1935), p. 62.

2 VARIOS [Ramón J. SENDER], «Historia de un día de la vida española», Tensor, 5 y 6 (octubre de 1935), 104 pp.

3 Patrick COLlaRd, Ramón J. Sender en los años 1930-1936. Sus ideas sobre la relación entre literatura y sociedad, Gante, Rijksuniversiteit te Gent, 1980, p. 20.
} 
prácticamente el de protagonista. Asimismo poseemos el testimonio del propio novelista en Album de radiografias secretas:

A veces yo recibo cartas de testarudos y obstinados rusófilos más o menos amigos míos [...] Una de esas cartas me decía recientemente: «Pensamos si nos darías permiso para publicar en un volumen universitario los números que salieron de tu revista Tensor durante los años 1933-1934 y querríamos que nos dijeras quiénes te ayudaron, porque no firmaba nadie». Yo les contesté: «Sólo me ayudaba otro escritor joven: César Arconada, miembro del Partido Comunista [...]». 4

A la misma carta se refiere Sender en un artículo de Blanco y Negro, en términos que apuntarían hacia su probable exclusividad en la elaboración del texto en cuestión: «Terminaba mi carta diciendo a los maquiavélicos amigos que las páginas mías de Tensor estaban siendo incorporadas a mis Obras Completas». ${ }^{5}$ Aunque nunca apareciera dicha edición, la asunción por parte del novelista de la autoría del texto es evidente. Los críticos han rozado el tema, pero sin profundizar. Collard advierte que "no le ha sido posible determinar con seguridad qué parte redactó Sender». Empieza a intentarlo y concluye que al menos dos textos - los que luego señalaremos como 1 y 4-serían de Sender. Pero puestos a buscar coincidencias "con este juego uno llega a la conclusión que en casi cada una de las 24 partes había algo que hubiera podido ser de Sender", 6 lo que le parece tan arriesgado que desdeña la idea de la exclusividad. JoséCarlos Mainer también vislumbra la idea en «La corona hecha trizas», llegando a la conclusión de que, a pesar de la brillante nómina de colaboradores, lo más seguro es que «bastantes rasgos de estilo permitan atribuir a Sender una parte muy importante del conjunto y quizá la necesaria tarea de una coordinación». ${ }^{7} \mathrm{Y}$, aunque analiza el texto en cuestión, en su coherencia literaria y por su relación con otras obras publicadas en el bienio, en cuanto al tema de la autoría se limita a aludir a las dos "coincidencias» aportadas por Collard, ampliándolas con otra referida a Contraataque y a lo que luego llamaremos secuencia 17 , que más adelante detallaremos.

La última aportación es la de Marshall J. Schneider, que en un completo trabajo y, sin entrar más de lo dicho en el tema de la autoría, desarrolla las bases teóricas del texto de Tensor, encajándolas en la literatura propagandística de influjo marxista, cuyos ideales de colectividad y ano-

\footnotetext{
${ }^{4}$ Ramón J. SEnder, Álbum de radiografías secretas, Barcelona, Destino, 1982, p. 104.

5 Ramón J. SeNder, “Otro espejo infausto", Blanco y Negro, 3338 (24 de abril de 1976), p. 65.

6 Patrick COll.ARD, op. cit., pp. 20 y 21.

${ }^{7}$ José-Carlos MAINER, «La corona hecha trizas (La vida literaria en 1934-1936)», La II República. Bienio rectificador y Frente Popular, 1934-1936, Madrid, Siglo XXI, 1988, p. 138.
} 
nimia pone en práctica. Con todo, no deja de detectar una cierta univocidad en la construcción textual y en la intencionalidad. ${ }^{8}$

Y volviendo a Sender, en uno de los últimos artículos que escribió para La Libertad, en diciembre de 1935, se refiere al texto y curiosamente usa la primera persona del plural sin que se sepa a ciencia cierta quién está incluido en ella: "Nosotros acabamos de hacer en el número 5-6 de Tensor un intento de trabajo literario colectivo bastante estimable». ${ }^{9}$ La rotundidad de la primera persona del plural es matizada por el tímido vocablo de «intento», que confirmaría el texto como trabajo literario que no llegó a ser colectivo, que se quedó tan sólo en «intento".

Lo que se nos dice sobre el tema en la introducción del texto, subtitulada «Algunas observaciones» y firmada por un impersonal «La redacción", no es muy creíble por las contradicciones en que incurre desde un principio; se nos informa de que han intervenido "casi todos los escritores cuyo nombre va en la lista de colaboradores». Estos colaboradores son ¡cincuenta y ocho! según la contratapa posterior; pero en la introducción se concreta: «Nos hemos repartido las glosas entre veinticuatro escritores. Tocamos a una hora del día cada uno».

Como veremos, la pretensión de colectividad responde más a la intención que a la realidad. Para referirnos a las secuencias y para tratar de demostrar las interrelaciones existentes entre ellas, será preciso numerarlas, toda vez que carecen de ordenación numérica o de cualquier otro tipo; entre paréntesis van las secuencias sin título en el texto:

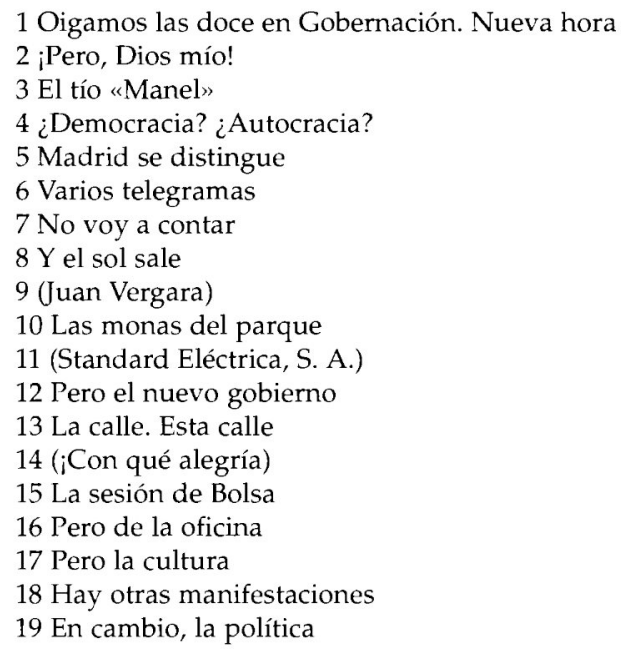

\footnotetext{
8 Marshall Jerrold SCHNEIDER, «Historia de un día de la vida española: Ramón J. Sender and His Contemporaries», Letras Peninsulares, 6/1 (primavera de 1993), pp. 179-195.

${ }^{9}$ Ramón J. SENDER, «Hoy. P. E. N. Club, crepúsculos y otras evasivas», La Libertad, 4899 (13 de diciembre de 1935), p. 7.
} 


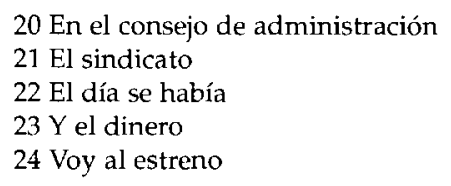

Podemos ir esbozando un recorrido por dichas secuencias para ir primero rastreando qué indicios pueden resultar propios de Sender, principalmente por coherencia con otros textos. Posteriormente y con simultaneidad podremos comprobar qué cadenas de relaciones temáticas se producen entre las distintas secuencias, de manera que podamos atribuirlas a idéntica autoría.

La secuencia 1 resume y comenta el programa radiofónico propio del comienzo del día. Empieza con el parte meteorológico e inmediatamente se nos dice: «Pero no alteremos el orden, ningún orden. Primero es el orden público. Luego, el orden privado». La conexión temática es evidente cuando recordamos que $O$. $P$. empezaba con un parte meteorológico, muy significativo, como cita inicial en página 9, que luego el libro desarrollaría. Más adelante se produce una conexión de ideas bastante caprichosa: al oír por la radio un fragmento de zarzuela de tema napoleónico, la guerra de independencia española le recuerda al autor la guerra de independencia que Abisinia - hoy Etiopía- libraba por aquellos días contra Italia. Pues bien, en el mismo mes de octubre Sender publicaba en La Libertad un artículo sobre el tema de la guerra abisinia, ${ }^{10}$ en términos similares, es decir, considerándola una guerra de distracción del fascismo para con el pueblo italiano; lo más curioso es que también se relaciona esta guerra con la guerra de independencia antinapoleónica. La primera parte de las tres en que se subdivide la secuencia termina con una frase de clara resonancia senderiana: « Esta España! Estos gigantes vencidos y explotados del campo español, que han hecho el cubo gótico, el minarete, el acueducto, el ajimez, el naranjal y las trojes [...]». Esta concepción de la historia española como yuxtaposición de las tres culturas —romana, visigoda y árabe- aparece repetida en muchos textos de Sender con referencias históricas.

Al finalizar la segunda parte de la primera secuencia aparecen dos datos interesantes: el primero es una clara alusión, que desvela que su autor conoce la ordenación o la elaboración y procedencia del material de las secuencias que van a venir después: «[...] también suceden grandes cosas que nos contarán luego los periódicos de derechas [...] [los santos Cosme y Damián] Más adelante volveremos a encontrarlos». Está claro que quien escribe es el organizador. Por otro lado la alusión a los santos Cosme y Damián, como advocación frecuente en «las aldeas del Norte», recuerda las descripciones que Sender escribe a menudo sobre los aldeanos de su región. En Solanar y lucernario aragonés dice:

\footnotetext{
10 Ramón J. SENDER, «Hoy. La guerra», La Libertad, 4846 (12 de octubre de 1935), p. 3.
} 


\begin{abstract}
Entre los mil recuerdos de Aragón que me han acompañado por el mundo figura el santuario de San Cosme y San Damián, uno de los lugares más pintorescos y típicos de nuestro Alto Aragón. ${ }^{11}$
\end{abstract}

Y a continuación copia la misma coplilla — con alguna variante, no en vano han pasado más de cuarenta años- alusiva a los santos que aparecía en la secuencia citada. Los santos volverán a aparecer, como se promete en la cita anterior, en la secuencia 13, glosando la letra de la coplilla y aludiendo al santuario de la sierra de Guara, otro de los lemas repetidos en las memorias aragonesas de Sender. En la página siguiente se comenta la celebración de una festividad a cargo de una hermandad sanitaria acogida al patronazgo de los santos. $Y$ en términos parecidos volverá a aparecer en la secuencia 17. El detalle de san Cosme y san Damián era una de las dos conexiones que ya había vislumbrado Collard.

En la tercera parte de la secuencia se alude a un film en cartelera, «El delator». De nuevo en La Libertad, en noviembre, Sender publica un artículo de crítica cinematográfica dedicada a dicha película. ${ }^{12}$

En la secuencia 2 se habla de la redacción de un periódico. La sala de máquinas está en marcha a esta hora temprana de la madrugada: «Es un gran diario reaccionario. Esta descripción nos la hace uno de sus redactores y volvemos a escribirla parafraseando sus ideas para que no se note el estilo y no puedan tomar contra ese redactor represalias». De ello se desprende que el narrador, si cuenta con alguna colaboración ajena, en cualquier caso la parafrasea o la enmarca en el texto general. La redacción, pues, es prácticamente única. La descripción de las preocupaciones políticas del director de la redacción se recordará en la secuencia 12 , donde se nos da la cabecera del periódico que en la secuencia 2 quedaba de incógnito: «EL DEBATE.- En las primeras páginas de TENSOR damos una parte de un editorial».

La tercera secuencia, "El tío "Manel"», es uno de los cuatro textos narrativos que consideraremos como historias aisladas. Después reflexionaremos sobre ellas. Este tío «Manel» es un campesino levantino de sesenta años que muere pobre.

En la secuencia 4 se alude a un político que «se preocupa también de los explosivos", es decir, del movimiento en bolsa de las acciones de Explosivos Riotinto, alusión similar a la del director de periódico de la secuencia 2.

En la misma secuencia 4 se comenta una tesis histórica bastante peregrina, según la cual a Jesucristo lo mató la guardia catalana de Pilatos; ya Collard rastrea la aparición de esta anécdota en un artículo de Sender de 1933 en La Libertad y también en Hipogrifo violento. También se alude a una obsesión política del Sender del momento: el frente único. Recordemos

11 Ramón J. SFNDER, Solanar y lucernario aragonés, Zaragoza, Heraldo de Aragón, 1978, p. 171.

12 Ramón J. SENDER, «Un film. El delator», La Libertad, 4864 (2 de noviembre de 1935), pp. 1 y 2. 
que su etapa como director de La Lucha, paladín del frente único, sucedió en 1934; ahora se alude al "proletariado catalán, dividido y vuelto a dividir política y hasta "apolíticamente", discute en las cárceles, discute en los sindicatos...». En esta secuencia de temática catalana se copian las carteleras barcelonesas. Este recurso a la cartelera ya lo hemos visto en la secuencia 1 y lo volveremos a ver en la 18 y en la 24 (en la primera y en la última). En la secuencia 5 vuelve a aparecer una alusión al tema del frente único. Se describe la vida disipada de los burgueses trasnochadores $y$, en contraste, la policía vigilando y unos militantes que pintan un cartel en una pared: «Frente común y lucha», precisamente el lema obsesivo y el título del periódico que dirigió Sender. En esa descripción del ambiente trasnochador se esboza una rápida alusión al lugar de reunión de homosexuales — «algunos despojos humanos arrimados a los barandales de los urinarios»-, alusión que se desarrollará, por la misma mano, a juzgar por la similitud de la concreción y de la velada ambigüedad, en la secuencia 22: «[...] y se espantan — cuando pasamos junto a un urinario- del acto ridículo de un "muy digno ciudadano" —-tresillo y bastón-con un adolescente».

En la secuencia 6, desde la perspectiva de la redacción de un periódico liberal, un periodista contrasta la rigidez con que son juzgados unos obreros implicados de alguna forma en los sucesos de octubre de 1934 -principalmente por tenencia de armas- con la benevolencia con que son tratados dirigentes de Falange Española (por delitos similares). El texto simula haber sido enviado a Tensor por el periodista; no se nos desvela la cabecera del periódico, que se supone que es $\mathrm{La}$ Libertad, porque al final del fragmento Sender glosa el texto, propio o ajeno, de este modo: «Hasta aquí el compañero que rinde su inteligencia a la Prensa industrial, siquiera sea a la mejor Prensa posible políticamente bajo el régimen capitalista, como sucede en este caso». Los términos son inequívocos; de forma similar se ha referido Sender a sí mismo en numerosas ocasiones. Está claro que el anónimo periodista del periódico fantasma no es otro que el propio Sender.

La secuencia 7 narra la historia de Juan Simeón, un campesino sin trabajo que, harto de buscar estabilidad infructuosamente, decide ahorcarse bajo un puente manchego. Se trata de una narración larga —el texto más extenso de todo el número, con más de once páginas-, algo morosa y lenta, con bastantes torpezas estilísticas y aun morfosintácticas, como un par de casos de laísmo, error en que Sender apenas incurre. Por todo ello ésta se nos presenta como la primera secuencia que aparentemente podría no ser de Sender, pero sí es la segunda de las que llamamos «historias aisladas». Con todo, lo que sí hace es intercalar cuatro titulares - recurso que utiliza a menudo-, de los cuales dos son frases entresacadas del texto y resaltadas tipográficamente, pero otras dos son claramente glosas con intención de agilizar el texto y de reforzar su contundencia, en coherencia con otros titulares que luego comentaremos. 
La secuencia 8 describe el amanecer por Levante y Sender lo inserta como escrito por un "poeta de Levante», pero el estilo no disuena del típicamente senderiano. Antes, al contrario, lo recuerda, aunque como leve parodia de estilo poético. Se parece en parte al «Discurso del "dandy" sobre la sonrisa", que abría el libro Proclamación de la sonrisa, publicado el año anterior.

La secuencia 9 es otra historia de una persona aislada con nombres y apellidos. Juan Vergara es un obrero sin trabajo que acaba de levantarse de «un banco del paseo de la Castellana», «dormitorio» que frecuentó en un tiempo el propio Sender. La descripción es bastante realista. En un periódico que un burgués acaba de dejar, Juan Vergara lee noticias de la guerra de Etiopía, con lo que esta secuencia enlaza al menos con la primera. Otras notas que lee del periódico burgués confirman la idea de que la prensa revela la ideología del lector, detalle que aparecerá también en la secuencia 11.

La secuencia 10 se desarrolla en Zaragoza, ambiente de sobra conocido por Sender, con referencias a la Virgen del Pilar, las monas del parque y alguna que otra curiosidad local. Estos detalles aparecen en la lectura comentada de un periódico de la ciudad. En contraste con el frío de las monas en el parque, no se dice nada en la prensa del problema del paro y de la población penal. Pero la secuencia se interrumpe por la inclusión de la siguiente, tras la cual continúa la anterior.

La 11 es una descripción de la entrada al trabajo a las ocho de la mañana en la fábrica de la Standard. En ella tres datos remiten a la autoría de Sender. Se comentan las distintas ideologías obreras que compondrían el frente único, aunque en este caso reducidas a «comunistas y socialistas». Se vuelve a insistir en el tema de la prensa burguesa y en cómo, con la prensa obrera suspendida, «se ve con frecuencia El Liberal y La Libertad, especialmente esta última; también hay quien lleva el Heraldo de la noche anterior». Por último se alude a la temática antiespiritualista propia de Proclamación de la sonrisa o de La noche de las cien cabezas, y con ideas análogas: «[...] abunda el trabajador que se dedica con insistencia a destruir en ciertos compañeros un residuo todavía latente de ilusión idealista burguesa».

Después de la secuencia 11 se continúa con la 10, que había quedado interrumpida para evitar la monotonía de la mera transcripción o comentario de las noticias de la prensa de provincias; en este caso se copian noticias de periódicos de Andalucía, siempre fechadas el día 27. Las noticias informan de conflictos entre obreros y burgueses o entre obreros y el Estado, siempre desfavorables para los primeros. En concreto dos de las noticias se refieren a sendos suicidios de obreros sin trabajo, detalles que se suman al de Juan Simeón.

La secuencia 12 vuelve a comentar las noticias de diarios de provincias, identificándose con las distintas secuencias que consideran la prensa como termómetro significativo del panorama social. Su autor es el que 
organiza todas las secuencias, pues está al tanto de dicha organización: «En las primeras páginas de TENSOR damos una parte de un editorial». Y en otro editorial que se copia vuelve a aparecer el concepto de intrahistoria que justifica la procedencia y temática del material empleado para captar la esencia de «un día de la vida española»: «[...] la política, cada día que pase lo prueba con mayor elocuencia, no está en los alcázares, ni en las tertulias de los próceres, ni en las cámaras y camarillas, sino en la calle y en la plaza pública».

La secuencia 13 vuelve a estar subdividida como la 10 , yendo la 14 intercalada entre las dos partes. La 13 desarrolla el tema de la calle que en la cita precedente se fijaba como centro de la vida social. En la primera subdivisión se narra una escena en una taberna. Continúa la 14 con una escena distinta, en un tranvía, pero en correlato con la 13, a título de manifestación de la cotidianeidad. La segunda parte de la secuencia 13 comenta la postura de la burguesía con respecto a la religión y describe un consejo de administración de una industria química. Veremos cómo Sender está presente en los cuatro temas de estas dos secuencias.

En La Libertad de 22 de mayo de 1932 se publica un artículo del novelista ineludiblemente ligado a dichos cuatro temas. Es fecha ya lejana al texto que nos ocupa, pero no casualmente este artículo es uno de los reproducidos en Proclamación de la sonrisa, que se publicó en $1934 .{ }^{13}$ En él se relatan tres escenas representativas de la vida cotidiana, que equivalen exactamente a las relatadas en las secuencias 13 y 14, en el mismo orden, aunque con distinto material descriptivo y discursivo. La primera escena sucede en una taberna: en La Libertad se oponían dos personas de ideologías opuestas en relación inversa a la propia de su medio social; en «Historia...» se comenta la figura de una señora, imagen del espíritu avariento de la burguesía católica; pero en ambos textos se habla de dos ideologías distintas, observadas en una taberna. La segunda escena se desarrolla en un tranvía: en La Libertad se narra un altercado de una muchacha con el cobrador de la compañía; al salir es piropeada por un joven, lo que es mal recibido por ella; en «Historia...» el altercado se produce entre un obrero y un burgués, con motivo de la escasez de espacio, lo que no parece ser problema si la que sube al tranvía es «una linda obrera"; cuando sale el burgués y se deshace el altercado, la obrera es interpelada por el obrero, lo que no es tan mal recibido en esta ocasión; aunque lo narrado es distinto, se trata de escenas con similar estructura narrativa e idéntico ambiente. La tercera concomitancia se compone de varias alusiones al espíritu religioso de la burguesía: en La Libertad aparecen sólo tres alusiones inconexas referentes a manifestaciones religiosas, en "Histo-

13 Ramón J. SENDER, “El domingo madrileño y la incongruencia», La Libertad, 3798 (22 de mayo de 1932), pp. 1 y 2. Reproducido en Ramón J. SENDER, Proclamación de la sonrisa, Madrid, Pueyo, 1934, pp. 132-136. 


\section{EL LUGAR DE SENDER}

ria...» el texto está más construido alrededor de la descripción de una misa.

En «Historia...» los textos simulan una procedencia distinta: el 13 se diferencia tipográficamente del 14 y a su vez éste está narrado por «un camarada» que va en el tranvía, mientras que la segunda parte del 13 está redactada a partir de la información de «la repórter», "nuestra compañera», de la que se utiliza una información aparentemente oral sin utilización clara de ningún texto escrito aportado. A pesar de ello el artículo de $L a$ Libertad los declara como procedentes, no sólo de Sender, sino además de un mismo texto previo del escritor.

Además de lo dicho, algunos datos de la primera parte de la segunda subdivisión de la secuencia 13 apuntan en dirección de distintos textos previos senderianos: en ella se describe un censo de la usual feligresía de una parroquia en el cual aparece un capítulo destinado a "Padres de familia, usureros, administradores de duques, pequeñoburgueses, etc.». Con vocablos similares se refiere en varias ocasiones Sender a su propio padre, del que rechaza principalmente su autoritarismo paterno, origen de varios incidentes que se relatan por ejemplo en Crónica del alba. En segundo lugar el calificativo de usurero le cuadra en la época de negocios especulativos en Zaragoza, de los que salió mal librado. En otra época anterior el padre de Sender también fue administrador de algún terrateniente, situación similar a la desencadenante del drama argumental de Réquiem por un campesino español. También en La noche de las cien cabezas se puede ver una alusión paterna poco respetuosa, relacionada con una de las varias profesiones que desempeñó el padre de Sender: "un rey de entonces era mucho menos culto que un secretario de Ayuntamiento rural de hoy». ${ }^{14}$ En cuanto al cuarto calificativo, "pequeñoburgueses», es un lugar común en toda esta época comunista de Sender.

Un segundo dato es una nueva alusión a los santos Cosme y Damián en términos similares a los de la secuencia 1 (letra de la copla popular, alusión a su oficio sanitario). Y un tercer dato es un párrafo en el que se resumen contundentes acusaciones contra el comportamiento de la Iglesia católica con respecto al Estado; por supuesto se refieren al Estado español, pero en El problema religioso en Méjico se desarrollan idénticas acusaciones contra la Iglesia mejicana con respecto al Estado de su país: exenciones fiscales, fuentes de ingreso no declaradas ni fiscalizadas, nivel de vida superior al de la feligresía, declaración por parte de la jerarquía eclesial de más plantilla de la existente para defraudar en las subvenciones estatales, etc. Las coincidencias son demasiado significativas y de peso en el núcleo temático de El problema religioso en Méjico para ser casuales.

En la segunda parte de la segunda subdivisión del texto se menciona el consejo de administración de una empresa jabonera que ante la posibi-

${ }^{14}$ Ramón J. SENDER, La noche de las cien cabezas, Madrid, Pueyo, 1934, p. 89. 
lidad de quiebra por falta de mercado encuentra una salida en la reconversión «para la producción intensa de gases venenosos» - lo que hoy llamaríamos «armas químicas»- para una guerra que se acaba de declarar. De nuevo la obsesión bélica o antibélica que ya hemos comprobado en textos de La Libertad y en «Historia...» (guerra entre Italia y Abisinia).

La secuencia 15 describe una sesión de Bolsa. En ella los comentarios políticos derivan hacia la formación del nuevo gobierno de Chapaprieta, con lo que se continúa la temática abierta en la secuencia 2. Por otro lado el autor recuerda con frecuencia la composición ideológica de los especuladores bursátiles —burgueses, monárquicos feudales y jesuitas-, combinación repetida a menudo por Sender. En concreto, la presencia de los jesuitas en las finanzas volverá a aparecer en las secuencias 20 y 23.

La secuencia 16 recoge los comentarios de un oficinista. Uno de ellos relata las sesiones de un cinematógrafo juvenil controlado por curas, que censuran escenas atrevidas tapando burdamente el objetivo con un sombrero. Este episodio lo utiliza Sender en alguna ocasión, pero en Crónica del alba aparece la estructura del episodio curiosamente referida a un jesuita, precisamente de la orden religiosa aludida en varias ocasiones en la secuencia anterior. ${ }^{15}$ A continuación se comenta la actitud instintiva de las «jovencitas», que superan la censura con la imaginación, temática recogida ampliamente en Carta de Moscú sobre el amor, que se publicó el año anterior, en 1934.

La secuencia 17 gira alrededor de la vida científica y universitaria. Se opone rotundamente la labor de las facultades de ciencias a la de las de letras, con claro menosprecio de éstas; en repetidas ocasiones en los últimos años Sender había anunciado la destrucción de la cultura burguesa, de la que sólo se salvaría la actividad científica y técnica. En líneas generales se opone la nueva cultura progresista — de la que se detallan tres ejemplos - a la cultura burguesa, de la que se narra un episodio con respecto a sus consecuencias deshumanizadoras para la mente de un niño. Frente a este caso, el primer ejemplo trata de un universitario de la FUE que describe la labor investigadora de un histólogo de la Junta para Ampliación de Estudios e Investigaciones Científicas; en el segundo, un alumno del Centro de Estudios Históricos nos describe la tarea desarrollada por este Centro, y en el tercero una muchacha describe la vida en un centro obrero cultural. Un año antes publicaba Sender, en La Libertad, un artículo dedicado a exaltar la figura de Cajal, histólogo eminente por antonomasia. ${ }^{16} Y$ otro año antes, en otro artículo del mismo diario, Sender exaltaba la actitud de la FUE y, en general, de toda la juventud investigadora y estudiosa y abiertamente científica frente a la torpe rutina del aca-

15 Ramón J. SEnder, Crónica del alba, Madrid, Alianza, 1971, p. 90. En «Historia...», cit., p. 66.

16 Ramón J. SENDER, «Después Ramón y Cajal, montañés del Alto Aragón», La Libertad, 4540 (19 de octubre de 1934), p. 1. 
demicismo. ${ }^{17}$ Otro detalle más: en la secuencia se alude de nuevo a los santos Cosme y Damián como patronos del gremio sanitario. $\mathrm{Y}$, por fin, como señala Mainer en el trabajo a que aludíamos al principio, el episodio en que un niño pregunta si se comen los sesos de pobre aparecerá con posterioridad en Contraataque. ${ }^{18}$

La secuencia 18 comenta las carteleras de Valencia, La Coruña y otras ciudades, extraídas de la prensa. La utilización de material de dicha procedencia es una constante a lo largo de todo el texto y en concreto con un uso similar apareció en la secuencia 12. La temática de la cartelera además es común a las secuencias 4 y 24 , donde se comentan las de Barcelona y Madrid respectivamente; pero no es casual, pues se desvela claramente que las tres secuencias proceden del mismo autor: «[...] éste es el tono general de las salas de espectáculos en toda España. Al principio hablamos de las de Barcelona. Luego hablaremos de las de Madrid».

La secuencia 19, de nuevo con textos procedentes de la prensa, opone los decretos gubernativos - referentes al Ejército, la Iglesia y la economía, como manifestación de la clase burguesa - a las noticias que interesan a la clase obrera - accidentes laborales y detenciones-, en dicotomía que refleja claramente el maniqueísmo marxista del Sender del momento. Por si no fuera suficiente, en un párrafo que resume la secuencia se alude al tema del frente único o unidad de la clase obrera por encima de las «tendencias»:

\footnotetext{
A los burgueses de todos los partidos políticos los identifica la renta. A los obreros de todas las tendencias, la necesidad de organización, de lucha, de protesta. La inseguridad de las condiciones del trabajo. Esos dos trabajadores eran de la CNT. Uno de ellos, por lo menos, anarquista. Todos los trabajadores - socialistas, comunistas - compartieron la desolación de las familias de las dos víctimas. Todos se sintieron más cerca entre sí.
}

La secuencia 20 describe un consejo de administración en el que se decide una fusión de empresas y la consiguiente reducción de plantilla. De nuevo se califica al alto capitalismo español como fluctuante entre dos vertientes, la torpe y feudal y la sibilina del monopolismo, controlada por jesuitas, lo que ya aparecía en la secuencia 15 y se repetirá en la 23. Otra conexión senderiana la constituye una paródica y degradante alusión al grupo poético del 27, cuya poesía pura - denostada a menudo por Sender - se presenta de alguna forma relacionada con los intereses económicos del presidente del consejo de administración. Es de resaltar cómo los títulos de supuestos libros conjugan en

\footnotetext{
17 Ramón J. SENDER, «Hechos y palabras. Los muchachos de la F. U. E.», La Libertad, 4094 (3 de mayo de 1933), p. 1.

18 Ramón J. SENDER, Contraataque, Barcelona-Madrid, Nuestro Pueblo, 1938; Salamanca, Almar, 1978, pp. 35-36. José-Carlos MALNER, op. cit., p. 138.
} 
claro recurso paródico temas centrales de dicha poética con títulos reales del grupo:

\begin{abstract}
En un arranque de malhumor, libros preciosos de poesías puras, intachablemente encuadernados, tales como Sombra del olvido, Halo, Esencia y perfil del tedio y Espiritual neurastenia de un adolescente, fueron rodando a parar debajo del fichero donde D. Valentino guardaba el detalle de sus imposiciones.
\end{abstract}

La secuencia 21 informa de la reconstrucción del sindicato de la Construcción de Oviedo después de la represión y derrota de la «comuna». Se trata de un texto muy corto - algo más de una página- en el que apenas se encuentran detalles de tema o estilo que apunten hacia Sender; salvo la ordenación lógica que busca el contraste con la secuencia anterior: después del consejo de administración, célula básica del capitalismo, se presenta el sindicato, célula básica de la clase obrera.

La secuencia 22 es muy interesante porque, ya casi al final del texto, combina el fingimiento de una acción coordinada y colectiva en su elaboración, junto con la velada consideración del mismo como una obra casi personal, refrendado todo ello por la serie de alusiones de inconfundible procedencia senderiana más larga de toda la obra. En principio se dice que al autor de la secuencia se le «encargó la inspección [...] de una hora del día». Pero inmediatamente el mismo autor reflexiona sobre la forma de reflejar la esencia de ese día y llega a la conclusión de que la mejor forma de llevar a cabo el encargo consistiría en un mosaico de realidades, tal como se va articulando el propio texto; en ese sentido esta secuencia se convierte en microcosmos y explicación de la obra total:

\footnotetext{
Hasta el momento en que integrando en mi atento mirar diversas acciones, variables sucesos, diferentes acaeceres, un día iba a tener para mí una muy concreta significación, pensé con los más en el día, como en un cañamazo donde desenvolver, más inconscientemente que conscientemente, unas cuantas acciones muy poco bordadas.
}

A partir de ahí el autor se identifica con el viento en términos similares a los utilizados en $O . P$., para dedicarse a contar, no lo particular de un día, sino lo general, lo que se repite, ciñéndose a analizar las lecturas de la gente. Después de considerar los distintos tipos de publicaciones que leen personas ideológicamente diferentes, se vuelve a aludir a una disputa en el tranvía; ambos hechos no tienen conexión lógica, pero en ese orden aparecieron en la secuencia 14 y además en el artículo de La Libertad, que luego se integró en Proclamación de la sonrisa. ${ }^{19}$ Precisamente en esta secuencia aparece también repetidas veces este tema de la risa o la sonrisa, pero

19 Ramón J. SFNDFR, «El domingo madrileño...», art. cit. 


\section{EL LUGAR DE SENDER}

en sentido distinto al del título del libro, es decir, como proclamación de la alegría revolucionaria frente al pesimismo decadente burgués:

El segundo iba como riendo. Con una risa que sentía una muerte. Con una risa que respiraba clara al comprender el magno suceso de una vida extinta, sin embargo.

Actuaba de modo bien diferente al albañil risueño que, en su andamio, momentos después, lanzaba contra la pared de su trabajo su masa y su risa. La risa le servía como músculo en su trabajo. Comprendí que la risa era en él un profundo y sano desprecio.

Se habla de la feria del libro y de escritores que comentan el aspecto económico de la escritura, cuestiones ambas que se tratan en dos artículos de La Libertad, igualmente integrados en Proclamación de la sonrisa. ${ }^{20}$ Se alude a Gide y a Essad Bey, que son precisamente los protagonistas de sendos artículos de La Libertad integrados consecutivamente en Proclamación... ${ }^{21}$ Se comenta una escena de homosexualidad en urinarios, como en el subtexto 4 . Se habla de una trilogía — "vagos, rameras y soldados»- extraída de la cotidianeidad callejera, similar a la utilizada en otro artículo de Proclamación... ${ }^{22}$ Se vuelve a utilizar el tema de la cartelera, como en las secuencias 4, 18 y 24 . Se utilizan los conceptos de «decadente» y «diletante", constantes en toda la época de Proclamación... y La noche de las cien cabezas; precisamente el segundo de los términos resume el tema desarrollado en un artículo de La Libertad del mismo año de $1935 .{ }^{23}$ Y por fin una prostituta interpela a un viandante - «Lo que es con Abisinia, no hacéis a nadie caso»- reprochándole su indiferencia causada por la obsesión política, con desparpajo castizo similar al de la prostituta, que en idéntica situación aparece en otro artículo de Sender, muy lejano en el tiempo, de su etapa de La Tierra, y al de otra que aparecerá en Mister Witt en el cantón. ${ }^{24}$ La larga serie de «coincidencias» no deja lugar a dudas; precisamente en la secuencia en que más se finge la autoría colectiva aparece una mayor cantidad y densidad de rastros senderianos.

La secuencia 23, ya al borde del agotamiento, redunda en la descripción de la ociosidad de la vida burguesa; se alude de nuevo a la moralidad jesuita y se extrae otra nota de prensa, esta vez fechada en Salamanca.

\footnotetext{
20 Ramón J. SENDER, «La Semana del libro», La Libertad, 3774 (23 de abril de 1932), p. 1. Ramón J. SENDER, «Hechos y palabras. Veinte mil duros», La Libertad, 4069 (4 de abril de 1933), p. 1. Proclamación..., cit., pp. 73-75 y 144-148.

${ }^{21}$ Ramón J. SENDER, «Hoy. André Gide en el Cenit», La Libertad, 3939 (3 de noviembre de 1932), p. 1. Proclamación..., cit., pp. 148-151. Para Bey, pp. 151-155.

22 Op. cit., p. 171.

23 Ramón J. SENDER, «Pasatiempo. Los diletantes», La Libertad, 4619 (19 de enero de 1935), pp. 1 y 4

24 "El Diablo Hariman", «Entre paréntesis. Sesiones matutinas», La Tierra, 22 de junio de 1922. Ramón J. SENDER, Mister Witt en el cantón, Madrid, Espasa-Calpe, 1936 (p. 186 en la edición a cargo de José María Jover, Madrid, Castalia, 1987).
} 


\section{JOSÉ-MARÍA SALGUERO RODRÍGUEZ}

La secuencia 24, la última -una por hora del día, aunque no correspondan exactamente-, retoma el tema de la cartelera. Primero se critica la película "La Pimpinela escarlata», achacándole maniqueísmo de "buenos y malos», aquéllos «con una malsana, jesuítica y "cinematográfica" bondad», con lo que se repite una vez más la obsesión por los jesuitas. Después se comenta la cartelera teatral en términos coincidentes con la crítica de Teatro de masas: «Es un teatro estúpido, que a fuerza de buscar el halago de un espectador inferior al "standard" hace que éste baje cada día. Por otra parte, nada tiene de teatro esa baratería de feria, aunque en todo caso es todo el teatro que merece la burguesía para quien está escrito».

El texto finaliza con el programa de una representación sobre la figura de Teresa de Ávila, que fue ya protagonista de El Verbo se hizo sexo y será continuamente una figura de referencia con respecto al sentimiento espiritualista; precisamente en este programa se habla de «nueve cuadros teresianos» en expresión que apunta al título futuro Tres novelas teresianas. Pero en este caso la transcripción del programa en cuestión, realizada en tono irónico, persigue ridiculizar la utilización de la figura de la santa por la derecha reaccionaria.

Las que hemos llamado "historias aisladas» o historias de personajes aislados - secuencias 3, 7 y 9 y, en menor medida, 16- repiten una serie de constantes que eluden la casualidad: el protagonista tiene nombre, está solo, es pobre, se muere, no es noticia, está localizado geográficamente y en la secuencia se hace referencia al 27 de septiembre y a la hora del día.

El entramado de conexiones temáticas entre las secuencias alcanza prácticamente a casi todas en una cadena de interrelaciones mutuas, ${ }^{25}$ de manera que sólo dos secuencias - la 8, sobre un amanecer en Levante, y la 21, sobre la reapertura del sindicàto de la Construcción de Oviedopodrían no haber sido escritas por Sender. Por otro lado vimos alguna prueba documental de que César Arconada contribuyó de alguna forma a la elaboración de esta «Historia de un día de la vida española»; pudo escribir alguna de estas secuencias menos senderianas. El resto - más de veinte al menos-, así como la programación y ordenación de todo el volumen, sería obra del novelista aragonés, no sólo por las conexiones temáticas reseñadas, sino también por la insistencia en detalles de carácter técnico: material procedente de la prensa, alusiones a la hora o al número $27 \mathrm{del}$ día objeto del texto, noticias de signo negativo para la clase obrera, titulares intercalados de carácter blasfemo o escatológico... Todo ello nos lleva a considerar el texto como un libro más en la bibliografía senderiana a pesar de que pueda incluir algún texto de pluma ajena, pero irrelevante cuantitativamente, y abundante material de prensa, en técnica próxima a la del collage pictórico de la época.

25 Introducción con 2 y $12 ; 1$ con $2 ; 2 \operatorname{con} 4,6,13$ y $17 ; 3 \operatorname{con} 7$ y $16 ; 4$ con 5,18 y $24 ; 5$ con $22 ; 6$ con $10 ; 7$ con $10 ; 9$ con $11 ; 10$ con $19 ; 12$ con $18 ; 14$ con $22 ; 15$ con 20 y 23 . 


\title{
El otro lado del muro en \\ Los tontos de la Concepción
}

\author{
Gilberto Triviños \\ Universidad de Concepción
}

Los tontos de la Concepción, publicada por primera vez en 1963 (Nuevo México, Coronado Press) e incluida cinco años después en el libro El extraño señor Photynos y otras novelas americanas (Barcelona, Delos-Aymá), no ha suscitado entre los estudiosos de Sender una fascinación semejante a la provocada por El lugar de un hombre, Epitalamio del prieto Trinidad, Réquiem por un campesino español, Crónica del alba o La aventura equinoccial de Lope de Aguirre. La denominación obrita traduce con exactitud su exclusión del privilegiado grupo formado por las grandes obras de Sender. Los llamados defectos del librito parecieran justificar tal marginación. Antonio Tovar, por ejemplo, critica el modo inverosímil de construir la figura del militar ateo, «un capitán que en la España de 1780 habla como un capitán de las milicias republicanas de 1936» (Carrasquer, 1970, 137, 160). Josefa Rivas, por su parte, alude a «la novelita de Sender Los tontos de la Concepción» como una "publicación que lamentablemente es muy limitada», sobre todo por el predominio de los personajes «faltos de ese calor con que su creador suele dotar a sus otros hijos salidos de su pluma" y la disposición de los acontecimientos como si fueran concebidos por separado (ibid., 133, 141).

La obrita-que-es-una-novelita-también-llamada-librito tiene, no obstante, un prestigioso defensor. El maestro Francisco Carrasquer comienza 
su lúcido estudio sobre ella diciendo que «[d]e momento, parece que Los tontos de la Concepción [es] un libro de relleno en un hueco de su producción, una curiosidad incapaz de mantenerse mucho tiempo ni de acaparar todas las potencias del escritor, porque la obra da la impresión de estar escrita de prisa y sin poner toda la carne en el asador» (ibid., 132), pero después de refutar o matizar uno por uno los juicios negativos de Tovar y Rivas concluye que la novela escrita en Tocoma, Nuevo México, es realmente una hermosa historia del pasado («como dice Tovar») singularizada por «el encanto de su variedad folklórico-descriptivo-narrativo-épica», por la riquísima galería de personajes, por el "garbo y sencillez" del relato de lances y aventuras, por la información directa y sugestiva sobre las misiones españoles en América en pleno "siglo de las luces" (ibid., 160).

El estudio de Carrasquer no nos libera, con todo, de la duda sobre la importancia de Los tontos de la Concepción dentro de la narrativa senderiana. Descubre en ella los elementos distintivos del estilo senderiano (realismo que puede ser muy crudo, escapes de mentalidad mágica, filosofía personal a través y al margen de los personajes), discute el grado de inverosimilitud atribuido a la elaboración de la figura del capitán ateo ( «la noción de verosimilitud de Sender no es la misma que la del realismo tradicional»), evidencia «la coherencia entre las partes del relato y la progresión de todas ellas hacia un desenlace muy bien conseguido", destaca la fidelidad relativa de la historia mantenida con visible documentación fidedigna, demuestra que la novela no simplifica el problema de la colonia y de la obra misionera, reconoce que deleita, entretiene y hasta estremece, pero no deja de considerarla una obra "sin pretensiones», de designarla con la misma palabra desvalorizadora empleada por Josefa Rivas. No niego, por supuesto, el derecho a denominar novelita a Los tontos de la Concepción ni a mantenerla fuera del aristocrático grupo formado por las «grandes obras» de Sender. Intento, no obstante, contribuir, por lo menos, a sacarla de la jaula de los libros de relleno escritos «de prisa y sin poner toda la carne en el asador». La crónica misionera, que parece cifrar y sellar la búsqueda senderiana del «único humanismo revolucionario posible», iniciada literariamente en 1939 con la novela del descubrimiento de la verdad significativamente convertida en el lema mismo de este Congreso ("cada hombre, hasta el más miserable, ocupa un lugar en el mundo»), no debería destinarse precisamente al lugar reservado a las obritas (¿cuáles son ellas?) sin pretensiones (¿las hay realmente?) del autor de Crónica del alba, a los rellenos de los huecos dejados por su "decena larga de novelas de irrefutable calidad». La constatación hecha en 1983 por el prologuista de la antología crítica Ramón J. Sender. In memoriam (Zaragoza) tiene plena validez en 1995: el conocimiento de Sender no está aún normalizado.

He planteado en otra ocasión que la «gran fatalidad» o «círculo vicioso» de la violencia humana es a la vez causa de la escritura senderiana ( «la necesidad de definir el mal y hacerlo patente en las conciencias de todos»), materia predominante, principio estructurador (simetría, alternancia, 
mudanza) y tema de debate o reflexión de los mismos protagonistas. La escenificación dramática o narrativa de historias trágicas cuyos protagonistas saben, descubren o piensan que el hombre siembra la vida y la muerte del hombre; que todo parece reducirse a un patético juego de monos irritados por el hambre de pan, de sexo o de poder; que lo humano es el odio, la envidia, el crimen, la traición; que matar, asesinar, derramar sangre es la fatalidad de la que no escaparemos nunca, no es privativa, en efecto, de Siete domingos rojos (1932), Epitalamio del prieto Trinidad (1942), Jubileo en el zócalo (1964) o La aventura equinoccial de Lope de Aguirre (1964). El descubrimiento del saber de la violencia que está en todas partes, afuera pero también adentro, en los otros pero también en nosotros, singulariza, por el contrario, muchas de las obras publicadas por Sender, erosionadoras todas ellas de la ilusión ancestral que lleva a los hombres a exorcizar el mal atribuyéndolo a una pestilencia que proviene de afuera, traída siempre por el otro.

René Girard ha evidenciado el mecanismo de la víctima propiciatoria mediante el cual los hombres consiguen expulsar el saber de la violencia pasada, que envenenaría el presente y el futuro si no consiguieran liberarse de él, rechazarlo por entero sobre un individuo considerado el único responsable de la mímesis violenta. «Para los tebanos, en suma, la curación consiste en adoptar el mito, convertirlo en la versión única e indiscutible de la crisis ahora superada, la Carta Magna de un orden cultural renovado, en convencerse, en otros términos, de que la comunidad sólo ha sufrido la enfermedad de la peste. La operación exige una firme creencia en la responsabilidad de la víctima propiciatoria. Los primeros resultados, la paz repentinamente restaurada, confirman la identificación del culpable único, acreditan para siempre la interpretación que convierte a la crisis en un mal misterioso aportado desde fuera por la mancha infame y cuya propagación únicamente es capaz de interrumpir la expulsión de este portador de gérmenes» (Girard, 1983, 91). La violencia está afuera, procede del otro. Ilusión y engaño, dice el autor de La violencia y lo sagrado, pero la ilusión y el engaño más formidables y más ricos de toda la aventura humana. «Persuadidos como estamos de que el saber siempre es algo bueno, sólo concedemos una importancia mínima, cuando no nula, a un mecanismo, el de la víctima propiciatoria, que disimula a los hombres la verdad de su violencia. Este optimismo podría constituir perfectamente la peor de las ignorancias. Si la eficacia de la transferencia colectiva es literalmente formidable, se debe precisamente a que priva a los hombres de un saber, el de su violencia, con el que nunca han logrado coexistir» (ibid., 90). Las novelas de Sender se inscriben de modo singular en la historia de la ilusión ancestral que lleva a los hombres a convertir su violencia en un dios, un destino o un instinto del que ya no son responsables y que los gobierna desde fuera. El escritor, que se ha impuesto la obligación de definir el mal, el cual «siempre se manifiesta por la violencia», no quiere ocultar la verdad de la violencia humana. Escribe precisamente para evidenciar que 
es necesario mirar directamente la verdad de la violencia humana, no sólo porque toda la triste dignidad que se nos permite consiste en mirar cara a cara una verdad (Epitalamio del prieto Trinidad), sino también porque sólo así aprenderemos, tal vez un día, a atenuar el mal "que nadie lleva a ninguna parte porque está en todas» ( $E l$ bandido adolescente).

La conversión moral del autor de Siete domingos rojos, sobrevenida antes del desencadenamiento de la guerra civil española y relacionada con la crisis de su ideología revolucionaria del bienio 1933-1935, introduce la primera gran variación significativa en la exploración del círculo vicioso de la violencia. De esta situación de crisis, dice José María Jover en el prólogo de su edición crítica de Míster Witt en el cantón (Jover, 1987, 134), hubo de emerger esa nueva sensibilidad ante valores humanitarios, expresiva de un talante distinto del que informa sus novelas anteriores y que en los recuerdos personales de Sender irá asociada, ya en los años del destierro, con la imagen del hermano lego del Colegio de Reus. Esta tesis es correcta, aunque incompleta, pues no permite determinar con exactitud las diferencias existentes entre, por ejemplo, Siete domingos rojos, exaltación de las "hermosas palabras de la ira" de los revolucionarios, que no discuten la licitud de matar a los enemigos de clase, porque el burgués no es una persona ni un hombre ("Es nada»), y El verdugo afable, cuyo protagonista descubre que "[el anarquista mata] en nombre de la justicia social, en nombre de la ley matan los guardias, en nombre del amor mata el amoroso transido y en nombre del odio el vengador". O entre La noche de las cien cabezas, alegoría de la revolución como tormenta liberadora que permitirá el advenimiento de la verdadera justicia, y Crónica del alba, relato de la orgía de sangre protagonizada por muchos Juan Pérez suicidándose en muchos Juan Pérez. La irrupción de lo nuevo no se reduce en estos casos a la pura emergencia del «discurso de la compasión y del humanitarismo». Lo realmente distintivo en las novelas así contrastadas proviene sobre todo del pasaje del lenguaje de la diferencia (dominio de los dualismos disyuntivos) al lenguaje de la indiferenciación (dominio de los dualismos no disyuntivos); del pasaje de la visión mítica de la violencia, regida por la ilusión de una distancia irreductible entre un paroxismo benéfico (revolución) y un paroxismo maléfico (represión burguesa), a la visión trágica, caracterizada por la abolición espectacular de la oposición entre la ira redentora de los oprimidos y la furia monstruosa de los opresores, por la multiplicación de los efectos de espejo producidos por la reciprocidad violenta.

Epitalamio del prieto Trinidad, La aventura equinoccial de Lope de Aguirre y El bandido adolescente ilustran de modo ejemplar el señalado pasaje del lenguaje de la diferencia mítica al lenguaje de la indiferenciación trágica. Siete domingos rojos y La noche de las cien cabezas, regidas por el espejismo de la revolución como advenimiento de la "verdadera justicia humana", inmovilizaban todos los signos de lo perverso, de lo maléfico, sobre la violencia de la «bestia burguesa». La furia luciferina del monstruo burgués se distingue siempre radicalmente de la santa furia proletaria. Los anarquis- 


\section{GILBERTO TRIVIÑOS}

tas Progreso, Espartaco, Germinal, Helios y Liberto son siempre víctimas inocentes, irreductiblemente opuestos a sus victimarios, los guardias de asalto y los agentes policiales, llamados "perros", "cosas» o "bestias», que deben exterminarse sin compasión. Las historias de Lope de Aguirre, Billy the Kid y Ramiro Vallemediano descubren, por el contrario, el devenir semejante de los protagonistas uniformizados por la misma locura homicida. Nadie representa en ellas la esencia del bien o la esencia del mal, simplemente porque todos desempeñan alternativamente los mismos papeles, los mismos roles, en el siniestro juego de la reciprocidad violenta. No es por ello un azar que el universo de El epitalamio del prieto Trinidad, El bandido adolescente y La aventura equinoccial de Lope de Aguirre evoque el universo de Las bacantes, La locura de Heracles, Edipo rey, Alcestes, Las fenicias o Los siete contra Tebas. La imaginación trágica de Sender, como la de Sófocles, Eurípides o Esquilo, difiere también radicalmente de la imaginación mítica, cuyos dualismos disyuntivos disimulan las simetrías engendradas por la mímesis violenta. Lope de Aguirre y Felipe II, Zalduendo y La Bandera, Trinidad y Seisdedos, Billy the Kid y Pat Garrett devienen semejantes, dobles intercambiables, por las mismas razones por las que devienen idénticos Edipo y Creonte, Dionisios y Penteo, Eteocles y Polinice. Se trata siempre de los efectos especulares producidos por el paroxismo de la rivalidad mimética, de las expulsiones recíprocas entre los hombres prisioneros del círculo vicioso de la violencia. La tragedia reúne todo lo que el mito diferencia arbitrariamente, dice René Girard en un bello estudio sobre Las bacantes de Eurípides, lo que también puede decirse de las novelas de Sender regidas por la proliferación de los dobles:

Si lo trágico nos elude es porque nos separamos sistemáticamente de lo idéntico. Los trágicos nos muestran unos personajes enfrentados con una mecánica de la violencia cuyo funcionamiento es demasiado implacable para dar pie al menor juicio de valor, para permitir cualquier distinción, simplista o sutil, entre los «buenos» y los «malos». A ello se debe que la mayoría de nuestras interpretaciones modernas sean de una infidelidad y de una indigencia extraordinarias; nunca escapan del todo a ese "maniqueísmo" que triunfa en el drama romántico y que, a partir de entonces, sigue exasperándose. Si no hay diferencias entre los antagonistas trágicos, es porque la violencia las borra todas [...] Sería pecar de arbitrariedad reservar a Edipo y bautizar como "rasgo de carácter» lo que pertenece a todos en igual medida, sobre todo si esta pertenencia común procede del contexto trágico, si la lectura que permite es de una coherencia superior a cualquier interpretación psicologizante. Lejos de aguzar las aristas de unos seres estrictamente individuales oponiendo los unos a los otros, todos los protagonistas se reducen a la identidad de una misma violencia, el torbellino que les arrastra les convierte a todos exactamente en una misma cosa. (Girard, 1983, 54, 78, 80)

La tragedia asemeja lo que el mito diferencia arbitrariamente. No sabemos, por ejemplo, la identidad de los dobles descubiertos por Alonso Paredes, el soldado de La aventura equinoccial de Lope de Aguirre que encuentra por doquier dobles de sí mismo, dobles de Lope de Aguirre, 


\section{EL LUGAR DE SENDER}

dobles de Pedrarias, dobles de otros. Conocemos, sin embargo, los nombres de los gemelos que llevan a su máximo desarrollo el significado profundamente transgresivo del desplazamiento de la diferencia mítica por la simetría trágica en la narrativa senderiana. La escena en que Pedrarias de Almesto reconoce la dificultad de calificar de un modo vejatorio al Peregrino permite conocer la primera indiferenciación impensable en los textos del siglo XVI, regidos por el mecanismo de la víctima propiciatoria. El lenguaje de la diferencia predominante en las crónicas, romances y epopeyas coloniales hace inconcebible la asociación de Julio César, "divino caudillo", "general ejemplar", "guerrero piadoso", con Lope de Aguirre, «fiera entre los hombres», «traidor por antonomasia», «agente del infierno». El amigo de Elvira hace patente, sin embargo, el carácter ilusorio de su oposición irreductible: «Pedrarias reía mirando a Lope de Aguirre y pensando: "Qué gran camarada sería este Lope si no fuera tan...". Y no acertaba con la palabra. Miserable no le iba. Vil, tampoco. Era difícil calificarlo de un modo vejatorio porque veía en él un Julio César con la cabeza reducida al tamaño de un puño, como hacían los indios tupíes. Pero Julio César». El paroxismo uniformador es, sin duda, la violencia soberana. «También el caudillo romano había matado gente culpable y gente inocente. Con el lazo o el cuchillo y, frecuentemente, por la mano de negros de la Libia antigua, como el llamado Vos. Ni más ni menos» (Sender, 1968, 302). La indiferenciación más perturbadora de nuestros dualismos morales es, no obstante, la que convierte a Lope de Aguirre en gemelo de Felipe II. El personaje histórico llamado Pedrarias de Almesto escribe la espantable historia del tirano más cruel del mundo, del monstruo tan perverso que nadie podría parecérsele. El personaje novelesco del mismo nombre relativiza esta verdad declarando que no le espantan las muertes y crueldades de Lope de Aguirre porque más muertes y crueldades hace Felipe II en una semana. El cronista de la historia escribe cuando la violencia recíproca (todos contra todos) ha sido ya sustituida por la violencia unánime (todos contra uno), por el mecanismo mediante el cual los hombres consiguen persuadirse de que sólo uno de ellos es el responsable de la mimesis violenta (Girard, 1983). No es posible decir entonces que los crímenes del marañón imitan los crímenes del soberano sin exponerse a la represalia del orden monárquico restaurado. La necesidad de liberarse de la persecución de los vencedores hace que el soldado que fue marañón adopte el lenguaje estigmatizador contra los marañones. El cronista de la ficción, en cambio, habla en el tiempo mismo de la turbulencia trágica, cuando la responsabilidad de la violencia indiferenciadora todavía no se inmoviliza sobre un solo individuo. Sabe ya entonces que no se puede decir la verdad en público y a veces tampoco en privado, pero ello no le impide descubrir la gran semejanza del «crudelísimo» Lope de Aguirre con el "clementísimo" Felipe II. La siniestra repetición de lo idéntico, materia misma del relato de la aventura equinoccial, no respeta la formidable diferencia entre los antagonistas trágicos. La convierte, por el con- 
trario, en la semejanza más formidable de todas las producidas por el imperio de la reciprocidad violenta. Lope de Aguirre, doble de Julio César, lo es también de Felipe II. «Ni más ni menos».

La posesión de la verdad trágica, surgida de la disolución de la verdad mítica, no es con todo el infringimiento "más hondo" en la escritura de Sender. La enigmática escena del ángel moreno en El verdugo afable, donde la estatua indiferente de María Mármol ha observado durante treinta siglos que los hombres derraman su sangre en nombre de todos los dioses y todas las leyes, testimonia literariamente el itinerario de la exploración senderiana del "círculo vicioso" de la violencia humana. El descubrimiento de la verdad de los gemelos es sólo el comienzo, no el final de la búsqueda. Ramiro Vallemediano dice que «matar, asesinar, derramar sangre» es la fatalidad de la que nunca escaparemos. El ángel mulato replica que en todos los hombres hay un secreto más alto que el crimen y que nadie, ni siquiera Satán, que suele ganar la olimpíada de la risa cada siglo, puede reírse de él. El amigo de los anarquistas pregunta qué secreto es ése, pero el ángel con alas negras desaparece sin contestarle. Los tontos de la Concepción tiene en este sentido una función clave en la historia de los desciframientos senderianos de las palabras del ángel mulato. Mister Witt en el cantón, Epitalamio del prieto Trinidad, El verdugo afable, Tres novelas teresianas y Crónica del alba, las grandes novelas de Sender cuyos protagonistas aprenden que hay un caminito entre los monstruos ("un caminito para cada cual»), pertenecen sin duda a tal historia. Froilán Carvajal, la Niña Lucha, Darío, Ramiro Vallemediano, Teresa de Jesús, fray Hernando, el hermano lego y José Garcés así lo testimonian. El secreto más alto que el crimen, nos dicen todos ellos, es descifrable. Ninguno de estos personajes novelescos posee, sin embargo, la fuerza utópica, la belleza, el poder perturbador de la figura del franciscano, que en el momento mismo de su muerte pronuncia palabras impensables en los relatos regidos por la diferencia mítica (Siete domingos rojos) y la simetría trágica (La aventura equinoccial de Lope de Aguirre).

La lectura de Los tontos de la Concepción como «hermosa historia del pasado» que descifra el significado utópico de las palabras del ángel mulato hace evidente la profunda unidad del relato, la intensa coherencia entre sus partes y la progresión de todas ellas hacia un desenlace "muy bien conseguido». Los críticos de la llamada obrita nos dicen que en ella los hechos están relatados como si fueran concebidos por separado. Olvidan con ello que uraramente encontramos en la obra de Sender cuerpos de novela monolíticos; lo normal es que tengan brazos y piernas, colas o crines, y que acarreen en su marcha cuerpos extraños, enredados, pegados o arrastrados por su corriente» (Carrasquer, 1970, 133). No advierten sobre todo la necesidad estructural de los relatos de las dos masacres de Acoma en la novela de la verdad de la reciprocidad violenta no mostrada en los relatos coloniales de la evangelización. La historia del martirio de los sacerdotes y los soldados de las misiones de la Concepción y Bicuñer (julio 
de 1781) no es excepcional ni sorprendente. Repite de modo invertido la historia del martirio de los indios de Acoma (enero de 1699), reiteración a su vez simétricamente inversa del martirio de los españoles en Acoma (diciembre de 1698). Constituye una represalia en un universo de represalias uniformizadoras de los antagonistas. Una venganza más en ese ciclo interminable de venganzas cuya lógica implacable es señalada significativamente por el mismo Francisco Garcés después de escuchar a los indios de Acoma la historia de sus dos combates con los españoles, "el primero favorable a los indios y el segundo a los invasores»:

El mismo Zaldívar cayó tres o cuatro veces gravemente herido para levantarse y seguir peleando hasta que la última vez, al tratar de levantarse, recibió varias flechas en el pecho y quedó en tierra para siempre. Su cadáver fue obscenamente mutilado.

Los cinco soldados heridos, pero con vida, decidieron saltar al vacío para salvarse o tal vez para morir.

[...] Entretanto, el gobernador quiso castigar a los indios de Acoma y organizó con tal motivo una expedición punitiva.

Recordando todo esto el padre Garcés se decía: «No es humana ni cristiana la venganza. Mejor es en esos casos el perdón. Los indios, si se les perdona después de un hecho sangriento lo agradecen tanto más cuanto menos pueden comprenderlom. El padre Garcés habría perdonado, si dependiera de él. La venganza no hacía sino provocar la ira de los indios, quienes se preparaban a responder de nuevo con las armas en un futuro más o menos lejano. (Sender, 1973, 106)

La reflexión del sacerdote aragonés sobre la represalia que termina con la masacre de los indios dirigidos por Zutucupán tiene resonancias trágicas. El franciscano no sabe entonces que está vaticinando su misma muerte. El futuro «más o menos lejano» por él profetizado no es sino su propio presente. El presente de la mimesis violenta que nuevamente invierte las relaciones de poder en las tierras donde «la mejora de cada [español] es a costa del indio, si hemos de ser francos». Las víctimas del colonialismo transmutadas en victimarias no distinguen entre militares y sacerdotes, entre misioneros castos y sensuales, entre españoles puros e impuros. Francisco Garcés respeta profundamente la inteligencia de los indios, ha aprendido su lenguaje, ha reconciliado enemigos, es sincero deseando «la paz de los indios, su salud y su prosperidad y sobre todo la salvación de sus almas", pero el recuerdo de sus virtudes no reprime la furia de los yumas poseídos por el deseo de represalia. El torbellino de la reciprocidad violenta, que no deja nada fuera de su campo, devora por igual al sacerdote casto, al militar que odia a los indios («el mejor indio es el indio muerto y enterrado») y al sacerdote convertido en rival enconado de Ginesillo por la propiedad de la niña Concepción. Una breve escena de la masacre cifra ejemplarmente la pérdida de la diferencia constitutiva del paroxismo violento. El indio centenario pide a los indios de guerra que no maten a los curas. El indio joven replica que «esos dos hombres son los peores de todos». La extensa secuencia en la que los sacerdotes y los mili- 


\section{GILBERTO TRIVIÑOS}

tares de las misiones de Bicuñer y la Concepción discuten sobre el derecho a explotar a los indios muestra aquí su pertinencia narrativa dentro de la serie de diálogos (disputas entre Ginesillo y Barraneche), historias (masacres de Acoma) y episodios (huida del yuma tonto) prefiguradores de las trágicas escenas finales de Los tontos de la Concepción. El capitán Rivera recuerda en ella que los indios no han dicho todavía su opinión, que nadie se la ha pedido hasta ahora, que podría ser que no quisieran "ponerse calzones ni ir al cielo después de muerto[s]». Francisco Garcés, el mismo sacerdote que entonces ha preguntado "¿qué pueden tener contra nosotros los indios?», conoce esa opinión en el momento mismo de su muerte.

El relato de la proliferación de los dobles de la violencia en las vidriosas tierras americanas no concluye, sin embargo, con la pura multiplicación de los efectos de espejo, tal cual acontece en otras "novelas americanas» de Sender también reveladoras de la verdad de la violencia en el Nuevo Mundo («todos matan»). Ninguna escena perturba, por ejemplo, el triunfo ostentoso de los efectos de la reciprocidad violenta en el desenlace de El bandido adolescente. La conclusión literal misma de la novela del desperado de Nuevo México, por el contrario, testimonia ejemplarmente la fuerza del contagio de la violencia, que «nadie lleva a ninguna parte porque está en todas». El propio narrador de la historia de Billy the Kid está en ella poseído por la «misma locura» de adorar al «Dios terrible de la venganza»: "aunque yo no tenía nada que ver con los problemas de aquella buena gente me alegré al saber la noticia. Lealtad por lealtad, siempre está bien la que los amigos se guardan entre sí» (Sender, 1982, 252). La noticia que así alegra al forastero que la escucha durante la danza de la muerte presidida por la comadre Sebastiana es que «poco después de la muerte de Billy ese tal Jesse Evans buscó a Garrett, el marshall, lo encontró en el despoblado y le voló la cabeza» (ibid., 252).

María Zambrano ha evidenciado en su lúcido prólogo de La tumba de Antígona (1967) que "el conflicto trágico no alcanzaría a serlo, a ingresar en la categoría de la tragedia, si consistiera solamente en una destrucción; si de la destrucción no se desprendiera algo que la sobrepasa, que la rescata. Y de no suceder así, la Tragedia sería nada más que el relato de una catástrofe o de una serie de ellas, en el cual, a lo más, se ejemplifica el hundimiento de un aspecto de la condición humana o de toda ella. Un relato que no hubiese alcanzado existencia poética, a no ser que fuera un inacabable llanto, una lamentación sin fin y sin finalidad, si es que no iba a desembocar en la Elegía - lo que es ya otra categoría poética» (Zambrano, 1986, 201). Antígona se distingue en este aspecto con singular nitidez entre todos los protagonistas de la tragedia griega. Muestra precisamente del modo más puro y más visible la trascendencia propia de la tragedia, donde "parece que la condición sea ésta de haber de descender a los abismos para ascender, atravesando todas las regiones donde el amor es el elemento, por así decir, de la trascendencia humana; primeramente fecundo, seguidamente, si persiste, creador. Creador de vida, de luz, de conciencia" 
(ibid., 204). El tiempo de permanencia en la tumba es un tiempo con múltiples funciones. La más importante de todas es, sin embargo, que Antígona descubre en él que el sueño de la ciudad nueva consume y se consume si no se le cuida. La víctima de sacrificio movida por el amor desciende a los infiernos creados por los hombres que creen que matando van a ser los Señores de la Muerte («Siempre hay enemigos, patrias, pretextos»), pero también asciende transfigurada por la visión de la ciudad capaz de desatar el nudo del mal. La tumba de Antígona cifra así bellamente el «rescate de la fatalidad». La doncella descubridora de que «la vida está iluminada tan sólo por esos sueños como lámparas que alumbran desde adentro, que guían los pasos del hombre, siempre errante sobre la Tierra», no se suicidó en su tumba, «según Sófocles, incurriendo en un inevitable error, nos cuenta». Sigue enterrada en ella, «hablando a viva voz para que todos la oigamos», perturbándonos sin descanso para alimentar el sueño de la edificación de la ciudad donde no hay sacrificio y el amor no está cercado por la muerte.

La «novela americana» de Sender que opone la fuerza de la verdad del ángel mulato a la fuerza de la verdad de la «gran fatalidad» de la violencia humana muestra, asimismo, la trascendencia propia de la tragedia. También en ella no se narra sólo la mezcla «informe, deforme, monstruosa" de los personajes uniformizados por el "sacrilegio" de decir no "con sangre o con ponzoña o con la soga encerada». También en ella el amor y su ritual viaje a los ínferos es la trascendencia que alumbra el nacimiento de la conciencia. También en ella hay un hombre puro que manifiesta «la ley siempre nueva, siempre reveladora; la ley sepultada que ha de ser resucitada por obra de alguien humanamente sin culpa [...] La ley en que el destino se configura y, por ello mismo, se rescata. Pues que la hazaña ha de ser ésa: rescatar la fatalidad» (Zambrano, 1986, 212). Los tontos de la Concepción no dialoga en este sentido con El bandido adolescente ni con La aventura equinoccial de Lope de Aguirre, las «obras americanas» de Sender monopolizadas narrativamente por la proliferación de los dobles de la violencia en las tierras donde todo es "matar, asesinar, derramar sangre». Dialoga sobre todo con Epitalamio del prieto Trinidad, la novela que finaliza cuando Darío y la Niña regresan a «hacer algo» por los criminales que pudieron haberlos asesinado. No es arbitrario afirmar que el desenlace del relato fechado en Acoma, Nuevo México, marzo de 1963, está ya nítidamente prefigurado en el desenlace del relato fechado en Guatemala, diciembre de 1941. La crónica de misioneros y la novela de criminales se asemejan precisamente porque descifran en América el mismo secreto descifrado por Froilán Carvajal, Ramiro Vallemediano, Teresa de Jesús, el hermano lego, fray Hernando y José Garcés en el interior mismo de las turbulencias trágicas españolas (revolución, guerra civil).

«Felices los que guardan en la memoria palabras de Virgilio o de Cristo, porque éstas darán luz a sus días". La novela Los tontos de la Concepción reduce este texto de los Fragmentos de un Evangelio apócrifo de Borges por- 


\section{GILBERTO TRIVIÑOS}

que sólo testimonia el poder transfigurador de las palabras de Cristo, pero a la vez lo amplía porque dichas palabras iluminan la vida y también la muerte del hombre que las practica. La lectura del Nuevo Testamento es en este caso la clave del desciframiento del secreto más alto que el crimen. Los sacerdotes de la misión de la Concepción ya devastada por los indios de guerra celebran una misa después de rechazar la tentación de la fuga ( Sería desertar. Yo no puedo abandonar la misión»). El padre Garcés comienza el oficio religioso como si las crueles desgracias del día anterior no hubieran sucedido y abre los Evangelios al azar para ver qué le aconseja la Providencia. Las palabras encontradas en lo alto de la página izquierda pertenecen al Sermón de la Montaña que un día maravilló a las muchedumbres de Galilea. El Hijo de Dios, que en los versículos inmediatamente anteriores ha rechazado la pena del talión ("Habéis oído que se dijo: Ojo por ojo y diente por diente. Pero yo os digo: No resistáis el mal, y si alguno te abofeteara en la mejilla derecha, dale también la otra»), descifra en ellas el secreto que el ángel mulato no revela a Ramiro Vallemediano porque sabe que el caminito entre los monstruos es un caminito que se lo encuentra cada cual:

Comenzó su misa el padre Garcés como si no sucediera nada. Al abrir los Evangelios al azar (solía hacerlo para ver qué le aconsejaba la Providencia) vio en lo alto de la página izquierda: «Porque si amáis a los que os aman, ¿qué gracia tendréis? También los pecadores aman a quien los ama... Amad, pues, a vuestros enemigos y haced bien y será grande vuestro galardón y seréis hijos del Altísimo porque él es benigno con todos".

La historia del Crucificado, que así nos pide hacer más ( $Y$ si saludáis solamente a vuestros hermanos, ¿qué hacéis de más?»), contagia con su belleza la historia del misionero que muere llamando hermanos a sus victimarios. El misionero sabe que el tránsito del camino revelado en el Sermón de la Montaña requiere una perfección que él tal vez no posee, pero decide hacer lo posible por tenerla. Reconoce que es difícil amar a los indios asesinos de religiosos y militares, pero no olvida que ellos supieron respetar la vida de niños y mujeres. Siente miedo de amar a "los hombres que tienen sus voluntades ebrias de sangre inocente y con una sed renovada de esa sangre», pero declara que quiere amarlos. Ahí reside precisamente la ejemplaridad del «hombre justo que murió por Jesús de Nazaret, siempre vivo en nuestra imaginación. Una imaginación capaz de grandeza, como se ve». Felipe II y Lope de Aguirre (La aventura equinoccial de Lope de Aguirre), Billy the Kid y Pat Garrett (El bandido adolescente), Hitler y Stalin (Crónica del alba), Trinidad y Careto (Epitalamio del prieto Trinidad) dicen que la violencia sólo se elimina con la violencia, que es preciso matar antes de ser matado, que la capacidad de ensueño no resiste a los aviones de bombardeo, que «el ideal» es el arma de los débiles, que estamos condenados a vivir como cerdos aun cuando nuestros sueños sean los sueños de Dios, que lo único eficaz es el «ojo por ojo y diente por diente», que sólo 
los fuertes, «los despreocupados de lo moral y lo ideal», conquistan el dominio. El religioso franciscano y, con él, Darío, la Niña, José Garcés, el hermano lego y Teresa de Jesús replican que el mal puede ser expulsado, que es posible amar al enemigo, que la energía de agresión no lo es todo, que «lo sublime es el sueño, el ideal», que hay un caminito entre los monstruos, que los dioses de la violencia devienen inanes ahí donde se descubren los "hermanos potenciales que todos tenemos al otro lado del muro».

El misionero español que descifra el secreto capaz de desatar el nudo del mal en el momento mismo de su martirio no constituye, con todo, la única figura textual liberada de la fascinación del odio en Los tontos de la Concepción. Una escena del relato de la misa en el templo profanado por los indios de guerra tiene en este sentido máximo interés para percibir la especificidad de la novela de Sender, en la que el protagonista mismo de la historia más hermosa concebida por la mente del hombre (Crónica del alba) deviene el mayor intérprete de las enigmáticas palabras del ángel mulato. Se trata del momento de las dudas de Francisco Garcés después de su lectura al azar de los Evangelios. Dos personajes innominados, trascendente uno a la esfera de lo humano («una voz misteriosa») y el otro a la de lo contado (narrador), testimonian entonces la verdad del secreto más alto que el crimen:

-Yo quisiera amarlos, Señor —decía con los ojos puestos en el cáliz de la consagración-, pero tengo miedo. ¿Cómo amar a los hombres que tienen sus voluntades ebrias de sangre inocente y con una sed renovada de esa sangre? ¿Cómo amar al verdugo que tiene el hacha suspendida sobre nuestro cuello? ¿Es posible amar al apóstata que se bautizó un día y hoy vuelve la espalda a la cruz y asesina a sus hermanos?

Porque algunos de aquellos yumas habían sido bautizados.

Pero una voz misteriosa le decía, como respondiéndole: «Si los hombres fuéramos capaces de amar a nuestros verdugos, dejaría de haber verdugos. Si fuéramos capaces de amar a nuestros enemigos, dejaría de haber enemistad en la tierra. Si fuéramos capaces de hacer bien a los que nos hacen mal, desaparecería el mal y sería el reino de Dios sobre la tierra». Aquello era verdad. (Sender, 1973, 156)

El relato final de Los conjurados de Borges narra una historia ocurrida en 1291 en el centro de Europa. Hombres de diversas estirpes, diversas religiones y diversos idiomas, entre ellos «Paracelso y Amiel y Yung y Paul Klee», toman la extrema resolución de ser razonables, olvidar sus diferencias y acentuar sus afinidades. El narrador del crecimiento de esta torre de razón y de firme fe («mañana serán todo el planeta») concluye así la historia de estos conjurados: «Acaso lo que digo no es verdadero; ojalá sea profético". El significado de Los tontos de la Concepción podría cifrarse con las mismas palabras. El autor de Crónica del alba dice en 1978, en la introducción de su novela Contraataque, publicada en Salamanca (Ediciones Almar) cuarenta años después de su primera edición en inglés (The War in Spain, Londres, Faber \& Faber Ld., 1937), «que uno quiere tener derecho a soñar, a hablar y escribir. A soñar también. Las utopías son nece- 
sarias. Si no existieran las utopías, no existiría "lo posible"; como si no existiera el infinito, no existiría el reloj. El mío va siempre veinticuatro horas exactas adelantado. Nadie lo sabe más que yo» (Sender, 1978, 16). La "crónica misionera», que acaso no es verdadera pero que ojalá sea profética, testimonia con singular nitidez lo que Borges llama nuestro hermoso deber de imaginar que hay un laberinto y un hilo ahí donde ni siquiera sabemos si nos rodea un laberinto, un secreto cosmos o un caos azaroso. Los tontos de la Concepción figura realmente en el lugar "más alto» de la exploración de los sentidos de las enigmáticas palabras del ángel mulato. Testimonia la fascinación de Sender por la divinidad, «demasiado débil» para admitir el crimen («Yo creería en Ti y te adoraría si Tú aceptaras el crimen»), muestra una vez más que la historia más bella de todas es la matriz estructural misma de sus relatos de muertes de inocentes (Réquiem por un campesino español), pero, sobre todo, revela que los sueños de los hombres puros creados por el novelista son los sueños mismos de Dios. Los sueños de la divinidad, que no enarbola "el hacha de las ejecuciones» y las represalias. Los sueños que Antígona, la que alimenta la utopía de la ciudad de los hermanos, no llegó a soñar. Los sueños de Cristo revelados en el Sermón de la Montaña.

Nuestra época no se define por el triunfo de la técnica, el nihilismo o el arte por el arte. Es acción para un mundo que viene, superación de su época, superación de sí que requiere la epifanía del Otro. El hombre que así habla en 1964, un año después de la publicación de Los tontos de la Concepción, es Emmanuel Levinas, el filósofo según el cual la obra, en tanto que orientación absoluta del Mismo hacia el Otro, es como una juventud radical del impulso generoso. «En tanto que orientación absoluta hacia el Otro - en tanto que sentido- la obra sólo es posible en la paciencia, la que, llevada hasta sus últimas consecuencias, significa, para el Agente: renunciar a ser el contemporáneo de la conclusión, actuar sin entrar en la Tierra Prometida» (Levinas, 1974, 51). Léon Blum, el prisionero que en el tiempo mismo del triunfo del hitlerismo, «agujero en la historia», escribe que «trabajamos en el presente, no para el presente», testimonia ejemplarmente la cima de la nobleza en el Humanismo del otro hombre. «Un hombre en prisión continúa creyendo en un porvenir irrevelado e invita a trabajar en el presente por las cosas más lejanas, de las que el presente es un desmentido irrecusable. Hay una vulgaridad y una bajeza en una acción que sólo se concibe para lo inmediato, es decir, al fin de cuentas, para nuestra vida. Y hay una nobleza muy grande en la energía liberada de la opresión del presente. Actuar para cosas lejanas, en el momento en que triunfaba el hitlerismo, en las horas sordas de esta noche sin horas -independientemente de toda evaluación de "fuerzas presentes" - es, sin duda, la cima de la nobleza» (ibid., 54). También Ramón J. Sender, el sobreviviente de la guerra civil que desea enseñar con sus «pobres medios» un «poco de respeto» por los hombres, aun cuando la visión del "vacío absoluto» le da derecho a ser un degenerado, un criminal, un cínico o un escéptico. El 
español inactual («lo inactual significa aquí lo otro que lo actual») que no renuncia al hermoso deber de imaginar que hay un laberinto y un hilo en un mundo que ha proclamado el fin del humanismo y la metafísica, la muerte de Dios y del hombre, el fin de la utopía y de la historia. El escritor de novelas sobre la "gran fatalidad", cuyos protagonistas descubren que la gran tarea es inventar estados de conciencia para los cuales no hay palabras todavía, que las palabras de Cristo en el Sermón de la Montaña son un recuerdo del porvenir, que «siempre el futuro tiene razón y, en definitiva, es lo único que nos queda a todos, ya que el pasado es experiencia mortal, vida cancelada y fosa común». El hombre imantado por la «extraña fuerza» de trabajar «en el presente, no para el presente», que llega a vislumbrar lo que quizá constituye la verdadera y única fuerza: «Una fe tranquila en los últimos fines, por encima de todas las miserias que uno mismo suscita» (Epitalamio del prieto Trinidad).

«Paracelso y Amiel y Jung y Paul Klee». El narrador de la historia de los hombres de diversas estirpes, lenguas y religiones que toman la «extraña resolución" de alimentar el sueño de la ciudad de los hermanos, donde el sacrificio no existe y el amor no está cercado por la muerte («el olvido de sangres y de naciones, la solidaridad del género humano"), silencia la identidad de muchos de los conjurados de 1291. No nos dice, por ejemplo, que ahí también estuvieron «Buda, el dulce Jesús, San Francisco [y] Gandhi». Antígona, José Garcés, el hermano lego y Teresa de Jesús. Froilán Carvajal, Darío, la Niña y Ramiro Vallemediano. Léon Blum, María Zambrano y Emmanuel Levinas. Francisco Garcés y Ramón J. Sender.

\section{BIBLIOGRAFÍA}

BORGES, Jorge Luis, "Los conjurados», en Los conjurados, Obras Completas, tomo III, Buenos Aires, Emecé Editores, 1989, p. 501.

CARRAsquer, Francisco, "Imán» y la novela histórica de Sender, prólogo de Ramón J. SENDER, Londres, Tamesis Books Limited, 1970.

GIRARD, René, La violencia y lo sagrado, Barcelona, Anagrama, 1983.

- El chivo expiatorio, Barcelona, Anagrama, 1985.

JOVER, José María, «Introducción biográfica y crítica», en Ramón J. SENDER, Mister Witt en el cantón, Madrid, Castalia, 1987, pp. 7-146.

Levinas, Emmanuel, Humanismo del otro hombre, México, Siglo XXI, 1974.

Mainer, José-Carlos, ed., Ramón J. Sender. In memoriam. Antología crítica, Zaragoza, Diputación General de Aragón, Ayuntamiento de Zaragoza, Institución Fernando el Católico y Caja de Ahorros de Zaragoza, Aragón y Rioja, 1983.

SENDER, Ramón J., Los tontos de la Concepción, en El extraño señor Photynos y otras novelas americanas, Barcelona, Destino, 1973, pp. 57-162.

—, "Introducción» a Contraataque, Salamanca, Almar, 1978, pp. 13-18.

- La aventura equinoccial de Lope de Aguirre, Madrid, Magisterio Español, 1968.

- El bandido adolescente, Barcelona, Destino, 1982.

TRIVIÑos, Gilberto, Ramón J. Sender. Mito y contramito de Lope de Aguirre, Zaragoza, Institución Fernando el Católico, 1991.

Zambrano, María, “La tumba de Antígona», en Senderos, Barcelona, Ánthropos, 1986, pp. 201-265. 


\title{
Autobiografismo en Las gallinas de Cervantes
}

\author{
Ángeles Pons Laplana \\ I. E. S. Maria Àngels Cardona, Ciutadela de Menorca
}

Las gallinas de Cervantes, relato que da título al libro de narraciones aparecido en 1967 y, de nuevo, forma parte de Novelas del otro jueves, ${ }^{1}$ editado en 1969,2 se nos presenta en forma de parodia de una realidad y quizás sea el mejor homenaje que Ramón J. Sender podía ofrecer al autor del Quijote.

Aparecen muchos rasgos de la novela cervantina, de larga tradición, por otra parte, en toda la novelística posterior; así, el deseo de justificar la veracidad del relato, común a diversos autores, o la transformación de un personaje, en este caso doña Catalina, esposa de Cervantes, que va adquiriendo carácter y aspecto gallináceo, con todo el valor simbólico que ello conlleva, por cuanto representa la mentalidad de toda una sociedad, frente a la cual se alzan algunos espíritus críticos asfixiados en un ambiente mediocre y utilitarista que no les permite la respiración ni el sosiego.

En este proceso de animalización hemos de recordar el lenguaje que utilizaron grandes literatos como Quevedo o Valle-Inclán, en ese deseo de plasmar, mediante un lenguaje excesivo, la deformación de la sociedad, y

\footnotetext{
1 Ramón J. SENDER, Navelas del otro jueves, México, Aguilar, 1969, p. 59.

2 Jesús Vived MAIRAL, «La vida de Ramón J. Sender al hilo de su obra», Alazet, 4 (1992), p. 265. (Autor al que agradezco profundamente el haberme facilitado el ejemplar objeto de estudio.)
} 
es relevante esta mezcla de personajes y escenarios reales e imaginados con los que juega Sender, como otrora hiciera el manco de Lepanto, ${ }^{3}$ enriquecido ahora con el lenguaje vanguardista, sobre todo surrealista y expresionista, alcanzando ese carácter simbólico que le confiere valor universal.

Sender, como representante destacado de la «generación del 27», aúna el equilibrio entre vanguardia y tradición y el lema del grupo, el paso de la literatura de vanguardia a la de avanzada, ya que siempre cultivó la novela social, aun antes de la propuesta de Jean-Paul Sartre por la literatura comprometida, que tanto influyó en los escritores de la época.

Considerado un estudioso más de la obra cervantina, el narrador nos muestra cómo ese proceso de transformación grotesca de doña Catalina Salazar se inicia justamente el día de la boda, en el acto tan prosaico de tomar nota de los «bienes» que configuran el ajuar de la novia y que son cinco colchones de lana, seis jergones de estigmas de maíz, algunos pliegos de papel de estracilla, dos cerdos y las inevitablemente omnipresentes y motivo de parodia veintinueve gallinas.

Asistimos en el texto a la incorporación de personas reales (don Miguel y doña Catalina) y de los personajes más famosos de la obra cervantina, uno de los cuales, don Alonso Quesada, presenta obvias similitudes con la fisonomía que Cervantes confiere al entrañable hidalgo de la Mancha, «alto, flaco y membrudo». En esta tradición de la reescritura literaria podemos recordar la técnica de universos compartidos tan en boga en las novelas de ficción de la década de los 80 . La admiración de Cervantes por el caballero don Alonso se torna perplejidad cuando al inventario del ajuar hay que incorporar el dato tan baldío de las veintinueve gallinas, más el gallo.

Con la ironía que refleja este hecho tan prosaico se muestra la gran paradoja de un don Alonso Quesada puntillosamente preocupado no por problemas acordes con su rango sino por unas simples gallinas. Este personaje encierra la contradicción y la duplicidad del ser humano, algo tan querido por el gran conocedor del alma humana que fue Cervantes.

En la forma en que doña Catalina y don Miguel se conocieron nos muestra Sender una reflexión acerca de la relación teatro-literatura y vida, tan afianzada en el escritor desde los lejanos tiempos escolares en que representara el personaje de Segismundo y presente además en la motivación de la escritura autobiográfica, como luego veremos.

También cede el protagonismo a doña Catalina niña, ensalzada en su espontaneidad. Y lejos de tener que redimir ni la locura ni la estupidez que Cervantes veía en otras muchas mujeres a través de la maternidad, circunstancia imprescindible para que la mujer alcanzara un mínimo estatus social. Al margen del matrimonio, otro personaje relevante será la sobrini-

\footnotetext{
3 Ángel BASANTA, Cervantes y la creación de la novela moderna, Madrid, Anaya, 1992, p. 69.
} 
ta, niña que encierra capacidades de carácter gnóstico ${ }^{4}$ ya que con su intuición será la primera en hablar del problema de la tía (primero fue el verbo, nos dirá la Biblia). Recordemos en este tema tan apasionante del lenguaje como creación a autores tan relevantes como Juan Ramón Jiménez, Luis Martín Santos o Emerson.

Vemos amplificado este homenaje a Cervantes en la paulatina transformación de doña Catalina en gallina y en los diversos personajes, unos reales, como Cervantes y su esposa, y otros ficticios pero nacidos de su pluma, como don Alonso o la sobrinita; en alusiones a autores como Sem Tob, David o Quevedo, y en la incorporación de Urganda, la desconocida, referencia al elemento mágico y cósmico tan querido y respetado por Sender, encarnación del encantamiento y la metamorfosis, propiciadora de la anagnórisis en Amadís de Gaula y ángel sanador en El Quijote.

Sender, siguiendo el ejemplo de Cervantes, persigue la superación de las diferencias entre novela, relato verídico y romance o narración libre, relato fabuloso. En El Quijote ${ }^{5}$ se logró por primera vez el equilibrio entre «lo poéticamente ideal y lo históricamente posible» $\mathrm{y}$, con ello, una magistral integración de «vida soñada y vida vivida», eterno problema calderoniano, machadiano o senderiano. He ahí el fundamento de su maravillosa síntesis de realismo y fantasía.

El personaje de la sobrina, trasunto de la cervantina Antonia Quijana, encarna la mezcla de ilusión y realidad, al igual que el perro de nieve, fundiéndose tras esa imagen de la meada grande. Don Alonso nos remite con su lenguaje a su origen literario, a los libros de caballerías; espera el «ineluctable desenlace», ${ }^{6}$ por lo que sufre las críticas del narrador, del protagonista, Cervantes, y del autor, que ve por los ojos del escritor.

La onomatopeya, frecuente en la obra de Sender, como el sonido familiar de las campanas o el de los "cucutes" — «"cu-cut", "cu-cut", el dos de mayo Santa Cruz»—, ${ }^{7}$ cobra en esta obra un carácter amenazante. Así, el cacareo de las gallinas — «iPor por por por por... poner!»— ${ }^{8}$ a la niña le recuerda insistentemente su derecho al maíz, en contraposición a la amarga ironía que siente Cervantes ante la desvalorización de su trabajo como escritor, acrecentada por la forma en que el valor de la dote, como aporte y mantenimiento del patrimonio, ha sido deformado grotescamente. Cervantes se plantea su papel de proveedor de la hacienda familiar e, irónicamente, una gallina sería suficiente para socavar su honor. Es de resaltar

\footnotetext{
${ }^{4}$ José-Carlos MAINER, «El territorio de la infancia y las fuentes de la autobiografía senderiana», en Ramón J. Sender. In memoriam. Antología crítica, Zaragoza, Diputación General de Aragón, Ayuntamiento de Zaragoza, Institución Fernando el Católico y Caja de Ahorros de Zaragoza, Aragón y Rioja, 1983, p. 143.

5 Ángel. BASANTA, op. cit., p. 75.

6 Ramón J. SENDER, «Las gallinas de Cervantes», Novelas del otro jueves, cit., p. 66.

${ }^{7}$ Ramón J. SENDER, El lugar de un hombre, Barcelona, Destino, 1992, p. 7.

8 Ramón J. SENDER, Novelas..., cit., p. 65.
} 
además este pasaje por la riqueza de voces aragonesas, referidas sobre todo al mundo animal, como esparver, hociquitos, solanar, rompientes, falconete, torcaces y otras, algunas de ellas cuidadosamente explicadas por el autor. ${ }^{9}$

El barbero y el cura, otrora personajes cervantinos, aquí en comunión con su creador y de paseo por el campo, encuentran un halcón joven, caído del nido, ante el cual todos se enternecen. Ante la propuesta de educar al animalito para la caza, Cervantes rápidamente rechaza la idea alegando que "sería injusticia hacer esclava a un ave a quien Dios había hecho libre». ${ }^{10}$ Ave, símbolo de tantas servidumbres que algunos hombres deben soportar, para quienes la mayor de ellas sería la incomprensión y la incomunicación entre los seres humanos, por las distancias tan diferentes que les separan del sentido utilitarista de la vida, tan demostrado igualmente por otros escritores como los modernistas. El clérigo sostenía que aquellas aves no eran buenas para comer y, por lo tanto, era inútil criarlas. La equivalencia hombre - alimaña que no produce y ensucia se emparejaría soterradamente con el sentido no útil de la literatura, y más habiendo cambiado doña Catalina la denominación coloquial de halcón por la peyorativa de «buitre». La acusación de Sender es clara ante el deseo de la mediocridad de cortar las alas al ave, con lo cual, sin los atributos que le son inherentes, queda convertida en una criatura tan antagónica como el sapo.

El proceso de gallinificación de doña Catalina al que asistimos alcanza un punto culminante porque, simbólicamente, cuando el hombre no respeta la naturaleza ni a los otros seres vivos se convierte en un animal ignominioso.

El sentido parabólico de este texto y la incomprensión en que han vivido escritores como Cervantes, Valle-Inclán, Ramón Gómez de la Serna y muchos otros quedan aquí magistralmente plasmados por Sender, un autor que no les tiene miedo a las palabras ni a las imágenes; a este propósito, puede recordarse cómo en el paso de esta obra al celuloide se plasma la noticia que Cervantes le da a Quevedo del problema de su esposa y, según nos informa el estudioso Vived Mairal, es cierto que en su día ambos escritores se conocieron.

Doña Catalina muestra su faceta vengativa cuando, al no poseer los atributos voladores del halcón, lo mutila. Podrían deducirse muchas lecturas de este texto, pero que cada cual le dé su propia interpretación, pues la envidia, atribuida milenariamente al hombre, no es fácil de reconocer. Es necesario vivir con dignidad y al halcón se la han robado. Ante esta situación, Cervantes-Sender se pregunta si no sería mejor la muerte para un animal que, llamado a realizar grandes empresas, se ve condenado a una vida tan rastrera.

${ }^{9}$ Ibid., p. 66.

10 Ibid., p. 67. 
La desazón ante la necesidad de preocuparse por lo más prosaico es desesperante y Sender nos sume en esa angustia ante las inevitables veintinueve gallinas que deben permanecer intactas como patrimonio conyugal. El humor y la ironía nos hacen sonreír en este proceso de gallinificación, pero la amargura subyace en todo el relato.

Se suceden la enumeración y las características de las cluecas. Aparece de nuevo la sobrinita portadora de nuevas noticias. Y Cervantes se pregunta entristecido si la Inquisición intervendría el caso si continuara la metamorfosis de doña Catalina. Llegados a este punto, hemos de valorar que la crítica ha alabado esta obra como representativa de la fidelidad amorosa - Cervantes nunca se replantea el amor por su esposa, aun en esta situación- y como muestra asimismo del realismo mágico emergente en la literatura del momento. ${ }^{11}$

Esta obra simbólica, donde juegan un papel esencial la imaginación y la fantasía, nos invita a reflexionar sobre la importancia del nominalismo. Doña Catalina, identificada con el mundo gallináceo, ha disfrutado buscando los nombres adecuados, según sus características, para cada una de sus aves y de nuevo sentimos esta cercanía ante términos aragoneses, algunos netamente familiares y actuales, como la Coquita, la Buchona, la Pintada, la Clueca, la Papuda, la Gallineta viuda, la Pechugona, la Cobadora o la Mantuda. Sorprendemos a doña Catalina preguntándole a su esposo por su «camarada de la carta de Caracas» o explicándole que «la Pollera [...] se ocupa de los pollos tomateros, hasta que los capolamos». ${ }^{12}$ Sender ha escogido en esta obra un léxico rico y plagado de connotaciones simbólicas, por cuanto con toda su complejidad, dentro de su sencillez, muestra el apego del espíritu de doña Catalina a lo más terrenal, prosaico, material y utilitarista de la vida. Sin desdeñar el tesoro de metáforas y metonimias que genera el lenguaje rural aragonés.

Mientras todos en la casa están inmersos en un entorno de gallinas, el escritor se siente aislado por su incomunicación. Son dos mundos, el suyo y el que gira alrededor, totalmente alejados. Frente a las reflexiones de Cervantes, los otros personajes pasan las horas despreocupados echando unas partidas de guiñote, juego tan representativo de Aragón que nos trae todo un léxico específico, frases hechas incluidas:

Don Alonso echó a la mesa un tres de copas y dijo: -Arrastro. ${ }^{13}$

Este ambiente surrealista y absurdo nos recuerda que, aunque se ha considerado a Sender incardinado en la tradición realista de nuestro país,

\footnotetext{
${ }^{11}$ Entrevista realizada a Asunción Sender, hermana menor del escritor, por el periodista Fernando HerCe y publicada en El Periódico el día 10 de febrero de 1991, p. 4.

12 Ramón J. St.voer, Novelas..., cit., p. 73

13 Ibid., p. 75.
} 
no debemos olvidar que es un autodidacta que une a la admiración por los clásicos, reflejada en su obra, esa inclinación vanguardista que ha recorrido la literatura a lo largo del presente siglo.

Podemos apuntar aquí ese proceso de animalización que el admirado maestro Valle-Inclán imprimía a algunos personajes de los esperpentos. Podemos entender el surrealismo que late en el presente texto y la anticipación del realismo mágico como contribución de un hombre inquieto por experimentar nuevas formas literarias en que plasmar su rico y complejo pensamiento o quizás sus más hondas vivencias.

La descripción de la metamorfosis de doña Catalina es antológica:

Un día descubrió que podía mirar de medio lado sin volver el rostro, con un solo ojo y que éstos tenían tendencia a hacerse planos, como en las pinturas egipcias, e independientes el uno del otro.

La cara de la muchacha estaba haciéndose más afilada, el hociquito saledizo y puntiagudo, la nariz en pico y las orejas disminuían debajo del pelo. Un día acariciándoselo descubrió Cervantes dos plumas, quiso quitárselas y doña Catalina se quejó. Estaban bien enraizadas en su piel. Dos plumas largas como las plumas remeras de las alas o las del rabo. 14

Tras un viaje de don Miguel, a la vuelta a Esquivias encuentra al halcón mutilado:

— ¡Ah, el pícaro buitre! — dijo doña Catalina-. Quiso escapar y casi lo consiguió porque la verdad es que le habían crecido bastante las alas, pero yo se las corté y ahora no puede volar y me sigue a brinquitos como un sapo. 15

\section{Entonces comenzó a pensar que}

la gallinificación de doña Catalina estaba ya en un grado crítico y tal vez su decisión de cortar las alas al halcón representaba alguna tendencia más o menos consciente de gallina vengadora. Porque los halcones son enemigos milenarios de las gallinas. ${ }^{16}$

Aquí Sender se adentra en la concepción del realismo mágico y, así, tras este retrato, prosopografía y etopeya para que resulte más evidente, lo extraño es la hipocresía de todos, excepto de la niña, que con su inocencia, ingenuidad y sinceridad expresa la realidad $y$, con sus preguntas, además aporta otro tema candente que también fustigó a Cervantes: las diferencias existentes en España entre cristianos viejos y judíos conversos. Además, tanto Cervantes como Sender habían estado por diferentes motivos en tierras moras.

\footnotetext{
14 Ibid., pp. 61-62 y 66-67.

15 Ibid., p. 68.

16 Ibid., p. 69.
} 
La metamorfosis había concluido y el miedo a la Inquisición no dejaba de planear en la mente de Cervantes. Pero al menos el halcón, que era considerado un parásito - aunque doña Catalina jamás se hubiera desprendido de él-, en esas fechas se escapó, recobrando así su libertad.

Cervantes se sentía abrumado y denostado por las noticias sobre otros parientes que hacían dinero, "que valían mucho».

Aparece la intencionada confusión o locura de Cervantes - buitregato-tigre- o quizás la figura inquietante del escritor, que ya no sólo no aporta sino que amenaza con destruir el patrimonio gallineril. El juego apariencia-realidad vuelve con la anécdota referida a los huevos del de Pinto, que el hidalgo pasaría a recoger en Valdemoro (lugares no desconocidos para Sender, dado que allí fue jefe de Estado Mayor de la Primera Brigada Mixta durante la guerra). ${ }^{17}$

En estas correspondencias en que el halcón y Cervantes atentan contra las gallinas, la hacienda y, en definitiva, contra doña Catalina, vemos cierto carácter fantasioso, pues después de su separación el matrimonio conservó buenas relaciones.

A Cervantes le sobrecoge la situación de la gallina herida, todos van a picarle. Sabido es que las alimañas se ceban donde ven sangre, lo que causaba gran desazón al escritor por la actitud que observaba en torno suyo. Y sufría, identificado como estaba con el halcón y con la gallina heridos y por las continuas alusiones a sus orígenes de cristiano converso.

Situando en la tradición de la estética deformante a un autor como Quevedo con su famoso soneto «Érase un hombre a una nariz pegado»o la obra dramática de Valle-Inclán Divinas palabras. Tragicomedia de aldea, obra renovadora no sólo en Valle-Inclán sino en todo el contexto europeo y que supone ya el límite con el esperpento, relacionado con el expresionismo, en especial por las escenas de Juana la Reina o por la mutilación del cuerpo del idiota, cuando una vez muerto por una borrachera de anís Mari-Gaila deja su cadáver a la puerta de otro familiar hasta que los cerdos comen una parte del mismo, vemos las similitudes estéticas con este pasaje del ave mutilada y con el presunto cadáver de Sabino en El lugar de un hombre.

La muerte de la gallina herida, que le recordaba a Cervantes su manquedad, el huevo que puso doña Catalina y las crecientes alusiones a su sangre, que ya importaban más que la metamorfosis de la dama, acrecentaban la consternación del escritor.

Las notas culturalistas, características del renacer vanguardista, referidas a Quijano o Quijada o a Dulcinea del Toboso, en imitación de Melibea o Melisendra, marcan con fina ironía a dónde ha llegado la situación que tan idílicamente soñara Cervantes en su época de novio galante.

El desencuentro es ya patente y la única salida es el exilio o la huida. Pero ante esta comparación pecuniaria en que pierde el libro frente a las

\footnotetext{
17 Jesús Vivfo MAIRAI, art. cit., p. 253.
} 
gallinas, y la duda ante la escritura - porque, aunque el autor se sabe un dios, el precio de su obra es mostrar cual Pigmalión, a través de la criatura hecha a su imagen y semejanza, las debilidades trágicas y secretas de su alma y, además, debería utilizar las resmas de estracilla que también figuraban en el contrato si quería escribir la segunda parte de la Galatea, que tanto le tentaba-, Cervantes no se atrevía a tomar la decisión de marchar.

Doña Catalina, cual gallina total, se va convirtiendo en el símbolo de la vida exterior, de la sinsustancia. Su actividad es ya monotemática: visitar a la mujer del albéitar, hablar con un gorgoreo de gallina y observar cómo la Mantuda se sostobaba las plumas. El relato va in crescendo y la ironía se vuelve más agria, al tiempo que la simpleza ocupa un lugar preferente en la conversación de doña Catalina. La degradación de todo lo clásico y la parodia del gallo don Caracalla llevan a la vulgarización y a la falta de respeto que merecen hechos y cosas importantes. Recordemos que cuando los ingleses se enteran de que Cervantes no tenía casi ni para comer se extrañan porque piensan que España debería cuidar a un escritor de su talento.

En este mundo reducido a gallinas, doña Catalina le tiene un gran respeto al gallo, hasta el punto de que Cervantes siente celos de él como dominador y gobernador del gallinero. El gallo le ha arrebatado el poder. Ante esta situación tan absurda, el protagonista ansía convertirse en el carnicero de tamaño fantoche, en clara alusión a la Dictadura española. El carácter parabólico del texto le supondría a Sender la censura en España, hasta tan tarde, de ésta entre otras obras.

Cervantes ya no resiste más la situación. Critica la avaricia del clero, que además le hace alusiones a su procedencia de conversos. Todo se vuelve contra él en un proceso asfixiante y el simbolismo de este texto nos hace reflexionar sobre el carácter cíclico de la Historia. Al final, Cervantes descubre que los que le criticaban a él quieren hacer lo mismo, estar por encima de todas las cosas, colocarse más allá del bien y del mal. Don Miguel, gran conocedor del alma humana y de sus debilidades, disculpa a los que tan mal le han tratado y abandona Esquivias; Sender no deja pasar la ocasión para lucir su fina ironía al referirse a la Armada Invencible.

Sender nos presenta diversas reflexiones, como la relación entre vida y literatura, la función de este autobiografismo trascendente y universalizador, ${ }^{18}$ el precio de la escritura - para Sender el exilio, por la soberbia de escribir, ${ }^{19}$ por el pensamiento, por el compromiso, por la denuncia; para Cervantes, cual Pigmalión en La Galatea, mostrar lo más profundo de su

\footnotetext{
18 Roger DuVIVIER, «Les prémisses de l'œuvre autobiographique dans la première époque de l'écrivain Ramón J. Sender", en L'Autobiographie en Espagne, Aix-en-Provence, Université de Provence, 1982, p. 214; «Las premisas de la obra autobiográfica en la primera época del escritor Ramón J. Sender», en Ramón J. Sender. In memoriam, cit., p. 145.

19 Nora Catelli, El espacio autobiográfico, Barcelona, Lumen, 1991, p. 49.
} 
alma-; el autobiografismo, que, como memoria evocada, vivida o soñada, al igual que en Machado, supondría la recuperación de una existencia. ${ }^{20}$

En este sentirse culpable del protagonista quizás Sender se reprocha el que ellos, los intelectuales, no habían sido capaces de parar el sinsentido de la guerra, de ayudar al pueblo para que no sufriera tamaña sangría, al igual que tampoco Cervantes fue capaz de ayudar al halcón herido, que no podía "seguir su instinto de ave de altura». Este sentimiento - "yo también lloraría a veces si no tuviera miedo a parecer ridículo»- es la expresión muda del dolor. El hombre se va alejando de la naturaleza, del instinto, de la intuición como fuentes de conocimiento y con ello pierde sabiduría y autenticidad. Lo autobiográfico, en este texto, se nos presenta desde dos perspectivas: por un lado, una identificación del autor con el narrador y el protagonista acerca de una serie de circunstancias dolorosas derivadas de la labor de escribir, y, por otro, una determinada realidad, compleja y frustrante para el escritor, plasmada a través de la biografía de Cervantes. Como vemos, la sutileza de Sender cobra en este texto sus mayores cotas.

No debemos desdeñar que antes de que lo autobiográfico cobrara carta de género literario con la publicación de las Confesiones de Rousseau, estas manifestaciones correspondían, nos explica May, ${ }^{21}$ a temperamentos vigorosos y decididos a expresarse, desafiando las tradiciones y las modas del día. Ambos escritores, Cervantes y Sender, presentan estos rasgos, lo que sin duda facilita la elección del primero para poder plasmar el autor sus pensamientos, sin olvidar que Sender leyó El Quijote cuando aún era un adolescente incipiente y la tristeza que, según propia confesión, le produjeron las andanzas del añejo caballero.

En otros textos netamente autobiográficos - Crónica del alba- la literatura se nos presenta como forma de conocimiento. "Señor del saber», denominará Valentina a Pepe Garcés. Abstraer, elegir, dar valor, hacer que la atención se centre en elementos específicos y, al fijarnos en ellos, darles vida sería una forma de afirmación. $Y$ al reivindicar una vida pasada y feliz, frente a una realidad fría y despersonalizadora, Sender se propone ese huir de la nada mediante la evocación de la memoria. Tras la crítica a la situación de la patria, ese mirar atrás con nostalgia sería la segunda etapa en la escritura, común a los demás exiliados, antes de tratar de incardinarse en la vida del país de acogida. Se da entre los exiliados esta mezcla entre angustia y despersonalización en un mundo adverso. Así, Ramón Gómez de la Serna confiesa en Automoribundia que salió de España como emigrante y entró en América como inmigrante.

Frente a un Dalí que trataría de reivindicar su figura en Diario de un genio, el recuerdo vivido o soñado, la evocación de la paz, de la serenidad,

20 Georges MAY, La autobiografia, México, Fondo de Cultura Económica, 1982, p. 220. Título original: L'autobiographie, París, PUF, 1979.

21 Georges MAY, op. cit., p. 25. 
supondría la afirmación mediante el “yo» de alguien arrojado a un mundo que le es extraño.

Lo autobiográfico en este texto iría ligado a los sentimientos como escritor, en una sociedad en que se pierde el sentido de las cosas y un déspota se hace con el poder de un gallinero-sociedad degradado y ajeno a la razón. La percepción de esta situación desde la distancia es más nítida y dolorosa. No se cumpliría aquí ortodoxamente el denominado por Lejeune pacto autobiográfico ${ }^{22}$ pero es manifiesto el carácter hiperbólico de una situación sufrida y pagada por el autor con el exilio.

Según Romera Castillo ${ }^{23}$ esta literatura constituiría un género vecino a la autobiografía, tendría rasgos de los relatos autobiográficos de ficción, otra modalidad de la literatura referencial íntima basada en la semejanza del protagonista con el autor de la obra, similar a obras como Tiempo de silencio, en que el autor, Luis Martín Santos, además de dar forma al caos a través de la palabra - Sender evoca sus vivencias para evitar la nada-, va exponiendo su existencia decantada tanto en sus actividades profesionales - autor y personaje son médicos - como amorosas, sociales y culturales.

Pío Baroja, en El árbol de la ciencia, entre otras obras, comparte estos rasgos y también el mismo Cervantes dejó múltiples huellas autobiográficas en la mayoría de sus obras.

Los documentos hallados para atestiguar la veracidad del relato rememoran la técnica cervantina del «manuscrito encontrado», que constituye para Gonzalo Torrente Ballester «la más honrosa de las convenciones vigentes para el arte de la novela». ${ }^{24}$ En este homenaje a Cervantes, igual que don Quijote viera colmada su ambición de «ser» personaje de un libro, el mismo don concede Sender al novelista universal, aunque éste no lo pudiera ver. "La innoble servidumbre... que es amarse a sí mismo", en palabras de Jaime Gil de Biedma, no tendría sentido en nuestros dos autores; para otros críticos lo autobiográfico no sería muy diferente de la ficción, puesto que básicamente es ficción, literatura, pero no vida. ${ }^{25}$ Por otra parte, «todo texto autobiográfico habita en su entraña la fascinación y el canto de la otredad, imagen de sí y de un tú dialógico y abierto que se ofrece en encuentro de reciprocidad. Una luz y una estrella que abren siempre el horizonte de la vida y de la historia». ${ }^{26}$

22 Philippe LEjEUNE, «El pacto autobiográfico», en La autobiografía y sus problemas teóricos. Suplementos Ánthropos, 29 (diciembre de 1991), p. 47.

23 José Romera CASTILlo, «La literatura, signo autobiográfico», en La literatura como signo, Madrid, Playor, 1981, p. 27.

24 Darío Vחi.Anueva, «El cervantismo de Gonzalo Torrente Ballester», en El polen de ideas, Barcelona, PPU, 1991, p. 194.

25 Op. cit., p. 110.

26 José RoMERA CASTILLO, «La autobiografía como fascinación de la otredad», en Laberintos. Transcurso por las señas del sentido. La autobiografía en la España contemporánea, Ánthropos, 125 (diciembre de 1991), p. 64. 
Al igual que en todos sus textos, en el intento de recuperar su infancia y su territorio Sender salpica su léxico de frecuentes aragonesismos que encierran gran valor simbólico, prueba de su fantasía e imaginación, así como el gran valor evocador de su verbo, que abarca todas las situaciones de la vida, nombres de parajes, de ríos, de plantas, de animales o el uso afectivo de los diminutivos, tan frecuente en el habla aragonesa. Una lengua, en suma, rica y popular, cuyo estudio nos llega a través de la pluma de diferentes críticos. ${ }^{27}$

Esta obra, que aúna en sus páginas diferentes lecturas, pues su autor domina perfectamente, como gran creador que es, la palabra, el pensamiento, los símbolos y las imágenes, estuvo prohibida en España, junto a otros de sus textos, hasta que, ante su visita y como condición previa, Sender consiguió su publicación en el año $1974 .^{28}$

27 José $\mathrm{M}^{a}$ Engurta UtRlLLA, «El aragonesismo lingüístico en Ramón J. Sender», en José $\mathbf{M}^{a}$ EnGUITA UTRILLA, ed., III Curso sobre Lengua y Literatura en Aragón (siglos XVIII-XX), Zaragoza, Institución Fernando el Católico, 1994, p. 191.

28 Jesús VIVed MAIRAL, art. cit., p. 267. 


\title{
Literatura y novela histórica. Una lectura de Carolus Rex
}

\author{
Alberto Álvarez Sanagustín \\ Universidad de Oviedo
}

En los últimos años la teoría literaria ha concedido una gran importancia al estudio del discurso histórico, tratando de ver sus afinidades con el discurso de ficción. Se trata de ver en qué coinciden y en qué se diferencian el discurso histórico y el discurso ficcional o literario.

En esta comunicación me propongo analizar Carolus Rex de Sender a partir de conocimientos actuales sobre la historia y la ficción. También una confrontación de esta obra con El hechizado de Francisco Ayala, al que he dedicado mi atención en trabajos anteriores. No hay que olvidar la peripecia vital de Francisco Ayala, similar en tantos aspectos a la del autor aragonés.

Nadie duda de que el historiador $-y$ en esto se diferencia de otros narradores- quiere construir una historia (story) objetivamente verdadera, pretende construir un relato cuyos enunciados traten de hechos del pasado verificados o verificables a partir de los procedimientos aceptados en nuestra cultura. Sin embargo, hay que decir que no todos los enunciados que organizan una narración histórica hablan de hechos. Puede ocurrir también que hablen de hechos pero que no sean verificados 0 verificables. Finalmente, podemos encontrarnos con juicios evaluativos y, 
además, lo que es más importante, con unas conexiones establecidas entre los mismos hechos. ${ }^{1}$

Enunciar hechos resulta una tarea bastante sencilla. Lo más complicado es su conexión y la posible evaluación. La experiencia diaria muestra que una misma serie de acontecimientos pueden ser contados de manera muy diferente. Nos podemos encontrar con un solo narrador o con diferentes narradores que, en perspectiva, nos ofrezcan sus visiones. Podemos ver elipsis más o menos significativas. Pueden retenerse todos los hechos o los que resultan más atractivos. En función de la parcialidad o imparcialidad, cultura o incultura del narrador, podemos encontrarnos con relatos sustancialmente diferentes en la articulación discursiva. Eso sí, los hechos aludidos en la historia deben ser verificados o verificables.

En el extremo opuesto del discurso histórico encontramos el discurso que podríamos llamar fabuloso. Los acontecimientos que se narran en este tipo de relatos rebasan la experiencia de los hombres. El discurso se puebla de seres de fuerza extraordinaria, con capacidades que nos admiran por lo insólitas. Todo ocurre o puede ocurrir en lugares alejados, en tiempos también lejanos. Estos relatos, además, no están condicionados enunciativamente. El narrador puede contarnos lo que ya ha pasado o ha imaginado que ha ocurrido, pero también puede narrar en presente y en futuro proporcionando al lector un relato profético, el discurso tan caro a los arúspices y adivinadores. ${ }^{2}$

Ahora bien, es evidente que en el universo del relato y, quizás, por una extraña magia el relato histórico tiene dificultades para mantenerse en el nivel de la pura crónica, atenerse al enunciado de los hechos verificables. El historiador está obligado a seleccionar unos y a relegar otros, a organizarlos de una manera determinada y no de otra. Más aún, en muchas ocasiones no puede prescindir de hacer juicios de valor, de teñir, en suma, su relato de elementos que tienen que ver con su sistema de valores, con su ideología. ${ }^{3}$

En Carolux Rex, Ramón J. Sender utiliza el molde del discurso histórico para construir su novela. Ya en el subtítulo - entre paréntesisalude a Carlos II el Hechizado y, además, cataloga la obra como novela histórica. ${ }^{4}$

Quiero decir que, como muchos autores anteriores a él y como otros en nuestros días recientes -recordemos los nombres de Claude Simon,

\footnotetext{
${ }^{1}$ Para las posibilidades que ofrece la reescritura de la historia, vid. SEVILLA, S., «El imaginario y el discurso histórico», Eutopías, $2^{a}$ época, Documentos de trabajo, 23 (1993).

2 Sobre la teoría de los «mundos posibles», vid. ECO, U., Lector in fabula, Milano, Bompiani, 1979.

3 BARTHES, R., «Le discours de l'histoire», Social Science Information. Information sur les sciences sociales, VI/4 (1967).

4 Sender, R., Carolus Rex (Carlos II el Hechizado). Novela histórica, México, Editores Mexicanos Unidos, 1963.
} 
Marguerite Yourcenar o el mismo Umberto Eco-, teje una historia sobre acontecimientos conocidos, acontecimientos que han tenido ilustres protagonistas, en este caso un rey español de la casa de Austria, un rey que el lector ya ha conocido en los libros de historia y del que no guarda un recuerdo muy favorable. También Francisco Ayala, unos años antes que Sender y en un relato titulado El hechizado, construyó una ficción sobre el reinado de este malhadado protagonista. ${ }^{5}$

¿Cómo ha construido Sender su relato? ¿Cómo ha convertido un material histórico en ficción, en literatura? Vamos a verlo.

Sender ha escogido no la totalidad del reinado de Carlos II, desde que accede al trono hasta su muerte, como haría un historiador convencional, sino que ha seleccionado dos momentos clave: los que preceden a su matrimonio con María Luisa de Orleans y los que lo siguen, dando atención preferente al hecho de que no tengan hijos y se origine un problema de estado. Precisamente la obra termina cuando el rey acaba de ser sometido a exorcismo para librarlo de los demonios que lo habitan y le impiden tener descendencia que aquiete el reino y los temores de desórdenes si no nace pronto un heredero. La obra queda abierta en este punto.

Esta selección de acontecimientos se sitúa en el primer plano de la historia, pero en el conjunto se alude a otros que contribuyen a la recreación histórica. Se da, por ejemplo, noticia del malgobierno del país, del poder que tiene y del miedo que suscita la Inquisición, de la arbitrariedad de los poderosos y de la miseria de los más pobres.

En la descripción que se hace del rey se acentúan los rasgos desfavorables ya desde el principio: «La sonrisa de Carlos era lamentable como una alusión a todas las miserias de un carácter que comienza a decaer y declinar antes de haber alcanzado integridad y madurez. (Como una fruta que se pudre antes de madurar.)" (p. 20). Se habla de "su sonrisa de mono bajo la gran pelambre sucia» (p. 21). También se afirma que «Con las narices obstruidas su habla era gangosa y en esos trances carecía de majestad» (p. 22).

En algunas ocasiones acentúa el ridículo de su atuendo en momentos de especial solemnidad: «Llevaba aquel día [el del cumpleaños de la princesa de Orleans] el rey un sombrero nuevo todo cuajado de pedrería y de perlas en honor de la novia y esta fue su única rareza de aquel día. Según costumbre, no se lo quitaba. Cuando recibía a sus palaciegos acostado en la cama lo hacía con el sombrero puesto, también, y no por capricho sino por protocolo. Además, así no tenía que peinarse» (p. 24).

La caracterización negativa del rey queda reforzada por la presentación también desfavorable de algunos personajes próximos. De la duquesa de Terranova se dice: "Al lado de doña Laura y de la reina la duquesa de Terranova parecía un raro estafermo» (p. 72). Su figura hace sonreír en

5 AyalA, F., «El hechizado», en Obras narrations completas, pról. de Andrés AMorós, México, Aguilar, 1969. 


\section{EL LUGAR DE SENDER}

una ocasión a María Luisa de Orleans: «[...] la reina montó a caballo seguida de la duquesa de Terranova, que hacía a su lado una figura impresionante en su mula con gualdrapas negras. La novia, que había leído el Quijote, pensaba en las dueñas a quienes el buen Sancho odiaba y a veces sonreía, disimulando» (p. 44).

En la obra aparecen animales maltratados que representan por el juego metonímico la violencia soterrada entre los personajes: «Se oían lejos los ladridos atiplados de los dos perritos spaniel» (p. 171); "Dijo el rey que no era tarea para María Luisa reina de España andar por la noche a oscuras detrás de una perra. Diciendo estas palabras dio un puntapié al animalito que gritó como si lo mataran» (p. 106).

De hecho, los personajes aparecen también animalizados. Se habla de la "corte de sabandijas" (p. 85); del embajador Vintimiglia, "con sus ojos de hurón»; del rey mismo, que «reía con un extraño trémolo [...] y que recordaba a veces el arrullo de las palomas en la época del celo» (p. 52).

Se observa una tendencia general hacia la caricaturización y lo grotesco: «la reina madre no reía y si reía era sólo por el lado izquierdo, ya que tenía una tendencia hemipléjica» (p. 60). Del mismo rey se afirma: «El rey callaba y se reía a solas de aquella broma con unas muecas que daban a su rostro extrañas asimetrías" (p. 65).

Hay una tendencia creciente hacia la demonización del rey. Él mismo, en un determinado momento, dice de sí mismo a su confesor: «Hay como un demonio a mi lado que me empuja a hacer cosas contra mí mismo, digo contra mi decoro» (p. 79). Esta demonización es aún más evidente al final, en la escena del exorcismo al que se ve sometido y que representa el punto culminante de la obra. El rey acepta esta humillación como necesaria, ya que se piensa que los demonios que lo poseen son los que le impiden engendrar un hijo que dé tranquilidad al reino.

A diferencia del rey, el tratamiento que se da a María Luisa de Orleans es más positivo. Se alaba su belleza, su educación, su buen gusto. El rey mismo la tiene totalmente idealizada, al menos en la primera parte, cuando, aún sin conocerla en persona, espera con impaciencia su llegada a España para las previstas nupcias.

Es verdad que, una vez contraído el matrimonio, su fervor por la reina disminuye. Esta se ve constreñida por el protocolo de una corte excesivamente rígida, por unas formas de vestir que no son de su agrado, por la intolerancia del rey y de los más próximos cortesanos. Ha de hacer frente, además, a la maledicencia, a ciertos recelos del rey hacia su persona, a un ambiente negativo. La reina madre, en cierta ocasión, siente lástima de ella y piensa para sí: "Pobrecita, tan niña, en medio de esta corte de sabandijas y tarascas» (p. 85). Todos alaban, sin embargo, «su gracioso continente, su manera armoniosa de manejar el caballo y el encanto natural de su persona" (p. 73).

Las dificultades de adaptación de la reina, la desconsideración de la que es objeto, las simboliza Sender mediante una imagen de gran drama- 
tismo plástico, la caída del caballo: «Pocos días después hizo a su esposa el regalo de tres caballos alazanes que le enviaron de Andalucía. La reina quiso probarlos en el parque mientras el rey miraba desde un balcón. El primer caballo comenzó a hacer cabriolas en cuanto sintió a la reina encima y por fin la derribó. Uno de los pies de María Luisa quedó enganchado en el estribo y el caballo se encabritaba y arrastraba a la reina por el suelo" (p. 104).

Esta imagen de fuerte impacto recuerda la escena del funeral de Paco en Réquiem por un campesino español, el momento en que su caballo suelto penetra en la iglesia, a la que sólo se han presentado los ricos del pueblo y que simboliza su presencia muda pero también la opresión a la que se vio sometido y que acabó con su muerte.

El sufrimiento de la reina, la violencia que se ejerce contra ella, encuentra su correlato en los sufrimientos de otras mujeres que se ven injustamente tratadas por los inquisidores. La obra presenta, a modo de historia intercalada, la peripecia de una mujer, Irene Ballabriga, que es arrebatada a sus padres, vejada y privada de libertad por un dominico, Francisco Torrejón, segundo inquisidor del Santo Oficio. La misma Irene Ballabriga cuenta su historia al embajador inglés y al padre Gavín, un sacerdote de Huesca que había colgado los hábitos y se proponía ir a Inglaterra. Su historia es la de otras muchas mujeres cuya única desgracia era su belleza y que despertaban las pasiones lúbricas de los inquisidores.

Carolus Rex presenta el poder omnímodo de los poderosos y la desgracia de los humildes, la mala administración del reino, la nula capacidad del monarca para atender sus obligaciones, su arbitrariedad, que le hace subir y bajar los precios de las cosas sin control, por puro capricho: "Hacía tiempo que la administración pública estaba paralizada y el país iba cayendo en la incuria y el abandono. Asuntos que debían haber sido resueltos llevaban años sin ser tomados en consideración por el gobierno y en cierto modo se podía decir que no existía siquiera ninguna clase de gobierno» (p. 94).

He tenido la curiosidad de comparar esta obra con la que en 1944 escribió Francisco Ayala con el titulo El hechizado y que también tiene como protagonista al rey Carlos II. El tratamiento es distinto pero encontramos muchas similitudes que voy a tratar de poner de relieve.

La obra de Ayala presenta la historia del indio González-Lobo, que abandona su casa en los Andes americanos y se dirige a España, a la corte del rey hechizado. Cuando tras muchas peripecias consigue llegar a su presencia aprovecha una distracción del rey para abandonar el salón del trono. Se retira a Mérida, a casa de una tía suya, Luisa Álvarez, donde se dedica a escribir y a redactar entre otras cosas su encuentro con el monarca.

La narración ayaliana consta de catorce páginas y lo más destacable es el esfuerzo que hace el narrador por seleccionar lo que cree más destacable del 
manuscrito del indio, de su fallida entrevista con el rey. Según este narrador lo más importante del manuscrito es el encuentro del indio con el rey. La descripción que hace González-Lobo acentúa los rasgos desfavorables: «Describe [dice el narrador] desde sus piernas flacas y colgantes hasta el lacio, descolorido cabello, nos informa de cómo el encaje de Malinas que adornaba su pecho estaba humedecido por las babas infatigables que fluían de sus labios" (p. 543). Esta descripción del rey permite conjeturar que el indio renuncia a sus pretensiones cuando ve el estado físico y mental del rey. Ésta es la interpretación que parece más verosímil, pero no puede excluirse cualquier otra, ya que González-Lobo no expresa sus pensamientos.

En un momento dado, el comentarista se centra en las andanzas de González-Lobo en la corte: «Hay un pasaje, un largo pasaje, en que González-Lobo aparece perdido en la maraña de la corte. Describe con encarnizado rigor su recorrer el dédalo de pasillos y antesalas, donde la esperanza se pierde y se le ven las vueltas al tiempo» (p. 536). Según el narrador parece como si el indio sintiera algún raro placer en desarrollar el manuscrito, en sentir cómo aumentaba su volumen amenazando cubrir con la longitud del relato la medida del tiempo efectivo a que se extiende.

Hay otros momentos recurrentes en los que se pierde el sentido de las cosas: «Le vemos resurgir [en Sevilla] de un laberinto de consideraciones morales, económicas y administrativas, siguiendo a un negro que le lleva al hombro su cofre y que, a través de un laberinto de callejuelas, lo guía en busca de posada» (p. 534). Aquí domina con fuerza la isotopía "confusión": idas y venidas que se enmarañan alrededor suyo, laberinto de consideraciones morales, laberinto de callejuelas, confusión de las fechas, los datos, confusión bulliciosa, perplejidad, en fin, del propio narrador, que no se acaba de explicar el sentido del manuscrito.

Está claro, en cualquier caso, que Francisco Ayala utiliza la historia, el discurso histórico como punto de referencia para su relato, pero lo hace de una manera más abstracta que Sender. El viaje de González-Lobo se vislumbra, aunque de una manera enigmática, como una iniciación, como una búsqueda, que, a la postre, resulta fracasada. Ayala ha utilizado la conocida técnica del manuscrito encontrado que suscita un comentario. De ahí que la historia originaria se diluya en el fondo.

Entre ambas narraciones hay similitudes en los diferentes planos de composición. Las encontramos en el nivel figurativo: la principal, la caracterización del rey hechizado, más detallada en Sender, más patética en Francisco Ayala; en el primero el monarca mantiene una cierta iniciativa que no aparece en el segundo, donde se muestra estático hasta el punto de hacer que el indio se retire de su presencia sin haber formulado una sola pregunta.

Esta semejanza en lo figurativo se extiende a personajes secundarios. En el relato de Ayala es la enana Antoñita la que consigue que el indio llegue a la presencia del rey. En Sender también los enanos aparecen en diferentes momentos: «El enano don Guillén pedía permiso al rey para entretener a las meninas de la casa de la reina» (p. 23); «Tuvo la fiesta caracteres 
alucinantes. Aquella noche el rey tenía a su lado al enano negro con un largo cirio de cera blanca y perfumada para iluminar el retrato de María Luisa cada vez que el rey quería mirarlo" (p. 30).

Las semejanzas tienen también su lugar en el nivel temático. Ya hemos visto la idea general de confusión que planea en el relato ayaliano. Esta misma sensación de caos aparece en la obra de Sender, enunciada también de manera explícita: "En el aire de altura del Escorial aquellos rumores [los del viento, pero también los de la corte] daban una impresión de irrealidad porque al principio no se sabía de dónde venían» (p. 149).

Vemos también semejanzas en el plano estructural: en el relato de Ayala la intriga se mueve gracias al deseo que el indio parece tener de llegar a la presencia del rey; en el de Sender, por las expectativas que despierta su matrimonio con María Luisa de Orleans. En uno y otro caso, ambas esperanzas se ven truncadas. Los personajes que proceden del espacio exterior — el indio, la nueva reina - se verán defraudados por ese centro de poder estéril, demoníaco. ${ }^{6}$

Hay un momento importante en ambas narraciones, se trata del encuentro de estos personajes que llegan de fuera con el rey. En el caso del relato ayaliano ya hemos visto que lo preside el silencio. La visión del rey hace que González-Lobo abandone la corte sin decir una sola palabra. En la obra de Sender leemos: «Habiendo pasado la princesa la noche en Quintanapalla, el día siguiente a las diez de la mañana fue advertida de que el rey había llegado. Salió a recibirlo con su vestido español y en la antecámara se arrojó a sus pies y besó su mano, pero el rey la levantó y la saludó oprimiendo suavemente sus brazos y diciendo varias veces: " $\mathrm{Mi}$ reina, oh mi reina". Charlaron un rato sin conseguir entenderse el uno al otro, lo que era bastante incómodo para los dos» (p. 49).

Francisco Ayala ha dado a su relato una dimensión moral. En el curso de la obra dice el narrador: "[...] se me ocurrió pensar si su obra [la del indio] no sería una mera invención literaria, calculada con todo esmero en su aparente desaliño para simbolizar el desigual e imprevisible curso de la vida humana, moralizando implícitamente sobre la vanidad de todos los afanes en que se consume la existencia [...]» (p. 536).

El sentido alegórico que percibimos en la obra de Ayala, ${ }^{7}$ en un plano más abstracto, también es perceptible en la obra de Sender, quizá de una forma más expresionista, cuando observamos lo profundo de la vida tras el juego desordenado de los personajes en sus afanes y en sus pasiones. ${ }^{8}$

\footnotetext{
${ }^{6}$ Para la distinción entre el plano figurativo, temático y estructural de los discursos, vid. GREIMAS, A. J., y CourTès, J., Semiótica. Diccionario razonado de la teoría del lenguaje, Madrid, Gredos, 1982.

${ }^{7}$ El estudioso norteamericano Th. MERMALL, en su trabajo Las alegorías del poder en Francisco Ayala, Madrid, Fundamentos, 1983, insiste en este extremo.

${ }^{8}$ La idea de la expresividad alegórica de Sender la encontramos ya en PEÑUELAS, M. C., La obra narrativa de Ramón J. Sender, Madrid, Gredos, 1971.
} 
Quisiera terminar rindiendo un homenaje a Sender, a su obra, que engrandece la literatura española. He tratado de verlo en la aproximación a la historia, al discurso histórico, que es verdad, pero también sueño e invención; en la aproximación a Francisco Ayala, que sufrió como él los rigores del destierro y al que, en tantos aspectos, se parece por el sentido de moralidad profunda que nos transmite en su pródiga aventura narrativa. 


\title{
Sender «en la mancebía»
}

\author{
Ma Teresa González de Garay \\ Universidad de La Rioja
}

\begin{abstract}
«El garbo de don Juan es teatral. Sin garbo, don Juan aparece desdichadamente amputado». ${ }^{1}$ Así, sin apelar a teorizaciones dramatúrgicas ni a terminologías retóricas, Torrente Ballester nos insinúa que el personaje de don Juan es predominantemente, incluso esencialmente, teatral. Pocas líneas antes, se había preguntado: «¿Quién es el guapo —quiero decir el novelista- que consiga describir lo que de plástico, de materialmente vibrante, de elegantemente nervioso, hay en la figura física de don Juan?».2 Tal vez la convicción de que sólo a través del género dramático podía acercarse al mito donjuanesco llevó a Ramón J. Sender a dedicar una de sus escasas obras teatrales a tan asendereado protagonista, a pesar de que sus condiciones creadoras le inclinaban con predilección hacia la novela. Paradóiicamente, Torrente Ballester, que consideraba no novelable el garbo donjuanesco, concluiría el año 1963 por ofrecernos una extensa, e intensa, novela, centrada en el tema, y ello a pesar de que los primeros escarceos juveniles del narrador gallego habían tenido carácter escénico. Y para que la paradoja resultara más incitante, mientras Torrente novelaba a don Juan y Sender le dedicaba un «drama litúrgico en cuatro actos», Sen-
\end{abstract}

1 Gonzalo TORRente Ballester, Teatro español contemporáneo, Madrid, Guadarrama, 1957, p. 163.

2 Ibid., p. 163. 
der novelaba a Lope de Aguirre y Torrente componía una obra teatral centrada en el sombrío explorador vascongado. ${ }^{3}$

El hecho es que Ramón Sender editaba el año 1968 su personal versión, o su personal visión, sobre el ya para entonces más que tricentenario don Juan Tenorio. Una versión que, según el criterio de María C. Dominicis, «presenta una combinación casi caótica de personajes y alusiones literarias que, a primera vista, parecen innecesarias, aunque responden a sugerencias que el escritor quiere hacer al lector». Aunque, en el subsuelo de esa "combinación casi caótica», María C. Dominicis asegure que «es evidente que Sender va al mito, no a través de Tirso, sino de Zorrilla». ${ }^{4}$ Los elementos de intertextualidad son, en efecto, numerosos y complejos, pero en tal aspecto, a nuestro entender, Sender sólo corrobora una larga tradición, que ya había sintetizado Weinstein en 1967, cuando afirmaba que el Tenorio era «una síntesis de las corrientes e interpretaciones que habían evolucionado durante los años precedentes del siglo XIX». ${ }^{5} \mathrm{Y}$ que a Jean Louis Picoche le permitía distinguir en la descendencia del Burlador tres familias, la extranjera italiano-franco-alemana, la española, que va desde Tirso a Zorrilla, pasando por Córdova y Maldonado y Zamora, y la que Picoche denomina bastarda, que procede en buena parte de Mérimée, aunque tenga su antecedente español en Cristóbal Lozano. ${ }^{6} \mathrm{Y}$ todo ello, exclusivamente, desde la perspectiva del Tenorio romántico del dramaturgo vallisoletano. Porque, sin duda alguna, la intertextualidad continúa funcionando con idéntica intensidad durante el siglo XX, hasta convertirse en una de las coordenadas básicas del mito donjuanesco. Lo expresa con claridad Torrente Ballester en el «Prólogo» a su Don Juan: «Si algún erudito se entretiene alguna vez en analizar mi historia, a sus cuidados encomiendo poner en claro, de acuerdo con su oficio, los muchos préstamos tomados a mis muchos predecesores. Pero creo haber puesto también algo de mi cosecha, algo en virtud de lo cual este don Juan sea "mi" don Juan». ${ }^{7}$ Sender también funciona desde idéntica perspectiva. En las curio-

\footnotetext{
${ }^{3}$ Respecto al drama de Ramón J. Sender, los datos de la primera edición son: Don Juan en la mancebía (Drama litúrgico en cuatro actos), México, Mexicanos Unidos, 1968. La que manejo para este trabajo es la edición española, segunda y última hasta el momento, de la obra, Don Juan en la mancebia, Barcelona, Destino, abril de 1972, en cuyo volumen el texto viene precedido de unas inéditas "Consideraciones sobre don Juan", en las pp. 7 a 32. En cuanto a la novela de Torrente, Gonzalo Torrente BAllester, Don Juan, Barcelona, Destino, abril de 1963. No creo necesario añadir datos bibliográficos sobre la novela de Sender La aventura equinoccial de Lope de Aguirre ni sobre la obra teatral de Torrente Ballester El casamiento de Lope de Aguirre, ambas sobradamente conocidas.

4 María C. Dominicis, Don Juan en el teatro español del siglo XX, Miami, Ediciones Universal ("Colección Polymita»), 1978. Las pp. 70 a 74 están dedicadas al drama de Sender, aparte otras alusiones en diversos momentos del desarrollo de la obra. Las citas literales, en la p. 70. ${ }^{5}$ Leo WeINSTEIN, The metamorphoses of Don Juan, Nueva York, AMS Press, 1967, p. 120.

6 José Zorrilla, Don Juan Tenorio. El capitán Montoya, ed. de Jean Louis Picoche, Madrid, Taurus, 1992 , p. 33.

${ }^{7}$ Gonzalo Torrente Ballester, op. cit., p. 12.
} 
sas «Consideraciones sobre don Juan», que anteceden a la edición de 1972, nos indica: «Pero habiendo leído otros dramas sobre don Juan sentí ganas de escribir el mío. En mi tratamiento del tema querría mostrar algún aspecto nuevo de esa fatalidad que acaba por destruir al héroe». ${ }^{8}$ Sender, como Torrente, está dispuesto, sobre la base de la imprescindible intertextualidad del mito, a ofrecernos «su» don Juan. De tal manera que esa «combinación casi caótica» a que hacía referencia María C. Dominicis adquiere en la intención autorial un objetivo preciso: «Lo peor que le sucede a don Juan es su vejez, en la cual tiene que resignarse a su media soledad infausta (sin mujer), que lo lleva a la destrucción». ${ }^{9}$ Otra cuestión sería la de la pertinencia o impertinencia de los materiales acarreados y aleados. Pero ese es, sin duda, un problema de coherencia y calidad literarias, que no de coherencia y claridad conceptuales. Sender está convencido de la transparencia metafísica de su Don Juan en la mancebía, como se deduce de sus propias afirmaciones: «Las obras de teatro no deben ser difíciles de entender, es decir, que la oscuridad las daña [...] Pero el misterio puede serlo también por exceso de luz. Es lo que quisiera que sucediera en estas páginas». ${ }^{10}$

En cuanto a la afirmación de que Sender se acerque al mito a través de Zorrilla, olvidándose de los orígenes tirsianos, sin entrar, por supuesto, en el problema de quién fue el verdadero autor de la comedia a Tirso atribuida, exigiría para su congruente comprobación un detallado análisis. De Zorrilla, en efecto, hay en el texto de Sender numerosos rasgos temáticos, actoriales y hasta estructurales (recuérdese que el Don Juan Tenorio se desarrolla en dos noches, una para cada una de sus partes, y que en Sender, con riguroso y aristotélico tratamiento temporal, la única parte de que consta la obra transcurre a lo largo de la tarde y noche del día de Ánimas de 1635). Se repiten personajes, alguno de ellos tan característico del Tenorio como el escultor, que jugará en el drama de Sender un papel relevante. Se mantiene para el criado de don Juan el nombre de Ciuti, aunque también, de pasada, se haga referencia al Leporello del libreto de Da Ponte con música de Mozart, como si los nombres, lo mismo que los personajes, se vincularan a concretos momentos de la trayectoria geográfica del mito y aunque, en última instancia, para ocultar la personalidad de don Juan y la suya propia, Ciuti'se haga llamar Gino. No menos inspiradas en Zorrilla están las figuras del comendador y de doña Inés, presentes mágicamente primero en la mancebía, escenario inicial de la pieza, y más adelante en piedra en el cementerio, obras ya de maese Hermenegildo. La vieja magia de la aparición fantasmal, donde Zorrilla entronca, como ha visto muy bien David T. Gies, con uno de los géneros más populares de los siglos XVIII y XIX, las «comedias de magia», se sustituye, en Sender, por las fór-

\footnotetext{
8 Ramón J. SENDER, op. cit., p. 14.

${ }^{9}$ Ibid., p. 15.

10 Ibid., p. 14.
} 
mulas tecnológicas del moderno proyector, pero manteniendo los efectos, aunque sea rozando levemente las fronteras del pastiche o tal vez de la parodia. Doña Inés se mantiene en el nombre y en los lineamientos de la historia, aun cuando modifique Sender el carácter virginal de la protagonista. Y la aparente dependencia Sender-Zorrilla puede llegar al extremo de situar el creador aragonés en el purgatorio el alma de doña Inés, a punto ya de redimir la pena temporal debida por sus pecados, del mismo modo que el dramaturgo vallisoletano pone en boca de la amada de don Juan, en la escena del cementerio (parte II, acto I, escena IV), aquellos versos: «Mas tengo mi purgatorio / en ese mármol mortuorio / que labraron para mí. / Yo a Dios mi alma ofrecí / en precio de tu alma impura, / y Dios, al ver la ternura / con que te amaba mi afán, / me dijo: "Espera a don Juan / en tu misma sepultura [...]"». Con lo que, de alguna manera, Sender da muestras de una mayor ortodoxia teológica tridentina respecto al funcionamiento del purgatorio que el vate romántico, al menos a la hora de plantear el tema. ${ }^{11}$ Frente a este cúmulo de elementos conectados con el Tenorio de Zorrilla, apenas si queda de El burlador de Sevilla y convidado de piedra el recuerdo prologal del «tan largo me lo fiáis» y el personaje senderiano de Octavia, una vieja que rememora el engaño de don Juan a Isabela, la mujer del duque Octavio, en el comienzo mismo de la comedia atribuida a Tirso, sosteniendo que la duquesa siempre supo que el caballero que penetraba en su alcoba era Tenorio. ${ }^{12} \mathrm{E}$ incluso esa reminiscencia juega con la confusión de nombres - se habla siempre de la duquesa Octavia- o de sexos, en un característico equívoco senderiano.

Pero, si entre el Tenorio y el Burlador la victoria, evidentemente, se la apunta el Tenorio, corroborando así la observación de María C. Dominicis que anotamos con anterioridad, convendría, sin hacer excesivo caso de las simpatías del autor, enlazar en directo con el personaje mítico. Porque, eso sí, las simpatías del autor están claras. Después de haber calificado de "torpe» el texto del mercedario - para Sender no existe la más mínima duda respecto a quién escribió El burlador de Sevilla, cosa lógica el año 1968-, nos asegura: «El Don Juan de Zorrilla es mejor en su estructura escénica si no en sus versos. Todos nos burlamos de Don Juan Tenorio, pero vamos a verlo la noche de difuntos, en otoño. Sabía mucho Zorrilla de teatro y sus versos a menudo pueriles son plásticos y vivos». ${ }^{13} \mathrm{Y}$ así se iden-

\footnotetext{
11 José Zorrilla, Don Juan Tenorio, ed. de David T. Gies, Madrid, Castalia, 1994. Para las referencias a la comedia de magia, pp. 23-30. En cuanto a la escena del sepulcro, vv. 2995-3003, p. 205. Utilizo también el Don Juan Tenorio, ed. de Luis FERNÁNDEZ CIFUENIES, estudio preliminar de Ricardo Navas Ruzz, Barcelona, Crítica («Biblioteca Clásica»), 1993.

12 Ramón J. SENDER, Don Juan en la mancebía, ed. cit., p. 10. Para la obra de Tirso, Don Juan. Evolución dramática del mito, edición, estudio preliminar y bibliografía seleccionada por D. Amando C. IsASI ANGulo, Barcelona, Bruguera, octubre de 1972, pp. 93-210. La escena con Isabela, la mujer del duque Octavio, en pp. 93-94.

13 Ramón J. SENDER, op. cit., p. 13.
} 
tifica Sender con la conocida frase de Ruiz Ramón: «Cuando en el teatro nosotros, tan alejados de la sensibilidad y de la concepción del mundo de los románticos, aplaudimos Don Juan Tenorio no aplaudimos otra cosa que la plenitud del absoluto teatral que es el don Juan zorrillesco; es decir, una categoría: la categoría de lo teatral hecho personaje». ${ }^{14}$ Sender es, si no ferviente, sí al menos decidido partidario de Zorrilla y, al situar su Don Juan en la mancebía "en la tarde del día de las ánimas en 1635», rinde un silencioso homenaje a las representaciones que él tuvo la satisfacción de contemplar en el Madrid de los años veinte y los años treinta de nuestro siglo. ${ }^{15}$

Más allá de esas simpatías, de esas empatías, ¿cómo se relaciona Sender con el mito del don Juan? ¿En el mismo plano o desde la misma perspectiva que se relacionara Zorrilla? De ningún modo. Porque Sender plantea su versión donjuanesca desde la vejez del personaje, como subrayábamos por anticipado, y don Juan es precisamente el personaje que, para la mayor parte de sus analistas, no puede envejecer. "¿Por qué no existe un don Juan anciano?», se pregunta Max Frisch, el dramaturgo suizo autor del Don Juan oder die Liebe zur Geometrie. Y se responde: «Don Juan, espiritualmente determinado, es el hibridismo, el que uno solo, hombre o mujer, quiera ser el ser humano; su espíritu se mantiene pueril en relación con la creación, por eso el telón tiene que caer antes de que don Juan cumpla los treinta y cinco, ya que de lo contrario quedaría un necio desagradable precisamente por ser una figura espiritual». Y añade entre paréntesis y entre admiraciones: "¡Casanova puede llegar a viejo!». ${ }^{16}$ María C. Dominicis, por su parte, realiza una breve incursión en el mundo de los don Juanes maduros que han jalonado el teatro español de nuestro siglo, los de Joaquín Dicenta, José Echegaray, Gregorio Martínez Sierra (sin duda, el de su mujer María Lejárraga) y Jacinto Grau, uno de los dos don Juanes de Jacinto Grau, sin olvidar a Sender, para concluir su exposición con una frase casi lapidaria: «Tenorio no puede mantener una postura digna si sobrevive indefinidamente, y lo mejor que puede hacer para preservar su grandeza mítica, es morirse a tiempo». ${ }^{17}$ Sin entrar en la dilucidación de si un don Juan viejo, ni siquiera maduro, como el que aparece en el drama de Sender, pierde su carácter mítico, sí habrá que convenir al menos en que se evade radicalmente de las premisas establecidas por Zorrilla. Cuando don Juan, además, tiene hijos, como les ocurre a los protagonistas de los cuatro dramas mencionados, porque la hija del don Juan senderiano sólo lo es de modo adventicio, hipotético, hasta que se descu-

\footnotetext{
14 Francisco Ruiz Ramón, Historia del teatro español (desde sus origenes hasta 1900), Madrid, Cátedra, 1979 , p. 330.

15 Ramón J. SENDER, op. cit., p. 35, acotación del acto primero.

$16 \mathrm{Max}$ FrIsCH, La muralla china. Don Juan o el amor a la geometría, Buenos Aires, Editorial Sudamericana, 1964. El texto en los «Pospuestos» a la comedia dedicada a don Juan, p. 209.

17 María C. Dominicis, op. cit., p. 169.
} 
bre en las postrimerías del drama que se trata de una filiación equivocada, nos alejamos aún más del prototipo donjuanesco tradicional. Oigamos de nuevo a Max Frisch: «Don Juan no tiene hijos, me parece, aunque existiesen 1.003 hijos. No los tiene del mismo modo que no tiene un tú. Al convertirse en padre - al admitir el ser padre- deja de ser don Juan. Esa es su rendición, su primer movimiento hacia la madurez». ${ }^{18}$ Pero ni siquiera el hecho de que Beatriz, la supuesta hija de don Juan y doña Inés en la pieza de Sender, no pertenezca biológicamente al protagonista puede hacerle recuperar al personaje el parentesco con su antecesor romántico. Porque lo que le desgaja de esa tradición, lo que le hace distanciarse de Zorrilla hasta el infinito es la destrucción del personaje de doña Inés, que, tras su noche de amor con don Juan, su única noche de amor con don Juan, que ya Zorrilla hubiera abominado, cae en los brazos de Mañara, el enemigo acérrimo de don Juan en el drama senderiano. Con lo que doña Inés, parece evidente, no muere destruida por el desengaño, como ella misma se encarga de insinuárnoslo en su última conversación con don Juan, al final de la obra: «Beatriz nació once meses después de haberte alejado tú de mi lado. (Riendo.) Tú me despertaste para el amor y escapaste [... $] » .{ }^{19}$ Aunque permanezca fijada eróticamente a su experiencia con don Juan. Tal vez este sea uno de los motivos menos coherentes en el conjunto del texto senderiano. Pero lo que sí salta a la vista es su inversión del mito, tal y como lo imaginó Zorrilla, según se desprende de sus Recuerdos del tiempo viejo: «Mi obra tiene una excelencia que la hará durar largo tiempo sobre la escena, un genio tutelar en cuyas alas se elevará sobre los demás Tenorios: la creación de mi doña Inés cristiana; los demás don Juanes son obras paganas; sus mujeres son hijas de Venus y de Baco, y hermanas de Príapo; mi doña Inés es la hija de Eva antes de salir del Paraíso; las paganas van desnudas, coronadas de flores y ebrias de lujuria, y mi doña Inés, flor y emblema del amor casto, viste un hábito y lleva al pecho la cruz de una Orden de caballería». ${ }^{20}$ Merecía la pena reiterar esta conocidísima cita, porque enmarca a la perfección el tipo de amor que, según Zorrilla, salva a don Juan, el tipo de mujer capaz de generar ese amor salvador. Pero la doña Inés de Sender es, a juzgar por sus hechos y por sus palabras, al menos desde que conoce a don Juan, la «hija de Venus y de Baco» contra la que pronunciaba sus anatemas Zorrilla. Insiste Sender en sus consideraciones prologales: «Porque don Juan el ateo, o casi ateo a la manera española de los hombres de acción, no podía comprender que el dios de sus mayores fuese superior al dios natural. Quiso ver si Dionysos tenía las mismas probabilidades de ganar, después de la victoria de Cristo». ${ }^{21}$

\footnotetext{
18 Max FrISCH, op. cit., pp. 208-209.

19 Ramón J. SENDER, op. cit., p. 169.

20 José Zorrilla, Recuerdos del tiempo viejo, en Don Juan Tenorio, ed. cit., apéndice, p. 230.

21 Ramón J. SENDER, op. cit., p. 20.
} 
Dionysos, el Baco originario, penetra en el cuerpo y el alma de doña Inés y rompe la vinculación con el mito romántico a lo Zorrilla de manera definitiva, otorgando además a don Juan el laurel de amante engañado. Como dice María C. Dominicis: «¿Puede haber penalidad más terrible para don Juan que verse convertido en un cornudo?».22

El mito, por tanto, ha tomado otro carácter en el drama senderiano. Don Juan penetrará en el cielo, cuando ninguna de las mujeres por él engañadas tenga interés, frente a la figura escolástica de san Pedro, en querellarse, porque para todas esas mujeres el recuerdo de don Juan es un recuerdo de felicidad. Su infierno quedará en el mundo, en el modo y manera que Sender mismo intenta aclarar en las «Consideraciones" previas a la edición de 1972: "Las puertas del infierno están ahí y don Juan debió verlas más de una vez. Son el paroxismo de la negación, el deslumbramiento (no de luz, sino de sombras) de la nada». Y ese deslumbramiento de la nada es consecuencia de que "para cancelar el horror vacuum que sucede a cada orgía, tiene que repetir esa orgía con un objeto nuevo y diferente [...] y cuando la edad lo obliga a replegarse sobre sí mismo las sombras del pasado se le van sublevando y acaban con él. Dos de ellas bastan para destruirlo y son precisamente las sombras de dos mujeres que él ama». ${ }^{23}$ Lo que pasa es que las reflexiones posteriores de Sender, posteriores a la creación textual, no están presentes con la precisión y el alcance que él hubiera deseado, sin duda, en el texto mismo. El texto es mucho más ambiguo. Aunque sí se deduzca implícitamente de él el infierno interior de don Juan, un infierno, por cierto, que se identifica prácticamente con el proclamado por Torrente Ballester en el «Prólogo» a su novela Don Juan: «Condenado al individualismo, a ser él, sólo él, per sæcula sæculorum. Como se es, según dicen, en el infierno. En lo cual me aparto de la conocida concepción sartriana de que el infierno son los demás. Para mi don Juan, el infierno es él mismo». ${ }^{24}$ Pero en la novela de Torrente, ese infierno donjuanesco se describe desde dentro del personaje con suficiente exactitud. $Y$ en el drama de Sender, en cambio, de modo vacilante y contradictorio.

Sender funciona, por lo tanto, no sólo «después de Zorrilla», en el tiempo interno del drama, sino "contra Zorrilla», modificando sustancialmente algunos de los antecedentes fijados por la tradición romántica española y, lo que es decisivo, «más allá de Zorrilla», tanto en el sentido de evolución literaria como en las intenciones metafísicas, teológicas y estilísticas. El viejo Tenorio está ahí, pero solamente como un dato erudito, tamizado por el cariño y un cierto regusto nostálgico. Zorrilla tituló el acto cuarto de la parte primera de su Don Juan «El diablo a las puertas del cie-

\footnotetext{
22 María C. DOMinicis, op. cit., p. 169.

23 Ramón J. SENDER, op. cit., pp. 15 y 16.

24 Gonzalo TORRENTE BALlester, Don Juan, ed. cit., p. 13.
} 
lo», dando así un mentís al demonismo barroco del Burlador de Tirso y Zamora y trastrocando la teología del confiado, que presidía las actitudes del «qué largo me lo fiáis». Ese diablo de Zorrilla llega a las puertas del cielo en su quinta a orillas del Guadalquivir, porque el cielo está en doña Inés. $\mathrm{Y}$ ese diablo, frente a la "paloma», en la escena paradigmática del diván, comienza el proceso de su conversión, que es también el proceso de su salvación. También en Sender, don Juan llega a las puertas del cielo, de un cielo surrealista, donde, según marca la acotación, se vislumbra, proyectada por una máquina de cine, la laguna Estigia, donde se arraciman "multitud de mujeres desnudas [...] todas hermosas, con expresión triste, gritando de un modo que recuerda las voces del panteón». En ese cielo, además de san Pedro, «dormitando de bruces en una mesita blanca», nos encontramos con un superintendente que calza coturno y un teléfono blanco que comunica con las secretas galerías y salones donde debe pasear el Dios del antiguo Testamento, con su barba blanca y su cansancio de eternidades. Don Juan ha dejado definitivamente de ser diablo, por supuesto, y trata de convencer a san Pedro y al superintendente de que destruir la obra erótica de don Juan sería como destruir la propia obra de Dios. Y las voces de las mujeres corroboran las argumentaciones, llamando emocionadas al seductor y susurrando lo de «hemos pecado por amor». Nada tan corrosivo, frente a los ángeles de Zorrilla recibiendo a la pareja de enamorados en el final de su versión, como este pórtico del cielo senderiano, donde a san Pedro le vuelve a cantar el gallo y donde don Juan hace sus pinitos metafísicos, ingenuamente, a instancias del superintendente, calificado por san Pedro de "seudodivinidad", llegándose entre ambos a la conclusión de que don Juan es la demostración palmaria de que la existencia es necesariamente anterior a la esencia. Como asegura el superintendente: «Entonces toda tu vida fue un simple y sostenido acto de presencia». Y ante el corolario interrogativo: "¿Y lo otro, digo, la esencia?», responde don Juan: «Supongo que es cuestión de ustedes».25

En última instancia, para Ramón Sender, olvidado ya del segundo ingrediente del donjuanismo, el del banquete, al que tan sólo hay una referencia irónica, un guiño para el enterado, en una de las conversaciones con la estatua del comendador, lo que importa es el primer ingrediente, el universalizador, don Juan mismo. Pero lo sugestivo es que Sender no se conforma con el nomen mítico, aunque tampoco le importe el apellido familiar, Tenorio, sino que, tras hacer desaparecer la conjunción copulativa o disyuntiva, encadena a don Juan a un complemento circunstancial de lugar, a mi entender, y en principio, absolutamente insólito. Ahora don Juan se ha convertido en «Don Juan en la mancebía» y lo recuerdo, ya no

\footnotetext{
25 Respecto al tema de la demonología y su relación con don Juan, vid. Aurora EGIDO, «Sobre la demonología de los burladores (de Tirso a Zorrilla)", Cuadernos de Teatro Clásico, 2. El mito de Don Juan, 1988, pp. 37-54; especialmente, para la versión de Zorrilla, pp. 52-53. Las citas de Sender, en Don Juan en la mancebía, ed. cit., pp. 127-131 y 133, dentro del acto tercero.
} 
como título de la obra, sino como ubicación psicológica del protagonista, como centro estético de la pieza y como punto de partida para el análisis estilístico e ideológico del conjunto textual. Había primero que desembarazarse de la nebulosa forjada por la tradición, que desembarazarse sobre todo de los falsos señuelos que el autor va sembrando para despistar la caza. Esos falsos señuelos se vinculaban singularmente con el Tenorio de Zorrilla y por eso hemos planteado nuestro trabajo como un primer paso hacia el desvelamiento de lo que en Sender es ruptura del modelo aparente.

Pero si el falso señuelo del Don Juan Tenorio marca los mojones más llamativos no conviene olvidar que hay, por lo menos, otros dos conjuntos de signos equívocos que contribuyen a despistar al curioso lector: el de las alusiones a Lope de Vega, directas y reiteradas, y el de la intervención de la justicia inquisitorial junto a la civil en el proceso final a Beatriz, la hija de doña Inés pero no de don Juan. La pieza senderiana se desarrolla, lo volvemos a recordar, «en la tarde del día de las ánimas en 1635», según reza la acotación inicial. ${ }^{26}$ Día 2 de noviembre, por tanto. El 27 de agosto de ese mismo año de 1635 había muerto en Madrid Lope de Vega, a las cinco y cuarto de la tarde. Un lunes de fin de agosto. Camila, la dueña del burdel, ese es el nombre en la acotación aunque se utilice el de «mancebía» en el título general de la obra, trata de rememorar, y así se hace constar en el desarrollo dramático, a Camila Lucinda, la Micaela Luján amante de Lope durante los primeros años del siglo XVII, que precisamente arrastró a Lope hacia Sevilla, lugar mítico del donjuanismo y como tal incorporado por Sender a su drama: «La acción en Sevilla a mediados del siglo XVII», 27 en los primeros años de dicho siglo, entre 1602 y 1604. Incluso se permite el dramaturgo atribuir a Lope un hermoso soneto de la cosecha de Sender, que habría dedicado «el Fénix de los Ingenios» a Beatriz de Ulloa, la hija postiza de don Juan. ${ }^{28}$ La intervención de la justicia, de la civil y de la inquisitorial, por su parte, desenlaza el drama con la muerte de Beatriz y su paso al trasmundo, junto a los espíritus de don Juan y doña Inés, y permite que el autor haga su particular requisitoria contra el Tribunal de la Fe y contra la picaresca de los burócratas y funcionarios de la administración real. $Y$ es entonces cuando surge la figura del inquisidor Aliaga, cuyo nombre, naturalmente, está tomado de fray Luis de Aliaga, que fuera inquisidor general durante los últimos años del reinado de Felipe III,

\footnotetext{
26 Ramón J. SENDER, op. cit., p. 35.

27 Ibid., p. 34.

${ }^{28}$ El día 31 de diciembre de 1603 firmaba Lope en Sevilla el manuscrito autógrafo de El peregrino en su patria. Véase, para este periodo de la vida de Lope, Federico Carlos SÁINZ DE ROBLES, estudio preliminar, biografía, bibliografía, notas y apéndices, en LOPE DE VEGA CARPIO, Obras escogidas, I. Teatro, Madrid, Aguilar, 1958, pp. 96-112, esp. pp. 102-103. En cuanto al soneto de Sender, en Don Juan en la mancebia, ed. cit., p. 78, titulado por el autor "Al jardín secreto de Beatriz».
} 
entre 1618 y $1621 .^{29}$ Se trata, sin duda, de otro guiño seudohistórico, del mismo corte que la seudodivinidad del superintendente en las puertas del cielo, que nos remite, en realidad, al mundo de la mancebía, del que nos hemos escapado al final del acto segundo.

Queda al desnudo, pues, tras el entramado de apariencias y acercamientos literarios más o menos postizos, esa «mancebía», que parece, en principio, el último lugar adonde don Juan hubiera de acudir. Porque don Juan no compra el amor, sino que seduce. Y si el "ambiente prostibulario» al que hacía referencia Aurora Egido en su trabajo sobre «La demonología de los burladores», cuando describía el Burlador de Tirso de Molina, puede caracterizar el entorno de don Juan en la Sevilla del drama originario, jamás se vincula internamente con las actuaciones del personaje. ${ }^{30}$ Pero, para Sender, la mancebía no es lugar donde ejercite sus actividades eróticas don Juan, sino localización dramática con vistas a la aparición de Beatriz, y, especialmente, localización estética, que permite la valleinclanesca aparición, y la cervantina aparición, de una serie de tipos y caracteres que enlazan con, ahora sí, el prostíbulo o «La casa del pecado», en expresión del Valle-Inclán de El esperpento de las galas del difunto, o con la «daifa» del entremés cervantino El rufián viudo, cuyo protagonista se llama, no casualmente, Trampagos, como el chulo de la mancebía senderiana.

Es en la mancebía donde reside, a mi entender, el meollo humano, el núcleo estilístico y la originalidad perceptiva en la versión que del mito donjuanesco ha realizado Sender. Puede hacerse, desde luego, un análisis de la obra de Sender desde el cementerio, desde la tumba preparada para el propio don Juan por el escultor, maese Hermenegildo. Pero el análisis que me parece más rico, menos tópico y con más interés literario es el que conecta la mancebía del drama con casi todas las obsesiones filosóficas y místicas del Sender maduro, con el quietismo de Molinos, con el silencio de la mística de Osuna, con el sexo de los ángeles y los ángeles de Swedenborg y con las reminiscencias y conexiones personales del novelista y dramaturgo con los hombres del 98, desarrolladas ampliamente en su libro Examen de ingenios. Los noventayochos, sin olvidar los excursos metafísicos de sus Ensayos sobre el infringimiento cristiano. Todo el Sender de los setenta, el de la postrera década de su vida, está, de algún modo, reflejado en el espejo cóncavo de la mancebía de don Juan. Por eso, mejor aún que Don Juan en la mancebía, el drama debiera haberse titulado «Sender en la mancebía». Es Sender, en fin, el que, como en la copla, canta y cuenta sus vejeces de don Juan con el pelo gris, "apoyado en el quicio de la mancebía».

29 J. MARTínEZ MiLlÁN, «Los Inquisidores generales durante el reinado de Felipe III», en Historia de la Inquisición en España y América, obra dirigida por Joaquín PÉREz VILLANUEVA y Bartolomé ESCANDELl BONET, I, Madrid, BAC y CEI, 1984, pp. 891-892.

30 Aurora EGIDO, art. cit., p. 53. 


\title{
Dos Hogueras en la noche (1923 y 1980) de Ramón J. Sender: de inclinaciones modernistas a estrategias posmodernistas
}

\author{
Marshall J. Schneider \\ Baruch College, City University of New York
}

Sea equivocación, «mentira» creativa o verdad deconstructiva, la lúdica posdata — «Zaragoza, 1917» (139)— de la edición de Una hoguera en la noche de Ramón J. Sender de 1980 proporciona en cualquier estudio comparativo de las dos Hogueras un problema inicial. Las palabras finales del texto, que además se refieren a la supuesta fecha y al lugar en que se escribió la primera Hoguera, obligan al crítico a redefinir o al menos a contextualizar la palabra «comparativo». Luego de leer la Hoguera de 1980, se evidencia de inmediato que esta novela no es simplemente la reescritura de la Hoguera de 1923, emprendida en la temprana juventud del autor; mejor dicho, la segunda Hoguera representa para Sender una importante reconsideración de la función del discurso novelístico y de la naturaleza de toda representación en general. Un estudio narratológico de la Hogue$r a$, por consiguiente, se convierte en estudio obligado para el investigador senderiano.

Los investigadores literarios no le han dado un trato favorable a la segunda Hoguera, ya que han ignorado casi todas las mejoras semánticas que Sender incorporó como resultado de la reescritura. Ignacio Martínez 
de Pisón se muestra intransigente en su desprecio por la obra; la llama «incoherente» $y$ aborrece especialmente los cambios estructurales que Sender efectuó (17). José Domingo Dueñas Lorente, más moderado, en sus recientes y negativos comentarios afirma respecto a los efectos de la reelaboración en la redacción de Sender: «[...] pierd[e] buena parte de su coherencia interna y resulta asimismo gravemente adulterada en cuanto a sus ingredientes estéticos originales» (22). Por último, Jesús Vived Mairal, quien sólo critica con delicadeza las reelaboraciones novelísticas senderianas, lamenta no obstante que en algunos casos «la redacción primitiva pierda la frescura original y que se resienta el contexto que da sentido al escrito» (XXIX). A pesar de estos juicios críticos tan provocativos, me permito afirmar que lo que deseo aquí no es llevar a cabo un detallado análisis que valore las diferencias y semejanzas entre las dos Hogueras; más bien las señalaré solamente cuando otorguen un fuerte carácter semántico y emblemático a la actividad de reescritura en general, una empresa a la cual Sender se entregaba a menudo. Parece ser que para el escritor la actividad de revisión se convirtió en un fuerte y confiable marcador de significación y desarrollo artístico. Lo que se perdió en frescura y cohesión, pérdida muy lamentada por algunos críticos, lo ganó fácilmente en sabiduría y en estrategias más complejas para desarrollar la ficción. Éste es el supuesto en el que se basa la presente investigación crítica.

Para plantearlo más clara y simplemente: Sender publicó dos novelas diferentes con el mismo título; ambas, además, nacen de una trama similar, se ubican en el mismo lugar y utilizan elementos exóticos comparables que instructivamente se reflejan y mutuamente se hacen referencia. Las dos Hogueras, por lo tanto, permanecen como obvios intertextos y piden (re)leerse una frente a la otra. Si la Hoguera original de 1923 es la historia de una aventura absorbente, por consiguiente la segunda Hoguera es la historia absorbente de una aventura. De modo que vamos de un énfasis en histoire a uno que privilegia el discours, repleto de autorreferencialidad intencional, de una estetizante ficción con poca ironía narratológica a una alegoría sin fin y con reminiscencias y posibilidades literarias.

Hasta una simple investigación de la relación cronológica entre las fechas de publicación de las dos Hogueras, así como el tema más complicado de la conexión cronológica entre la(s) fecha(s) en que se escribió y la de publicación de la obra de 1923, sustenta paradojas, dificultades y contradicciones. Desde el punto de vista del lectorado y la recepción por el lector, la novela de 1980 puede muy bien informar la Hoguera original ya que en casi todos los casos el lector ha leído la segunda Hoguera primero, dado el hecho de que la versión de 1923 fue prácticamente inaccesible hasta que aparece la Antología de Dueñas Lorente en 1992. Contrariamente a la normal expectativa, la última y más compleja versión prepara el camino para el trabajo anterior. De modo casi análogo al funcionamiento de un 
museo, la segunda Hoguera "alberga» una forma de la Hoguera original, redescubriéndola y convirtiendo en segunda lectura lo que debería haber sido la primera.

Para abarcar problemas de otra índole, el segundo asunto se refiere al año en que el joven Sender escribió su primera gran obra de ficción, que luego sería publicada. Vived Mairal argumenta, muy convincentemente, que a pesar de publicarse en 1923 como la novela corta ganadora del concurso de la popular Lecturas de Barcelona, Hoguera fue escrita en algún momento entre 1916 y 1917 (XXIV-XXVII). La evidencia es mayormente anecdótica y se basa en entrevistas con gente que conocía al adolescente Sender. Muchos de ellos "se acuerdan» - según informan- de que cuando Sender tenía como dieciséis años había escrito alguna historia sobre Marruecos, un país que le interesaba sumamente y sobre el cual había leído mucho. Sender asimismo mantiene recuerdos similares en varias entrevistas. A pesar de que admiro la dedicación investigadora de Vived Mairal, quien ha hecho mucho por incrementar nuestro conocimiento acerca de "el primer Sender», debo señalar que existen ciertos elementos textuales, paratextuales y hasta detalles históricos de la versión de 1923 que desmienten la primera fecha propuesta por aquellos que han facilitado esta información.

En primer lugar, las observaciones preliminares de los editores (un paratexto útil) que nos presentan a Sender informan a los lectores de que el manuscrito recibido por la revista fue compuesto por el autor cuando éste era un recluta en el conflicto marroquí:

\footnotetext{
Allí, en ratos de descanso y restándose horas de dormir, concibió y escribió esta narración; y como la compuso viviendo aquel ambiente, hay en toda su obra ese encanto especial, ese sabor de vida y de verdad que da siempre el natural. (677)
}

Vived Miral, sin pensarlo dos veces, descarta esta afirmación, lo que yo actualmente no me siento inclinado a hacer. Él acusa a los editores de estar confundidos, lo cual puede muy bien ser una posibilidad, ya que la presentación de los manuscritos para el concurso tuvo lugar en octubre de 1922, cuatro meses antes de la llegada de Sender a Marruecos, en febrero de 1923.

En segundo lugar y con mayor decisión, sin embargo, existe el apoyo histórico definitivo encontrado en el texto que da cuenta de una fecha posterior de escritura: la horripilante ironía del desenlace del cuento, que tiene al protagonista camino a Xauen para reunirse con la recientemente constituida Legión de expertos soldados, reunidos por Millán Astray. Sólo como dato histórico, la Legión sí llegó hasta el estratégico pueblo, pero no fue sino hasta mediados de octubre de 1920 (García Figueras, 179-181; Carr, 520, 573-574; Woolman, 69-72). El acontecimiento de mediados de octubre, que cierra la novela, cronológicamente tiene sentido desde el punto de vista de las observaciones iniciales que enmarcan el tiempo en 
«aquel interminable día de septiembre» (677). De modo que, si el joven Sender tuvo el manuscrito preparado ya para el año 1917, hubiera tenido que reconcebirlo por lo menos alrededor de fines de 1920 a más tardar; salvo error, ¿cómo pudo prever la formación de la Legión y la ocupación de la venerable y antes impenetrable ciudad de Xauen, ambas ocurridas en 1920 ?

Por último, existe un hito textual que presta credibilidad a las observaciones preliminares de los editores acerca del tiempo y lugar de la composición de la novela. Los comentarios del narrador acerca de Ojeda a continuación prefiguran un modelo que Sender utiliza una y otra vez en subsiguientes obras para dar forma a la experiencia novelística: Ojeda, el héroe agonizante de Hoguera, quien encarna temáticamente las dificultades de representación, se convierte en el álter ego del autor y el signo de las preocupaciones literarias de Sender:

Un poco desilusionado por la falta de emoción artística que brindaba la ciudad marroquí, sintió que todas sus ansiedades por llegar a Marruecos y saborear el encanto de la tierra prometida a su fantasía por el fárrago bibliográfico de tanta lectura anterior se deshacía en una realidad demasiado fría. Tenía caracteres de fracaso, de cruel fracaso sentimental tamaña desilusión. (677)

Las palabras del narrador podrían fácilmente recaer sobre Sender en su juventud, quien ahora como escritor y soldado acosado en Marruecos legítimamente no puede ser víctima por causa de la carencia de material de lectura o la falta de una experiencia personal y tangible en Marruecos. Sin embargo, esta afirmación, que fue eliminada de la versión de 1980 por irrelevante, sólo tiene sentido como referencia si hubiese sido escrita poco después de la llegada del escritor a África del Norte a inicios del año 1923. De todas maneras, esta afirmación destaca una creencia senderiana: que el mundo de la ficción nunca debe primar sobre la experiencia de la vida real.

Desearía concluir esta problemátiça discusión acerca de cuándo fue escrita la Hoguera de 1923 manteniéndome en la posición intermedia que propone una fecha posterior a 1917 para la Hoguera original, esto es, probablemente un poco después de 1920, cuando ya las tropas españolas habían ocupado Xauen. Sin embargo, es posible - aunque indudablemente admito que esto no sea probable - que Sender pudiera haber corregido o hasta reelaborado la obra como joven soldado en Marruecos a pesar de que la fecha límite de entrega era el otoño de 1922. Coincidiendo con Martínez de Pisón, creo que existe todavía una "sombra de duda" (16) acerca del año en que Sender escribió la primera Hoguera.

Tal vez la mejor descripción de la primera Hoguera la den los editores en sus breves comentarios de presentación. La llaman «un poema interesantísimo de combates y amor» (677), pronosticando la mayoría de los intereses novelísticos de Sender, los cuales abrazan lo lírico y lo real. Des- 
de una perspectiva comparada, la temprana Hoguera modernista es más oblicua y más objetiva en su estética que la versión tardía. Es una novela más dedicada a un desarrollo lineal del argumento y mucho más descriptiva que la versión de Hoguera sumamente gnómica y divagante de 1980. El escritor del texto del año 1923, a pesar del tono neutral, quiere asegurar que el lector aprende y disfruta del paisaje exótico, el folclore y las costumbres de Marruecos, el país anfitrión de los tremendos esfuerzos colonialistas de España. Por esta razón la primera Hoguera de Sender es más informativa que la versión de 1980, ya que la meta principal de aquélla es la de contar una aventura agridulce de vida, amor y muerte en un tiempo difícil de guerra y de tedioso aburrimiento. El texto de 1923 se nutre casi completamente de esas oposiciones temáticas y no de otros textos ni de complejas teorías literarias.

La novela original detalla - así como lo hace casi totalmente la tardía reencarnación - las peregrinaciones del teniente de veinticuatro años Ojeda, quien después de haber comandado un blocao en N'Taixa, el territorio español más distante que colinda con territorio rebelde, sufre el resultado de la victoria de Thanatos sobre Eros. En N'Taixa, ignorando la deslealtad de su asistente marroquí Alí y en la penumbra de infrecuentes y bastante inconsecuentes escaramuzas, Ojeda se enamora a lo lejos de Dayedda, una bella y núbil doncella mora de unos dieciséis años y de noble cuna. Dayedda es raptada por un potentado rebelde y puesta en cautiverio para provocar su rescate. Obsesionado con la belleza de Dayedda, el teniente obtiene permiso extraoficial de su comandante, siempre y cuando no haya bajas en las tropas españolas. Ojeda triunfa brillantemente en el rescate sólo para ver a Dayedda pérfidamente asesinada en manos de Alí poco después, durante una vengativa escaramuza de las fuerzas rebeldes. El corazón del amante está hecho pedazos. Después de haber quedado profundamente deprimido, Ojeda se recupera en un hospital y rehúsa regresar a N'Taixa, el lugar de su pérdida irrecuperable. El teniente decide unirse a la Legión en los territorios conquistados de Xauen, los cuales habían sido anteriormente prohibidos a ciudadanos europeos.

Así termina el sentimental y dramático viaje de Ojeda, quien, recién llegado a Ceuta, estuvo ansioso por buscar sus orígenes, lo cual podría interpretarse como una posible metáfora del joven escritor en busca de un estilo y una voz literarios. Sin embargo, al final de la corta novela, el teniente experimenta una gran desilusión y un profundo desagrado al darse cuenta cabalmente de lo que había sospechado desde el principio: que es imposible ser soldado y turista a la vez; es decir, que es inútil abandonarse a la recreación ficticia y a una vida llena de sensaciones y sentimentalidad —con seguridad, deseos modernistas - cuando uno está obligado a atender a las rigurosas demandas de la realidad. Y aun así el arte puede ser sólo el único consuelo del escritor y del lector de Hoguera, si comprendemos correctamente algunos de los comentarios finales del narrador: 
[Ojeda] iba a la Legión desprovisto de las ilusiones bélicas que en la mayoría despertaba el nuevo cuerpo, bravo, audaz, formado por las levas cosmopolitas..., que llevaban en sus pechos, fulgente triunfadora, la estrella de la aventura y en su sangre la fiebre nómada, ansiosa de nuevos horizontes y emociones nuevas. Todos sus desengaños de vencidos, todas sus tristezas de desengañado iban a verterse en aquella nueva empresa, sin impulsos varoniles, sin el aliciente patriótico — siquiera - que le animara en otras circunstancias. (805)

A la vez que utiliza casi todo el material del argumento de la Hoguera de 1923, el trabajo más reciente extiende y complica las operaciones narrativas de la aventura de Ojeda intercalando un cuento doblemente revisado, "La fotografía del aniversario", escrito varias décadas antes de la publicación de la Hoguera de 1980. A este respecto, la novela de 1980 se puede considerar una alegoría posmodernista, puesto que la alegoría suele ocurrir cuando un texto es duplicado por otro y se reescribe el primero en sentido figurado (Owens, 68-69). En el caso de Hoguera tenemos una doble o, quizás, hasta una triple reescritura, ya que la nueva obra comenta los dos textos previos del autor. Es entonces cuando se crea aún otro significado a partir del nuevo vínculo de los textos últimamente revisados que ahora constituyen la novela de 1980. Así, la nueva Hoguera se convierte en una especie de museo metafórico, un lugar de descanso para "otros" trabajos del escritor, que ahora pueden ser redimidos en todas las futuras relecturas. Dicho de otra manera más simple, esta Hoguera es una alegoría sobre los orígenes de la creatividad y la significación, así como también sobre el acto redentorio de escribir. La clave para comprender el impulso alegórico yace en el cuento intercalado, "La fotografía del aniversario", un trabajo sumamente admirado por su mérito propio pero cuya inclusión en la Hoguera, sin embargo, la crítica no ha logrado apreciar.

Con la excepción del texto interpolado, la Hoguera de 1980 más o menos se adhiere a la línea de argumento antes expuesta, a pesar de que ahora sí encontramos a un Ojeda - debido al exceso y al hachís- más sabio y sexualmente agresivo. Sin embargo, el aporte del cuento nos obliga a dar un pequeño resumen de su argumento antes de comentar la significación de su función textual. «Fotografía» trata del fotógrafo Teodosio y su esposa Rosario, quienes están celebrando su vigésimo aniversario de matrimonio. A Rosario le agradaría tener una fotografía en honor de la ocasión y Teodosio le dice que él no puede por el momento, porque todavía le es imposible capturar el ser interior de ella. Su vigésimo aniversario marca una fecha doblemente importante puesto que Rosario, después de muchos años de matrimonio, ha quedado finalmente encinta, lo cual ella comunica al suspicaz Teodosio, a quien los médicos frecuentemente le han dicho que no habrá niños para ellos ya que existe la posibilidad de que él sea estéril. Los mira fijamente desde una de las muchas fotografías de la galería su querido amigo Gustavo, quien, víctima de un supuesto suicidio, ha estado muerto desde hace varios meses. Pronto se descubre que, ya que 
Gustavo es en realidad el padre biológico de «su» niño, ella le ha matado para sellar su silencio. Por supuesto, incidentalmente, Ojeda es el hijo de esta infeliz pareja, quien durante el cuento les visita en su vida actual con su «amada novia» Dayedda. De esta forma la novela exterior transgrede los límites de este breve segundo cuento, arriesgando de una manera de lo más posmodernista la integridad de los niveles lógicos de la realidad textual de la novela.

El cuento intercalado, el cual nació de las alucinaciones de Ojeda, ocasionadas por el mucho hachís, funciona aquí como una provocativa mise en abime que refleja los mismos temas de orígenes, nacimiento, muerte, amor y decepción ya presentados en el texto exterior. El cuento intercalado funciona también como un exemplum sobre la construcción literaria que trasciende los límites del texto que lo contiene. La mise en abîme implícitamente revela lo que origina, motiva y unifica el trabajo (Dällenbach, 102104). Además, se debe recordar que Ojeda es el autor ficticio de la historia intercalada, narrada por un agente anónimo, quien difiere en un aspecto del narrador del primer nivel diegético: el narrador del cuento interpolado utiliza la primera persona singular del verbo una vez, con lo cual se distancia por el momento de la tercera persona: «Es verdad que en el tiempo en que se producía aquella escena del hashis el teniente no había nacido aún, según advertí antes» (117).

Los rigurosos esfuerzos de Ojeda por localizar y descubrir las circunstancias de su nacimiento están manifestados en su desastrosa peregrinación y viaje de escape a lo largo de la novela; simultáneamente, su viaje transgresor y retrospectivo a casa de sus infelices padres del texto intercalado refleja a Sender en la búsqueda de los orígenes de su propia carrera como novelista. Esta búsqueda metafórica ocurre en el nivel del diseño estructural de la novela, el cual combina revisiones de trabajos iniciales, formando así un extraño collage que lleva al lector a aceptar la producción de la trayectoria novelística de Sender no sólo como un artefacto diacrónico sino también como uno que es sincrónico por naturaleza. Ahora se puede apreciar completamente que la Hoguera de 1980 es una alegoría, puesto que, como todas las alegorías, ofrece un significado importante y suplementario a los textos existentes. Es posmodernista porque se descifra a sí mismo y es por lo tanto evidentemente autorreferencial a la misma vez que plantea de un modo problemático la actividad de hacer referencias.

Bajo el influjo del hachís, Ojeda desea resolver el hermenéutico rompecabezas de su nacimiento regresando al lugar de sus orígenes, de la misma manera que el lector, que (sin el beneficio del hachís) se traslada a la primera Hoguera en búsqueda de los orígenes del texto tardío. Como una seductora invitación a la interpretación, Ojeda compone una alucinadora mise en abime en favor de la necesidad de sí mismo, del lector y del autor verdadero. Además de retornar al estudio de su padre - muy simbólico del útero-, donde puede literalmente «verse» in utero, Ojeda se sitúa o se 
sueña a sí mismo allí, gracias a la terapéutica luz que falta en su sede del austero desierto de Marruecos y que le va a permitir ver:

En todo caso y en las alucinaciones de hashish vio a su padre en su gran estudio de fotografía. Las imágenes de él y de su madre se le aparecian con toda la luz que faltaba en las dulcísimas noches del morabito, la misma luz de las entrañas de la hoguera de Yebel Alan. (93)

Como narrador de cuentos y soñador —es esta última palabra la metonimia favorita de Sender para "creador»-, Ojeda imita el talento de su padre como fotógrafo, quien no crea meros mensajes sin código de la realidad sino más bien, como un real artista, extrae punzantes documentos del alma. El teniente percibe que hay un nexo profundo entre la noción de orígenes y la necesidad de luz:

[...] porque toda luz viene de alguna clase de fuego. Y el fuego es el origen del universo, lo mismo del universo interior que del exterior. Los dos son difíciles de investigar y explorar hasta el fondo. Si es que hay fondo. (23)

Así pues, en un nivel narrativo, donde los temas operan generalmente, Ojeda entiende que regresar a los origenes es estar ilustrado - espacio en el cual la creación más a menudo comienza.

La decisión de incluir la mise en abîme en la última Hoguera evidencia lo que la novela corta original silencia: la versión de 1980, a fuerza de usar la estrategia de intercalar, revela el hecho de que evidentemente existe un autor mientras que la otra Hoguera parece escribirse por sí misma. La mise en abîme asimismo cambia el enfoque y el énfasis del proyecto novelístico de Sender, haciéndolo una empresa posmodernista. Es decir, el interés del lector se encuentra realineado hacia el «cómo» de la obra, hacia sus operaciones, desviando provisionalmente la atención del lector del contenido de la trama central. Además, el texto exterior o principal se permite funcionar como referente de la historia intercalada, de modo que autoriza la narrativa primaria dándole cierta anterioridad o exterioridad a la mise en abîme. El sueño de Ojeda, por lo tanto, no se refiere meramente a la verdad sino que se convierte también en parte de la verdad ficticia, porque resalta el potencial de la obra por ejemplaridad. Es esta ejemplaridad lo que eventualmente hace que el lector regrese al contenido de la obra, reafirmando los fuertes intereses morales y éticos de Sender.

La narración del fotógrafo es una analogía de las operaciones del texto principal, ya que fácilmente se aprecia que Ojeda es el autor "real» de esta interpolación; por lo tanto la novela -como todos los textos- necesariamente también debe de tener un autor. Además, Ojeda es simultáneamente un personaje dentro de su propia creación, aunque nunca el narrador. Al aparecer en el texto de su propia creación transgrede la jerarquía de los niveles diegéticos y entra en la narración intercalada como un hombre adulto, a un segundo nivel de la diégesis. Ojeda es el adulto del 
nivel exterior y su otro yo es el feto del segundo nivel diegético, donde su presencia es entonces doblada; se miniaturiza adecuadamente a sí mismo. Ojeda es en la novela a la vez visible e invisible, creador y creado; igual que anterior y posterior a su propia existencia. Las diversas apariencias de Ojeda en la última Hoguera son así un signo no sólo de las cambiantes jerarquías diegéticas dentro de la narrativa sino también de la relación que las dos Hogueras comparten. Es, como sabemos, una relación indicativa de lo compleja que es la ironía de crear ficción en Sender. Consecuentemente, al fin del relato intercalado, cuando el narrador nos advierte: "Pero no había que confundir el sueño con la realidad» (120), el lector sólo puede quedar perplejo o, quién sabe, simplemente encantado ante los lúdicos comentarios autorreflexivos del narrador sobre la representación.

\section{OBRAS CITADAS}

CARR, Raymond, Spain 1808-1939, Londres, Oxford University Press, 1966.

DÄLlEnBACH, Lucien, The Mirror in the Text, Chicago, University of Chicago Press, 1989.

DUEÑAS LORENTE, José Domingo, "Introducción» a Ramón J. SENDER, Literatura y periodismo en los años 20 (Antología), Zaragoza, Edizions de l'Astral, 1992, pp. 7-46.

García Figueras, Tomás, Marruecos (La acción de España en el norte de África), Barcelona, Ediciones $\mathrm{Fe}, 1941,2^{\mathrm{a}}$ ed.

MARTíneZ DE PISÓN, Ignacio, "Corregir al corrector (A propósito de Una hoguera en la noche, de Sender)", Rolde, 28-29 (1985), pp. 16-18.

OWENs, Craig, "The Allegorical Impulse: Toward a Theory of Postmodernism», October, (primavera de 1980), pp. 67-86.

SENDER, Ramón J., "La fotografía del aniversario", La llave y otras narraciones, Madrid, Magisterio Español, 1967.

—, «Una hoguera en la noche», Lecturas: parte I, 26 (julio de 1923), pp. 677-694; parte II, 27 (agosto de 1923), pp. 785-805.

-, Una hoguera en la noche. Bajo el signo de Aries, Barcelona, Destino, 1980 (ed. rev.).

Vived MaIral, Jesús, ed., Ramón J. Sender, Primeros escritos (1916-1924), Huesca, Instituto de Estudios Altoaragoneses, 1993.

Woolman, David S., Rebels in the Rif: Abd el Krim and the Rif Rebellion, Stanford, California, Stanford University Press, 1968. 


\title{
Intertextualidad y proceso creativo en El extraño señor Photynos
}

\author{
Josep Mengual Català \\ Universitat Autònoma de Barcelona
}

Pertenecemos o no al círculo mágico de las palabras, teologales y sensoriales, y por su conducto se anuda el vínculo definitivo con los hombres y los tiempos. (Manuel Andújar, Los aniversarios)

El extraño señor Photynos es una de las muchas narraciones de Sender cuya valoración está por debajo de sus méritos. Hasta ahora se le ha dedicado escasa atención, pero este relato ofrece al lector varios puntos de interés y algunas sorpresas, especialmente si éste se acerca al texto con cierta experiencia como lector senderiano.

En primer lugar hay que aclarar, en la medida de lo posible, la génesis de la obra y sus sucesivas transformaciones. El extraño señor Photynos se publica por primera vez en español en una espléndida revista dirigida por Max Aub, Los Sesenta, ${ }^{1}$ a principios de 1965 y con el título de El Tonatio

\footnotetext{
${ }^{1}$ Los Sesenta [México], 3 (1965), pp. 53-99. El resto de colaboradores de este número, todos ellos mayores de sesenta años (condición indispensable para participar en la revista), tal ve $z$ dará una idea de la entidad de esta empresa aubiana: Enrique Díez-Canedo, Alfonso Reyes,
} 
(Historia de un soneto). Gracias al epistolario aubiano, se conoce la fecha en que Sender mandó este relato a la redacción: el 22 de junio de 1964. La segunda edición es la que aparece en el volumen Cabrerizas Altas, ${ }^{2}$ que terminó de imprimirse en diciembre de 1965 , con un título ligeramente distinto: El Tonatiu (Historia de un soneto). Entre estas dos versiones hay, además, abundantes e importantes variantes que hacen suponer que la de Cabrerizas Altas es anterior a la de Los Sesenta y, por tanto, fechable antes de junio de 1964. Esta idea se ve reforzada al examinar la tercera edición, que puede considerarse la definitiva, en el volumen El extraño señor Photynos y otras novelas americanas, editado por Delos-Aymá en $1968 .{ }^{3}$ En esta edición aparece por primera vez el título definitivo, pero recupera exactamente la versión de Los Sesenta con tan sólo algunos cambios de puntuación. Introduce la dedicatoria del libro a John E. y Joan Longhurst y una grave errata en el relato («indios yanquis» por «indios yaquis»), que pasarán sin alteración al libro editado por Destino en 1973 con el mismo título que el de Delos-Aymá. ${ }^{4}$

Aceptando su prioridad en el tiempo, el texto de Cabrerizas Altas puede verse como el ante-texto ${ }^{5}$ principal del relato y del cotejo con la versión definitiva se deduce, sobre todo, un importante cambio de actitud del narrador respecto a la cultura y las creencias autóctonas mexicanas. Así, por ejemplo, mientras en la versión de Cabrerizas Altas Photynos explica que los hijos del Sol son todos de origen griego, en la siguiente versión rectifica: «aparte de los mexicanos, que son por decirlo así los hijos predilectos del Sol, los griegos le proporcionamos al Sol los mejores delegados aquí en la tierra" (p. 27). En este sentido, otro cambio interesante es el que se produce entre «Ese poema revela bien —creo yo- la inspirada memez de los pueblos primitivos» ${ }^{6} \mathrm{y}$ «Ese poema sugiere bien -creo yo- la inspirada simplicidad de los pueblos primitivos" (p. 9). La substitución de «memez» por «simplicidad» ejemplifica la anulación del tono despectivo respecto a las antiguas civilizaciones americanas, aspecto éste importante para hacer más verosímil el proceso de persuasión del narrador, que, en la

Juan Rejano, Juan José Domenchina, Jorge Guillén y Max Aub. A lo largo de sus cinco números, Los Sesenta publicó textos de Unamuno, Juan Ramón Jiménez, Esteban Salazar Chapela, André Malraux, Rafael Alberti, Emilio Prados, Manuel Altolaguirre, León Felipe, Américo Castro, José Gaos... Francisco Carrasquer registra una edición anterior en inglés: «The Tonatiu», en Tales of Cibola, Nueva York, Las Américas, 1964 (Francisco CARRASQUER, «Imán" y la novela histórica de Sender, Londres, Tamesis Books, 1970, p. 286).

2 Cabrerizas Altas, México, Editores Mexicanos Unidos, 1965, pp. 91-124.

3 El extraño señor Photynos y otras novelas americanas, Barcelona, Delos-Aymá, 1968, pp. 7-53.

4 El extraño señor Photynos y otras novelas americanas, Barcelona, Destino ("Áncora y Delfín", 409), 1973, pp. 9-55. Esta edición reproduce exactamente la de Delos-Aymá.

5 Se toma el término ante-texto con el significado que le atribuye Cesare SEGRF de «conjunto de los materiales que preceden a la redacción definitiva» en Principios de análisis del texto literario (traducción de María PARDO DE SANTAYana), Barcelona, Crítica («Filología», 13), 1985.

6 Cabrerizas Altas, ed. cit., p. 91. 
primera versión, era muy breve y el paso de la incredulidad a la convicción se producía de un modo abrupto. La transformación de la actitud inicial del narrador (del desdén y el desprecio a un escéptico interés respetuoso) permite al autor abreviar el texto, podándolo de algunos pasajes farragosos, y concentrar el efecto del relato. Además, posiblemente se acerca mucho más a la postura del propio Sender hacia lo mexicano. ${ }^{7}$ En cuanto al pueblo mexicano, la segunda versión añade que «[1]os mexicanos, pueblo viejo, maduro y complicadísimo en el mejor sentido, saben eso muy bien. Mejor que nosotros» (p. 21), y se introducen menciones a personajes relevantes de la cultura mexicana como Siqueiros, Tamayo o Alfonso Reyes, a quien se cita como un caso representativo de los «gordos helénicos inspirados y exactos» en oposición al tipo de gordos «radiantes y expansivos; es decir, locuaces sin verdadera precisión» (pp. 36 y 37). ${ }^{8}$ Como inmejorablemente expresó Manuel Andújar: "Además del nexo argumental que en relación con el Epitalamio del prieto Trinidad aporta $E l$ extraño señor Photynos, esta historia reviste alcance propio y, sobre todo, pone de relieve el rechazo y seducción que México significó para Sender, en sístole y diástole anímicos, desde su llegada, y que el tiempo, la estancia prudencial, frecuentes viajes, succionadoras lecturas y probablemente sugeridoras gamas de humano trato acendraron». ${ }^{9}$

Al reseñar este relato, José-Carlos Mainer lo describió como «el desarrollo de una de las habituales mitologías metafísico-totémicas de Sender, que aquí pretende aclarar la elaboración de otra obra del autor: la alucinante novela Epitalamio del prieto Trinidad». ${ }^{10}$ En concreto, Sender parte del

\footnotetext{
7 Jesús Vived Mairal ha publicado un documentadísimo artículo sobre este tema titulado «Sender y América», Turia [Teruel], 27 (marzo de 1994), pp. 145-155.

${ }^{8}$ Entre los abundantes cambios, puede citarse la transformación del pasaje que habla de los vendedores de lotería: «Lo que quieren es ir por las calles dando voces y ofreciendo fortunas a toda una multitud de ilusos codiciosos. La lotería de México es la más cara y la menos prometedora del mundo. Es decir, la que tiene menos premios» (Cabrerizas Altas, ed. cit., p. 103), en «Claro es que hay la probabilidad de que les toque un premio, pero es muy remota y ellos lo saben mejor que nadie y no aceptan riesgos. Tampoco quieren ser ricos. Les basta con ganarse la vida sembrando un poco de ilusión entre los humildes" (p. 24). A la frase sobre México «todo era en aquel país un eco y consecuencia solar» se le añade «de ahí su originalidad y su ocasional grandeza». Otro cambio notable es la reducción del papel desempeñado por el personaje femenino, Nadia, que prácticamente se convierte en nadie.

9 Manuel ANDÚJAR, "Ramón J. Sender y el nuevo mundo», Grandes escritores aragoneses en la narrativa española del siglo XX, Zaragoza, Heraldo de Aragón, 1981, pp. 95-115. Cito por la reimpresión en José-Carlos MAINER, ed., Ramon J. Sender. In memoriam. Antología crítica, Zaragoza, Diputación General de Aragón, Ayuntamiento de Zaragoza, Institución Fernando el Católico y Caja de Ahorros de Zaragoza, Aragón y Rioja, 1983, pp. 213-214.

10 José-Carlos MAINer, "Cabrerizas Altas», Insula, 240 (noviembre de 1966), p. 8. En palabras de Manuel Andújar, coincidentes con las de Mainer, El extraño señor Photynos es «un acercamiento - epilogo sería un calificativo complementario - a la que sería una de las obras máximas en la producción de Sender y la más notable de su temática adherida al Nuevo Mundo: Epitalamio del prieto Trinidad» (Manuel ANDúJAR, "Ramón J. Sender y el nuevo mundo», cit., p. 212).
} 
mito del Tonatiuh, el dios solar de los aztecas, a quien, durante el curso solar (Tonatiuh Ichán), acompañaban los guerreros muertos en el campo de batalla o personas que eran sacrificadas y las mujeres muertas durante el parto; por la noche iluminaba el mundo de los muertos y los días nublados bajaba a la Tierra. Pero Sender altera el mito, lo actualiza y le da una nueva dimensión, al ponerlo en relación con otros sistemas mitológicos y con especulaciones científicas, conformando, de este modo, una síntesis de textos que, a su vez, se proyecta hacia otros posteriores en forma de extensas y variadas relaciones transtextuales. ${ }^{11} \mathrm{Si}$ se considera la versión de Cabrerizas Altas como el ante-texto principal de El extraño señor Photynos, hay que entender el proceso creativo de Sender como el reflejo de una gradual asimilación del contexto cultural en el que le tocó vivir.

En 1965 está fechada la novela Las criaturas saturnianas, en la que dos de sus protagonistas, Spinac y Cagliostro, exponen la idea de la llegada de un cometa que transformó el ecosistema y que, «después de chocar con la tierra, saltó al espacio otra vez y quedó fijado como un planeta más entre la tierra y el sol con el nombre de Lucifer. Era una serpiente, un ogro, un animal volante y cornudo, hijo de Dios (del Sol) que se rebeló contra él y fue condenado a los abismos de la creación. De todo eso habla la biblia y también algunos códices antiguos egipcios y aztecas mexicanos». ${ }^{12}$ Quienes también hablan de ello son los personajes de Los cinco libros de Nancy y La cisterna de Chichén-Itzá, así como Enrique Lavedan, el protagonista de Tánit, quien establece una identificación entre los mitos europeos y los americanos. Según Lavedan, la llegada del devastador cometa (Typhon) que pasó luego a ser un planeta (Venus) provocó el hundimiento de la Atlántida, que, al dejar incomunicada América de África y Europa, propició las divergentes evoluciones del mito. ${ }^{13}$ También es Lavedan quien establece la correspondencia entre Venus y quien en latín es llamado Lucifer. Recuérdese que en Tánit Enrique Lavedan es autor de una original obra geogénica en la que expone esta teoría, pero otro texto senderiano, un ensayo del otro mundo titulado «Los atlantes y el binomio Cortés-Quet-

\footnotetext{
11 Siguiendo a Gérard Genette, se emplea aquí el término transtextualidad con el significado amplio de "todo lo que pone al texto en relación, manifiesta o secreta, con otros textos" (Gérard Genetre, Palimpsestos. La literatura en segundo grado, traducción de Celia Fernández PRIETO, Madrid, Taurus [«Persiles», 195], 1989, pp. 9-10).

12 Las criaturas saturnianas, Barcelona, Destino («Destinolibro», 253), 1968, p. 269. La misma idea expresa Spinac (o Spic) en las pp. 238-239.

13 Lavedan defiende que «la religión heliosística era la misma en Europa y América y los indios desde Yucatán al norte de México actual que llaman al sol Tonatiuh cuando se refieren al diluvio universal, llaman al dios que lo presidió Atltonatiuh. Porque en los dos lados del Atlántico se sabía del diluvio y de Noé y del arca. A veces los curas católicos se quedaban asombrados en tiempos de Cortés viendo que había en el lado de acá tradiciones y cultos semejantes a los europeos, y lo atribuían al diablo» (Tánit, Barcelona, Planeta [“Colección Popular»l, 1976, pp. 98-99). Este fragmento se reproduce casi exactamente en "Los atlantes y el binomio Cortés-Quetzalcoatl», en Ensayos del otro mundo, Barcelona, Destino («Áncora y Delfín», 357), 1970, p. 141.
} 
zalcoatl», ${ }_{1}^{14}$ pone de manifiesto que el personaje Lavedan es un plagiario del escritor Sender. El ensayo de Sender se inicia con una explicación sobre Atlantis, un estudio de Ignatius Donnelly que según nos dice "se publicó por primera vez en 1882, y en 1949 se volvió a imprimir con algunas aclaraciones y notas editoriales que lo ponían al día», y que «no es una novela sino un escrupuloso estudio antropológico, histórico, filológico. El autor era hombre de prestigio entre sus colegas. Y lo que ese libro nos dice es de veras revelador $[. .$.$] . De la lectura de este libro de Donnelly y de su rela-$ ción con otros anteriores y posteriores sobre la materia se pueden deducir un poco ligeramente hipótesis de un interés alucinante». ${ }^{15}$ Además del libro de Donnelly, Sender glosa en este ensayo el de Velikowsky, Worlds in collision, ${ }^{16}$ en el que se expone la teoría del cometa Typhon, de la que también se apropia Lavedan. Siguiendo la sugerencia de Sender, Lavedan combina, para construir su hipótesis, el estudio de Velikowsky con las teorías de Donnelly sobre la civilización atlántica. Pero lo más curioso es constatar que, en Tánit, Lavedan reproduce exactamente las palabras de Sender, quien escribe: «Según Donnelly, la cuna de la civilización estuvo en la Atlántida, desde donde se extendió por el Mediterráneo haciéndose especialmente poderosa en Egipto. Pero no era la Atlántida un imperio militar, sino un centro democrático de influencia y de cultura. Sus reyes, por esa razón, pasaron más tarde a ser los dioses-hombres griegos y romanos [... $\gg .{ }^{17}$ Lavedan, además de reproducir este pasaje, tiene la desfachatez de suprimir "según Donnelly" al principio de la cita y añadir al final "eso se puede probar», cuando presenta su teoría en la editorial Brand \& Phillips. ${ }^{18}$ Lo que puede llamarse la teoría atlántica reaparecerá desarrollada y ampliada en Los cinco libros de Nancy y en La cisterna de Chichén-Itzá. Mientras la relación que guarda «Los atlantes y el binomio Cortés-Quetzalcoatl" con los libros a los que alude es un ejemplo cercano a la metatextualidad, ${ }^{19}$ a la relación crítica, en los casos de Las criaturas saturnianas y Tánit se trata de relaciones intertextuales en sentido estricto, que llevan implícita una transcodificación externa ${ }^{20}$ por la cual un texto ensayístico se

\footnotetext{
14 Ensayos del otro mundo, cit., pp. 137-152.

15 Ibid., pp. 139 y 141.

16 De Worlds in collision existe una edición de Pocket Books Inc. de 1980 y de Atlantis: Antediluvian world, una de Harper \& Row de 1981.

17 «Los atlantes y el binomio Cortés-Quetzalcoatl», cit., p. 142.

18 Tánit, ed. cit., p. 99. Los mencionados no son los únicos fragmentos que aparecen tanto en «Los atlantes y el binomio Cortés-Quetzalcoatl» como en Tánit.

19 Genette define la metatextualidad, entendida como un tipo de transtextualidad, del siguiente modo: "es la relación - generalmente denominada "comentario" - que une un texto a otro que habla de él sin citarlo (convocarlo), e incluso, en el límite, sin nombrarlo» (Gérard GENETTE, op. cit., p. 13).

20 Se usa aquí el término intertextualidad aceptando las restricciones propuestas por Segre, que lo distingue de la interdiscursividad y lo limita a "las relaciones entre texto y texto (escrito y particularmente literario)" (Cesare SEGRE, "Intertestuale-interdiscorsivo. Appunti per
} 
inserta en uno novelístico. Este paso afecta notablemente al estatuto ontológico del texto, pues, si bien en el ensayo se mantiene como no ficticio, en las novelas este carácter es más inestable. En Las criaturas saturnianas la intertextualidad se produce en relación con las palabras de dos personajes, Cagliostro y Spinac, vinculados precisamente por sus creencias y ejemplos, los dos, de "criaturas saturnianas". En el caso de Tánit, un historiador ficticio, Enrique Lavedan, recoge una sugerencia explícitamente formulada por Sender y la considera como no ficción. En ambas novelas la presencia del texto ensayístico cumple principalmente una función de caracterización de los protagonistas y de diferenciación respecto al resto de personajes, aunque en el caso de Lavedan esta presencia revele un nuevo dato sobre su personalidad: además de un asesino frustrado es un plagiario sin escrúpulos. $Y$ en ambos casos el contexto narrativo altera el grado de ficcionalidad de estos fragmentos y permite considerarlos como puramente ficticios sin que ello altere substancialmente el conjunto de las novelas ni su significado global.

Atendiendo a la red intertextual que forman Las criaturas saturnianas, Tánit y «Los atlantes y el binomio Cortés-Quetzalcoatl» (que a su vez se basa en otros textos que Sender sí cita), cabe deducir que, condenado por Dios, Typhon fue obligado a descender a la Tierra y provocó una serie de catástrofes naturales, entre ellas el diluvio universal y el hundimiento de la Atlántida; luego saltó de nuevo al espacio y se situó entre Mercurio y la Tierra, desde donde nos rige. Pero precisamente el hundimiento de la cuna de la civilización provocó divergencias en la explicación de un mismo fenómeno. Según la versión helénica, se trata de la diosa Venus (y los cuernos del planeta Venus son las dos colas abiertas de su cabellera), según la Biblia este cometa era Lucifer desterrado y según la azteca se trata del Tonatiuh, en los tres casos una divinidad expulsada del cielo.

Aunque en Las criaturas saturnianas ya queda perfectamente establecida por Cagliostro y Spinac la identificación entre Venus y Lucifer, lo que se descubre en El extraño señor Photynos es que, como ya anuncia su nombre, Photynos es la misma persona y, según él, «[1]os toltecas se equivocaban en esta materia del Sol que baja a los poblados. Es pura superstición. [...] Pero el Sol tiene hijos. Cada ser vivo en este planeta es hijo del Sol y los más conscientes de ellos nos convertimos tarde o temprano en una

una fenomenologia delle fonti», en Girolamo y PACCANFlla, eds., La paravola ritrovata, Palermo, Sallerio, 1982). Por su parte, Genette, que lo considera como uno de los cinco tipos de transtextualidad, lo define como "una relación de copresencia de un texto en otro" (Gérard GENETTE, op. cit., p. 10). El término transcodificación, tomado de Lotman, alude a la transformación de sentido producida por el cambio de código. Siguiendo a Lotman, se denominari transcodificaciones externas las que se refieren a las relaciones extra o intertextuales (Yuri M. LOTMAN, Estructura del texto artístico, traducción de Victoriano IMBERT, Madrid, Istmo [«Fundamentos», 58], 1978, pp. 99-101). 
especie de delegados" (p. 27). ${ }^{21}$ Es decir, el Tonatiuh es también la evolución, en forma de mito, de ese cometa y Photynos es un delegado o representante suyo en la Tierra. En la versión de Delos-Aymá, pero no en la de Cabrerizas Altas, el narrador informa a su acompañante, Nadia, de que en realidad los indígenas no creían "al pie de la letra en ese mito, pero les gustaba entonces igual que hoy mezclar la fantasía a la realidad y gozar de las dos. Sabia determinación, ésa» (p. 22). Inicialmente el narrador considera el mito totalmente ficticio, pero el desarrollo del relato será la demostración de su error.

Si bien el mito del Tonatiuh es el punto de partida o el motivo generador del relato, éste avanza, fundamentalmente, mediante la exégesis de una obra literaria, un soneto que el narrador compuso inspirándose en la visión de un hombre fumando marihuana, que «[r]ecordaba a esos indios yanquis, ${ }^{22}$ altos, sin bautizo ni nombre español, que pasean sus largas zancas desnudas por Sonora» (p. 10). En la edición de Delos-Aymá, dice así el poema:

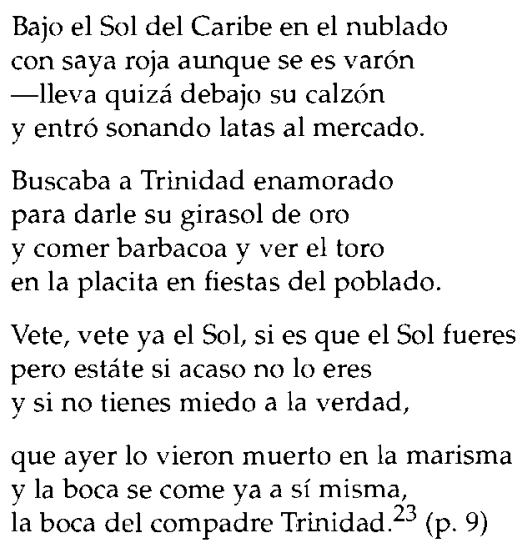

En el comentario que Photynos hace del poema hay diversos juicios que permiten deducir una determinada idea de la poesía y, por extensión, de la creación literaria. En el primero de ellos le dice al narrador: «No es muy bueno su poema, pero tiene invención, lo que rara vez se encuentra ahora en la poesía» (p. 26), en lo que va implícita una valoración positiva

21 Todas las citas de El extraño señor Photynos, si no se indica lo contrario, proceden de la primera edición de la versión definitiva, la de Delos-Aymá.

22 He aquí la errata mencionada al principio. Evidentemente, la lectura correcta es la que dan Cabrerizas Altas y Los Sesenta: «indios yaquis».

23 En la edición de Cabrerizas Altas, aparece «tulipán» por "girasol» (v. 6), "y quédate» por "pero estáte» (v. 10) y «Sol» está siempre en minúscula. La edición de Los Sesenta es la única en la que no aparece la palabra «muerto» (v. 12) y por tanto el verso queda cojo; es posible que sea un error tipográfico. 
de la imaginación poética. Posteriormente, comentando el verso «y entró sonando latas al mercado», opina que en él está su orientación en cuanto al tratamiento literario de las superficies brillantes. Porque «no basta con decir el Sol, la Luna, Sirio, Anthares. No basta. Hay que buscar un ángulo peculiarmente sensual» (p. 31). Pero la imaginación no debe suponer una merma de realismo y en la mención del girasol ve una acertada alusión, pues es «la flor que mejor copia la apariencia solar» (p. 34). También alaba la duda respecto a la identidad del Sol, puesto que, según dice, «[e]sa duda hace más verosímil la probabilidad. La duda es un poco boba y arbitraria y musical, como suele ser en la poesía de los pueblos antiguos" (p. 35). En cambio, censura el verso «y si no tienes miedo a la verdad» por considerar «[i]rresponsable y ligera literatura» (p. 38) suponer que el Sol pueda tenerle miedo a la verdad, que es la luz misma. Photynos defiende, al parecer, una poesía ingenua y cercana a la tradición, a la mitología y al subconsciente colectivo, en la que la imaginación desempeña un papel destacado, pero sujeta a una lógica interna, por muy fantasiosa que ésta sea; una poesía, y una literatura, que crean su propia lógica y se someten a ella. ${ }^{24}$ ¿Y qué otra cosa hace Sender, en El extraño señor Photynos, sino crear un relato con su propia lógica, cuya base imaginativa es un mito popular, y adoptando un ángulo sensual desde el que va despejando la duda y revelando el misterio? Refiriéndose a las narraciones que componen Mexicayotl, Manuel Andújar sintetizó perfectamente el carácter de este tipo de relatos de Sender «que aúnan profundo realismo, coherente fantasía y hábil apropiación de los valores simbólicos». ${ }^{25}$ El extraño señor Photynos es una narración acerca del proceso creativo, hasta cierto punto inconsciente, de este misterioso narrador sobre cuya identidad sólo se explicita que no se llama Ramírez; pero es también la exposición de algunas ideas senderianas referentes a su propio y personal modo de entender la literatura.

$\mathrm{Si}$, en un agudo artículo, ${ }^{26}$ Jean-Pierre Ressot acudía a esta narración para clarificar la naturaleza de Las criaturas saturnianas y sus característi-

${ }^{24}$ El término poesía ingenua procede de Schiller, que la opone a la sentimental y la describe como una poesía natural, objetiva, plástica (por oposición a la musical) e instintiva. Según Schiller, «el poeta ingenuo se limita a la simple naturaleza y al sentimiento y se reduce sólo a la imitación de la realidad" (Sobre poesía ingenua y sentimental, Buenos Aires, Novo, 1963, p. 89). En otro lugar escribió Sender: «Los poetas verbosos y sin profundidad son oscuros en la palabra. Los poetas genuinos, según mi modesta opinión, son claros en las palabras y en los conceptos, exactos en las alusiones y en las sugerencias. Y difusos en cuanto a la dimensión trascendente final» («Los Lawrence de Tao», en Ensayos del otro mundo, cit., pp. 119-120). Y en otro ensayo del mismo libro aclara la función de la imaginación: «La fantasía libre es la locura, pero es una locura que dominamos y que el poeta hace tributaria de la belleza y de la verdad. El poeta la domina con la imaginación, mientras que el loco es dominado por ella» ("La risa, la sonrisa y otros problemas", ibid., p. 244).

25 Manuel ANDÚJAR, art. cit., p. 189.

26 Jean-Pierre RESSOT, «Más allá del bien y del mal: Las criaturas saturnianas de Ramón J. Sender", recogido en Ramón J. Sender. In memoriam. Antología crítica, cit., pp. 465-472. De este excelente artículo, en el que se explotan las relaciones transtextuales y se sugiere el carácter 
cas específicas, sirviéndose de las relaciones transtextuales, para comprender las consecuencias del poema que sustenta la trama de El extraño señor Photynos debe recorrerse el mismo camino en sentido inverso. El señor Photynos no aparece de un modo casual, sino que su presencia en México, naturalmente un día nublado, responde a la invocación que, probablemente sin ser consciente de ello, hace el narrador. Como explica Cagliostro en Las criaturas saturnianas, «el misterio del número se nos hace presente en el uso del ritmo y por tanto desaparece. Por la simpatía del número y el uso del ritmo numérico [...] nos acercamos a un estado de embriaguez por el cual comprendemos que la divinidad podría tal vez descender hasta nosotros. Esto lo han hecho desde la edad de piedra todos los pueblos».27 Recuérdese que los indios, en el Epitalamio del prieto Trinidad, invocan al Sol cantando los versos: «El sol bajará como un hombre, / como un hombre entre los hombres». ${ }^{28}$ Con su soneto de endecasílabos con rima consonante y ritmo predominantemente yámbico, el narrador consigue atraer al Tonatiuh en la persona de Photynos y luego será él mismo quien deba descubrir la auténtica identidad del griego, tarea especialmente compleja teniendo en cuenta que se trata de un narrador escéptico ante este mito.

Las relaciones intertextuales más evidentes, sin embargo, son las que este relato mantiene con el Epitalamio del prieto Trinidad y el vínculo con esta obra se extiende hasta más allá de lo puramente textual. Según Sender, la génesis y motivación de la novela estuvo en su deseo de "castigar a una de esas bestias apocalípticas», a uno de esos «bárbaros vestidos de un modo medio militar, medio civil; primitivos, mascando un puro, mirando por encima del hombro y con ganas de agredir sin saber a quién» que con frecuencia se encontraba por la ciudad americana en que vivía. ${ }^{29}$ También al narrador del relato que nos ocupa el impulso creador le viene de la observación de un personaje "primitivo» que viste, además de la saya roja, una chaqueta militar, aunque el carácter de ambos personajes, así como la actitud del creador ante ellos, son muy diferentes. Inducido por su desconocimiento, el narrador, al componer su soneto, relaciona al indio de la saya roja que fuma marihuana con el Tonatiuh, cuando, en realidad, con quien cabe relacionarlo es con Juanito, el Emotivo, que viste "su saya roja cubierta de lentejuelas y chapitas de cobre» durante la toma de poder del

de ante-texto de la versión contenida en Cabrerizas Altas, surgió la idea de centrar el presente estudio en las relaciones intertextuales y el proceso creativo de El extraño señor Photynos. Escribe Ressot sobre Las criaturas saturnianas: «Además de una novela, se trata, de hecho, de varios cuentos unidos para formar un todo novelesco" y, más adelante, «la calidad de la obra reside, pues, en la densidad particular de esos momentos novelescos yuxtapuestos».

27 Las criaturas saturnianas, Barcelona, Destino («Destinolibro», 253), 1968, p. 264.

28 Cito por la edición de Salvat-Alianza de Epitalamio del prieto Trinidad, Madrid, 1972, p. 182.

${ }^{29}$ Explicación citada por Manuel ANDĹJAR en otro artículo justamente célebre, «Narrativa del exilio español y literatura latinoamericana: recuerdos y textos», Cuadernos Hispanoamericanos, 295 (enero de 1975), pp. 63-86. 
Seisdedos en Epitalamio del prieto Trinidad ${ }^{30}$ Aparte de que aparece en el poema, Photynos hace algunos interesantes comentarios sobre Trinidad. Por ejemplo, dice: «Ah, sí, Trinidad. Ese nombre corresponde a un tipo que puso alguien en una novela, ¿no es eso? [...] ¿Qué cosas pasan en esa novela! No digo que esté mal. No es buena ni mala. Es otra cosa, y habría que inventar un calificativo adecuado, lo que no sería fácil" (p. 31). El extraño señor Photynos es, entre otras cosas, una justificación del tipo de personajes que aparecen en la novela, y dice Photynos al respecto: «en ese libro, todos los individuos que intervienen son productos, no sociales ni religiosos ni morales, sino solares». ${ }^{31}$ A diferencia de ellos, el narrador del relato, según Photynos, es un personaje regido por Saturno en lugar de por el Sol y define lo saturniano como «la antivirtud en cualquiera de sus formas cuando esa antivirtud es más afirmativ[a] que la vida misma de donde la virtud procede. [...] los saturnianos son los únicos seres verdaderamente virtuosos».32 Lo interesante es descubrir que la presentación de los personajes como productos solares es, para Photynos, la más fiel a la realidad, la que permite llegar a la verdad, y, así, dice sobre el autor del Epitalamio: «A mí me gustan sus novelas porque el autor ve a los hombres como son en realidad $\gg .33$ Según Photynos, todos los hombres son un poco de vida solar en constante combustión, son expresión de la divinidad, y, en el caso de Trinidad, su permanencia en la isla después de muerto es la pervivencia de la combustión que genera su amor, no sólo por la Niña Lucha, ${ }^{34}$ sino por la vida en general: "su amor, que era el punto más alto de su oxida-

30 Epitalamio del prieto Trinidad, ed. cit., p. 182.

31 Cabrerizas Altas, ed. cit., p. 110. Cito por esta edición porque en las siguientes se abrevia este pasaje. Idea muy similar a la expresada en este fragmento aparece en «Los Lawrence de Tao" (cit., pp. 204 y 210): «Todo lo que dijo Lawrence a lo largo de su extensa obra fue que no debemos ser entidades morales, ni intelectuales, ni esteticistas, ni civiles, ni religiosas, ni políticas. Que debemos ser "vitales". Con eso quería decir que antes que nada son los instintos y que nadie debe avergorzarse ni mucho menos defenderse de ellos [...], los personajes de las novelas de Lawrence parecen más que los de ningún otro escritor lo que en realidad somos todos: sueños de la materia, de la tierra y expresión de la divinidad de esa tierra y esa materia».

32 Cabrerizas Altas, ed. cit., pp. 109-110. La segunda parte de esta cita, como ya observara JeanPierre Ressot en su artículo, desapareció en la edición de Delos-Aymá.

33 Ibid., p. 108. Fragmento eliminado en las versiones posteriores.

34 Ya en el nombre de la protagonista femenina de Epitalamio del prieto Trinidad se anuncia su relación con la protagonista de los textos de Valle-Inclán «La Niña Chole» (de Femeninas) y Sonata de estío, que es descrita como «una figura hierática y serpentina, cuya contemplación evocaba el recuerdo de aquellas princesas hijas del sol, que en los poemas indios resplandecen con el doble encanto sacerdotal y voluptuoso". Y recuérdese que la sirvienta que aparece en el Epitalamio se llama precisamente La Chole. Cito por la edición de Antonio DE ZUBIAURRE de Femeninas. Epitalamio, Madrid, Espasa-Calpe, 1978, p. 114. El fragmento citado aparece reproducido en las primeras páginas de la Sonata de estio. Francisco CARRASQuER estudió las relaciones textuales entre La aventura equinoccial de Lope de Aguirre y Tirano Banderas en "Imán» y la novela histórica de Sender, cit., pp. 200-203 (reproducido en La integral de ambos mundos: Sender, Zaragoza, Prensas Universitarias de Zaragoza, 1994, pp. 149-152). 
ción y de su vida solar, quedaba después de su muerte irradiando oscuridad mágica - y magnética- por la isla», dice (p. 33). El penúltimo verso del soneto, "y la boca se come ya a sí misma", que para el narrador es un final inesperado y una sorpresa fácil, lo interpreta Photynos como "viva imagen de la podredumbre de la muerte bajo el sol» ${ }^{35}$ y como una manera de referirse al egocentrismo de Trinidad (p. 52). Photynos se erige en comentador, no sólo del soneto del narrador, sino también de la novela senderiana, dando una serie de claves para interpretar correctamente ambos textos.

En cuanto al mito del Tonatiuh, Photynos acaba por sentenciar que él, "[e]l tonatio y Buda, y el Cristo y Mahoma, y Trinidad en su isla, en la marisma o en el ataúd, son una misma oxidación como usted y como yo" (p. 52), con lo cual expone la idea, compartida por Sender en otro texto, de que todos los hombres son «sueño de la materia, de la tierra y expresión de la divinidad de esa tierra y esa materia», ${ }^{36}$ pero Photynos, al final del relato, da aún una nueva clave: la «víscera que rige, preside y ordena nuestras oxidaciones» (p. 53) la tienen, la mayor parte de los seres vivos, en el lado izquierdo del cuerpo. Por tanto, lo que une a todos los seres, sean saturnianos o solares, es el corazón. El narrador, un ser saturniano y por tanto perteneciente a una elite de iniciados conocedores de la verdad que asumen lo que hay en ellos de brutal, instintivo y primitivo, ${ }^{37}$ está en condiciones de invocar al Tonatiuh y acceder a los conocimientos que éste le revela.

Si no hace mucho tiempo Gilberto Triviños lamentaba la escasa atención que ha recibido la serie narrativa formada por las novelas senderianas centradas en el Nuevo Mundo (en la que se inscribe El extraño señor Photynos), ${ }^{38}$ el estudio de las relaciones transtextuales que aparecen en esta serie tal vez sea un punto de partida interesante desde donde acometerla. Los textos de Sender, especialmente los que componen esta serie, no pueden interpretarse aisladamente sino que deben verse en relación con otros a los que remiten, formando con ellos un laberíntico macrotexto ${ }^{39}$ que aún está por vertebrar.

\footnotetext{
35 Cabrerizas Altas, ed. cit., pp. 123-124. Pasaje inexistente en las otras versiones.

36 «Los Lawrence de Tao», cit., p. 210.

37 Recojo esta caracterización de las criaturas saturnianas del ya citado artículo de JeanPierre RESSOT.

38 Gilberto Triviños, Ramón J. Sender. Mito y contramito de Lope de Aguirre, Zaragoza, Institución Fernando el Católico, 1991. El texto se inicia con una metáfora especialmente acertada: "La obra americana de Sender constituye un variado y sistemático tapiz que abarca muchos siglos y muchas regiones del Nuevo Mundo» (p. 5). Francisco CARRASQUER ha contribuido a llenar esta laguna en los estudios senderianos con la obra La integral de ambos mundos: Sender, cit.

39 Cesare Segre se refiere con este término a la unidad formada por textos, total o parcialmente autónomos, que mantienen relaciones de conjunto: «cada texto mantiene en general autonomía y cohesión internas, pero queda después comprendido en una autonomía y en
} 
El extraño señor Photynos es un texto denso en el que convergen diferentes líneas de una compleja red intertextual en la que, además del Epitalamio del prieto Trinidad y Las criaturas saturnianas, son reconocibles Tánit, «Los atlantes y el binomio Cortés-Quetzalcoatl» (y los textos que allí se mencionan) y los pasajes del Evangelio y el Apocalipsis de san Juan que Photynos y el narrador citan (pp. 39 y 50-51). ${ }^{40}$ Además de una obra sobre el proceso creativo, la literatura y el valor y defectos de un poema, es la defensa de una determinada concepción de la literatura, que es la que se encuentra en las novelas de Sender sobre el Nuevo Mundo: combinación de imaginación y mito, adopción de un ángulo sensual, formulación de una lógica interna del relato original, creación de personajes "solares", atendiendo para ello a lo más intrínsecamente humano y, lo que aparentemente resulta más paradójico, el empleo de estos recursos para llegar a un auténtico realismo, más veraz y profundo, que ponga al descubierto «la víscera que rige, preside y ordena nuestras oxidaciones».

una cohesión más amplia» (C. SEGRE, op. cit., pp. 47-49). Entre los antecedentes de esta línea de estudios centrada en las relaciones textuales sería injusto no citar a Carole ADAM («The reuse of identical plot material in some novels of Ramón J. Sender», Hispania, $43 / 3$ [septiembre de 1960], pp. 347-352), Jean-Pierre RESSOT, por el artículo tantas veces citado, y Francisco CARRASQUER ( Imán» y la novela histórica de Ramón I. Sender, cit., pp. 200-203 y 243-246, especialmente; «La parábola de La Esfera y la vocación intelectual de Sender», recogido en Ramón J. Sender. In memoriam, cit., pp. 399-424; “¿El derecho de autor frente al deber de enmienda?», compilado en La verdad de Ramón J. Sender, Leiden, Cinca, 1982, pp. 49-57, y diversos capítulos de La integral de ambos mundos, cit.). Sin embargo, aún hay un vasto campo de estudio virgen y, además, la posibilidad de enfocar el tema con una terminología y un soporte teórico más precisos y rigurosos que hasta ahora.

40 Se trata de San Juan I, 1, y Apocalipsis XIII, 1-4, respectivamente. 


\title{
El lugar de El bandido adolescente en la mitología de Billy the Kid
}

\author{
Juan Espadas \\ Ursinus College, Collegeville (Pennsylvania)
}

El historiador estadounidense Robert M. Utley, en su estudio sobre la guerra del condado de Lincoln (Nuevo México) que culminara con la batalla de julio de 1878, dice lo siguiente:

Amid the savagery of gangsters like Selman's Wrestlers, Billy the Kid shines brightly as the Lincoln County war's lone "social bandit». The test is not whether the social bandit, like Robin Hood or Jesse James, robbed from the rich and gave to the poor, but rather whether people thought he did and thus accorded him the status of folk hero. In his own time, however undeservedly, Billy the Kid won this accolade, especially from the unsung Hispanic plowmen and herdsmen of Lincoln County. No other frontier fight can boast a personality that has had so powerful an impact on the world's imagination. ${ }^{1}(1991,178)$

Este impacto del que habla Utley, y que hasta el momento no ha cesado, contaba ya en 1965, año de la publicación de El bandido adolescente, con al menos 800 títulos (Tatum, 5). Es de suponer que esta cifra se haya incrementado en los últimos treinta años al menos en un cincuenta por ciento.

1 Todas las citas son de la tercera edición. 
Sea cual sea este número, el hecho es que a pesar de que el papel de Billy the Kid en el corto contexto histórico que le tocó vivir es trivial e insignificante (Steckmesser, Tatum, Cline, Tuska, Utley, 1989, 1991), su vida, ya hecha leyenda por las novelas de a diez centavos (dime novels) antes de su temprana muerte, sigue atrayendo la atención no sólo de la cultura popular sino de los medios académicos.

En el rápido recuento de Stephen Tatum (6-8) podemos comprobar cómo Billy es el sujeto de narrativas personales (Pat Garrett, Charles Siringo, Lew Wallace, Miguel Otero o Ma'am Jones of the Pecos), artículos en revistas de masas (Life, Saturday Evening Post) y en numerosas revistas académicas especializadas, antologías, cómics y las ya mencionadas monografías escritas por historiadores, las menos, y por seudo-historiadores, las más. Tatum señala el interés que nuestro personaje ha despertado entre novelistas (Zane Grey quizás sea el más conocido del público español), poetas (Michael Ondaatje, el mejor sin duda), dramaturgos (Gore Vidal) y numerosos profesionales de la música popular (Woodie Guthrie, Bob Dylan, Billy Joel) y de la clásica (Aaron Copland). Finalmente, el cine y la televisión han ofrecido toda suerte de interpretaciones de la vida y milagros de Henry McCarthy / Henry Antrim / William Bonney / Billy the Kid. ${ }^{2}$

No nos debería parecer extraño que el mítico Billy y el real se hayan confundido a lo largo de los años, porque desde su mismo nacimiento comienzan los misterios. ${ }^{3}$ Casi todos los historiadores coinciden sin embargo en señalar que nació en Nueva York, quizás el 23 de noviembre de 1859, el primero de dos hijos de Michael y Catherine Mc Carthy, Henry (Billy) y Joseph. Aparentemente Catherine quedó viuda durante la guerra civil y se trasladó a Indianápolis, donde conoció a William Antrim. En el verano de 1870 Catherine y William tomaron el camino del oeste, asentándose en Wichita, Kansas, donde Catherine trabajó en la lavandería de un hotel mientras que Antrim hacía diferentes trabajos (granja, carpintería, camarero). Catherine contrajo tuberculosis y la familia se mudó una vez más, no sabemos si a Colorado, Nuevo México o quizá Nueva Orleans (Tatum, 18), aunque el clima del delta del Mississippi no podía ser bueno.

Lo que sí sabemos es que Henry y su hermano fueron testigos de la boda de su madre con Antrim el 1 de marzo de 1873 en Santa Fe, Nuevo México. La familia se mudó a Silver City, en el mismo estado, donde

\footnotetext{
${ }^{2}$ El más completo estudio bibliográfico sobre Billy the Kid, que incluye una detallada filmografía, es el de Jon Tuska. Aunque ya algo anticuados, son importantes los dos libros de Ramon F. ADAMS por su sistemática exposición de los errores cometidos por biógrafos e historiadores. Finalmente, son de gran utilidad las numerosas notas y fuentes bibliográficas de la biografía del Kid de Robert UtLeY (1989).

${ }^{3}$ Este resumen biográfico se basa esencialmente en TATUM (18-34) y STECKMESSER (cap. VI). Además de las biografías que trataremos en el texto, son de interés también las de CLiNE, TusКА y UT.FY, todas ellas en la bibliografía de este trabajo.
} 
William trabajó como minero y Catherine regentó una pensión. Los chicos asistieron a la escuela, donde aparentemente Henry era uno más en las travesuras propias de su edad, pero distinguiéndose en los bailes y las pequeñas obras teatrales representadas por los escolares. La enfermedad de Catherine siguió, sin embargo, su fatídico curso y acabó con su vida el 16 de septiembre de 1874 . La leyenda, una vez más, adquiere prominencia en este momento de la vida del joven Henry. Lo cierto es que se le acusó injustamente de robar ropa de una lavandería china y fue arrestado. Dos días más tarde Henry escapó de la cárcel. Quizás consiguiera algún dinero del padre y tomó la diligencia para Globe, Arizona. En este territorio transcurrieron los dos años siguientes de su vida, en los que realizó diferentes trabajos, incluido el de cargador de troncos para Fort Grant. De 1877 conocemos la primera muerte atribuida a Henry (por entonces Austin Kid Antrim), la de un tal Cahill, tras un intercambio de insultos. Después de su arresto y una nueva escapada, pasó un tiempo en Nuevo México, donde comenzó a usar su nuevo alias, William H. Bonney. Por esa época quizás practicara la cuatrería con el grupo de Jesse Evans. Después de recuperarse de un encuentro con unos apaches del que no salió bien librado, Bonney conoció a los pequeños rancheros Coe y Brewer, quienes lo introdujeron en el círculo del ranchero inglés John Tunstall, entrando así de lleno en la famosa guerra del condado de Lincoln. ${ }^{4}$

La actuación de Billy en esta guerra, por lo menos hasta la muerte de Tunstall, no está muy clara. Lo mismo sucede con su relación con el ranchero inglés, como se verá más adelante. El hecho es que en la tarde del 18 de febrero de 1878, Billy fue testigo del asesinato de John Tunstall por una partida formada por lacayos de su enemigo James Dolan, entre los que se encontraba Jesse Evans. Este asesinato puso automáticamente a Billy del lado del abogado Alexander Mc Sween, quien llevaba ya tiempo, junto con Tunstall, intentando romper por todos los medios, legales o no, el monopolio de Dolan y el "círculo de Santa Fe». Billy pasó a formar parte del grupo de los «Regulators» organizado por el juez Wilson para aprehender a los asesinos de Tunstall. Como miembro de este grupo participó, aunque es dudoso que él fuera el autor, en el asesinato del sheriff Brady por el que tres años más tarde sería condenado a muerte.

La guerra del condado de Lincoln llegó a su final sangriento en julio de 1878, con el sitio de la casa de Mc Sween, en el que murió el abogado. Billy escapó con otros y se dedicó al robo de ganado, principalmente, estableciendo la base de operaciones en los alrededores de Fort Summer. Por aquella época parece que tuvo una cierta amistad con Pat Garrett, entonces tabernero. El nuevo gobernador de México, Lew Wallace, con-

\footnotetext{
${ }^{4}$ Sobre la guerra del condado de Lincoln, una de las muchas habidas en diversos territorios del Far West entre diferentes grupos por el control de la economía de una u otra región, véase UTLEY (1991). Mucho se ha escrito sobre esta guerra y la bibliografía de Utley es completísima.
} 
cedió una amnistía general a los participantes en la guerra del condado de Lincoln. Billy, sin embargo, no pudo beneficiarse ya que las maquinaciones de los del "círculo de Santa Fe" pudieron más que la voluntad del gobernador, quien por otra parte parecía más interesado en acabar Ben Hur que en encontrar a los culpables de subsecuentes asesinatos. Al escapar de la ficticia prisión en la que de mutuo acuerdo con Wallace había sido encarcelado por su seguridad antes de testificar, Billy perdió todos los puntos que hasta entonces pudiera haber ganado y se puso abiertamente fuera de la ley.

Hasta la elección de Pat Garrett como sheriff de Lincoln en noviembre de 1880 , Billy y su banda pasaron el tiempo dedicándose a la cuatrería y divirtiéndose en Fort Summer y sus alrededores. En enero del 80 Billy se enfrentó en una típica pelea de bar con su segunda víctima, un tal Joe Grant, un episodio deformado en varias ocasiones en la leyenda. Parece que Billy ni fue más rápido ni engañó a Grant, simplemente se aprovechó de uno de los muy corrientes fallos de los revólveres de la época y, por supuesto, no le dio a Grant una segunda oportunidad. Después de la elección de Garrett, tiene lugar la muerte de Jim Carlyle, miembro de un grupo de ciudadanos de White Oaks en persecución de Billy y su banda. Carlyle, quien había sido capturado por los fugitivos, fue asesinado por éstos cuando intentaba escapar. La participación de Billy está por demostrar.

A finales de diciembre de 1880 Garrett puso cerco a Billy y su banda, que culminó con la captura de los bandidos el 23 de diciembre en Stinking Springs, cerca de Fort Summer. Billy fue encarcelado en Las Vegas y posteriormente en Santa Fe, recibiendo en ambos casos el apoyo de la población hispana. El juicio se celebró unos 200 kilómetros más al sur, en Mesilla, y allí el 13 de abril de 1881 era condenado a la horca por el asesinato del sheriff Brady, del que irónicamente era inocente. Trasladado a la cárcel de Lincoln y al ver que no recibía clemencia del gobernador, se escapó dramáticamente asesinando a su guardián con un revólver que le habían dejado en la letrina y después al carcelero Ollinger con la propia escopeta de éste.

Desde entonces, y hasta su muerte, Billy siguió merodeando por Fort Summer, no está claro exactamente por qué, cuando lo lógico, y muchos así pensaban, era que se hubiera refugiado en México, donde ya había pasado un tiempo en sus primeros años de vagabundeo. Fuera por las razones que fuera, y las románticas parecen convincentes, llegó a los oídos incrédulos de Pat Garrett que Billy andaba por Fort Summer en julio de 1881. Garrett se presentó en el pueblo la noche del 14 de julio y se fue a casa de Pete Maxwell. Billy salió a cortar un filete de una vaca que Maxwell había matado el día anterior. Al llegar, preguntó a Pete quiénes eran los extraños que había alrededor. Garrett, que había reconocido su voz, esperó a que entrara en la habitación de Maxwell, donde le descerrajó dos tiros, el segundo innecesario puesto que Billy estaba ya muerto. 
La muerte del bandido, que como ya se ha dicho era ya parte del folclore del lejano oeste en la costa este de los Estados Unidos, fue divulgada ampliamente y dio ocasión a la aparición de nuevas novelitas. La prensa, incluida la local, no fue ajena a la creación de la leyenda del «Billy satánico» (Steckmesser, cap. VII). Así, en el obituario del 21 de julio el Weekly Democrat de Santa Fe afirmaba que Billy había acabado con dieciséis hombres, aunque él se jactaba de haber matado a veintiuno, uno por cada año de su vida. Al día siguiente el periódico de Denver, Republican, para no ser menos, daba los nombres de las veintiuna víctimas. Los periódicos de Nueva York reafirmaron la famosa y mítica cifra, que desde entonces se convirtió en parte de la vida de Billy (Steckmesser, 72-73). ${ }^{5}$

El mismo año de la muerte de nuestro personaje apareció la novela de Don Jenardo, seudónimo de John Woodruff Lewis, The True Life of Billy the Kid. Además de presentarnos a Billy como un verdadero monstruo, incluso con las mujeres, cosa a todas luces contraria a la realidad (Steckmesser, 74), Lewis introduce el bulo de la señora Mc Sween tocando el piano mientras asediaban y quemaban su casa (Tuska, 140). En 1882 el mismísimo Pat Garrett, movido por "an impulse to correct the thousand false statements which have appeared in the public newspapers and in yellow-covered, cheap novels» (3), publica su «auténtica» biografía del Kid. Este librito, que ha sido el que más influencia ha tenido hasta nuestros días en la creación de la imagen de Billy y de los acontecimientos asociados con él, no fue ni escrito por Garrett, sino por el periodista Ash Upson, y está lleno de errores. Solamente Tuska menciona setenta y cinco en lo que él llama una lista parcial, de los que nos interesan para la relación de Garrett con Sender los siguientes: $1^{\circ}$ ) en Silver City Billy y Jesse Evans eran uña y carne; $2^{\circ}$ ) la primera víctima de Billy es un hombre que había insultado a su madre; $3^{\circ}$ ) amistad con un tal Melquíades Segura y asesinato de un jugador de monte; $4^{\circ}$ ) vida de crimen otra vez con Jesse Evans y ayuda a un convoy de pioneros contra los apaches; $5^{\circ}$ ) Billy defiende que Evans no participó en la muerte de Tunstall; $6^{\circ}$ ) Billy asesinó a Bernstein, de la agencia india, con un tiro de su Winchester (114-119).

Tanto Tuska como Steckmesser coinciden en que el libro de Garrett/Upson es seguramente el que crea la leyenda del héroe romántico que se continuó con los libros de Charlie Siringo A Texas Cowboy (1885) y A History of Billy the Kid (1920), en el que Billy mata a Bernstein porque no le gustaban los judíos (Tuska, 120).

La leyenda de Billy había perdido interés durante los años 20, sin duda porque el gangsterismo de la época dejaba chico lo ocurrido cincuenta años

\footnotetext{
5 En el repaso que se hará sobre la formación de la leyenda de Billy hasta la aparición de El bandido adolescente, nos detendremos, y esto brevemente, sólo en algunas de las obras más notorias por lo que contribuyen a la figura de Billy que se acerca más a la que nos presenta Sender. Nos basamos muy poco en algunas de las obras originales leídas, más bien seguimos a Steckmesser, Tuska y Tatum.
} 
atrás. Sin embargo en 1926 aparece The Saga of Billy the Kid, de Walter Noble Burns, que inmediatamente se convirtió en un best-seller (Tuska, 125). Toda la crítica contemporánea, y alguna de la época, coincide en señalar el hecho de que, aunque apareciera como biografía, el libro de Burns es prácticamente ficción. ${ }^{6}$ Burns repite muchas de las leyendas sobre Billy, siguiendo a Garrett. Su actitud hacia el bandido es claramente positiva:

But Billy the Kid was not the stuff of ordinary men. [...] For him there was no past. He lived in the present from minute to minute, yet he lived happily. [...] Surrounded by enemies who would have killed him with joy, breathing an atmosphere of bitter hatred, in danger of violent death every moment, he went his way through life without remorse, unracked by nerves or memories, gay, light-hearted, fearless, always smiling. (63-64)

Burns es también el primero en explotar lo mexicano, sobre todo en lo que para el estadounidense tiene de romántico. «The net effect was the creation of just the right atmosphere for a folk legend and added sympathy for the Kid as a friend of the simple and gentle natives» (Steckmesser, 87).

En 1936, el ex gobernador Miguel Otero publicaba su The Real Billy the $K i d$, basado en entrevistas con muchos de los informantes que había usado Burns. Otero, quien conversó largamente con Pat Garrett, considera el libro del sheriff como el más auténtico y, así, a veces lo copia palabra por palabra. Según Otero, Garrett siempre le habló bien de Billy: «[he] was one of the nicest little gentlemen I ever knew - kind and considerate, true and loyal to his friends, afraid of nothing on earth that walked on two legs or four» (93). Este tono admirativo es el predominante en el libro del gobernador; así, Billy era un gran bailarín, siempre respetuoso con las mujeres, con quienes tenía gran éxito, y desde luego gran amigo de los neomexicanos, quienes a lo largo de la biografía de Otero no cesan de alabar al bandido, como Higinio Salazar, compañero de Billy con las fuerzas de Mc Sween:

Billy the Kid was the bravest man I ever knew. [...] Every one who knew him loved him. He was kind and gave food to poor people, and he was always a gentleman, no matter where he was. [...] He was as quick as a kitten and when he aimed his pistol and fired, something dropped; he never missed his mark. (129)

\footnotetext{
6 TUSKA: "[Burn's] book is rightly classed as fiction by librarians, and not as biography or history" (125). STECKMESSER se expresa así: “[The Saga] is neither an objective narrative of the Lincoln County War nor a reliable account of the Kid's career. It is rather a magnificent classic of American folklore and mythology» (85). Es curioso que, de acuerdo con William ECENBARGER, la novela Tombstone (1927) de Burns fuera responsable de la atención del público hacia la famosa pelea del O. K. Corral del 26 de octubre de 1881 entre los hermanos Earp y Doc Holiday contra el clan de los Clanton y sus compinches (28). Sobre esta obra de BurNS, véase también AdAMs (1964, 99-101).
} 
Las palabras de Salazar resumen no sólo el tono de la biografía de Otero sino la leyenda misma del «Saintly Billy» (Billy, el Santo), en palabras de Steckmesser (cap. VIII). Como sucede a menudo en este tipo de leyenda, siempre existe la posibilidad de que el héroe no haya muerto. Pues bien, según Steckmesser, todavía en 1940 quedaban personas viviendo en zonas remotas de Nuevo México que creían que Billy seguía vivo (93).

La leyenda de Billy the Kid quedaba, pues, redondeada en los años treinta y permanecería inalterada hasta los sesenta, cuando comienzan a aparecer investigaciones históricas más serias, que llegan hasta nuestros días. Seis serían los principales componentes de esa leyenda según Steckmesser (100-101): $1^{\circ}$ ) Billy es el defensor de los débiles y de los perseguidos contra los poderosos; su pequeña estatura, su apodo (Kid, el chivato) y su juventud le añaden credibilidad; $2^{\circ}$ ) se convierte en bandido para vengar el asesinato de un amigo (Tunstall); $3^{\circ}$ ) el gobernador Wallace lo engaña con la promesa de amnistía y su "amigo" Garrett, igualmente; $4^{\circ}$ ) Billy es simpático, popular con las mujeres y la población hispana, generoso y leal con sus amigos; $5^{\circ}$ ) es también hábil con las pistolas, no le tiene miedo a nadie, es osado y tiene una increíble sangre fría, y $6^{\circ}$ ) el ambiente hispánico añade un aura de romance a toda la historia en el mundo anglosajón.

Todos los componentes de la leyenda que menciona Steckmesser están presentes en la novela El bandido adolescente de Ramón Sender, hasta el momento la única obra de ficción en castellano sobre Billy the Kid. Sender sigue en su obra esencialmente a Garrett: "[u]]n detalle interesante que cita el mostachudo y honesto sheriff Garrett [...]» (8), "[d]ice el sheriff Garrett, a quien otras veces me he referido $[\ldots]$ » $(81) .{ }^{7}$ En ocasiones llega a traducir casi literalmente del sheriff:

Hace tiempo que no nos vemos, Jesse. Anda, ven a casa de Cedillo y almorzaremos juntos. Hace tiempo que quería echar un párrafo contigo, pero ahora tengo demasiada hambre para hablar. ¿No vienes? Cedillo nos convida. (89)

It's a long time since we met. Come over to Miguel Sedillo's and take breakfast with me; I've been waiting to have a talk with you for a long time, but I'm powerful hungry. (Garrett, 59)

En este mismo episodio Garrett, al describir el encuentro inesperado entre Billy y Jesse Evans, cita los siguientes versos de un antiguo poema:

Their very courses seemed to know that each was other's mortal foe. (58)

pero Sender:

7 Todas las citas corresponden a la tercera edición. OTERO (123). 
Los caballos parecían darse cuenta

de que sus amos habían sido amigos..

dice Garrett, el policía bandido o el policía trovador, según los casos. Y decía verdad, aunque la situación era más compleja, y Billy y Jesse si no eran enemigos mortales eran amigos mortales, que suele ser peor. (88)

Pero, claro, Garrett no dice lo que le hace decir Sender, de quien por otra parte no hay que pensar, ni por un momento, que se equivocara al traducir al sheriff. Habría que concluir que don Ramón nos estaba guiñando un ojo con este giro inesperado que le dio al tópico tradicional. De hecho, a lo largo de la novela, los rasgos de humor contrastan constantemente con la seriedad de Garrett. Baste un ejemplo: durante la batalla que culminó la guerra del condado de Lincoln, dice Sender que según un periodista del New York Sun la señora Mc Sween animaba a los concurrentes tocando el piano, aunque él, siguiendo a Garrett, lo niega. ${ }^{8}$ Pero continúa:

Lo que según el sheriff Garrett sucedió fue que, en medio de la batalla, el segundo día la señora de Mc Sween pidió que la dejaran volver a buscar algunas cosas que había olvidado, entre ellas una cajita de píldoras, una labor de gancho con agujas clavadas en el ovillo de lana y el gato que se llamaba Ceferino.

Cuando salió con todo aquello y se alejó del lugar de la batalla se oyó la voz de Mc Sween:

-Darling, espérame.

Pero los disparos cubrieron la voz del pobre Mc Sween que gritaba desde el zaguán, todavía:

- ¡Darling!

Había sido siempre hombre de hogar. Aquello de que su esposa salvara el gato, pero lo dejara a él, no lo entendía. (110)

Garrett, por el contrario, se limita a decir: «It is also true that she requested permission to return for some purpose, the firing ceased - she went bravely in- returned almost immediately, and the firing was resumed" (64). Una vez más no es lo que dice Garrett, lo cual es naturalmente de esperar puesto que los motivos que impulsaron al sheriff son diferentes de los de Sender, no sólo porque aquél viviera los hechos y nuestro novelista no, sino también por razones de género: biografía frente a ficción.

Discrepancias como las mencionadas hasta ahora son, por tanto, bastante comunes entre Sender y Garrett. Pero hay tres ocasiones en que el novelista difiere no sólo del sheriff sino de otros biógrafos e historiadores. Son éstas, aparte del importante papel de lo hispano en Sender, las que hacen que El bandido adolescente ocupe su propio, aunque hasta ahora no reconocido, lugar en la "mitología» de Billy the Kid. ${ }^{9}$

\footnotetext{
${ }^{8}$ La viuda de Mc Sween negó también esta imputación del periodista en conversación con Miguel OTERO (The Real Billy the Kid, 123). Sobre su actuación durante la batalla, puede verse UTLFY $(1991,100-103)$.

${ }^{9}$ CARRASQLER (155) menciona una traducción al inglés que me es desconocida.
} 
El primero de estos casos es el personaje de Melba, la sobrina del contable de la Agencia India, Bernstein, cuya muerte fue achacada a Billy, aunque realmente parece haber sido asesinado por ladrones mexicanos (o neomexicanos) (Tuska, 56). La tal Melba no aparece en ninguna de las fuentes consultadas, por lo que hay que deducir que es invención de Sender, quien la hace aparecer a raíz del asesinato de Bernstein. Sender, como Garrett, hace que Billy dispare a sangre fría contra el pobre contable, quien era de origen judío. Con esto terminan las coincidencias, ya que Sender nos informa (cap. VIII) de que Melba era, entonces, amante de Billy e incluso nos da a entender que quizás las relaciones entre tío y sobrina iban más allá de los simples lazos familiares. Billy, por aquel tiempo, «buscaba la muerte, de tal modo osaba las empresas más arriesgadas. Luego fue viendo la gente que algunas de sus violencias inmotivadas tenían una congruencia difícil de explicar" (115), aunque esas mismas gentes son las que, al enterarse de la muerte de Bernstein y de los amores de Billy y Melba, comienzan a sospechar de las relaciones entre tío y sobrina (116). Las sospechas sobre los motivos de Billy las aclara el mismo Sender: no fueron los celos sino las "contingencias de la aventura» (117) las que motivaron el asesinato.

A Melba la hace Sender mestiza de alemán y mexicana. Huérfana desde niña, pasó a vivir con su tío. Había sido la amante de Bernstein y de otros aventureros que habían pasado por el condado de Lincoln, pero su favorito era sin duda Billy, de quien sabía toda su vida aun con detalles que él casi no recordaba (118). Billy se la llevó a Fort Summer y allí la empleó en La Arquita, el tendejón (taberna) de Pete Maxwell, «un viejo amigo, buena gente que a pesar de su nombre escocés hablaba españolmejicano» (119). A partir de entonces, la presencia de Melba en La Arquita era indicio de la ausencia de Billy de Fort Summer y viceversa. Melba resulta ser un personaje enigmático:

\footnotetext{
Es curioso anotar que en ninguna de las solemnidades religiosas ni en el entierro estuvo presente Melba. La gente lo atribuía a su desesperación. Tampoco se vio en aquellos actos a Maxwell, que andaba con la conciencia turbia. (250)
}

Garrett, de hecho, había explotado la certeza de un triángulo amoroso Maxwell-Melba-Billy para conseguir información sobre las andanzas del bandido la noche de su muerte. De esta forma Sender logra dar un toque romántico y misterioso a lo que, por otra parte, fue un puro, simple y cobarde asesinato a sangre fría. Billy, el simpático donjuán leal a sus amigos, muere, quizá, delatado por éstos. ${ }^{10}$

\footnotetext{
10 Sobre la popularidad de Billy con las mujeres, algunas de ellas esposas de amigos, véanse CLINE (87-88), TUSKA (101) y UTLEY $(1989,127)$. STECKMESSER parece dar la razón a Sender cuando, al tratar de explicar por qué Billy siguió merodeando por Fort Summer después de
} 
El tema de la lealtad a los amigos está relacionado con la inclusión por Sender de un personaje ahistórico, un hermano gemelo de Tunstall, y la igualmente ahistórica continua «amistad mortal» entre Billy y Jesse Evans, así como la revancha de éste por la muerte de Billy. El hermano gemelo de Tunstall, quien realmente era hijo único (Tuska, 14), es, como Melba, una pura invención de Sender, quien, siguiendo la leyenda, hace que Billy se convierta en desperado a raíz de la muerte del ranchero de la historia, por quien sentía gran admiración (67). ${ }^{11}$ Según Sender la admiración era mutua y, así, Tunstall, quien consideraba a Billy un filósofo, gustaba de tener largas parrafadas con su joven amigo, casi siempre sobre temas históricos. El hermano "senderiano" de Tunstall se nos aparece al principio como continuación de John. Este nuevo se llama Peter y mantiene también largas conversaciones con Billy sobre la sociedad y la naturaleza del estado. Según Peter, John era amigo de Marx y de Engels, a los que había tratado de convencer, sin éxito, de que estaban equivocados en sus ideas sobre el origen del Estado (173). Pero el papel de este Tunstall en la novela es el de contraste, no sólo con su hermano, sino con Jesse y con el mismo Billy.

En efecto, el gemelo acusa a Billy de haber sido el causante de la violencia que acabó con la vida de John. A pesar de esto le declara a Billy su amistad, para al poco tiempo traicionarlo instando a un tal Mason a delatarlo a Garrett (182). Tunstall le da una carta para el sheriff, que más tarde encuentra Billy por casualidad en la cárcel de Lincoln, en la que ofrece a Garrett hasta cinco mil dólares por la muerte de Billy. Cuando éste escapa, va a casa de Tunstall, a quien le hace quitarle las argollas que todavía lleva en los pies y poner una posdata a la carta diciendo que los cinco mil dólares son ahora para la liberación de Billy. Éste le perdona la vida y Tunstall sale de estampida de Lincoln.

Contrasta pues Peter con su hermano, el gentleman John, pero sobre todo con el bandido Jesse Evans y, claro, con el mismo Billy, quien por lealtad a Tunstall se convierte, en la novela, en un fuera de la ley. Billy, además, tenía afecto a Peter al principio, como le indica a Jesse (178). Este mismo, aunque bandido, tiene también un código de honor que contrasta con la duplicidad de Tunstall. Ya se ha indicado que Sender le da un papel mucho más protagonista a Jesse que el que tuvo en la historia, al menos en cuanto a su relación con Billy. Así, contrariamente a toda evidencia histó-

su escapada de la cárcel de Lincoln, señala: «Some writers have said that he stayed for the love of a sweetheart, and the names mentioned include Celsa Gutiérrez, Paulita Maxwell, and the pseudononymous [sic] "Dulcinea del Toboso". A love affair at this point has somehow seemed appropriate to the story, but there is no solid evidence to support it" (70).

11 Parece que la «estrecha» relación entre John Tunstall y Billy the Kid no lo fue tanto y así lo indican STECKMESSER (60-61), TATUM (12) y TUSKA (14-15). Sue Mc Sween, ya viuda, le dice a Miguel Otero que Billy «loved» Tunstall y que bajo la tutela de éste se hubiera convertido en un ciudadano ejemplar "for he was a remarkable boy, far above the average of the young men in those times..." (OTERo, 121). 
rica (Tuska, 63-64; Utley, 1991, 33), Billy y Jesse siguen viéndose a menudo después de la guerra del condado, Billy justifica la muerte por la espalda de Carlyle en su amistad con Jesse (222-223) y éste es el vengador de su «amigo mortal» matando a Garrett: «Todo el mundo sabe que poco después de la muerte de Billy ese tal Jesse Evans buscó a Garrett, el marshall, lo encontró en despoblado y le voló la cabeza», le dice un viejo pariente de los Maxwell a Sender, quien responde: «[...] me alegré al saber la noticia. Lealtad por lealtad, siempre está bien la que los amigos se guardan entre sí» (252). ${ }^{12} Y$ así termina la novela.

El último aspecto de El bandido adolescente que separa a Sender de los demás es el extraordinario papel que lo hispánico tiene en la novela. Nadie, ni siquiera Miguel Otero, da tanta importancia al origen hispánico de los personajes, el uso de la lengua, las costumbres o el conflicto entre la población de origen hispano y la de origen anglo.

Está claro que una de las razones por las que Sender se interesó en Billy es porque en siete ocasiones diferentes en sus viajes por Nuevo México le enseñaron un cráneo de Billy. ${ }^{13}$ Como muchos otros anglohablantes en aquella época, Billy hablaba bien el castellano neomexicano y parece que se dirigió a Pete Maxwell en castellano antes de su fatídico encuentro con el colt de Garrett. Es igualmente verídico que los mejores amigos y más ardientes defensores de Billy eran los neomexicanos.

Sender va mucho más allá que cualquier otro biógrafo o historiador, llegando incluso a hacer a casi todos los personajes semihispánicos: Billy mismo, a quien su madre le recordaba que como irlandés tenía sangre hispana; Melba, como ya hemos visto, era mestiza; los pioneros a quienes Jesse y Billy salvan de los apaches "eran mejicanos españoles y el otro mulato cubano, es decir, español también» (37), mientras que Garrett los llama únicamente «Texans» (24) y los amigos de Billy casi lo son: Bowdre es «más mexicano que los de Veracruz" (84).

La influencia de la lengua y las costumbres hispánicas es tan importante en el Nuevo México de la novela que Billy y Chisun (John Chisum) hablan de la muerte como «La comadre Sebastiana» (leyenda neomexicana). Sender capta muy bien la lengua de esta parte del mundo hispánico: "¿Vienes del entierro? - Ahora merito» (94), o esta contestación de Billy a Jesse: «Yo también quería encontrarte y no precisamente aquí ni en una balacera» (89).

Aunque la guerra del condado de Lincoln pasó a la leyenda como un conflicto entre los grandes ganaderos y negociantes contra los pequeños

\footnotetext{
12 Sobre el asesinato de Garrett por un tal Wayne Brazel en 1908, véase BURNS (315-318).

13 En su columna de prensa «El obispo de los apaches», publicada doce años más tarde que El bandido, dice Sender: «[p]or cierto que siete lugares diferentes de Nuevo México presumían de tener su cuerpo en el cementerio. Así que Billy tenía siete cabezas y a mí me han mostrado tres o cuatro cráneos diferentes en otros tantos poblados». Hasta el momento no he podido verificar la existencia de tales leyendas.
} 


\section{EL LUGAR DE SENDER}

propietarios, los hechos fueron mucho más complejos. Según Steckmesser y otros historiadores, había neomexicanos luchando en ambas facciones, pero éste reconoce que la mayor parte lo hacía a la fuerza (61). El hecho es que los conflictos entre anglos e hispanos por el control y uso de la tierra en Nuevo México han continuado hasta nuestros días. Es imposible pensar que la población hispana se inventara sin base alguna el papel de Billy como amigo de sus intereses. Papel que tampoco se inventa Sender, por supuesto.

Billy, pues, llegó a los hispanos de alguna forma y esto no lo pone en duda nadie, aunque solamente Sender lo hace el centro de su aportación a la leyenda. De hecho, puede decirse que El bandido adolescente "hispaniza" esa leyenda. En la novela senderiana, lo hispano es esencial y no sólo porque enmarca la novela. Aquí no se habla de folclore barato de guitarras, señoritas con mantillas y bandidos guapísimos tipo Hollywood, ni tampoco del no menos romántico ambiente de Burns. Aquí hablamos de una casi total identificación de Billy con lo hispano y de lo hispano con Billy, de forma que la novela parece estar contada desde ese lado. Es como si Sender, en nombre de los hispanos, le estuviera devolviendo a Billy la lealtad que aquéllos le debían.

\section{OBRAS CITADAS}

ADAMS, Ramon F., Burs Under the Saddle, Norman, University of Oklahoma Press, 1964.

- More Burs Under the Saddle, Norman, University of Oklahoma Press, 1979.

Burns, Walter Noble, The Saga of Billy the Kid, Nueva York, Doubleday, 1926.

CARRASQuer, Francisco, La integral de ambos mundos: Sender, Zaragoza, Universidad de Zaragoza, 1994.

Cuine, Donald, Alias Billy the Kid. The Man Behind the Legend, Santa Fe, Sunstone Press, 1986.

ECEnbarger, William, "Shooting Down the Myths", Philadelphia Inquirer Magazine (21 de septiembre de 1991), pp. 14-31.

Garretr, Pat F., The Authentic Life of Billy the Kid, Santa Fe, New Mexican Printing and Publishing Co., 1882 (reimpresión, Time-Life Books, Classics of the Old West, 1980).

OtERo, Miguel Antonio, The Real Billy the Kid. With New Light on the Lincoln County War, Nueva York, Rufus Rockwell Wilson, 1936.

Sender, Ramón J., El bandido adolescente, Barcelona, Destino, 1965 (3ª ed., 1974).

-, «El obispo de los apaches» (serie «Los libros y los días»), ALA Press Service (enero de 1977).

STECKMESSER, Kent Ladd, "The Western Hero", en History and Legend, Norman, University of Oklahoma Press, 1965.

TATUM, Stephen, Inventing Billy the Kid. Visions of the Outlaw in America, 1881-1981, Albuquerque, University of New Mexico Press, 1982.

TUSKA, Jon, Billy the Kid. A Handbook, Lincoln, University of Nebraska Press, 1983.

UTLEY, Robert M., High Noon in Lincoln. Violence on the Western Frontier, Albuquerque, University of New Mexico Press, 1987 (3 ${ }^{\text {a }}$ ed., 1991).

_- Billy the Kid. A Short and Violent Life, Lincoln, University of Nebraska Press, 1989. 


\title{
Una nueva lectura de El bandido adolescente de Ramón J. Sender
}

\author{
Fermín Sierra Martínez \\ Universiteit van Amsterdam
}

\begin{abstract}
La lectura de Sender siempre puede causar sorpresas. Sabemos que es un narrador tan sumamente imprevisible, tan ameno e inconformista que cada vez que se abren las páginas de sus escritos se está seguro de poder encontrar elementos nuevos que animan a seguir leyendo, tanto por la historia, la anécdota de la narración, como por las sabias máximas, los conceptos metafísicos, el abrirte los ojos ante nuevos aspectos del vivir humano. Así nos ocurrió al adentrarnos en la novela que a continuación vamos a presentar.

Comenzaremos agradeciendo la ayuda que representa el libro de Francisco Carrasquer La verdad de Ramón J. Sender, en cuya portada se señala: «Con bibliografía de Elisabeth Espadas». ${ }^{1}$ En él podemos encontrar una amplia reseña bibliográfica sobre Sender y seis referencias dedicadas a la novela motivo de este estudio. Son pequeñas reseñas de aspectos muy generales. Además, no habrá de olvidarse que el Instituto de Estudios Altoaragoneses (Huesca) posee un centro de documentación senderiana con prácticamente la totalidad de la bibliografía primaria y secundaria del autor.
\end{abstract}

\footnotetext{
${ }^{1}$ Francisco Carrasquer, La verdad de Ramón J. Sender, pp. 121-177.
} 
Sin embargo, es realmente extraño que la indagación hecha en la Biblioteca Nacional nos descubra que no poseen la primera edición, de 1965, y tan sólo encontremos referencia a la $4^{a}$ edición, de 1980, en Destino ("Âncora y Delfín»); a la $2^{2}$, también de 1980; a la $3^{\text {a }}$ edición, de 1982, y a la $4^{\mathrm{a}}$, de 1984, todas en Destinolibro. Se complementa con la $5^{\mathrm{a}}$ edición, de 1986, en Destinolibro, y con la reseña de ser la reimpresión de la $1^{a}$ edición de 1978. Además se puede encontrar una edición de 1982 de Salvat con prólogo de Rafael Vázquez Zamora. Hay, como se sabe, una última edición de la novela aparecida en 1994, editada por RBA Editores, Barcelona, conjuntamente con Réquiem por un campesino español.

Por último, queremos señalar que ciertas dificultades tenidas, por nuestra parte, en conseguir mayor información sobre la novela objeto de este estudio pueden hacer posible que algunas de las reflexiones que se presenten en esta lectura personal de la obra puedan estar ya reflejadas en otros trabajos. No obstante, aun a riesgo de caer en alguna repetición, nos parece de sumo interés volver a "refrescar" algunas ideas sobre el discurso y la historia que Sender nos ofrece en El bandido adolescente. ${ }^{2}$

De una lectura pormenorizada podemos obtener un vasto panorama de tópicos de muy diversa índole que nos hablan de una novela con características tan especiales que la individualizan en el conjunto de la obra de Sender y, por otro lado, nos ofrece una muestra más de ese su quehacer especial, en el que la narración cumple de forma explícita la función clásica del "enseñar deleitando". A fin de poder clarificar todos los aspectos que, según nuestro punto de vista, hemos obtenido, los hemos agrupado en seis grandes apartados:

1. Aspectos sobre el narrador

2. Aspectos lingüísticos

a) De tipo léxico

b) Bilingüismo/biculturalismo

c) Expresiones varias y referencias al refranero

d) Ortografía de algunos términos

3. Reflexiones de Sender, expresadas por boca de Billy the Kid, sobre:
a) La vida
b) La muerte
c) La amistad
d) Varias, expresadas por el propio Sender u otro personaje

4. El romancero y el cancionero como elementos constitutivos de la narración

5. Bestiario comparativo

6. Otras referencias

a) Complejo de Edipo

b) Notas a pie de página

2 Todas nuestras referencias y citas provienen de la $6^{a}$ edición, Barcelona, Destino ( Destinolibro»), 1987. 


\section{EL NARRADOR/COMPILADOR}

Creemos que lo primero que hay que señalar es el llamemos juego de la confección clásica de la novela como romance épico en prosa, toda vez que:

-Hay un narrador/compilador de la historia, el sheriff Garrett, diferente al que escribe la novela/poema, Sender. ${ }^{3}$

-Es la historia de un héroe/guerrero inmerso en un mundo que se está conformando, donde varios pueblos, en el sentido más amplio de la palabra, luchan para sobrevivir: mundo anglo, mundo hispano, mundo indio.

-Los personajes son presentados con profusión de detalles en retahíla cuya fórmula nos recuerda o se asemeja a la Ilíada, a la Odisea o a cantares de gesta como el del Cid, etc.

- Además diríamos que en muchos momentos estamos ante un cronista clásico también. Nos cuenta hechos ocurridos históricamente, al margen de la propia biografía de Billy; hay profusión y exactitud de fechas, así como se nombran lugares debidamente ubicados y claramente localizables.

En apoyo de nuestra primera aseveración - autor diferente al narrador- tenemos las varias indicaciones con descripción y comentarios que Sender nos hace de Garrett: «Un detalle interesante que cita el mostachudo y honesto sheriff Garrett [...]" (p. 8). Ésta es la primera referencia que sirve de introducción «inmediata» del sheriff sin más explicaciones. Nótense ya los calificativos que acompañan al personaje.

Continúa Sender con sus referencias, de las que ofrecemos algunos ejemplos: "No se veía en Billy todavía el desperado que había de ser más tarde. Así dice al menos el sheriff Garrett» (p. 10); "Según el sheriff Garrett, que tenía una copia de aquella carta [...]» (p. 71); «Dice el sheriff Garrett, a quien otras veces me he referido [...]” (p. 81).

Poco a poco irá perfilando más el personaje. $\mathrm{Y}$, así, nos aclarará: «El mismo Garrett dice con un estilo que no puede menos de resultar pintoresco en un sheriff [...]» (pp. 32-33). Y. más adelante, apoyándose en los versos del funcionario de la ley:

También Garrett componía versos, pero lo suyos eran versos de policía. Entre dos cabalgadas el sheriff dejaba el revólver montado al pelo, por si acaso, y se ponía a escribir sobre Billy chupando el lápiz:

Inmerso en los peligros de la vida amaba a las mujeres, por fortuna... (p. 44)

\footnotetext{
${ }^{3}$ Según Charles L. KNG, en su reseña a El bandido adolescente, en Hispania, p. 389, el texto que Sender siguió fue el libro del propio Pat Garrett The Authentic Life of Billy, editado en 1882. Además, el propio escritor explica que el personaje de Francisco de Aragón (¿Agustina de Aragón?) también lo obtuvo de una documentación leída: «[...] que se llamaba nada menos que Francisco de Aragón. Uno de los documentos que he leído para reconstruir la escena dice: "Francisco de Aragón era un verdadero Quijote... con la boca"”. Para añadir a continuación de forma irónica: «Ah, vamos! Porque un verdadero don Quijote no puede conducirse como se condujo el señor de Aragón [...]» (p. 196).
} 
Las calificaciones empiezan a ser más capciosas: «[...] dice Garrett, el policía bandido o el policía trovador, según los casos» (p. 88).

Hay que señalar que hasta el capítulo XI encontramos once referencias a Garrett, más o menos esporádicas, pero a partir del comienzo de este capítulo (p. 162) la aparición del policía biógrafo aumentará visiblemente en cantidad e intensidad, de tal manera que tomará el protagonismo en muchos momentos, quedando Billy claramente en un segundo plano. Es en esta segunda parte donde podremos leer la descripción del carácter de Garrett a partir de su retrato físico, añadiendo el comentario irónico: "Aficionado a la poesía que rima amor con dolor y canción con corazón». ${ }^{4}$ Sender no cobijaba ningún buen concepto de las cualidades líricas de Garrett. $Y$ de forma satírica escribirá: "No era Garrett hombre de alardes, pero tampoco de prudencias excesivas, y mucho menos de miedos. Tenía esa seguridad en sí que sólo puede tener un mal poeta. (Porque, como dije antes, Garrett escribía versos.)» (p. 188). Y terminará sus comentarios más o menos jocosos sobre la actividad poética: «Ser perseguido por un policía de Washington como Garrett, viejo, padre de familia, que escribía versos chupando la punta del lápiz, le desorientaba» (p. 231).

\section{ASPECTOS LINGÜISTICOS}

Otro apartado de suma importancia es la aparición de diversos aspectos de tipo lingüístico al margen $o$, si se quiere, como complementación del lenguaje del discurso narrativo. Estos aspectos los hemos clasificado en:

a) Aspectos de tipo léxico, es decir, disquisiciones sobre significado y uso de determinados vocablos o expresiones. $\mathrm{Y}$, así, tenemos explicaciones con respecto al español:

Aprendió con los pilluelos de piel oscura a hablar un español mejicanizado como se puede suponer y un poco arcaico. Decía trujo y asina y denantes. También decía reñire por reñir, dolore por dolor y plebe por multitud. (p. 9)

Todavía se usaba la palabra pecunia en todos los países como expresión del factor económico y venía esa palabra de pecus, es decir, animal de pezuña. (p. 64)

Pero lo que es más frecuente es la aparición de términos en inglés seguidos por una explicación del significado en español. Ejemplos son:

"[...] hacernos un scalp». Es decir, en arrancarles a los blancos el cuero cabelludo y llevárselo como trofeo. (p. 10)

Los tenderfoot, es decir, los individuos flojos para la lucha por la existencia [...]. (p. 11) [En referencia a la madre de Billy.]

\footnotetext{
${ }^{4} \mathrm{El}$ subrayado es nuestro y su aparición indicará pasajes que requieren nuestra atención.
} 
Explicaciones que pueden ser extremadamente extensas, como la que citamos a continuación, donde a lo meramente léxico se une un deseo claro de diferenciar características morales y sociales:

No se veía en Billy todavía el desperado que había de ser más tarde. Así dice al menos el sheriff Garrett. En el suroeste la gente de habla inglesa llama así -es decir, desperados- a los hombres que tratan de escapar a sus perseguidores después de haber hecho alguna fechoría grande. Desperados. La presencia de los españoles en el mundo ha dejado palabras que aluden frecuentemente a la violencia. Un desperado (es decir, desesperado) es lo que los yanquis llaman en su idioma un gangster. En inglés expresan con esta palabra la peculiaridad social del hombre. Un gangster es un hombre de gang, es decir de cuadrilla. Un desperado es una definición moral y además un tipo de criminal individualizado e individualista. Hay que distinguir entre el gregario violento y el verdadero héroe solitario que va y viene sin compañía entre el cielo y la tierra. (p. 10)

- Tengo oído que es un gentleman.

Tuvo que explicar a Melquíades lo que era un gentleman: «Un hombre que nunca juega sucio». (p. 43)

[...] en actuar como lo que era: un fast gun, un revólver ágil. (p. 89)

Chisun podía escuchar con pocker face, es decir, sin pestañear. (pp. 100-101)

[...] dijo que tenía varios warrants (mandamientos judiciales de arresto) contra ellos. (p. 107)

- Ha pasado un minuto, Smithy.

Llamarle así equivalía en español Perezito. (p. 108)

Billy desdoblaba una carta y leía: "Mr. William Bonney». Ni siquiera dear Mr. Bonney, como se dice en una carta comercial. (p. 129)

Y me dijo un día: «Billy, hay muchas clases de seres vivos. $Y$ usted y yo pertenecemos a la misma casta. ¿Qué casta? La de una clase de elefantes que en la India llaman rogues". Yo me reí porque esa palabra tiene dos sentidos: el rogue, es decir, el sinvergüenza, y el elefante rogue, es decir, el que va solo. (p. 165)

Cada vez que lo llamaba por su primer nombre - Pat - sonaba como "pa», es decir, padre. (p. 221)

A veces la explicación puede ser al revés, del español al inglés: «[...] que se atribuía la autoridad del ayudante del sheriff (deputy sheriff)" ( $\mathrm{p}$. 64). No obstante, también nos ofrecerá un repertorio de explicaciones sobre el uso especial de términos en el español de Méjico:

Algunos meses después de vagar por San Simón, San Carlos y otras placitas (así se llama allí a las aldeas que han servido o sirven de aposentamiento de fuerzas) [...]. (p. 15)

-Al otro lado, donde tiene sus aposentos don José Martínez, un tagarote que le huele la nariz diez millas a la redonda.

Queria decir que tenia mucho dinero. [...]

- No se dejaría ahorcar por medio millón, el viejo cabra y, eso sí, tiene su historia negra y es un bragado. 


\section{EL LUGAR DE SENDER}

-¿Un qué?

-Un puro machote. No sería yo quien le llevara la contraria. (p. 23)

- ¿Y cómo sabe su mercé que no soy del país? [Habla don José, cacique y jugador de Cananea, Méjico.]

- Porque tiene la pinta del recién llegado de la madre patria.

Apoyada y subrayada esa palabra (madre) era una mentada y la cosa se ponía fea de verdad. (p. 25)

Solía Billy tener su cuartel general en el valle de Pecos, donde se divertía en los lugares de recreo o, como decían con una palabra española hoy en desuso, en los tendejones. (p. 55)

El que estaba en la despensa era sobrealimentado -la cocinera decía empapuzado - con nueces y otros manjares. (p. 56)

Billy y sus amigos tenían al sheriff acorralado en su oficina o, como decían los mexicanos, acochinado. (p. 79)

Billy no le escuchaba aquellas «babosadas» [...]. (p. 84)

Llamaban los hispanos comadre Sebastiana a la alegoría de la muerte (el esqueleto con la guadaña) [...]. (p. 102)

[...] parecía una vieja «turca», es decir, una mendiga nómada. (p. 114)

Toda la noche estuvo la viuda de Bowdre llorando mientras sus vecinos hispanos recitaban alabados, bebían anís y despabilaban las velas.

Como se puede suponer, los alabados eran elogios al muerto. (p. 215)

Los habituales de la taberna lo llamaban "el gringo murcio". Este apodo venía de la miopía de O'Leary que, sin sus gruesas gafas color rosa, estaba perdido. Era murcio una alusión al murciélago - animal ciego - y al mur, al ratón, es decir, al hocico ratonil del irlandés. (p. 236) inocente:

Se reían de él. Por ejemplo, le preguntaban a veces con una expresión

- ¿Qué día nació?

-El doce de agosto.

-Digo, el año.

-El cuarenta y uno

Y los mexicanos soltaban a reír a coro porque a los invertidos sexuales les llamaban en México los cuarentayunos. [...] Y se decía: «Un nuevo Tuatha de Danann, es el Kid. Es decir, un héroe milesiom. (pp. 240-241)

Encontramos también la inversión de pares de palabras: «La verdad es que Filomeno y yo éramos carne y uña» (por uña y carne). Suponemos que es un ejemplo más de caracterización de un individuo como bilingüe.

b) Otro aspecto de absoluta relevancia es el que vamos a llamar sociolingüístico: el bilingüismo de los personajes, el cambio de código en el discurso, las actitudes biculturales y sus consecuencias, sobre todo en Billy. Sender es un conocedor de este mundo en el que muchos de nosotros nos hemos de desenvolver y ante el cual hay que tomar posiciones, no siempre fáciles por los contrastes que suponen las diferentes costumbres y las diferentes actitudes que esto produce en los individuos de las diversas comunidades. Además, con este continuo vaivén entre las dos lenguas, las dos culturas y las posiciones que ha de tomar el individuo, crea con intensidad ese mundo mixto de las zonas fronterizas. 
Para Sender hay una igualdad de nivel social entre los hispanos y los anglos. No así con los indios. Lo curioso es poner una situación ambivalente en Billy, de origen irlandés, pero entre los que reclaman el origen español del grupo. Es un híbrido donde lo anglosajón es quizás la mínima parte. $^{5}$

Tenía a gala hablar español. Era un caballerito hispano-irlandés: un milenio rezagado de los que salieron de Iberia para Grecia y de Grecia para Irlanda seis siglos antes de la era cristiana. [...] A los once años usaba ya con sus enemigos infantiles aquella amenaza tan frecuente entre los aventureros españoles del siglo XVI: «Me vais a soñar, hijos de puta». (p. 9)

Los mejores amigos de Billy (a los cuales el muchacho fue leal) eran de origen hispánico. Si los anglos despreciaban a los spicks (así llamaban a los spanish) por su piel oscura, Billy the Kid los admiraba. Y cuando Billy se sentía en una situación esforzada, difícil o heroica hablaba español instintivamente. [...] Por esas razones la gente hispana de New México quería a Billy. El poder de identificación del muchacho con el ambiente era prodigioso [...]. (p. 12)

Una de las facetas que siempre se comenta ante el individuo bilingüe es la de que en determinadas ocasiones predomina una lengua más que la otra, como si esa lengua fuera la que se halla en lo más profundo del ser y es la que te permite expresar lo más íntimo o intenso.

El cambio de código en el hablar, característica de todo individuo bilingüe y sobre cuyo fenómeno hay importantes estudios, como se sabe, lo veremos usado con profusión, acompañado muchas veces por esas explicaciones constantes que Sender no parece dejar de hacer. Con seguridad, el profesor de la lengua española está pensando en sus lectores monolingües y quiere que se le entienda de verdad. Veamos los ejemplos:

Refiriéndose más tarde a aquel incidente, Billy solía contarlo asî: «Fue un caso de ground hog (el ground hog es un animalito que señala la buena suerte a los campesinos o a los aventureros) [...]. (p. 15)

Respondió Billy con el sacramental son of a bitch [...]. (p. 20)

— ¿Un six shooter y de los caros!

- Llevo un cartucho quemado para aguantar el gatillo. Así que sólo es five shooter. (p. 22)

Mala suerte han tenido esos sonobiches, pero no creo que merecieran otra. (p. 75)

[...] sin miedo de ningún gringo - ni sheriffes ni marshalles [...]. (p. 248)

Notemos en estos últimos ejemplos cómo los vocablos ingleses se han «hispanizado». Otro de los efectos conocidos en el caso de los individuos

5 La madre en algún momento le explica: «-Nosotros los irlandeses también venimos de españoles. Sólo que unos llegaron a Irlanda antes de Cristo y otros después del desbarate de la armada de Felipe II, como náufragos» (p. 9). 
bilingües: la realización de nuevos términos fruto de la combinación de las dos lenguas que hablan. Piénsese en el «pichinglis» o la lengua actual de los chicanos, plagada de anglicismos absolutos y relativos; incluso su inglés está marcado por cientos de interferencias, de todo tipo, del español.

Otros ejemplos de cambio de código encontrados son:

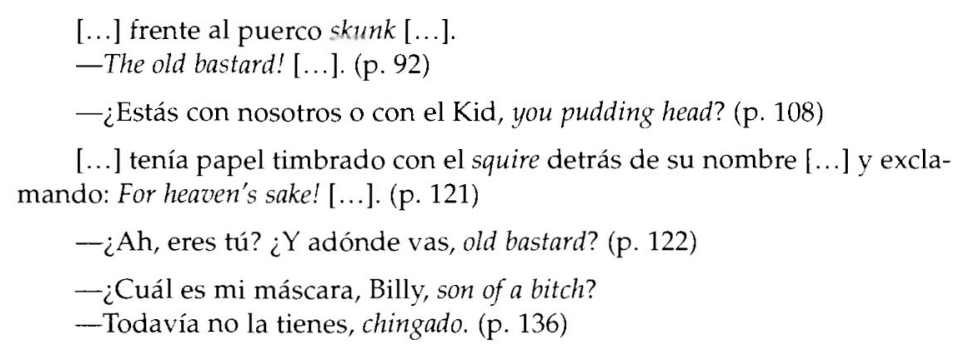

Como podemos observar, la mayoría de los cambios de código se dan para expresar los insultos hacia otra persona o simplemente como palabras mal sonantes de refuerzo del diálogo, fenómeno tan típico entre el habla de gente menos educada. Ni que decir tiene que el aspecto funcional de este estilo de escribir es claro. Nos hallamos ante sujetos bilingües que usan de cada idioma aquello que más les conviene o aquello que expresa lo que ellos quieren decir, marcando además lingüísticamente a un individuo para indicar su procedencia. En el último ejemplo dado, hay mezcla del inglés y el español mejicano para diferenciar a los dos individuos que hablan. El de origen inglés proferirá un «taco» en inglés y Billy, en español. Y seguimos:

- iBasta de bromas, you big mouth! (p. 152)

Cuando el bartender [camarero / dueño del bar] sirvió a Billy su whisky [...]. (p. 154)

-El sap de Redmond —dijo Folliard—salva la vida por el amor de Billy a su gabán. (p. 156)

- ¿Qué hace ahí ese bastard? - gritó Wilson amistosamente. (p. 159)

Prefería ser injusto a ser unkind con sus amigos. (p. 166)

-Yo tengo un amigo que sería también un rogue, pero es un albino son of a bitch. [...] siendo transportados por la corriente hasta las serradurías y los almacenes de timber. (p. 167)

-[...] Me dirigí al más conocido de los gun boys de Dolan [...]. (p. 172)

-Es un enviado del attorney de Santa Fe. Un correo. Un special delivery. (p. 174)

- [...] Y que aquí todo es cuestión de dinero y de guts. (p. 182) inglés:

El Kid se apartó golpeándose la pierna con el rebenque y repitiendo en

-I smell a rat. (p. 183) 

inglés:

"Vamos a tener una Navidad blanca», dijo Garrett. Mason lo repitió en

-A white Christmas. (p. 200)

Llamaba Billy a Garrett grand pa [...] (p. 212)

Al amanecer, otra de las que acudían, que acudían como cornejas, comentó desde la puerta en inglés:

-Very dandy, the dam Kid.

$Y$ añadió en español:

-Es verdad que la muerte le sienta bien. (p. 247)

Tras todos estos ejemplos se reafirma nuestra aseveración anterior de que con ello se crea un mayor ambiente bilingüe y de zona fronteriza.

c) Dadas las características de la novela, no podían faltar las notas de la sabiduría popular, en muchos casos cercanas al refranero y posiblemente inventadas o reelaboradas por Sender. Lo que sin duda rezuman algunas de ellas es un gran humor socarrón. Véanse los ejemplos obtenidos:

Vivía Ed, hombre fuerte, feo y formal - las tres efes-, frente a la casa de Billy. (p. 13) [En este caso podemos pensar que Sender conociera una canción popular cuya letrilla satírica decía así: «Una novia que yo tuve / todas las efes tenía: / Francisca, franca, fregona, / flaca, fea, floja y fría».]

El negocio había sido redondo y los indios habían hecho el... indio, como se suele decir. (p. 19)

Como él decía: «Vista larga, lengua quieta y revólver a mano». (p. 133)

Garrett, que era hombre burocrático (burrocrático, decían algunos hispanos de Lincoln) [...]. (p. 191)

Era como las putas que tienen tienda y comercio abierto y a todos les satisfacen y a ninguno les convencen. (p. 222)

[...] volvía a pensar: «Hay que seguir esperando, porque la ciencia del cazador es más paciencia que ciencia». (p. 243)

Creemos que los ejemplos hablan por sí solos y no necesitan más comentario. Hay, eso sí, una referencia explícita al refranero, en este caso al de Méjico: «Pensando en él Billy recordaba un refrán mejicano muy largo, pero bastante expresivo: “El valiente de El Paso, que apaga el candil de un trabucaso"» (pp. 49-50).

d) Para terminar este apartado, queremos llamar la atención sobre el hecho de que en la novela nos encontramos con una ortografía cambiante de las palabras que se refieren a Méjico y a lo mejicano. Y, así, hallaremos las palabras mejicanizado (p. 9); mejicano, mejicana, mejicanos —un total de 25 veces a lo largo de la obra-, y neomejicano (p. 202). Pero, junto a esto, tendremos México - que aparece nueve veces-; "más mexicano que los de Veracruz» (p. 84); «los pinches mexis [...] Llamaba Folliard así a los neomexicanos» (p. 85); «las consideraban mexicanas» (p. 120); «los mexicanos» (p. 241).

Por otro lado hallaremos el sustantivo Texas y, sin embargo, siempre escribe tejano, tejanos. El último ejemplo se da en la nota al pie de la pági- 
na 230, donde se combina la doble ortografía: «[...] nacido en el viejo Méjico y no en New Méxicom. ${ }^{6}$ No nos atrevemos a sacar conclusiones muy firmes, pues no parece hallarse una razón lógica para unas veces escribir con $j$ y otras con la grafía $x$. Quizás nos hallemos ante un elemento más de creación de ambigüedad o ambivalencia del mundo que se nos presenta a los lectores.

\section{REFLEXIONES DE SENDER}

En este apartado hemos querido reunir todos aquellos comentarios, reflexiones y posturas que Billy expresa en su andadura novelesca, pero en los que se ve claramente que son la expresión del sentir de Sender ante temas tan importantes como la vida que nos toca recorrer, la muerte como algo inevitable, la amistad a la que uno puede entregarse y algunos otros aspectos curiosos que demuestran una agudeza especial de contemplar el mundo que nos rodea o nos toca vivir.

Aunque algunos ejemplos los hemos ubicado en un solo apartado, se podrá comprobar fácilmente que el juego de la vida y la muerte juntos aparece con frecuencia. No es fortuito, por supuesto. De esta forma se marcan las dos facetas de la existencia como algo indisoluble. $Y$ así nos lo hará experimentar nuestro novelista. Los ejemplos son de tal profundidad y variedad que cada uno de ellos nos permitiría un comentario extenso, pero se nos va a perdonar no adentrarnos en ellos y hacer una simple enumeración, dejando al lector que elabore sus propias conclusiones. Sí queremos puntualizar que esto mismo nos hace poder asegurar que estamos ante dos protagonistas de la novela, casi mayores que el propio Billy the Kid. Desde las primeras páginas, la vida y la muerte estarán presentes marcando la trayectoria de nuestro héroe.

Como tercer elemento determinante tendremos la amistad. Es tan repetitiva la actitud ante lo que es la amistad para Billy que no podemos dejar de pensar que así era como Sender sentía esta cualidad del ser humano, ese sentimiento tan especial que nos produce la persona en quien confiamos y a quien le damos nuestra confianza, poniéndonos en sus manos a sabiendas de que no habrá traición ni exigencia. Por último ofreceremos las diversas posturas de Sender ante temas muy variados expresadas por él o a través de otros.

a) La vida

- Se vive sólo una vez; los días pasan uno detrás del otro y hay que saberlos gozar. (p. 55)

$Y$ en la vida todo lo hace la voluntad. Los animales y hasta las cosas tienen voluntad como nosotros los hombres. (p. 64)

\footnotetext{
${ }^{6}$ El nombre de Nuevo Méjico siempre está escrito New México.
} 
-Poniendo la vida por delante tanto vale una ley como otra, Billy, y nadie es más que nadie. (p. 90) [En boca de Jesse.]

-[...] Al fin Morton y los suyos lo mataron a él pensando en usted.

-El hecho es que si lo mataron pagaron también con su vida.

-Nunca una vida paga por otra.

- Seis vidas pagaron por la de su hermano.

- Ni seiscientas pagarian por la vida de un hombre justo.

-En eso de acuerdo. (p. 172)

Yo maté a Carlyle, pero es la vida la que nos mata a todos y adelantar la fecha o atrasarla no quiere decir gran cosa. (p. 221)

b) La muerte

El otro callaba y Billy añadió: «Morir no tiene malicia y algún día lo haremos, pero siquiera que no sea de sed ni de hambre». (p. 47)

La muerte cara a cara era noble y la habían cultivado los hombres desde Adán y Eva. (p. 61)

- ¿Qué importa? - preguntó a su vez Billy-. Matar a un hombre no es ofenderlo. La muerte la lleva todo el mundo en la sangre desde que nace. Lo único que hacemos es adelantarle la fecha a nuestro enemigo para impedir que él haga lo mismo con uno. Eso es. Lo malo en la vida no es matar a otro, sino ofenderlo con alguna clase de humillación o mala palabra. Yo puedo darle un plomazo a cualquiera, es verdad. Pero no lo insulto. [...]

- ¿Qué necesidad hay de insultar a nadie y menos si va uno a quitarle la vida? (p. 63) [Frase, esta última, que sirve de conclusión lógica de todo lo anterior.]

[...] pero se equivocaban los que entendían la jovial confianza en sí mismo del Kid como seguridad del futuro. Porque el problema no está en evitar la muerte, lo que es imposible, tarde o temprano, sino en evitar el miedo a la muerte. (p. 105)

En la página 124 encontramos toda una reflexión sobre morir de mala o de buena manera. Para Billy la buena manera es morir de golpe, de un disparo en el corazón, sin darse cuenta, mientras que morir en la cama y poco a poco sólo trae malos momentos porque se rabiará pensando las cosas que pueden pasar después de muerto.

c) La amistad

Comienza ya muy pronto a hablarnos de la actitud que ha de prevalecer entre los amigos, la lealtad: "Los mejores amigos de Billy (a los cuales el muchacho fue leal) [...]" (p. 12). Y no le importará arriesgar su vida por aquel que considera amigo. De esta forma realizará una cabalgada larga y peligrosa y correrá un gran riesgo por ir a salvar a su «antiguo compañero Melquíades" (pp. 41-42). En otro momento y aun habiendo sido en realidad abandonado por otro compañero de aventuras, su paisano $\mathrm{O}^{\prime}$ Keefe, cuando iban a buscar agua en territorio indio, irá a buscarle, ya que «tal vez necesitaría ayuda»:

Como se ve, el recuerdo de la deserción forzosa de Tom (con el fantasma y todo de su filantrópico padre) no le impedía al Kid tratar de ayudar al 
paisano irlandés. Tenía Billy un sentido de solidaridad que no era de familia ni de clan sino de especie humana, excluidos los indios. (p. 52)

En razón de su amistad, "[n]o era gustoso defender a la gente que en nombre de la ley robaba a los hispanos» (p. 55). Y, como señal suprema de este sentido profundo por el amigo, la muerte de forma violenta y traicionera de su amigo Tunstall le convierte en "un genuino enemigo no sólo de la sociedad, sino del hombre» (p. 67). Se convierte en un desperado. La venganza de su amigo le lleva a no parar de matar e incluso lo hará a traición, algo poco normal en él. Ante la muerte de aquella persona admirada, cambiará por completo el rumbo de su vida y no habrá posibilidad de redención para él. Sin embargo, seguirá practicando la actitud altruista con aquellos que no perdieron su amistad y, así, aunque no tenga ningún interés personal ante el robo de unos caballos, intervendrá en su recuperación por amistad:

\footnotetext{
- ¿Qué nos va ni nos viene en este asunto de los caballos de Cedillo?

- Nada de nada - respondía Bowdre.

-Algo nos va, ¿verdad, Folliard?

Éste, que era tardo de meollo, meditaba un poco:

-Nos va la amistad de los pinches mexis, como el que dice. [...] (p. 85)

-Más quiero yo la amistad de Cedillo que la del fiscal federal Catron.
}

En esas mismas páginas podemos leer: «Folliard, hombre silencioso y malcarado, no abandonó nunca ya a Billy en fortuna ni en desgracia y formaba con Bowdre la pareja de amigos más leal que ha podido tener hombre en el mundo».

Esa actitud de respeto a la palabra amistad dada a Jesse Evans, con quien compartió una buena parte de sus primeras fechorías, hace que un par de encuentros con él no terminen en una matanza; aunque Jesse se halla, a partir de un momento determinado, precisamente en el bando de sus enemigos. No hablan las armas, no vence la muerte. Habla la vida, vence la amistad:

[...] porque Billy no quería ventajas y se había puesto en las mismas condiciones que Jesse. «Matarse entre amigos - había dicho una vez el Kidrequiere cierta limpieza». (p. 88)

- [...] Soy amigo de mis amigos y no me gusta que les hagan eso a mis amigos, Jesse.

Solía repetir la palabra amigos, que le gustaba. (p. 90)

El Kid, quizá por su extrema juventud, creía en la amistad lo mismo que en el amor. La mujer es necesaria - el amor-, pero la amistad es sólo un lujo y por eso en ocasiones puede ser más preciada.

El ideal sería que la mujer amada fuera al mismo tiempo la amiga ideal.

[...] y decía a Folliard:

- No me importa mucho la vida, pero no es fácil vivir sin una mujer y un amigo. Una verdadera mujer y un verdadero amigo. ¡Regalos del cielo, Folliard! [...]

Sabian que una vez hecha promesa de lealtad los amigos eran sagrados para el Kid. (p. 140) 
¿Aprecia Sender la amistad y el amor porque son un lujo escaso? En dos momentos nos hace reflexionar ante tal afirmación, que a nuestro gusto se contradice un poco con la rotunda postura que parece ha de caracterizar al hombre que haga de la amistad su bandera. Quizás las experiencias no siempre positivas que Sender tuvo en su vida le hicieron añorar una amistad como la que demostraba Billy y considerarla un lujo poco accesible. Como consecuencia lógica del sentido de la amistad de Billy, veremos tomar postura a la gente que va con él. Pero en nombre de esa amistad será capaz de matar a un hombre por la espalda:

\footnotetext{
- Hace poco maté a un hombre sólo porque sabía que era enemigo de Jesse Evans.

—Ya lo sé. Jesse es su amigo mortal [...]. (p. 163)
}

Y el Sender creador del lenguaje se nos manifiesta con ese término "amigo mortal» que repetirá a lo largo de la obra. Las reflexiones sobre la amistad se irán desgranando en escenas como la charla con el hermano del Tunstall asesinado (pp. 165, 168, 170) o en la segunda explicación de por qué mató al herrero Carlyle por la espalda: no había sido por cobardía sino por hablar mal de Jesse (pp. 213, 214).

d) Varias

Si hasta ahora hemos dejado hablar a Sender por boca de Billy the Kid, a continuación queremos presentar toda una antología de pensamientos y sentencias varias que el propio Sender nos va a ofrecer, unas veces expresadas por él mismo como autor explícito de la novela, otras poniéndolas en boca de algún otro personaje. Volveremos a ofrecer ejemplos sin más explicaciones, pues hablan por sí solos.

Comencemos con los primeros renglones de la novela, donde se nos ofrece una definición sociológica de la ley natural y una especie de justificación del uso de la violencia:

Representaba Billy la ley natural en un país y en un tiempo--tan reciente, por otra parte - en que el derecho escrito apenas si existía. Era Billy the Kid ese brazo del instinto social que precede históricamente en todos los pueblos al establecimiento de alguna clase de orden jurídico. El rifle hacía la ley y a veces la ley era casi razonable. (p. 7) [Nos preguntamos si Sender al escribir este comienzo no está pensando en lo vivido en España en los años 300 en la guerra - la guerra civil-como situación primitiva que lleva en algunos momentos a justificar el acto violento. Sabemos que nuestra aseveración es más intuición que prueba. Pero ese "tan reciente, por otra parte" nos ha hecho pensar en experiencias vividas.]

El chico asimiló de los labios de su madre alguna clase de inclinaciones románticas que no iban a ayudarle mucho, pero pronto aprendió también que el hombre ialiente es el que dice la última palabra. (La primera la dice el tonto.) Así su romanticismo se hizo realista y prudente desde el principio. (p. 12)

Daba lástima oírselo decir. Melquíades le había gustado a Billy, pero en poblado hacer amistad lleva más tiempo que en campo abierto. Y estaban en poblado donde las relaciones tienen sus laberintos y sorpresas. (p. 23) 
$\mathrm{Al}$ joven pistolero le gusta lo arriesgado. En uno de esos momentos su compañero le dirá:

\footnotetext{
—Eso es tentar a Dios, Billy — replicaba Melquíades-. Mira que en esa serranía dos hombres solos están fregados. vida. (p. 45)

- QQué tentar a Dios! Más nos ha tentado él a nosotros trayéndonos a la
}

La contestación no puede ser más dura. Qué no habrá de la propia experiencia de la vida de Ramón J. Sender para pensar así: «Solía Billy comprender el miedo de los otros y decir: "Al cobarde su pánico lo castiga"» (p. 50). De Tunstall, Billy recuerda determinadas enseñanzas del inglés y reflexiona: «[...] pero en una ocasión había dicho que no quería esclavos, sino amigos. Ciertamente, es incómoda una actitud demasiado personal lo mismo en la paz que en la guerra. La impersonalidad es decorosa e inteligente, lo mismo en la virtud que en el delito" (p. 69). ¿No estamos aquí oyendo una nueva versión del pensamiento horaciano del aurea mediocritas?

Uno de los momentos más intensos e importantes de la narración es, como ya hemos dicho, el asesinato de Tunstall. La muerte de aquella persona admirada por Billy — de forma inesperada, en realidad-y el no poder acostumbrarse a la idea le harán expresar a Sender uno de los razonamientos más profundos de la novela:

Las grandes desgracias cuando nos cogen de sorpresa traen consigo una especie de lenitivo que consiste en hacerse irreales. No reaccionamos por medio de la desesperación ni del llanto porque sencillamente nuestra naturaleza nos invita a no creer en lo que tenemos delante.

No sólo la desgracia sino el mal — todo mal posible - se hace irreal desde el primer momento y el creer en él lleva mucha reflexión y largos espacios de tiempo. (pp. 81-82)

Es sin duda todo un tratado de conocimiento del alma humana, fruto de un ser observador lleno de sabiduría.

Continúa Sender ofreciéndonos observaciones curiosas de todo tipo:

La iniciación amorosa de Billy había sido con ella [una mestiza]. Fue algo a un tiempo deslumbrador y fútil. Un lujo. Sin saberlo coincidía Billy con los biólogos en aquella opinión: el coito es el lujo del organismo humano, solían decir los doctores solemnemente ya entonces en sus academias o en sus libros de texto. Un lujo. ¿Pero és sólo para esos lujos para los que vive el hombre? (p. 83)

Riendo con sus amigos, Bowdre dijo algo ofensivo y sucio contra Jesse, pero Billy le atajó:

-No hables así, Bowdre, que cuanto más vale el enemigo más vales tú. (p. 93)

Muchos hombres al hacerse viejos se acercaban a la gente de papel sellado como otros se acercaban a la iglesia. (p. 99) 
Tenía Chisun la tendencia a lo impersonal que suelen tener los ricos de la ciudad cuando hablan con sus inferiores. La gente pobre siempre es personal en sus conversaciones. Billy no era ni pobre ni rico. Sus temas de conversación eran imprevisibles [...]. (p. 103)

Se sentía Billy derrotado, pero no vencido, ya que sólo está vencido en la guerra el que acepta los términos del vencedor, según las normas de los viejos tiempos. (p. 113)

La abstinencia de amor durante largos periodos hacía de aquellos hombres, a veces, gente más dura todavía y esquinada. Sabido es que el comercio de la mujer suaviza, domestica y civiliza al macho y por eso los libertinos amorosos suelen ser gente amable en todas partes.

En los pasados siglos un hombre adamado no era un tipo de aire equívoco, sino suavizado por la demasiada frecuentación de la dama. (p. 133)

Ante el robo de un caballo de Billy por Melba y comentar ella jocosa que había robado a un ladrón, él, serio, le dirá: «-iCuántas veces te voy a decir que yo no soy ladrón? El que pone limpiamente su vida en la aventura ése no es ladrón, sino guerrillero o conquistador. Tú eres la ladrona que te llevaste el caballo sin arriesgar nada» (p. 151). Junto a las explicaciones de todo tipo, Sender nos ofrece sus clasificaciones. Aquí tenemos la de los bandidos: «Era Tom un bandido urbano de taberna, población, burdel, casa de juego. El campo lo ponía melancólico [...]» (p. 46).

\section{EL ROMANCERO Y EL CANCIONERO}

Ya nos hemos referido, al hacer nuestra valoración de El bandido adolescente, a su carácter de poema épico en prosa. Sender lo tiene en mente y lo expresará en alguna ocasión. Así, cuando Billy, joven de doce años, sale en defensa de su madre, el comentario es: «La primera aventura del muchacho fue digna del romancero» (p. 12). Estamos seguros de que aquí nos está dando la clave del resto de la historia. Más tarde las alusiones y citas de los cancioneros populares también son numerosas; termina la novela, en realidad, con un gran canto de las aventuras de Billy y los suyos. Veamos los ejemplos:

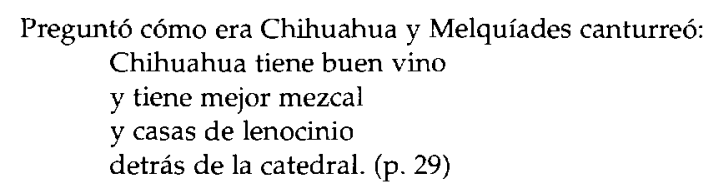

En New México hay baladas que recuerdan los hechos de heroísmo de sus hombres famosos y en esos romances los caballos tienen a veces un papel lucido: Corre caballo en las horas sin luz de la madrugada... (p. 44)

Más adelante tendremos pasajes que nos recuerdan las enumeraciones y retahílas que hallamos en los poemas épicos clásicos: «El día nueve de 
marzo el juez Bruer dejó el rancho de Chisun con su comitiva y sus presos. Iban las siguientes personas: el constable Skurlock [...]» (p. 71), y así hasta una docena de nombres. En la página 84 volverá a repetir esta fórmula, ahora aún más clásica si cabe: «Los que iban con Billy eran el tostado y flaco Bowdre - más mexicano que los de Veracruz-, el silencioso Brown, Skurlock, que dio de beber al agonizante en la calle, John Middleton y Tom Folliard, este último un aventurero de Texas que había acudido a la fama de Billy [...]». Incluso habrá una referencia al medioevo: «Igual que los nobles en la Edad Media, comenzaba el Kid a percibir tributos de algunos pecheros» (p. 140). Entre las páginas 237 y 242,7 podremos leer trozos del denominado "corrido de Folliard", compuesto de forma popular y colectiva, más cuatro versos de una posible canción: «... yo soy el mero pistolo / Juan del Río, mexcalero, / y si no me puede ver / arremánguese el sombrero". Al final (pp. 248, 249, 250), la novela terminará con la escena popular y espontánea de la creación de un "alabado» durante el funeral del joven, que podría denominarse «Romance de Billy».

\section{BESTIARIO COMPARATIVO}

Creemos también interesante señalar el gusto de Sender por comparar constantemente a los personajes con animales varios. Hay todo un muestrario. Es más, ya sabemos que para Billy, reconocer en la cara de una persona a un animal era sinónimo de muerte. Y así lo expresará él mismo:

\footnotetext{
--Todo era Tunstall para mí y los que estaban presentes cuando lo mataron me han enseñado su hocico de animales salvajes antes de vomitar su sangre. Todos. Porque no sé si tú lo sabrás, Jesse, pero a mí cuando una persona me enseña su máscara de animal salvaje es que ha entrado ya en la cuenta secreta. (p. 136)
}

Refiriéndose a su amigo Evans: «Admiraba Billy su franca y violenta amoralidad, pero sabía que los animales albinos (caballos blancos, perros y gatos blancos) tienen taras contra las cuales hay que precaverse» (p. 36). En la página 82 , se nos narra cómo Billy halla parecidos con animales a los enemigos muertos. Tendrán cara de «chipmunk», apariencia de «ave con ala rota», de un "gato ahogado», de «caballo con dientes descubiertos y amarillos». Los ejemplos se repiten, aunque sólo añadiremos dos más, muy representativos también:

Y me dijo un día: «Billy, hay muchas clases de seres vivos. Y usted y yo pertenecemos a la misma casta. ¿Qué casta? La de una clase de elefantes que en la India llaman roguesw. (p. 165)

\footnotetext{
7 En la nota a pie de página (p. 229), hay otra referencia muy significativa al interés del romancero en la creación literaria de Sender.
} 


\begin{abstract}
¿Cómo iba a ser pato un cristiano con nombre de persona? Pero el tolentino -explicaba el mejicano- era un macho cabrito que sacó aquella otra copia en honor de su tío. (p. 242)
\end{abstract}

\title{
OTRAS REFERENCIAS
}

Para terminar, deseamos hacer referencia a dos aspectos un tanto marginales, pero que no dejan de tener su significado:

a) Complejo de Edipo

Señalemos el comentario a la actitud de Billy con respecto a su padrastro y la apostilla personal de que no va a extenderse en el posible complejo de Edipo del joven: "Se instaló la familia en las afueras de Santa Fe y el muchacho comenzó a odiar a su padrastro y a amar a su madre, pero no voy a hablar del complejo de Edipo aunque decepcione a alguno» (p. 8). Es cuando menos interesante que Sender mencione este complejo y más cuando sabemos que tuvo sus propios problemas a este respecto. ${ }^{8}$

b) Notas a pie de página

Cosa extraña y señal de peculiaridad de esta novela son las notas aclaratorias que aparecen a pie de página: en la página 95, esa nota sobre lo que se consideraba turco en la España del siglo XVII y su paso a Hispanoamérica, y, a partir de la página 192, las notas con indicaciones de los lugares en los que le han mostrado diversas calaveras de Billy. Esto le dará motivo para hacer comentarios jocosos sobre esas reliquias extrañas y mostrarnos su erudición, regalándonos con citas poéticas de muy diversa procedencia como la Biblia o poetas ingleses.

Terminamos este trabajo con unas breves líneas a modo de conclusión. En las páginas precedentes, creemos haber dejado claro que la recreación de la vida y andanzas de Billy, "el Niño", alcanza en la novela de Sender dimensiones que sobrepasan lo puramente novelesco. Nos atreveríamos a decir que es un pretexto más para adentrarse en aspectos de la convivencia humana y convertir la amistad, la lealtad, la vida y la muerte en los personajes principales de la narración.

\section{BIBLIOGRAFÍA}

CARRasquer, Francisco, La verdad de Ramón J. Sender, Leiden-Tárrega, Ediciones Cinca, 1982. —, La integral de ambos mundos: Sender, Zaragoza, Prensas Universitarias de Zaragoza, 1994.

\footnotetext{
${ }^{8}$ Hay referencia a este complejo, por ejemplo, en el libro ya citado de Francisco CARRASQUER, p. 23: «[B. Diferencias.] 2ª . Entre Sender-Samblancat y Aláiz: Tanto Sender como Samblancat parecen haber tenido con la familia relaciones de franca hostilidad (o con parte de la familia). De la obra de Sender podríamos entresacar docenas de alusiones directas o indirectas de su odio edipiano».
} 


\section{EL LUGAR DE SENDER}

DELGADO, Feliciano, Reseña, 3/12 (abril de 1966), pp. 114-115.

KING, Charles L., [Reseña], Hispania, 50/2 (mayo de 1967), p. 389.

PONCE DE LEÓN, José Luis, «Ramón Sender, español sobre fronteras», Estafeta Literaria, 344 (21 de mayo de 1966), pp. 15-16.

RoIG, J. A., [Reseña], Razón y Fe, 2/824-825 (septiembre-octubre de 1966), pp. 276-277.

SENDER, Ramón J., El bandido adolescente, Barcelona, Destino, 1987 ( $6^{\mathrm{a}}$ ed.).

—. El bandido adolescente, prólogo de Rafael VÁzquez Zamora, Pamplona, Salvat, 1982. 


\title{
De Siete domingos rojos a Las Tres Sorores: un proceso de reescritura
}

\author{
José Miguel Oltra Tomás \\ Universidad de Zaragoza
}

\begin{abstract}
De todos es bien conocida la constante preocupación de Ramón José Sender por reescribir y refundir obras anteriormente editadas y conocidas, ${ }^{1}$ transmitiéndonos la imagen arquetípica del escritor desvelado por conseguir la fijación de los textos que mejor revele su perfil a la posteridad. ${ }^{2}$ De uno de estos procesos de constante reescritura quisiera ocuparme, aunque bien brevemente, con el objeto de centrar la evolución de su

\footnotetext{
${ }^{1}$ Desde El verdugo afable hasta Crónica del alba los ejemplos pueden ser abundantes, lo que ya se ha señalado tempranamente; reescrituras más amplias pudieran ejemplificarse en Jubileo en el Zócalo o Tres novelas teresianas. Remito al trabajo de Carole ADAM, «The Re-use of Identical Plot Material in Some of the Novels of Ramón J. Sender», Hispania, 43 (1960), pp. 347-352. 2 En el prólogo a la segunda edición de Siete domingos rojos (Buenos Aires, Proyección, 1970, p. 8), Ramón J. SENDER escribió: «En realidad, una novela, como un poema, no está acabada mientras vive su autor. Sólo hay que tener en cuenta las últimas ediciones de los poetas que ya nos dejaron y las de las novelas de los que vivieron antes que nosotros. Espero que si alguien quiere acordarse de mí en el futuro, sean estas últimas ediciones las que tome en consideración. Pero si no es así, estará en su derecho y a mí no me importa gran cosa [...]»; este derecho de lector es el que ejerció Francisco CARRASQUER en «¿El derecho de autor frente al deber de enmienda?», Camp de l'Arpa, 17-18 (febrero-marzo de 1975), pp. 18-20; reed. en La verdad de Ramón J. Sender, con bibliografía de Elizabeth EspaDAS, Leiden-Tárrega, Ediciones Cinca, 1982, pp. 48-57.
} 
perfil ante la historia. El caso que propongo me parece representativo por varias razones: en primer lugar, por abarcar la casi totalidad de la vida de Sender como escritor; en segundo, por afectar a su aspecto ideológico más representativo, el anarquismo; finalmente, por la transcendencia que la última versión alcanzó en su viaje a España, el viaje a los orígenes que emprendió en 1974.

Expongamos sucintamente la cuestión de los textos y su significación. En 1932 - dos años después de la publicación de Imán, su primera gran novela-, Sender entrega en la Colección Balagué, de Barcelona, los Siete domingos rojos, sin duda una de sus novelas más comprometidas y entreverada de datos autobiográficos y abundantes recuerdos literaturizados. ${ }^{3}$ En ella el autor muestra una militancia anarcosindicalista inequívoca, ${ }^{4}$ aun cuando se halle «en trance de despedida», como en numerosas ocasiones se ha señalado. ${ }^{5}$ El alter ego de Sender en la novela, el periodista Lucas Samar, es un sujeto lúcidamente consciente del fracaso al que se ve abocado, así como de la frustrante inviabilidad del anarquismo, esterilizado en cuestiones bizantinas, para articular una alternativa real de poder. Por esta época en que se publica Siete domingos rojos, nuestro escritor experimenta una aproximación al Partido Comunista, aún minoritario pero de sólida estructura organizativa y férrea disciplina al servicio de una estrategia posibilista, aspectos que más le atraerán en su apariencia. ${ }^{6}$

3 Buena muestra de este proceso de literaturización se desgrana entre las páginas del Álbum de radiografias secretas (Barcelona, Destino, 1982), revelándonos la personalidad histórica de algunos de los personajes de su novela. No obstante, quedamos a la espera de la necesaria biografía senderiana que sólo Jesús Vived puede realizar con el rigor y la dedicación que la empresa merece.

${ }^{4}$ Especialmente, remito a los estudios de Michiko NONOYAMA, «La visión del anarquismo español en Siete domingos rojos", en Homenaje a Ramón J. Sender, ed. Mary S. VÁsQuez, Newark, Delaware, Juan de la Cuesta, 1987, pp. 47-62; Patrick Collard, Ramón J. Sender en los años 1930-1936. Sus ideas sobre la relación entre literatura y sociedad, Gante, Rijksuniversiteit, 1980, pp. 163-169, especialmente; y Francis LouGH, The Early Novels of Ramón J. Sender, Ph. D., University of Salford, 1985, pp. 127-162. También, aunque poniendo mayor énfasis en el conflicto interno del protagonista/autor, Anne BuYs, «Siete domingos rojos (1932) de Ramón José Sender: un compromiso político-social y un conflicto existencial», Ibero-Romania, X (1979), pp. 112-127.

${ }^{5}$ En especial, Patrick COLlaRd (op. cit., p. 163) se distanció prudentemente de quienes interpretaban Siete domingos rojos como visión exegética del anarquismo. Aunque no de forma tan explícita, también Eugenio DE NORA (La novela española contemporánea, Madrid, Gredos, 1968, vol. II, pp. 468-469) y Anne BuYs (art. cit., pp. 119-120; también «Ramón José Sender y Siete domingos rojos: tres etapas en la evolución ideológica de un autor exiliado», Boletín de la Asociación Europea de Profesores de Español, XVII [1977], pp. 103-104). Abundo en esta tesis en mi artículo "A propósito de la intención del estilo en Siete domingos rojos (1932), de R. J. Sender», pp. 115-116 (Style et image au XXème siecle, en Hispanística XX, 11 [1984], pp. 113-132).

6 El mismo Patrick COLLARD (op. cit., pp. 48-54) ha puesto de relieve la aproximación, entre 1933 y 1936, al Partido Comunista, así como las contradictorias declaraciones de Sender al respecto en los años 70. Tan debatido aspecto es elucidado por Antonio ElorzA en las páginas de estas mismas Actas; después de una intensa investigación en las fuentes pertinentes, parece que la relación de Sender con el PCE no fue más allá de la de un «compañero de via- 
Esta primera edición presenta ciertas deficiencias; unas habremos de achacarlas a la casa editora (alguna errata; la puntuación, de otra parte, es desastrosa, quizá debido a la prisa con que se imprimió); otras, por contra, sólo son imputables al autor. ${ }^{7}$ Sin embargo, aun a pesar de sus fallos, Siete domingos rojos muestra el carácter de recio novelista de Sender, con espléndidos fragmentos de escritura desatada, portadora de una extraña fuerza que tiene su origen en las telúricas entrañas del «hombre natural». Por muchos conceptos, me parece que la adecuación entre «ideología» ${ }^{8} \mathrm{y}$ escritura alcanza un grado más que satisfactorio. Tratándose del anarquismo, el narrador no es uno solo, sino varios; estamos, pues, ante una obra polifónica (multiplicidad de voces y armonía entre las mismas; sólo la nota discordante es aportada por una luna personificada que coadyuva al triunfo de la represión). En cualquier caso, destaca el hecho de ser una novela escrita desde el interior de los acontecimientos narrados; esto es, el distanciamiento histórico, intelectual y afectivo con respecto a la trama es nulo. Como decía, en muchos sentidos es una obra testimonial y autobiográfica, esto último en su más profunda dimensión: autobiografía externa y autobiografía anímica y espiritual. En síntesis, un ejemplo espléndido de literatura comprometida con presencia lírica notable, cuya novedad fue percibida ya por Cansinos Assens en esa excelente serie de artículos publicados en La Libertad, a comienzos de 1933, «Ramón J. Sender y la novela social». ${ }^{9}$

je» al que se intentó manipular y del que se receló. En las páginas del Álbum de radiografias secretas, por muchos conceptos "testamento" literario de un autor terminal, manifiesta su decepción con el comunismo (p. ej., p. 320).

7 En el aspecto estilístico, ciertas redundancias y algunos anacolutos e impropiedades sintácticas, cuestiones que se le han afeado a nuestro escritor en múltiples ocasiones. En un terreno más amplio, en el de la técnica novelística, también se producen ciertas deficiencias, tal vez resultado de una inexperiencia de quien no hacía mucho se había iniciado en la novela. Un ejemplo: el descontrol narrativo del tiempo induce a un confusionismo impropio de la técnica novelística; baste, como muestra más aparente, la distribución de los "domingos rojos» en cada una de las tres versiones que conocemos de Siete domingos rojos. En Las Tres Sorores la cuestión se diluye ante la presencia de un tiempo más amplio, sobre todo en el tercio final de la novela.

8 Entiendo por «ideología» una superestructura mental con la que un narrador -que no autor- se identifica, aunque sea de forma ficticia, puesto que ningún escritor está obligado a identificarse con la expresión de todos y cada uno de sus narradores. Bien pudiera considerarse contradictorio cuanto digo con lo que afirma Sender en su confesión a Marcelino PeÑuelas (Conversaciones con Ramón J. Sender, Madrid, Magisterio Español, 1965, p. 169): «La novela seguirá siendo, como lo ha sido hasta ahora, un medio directo de expresión de la naturaleza del hombre. No del protagonista de la novela, sino de la naturaleza del autor". Pero la no discriminación de Sender entre autor y narrador no impide que la ficción (en términos de teoría literaria) imponga una ideología del narrador que no coincida con la del autor.

${ }^{9}$ Publicados los días 4, 8, 19, 25 y 31 de enero y 9 de febrero de 1933; reproducido íntegramente en Ramón J. Sender. In memoriam. Antologia crítica, ed. José-Carlos MAINER, Zaragoza, Diputación General de Aragón, Ayuntamiento de Zaragoza, Institución Fernando el Católico y Caja de Ahorros de Zaragoza, Aragón y Rioja, 1983, pp. 37-61. 
Pasemos a la segunda edición de Siete domingos rojos, aparecida en 1970, en la Editorial Proyección de Buenos Aires. La confrontación de las dos ediciones muestra, como también es conocido, un nuevo texto corregido. ${ }^{10}$ Las correcciones persiguen, en numerosos casos, objetivos no muy diferentes de lo que suele ser normal en estas circunstancias: corrección de erratas, fijación más académica de la puntuación, correcciones de errores (léxicos y sintácticos), etc. Pero este tipo de modificaciones tiene poca relevancia frente a aquellas que sí suponen una alteración profunda del texto primitivo. De forma sintética, las modificaciones ${ }^{11}$ detectadas permiten ser clasificadas en tres grupos: modificaciones por adición, modificaciones por supresión y modificaciones por sustitución.

Comencemos por las últimas, las modificaciones por sustitución. Son éstas las más simples, puesto que el procedimiento sólo permite la sustitución de un término por otro o de unos escasos términos por otros: el objeto de las mismas es afinar estilísticamente el texto, bien porque se persigue alguna corrección sintáctica, ${ }^{12}$ bien porque se procura una mayor variedad léxica (huyendo de alguna redundancia), ${ }^{13}$ ya porque se juzgan impropios algunos términos, ${ }^{14}$ ya por un simple cambio en el gusto per-

\footnotetext{
10 Téngase presente que en los prolegómenos legales de la edición, el copyright, se lee: «Nueva versión, revisada y corregida por el autor, para esta edición 1970 ". Sin duda que lo es.

11 Rehúyo deliberadamente el término clásico de la crítica textual, el de variante, puesto que algunas modificaciones suponen un claro ejemplo de reescritura que nada tiene que ver con los problemas que afectan en la filología clásica a la transmisión de los textos.

12 Sirva como muestra la corrección siguiente: «Y no me convencieron, porque cuando salía yo me sentía algo republicano" (Barcelona, 1932, p. 15) / "Y no me convencieron, aunque cuando salía yo me sentía algo republicano» (Buenos Aires, 1970, p. 17); el sentido se hace coherente en boca de un anarcosindicalista como Villacampa en la segunda edición. Destacan, por su número, ciertas correcciones del leísmo: «No sabe la viga de intereses generales [...]. Le ayudan en el centro de la sala dos columnas ágiles y redondas que también hablan ese lenguaje» (Barcelona, 1932, p. 20) / «No sabe la viga de intereses generales [...]. La ayudan en el centro de la sala dos columnas ágiles y redondas que también hablan ese lenguaje» (Buenos Aires, 1970, p. 21); o bien: "Le llaman Al Capone y le va muy bien» (Barcelona, 1932, p. 29) / «Lo llaman Al Capone y le va muy bien» (Buenos Aires, 1970, p. 28).

13 Vaya algún ejemplo: Villacampa, tras dirigirse en varias ocasiones al «presidente del Gobierno" en la sesión inaugural de las Cortes republicanas (Barcelona, 1932), sustituido por el "secretario primero" (Buenos Aires, 1970) —vid. nota siguiente-, se dirige en un momento preciso a otra persona: «Al salir, en los pasillos me acerqué al Presidente otra vez y le pregunté si creía que todo aquello serviría para algo" (Barcelona, 1932, p. 15) / "Al salir, en los pasillos me acerqué a un ujier y le pregunté si creía que todo aquello serviría para algo" (Buenos Aires, 1970, p. 17). En medio del estrépito que hace fracasar el mitin, un solitario altavoz proclama: «—iBárbaros! ¿Qué hacéis? ¿Y el espíritu? ¡Acordaos del espíritu!» (Barcelona, 1932, p. 32) / «-¡Bárbaros! ¿Qué hacéis? ¿Y el espíritu? ¡Acordaos de los valores espirituales!» (Buenos Aires, 1970, p. 30). Pueden documentarse numerosos casos.

14 Otros ejemplos, entre los muchos: Villacampa abandona el medio familiar por las disputas entre sus padres: «Mi padre al llegar un día de la Iglesia tuvo una bronca con mi madre y la mató a palos» (Barcelona, 1932, p. 12) / "Mi padre al llegar un día de la iglesia tuvo una bronca con mi madre y le dio una paliza" (Buenos Aires, 1970, p. 15); poco más adelante se produce una sustitución paralela: «Lo mismo podían celebrar el suceso que motivó mi salida de la casa de los padres: "El marido mata a palos a su mujer antes que permitir la más ligera tras-
} 
sonal. ${ }^{15}$ Estas modificaciones suelen afectar a sustantivos y adjetivos principalmente, aunque verbos, adverbios y preposiciones no queden ajenas a las sustituciones. Cualitativamente, destacaría la sistemática sustitución de la voz burgués ${ }^{16}$ _y sus derivados - por términos más matizados, pero retraso un poco su análisis, pues debo indicar que este problema nos ocupará una parte interesante en las modificaciones por supresión.

Constituyendo el grupo más importante cuantitativamente tenemos las modificaciones por supresión. Dentro de éstas, la voluntad dominante es la de esencializar el relato, despojándolo de cuanto se considera superfluo o poco ilustrador del núcleo narrativo. Desaparecen de Siete domingos rojos fragmentos, frases o palabras que Sender considera prescindibles, sobre todo porque quizá fuera consciente de esa tendencia que se le achaca desde un sector de la crítica de propender a lo discursivo y teórico. Resulta difícil no coincidir con el autor en la prescindibilidad de algunos fragmentos elididos. ${ }^{17}$ Pero algunas de estas supresiones también se me antojan significativas, no tanto desde el punto de vista estrictamente literario como desde el ideológico. Sender procura la sensación de estar interesado en atenuar el sentimiento visceral de su anarquismo original,

gresión de la moral familiar"» (Barcelona, 1932, p. 17) / "Lo mismo podían celebrar el suceso que motivó mi salida de la casa de los padres: "El marido le pega a su mujer antes que permitir la más ligera trasgresión de la moral familiar" (Buenos Aires, 1970, p. 18). El mismo Villacampa, cuando asiste a la sesión inaugural de las Cortes republicanas, merodea entre los asistentes: «Luego fui al que llamaban presidente del Gobierno y hablé con él» (Barcelona, 1932, p. 14) / "Luego fui al que llamaban secretario primero y hablé con él» (Buenos Aires, 1970, p. 17). O bien, cuando el narrador explica la trayectoria de los tres anarquistas muertos: «El secreto de Espartaco para mantener la paz familiar era lo que él llamaba - lo había leído en un folleto- la coacción moral» (Barcelona, 1932, p. 38) / «El secreto de Espartaco para mantener la paz familiar era lo que él llamaba - lo había leído en un folleto- la influencia moral» (Buenos Aires, 1970, p. 35). También, en este caso, los ejemplos son numerosos.

15 Algún ejemplo puede ayudar: el panegírico sobre los tres obreros muertos incluye alguna variación del narrador: « $i[.$.$] soñaban con una sociedad más justa edificada sobre realidades$ vivas y no sobre mentiras espiritualistas e intelectualistas?» (Barcelona, 1932, p. 37) / « ¿...] soñaban con una sociedad más justa, edificada sobre realidades vivas y no sobre mentiras moralizantes?» (Buenos Aires, 1970, p. 34). En otras ocasiones, la sustitución pertenece, más bien, a la esfera de lo subjetivo: «Una mujer envuelta en tules, con un seno fuera, llora sobre la almohada» (Barcelona, 1932, p. 68) / «Una mujer envuelta en tules, con un pecho fuera, llora sobre la almohada» (Buenos Aires, 1970, p. 57); la misma sustitución: (Barcelona, 1932, p. 88) / (Buenos Aires, 1970, p. 69).

16 Anne BuYs («Ramón José Sender y Siete domingos rojos: tres etapas en la evolución ideológica...», cit., p. 102) califica la novela senderiana de 1932 de "crónica tendenciosa en favor de la clase obrera". Entre otros elementos que analiza figura la voz burgués (que registra en más de cien ocasiones), siempre con connotación negativa o peyorativa; en la edición de 1970, la palabra desaparece en 82 ocasiones o es sustituida por voces neutras. Insiste en denominar Siete domingos rojos como relato tendencioso («Siete domingos rojos (1932) de Ramón José Sender: un compromiso político-social...», cit., p. 114), repitiendo su análisis sobre la misma voz (p. 115).

17 Los pasajes eliminados son numerosísimos; su frecuencia y longitud aumentan de principio a fin de la novela. No reproduzco ejemplos para no descontextualizarlos en la síntesis resultante. 
poco matizado en sus manifestaciones, no sólo individuales, sino colectivas, en aquellos años tan turbulentos de finales de la Dictadura de Primo y de la República. ${ }^{18}$ Representativa de esta preocupación pudiera ser la actitud que Sender toma ante la virulenta y negativa utilización del término burgués y sus derivados: lo que en 1932 representaba la oposición a cualquier forma de progreso - un insulto terrible que ningún ácrata podía soportar - en 1970 ha perdido sobre todo la emotividad conflictiva (no creo que podamos extrapolar consideraciones personales del autor sobre su posición en la sociedad en un momento y otro, cuando menos de manera determinante). La actitud más generalizada en Sender es la de la supresión de la voz en funciones adjetivas o la de la sustitución, en las sustantivas. ${ }^{19} \mathrm{Al}$ respecto, no podemos descartar que la perspectiva histórica

18 Si cotejamos la «letanía de la Virgen Joquis» en una y otra ediciones (pp. 269-270 y 183-184, respectivamente), los exabruptos y las deprecaciones quedan muy atenuados en la edición de 1970. Por supuesto, en la "reescritura» de 1974 (Las Tres Sorores) desaparecen por completo. Otro ejemplo, bien breve, de los muchos que pudieran alegarse: «Parece que debíamos limitarnos a hacer una huelga lo más completa posible. Pero, en cuanto salimos a la calle y vemos un guardia sentimos la necesidad de matarlo. La organización está detrás dispuesta a ir siempre adelante» (Barcelona, 1932, p. 101) / "Parece que debíamos limitarnos a hacer una huelga lo más completa posible. Pero la organización está detrás, dispuesta a ir siempre adelante» (Buenos Aires, 1970, p. 77), con lo que se altera la lectura final, además de ser significativo el sintagma suprimido.

19 Veamos ejemplos de supresión y de sustitución. Supresión: «Ya está el presidente en su puesto. Y periodistas burgueses — ¿a qué vendrán? - que fingen en su mesa de trabajo del escenario una curiosidad de parque zoológico" (Barcelona, 1932, p. 29) / "Ya está el presidente en su puesto. Y periodistas - - ¿a qué vendrán?- que fingen en su mesa de trabajo del escenario una curiosidad de parque zoológico» (Buenos Aires, 1970, p. 28); «[...] pero han salido [los altavoces] con curvas finas y suaves, femeninos y burgueses. Los altavoces sabotean el mitin hablando por su cuenta» (Barcelona, 1932, p. 32) / «[...] pero [los altavoces] sabotean el mitin hablando por su cuenta» (Buenos Aires, 1970, p. 30); “No quería complicar la limpieza y sencillez de sus conceptos sobre la revolución con una doctrina que se le hacía sospechosa de intelectualidad burguesa» (Barcelona, 1932, pp. 38-39) / «No quería complicar la limpieza y sencillez de sus conceptos sobre la revolución con una doctrina que se le hacía sospechosa de intelectualidad» (Buenos Aires, 1970, p. 35). Sustitución: «¿Cómo se le habla a un burgués en la cubierta de un barco anclado en plena calle de una ciudad castellana?» (Barcelona, 1932, p. 22) / «Cómo se le habla a un empresario en la cubierta de un barco anclado en plena calle de una ciudad castellana?» (Buenos Aires, 1970, p. 23); "Sigue el altavoz: "Las vilezas de la burguesía, siempre dispuesta a mantener sus privilegios se acumulan sobre la vida del proletariado [...]" (Barcelona, 1932, p. 30) / "Sigue el altavoz: "Las vilezas de la reacción, siempre dispuesta a mantener sus privilegios, se acumulan sobre la vida del proletariado [...]" (Buenos Aires, 1970, p. 29). Cuanto acabo de señalar no implica la existencia de una regla fija, habiendo casos de sustitución en funciones adjetivas y de supresión en las sustantivas: «En cambio mi pequeña burguesa, Amparo, cree que la fecundación se produce por un beso» (Barcelona, 1932, p. 89) / «En cambio, mi novia Amparo cree que la fecundación se produce por un beso» (Buenos Aires, 1970, p. 70). De la otra manera: «-Que el ejército y la idea de patria son para defender a la burguesía y para tenernos más esclavizados» (Barcelona, 1932, p. 40) / «-Que el ejército y la idea de patria son para tenernos más esclavizados» (Buenos Aires, 1970, p. 36); "Ahí está tu padre. Ha muerto. Tienes razón. Lo ha asesinado la burguesía. Ya no lo oirás hablar nunca» (Barcelona, 1932, p. 51) / "Ahí está tu padre. Ha muerto. Tienes razón. Lo han asesinado. Ya no lo oirás hablar nunca" (Buenos Aires, 1970, p. 44). 
adquirida con el paso del tiempo haya impuesto un análisis más matizado sobre las voces usadas, despojándolas de la «tendenciosidad» que procuraba la inmersión en los mismos acontecimientos narrados en 1932.

Pero también entre las supresiones destaca la desaparición de capítulos enteros y la fusión de otros, sobre todo en el último tercio de la novela, lo que supone una alteración en el resultado final de la misma. La abreviatio de la retórica clásica se hace cómplice de una voluntad extratextual, en nuestro caso. De forma sintética la situación es como sigue: hasta el capítulo XVIII se produce una coincidencia básica entre las ediciones de 1932 y 1970. En el capítulo XVIII empiezan a producirse alteraciones importantes: si en la edición príncipe la visión del mapa de España por Samar y la "virtuosa» Emilia tiene lugar desde la perspectiva poética de una balaustrada cósmica, en la edición de 1970 se impone una visión más descriptiva de tal mapa en relieve.$^{20}$ Bien es cierto que a esta consideración ayuda el hecho nada inocente, desde el punto de vista narrativo, de que el narrador omnisciente explicite o no al comienzo del capítulo la situación espacial de los dos personajes; en el texto de 1932, sólo al final del capítulo se nos hace saber el «lugar» desde el que observan: «Están Samar y Emilia acodados en la barandilla que circunda un mapa de España en relieve, al final de la arboleda de la Moncloa" (p. 313); en la edición bonaerense, la precisión abre el capítulo: «Estábamos ${ }^{21}$ al lado de un mapa de España en relieve —en el suelo- en el parque del Oeste, en la Moncloa. Un mapa muy bien hecho, con montañas y agua "verdadera" en los mares, y litorales color gris-azul» (p. 205). Por otra parte, desde este momento las supresiones empiezan a ser mucho más largas y frecuentes, en alguna ocasión de hasta páginas enteras.

Los capítulos XIX y XXV de la edición de Balagué se suprimen enteros en la de 1970: se trata de la prisión de Liberto García, Elenio Margraf, José Crousell y Helios Pérez, por causa de la delación de Fau, ${ }^{22}$ así como del posterior asesinato de los mismos cuando son «trasladados», aplicándoseles de forma implícita la contestadísima y terrorífica «ley de fugas» de 1919.23 También desaparecen los cuatro capítulos finales en 1970, de los

\footnotetext{
${ }^{20}$ Conviene anotar también que los elementos líricos, más propios de un hacer poético, desaparecen gradualmente en los textos que estamos estudiando.

21 A pesar de la utilización de la primera persona del plural, se trata de un relato en tercera persona, como si el narrador "desconocido" $y$ omnisciente se ubicara junto al periodista y Emilia.

22 Se produce la chivata traición en la p. 186 de la ed. de 1932 y en la 129 de la ed. de 1970 (el nombre de Miguel Palacios no aparece estrictamente vinculado a los acontecimientos posteriormente narrados; estaba en los calabozos de la Dirección General de Seguridad en el momento en que se produce la muerte del policía que seguía a Samar, cuando éste preparaba el sabotaje de la línea de alta tensión). La vileza de la delación se nos antoja mayor aún al saber que es Urbano Fernández quien se desprende expeditivamente del entrometido agente que se apodera de la carta con el croquis dibujado.

23 Sender denuncia la vesania de tal ley en la p. 31 (ed. de 1932) y p. 29 (ed. de 1970).
} 
treinta que tiene la edición de 1932: en esencia, describen el languidecer de la huelga (y el triunfo de Villacampa), así como el alegórico sueño de Samar en la cárcel y la autoinmolación de éste provocando un amotinamiento suicida. ${ }^{24}$

Por otra parte, algunos capítulos son fusionados, concatenándolos y aligerándolos de digresiones y elementos secundarios del relato: así, los capítulos XX y XXI son fundidos en uno solo, dando origen al XIX de la edición de 1970. Se refieren los capítulos de 1932 a la muerte trágica de Casanova, el anarquista alienado por no tener una pistola, y a la detención del comité de huelga durante una reunión clandestina por la noche del cuarto "domingo rojo"; entre los detenidos se encontraba Samar, que es conducido al Cuartel de Artillería ${ }^{\circ} 75$, en presencia del coronel García del Río, padre de su novia. Por avatares del cargo, el coronel tiene que ausentarse de su casa cuartelera, momento que Samar y Amparo aprovechan para consumar su amor y tomar conciencia trágica de la imposibilidad de su relación, tras lo que el periodista huye con la complicidad de su novia. En la edición de 1970 desaparece la circunstancia de la detención de Samar y su conducción a presencia del coronel, así como el largo parlamento que ambos mantienen. Estamos ante una esencialización básica del relato, pero ello implica la pérdida de elementos y detalles que redondean el universo de la narración primigenia; de hecho, algunos de estos elementos serán posteriormente recuperados en Las Tres Sorores.

Otro tanto podría decirse de la refundición de los capítulos XXIII, XXIV y XXVI -recuérdese que el XXV desaparece- de la edición de Barcelona, originando el capítulo final, el XXI, en la de Buenos Aires. En la edición primera se nos narra la dramática visita de Star García a Amparo del Río y el posterior suicidio de ésta, inducido por la joven anarquista en el plano mediato; la recepción de la noticia en la prensa por Lucas Samar y las consecuencias alienatorias que tiene en éste; finalmente, la visita del periodista al Depósito de Cadáveres y el encuentro con el cuerpo inanimado de Amparo y los cuatro compañeros muertos (en aplicación de la aludida «ley de fugas»). Conviene añadir, llegados a este extremo, que Sender varía notablemente el final de su novela, puesto que en poco menos de una página (a modo de colofón que sustituye a los cuatro capítulos finales de 1932) se nos anuncia el destino de Samar, un suicidio frustrado:

Samar salió. Iba a escribir el manifiesto. Ya fuera, seguía viendo la sonrisa de Amparo. También ella se reía de él. Al menos era lo que él creía. Así y todo fue a escribir el manifiesto.

\footnotetext{
${ }^{24} \mathrm{El}$ proceso de aniquilamiento y vaciado interior como resultado del fracaso de la huelga y del suicidio de su novia Amparo - fracaso ideológico y amoroso, esto es, espiritual (otra voz muy suprimida o sustituida en la ed. de 1970)-, conduce al cumplimiento de la ley enunciada implícitamente por Star García cuando le entrega la bala grabada con las iniciales de ambos: S. G. y L. S.
} 
No pudo porque aquel mismo día lo detuvieron y lo enviaron a la cárcel. Dos días después consiguió un lápiz y se puso a escribir un manifiesto muy raro que comenzaba diciendo: «Por la libertad, a la muerte. Que es metafísica y sentimental y físicamente la única libertad posible».

Amparo la tenía ya y Samar quiso seguirla y gozar de ella - de la libertad-. Miró los barrotes de la reja y buscó su cinturón. No recordaba que se lo habían quitado los carceleros. También le quitaron los cordones de los zapatos, lo que le pareció innecesario porque con esos cordones no puede ahorcarse uno. (p. 240)

Así, el autor clausura narrativamente los dos «domingos rojos» finales, convirtiéndose de hecho en un relato de cinco domingos rojos. Sender, no obstante, establece un nexo con el final de 1932, mediante una pirueta de naturaleza exclusivamente dialéctica (puesto que los argumentos parecen servir tanto para una ocasión como para su contraria): cuando Samar, al frente del motín carcelario, camina hacia la muerte, exclama:

La guardia de la cárcel chascaba los cerrojos de los mausers, desplegada en la confluencia de las cinco galerías:

— jPor la libertad, a la muerte!

Iba a estallarles de entusiasmo el corazón dentro del pecho, bajo el estruendo:

— ¡Por la libertad, a la muerte! 472-473)

Que es - metafísica y sentimentalmente - la única libertad posible. (pp.

El final de la novela de 1970 se nos antoja incompleto, precipitado, máxime después de conocer el texto de $1932 ;{ }^{25}$ por supuesto que, cuando no mucho después reelabore la novela en Las Tres Sorores, Sender tendrá en cuenta este proceso de salvación del héroe, aunque para ello su novia -que ya no se llama Amparo, sino Elvira- sólo es víctima de un suicidio frustrado. Sin duda, casi cuarenta años después de escribir Siete domingos rojos, el autor la juzga excesivamente truculenta o trágica, ya no sólo alejada en lo ideológico. ${ }^{26}$ Este proceso de alejamiento y desactivación se había

\footnotetext{
25 Por cierto, no deja de ser un lapsus curioso el hecho de que Sender, en la edición de 1970 (firmada en Los Ángeles), feche al final la novela en Madrid, 1933, lo que se sigue manteniendo en la edición de 1973, también de Buenos Aires. Sin embargo, el final del «Prólogo a la primera edición", reproducido en las ediciones de 1970 y 1973, se fecha en Barcelona en 1932 , cuando en la primera edición nada se dice tras las iniciales «R. S.». No obstante, sí parece más grave que Sender reincida en tal inexactitud en el «Prólogo a la segunda edición»; puesto que extiende una mirada condescendiente y benévola sobre su pasado, solapándose en la baza segura de la también historia pasada, hemos de preguntarnos si tal error cronológico es consciente; ¿no será una manera de reafirmar su crítica hacia el anarcosindicalismo desde unas posturas que, aunque se omiten y posiblemente se desprecien en 1970, rechazaron lo que de incontrolable había en tan monumental movimiento de masas?

26 Como se comprenderá, no puedo estar de acuerdo con cuanto sostiene Anne BuYs («Ramón José Sender y Siete domingos rojos: tres etapas en la evolución ideológica...», cit., p. 105): “Ahora bien, el comentado descenso en volumen de la novela no altera la aventura
} 
iniciado mucho antes; en boca de Ramiro, el protagonista de El verdugo afable, publicada en 1952, ${ }^{27}$ Sender se justifica: «Acepto que el español que a los veinte años no es anarquista es un pobre diablo, pero el que sigue siéndolo después de los treinta es un idiota». Sin ningún afán acusatorio, sino más bien desde la comprensión del exiliado, debemos señalar que el factor sentimental jugará una importancia creciente.

En esta breve síntesis de los problemas textuales pasemos a las modificaciones por adición, aunque lo que hay que decir es mucho menos. Las adiciones son bastante escasas, si las comparamos con las supresiones o las sustituciones. En general, son mucho más breves que las supresiones y tienden a un reforzamiento de aspectos que pudieran parecer confusos al lector, bien como resultado de algunos pequeños fallos del texto de 1932 (incluidos los que pertenecen a la gramática), bien como necesidad de establecer tránsitos o puentes sobre los fragmentos desaparecidos en 1970. La voluntad dominante en las adiciones, por tanto, es la de reforzar la coherencia del relato, siendo mucho más inocentes que las supresiones. Tan sólo, si merece ser considerada como tal, la adición al final de 1970 puede tenerse como significativa, lo que ya he procurado señalar. Queda, no obstante, una adición importante: el breve «Prólogo a la segunda edición» (pp. 7-8). En este prólogo hay alguna afirmación sorprendente, al menos para mí, como la voluntad de realzar lo que la novela tenía de poético; también considera Sender que la estructura se refuerza, lo que no se consigue en la realidad. Pero también clarifica enormemente la concepción de la literatura que tenía nuestro autor por una época y otra. Destaca asimismo su apego creciente a la libertad como sentimiento individual, aunque insiste en que la única libertad posible es una libertad metafísica que nos llega con la muerte.

Sin embargo, esta edición de 1970 no es la única que Sender autorizó antes de la aparición del «texto definitivo» de 1974. Justo el año antes, también en la Editorial Proyección de Buenos Aires, aparece una nueva versión de Siete domingos rojos, aunque esta vez sólo «ampliada por el autor». $Y$, en efecto, de una ampliación se trata, puesto que añade tres capítulos enteros, que dan origen a una reordenación de la semana (volvemos a la explicitación narrativa de los siete domingos rojos). Por lo demás, no hay adiciones interpoladas con respecto al texto de $1970 \mathrm{ni}$, aún menos, supresiones o sustituciones. La impresión de 1973 se limitó al aprovechamiento de las planchas usadas en 1970, acomodándose la paginación, como es obvio, a los nuevos capítulos añadidos. Hasta el capítulo XVIII incluido, se reproduce exactamente el texto de 1970. El capítulo XIX es nuevo por completo, así como el XX; abren ambos el quinto «domingo rojo». En realidad, estos dos capítulos forman una unidad estructural con el XVIII, del

narrada; la modifica en la medida que alega una información reducida en cuanto a unos sucesos que no cambian en nada la esencia del relato».

27 Santiago de Chile, Nascimento, p. 142. 


\section{JOSÉ MIGUEL OLTRA TOMÁS}

que son continuación y desarrollo: tras la "visión cósmica» del mapa en relieve de España, aquel que se hallaba situado en el parque del Oeste, Samar y la "virtuosa» Emilia permanecen juntos reflexionando y durmiendo durante casi todo el día. Sender, incidiendo nuevamente en los aspectos más digresivos de la escritura, desarrolla su teoría de las dos Españas, la del castro y la colonial, fruto sin duda de sus largas reflexiones sobre la historia trágica de este país, reflexiones condicionadas por su carácter de exiliado. Consciente el autor de la naturaleza discursiva del relato, acude a fórmulas de parodia de las artes sermocinarias. ${ }^{28}$ Mucho le interesó a Sender el alcance de sus reflexiones porque, de forma casi literal, las incorporó posteriormente a Las Tres Sorores. Sin embargo, la preocupación por dar un desarrollo diferente a las relaciones de Samar y Emilia es bastante antigua en don Ramón; nos sorprende que no las hubiera modificado ya en la edición de 1970 . Según confesión de Sender, ${ }^{29}$ por los días en que estaba en el París prenazi, esto es, en 1938, y con la amistad de escritores como Céline, Blaise Cendrars o Jacques Roumain, Emilio Prados o Manuel Altolaguirre, comenzó a tomarse la literatura en serio, "cosa que no me había sucedido hasta entonces». ${ }^{30}$ Parece que el primer empeño de su nueva conciencia literaria fue la reescritura de nuestros Siete domingos rojos, empeño que no culminaría hasta 1974, como veremos. Pero, y leemos a Sender,

\footnotetext{
Además se me ocurrió intentar una proyección titulada Emilia sobre la persona de ese nombre que aparece en la novela. Me repetiría allí consciente $y$ deliberadamente. $Y$ a ser posible inspiradamente porque tomaba por vez primera la literatura en serio. El exilio me ofrecía perspectivas nuevas.

Fue entonces cuando comencé con Emilia. No escribí muchas páginas, pero me sirvieron para recordar mi conquista de Emilia, la linda mecanógrafa.

El lector recordará tal vez que en aquella novela anterior [...] el protagonista, Lucas Samar, entabla relaciones amistosas que se complican sexualmente con una mujer de veintinueve años que se llama Emilia.
}

\footnotetext{
28 Francisco CARRAsQUER ( ¿ ¿El derecho de autor...», cit., p. 19b) puso de relieve la naturaleza "molesta" de los comentarios que se engarzan en el viaje alegórico por las regiones de España. Con mucha mayor concisión obtendrá Sender en Las Tres Sorores (pp. 190-193) unos resultados mejores. No obstante, la parodia y el humor entreveran el largo parlamento de Samar, como si el autor fuera consciente de que algo fallaba estrepitosamente en su larga perorata de la versión de 1973: «-Tienes una verba de hombre de pro. ¿Qué quiere decir hombre de pro? - ¡Calla, coño! Cualquier español conoce a su compatriota como colonial o castrense [...]» (p. 214, ed. de 1973); o bien, más adelante: «-[...] Seremos felices o desgraciados, pero lo seremos todos juntos y trabajando en una misma dirección, si eso es posible aún. Ad majorem Dei gloriam. Y tú que lo veas, fémina dilecta. He dicho" (p. 218). Posiblemente Sender se dejó arrastrar por unas reflexiones que le apasionaban, fruto como digo de su visión histórica desde el exilio, ya asumido el desarraigo y preocupado por alcanzar la síntesis pacífica de los extremos que hagan posible la convivencia.

${ }^{29}$ Remito a cuanto escribe en el Álbum de radiografías secretas, cit., pp. 360-364.

30 Ibid., p. 360.
} 


\section{EL LUGAR DE SENDER}

En mi nueva novela yo quería extender y dramatizar esas relaciones con Emilia, que habían sido muchísimo más complicadas de lo que parece en las Tres Sorores (Siete domingos rojos). ${ }^{31}$

Después reproduce Sender las notas literales del esbozo de la nueva novela e indicaré que aquéllas nada tienen que ver en su desarrollo con lo que leemos en la edición de 1973, aunque sí con Las Tres Sorores, sobre la que volveremos más adelante. Pero también Sender sabía que algo fallaba en el proceso mental de su escritura por aquellos días: «Mientras escribía estas cosas en París yo sabía que no tendría ánimos para continuar y acabar la novela», 32 o más adelante, al final de su esbozo: "No escribí más. En París no podía sino vagabundear, discutir en los cafés y hacer el amor con Ania». ${ }^{33}$ En cualquier caso, lo que aquí y en este momento me interesa poner de relieve es la antigua preocupación senderiana por explorar y desarrollar nuevas posibilidades a partir de su texto de 1932, del que, al parecer, se quedó poco satisfecho.

El otro capítulo que añade en la edición de 1973, el XXII, marca el arranque del sexto «domingo rojo». La verdad es que resulta un tanto incomprensible la razón por la que Sender introdujo esta modificación: un largo discurso construido sobre extensos monólogos, podríamos decir, donde destacan dos núcleos esenciales, la futurista visión de los placeres del siglo XXI y la larguísima disquisición sobre el papel desarrollado por la CNT. Por varios conceptos, creo que se trata de una interpolación que rompe con cierta violencia con el conjunto de la novela. Sin embargo, varios de estos elementos pasaron posteriormente a integrarse en las Tres Sorores, sobre todo del primer núcleo señalado, aunque también del segundo, como el pergeño del personaje de Escartín, el primo de Leoncio Villacampa. Valorativamente pondría un especial énfasis en la reflexión histórica sobre el papel de la CNT, donde pone de relieve la vertiente sublime, pero también ridícula, que el movimiento anarquista encerraba; se trata de una crítica a tan formidable movimiento de masas, pero nada amarga, ni muchísimo menos, sino una crítica bondadosa y entrañable, fruto de un alejamiento emotivo propio del «héroe cansado», como señala José-Carlos Mainer sobre el Sender de estos años. ${ }^{34}$

Pasemos finalmente a Las Tres Sorores, la "remodelación" de los Siete domingos rojos -como la califica el mismo Sender-, 35 aparecida en noviembre de 1974, en la Editorial Destino de Barcelona. Volvemos a hallarnos ante la profunda preocupación senderiana por fijar su perfil ante la posteridad; llama la atención esta "reescritura" total de la novela de

\footnotetext{
31 Ibid., p. 361.

32 Ibid., p. 363.

33 Ibid., p. 365.

34 Léase la ponencia inaugural de las presentes Actas.

35 Así se expresa en Monte Odina, Zaragoza, Guara Editorial, 1980, p. 56.
} 


\section{JOSÉ MIGUEL OLTRA TOMÁS}

1932 un año después (aparece firmada en el colofón desde Niza) de la edición de 1973. ${ }^{36}$ Posiblemente Sender se halló bastante insatisfecho de los resultados obtenidos con esta penúltima versión y, tal vez, decidió tomar el problema de frente y buscar una solución definitiva a lo que hemos de considerar un ajuste de cuentas atingente al creador. Ciertamente, con el tránsito de los años, los Siete domingos rojos habían ido desnaturalizándose en las sucesivas versiones, convirtiéndose al final en un texto con quiebras sentimentales, ideológicas, estructurales y estéticas importantes. Replantea de nuevo toda la trama y la va a entreverar con una historia paralela sobre ciertos acontecimientos ocurridos en un convento de monjas bernardas a finales del siglo XVI. ${ }^{37}$ Sobre la obra de 1932 Sender introduce numerosas modificaciones, sometidas a un proceso único y continuo de escritura: Lucas Samar, que ya no es periodista, sino un estudiante de Filosofía y Letras de 29 años —voluntarioso estudiante, diría desde la perspectiva reticente de profesor universitario-, se convierte todavía más en el protagonista dominante de la novela, con lo que en cierto modo Las Tres Sorores deja de ser una novela de masas como es Siete domingos rojos. La técnica narrativa pasa a ser únicamente la del narrador omnisciente, en tercera persona, obviando su carácter de novela coral que tuvo en su origen. Adquiere, por otra parte, un mayor relieve la figura de Star García, ${ }^{38}$ quien termina por enamorarse abiertamente de Samar, lo que propicia un final completamente diferente: Samar y Star García acaban por constituir una pareja y unir su destino, mientras Elvira (antes Amparo), cuya importancia se ve aminorada en el texto de 1974, es víctima de un suicidio frustrado. La trama amorosa se impone sobre cualesquiera otras, reforzada

\footnotetext{
36 Un pequeño dato que llama la atención es que, después de aparecida la "versión definitiva" de Las Tres Sorores, todavía autorizó Sender la reedición de la tercera versión de Siete domingos rojos; por lo menos, en junio de 1975 y en junio de 1976 la Editorial Proyección de Buenos Aires reedita la novela. ¿Hemos de interpretar este hecho como la admisión por el autor de dos «novelas" diferentes? ¿Sólo habremos de ver una cuestión de rentabilidad sin mayor importancia? Lo que me parece descartable es que fueran razones políticas las que motivaran el mantenimiento de ambas, restringiendo la circulación de Las Tres Sorores al ámbito peninsular; pero esto no significa que esas razones políticas no aconsejaran la progresiva desvitalización ideológica de la novela de 1932, máxime cuando Sender había viajado a España a mediados de 1974 (vid. la crónica pintoresca de este regreso en Luz Campana DE WATTS, Veintiún días con Sender en España, Barcelona, Destino, 1976).

37 Esta trama paralela, como verdadero Guadiana narrativo, se entrecruza inoportunamente en el relato de los acontecimientos huelguísticos, sin aportar nada novedoso en lo simbólico, como parecería su objetivo. En realidad podría constituir una novela independiente, por lo que tal vez con severidad de juicio Francisco CARRASQUER (“¿El derecho de autor...?», cit., p. 20a) la calificó como "pegote».

38 Eva es el nuevo nombre de la adolescente anarquista, pero Eva «de Evarista o Evangelina, nadie más que su abuela lo sabía» (Las Tres Sorores, p. 39). También muda su nombre la Amparo de 1932, pasando a llamarse Elvira. Por tanto, podemos señalar que el triángulo amoroso de Samar queda constituido por tres $E$ (pues hay que añadir a Emilia). De alguna forma, este hecho se convierte en simbólico y paralelo a la pureza de las tres sorores (Ana, Clara y Pilar).
} 
por la «novela histórica» de las tres monjas bernardas. La acción anarquista es desviada hacia el grupo Espartaco (definido en pp. 15-17), al tiempo que Samar es descargado de muchos rasgos de militante radical y violento, por lo que nunca pasa por la cárcel. Aumentan los elementos digresivos, en especial reflexiones históricas, juicios literarios e incluso divagaciones de naturaleza mitológica. ${ }^{39}$ Asimismo, la inicial estructura sostenida sobre siete días de una ajetreada semana de huelga, desde su inicio hasta su fracaso, se diluye en Las Tres Sorores en una estructura más abierta, perdiendo su carácter de relato hermético y circular, difuminándose en un tiempo prolongado (se mantiene inicialmente la estructura sobre los siete días, pero el último tercio de la novela acumula el indefinido paso de los días). Otra diferencia notable es la intensa «aragonesización" de Las Tres Sorores, en la que se encierra una concepción de su tierra que la nostalgia había convertido en mítica.$^{40} \mathrm{Es}$, finalmente, un relato el de 1974 que termina en un acaramelado happy end, frente al sentimiento trágico que encierra Siete domingos rojos; la conflictividad histórica e ideológica no son las únicas en haber desaparecido. Cierto que, en otros aspectos, Las Tres Sorores sale reforzada: aunque variada (y ocultada por adornos narrativos, en parte), la estructura se recompone y se refuerza, como también el estilo se mejora mucho, principalmente por la unidad reconquistada desde la experiencia fructuosa del autor. El simbolismo, tan importante en la novela de 1932 y mantenido en sus aspectos más interesantes en las dos versiones siguientes, resulta algo desvaído en el texto de 1974.

Me parece ocioso seguir con las diferencias en los puntos de partida y de llegada entre los textos de 1932 y 1974. Un lector más atento podrá hallar muchas más de cuantas he señalado. Es llegado el tiempo de las conclusiones, aunque tal vez puedan resultar precipitadas. Básicamente, dos son las que se presentan como más evidentes. La primera, la progresiva pérdida de la "memoria ideológica», sin duda propiciada por el alejamiento de los acontecimientos que se narran en Siete domingos rojos, que difícilmente podían, en 1974, inspirar en Sender la emotiva conflictividad de una militancia que envolvía como un torbellino la vida española de 1932. Por aquellos días en que preparaba su regreso a España, a una España en la que la decadencia del «vencedor» era patente pero que aún tenía la fuerza terminal del agonizante para dar algún coletazo mortífero, la ideología de Sender ya no era beligerante, habiendo dejado demasiados

\footnotetext{
39 Vaya un ejemplo: el discurso del oso de Diana: pp. 128-130.

${ }^{40}$ Como señalan Gemma Mañá Deigado y Luis A. Esteve Juarez ( $«$ Vida de Pedro Saputo, de Braulio Foz, y la construcción de El verdugo afable, de Ramón J. Sender", Homenaje a José Manuel Blecua, Huesca, 1986, p. 120), «conforme se va dilatando su exilio, el desarraigo lleva a Sender a una vuelta cada vez más mitificada a sus orígenes aragoneses». Remito, también, al artículo de Ángel AlCALÁ, "Sender y sus novelas, y su Aragón», en Ramón J. Sender. In memoriam, cit., pp. 177-188.
} 
jirones por el camino. Don Ramón, sentado en su mecedora americana, podía entornar los ojos, mirando al infinito literario, y complacerse en proclamar la libertad como único norte del «hombre natural». El anarquismo faísta quedaba atrás, contemplado con simpatía, ciertamente, pero desactivado: un «anarquismo individualista», tal vez de resistencia interior, que impedía la disolución de su personalidad manteniéndolo en pie, humana y literariamente. Su paso por el comunismo debió de resultar una prueba poco reconfortante, lo que le reafirmaría en el sentimiento anarquista de la individualidad, aunque invalidado ya para la experiencia colectiva por su contacto con el liberalismo. Sin embargo, antes y después de la traumática salida de España, Sender era un humanista que tuvo que elegir.

La segunda conclusión ya no afecta al escritor, sino al lector: inevitable es que en toda comparación uno de los términos salga mejor librado. Después de leer las cuatro versiones o reescrituras, me inclinaré por el relato de 1932, el que surge desde el interior mismo de los hechos narrados; incluso el valor profético que encierra la original Siete domingos rojos se desdibuja en las versiones posteriores. Narración turbulenta y lírica, violenta y tierna, con numerosos defectos técnicos, si se quiere, pero con esa prosa desatada y visceral, «ganglionar» como dice en numerosas ocasiones el mismo Sender, ${ }^{41}$ que arrastra al lector por sus páginas con la misma fuerza con que el autor vivió los acontecimientos. Al fin y al cabo, como nuestro autor escribió a propósito de Sherwood Anderson - el autor de Winesburg, Ohio-, «escribir es acción». ${ }^{42}$

\footnotetext{
41 Reconforta en tal elección el hecho de que, quizás inesperadamente, muchos de cuantos han participado en este Congreso han acudido a los Siete domingos rojos para explicarnos las múltiples facetas de Ramón José Sender Garcés. Sin duda, la novela de 1932 merece una recuperación para el lector actual.

42 Álbum..., cit., p. 277. Una conclusión semejante, aunque más vehemente, es la mantenida por Francisco CARRASQUER ( “¿El derecho de autor...?”, cit., p. 20b) cuando reivindica su lugar en la lectura: «Porque el lector también tiene sus derechos. Y como lector, protesto ante esa mutilación que constituiría el querer imponérsenos $3 S$ en lugar de $7 D R$. Las Tres Sorores vale como expresión del Sender de 1974, pero no del Sender de 1932. [...] Es todo el tenor del libro el que traiciona aquél de antes de la guerra. Y es toda la intención".
} 


\title{
Nueva lectura de "Aventura en Bethania»
}

\author{
Kathleen M. Glenn \\ Wake Forest University, Winston-Salem (North Carolina)
}

\begin{abstract}
La obra de Ramón J. Sender es, tal y como ya ha señalado José-Carlos Mainer, «vasta y desigual, tan pródiga en hallazgos cuanto en descuidos casi imperdonables» (325). Otros críticos coinciden en esta apreciación (King, 166; Vásquez, 353) y hasta Marcelino Peñuelas, tan devoto admirador del escritor aragonés, reconoce que éste no solía revisar sus novelas con cuidado (260). Hay, no obstante, textos senderianos que por una razón u otra merecen más atención y este Congreso Internacional es una ocasión propicia para acercarse a ellos. Esta comunicación propone una nueva lectura, una «re-visión» de una narración poco estudiada, "Aventura en Bethania». Sigo a Adrienne Rich en su utilización de la palabra "re-vision» en referencia al acto de mirar hacia atrás para ver con otros ojos lo antes leído, es decir, para entrar en un texto viejo desde una nueva dirección

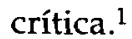

«Aventura en Bethania» forma parte de Novelas ejemplares de Cíbola, obra publicada en 1961. El libro consta de doce narraciones. Seis (los números impares) son novelas cortas de 30 a 72 páginas de extensión y se publican aquí por primera vez. Las otras seis (los números pares) son

1 En palabras de RucH, «Re-vision [is] the act of looking back, of seeing with fresh eyes, of entering an old text from a new critical direction» (90).
\end{abstract}


cuentos, en su mayoría de 7 u 8 páginas, que habían aparecido antes en Mexicayotl (1940). "Aventura» es el séptimo relato del volumen y es importante notar que tanto el título de la colección como el del relato son significativos. Peter Rabinowitz nos recuerda que ciertas partes de una obra literaria - el título, el comienzo, el final- son especialmente importantes por su posición privilegiada (58-65). Así, un título puede funcionar como guía, orientarnos e indicar dónde concentrar nuestra atención o puede ser como un esqueleto sobre el que edificamos una interpretación, y si es ambiguo o metafórico nos avisa de que tendremos que tratar de descifrar un significado oculto. Además, el título puede tener resonancias literarias, religiosas o históricas. Novelas ejemplares de Cibola nos remite por un lado a los exempla medievales que enseñaban una lección moral y también a las Novelas ejemplares de Cervantes y a las Novelas amorosas y ejemplares de María de Zayas y Sotomayor, por citar sólo dos de los más famosos textos «ejemplares». Por otro lado el título del volumen nos recuerda leyendas sobre una región fabulosa en la cual se suponía la existencia de siete ciudades maravillosas que los conquistadores del nuevo mundo buscaron con afán en el norte de México. Sender llama Cíbola al sudoeste de los Estados Unidos. El título del relato contiene otra referencia geográfica, ya que Bethania es la aldea palestina cerca del monte de los Olivos y de Jerusalén donde vivían Lázaro y sus hermanas Marta y María. ${ }^{2}$ Es bien conocido que, aunque Sender rechazaba los dogmas del catolicismo, era un hombre profundamente religioso, en el sentido más amplio de la palabra, y muy preocupado por cuestiones morales; y es obvio que un escritor, sea creyente o no, puede recurrir al simbolismo religioso para realzar el sentido de una obra, como lo hizo don Ramón en Réquiem por un campesino español. En el caso del relato que nos concierne ahora, Bethania despierta ciertas expectativas y nos prepara para el «milagro» contado en sus primeras páginas. Mientras que el otro título, Novelas ejemplares de Cibola, sugiere que nos espera una narración que tendrá ribetes de fantasía y de la cual podemos sacar un ejemplo provechoso con respecto a la existencia humana.

Diez años antes de la llegada del protagonista Laner a una aldea, una compañía de teatro había representado allí la pasión de Cristo. El público, compuesto mayormente de indios, quedó impresionado por la «realidad» de lo que vio y pidió al actor principal que devolviera la vista a un ciego. Aquél, como si estuviera todavía en la escena, extendiendo sus manos sobre el ciego, dijo: «Hombre de Dios, hágase según tu fe» (180), y se realizó el milagro. Para conmemorar el acontecimiento, se cambió el nombre de la aldea y en adelante se llamó Bethania. Esta historia intercalada en el relato, en que la realidad y la ficción se entrecruzan, los personajes representados parecen convertirse en seres de verdad y la fe mueve montañas

2 Según san Mateo (21:19) fue cerca de Bethania donde Jesucristo vio una higuera sin higos y le dijo: «Qué jamás nazca fruto de ti. Y la higuera se secó al instante». 
metafóricas, es la introducción a la historia de un hombre que no tiene fe, que ha pasado la vida representando papeles y proyectándose en otros y que confunde realidades y fantasías. La ceguera metafórica de Laner alude a la del ciego, pero, a diferencia de éste, Laner no recupera la vista.

Las primeras palabras del relato - «Viajaba Mr. Laner por las llanuras calcáreas de Cíbola» (176) — introducen el tema del viaje, que según Cirlot es expresión del deseo de descubrimiento y cambio (164). En este caso el viaje es literal y figurado, geográfico y espiritual, exterior e interior. El escenario físico es una aldea desierta que recuerda algo a la Comala de Pedro Páramo. El otro escenario es la mente de Laner, quien, recluido y aislado en un pueblo fantasmal, va a encontrarse con sus propios fantasmas y entablar un diálogo con ellos. ${ }^{3}$ Laner es ventrílocuo de profesión y, así, es hombre que "tiene la habilidad de dar a su voz distintas entonaciones y modificarla de modo que parece proceder de distintos sitios, con lo cual puede simular un diálogo entre varias personas» (Moliner, s. v. «ventrílocuo»). Tiene 65 años y su joven esposa de apenas 27 acaba de divorciarse de él. Laner se ha marchado de Nueva York y ha emprendido este viaje al sudoeste buscando una «cura de soledad» (181), huyendo de su sensación de fracaso y de su sombra. Sus esfuerzos, como era de esperar, resultan inútiles.

Poco a poco nos enteramos de los detalles de la triste historia de un viejo que se ha casado con una mujer mucho más joven. La timidez y sentimiento de inferioridad de ella le encantan, le dan confianza y le hacen sentirse muy superior. La abuela de Angélica había regentado un burdel en Nueva Orleans y la chica había trabajado en una funeraria, donde maquillaba a los muertos. Laner está convencido de que él le ha hecho un gran favor al tomarla por esposa, dados los antecedentes familiares de la chica y su historia laboral, y espera que ella le estará eternamente agradecida, pero no es así. Durante el viaje de novios a París todo empieza a ir mal desde la perspectiva de Laner, porque Angélica va perdiendo su timidez. En vez de alegrarse de la nueva seguridad de su esposa, Laner se alarma y organiza la defensa para "compensar de algún modo aquel súbito desequilibrio de poderes» (186; el subrayado es mío). Inventa la calumnia de que el aliento de Angélica huele mal para humillarla y socavar su nueva confianza. Enterados de esta canallada, no podemos menos que ver a Laner como un pobre diablo, un ser mezquino y patético a la vez. En una carta escrita desde Bethania, él pone al descubierto su inseguridad y el deseo de darse importancia y despertar los celos de Angélica cuando afirma que está en un pueblo encantador, rodeado de gente adinerada, artistas conocidos y mujeres seductoras que le asedian. Estas mentiras están en desacuerdo con su declaración de que quiere ser completamente sincero con Angélica y confesarse con ella. En otro momento, el ventrílocuo, imitanto la voz de su antigua esposa y dando una entonación «dulcí-

\footnotetext{
${ }^{3}$ MAINER (336-338) estudia el relato como un ejemplo de la afición de Sender por lo teatral.
} 
sima» y "rendida» (192) a sus palabras, le hace decir lo que él quiere escuchar: "[Y]o te quería porque sabía ver tus cualidades secretas. [...] tu superioridad natural y tu grandeza. [...] Yo te quiero suceda lo que suceda. [...] encanto de mi vida, corazón mío, viejito mío primaveral. Redentor de mis días lúgubres" (192-193; el subrayado es mío). El hecho de que Laner se refiera a Angélica como una de las parcas, implacables dueñas de la vida de los hombres, demuestra el poder que ella tiene sobre él y la enorme inquietud que esto le provoca.

En la soledad de la aldea abandonada Laner imagina una serie de interlocutores. Así, en el antiguo bar hace hablar a un imaginario barman gordo y bondadoso y conversa también con varios hombres que él sospecha han sido amantes de Angélica. Maurice, de quien Laner siente los celos más feroces, menciona a Paul (dulce y tímido), André (infantil e inocente) y Harry («un bárbaro podrido de dinero» [203]). Aunque Maurice asegura que no hubo nada entre ninguno de ellos y Angélica, como tampoco lo hubo entre ella y él, no logra convencer a Laner. Es importante recordar que las palabras de Maurice son en realidad las de Laner y descubren la ambivalencia que éste siente. Desconfía de Angélica, a la vez que parece saber que sus sospechas en cuanto a la fidelidad de ella son irracionales y carecen de fundamento; así, en una de sus conversaciones imaginarias con Angélica le dice: «Yo sé que tú no querías a Maurice» (200). Uno de los interlocutores más importantes de Laner es Horacio, el muñeco que ha sido durante años su alter ego y que ha expresado lo que Laner no se ha atrevido a decir en voz alta. Son de Horacio los insultos más hirientes y procaces dirigidos a Angélica y también el calificar a Laner como "estafermo ramplón» y "amante desconfitado" (184).

El rencor y resentimiento que siente Laner le lleva a aceptar la solución que le ofrece la Coyota: matar a Angélica por medio de un sello envenenado. Como ella se había mudado de casa no recibe el sello y se escapa de la muerte que su esposo había planeado. Laner, según la Coyota, se ha librado de Angélica porque la ha matado en su mente:

Laner puso el coche en marcha. A pesar de todo era verdad que tenía la impresión de que sus problemas se habían hecho mucho más ligeros con aquel asesinato frustrado. Callaba, pero la Coyota hablaba por él:

-No es bueno que viva usted como vive porque tiene el saco de los sentires lleno de malas figuras. El sello trajo la mala y la contramala. Soñada la muerte, curado el relajo. Míster - añadió jovial-- ¿no sabe que hay males que traen venturas?

Decía venturas a la manera antigua. Laner conducía el coche y sentía a la Coyota allí a su lado con cierta admiración de gringo civilizado y errante. (220)

La reiteración de la palabra venturas despierta ecos de frases como a la ventura, por ventura y probar ventura y nos remite al título del relato, «Aventura en Bethania». Si bien Laner ha tenido ventura en este caso y sus problemas parecen haberse resuelto de manera feliz, Angélica y los otros personajes femeninos del relato no corren igual suerte. 
La primera persona con quien se encuentra Laner es la dueña de una estación de gasolina localizada en un cruce de caminos: "Salió una vieja muy rubia, despeinada y flaca con un cigarrillo en los labios. [...] La vieja rubia parecía una bruja, más apta para despojar a los muertos después de una batalla que para dialogar con turistas desorientados» (176). Se porta de una manera desagradable, mirando agriamente a Laner, hablando con sorna y sin quitarse el cigarrillo de los labios, empleando una palabra soez y dando una patada a una de las ruedas del coche de Laner, quien «tuvo la impresión de haber recibido aquella patada él mismo» (177). Cuando el hombre le critica su falta de cortesía e insinúa una amenaza, recordándole que su conducta es poco prudente, ya que está sola y en medio del desierto, «la vieja walkiria» coge un hacha de mano y Laner huye. Mientras en la mitología escandinava las walkirias son mensajeras de Odín y tienen por misión escanciar la cerveza y el hidromel a los héroes muertos en el combate, esta mujer es presentada como un verdadero monstruo: poderosa, amenazante, bruja, grosera, vieja y antinatural, o sea, poco femenina, lo que se conoce en inglés como una battle-axe. La imagen de la Coyota, otra bruja, no es mucho más atractiva. Vieja y harapienta, mestiza de negro y esquimal (según la walkiria), es tan flaca uque sus huesos parecían mantenerse juntos por prodigio» (205). Su nombre la identifica con un animal conocido en el folclore por su astucia y malicia. ${ }^{4}$

Hay otros dos personajes femeninos. La joven Betsy es camarera de café en un poblado cercano y Laner se fija en sus manos hermosas, así como en la flexibilidad de su cintura y la altura de sus caderas. Una alusión a su mirada vacía y lenta la asemeja a una vaca. Si Betsy es toda carne, Angélica es su antítesis, por lo menos inicialmente. Laner afirma que es «una mujer exquisita, suculenta, impoluta» (184). Los adjetivos escogidos son curiosos. Exquisito, aplicado a lo que es capaz de satisfacer un gusto refinado, nos revela más lo que Laner piensa de sí mismo que lo que piensa de Angélica; suculento la convierte en un plato sabroso, e impoluto la idealiza, subrayando que es limpia, inmaculada, sin mancha. Durante su noviazgo Laner a veces se irrita y le dice a Angélica: «Un poco menos de respeto y un poco más de amor, querida» (185), pero en el fondo le alivia la falta de pasión de ella porque garantiza, según él, que la mujer le será fiel. Se ha comentado la frecuencia en la obra de Sender de una mujer que es símbolo del ideal (Jones, 87, por ejemplo) y Peñuelas llama la atención sobre la presencia de mujeres que encarnan la delicadeza y la inocencia. Menciona a la Niña Lucha de Epitalamio del prieto Trinidad, a la princesa María de Bizancio, a María Luisa de Orleans de Carolus Rex, a Elvira de La aventura equinoccial de Lope de Aguirre, a la princesa Lizaveta de Las criaturas saturnianas y a Valentina de Crónica del alba (232-233). Laner constru-

\footnotetext{
${ }^{4}$ Uno de los personajes más conocidos de los dibujos animados es Wile E. Coyote, creado por Chuck Jones. El nombre da a entender que el coyote es mañoso por definición, ya que wily quiere decir «astuto, mañoso».
} 
ye una imagen idealizada de Angélica y luego, cuando sospecha que ella no se corresponde con la imagen fabricada por él, trata de matarla. Al empezar el relato Laner subraya el hecho de que Angélica «era de costumbres recatadas» (185) cuando la conoció y era virgen cuando se casaron. El nombre de ella es claramente simbólico. Las cuatro mujeres de "Aventura en Bethania" son figuras polarizadas. Las viejas son monstruos de fealdad o de agresividad, desprovistas de atractivo sexual. De las jóvenes, Betsy es puro cuerpo y Angélica es puro espíritu. Monstruo o "ángel», bruja o santa. Todas estas imágenes exageradas y estereotipadas cosifican a la mujer y le roban su individualidad. Todas son falsas y dañinas para ella. Todas revelan los recelos e inquietudes de los hombres que las proyectan.

«Aventura en Bethania» es una historia dominada por los recuerdos y voces de un solo personaje, un estudio psicológico de la inseguridad y las obsesiones de un hombre que sufre de «una sensación penosa de fracaso a la que no se acostumbraba» (181). El narrador de "Aventura» es partidario del protagonista, a quien mira con buenos ojos. Describe a Laner como un hombre cortés (aunque no lo es con la vieja de la gasolinera y por eso ella se enfada con él) y como buena persona (aunque maltrata a Angélica y trata de asesinarla), confuso ante la incomprensible conducta de las mujeres, enojado por la descortesía e ingratitud que él les atribuye y atemorizado ante su poder. Ésta es una historia escrita por un hombre, narrada por otro y protagonizada por un tercero. Esto es perfectamente lícito. Pero no nos olvidemos de que las historias, como las monedas, tienen más de una cara. Molly Hite hace hincapié en que la persona que narra da una versión de lo que ha pasado. Otro narrador o narradora, con otros ojos y valores, lo vería de manera distinta. La segunda versión no enfatizaría las mismas cosas ni reflejaría los mismos valores. ${ }^{5}$ La historia "oficial» de Ulises u Orfeo, vista desde la óptica de Penélope o Eurídice, no sería igual. ${ }^{6}$ Tal cambio de perspectiva modificaría de manera fundamental la naturaleza de lo contado y las presuposiciones subyacentes. Lo mismo ocurriría si "Aventura en Bethania» fuera presentada desde el punto de vista de Angélica, joven que se casa con un solterón que quiere dominarla, espera que le agradezca su "generosidad» y es tan desconfiado, celoso e inseguro que no puede tener confianza en ella ni permitir el desarrollo de su personalidad. Laner quiere llevar la voz cantante durante su matrimonio y después de separado de su mujer sigue hablando por ella. Le quita la voz

\footnotetext{
${ }^{5}$ HITE escribe que «Stories in the modern sense are always somebody's stories: even when they have a conventionally omniscient narrator they entail a point of view, take sides [...] [T] he coherence of one line of narration rests on the suppression of any number of "other sides," alternative versions that might give the same sequence of events an entirely different set of emphases and values» (4).

6 Vid. DuPLESsis (105-122), "Perceiving the other-side of everything": Tactics of Revisionary Mythopoesis".
} 
como piensa quitarle la vida. La frase su mujer, tan inocente a primera vista, tiene aquí un sentido inquietante, porque el hombre retratado en esta narración cree que Angélica le pertenece a él, que casándose con ella la ha comprado y ella tiene que estarle agradecida y serle fiel como el perro vagabundo a quien se da comida y casa. Sin embargo, ¿qué sabemos de verdad de Angélica?, ¿qué cree ella?, ¿qué piensa? Como no tiene voz propia en este relato las preguntas quedan sin contestar.

Hace años Judith Fetterley propuso el concepto de resisting reader, quien lee al trasluz y se niega a tragar o cuestiona visiones masculinistas del mundo. Fetterley analizó el cuento «Rip Van Winkle», además de los estudios canónicos dedicados a él, estudios escritos todos por hombres. Éstos coinciden en ver a Rip como un tipo simpático que tiene la mala suerte de estar casado con una arpía tan poco comprensiva que critica la holgazanería, irresponsabilidad e inmadurez de su esposo. Vista desde la óptica de la mujer, esta historia no sería la misma. Rip dejaría de ser víctima para convertirse en victimario, papel para el que está bien calificado Laner. Si es posible derivar ejemplos provechosos de «Aventura en Bethania» sospecho que un lector masculino no encontrará los mismos ejemplos que una lectora femenina, quien es una «resisting reader».

\section{OBRAS CITADAS}

Cirlot, J. E., A Dictionary of Symbols, Nueva York, Philosophical Library, 1971.

DuPLEssis, Rachel Blau, Writing beyond the Ending: Narrative Strategies of Twentieth-Century Women Writers, Bloomington, Indiana UP, 1985.

FetTerley, Judith, The Resisting Reader: A Feminist Approach to American Fiction, Bloomington, Indiana UP, 1978.

HITE, Molly, The Other Side of the Story: Structures and Strategies of Contemporary Feminist Narrative, Ithaca, Cornell UP, 1989.

JONES, Margaret E. W., "Psychological and Alchemical Motifs in Sender's El rey y la reina», Revista Canadiense de Estudios Hispánicos, 14 (1989-1990), pp. 79-93.

KING, Charles L., Ramón J. Sender, Nueva York, Twayne, 1974.

MAINER, José-Carlos, "La narrativa de Ramón J. Sender: la tentación escénica», Bulletin Hispanique, 85 (1983), pp. 325-343.

Moliner, María, Diccionario de uso del español, Madrid, Gredos, 1966-1967.

Peñuelas, Marcelino C., La obra narrativa de Ramón J. Sender, Madrid, Gredos, 1971.

RaBINOWITZ, Peter J., Before Reading: Narrative Conventions and the Politics of Interpretation, Ithaca, Cornell UP, 1987.

RICH, Adrienne, «When We Dead Awaken: Writing as Re-Vision», en Barbara Charlesworth GelPI y Albert GelpI, eds., Adrienne Rich's Poetry, Nueva York, Norton, 1975.

SENDER, Ramón J., Novelas ejemplares de Cíbola, Nueva York, Las Américas, 1961.

VÁsQuEZ, Mary S., «Sender's Imán: Narrative Focus in a Portrayal of Horror», en Gilbert PAOLINI, ed., La Chispa'81. Selected Proceedings, Nueva Orleans, Tulane UP, 1981, pp. 353-360. 


\title{
Monte Odina como síntesis de la narrativa senderiana
}

\author{
Clemente Alonso Crespo \\ I. E. S. Luis Buñuel, Zaragoza
}

\begin{abstract}
Quisic uisiera acercarme a éste, uno de los últimos libros publicados por Ramón J. Sender, desde la perspectiva del lector sereno, atento y plácido de sus narraciones, evitando la actitud del crítico, «donde se juzga en pandillas y en pandillas se escribe" (p. 463), ${ }^{1}$ para evitar también el propio juicio senderiano en las memorias apócrifas que nos ocupan y no aparecer como el crítico, que «suele ser - con excepciones escasas, pero notables y memorables - un hombre extraño y un poco parásito" (p. 479).

No quisiera parasitar mi fervor y pasión lectora enturbiando con mis críticas, sino simplemente imaginar con las palabras que nos regala el autor, vibrar con sus emociones, que pueden coincidir con las mías, asentir en los encuentros mutuos con un territorio, con unos personajes, con la imaginación libresca de esta imaginada biblioteca, volar con su albatros y hasta disentir de sus digresiones cuando me parece que se le escapa el hilo narrativo. Al comienzo de Monte Odina escribe Sender: «Este libro tiene un carácter inusual que podríamos definir con una expresión igualmente

\footnotetext{
${ }^{1}$ Citaré siempre por la indicación de página correspondiente a Ramón J. SENDER, Monte Odina, Zaragoza, Guara, 1980.
} 
infrecuente: memorias apócrifas. Es decir, para mayor exactitud: verdaderas memorias apócrifas» (p. 17).

Después de leer con calma Monte Odina puedo llegar a la conclusión de que las páginas de esta casi postrera obra senderiana responden, en su realismo de esencias que es toda su narrativa, a unas memorias tan verdaderas cuanto contradictoriamente apócrifas. Así pues, responden a un memorial biográfico, tanto en el territorio senderiano aragonés cuanto en los retazos novelescos de la propia biografía, como en su digresivo estilo tan definidor de sus novelas.

El autor fabula (noveliza, narra, ensaya) con su realidad real, biográfica, personal y el invento - también con base real y autobiográficade la organización de la biblioteca de don Francisco Laguna en Monte Odina, como archivero caprichoso (novelador) de los documentos inexistentes - o existentes en la imaginación senderiana- que allí se guardan.

Todo como búsqueda, al final de sus años, ${ }^{2}$ del mito del eterno retorno que es Aragón -el Alto Aragón-, para nuestro autor, al encuentro de la libertad ansiada simbolizada por el volar del albatros, llegándose a la búsqueda del cometa Halley, dejado libre desde la mítica sierra de Guara, como termina el libro.

Qué mejor lugar como mito del retorno que encerrarse en una biblioteca apócrifa con los libros, personajes, recuerdos, paisajes y paisanajes, seres reales o ficticios, construcciones compactas o digresiones de cualquier dimensión.

Esto es lo que hace Sender con Monte Odina, la metafórica biblioteca junto a su ciudad por antonomasia, Huesca, su paisaje preferido, Guara, hacia los espacios abiertos pirenaicos y al encuentro de la libertad personal singularizada en el albatros que vuela con la esperanza del retorno del cometa Halley, que le devolverá a la infancia perdida y feliz con el abrazo definitivo a su desaparecido amigo Froilán.

Con la obligada apretada síntesis que me marca el tiempo adjudicado a esta comunicación veamos cómo discurren estas memorias apócrifas sobre un territorio, con una biografía y con un estilo digresivo característico del novelar senderiano.

\section{UN TERRITORIO}

Monte Odina, aunque no se diga expresamente en el libro epónimo, es o fue una finca perteneciente a las tierras del caserío de Ilche, a $7 \mathrm{~km}$ del núcleo de la población.

Es así como la recuerda el propio autor: «Al parecer, Monte Odina estaba en una llanura desierta como hay tantas en el Somontano aragonés

\footnotetext{
2 Escrita en 1976, publicada en 1980. Sender muere en enero de 1982.
} 
o en los Monegros, ricos de vino, de frutas y de cereales, y en esa dulce soledad que los que hemos andado por las grandes ciudades del mundo añoramos o envidiamos" (p. 31).

Quizá los recuerdos y el sueño del eterno retorno se le desatan a nuestro autor cuando recibe una carta de su hermana Carmen remitida tras la lectura por parte de ésta de un artículo del novelista leído en Heraldo de Aragón. «La casa era rara, porque toda la planta baja era almacenes de maquinaria, vivienda de los guardas, cosas raras. Una escalera exterior subía a la terraza y allí estaban las puertas de la vivienda de don Francisco, como un piso grande. No era la idea que yo me hacía de una casa de campo. Y no había pueblo. El pueblo, que se llamaba Odina, estaba a unos pocos kilómetros y abandonado por completo. [...] Tu biblioteca, que recuerdo claramente, daba a la terraza» (pp. 28-29). En ese lugar, Monte Odina, dice el autor: "estoy en "mi biblioteca" —una especie de gustosa cartuja-» (p. 27), y en otra ocasión: «Es éste un lugar ideal para ejercitar la memoria, la voluptuosidad intelectual y aguzar incluso el sentido crítico» (p. 19).

La memoria apócrifa de su esencialidad novelada, cuando contempla «desde la terraza [...] con los gemelos las lomas lejanas de Berbegal y de una finca parecida a Monte Odina que se llama Terreu, muy vasta y hermosa» (p. 79).

En definitiva, Monte Odina no es más que todo el territorio aragonés, el que una vez declaró que le acogió como ilergete del Alto Aragón y a él se atenía en su esencialidad humana, lo mismo que Monte Odina «[q]uedó en mi memoria [...] como una semilla que debía germinar y fructificar un día. Estas páginas las escribo pensando en aquella biblioteca en medio de un paisaje casi desierto, con cuervos graznadores y cigüeñas navegadoras, perros guardianes y noches estrelladas. Y grandes trigales ondulantes» (p. 32)

Por Monte Odina va a pasar todo un territorio aragonés y lugares como Jaca, Santa Orosia (p. 54), Boltaña (p. 55), Fraga (pp. 57, 250), Zaidín (p. 62), Loarre (p. 157), Benabarre (p. 64), Siétamo (p. 66), Huesca (p. 67), Zaragoza (p. 69), Tauste (p. 441), Caspe, Chalamera (p. 405), entre otros que recogen los recuerdos y memorias apócrifas senderianos desde su redacción americana con la imaginación anclada en la biblioteca mítica. $Y$ hasta la referencia a la soñada España es traída hasta estas páginas entremezclada con sus propias creaciones literarias: "iLas Tres Sorores! Restos del animismo primitivo. Yo he escrito una novela -es decir, he remodelado Siete domingos rojos - con ese título y sobre ese tema. Lejos de España las Tres Sorores crecen en el recuerdo» (p. 56). O por citar otras novelas y otros lugares: «Ese castillo de Fraga es, según el pintor Villadric, el de Urganda la Desconocida, nada menos. También he hablado de él en otra novela titulada El fugitivo» (p. 57).

Pero no quiero dejar pasar la referencia a los lugares de la infancia y juventud de Sender, nominados con pasión no exenta de lirismo como baterías que han recargado siempre las pilas de su creación novelesca, 
aunque disfrazada y no expresada con la rotundidad con que lo hace en estas páginas donde el autor se confiesa. Así, sobre Huesca escribe: «Vivía yo entonces en el número 13 de la calle de Sancho Abarca, en un alto edificio mudéjar coronado de galería árabe que había formado parte de los palacios de veras regios de Lastanosa. [...]» (p. 67). Y a continuación hace un amago intimista, lírico, referido a uno de los seres por él más queridos, su madre, tan delicadamente pincelada en muy pocas ocasiones en sus escritos: «En el cuarto que hace esquina (piso principal) y que tiene un gran balcón al norte, por el que se ve el Salto de Roldán y otro al oeste, allí murió mi madre el día de Viernes Santo de 1926» (p. 67).

Las ruinas de los lugares no nominados como grandilocuentes de la historia pero intimizados cobijan y refugian a nuestro autor. Así: «el castillo-mansión de Siétamo, en el que tantas veces estuve, es uno de los que me habría gustado habitar. Es fuerte, hosco, bronco y nada pretencioso. Tiene historia sin abrumarnos con alguna clase de grandiosidad. Entre la historia, la memoria de las cabalgadas y la sangre de los vencidos se percibe el aliento de las vacas oloroso a heno mascado. Y el ruido del yunque donde un fuerte gañán repasa el filo de la guadaña. $O$ la reja del arado. $O$ del aladro, como dicen por allí» (p. 68).

Fuerte, hosco, bronco y nada pretencioso, referido al castillo de Siétamo. Quizás Sender está hablando de sí mismo.

El mismo que rememora las palabras aldeanas donde se asentó su personalidad, recogidas en Imán o en Crónica del alba o en Réquiem por un campesino español y también en El lugar de un hombre, por citar sólo algunos títulos, donde "[s]on los campesinos de las aldeas de Aragón los que se burlan ingeniosa y bondadosamente - sin intención satírica- del pijaito de la ciudad. Cada comarca tiene un nombre especial para ellos» (p. 122). Nombres, palabras que se convierten en señas de identidad territoriales, como cuando recuerda al zapatero de Ayerbe, que recibe tras largo tiempo a don Santiago Ramón y Cajal y le espeta: «Mal aconsejao andaste cuando te fuiste de mi taller, Santiaguico, que ahora mis parroquianos serían tuyos, porque viejo soy y barrunto el acabose» (p. 20).

Pero deseo sólo referirme a tres lugares muy queridos por nuestro autor y muy novelados en sus obras. Así, Loarre, del que escribe: «Para mí Loarre es el refugio oscuro del inconsciente histórico de Aragón. [...] En Loarre se siente uno satisfecho de ser aragonés y orgulloso de un pueblo que haría honor a los pueblos más nobles de Europa" (pp. 157-164). Así, también Alcolea, donde rememora una tormenta sobre las ripas, tan presentes en su obra:

[...] las [tormentas] más dramáticamente hermosas que he visto en mi vida son las de Alcolea de Cinca. Ni las de las turbulentas Antillas, ni las del frígido Canadá, ni las de los Estados Unidos o Méjico o Perú pueden compararse.

Las de Alcolea producen unas exhalaciones con estampidos de distintas categorías, largos y cambiantes. A veces parece que arrojan desde lo alto de 
las ripas centenares de toneles vacíos de diferentes tamaños que bajan trompicando. Otras los sonidos son secos y graneados ascendentes o descendentes, como los de una enorme matraca.

Las nubes, cargadas de electricidad, quieren pasar las ripas, la ribera feraz, el río caudaloso y llegar a Albalate, pero a veces las corrientes de viento cambian y las nubes regresan sobre Alcolea. Entonces es cuando la tormenta alcanza su clímax y el dramatismo es tal que pone a grandes y chicos los pelos de punta. (p. 87)

Y Chalamera, su pueblo natal:

Algunos se extrañarán de lo que voy a repetir o lo atribuirán a mi amor por la aldea donde nací. Pero la ermita donde se venera la Virgen de Chalamera es sin duda la más puramente románica y la más notable arquitecturalmente de todas las que he visto en mi vida. (p. 405)

Y mientras tanto la síntesis territorial,

La luz [...] de Aragón es de una variedad infinita, condicionada por las nieves y los pinares de los Pirineos, los desiertos del Somontano, las dobles y triples tonalidades del Moncayo según el sesgo del sol y las serranías carrasqueras de Albarracín. (p. 306)

Pero sobre todo este territorio donde se ancla su obra planea el abandono, como ya escribiera en el final de su novela más emblemática, Imán:

En una de esas mulas yo he ido al pueblo desierto del que me hablaba mi hermana Carmen. Verdaderamente es inquietante. Tanta puerta abierta o cerrada, con interiores rumorosos por el viento o las ratas. Las calles desiertas en las que a veces se oyen pasos que son tal vez el eco de los míos, y sobre todo la iglesia sin cura, pero con campanas todavía que a veces tocan solas en la noche, es $\tan$ misterioso [...]. (p. 298)

Tan misteriosa como la creación senderiana asentada en su territorio, rememorado en la ensoñación de la biblioteca apócrifa.

\section{UNA AUTOBIOGRAFÍA}

En realidad soy de los que piensan que los escritores no hacen más que contar las experiencias personales que les han ido sucediendo a lo largo de su acontecer diario o bien desarrollado en el laboratorio personal, íntimo, de su imaginación. Pero en el caso de Sender sus aconteceres cotidianos, personales, familiares, amicales nos los ha ido ofreciendo en sus novelas, bien explícitamente como es el caso de Crónica del alba o bien con el tamiz de la tela ariádnica como acontece en La esfera o Los cinco libros de Ariadna, por referirme tan sólo a una muy exigua parte de su producción. En Monte Odina sus recuerdos y vivencias biográficas ni siquiera están disfrazados con la envoltura novelesca puesto que ya nos ha advertido desde el 
comienzo de que se trata de unas memorias, apócrifas, eso sí, pero por muy falseadas que nos las quiera dar el novelista, por muy imaginadas que las ofrezca quedan los rasgos más perennes de la tierra, de la familia más íntima y de la amistad.

Veamos algunos de estos aspectos en una apretada síntesis selectiva de los aconteceres de Monte Odina.

Ramón J. Sender no pudo contemplar la vuelta del cometa Halley (1986) puesto que murió casi cinco años antes de que completara de nuevo su órbita, pero a lo largo de estas memorias apócrifas se hacen numerosas referencias, al mismo tiempo que rememora, como ha ido filtrando en muchos apartados de otras de sus novelas, su infancia perdida, salpicada de aventuras con Froilán, sin desdeñar el efecto vitalista que le ofrece el propio léxico y los giros lingüísticos del territorio cercano a su aldea natal, Chalamera. Así:

Todos los años «el tiempo de las cometas» comenzaba en la primavera, a fines de marzo, cuando los vientos son más veloces y sostenidos. Porque cada año había «el tiempo de las galdrufas» - peonzas-, el del «richoler», que consistía en hacer rodar una pequeña pelota hasta que caía en un hoyo $[\ldots]$.

La gente decía que Froilán había muerto en un accidente muy extraño [...]. Yo no lo creía. Pensaba que se lo había llevado el cometa Halley [...]. Debe estar impaciente después de haber recorrido medio universo con Halley, el cometa color escarcha matutina. $\mathrm{O}$ «rosada», como llaman los campesinos a la escarcha, porque al amanecer, con la luz solar de soslayo, toma ligeros matices rosáceos. (pp. 223-224)

Su amigo Froilán, con quien nuestro autor entre otras aventuras corría poniendo esquilas a los buitres, murió electrocutado después de que la cometa que estaba volando se enredara en unos cables de alta tensión. Este dato real sirve a nuestro novelista para memoriar el hecho apócrifamente regalándonos los oídos con la remembranza de las palabras de su biografía lingüística:

Cada cual lo decía a su manera, pero todos coincidían en ligar su muerte a la influencia del cometa. Por otra parte, como la cometa del chico y el cometa de Halley tenían un mismo nombre específico, la confusión y la unanimidad se comprendían.

Murió de un relumbre.

De una fulgarada.

De una refulgencia.

De un centellón.

La hornera mayor decía de una encandilada repentina. Otros de un patatús rutilante. O de un chupinazo celestial. (p. 231)

Lo ampliamente desarrollado en Crónica del alba viene aquí en ocasiones servido en la mano al hilo de los recuerdos entre libros: «Froilán como amigo y Valentina como novia han llenado toda mi infancia y gran parte de mi vida adulta y secreta. (No tan secreta, puesto que conté lo de Valen- 
tina y pienso contar lo de Froilán.)» (p. 90). Aspectos biográficos de su propia familia han sido novelados por nuestro autor. No faltan en este memorial escrito en el refugio de la biblioteca de Monte Odina. Veamos algunos: «Mi familia era una familia un poco rara. El único que se salva en mis recuerdos es mi hermano Manuel, asesinado por los fascistas en 1936 . Y mi madre, claro. Ella era angelical. $Y$ un poco víctima, como la mayor parte de las esposas de la clase media en aquellos tiempos» (p. 444). A continuación añade: «Pero no me gusta hablar de mi familia» (p. 444). En realidad ha ido dejando retazos de sus familiares, abuelos, padres y hermanos en muchas de sus novelas. ${ }^{3}$ Estas aportaciones de carácter autobiográfico están preñadas de un pudoroso intimismo, como se puede apreciar en:

\footnotetext{
Yo tuve víctimas en mi propia familia que dejaron cicatrices imborrables en mi corazón y en mi atormentada alma.

Prefiero no volver a hablar de ellas. Todo el mundo las sabe. $Y$ hay, como he dicho otras veces, el pudor masculino de la tragedia. De la tragedia de uno que ha sido de la España entera. (p. 367)
}

La tragedia de la muerte de su esposa, Amparo, ha sido disfrazada novelescamente al menos en dos obras: La esfera y Los cinco libros de Ariadna. A la biblioteca de Monte Odina, la solitaria y apartada biblioteca, como metáfora del retorno, la lleva saturado de pudor:

\footnotetext{
Siempre he gozado de alguna forma de soledad después de la muerte trágica de Amparo, la madre de mis hijos, de la que no suelo hablar porque no quiero vender mi dolor poniéndolo en los libros que tienen precio.

Eso cualquiera lo puede comprender. Digo, cualquier español. (p. 350)
}

Ya he señalado algo, aunque breve, referido a su hermano Manuel. No podía dejar de hablar en estas páginas de ese espejo humano que fue para el novelista. Así: "No sé qué me pasa, pero cuando un hecho sacude profundamente mi vida, hay una especie de inhibición intelectual que hace difícil escribir sobre él. Por ejemplo, la muerte de mi hermano Manuel, que era y es en mi recuerdo el hombre más noble y puro que he conocido en mi vida» (p. 206); «Fue tan noble el destino de mi hermano que cualquier cosa que escriba sobre él lo empequeñece» (p. 208).

En este memorial, ya al final de su vida, Sender recorre los territorios de la memoria, de su memoria personal, y trae el filtro de su existencia, de su esencialidad como hombre, de lo más auténtico que lo justifica como tal y como escritor, que vendría a ser la tesis principal de mis palabras. De este modo:

A mí, en casa, me llamaban Pepe, porque era el nombre del jefe de la tribu y yo era el hijo mayor. Mi padre se llamaba José, y también mi abuelo y

\footnotetext{
${ }^{3}$ Dado el espacio de que dispongo sólo haré referencia a la dedicatoria a su hermano Manuel en El rey y la reina.
} 


\section{EL LUGAR DE SENDER}

mi bisabuelo. Aunque mi nombre de bautismo es Ramón José, todos me llamaban dentro de casa Pepe y fuera de ella Ramón. Era como una invitación del destino para la esquizofrenia. (p. 100)

La esquizofrenia escrituraria que los lectores de sus obras conocen muy bien. ${ }^{4}$ De todas formas uno de los seres más queridos por Pepe, el nombre familiar de nuestro autor, es, sin duda, su madre. También, curiosamente, es uno de los que menos se asoman a sus obras de creación. Éste y el de su esposa, Amparo. Quizás la cercanía del afecto y el dolor de su pérdida han impedido su traspaso a la creación literaria, al menos con la diafanidad con que pueden aparecer las figuras de su padre e incluso de su abuelo. De todas formas y con el reencuentro de Sender con sus ilergetes del Alto Aragón, con las tierras del Cinca, cuando regresa en 1974, nos regala en estas páginas trazos de un lirismo intimista que habla por sí solo:

Mi madre fue durante dos años maestra de escuela en aquella villa en la que mi padre era secretario municipal. Eran los dos muy jóvenes. Cuando yo fui a Chalamera conocí en un viaje anterior [...] a la maestra actual (1976) y ella debió darse cuenta de mi sorpresa al ver que era rubia, joven y bonita como mi propia madre, quien, aunque no volvió a ejercer porque regresó con mi padre a Alcolea y tenía un hijo cada año, estuvo toda su vida muy orgullosa de haber trabajado aquellos dos cursos escolares en Chalamera. (pp. 406-407)

Y más adelante: «La maestrita rubia y joven por un lado y la ancianita que me dio de mamar antes de nacer representaban para mí los heraldos de una tierra prometida que no sé dónde ni en qué consiste. La maestra era -repito- bonita como mi madre y dulce como podría ser una hija mía» (p. 410). Y hasta repite insistiendo, al menos en otra ocasión: "Sentía sin embargo no saludar a la maestra de la escuela primaria, que era rubia como fue mi madre, y como ella dulce y afable y sin el menor asombro de afectación» (pp. 376-377).

Las gentes de Chalamera, aparecidas y reflejadas en novelas como Réquiem por un campesino español, El fugitivo o El lugar de un hombre, entre otras, así como sus tierras, en éstas y otras narraciones, son citadas con precisión en este memorial de la biblioteca de Monte Odina, y así: «[...] a Antonio Villas, nieto de mi madrina de bautismo. $Y$ al alcalde, hombre enterizo y responsable. $Y$ al cura también, aunque no tuve nunca el placer de comprobar que me toleraba, al menos en tiempos de Franco. Tal vez me equivoco porque sin su permiso las campanas de la torre no voltearían y la última vez que fui lo hicieron locas de entusiasmo» (p. 377); "Antonio Villas, hijo de mi padrino de bautizo, me mostró una vez más las caracolas marinas que de niño me intrigaban con sus rumores de brisas oceáni-

\footnotetext{
${ }^{4}$ Sirvan como referencia Crónica del alba o El lugar de un hombre, por citar sólo dos títulos.
} 
cas lejanas» (p. 411). El propio autor se cita a sí mismo como novelista trayendo a colación sus recuerdos biográficos:

También me recordaba las chimeneas del tejado de enfrente en las mañanas de invierno cuando aparecía cubierta de rocío helado.

Y sobre todo, no sé por qué me sugería la etemidad. Esa etemidad que nadie puede imaginar y que más tarde yo he tratado de materializar en la esfera. En la esfera con sus caminos sin fin. (p. 263)

Mito del eterno retorno es Monte Odina, como lo es Aragón y su tierra natal en tantas obras que ahora no puedo referenciar. ${ }^{5}$ Dejemos que sea el propio Sender quien nos lo diga:

Duermo muy bien, en Monte Odina. Al amanecer oigo zureo de palomas y en él se entretienen mi alma y los sentidos.

Luego pienso en una novia lejana - de mi adolescencia- que dejé en Huesca y acabó casándose con otro. En mi inocencia pensaba haberla dotado con la nostalgia y la melancolía, pero pronto supe que estaba fresca, gordita y exultante de felicidad con su marido. (p. 313)

Las Valentinas y Adelas que pueblan femeninamente las páginas noveladas de Sender son rememoradas también entre los libros que le transportan de un recuerdo a otro a nuestro autor. De este modo,

La muchacha más hermosa que vi en mi vida fue en Alquézar. Una joven de cabeza prodigiosamente noble en su brevedad, en sus gruesas trenzas de cáñamo, en sus ojos claros y humildes, [...] en el timbre de su voz, en el continente ni altivo ni humilde, en la gracia callada con que llevaba aquel hecho escandaloso de su belleza. (p. 320)

Y se nos confiesa personalmente, con desnudez más rasgada:

A veces me he quejado de no haber tenido en mis brazos sino mujeres que me gustaban, pero nunca mujeres a quienes de veras quería. La culpa es mía, tal vez. A aquella mocita la he querido toda mi vida. Y no hice nada por tenerla. En el recuerdo la quiero aún ahora. Seguramente se ha casado, ha tenido hijos y tiene nietos casaderos. O murió, tal vez, soltera y virgen. (pp. 321-322)

Su padre, que traspasa las páginas de Crónica del alba una y otra vez y hasta, junto a su abuelo, es retratado en El lugar de un hombre, queda atrapado en este memorial de esta forma: «Yo fui al cementerio a poner flores en la tumba de mi padre con quien, según he dicho, nunca estuve de acuerdo, pero a quien siempre le tuve respeto y cariño» (p. 339). Y hasta de sí mismo, sin tapujos una y otra vez, esencializándose al menos en estas

5 Pensemos tan sólo en el final de Imán y en la recuperación del personaje Viance en una de las últimas obras de Sender, Chandrío en la plaza de las Cortes. 
pocas palabras que traigo a colación: «Mi dosis de divinidad consiste en que soy, como tú, como todos los demás hombres, infinitamente limitado. Infinitamente. Piénsalo despacio, lector» (p. 467).

Lector. En definitiva el interlocutor anónimo que siempre busca cualquier escritor, el ansia de comunicación a través del soliloquio que establece el escritor con lo que cuenta en sus obras, con los personajes y las acciones que inventa. En esencia, en Monte Odina, el escritor, novelista, Ramón J. Sender, que se fusiona en la metáfora que simboliza el albatros:

El albatros es [...] un ave de la parte astral del planeta, pero vagabundea por todas partes, alcanza alturas enormes hasta hacerse invisible y toda su larga vida vuela errante y a veces extraviado, bajando solamente para alimentarse. Su vida está en los cielos y es fama que duerme en ellos con las enormes alas abiertas. Ellas son su lecho, su nave y sus gavias veleras. (p. 399)

El albatros..., como Sender, el hombre, el novelista, síntesis de su vida y de su narrativa.

\section{UN ESTILO}

Está claro que, con Monte Odina, Sender quiere cerrar su ciclo narrativo, y quizás vital. Esta obra es la última aportación a los libros que pueblan los anaqueles de la biblioteca que nuestro autor está organizando en esta narración apócrifa. En ella, además de construirla como si de una narración se tratara, narración que se mueve ante los impulsos de la memoria dormida de la vida del escritor, despertada a medida que se van tomando uno $\mathrm{u}$ otros volúmenes colocados, clasificados, organizados en las estanterías, además, digo, se permite juicios, valoraciones, interpretaciones de la obra y vida de muchos seres, personajes, autores, críticos, en algunos casos practicando la digresión que impera en cierto momento en sus novelas anteriores y que constituye a mi modo de ver uno de los vicios que afean algunas de las obras senderianas.

En Monte Odina, se habla, se opina, entre otros y sin mucho orden ni concierto, de la vida y la obra de Goya, Yeats, Wilde, Tirso, Zorrilla, Malraux, Picasso, Pau Casals, Balzac, Mann, Unamuno, Valle-Inclán, Ramón y Cajal, Stalin, Bertrand Russell, Franco, M. Monroe, Sartre, Beckett, Camus, Einstein, Kafka, Buero Vallejo, Sastre, Gala, Casona, Mihura, Arrabal, Azorín, Benavente, Shaw, Englekirk, Neville, O'Neill, O'Casey... También se rememoran momentos de vida traspasados a su novela Imán: «Algunos días me levanto especialmente memoratorio y vienen a mí unidades de vida ya agotadas, pero no muertas. Hoy, por ejemplo, recuerdo a aquel suboficial de complemento de Ceriñola 42 que era $\mathrm{mi}$ enemigo mortal no sé por qué [...] y un día [...] empuñamos los sables 
con la vaina puesta y nos liamos a golpes» (p. 140). Abundan los juicios que una y otra vez ha ido dejando en boca de los personajes de sus novelas anteriores o de la opinión del narrador omnisciente, que no es otro que las heridas personales del múltiple Sender. Así: «En todo caso yo trataré de añadir a los libros de la hipotética biblioteca de Monte Odina una corona de laureles y crisantemos. Una corona otoñal, bien cierta y verdadera. En esa biblioteca me instalo a voluntad sin dejar de ir y venir por el mundo" (p. 32).

No deja de reflexionar sobre las bases de sus recuerdos infantiles, tan presentes en su novelar: "Quizá lo mejor que tienen los hombres en su madurez y en su vejez es lo que conservan de la lejana infancia» (p. 21), buscando las esencialidades biográficas, las que coinciden con su apografía: "Monte Odina, tal como lo soñaba en mis buenos dieciocho años, sigue con vida propia en mi imaginación y estoy tratando de demostrarlo. Con descripciones de nuestra tierra tal como la recuerdo o como querría recordarla» (p. 32).

Hace incluso referencias personales, recordando sus comienzos literarios: «Mi vida literaria comenzó así, en Huesca. Con el estreno en el Teatro Principal de una comedia de sociedad que debía ser una tontería, pero que llenó el teatro hasta las galerías más altas porque fue a beneficio de los chicos del hospicio» (p. 34).

Entre los abundosos juicios sobre personas y escritores quiero entresacar tan sólo dos. Uno, digamos, positivo, el referido a don Santiago Ramón y Cajal, y otro, digamos, negativo, dedicado a Unamuno. Del primero, en algún momento escribe:

\footnotetext{
Yo viví algunos años en Madrid no lejos de la casa de don Santiago, que estaba en la calle Gutenberg, cerca de Pacífico y del Museo de Antropología, en el que por cierto transcurre la acción de una de mis novelas cortas titulada La hija del doctor Velasco, sobre un hecho misterioso e histórico. (p. 20)
}

En muchas páginas existe, aparece una especial identificación entre el joven Cajal y el que también fue joven Sender, siguiendo en parte las propias palabras que el sabio médico escribe en Mi infancia y juventud, una obra que merecería ser conocida, como ejemplificadora, para todos aquellos que un día sean jóvenes, por otro lado tan apegada a los mismos territorios hollados por Sender cuando vivió en Huesca, trabajó en La Tierra o noveló una y otra vez.

El personaje negativo de la época madrileña de nuestro autor es $\sin$ duda Unamuno, por el que Sender tuvo una especial inquina. Así, «[n]ada hay original en Unamuno, quien suscitó algún respeto por esa superstición un poco boba que existe todavía en España por la burocracia cultural. Ser rector de Salamanca, era algo" (p. 23). Y en otra ocasión: "El charlatán don Miguel de Unamuno decía que el sufrimiento acerca y une a los hombres. Si es así no sufrieron mucho los hombres del 98. Sobre todo con sus eternas y frívolas agonías» (p. 337). 
Abundan las digresiones sobre multitud de aspectos, entre las referidas al teatro, según los gustos del autor. Traigo tan sólo aquí una muy breve: «de Calderón, el supercastrense español, a Camus, el ultracolonial francés hay no sólo tres siglos y medio, sino toda la historia accidentada y heroica del liberalismo moderno» (p. 37). Juicios sobre el hombre español no faltan, el hombre que ha transitado por sus novelas: «el hombre podrá tomar a broma la vida, pero no llega a tomarse en broma a sí mismo. Ni a los otros. Hay a pesar de todo un cierto respeto por el hombre. Se le puede matar (eso es otra cosa) pero no ofender. Es decir, que si lo afrentamos hay que matarlo. El respeto de otros países por el hombre lleva implícito un cierto desdén» (p. 27).

Los tipos humanos que han ido desfilando por sus novelas, salvo algunos del otro lado del océano, son siempre españoles y quizás respondan a este juicio: «El ego de los españoles es de veras satánico y para estudiarlo no valen los textos de psiquiatría conocidos. Habría que crear otros, como otra es nuestra locura. Freud se queda muy atrás en relación con nosotros» (p. 72). Y sobre las mujeres, tan delicadamente trazadas en sus novelas y tan, siempre, en un discreto segundo plano, opina, citándolas como hembras: "Las hembras son seres extraños y encantadores. Uno se acerca a ellas con hambre [...] y ellas entienden esa hambre que a mí me parece viciosa y fraudulenta como un homenaje. Un motivo de gloria que justifica su existencia» (p. 73). Y más adelante añade: «Nosotros fingimos el amor, ellas fingen creernos y se produce entre dos engaños la flor de la maravilla, la orquídea sacramental [...] donde millares de potenciales seres pelean para venir a la vida» (p. 75).

Son abundantes las muestras de léxico aragonés que aparecen en sus novelas. Vaya tan sólo una que considero auténtica perla de Monte Odina: "Un ayudante del hortelano me dijo un día mientras afilaba una vara para sujetar los dos tallos de un injerto: - Cuando un hombre tiene la fachenda de nacimiento libresco no necesita echar roncas» (p. 86). Que vale casi como un tratado de poética. El hombre campesino, o el de ascendencia campesina, el rusoniano con su hombría primitiva, ${ }^{6}$ siempre han interesado en el novelar senderiano, quizás porque «[n]o es que yo crea que los campesinos son perfectos como seres humanos. No hay un ser humano perfecto en el orbe, y si alguna vez hemos creado un arquetipo de perfección nos hemos apresurado a crucificarlo. Pero el campesino está en sus vicios y defectos más cerca de la naturaleza elemental, y eso lo salva» ( $p$. 174). Y no me resisto a recoger un giro lingüístico que molesta especialmente a Sender, tan avispado por otro lado en observar la manera de hablar de las gentes para después trasplantarla a sus novelas: «la epidemia más extendida de nuestro tiempo es la estupidez "a nivel" (como dicen) internacional y mundial. Porque eso de "a nivel" es un barbarismo. Se debe decir "en el nivel"» (p. 173).

${ }^{6}$ Recuérdense Paco, el del molino, Viance, Sabino... 
A veces ciertas digresiones le llevan a perderse en variopintos circunloquios que desmerecen, como ocurre en algún momento de sus novelas. Así, entre las páginas 215 a 220, cuando habla entre otras cosas de «nuestra psique», que "vive de la masa activa de los protones llamados negativos y de la noción que en ellos reside [...] de la antimateria", o el episodio del té y del taoísmo, que ofrece tedio (p. 290 y ss.). Ripiosos son también los «poemas» que intercala en Monte Odina, como algunos de los publicados en su Libro armilar de poesía y memorias bisiestas. Pero, como «todas las bibliotecas son un vano intento de salvar a nuestra imaginación del caos" (p. 109), esta de Monte Odina queda, entre otros múltiples aspectos, justificada por algunos rasgos de estilo y de construcción escrituraria. Así, nuestro autor, que no ha hecho más que novelar la vida sencilla de las gentes sencillas a lo largo de su vida, escribe: «La gente sencilla sabe más de lo que ella misma cree saber. Es un saber latente e inconsciente que de pronto y por algún motivo inesperado se ilumina y se puede comunicar a los otros con palabras» (pp. 273-274).

Pero ¿por qué escribe todo esto Sender y por qué se ha pasado toda su vida escribiendo? Quizás porque «tengo la impresión de regresar a mi infancia y muchas de esas viñetas de la vida rural tendrán pronto algún interés en un mundo que cambia tan deprisa" (p. 319). Y justifica que sus novelas se basen siempre en la observación de la realidad real, porque

yo sé muy bien que todo lo que puede imaginar nuestra fantasía o nuestra razón está en la realidad, porque sólo puede alcanzar nuestra capacidad de ensoñación aquellas cosas que están en el campo del cual hemos venido y dentro del cual nos movemos y del cual somos subsidiarios. (p. 285)

Aunque haya que inventar la realidad novelada, no en balde el escritor nos refiere:

\footnotetext{
Un hermano mio [...] me dijo: «Las cosas que inventas son mejores y más convincentes que las cosas verdaderas». Esas palabras de mi hermano caído en sangre inocente, como tantos otros gloriosos mártires de los años 1936-39, me han acompañado cuando pensaba en mí mismo y en mis tareas de hombre que recuerda cosas y las escribe para que las lean los demás. (p. 285)
}

Hasta opina sobre la utilización de la primera persona gramatical, tan presente, por otro lado, en sus novelas. «Escribir en primera persona estimula la curiosidad del lector de una manera que podríamos llamar natural y no artificiosa, lo que es siempre importante» (p. 189).

Abundan en esta obra los guiños o, mejor, palos hacia los críticos, como ya he señalado al principio, y deberemos aprender la lección cuando escuchamos sus palabras: "el que puede producir algo en arte lo produce, y el que no puede se dedica a enseñar a hacerlo a los demás» (p. 52). $Y$, si faltaba algo, sin tapujos escribe: 
Quiero decir que escribo para mí mismo, sobre todo la poesía, y que cuando la publico me tiene sin cuidado lo que digan de ella, hasta el extremo de que no envío ejemplares a los críticos, aunque los hay excelentes y no oculto mi admiración por alguno de ellos. (p. 78)

$\mathrm{Y}$, como final, el refugio de siempre en su infancia y en su territorio, tan importantes en su novelar, que justificarían sus palabras «mi territorio es Aragón y a él me atengo», ${ }^{7}$ pronunciadas hace tiempo y en Monte Odi$n a$ hechas presentes de nuevo: «yo también hago mis pequeñas excursiones. Una de ellas — quién iba a decirlo- a Chalamera, mi aldea natal. No era necesaria mi visita porque llevo a esa querida y pequeña villa en $\mathrm{mi}$ memoria y en lo mejor de mis infantiles recuerdos» (p. 375). Chalamera como útero materno que ha acogido siempre las maneras noveladas de Ramón J. Sender, sintetizadas en los libros de la extensa biblioteca que como metáfora mitológica del eterno retorno nos ha ofrecido, porque «[d]esde Monte Odina se puede intentar un resumen del mundo. Tal vez del universo. Al menos del mío» (p. 61).

${ }^{7}$ En Conversaciones con Ramón J. Sender, Madrid, Magisterio Español («Novelas y Cuentos»), 1969. 


\title{
Psicologías de autor y lógica de personajes femeninos: Star, la adolescente anarquista; Amparo, la novia burguesa; Milagritos, la fiel esposa cantonalista
}

\author{
Ma Pilar Martínez Latre \\ Universidad de La Rioja
}

\begin{abstract}
$M_{i}$ comunicación va a centrarse en el análisis de los personajes femeninos de dos novelas senderianas que corresponden a la primera etapa de la producción narrativa del prolífico autor aragonés. Esta lectura crítica se centra en una selectiva nómina: Star, Amparo, Milagritos, mujeres que actúan en sus respectivos mundos novelescos como protagonistas o coprotagonistas y revelan una fuerte personalidad.

Me propongo para ello seguir las pautas de análisis desarrolladas por Ricardo Gullón ${ }^{1}$ en sus estudios narratológicos y, de manera especial, aquellos que abordan las relaciones entre el autor y sus personajes. Me interesa comprobar cómo el personaje femenino de Sender se hace en el contexto en el que es y actúa e, igualmente, cómo funciona la lógica de estas mujeres según la psicología que les atribuye el autor. Este punto de
\end{abstract}

${ }^{1}$ Ricardo Gunıón, Psicologías de autor y lógicas de personaje, Madrid, Taurus, 1979, y Espacio y novela, Barcelona, Bosch, 1980. 
partida me obliga a hacer referencia al contexto literario de las novelas en que se presentan, a sus relaciones con el espacio social e histórico, a sus funciones actanciales, a su caracterización directa e indirecta, así como a la focalización adoptada por el narrador o narradores para darles consistencia y vida, hasta llegar a su individualización. Dicho de otra manera, de acuerdo con la teoría expuesta por Milagros Ezquerro en su artículo sobre "La paradoja del personaje», ${ }^{2}$ me propongo ahondar en la construcción de determinados personajes novelescos y comprobar cómo se construyen en armonía con todos los elementos que componen la novela y cómo son solidarios, a la vez, de los otros personajes, de la acción, del tiempo y del espacio dentro de los cuales evolucionan.

He seleccionado para ello dos obras emblemáticas de este periodo, Siete domingos rojos y Míster Witt en el cantón, escritas en los años 1932 y 1935, respectivamente. Una vasta nómina de críticos especializados en Sender (Cansinos Assens, Carrasquer, Peñuelas, Michiko Nonoyama y Mainer, entre otros) las reconocen como novelas de una gran madurez, aunque se sitúan en la primera etapa de su producción literaria, en la que obtiene el Premio Nacional de Literatura con Míster Witt en el cantón. Escritas con moldes narrativos diferentes, la primera es clasificada como novela social y la segunda como novela histórica, aunque las dos pueden ser consideradas novelas testimoniales. Ambas proyectan el imaginario de un escritor comprometido con la revolución popular, que va progresivamente mostrando un cierto pesimismo ante la revolución fracasada. En Siete domingos rojos, asistimos, como ha mostrado Jover, a un reportaje proyectado sobre la actividad revolucionaria presente, mientras que «Mister Witt en el Cantón significa la retrospección en busca de una revolución del pasado». ${ }^{3}$ Para Víctor Fuentes ${ }^{4}$ las novelas de este periodo son crónicas históricosociales que esconden, no obstante, una fuerte dosis de escepticismo y pesimismo pequeño-burgués y, a la vez, novelas ontológicas que narran la lucha de clases desde la perspectiva obrerista y desde el transcendentalismo materialista, los avatares del ser y de la materia.

Empezaré centrándome en dos personajes femeninos de Siete domingos rojos, novela en que defiende los ideales anarquistas y en la que presenta dos perfiles psicológicos femeninos de extracción social antitética: Star, la adolescente anarquista, que despierta a la vida inmersa en el movimiento

2 Milagros EzQuerro, «La paradoja del personaje», en Marina MaYOral, coord., El personaje novelesco, Madrid, Cátedra, 1993, pp. 13-19.

3 José Ma Jover, en «Introducción» a Míster Witt en el cantón (Madrid, Castalia, 1978, p. 71), novela de la que este crítico realiza una espléndida edición crítica, manejada para mi estudio. En cuanto a Siete domingos rojos, cito por la edición revisada por el autor de 1973, Buenos Aires, Proyección.

4 Víctor FUENTES, "Sobre la narrativa del primer Sender", Norte. Revista Hispánica de Amsterdam, XIV/2-4 (marzo-agosto de 1973), pp. 35-40. Véase también su estudio «La novela social (1931-1936): Temas y significación ideológica», La marcha al pueblo de las letras españolas, 19171936, Madrid, Ediciones de la Torre, 1980, pp. 95-105. 
obrero, y Amparo, la joven burguesa, novia de Samar, el intelectual anarquista, por el que siente un amor irreconciliable con su ideología.

Milagros Ezquerro ${ }^{5}$ señala cómo el personaje novelesco es a la vez una forma y una estructura global. Cuantos más rasgos se añaden en el desarrollo de la acción narrativa, más complejo, rico y apasionante es el personaje. Así va a ocurrir con estas mujeres de Siete domingos rojos, ${ }^{6}$ que hacen su entrada en la ficción en medio de un mundo poblado principalmente por hombres. Sin embargo, los numerosos personajes masculinos que pululan por la obra son en su mayor parte secundarios (como los tres sindicalistas muertos en una manifestación, víctimas de la represión policial: Espartaco Álvarez, Germinal García y Progreso González, a los que erige en arquetipos del obrero anarquista, por medio de una concentrada caracterización en bloque y una denominación onomástica simbólica). Pero, sobre todo, abundan los personajes anecdóticos e incidentales, trazados con sobrias pinceladas.

Los verdaderos protagonistas masculinos se reducen al camarada Villacampa, un joven militante del sindicato mercantil, y al periodista Samar, el anarquista intelectual. ${ }^{7}$ Cansinos Assens, en su lectura crítica realizada en $\mathrm{La} \mathrm{Libertad}^{8}$ en 1933, opina que Samar es el personaje central de la obra, el controlador de su fuerza trágica, y que a su lado se sitúan las figuras representativas de dos mujeres: Star, que aporta a la novela el alma sencilla del sainete, y la señorita Amparo García del Río, que introduce el anhelo de fusión de clases tan del gusto del melodrama sentimental burgués. Es evidente que estas dignas coprotagonistas están construidas con un conjunto de rasgos semánticos que se van completando a medida que se desarrolla la historia novelesca.

En el prólogo a la segunda edición leemos algunas opiniones del novelista sobre la idea directriz que le mueve en la construcción de su mundo de ficción y que va a condicionar el perfil psicológico de estos personajes. Sender pretende elaborar una novela testimonial que presente un referente histórico muy próximo a los acontecimientos novelados. El autor reco-

\footnotetext{
5 Art. cit., p. 14.

${ }^{6}$ Sigo las sugerencias del propio Sender, que aconseja sean leídas sus obras en su edición última (Buenos Aires, Proyección, 1973), pues sólo entonces nos encontramos con la obra definitivamente cerrada.

${ }^{7}$ Samar es el personaje de mayor consistencia psicológica pues es el soporte de la trama sentimental y de la trama política. En su actuación como alter ego de Sender, este ideólogo revisionista, que milita en la CNT, presenta las preocupaciones políticas vividas en esta etapa por nuestro autor, como sus dudas sobre los modos de actuación de los anarquistas y sobre su acercamiento a la estructura organizativa de los comunistas. Véase Michiko NONOYAMA, El anarquismo en las obras de Sender, Madrid, Playor, 1979.

8 Rafael CANSINOS ASSENS, «Ramón J. Sender y la novela social», artículo que cito por JoséCarlos MaINER, ed., Ramón J. Sender. In memoriam. Antología crítica, Zaragoza, Diputación General de Aragón, Ayuntamiento de Zaragoza, Institución Fernando el Católico, Caja de Ahorros de Zaragoza, Aragón y Rioja, 1983, pp. 37-57.
} 
ge en su ficción a las masas representadas por los sindicalistas anarquistas que sueñan con la libertad, el bien y la justicia y que intentan derribar el orden social vigente mediante una serie de huelgas e insurrecciones. Sus personajes, en el contexto de radicalización del movimiento obrero en los años más problemáticos de la Segunda República, ${ }^{9}$ derrochan heroicidad y generosidad y viven al mismo tiempo sus pequeños dramas cotidianos durante siete domingos rojos, tiempo novelesco al que se ajusta el relato.

Cuando escribe esta novela Sender es ya un brillante periodista que quiere, como él mismo confiesa en el prólogo, «perderse en la realidad misma del momento» y recoger de manera especial «[e]l amor por la libertad», que "es entre los anarcosindicalistas españoles natural» (p. 7). Se trata de un amor que lo abarca todo y condiciona todas las otras formas de amor. El escritor deja también claro al lector antes de adentrarse en la ficción que no estamos ante una novela que defienda una tesis sino ante la presentación de «una realidad simplemente humana, con lo estúpido y lo sublime» (p. 9).

Los rasgos físicos y psicológicos que van revelando Star y Amparo atrapan y seducen al lector por su candor, ingenuidad, desprendimiento y capacidad de entrega, aunque sus caracteres presenten notables diferencias que las individualizan. En su constitución participan diversos narradores, ${ }^{10}$ que comparten la narración de la historia y proyectan sus particulares puntos de vista, dejándose también seducir en algunos momentos por ellas.

La primera presentación de Star en la ficción se produce desde el ángulo de focalización subjetivo y limitado del joven camarada Villacampa, militante sindicalista apasionado, enemigo de la burguesía y fascinado por el anarquista Samar. El "hortera» Villacampa hace su aparición, reconociendo su condición de personaje de ficción, mediatizado por el poder del autor, aunque su narración en primera persona lo convierte en un ser real a los ojos del lector. El encuentro casual en el tranvía con Samar y su novia, la bella Amparo, despierta sus deseos eróticos. Su afán de emular a Samar en el terreno amoroso le lleva a evocar su objeto de deseo, la adolescente Star, cuya influencia trata de neutralizar presentándola como una joven que carece de méritos para ser su novia y a la que cree un poco boba.

Aunque el personaje se irá construyendo poco a poco, estamos ante la primera mención de Star, sobre la que el narrador subjetivo homodiegéti-

\footnotetext{
9 Antonio ElorzA, en La utopía anarquista en la Segunda República (Madrid, Ayuso, 1973), señala el año 1932 como el cenit de los intentos revolucionarios del anarquismo español.

${ }^{10}$ Cuando estoy finalizando la comunicación me encuentro con el artículo de Gilberto TrRvNos y $\mathrm{M}^{a}$ Nieves ALONSO «La novela de la creación humana del mundo: Siete domingos rojos de Ramón J. Sender», editado en la revista Acta literaria, 18 (1993), pp. 83-112. Estos críticos destacan en su interesante análisis la importancia de la polifonía en la obra y llaman la atencion sobre la pluralidad de «lenguajes sociales», que contribuye a producir la ilusión de una realidad que a la vez es una y múltiple, como son las subjetividades que la perciben (p. 94).
} 
co, en su desdoblamiento autorial y actorial, realiza una primera descripción, que proporciona al lector una caracterización bastante completa. Sin embargo, algunos de estos rasgos sugieren connotaciones que se reiteran a lo largo de la acción y que logran una convincente individualización del personaje al finalizar la novela.

En su caracterización, Leoncio Villacampa recurre a una serie de variados procedimientos como el simbolismo onomástico, la descripción física y el rol profesional. Villacampa actúa en lógica correspondencia con su psicología y en su descripción se proyecta como un enamorado inseguro pero muy interesado por Star; así lo demuestra cuando informa sobre la edad de la joven, pues, aunque duda sobre si tiene 15 ó 16 años, sin embargo conoce sus íntimos deseos de ser mayor para poder cambiar por las medias y zapatos de tacón los calcetines y los zapatos bajos que le obliga a llevar su padre, probablemente queriendo frenar el rápido crecimiento de la adolescente. Leoncio informa igualmente con precisión sobre sus rasgos físicos: morena, de ojos grandes y quietos pero de color azul y cara redonda con hoyuelos cuando se ríe; da detalles de la vestimenta, a la que califica de desenfadada y de la que destaca su jersey rojo (evocador del clima revolucionario que el propio título de la novela connota también con fuerza). Su enamoramiento por Star se vuelve a descubrir cuando manifiesta que podría ser tan guapa como la novia de su compañero Joaquín si se vistiera mejor o cuando desecha con repulsión la imagen de un calendario lésbico en el que una de las jóvenes fotografiadas se parece a Star, por considerar que la joven no puede caer en esas viciosas costumbres.

En cuanto a la denominación onomástica de la adolescente, Star, en lugar de Estrella, el autor consigue que el apelativo pierda su posible connotación snob al proporcionar la explicación del origen y significado de su cambio. Estamos ante un apelativo anglosajón con el que el padre, el revolucionario Germinal, ha bautizado a la hija como grato recuerdo de su estancia en Inglaterra; evocador, también, de su pistola predilecta (no olvidemos que las pistolas forman parte de la indumentaria más querida por el anarquista, pues son el arma imprescindible en sus actuaciones revolucionarias). Con este nombre tan rico en connotaciones es identificada por todos los amigos y compañeros a lo largo de la acción; algo tiene la adolescente de la luminosidad de una estrella, pues con su disponibilidad, coraje y desprendimiento ayuda a los desnortados anarquistas a recuperar su norte.

Junto con los signos del ser, añade Villacampa signos de la acción de Star al mencionar su rol profesional como vendedora en una fábrica de lámparas y su actuación como sindicalista, aspirante a delegada sindical. Sus informaciones traslucen, de nuevo, cierta rivalidad no exenta de tics machistas pues la descalifica, juzgándola de «ignorante», cuando la presenta disputándose con ella la entrada en el comité sindical. Villacampa opina que Star tiene poco que ver con su padre, al que considera un sin- 
dicalista ejemplar, y se muestra persuadido de la pureza del anarquismo, ${ }^{11}$ que no admite la promoción de los hijos sirviéndose de la influencia paterna.

El lector se enfrenta después de esta completa presentación de Star con lo que Milagros Ezquerro llama la paradoja del personaje. Star, como personaje novelesco, es un sistema que la obra va construyendo progresivamente, pero al mismo tiempo es una entidad global que el texto entrega en su primera ocurrencia, una figura cabal que se impone al lector mucho antes de que la novela haya podido construirla. Pero de ello no debe inferirse que estemos ante un personaje plano, esquemático y lineal, sino que por el contrario nos enfrentamos a un personaje que va a ir enriqueciéndose a lo largo de la aventura novelesca, que madura y se hace adulto ante las duras experiencias vividas, aunque el tiempo de los acontecimientos novelados sea reducido y concentrado.

La segunda aparición de Star se hace a través de la mirada de un narrador testigo, que habla en tercera persona y que adopta, en ocasiones, el punto de vista de un narrador implícito, autorial y omnisciente. Esta nueva instancia narrativa innominada se presenta como sindicalista anarquista conocedor de sus compañeros, por los que llega a sentir un afecto especial, como así demuestra al presentar a la joven Star. Su participación directa en los acontecimientos le permite narrar con detalle el mitin dominical celebrado en el teatro del barrio obrero, al que no puede faltar la «compañera» anarquista Star. Esta nueva descripción física es ahora breve y fragmentaria y en ella destacan algunos rasgos que el lector ya conoce después de la descripción hecha por Villacampa. Estamos ante pinceladas sígnicas anafóricas, con las que queda identificada la adolescente, referidas a sus piernas y vestimenta; son rasgos emblemáticos enriquecidos con comparaciones muy plásticas que quedan impresas en la retina del lector: "Sus piernas desnudas sobre el tosco calcetín de su padre eran las piernas bucólicas que aparecen en las tapas de laca de las tabaqueras» (p. 25). En cuanto a su vestimenta, vuelve a destacar «el rojo de su jersey", al que le añade un toque de voluptuosidad al aludir a su «frutal» garganta; no obstante, advierte que sus senos y gestos son todavía infantiles: «Llevaba su mercancía sobre el pecho izquierdo, apenas acusado. A veces descansaba sobre un pie u otro como si meciera a una muñeca» (pp. 27-28).

Este puntilloso narrador destaca también un signo de la acción, la condición de propagandista de Star, que aprovecha la reunión anarquista para difundir y vender propaganda. El narrador ennoblece su visión y la presenta imbuida en su papel, adoptando una actitud grave y seria: «Llegaba

11 Sin embargo, como ha señalado Michiko NONOYAMA en su ya citado estudio El anarguismo en las obras de Sender, ambos personajes comparten la misma actitud ideológica con la clase burguesa, a la que consideran culpable y merecedora de la muerte por ser instrumento de la injusticia social. 
Star García con mercancía nueva. Vendía rosetas de trapo rojo para los presos sociales. La piedad se hacía en ella estatua, se consagraba en mármol» (p. 25). Poco después este mismo narrador se comporta como un mirón que se divierte sorprendiendo a Star, quien se mueve entre el gentío con facilidad a la búsqueda de sus amigos preferidos.

Para completar los signos del ser de Star el autor profundiza en su estatuto sociológico; para ello hace intervenir a un tercer narrador que, aunque adopta un punto de vista más objetivo que el anterior, sigue identificándose con el autor implícito simpatizante con los anarquistas. En este nuevo capítulo narra el trágico final del mitin, en el que mueren tres sindicalistas, abatidos por la violenta carga de los guardias de asalto mientras revientan el acto. Uno de estos hombres es Germinal, el padre de Star, del que nos presenta una breve ficha biográfica que contribuye a conformar el entorno familiar y la atmósfera en la que ha discurrido su infancia. Estamos ante un idealista que lucha por una sociedad más justa, un operario ejemplar, de profesión fumista, buen padre de familia, que queda muy pronto viudo y tiene a su cargo a una anciana madre, la abuela Isabel, y a su hija Star, por la que muestra una especial ternura. La única preocupación de Germinal mientras agoniza en la calle es ver a Star a salvo y, así, cuando la ve bajo la protección del camarada Samar, en el que ha depositado su confianza, encara serenamente la muerte.

El espacio familiar en el que ha crecido Star es una humilde casa, situada en un barrio obrero del norte de Madrid que es incapaz de controlar la brigada social, un espacio refugio abierto a todo el que necesita asilo. En este sencillo pero cálido hábitat, en el que se respira solidaridad, crece Star, en compañía de una anciana abuela - que vive obsesionada por reivindicar la muerte del hijo- y de dos animales: un esquivo gato y un arrogante e inteligente gallo, acompañante inseparable de Star. Éste es el espacio que la prepara para adoptar una actitud hombruna y camaraderil con sus compañeros sindicalistas.

El gallo, que para Cansinos Assens «anuncia auroras rojas cual centinela soviético", es parte de la caracterización habitual con la que se presenta Star. La adolescente mantiene con él un comportamiento ambivalente, pues unas veces parece la niña que hace de él su juguete y otras adopta la actitud protectora de una madre con su bebé, desconfiada de lo que pueda pasar cuando la casa queda sola, y lo lleva en brazos en sus correrías por la ciudad, cuando va a "actuar» con sus compañeros. Este curioso animal, tan poco dado a la domesticidad, da un toque de extravagancia a la personalidad de la adolescente. La jovencita, que ha logrado crear una cariñosa relación con el gallo arrogante y peleón, parece proyectar en él sus carencias afectivas, que se intensifican al producirse la muerte violenta del padre. Sólo Samar es el confidente de esta frustración infantil, que llevaba a Star a construir sus propias muñecas con trapos y serrín desde los ocho años ante la mirada divertida y socarrona de su abuela, que les encontraba parecido con los sapos. 
El abandono de la infancia y la entrada en la adolescencia se produce en este tiempo reducido en que se desarrollan los acontecimientos narrativos- con la experimentación de una crisis existencial provocada por la violenta muerte del padre, superada con el apoyo de Samar y Villacampa, agentes benéficos que comparten la protección de la joven en diferentes momentos. Star ha dado un paso hacia el mundo de los adultos en el dramático escenario del depósito de cadáveres, empujada por un Samar analítico y frío que la enfrenta con la cruda realidad y por un Villacampa apocado y paternalista. El desenlace de esta patética secuencia es presentando hábilmente por el narrador con una perspectiva dual: en una primera reacción se nos muestra a una Star que interioriza el dolor y adopta una actitud reivindicativa, dejando de ser «la estatuilla fría e inexpresiva» para pasar a adquirir una expresión de «furia salvaje» y de "odio concentrado»; pero poco después nos la presenta sorprendiendo a sus amigos, cuando con una actitud práctica se dispone a comprar maíz para el gallo antes de regresar a casa, en previsión de la huelga general que se avecina.

Un nuevo capítulo con un título de folletín nos presenta a Star como narradora autorial y actorial: «Habla la compañera de Oficios Varios Star García, que se ha quedado sola en el mundo» (p. 47). Es ésta una noche iniciática en la que Star, desvelada tras los duros acontecimientos vividos, asume su orfandad, rechaza la invitación de las vecinas y elige como receptor de su discurso al gallo, testigo indiferente de sus agitados sentimientos. Por medio de este falso diálogo Sender consigue dar más autenticidad al personaje y a sus sentimientos. Asistimos a un monólogo vivo, que adopta la forma de estilo indirecto libre. Star vuelve a presentar algunos de sus datos biográficos, que el lector ya conoce, y añade algunas puntualizaciones: la edad, 14 años, y el sueldo que cobra como trabajadora en la fábrica de lámparas, 17 pesetas a la semana. Recuerda, también, los miembros que componen su familia: la abuela, el gato y el gallo, de los que se siente responsable en sus necesidades más perentorias, pero menciona la incomunicación que existe con la abuela, "que no hace más que reñirme» $\mathrm{y}$ «no representa nada porque se va del mundo y yo estoy viniendo».

El monólogo desvela su fuerte pulsión vital, su carácter optimista e independencia de criterio y, así, afirma ser «joven y guapa» y rechazar la visión negativa que su padre tenía de la sociedad, a la que calificaba de "criminal», mientras ella la considera sólo tonta y simple; no obstante, se muestra como una joven que todavía se mueve con vacilaciones en el umbral de los adultos, un mundo que se le presenta enigmático y contradictorio. Por eso se extraña de los consejos de las vecinas, que le hablan de su edad peligrosa y le aconsejan vestirse de luto, cuando está firmemente decidida a comprar sus primeras medias de mujer.

Finalmente, con una sinceridad propia de la psicología de la ingenua adolescente anarquista, descubre su despertar a la sensualidad cuando confiesa su atracción sólo por algunos compañeros $\mathrm{y}$, especialmente, por 
dos hombres, Leoncio y Samar - cuyos nombres escamotea al lector, que, sin embargo, tiene la respuesta por los indicios sembrados en la obra-, a los únicos que confiesa sería capaz de besar en la boca venciendo sus ascos. Este rechazo del contacto físico forma parte de los temores de la adolescente en su iniciación a la sexualidad, similares a los que presenta el adolescente Pepe Garcés, protagonista de Crónica del alba y alter ego de Sender.

Star desarrolla un rol actancial complejo: como anarquista libertaria participa en las movilizaciones, asiste como espectadora muda a sus reuniones, apoya sus actuaciones interviniendo como correo, introduce propaganda anarquista en los cuarteles para que se sumen a la rebelión; sin embargo, no muestra interés alguno por las armas, pues, aunque se acompaña en sus correrías de un pequeño revólver, en el cargador sólo hay una bala simbólica en la que están grabados los nombres de Samar y el suyo. Este desprecio por las armas lo atribuye el joven anarquista Villacampa a la incapacidad de Star para odiar.

Pero la actuación de Star es también la de un personaje anáfora que siembra e interpreta indicios. Con la red de llamadas que va creando hace cómplice al lector, que comparte sus sentimientos y participa de sus descubrimientos. A través del discurso monologal, el autor nos pone delante de una joven inteligente y realista, con una base ideológica revolucionaria, que se aleja de la estereotipada figura del folletín; así, cuando deja de contemplarse y se detiene en la observación de su entorno participa del discurso político. Empieza centrando su atención en el gato. Aunque su padre le había bautizado con el nombre del anarquista ruso Makno, ella cree que sus mañas son de comunista autoritario. El autor proyecta en Star una psicología basada en una sencilla y eficaz percepción femenina y su discurso se desarrolla con la lógica asociativa, como se percibe en la expresiva comparación entre las actitudes antagónicas de los animales de su entorno vital: el gato y el gallo frente a los hombres de la izquierda. Está convencida de que, así como ella va a convivir en armonía con los animales, los partidos políticos de la izquierda, comunistas y anarquistas deben pactar si quieren ser eficaces en la lucha contra el capitalismo: «Me parece que, en una época de lucha contra el capitalismo, como la que vivimos, debemos ir juntos todos». Star descubre al lector las opuestas tendencias políticas de sus amigos, Samar y Villacampa, que se irán matizando a lo largo de la acción narrativa: «Samar no es anarquista y si está con nosotros es porque tiene más fe en la organización y en la valentía revolucionaria de los individuos. A mí no me la da. Villacampa es anarquista. Tiene la cara quieta y los ojos tranquilos y habla un poco por demás. Ésos son anarquistas, mientras que los comunistas siempre parece que tiene prisa y miran de reojo [...]» (p. 49). Star actúa ahora como un personaje de acoplamiento o engranaje y se convierte en portavoz del autor, pues, aunque su lenguaje, coloquial, sea propio de una jovencita poco formada, que razona de manera sencilla, sus ideas proyectan la psicología de un autor 
implícito, que atraviesa una etapa política en la que se cuestiona la eficacia de las organizaciones anarquistas.

El capítulo se cierra volviendo a mostrar la facultad de Star para interpretar indicios, que le permiten arrojar nuevas luces sobre la personalidad del protagonista Samar: «Ahora comprendo a este hombre. No veía muy claro. Siempre quedaba una zona oscura, pero yo lo echaba al comunismo" (p. 51). Esta actuación se produce cuando se convierte en destinataria involuntaria de una epístola amorosa que Samar dirige a su novia. Ante sus ojos se revela un nuevo hombre, inmerso en una pasión amorosa que ella no logra entender, pues como ingenua adolescente desconoce los ardientes sentimientos de los enamorados. Todo ello se trasluce en los juicios que emite: «nunca pude imaginar que las cartas de amor se escribieran así». Star dispone ahora de una información privilegiada, pues conoce la pasión alienante de su amigo, que califica con ironía como una enfermedad, algo así como «el tifus o la gripe»; acepta, no obstante, actuar como correo de su correspondencia amorosa.

Las relaciones entre Star y Samar, al que admira como si se tratara de un líder carismático, se van intensificando a lo largo de la acción, seducida por su brillante retórica, su afectuoso trato y su belleza física. Un narrador testigo lo pone en evidencia cuando en una reunión de un grupo de anarquistas en la Casa de Campo dice: « $Y$ allí estaba Samar y Star García, que parece su sombra [...]. Star sigue interesada por ese intelectual burgués alumbrao que viene con nosotros como un turista, aunque urgándose a veces la piel». Y es la propia Star la que en un nuevo monólogo desvela sus sentimientos y confirma estas inclinaciones amorosas por el intelectual después de recibir su primer beso en los labios. Estamos de nuevo ante la joven intuitiva consciente de la lucha existencial que desgarra a Samar y dispuesta a ofrecérsele sin condiciones: «Pero yo lo curaría. Ese beso ${ }^{12}$ que me ha dado me ha revelado el secreto. [...] ¿Cómo? No lo sé. Estando a su lado. Si me arrastrara consigo no me importaría» (pp. 144-145).

Las últimas actuaciones de la joven coadyuvan al desenlace de la novela al convertirse en agente protector de Samar, demasiado romántico, voluptuoso y sensible, prisionero de su amor burgués, que le obsesiona y que le lleva a realizar torpezas que ponen en peligro a la organización. Lejos quedan ya esos momentos felices en que una Star ingenua ha compartido con su amigo y compañero un inocente baño nudista, en una hermosa escena neorromántica que «resucita - para Cansinos Assens- todo el candor de la égloga antigua». La joven libertaria irrumpe en la casa de la novia burguesa con gesto decidido y sencillos argumentos e intenta convencerla de la falta de amor de Samar y de la necesidad de romper el noviazgo. Ahora son dos rivales que se observan y califican, enemigas

12 También Pepe Garcés, el adolescente que representa la infancia de Sender en Crónica del alba, entra en la pubertad cuando logra superar sus ascos sobre los besos en la boca. 
ante el hombre que aman y que no pueden compartir. Star, con su decidida intervención en la trama sentimental, correlato de la trama política, contribuye a que Samar se libere de la cárcel del amor y se arroje a los brazos del anarquismo.

El segundo personaje de mi análisis se centra en Amparo, que, como Star, alcanza en su caracterización el vigor de los seres reales. Su configuración semántica se construye, no obstante, con una limitada intervención de narradores, al no formar parte como la joven revolucionaria de la visión caleidoscópica que presenta el autor del anarquismo. La primera mención de esta mujer procede de Star, que descubre por azar sus vinculaciones sentimentales con Samar. Nuestra informante la reconoce como la hija del coronel de artillería del 75 , cuyo cuartel está en las proximidades de su casa, y nos proporciona la denominación onomástica completa, Amparo García del Río.

Pero la mayor parte de la información de que dispondrá el lector procede de Samar, que proyecta la visión subjetiva y alterada del enamorado, enfrentando al lector con la dialéctica del amor burgués frente al revolucionario. La focalización entra dentro de la lógica de los determinantes que afectan a la psicología de este personaje femenino. Amparo, como hija de la alta burguesía, vive de espaldas a la conflictiva realidad social, aislada en un espacio vital protector, «un pabellón» anejo al cuartel donde vive con su familia, de la que no hay información detallada. Su conocimiento de la vida que acontece a su alrededor le llega a través de Samar, que actúa como filtro, derrochando una actitud protectora no exenta de egoísmo para poder vivir una pasión amorosa en flagrante contradicción con su ideario político.

Sus rasgos caracterizadores llegan al lector de la voz de Samar, que proyecta en su retrato una sensibilidad romántica ${ }^{13}$ en comunión con la atmósfera de las rimas becquerianas, marco adecuado para la presentación de la amada: "Nos desviamos un poco, porque yo quiero ver el balcón de Amparo. El muro de ladrillo rojo está cubierto de trepadoras hasta el balcón mismo. [...]. Algunas campanillas azules tiemblan mojadas de rocío. La mañana es femenina; rubia como ella; alta y de una delgadez sazonada. Azul de ojos - inmensa de luz - como ella, y tierna y dulce con sus brazos frescos» (pp. 66-67). El lector vuelve a encontrar el mismo paisaje idílico cuando Samar enumera las cualidades de la novia: «Ella es agua transparente, serena, inalterable. [...] Un remanso entre mirtos, campánulas y caminitos de arena, mientras en el mundo todo es roca viva» ( $p$. 105). Estamos ante una imaginería tópica preciosista y artificiosa que evoca el arquetipo femenino romántico.

El lector es también informado por Samar de su primer encuentro con Amparo y de su súbito enamoramiento cuando responde a las curiosas

\footnotetext{
13 Sensibilidad que se corresponde con «El nuevo romanticismo» de esta generación de escritores sociales de la que habla en 1930 Díaz Fernández.
} 
preguntas de Star. El descubrimiento se produce en una visita de cortesía a un colegio de monjas donde están también de visita los padres de la joven, amigos de su familia. En este fugaz contacto, que se describe brevemente, Samar se convierte en un rendido enamorado de la adolescente, impresionado por su belleza e ingenuidad.

Una mayor concreción de sus rasgos físicos la obtenemos de nuevo de Samar cuando, en una de sus citas amorosas, se acoge a la intimidad de la sala de cine, donde interrumpe las visión de las imágenes de la pantalla para sumirse en la voluptuosa contemplación de la novia: «La miro y distingo sus contornos: las mejillas frutales, la sonrisa lozana, los ojos rasgados y brillantes».

Su personalidad, como nos hace notar el enamorado, está marcada por su ascendencia burguesa, que se manifiesta tanto en su forma de vestir, que tiene el sello de la elegante clase acomodada, como en su escritura — «su letra picuda»— o su modo de expresarse. ${ }^{14}$ Samar va desvelando el perfil psicológico de la joven burguesa, que carece de conciencia porque «está por crear todavía» y que se mantiene en una «infancia moral». Nuestro narrador subjetivo hace hincapié sobre esta inocencia e infancia psicológica al compararla con Star, a la que considera más preparada para afrontar la vida, pues «lo conoce todo sin curiosidad ni misterios». Adopta también con ella una actitud protectora, teñida de paternalismo, que se pone de relieve en sus fugaces encuentros y que entorpece su madurez: «Necesito seguir envolviéndola, rodeándola [...]. Nada debía llegar a ella. Nadie podría rozarla con una palabra ni con un pensamiento» (p. 108). El intelectual anarquista, condicionado por sus orígenes burgueses y traicionado por sus sentimientos, se siente subyugado por el estadio de inocencia de su amada hasta el punto de cultivar su candor y resolver con mentiras y «cuentos chinos» sus ingenuas preguntas sobre el sexo.

El perfil psicológico de Amparo lo completa ella misma en sus limitadas entrevistas con el novio. En sus conversaciones se intensifica su perfil burgués o su ascendencia burguesa, defensora inconsciente de los valores tradicionales; sueña con un horizonte en el que se contemplan el hogar apacible y confortable y los futuros hijos, a donde quiere arrastrar a Samar. De la intensidad y fuerza con que se entrega al amor - volcada en los preparativos de su ajuar - tenemos el testimonio de la carta que escribe a Samar, en cuya lectura se sumerge hipnotizado este amante cortés anarquista. Las cartas presentan indicios del llanto de la joven y revelan su estado emocional al conturbado enamorado: «Estoy viendo sus ojos inquietos, su pecho convulso y agitado, y sigo leyendo, ajeno a todo» (p. 74).

A medida que la revolución popular arrecia, esta mujer apasionada teme por la integridad de su novio y a pesar de su fragilidad adopta una

\footnotetext{
14 Sobre la superficial formación cultural que reciben las jóvenes de la burguesía en los colegios de monjas informa también en los primeros capítulos de Crónica del alba cuando habla de su hermana Concha e ironiza sobre las faltas de ortografía y su letra picuda.
} 
actitud protectora cuando se encuentran en público; llega incluso a iniciar con pasos vacilantes de neófita un tímido acercamiento al mundo anarquista, pero no logra entender el significado y el alcance de su revolución. Así lo percibe Samar, que valora sus esfuerzos, aunque no los toma en serio: «No tiene miedo. Yo soy feliz viéndola desafiar con la mirada a los tipos equívocos que se acercan [...]. Mi ángel bonito se siente pantera con su garganta frutal [...]. Está dispuesta a repetir de buena fe que es anarquista y si lo hiciera no tendría más remedio que reírme con todas mis fuerzas» (p. 109). No obstante, antes de asumir la imposibilidad de su amor, actúa como colaboradora de los anarquistas y proporciona a Samar los salvoconductos para entrar en el cuartel. Pero, a medida que aumentan los enfrentamientos entre los sindicalistas y la policía y crece el clima de tensión en la ciudad, se abren sus ojos a la cruda realidad; a ello contribuye la muerte del confidente de la policía, Fau, en manos de los revolucionarios y la presencia del cadáver debajo de su balcón. La mujer pierde su inocencia y reconoce el abismo ideológico que le separa de Samar, pues nunca podrá justificar sus asesinatos. Una sobria escena con ribetes melodramáticos, presentada por un narrador omnisciente, desvela esta transformación. Amparo es ahora la doncella oferente que espera al amado vestida de novia y se le entrega sin condiciones, pues si el espíritu los separa el deseo carnal los une. El amante, aturdido por su entrega, saborea las delicias de esta unión; pero Amparo, que ha sucumbido a la pasión de su amado, lo hace de manera pasiva, consciente de que este acto representa el «final de su vida». Con estas bodas desacralizadas asistimos a la quiebra de sus ideales y a la expulsión del paraíso de la novia burguesa. Sender añade más profundidad al significado de su entrega al contrastar la actuación de Amparo con la de otro personaje femenino, Emilia, que se erige en símbolo de la mujer anarquista, defensora del amor libre. Esta mujer elige a Samar, al que persigue por las calles madrileñas, para vivir su primera experiencia sexual. Estamos ante una joven militante, que sin abandonar sus creencias religiosas rechaza la virginidad como principio burgués y defiende la existencia de hijos fuera del matrimonio y el placer como satisfacción de los instintos.

Al acercarnos al desenlace de la novela, el personaje de Amparo alcanza su pleno desarrollo. La confusa conciencia de la novia, su lucha agónica entre eros y tánatos, es presentada por un narrador que en estilo indirecto libre va creando una red de indicios que preparan al lector para afrontar el trágico y emotivo desenlace. Amparo actúa, ahora, como una mujer que, expulsada del paraíso burgués al entregar su virginidad, se enfrenta con un hogar frío e impersonal en una soledad absoluta, «que la rodeaba de altas murallas que sólo le permitían ver cielo y nubes».

Con la inesperada visita de Star al día siguiente, a la que contempla como su rival, la novela roza el melodrama. Los sinceros argumentos de la joven anarquista para que Amparo se aleje de Samar la empujan decididamente al abismo. Su suicidio, que se presenta con el registro narrativo 
de una sobria crónica urbana, lo lleva a cabo con la pequeña pistola que Star ha dejado involuntariamente olvidada. El disparo queda amortiguado con el sonido de los truenos, pues el narrador ha enmarcado con habilidad la escena en un clima atmosférico de tormenta que acrecienta su dramático desenlace.

Este acto de generosidad de Amparo engrandece su personalidad. Y será el propio Samar quien, tras superar el dolor que provoca su muerte, sumido en una profunda crisis que le coloca al borde del suicidio, reconozca la grandeza de su espíritu. El azar ha hecho que la novia burguesa repose al lado de los camaradas libertarios y a ellos se la encomienda el enamorado. Amparo es otra víctima libertaria que, arrojada del paraíso burgués, ha ganado un lugar en el paraíso de los anarquistas, aunque para ello ha tenido que entregar su vida. El héroe queda libre para la lucha pero es ahora un anarquista herido, derrotado, que se lanza a la escritura de un manifiesto libertario en actitud desesperanzada. ${ }^{15} \mathrm{El}$ futuro que Sender ofrece al lector no tiene el horizonte reivindicativo tan firme como el que presenta Díaz Fernández con Víctor Murías, otro periodista comprometido que se dispone a salir de la cárcel para hacer la revolución; pero éste tiene a su lado a su abnegada esposa Obdulia, que ha roto con su pasado burgués, de Venus mecánica, ${ }^{16}$ y se ha entregado a la causa revolucionaria.

Con Mister Witt en el cantón Sender abandona el escenario madrileño para dirigir su mirada al sur, en cuyo marco paisajístico crea un atractivo retrato de una mujer murciana, Milagritos, que adquiere un papel de personaje femenino central de una de sus novelas históricas de mejor factura y vigor dramático.

Han transcurrido tres años desde la realización de Siete domingos rojos y Sender sigue en Mister Witt proyectando el imaginario del intelectual de izquierdas que participa en la lucha por el cambio de sociedad desde su posición ideológica, aunque Jover ${ }^{17}$ cree vislumbrar cierto pesimismo histórico que se podría definir como crisis de confianza en el futuro. Estamos ante un periodo en el que el devenir histórico tiene una influencia decisiva en el escritor, que pretende influir en el lector de su tiempo, alertándole sobre los problemas cotidianos. Sender sigue siendo el novelista social que sitúa la acción en un pasado próximo -60 años la separan de la Segunda República, fecha de redacción de la

\footnotetext{
15 Este desenlace, que para Francisco CARRASQueR ( «Míster Witt en el Cantón», en «Imán» y la novela histórica de Sender, Londres, Tamesis Books, 1970, pp. 87-107) está envuelto en términos

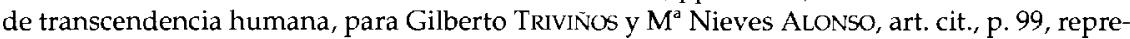
senta la inmersión en la masa del personaje, que ha triunfado sobre la tentación de abandonarse.

$16 \mathrm{M}^{\text {a }}$ Pilar MARTínez LATRE, «Aspectos vanguardistas de una novela comprometida», en Actas del Congreso en homenaje a Rosa Chacel, Logroño, Universidad de La Rioja, 1994, pp. 185-196.

17 José $\mathrm{M}^{\mathrm{a}}$ JOVER, «Introducción» a Míster Witt..., ed. cit.
} 
novela--, una etapa que se presenta como ejemplo o revulsivo respecto del mundo en el que vive el lector. ${ }^{18}$

La novela desarrolla un mundo de ficción en el que Sender teje y entrecruza hábilmente una intriga histórico-política y una intriga sentimental en la que se mueve nuestro personaje protagonista femenino, así como una extensa nómina de personajes masculinos, partícipes de su epopeya revolucionaria. La trama histórica se centra en un protagonista colectivo, el cantón de Cartagena, sitiado por fuerzas gubernamentales durante varios meses. Una población decepcionada con la república federal les hace frente luchando enfebrecida hasta la extenuación, estimulada por sus líderes populares, Antonete y Colau. La trama sentimental gira en torno a un protagonista individual, mister Witt, un ingeniero inglés, de educación victoriana, casado con Milagritos, una burguesa nacida en Lorca, diecinueve años más joven, por la que siente unos celos enfermizos que se acrecientan al comenzar su decadencia física y comprobar cómo la esposa vive entregada al movimiento revolucionario. El narrador presenta a un hombre que comienza a sentir el peso de los años, inmerso en una crisis moral que le lleva a envilecerse colaborando en la muerte de hombres inocentes (pues no intercede para lograr el indulto de Carvajal, fusilado por defender sus ideales, y manda incendiar la fragata de Colau, para destruir la fascinación que ambos líderes ejercen en su mujer).

El lector encuentra en Míster Witt en el cantón un doble discurso testimonial y poemático cuyo nexo de unión lo constituye Milagritos, que actúa como personaje de engranaje ante la peripecia pública y privada. Sender la dota de una fuerte y atractiva personalidad, ${ }^{19}$ que supera con su psicología a la de las protagonistas de Siete domingos rojos, Star y Amparo, de las que conserva, sin embargo, algunos rasgos. Estamos ante una mujer madura que se entrega con el ardor juvenil de la joven Star a la lucha popular contra la tiranía de un gobierno represivo; pero ahí se acaba su parecido, pues en su esfera familiar Milagros no encuentra el apoyo de la joven anarquista sino que debe enfrentarse con un esposo conservador que pone en tela de juicio sus actuaciones, cuando no las ridiculiza. Así, le escuchamos reírse de ella recordándole su extracción social: “iuna revolucionaria con las rentas bien seguras!». Este burgués conservador, mister Güi, encastillado en su hogar con sus reliquias victorianas, muestra sus temores por las constantes salidas a la calle de la esposa, que se va distanciando de él al acercarse al pueblo proletario. No obstante, encontraremos momentos en que Witt se muestre conmovido y abrumado por la firmeza de las convicciones ideológicas de Milagritos.

18 Estas reflexiones sobre la literatura de compromiso en la que se sitúa la obra de Sender corresponden al estudio de Fulgencio CASTAÑAR, «La España del siglo XX en la narrativa del compromiso (1923-1936)", Letras Peninsulares, 6/1 (primavera de 1993), pp. 69-82.

${ }^{19}$ José $\mathrm{M}^{\mathrm{a}}$ JOVER, en la «Introducción» a Míster Witt..., ed. cit., opina que estamos ante el personaje femenino más humano, complejo y vigorosamente esbozado entre cuantos diera a la luz hasta entonces la pluma de Sender. 
Con Amparo coincide, únicamente, en su atractivo físico, pues aunque ambas sean de origen burgués las actuaciones de Milagritos no están condicionadas por los prejuicios de su clase y su temperamento espontáneo e intuitivo contrasta con la sensibilidad romántica destructiva de la hija del coronel. Milagros, independiente de criterio, está en disposición de entender la crisis moral de su esposo y de perdonar sus actuaciones reprobables, que lo degradan moralmente al colaborar en la muerte de los héroes de la libertad. Es capaz, también, de reconciliar lo irreconciliable haciendo compatibles su amor de esposa fiel con su admiración por los líderes del movimiento cantonal, adoptando el comportamiento de una mujer capaz de reivindicar su individualidad.

En esta actuación, en la que se muestra liberada de prejuicios burgueses, Milagritos presenta afinidades con Samar, el protagonista masculino de Siete domingos rojos, tal como señalan Gilberto Triviños y $\mathrm{M}^{\mathrm{a}}$ Nieves Alonso, pues ambos personajes representan «la marcha del protagonista no proletario hacia el pueblo airado percibido como [...] fuerza elemental portadora del porvenir». ${ }^{20}$ Sin embargo, estos críticos no han tenido en cuenta que nuestro personaje femenino ha dado un paso más al lograr superar la lucha dialéctica de Samar, incapaz de conciliar el mundo burgués y el proletario.

La presentación y caracterización de Milagritos corre a cargo de un narrador extradiegético innominado; éste proyecta el imaginario de un autor implícito que siente un especial afecto por su personaje, del cual hace partícipe al lector. En esta novela abandona la polifonía de Siete domingos rojos y opta por la voz de este narrador omnisciente selectivo que alterna su visión con la de mister Witt, al que hace intervenir con frecuencia por medio del discurso en estilo indirecto. De esta manera proyecta un ángulo de focalización que responde al de un marido celoso y egoísta que se siente a sus cincuenta y tres años en el umbral de la senectud.

El primer rasgo caracterizador de Milagritos procede de su denominación onomástica. El diminutivo afectivo, unido a un nombre que posee una carga semántica connotativa, nos coloca ante la mujer de aire juvenil que con su vitalismo y desprendimiento realiza todos los días el pequeño milagro de insuflar de esperanza la vida del esposo, de los parientes y del pueblo cartagenero.

Su estatuto psicológico se construye, principalmente, en los tres primeros capítulos y, de manera especial, en el espacio íntimo de la casa, donde Witt permanece encerrado, ajeno al mundo exterior y dedicado a escudriñar, obsesionado, en su vida íntima. Este narrador subjetivo comienza informando sobre el descubrimiento de Milagritos y su breve noviazgo mientras evoca nostálgicos retazos de su vida sentimental. En esta primera presentación proporciona al lector detalles físicos, de edad y carácter,

20 Gilberto Triviños y $\mathrm{M}^{\mathrm{a}}$ Nieves AlONso, art. cit. 
tales como su aire juvenil («tenía un aire ligero y juvenil»), que contrasta con el comienzo de su senectud. La oposición biológica de los esposos se observa en la incapacidad de Witt para sentir la llegada de la primavera con su fuerza renovadora mientras la mujer está en la plenitud de su atractivo femenino. Su belleza física está moldeada con refrescantes y coloristas aires marinos y voluptuosos detalles de indumentaria burguesa: «Toda ella era jarcia, algas y sal. Cabello de estopa clara, sedoso y abundante. Ojos verdes. $Y$ besos salados, lágrimas saladas [...] no se sabe si por la brisa marina o por el sudor evaporado entre holandas y batistas» (pp. 163164). A esta pulsión erótica que emana de Milagritos hace referencia en otras secuencias este hombre que vive obsesionado por la proximidad del climaterio: «A veces resistía la tela y en el ímpetu recomenzado y contenido le temblaban los senos. Míster Witt la veía en plena sazón, con la risa fresca y los dientes blancos como sábanas de boda» (p. 404).

En lo que respecta al carácter de Milagritos, el analítico y observador intelectual inglés destaca su espontaneidad, "sus salidas violentas o dulces" pero siempre inesperadas, que le siguen sorprendiendo después de 19 años de matrimonio. Estamos ante dos caracteres antitéticos, acentuados por sus diferentes culturas y puntos de vista ideológicos. El lector tiene una prueba de ello en el relato retrospectivo en el que Witt evoca los inicios del noviazgo, cuando comienza a descubrirla y queda sorprendido por sus decisiones y atrevidas propuestas, pues aunque Milagritos le obliga a formalizar la relación también le propone su rapto, para darle un toque romántico a la boda, que Witt rechaza escandalizado. Esta personalidad desconcertante de Milagritos es señalada con énfasis por el marido, incapaz de entender sus inesperadas salidas, en las que cree ver combinadas «dulzura y serenidad con el aire bravío y hablar desgarrado y callejero».

Otro detalle de su personalidad que no pasa desapercibido al lector - pues se trata de un rasgo emblemático con el que se la identifica- es su graciosa forma de expresarse: un lenguaje directo, plagado de expresiones populares y con una fonética que evoca libremente un dialecto meridional (uso del seseo y eliminación de sonidos finales). Esta dicción hace las delicias del esposo enamorado, que «[1]a oía hablar saboreando con deleite algunas palabras». Su particular forma de expresión contrasta con la corrección del marido.

Señalo, para no alargarme, algunos ejemplos de las frecuentes conversaciones de los esposos, que añaden nuevos matices a su personalidad, tales como la preocupación de Milagritos por los acontecimientos que se van sucediendo en la ciudad: «¿Tú has visto llegá estos días al Darro? Yo creo que he sentio la sirena, pero no lo veo» (p. 163), o su desprecio por lo que considera veleidades eruditas de Witt: « ¿Sabes lo que te digo? Que a mí no me gusta que te tomen por un tío chiflao. Eres un ingeniero de la Maestranza y un buen mozo. ¡Eso es! [...] No hasen falta [los hijos]. Tú pa mí y yo pa ti, y se acabó» (p. 221). 
Milagritos se impone en el discurso narrativo y exige ante la fuerza de su personalidad y su activa participación en los acontecimientos un procedimiento de caracterización fragmentario y disperso. A pesar de que la formación de esta mujer responde al molde ${ }^{21}$ de la sociedad burguesa de los años treinta (la perfecta ama de casa, de conversación entretenida, costumbres desenvueltas, agradable aspecto y una superficial pátina cultural, como sus rudimentarios conocimientos de francés), Witt muestra su admiración por su buen juicio y su buen hacer. Veamos un ejemplo en el que destaca su gracia y distinción: «A veces encontraba míster Witt a su mujer rasgos de una distinción inesperada. Aquella actitud no hubiera podido aprenderla en ninguno de los colegios de la aristocracia inglesa” (p. 253).

El lector conoce también detalles del espacio familiar en el que crece Milagritos hasta su pubertad y donde según Witt su mujer vivió «la época dorada de su vida", la que provoca sus celos en su delicada travesía hacia el climaterio. Se trata de un caserón situado en uno de los pueblos murcianos de más solera, Lorca, del que proceden algunos de los objetos más queridos que decoran su casa en Cartagena: un historiado bargueño lleno de cajones, en el que guarda sus cartas y otros objetos íntimos, y un tiesto de ruda «desmelenado» que evoca los sensoriales aromas de su tierra. Estamos en el paraíso de su infancia y de su romántica adolescencia, pues allí creció su admiración y afecto por su primo, el poeta revolucionario Carvajal; un lugar al que está dispuesta a volver si no se consigue la victoria popular. Con la evocación de este espacio protector, Milagritos espolea al indolente esposo, indiferente ante los esfuerzos del pueblo, para que utilice su influencia y garantice la neutralidad de los ingleses en la lucha cantonal.

Un último detalle de su perfil psicológico nos lo ofrece el narrador omnisciente, puntilloso, que da detalles de su atuendo cuando Milagritos interviene como responsable del equipo de enfermeras de la Cruz Roja y se embarca en el Buenaventura. No estamos ante la mujer trabajadora independiente sino ante una buena «ama de casa», que sabe también mostrar su capacidad organizativa en esas difíciles circunstancias y se viste con una sobria indumentaria que no puede ocultar su espléndida belleza: "Milagritos se había vestido muy recatadamente. La falda, no muy abultada por el polisón, era de un tono gris claro [...]. El cuerpecillo, de seda clara, apenas llevaba descote. Al llegar a bordo se puso una bata blanca [...]. La bata se hinchaba sobre los pechos y se retiraba algo más arriba, dejando asomar por el cuello bajo, sin vueltas, la garganta de laca y la cabeza, más aguda y breve» (p. 428). La altura moral de esta mujer («su instinto maternal», su "piedad y humanidad») se refuerza con la opinión vertida por personajes secundarios como Bommatí, el responsable de la Cruz Roja, opiniones que enorgullecen al esposo enamorado: «Le gustó

21 Susana CAVALLO, en su artículo «El feminismo y la novela social de los años treinta», Letras Peninsulares, 6/1 (primavera de 1993), p. 170, informa sobre la situacion de la mujer. 
aquella impresión, aquel hecho de encontrar en Milagritos algo superior y purísimo» (p. 400).

Para completar el estatuto psicológico de este interesante personaje femenino tendríamos que verla actuar con más detenimiento en los acontecimientos narrativos. Señalaré, por falta de tiempo, dos detalles que afectan a sus funciones en la esfera pública y privada: Milagritos es colaboradora activa en la lucha cantonal y cuando las dificultades arrecian para este pueblo asediado ella se vuelca totalmente. En su vida privada actúa como la salvadora del esposo, al que tiende la mano protectora para salir de Cartagena y evitar que sea juzgado por su acto de sabotaje contra la flota cantonal. Es capaz de entender su conducta reprobable y de encontrar un horizonte esperanzador que le permita remontar sus crisis, salvándole de su destrucción física y moral. Milagritos decide para ello poner los medios para ser fecundada por su esposo; éste demostrará así su virilidad y volverá a sentir renacer la primavera con la savia nueva del hijo. A través de esta intuitiva mujer, Sender parece cuestionar la superioridad del varón que presume de intelectual. De la importancia que alcanza en la obra este personaje femenino informan los críticos Carrasquer y Jover, que discrepan de las interpretaciones más generalizadas que dan protagonismo a la figura de mister Witt, pues ven en ella «el símbolo de la mujer española, atada de cuerpo y volandera de espíritu", y, por su firme apoyo a la causa revolucionaria cantonal, un arquetipo humano que representa el subconsciente colectivo cartagenero.

Muñoz Molina ${ }^{22}$ cree que el personaje novelesco es el centro de la creación y que su recuerdo perdura en el lector después de olvidado el argumento y el estilo de la obra. Y así va a suceder con estas criaturas senderianas de sus novelas sociales: Star, la adolescente anarquista; Amparo la novia burguesa, y Milagritos, la fiel esposa cantonalista; tres personajes femeninos que, por medio de un eficaz discurso semantizado, se han transformado en mujeres con el vigor de los seres reales y cuyo recuerdo perdurará en el lector sensible.

22 Antonio MuÑoz MOLINA, «La invención del personaje», en Marina MAYORAL, coord., El personaje novelesco, cit., p. 90. 


\title{
El cantón de Cartagena en Sender y Galdós
}

\author{
Geoffrey Ribbans \\ Brown University, Providence (Rhode Island)
}

\begin{abstract}
Nada más natural, como ya han advertido varios eminentes críticos tales como Collard, Carrasquer y Jover, ${ }^{1}$ que comparar la manera en que tratan el tema del cantón de Cartagena dos novelistas del relieve de Pérez Galdós y Sender, preocupados como estaban ambos por la continuidad histórica desde el pasado inmediato hasta el presente y unidos en cierto grado en la admiración matizada que sienten hacia la utópica y descabellada empresa. No hay que pensar desde luego en dependencia, ni siquiera en conocimiento, y cabe creer sin titubeo la afirmación de Sender de que no había leído los episodios pertinentes (Collard, 195; Jover, 74-75).

Dentro de la trayectoria vital de ambos escritores, el papel del cantón es muy distinto. En el caso de Galdós, se trata en primer lugar de una forma específica únicamente suya: el episodio nacional, que conlleva sus características especiales, acuñadas mucho antes para un propósito históricodidáctico y desarrolladas ampliamente durante varias décadas. El episodio
\end{abstract}

\footnotetext{
1 Patrick COLLARD, Ramón J. Sender en los años 1930-1936. Sus ideas sobre la relación entre literatura y sociedad, Gante, Rijksuniversiteit te Gent, 1980; Francisco CARRASQUER, «Imán» y la novela histórica de Sender, Londres, Tamesis, 1970; José María JOVER ZAMORA, "La reeelaboración galdosiana del mito del 73», en Realidad y mito de la Primera República, Madrid, Espasa Calpe, 1991, 2 ${ }^{a}$ ed., pp. 111-194, y en su edición escrupulosamente documentada de Mister Witt en el Cantón, Madrid, Castalia, 1987, a la cual remito siempre para las referencias textuales.
} 


\section{EL LUGAR DE SENDER}

está caracterizado por un denso contenido histórico, una coherencia estructural, cierta brevedad y regularidad de forma, además de que mantiene una distancia considerable entre el tiempo evocado y el tiempo de escritura, junto con una constante preocupación por el lenguaje corriente. ${ }^{2}$ En cuanto al cantón de Cartagena, se trata además de dos episodios muy tardíos, el antepenúltimo y penúltimo de la quinta serie, La primera República y De Cartago a Sagunto, los dos escritos en 1911. Relatan además acontecimientos entrañablemente relacionados con la vida anterior del autor. Es un momento en que el novelista canario, políticamente desilusionado, además de envejecido y casi ciego, reducido ya a dictar sus obras, se esfuerza por seguir adelante con una forma histórica que cada vez le satisface menos.

A propósito de estos relatos poco representativos, Carrasquer se muestra muy duro con Galdós:

El tratamiento de Galdós, comparado con el de Sender, es el de un cuento de serie (o folletón de serial) frente a una novela hecha y derecha, con su unidad perfecta. ¡Y qué progreso de vocabulario y sintaxis, de presentación situacional y de juego de contrastes dentro de la acción de la novela en ésta de Sender! El lenguaje de Galdós --total, sólo a un cuarto de siglo de distancia - resulta amanerado, trufado de tópicos de literatura costumbrista y de expresiones que quieren ser graciosas pero que delatan el grado de candidez de la literatura de entonces. (87)

Aunque no dudo de la superioridad de Sender en este caso determinado, creo algo exagerado este juicio, especialmente si se toman los episodios en conjunto.

El hecho es que, acabada ya la primera década del siglo XX, Galdós sólo ve en la actualidad política un estancamiento pernicioso, con limitadísimas perspectivas de adelantos concretos. También es cierto que en estas obras Galdós ha abandonado en gran medida su fórmula anterior, que le había servido muy bien a lo largo de la segunda etapa de los episodios, redactada a partir de 1898; se trata de la tercera y cuarta series y los dos primeros tomos de la quinta. Fórmula, por otra parte, eficaz y consecuente, que consistía en aunar la historia y la ficción, mediante una acertada interacción entre historia grande e historia chica, entre los magnos eventos y las reveladoras anécdotas personales. Sirvan como insignes ejemplos de evocación de acontecimientos anteriores el asesinato de Chico ( $O^{\prime}$ Donnell) y el fusilamiento de los sargentos de San Gil (La de los tristes destinos),

\footnotetext{
2 Véanse las precisiones que intentamos ofrecer de las características de los episodios nacionales en relación con las novelas contemporáneas en nuestros estudios « ¿Historia novelada o novela histórica? Las diversas estrategias en el tratamiento de la historia en las Novelas contemporáneas y los Episodios nacionales» (incluido en Peter BLy, ed., Galdós y la historia, Ottawa, Dovehouse, 1988, pp. 167-186) y History and Fiction in Galdós's Narratives, Oxford, Clarendon Press, 1993. Es, como explica CARRASQUER, un caso límite (70) dentro de la novela histórica.
} 
magistralmente estudiado por Jover, ${ }^{3}$ a los cuales cabe añadir la creación de figuras ficticias, tales como Beramendi y Teresa Villaescusa, ${ }^{4}$ de sobresaliente integración histórica. Aún subsiste algo del mismo impulso en la evocación del golpe de estado de Pavía en De Cartago a Sagunto, si bien, como creo haber demostrado, con menos destreza que en Fortunata y Jacinta. La irrupción militar del capitán general en el Parlamento no es, sin embargo, más que uno solo de los tres notables sucesos históricos, con el cantón y la guerra carlista, a que da cabida dicho episodio, que por otra parte no llega siquiera al evento (el pronunciamiento de Martínez Campos) anunciado en el título. Adolece por tanto de cierta falta de unidad e incluso de coherencia. Como ha indicado Jover Zamora, «el panorama general que esboza Galdós de la insurrección cantonalista es pobre y ligero» (1991, 150), a lo cual añade con razón que «el tono general del relato es de acentuada ironía, cuando no de pura zumba» (1991, 150, n. 58).

La nueva técnica, emprendida desde Amadeo I (1910) por un afán de renovación para mí poco feliz, consiste en el abandono del realismo, que se trasluce en una fuerte inclinación hacia la alegoría y una equívoca voz narrativa. El nuevo narrador, Tito, «chiquitín, travieso, enamorado, con tendencias a exagerar estas cualidades o defectos, si es que lo son» (1115), ${ }^{5}$ reviste un carácter humorístico y poco verosímil, como el ibero extrañamente desdoblado del guanche que le remite a su amigo la tarea de cronista. Interviene asimismo la musa de la historia, hecha humilde y casera, Mariclío, en vez de la más solemne Clío de la mitología clásica.

Ya en La primera República los principios del cantón están entretejidos con una fantasía completamente alegórica, situada, eso sí, en el típico barrio de Santa Lucía. Está capitaneada por Mariclío, que en compañía de las musas hermanas rige un mundo mítico y atemporal, en el cual reina una figura misteriosa llamada Floriana, quien encabeza un equipo educativo de tipo ideal consistente en figuras alegóricas como Doña Gramática, Doña Aritmética, Doña Geografía y Doña Caligrafia. En la misma mágica esfera gira la extraña figura de Graziella. Galdós, dándose cuenta cabal de la imposibilidad de éxito del movimiento cantonalista, quiere proteger a toda costa su empuje idealista para inspiraciones posteriores. Así, Mariclío se proyecta hacia el futuro, afirmando que

La idea federal es hermosa; es mi mayor encanto, la ilusión de mi vida en ésta y en todas las tierras que visito, pero dudo, ¡ay!, que pueda implan-

\footnotetext{
3 «El fusilamiento de los sargentos de San Gil (1866) en el relato de Pérez Galdós: Los dos primeros capítulos de La de los tristes destinos», en Política, diplomacia y humanismo popular en la España del siglo XIX, Madrid, Turner, 1976, pp. 365-427, y History and Fiction..., cit., pp. 125-130. 4 Véase, además de nuestro libro ya citado, History and Fiction..., «Una creación galdosiana -Teresa Villaescusa - entre la historia y la ficción", en Juan VII.LEGAS, ed., Asociación Internacional de Hispanistas; Actas Irvine 1992, 5 vols., 1994, II, pp. 112-121.

5 Para las citas de los Episodios galdosianos me refiero siempre a Obras completas, Madrid, Aguilar, ed. de Federico Carlos SAINZ DF. ROBLES, III, 1968, 9ª ed.
} 
tarla de una manera positiva y duradera un pueblo que ayer como quien dice ha roto el cascarón del absolutismo [...] yo, que soy vieja eterna espero ver algún día [...] algún día triunfante y dichoso el «Antifictionado español». (1204)

Otra proyección hacia el porvenir idealizado es la nueva raza de hombres parecidos a los dioses que aparecen como los «forjadores de los caracteres hispanos del porvenir» (1210) y enlazados con la escuela de Floriana; uno de los artesanos-sobrehombres declara que ésta es su novia. Galdós está postulando un ideal utópico de una raza, nueva y perfectible: «Las divinidades que gobiernan el mundo han dispuesto que el Fuego plasmador se una en coyunda estrecha con la Feminidad graciosa y fecunda, para engendrar la felicidad de los pueblos futuros» (1212). Es la misma inspiración que produce la novela tardía El caballero encantado. El cantón galdosiano posee asimismo su idealismo y sentido heroico especiales; siendo absurdo, es una «jactanciosa hinchazón de nuestras fantasías» (1217), a la vez que la flamante salida de los buques de la armada — en la cual hace Galdós especial hincapié- es "un Lepanto en zapatillas» (1223). En el segundo episodio, a la par del fracaso del cantón, los elementos idealizados -la forja de los nuevos hombres, la escuela de Floriana- han caído en desuso: es un doble retrato, casi un réquiem, de oportunidades perdidas. Manrique pronuncia su elegía: «Adiós, Cantón! ¡Adiós, República ingenua y romántica, que a la Historia diste más amenidad que otros y más fecundos ejemplos!» (1262). De este modo algo desesperado, el viejo escritor procura sacar algunas miajas de consuelo del derrumbe general del ímpetu revolucionario. ${ }^{6} \mathrm{Si}$ bien se entiende el motivo de tal técnica, no creo que el fuerte de Galdós, gran observador pero visionario más bien rutinario, se encuentre ni temática ni estructuralmente en estas extravagancias alegóricas. ${ }^{7}$

Evidentemente Sender no tiene por qué aceptar las mismas obligaciones de cronista detallado implícito en el episodio galdosiano. Incluso no queda nada claro si domina en esta novela de doble filo lo ficticio — mister Witt - o lo histórico: el cantón. Sea cual sea la prioridad que se concede a su calidad de novela psicológica ${ }^{8}$ o de novela histórica - y para mí tiene el gran mérito de mantener un equilibrio muy ajustado entre los dos factores-, 9 asombra ver la densidad referencial que Sender establece en novela

\footnotetext{
6 Importante en su ideología de entonces es su casi incondicional admiración por Nicolás Estévanez, cuyo Fragmento de memorias utiliza extensamente.

7 En esto estoy de acuerdo con la generalidad de los críticos, pero hay que tener en cuenta la opinión favorable de eminentes eruditos como Diane UREY, The Novel Histories of Galdós, Princeton, Princeton UP, 1989.

${ }^{8}$ Eugenio G. NORA, La novela española contemporánea (1927-1939), Madrid, Gredos, 1978, $2^{\text {a }}$ ed. corr., p. 471.

9 Véase el perspicaz artículo de Francis LouGH, "History and Fiction in Mister Witt en el Cantón», Anales de la Literatura Española Contemporánea, 16 (1991), pp. 275-290, en el que matiza
} 
tan extensa, así como la exactitud histórica con que, con muy pocas excepciones, desarrolla su narración. ${ }^{10}$ No cabe duda, como indica Jover (ed., 122), que la aventura idealista que produjo la República federal da poderosos motivos de reflexión sobre aquella segunda República ya amenazada y polarizada; mas no dudo tampoco de que Sender sintió un gran interés en sí en esta singular tentativa revolucionaria. A la exactitud histórica se añade además el sobrio, exacto e impresionante escenario social de la taberna de «la Marquesa» en el barrio popular del Molinete, junto con un bien calculado uso de un elemento folclórico: la canción popular. Y no faltan consideraciones comerciales de la peor especie en los mezquinos cálculos del médico don Eladio, en angustiada espera de heredar a su anciano padre, pero también implicado por fuerza en las actividades del cantón.

Resulta sumamente interesante ver cómo coinciden los dos novelistas en el protagonismo que otorgan al líder de más relieve de la insurrección, Antonete Gálvez. Común a los dos libros es el insistente tema de la traición y cómo Antonete se enfrenta con ella. Mientras Contreras y Roque Barcia juegan los papeles oficiales rutinarios y absurdos de un gobierno de muñecos, Galdós señala a Gálvez como el hombre que «poseía tanta bravura como agudeza y era el hombre de mando en la República cantonal, con dotes militares, con dotes de estadista y toda la malicia y sagacidad que siempre han sido complemento de aquellas cualidades [...]». Así, Antonete supo cortar de raíz las maniobras sospechosas del coronel Carreras y algunos miembros de la Junta Soberana. Manuel Cárceles, por su capacidad organizadora, tiene una parte algo más positiva que en Sender. Además se agregan a éstos otras figuras menores; muere en el conflicto Elcano, el veterano de Trafalgar, que había surgido antes como señal de la continuidad de la historia española; y aun el más insignificante de los habitantes, como Pepe, el Empelmao, asociado por Jover con Paco, el de la Tadea, se convierte en héroe y perece en la acción.

En la narración senderiana se destaca en numerosas ocasiones la extraordinaria cualidad humana de Antonete, en la entrevista con mister Witt, en que busca sus ideas y le pide apoyo, o destacándose frente a un Contreras, rígido e incompetente, o bien en la confrontación magistral con esta misteriosa sombra que resulta ser Paco, el de la Tadea, y al enfrentarse con los obreros militantes encabezados por Hozé. En todos estos incidentes demuestra dos características esenciales: capacidad de mando y compasión hacia los no privilegiados. Lo esencial de su actuación es que no reconoce discrepancia alguna entre el ideal cantonalista y el pueblo ${ }^{11}$ y por eso

con razón los argumentos del ensayo de Jaime PÉREz MONTANER, «Novela e historia en Míster Witt en el Cantón», Cuadernos Hispanoamericanos, 95 (1974), pp. 635-645.

10 Como ha demostrado plenamente Jover, la fuente esencial de la novela es Antonio PuIG CAMPILlo, El cantón murciano, Cartagena, 1932.

${ }^{11}$ Como dice CollaRD, «Es otra novela en la que el pueblo se convierte en el principal protagonista del movimiento histórico» (199). 
se aferra a una simpatía hacia éste apenas compartida por sus compañeros de profesión militar. ${ }^{12}$

También coinciden Galdós y Sender en su estima por Colau. Para aquél, Colau, a pesar de su profesión apenas ortodoxa de contrabandista, es un hombre sencillamente bueno, heroico sin pretensiones, compasivo con otros, de expresión llana y algo avergonzado de la Legión de Honor francesa que ostenta. En este caso hay todavía, de parte de Galdós, cierto intento, bien intencionado pero rezagado, de integrar la historia grande con la chica en la ayuda que Colau presta a la ambiciosa y simpática cortesana Leona, la Brava. Lo que, no obstante, más separa a Sender de su antecesor es el efecto de unidad que consigue el novelista aragonés, enlazando con Colau la figura histórica anterior al cantón, Froilán Carvajal. ${ }^{13}$ Con una admirable mirada hacia atrás Sender dota la actuación de Carvajal durante la revolución gloriosa con un recuerdo que se sostiene, por una magnífica sinécdoque, durante todo el primer libro. Mediante la urna que lleva sus cenizas y la bandeja ensangrentada de su ajusticiamiento perduran a través del tiempo varios factores imprescindibles: las relaciones de Froilán con Milagritos en Lorca, junto con el resentimiento y celos de mister Witt, a medida que poco a poco se nos van revelando, a través de los recuerdos del inglés, las circunstancias de su primera traición. Por ser el fuerte nombrado «Froilán Carvajal» el escenario de uno de los bombardeos, vuelve a actualizarse su recuerdo en el momento del cantón. No hay nada comparable a este incidente en la narrativa galdosiana, a no ser que tal vez sea lícito cotejarlo con el efecto espeluznante del fusilamiento de los sargentos de San Gil sobre el joven protagonista en Ángel Guerra.

Esencial a la estructura de la novela es la insistente asociación que se hace entre Carvajal y Colau. A mister Witt éste le provoca en seguida antipatía y lo trata con desdén. La identificación mental con Froilán no tarda en presentarse y los celos vuelven a surgir. Luego se nos insinúa la traición consumada por Witt con Ricardo Yuste - hábilmente empalmado con el hecho histórico de la voladura de El Tetuán-, sin aclaración palmaria pero también sin apenas duda. Surge aquí otro factor clave. En el momento culminante del incendio del buque, se nos da la falsa impresión de que es el mismo Colau el pobre marino calcinado, descrito con macabra sobriedad y presenciado el suceso con repugnante frialdad por mister Witt («Debe estar asándose», 531) y con un frenético grito de dolor por Milagritos. Sólo más tarde nos enteramos de que él se escapó en La Numancia.

Como resultado, los detalles históricos se relacionan íntimamente con la ficción psicológica: las actitudes contrastadas de un mister Witt oficial $\multimap$ un mister Güi de la imagen popular-, cauto, racionalista, hipócrita y

12 Cabe notar asimismo la figura, a la vez simpática y ligeramente ironizada, de Antonio Bonmatí, que desempeña de manera tan resuelta su misión humanitaria.

13 Hay razones convincentes para creer que al evocar la figura de Carvajal Sender tenía en cuenta al mártir de la insurrección prerrepublicana Fermín Galán. 
envejecido, y una Milagros vital, espontánea e indomable. Me falta tiempo para examinar un aspecto fundamental de la novela que cae fuera de mi propósito de hoy, pero conviene notar que, en la cima de la crisis del cantón, mister Witt personifica todo lo que no caracteriza y no debe caracterizar los ideales revolucionarios: la indiferencia frente al compromiso activo; la frialdad y el cálculo frente a la espontaneidad; la hipocresía, el resentimiento y los celos frente a la serena confianza; la cobardía frente a la resolución, y, en última instancia, el explícito reconocimiento que merece el calificativo de "canalla» más que el de honrada inconsciencia. Resumido todo ello al final en un sentimiento de suprema introspección - «seco y vergonzante egoísmo»- relacionado aptamente con un sentido de envejecimiento así ético como físico. Todo esto opuesto a la entereza moral de Milagritos, que ha recibido ya, con sentida pero silenciosa dignidad, primero las noticias de la traición hecha a Carvajal y luego las indicaciones de la segunda traición a Colau. Sostenida por la remota esperanza de un hijo, Milagritos adopta una actitud de madre hacia su despreciable marido y aguanta las múltiples cavilaciones de éste con apenas perceptibles lágrimas. Se plantea la pregunta: «¿Por quién lloraba? ¿Por Carvajal? ¿Por Colau? ¿Por el Cantón? ¿Por sí misma?» (540). Será, sin duda alguna, por cada uno y por todos a la vez. Así sigue enlazada de modo insoluble la suerte de esta mujer insobornable, merecedora de toda la atención crítica que por fin se le viene dedicando (Lough, 289), con los héroes del cantón, con el cantón mismo, aun en la vida que a lo mejor le tocará continuar, en la misma Cartagena, después de la destrucción de aquel irrealizable esfuerzo idealista. 


\title{
Proyección biográfica de Sender en Ramiro Vallemediano y Pepe Garcés: documentos y testimonios
}

\author{
Ramón Oteo Sans \\ Universitat Rovira i Virgili, Tarragona
}

\begin{abstract}
Cuando el 16 de enero de 1982 murió Ramón J. Sender en el amargo silencio del exilio, el seminario de Lengua y Literatura Españolas del Instituto de Bachillerato Salvador Vilaseca de Reus y el colectivo Etcétera de la actual Facultad de Letras de la Universidad Rovira i Virgili de Tarragona organizaron una serie de actos en memoria del fecundo novelista, que constituyeron seguramente el primer homenaje de la cultura española al escritor aragonés a raíz de su muerte. El 20 de enero, un día después de que la prensa estatal diera la noticia de su fallecimiento, se inauguraba una exposición bibliográfica que reunía un centenar de obras de y sobre Sender y algunos documentos inéditos, entre los cuales tenía particular interés el expediente académico del escritor (véase su reproducción en pp. 638 y 639), que, cuando niño, había cursado en el entonces Instituto General y Técnico de Reus parte de su bachillerato. Aunque el joven Sender sólo residió allí durante un curso, la ciudad dejó en él una profunda huella, patente en algunas de sus obras más importantes: El verdugo afable (1952), Monte Odina (1980) y en especial en la segunda parte de Crónica del alba, Hipogrifo violento (1954), cuya acción se sitúa en el Reus de su infancia. Por ello el Claustro del Instituto de Bachillerato, reunido en sesión
\end{abstract}


extraordinaria a propuesta de la cátedra de Literatura Española el 25 de enero, tomó el acuerdo de elevar al Ayuntamiento de Reus una petición razonada en la que se solicitaba el nombre de una calle para el escritor aragonés, petición que fue aprobada en sesión del Pleno Municipal del 5 de abril de 1982. De este modo la ciudad reconocía el afecto con que el novelista la recordó a lo largo de su vida, como lo confirma el hecho de que "en unas últimas declaraciones de Sender, publicadas en El Noticiero Universal, recordara su propósito de regresar a España y fijar su residencia en Salou porque conservaba de Reus y sus alrededores recuerdos entrañables de cuando era niño". 1

La evocación de la infancia es casi siempre una parte fundamental del relato autobiográfico, sobre todo si el narrador tiende a buscar en los recuerdos de la niñez el testimonio de un ámbito entrañable que a menudo se contempla con nostalgia en una reconstrucción idealizada. José-Carlos Mainer ha señalado oportunamente que «para el Sender posterior a 1939 escribir ya será siempre apostar contra la usura del tiempo y buscar en un inevitable pasado colectivo el paisaje feliz de la inocencia perdida», ${ }^{2}$ afirmación coincidente en la delimitación cronológica con la de Donatella Pini Moro, que en las dos primeras novelas de Sender publicadas en el exilio - Proverbio de la muerte y El lugar del hombre, ambas de 1939- ve «surgir la copiosa vena autobiográfica de Sender, destinada a encontrar su expresión más plena en las dos series narrativas Crónica del alba (19421966) y Los cinco libros de Ariadna (1955-1957)».3

Sin embargo ya Imán, que en 1930 inaugura con madurez su fecunda obra narrativa, «marca con un sello particular el advenimiento simultáneo y prácticamente indisociable, de las vetas autobiográfica y novelística de la obra senderiana", 4 a la vez que su protagonista, Viance, personaje afín al escritor en muchos aspectos, ${ }^{5}$ al reflexionar sobre la desaparición de su pueblo y su pasado bajo las aguas del pantano al final de la novela, evoca la infancia como un espacio vital no invadido por las miserias de la con-

1 Heraldo de Aragón, 27 de enero de 1982.

2 José-Carlos MAINER, «El territorio de la infancia y las fuentes de la autobiografía senderiana", en José $\mathrm{M}^{\mathrm{a}}$ ENGUITA (ed.), III Curso sobre Lengua y Literatura en Aragón (Siglos XVIII-XX), Zaragoza, Institución Fernando el Católico, 1994, pp. 139-159 (147).

3 Donatella PINI MORo, Ramón José Sender tra la guerra e l'esilio, Alessandria, Edizioni dell'Orso, 1994, P. 117. La traducción de la cita al castellano es mía.

4 Roger DuvivieR, «Les prémisses de l'œuvre autobiographique dans la première époque de l'écrivain Ramón J. Sender», en L'autobiographie en Espagne (Actes du II Colloque International de la Baume-les-Aix, 23-25 mai 1981), Aix-en-Provence, Université de Provence, 1982, pp. 203226 (215). Hay traducción española en José-Carlos MAINER (ed.), Ramón J. Sender. In memoriam. Antología crítica, Zaragoza, Diputación General de Aragón, Ayuntamiento de Zaragoza, Institución Fernando el Católico y Caja de Ahorros de Zaragoza, Aragón y Rioja, 1983, pp. 137153 (146).

5 Marcelino C. Peñuelas, Conversaciones con Ramón J. Sender, Madrid, Magisterio Español («Novelas y Cuentos»), 1970, p. 116. 
dición humana y, por ello, ámbito de la vida verdadera, donde reencontrar la propia identidad: "Antes, hasta en los momentos peores de la campaña, tenía una base moral firme: su niñez, su pueblo, los campos familiares, las calles, los niños de entonces, hechos ya hombres. Ahora cree pisar sobre la niebla, sobre el aire. Su vida comienza en el infinito, sin base, sin donde poner los pies para tomar impulso". ${ }^{6}$ Sumergido el pueblo bajo el pantano, la vida de Viance ha perdido sus orígenes: «Su casa, el suelo que pisaron sus padres, todo es ahora limo, barro, algas. Le han robado su pueblo. Aquellos recuerdos vivos que flotaban en las esquinas, en el pozo de la plaza, en la abadía, y que eran el punto de partida de toda su vida han desaparecido para siempre». ${ }^{7}$ La situación existencial de Viance al regreso de la guerra de Marruecos, vencido y desengañado, podría compararse, como metafórica premonición, con la propia circunstancia del autor y de todos aquellos que, víctimas de un largo exilio tras la guerra civil, sintieron perdidas para siempre las raíces de su existencia porque, como a Viance, les habían robado su pueblo, anegado no ya por un pantano sino por un alud de escombros y de sangre después de 1939.

Como otros escritores de la España peregrina, Sender sintió la necesidad de reconstruir el pasado, de recuperar sus raíces a través de la literatura, de bucear en el tiempo para reencontrar, al otro lado de la experiencia traumática de la guerra civil, una imagen de la vida más pura, más plena, más dichosa. La encontró en la edad de la inocencia, con la recreación de un paraíso inexistente o irrecuperable del que se nutren la fantasía y la memoria, una memoria "no estrictamente intelectual sino sensitiva y muy discriminadora, es decir, selectiva", como puntualizaba el escritor al contestar a un cuestionario que Francisco Carrasquer le propuso en $1966 .{ }^{8}$

Manuel Andújar, uno de los primeros en advertir el creciente desarrollo después de la guerra civil de la literatura memorialista, en especial entre los escritores del exilio, hace notar en los testimonios autobiográficos de la emigración, frente a las abundantes descripciones de interiores, «la falta de fijaciones en lo que concierne al paisaje, urbano o campestre", 9 a pesar del largo peregrinaje de la mayor parte de los autores por distintas geografías. Por el contrario, subraya Andújar la entrañable recuperación, por parte de algunos - Alberti, Corpus Barga, Ayala-, de los escenarios de la memoria que dejó atrás la guerra civil y el exilio, con particular atención a la infancia, y el carácter novelesco en perfecta armonía con lo autobiográfico de obras como Los pasos contados, espléndido fresco y crónica de «una vida española a caballo en dos siglos», tal como

${ }^{6}$ Ramón J. SENDER, Imán, Barcelona, Destino («Destinolibro», 71), 1979, p. 303.

${ }^{7}$ Ibid., p. 300.

8 Francisco CARrasquer, «Cuestionario», en «Boletín senderiano», Alazet [Huesca], 3 (1991), pp. 175-185 (176).

9 Manuel ANDÚJAR, «Memorias españolas», Cuadernos Hispanoamericanos, 412 (octubre de 1984), Pp. 63-100 (69). 
x. $31 \%$

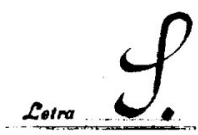

Instituto General y Téenico de Reus Expediente personar de Clamón Jose $\mathscr{I}_{\mathrm{en}}$ ENSENA ÑZ A

is: isiri is. der Garcés.

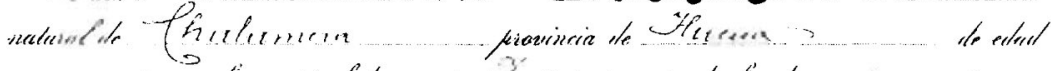

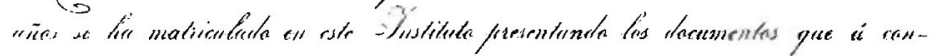

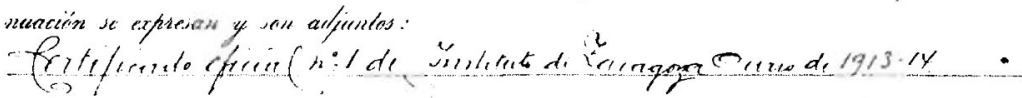

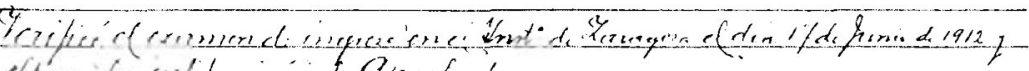

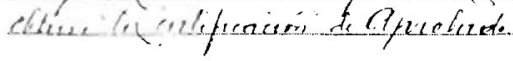

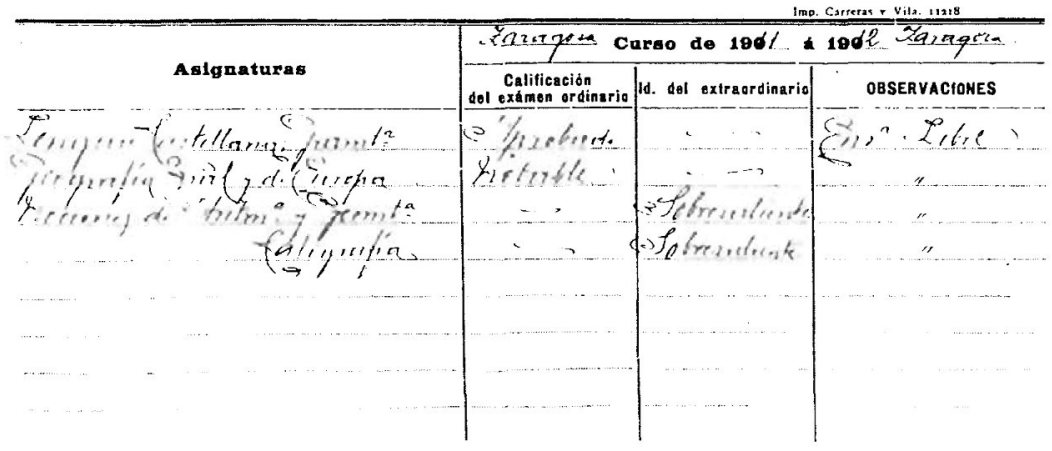




\section{RAMÓN OTEO SANS}
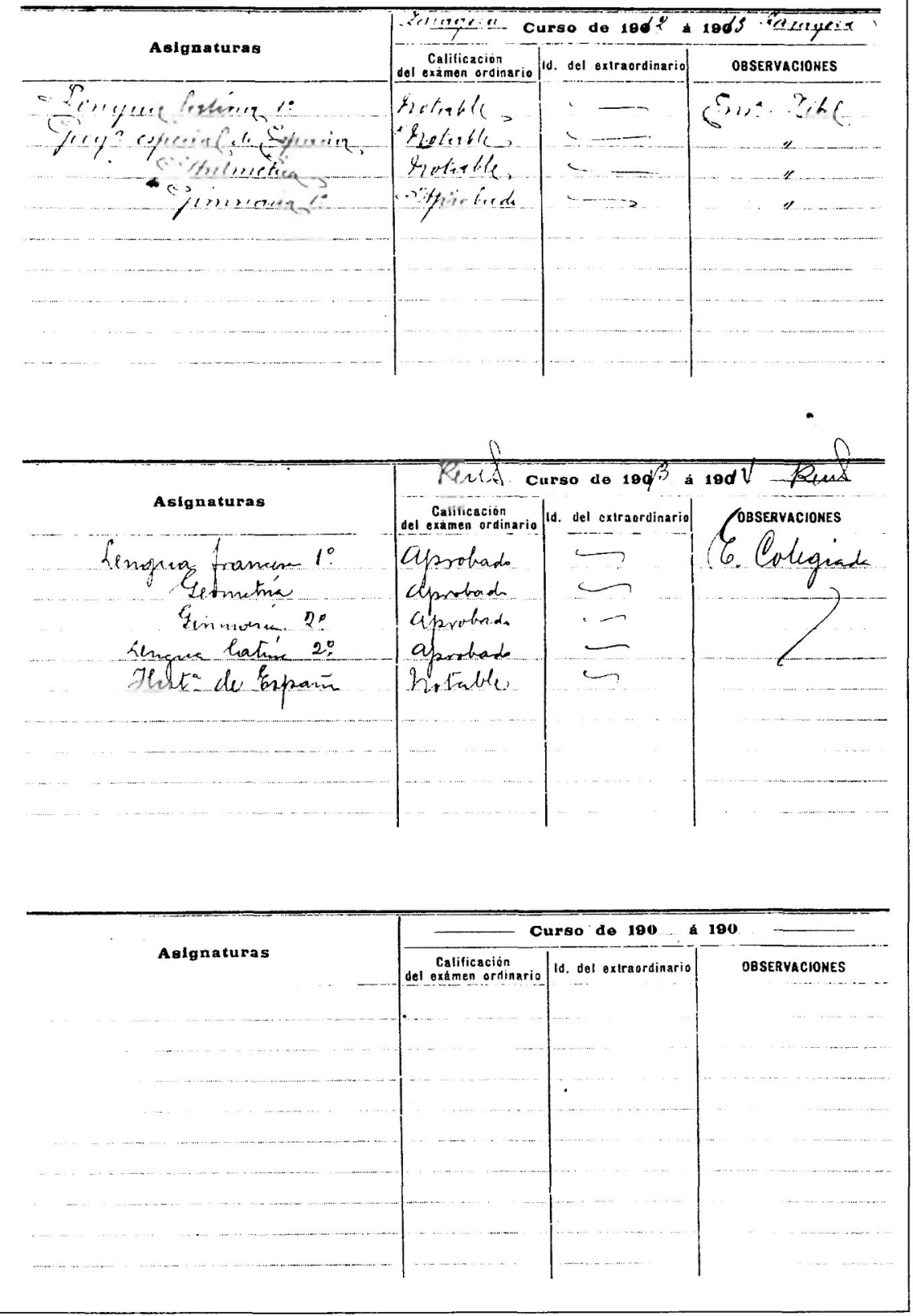

Expediente de Sender en el Instituto General y Técnico de Reus. 
subtitula Corpus Barga la tetralogía de sus memorias, lamentablemente incompletas, cuyo primer volumen abarca justamente Mi familia. El mundo de mi infancia.

Aunque ajeno sin duda a los «silencios conspirados» de cierta crítica, que Carrasquer denuncia sin ambages en su introducción a Imán, ${ }^{10}$ Andújar, que admite en otra ocasión el carácter memorialístico de «las primeras secciones de su Crónica del alba», 11 se ciñe esta vez rigurosamente a los límites del género autobiográfico memorial y ni siquiera cita en su estudio la obra, coincidente en más de un aspecto concreto con la de Corpus Barga - el testimonio fundamental de la memoria sensitiva, la presencia de digresiones ensayísticas, la inclinación hacia un anarquismo idealista-, pero, sobre todo, en la fusión fecunda de lo autobiográfico y lo creativo que hace de Crónica del alba "una serie de memorias», en palabras de Ricardo Senabre. ${ }^{12}$ Ambos autores - Corpus Barga y Sender-confirman en sendos prólogos la estrecha relación entre la propia vida y la creación literaria. Corpus Barga, en declaraciones que recoge Gregorio Coloma en las páginas preliminares del primer volumen de Los pasos contados, dice: «Otra cosa que comprobé, a medida que avanzaba en mi obra, era la similitud de las memorias y las novelas. El novelista escribe como el memorialista, por lo que ha visto y oído o por lo que ha leído. Mis memorias se iban convirtiendo insensiblemente en novelas, no se trataba ya de presentar el recuerdo sino de que se presentara él mismo. El tomo tercero, Las Delicias, es una novela, dentro del sentido más propio del término". ${ }^{13}$ Y Sender escribe en el prólogo de Los cinco libros de Ariadna: "Todo lo que podemos decir de nosotros mismos - digo, los que escribimos- es lo que hemos hecho y por qué. Cada cual hace una buena tarea diciéndolo en estos tiempos de confusión y responsabilidad. Libres los demás de entenderlo como les parezca. He escrito varios libros sobre los tiempos de mi infancia y juventud, continuación de Crónica del Alba, que irán saliendo. La obra alcanzará cronológicamente a los días en que la escribo, si no se alejan demasiado

\footnotetext{
10 Francisco CARRASQUER, «Sender entero ya en Imán», introducción a Ramón J. SENDER, Imán, Huesca, Instituto de Estudios Altoaragoneses (“Larumbe», 4), 1992, pp. IX-CLXXXIII (XIXXXII). En la p. XXXVII (n. 25) aporta el punto de vista sobre esta cuestión de José R. MARRALOPEZ, Narrativa española fuera de España (1939-1961), Madrid, Guadarrama («Colección Guadarrama de Crítica y Ensayo», 39), 1963, pp. 352-353 y no 252-253, como el duende de la imprenta ha escrito en la nota de Carrasquer.

11 Manuel ANDÚjAR, «Ramón J. Sender y el nuevo mundo», en Grandes escritores aragoneses en la narrativa española del siglo XX, Zaragoza, Ed. Heraldo de Aragón, 1981, pp. 95-155, recopilado en José Carlos MAINER (ed.), op. cit., pp. 189-240 (189), de donde tomo la cita.

12 Ricardo SENABRE, «Una novela-resumen de Ramón J. Sender: El verdugo afable», en Manuel Alvar y otros, La Literatura en Aragón (Estudios coordinados por Aurora Egido), Zaragoza, Caja de Ahorros y Monte de Piedad de Zaragoza, Aragón y Rioja, 1984, pp. 151-162 (155).

13 Gregorio Coloma, "Prólogo" a Corpus BARGA, Los pasos contados. Una vida española a caballo en dos siglos (1887-1957). 1. Mi familia. El mundo de mi infancia, Madrid, Alianza Editorial («Alianza Tres», 44), 1979, pp. I-XVI (XIII).
} 
rápidamente [...]». ${ }^{14}$ Hace bien poco Miguel Delibes abundaba en lo mismo a raíz de la publicación de su última novela, Diario de un jubilado (1995): "Las novelas brotan de tres fuentes: la autobiografía, la invención y la observación, pero en la mayor parte de ellas, al menos en los detalles, prevalece lo primero». 15

En Monte Odina (1980), Sender, ya al final de su vida literaria, nos lega una obra en la que la autobiografía, la invención y la observación se funden en un fluido proceso discursivo que se abre camino alternativamente entre la literatura memorialista, la ficción y el ensayo, adecuando el molde tradicional de los géneros a su voluntad creadora, como es propio de los grandes escritores. En la obra, el pasado remoto de la niñez se proyecta positivamente en el futuro del hombre: «Quizá lo mejor que tienen los hombres en su madurez y en su vejez es lo que conservan de la lejana infancia», ${ }^{16}$ idea en la que insiste mucho más adelante: "los hombres conservamos algunos rasgos de carácter de la infancia y suele ser lo mejor que tenemos cuando llegamos a la madurez». ${ }^{17}$ La infancia tiene, pues, una influencia benéfica en el adulto y por ello la imagen del niño representa de antiguo la conquista de la paz interior y la confianza en uno mismo.

Al iniciar el capítulo XI de Monte Odina Sender escribe: "Quiero apartar de mí esos recuerdos tristes refugiándome por algunos días en otros mejores de mi infancia», 18 actitud en la que insiste en el capítulo $\mathrm{XX}$ : «Yo me refugio en mis relaciones con el albatros o en mis recuerdos de mocedad». ${ }^{19}$ Vemos, pues, que en Monte Odina Sender proyecta la influencia de los años infantiles en dos direcciones, con sentido positivo en ambas: hacia el futuro, como origen de las mejores cualidades del hombre, y hacia el pasado, como refugio ante los embates y las tristezas de la vida. Esta doble imagen de la infancia es fruto sin duda de su dimensión sobrehumana, que se pierde al llegar a la edad madura: «Éramos, él y yo, una de esas parejas de chicos que a los siete $u$ ocho años andan siempre juntos y cultivan una apasionada amistad y darían la vida el uno por el otro si fuera necesario y sin sentimentalismo alguno. Por una especie de lealtad viril precoz y sobrehumana. Porque en los chicos hay muchas cosas sobrehumanas. Precisamente por no haber entrado todavía en la pecadora madurez». ${ }^{20}$ «Y es que la niñez como perspectiva —escribe José-Carlos Mai-

\footnotetext{
14 Ramón J. SENDER, «Prólogo» a Los cinco libros de Ariadna, Barcelona, Destino ("Áncora y Delfín», 500), 1977, pp. 7-18 (16).

15 Javier GoNil, "Vuelve Delibes novelista. El escritor recupera a Lorenzo, su personaje de hace 40 años, en Diario de un jubilado», El País (supl. «Babelia», 178), 18 de marzo de 1995.

16 Ramón J. SENDER, Monte Odina, Zaragoza, Guara («Nueva Biblioteca de Autores Aragoneses»), 1980, p. 21.

17 Ibid., p. 331.

18 Ibid., p. 211.

19 Ibid., p. 441.

20 Ibid., p. 89.
} 
ner- nos acerca más a ese mundo mágico en el que Sender se mueve tan a gusto. El niño encarna, frente a lo racional, lo intuitivo y lo espontáneo; frente al cálculo, la certeza; frente a la complejidad de lo intelectual, la oscura selva de los motivos emocionales; frente a lo cerebral, lo que reiteradamente Sender gustó llamar lo ganglionar». ${ }^{21}$

Convencido de la intensidad sobrehumana y mágica de la niñez, Sender nos transporta a su propia infancia a través de su obra y recupera, con su memoria esencialmente sensitiva, imágenes, tipos, ambientes y personajes relacionados con su mundo infantil y adolescente, que el autor proyecta en el de dos de sus grandes criaturas literarias, jóvenes antihéroes en los que «campa por sus respetos el niño con su creatividad incontrolable y su visión mágica del mundo". ${ }^{22}$ Son Ramiro Vallemediano y Pepe Garcés, uno y otro personificaciones de un álter ego del escritor y ambos, protagonistas respectivamente de El verdugo afable (1952) y de la serie narrativa de Crónica del alba (1942-1966).

"Confesión íntima y crónica de medio siglo de vida española vista por un espíritu crítico y contradictorio", en palabras de Ricardo Senabre, ${ }^{23} \mathrm{El}$ verdugo afable incluye fragmentos de libros anteriores en los que Sender, en quien a veces se impone el periodista fiel a los hechos con la fuerza del testigo presencial, recupera episodios de su tiempo histórico entretejidos con su propia trayectoria humana, con una decidida voluntad de síntesis. Por el contrario, el episodio en que relata la niñez del protagonista en el internado de un colegio religioso de Reus, que no procede de obras anteriores, se amplificará dos años después hasta constituir Hipogrifo violento, segundo volumen de Crónica del alba. La infancia de Sender adquiere así un especial relieve en El verdugo afable, al fundir literatura y biografía en el relato de circunstancias y recuerdos hasta entonces no recogidos en sus libros, contrariamente a lo que sucede con otros significativos acontecimientos de una obra en la que el autor "parece haber renunciado casi por completo a la invención". 24

El verdugo afable arranca de un hecho circunstancial y episódico. A principios de 1924, tras cumplir el futuro novelista su servicio militar en Marruecos, "se concluye un ciclo de su vida o, dicho de otra manera, termina el "primer Sender"", según la periodización de su biografía que establece Jesús Vived, gran conocedor de su vida. ${ }^{25}$ Es entonces cuando, por mediación de su hermano Manuel, Sender es recibido por Nicolás María

21 José-Carlos MAINER, art. cit., p. 146.

22 Francisco CARRASQUER, op. cit., p. LXIX.

23 Ricardo SENABRE, art. cit., p. 162.

24 Ibid., p. 159.

25 Jesús VIVED MAIRAL, "El primer Sender», introducción a Ramón J. SENDER, Primeros escritos (1916-1924), Huesca, Instituto de Estudios Altoaragoneses («Larumbe», 5), 1993, pp. XICXXII (CIV). 
de Urgoiti, financiero promotor del diario El Sol, donde inicia el escritor su actividad periodística en Madrid. Tiempo después asiste "como testigo en nombre de la ciudad ${ }^{26}$ a unas ejecuciones en la cárcel Modelo, que le producen una fuerte impresión. En los capítulos primero y último de la novela, escritos en primera persona, un periodista, identificado como el mismo Sender al final, describe el cumplimiento de las sentencias y narra su cita y encuentro con uno de los verdugos, movido por la necesidad de entender la razón de su existencia: "si no la hay estamos todos perdidos». ${ }^{27}$ Ambos capítulos enmarcan, como si pudiera tratarse de un reportaje, la parte central y extensa del relato, en la que, por el contrario, se narra en tercera persona la historia del verdugo Ramiro Vallemediano. El novelista no oculta su simpatía por el ejecutor de la justicia, en cuyo aspecto físico reconoce que "había cierta distinción», que «era un hombre de apariencia refinada", al tiempo que "daba la impresión tranquilizadora de cualquier honesto ciudadano». Mientras espera en un café, Sender apunta una posible identificación con el verdugo — «Yo mismo - pensaba, mirándome de reojo en la superficie bruñida del cubo de hielo- podría dar mejor la impresión de ser un verdugo»—, identificación que ha percibido ya al salir de la cárcel en la mirada de los curiosos: «Yo pensé que me tomaban quizá por el verdugo». Y, sin embargo, "esto no me ofendía. Únicamente pensaba que para ser verdugo era yo demasiado joven». ${ }^{28}$

Muchos años después, cuando escribe la novela, Sender, al iniciar la parte del relato en tercera persona, proyecta su biografía en la de su personaje, que se convierte así en "contrafigura del propio autor" en palabras de Ricardo Senabre, ${ }^{29}$ quien ve en la novela una «especie de compendio de la primera época — biográfica y literaria-de Sender», cuya identificación con el verdugo vendría a ser un descargo de conciencia del propio novelista — «Late en el fondo de El verdugo afable una desoladora confesión de culpabilidad»-, psíquicamente confuso por sus vivencias de la guerra civil, «en un intento de aclarar, mediante la biografía de un personaje no enteramente ficticio, su claudicación final, su caída en el conformismo, su complicidad - por omisión - en una gigantesca culpa colectivan..$^{30}$

Por el contrario, Sender evoca positivamente la infancia de Ramiro, cuando «la vida le parecía un milagro continuo» porque el niño gozaba de la plenitud de lo simple, en un estado de primitiva inocencia y de placer puro - «Cuando tenía sed y bebía sentía un placer inmenso. Lo mismo le sucedía al comer y al acostarse después de jugar todo el día»-, estado que se prolongaba en el sueño y en sus relaciones con la naturaleza y la divi-

\footnotetext{
26 Ramón J. SENDER, El verdugo afable, México, Aguilar («Novela Nueva»), 1970, p. 368.

27 Ibid., p. 29.

28 Ibid., pp. 16-29.

29 Ricardo SENABRE, art. cit., p. 156.

30 Ibid., pp. 160-161.
} 
nidad, en las que se manifiesta la dimensión sobrehumana de la infancia cuando Dios le concede el día de su comunión la tormenta de granizo que el niño le ha pedido, porque «Ramiro encontraba mágica aquella lluvia de bolitas de cristal que se deshacían en su mano temblando». ${ }^{31}$ Una vez que Ramiro ha aprendido a los doce años y en muy poco tiempo «todos los oficios de la aldea", en pasaje que Sender incorpora, entre otros, de la Vida de Pedro Saputo de Braulio Foz, y prefiere «seguir sin hacer nada», la madre «escribió a un tío suyo contándole lo que sucedía y al cabo de algunas semanas recibió una carta en la que el pariente se ofrecía a pagar la educación del muchacho. Por lo pronto, debía enviarlo al colegio de San Ildefonso en Reus (Cataluña), donde él mismo se había educado. Con la carta le enviaba una cantidad para los primeros gastos».32 Sender introduce ahora en la novela una referencia biográfica concreta: él mismo fue también alumno interno del colegio de San Pedro Apóstol de los frailes de la Sagrada Familia, orden que se había establecido en Reus en 1895 en un edificio construido a tal fin en la calle Ample, cerca de la estación. El colegio, que había de ser en el primer tercio de siglo el centro de enseñanza privada más prestigioso de la ciudad, impartía educación primaria, comercio y bachillerato. Los alumnos, hijos de la media y pequeña burguesía de la ciudad y de los propietarios de las zonas rurales del área de influencia económica de Reus, pasaban de 300 en 1905. De ellos, un diez por ciento eran internos.

Vuelto a su aldea, Ramiro evoca con nostalgia su estancia en Reus y el novelista describe la ciudad que conoció en su infancia con adjetivos elogiosos reforzados enfáticamente - «en la parte céntrica había unas calles tan hermosas, unas plazuelas tan limpias y cuidadas, unos comercios tan esplendorosos»- para concluir con una elocuente hipérbole: «que Ramiro se creía trasladado a otro planeta». De cuanto ve en la ciudad, el monumento al general Prim es lo que más le impresiona; ante él, Ramiro imagina de una forma infantil la gloria humana: «Le dijeron que a aquel hombre lo habían asesinado, y obsesionado por el monumento Ramiro creía que la gloria humana consistía en ser asesinado y tener después una estatua como aquélla en una plaza pavimentada con adoquín menudo-mojado por la llovizna- sobre el cual rodaban silenciosamente los coches con llantas de goma». ${ }^{33}$ En un segundo curso de estancia en el colegio, Ramiro llega instintivamente al placer solitario, que genera en él un conflictivo sentimiento de culpa, coincidente con su entrada «en la pecadora madurez», que puede representar la pérdida de aquellas «cosas sobrehumanas» que hay en los niños, como escribirá más tarde en Monte Odina. ${ }^{34}$

\footnotetext{
31 Ramón J. SENDER, El verdugo afable, ed. cit., p. 34.

32 Ibid., p. 36.

33 Ibid., p. 37

34 Ramón J. SENDER, Monte Odina, ed. cit., p. 89. Se hace referencia a este mismo texto en la n. 20.
} 
El relato de la estancia de Ramiro en el internado de Reus pasará a las páginas de Hipogrifo violento (1954), segunda parte de Crónica del alba, serie en la que los materiales autobiográficos tienen un papel fundamental en el personaje de Pepe Garcés, que, como Ramiro Vallemediano, se constituye en álter ego del novelista. Aunque a los ojos del lector común la diferencia de nombre entre el autor y el yo narrador aleja aparentemente cualquier posibilidad de pacto autobiográfico, es evidente que Sender elige para el segundo su nombre más estrechamente vinculado al ámbito familiar y privado - «A mí, en casa, me llamaban Pepe, porque era el nombre del jefe de la tribu y yo era el hijo mayor. Mi padre se llamaba José, y también mi abuelo y mi bisabuelo»-, ${ }^{35}$ al que añade el apellido materno, testimonio del profundo afecto que el escritor sentía por su madre.

En las últimas páginas del volumen que da nombre a la serie se cuenta la llegada a Reus de Pepe Garcés, acompañado por su padre, para ingresar en el «Colegio de San Pedro Apóstol, enorme edificio en la Avenida de la Estación», ${ }^{36}$ que, al contrario de lo que ocurre en El verdugo afable, es denominado aquí con su nombre histórico. En su primera noche en el colegio Pepe Garcés descubre asombrado desde su celda unas grandes luminarias urbanas. Averigua después que "la ciudad aparecía engalanada por las fiestas del centenario de Constantino el Grande». Hipogrifo violento empieza, pues, en octubre de 1913, cuando se cumple el centenario del edicto de Milán (313), que la Iglesia conmemoró solemnemente. Los festejos comenzaron en Reus el viernes 17 de octubre, con el encendido de la iluminación eléctrica del campanario y la fachada de la iglesia arciprestal de San Pedro. Unos días más tarde, el 21, una prolongada llovizna seguida de vendaval había de deslucir los actos al averiar mayormente las luminarias. Podemos afirmar, en consecuencia, que Sender/Pepe Garcés llegó al colegio de la Sagrada Familia de Reus entre el 17 y el 21 de octubre de 1913 y que su internado fue fruto de una decisión tardía y apresurada, tal como se presenta en Crónica del alba - «Había decidido enviarme interno a un colegio. Mi madre advertía que tenían que hacerme ropa interior, pero mi padre insistía: - Mañana mismo»- y se deduce de su documentación académica, puesto que la solicitud de matrícula en el Instituto, fechada el 10 de octubre, no fue suscrita por el interesado y la matrícula propiamente dicha se registró con el número 22 el día 15. Es lógico pensar que, una vez resuelto el traslado del expediente y formalizada aquélla, tendría lugar el viaje a Reus de padre e hijo. Sender fue matriculado de tercer curso de bachillerato en el Instituto General y Técnico de Reus cuando tenía 12 años, según consta en algunos documentos de su expediente, por el que se confirma que

35 Ibid., p. 100.

36 Ramón J. SENDER, Crónica del alba, Barcelona, Delos-Aymá, 1965, p. 136. 
nació en Chalamera en 1901 - como demostró en su día Marcelino C. Peñuelas - -37 y no en Alcolea de Cinca en 1902, como se venía publicando hasta hace unos años.

A lo largo de las páginas de Hipogrifo violento, que transcurre íntegramente en el internado de Reus, Sender, a través de los recuerdos que Pepe Garcés hilvana en los cuadernos escritos en el campo de concentración de Argelés, reúne nombres, descripciones, imágenes precisas que demuestran que su estancia en Reus, aunque sólo fue de un curso escolar —el de 1913-1914-, dejó profunda huella en el recuerdo y tal vez en el carácter del futuro escritor y combatiente anarquista, para el que la situación social de la ciudad, a menudo conflictiva, pudo ser en algún momento un escenario revelador e inquietante: durante las fiestas constantinianas más de 500 obreras textiles estaban en huelga y de enero a junio de 1913 se sucedieron en la ciudad paros prolongados de distintos gremios. A la conflictividad social contribuía también el crecimiento demográfico, un creciente estancamiento económico aliviado más tarde por la primera guerra mundial y las rivalidades políticas, que habían llevado al socialismo a ganar la batalla al anarquismo en el mundo obrero local. Se podría argüir que esta situación histórica apenas sería advertida por un niño y menos aún habría de influir en su carácter. Será oportuno recordar entonces la precocidad de Sender, que a los 13 años forma parte de la redacción de la revista estudiantil El Escolar, del Instituto de Zaragoza, y a los 15 publica ya en el diario La Crónica de Aragón. ${ }^{38}$

Hasta las páginas de Hipogrifo violento llega el eco de los «disparos lejanos", 39 de los "desórdenes callejeros con motivo de las huelgas de las fábricas», y los alumnos comentan y fantasean acerca de la situación social hasta el extremo de atribuir a los religiosos insólitas medidas de seguridad: «había oído decir que los frailes solían conectar las verjas del parque y las ventanas bajas con cables de alta tensión en tiempo de revueltas y peligros». El pequeño Sender manifiesta entonces sus preferencias: "La gente de la calle, el pueblo, me parecía incapaz de hacer daño $[\ldots]$ y pensaba no sé por qué en la amistad de los obreros que trabajaban allí». Entre la realidad y la fantasía, el niño identifica la lucha obrera con la conquista de la libertad y, obsesionado por el personaje que interpreta en la representación escolar de La vida es sueño, se siente un nuevo Segismundo: «Si un día asaltaban el convento y lo incendiaban me sacarían de allí lo mismo que sacaban a Segismundo los conspiradores $»{ }^{40}$ Aquel personaje «en

\footnotetext{
37 Marcelino C. Peñuelas, La obra narrativa de Ramón J. Sender, Madrid, Gredos («Biblioteca Románica Hispánica", 153), 1971, p. 18, n. 1. En ella, el autor transcribe, casi completa, la partida de nacimiento de Sender para aclarar "definitivamente» la fecha y lugar de su nacimiento.

38 Jesús VIVED MaIRAL, op. cit., pp. XIV y XX.

39 Ramón J. SENDER, Hipogrifo violento, en Crónica del alba, ed. cit., p. 258.

40 Ibid., pp. 151-152.
} 
quien el escritor palpa la difícil dualidad entre la conciencia y el destino, la lucidez perpleja y la vivencia inconsciente, la oscura reminiscencia de la culpa y la convicción de la inocencia". ${ }^{41}$ Aquella convicción de la inocencia que hace de la infancia la piedra angular de la vida entera, la fuente natal perdida, el tiempo de la ya imposible salvación.

${ }^{41}$ José-Carlos MAINER, art. cit., p. 141. 


\title{
El yo narrador y el otro
}

\author{
Ricardo Crespo \\ International College of Sevilla
}

\begin{abstract}
José Cadalso, en la «Introducción» de sus Cartas marruecas y Ramón J. Sender en repetidas ocasiones a lo largo de Los libros de Nancy confiesan ser meros editores-transcriptores de las cartas que estructuran estas obras, otorgándose muy limitadas intervenciones correctoras. Los dos autores parecen querer situarse antes de la novela, como esos autores-ausentes que pretenden así desliteraturizar la obra, suponiéndola documento o testimonio, fingiéndola sin autor (Tacca, 37). Pero Cadalso pronto descubre su máscara y afirma que Gazel —l corresponsal marroquí de las Cartas marruecas- nace «el mismo año, mes, día e instante» (Cadalso, 4) que él. De modo que, aplicando la reflexión de Todorov a propósito de las Lettres persanes de Montesquieu, puesto que ni Gazel ni Nuño ni Ben-Beley existieron en realidad, esa penetración y esa lucidez de su propia sociedad le pertenecen al autor, quien "primero se hizo extranjero en su propio país con objeto de conocerlo mejor" (Todorov, 1991, 401). ${ }^{1}$ No es éste el caso del
\end{abstract}

\footnotetext{
1 Traer a colación aquí la afirmación de Robert Kissner de que las novelas de Sender nacen como "expresión literaria de la tragedia humana del exiliado" (R. KISSNER, "La tesis de Nancy de Ramón J. Sender: Una lección para exiliados", Papeles de Son Armadans, 71/211 [1973], pp. 13-20) puede ser arriesgado, pero sin duda no poca ventaja debió de serle a nuestro autor su larga y forzada ausencia de España.
} 
autor aragonés, quien mantiene hasta el final la ilusión de factualidad por la sencilla razón de que no puede atribuirse los errores que Nancy comete: «Según he dicho varias veces, los libros sobre Nancy los ha escrito ella misma, puesto que mi tarea ha consistido sólo en retocar sus cartas [...]» (Sender, 611). Antes bien, Sender sitúa a Nancy a su mismo nivel de «realidad» a medida que él va introduciéndose en la historia, pasando de la "Nota previa», de los títulos y entradas cada vez más extensas de los capítulos -donde dialoga con ella y con otros personajes- hasta dirigirle la carta-epílogo para subsanar la laguna que la estudiante norteamericana tiene de la fiesta de los toros. Pero tanto porque «[d]ès que le sujet de l'énonciation devient sujet de l'énoncé, ce n'est plus le même sujet qui énonce» (Todorov, 1968, 65), como porque Nancy es la destinataria interna de este largo epílogo ensayístico, se podría afirmar que los dos actúan al mismo nivel diegético y el narrador-autor alcanza así su grado máximo de ficcionalidad, por la misma razón que no adquiere el relato un nivel autobiográfico por mucho que Luz Campana de Watts nos asegure que conoció y fue amiga de una tal Nancy. Al fin y al cabo, como diría Genette, incluso cuando el autor es igual al narrador «nada impide a un narrador, identificado con el autor, contar una historia ficcional, pues lo que define la identidad narradora es [...] la adhesión seria del autor a un relato cuya veracidad asume» (Genette, 1993, 69). Y, que nosotros sepamos, Sender sólo en broma ha pretendido tal cosa. Es decir, en la ficción. ${ }^{2}$

Temáticamente, Nancy viene a España con el propósito de hacer su tesis de antropología en un estudio de campo - «de primera mano sobre el terreno", dice ella (Sender, 50) - y esta tesis es aceptada por el profesor finlandés Blacksen como un "estudio de costumbres» (Sender, 216). Corrían los años en los que la sociedad norteamericana entraba en crisis a causa de la guerra de Vietnam y en los campus universitarios sobraban exotas idealistas de escrupulosa conciencia que, a través de los Cuerpos de Paz y asociaciones afines no siempre tan escrupulosas, se abonaban a la "ley de Homero": el país más alejado del nuestro es el mejor. Muchos jóvenes estudiosos y aventureros se desparramaron por el mundo con más o menos rigor científico para estudiar al otro, en un momento en el que, como dice Clifford en aras de una antropología del lenguaje, «el equilibrio entre lo objetivo y lo subjetivo se derrumba [...]: los etnólogos empezaron a escribir las experiencias de campo desde el yo. El uso de la narración en primera persona [...] se extiende en las últimas tendencias. Junto a las notas del cuaderno de campo, aparece ya, sin trampas, lo retórico, la experiencia vivida, lo autobiográfico e, incluso, el autorretrato irónico" (Clifford y Marcus, 41). En algunos de los escasos trabajos críticos sobre estos libros de Sender se ha apuntado este blanco de la sátira senderiana.

\footnotetext{
2 Otra cosa es que, cuando la crítica se afanaba en decretar la muerte del autor, Sender aparezca en estas novelas confundiendo al diablo. Sobre este aspecto preparo un estudio más detallado.
} 
Justamente por ello, ya ha pasado más desapercibido el hecho de que, desde el plan argumental de la obra a la estructura epistolar de la serie, los Libros de Nancy se deban inscribir genéricamente dentro de una tradición literaria que, en España, inicia Cadalso: la del extranjero que, al no compartir ni sufrir las costumbres del nativo, posee el "claro privilegio epistemológico» (Todorov, 1991, 400) de percibirlas en su verdad. También Gazel quiere "viajar con utilidad y observar las costumbres de este pueblo" (Cadalso, 10), porque, como dice la misma Nancy, "[n]o hay como los extranjeros para ver [las] cosas» (Sender, 60). Naturalmente, aquí, con esta ironía, termina la coincidencia entre los dos textos, pues digamos ya que la serie senderiana (o al menos las primeras novelas) puede considerarse, en forma paródica, una transformación heterodiegética ( $\mathrm{y}$ acaso transexualizada por el papel protagonista de Nancy) de este hipotexto cadalsiano que sí buscaba, ciertamente, censurar los vicios y costumbres de los españoles. En la peripecia de Nancy por España no hay tal propósito de crítica social: Nancy se detiene en Andalucía y estudia al "gitano como entidad frenética» de paso hacia la Atlántida, en un viaje hacia el mito, al límite de la historia. En este primitivismo de raigambre lévi-straussiana que Nancy busca en los gitanos no podemos identificar a Andalucía, cuyo sustrato étnico es más profundo y diverso.

La forma epistolar del género canónico sirve perfectamente al tema señalado más arriba. Por un lado, las cartas permiten que el relato sea asumido por un personaje, el que escribe, pero, por ello, su punto de vista es "limited almost entirely to his own thoughts, feelings, and perceptives" (Philip Stevick, 126). Además, es sabido que el relato a cargo de un personaje obliga a un ángulo de visión preciso, a una perspectiva constante, a una información limitada. En el caso de Nancy, muy limitada, diríamos, por su insuficiente conocimiento de la lengua y de la cultura españolas. Nancy se pierde en las anfibologías de las palabras y en la especificidad del comportamiento. Constante y casi patéticamente confiesa la narradora que «yo tampoco entendí aquello» $\mathrm{o}$ «es gente difícil de entender» 0 cae en las más chuscas o trágicas - según se mire- de las situaciones. Por otro lado, mucha de esta información de primera mano en su investigación de campo le viene a Nancy a través de Curro - su novio, «ocho octavos de gitano y uno de son of a bitch», en la valoración del duque (Sender, 191)-, quien no es mucho más culto que ella y, para salir del paso, le explica "míticamente», es decir, inventa lo que desconoce. Véase, entre los múltiples ejemplos, la explicación que le da Curro del nombre del coto de Doñana. ${ }^{3}$ Por ello, no es ya que nos temamos que, como dice Clifford, los dis-

\footnotetext{
${ }^{3}$ Que el nombre del coto de Donana «venía de una princesa de los bártulos que era hechicera y tenía celos de una esclava que se llamaba Ana, a la cual convirtió en corza. El rey de los bártulos se fue a cazar y encontró a la corza, que le habló como una doncellita. Le dijo los nombres de todas las personas de su familia desde el más viejo al más joven. El rey de los bártulos le preguntó: ¿Y tú quién eres? Y ella dijo: Ana. Desde entonces está prohibido matar en este coto ciervos hembras, es decir, venaditas" (SENDER, 1984, 105).
} 
cursos sean siempre «condicionados por la propia cultura del etnógrafo» (Clifford, 16) —en este caso, la de Nancy - sino que nos tememos que es muchísimo peor creer que «nada es más transparente que dar la palabra al interlocutor» (Clifford, 47), es decir, a Curro.

No obstante, lo que Nancy crea no es tan importante como que nosotros sepamos, siguiendo con el ejemplo anterior, que los bártulos no son un pueblo histórico, como lo son los alanos o los suevos, y que no ha existido ni un rey de los bártulos ni una princesa Ana que..., etc. Esta información que el lector posee gracias a su cultura y que le permite desmentir la explicación de un personaje capaz de engañar y un narrador capaz de equivocarse, o indigno de confianza, le pone en solidaridad con el autor implícito y contra el narrador en primera persona. Es el momento de hilaridad para unos y acaso de embarazo para otros. (Un lector chino o norteamericano para el caso, a quien lo nuestro le sonara a chino, no se reiría.) El autor no interviene directamente para corregir a Nancy; ¿para qué, si está el lector? Adquiere la novela en este punto parte de su actualidad teórica. Pero, si desconociéramos la historia, si ignoráramos el significado de las palabras de una lengua, si el significante no reenviara a un significado dado por el contexto cultural, si «la fonction référentielle du langage disparaît au profit de la fonction métalinguistique», creando el pleonasmo y la tautología, como denuncia Lefebvre a propósito de la pretensión estructuralista (Lefebvre, 70), estaríamos actuando como Nancy, aceptaríamos la explicación de Curro. Por contra, podemos responder con un ¡desde luego! a la interrogación de Todorov: "las narraciones de los antiguos viajeros son ciertamente placenteras pero ¿acaso lo que nos dicen no resultan, la mayor parte del tiempo, de interpretaciones erróneas?» (Todorov, 1991, 103).

De aquí se desprende que Sender duda de la posibilidad de que uno pueda convertirse en otro o de que uno pueda hacerse parte de la cultura del otro ni aun viviéndola. Nancy busca durante todo su tiempo de estancia en Andalucía el significado de paripé y sólo al final, encerrada en la cabina de teléfonos, apretujada contra el viejo duque, a quien llama your highness adulatoriamente como es costumbre en los gitanos, cuando ve la intención seductora de él y él detecta la alarma en ella, le dice, por decir algo, que el decorado es pompeyano. Entonces, Nancy hace el paripé y trata de campear el temporal de la seducción explicando el arte pompeyano, ante la mirada jocosa de los criados, quienes les ven, no como se presentan, sino como la Notaria y el Carámbano, pues «son los otros los que nos deterioran y nos gastan» (Sender, 196). Y, por ello, pese a las repetidas vivencias de Nancy entre gentes de la lengua de Cervantes, al final de su «epopeya» una grotesca confusión fonética le sume en el ridículo, al pedir en un establecimiento algo que sonaba a pichas en lata cuando sólo quería comprar unos inocentes peaches... Nos parece que se perfila aquí el concepto de «raza lingüística» tipo Renan.

... Pompeya, decíamos: arte de segundo grado, imitación en maneras clásicas griegas, refinamiento, ilusionismo y efectos de espejo. Ese mismo 
año de 1968, en una conversación mantenida con Marcelino Peñuelas, Sender se confiesa saturado de narración realista y prevé novelas en las cuales «se fundirá lo lírico, lo científico y lo metafísico de dimensión misteriosa, es decir, más o menos religiosa [...]». Considera que los griegos superaron la realidad inmediata o exterior de su tiempo para exponer figuras míticas perdurables. ${ }^{4}$ Pero, con ser interesante $y$, acaso, también preocupante la evolución del realismo en el arte senderiano, el problema es, como ya dijimos, más grave y de una naturaleza epistemológica: cuando Nancy lee lo que Shulton opina sobre los tartesos, ¿debe creerle más que a Curro? ¿Debemos creer a Sender, cuando en el Epílogo a Nancy nos habla del origen de las corridas de toros basándose en información libres$\mathrm{ca} ?^{5}$ El mundo muestra su naturaleza de texto, de palimsepto: en el principio fue el Verbo. En esta época barroca en la que el autor se siente vivir (Sender, 222), él aparece —como Velázquez en Las Meninas- pintando a Nancy y pintándose. La realidad se crea y nos crea en un relativismo que se ha hecho lugar común en nuestra sociedad. $Y$, así, si todo es relativo, si "cada uno tiene su manera de vivir - como Sender le dice a Nancy al final del epílogo- inventada más o menos inspiradamente. Eso es lo que llamamos realidad. $Y$ no hay otra, como tú sabes hace tiempo» (Sender, 680); o si, en el mejor de los casos, sólo existe una realidad inmanente a cada individuo (ipara Curro sería la Guardia Civil!), entonces, puede aceptarse el mito como una explicación tan válida de lo real como cualquier otra. $Y$ no es sólo que el Sender-autor-personaje comente con el profesor Blacksen las teorías de Lévi-Strauss y se identifique con éste en lo referente a la invariabilidad esencial del ser humano (Sender, 204), sino que también parece considerar «la historia como una prolongación de la mitología» (Lévi-Strauss, 65).

Volvamos ya, pues, al comienzo, a ese siglo XVIII donde arranca el modelo que informa estos libros de Sender. De ahí parten los valores universales que se oponen al relativismo de moda hoy: la verdad objetiva que buscaba la Ilustración ha sido sustituida por la interpretación, la civilización por la cultura, la razón se anula ante el Volksgeist y, como dice Alain Finkielkraut, un par de botas equivale a Shakespeare. ( $Y$, por ende, al mismo Sender.) Al presentarnos la realidad relativizada desde la perspectiva de cada uno, al diluir el otro en el yo, no podemos sustraernos a la impresión de que, entre bromas, un Sender escamado o escaldado ante los totalitarismos sigue a Lévi-Strauss en el intento de sentar al Siglo de las Luces en el banquillo.

4 «La novela del futuro. Diálogo con Ramón J. Sender», Asonante, 24/2 (1968), pp. 24-28. Parecidas declaraciones nos hizo a nosotros por esas fechas. Véase «La estética de Ramón J. Sender (Entrevista póstuma)", El Correo de Andalucía, 8 de febrero de 1987.

5 Carlos Murciano, flamenco, flamencólogo y taurino, en Nueva Estafeta, 51 (1983), p. 88, se entretiene en rastrear los errores de Sender y, contra lo que éste afirma, nos asegura "que el toro asesino de Joselito no se llamaba Niñato, sino Bailaor, ni fue, como Sender quiere, el tercero de la tarde, sino el quinto". ¿Se equivoca Sender adrede? 


\section{EL LUGAR DE SENDER}

\section{BIBLIOGRAFÍA}

CADalso, José, Cartas marruecas, Madrid, Espasa-Calpe, 1971.

Clifford, James, y MARCus, George E., eds., Retóricas de la antropología, Júcar, Universidad, 1991.

FINKIELKRAUT, Alain, La derrota del pensamiento, Barcelona, Anagrama, 1987.

GENETTE, Gerard, Ficción y Dicción, Barcelona, Lumen, 1993.

LEFEBVRE, Henri, L'idéologie structuraliste, Éditions Anthropos, 1971.

LÉvi-STrauss, Claude, Mito y significado, Madrid, Alianza, 1987.

SENDER, Ramón J., Los cinco libros de Nancy, Barcelona, Destino, 1984.

STEvick, Philip, The theory of the novel, The Free Press, 1971.

TACCA, Óscar, Las voces de la novela, Madrid, Gredos, 1973.

TODOROv, Tzvetan, Poétique, Éditions du Seuil, 1968.

—, Nosotros y los otros, México, Siglo Veintiuno Editores, 1991. 


\title{
Notas lingüísticas sobre Solanar y lucernario aragonés
}

\author{
José $\mathrm{M}^{\mathrm{a}}$ Enguita Utrilla \\ Universidad de Zaragoza
}

1. En 1978 y 1981, la Editorial Heraldo de Aragón recogía en sendos volúmenes una serie de colaboraciones publicadas por Ramón J. Sender en ese periódico zaragozano durante los últimos años de su vida. ${ }^{1}$ No tratan primordialmente estos artículos ${ }^{2}$ de cuestiones lingüísticas; antes bien, a través de ellos, Sender presenta retazos de la historia y de las tradiciones aragonesas (influencia semítica en Aragón, 2.158; la campana de Huesca, 2.99; Agustina de Aragón, 2.108; san Jorge y el dragón, 2.49; vírgenes ara-

\footnotetext{
1 Solanar y lucernario aragonés, Zaragoza, Heraldo de Aragón, 1978, y Segundo solanar y lucernario, Zaragoza, Heraldo de Aragón, 1981; serán citados mediante los números 1. y 2., respectivamente, seguidos de las páginas que en cada ocasión correspondan. En el primer volumen se incluye el título «La narración televisada» (1.103-146), en realidad reproducción del relato El regreso de Edelmiro, autorizada por la Editorial Aguilar; en el segundo consta un largo ensayo («Iberia, ferax venenorum», 2.81-116), escrito expresamente para esta publicación.

2 Excluyo de los comentarios que siguen dos capítulos, ambos de carácter narrativo, que merecerían análisis particulares: «En la Val d'Onsera» (1.49-53), cuyo texto se desarrolla dentro de una estructura cuentística muy diferente del carácter ensayístico que define a los demás escritos recopilados; y, por motivos análogos, el que se titula «La narración televisada» (1.103-146), ya citado.
} 
gonesas, 1.154; santa Orosia y la procesión de endemoniados, 1.24, 2.94; la leyenda del Santo Grial, 1.46; los amantes de Teruel, 2.108), pero sobre todo recrea recuerdos personales en los que entremezcla, lógicamente, datos biográficos concretos y anécdotas reales que a veces han servido de materia literaria para algunos de sus relatos: ${ }^{3}$ aquí concurren el corralico de Chalamera y la tía Ignacia $(1.15,1.159,1.185)$, Valentina $(1.156)$, las relaciones paterno-filiales (1.87), la muerte del abuelo (2.149), el misterioso cometa Halley (1.36), los duendes de Zaidín (1.84, 1.165), los gigantes de Tauste (1.154), las vivencias zaragozanas $(1.182,2.43,2.67)$-incluidos detalles como el Pilar (1.81), el tío Toni, barquero del Ebro $(2.31,2.68)$ y una fiesta del árbol en el cabezo de Buenavista (1.181)-, Monte Odina (1.87), la guerra civil $(2.96,2.125,2.131,2.145)$, así como las visitas a distintos lugares aragoneses (Echo, Villanúa y Jaca, 1.21, 2.94; Alquézar, 1.31; Rioseta, 1.39; Arañones, 1.43; Fraga, 2.61; Benasque, 2.142).

No ha de olvidarse, por otra parte, que desde su presente de escritor Ramón J. Sender manifiesta su interés y su amor por la tierra aragonesa a través de noticias, a veces curiosas (existencia del apellido Aragón en Nuevo México, 1.98; posible canonización de un gitano, Ceferino Jiménez Malla, nacido en Alcolea de Cinca, 2.129-132), pero de manera especial a través de sus reflexiones sobre el ser de los aragoneses -particularmente de los que habitan en el medio rural, es decir, de aquellos que "comen pan, beben vino y dicen la verdad» (2.114)--, a los que caracteriza mediante rasgos como la reciedumbre (2.109), la hombría $(2.137,2.167)$, la tozudez y el individualismo $(1.9,1.203,2.118,2.161),{ }^{4}$

\footnotetext{
3 Así, en 2.12, Sender informa sobre su visita a Cuenca, a la edad de veintiséis años, para investigar sobre "un escandaloso error judicial», origen de El lugar de un hombre [1939]; en 1.93 relata que en Tauste había un médico llamado Indalecio y una aldeana, que no recordaba su nombre, le gritó: «iSeñor... señor... relampago!», haciendo uso del significado de andalocio, forma dialectal muy próxima fonéticamente al nombre del médico: el suceso se incorpora a La onza de oro (de Crónica del alba [1963-1973], Madrid, Alianza Editorial, 7 a ed., 1984, p. 235), por consiguiente con localización literaria en el Bajo Cinca; en este último relato también se designa a una mujer con el nombre de (la) Ripamilán o (la) Ripamilana (pp. 273 y 275), que figura en 1.155 con referencia a una ganadería de Tauste.

${ }^{4}$ Sender ilustra sobre este individualismo a través de una rica galería de apellidos como Azlor, Luna, Aragón, Villahermosa, Borja, Bolea y Abarca, Lanuza, Aranda, Gurrea, Espés, Urrea (1.11, 1.192), y de personajes, entre los que se mencionan el rey Ramiro II, el filósofo judío Crescas, el antipapa Pedro de Luna, Damián Forment, Miguel Servet, fray Luis de Aliaga, Juan de Lanuza, Zurita, los Argensola, Juan de Lastanosa, Gracián, Miguel de Molinos, los Garcés (misioneros en el Nuevo Mundo), Félix de Azara, el conde de Aranda, Goya y, ya en época más reciente, Costa, su discípulo Manuel Bescós, el músico oscense Daniel Montorio, Ramón y Cajal, Moneva y Puyol, Ricardo del Arco, Miguel Fleta, etc. (1.10, 1.11, $1.24,1.79,1.92,1.151,1.191,1.192,1.212,2.44,2.62,2.63,2.75,2.79,2.83,2.90,2.96,2.99,2.102$, $2.104,2.109,2.118,2.158$ ). Es curiosa la anécdota que refiere a propósito de Ramón y Cajal: "No lejos de Villanúa había una "fuente milagrosa" a donde iban las beatas a beber. A veces vi en ella también beber a Ramón y Cajal, quien lo hacía después de percatarse de que no lo veían. [...] Cajal sabía más que nadie de fisiología del cerebro, pero no tenía, supongo, mucha fe en la medicina» (1.24).
} 
la ausencia de "máscara» $(1.45,2.62,2.118,2.137,2.167)$ y la falta de pasión regionalista $(2.137) .^{5}$

2. A lo largo de todas estas consideraciones están presentes -como cabía esperar - las peculiaridades lingüísticas que posee el territorio aragonés frente al español normativo, como una manifestación más de la cultura regional. Su análisis podría realizarse desde una triple perspectiva: en primer lugar hay que destacar que, en estos artículos, Ramón J. Sender expone sus saberes sobre las particularidades idiomáticas aragonesas, unas veces de carácter impresionista, otras - menos frecuentementeapoyado en oportunas referencias bibliográficas; en segundo lugar debe señalarse que, al ser Aragón el tema primordial de estos ensayos, es lógico que a lo largo del discurso expositivo se utilicen términos y expresiones de raigambre regional, ya que "la literatura - afirma $O$. Flores $-6{ }^{6}$ no puede dejar de ser un testimonio de la realidad, una realidad elaborada, sin duda, por la sensibilidad del escritor, pero que conserva matices identificables que la vinculan a su contexto real, con la experiencia vivencial que fue su fuente». No hay que olvidar, por otro lado, que el origen aragonés de Sender puede determinar la selección y empleo de vocablos y expresiones regionales, en lugar de los equivalentes del español general, sin que se den las circunstancias señaladas. ${ }^{7}$

De esas tres perspectivas, me ha parecido oportuno prestar atención, en esta comunicación, a la primera de ellas, es decir, a la que muestra una vertiente que podríamos llamar "filológica» en las reflexiones de Ramón J. Sender. ${ }^{8}$ Se recordará que filología, en un sentido amplio, es la disciplina que «estudia el lenguaje, la literatura y todos los fenómenos de la cultura de un pueblo o de un grupo de pueblos por medio de textos escritos».9

\footnotetext{
${ }^{5}$ En más de una ocasión, por otra parte, Sender se refiere a las diferencias existentes entre los aragoneses de las tierras altas y los que viven en las tierras bajas de la región $(1.191,2.161)$. 6 Vid. «El escritor frente al habla regional», Primeras Jornadas Nacionales de Dialectología, Tucumán, Facultad de Filosofía y Letras, 1977, pp. 523-528; lo citado, p. 525.

7 En este principio se ha apoyado J. A. FRAGo para determinar la raigambre aragonesa de Juan de Luna, a quien se debe la Segunda parte del Lazarillo (1620), y para establecer este origen geográfico para el anónimo autor de Los veintiún libros de los ingenios y de las máquinas, tratado técnico de finales del siglo XVI; vid. respectivamente «El aragonesismo lingüístico en Juan de Luna», AFA, XLII-XLIII (1989), pp. 9-20, y, en colaboración con J. A. GARCíA-DiEGO, Un autor aragonés para los «Veintiún libros de los ingenios y de las máquinas», Zaragoza, Diputación General de Aragón, 1988.

8 A la aparición de peculiarismos en sus relatos de ambiente regional he dedicado el trabajo «El aragonesismo lingüístico en Ramón J. Sender», III Curso sobre Lengua y Literatura en Aragón (siglos XVIII-XX), Zaragoza, Institución Fernando el Católico, 1994, pp. 191-215; vid. también F. NAGORE LAÍN, "Cleto Torrodellas en Ramón J. Sender", 53 escritores a Ramón J. Sender, Zaragoza, Heraldo de Aragón (Col. «Sender»), 1980, pp. 74-76, J. VÁzQUEz OBRADOR, «Aragonesismos en Crónica del alba, de Ramón J. Sender", Argensola, XXII (1980), pp. 369-392, y J. L. NEGRE CARASOL, "Aragonesismos en Réquiem por un campesino español» [1983], Alazet, 0 (1988), pp. 273-284. ${ }^{9}$ Se lee esta definición en F. LÁZARO CARRETER, Diccionario de términos filológicos, Madrid, Gredos, $3^{\mathrm{a}}$ ed., 1971.
} 
Dentro de este planteamiento, ciertamente son de interés los datos que sobre literatura aragonesa ofrece Ramón J. Sender en las dos entregas del Solanar. El escritor centra su atención especialmente en la poesía popular y en su manifestación más sobresaliente, la jota, a la que define como la «única música no decadente de España» (2.16-18; vïd. asimismo 1.62, 1.98, $1.163,2.57,2.114) ; 10$ dedica también comentarios jugosos a Gracián (2.117$119)$, a desentrañar la identidad de Avellaneda, autor probablemente aragonés de un falso Quijote (1.183-184, 2.163-168), ${ }^{11}$ a José Martí, poeta cubano que realizó sus estudios universitarios en Zaragoza (2.71), a la obra poética de Francisco Carrasquer (1.75-79); y todavía inserta a vuelapluma alusiones a la prensa regional (Diario de Avisos, 1.183, La Crónica de Aragón, 2.108, Heraldo de Aragón, 1.183, 2.49, 2.65, de Zaragoza; La Tierra, 1.35, $1.178,1.198,1.209,2.100$, El Diario de Huesca, 1.210, de Huesca) ${ }^{12}$ y curiosas noticias como la aparición en La Puebla de Hijar, en caracteres hebraicos, de la primera Biblia (Antiguo Testamento) que se imprimió en el mundo $(2.157)^{13}$ o la presencia de los Pirineos y del Santo Grial en los textos del Parsifal wagneriano (1.46). ${ }^{14}$

Más nos interesa, sin embargo, para los objetivos de esta comunicación, fijarnos en los comentarios de tipo lingüístico que realiza Ramón J. Sender en este conjunto de ensayos. Casi todos ellos se refieren a Aragón, salvo algunas reflexiones generales sobre el cambio linguiístico («[...] el idioma escribe - lo hacen y cambian, modifican y consagran las gentes del pueblo con sus hábitos permanentes o evolutivos. Porque todo se mue-

\footnotetext{
10 Acompaña sus explicaciones con citas de Julio Cejador, Julián Ribera, Juan Domínguez Berrueta y Ricardo del Arco (1.163-164, 2.17-18). Reproduce, además, composiciones estróficas de carácter popular $(1.16,1.17,1.21,1.34,1.160,1.164,1.171,1.172,1.176,1.193$, 1.199 , etc.).

11 Ramón J. Sender coincide con Jerónimo BORAO (Diccionario de voces aragonesas [1859], Zaragoza, Imprenta del Hospicio Provincial, 1908, pp. 70-76) en atribuirlo a fray Luis de Aliaga, aragonés e inquisidor general; entre los rasgos lingüísticos que orientan hacia dicha atribución menciona Borao la omisión de artículos. Sender apostilla: «Es verdad que en Aragón se prescindía y se prescinde aún con cierta graciosa frecuencia no sólo de los artículos sino de los pronombres personales y de las partículas» (2.164-165). Ninguno de esos fenómenos se considera en los estudios dialectales como peculiaridad que confiera una gran personalidad a las hablas aragonesas actuales.

12 Recuerda, además, que don Juan Moneva y Puyol intentaba en 1914 iniciar un nuevo diario titulado La Noche; vid. 2.106. Cita, por otra parte, diversos periódicos nacionales: El Sol $(1.167,1.199,2.77)$ y El Imparcial $(2.32)$, de Madrid; El Correo Español, cuya afinidad con el partido carlista destaca (2.98), y La Vanguardia de Barcelona (2.81).

13 Vid. al respecto la Gran Enciclopedia Aragonesa, Zaragoza, UNALI, 1981, vol. VII, p. 1.795, con una diferencia respecto al texto de Sender: la imprenta se localiza en Hijar.

14 Según una tradición del siglo XV, san Lorenzo trajo el Santo Grial desde Roma a Huesca y, después, con la invasión musulmana, hubo de ser trasladado a Siresa y a San Juan de la Peña. Pero Wagner se inspiró, para esta ópera, en el Perceval de Chrétien de Troyes, poeta francés del siglo XII. Para estos datos, vid. de nuevo la Gran Enciclopedia Aragonesa, Zaragoza, UNALI, 1982, vol. XI, p. 2.997, y la Nueva Enciclopedia Larousse, Barcelona, Planeta, 1985, vol. XV, s. v. Parsifal, y vol. XIX, s. v. Troyes.
} 
ve avanzando, en este universo nuestro diáfanamente misterioso", 2.13), sobre la reduplicación innecesaria del artículo en voces como el albornoz, la almunia, etc., dado que ya está aglutinado el artículo árabe en esos significantes (2.135-136), sobre el origen del sufijo $-z$, de carácter patroními$\mathrm{co}^{15}$ sobre el influjo del léxico español, especialmente del relacionado con la marina comercial o de guerra, en otras lenguas, ${ }^{16}$ porque «cuando España era la primera potencia del mundo todos los demás países la imitaban», y contrariamente, sobre la penetración de anglicismos en nuestra lengua en tiempos recientes (2.135). ${ }^{17}$

\section{ASPECTOS GENERALES}

3. En relación con Aragón, el escritor de Chalamera recuerda, con la mirada puesta en los hechos históricos, los antecedentes prerromanos del territorio, para lo cual aprovecha las enseñanzas de M. Alvar, J. Hubschmid y G. Rohlfs: «Los topónimos aragoneses del centro, del norte o del sur son a veces mucho más viejos que el latín y el griego. Prerromanos indoeuropeos son Navardún, Verdún [Berdún], Verdú [i?], Sesalú [¿?], Huesca (Osca, del idioma osco, anterior al latín, que los romanos latinizaron [...]), Ligüerre, Laguarres, Aragüés, Larrés, Caspe, Azpe [¿?], Serrablo, Serrasduy [Serraduy], Alastruey, Araguás, Arguís [Arguis] y tantos otros» (2.138). ${ }^{18}$ No olvida tampoco el influjo idiomático derivado del contacto con la cultura árabe (2.46), no sólo en el léxico común (alberge 'albérchigo', almenara 'zanja por la cual se conduce al río el agua que sobra de las acequias', alifara-lifara 'comilona excepcional', aliaga 'aula-

\footnotetext{
15 Sender le asigna un origen ibérico: "Yo le dije un día para dármelas de listo [...] que su nombre quería decir 'hijo de Juan', como Fernández 'hijo de Fernando' y González 'hijo de Gonzalo', por el subfijo ibérico" (2.58); hubiera sido conveniente matizar que su consolidación hubo de producirse a través de los numerosos genitivos góticos latinizados en -RICI > -riz; vid. R. LAPESA, Historia de la lengua española, Madrid, Gredos, 9ª ed., 1981, pp. 45 y 122.

16 Nuestro autor afirma, en este sentido, que los nombres de las partes funcionales del barco (proa, popa, puente, bauprés, gobernalle, jarcia, almirante, etc.) son mayoritariamente españoles; sin embargo, los datos de que hoy disponemos señalan que sólo proa y gobernalle pueden poseer este origen (concretamente catalán), mientras que popa, puente y jarcia son comunes, desde tiempos antiguos, a varios romances; por otro lado, bauprés se toma del francés beaupré y el significado marítimo de almirante pudo nacer entre los normandos de Sicilia y, desde allí, difundirse por Europa; vid. J. CoRominas (con la colaboración de J. A. PASCUAL), Diccionario crítico etimológico castellano e hispánico [DCECH], 6 vols., Madrid, Gredos, 1980-1991).

17 Cabe referir todavía una curiosa anécdota que podría servir para completar festivamente la biografía de Tomás Navarro Tomás. Ramón J. Sender viajó a Nueva York, al acabar la guerra civil, en el mismo barco que el renombrado filólogo. Al llegar al puerto, Tomás Navarro Tomás tuvo dificultades para recuperar diez o doce cajas metálicas con fichas y otros papeles académicos, custodiadas por la policía. Y es que cada caja llevaba unas sospechosas iniciales: TNT (T[omás] N[avarro] T[omás]).

18 Entre corchetes se incluye información complementaria de la que ofrece Sender.
} 
ga', ${ }^{19}$ etc.), sino también en la toponimia (Almozara, Alfajarín, Alcañiz, Alcubierre, Alcolea, Albalate, Alhama, Almunia)..$^{20}$

Desde una perspectiva sincrónica, hay que señalar que Ramón J. Sender no es ajeno al renacer, y no sólo como materia científica, de las cuestiones dialectales en tiempos recientes: «[...] últimamente [...] se ha puesto en circulación el tema de la particularidad regional y de la "diferencia". Lo curioso es que antes era una preocupación de gente vieja y conservadora y ahora parecen los más jóvenes los interesados en poner en circulación la fabla de Sobrarbe y Ribagorza (y de Cinco Villas y el Ancho y Bajo Aragón). Es una señal de los tiempos, que parece que van (a muy larga vista) a la resurrección de los grupos culturales y al debilitamiento de las fronteras políticas» (1.94). ${ }^{21}$ No está en desacuerdo Sender con este proceder, aunque matiza y gradúa muy claramente cuál ha de ser el valor de los elementos lingüísticos en el renacer de la conciencia regional: «Los jóvenes universitarios —escribe a continuación-pueden hacer despertar con el amor a la tierra natal (no hecho de exclusivismos ridículos) toda la mitología que va desde los mallos [...] hasta las tozaletas, los omprios, las midas supersticiosas y sobre todo las formas de solidaridad humana y pacífica en las cuales se ha basado nuestro desarrollo" (1.94).

Dentro de este pensamiento, es razonable que el escritor considere que, en la expresión escrita, no hay necesidad de abrumar al lector con localismos difíciles como misache 'adefesio', 'esperpento', chandra 'puta' o chandrio 'puterio', 'cualquier clase de despropósito vergonzante', ${ }^{22}$ porque «hacer uso de la fabla ribagorzana - pone ese ejemplo concreto-sólo por singularidad y afectación carece de sentido. Hay cosas más perdurables que el habla del siglo XIII» (2.13). Desde este mismo planteamiento, Sender no considera «desdén o desdoro» la omisión de los regionalismos léxi-

19 Bromea el autor cuando se pregunta si el inquisidor Aliaga -con ese mismo significante en el apellido - cultivaba sin darse cuenta una tradición árabe milenaria al mandar a la hoguera a los judíos que "seguían en sus trece», es decir, en las trece proposiciones axiomáticas de Maimónides. Vid. 2.46-47.

${ }^{20}$ Añade en otro lugar: «La base semítica de la población era entonces muy extensa. Morisca o judía. Todo Aragón (desde Aínsa hacia abajo) está lleno de nombres semíticos de aldeas o de monumentos, de aljaferias, almunias, alcalás, alcoleas y alquézares, de alhóndigas, de alamines y de albaranes, de aljecerias, de almudainas y al menos de alcantarillas" (2.158); dice, además, que los nombres judíos abundan igualmente, sin citar ejemplos concretos, y que de modo particular el influjo cultural hebreo es más notorio en la ribera del Jalón, donde localiza la costumbre de utilizar una silleta para los partos, documentada ya en el Libro de los Éxodos; vid. 2.159.

21 Vid. también al respecto 1.27 .

22 Elige Sender en estos ejemplos las acepciones más negativas que poseen las palabras mencionadas; en BORAo, mesache 'muchacho, mozo', chandro 'flojo, desaseado, haragán, ocioso y vago', chandra 'ramera', chandrio 'desbarajuste, cualquier desgracia o desperfecto causados principalmente en los muebles o ropas'; vid. asimismo R. ANDOLZ, Diccionario aragonés, Zaragoza, Mira Editores, $4^{\text {a }}$ ed., 1992, y G. RoHt.rs, Diccionario dialectal del Pirineo aragonés, Zaragoza, Institución Fernando el Católico, 1985. 
cos por el Diccionario académico, ${ }^{23}$ aunque existe un cuantioso inventario de términos peculiares, ${ }^{24}$ que suenan «muy bien», son «expresivos» (1.27) y tienen una "estirpe digna de respeto», por lo que al menos deberían figurar en los vocabularios regionales, pues "[e]l idioma lo hace el pueblo y no las academias» (2.154). A propósito de la dignidad de los aragonesismos léxicos comenta en otra ocasión: «Hay palabras como sobrejuntero, boira, chandrio, carasol y centenares de otras registradas o no por Borao que sugieren todo un mundo rico de valores y no sólo en extensión histórica sino en profundidad» $(1.66)$.

\section{ASPECTOS DESCRIPTIVOS}

\section{Fragmentación lingüística del territorio aragonés}

4. Ramón J. Sender reconoce, de manera global, rasgos idiomáticos que diferencian el territorio aragonés del español estándar: hay muchas palabras y expresiones, incluso frases enteras, que se usan exclusivamente en Aragón, "y no en el alto, sino también en el medio (Cinco Villas) y en el bajo, como Alcañiz y [La] Puebla de Híjar» (1.28). Si bien en una ocasión utiliza el sintagma genérico «lengua aragonesa» («con la que se cumple de veras el milenio de la castellana», 1.28), habitualmente es consciente de la variación lingüística que existe en la región, aunque no llega a citar las modalidades catalano-aragonesas de la franja oriental, que sin duda debió conocer por proximidad geográfica.

El escritor no ignora la existencia de peculiaridades idiomáticas en la zona pirenaica; de hecho, en sus reflexiones sobre la separación "psicológica» entre las tierras altas y las tierras bajas de Aragón se sirve de unos

23 Tal afirmación debe estar motivada por las declaraciones, en sentido contrario, de los lexicógrafos aragoneses: «Puesto que se ha perdido literariamente, aun en las márgenes del Ebro -escribe BORAO en la "Introducción» a su Diccionario, pp. 103-104_, el habla aragonesa; puesto que, lejos de perfeccionarse ni aun conservarse estos dialectos, amenazan con fundirse poco a poco en el idioma general; bueno fuera que la lengua conquistadora utilizara en beneficio común esos restos lingüísticos que de otro modo han de perderse, y entonces, ya que el vocabulario aragonés no se conservara sino en libros como éste u otros de mejor desempeño, ni sirviera sino como una curiosidad filológica; contribuiría por lo menos a enriquecer el acervo común de la sin par lengua española, y a cambio de tantas glorias abdicadas en favor de la unidad ibérica, conservaría el Aragón la de haber mejorado con su hermoso dialecto el habla rica de Cervantes»; ideas semejantes pueden leerse en J. PARDO Asso, "Prólogo" al Nuevo diccionario aragonés etimológico (voces, frases y modismos usados en el habla de Aragón), Zaragoza, Imprenta del Hogar Pignatelli, 1938.

${ }^{24}$ Entre los que no menciona el Diccionario académico cita repalmar 'repisa', ripa 'ribera', misache 'persona o figura inarmónica o grotesca', pardina 'hacienda en el monte donde hay alguna choza' (consta, sin embargo, como aragonesa en las últimas ediciones del DRAE), jende! 'exclamación de sorpresa' en las Cinco Villas, todos citados a propósito de una conversación mantenida por el escritor con A. Alonso en la Universidad de Harvard (1.27-28); además, enzurizar 'provocar', fardacho 'lagarto', aquí, sinónimo de 'caimán' (2.154), aunque ambos vocablos aparecen en las últimas ediciones del DRAE sin localización regional. 
versos que localiza en la parte septentrional de la región (1.193), redactados en una variedad dialectal:

Muller d'arriba con home d'abaixo,
casa arriba.
Muller d'abaixo con home d'arriba,
casa abaixo.

Destaca de la zona pirenaica, a este respecto, que posee un fondo vascónico anterior al «latín y castellano o catalán» (1.43) y que sus peculiaridades culturales no fueron contaminadas por árabes ni judíos, por lo que los rasgos dialectales son anteriores a ellos y a veces incluso a las formas latinas y helénicas (2.153), del mismo modo que existen expresiones latinas y helénicas cultas indigenizadas y con deformaciones célticas (2.156). Señala además que «a medida que subimos hacia las montañas [las palabras] se hacen más peculiares y raras» (2.156). Sin embargo, no llega a separar nítidamente las variedades que constituyen herencia medieval y las que derivan del proceso castellanizador de finales del siglo XV. Cierto es que se refiere a la «fabla ribagorzana» (1.12), sin atender a la complejidad lingüística de la zona, ${ }^{25}$ al habla sobrarbense ( Una albada te faré, / no sé si será bien feita, / mañana te la pondré / por o forato da puerta», 1.164) y a la «lengua de Boltaña» (1.48), ${ }^{26}$ que podríamos considerar dentro de las modalidades autóctonas - esta última en el adecuado contexto cronológico--; cierto es también que en una ocasión se refiere a palabras que "no entenderían sino los campesinos de algunas comarcas que las usan cada día». Pero en el momento de enumerar específicamente las variedades lingüísticas de Aragón considera con el mismo rasero - ya se ha aludido a ello - la «fabla de Sobrarbe y Ribagorza (y de Cinco Villas y el Ancho y Bajo Aragón)» (1.94). En otra ocasión comenta: «Porque la atmósfera cultural, social y política de Aragón se podría emparejar y definir con la de Suiza, por cantones o comarcas. Aunque suena un poco extravagante lo pienso y lo digo en serio. Monzón, Alcañiz, Jaca, nos sugieren formas de cultura propias y diferentes. Como Barbastro, Calatayud, Sariñena, etc.» (2.156). Nótese la escasa atención que se presta, en este enunciado, a las culturas pirenaicas, precisamente las que aportan al conjunto aragonés — con la franja orientallos hechos lingüísticos más diferenciadores.

\footnotetext{
25 Para una visión completa y clara de esta cuestión, vid. M. L. ARNAL PURROY, "Hablas bajorribagorzanas», III Curso sobre Lengua y Literatura en Aragón (siglos XVIII-XX), Zaragoza, Institución Fernando el Católico, 1994, pp. 287-310, especialmente pp. 287-291.

26 El pretexto a través del cual nuestro autor alude a esta variedad pirenaica se encuentra en Parsifal, la ópera en que se desarrolla la leyenda del Santo Grial: «Pero sin duda la hermosa Kundry debía andar por la garganta de Port de l'Enfer hablando la lengua de Boltaña o de Languedoc y no la de Baviera» (1.48); vid. al respecto n. 14.
} 
Rasgos fonéticos

5. En el plano propiamente descriptivo, el interés de Ramón J. Sender se orienta sobre todo hacia el léxico, de modo que las peculiaridades fónicas y morfosintácticas ocupan en sus reflexiones un lugar muy secundario. Hay, sin embargo, algunos datos en relación con estos últimos aspectos que comentaré brevemente.

En lo que concierne al subsistema fonético-fonológico, interesa destacar que no pasa desapercibida para nuestro autor la tendencia, de raigambre rural, a eliminar la acentuación esdrújula por traslado del acento hacia la posición llana de las palabras. A propósito de una anécdota, ya mencionada (vid. $\S 1, n .3$ ), reproduce Ramón J. Sender las palabras de una mujer de Tauste: « ¿Señor... señor... relampago!»; y añade la siguiente observación: «sin el acento esdrújulo, que parecen odiar los campesinos aragoneses» (1.93). ${ }^{27}$ Tal afirmación conlleva una excesiva generalización, pues la tendencia no alcanza a toda la región de igual modo: en bastantes puntos pirenaicos, en el suroeste de Zaragoza y en la parte meridional de Teruel se advierte en nuestros días la solución esdrújula o, al menos, alternancia de variantes. ${ }^{28}$ Menos acierta Sender en la explicación de ciertos procesos evolutivos genuinos al asignar a Osca - aparte de un origen osco y no vascón-29 una diptongación "aragonesa» $(o=u e)$ que, en este caso concreto, coincide con el resultado castellano. ${ }^{30}$

$\mathrm{Y}$, sin duda, la limitación de sus conocimientos sobre este tema resulta muy evidente en el uso inapropiado del tecnicismo fonema. Unas veces se aplica a diferenciaciones gráficas que no conllevan distinciones articulatorias: «Por cierto que también el fonema badina ${ }^{31}$ —on $b$ - creo que debía ser vadina y no es cualquier balsa o charca en los caminos -como dice Borao-, sino precisamente las pequeñas lagunas que quedan separadas

${ }^{27}$ En «La narración televisada», hace un comentario semejante: «No decían pródigo, sino prodigo, con el acento en la $i$, como siempre» (1.146).

$28 \mathrm{Vid}$. al respecto J. M. ENGUTA, «Modalidades lingüísticas del interior de Aragón», Actas del I Congreso de Lingüistas Aragoneses, Zaragoza, Diputación General de Aragón, 1991, pp. 103151; lo citado, pp. 109-110; los datos proceden del Atlas Linguiústico y Etnográfico de Aragón, Navarra y Rioja (ALEANR), realizado por M. AlVAR, A. LLORENTE, T. BLESA y E. Alvar, 12 vols., Madrid (Departamento de Geografía Lingüística del CSIC) - Zaragoza (Institución Femando el Católico), 1979-1983.

29 «Hoy - señala G. ROHLFs- es posible saber con mayor seguridad que hace treinta años que Osca no tiene nada que ver con los oscos, porque ya los iberos llamaron a esta ciudad Olscan (Bolscan)»; vid. "¿Latinidad osca en España?» [1955], AFA, XL (1988), pp. 61-66; lo citado, p. $65 ; \mathrm{G}$. Rohlfs coincide en esta apreciación con $\mathrm{A}$. Tovar.

${ }^{30}$ Existen, sin embargo, variantes regionales como $[u o, u a]$, bien documentadas en los textos septentrionales correspondientes a la Edad Media e incluso en las hablas pirenaicas contemporáneas; vid. J. M. ENGUITA y V. LAGüÉNS, «El dialecto aragonés a través de algunos documentos notariales del siglo XIII: una posible interpretación de variantes», Al Profesor Emérito Antonio Ubieto Arteta en homenaje académico. Aragón en la Edad Media, VIII, Zaragoza, Departamento de Historia Medieval - Facultad de Filosofía y Letras, 1989, pp. 383-398.

31 Según el DCECH, badina procede del ár. bâtin 'paraje de tierra baja donde se estanca el agua'. 
del río, en la glera, después de las crecidas de la primavera, y que se pueden vadear a pie» (1.93). ${ }^{32}$ En otras ocasiones fonema es equivalente de voz o sufijo: «Todo en Aragón y en la misma Zaragoza está lleno de ecos mudéjares que además han extendido sus fonemas por toda España» (2.46), texto que se ilustra con términos como alberca, albergue, almadía, etc.; «Digo languedoceño, extraña palabra. También las tenemos en España para calificar a los productos (humanos o culturales) de las comarcas y las ciudades. Y son todavía más extraños. Cuando se trata de fonemas nacidos en el clásico latín, menos mal» (2.141), enunciado al que sigue una enumeración de términos gentilicios (jacetanos, caspolinos, etc.), a partir de los cuales se quiere hacer hincapié en la supuesta rareza de algunos sufijos aragoneses.

\section{Rasgos morfosintácticos}

6. Encontramos, en este campo de análisis, una breve referencia a la forma analógica del pretérito indefinido s'alantón 'se adelantaron', localizada en Aínsa (2.156), que es corroborada por otras que cita Borao en su Diccionario (tuvón 'tuvieron', vinón 'vinieron'), ${ }^{34} \mathrm{y}$, sobre todo, comentarios sobre la formación de palabras.

Ramón J. Sender muestra especial interés por el diminutivo -ico; aunque la reflexión se inicia tras una conversación con amigos del escritor procedentes del Oriente europeo, probablemente sefardíes, que hacen uso del morfema, es también Jerónimo Borao ${ }^{35}$ quien le abre el camino en sus consideraciones sobre este apreciativo, al que dedica un capítulo completo (1.55-58). Las referencias literarias que de él se aportan son, todas ellas, castellanas y en buena parte remiten a los siglos áureos. No obstante, de la permanencia del sufijo -ico en Aragón - por tanto, con carácter arcaizante-

\footnotetext{
32 Tampoco resulta clara la distinción entre sonido y grafia, a tenor de este ejemplo: «En Aragón dirían Onsa de la Riba o de la Ripa. Onsa, con una sola ese, pero una ene [frente a Ossa de la Vega en Cuenca]. Los franceses de Languedoc se acercan un poco a nuestra pronunciación y dicen Osau. En esos niveles fonéticos nosotros decimos mueso, imitando el morceau de los galos. Aunque el mueso resulta un poco más ahincador que el morceau. Y hacemos del diptongo final (au) una o" (2.12). El texto no requiere comentarios más amplios; sí cabe aducir otro fragmento, con cambio gráfico del significante incorrecto Osau por Ossau, que contradice la oposición señalada por Sender entre Ossa y Onsa (ss / s), de todos modos sin validez en la pronunciación real: «Desde cualquier cresta orográfica de las que nos esperan entre Collarada (Jaca) y Benasque se puede ver al otro lado de la frontera el famoso Pic du Midi d'Ossau. En francés moderno el oso se llama ours, pero en el mediodía languedoceño se llama ossau, más parecido al español» (2.141).

33 Vid. asimismo 1.92: «Desde mi casa [en San Diego] oigo de noche y a veces de día voces que entre los animales deber ser tan raras como algunos fonemas aragoneses entre los españoles»; 2.84-85: «fonemas sustantivos».

34 En el ALEANR todavía se anotó esta variante en Yebra de Basa, Fanlo y Laguarta; vid. T. BUESA y R. M. CASTAÑER, «El pretérito perfecto simple en las hablas pirenaicas de Aragón y Navarra", AFA, L (1994), pp. 65-132; lo citado, pp. 78-79.

35 Vid. Diccionario, pp. 91-97.
} 
da cumplida cuenta nuestro escritor a partir de su experiencia personal: «En las aldeas, cuando éramos chicos y llegaba algún muchacho de la ciudad -de Madrid, por ejemplo- haciendo los diminutivos en -ito los zagalicos indígenas lo apedreaban, como disidente snob y pijaito. ${ }^{36}$ Esta última palabreja era equivalente en nuestros valores ribereños al snob de ahora» (1.57). Y añade seguidamente: "Hay un contrasentido curioso en el hecho de que el aragonés que tiene fama de tosco y poco amigo de zalemas sea el que ha conservado y hecho suyo con caracteres regionales distintivos ese diminutivo que lleva una cierta ternura implícita. Un ave es un pájaro extraño y no familiar. Tal vez un ave de presa, carnicera y pugnaz. Una avecica sólo puede ser una tórtola amorosa o un mensajero del cielo. [...] En el -ico hay buena fe y disposición al amor» (1.58). Valora además Sender otros detalles, como la diferente proyección semántica de los apreciativos -illo e -ito o el empleo en el lenguaje infantil y en otras esferas de la vida (ladrón-ladroncico, diablo-diablico) del sufijo -ico, para el que entrevé relaciones con elementos lingüísticos análogos de los países balcánicos y de la Rusia occidental. Tales comentarios entrañan, ciertamente, una fina percepción de los matices expresivos del sufijo -ico; pero, frente a lo que podría inferirse de esos textos, el uso de este morfema no es ni mucho menos general en el territorio aragonés. El mismo Sender distingue en $\mathrm{La}$ onza de oro diversos apreciativos propios de Chalamera, el lugar donde parece localizarse la acción de este relato: -ico, -er, -eta; ${ }^{37}$ el ALEANR viene a confirmar la vitalidad de estas variantes, puesto que a través de sus mapas puede delimitarse con claridad la difusión de -ico y $-e(t)(e)$, salvo en una zona de entrecruzamiento -en la que también concurre la variante -er-, que comprende el sur de la provincia de Huesca y llega incluso a algunos puntos orientales de Zaragoza y Teruel. ${ }^{38}$

Ramón J. Sender atiende asimismo a la formación de los gentilicios aragoneses y lo hace desde una perspectiva impresionista en exceso, aunque en este punto concreto las explicaciones llevan implícito un no disimulado tono festivo: «Llamar jacetanos a los de Jaca, oscenses a los de Huesca e incluso bilbilitanos a los de Calatayud tiene su razón lógica», ya que en la interpretación del escritor estos nombres se han formado de una manera acorde con el modelo latino;, 39 señala a continuación: «Pero chesos a los de Hecho, alcoberreños a los de Alcubierre, caspolinos a los de Caspe, fonticonenses a los de Fonz, lanajinos a los de Lanaja y sobre todo montisonenses a los de Monzón ya pasa de castaño oscuro. Es verdad que no llegan tan lejos como en algunos lugares de Castilla. En [E]l Escorial se llama a sus nativos gurriatos. La palabreja es inocente pensando que quiere decir

\footnotetext{
36 La anécdota también es recogida por Ramón J. SENDER en La onza de oro, cit., p. 181.

37 Vid. p. 181 de la ed. cit.

38 Vid. ALEANR, mapa 1.576, y J. M. ENGUTTA, «Notas sobre los diminutivos en el espacio geográfico aragonés», AFA, XXXIV-XXXV (1984), pp. 229-250.

39 «Fonemas nacidos en el clásico latín» en expresión del autor; vid. $§ 5$.
} 
'gorriones', pero así y todo...» (2.141). La dificultad de establecer la etimología de algunos de los gentilicios enumerados es evidente (cheso), pero en otros casos las apreciaciones de Ramón J. Sender son claramente inadecuadas, ya que lo que se constata es el empleo regular de determinados sufijos (alcoberreños como madrileños, malagueños; lanajinos como santanderinos, palentinos) o de derivados establecidos sobre la base primitiva del correspondiente topónimo (por ejemplo, montisonenses < Montisone) ${ }^{40}$ y en lo que concierne a gurriatos, parece más bien un sustituto del gentilicio previsible, del mismo tipo que los que se dan en la región aragonesa: así, el mapa 6 del ALEANR proporciona, entre otros, pelaires (Biel), zarumaus (Ardisa), cucullos (Tronchón), traperos (Alfambra), rinconeros (Lasieso) o morcilleros (La Puebla de Castro). La extrañeza de Sender ante estas designaciones es, por tanto, injustificada.

\section{Rasgos léxicos}

7. Una notable preocupación merecen a nuestro escritor las peculiaridades léxicas aragonesas, tema al que están dedicados tres títulos de los recogidos en los ensayos que analizo: «Varias palabras y una infanta» (1.27-31), «Palabras y áreas culturales» (1.91-95), que constituye más bien una reflexión sobre el Diccionario de Borao, y «Palabras y costumbres» (2.153-156).

Ramón J. Sender observa que en Aragón se encuentran centenares de palabras no registradas en las obras lexicográficas, o incorporadas, pero mal interpretadas; ${ }^{41}$ como se ha visto en $\S 3$, no considera tales hechos negativamente cuando se trata del Diccionario académico, pero le resultan menos positivos desde la perspectiva de los trabajos lexicográficos regionales, representados por el Diccionario de Borao, sin duda la obra más cita$\mathrm{da}^{42}$ en el conjunto de artículos recopilados.

De esos centenares de vocablos ignorados o mal definidos en los vocabularios aragoneses enumera en "Varias palabras y una infanta» (1.29) los siguientes: ${ }^{43}$ caballón, cuya grafía corrige por cavallón ${ }^{44}$ 'tierra acumulada en filas paralelas de una altura aproximada de cuarenta centímetros, don-

\footnotetext{
40 Así consta en la documentación medieval, y también hace referencia a esta forma, con la variante Montisonus, P. MADOz, Diccionario Geográfico Estadístico Histórico. Huesca, ed. facsimilar llevada a cabo por la Diputación General de Aragón (Valladolid, Ámbito Ed., 1986) de la de Madrid, 1845-1850.

41 Afirma que él mismo posee un rico acervo léxico regional: «Podría citar ahora de memoria muchos centenares [de aragonesismos] más e incluso componer con esas palabras narraciones o poemas $[\ldots]$ ) (2.156).

42 Concretamente la edición de 1908, que incluye los apéndices de Benito Colt, por un lado, y de Luis V. López Puyoles y José Valenzuela la Rosa, por otro; vid. 1.91.

43 En paréntesis consta la información correspondiente -escasa- que aporta el Diccionario de Borao.

44 El DCECH recoge, s. v. caballo, el sufijado caballón, que define como 'lomo entre surco y sur$\mathrm{Co}^{\prime}$, mientras que no registra ningún derivado semejante a partir de cavar.
} 
de se plantan frutos como tomates y patatas $\mathrm{u}$ otros menos ultramarinos como ajos y cebollas' (Borao: caballón 'lomo de tierra que divide las eras de los huertos'), melico 'ombligo', bembolón 'abejorro', misache 'persona cómicamente disforme' (Borao: mesache 'muchacho, mozo'; vid. n. 22), batán 'paliza', borde 'bastardo', abocinar 'obligar por la fuerza al contrario en una riña o juego a bajar la cabeza y la parte superior del cuerpo', enfornar [escrito enformar] 'meter la masa de pan en el horno', falceñas 'vencejos' (Borao: falcino íd.), omprio 'lugar de pastos comunales', falce 'hoz' (Borao: falce 'cierto árbol infructífero'), ferrincallo 'chatarra', meno 'ternero', entimar 'multar' (Borao: intima 'acto de apenar'), etc. Y en repetidas ocasiones, a partir de su experiencia personal, matiza acepciones y añade términos al Diccionario de Borao: "tampoco está la palabra [mallos 'montaña rocosa en forma de gigantesco obelisco'] en Borao ni en el Larousse español» (1.94); «A propósito: la palabra forato ['agujero'] no está en el vocabulario de Jerónimo Borao" (1.164); y, del mismo modo, emporio 'ciudad', palabra que relaciona con los pastores de Boltaña, mairal 'mayoral', mairalesa 'mujer del mayoral', 'título honorífico que equivale a reina de las fiestas o similar', osillo 'parte de la estructura de una carreta que corresponde al centro mismo de la rueda donde va encajado el eje, que en tiempos remotos quizás era un hueso de animal', revulcazo 'revolcón', richoler 'juego infantil', sinsubstancia 'persona insustancial o frivola' (1.93-94); «Una palabra [...] que debo rectificar en el Diccionario de Borao es andalocio», para la que propone el sentido de 'relámpago' en lugar de 'lluvia de corta duración' (1.93; vid. $\S 1$, n. 3); «Por cierto que [...] badina [...] creo que debía ser vadina», y no con el sentido de 'cualquier balsa o charca en los caminos' sino con la acepción de 'pequeña laguna separada del río, después de las crecidas de primavera' (1.93; vid. § 5). Pero tales correcciones no son obstáculo para que Sender muestre el gran aprecio que siente hacia la obra del lexicógrafo aragonés: "Algunas [voces] no las encuentro y otras están, aunque, en mi entender, exigen aclaración y hasta rectificación. Nada de eso merma el considerable valor de la obra del glorioso don Jerónimo». Y apostilla: "Rectificar a Borao debe parecer impertinencia, pero él mismo lo agradecería, porque el verdadero erudito, el sabio historiador y el investigador concienzudo agradecen siempre cualquier clase de colaboración» (1.92).

Las enumeraciones se repiten cuando el escritor advierte de la antigüedad de las formas dialectales pirenaicas (branquil 'piedra básica del umbral', dula 'rebaño colectivo', abrío 'caballería mayor', aladro 'arado', aguaitar 'mirar sin ser advertido', enzurizar 'provocar', zolle 'pocilga', sargantana 'lagartija', 2.153), así como de su mayor «rareza» (lamin 'golosina', trompichón 'perinola', amerar 'mezclar para atenuar los sabores o los efectos', serena 'cantera de piedra', triar 'elegir', esbafar 'evaporar', chandra 'ramera', 'mujer descuidada en las apariencias', estral, destral o destraleta 'azuela', 2.156). El recuento sirve también a Ramón J. Sender para resaltar el «uso corriente en el campo» de estas formas léxicas: encendallo 'brizna de rama para encender el fuego', falceña 'vencejo', bolisa 'pavesa', escarrón 
'arce', morro 'loma, galayo, cerro', zapo 'sapo', balsa 'hueco de terreno que se llena de agua, natural o artificialmente', abarca 'calzado de cuero crudo', rujiada 'rociada', socarrón (y secarrón) 'quemadura' (2.138). En estos últimos casos las coincidencias con Borao, dada la finalidad de estas enumeraciones, son mayoritarias, de manera que sólo faltan en su Diccionario los términos branquil, zolle, serena, encendallo, escarrón, bolisa, balsa, abarca y socarrón (secarrón), y únicamente se produce una discrepancia semántica (triar 'formar carril o tría') y otra formal (la ya citada variante falcino en lugar de falceña).

Las matizaciones de Ramón J. Sender respecto del vocabulario regional, basadas en su propia experiencia, son generalmente adecuadas en relación con las fuentes de comparación que utiliza; pero contienen erradas interpretaciones etimológicas ${ }^{45} \mathrm{y}$, sobre todo, adolecen de los defectos que la lexicografía dialectal arrastra desde sus comienzos y que, de manera particular, derivan de un hecho muy concreto: la imprecisa delimitación del concepto de dialectalismo léxico (o provincialismo o regionalismo o, si nos atenemos a nuestra área geográfica, aragonesismo), ${ }^{46}$ lo que hace que se traten de modo parigual materiales a veces bastante heterogéneos. Si prestamos atención a las discrepancias entre nuestro autor y el Diccionario de Borao, observaremos en seguida que palabras como caballón, abocinar, husi$l l o$ (por osillo), sinsustancia, balsa, abarca, socarrón aparecen en la última edición del Diccionario académico sin localización regional, igual que borde y falce, términos que, de todos modos, por razones fonéticas o documentales, pueden adscribirse con cierta seguridad al territorio aragonés; y en lo que concierne a las coincidencias entre ambos autores, también se observa que dula, aguaitar, enzurizar, estral y morro constan en la obra de la Academia sin nota de aragonesismo, así como bolisa y aladro, aunque la difusión de los dos últimos significantes se restringe en ésta, vagamente, a «algunas partes». ¿En qué medida pueden ser definidas, por consiguiente, estas voces como aragonesismos?

\section{OBSERVACIONES ETIMOLÓGICAS}

8. Una faceta por la que Ramón J. Sender siente indudable afición es la de descubrir la etimología de las palabras y su valor primigenio. Los comentarios, en este sentido, son frecuentes en las dos entregas del Solanar.

El escritor de Chalamera se refiere al origen de nombres comunes y de términos onomásticos; entre los primeros cabe citar almirante (2.135; del árabe alemir), anillo (2.106; diminutivo de ano), baturro (2.154; de una raíz

45 Ya se han realizado algunos comentarios al respecto, aunque esta cuestión será tratada de modo más pormenorizado en $\S 8$.

46 Vid. H. López MORAles, Augusto Malaret, diccionarista, San Juan de Puerto Rico, Academia de Artes y Ciencias de Puerto Rico, 1983, p. 25. 
bato, "que en griego quiere decir [...] 'tartamudo'»), berberisco (2.37; de beriber, es decir, 'los de Iberia'; ber-iber, según indica en 2.103, significa 'hijo del Ebro'), ${ }^{47}$ borde (2.34; "misteriosa palabra anterior al latín y al griego"), calavera $(1.72,1.74$; 'frecuentador de los cementerios, por amor', según la costumbre árabe de reunirse las mujeres con sus amigas en los cementerios, de modo que los galanes aprovechaban para acudir y hacerles la corte), cáliz (1.46; de cráter), cavallón (1.29; de cavar y no de caballo, es decir, debe escribirse con $v$ ), jende! (1.28; exclamación de sorpresa, «que creo que tiene una alcurnia altísima en la historia helénica»), ibón (1.65-66, 2.156; de Epona, divinidad griega; sugiere además que los ibones, según la tradición helénica, habrían sido abiertos en la roca por una coz de Pegaso), judía (2.160-161; de judío, porque las judías conservaban el calor mejor que ninguna otra gramínea, por lo que «las cocían los judíos el viernes y podían comer caliente el sábado sin necesidad de encender fuego [que les está prohibido ese día]»), macadamizar (1.29; de Mc Adams, escocés que inventó una mezcla de asfalto, grava y cemento para la construcción de carreteras), mallo (2.94-95; de Malleum Maleficarum, «que quiere decir 'el martillo del diablo', o mejor, 'contra el diablo', y que daba avisos, instrucciones, exhortos, letanías lauretanas, jaculatorias y conjuros para sacar los demonios del cuerpo. [...]»), mengue (2.130; gitanismo que significa 'demonio'), ojalá (1.31; de Oh, Alá), pardina (1.28; «Por cierto que a esta palabra que Menéndez Pidal cita en su famosa Gramática histórica, tan justamente celebrada, le da el gran historiógrafo y filólogo una etimología dudosa. Dice que viene del latín parietinæ. Sin pretender enmendarle la plana [...], yo diría más bien que pardinas viene de pardo, y esta expresión, de barro, que los campesinos de mi comarca llaman bardo. De bardo a pardo y a pardinas la solución se nos ofrece ella sola, ya que esas pardinas suelen ser, en la mayor parte de los casos, de muros de adobe erosionados por la lluvia y el viento"), perra (1.177; según relato del Samarugo, "tonto titular" de una localidad oscense, las monedas más bajas - de cinco y diez céntimos- tenían un león marcado en un lado, pero un antepasado suyo comenzó a decir que aquel león era un perro, es decir, una perra, porque esas monedas paren otras más pequeñas — «así como los centimicos»-, de donde derivan los sintagmas perra chica y perra gorda. Tras conceder a la interpretación un carácter humorístico, Sender apostilla: «[...] aquello de convertir el león en una perra debió suceder a principios del siglo pasado, cuando Fernando VII y el aguador Chamorro gobernaban mientras se perdía el imperio en América»), seguir en sus trece (1.92-93; de las trece proposiciones que Maimónides enuncia en su Guía de perplejos: «Los rollos judiciales de la Inquisición estaban llenos de sigue en sus trece para decir que el reo

\footnotetext{
47 Señala además: «[...]. Eran aquellos vascos especialmente ibéricos. Eso creía mi amigo y compatriota Julio Cejador y Frauca, quien los asociaba con los berberiscos (ber-iber) porque eran muy oscuros de piel y tenían la misma manera de formar sus fonemas sustantivos, por asociación acumulativa" (2.84-85).
} 
no renegaba de sus creencias»), trovador (2.60; del mozárabe torob o trob 'canción', y no del provenzal), Undivé (2.130; gitanismo para referirse a 'Dios'), vadina (1.93; con $v$, porque se relaciona con vadear).

Entre las designaciones onomásticas encontramos Alcolea $(1.168,2.15$; del árabe: 'pequeño castillo'), La Almunia de Doña Godina $(1.72,1.89,2.135$; mezcla de árabes y visigodos: almunia procede del árabe munia 'granja o casa de campo', sustantivo al que se ha soldado el artículo al- de ese mismo origen), Chalamera (1.17, 2.15; del árabe shala 'miel', mozárabe salamera 'colmenar'), Gratal (1.46; de cratal, que Sender parece relacionar con cráter), Guatizalema (1.31, 1.72; del árabe: 'río de la salutación sagrada'), Macarena (2.161; del árabe makrina 'matadero de reses'), Odina (1.89; de Odín, dios de la mitología escandinava), Pirineos (1.66; del griego), Ramón (2.105; del egipcio Ra 'sol' y mon o amon 'ritual de la urbe sagrada'), Sefarad (grafiado Sefarard] (2.158; del hebreo: 'España'), Sender (1.17, 2.34-35; de la dinastía musulmana de Sender, que extendía sus dominios por toda la costa malabar de la India, donde según la tradición culta estuvo situado el paraíso terrenal), Sos del Rey Católico (1.72; 'secretos', en hebreo, del Rey Católico), El Toboso (2.166; nombre hebreo que significa 'bondad secreta'), Toledo (2.158; nombre hebreo que quiere decir 'base fundacional').

Es asimismo notoria la preocupación de Sender por llegar al primero - y más profundo - significado de las palabras, sobre todo cuando éstas son de carácter culto: Baltasar [baaltasar] (2.118; 'rey de reyes'), castrense (1.92; 'guerrero'), colonial (1.192; 'labrador'), currinches (2.163; 'escritorzuelos'), fable (2.86; 'expresable'), idiota (2.118; 'identificado'), inefable (2.86; 'inexpresable'), liberal (2.64; 'generoso'), licantropía (1.186; 'condición de hombre-lobo'), marranen (2.159; 'sefardíes católicos conversos'), metecos (2.85; 'bárbaros extranjeros'), persona (2.63, 2.137; 'máscara'), pontifice (2.105; 'fabricante de puentes'), pornográfico (1.150; 'prostitución'), Soldevilla (2.105; 'sol sobre la urbe'), Supervía (2.105; 'caminos elevados'). ${ }^{48}$

9. En todos estos comentarios hay, indudablemente, aciertos; pero otras veces las reflexiones de Ramón J. Sender son resultado - como se ha visto en lo relativo a distintas cuestiones ya examinadas- de su intuición personal y, por lo tanto, carecen de rigor científico. ${ }^{49}$ Sirvan como demostración algunos ejemplos: así, cáliz y cráter no tienen parentesco entre sí, pues ambos términos derivan de étimos independientes (CALICE y CRATERE respectivamente) $;{ }^{50}$ tampoco para ibón, palabra aragonesa y occitana, reco-

\footnotetext{
48 Por otros motivos - facilitar la comprensión de los aragonesismos léxicos al lector no familiarizado con ellos - nuestro escritor ofrece frecuentemente la definición de las voces de raigambre regional: bresca (1.67; 'miel'), boira (1.67; 'niebla'), caliwo (1.68; 'rescoldo y cenizas'), falceñas (1.69; 'vencejos'), laminerias (1.71; 'confites, postres dulces'), etc.

49 Nuestro autor confiesa sin ninguna ambigüedad el valor impresionista de sus consideraciones, a propósito del árabe y del hebreo: «Me he referido [...] a las influencias árabes y judías en nuestro Aragón y vale la pena insistir, aunque sin pretensiones, y más con carácter literario que histórico. Dejemos este aspecto, tan rico en matices, a los especialistas» (2.153).

50 Vid. el DCECH, s. vi.
} 
nocen los especialistas una ascendencia griega, sino un origen prerromano que se pone en relación con el vasco ibai 'río'; ;1 en cuanto a pardina, cabe señalar que resulta sumamente difícil la evolución $b>p$ que propone Sender para explicar su origen desde barro; aunque dudosa, la etimología PARIETINAE 'paredes ruinosas, ruinas ${ }^{\prime 52}$ parece más razonable y es seguida, entre otros, por Corominas. ${ }^{53}$

\section{CONSIDERACIONES FINALES}

10. Del análisis precedente se infiere que Ramón J. Sender da muestras de mesura y sentido común al reflexionar sobre aspectos generales relativos al dominio lingüîstico aragonés (variación diatópica, diversificación cultural de las comarcas que conforman la región, escala de valores en la que han de considerarse las peculiaridades idiomáticas para definir el ser de los aragoneses); desde el punto de vista descriptivo, los datos resultan, con frecuencia, impresionistas $y$, consecuentemente, desprovistos de rigor filológico. Pero estas limitaciones no deben ser objeto de reproche: en primer lugar, porque Ramón J. Sender no se presenta ante los ojos del lector como filólogo, sino como aragonés preocupado por la cultura de su tierra («No se trata [...] de profundizar en estas cosas sobre las cuales no estoy bastante enterado», 1.28; «[...] Sin pretender enmendarle la plana [a R. Menéndez Pidal], ya que no soy un especialista en esas materias, y sin otro bagaje que el de un aragonés que cree conocer nuestro idioma regional", 1.28); en segundo lugar, porque la colección de artículos que he analizado -destinados a un medio de comunicación regional, lo que ha de tenerse en cuenta- constituye una evocación de Aragón y de la personalidad de sus gentes a partir de la interpretación de acontecimientos históricos y de la reflexión sobre hechos culturales definidores, en el conjunto de los cuales los peculiarismos idiomáticos representan sólo una de las parcelas diferenciales; en tercer lugar, porque los datos sobre las particularidades lingüísticas de Aragón se nutren de intuiciones personales y de recuerdos,

\footnotetext{
51 Vid. el DCECH, s. $v$.

52 Ramón J. Sender la atribuye a R. MENÉNDEZ PIDAI, Manual de gramática histórica de la lengua española, pero no he podido descubrirla en la $16^{\mathrm{a}}$ edición de este libro, realizada en Madrid, Espasa-Calpe, 1980.

53 En el DCECH se aducen otros datos favorables a dicha forma latina; añadamos todavía que, aunque el maestro de la filología española recoge en los Origenes del español. Estado lingüístico de la Península Ibérica hasta el siglo XI (Madrid, Espasa-Calpe, $9^{a}$ ed., 1980, p. 323) algunos registros de bardina extraídos de un documento del año 1024 perteneciente al monasterio de San Victorián (término de Aínsa), de acuerdo con la información que facilitan los lexicógrafos aragoneses en la actualidad no se conoce ninguna variante con $b$-inicial, salvo un excepcional testimonio anotado por G. RoHi.fS en su Diccionario. Antes de concluir conviene recordar que se han aportado otras explicaciones etimológicas: así, M. ALVAR (El dialecto aragonés, Madrid, Gredos, 1953, p. 274) piensa que podría relacionarse con PRATU.
} 
lejanos en el tiempo y recreados también desde la lejanía geográfica, lo que provoca a veces imprecisiones e inexactitudes. No es infrecuente que el propio escritor se refiera a los recuerdos como fuente de sus reflexiones: en el capítulo IV del primer Solanar («Varias palabras y una infanta», 27-31) declara, en este sentido, su propósito de ligar las cuestiones dialectales «con algún recuerdo anecdótico de mi juventud» (1.28); en el capítulo II de ese mismo volumen («El corralico de Chalamera», 15-19) indica: «Puesto a recordar cosas de Aragón se me ocurren sólo las más lejanas, las de mi más temprana infancia» (1.15); y al comienzo del capítulo XVI («Palabras y áreas culturales», 91-95), Sender confiesa que aviva sus recuerdos de España, desde América, a través de lecturas de «algún viejo libro castellano o aragonés» y cita entre estos últimos - no podía ser de otro modo, dado que el léxico es el tema al que presta mayor atención- el Diccionario de Borao: «[...] recuerdo palabras aragonesas de mi infancia - añade- y voy viendo si figuran en este diccionario», para después, incluso, introducir algunas correcciones a los significados que éste propone. $Y$, salvo la esporádica mención de lingüistas como Menéndez Pidal, Alvar, Cejador y Frauca, Hubschmid o Rohlfs, el novelista desconoce los avances que se han producido en nuestros estudios filológicos en las últimas décadas, lo cual no oculta en ningún momento.

Así, pues, el hecho de que Ramón J. Sender haya querido acercarse en sus comentarios a los particularismos lingüísticos de la tierra en que nació, consciente de sus limitaciones y del carácter superficial de sus opiniones, ha de valorarse positivamente, pues muestra una clara voluntad del escritor por atender de modo global a los elementos que conforman la cultura de la región y el aprecio que éstos le merecen. ${ }^{54}$ Tal interpretación no resulta arriesgada, puesto que de manera muy explícita el escritor ha confesado en numerosas ocasiones su apego a la «entrañable patria aragonesa»:55 "He podido equivocarme alguna vez en niveles políticos o religiosos, como cada cual, o más que los demás, pero hay algo en lo que he seguido siempre igual y permanezco invariable: mi sentido de lo aragonés y mi amor por la tierra aragonesa» $(1.197)$.

\footnotetext{
54 Dicha voluntad está en consonancia con su proceder como creador literario: ni en El lugar de un hombre ni en La onza de oro, cuyas acciones se sitúan en espacios aragoneses, particularmente en el medio rural, Ramón J. Sender introduce los regionalismos con gran espontaneidad, como se deduce de su excesiva preocupación por definir su significado, ni tampoco quedan fielmente reflejados los fenómenos idiomáticos propios del habla popular. Pero a través de ese entomo geográfico, de ese contexto social y de su recreación lingüística (que corresponden a un cúmulo de experiencias del autor en la primera etapa de su vida y que emergen en su quehacer literario desde fuera de Aragón y también en la lejanía cronológica) puede ambientar en Aragón unas historias que no son necesariamente aragonesas y, asi, manifestar de manera bien patente sus raíces. Vid. «El aragonesismo lingüístico en Ramón J. Sender», art. cit., p. 209.

55 No separa ese apego del de sentirse español, según consta en el fragmento completo del que se ha extraído la cita precedente: «[...] y me quitaron más tarde —con una clara referencia al exilio- el del latir entrañable de la patria aragonesa y la otra, la española. Que solían ser armoniosos» (1.18-19).
} 


\title{
El Don Juan de Sender
}

\author{
Jean-Marie Lavaud \\ Université de Bourgogne
}

El Don Juan de Ramón J. Sender publicado en $1968^{1}$ se inscribe en la larga trayectoria de un mito que nace con El burlador de Sevilla y convidado de piedra, texto fundador, del ilustre monje mercedario Tirso de Molina, $\mathrm{y}$ se desarrolla luego en innumerables obras, tanto españolas como extranjeras, muchas de ellas teatrales, pero también narrativas, obras de poetas, sin olvidarnos de la ópera Don Giovanni, primera de otras muchas.

Esta breve comunicación no es sino una serie de reflexiones y una tentativa de mostrar cómo se construye el texto de Ramón J. Sender a partir de las indicaciones que dan los títulos, las dramatis personæ que encabezan la obra, y a partir de la lectura del texto de las Ediciones Destino que manejé para el presente trabajo. ${ }^{2}$

En una primera parte estudiaré cuáles son los personajes que desaparecen o aparecen con relación sobre todo a Don Juan Tenorio, que me sirve de punto de comparación. ${ }^{3}$ En una segunda parte, intentaré definir cómo la organización del texto le permite a Sender proponer su visión del mito de don Juan.

${ }^{1}$ Don Juan en la mancebia (Drama litúrgico en cuatro actos), México, Mexicanos Unidos, 1968, 128 pp.

2 Don Juan en la mancebia, Barcelona, Destino («Áncora y Delfín», 399), 1972, $2^{a}$ ed., con unas "Consideraciones sobre don Juan» de Ramón J. SENDER.

3 José Zorrilla, Don Juan Tenorio, Madrid, Cátedra («Letras Hispánicas», 114), 1984. 
Una primera aproximación se puede hacer comparando los títulos de las tres obras. Con El burlador de Sevilla y convidado de piedra, Tirso remitía a lo que, en palabras de Víctor Said Armesto, es La leyenda de don Juan. ${ }^{4}$ Zorrilla daba a su Don Juan Tenorio, gracias al subtítulo, Drama religioso-fantástico en dos partes, una perspectiva religiosa. El Don Juan en la mancebía, de Ramón J. Sender, Drama litúrgico en cuatro actos, tiene más ambición. ${ }^{5}$ Según el Diccionario de la Real Academia "drama litúrgico" es un «texto literario dialogado, de alguna extensión, desarrollado durante la Edad Media a partir del tropo, que dramatizaba pasajes de los Evangelios, y que se representaba durante los oficios religiosos en algunos días solemnes». Por otra parte, en la edición francesa de la Encyclopædia universalis, «drame liturgique» remite a «mystère» y también a «auto sacramental». El subtítulo de Sender nos propone, pues, considerar Don Juan en la mancebía como un auto sacramental. ¿Sería el título completo revelador de un eje de lectura alegórico de la ficción senderiana? Es una perspectiva que estudiaremos más adelante.

Comparando las dramatis personæ de Don Juan en la mancebía con las de Don Juan Tenorio, el texto más afín, sacamos ya algunas conclusiones. En la obra de Zorrilla buscamos en vano el mundo de la prostitución. Los personajes aparecen en el orden siguiente:

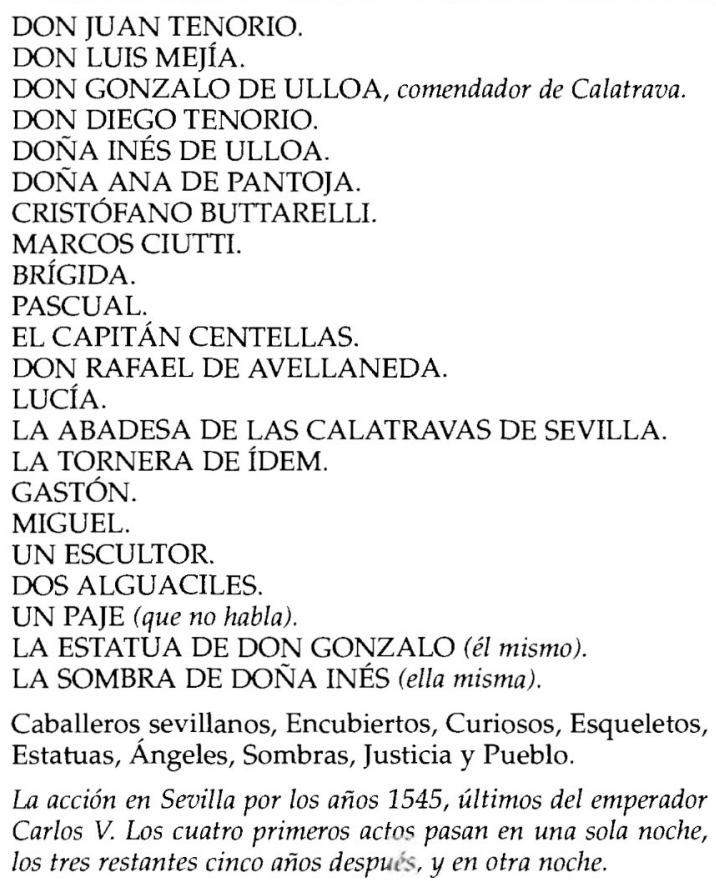

La acción en Sevilla por los años 1545, últimos del emperador Carlos V. Los cuatro primeros actos pasan en una sola noche, los tres restantes cinco años después, y en otra noche.

\footnotetext{
${ }^{4}$ La leyenda de don Juan, Buenos Aires, Espasa-Calpe Argentina («Austral», 562), 1946.

${ }^{5}$ Curiosamente, en las Ediciones Destino que he manejado y por las que cito ha desaparecido el subtítulo: Drama litúrgico en cuatro actos.
} 
El espacio creado por Zorrilla es el de la nobleza y del poder: los personajes, con la excepción del escultor, de los criados y de los guardias, pertenecen a lo que llamaremos, con Anne Ubersfeld, "La Cité» o "La Société", es decir, esta parte de la sociedad instalada en el poder. ${ }^{6}$ En Don Juan Tenorio Zorrilla adopta una perspectiva aristocrática -que se puede comparar en cierto modo con la de El burlador de Sevilla-muy diferente de la sociedad tal como aparece en los dramatis personæ de la obra de Ramón Sender. ${ }^{7}$

La desaparición de don Diego Tenorio, don Luis Mejía, doña Ana de Pantoja y de la abadesa de las Calatravas de Sevilla reduce el mundo aristocrático presente en la primera parte de El Tenorio de Zorrilla: asoman ahora un Mañara y dos caballeros, caballero I y caballero II.

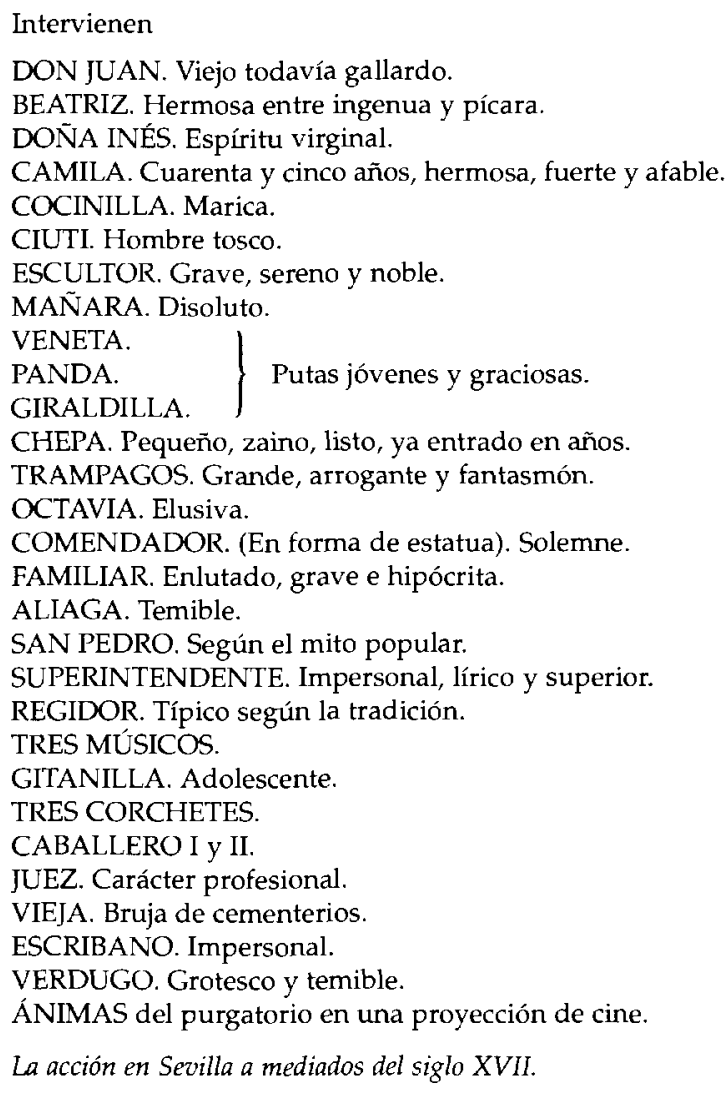

${ }^{6}$ Anne UbERSFeld, Lire le théâtre, París, Éd. Sociales, 1982 (ed. corregida y aumentada).

7 Para una comparación más detallada de la organización de los dos textos remito a mi trabajo "L'organisation fonctionnelle de Don Juan Tenorio", Cahiers d'Études Romanes [Université d'Aix en Provence], 11 (1986), pp. 49-74. 
Predomina el elemento femenino con el imprescindible personaje de doña Inés y ocho mujeres más, entre ellas tres prostitutas: son Camila, Veneta, Panda, Giraldilla, Octavia, la gitanilla, la vieja, sin olvidar a Beatriz, cuyo segundo rango en la lista dice el futuro protagonismo y provoca expectativa. Otro elemento de intriga para el lector, destinatario de los dramatis personæ, es la presencia de la Inquisición con el familiar, de la justicia con el juez, el escribano, el regidor y tres corchetes, sin hablar de un sorprendente superintendente de dudosa estirpe castellana. Desde luego se conservan los protagonistas esenciales del mito, don Juan, doña Inés y varias mujeres, la estatua.

Casi todos los protagonistas del drama están caracterizados brevemente por dos o tres palabras: así, Camila, "cuarenta y cinco años, hermosa, fuerte y afable»; Veneta, Panda y Giraldilla, "putas jóvenes y graciosas"... El nombre o apellido puede ser ya una perspectiva de lectura, como Chepa, Trampagos o Panda. Cuando han sido personajes de Don Juan Tenorio no siempre conservan los rasgos por los que los conocíamos: Ciutti es ahora un "hombre tosco», el escultor es "grave, sereno y noble» y el don Juan que está por salir a la escena es un «viejo todavía gallardo» cuando doña Inés es un "espíritu virginal». A veces un narrador parece inmiscuirse y juzgar a un personaje: así, con el familiar, «enlutado, grave e hipócrita». Con todo, estas dramatis personæe no aclaran nada, sino todo lo contrario: raras veces dan indicaciones, trazan la trayectoria de un personaje, y casi siempre intrigan, avisan al lector de que este don Juan que va a salir a la escena le ofrecerá unas aventuras nunca leídas. En vano buscamos en las dramatis personæ los personajes alegóricos de los autos sacramentales, una ausencia que pone en tela de juicio lo que anunciaba el subtítulo.

Determinar los diferentes espacios de Don Juan en la mancebía permite una segunda aproximación. El primer espacio que nos propone Sender es la mancebía, un espacio poblado por la mayor parte de los personajes presentes en las dramatis personæx. De modo esquemático, están físicamente presentes el personal de la mancebía y los parroquianos. Por una parte, la madre Camila y sus pupilas, Veneta, Panda, Giraldilla y Beatriz, y la servidumbre, Cocinilla, Chepa, Trampagos, Octavia, a los que podemos añadir los tres músicos. Por otra parte, don Juan y su criado Ciuti, Mañara, los caballeros I y II, el familiar y Aliaga, el inquisidor del que habla Camila. En este espacio interviene también la policía con el regidor y tres corchetes.

Este espacio es el espacio del burdel, pero también el de la aristocracia, de la justicia y del Santo Oficio: la corrupción por contaminación es obvia cuando, en el tribunal, Mañara está al lado del juez y el inquisidor sale con el familiar, los dos compañeros de Mañara en la casa de 
Camila. Beatriz sabe que está perdida cuando entran el juez, el escribano y Miguel de Mañara: «Si esto es cosa de Mañara perdida estoy [...]» (IV, p. 145).

El cementerio es el segundo espacio de Don Juan en la mancebia. Es un espacio dividido en dos subespacios, el primero a cargo de la vieja y donde se citan escandalosamente hombres y mujeres el día de las Ánimas, el segundo a cargo del escultor, creándose así una oposición lugar profano / lugar sagrado. Es un espacio de comunicación, comunicación con el más allá —doña Inés, la estatua, las voces plañideras-, comunicación entre Beatriz y don Juan, don Juan y el escultor. De los personajes que conocimos en el espacio de la mancebía no entra nadie más que Beatriz; aquí es donde se constituye la última pareja dramática, Beatriz - escultor.

El espacio del panteón es un espacio del mito y es el espacio en el que el lector empieza a ver las cosas desde otra perspectiva, la del más allá, con doña Inés: aquí es donde don Juan recobra su identidad ${ }^{8}$ y es el espacio definido como el infierno para el comendador: «Estáis en el infierno, en un infierno pequeño del que se sale» (I, p. 61).

El tercer espacio es un espacio situado en el más allá, una como antesala entre cielo y purgatorio, guardada por san Pedro y donde se organiza un tribunal - una parodia del juicio final- presidido por un superintendente delegado del Señor. Es espacio mítico también, en el que las víctimas de don Juan no le denuncian, en el que se salvan don Juan y doña Inés y se reconstituye la pareja don Juan - doña Inés, que consiguen el permiso de volver a la tierra. Así llegan a definirse tres espacios, siendo la tierra el espacio de la prostitución y el cementerio un espacio intermedio entre la tierra y el más allá del tercer espacio.

Queda el espacio del tribunal con los ministros de la justicia, el juez, el escribano, los corchetes, el verdugo y, luego, el inquisidor Aliaga con el familiar y con los culpados, el escultor y Beatriz. Noto que Mañara se sienta al lado del juez, mientras participan en la audiencia la madre Camila, sus pupilas y la servidumbre de la mancebía. En mi opinión, este espacio es más bien un subespacio de la mancebía: se trata sencillamente de un cambio de lugar. Por fin, la voz de la estatua, la voz de doña Inés, la aparición de doña Inés, la de don Juan y Beatriz después de muertos tienen tanto protagonismo como los demás personajes físicamente presentes de la ficción senderiana.

Estos espacios no son autónomos: la presencia de uno o de varios personajes en dos o tres de los espacios que acabo de caracterizar los relaciona y permite ver cómo se organiza el mito de don Juan en el drama de Sender. El cuadro que aparece a continuación permite la visión panorámica de la presencia o ausencia de un personaje en cada espacio.

${ }^{8}$ Es una identidad que se va reconstruyendo a lo largo del drama por boca de varios personajes que dan de don Juan un retrato diferente del tradicional. 
EL LUGAR DE SENDER

\begin{tabular}{|c|c|c|c|}
\hline \multicolumn{4}{|c|}{ LOS ESPACIOS DE DON JUAN EN LA MANCEBÍA ${ }^{9}$} \\
\hline Mancebia & Cementerio & Cielo/purgatorio & Tribunal \\
\hline DON JUAN & DON JUAN & DON JUAN a & DON JUAN a \\
\hline DOÑA INÉS a & DOÑA INÉS a & DOÑA INÉS a & DOÑA INÉS D \\
\hline CIUTI & CIUTI & & \\
\hline COMENDADOR o & COMENDADOR - & COMENDADOR a & \\
\hline DOÑA INES D & DONAA INÉS a & DOÑA INÉS a & DOÑA INÉS a \\
\hline CAMILA & & & CAMILA \\
\hline VENETA & & & VENETA \\
\hline PANDA & & & PANDA \\
\hline GIRALDILLA & & & GIRALDILLA \\
\hline BEATRIZ & BEATRIZ & & BEATRIZ, BEATRIZ ם \\
\hline DON JUAN & DON JUAN & DON JUAN a & DON JUAN \\
\hline COCINILLA & & & COCINILLA \\
\hline CHEPA & Chepa & & \\
\hline TRAMPAGOS & Trampagos & & TRAMPAGOS \\
\hline \multicolumn{4}{|l|}{ OCTAVIA } \\
\hline \multicolumn{4}{|l|}{ TRES MÚSICOS } \\
\hline & ESCULTOR & & ESCULTOR \\
\hline & BEATRIZ & & BEATRIZ, BEATRIZ \\
\hline & $V I E J A$ & & \\
\hline \multirow{6}{*}{$\begin{array}{l}\text { MAÑARA } \\
\text { ALIAGA } \\
\text { FAMILIAR } \\
\text { CABALLERO I y II }\end{array}$} & Mañara & & MAÑARA \\
\hline & & & ALIAGA \\
\hline & & & FAMILIAR \\
\hline & & & \\
\hline & & \multirow{2}{*}{\multicolumn{2}{|c|}{$\begin{array}{l}\text { SAN PEDRO } \\
\text { SUPERINTENDENTE }\end{array}$}} \\
\hline & & & \\
\hline \multirow{7}{*}{$\begin{array}{l}\text { REGIDOR } \\
\text { TRES CORCHETES }\end{array}$} & & & REGIDOR \\
\hline & & & TRES CORCHETES \\
\hline & & & JUEZ \\
\hline & & & ESCRIBANO \\
\hline & & & VERDUGO \\
\hline & & & GITANILLA \\
\hline & & & DOS GOLILLAS \\
\hline \multicolumn{2}{|c|}{ ÁNIMAS del purgatorio } & \multicolumn{2}{|c|}{ ÁNIMAS del purgatorio } \\
\hline
\end{tabular}

${ }^{9}$ Para una lectura más fácil aparecen las parejas dramáticas básicas: don Juan - doña Inés, don Juan - Beatriz, comendador - doña Inés. Los personajes relacionados con el espacio de la mancebía se escriben siempre en cursiva. Por fin, $\mathrm{a}$ señala la presencia de un protagonista muerto o su voz. 
En el espacio de la mancebía se forman varias parejas dramáticas: Panda - Trampagos, Panda - Mañara y, sobre todo, don Juan - Beatriz, Mañara - Beatriz, caballero I - Beatriz. Dos son básicas: estructuran el drama. Son las formadas por don Juan / alias don Carlos - Beatriz y Mañara Beatriz. Con la entrada de don Juan en el espacio se reconstituye alrededor de Beatriz el antagonismo mortal que hubo entre don Juan y Mañara padre. La oposición don Juan / Mañara hijo no es sino el desdoblamiento del personaje mítico de don Juan. ${ }^{10}$ En el drama de Sender, Mañara hijo es lo que fue don Juan, "disoluto»: así está caracterizado en las dramatis personæ mientras que don Juan es "viejo todavía gallardo". Tenemos pues la oposición entre un don Juan viejo y un don Juan joven. Es de notar que este don Juan / don Carlos es un extranjero, un personaje venido de fuera, con nombre y apellidos falsos: llega "disfrazado", lo que le permite al personaje asumir una doble función, formar la pareja don Carlos-Beatriz, al lado de la pareja don Juan - Beatriz, que parece sustituir a la pareja mítica don Juan - doña Inés. La aparición de Beatriz es un dato original en el tratamiento del mito de don Juan.

¿Quién es Beatriz? Beatriz es un personaje excepcional, el típico personaje dramático. Prostituta de oficio, es noble de nacimiento, ya que es hija de doña Inés y nieta del comendador. Es mujer de la calle y pura. Don Juan, que encuentra la situación «horriblemente pura» (II, p. 85), percibe su pureza, idea compartida por Mañara, quien, a propósito de Beatriz, sostiene que «sólo una prostituta es honrada» (II, p. 88), y tiene su justificación en el elogio de la prostitución por el escultor, que la juzga una costumbre que les permite a los hombres «elimina[r] los celos y también el falso sentido del honor que todo lo corroe» (III, p. 114). ${ }^{11}$ Esta perspectiva impone al lector de Don Juan en la mancebia una imprescindible inversión de los valores. Por eso Beatriz accede al espacio del cementerio, que es el espacio del escultor, el único personaje ajeno al espacio de la mancebía y por lo tanto totalmente puro. Cuando, para hacer feliz a su «hija», don Juan constituye la pareja escultor - Beatriz constituye la pareja ideal.

El drama de Sender adquiere nueva dimensión gracias también a un personaje del que no he hablado todavía y es Chepa, el administrador de la mancebía. Discípulo de Miguel de Molinos, declarado herético y muerto en una cárcel de Roma en 1696, Chepa se.identifica repitiendo cinco veces «en estado de quietud», lo que confiere a sus diálogos con don Juan una dimensión teológica. Dramáticamente, Chepa, jorobado, contrahecho, es la contraimagen de don Juan, no sólo físicamente, sino también porque nunca ha conocido a una mujer. Es de notar que la pareja don Juan - Beatriz sólo funciona dentro de un diálogo cuyo tema es el miedo a la nada, el tema del que tratan también Chepa y don Juan. El antagonismo entre

\footnotetext{
10 Notemos que el caballero II también se llama don Juan.

11 Véase «Consideraciones sobre don Juan», de Sender, cit., pp. 7-32.
} 


\section{EL LUGAR DE SENDER}

don Juan y Chepa termina con la muerte de aquél en su propio panteón sin que la desaparición de don Juan signifique la victoria del molinismo: ${ }^{12}$ dramáticamente, don Juan tenía que morir para seguir la trayectoria que le impone el mito.

En cuanto a la pareja mítica, noto que doña Inés es el elemento motor: ella es quien «desea» a don Juan, para emplear la terminología actancial que se aplica al caso al pie de la letra. ${ }^{13} \mathrm{El}$ discurso de doña Inés se sitúa en la perspectiva de la rehabilitación del sexo, con el elogio de la prostitución por el escultor y con las palabras de la estatua: «No hay ya padres ni hijos. Sólo queda el deseo antiguo, un deseo que rige el orden de los astros a lo largo y a lo ancho de las eternidades" (I, p. 65). Cuando doña Inés empuja a don Juan hacia Beatriz, lo empuja hacia la pureza de Beatriz: por eso le puede decir «En Beatriz te espero» (II, p. 80). No se oponen las parejas dramáticas don Juan - doña Beatriz y don Juan - doña Inés, sino que apuntan hacia el mismo objetivo. Don Estrafalario, el personaje del «Prólogo" de Los cuernos de don Friolera, quería "ver este mundo con la perspectiva de la otra ribera» y es lo que doña Inés quiere enseñar a don Juan:

\footnotetext{
Veremos más que cuando vivíamos. Veremos lo que piensan y sienten los demás aunque no lo digan. Bueno, lo sabré y lo veré yo, que estoy acostumbrada ya. Tu irás aprendiendo. Yo veré lo que piensan aunque digan todo lo contrario. (III, p. 139)

Son cosas que sólo entendemos los que hemos pasado por los estadios de la penitencia. (IV, p. 168)

$Y$ ya ves. El supuesto pecado que a ella la pierde aquí abajo a mí me ha sido perdonado allá arriba. [...] En este otro lado de la realidad las cosas son diferentes. (III, p. 169)

En la vida no hay saber ninguno. Hay sólo una especie de ignorancia puesta en orden. (III, p. 143)
}

Descubrir con don Juan el mundo desde arriba exige una lectura recurrente, una lectura que nos revela la relatividad de todo, especialmente la de los juicios del tribunal civil y del mismo Santo Oficio. En la manera como ven lo que pasa en el espacio de la mancebía, en la manera como consideran el destino de Beatriz, tanto don Juan como doña Inés parecen haber encontrado la serenidad, y es la única luz de esperanza en este don Juan senderiano, quien, al final, acompañado de doña Inés y doña Beatriz, sube hacia arriba, sin preguntarse más, parece.

Llegado el momento de concluir, quiero volver primero sobre el verdadero sentido del subtítulo de este drama, Drama litúrgico en cuatro actos: no remite como se pudiera pensar a un auto sacramental. Con un mali-

12 En el momento de morir don Juan trata a Chepa de «Hijo de Satanás» (III, P. 125).

13 Anne UBERSFELD, op. cit. 
cioso guiño Ramón Sender apunta hacia otra dirección, se refiere a la liturgia en el sentido que da la Real Academia: "orden y forma que ha aprobado la Iglesia para celebrar los oficios divinos, y especialmente la misa». Sólo que no se trata de ningún oficio divino sino del drama de don Juan y, mejor dicho, de la visión muy personal que del mito de don Juan tiene Sender. ¿Drama litúrgico? Pues sí, en la medida en que el mito de don Juan, como todos los mitos, tiene sus invariantes y aquí están las tres invariantes indispensables: el elemento femenino, la estatua y el seductor. En este sentido, hay algo litúrgico en la manera que tiene Sender de celebrar el mito de don Juan.

No era mi propósito entrar en el debate teológico enriquecido aquí por las teorías de Miguel de Molinos, cuya perspectiva confiere una gran originalidad a este Don Juan en la mancebía. Sólo he querido mostrar cómo se organizaba dramáticamente este debate alrededor de un don Juan viejo, impotente, moderno en su forma de dudar, gracias a una ingeniosa alegoría que le permite a Ramón Sender crear una ficción que da una nueva dimensión al mito que fundó Tirso de Molina con El burlador de Sevilla. 


\title{
Problemática y sentido del encuentro con el otro en la novela de Ramón Sender
}

\author{
Eduardo Godoy G. \\ Universidad Católica de Valparaíso
}

Dos hechos marcan tanto la vida personal como la creación literaria de Ramón Sender. Ellos son la guerra y el exilio. Al analizar cualquier aspecto de la creación senderiana son un punto de referencia inexcusable. Incluso lo escrito antes del estallido bélico, examinado desde esta perspectiva, ofrece líneas de interpretación que enriquecen lo realizado por el novelista aragonés.

Una línea temática interesante de analizar es la presencia de la dignidad, que a partir de El lugar de un hombre adquiere una connotación concreta. Escrita ya en el exilio, se vincula directamente con los dos hechos señalados. El quiebre espiritual que significa su participación en la guerra civil y el consecuente exilio marcan un adensamiento en una línea ya distinguible en la creación anterior y la convierten en eje vertebral de su pensamiento. Personajes encontrables en Imán (1930), Siete domingos rojos (1932) y Míster Witt en el cantón (1935) dan cuenta de su presencia.

Esa línea es llevada hasta sus últimas consecuencias en la etapa exiliada de Sender. Me basaré para examinarla en tres de sus creaciones de este último momento - El lugar de un hombre (1939), Crónica del alba (1942) y El rey y la reina (1949) - y en los tres personajes —Sabino, Pepe Garcés y Rómulo- que conducen la línea argumental en las novelas mencionadas. 
Los tres se encuentran en situaciones vitales difíciles, en situaciones límites: Sabino en extrema degradación, Pepe Garcés derrotado y en espera de la muerte y Rómulo deslumbrado ante lo desconocido. Este momento crucial los enfrenta -consciente o inconscientemente-con su ser más profundo e íntimo y se plantea la búsqueda de una identidad perdida. Es aquí donde surge, a mi parecer, el problema del otro, que se expresa en una doble perspectiva: por un lado, es el otro yo de uno mismo, el que uno fue y se perdió en los avatares vitales, y, por otro, el que uno es en relación con el o los otros. Se trata de una validación personal, por un lado, y global o social por otro: ambas confluyen en la configuración de la línea temática que he indicado: la búsqueda de la dignidad del hombre.

El primer aspecto - el encuentro con el otro yo- sumerge a la narración senderiana en la esencia de la identidad personal y confronta el presente con el pasado, el hoy con el ayer. En la raíz de esta concepción está el concepto de hombría, de la cual tan poco se ha dicho. En este sentido, se encuentra el ser que fue y que el transcurrir del tiempo ha oscurecido: lo que se busca en este rastreo temporal es el hombre en sí, definido en forma temprana (1934) como el ser «en plena puridad, sin la corrupción de la vieja personalidad adquirida y pegadiza» (La noche de las cien cabezas). En cuanto al segundo - reconocimiento en y por el otro- se realiza lo sostenido por K. Jaspers: "Yo soy sólo en cuanto estoy en comunicación con el Otro» (Philosophie, Berlín, 1939).

Ambos procesos llevan a los héroes senderianos al descubrimiento íntimo de lo que son realmente, a la transformación de objetos en personas y a la conciencia de su realización en y por el otro.

Su concreción en los tres personajes nombrados es lo que se intentará hacer en las líneas que vienen.

\section{EL LUGAR DE UN HOMBRE (1939)}

Tres momentos estructuran la existencia de Sabino, protagonista de la primera novela de Sender escrita en el exilio: su vida en el pueblo, su huida y permanencia durante dieciséis años, tres meses y once días en el saso y el regreso.

Su vuelta al pueblo aparece marcada por un cambio que señalan las dos personas que más cerca han convivido con él hasta entonces: su madre, que lo establece directamente: «-A ti te han cambiao, Sabino. Tú no eres el que eras» (p. 76), y Adela, su mujer, para quien «-La vida me ha engañao a mí contigo, Sabino" (p. 183).

¿Por qué y cuál es el cambio producido en Sabino? ¿Qué signa su permanencia en el roquedal? La variación que se observa en su personalidad está en directa relación con lo que se postula en este ensayo: el autoconocimiento y adensamiento en el otro yo y la validación por los otros. Veamos cómo se produce. 
Sabino, en su primera infancia, está convencido de su honorabilidad, la que se sustenta en que, "[e]n mi casa, todos tenemos oficio» (p. 62), sin percibir lo que esos oficios eran para los demás. Son oficios degradantes y desempeñados por los últimos de la escala social.

Se hunde, entonces, en esa condición degradante en que los demás lo ubican: es «[e]l más pobre del pueblo» (p. 54), nadie lo toma en cuenta: «[...] era, en el pueblo, el ser con quien nadie contaba» (p. 60), es rechazado en el momento de incorporarse a la milicia y su mujer lo traiciona.

Trata de salir de esa situación e intentando representar a los jóvenes de su pueblo se enfrenta a un mozo del pueblo vecino, que termina dándole una paliza y humillándolo: «[...] a partir de entonces la vida de Sabino era más vil aún. Pasaba por los lugares como un perro extraviado. Las mujeres se burlaban de él, también. Eso era al principio. Poco después ni siquiera se burlaban, lo desconocían. Sabino no existía» (p. 64).

En medio de ese clima degradante que los otros le han conformado, Sabino encuentra una salida que satisface su yo íntimo: su matrimonio con Adela. Debe entenderse este matrimonio - en el sentido al que apunta esta aproximación - como un intento de validación ante los otros. Ante la burla de los demás, que le recuerdan su condición de boñiguero, piensa: "Se burlan, pero yo tengo a la Adela» (p. 65), para recalcar el narrador: «Y acostado con ella creía vengarse de todos» (p. 65).

Trabaja esporádicamente y se da cuenta de su ubicación en la consideración social y decide abandonar el pueblo e irse a vivir en el roquedal de Aineto, lugar árido e inhóspito. El cura del pueblo lo dice en forma clara y precisa: «-Se cansó de ser un cero a la izquierda, de esperar sin esperanza" (p. 60). Sin embargo, algún rasgo de dignidad le queda al dar, a su regreso, sus razones para irse al monte y explicar ese barrunto que le dio: «-Me marché para no enviar a alguno al cementerio» (p. 159), en clara alusión a su condición de marido traicionado.

De su permanencia en el roquedal el narrador entrega dos datos de importancia para caracterizarlo: el primero alude al hecho de que no roba a los pastores, sólo se lleva alguna manta en invierno, que devuelve poco después; el segundo dice relación con el espacio que habita, el roquedal, al que califica como «una aldea encantada» (p. 44).

Son importantes, porque el primero muestra la permanencia en Sabino de una condición innata que alude a un sentimiento de dignidad que ha permanecido en él: todos los niños que recogían boñigas en el pueblo tenían por costumbre mendigar, pero Sabino nunca lo había hecho. En igual perspectiva debe situarse lo sucedido en el circo. Esta sensibilidad permanece en Sabino y se expresará a su regreso al pueblo. El segundo - la calificación como aldea encantada del roquedal de Aineto- dice relación con un espacio depuratorio en que se adensan las condiciones que hacen del hombre un ser digno de serlo; Sabino ha sido condenado por la sociedad, huye de ella y se refugia en la soledad del roquedal. De ahí será rescatado por un grupo de hombres encabezados por el poderoso don 
Ramón, que contribuyó a culpar a dos inocentes y a declararlo muerto por fines estrictamente políticos.

Como se aprecia, en la persona de Sabino chocan dos maneras de encuentro con el otro y con los otros. Respecto a lo primero, hallamos esa línea íntima que se conserva a través de todo el relato y que lo hace, finalmente, escapar del medio en que está inserto. Es el yo interior, el otro yo que se constituye en refugio de su condición humana. Por otro lado, el sentir del pueblo lo grafica la mujer de Vicente, al sostener que «[e]se poca substancia [...] por irse a vivir entre los lagartos hizo la desgracia de medio pueblo» (p. 156).

El regreso revoluciona al pueblo de Ontiñena. La permanencia de Sabino en el roquedal lo ha animalizado y la concreción de ello se encuentra en la manera como es descrito en el primer encuentro con el narrador, pero, como ya se ha sostenido, mantiene los rasgos humanos esenciales que lo hicieron escapar del pueblo. Su vuelta señala el reingreso a un espacio que como ser hombre le corresponde y en este sentido la recuperación del lenguaje es el primer signo de humanidad encontrable en este tercer momento: reconoce a don José, sonreirá y, frente a su casa, pronuncia el nombre de su mujer, Adela, hecho que finalmente lo identifica. Luego, un segundo elemento decidor, declara públicamente su identidad.

El proceso que ahora se inicia va a significar la recuperación de ese concepto de hombría que he señalado líneas atrás: un adensamiento y un reencuentro con lo que se es primigeniamente y un reconocimiento de los otros. La validación del ser hombre se hará, entonces, interna y externamente.

Los otros vacilan en cómo revalorar lo sucedido con Sabino y no saben si nombrarlo alguacil suplente o auxiliar del guardia de la acequia o guardamonte jurado o barrendero. Lo nombran, finalmente, guarda auxiliar de acequia, lo que ya significa un ascenso frente a la primera intención.

Sabino valora este nombramiento. Es la valoración de los otros lo que aquí juega. Todo ello coronado, además, por la conversión de su historia en romance. El mismo padre del narrador valora la reacción de Sabino ante el perdón de Juan y descubre una faceta desconocida en él: «[...] Sabino se ufanaba de aquel perdón [...]» (p. 175). De igual manera, lo que piensa el segundo marido de su mujer.

El último capítulo es un verdadero juego entre los conceptos indicados. Un incendio arrasa la finca Los Pinos de don Ramón. Es en este momento en el que se produce el primer encuentro con Adela, luego de su regreso. Ambos hechos se vinculan directamente. Él sostiene satisfecho: «-Eso es por mí» (p. 183) y ella «ardió por él aquella noche» (p. 183), no sin antes tomar posesión de un espacio que le pertenecía y que había abandonado; en la voz de Adela reconoce la intimidad primera y recuerda su relación perdida. Es el otro yo que surge. Por eso sostiene que ése es su puesto, que aún hay calor en su sangre, no permite hablar de traiciones porque «era como aceptar que a él, a Sabino, se le podía traicionar» 
(p. 183). La actitud de Adela revela la validación que de la condición de hombre hace de Sabino, es decir, la validación del otro.

Al día siguiente de producirse el primer acercamiento con su mujer, le entregan el fusil y la correa que identifica su cargo, va a ejercer su oficio y en medio de los campesinos se dice que «contemplaban a Sabino en silencio, rendidos de admiración. Llegaba en el aire, a favor del viento, el olor lejano del bosque en cenizas humeantes" (p. 184).

Pienso que todo el relato confluye a esta situación final que representa el encuentro con el otro yo y el reconocimiento que los otros realizan de su dignidad. En otras palabras, una doble validación -la propia y la de los demás - ha estructurado el texto en su integridad.

\section{CRÓNICA DEL ALBA (1942)}

Se entrega mediante la narración de Pepe Garcés, que concluye sus días en el campo de concentración de Argelès, Francia. Es un refugiado de la guerra civil y muere a los treinta y seis años, un 18 de noviembre de 1939, a los nueve meses escasos del término de dicha guerra.

El narrador básico es un amigo de Pepe Garcés que lo conoce en el campo de concentración y que es el encargado de conservar su testamento moral, el cual es, en el fondo, esta Crónica del alba construida en torno a recuerdos y a la recuperación de la primera etapa vital. El narrador básico da a conocer la situación en que Pepe se encuentra: «De su situación regular de hombre de 35 años, sano, inteligente y honesto a la manera española, [...] se vio convertido en un refugiado sospechoso a quien los negros senegaleses de Pétain trataban a culatazos» (p. 9). El talante espiritual de Pepe Garcés está marcado por haberse transformado de un hombre digno en un refugiado sospechoso. Lo único que lo mantiene vivo es la posibilidad de volver al campo de batalla, pero esta esperanza se cierra el día que sabe la caída de Valencia y Madrid.

La posibilidad de salir del campo de concentración y de rehacer su vida, solución planteada por el narrador básico, le parece imposible y en esa imposibilidad se encuentra implícito su rechazo absoluto y total del contorno:

-Es inútil. No quiero arrastrar la vida por ahí. Si salgo ¿sabes lo qué seré? En el mejor caso, un héroe engañado. [...] Y $Y$ es que la generación que tiene ahora el poder [...] es una generación podrida, de embusteros. [...] No tienen fe [...]. ¿Qué va a decir el hombre sin fe? ¿Tú sabes lo que dicen en nuestra tierra cuando descalifican a un hombre? No dicen «es un ladrón" ni "un criminal» aunque lo sea. Eso no tiene tanta importancia. Lo grave es si dicen: "es un sinsubstancia" o bien «un desubstanciado». En el hombre la substancia es la fe. Ésa es toda la cuestión. (p. 12)

Ésta es la situación épica en que está instalado el narrador Pepe Garcés. Ante ese contorno, comienza a escribir sus recuerdos y reconstruye su 
vida desde el hoy hacia el ayer. Su condición de refugiado, de vencido, lo sume en la indignidad y en la humillación. Los otros son, en este caso, sus enemigos, aquellos que lo han confinado en este denigrante campo de concentración: los sinsustancia, los desustanciados, los embusteros, los que no tienen fe. Ésa es la razón que lo lleva a rechazar tajantemente la posibilidad de vivir entre ellos, en esa generación podrida, como la llama; a ver la muerte como «la única puerta digna de nosotros» (p. 11) y a recuperar su vida escrituralmente porque "me ayuda a mantenerme en mi substancia" ( $p$. 13). Es esta situación extrema la que lo lleva a escribir sus recuerdos, a reconstruir su vida desde su infancia hasta el hoy. Las fracciones de la realidad vital en que se escinde la vida de Pepe Garcés - presente y pasadoaparecen marcadas por una diferencia radical; así lo establece el narrador básico: «Acordarse de todo aquello en medio de tanta miseria era una dulce broma de Dios» (p. 14).

El primer estadio que surge en estos momentos es la infancia, que se convierte en un motivo reiterativo: «La manía de hablar de aquellos tiempos y aquellas gentes era una defensa y una fuga" (p. 11). Aquí está la clave y la razón del texto que nos preocupa: defensa de su esencia, de su sustancia; fuga del tiempo presente. Se busca el otro, el ser que se perdió en el tiempo y que concluye en ese campo de concentración. La novela es el intento de encontrar esa sustancia perdida que lo valida como hombre digno de serlo.

La validación mencionada se da en una doble perspectiva: la dada por los otros y la dada por uno mismo, que no es otra cosa que el encuentro con el otro yo. La primera enmarca el texto en su integridad.

Respecto a la segunda, el reencuentro con el otro yo, estructura el texto. La incursión en el pasado significa un contraste violento con la situación épica desde la que se narra y, a la vez, reivindica su condición esencial de ser un hombre con sustancia, con fe, que lo conduce finalmente a la muerte. Esta muerte demuestra, a sus camaradas y a sus enemigos, que es la única salida digna, en aquellas circunstancias, para un hombre de fe.

La primera nota que, en este sentido, es descubierta por el narrador adulto es su capacidad de amar, que engloba el autoconocimiento y la relación con el otro. La vinculación con Valentina constituye la construcción de un paraíso para Pepe Garcés. La unión íntima de ambos pequeños alcanza su grado máximo en el momento en que Pepe se autoidentifica con Dios y a Valentina la convierte en el alma enamorada de acuerdo con los textos religiosos que extraen de Voces del alma enamorada que busca a Dios y Voces de Dios al alma enamorada y en el momento en que ambos, en medio de la excursión por las galerías subterráneas del castillo de Sancho Garcés y en sueños, son amenazados de muerte.

El segundo momento clave es el episodio en que Pepe encabeza la pandilla infantil de su pueblo contra otro pueblo vecino; su participación resulta fundamental en la victoria que se obtiene, lo que lo convierte en héroe, señalado y destacado por los otros niños: 
La voz había corrido y al pasar oía a veces: "Ése es Pepe, el de la plaza». Y dejaban sus juegos para mirarme. Yo me consideraba merecedor de todo aquello [...] y a veces me acercaba patriarcal y magnífico. (pp. 88-89)

La tercera situación es el episodio del balín, en que Pepe Garcés demuestra su valentía ocultando su dolor. Toda la situación causa la admiración de la pareja de médicos que opera su dedo y de su contorno familiar, en especial de Valentina. De nuevo funciona aquí la doble conceptualización del otro.

El cuarto momento está señalado por los exámenes que rinde en Zaragoza, en los que obtiene «dos sobresalientes y un notable» (p. 95), lo que le permite autocalificarse como "el señor del saber» (p. 95).

El último momento es el encuentro de un pergamino en el castillo de Sancho Garcés, que debe ser considerado como retrato moral del hombre español y vinculado con el estado actual desde el que Pepe Garcés, adulto, narra. Aquí se divide a los hombres en tres categorías: los santos, los poetas y los héroes, que encarnan la virtud, el saber y el heroísmo, cualidades que no son privativas de ninguna de las tres en particular, sino que se dan integradas. Esto queda vinculado con la expedición por el castillo de Sancho Garcés, en la que los muertos que recobran vida -imaginariamente- le dicen a Pepe que todos deben reconocer una meta final: la muerte. $Y$ todos - santos, poetas y héroes - mueren prematuramente, lo que debe verse en relación con la guerra civil y el exilio, cuyos efectos el narrador adulto acusa.

Los momentos mencionados - entre los muchos que pueden extraerse del texto- le permiten a Pepe Garcés adentrarse en el otro yo encontrable en su etapa infantil con el yo actual que se encuentra encerrado por medio de alambradas y que es otro respecto al primigenio. Cree ser el señor del amor, de las dominaciones y del saber, conceptos extraídos de textos que ha compartido con Valentina. Lo es del amor (por sus relaciones con ella), de las dominaciones (el episodio del balín y la batalla mantenida contra grupos enemigos le han convertido en héroe) y del saber (al aprobar sus exámenes). Como se puede apreciar, el texto se estructura en un permanente juego con el otro y los otros.

Por encima de las situaciones creemos que esta crónica está destinada a las siguientes generaciones, aquellas que existirán después del holocausto que significan la guerra civil española y la segunda guerra mundial. Sólo entonces esta escritura se abrirá a su más alto significado y, en este sentido, la plenitud del encuentro con el otro se consuma en una nueva dimensión que corresponde al propio lector.

\section{EL REY Y LA REINA (1949)}

Rómulo y la señora del palacio, el jardinero y la duquesa, son dos personajes sin historia al comenzar El rey y la reina y al terminar son el hombre y la mujer que se concretizan en el título. ¿Qué ha sucedido entre la 
abertura y el cierre del texto que ha hecho posible tal transformación? Un acontecimiento que es resultado directo de la guerra civil permite la realización de un proceso que lleva a ambos, al héroe y a la heroína, a un descubrimiento íntimo de lo que son realmente, a la conversión de objetos en personas y a tomar conciencia de sí y de su realización en el otro.

El acontecimiento a que nos referimos sucede unos días antes del estallido de la guerra civil. Rómulo debe entregar un mensaje a la duquesa, que se encuentra bañándose desnuda en la piscina del palacio. Permite el ingreso de Rómulo sin ocultar su cuerpo, no sin antes decir a la doncella que la acompaña, ante la condición viril del jardinero expuesta por ésta: «一 ¿Rómulo un hombre?» (p. 9).

Éste es el hecho clave que sume a Rómulo en una angustiosa indagación en torno a sí mismo. El narrador señala la situación en que se encuentra el jardinero: sin pestañear, sin ver, sin moverse: «Por el hecho de tener delante a la duquesa desnuda se sentía otro y la necesidad de comprender a "aquel otro" - que representaba una brutal sorpresa- le impedía darse cuenta de lo que estaba viendo. [...] No comprendía nada. Ni la sombra, ni sus pies ni sus propios ojos deslumbrados» (pp. 10-11).

Hace quince años que Rómulo está al cuidado de las flores del palacio y su vida ha transcurrido sin alteraciones. Estremecido y desorientado, busca una explicación a lo sucedido. Pregunta a su mujer si se dejaría ver desnuda por el duque y su respuesta lo confunde aún más: rotundamente no, confusión que aumenta al no tener respuesta de la doncella respecto a lo que ha sucedido. Ambas situaciones lo aíslan, lo dejan en radical soledad con su problema interior.

¿Qué sucede con la duquesa? Para ella el hecho no ha tenido la menor significación, puesto que Rómulo en su concepto no es un hombre.

Este hecho pudo haber quedado ahí, pero, días después, España estalla en llamas y Madrid se convierte en espacio clave de la convulsionada España. Y un hecho novelesco decisivo: el palacio ducal cae en manos de las milicias republicanas, Rómulo queda a cargo del mismo y se convierte en el protector y en el cuidador de la duquesa.

Desde ahora, la novela se desarrolla en torno a las relaciones -nuevas- entre el jardinero y la duquesa, que tienen como trasfondo el Madrid de la guerra civil. El autodescubrimiento se producirá por partida doble: el jardinero desde un presente se sumergirá en el pasado, en tanto que la duquesa, en menor medida, experimentará el mismo proceso, lo que, en último término, conlleva la consideración del ser hombre como objeto y su conversión en persona, lo que se concreta en el encuentro del otro en sí mismo y con el otro.

Ambos llevan, al comenzar el relato, una vida superficial y anodina que puede calificarse como inauténtica y que los ha convertido en objetos. Desde el punto de vista del jardinero, la duquesa ha sido considerada sólo por su rango social; desde el ángulo de la duquesa, la condición de jardinero que tiene Rómulo lo convierte en un no-hombre. Ambos se encuentran 
separados radicalmente, pero la guerra civil los pone en comunicación: el relato consistirá en un acercamiento que se producirá entre ambos y que, finalmente, se concretará en el descubrimiento del otro como persona.

Desde este momento, el relato se estructura en torno a un lento acercamiento entre ambos. En el fondo se trata de un proceso cuyo destino final es la autentificación de ser hombre. En Rómulo, la presencia del otro que se halla en su pasado es permanente y le lleva a recuperar su sustancia y su hombría. El amor es el elemento depurador que, además, le permite completarse con el otro, en este caso la duquesa.

Es necesario recordar que antes se produce una primera validación, que consiste en la manera como lo ven los demás, es decir, los otros, que, en este caso, son los milicianos. El Rómulo que decide ir al frente es aquel entrevisto luego del episodio de la piscina, es el otro que surge del pasado. En el momento en que sale del palacio con su equipo de dinamitero, el miliciano Ruiz certifica su condición viril al decirle: «-Así hacen los hombres, Rómulo» (p. 200). Su posterior vuelta, convertido en un ser superior por su desempeño en la llamada peña de Rómulo, destaca su hombría.

Distintos acontecimientos hacen surgir a aquel otro que ha permanecido oculto. Los acercamientos físicos, la entrega del duque, el rechazo de toda remuneración, los diálogos en torno al rey y la reina, la lectura y presencia de libros amorosamente simbólicos, la muerte de su mujer, el asesinato de un miliciano, las voces que surgen de la infancia...; todo ello le acerca lentamente a la duquesa, la que, a su vez, descubre otra duquesa y otro Rómulo. En los momentos finales, en que el jardinero la encuentra abandonada y agonizante, se produce el encuentro final. Unos dibujos que representan al rey y a la reina son mudos testigos de ese encuentro. La duquesa le confiesa que: «—Rómulo, tú... Tú eres el primer hombre que he conocido en mi vida» (p. 254). Rómulo la besa una vez que la vida la ha abandonado.

La novela se cierra con una representación de títeres en que sobresale lo dicho por uno de ellos: «-Al rescate todos de la juventud, desde el nacimiento hasta el ataúd» (p. 256).

Se ha llegado al final de un proceso en que se valida la condición de hombre en Rómulo y de mujer en la duquesa, lo que hace posible el encuentro en la unión final, que se concreta en el beso y en lo dicho por la duquesa. Ello ha sido posible porque los dos se han despojado de todos los factores externos que han condicionado sus vidas y han penetrado en su ser íntimo. En ese proceso se observa en ambos un doble movimiento, aunque con distinta intensidad: la búsqueda y el encuentro del otro significa la dignificación de ser hombre, que va de ser objeto a ser persona. En Rómulo, dicha validación se efectúa al encontrar en sí mismo al otro -el auténtico- perdido en el tiempo y en su relación con el otro - en este caso la duquesa-, que clarifica su condición viril, a la vez que ese otro es validado por los milicianos por su participación bélica; en la duquesa se da un proceso similar: el otro, en su caso, se despoja de su vida anterior y reconoce en sí al ser perdido en el pasado - mediante sus juegos infantiles- 


\section{EL LUGAR DE SENDER}

y que aflora al reconocer en Rómulo al primer hombre que ha conocido, con lo que reniega de todo su pasado. La validación existencial y social por el otro - en sus distintas dimensiones- y los otros es clave en la significación a que apunta esta novela de Sender. Además, todo lo que hemos dicho está en relación con el héroe y la heroína individualmente hablando, pero no se olvide que el texto plantea que todos los que participan en la guerra se encuentran al rescate de su juventud, es decir, de lo auténtico. Individual y globalmente, entonces, la búsqueda y el encuentro del otro y con el otro es una de las claves que permiten desentrañar el sentido del texto que revisamos.

El recorrido realizado en torno al mundo novelesco de Sabino, Pepe Garcés y Rómulo señala claramente que están insertos en un proceso en que la búsqueda, el encuentro y el reencuentro con el otro son claves y decisivos para comprender la instancia esencial de los personajes y del mundo creado por Ramón Sender.

\section{BIBLIOGRAFÍA}

Para la elaboración del presente ensayo se han utilizado las siguientes ediciones: El lugar de un hombre (Barcelona, Destino, 1968), Crónica del alba (Barcelona, Delos-Aymá, 1965, tomo I, pp. 5-138) y El rey y la reina (Buenos Aires, Editorial Jackson de Ediciones Selectas, 1949).

Menciono algunos ensayos que es útil consultar en el sentido en que la presente comunicación ha sido enfocada:

Ahumada, H., La novelística de R. Sender y su acceso a la dignidad, tesis inédita, Valparaíso, Instituto de Literatura y Ciencias del Lenguaje, Universidad Católica de Valparaíso, 1988.

BERTRAND, M., "Los símbolos en El rey y la reina de Ramón J. Sender», Papeles de Son Armadans, 220 (1974), pp. 37-55.

CollarD, P., «Las primeras reflexiones de Ramón Sender sobre el realismo», Actas del VI Congreso Internacional de Hispanistas, Toronto, Universidad de Toronto, 1980, pp. 179-182.

KING, Ch., "The role of Sabino in Sender's El lugar de un hombre», Hispania, 50 (1967), pp. 95-98.

MAINER, J.-C., «La culpa y su expiación: dos imágenes en las novelas de Ramón J. Sender", Papeles de Son Armadans, 161 (1969), pp. 116-132.

Peñuelas, M., Conversaciones con Ramón J. Sender, Madrid, Magisterio Español, 1969.

UCEDA, J., «Realidad y esencias en Ramón Sender», Revista de Occidente, 82 (1970), pp. 39-53.

He tratado el tema o lo he rozado en:

Godoy G., E., «Problemática y sentido de Réquiem por un campesino español», Letras de Deusto, 1 (1971), pp. 63-74.

- "Crónica del alba o la infancia como sustancia esencial», en La infancia en la narrativa española de posguerra, Madrid, Playor, 1979, pp. 27-55.

—, "El rey y la reina de Ramón Sender, y el encuentro con "el otro" ", Recista Chilena de Literatura, 56 (1995), pp. 21-33. 


\title{
Ramón Sender y la literatura francesa
}

\author{
Dalia Á. Molina \\ Universidad de Oviedo
}

El título de este trabajo puede parecer demasiado ambicioso habida cuenta de la extensión y dispersión de la obra senderiana. No es mi propósito abarcarlo todo, ni agotar las relaciones entre Sender y el ámbito francés, lo cual resultaría demasiado atrevido en el marco de una breve comunicación, pero sí me parece importante sugerir vías de investigación para los senderianos dentro del campo de la cultura francesa. Es mi deseo, en un segundo tiempo, destacar la admiración literaria que sintió Ramón Sender por L. F. Céline, al que dediqué mi tesis doctoral. ${ }^{1}$

El interés de Sender por la producción literaria gala es palpable. Ya en sus años de juventud publicó el joven escritor de Chalamera artículos que

\footnotetext{
${ }^{1}$ Cuando se le pregunta por sus autores contemporáneos preferidos, de Estados Unidos cita a Edmond Wilson, Miller y Ralph Ellison; de Inglaterra, a D. H. Lawrence y «algunos autores jóvenes», y de Francia, a Céline (cfr. Marcelino C. PeÑuelas, Conversaciones con Ramón J. Sender, Madrid, Magisterio Español, 1969, p. 268). De los clásicos franceses elige a Montaigne (Ramón J. SENDER, Álbum de radiografías secretas, Barcelona, Destino, 1982, p. 218).
} 
se referían a Balzac, ${ }^{2}$ Gide, $^{3}$ Zola $^{4}$ o Rabelais, ${ }^{5}$ entre otros, ${ }^{6}$ y como demuestra el reciente volumen de sus Primeros escritos (1916-1924) ${ }^{7}$ Sender permanecía al corriente de la actualidad literaria en Francia gracias a un poeta hispanista, hoy perdido en el olvido. Este escritor, M. Falgairolle, ${ }^{8}$ le proporcionaba los nombres de los autores que habían conseguido un reconocimiento en los años 20 más allá de los Pirineos. Algunos llevan un sello eminentemente místico-religioso, como Francis Jammes, Charles Péguy, Paul Claudel, Pierre Benoît, Georges Duhamel o Pierre Loti; otros aparecen como sucesores de Zola, al que se califica de autor del "naturalismo descarnado». Entre estos últimos se encuentran además dos autores próximos a Céline: Lucien Descaves, ${ }^{9}$ un escritor de tendencias libertarias, y Léon Daudet, uno de los que le prometieron en vano a Céline el Premio Goncourt en 1932. Maurice Barrès, el futuro paladín de la derecha, es mencionado, por otra parte, con profunda admiración por Falgairolle como artista ejemplar y gran amante de la cultura española. ${ }^{10}$ Resulta curioso observar cómo nuestro país parece estar en aquel entonces en una situa-

\footnotetext{
2 Concretamente sus relaciones amorosas con madame Hanska y, en tono de humor, su amor por el dinero. Ramón J. SENDER, «Pasatiempos. Balzac y madame Hanska», La Libertad [Madrid], 25-I-1935, p. 1.

3 Un autor del que opina que ha recorrido «todos los caminos de la sensualidad posible, todas las encrucijadas de la imaginación con un sentido moral que considera salvador: la estética». Para Sender lo que de verdad ha encontrado Gide es «un espejo que le ha devuelto su imagen». Ramón J. SENDER, "Hoy. André Gide en el cenit», La Libertad [Madrid], 3-XI1932, p. 1.

${ }^{4}$ Sender se indigna de que en 1925 el presidente de la «Société Littéraire des Amis d'Émile Zola" fuera Painlevé, un político burgués, y hace la crónica del homenaje anual en Médan de 1934. Lo que ignora, supongo, Sender es que dos años antes, en 1932, el pregonero había sido Céline. Ramón J. SENDER, “30-IX-1902. En el aniversario de Emilio Zola», La Libertad, 3-X1934, p. 1.

5 Un artículo en el que ironiza sobre la magnitud y perfección de las cocinas de los jesuitas de Aranjuez, apropiadas para servir comidas pantagruélicas antes que sobrias pitanzas. Las referencias a estos artículos de La Libertad las hemos encontrado en la tesis de $\mathrm{M}^{\mathrm{a}}$ Francisca VilChES DE Frutos, La generación del Nuevo Romanticismo. Estudio bibliográfico y crítico (19241939), Madrid, Universidad Complutense, 1984.

6 Cfr. José Domingo Dueñas LoRENTE, Ramón J. Sender (1924-1939). Periodismo y compromiso, Huesca, Instituto de Estudios Altoaragoneses, 1994.

7 En edición de Jesús Vived MAIRAL, Huesca, Instituto de Estudios Altoaragoneses, 1993.

8 Defensor a ultranza de la belleza del Alto Aragón y promotor de un «Comité de aproximación franco-español». Cfr. Ramón J. SENDER, «Hablando con monsieur Adolphe Falgairolle», La Tierra [Huesca], 12, 17 y 24 de agosto y 4 de septiembre de 1921, publicado en Jesús Vived Mairal, ed., Primeros escritos (1916-1924), cit., pp. 56-68.

${ }^{9}$ Descaves fue amigo de Jean Grave y publicó una novela en la que criticaba la institución militar y la vida en los cuarteles. Sous-offs, aparecido en 1889 , había provocado un escándalo en el panorama literario de su época. En su autobiografía Les ours se enorgullece Descaves de haber cometido errores en su vida pero ninguna villanía. Cfr. Thierry MARICOURT, L'histoire de la littérature libertaire en France, París, Albin Michel, 1990, pp. 240 y 447.

10 Ramón J. SENDER, «Hablando con monsieur Adolphe Falgairolle», cit., p. 67.
} 
ción similar a la actual: «En Francia están ustedes de moda. Todo lo espanol tiene una cotización superior en el mercado intelectual». ${ }^{11}$

A falta de una recopilación de toda la producción periodística de Sender referida a obras y autores franceses, que constituiría una labor interesante para cualquier especialista o amante de la literatura francesa, ${ }^{12}$ disponemos de dos importantes libros para saber de sus preferencias literarias. El primero es fruto de las conversaciones mantenidas con el profesor Peñuelas (1969) y el otro es el Álbum de radiografías secretas (1982).

Del primero se deduce que otras literaturas parecen serle más próximas: la norteamericana, con Faulkner, Miller, Ellison, pero sobre todo la literatura rusa, que es la que más ha conmovido a Sender. «Desde Pushkin a Tolstoi tienen los rusos la palma de la novela en el mundo». ${ }^{13}$ Más adelante, puestos a escoger entre Stendhal y Dostoievski, se decanta sin embargo por el primero en una defensa de una escritura alejada de todo artificio estilístico, ${ }^{14}$ lo cual explica su condena de otro movimiento literario muy francés, por lo menos en su teorización y acuñación, el del «nouveau roman». Éste es el paradigma, según él, de lo que llamó «novedosidad» frente a la «novedad» legítima: ${ }^{15}$ «me parece una manera de confundir la incompetencia con la originalidad». .6

Globalmente Sender considera la literatura francesa en su decurso histórico como una literatura algo académica, aunque no carente de ideas. Además, según él, todos los autores desde Rabelais ${ }^{17}$ usan la misma correctísima lengua: «Una cocinera francesa escribe su carta a la familia en el mismo estilo que el presidente de la academia. La diferencia es que la cocinera no dice nada interesante». ${ }^{18}$ En este punto se une precisamente al sentir de Céline, para quien, frente al vigor, a la vulgaridad en sentido propio y originalidad de la prosa de Rabelais, triunfó la lengua de Amyot, el que fuera traductor de Plutarco: «Ça c'est écrire de la m...: du langage figé. Les colonnes d'un grand quotidien du matin, qui se flatte d'avoir des rédacteurs qui écrivent bien, en est plein». ${ }^{19}$

\footnotetext{
11 Ibid., p. 64. Se habla de Blasco Ibáñez, de la música de Albéniz y Granados, de la pintura de Sorolla y Zuloaga, etc.

12 Ya existe un estudio comparativo de Contraataque y L'espoir de Malraux: Jean-Pierre REsSOT, "De Sender a Malraux», en José-Carlos MAINER, ed., Ramón J. Sender. In memoriam. Antología crítica, Zaragoza, Diputación General de Aragón, Ayuntamiento de Zaragoza, Institución Fernando el Católico y Caja de Ahorros de Zaragoza, Aragón y Rioja, 1983, pp. 333-341.

13 M. C. Peñuelas, op. cit., p. 135.

14 «En realidad, el estilo surge espontáneamente del fondo del ser y, naturalmente, el mejor estilo es el que no se percibe» (ibid., p. 223).

15 Ibid., p. 213.

16 Ibid., p. 176. También es verdad que reconoce que no ha leído lo suficiente de ese movimiento.

17 Especialmente desde la época de Luis XIV.

18 M. C. PEÑuelas, op. cit., pp. 253-254.

19 «Rabelais il a râté son coup», en Céline, París, Éd. de l’Herne, 1972, p. 44.
} 
Por otra parte, Álbum de radiografías secretas no es un libro de memorias, puesto que no existe pretensión alguna, por parte del autor, de contar su infancia o cualquier otra etapa de su vida con detalle. Tampoco existen condicionantes espaciales o temporales. Las referencias a épocas y lugares son diversas y sin orden aparente. ${ }^{20}$ Sender habla de amigos y conocidos unidos por redes de conexión difusa que no desvelan la supuesta lógica de la sucesión de capítulos. Si destacamos lo francés, desfilan por el libro escritores de perfil esbozado, como Simone de Beauvoir, Sartre, Breton, Saint-Exupéry o Saint-John Perse, junto a otros que sí parecen haber dejado una profunda huella en el autor, como Romain Gary, Vercors y sobre todo Albert Camus y Simone Weil, a los que dedica capítulo.

En el caso de Weil tal vez ocurra lo mismo que con Camus, ese «ordinario ser excepcional» 21 del que explica Francisco Carrasquer: «Puede que lo que de buenas a primeras más aproxima Sender a Camus sea la común simpatía por el anarquismo $\longrightarrow$ más propiamente por el anarquismo espanol- del autor de La peste». ${ }^{22}$ Casualmente el encuentro entre Weil y Sender también se produjo en las filas del movimiento anarcosindicalista, concretamente barcelonés, a cuyas cocinas había ido a parar la filósofa anónima. Al leer las palabras que Sender escoge para hablar de la escritora judía, diríase que encontró en esa mujer su alma gemela ${ }^{23}$ en su desprecio por los bienes terrenales puramente crematísticos, en su rechazo de la explotación de los seres humanos y, sobre todo, en su necesidad de alcanzar para su existencia una dimensión religiosa o mística, no ortodoxa. Queda reflejado el ambicioso vínculo entre ambos en la siguiente aseveración: «También buscábamos los dos, con la misma pasión secreta, la manera de lograr un pacto de nuestro espíritu (o del espíritu humano en general) con el universo, nada menos". ${ }^{24}$

Llegados a este punto, una pregunta nos asalta: ¿por qué Sender no cita nunca a ese «ateo místico» ${ }^{25}$ que era Anatole France? Dentro de la filiación literaria progresista sí alaba en cambio «la conducta de hombres como Voltaire, Rousseau, y más tarde los rebeldes de la Comuna. Bueno, y todos los demás, los de la famosa Enciclopedia». ${ }^{26}$ Aun reconociendo que le es impo-

20 «[..] prefiero comenzar por el nivel histórica y folklóricamente popular. Es lo que se entiende por abajo" (Álbum..., cit., p. 7).

21 O el "mestizo iluminado» (ibid., pp. 161-162).

22 «Sender por sí mismo», Alazet. Revista de Filología, 4 (1992), p. 90.

23 En un arrebato irónico de superstición recuerda Sender que ambos nacieron el mismo día del mismo mes, el 3 de febrero (Álbum..., cit., p. 64).

${ }^{24}$ Ibid., p. 64. Remitimos al artículo "Sender por sí mismo", del profesor Francisco CARRASQUER, para un estudio más en profundidad de las concomitancias filosóficas entre ambos.

$25 \mathrm{G}$. LONDEIX piensa que esta definición que hace A. France de Eurípides le sienta perfectamente al novelista, ya que así se ve a sí mismo ("Prólogo" al libro de Anatole FrANCE, Les fous dans la littérature, París, Le Castor Astral, 1993, p. 18).

26 Álbum..., cit., pp. 220-221. 
sible hablar de todas sus lecturas y que no pudo por razones cronológicas conocer personalmente al autor, echamos de menos a un escritor que, con todos los aciertos y carencias de su clasicismo, lo había sido todo en la cultura francesa de principios de siglo y que era leído con fruición por las capas progresistas de la sociedad, especialmente por los libertarios. ${ }^{27}$ La única referencia que encontramos encierra una buena dosis de desprecio y surge a propósito de los préstamos literarios: «No soy como aquel (creo que fue Anatole France) que dijo en una ocasión parecida, altivamente: "Je prends mon bien où je le trouve"». ${ }^{28}$ ¿Agrada tal vez el poeta y el periodista pero repele el académico y el Premio Nobel en que se convirtió France? Esa puede ser una de las explicaciones del desafecto o acaso creyó Sender como Breton que el estilo decimonónico del autor era ya cadáver. ${ }^{29}$

De todos modos, desde el rechazo de la literatura de pura evasión a través de parábolas y alegorías, hasta espacios autobiográficos, pasando por su compromiso en causas sociales y políticas, ${ }^{30}$ Sender, que también creyó en su juventud que «[e]l realismo [...] sólo encuentra su diapasón, su tono, en la literatura revolucionaria», ${ }^{31}$ tenía que reconocer en él a un escritor menos moderno en las formas, pero no menos radical, irónico y complejo en su percepción de la realidad y la literatura. Fantasía, realismo y lirismo fueron armas comunes a ambos escritores.

En verdad se echa de menos, como digo, el nombre de Anatole France, pero de ninguna manera su presencia. ¿Acaso es una mera casualidad que cuando Sender redacta en la adolescencia ${ }^{32}$ Orestiada de los pingüinos (Bajo el signo de Piscis), publicada posteriormente en 1981 entre sus novelas zodiacales, escoja un tema que France había novelado en L'île des pingouins en 1908, muy pocos años antes de esa primera redacción? La tesis del palimpsesto resultaría obviamente excesiva ya que la novela de Sender no es una reescritura de la obra francesa, a su vez reescritura de la historia de Francia y en última instancia de la de la humanidad. Sin embargo, el afán de condenar a unos animales, cuyo parecido con los hombres

\footnotetext{
27 M. C. BANCQUART expone su denuncia de la tiranía: "Tout pouvoir secrète l'abus. France annonce ici le Camus de L'Homme Révolté, et révèle une fondamentale an-archie» (CEuvres IV, París, Gallimard [«La Pléiade»], 1994, p. XVII).

28 Carta a Francisco Carrasquer, 17-XI-1977, publicada en Alazet, 3 (1991), p. 219.

29 Los surrealistas condenaron, a nuestro entender, de forma apresurada e irresponsable a Anatole France y en su entierro difundieron el panfleto "Un cadavre».

30 Sender tuvo "Casas Viejas" y Anatole France el «caso Dreyfus». Además, ambos se acercaron a los comunistas para desmarcarse de la revolución soviética posteriormente.

31 Alardo Prats y BeLTRÁN, "Vendaval de las letras: Siete domingos rojos de Ramón J. Sender», La Libertad, 31-VII-1932, p. 8.

32 Jesús Vived MAIRAL hace referencia a este hecho en el prólogo a Primeros escritos..., cit.
} 
es singular, ${ }^{33}$ a corromperse con las lacras de los seres humanos, a tropezar con las mismas incomprensiones e intolerancia es similar en las dos obras. En el planteamiento de Anatole France, los pingüinos evangelizados siguen los mismos pasos que los humanos, por lo que el relato de sus experiencias se transforma en una sátira parabólica de la vida pública y política francesa en sus grandes etapas. Sender baraja un camino inverso (de hombre a pingüino) e incluso su texto puede ser interpretado como una prolongación, desde una perspectiva personal distinta, de la novela de France: «Y es muy posible, y yo al menos lo creo, y tengo razones para mantenerme en esta creencia, que esos pingüinos han venido aquí después de haber vivido entre los hombres en tiempos remotos. ${ }^{34}[\ldots]$ Y han venido aquí no a rectificar lo que hicieron sino a comprenderlo repitiéndolo y volviendo a hacerlo [...]». ${ }^{35}$ Anatole France tenía puestas todas las esperanzas que le quedaban en la fuerza ejemplificadora de la novela con el fin de que, "[l]orsqu'ils verront leurs actions ainsi travesties et dépouillées de tout ce qui les flattait, les pingouins en jugeront mieux et, peutêtre, en deviendront-ils plus sages». ${ }^{36}$ Finalmente, divididos por credos de origen dudoso y arbitrario, ${ }^{37}$ los pingüinos son impulsados al asesinato $\mathrm{y}$ a la guerra en ambas novelas.

Que la historia se repite no lo duda tampoco ninguno de los dos autores. L'île des pingouins acaba, de forma circular, con la reconstrucción de una inmensa ciudad tras su aniquilación a manos de terroristas; ${ }_{r}^{38}$ en cuanto a Sender, aprovecha la Orestíada de los pingüinos para precisar de nuevo su teoría de la espiral: «Y lo que sucedió ayer vuelve a suceder mañana, no en círculo ni en elipse sino en espiral helicoide». ${ }^{39}$

\footnotetext{
33 En la obra de Anatole France un cura los confunde con una asamblea de notables y los bendice, siéndoles otorgada un alma inmortal. Para SENDER los pingüinos son «hombrecitos vestidos de gala» o de frac (Orestíada de los pingüinos [Bajo el signo de Piscis], Barcelona, Destino, 1981, p. 34).

34 Así sucede en la novela del escritor francés.

35 Op. cit., p. 35.

36 lbid., p. 11.

37 En Sender importa la orientación del contoneo y se distinguen los pingüinos emperadores de los adelias y de los pájaros bobos. En la obra de France, las clases sociales se basan en supersticiones como la del «Dragon de Silène», cuyo vencedor funda la primera dinastía real.

38 «Quinze millions d'hommes travaillaient dans la ville géante», pp. 241 y 255. Además, esta novela no es la única obra de Anatole France que se pueda relacionar con la Orestíada de los pingüinos. Les Dieux ont soif es, con un trasfondo amoroso bajo el terror revolucionario de 1793 y 1794, una reescritura del mito de Orestes. Frente al texto senderiano: «Ifigenia quiere que todo el mundo sea honesto y que la sociedad pingüina sea ejemplar pero esa ejemplaridad sería mortal», p. 153, se yergue premonitorio el de Anatole France hablando de Gamelin, el personaje principal atormentado por las Furias: «Il est vertueux, il sera terrible», p. 166.

39 Orestíada..., cit., p. 58.
} 
Se libera Sender de la angustia existencial ${ }^{40}$ a través de la carcajada que supone deificar a Charlot como arquetipo de los pingüinos ${ }^{41}$ y acercarse a Sileno, bufón del Olimpo y revelador del secreto de la vida humana. ${ }^{42}$ Sileno está presente a través del dragón que lleva su nombre en Anatole France. «Céline creía también que a pesar de todo hay grandes compensaciones y la mayor es la carcajada de Sileno, el único dios feo", ${ }^{43}$ afirmaba Sender, y él mismo escribía lo siguiente: «Orestes: ¿Y qué hace allí, Sileno? Ifigenia: Lo de siempre. Ríe y ríe y ríe», ${ }^{44}$ porque «[t]al vez aquella risa podía ser la única respuesta posible a ESO». ${ }^{45}$

Riámonos para no enloquecer: ésa podría ser la consigna. Sender simpatizaba, según Josefa Rivas, con los locos por encontrarse éstos más cerca de Dios. ${ }^{46}$ Anatole France dio muestras de la misma inclinación al publicar un libro titulado Les fous dans la littérature, además de ser el autor preferido de Freud. ¿A cuál de los dos novelistas, si no fuera porque queda desvelada la identidad en la propia cita, describe Ferenczi cuando opina que «Anatole France n'a rien d'un pessimiste chagrin. Il juge les actes de ses prochains avec bonne humeur, charité, même s'il s'y mêle quelque ironie?». ${ }^{47}$

Sender sentenció: «Para mí hay solamente dos cosas serias en la vida: la risa y la santidad $»^{48}$ y probablemente ambas cosas había encontrado en la obra de Céline. Una risa silénica, como ya se ha dicho, y una risa que, siguiendo las teorías literarias de Bajtín, Kronik o Rosen, puede ser calificada de «grotesca». Una santidad o religiosidad ${ }^{49}$ que Sender desvela

\footnotetext{
40 Siempre recalca, a pesar de haber expresado su intuición literaria en términos de «existencia» antes que de "esencia" (cfr. M. C. PeÑuelas, op. cit, p. 210), que no es "existencialista". "Como ve, no soy existencialista» (“Cuestionario" de Francisco Carrasquer a Ramón J. Sender, Alazet, 3 [1991], p. 185). En el libro de M. C. Peñuelas matiza la cuestión porque distingue el fondo "existencialista» que hay en toda literatura, especialmente la española, y el «existencialismo francés»: «Pero la diferencia con el existencialismo francés es que así y todo nosotros aceptamos la vida afirmativamente y sin resignarnos» (M. C. PENLELAS, op. cit., p. 152).

41 SENDER escibía en 1932: «La literatura ha hecho mucho daño a algunos de estos artistas, y últimamente al más celebrado de todos: a Charlot» («Hoy. Seis reales de risa», La Libertad, 8XI-1932, p. 1).

42 No todas las historias de la mitología concuerdan. Esta revelación se cita en el Larousse pour tous, 1910, pero el Diccionario de mitologia universal de J. F. M. NoËL, ed. facsimilar, Edicomunicación, 1987, p. 292, sólo alude a la capacidad de transformar las cosas en oro.

43 Álbum..., cit., p. 345.

44 Orestíada de los pingüinos..., cit., p. 135.

$45 \mathrm{Ibid}$., p. 164. Eso es la muerte, el caos y la condición humana...

46 " [...] parece tiene raíces en la idea islámica de que ellos [los locos], así como las criaturas de tierna edad están más próximas a Dios y a las verdades eternas", en El escritor y su senda. Estudio crítico-literario sobre Ramón J. Sender, México, Ed. Mexicanos Unidos, 1967, p. 238. Sender valora, sin embargo, la gran salud mental de Stendhal. Cfr. M. C. PENUUELAS, op. cit., p. 226. 47 A. FRANCE, Les fous dans la littérature, cit., p. 19.

48 Álbum..., cit., p. 87.

49 "Tal vez la suya era la exasperación de un santo" (ibid., p. 346).
} 
incluso antes de que la crítica celiniana más moderna se interesara por este aspecto. ${ }^{50}$ Sender intuye que Céline pretendía hacer poesía en sus novelas y en su vida al no atreverse a dedicarse en cuerpo y alma a la poesía pura. ${ }^{51}$

Para algunos estudiosos de la obra celiniana, su novelística, especialmente la de tipo lírico-teatral, marcada por leyendas celtas o dioses del Olimpo, emerge de la frustración de un mundo espiritualizado que no tuvo ningún éxito ante el público. ${ }^{52}$ Así se entiende que, como hiciera André Brissaud con su artículo «Voyage au bout de la tendresse», 53 Sender se dedicara a destruir el mito de un Céline "odiador», si se nos permite el neologismo: «En sus libros no hay odio, sino una especie de amor fermentado e imposible. Para un lector atento y sagaz hay detrás de las aparentes blasfemias de Céline un sentimiento religioso latente y vivo, que se extiende por toda su obra». .54

Ramón Sender visitó a Céline en los años $30^{55}$ y ofrece de él una descripción ajustada a la «realidad legendaria» del interlocutor. Usamos esta paradoja como homenaje a la voluntad del autor francés porque las contradicciones son en parte su esencia misma: «Tout, mes décisions et mes gestes sont fantasques». ${ }^{56}$ No conviene olvidar tampoco que la narración de las circunstancias que rodearon este encuentro es muy posterior a la fecha del mismo, por lo que el autor oscense pudo matizar sus opiniones a posteriori. Céline aparece en palabras de Sender como un "genio diabólico» ${ }^{57}$ o un "endemoniado», 58 palabras que enmarcan al autor en una dinámica binaria, sostenida por la mayor parte de la crítica; esa fusión de doctor Jekyll y mister Hyde a la que tan a menudo se ha recurrido para hablar de Céline. ${ }^{59}$

\footnotetext{
50 Varios son los estudios que se han interesado por la cuestión; entre ellos se pueden citar las obras de Paul dei. Perugla, Céline, París, NEL, 1987, y Nicole Debrie, Il était une fois Céline, Aubier, 1990.

51 Álbum..., cit., p. 338. Recuerda Rafael BoscH en «La species poetica en Imán, de Sender», que éste decía en Los cinco libros de Ariadna: "mi acento natural era la poesía”, en José-Carlos MAlNER, ed., Ramón I. Sender. In memoriam. Antología crítica, cit., p. 291. F. CarRasouer habla de "estado poético» en el prólogo de Imán, Huesca, Instituto de Estudios Altoaragoneses, 1992, p. XCVIII.

52 E. MAzET, «Céline et Mahé à bord de l’Enez Glaz», en Actes du colloque de Toulouse, París, Du Lérot Éd., 1991, p. 150.

53 Ésta era una respuesta a otro artículo publicado al poco del regreso de Céline del exilio y cuyo título era «Voyage au bout de la haine». Cfr. Céline, cit., pp. 313-317.

54 Álbum..., cit., p. 348.

55 Lo confirma J. Vived en su artículo del número monográfico de Alazet dedicado a Sender, donde explica que por esos años Sender se dedicó a visitar autores como el hispanista Jean Cassou, Céline o Jacques Roumain (Jesús VIVED MAIRAL, «La vida de Ramón J. Sender al hilo de su obra", Alazet, 4 [1992], p. 257).

56 Sender, en 1932, decía irónicamente de Gide que «un hombre de talento que se contradice siempre es sincero", en el artículo citado de La Libertad.

57 Álbum..., cit., p. 341.

58 Ibid., p. 342.

59 Cfr. D. Álvarez, «A vueltas con Céline», El Basilisco, 8 (primavera de 1991), pp. 91-95.
} 
Existe en Sender, como en casi todos los admiradores de la obra literaria de Céline, la voluntad de separar al escritor de Voyage au bout de la nuit y de Mort à crédit ${ }^{60}$ de la persona que redactó tales obras. Sender se apresura a precisar que no hubiera visitado a Céline si éste, el de 1938, hubiera sido el de 1942, olvidando que ya por aquellas fechas Céline había publicado por lo menos Bagatelles pour un massacre ${ }^{61}$ y tenía en prensa Ecole des cadavres, sus dos primeros panfletos antisemitas.

En un segundo tiempo, las reflexiones de Sender se ordenan según un libro de contabilidad con la resta por un lado y el haber por otro. Frente a lo que se ha condenado siempre en el autor francés (filofascismo, antisemitismo, ${ }^{62}$ colaboracionismo, vocabulario y, comportamiento soez $)^{63}$ surge lo que redime: una infancia desgraciada - se le puede perdonar todo al que ha sido odiado por su madre-,${ }^{64}$ la práctica desinteresada de la medicina para aliviar a los más necesitados, ${ }^{65}$ su benevolencia hacia los niños y los animales y, sobre todo, la penitencia que conlleva su postura, pues Céline se hunde en su desesperanza y se destruye ante la sociedad: «Et pour tout avouer, si je me suis mis tant de gens à dos, l'hostilité du monde entier, je ne suis pas certain que ça ne soit pas volontairement. Précisément pour ne pas être populaire, ne pas avoir à être flatté par un tel et prendre de l'importance [...]". ${ }^{66}$

60 A este respecto, SENDER confunde estas dos obras porque Mort à crédit no trata ni de su experiencia africana ni de la americana, como afirma en las páginas 338 y 342 del Álbum de radiografias secretas, cit.

61 Publicada en 1937, tuvo un éxito similar al de Voyage. Lo que sí es cierto, según J. P. Dauphin, es que el primer panfleto no fue todavía revelador: "Curieusement, l'abondant dossier de presse de Bagatelles pour un massacre ne présente pas le clivage politique que l'on a supposé depuis [...]. Il faudra attendre l'École des cadavres pour que Céline soit rejeté ou -mais avec des nuances parfois suspectes- revendiqué, accepté, voire seulement toléré" (Les cri tiques de notre temps et Céline, ed. de J. P. Dauphin, París, Garnier, p. 63).

62 Según Céline sólo en el plano literario pero no en el político ni en el social. Álbum..., cit., p. 345 .

63 «Los lectores pasan por todo a cuenta del placer de su prosa», Álbum..., cit., p. 344.

64 Al igual que una gran parte del público, antes de que las investigaciones demostraran la verdad, Sender cree que los padres de Céline fueron unos tiranos. Probablemente, por su amor a su madre Andrea le parezca todavía más cruel la supuesta maldad de la madre del autor de Voyage, cuando no se trata más que de uno de los montajes creados en parte por el propio escritor, pero también por una interpretación excesivamente simplista del carácter autobiográfico de la obra de Céline. Acerca de la infancia del escritor véanse los documentadísimos libros de Frédéric Vitoux, La vie de Céline, París, Grasset, 1988, y François Gibault, Céline 1e partie. Le temps des espérances (1894-1932), París, Mercure de France, 1977.

65 Incluidos algunos miembros heridos de la Resistencia. Cfr. «Céline ne nous a pas trahis», de Robert Champletury, en Céline, cit., pp. 246-251.

66 Esta reflexión nos permite entrever que Céline rechaza lo que Sender llama la «máscara». De hecho, Céline apenas se relacionó con el ambiente mundano de los cenáculos literarios y no se pavoneaba como suelen hacer tantos escritores de éxito. Pero no es menos cierto que hizo de su vida una creación literaria. Sender quedó decepcionado al conocer personalmente a Céline, pero "[s]eguía respetándolo porque a pesar de todo había en él una renuncia virtuosa a cualquier clase de respeto» (Álbum..., cit., p. 350). 
Céline alcanza según Sender dos estados: el de la independencia, que acarrea la pobreza - efectivamente murió pobre, aunque quejándose siempre de la avaricia de sus editores $-{ }^{67}$ y el de la sinceridad, que acarrea la soledad. Todo lo cual le permite realizar lo que, en opinión de Sender, tiene que ser la labor primordial del escritor, "la definición del mal»: 68 «Hay que tratar de colaborar en la definición del mal. Y la mejor manera, creo yo, consiste en ponerse al lado de los débiles». ${ }^{69}$

Los más débiles suelen ser siempre los que sufren las guerras, ${ }^{70}$ aquellos que se parecen a los personajes de Imán y de Voyage au bout de la nuit, ambas operas primas, ${ }^{71}$ moldes de respectivas escrituras y novelas de carácter semi-autobiográfico, seudo o para-autobiográfico, si utilizamos los términos de Roger Duvivier, ${ }^{72}$ y antimilitarista. El paralelismo es sorprendente si se tiene en cuenta que Louis F. Destouches (apellido verdadero de Céline) y Sender mostraron en un primer momento cierto entusiasmo patriótico. El primero fue voluntario y destacó por su valor; fue condecorado y fotografiado en una portada del Illustré National. Sender, según Charles L. King, fue «war cited for bravery in action and was awarded the Medal of Morocco» ${ }^{73}$ y, en opinión de Seco Serrano, era un chico con «clara vocación militar» ${ }^{74}$ plasmada en la redacción de las «Impresiones del carnet de un soldado», mientras Céline ejercitaba su pluma en «Carnet du cuirassier Destouches».

También Bardamu como Viance (un simple cambio de consonante le puede convertir en francés en «carne» de cañón: viande) acceden a la guerra, cayendo en una trampa muy similar. ${ }^{75} \mathrm{El}$ primero ve pasar un regimiento dirigido por un oficial montado en un espléndido caballo y se deja enrolar. Viance, seguramente, marchó «obedeciendo un impulso ajeno y

67 Cfr. Lettres à la NRF (1931-1961), ed. de Pascal FouCHÉ, París, Gallimard, 1991.

68 Album..., cit., p. 346.

69 M. C. PeÑuelas, op. cit., p. 222.

70 «Nada más abajo que la circunstancia bélica: la guerra» (Álbum..., cit., p. 7).

${ }^{71}$ Pero que marcaron una época en sus países respectivos. Para H. GODARD, en Voyage au bout de la nuit de L. F. Céline, París, Gallimard («Folio»), 1991, p. 11, la novela de Céline se describe de la forma siguiente: "Il est de ces livres qui surgissent dans l'histoire contemporaine et qui s'imposent à l'instant». Mientras para Luis Bello «Imán pertenece a esa serie [...] de libros que se escribieron porque debieron ser escritos" (apud F. CARRASQUER, introducción citada a Ramón J. SENDER, Imán, p. XLIII).

72 «Las premisas de la obra autobiográfica en la primera época del escritor Ramón J. Sender», en Ramón J. Sender. In memoriam..., cit., p. 147.

73 Ramón J. Sender, Nueva York, Twayne Publishers, 1974, p. 20 (apud J. VIVED MAIRAL, prólogo citado a Primeros escritos).

74 Jesús Vived recoge también esta opinión así como la de José Domingo Dueñas acerca del carácter irónico de los supuestos artículos «militaristas» de Sender.

75 El personaje senderiano atrae las desgracias como un imán, mientras Bardamu sufre todo tipo de desventuras: «Si elles ne se produisent pas d'elles-mêmes, il finit toujours par les provoquer» (Romans I, ed. de H. GodarD, París, Gallimard [«La Pléiade»], 1981, p. XXXIV). 
admirando a los héroes que salen retratados en los periódicos». ${ }^{76} \mathrm{La}$ única posibilidad de salir de esa pesadilla y de esa farsa sin sentido es la literatura y la «irrealidad»: «ante la maldad [...], la única defensa es hacer esa realidad inverosímil y salvarla. En este caso, por la irrealidad " 77 Céline no se expresaba de otro modo cuando decía: «la vie objective réelle m'est impossible [...] alors je la transpose tout en rêvant». ${ }^{78}$ Mientras el personaje de Sender es «acuciado por los trallazos de un extraño domador de circo que cabalgaba sobre las nubes y cuyo látigo restallaba aquí, allá a ras de tierra», ${ }^{79}$ los muertos se le aparecen a Bardamu por el cielo de Montmartre. La lectura en paralelo de ambas novelas es, pues, tan sugerente que se merece un futuro estudio en profundidad. Aunque sólo sea porque tanto Céline como Sender son autores de estructuras y de emociones antes que de palabras. Para Rafael Bosch se trata de "sensibilidad emocional» y no de inteligencia. ${ }^{80}$ Para Céline, "dans les Écritures, il est écrit: “Au commencement était le Verbe". Non! Au commencement était l'émotion». ${ }^{81}$

Ramón Sender percibía en la literatura francesa "zonas de sensibilidad perfectamente falsas», ${ }^{82}$ eso que ya decía en 1932 acerca de Gide en $L a$ Libertad: "se puede hacer un gran mosaico de verdades pequeñitas y fraccionarias - gran virtud francesa - que ofrezca, sin embargo, una visión de conjunto llena de contradicciones». ¿En qué medida Céline responde o escapa a esa tendencia? En la respuesta a esa pregunta reside gran parte de la fascinación que ejerce este autor sobre sus lectores. Como dijo muy bien Sender, "[s]u situación tiene un atractivo mágico para nosotros»" ${ }^{83} \mathrm{y}$ ambos, tanto Céline como Sender, vienen a confirmar lo que en una ocasión dijera el escritor de Chalamera: «la ciencia se equivoca y el arte no se equivoca nunca. La ciencia nunca es definitiva, es decir, Copérnico rectifica a Tolomeo y Newton rectifica a Copérnico, y Einstein rectifica a Newton. Pero Cervantes no rectifica a Homero, y Lorca no rectifica a Virgilio. Cada uno representa un nivel de la intuición exploradora y creadora que satisface a la humanidad de su tiempo y a la de hoy». ${ }^{84}$

\footnotetext{
76 En las notas a la primera edición de Imán (ed. cit., p. 4).

77 M. C. PENUELAs, op. cit., p. 123.

78 Milton Hindus, Céline tel que je l'ai vu, París, Éd. de l'Herne, 1969, p. 152.

${ }^{79}$ Imán, Ed. Orbis, 1985, p. 177.

80 En «La species poetica...», cit., p. 292.

81 En Cahiers Céline 2, París, Gallimard, 1976, p. 87.

82 Partiendo de Racine y Corneille cita incluso a Proust. En M. C. PfÑUEt.AS, op. cit., p. 253.

83 Álbum..., cit., p. 346.

84 M. C. Peñuelas, op. cit., p. 241.
} 


\title{
El imaginario literario de Sender en el norte de África
}

\author{
Vicente Moga Romero \\ Archivo Municipal de Melilla
}

\begin{abstract}
Una guerrera ensangrentada aparece sobre un romero. En el cuello sólo queda un número de metal: el 2; pero al lado se ve la huella del 4, no descolorida aún. Tiene la mañana tintes desvaídos. Es natural. Ha perdido tanta sangre, que no podrá ya curarse nunca esta anemia, recuperar una apariencia de salud. (Sender, 1992, 138)

-Dios. Yo soy Dios. ¿No lo ves en mi chilaba nueva, en el albornoz blanco?

- Dios es español.

- Me he pasado a los moros. Dios está siempre del lado del que puede más. (Sender, 1992, 178)
\end{abstract}

\begin{abstract}
Cuar
uando en el año 1990 reedité en Melilla la novela Cabrerizas Altas, de Ramón J. Sender, junto a las dos series de artículos que el autor había publicado en el periódico melillense El Telegrama del Rif, entre abril de 1923 y enero de 1924, bajo los títulos de "Arabescos» $\mathrm{e}$ "Impresiones del carnet de un soldado", tuve la certeza de que Sender había quedado de alguna forma profundamente marcado por la impronta de la ciudad a la que vino a realizar el servicio militar como alférez de complemento y no era sólo que el autor de Imán hubiera quedado «impresionado» por las secuelas del denominado «desastre de Annual», en julio de 1921, sino que, sobre todo,
\end{abstract}


me parecía detectar en algunas de las páginas literarias senderianas el marchamo de una huella imborrable provocada por su estancia norteafricana, cuando apenas despuntaba el «alférez banderado del amor» a la primera veintena de su existencia.

Las descripciones dedicadas al barrio melillense del Polígono, en Cabrerizas Altas, reiteradas en Crónica del alba, en el "Cuaderno sexto", a través del peculiar realismo senderiano, surrealista y expresionista a partes iguales - lo que Sender llamaba «juegos de fantasía con mi mundo inconsciente» (Sender, 1980, vol. 2, 363)-, cuando sin embargo han pasado casi cuarenta años desde la primera aparición de Imán, me llevaban a pensar que la ciudad en que Sender vivió durante su estancia de apenas un año en el norte de Marruecos había despertado en el incipiente escritor una sensibilidad definitiva que bien podría haber marcado el resto de su obra. No en vano escribió: "Allí [en el Polígono] aprendí yo a ver cómo Dios se contempla en los espejos de nuestras almas, especialmente los días nublos con un poco de fuego en las vertientes" (Sender, 1980, vol. 2, 333).

La tesis, atractiva para un melillense, no deja de tener apoyos en los discursos literarios y vitales de otros escritores coetáneos de Sender y que como él pudieron quedar marcados por la impronta «africana», como Ernesto Giménez Caballero, José Díaz Fernández, etc., en un proceso que desde luego parece continuarse en el tiempo hasta la época actual a través de otros muchos y cualificados hombres de letras que han tenido como única vinculación con Melilla la realización en ella del servicio militar, pero que de alguna manera han necesitado expurgar los sentimientos surgidos en una ciudad ya para siempre imborrable de su propio devenir a través de crónicas periodísticas, cuentos, novelas, poesías, etc. Un escritor especialmente cualificado por su propia experiencia histórica, Arturo Barea, expresa el impacto de la experiencia marroquí en Sender:

[Sender] sirvió en Marruecos, en el corrupto ejército colonial que peleó la guerra del Rif y en la que vio a gentes como las de su poblado masacradas, mutiladas, y a lo menos miserablemente desarraigadas por causa de una frívola política de prestigio, y a través de la ineptitud o avaricia de la casta militar. Cuando regresó a la vida urbana, describió lo que había visto --la lucha de soldados indefensos- en su primera novela, Imán. Fue un grito revolucionario, un trabajo de arte, y la primera novela realista española que fue más allá de lo superficial, hacia la vida semiconsciente de la mente, e hizo articular el mundo de la gente inarticulada a través de signos externos. Leí Imán cuando todavía mis propias experiencias de la desatrosa campaña marroquí estaban demasiado frescas en mi mente, y me pareció que Sender había expresado toda la miseria, la degradación, la confusión y el resentimiento de cualquier soldado que es involuntariamente parte de una fea máquina de guerra. (Barea, 1948, 11-12)

Sin embargo, la tesis que se plantea en este pequeño artículo - surgido como un esbozo, un rápido apunte de corazonadas e intuiciones literarias- puede centrarse en torno al tema del «imaginario senderiano» puesto a prueba, confrontado, durante un breve pero intenso periodo de 
tiempo, en el propio decorado de su fantasía o, al menos, de una de sus fantasías proclamadas a posteriori desde las páginas de sus escritos: la vivencia de África. Siempre me ha interesado saber el nivel de conocimientos y de comprensión que alcanzó Sender, en su época melillense, de la sociedad rifeña y cómo conjugó su prístino imaginario del mundo rifeño - es decir, el horizonte cultural que Sender tenía preestablecido al desembarcar en Melilla - con el choque que debió de suponerle la irrupción en ese mundo ya real que él había soñado en su juventud desde una biblioteca de Zaragoza - los jueves llegaba una revista "con una historieta de aventuras de dos exploradores ingleses en África» (Sender, 1980, vol. 1, 324) - y que había descrito más tarde como un «destino" conocido al señalar que no le había sorprendido su envío a Marruecos, ya que "había leído tanto sobre aquel sombrío y árido país y sobre las condiciones de la vida militar en las colonias que no me sorprendió nada en absoluto" (Sender, 1980, vol. 3, 125).

Qué contraste aparece si se compara con la narración pesimista de la vuelta de Viance, el desolado antihéroe de Imán, a España cuando encuentra que

El campo, el paisaje [de España], no son lo que se figuraba en Marruecos. No hay tanta diferencia entre aquel campo y éste. Matas, tomillo, tierra parda, blanca y alguna vez rojiza. Cuervos, lo mismo que allá. Esperaba que esta tierra le hablara al corazón. (Sender, 1992, 278)

Sabemos que entre sus lecturas de juventud podían figurar autores como Pedro Mata, autor de una novela «orientalista» de corte africano, titulada Los moros del Rifo el presidiario de las Alhucemas (Madrid, 1858), que transmite la imagen precolonial del rifeño, imagen que permanecerá casi intacta en todo el discurso colonial de la primera mitad del siglo XX:

Los berberiscos rifeños, de libres y vagabundas inclinaciones [...] ora porque con sus intransigentes odios a todo lo nuevo y extranjero no saben vivir en paz con nadie, y en especial con los cristianos [...]. A esa ferocidad verdaderamente africana se debe acaso que, siquiera yazca el Rif a las puertas de la civilización europea, y esté lindando con España, [...] sea al fin y al cabo tan desconocido.

Sus montes y sus ríos son bastardos; no tienen nombre ni pila bautismal; no se sabe si hay villas, pueblos o aldeas, o si viven sus aduares y kabilas debajo de cuevas, casas como colmenas, o de las tiendas portátiles [...] todo yace en la más profunda oscuridad para nosotros.

Ineficaces barreras de esos cafres y hotentotes septentrionales son nuestros presidios de África [...].

Cuando en el transcurso de esta historia penetremos ora en los montes, ora en las llanuras del Rif, ya descubriremos en las peñas o en las arenas alguna blanca calavera que nos relate los memorables hechos de armas de nuestros antecesores, mientras cruzaron sus espadas toledanas con el yatagán de esos salvajes. (Mata, 1934, 6-7)

Más aún pudo ver estimulado sin duda su primer horizonte literario del imaginario oriental con la lectura juvenil de la obra de Salgari, entre las 


\section{EL LUGAR DE SENDER}

que figura una dedicada a la región de Melilla, I briganti del Riff (Florencia, 1911), donde el joven Sender pudo leer una nueva descripción de los temibles rifeños:

I Barbari del Riff non somigliano ai Mori. Sono uomini biondi, di carnagione quasi bianca, che non conoscono né sultano, né kaid, e che non hanno altra legge all'infuori di quella del loro fucile. D'instinti sanguinari, dotati d'un coraggio a tutta prova, che nemmeno i cannoni europei hanno mai saputo domare, annidati sulle loro alte montagne, od imboscati sulle rive del Mediterraneo, entro le alte dune, sono stati quelli che hanno sempre dato da fare piú di tutti i Marocchini dell'ovest. (Salgari, 1992, 105)

Las propias crónicas firmadas por Víctor Ruiz Albéniz - «El Tebib Arrumi", es decir, el médico cristiano- en el periódico La Tierra y las de otros periodistas nutrieron de información al primer Sender (Sender, 1993, XXVII), aunque hay que hacer constar que siempre le llegaba una visión ya elaborada, a través de intermediarios más o menos cualificados, por lo que en realidad lo que obtuvo fue un análisis depurado, y sesgado, de la realidad «africana», bagaje con el que viajó a Melilla, capital de la región oriental del protectorado español en Marruecos, esencialmente configurada por el mítico Rif:

Er-Rif الرئ es una palabra árabe que significa país cultivado y fértil, normalmente sobre las orillas de un río y a continuación de un desierto. En kabilio rif significa borde, orilla. Los rifeños aplican este nombre a su país sin comprender el sentido.

El Rif está limitado: al norte, por el mar Mediterráneo; al este, por la provincia de Orán; al oeste, por la provincia de Djebala; al sur, por esta última provincia, y, al sudeste, sobre una pequeña superficie, por la provincia de Dhahra. [...]

Siendo la más pequeña de las diez provincias de Marruecos, el Rif ha sabido conservar su independencia desde los tiempos prehistóricos. No ha sido jamás sometida por el trono de Marruecos y ha servido constantemente de refugio a todos los rebeldes y pretendientes. En nuestros días este asilo es inviolable. Piratas, renegados, príncipes independientes, todos aquellos que no encuentran seguridad en otras partes del Imperio no tienen más que poner el pie sobre esta tierra clásica de la independencia, para no temer ser reducidos por ningún poder.

Los rifeños acogen a los extranjeros y sobre todo a los renegados españoles fugados de los presidios. La fórmula musulmana la ilaha illa Allah, Mouh'ammed rasoul Allah (no hay más Dios que Alá, Mahoma es el profeta de Alá) es un salvoconducto mágico para todo europeo que el destino envía a las manos de estos farrucos montañeses. (Mouliéras, 1895, 35)

Estando ya en Melilla, adonde había llegado en febrero de 1923, conoció que había ganado el concurso literario de novelas cortas de la revista Lecturas por su relato de ambiente marroqui «Una hoguera en la noche». La noticia se recogió en el periódico local, en el que colaboraba Sender, El Telegrama del Rif, el 18 de abril de 1923. Posiblemente este hecho le facilitara la colaboración en el propio diario melillense, que 
mantenía una línea conservadora, militarista y de clara opción intervencionista en Marruecos, desde su aparición, el 1 de marzo de 1902. Sender encontrará en la redacción de El Telegrama del Rif muchos aspectos concordantes con otros periódicos de juventud, como La Tribuna y La Tierra. Este último periódico, controlado por los dirigentes de la Asociación de Labradores y Ganaderos del Alto Aragón, estaba vinculado también a Enrique de las Cuevas, ingeniero industrial en Huesca, a quien Sender dedica "Una hoguera en la noche» (Sender, 1993, XCIX) y describe en $E l$ Telegrama del Rif, en la serie de "Arabescos", como "el apostol del árbol, sabio y caballero" (Sender, 1990, 185). Un hermano suyo, Francisco de las Cuevas, residía en Melilla y colaboraba en El Telegrama del Rif; suponemos que él sería el introductor de Sender ante Cándido Lobera Girela, fundador y director del periódico melillense, colaborador habitual de revistas como África Española (Madrid), España en África (Barcelona), Revista de Tropas Coloniales (Ceuta), etc., que había sido nombrado en 1916 por la República Francesa Caballero de la Orden de la Legión de Honor, que se retiró como capitán de artillería y que fue factótum de la sociedad colonial de la época:

Los indígenas, como gente inculta, son muy volubles. La volubilidad es uno de los rasgos más salientes de su carácter. Un día defienden lo que al día siguiente combaten; hoy erigen un ídolo y mañana lo echan por tierra; los entusiasmos de una hora se truecan en odios más tarde.

Son caracteres infantiles, niños grandes mal educados, árboles que se torcieron en su crecimiento, imposibles de enderezar; espíritus ligeros, impresionables, a los que sólo deslumbra y hace marchar derechos la energía, la firmeza, la justicia, y, sobre todo, la fuerza.

De ahí las dificultades de hacer efectiva la política de atracción, mediante razones y buenas palabras. (Lobera, 1909, 18)

Carlos Seco Serrano, haciéndose eco de la reedición, en el año 1990, de los artículos publicados por Sender en El Telegrama del Rif, en Melilla, los años 1923 y 1924, ha escrito, bajo el significativo título de «Un Sender insólito" (Seco, 1990, 7-8), cómo queda sorprendido de la insólita vocación militar del joven Sender, que muestra una actitud tan radicalmente diferente de la que plasmaría en 1930 en las páginas de Imán. Pero no parece extraño para el joven periodista que escribe con todo el aroma de la divisa de La Tierra — «Religión, Familia, Patria y Propiedad» (Sender, 1993, LXXXVI) - «Pinceladas» de exaltación de la raza española, donde «la jota ha dado siempre a todos la sensación de latido de una raza fuerte y hace pensar en aquellos cantos épico-líricos que llegaban a todas las almas hablándoles de epopeyas de raza» (Sender, 1993, 90).

Es lo mismo que ocurre con el tratamiento del "problema de Marruecos», cuando el "conformista» Sender de los primeros años achaca al líder rifeño y ya en 1923 presidente de la República Rifeña (Jumhuriya Rifiya, en rifeño), Mohamed Ben Abd el-Krim, la culpa de todos los males del ejército español y de la "patria», simbolizándola en la «rota de Annual», en 


\title{
EL LUGAR DE SENDER
}

julio de 1921, cuando publica en La Tierra, el 16 de junio de 1922, el artículo «Entre paréntesis. Responsabilidades»:

\begin{abstract}
Sustentamos una teoría sobre el problema [de Marruecos], que queremos exponer, seguros de que, cuando el expediente vea la luz en las Cortes, tendremos el honor de haber coincidido con el señor Picasso en que el responsable único de cuanto aconteció en julio del año pasado fue Abd-el Krim.

Serénense las conciencias y venga el lector a cuento. ¿Hubiera evacuado nuestro Ejército Annual si el cabecilla beniurriaguel no hubiera atacado? ¿Hubiera ocurrido la tragedia de Monte Arruit si el funesto guerrillero no hubiera sitiado a nuestros héroes? ¿Los valientes de Beni-bu-Hafar [sic; debe decir Beni Bu Gafar] hubieran sucumbido, a no ser por el empuje de las hordas rebeldes capitaneadas por el maldito rifeño? Pues, entonces, no discurramos más, no nos perdamos por los oscuros laberintos de la duda. Abd-elKrim es el único reponsable y, si no, al tiempo y al expediente de Picasso. (Sender, 1993, 108-109)
\end{abstract}

No es, pues, la época de la presencia en Melilla, nos parece así, la de la catarsis del pensamiento y la actitud de Sender, sino la Dictadura de Primo de Rivera y la radicalización de un sector de los intelectuales no sólo contra el dictador sino contra el propio rey, como ejemplifica la actitud, entre otros, del socialista Indalecio Prieto (Prieto, 1972). Podría decirse que de La Tierra a El Sol, pasando por El Telegrama del Rif, Sender realizó una verdadera pirueta ideológica, una suerte de conversión "paulina», pero siempre conservando unas referencias constantes adquiridas en su vivencia «africana»; así, el viento de Levante, visto como símbolo de la libertad (Sender, 1992, 184), azotando el barrio del Polígono y nutriéndolo de las emanaciones imaginarias del desierto africano y del más prosaico y cercano olor a mariscos (Sender, 1990, 181).

Imán fue desde luego la verdadera catarsis de Sender, para pasar del militarismo de pequeña monta (Sender, 1990, 199) y del odio al rifeño - posiblemente más odio a lo desconocido, a lo ignorado, es decir, odio de la ciega y soberbia ignorancia, mamada en las noticias censuradas y sesgadas de los periódicos de España- al nihilismo desolador de Viance, el antipatriota que diluye las responsabilidades en el colectivo y que desconoce al final de su peripecia el propio paisaje de su patria. Ha imaginado un enemigo sin patria en tierras de África - pensemos que a los rifeños los españoles les negaron su propia nacionalidad histórica: los españoles iban a África o a tierra de mores _ en la campaña de Marruecos ha imaginado una patria inexistente que no reconoce a su vuelta. En Imán aparecen eslabonados los nudos gordianos de un discurso ácrata y real de la España de los años veinte:

Es la guerra. Esto es la guerra. La banderita en el mástil de la escuela, la "Marcha Real», la historia, la defensa nacional, el discurso del diputado y la zarzuela de éxito. Todo aquello, rodeado de condecoraciones, trae esto. $\mathrm{Si}$ aquello es la patria, esto es la guerra: un hombre huyendo entre cadáveres mutilados, profanados, los pies destrozados por las piedras y la cabeza por las balas. (Sender, 1992, 168) 
El espirítu del Mío Cid, al que un paisano de Sender, Joaquín Costa, quiso encerrar bajo siete llaves, acompañó los cánticos de los soldados que iban a luchar a Marruecos, con «un impulso juvenil, una conciencia optimista" (Sender, 1992, 275), y que luego volvieron - aquellos que no figuraron en la nómina de casi veinte mil bajas- asombrados de su propia cobardía y de la visión de un país de labradores sumisos y embrutecidos por el "genético» odio al moro que poblaba España. La España negra y goyesca aparece casi al final en la amargura que destilan las palabras de Viance:

\footnotetext{
$-[\ldots]$ Si tiene usted dos hijos, procure que no vayan a la guerra. labrador]

¿Qué puede hacer uno contra eso? --replica con aire escéptico [un

- iMatarlos! (Sender, 1992, 277)
}

Podemos estar ya en condiciones de intentar una pequeña aproximación al horizonte cultural de Sender — su imaginario rifeño prístino- en Melilla, en 1923 y 1924, para lo que tenemos que recurrir ineludiblemente a sus "Arabescos", publicados en El Telegrama del Rif, y sobre todo al titulado «El rifeño por antonomasia»:

Entre todos los moros hemos hallado uno que lo es con mayor propiedad, uno que responde exactamente a la imagen que nos forjáramos a través de Ruiz Albéniz o - estilizando más- a través de Pierre Benoît.

No es exageradamente alto ni demasiado corpulento. Posee ese equilibrio de proporciones que, según dicen, determina la elegancia, Viste una chilaba blanca, blanquísima, de un albor que, sobre los hombros, en la amplia kabúa es casi azul al contrastar con el color - tierra de Siena- de su perfil duro.

Cuando lo hallamos sentímonos íntimamente satisfechos. Fue algo así como un éxito de intuición. Esa nueva facultad de los sentidos que un ateneísta llamaría conciencia estética; posee indudablemente el orgullo de su exactitud en las apreciaciones a larga distancia y a largo plazo. (Sender, $1990,183)$

El ateneísta Sender de 1923 podría llamarse el ateniense Sender cuando compara la ingenuidad y el heroísmo de sus compañeros sargentos con los de los «héroes de los poemas clásicos» de los días legendarios de Argos, Atenas y Troya (Sender, 1990, 190), lo que enlaza con su poema «Gesta de los Pirineos», publicado en La Tierra el 3 de enero de 1923 (Sender, 1993, 202). Más tarde en Imán surgen otros parámetros clásicos como la platónica concepción de la belleza unida a la justicia y al bien: «En la cantina está el cabo de intendencia, buen muchacho, "novio" de la morita que está con nuestra Rosa. Esa morita es de Beniurriaguel y le acompaña toda la estampa de terror que esa cabila sugiere: fea, denegrida sin ser negra, ferozmente seria» (Sender, 1992, 244). Apreciación que hace ver Arturo Barea cuando escribe: «El primitivo anhelo humano por lo bueno, lo agradable y lo bello, en medio de la crueldad y la fealdad, es un abuso 
y una fuerza eterna que Sender redescubre en cada una de sus novelas» (Barea, 1948, 12).

Pese a todo nunca cayó Sender en la cuenta de que se encontraba haciendo el servicio militar precisamente en el corazón de la Alcolea rifeña - la región de Melilla, Alkalaia, en árabe 'tierra de castillos', en español Guelaia, en rifeño la Confederación Iqari'yen, formada por las tribus de Beni Sidel, Beni Bu Ifrur, Mazuza, Beni Bu Gafar y Beni Shicar-. En esta última sitúa su relato "In illo tempore de Beni-Sicar", recogido en Segundo solanar y lucernario (1981), donde escribe sobre los tuareg:

Un tuareg. Más tarde conocí otros y me familiaricé con alguno de ellos. No son árabes, aunque visten casi lo mismo. La plebe tuareg se llama a sí misma «berberisca» y habla selha. [...]

No hay duda de que hubo una civilización antediluviana mucho más rica de conocimientos que la europea del siglo pasado y que esa civilización se conservó en Egipto y en Mesopotamia. Todavía las famosas tabletas de Ninive nos lo recuerdan. [...]

Parece que sobre aquellos hombres de culturas primitivas había otra raza (algunos dicen ahora que vino de fuera de la Tierra) avanzadísima en ciencias y artes. [...]

Todas estas cosas nos llevan una vez más a pensar en la Atlántida y en los tuareg que se salvaron en las montañas de África como en las de España. Es un tema de una gran fuerza de sugestión al cual dedican su talento interpretativo muchos especialistas de veras autorizados. (Sender, 1981, 39-41)

Sender enlaza a los «exóticos» tuareg con los montañeses de los Pirineos, las Alpujarras y la sierra de Albarracín, centrando la patria mística de los guerreros azules en el «Sáhara atlante y Egipto, cuyas pirámides consideran sagradas» (Sender, 1981, 39).

Sender desde luego no parece tener un gran conocimiento de estos tuareg (singular, targui) ni de sus costumbres, etnia y lengua, ya que no son, efectivamente, árabes ni tampoco se autodenominan «berberiscos» o «bereberes», lo que recuerda despectivamente la palabra «bárbaro». Son propiamente imaziguen (es decir, lo que la historiografía occidental actual traduce como bereberes), como los rifeños, los habitantes del Atlas y los del Sus de Marruecos. Estos últimos, los chleuhs, han dado, por deformación occidental, la palabra shelja o selha, que es la que atribuye Sender al idioma de los tuareg, al que ellos en realidad denominan tamasheq y que forma parte de la lengua tamazight, hablada históricamente en todo el norte de África, desde Egipto a Mauritania y desde Níger y Malí hasta el Mediterráneo. Los tuareg conservan en la actualidad su propia escritura basada en los signos tifinar, que las madres transmiten a los hijos.

Sender acusa en profundidad la influencia romántica de Pierre Benoît y de su libro La Atlántida, publicado en primera edición en París en 1920 y que fue traducido al español por Rafael Cansinos-Assens. La dedicatoria del libro recoge la alusión de Platón, en Critias, a que los tuareg son los herederos de la mítica Atlántida: 
Debo advertiros en primer lugar, antes de entrar en materia, que no os asombréis de oírme llamar

a unos bárbaros con nombres griegos. (Benoît, 1994, 5)

La influencia de Benoît es compartida por otros periodistas como Víctor Ruiz Albéniz. Éste, que inicia su experiencia marroquí en 1908 cuando es nombrado médico del recién constituido Sindicato Español de Minas del Rif, en Uixan, cabila de Beni Bu Ifrur (Uixan o Adrar Uixan, cuya traducción del rifeño sería 'monte de los caballos' —en árabe, Yebel Uixan-, y no Ujián o Uxián, como recoge Francisco Carrasquer en su completa edición crítica de Imán) (Sender, 1992, 210, n. 57), dibuja el estereotipo rifeño en sus páginas de joven africanista, en lo que entonces se denominaba la "psicología del rifeño", integrada por epítetos de la barbarie, como salvajes, traidores, vengativos, degenerados, falsos, inferiores, etc. (Ruiz Albéniz, 1994, passim). "El Tebib Arrumi», pseudónimo literario de Víctor Ruiz Albéniz, publicó también en La Tierra sus crónicas marroquíes, junto a otros escritores que sirvieron de primera fuente de información para el joven Sender (Sender, 1993, XXVII), y, como el autor de Imán, llegaría a preguntarse a través de uno de sus personajes la razón de la presencia española en Marruecos:

Los españoles no son ni más ni menos valientes que los otros hombres, y quizá lo sean menos que los rifeños, porque éstos defienden lo suyo, sus tierras, su independencia y nosotros... ¿Tú te has parado a pensar por qué y para qué estamos aquí? (Ruiz Albéniz, 1994, 85)

Influencias que confluyen en Sender, con los escritores de las campañas de Marruecos, desde la de 1893, con Melitón González (González, 1893, 692-695) y Rodrigo Soriano (Soriano, 1894), a la de 1909, con Eugenio Noel. Éste compartió la experiencia de Cabrerizas y del Polígono, como el propio Sender, escribiendo algunas de las páginas más brillantes de los cronistas de las guerras del Rif. Aún más, recogió el tremendo impacto de un elemento novedoso para muchos de los soldados de tierra adentro que tendrían en la "ruta de África» la primera experiencia marina:

El mar es la única palabra humana que no tiene definición posible. ¿Cómo definir esa respiración monstruosa y lenta, esas mareas y reflujos, esa vasta extensión que parece inmóvil, a veces, y es, a veces, la más gigante muestra de la irritación y la catástrofe? Su color en la calma es el del cielo. (Noel, 1910, 227)

También, José Ortega Munilla, con sus artículos de La Esfera, de Madrid (Ortega Munilla, 1919 y 1921), donde colaboraba igualmente Tomás Borrás, publicando artículos africanistas (Borrás, 1921 y 1922). A Ortega Munilla, viejo conocido de Sender, le dedica un recuerdo cariñoso en sus «Arabescos» junto a «Los corresponsales de guerra». Así como 
Francisco Gómez Hidalgo (Gómez Hidalgo, 1921) y otros (Sender, 1990, 194), ya situados en la campaña de 1921. Influencias que se rastrean también en los escritores de la generación del 98, de los que Sender ironiza en Cabrerizas Altas:

\footnotetext{
No hay nada más fácil que imitar a los escritores del 98 , porque casi todos son escritores de falsilla. [...] el moroso y sinsustancial de Azorín [...] Baroja es fácil de imitar por lo que tiene su desaliño de afectación. [...] Unamuno es más fácil aún en el ensayo, que era lo único de él que [...] nos gustaba. (Sender, 1990, 67-69)
}

Valle-Inclán es más respetado por Sender, así como Azorín es el más atacado, ya desde las propias páginas de El Telegrama del Rif, en sus «Arabescos»: «-En mi pueblo hay un tío que no sabe hablar y que todo lo hace por escrito. Le dicen "Azorín", pero eso es apodo" (Sender, 1990, 195).

Hay un lugar común a todos estos escritores: el desconocimiento del mundo rifeño, la imposibilidad de penetrar la alteridad rifeña y ello a pesar de que ejercían, en mayor o menor medida, y siempre dentro de grandes contradicciones literarias e incluso éticas, la crítica contra el sistema que permitía una irrupción tan violenta en Marruecos, más aún cuando se hacía derramando la sangre de tantos jóvenes españoles enviados al territorio ignoto de África a servir en el ejército del «rey gafe». Las contradicciones afloran en la inconsistencia del entramado teórico que sustenta el dibujo de la sociedad rifeña. Sender mezcla continuamente lo árabe y lo bereber, parece más bien que no es capaz de distinguir la enorme diferencia de ambas culturas, de ambos mundos tan diferentes. Es cierto que el islam es un elemento común, pero ni étnica ni lingüísticamente había referencias comunes. El mismo Sender recoge palabras aisladas del tamazight o rifeño, algunas tan usuales y significativas como Mlej (se traduce por 'bien', de bienestar) (Sender, 1992, 155), sin tener un mayor acceso a una lengua que le parece «misteriosa» y a una sociedad a la que simplifica en exceso:

\footnotetext{
Una vez más, se aprecia la diferencia entre el moro insumiso, rebelde y el «civilizado». Éste se ha contagiado de la seguridad en sí mismo y del desenfado del soldado español. Al discutir acaloradamente en su idioma intercalan exclamaciones en español — ¡coño!, ipuñeta!, ¡hijo de puta!- y siguen en su misterioso idioma. Ésa es una manera fácil y segura de identificarlos a primera vista. (Sender, 1992, 231)
}

El «moro», siempre el moro, despojado de sus vestimentas morales, ruin y bárbaro, reducido al ámbito de su chilaba (Sender, 1992, 118), al que se le imputa la tragedia de Marruecos, como escribe en su prólogo a Imán Ramón J. Sender, pero ¿no era también y esencialmente la tragedia de España? Tenemos que acudir a escritores autocríticos como Ciges Aparicio o Indalecio Prieto para tener unas coordenadas más objetivas de una guerra que, desde luego, no provocaron los rifeños sino, en todo caso, la oligarquía financiera, caso de Romanones, a quien tan ligado 
estaba Ruiz Albéniz y a quien Sender ataca duramente, y el ejército. Este último tendría en Annual una derrota implacable que mostraría al mundo la presencia de un pueblo capaz de plantar cara a la potencia colonial invasora. Poética y crudamente lo dice Sender en Imán, aludiendo a las muertes de oficiales tan destacados como el comandante Benítez (el denominado comandante B.) y el general Silvestre (general S.): «Los moros hicieron entonces [en Annual] buena cosecha de estrellas» (Sender, 1992, 67).

La fascinación del año veintiuno, la crueldad de los «bárbaros» rifeños —con esa «voluptuosidad sádica que les suele lucir en los ojos y que Viance sólo ha visto antes de ahora en los de algunas beatas españolas edificadas ante una imagen de Cristo en la cruz» (Sender, 1992, 175)-, a la que se responde con la crueldad más refinada de la civilización, sin eludir la guerra química a la que Sender alude en varios pasajes, como los bombardeos con gas iperita (Sender, 1992, 56, 263), que no sólo amputan o cercenan la vida sino que también, en uno de los rasgos ecologistas de Sender que recoge Imán, actúan «mutilando bárbaramente el paisaje» (Sender, 1992, 259). El joven Sender, que había considerado el cuartel como auténtica escuela de la vida, tan diferente «de la vida falsa de cuento de hadas» universitaria (Sender, 1990, 199), recrea paisajes de una turbia crueldad de seres embrutecidos por la sinrazón de la guerra.

Leyendo Imán, qué lejos queda la fascinación de los atlantes de Benoît, qué lejos el ideal griego que tuvo su máximo exponente teórico en el interventor militar español Emilio Blanco Izaga, autor de La vivienda rifeña y, sobre todo, de La ley rifeña (Blanco Izaga, 1930 y 1939), que estructuró el diagrama de la sociedad rifeña en un anagrama de rasgos arquitectónicos clásicos, sustentado por columnas y arcos de la Grecia clásica, rematados por el frontón social del Rif, y lo intentó aplicar a una sociedad segmentaria, sustentada en la agricultura, la ganadería y la pesca. Un pueblo, el rifeño, que vio la irrupción de las fuerzas coloniales hispanofrancesas a principios de siglo, lo que significó la alteración de todo su entramado social. En este contexto suenan a huecas las bellas frases de los africanistas españoles, que, como en el caso de Azorín, poetizaron con una realidad falseada:

Yo soy también un poco bereber. Este mismo blanco y esta bahía estrecha, han influido sobre mí; hay más allá y más acá del estrecho los mismos muros blancos y los mismas pequeñas ventanas misteriosas. (Azorin, 1949, 479)

NOTAS BIBLIOGRÁFICAS

Azorín (pseudónimo de J. MARTínez Ruiz), «Un africanista», Africa. Revista de Acción Española [Madrid], 96 (diciembre de 1949), p. 479. 


\section{EL LUGAR DE SENDER}

BAREA, A., "Introduction», en R. J. SFNDER, Dark Wedding (ed. de I. BAREA), Londres, Grey Walls, 1948, pp. 9-15.

Benoít, P., La Atlántida, Madrid, Debate, 1994. [1ªd., París, Albin Michel, 1920]

BLANCO IZAGA, E., La vivienda rifeña. Ensayo de característica e interpretación con ilustraciones del autor, Ceuta, Imp. Imperio, 1930.

—, El Rif ( $2^{a}$ parte). La Ley Rifeña. II. Los cánones rifeños comentados, Ceuta, Imp. Imperio, 1939.

BORRÁs, T., «Beduinos y berberiscos. La leyenda del niño», La Esfera [Madrid], 416 (24-XII1921), [s. p.].

—, «España en Marruecos. El soldado de cuota», La Esfera [Madrid], 428 (18-III-1922), [s. p.].

Gómez Hidalgo, F., Marruecos. La tragedia prevista, Madrid, Imp. Juan Pueyo, 1921.

GONZÁLEZ, M., «Una rifeña. La pesca del gallo en Melilla», Blanco y Negro [Madrid], 129 (octubre de 1893), pp. 692-695.

LOBFRA GIRELA, C., El problema rifeño, Melilla, El Telegrama del Rif, 1909.

Mata y Fontanet, P., Los moros del Rif, 2 vols., Madrid, Aurora, 1934 (la primera edición, de Madrid, Manini Hermanos, 1858, llevaba el título de Los moros del Rifo el presidiario de las Alhucemas).

Moultéras, A., Le Maroc inconnu. Première partie: exploration du Rif (Maroc septentrional), París, Librairie Coloniale et Africaine, 1895.

Noel, E., Notas de un voluntario. Guerra de Melilla, 1909. Primera serie, Madrid, Primitivo Fernández, 1910.

Ortega Munilla, J., «El fondak», La Esfera [Madrid], 304 (25-X-1919), [s. p.].

—, "De nuestro Protectorado en Marruecos. El Alto Comisario General Berenguer», La Esfera [Madrid], 370 (5-II-1921), [s. p.].

PRTETO, I., Con el Rey o contra el Rey, México, Oasis, 1972.

Ruiz Albéniz, V., España en el Rif (1908-1921) (introd. y ed. de V. Moga Romero), Melilla, Archivo Municipal, 1994.

SAlGaRI, E., I briganti del Riff, Milán, Mursia Editore, 1992. [1 ed., Florencia, Bemporad, 1911]

Sfco Sfrrano, C., «Un Sender insólito», El País [Madrid], 2-VIII-1990, pp. 7-8.

SENDER, R. J., Crónica del alba, 3 vols., Madrid, Alianza, 1980 (4ªimpr.; 1, 1971).

-, «In illo tempore de Beni-Sicar», Segundo solanar y lucernario, Zaragoza, Heraldo de Aragón, 1981, pp. 37-41.

- Cabrerizas Altas (Novela). Arabescos, Impresiones del carnet de un soldado (Artículos periodísticos) (notas históricas de F. SARO GANDARILlas; introd., notas y ed. de V. MOGa ROMERO), Melilla, Archivo Municipal, 1990.

—, Imán (ed. de F. Carrasouer), Huesca, IEA, 1992.

- Primeros escritos (1916-1924) (ed. de J. Vived MaIral), Huesca, IEA, 1993.

Soriano, R., Moros y cristianos. Notas de viaje (1893-1894), Madrid, Tip. de Ricardo Fe, 1894. 


\title{
El rey y la reina: ¿fábula, cuento, tragedia o novela?
}

\author{
Maryse Bertrand de Muñoz \\ Université de Montréal
}

\begin{abstract}
«Extraña novela esta de Ramón Sender! ¡Extraña novela, en la que lo real y lo irreal se confunden y mezclan, como se mezclan y confunden lo verosímil y lo inverosímil, lo lógico y lo absurdo", ${ }^{1}$ escribía Luis López Álvarez en 1956 al publicarse la traducción francesa de El rey y la reina. ${ }^{2}$ Poquísimas noticias se habían tenido hasta entonces en España de este hermoso libro publicado hacía ya siete años en América. El que quizá haya percibido más rápidamente su riqueza y su complejidad haya sido Domingo Pérez Minik ya en 1957; así se expresaba en su libro Novelistas españoles de los siglos XIX y XX: ${ }^{3}$
\end{abstract}

El rey y la reina es un relato que hubiera enamorado a nuestro Infante Don Juan Manuel y a todos los pequeños maestros del siglo XIV. A nuestro Infante le habría agradado mucho poner un subtítulo a este El rey y la reina, que dijera poco más o menos: "De lo que contesció al jardinero Rómulo y a la Duquesa de Arlanza en un palacio de Madrid». (302-303)

1 Cuadernos [París] (marzo-abril de 1956), p. 122.

2 Buenos Aires, Jackson, 1949. Utilizaré la edición española para las citas: Barcelona, Destino, 1970.

${ }^{3}$ Madrid, Guadarrama, 1957. 
Eugenio G. de Nora subrayó la atmósfera a la vez lejana y cercana, la «tendencia intemporalista» ${ }^{4}$ de la obra; varios señalaron su valor de parábola, simbólico, alegórico (Ponce de León, ${ }^{5}$ Peñuelas, ${ }^{6}$ Ferreras, ${ }^{7}$ Soldevila, ${ }^{8}$ Basanta, ${ }^{9}$ Bertrand de Muñoz $\left.{ }^{10}\right)$. Marcelino Peñuelas también insistió en la variedad de elementos integrantes de la novela: «trata de fusionar artísticamente la realidad exterior objetiva y la interna o subjetiva; lo racional y lo irracional; lo onírico, lo mágico, lo poético, lo místico y lo mítico" (60). Sin embargo, en realidad, pocas críticas un tanto profundas se han publicado sobre El rey y la reina. ${ }^{11}$ Es más, en muchos casos se ha ignorado: Marra López en 1962 afirmó no haber podido conseguirla;12 Ponce de León le dedicó muy pocas páginas generales; Soldevila apenas la mencionó en su ensayo de 1980; Birgitta Vance (1975) ${ }^{13}$ y Gareth Thomas (1990), ${ }^{14}$ dos estudiosos de la novela de la guerra civil, ni siquiera la incluyen en sus libros, y una revisión detenida de lo publicado desde 1980 revela solamente tres artículos sobre esta novela. ${ }^{15}$

No obstante, a pesar de la poca atención prestada a esta obra, casi todos insisten en su importancia, en su densidad, en su valor. Yo trataré en las líneas que siguen de dilucidar los varios elementos estructurales que componen este texto narrativo repleto de símbolos y de complejidad tanto temática como genérica.

\section{FÁBULA O CUENTO}

Ya he citado a Pérez Minik y recurriré a él de nuevo:

El Rey y la Reina - aun tratándose de unos episodios de nuestra guerra civil ocurridos en la capital de España en los primeros meses de lucha y entre

\footnotetext{
4 La novela española contemporánea, 1927-1960, II, Madrid, Gredos, 1962, p. 42.

5 La novela española de la guerra civil, Madrid, Ínsula, 1971, pp. 106-108.

${ }^{6}$ La obra narrativa de Ramón J. Sender, Madrid, Gredos, 1971, p. 15.

7 Tendencias de la novela española actual. 1931-1969, París, Ediciones Hispanoamericanas, 1970, p. 104.

${ }^{8}$ La novela desde 1936, Madrid, Alhambra, 1960

${ }^{9}$ La novela española de nuestra época, Madrid, Anaya, 1990, p. 11.

10 «Los símbolos en El rey y la reina de Ramón J. Sender», Papeles de Son Armadans, 74/120 (julio de 1974), pp. 37-56.

11 Hasta el presente Congreso, en el cual varios comunicantes han discurrido sobre ella.

12 Narrativa española fuera de España (1939-1961), Madrid, Guadarrama, 1962.

13 A Harvest Sown by Death, Nueva York, Peninsula Publishing Co., 1975.

14 The Novel of the Spanish Civil War, Cambridge, Cambridge University Press, 1990.

15 Margaret E. W. JONES, "Psychological and Alchemical Motifs in Sender's El rey y la reina", Revista Canadiense de Estudios Hispánicos, 14 (otoño de 1989), pp. 79-93. Haydee AHUMADA PEÑA, «El rey y la reina, búsqueda y encuentro de la dignidad a través del amor», Revista Chilena de Literatura, 37 (1991), pp. 45-66. Manfred LENTZEN, «El rey y la reina de Ramón J. Sender como parábola», Alazet. Revista de Filología, 4 (1992), pp. 155-163.
} 
unos personajes de una realidad inmediata- [está escrito] como si se tratara de contarnos un apólogo o una parábola o meramente "una crónica complida». (303)

En efecto, todo el texto se sitúa en un ambiente un tanto irreal, mágico, de ensueño. El palacio de los duques con el esplendor de antaño, su torreón y su sótano, sus numerosas habitaciones, pero también con sus cuartos misteriosos, sus puertas secretas, su fantasma y un aire enrarecido, una luz difusa - sólo el ascensor y la piscina dan un aire de modernidad-, todo parece salir de un cuento de hadas. El libro que lee la duquesa y que sirve de metatexto a la trama, los Esiemplos de las monarquías, así como los cristobillas y su reina Hipotenusa, la Tía Miserias, el juez Don Requerimientos, etc., añaden más elementos de intemporalidad. Hasta la frase final, "Acta est fabula!», en su doble sentido de obra de ficción y de fábula, todo colabora a situar al lector fuera del tiempo, en un universo de magia y mítico a la vez. Monique Joly, al comentar el carácter autobiográfico de varias obras de Sender, afirma que el autor crea una «mini-mitología» alrededor de su nombre y que:

Il projette certains de ses "doubles» dans le lointain historique, parant ainsi ce nom du prestige de l'épopée; il se sert, à cet effet de variantes archaïques: Rómulo dans $E l$ rey y la reina [...] Rómulo, le jardinier fruste, l'homme élémentaire, symbole du peuple espagnol, tout aussi symboliquement paré du titre de roi. ${ }^{16}$

\section{TRAGEDIA}

El escenario de la obra se reduce enteramente a un palacio y su jardín, la antigua mansión de los duques de Arlanza, habitada al principiar la acción por el duque de Alcanadre y su señora, hija de los difuntos duques de Arlanza. La unidad del lugar es notoria: toda la acción se desarrolla en este recinto reducido. Esta casa señorial llega a representar un verdadero cosmos; para Rómulo y la duquesa el mundo está concentrado en este espacio limitado: para ellos es «el» mundo, «su» mundo. Allí viven una vida entera en los meses que dura la novela y Rómulo es consciente de ello: "Cuatro años son en estas condiciones toda una vida» (76), se dice a sí mismo pensando en su vida con la duquesa mientras dure la guerra. Esta idea de vida, de ciclo por lo tanto, se refleja en varias expresiones o imágenes que evocan un círculo; así, la duquesa se siente cercada por la fatalidad («La duquesa sintiéndose acorralada por la fatalidad», 90) o por el horror del mundo («La violencia y el crimen nos envuelven para siempre», 124); se encuentra en medio de un torbellino («Estoy de lleno en el torbellino y las curvas son cada vez más estrechas», 126).

\footnotetext{
16 Panorama du roman espagnol contemporain (1939-1975), Montpellier, Université Paul Valéry, Centre d'Études Socio-critiques, 1979, p. 140.
} 
Un hecho capital contribuye a crear esta impresión esférica: las mismas palabras que sirven de eje, que constituyen la morfosintaxis de la obra, la búsqueda fundamental del protagonista, se encuentran al principio y al final del texto: toda la trama está basada en el juego de palabras "Rómulo un hombre» - «Rómula un nombre». Antes de la primera entrevista, a la cual asistimos, entre Rómulo y la duquesa, ésta pregunta irónicamente a su doncella: "¿Rómulo un hombre?». Esta ofensa a la hombría del jardinero será el origen de todo el proceso sicológico que se desarrollará en este hombre de condición humilde; querrá probarse a sí mismo y a la duquesa que sí es un hombre y al final oirá la respuesta tan deseada en las palabras emocionadas de la duquesa moribunda: «Rómulo, tú [...] tú eres el primer hombre que he conocido en mi vida» (187).

El único personaje que tiene acceso a este reino, este cosmos en miniatura, es Rómulo: nada más estallar la guerra civil, los milicianos le entregan las llaves y él puede circular con toda comodidad por donde quiere. La gente del palacio se ve separada del mundo exterior y su único contacto tiene lugar por medio de los milicianos. Rómulo y la duquesa están cada vez más aislados y él cerca poco a poco a la mujer que ha llegado a ser su obsesión, su ilusión; se erige en propietario, en dueño: le corta el teléfono, hace capturar al duque, penetra en la habitación de su amada, se niega a calentar los hornos, etc. Todo ello obliga a los dos sujetos del drama a penetrar en sí mismos y a tomar conciencia de su "yo" profundo.

Toda la obra se desarrolla en dos planos distintos: el de la realidad, el de la guerra civil, en la planta principal y en el jardín del palacio, invadidos por los milicianos; el plano irreal, el del ideal, en el torreón donde se esconde la duquesa y al cual acude de vez en cuando Rómulo. Se puede añadir otro plano, el del sótano del palacio, el mundo visceral e infrahumano.

El torreón, lugar donde se ve recluida la duquesa desde el 18 de julio de 1936, representa por su altura el ideal hacia el cual se quiere alzar Rómulo. El humilde servidor de los duques es el que hace de unión entre el mundo exterior y el interior. La guerra permite rescatar todas las ideas locas, las ilusiones que tuviera Rómulo en su juventud: «Aquellas ideas locas eran las únicas que tenían un verdadero valor, porque no nacían en la cabeza sino en la sangre» (97). Cada vez que sus ocupaciones le dejan libre, Rómulo sube al torreón para tratar de apresar su ideal; la línea vertical del torreón describe esta ascensión hacia la ilusión pero también la pérdida progresiva de este ideal. Dicho torreón consta de cinco pisos y la duquesa baja poco a poco hacia la realidad, el mundo, es decir, el mal, la sangre, la fealdad, la muerte: al principio se refugia en lo alto de la torre pero a medida que avanza el tiempo va bajando de un piso a otro. Pedirá la duquesa ayuda a Rómulo para evadirse; pero todo será inútil, éste quiere poseer su sueño acercándolo a sí mismo. El descenso progresivo de la duquesa revela el dominio cada vez mayor que ejerce Rómulo sobre ella; él se hace hombre, asciende hacia una mayor concienciación de su ser a medida que la duquesa se hace más humana, más condescendiente, se 
despoja de todos sus prejuicios y se adentra en su ser de mujer. Pero este acercarse del hombre hacia su ideal concluirá con la muerte de éste, porque «alcanzar la ilusión es matarla y realizar en ella la ambición de sí mismo no es posible sin pasar por esa muerte y desgracia» (143).

En el torreón se desarrollla la acción principal, la que verdaderamente importa; la autorrevelación de los sentimientos, la humanización progresiva y total de dos seres que hasta la guerra eran dos inconscientes de su verdadera condición. Esta transformación se hace siguiendo un orden totalmente cronológico que favorecen los acontecimientos exteriores. En efecto, la trama se desarrolla como una tragedia clásica en cinco actos:

1. La exposición del caso aparece ya en el primer capítulo: una mañana de julio de 1936, la duquesa de Arlanza se muestra desnuda en la piscina ante el jardinero Rómulo. Este hecho sorprendente obliga al criado a reflexionar sobre su condición: ¿es realmente un hombre o simplemente un objeto o un animal doméstico? A la mañana siguiente estalla la guerra, la duquesa se esconde en el torreón, el duque viene a verla pero ella es indiferente ante este hombre con el cual se casó por conveniencia.

2. El desarrollo de la acción, «ilustración del proceso de individuación en el cual ambos la Duquesa y Rómulo van a ser arrastrados uno hacia el otro en el curso de una realización sicológica», ${ }^{17}$ tiene lugar en los tres capítulos siguientes:

a) Rómulo va tomando conciencia de su ser, se rebela contra la situación en que se halla y vive obsesionado por la desnudez de la duquesa. Acaba por entregar el duque a los milicianos, pues es un obstáculo en la consecución de la mujer deseada; justifica su conducta repitiéndose que solamente ha cumplido su deber hacia la República.

b) En el tercer capítulo, el más largo de la obra, crece la inquietud de Rómulo, pues los milicianos se instalan y visitan la casa, aunque no llegan al torreón; solamente el capitán Ruiz intentará hacerlo, morirá en la empresa y el jardinero se deshará de su cuerpo. Pero, mientras tanto, un bombardeo ha destruido una parte del torreón y la conserjería y en este desastre ha muerto destrozada Balbina, la mujer de Rómulo. Éste ya se siente liberado y fuerte y afirma ante la duquesa: «No somos diferentes sino en el ser una mujer y un hombre" (118).

c) Eliminados los dos obstáculos mayores, el duque y Balbina, le queda a Rómulo convencer a la amada. Pero, al intuir que no lo va a lograr por la resistencia de ella y la presencia del "diablo», un amante suyo, parte al frente a luchar con los soldados republicanos. Es el momento de duda, de vacilación: ¿logrará o no su propósito el protagonista?

17 Margaret JONES, art. cit., p. 80. 
3. En el quinto capítulo presenciamos el desenlace: la duquesa, sola, hace gestiones para marcharse, pero se enferma, y Rómulo, herido, vuelve al palacio y constata rápidamente que su amada agoniza; delirante, ésta le llama y le confiesa antes de morir que él es el único hombre que ha conocido en su vida y le pide perdón. Desesperado, Rómulo la besa en la boca y pregunta: «¿Por qué ahora? [...] ¿Por qué? ¿Es la ley? ¿La antigua ley?». Mira luego el cuerpo muerto de la duquesa y en la puerta ve un muñeco que «ahora no era la Reina Hipotenusa, sino el juez Don Requerimientos, que parecía rescatar también su juventud gritando: -Acta est fabula!» (178-179).

\section{NOVELA}

Si El rey y la reina tiene estructura de tragedia clásica por su unidad de acción y de lugar y se acerca en muchos aspectos a la fábula o al cuento, es ante todo una novela, una novela sicológica y metafísica, una novela «en» la guerra, no «de» la guerra. Ambos calificativos de la novela de Sender se deben al asunto mayor de la obra, el comportamiento de Rómulo y de la duquesa y a la constatación de que el hombre y la mujer están hechos el uno para el otro; "El Rey y la Reina es una nueva propuesta de dignificación. Rómulo y la duquesa, encarnan un largo proceso que los lleva desde la anulación personal a la conciencia de su singularidad». ${ }^{18}$ Todo ello está resumido en la siguiente mise en abyme del quinto capítulo y sacado de El Libro de los Esiemplos de las Monarquías:

\footnotetext{
El universo es una inmensa monarquía [...] Todo lo que el hombre ha soñado, ambicionado, creado, lo ha sido por esta monarquía del hombre -rey- y la ilusión, su propia ilusión - reina-. El hombre y la ambición ideal que lleva consigo son el rey y la reina del universo. [...] pero cuando el rey - el hombre - quiere cumplirse en la posesión ideal de la reina hasta alcanzar los absolutos de Dios, la armonía se rompe y el orden del matrimonio se acaba. Que alcanzar la ilusión es matarla y realizar en ella la ambición de sí mismo no es posible sin pasar por esa muerte y desgracia. (143)
}

El episodio de la piscina lleva a Rómulo a meditar, a preguntarse si sueña o vive realmente y a optar por ir en busca de la ilusión, tratar de apresar su sueño. Ésta es la función esencial, el destinador, lo que le empuja a iniciar la lucha para conseguir el objeto de su deseo. De joven se sentía «otro», un hombre de verdad, y decide ir a la búsqueda de este "otro"; poco a poco va a rescatar el que fue, autoafirmándose frente a la duquesa. Este autorreconocimiento y reconocimiento socio-sicológico por la mujer que se mostró desnuda y pareció despreciarle constituyen todo el eje de la acción. Encuentra Rómulo varios oponentes - el duque, Balbina, el «diablo», algunos milicianos y la misma duquesa-, pero la guerra, los acon-

18 Haydee Ahumada PeÑA, art. cit., p. 65. 
tecimientos exteriores, su voluntad y la humanización de la mujer que ha llegado a ser la meta de su vida, todo ello favorecerá que se le reconozca su estatuto de hombre a la vez que el aprecio de aquélla; pero la condición humana es absurda y la duquesa muere cuando ya ha logrado el rey alcanzar su ilusión, la mujer amada.

La situación transforma tanto al jardinero como a su ama. Mientras que Rómulo se hace más tranquilo, menos tímido y respetuoso, sonriente, llega a ser feliz, radiante de dicha, y se atreve a mirar a la duquesa a la cara, ella se hace sonámbula, nerviosa, angustiada, su voz tiembla, su mirada se muestra asustadiza, extraviada. Rómulo empieza a ser hombre cuando la duquesa comienza a ser mujer; llega un momento en que él la abraza sin que ella se ofenda. La distancia física mengua poco a poco tanto por la intimidad que nace entre ellos como por la necesidad de la duquesa de bajar de piso, al estallar una bomba y al arreciar la guerra, acercándose a él. En el momento crucial en que Rómulo, celoso del «diablo», el amante, arranca el gabán que cubre el cuerpo de la duquesa, ésta cruza los brazos sobre su pecho y él percibe este gesto de pudor como un homenaje. Le dice con voz temblorosa: «¿No le queman mis ojos como brasas en la piel? ¿No son ojos de hombre los míos, quizá?» (119). La duquesa mantiene que ella no es una mujer sino un sueño, a lo cual Rómulo replica con voz ronca: «Pero si nos sueñan y nos adoran, nosotros tenemos que merecerlo siendo verdaderamente lo que somos. Usted, una mujer. Yo, un hombre" (120). Poco más tarde la duquesa "se repetía: "El hombre es el rey. La ilusión es la reina. Juntos los dos forman la monarquía que rige al mundo, el universo". Pensando en el rey simbólico lo materializaba en Rómulo y no en Esteban. Rómulo era el rey. Ella quizás era la reina, la ambición ideal» (128).

El relato cobra rápidamente un acento tragicómico. Los personajes parecen representar su papel ante un espejo deformante como en las obras de Valle-Inclán. El hombre y la mujer se asemejan a la rata Barreno, que vive en el sótano con su mujer Pascuala, y contra todos ellos lucha el sórdido enano Elena; también lo están con los cristobillas de la infancia de la duquesa que Rómulo pone en acción; por fin, están identificados con todo el mundo: al ceder poco a poco ella, regañan, él amenaza con matarla cuando quiere huir a Valencia, ella llora como cualquier mujer. El rey ha alcanzado su ilusión, ella deja poco a poco entonces de ser un sueño, un absoluto, y se esfuma, se desvanece lentamente, rindiendo a Rómulo el más hermoso homenaje: «Rómulo, eres el primer hombre que he conocido en mi vida» (177).

Las estrategias del relato son múltiples en El rey y la reina. En conjunto pertenece al género novelesco, a pesar de sus marcas de fábula, de cuento y su estructura cercana a la tragedia. ${ }^{19} \mathrm{La}$ estructura profunda aparenta

19 Margaret Jones también asimila el acercamiento del rey y de la reina al proceso sicológico por el cual los alquimistas pretendían alcanzar la perfección, proceso recordado por Karl Jung en Mysterium conjunctionis. 
la de una pieza de teatro, pero la estructura superficial, la intriga, se llena de peripecias, de escenas un tanto marginales (particularmente la del capitán), de símbolos - el agua, las flores, los cristobillas, las pinturas del torreón, los libros (del marqués de Sade y de Los esiemplos, etc.-, de metadiscurso, de mise en abyme. Por su meditación metafísica, por la imaginación desbordante, la estilización del tiempo alcanza el mito. Los acontecimientos se desarrollan durante la guerra civil, pero no se trata de una novela "de» la guerra a pesar de que sin ella el jardinero y la duquesa no hubieran podido soñarse como lo hacen. Pero estos hechos podrían casi pasar en cualquier conflicto cainita y la acción llega a ser intemporal, llega a lo más profundo del ser humano; se opone el bien - la felicidad, el ser reconocido como hombre - y el mal - la vida anterior sin sentido, sin alientos-. Esta organización semántica dualista es la que indica LéviStrauss como propia de los relatos míticos; en L'homme $n u^{20}$ afirma que el orden mítico se constituye exactamente de la misma manera que el funcionamiento binario de un pensamiento que se ha formado a partir de la oposición cielo-tierra. Rómulo y la duquesa logran hallar su ser verdadero gracias a la guerra, a través de la sangre, el crimen, la muerte. Su encuentro es el de dos soledades. Pero el lograr este encuentro es un homenaje recíproco, un rescate de la naturaleza humana, y este rescate, si bien efímero, se hace extensivo a todo el pueblo español en lucha por su existencia.

20 París, Plon, 1971, p. 539. 


\title{
Sir Peter Chalmers Mitchell, traductor al inglés de algunas obras de Sender
}

\author{
Luis Monferrer Catalán \\ I. E. S. Milà i Fontanals, Barcelona
}

\section{LA RELACIÓN ENTRE RAMÓN J. SENDER Y SIR PETER CHALMERS MITCHELL ${ }^{1}$}

Entre las personas con quienes Ramón J. Sender se relacionó en los años 30 encontramos al biólogo y periodista británico sir Peter Chalmers Mitchell. La amistad entre ambos tuvo, en nuestra opinión, considerable importancia para Sender, por cuanto por medio de Mitchell se empezó a dar a conocer en Inglaterra y en el mundo anglosajón la obra del aragonés. Sir Peter tradujo al inglés al menos tres de sus obras.

En 1936 Sender tenía 35 años y Mitchell unos 71. En julio de aquel año, Mitchell estaba viviendo en Málaga, donde daba los últimos retoques a su libro de memorias, titulado My Fill of the Days. ${ }^{2}$ Aunque apareció en 1937, el volumen estaba casi terminado en junio de 1936 y su publicación, preparada para el otoño de aquel año (Mitchell, 1937, 9). El estallido de la guerra civil alteró algo sus planes, pues le llevó a añadir un capítulo sobre

\footnotetext{
${ }^{1}$ Para la preparación de esta comunicación, he contado con las inestimables sugerencias de Luis ESTFVF y de Jesús VIVED, a los que les agradezco aquí su amabilidad y la ayuda prestada.

2 Sir Peter Chalmers Mitchell, My Fill of the Days, Londres, Faber \& Faber, 1937.
} 
la sublevación militar española. En sus páginas, escritas hacia octubre de 1936, hallamos las palabras del propio Mitchell que definen su relación con Sender:

Here in Málaga the outbreak took most of us by surprise [...]. Early in July I wished to make some arrangements for autumn, in particular whether or not to advise two delicate ladies to carry out or to postpone an autumn visit to my house. I wrote to my friend Ramón Sender, the author of Seven Red Sundays, and deep in the counsels of the extremer left. He replied saying that certainly before long the Army, the Fascists, the Monarchists and the Church would make a final and bloody effort to crush the People, but that he had taken a cottage in the high Somosierra for the autumn, and he invited me to lead the simple life there with him, his wife and his two babies. A week ago he was in the trenches defending Madrid; if still alive he is certainly leading the simple life. (Mitchell, 1937, 384)

\section{LAS TRADUCCIONES DE LA OBRA DE RAMÓN J. SENDER AL INGLÉS REALIZADAS EN INGLATERRA ENTRE LOS AÑOS 30 Y LOS 50}

Durante la guerra civil española, sir Peter Chalmers Mitchell se dedicó -entre otras actividades- a traducir al inglés algunas obras de la producción senderiana, que, de este modo, pudieron llegar en plena contienda al público lector británico más inquieto y deseoso de novedades.

Ya en 1934 se había publicado en Londres Earmarked for Hell, ${ }^{3}$ la primera traducción de Imán en inglés, realizada por James Cleugh.

En 1937 aparecieron en Londres Mr. Witt Among the Rebels (Mister Witt en el cantón $)^{4}$ y The War in Spain: A Personal Narrative, ${ }^{5}$ y en 1938, Seven Red Sundays ${ }^{6}$ (Siete domingos rojos), ${ }^{7}$ publicada por Sender en 1932. Las tres fueron traducidas por Mitchell, que contribuyó a divulgar la producción de Sender entre el público británico, a la vez que tales obras se convertían en un elemento más de la batalla propagandística que la República española llevaba a cabo en Inglaterra en defensa de su legalidad. ${ }^{8}$

Posteriormente, durante los años 40 , otras obras de Sender aparecieron en Inglaterra, traducidas al inglés. En 1941 se editó en Londres $A$

3 Londres, Wishart \& Co., 1934, VIII + $342 \mathrm{pp}$.

${ }^{4}$ Londres, Faber \& Faber, 1937, 367 pp.

5 Londres, Faber \& Faber, 1937, XI + 316 pp.

6 Harmondsworth, Penguin Books, 1938, 308 pp.

${ }^{7}$ Cfr. Keith HARRIS, «Books On Spain». Catalogue, invierno-primavera de 1994-1995, Twickenham, UK, entradas 464 y 465.

8 Mitchell fue asimismo el autor de una introducción que contenía la obra del exiliado en Londres Arturo Barea, The Forge (La forja), Londres, Faber \& Faber, 1944. La traducción al inglés era de Ilsa Barea —esposa de Arturo- (cfr. Maryse BERTRAND DE MUNoz, La guerra civil española en la novela, Madrid, José Porrúa Turanzas, 1988, pp. 52-53). Es posible que Mitchell revisara dicha traducción. 
Man's Place (El lugar de un hombre), ${ }^{9}$ del que desconocemos el nombre del traductor. En 1945 vio la luz Chronicle of Dawn (Crónica del alba), ${ }^{10}$ traducida del español por W. R. Trask. En 1948 se publicó la obra Dark Wedding (Epitalamio del prieto Trinidad), ${ }^{11}$ con una introducción de Arturo Barea, y en 1949 apareció asimismo The King and the Queen (El rey y la reina), ${ }^{12}$ cuya traducción era de una antigua militante de las filas del POUM durante la revolución española: la australiana Mary Low. ${ }^{13}$

Después, en 1954, Florence Hall tradujo al inglés The Affable Hangman (El verdugo afable). ${ }^{14}$ En 1959 apareció Before Noon (Antes del mediodia), ${ }^{15}$ volumen que contenía las obras The Chronicle of Dawn, Violent Griffin (Hipogrifo violento, publicada en 1954) y The Villa Julieta (La quinta Julieta, publicada en 1957). De este volumen dijo The Sunday Times que era «un gran libro»y The Observer, que era «una obra maestra».

Sin embargo, en esta comunicación sólo pretendemos reconstruir lo que fueron los trazos fundamentales de la vida de sir Peter Chalmers Mitchell. A este objetivo dedicaremos las siguientes páginas.

\section{LA TRAYECTORIA VITAL, INTELECTUAL Y PROFESIONAL DE SIR PETER CHALMERS MITCHELL}

Varias son las facetas de la vida de sir Peter Chalmers Mitchell que podríamos tratar. Pero aquí sólo nos centraremos en reconstruir su trayectoria vital, intelectual y profesional, y su relación con España. Existe poca información disponible en España sobre sir Peter Chalmers Mitchell para quienes estén interesados en su persona y actividades. Sin embargo, el propio Mitchell legó al mundo anglosajón un libro de memorias: My Fill of the Days. A lo largo de 440 páginas recoge los aspectos de más interés de su vida, desde 1864 hasta 1936.

El 23 de noviembre de 1864 Mitchell nació en la localidad escocesa de Dunfermline, cerca de Glasgow y Edinburg. Su padre era el reverendo presbiteriano Alexander Mitchell. Estudió en Aberdeen y, de 1880 a 1884, estuvo en la universidad (en el King's College). Sus aspiraciones profe-

\footnotetext{
${ }^{9}$ Londres, Jonathan Cape, 1941, 208 pp.

10 Londres, Jonathan Cape, 1945, 197 pp.

11 Londres, The Grey Walls Press, 1948, 299 pp.

12 Londres, The Grey Walls Press, 1949, 224 pp.

${ }^{13}$ Mary Low, junto con su compañero, el cubano Juan BREÁ, era la autora de la obra Red Spanish Notebook, Londres, Martin Secker \& Warburg. En ella, ambos autores reflejaron la experiencia que ambos habían presenciado en persona de los cambios generados por el movimiento revolucionario iniciado en julio de 1936 en los ciudadanos de distintos lugares de España, pero muy especialmente en Barcelona.

14 Londres, Jonathan Cape, 1954, 336 pp.

15 Londres, Victor Gollancz, 1959, 408 pp.
} 
sionales pasaban, como en la mayoría de los estudiantes, por ser funcionario civil en la India, ocupar cargos en la Iglesia o en la educación. Durante aquellos años, con la ayuda de sus profesores y leyendo las obras de Darwin y otros pensadores, adquirió interés por la biología. En octubre de 1884 consiguió una beca para ir al Christ Church College de Oxford, donde pudo realizar estudios experimentales de biología, con prácticas en la biblioteca Radcliffe y en las colecciones del British Museum. Finalmente fue elegido profesor ayudante de zoología del profesor Jackson hasta 1891.

En Oxford leyó las obras de escritores alemanes, estudió ruso, francés y español. Los autores rusos tenían gran impacto entre los estudiantes de Oxford y los franceses aportaban un aire nuevo en la concepción británica del humanismo. Después, trabajó como conferenciante y, en 1893, empezó a escribir artículos para la revista Nature y realizó reseñas técnicas de libros de zoología (Mitchell, 1937, 84 y 194). También conoció a prestigiosos intelectuales (como Alfred Russell Wallace, que obtuvo las mismas conclusiones que Darwin, sin conocerle) y escritores famosos del momento. Por entonces también entró en contacto con el editor William Heinemann.

En 1884 viajó por primera vez a Alemania. Desde 1887 hasta 1893 la siguió visitando por los estupendos zoos y por el interés que despertaba allí la biología (con Weissmann, Weidersheim y otros). ${ }^{16}$ En Inglaterra también había un entusiasmo semejante con Darwin, Huxley, Moseley y otros. Aunque en la Prusia de Bismarck existía un evidente militarismo, Mitchell nunca imaginó entonces a Alemania como un país poderoso a nivel internacional, ${ }^{17}$ aunque ya vio que se discriminaba a los judíos en el ejército alemán. Mitchell realizó abundantes informes y resúmenes en inglés de literatura alemana sobre biología para publicaciones científicas y de divulgación británicas (Mitchell, 1937, 116), difundiendo el "Weissmannismo" en Inglaterra.

Hasta 1893 trabajó en Oxford como profesor ayudante. Desde 1896 hasta 1903 escribió regularmente en la Saturday Review. A finales del siglo XIX, el Gobierno británico quería fomentar la instrucción técnica de los ciudadanos con la Technical Instruction Act (1889). Mitchell colaboró con conferencias en el mundo rural de Devon. Durante un año, entre la apatía y el escepticismo del alto clero y la burguesía, con ayuda de sacerdotes y

\footnotetext{
16 Recuérdese la defensa de la pureza de la raza que hizo el nacismo alemán en el primer tercio de este siglo.

17 Sin embargo, Mitchell parece pasar por alto que, en 1884-1885, catorce delegaciones de otros tantos países se reunieron en la "Conferencia de Berlín", auspiciada por Alemania. Allí se establecieron las bases para exportar a África las tres «C» de Occidente: cristianismo, comercio y civilización, a la vez que, de paso, se repartieron África (cfr. Jorge Juan SÁNCHr.z. GARCí, Mi viaje alrededor de Africa, Madrid, Tierra de Fuego [Col. «Viajeros Españoles», 5], 1994, p. 88).
} 
maestros de escuela, intentó enseñar a mejorar la alimentación de la gente con innovaciones en la manera de cocinar. Mitchell fue también secretario del comité que divulgaba estas cuestiones en el condado de Oxfordshire. Además, continuó estudiando zoología y escribiendo artículos e informes para Nature y The Daily Chronicle. Posteriormente obtuvo una plaza de profesor de zoología y botánica en la Escuela de Medicina del Hospital de Charing Cross (Mitchell, 1937, 103). Por entonces se casó y en diciembre de 1893 dejó su trabajo en Oxford, para instalarse en Londres hasta 1935.

Desde 1893 hasta 1903 viajó algo por Francia en bicicleta, y desde 1904 en coche. París fue el punto de referencia de su generación. En el Instituto Pasteur conoció al científico ruso Metchnikoff, que había descubierto el virus de la sífilis. Mitchell tradujo dos de sus obras. Sin embargo, Montpellier, Arlés y la Camargue fueron sus destinos favoritos. En las dos primeras y en Nîmes empezó su contacto con la cultura española.

Hacia 1894 escribió un libro de biología elemental para estudiantes de medicina. Por él conoció al escritor Herbert G. Wells (Mitchell, 1937, 165). En 1896, Mitchell sustuvo una ácida polémica pública con Wells en Saturday Review, a propósito de la base científica de la obra de Wells The Island of Dr. Moreau, y ello acrecentó su amistad. Aquel mismo año, tradujo la obra del alemán Oscar Hertwig The Biological Problem of To-Day (Heinemann). En 1902, estando en Fontainebleau, conoció brevemente a un Oscar Wilde huido de Inglaterra a causa de las censura social por su obra The Ballad of Reading Gaol. Wilde le confesó «I used you in Dorian Gray...» (Mitchell, 1937, 183).

Aquel mismo año de 1902, la Encyclopædia Britannica comenzó la publicación de su décima edición. Mitchel fue invitado a colaborar en los temas de evolución de las especies. Posteriormente, para la undécima edición (terminada en 1910), el director y amigo de Oxford Hugh Chisholm encargó a Mitchell y sus colaboradores toda la biología, paleontología y zoología (Mitchell, 1937, 210-211). Su amigo Moberley Bell también le propuso en 1902 reseñar libros para el suplemento literario de The Times. Esta tarea la realizó durante más de 30 años y fue muy gratificante para Mitchell.

En abril de 1903, fue elegido secretario de la Zoological Society de Londres. De su preparación decía el propio Mitchell: «I was an anatomist, interested in the structure and relationships of animals, but knowing little of them as living creatures» (Mitchell, 1937, 214). Durante más de 30 años -incluyendo una guerra mundial-, Mitchell realizó una importante tarea de reorganización del funcionamiento del zoo, no exento de conflictos. El zoo se transformó en un centro de investigación científica en anatomía, zoología, higiene, patología comparativa, fisiología y psicología. En 1935, el zoo de Londres era una institución modélica, fruto del trabajo voluntario de los socios, que habían hecho realidad el pensamiento de Mitchell:

There are many who, like me, have been driven to the belief that the hope of preserving civilisation is the replacement of the capitalistic system by 
an organisation of society in which money is neither the reward of work nor its chief incentive... (Mitchell, 1937, 232)

Por su responsabilidad en el zoo londinense, tuvo ocasión de conocer a distintas personalidades, entre ellos al propio rey de Inglaterra y al káiser (a este último en 1911), al que empezó a exponer el proyecto de crear grandes reservas naturales de vida salvaje en África -idea que gustó al káiser-(Mitchell, 1937, 125). Mitchell mantenía la relación con científicos alemanes. En 1906 tradujo al inglés la obra del alemán Weininger Sex and Character (Heinemann) y en 1913-1914 todavía visitó zoos de Alemania.

Mitchell conoció ampliamente el Londres del primer tercio de este siglo, participó en las tertulias, polemizó con el escritor Herbert G. Wells. Obtuvo también la plaza de profesor de biología del London Hospital Medical College, que compaginó durante nueve años con clases en la extensión de la Universidad de Londres, dejando su trabajo en el hospital de Charing Cross; propuso que se abandonase el latín y que se introdujesen lenguas modernas en los exámenes de ingreso a la Universidad y fracasó en obtener puestos apetecidos, como profesor de Historia Natural en la Universidad de Aberdeen o decano de la Universidad de Cardiff. Como con sus clases y conferencias Mitchell tenía pocos ingresos, había de completarlos con la publicación de artículos científicos y de divulgación en periódicos. Sus trabajos de investigación fueron editados regularmente por la Zoological Society de Londres. Escribió muchos artículos para Natural Science, reseñas para Academy, contribuciones para The Review of the Week, artículos para Daily Chronicle, The Pall Mall Gazette y Hospital. El suplemento literario semanal del Daily Mail le pagó bien algunos artículos; otros los publicó en New Review. Pero el Saturday Review, que dirigía Harris, fue su principal fuente de ingresos literarios desde 1894 hasta 1903. Allí publicó tanto como quiso. En Saturday Review colaboraban famosos escritores británicos. Durante más de diez años aparecieron en él todo tipo de notas, reseñas, editoriales, artículos de relleno. Cuando Hodge asumió la dirección, Mitchell escribió mayormente sobre temas científicos (Mitchell, 1937, 208).

En 1907, durante tres semanas, visitó diversos zoos y museos de Estados Unidos, se entrevistó con el presidente Roosevelt y vio experimentos. Desde entonces, Mitchell quiso construir un aquarium en Londres.

En 1914 comenzó la guerra entre Inglaterra y Alemania, alterando todos los planes de mejora del zoo y aun poniéndolo en peligro. Mitchell se declaraba antibelicista (Mitchell, 1937, 280). Aunque tuvo escaso contacto con la guerra, desde mediados de 1918 colaboró en el esfuerzo propagandístico en el Ministerio de Guerra. Examinaba literatura alemana de guerra y elaboraba contrapropaganda para ser distribuida en los frentes alemanes. Mitchell pasó igualmente mucho tiempo consultando a físicos y fabricantes de globos acerca de la construcción de artilugios para esparcir hojas de propaganda en los frentes. Para paliar la escasez de alimentos, en 1916 y 1917, en el zoo se hicieron demostraciones de cría 
intensiva de aves en los patios traseros y del uso de invernaderos para cultivar verduras.

A la muerte del periodista Henry Scherren, Mitchell continuó su trabajo en The Times, en la divulgación de las nuevas adquisiciones del zoo, hasta que dejó su puesto de secretario del mismo. Mitchell era una persona inquieta, por lo que acabó en la plantilla de The Times; aunque no consiguió ser diputado en el Parlamento. Durante sus cuatro primeros meses en The Times - al final de la primera guerra mundial-, escribía una columna diaria, "Through German Eyes», basada en la lectura diaria de prensa alemana. La columna concluyó en junio de 1919 con la firma de la paz. Mitchell también escribió artículos editoriales en The Times. Su conocimiento de los temas científicos le ayudó mucho. Desde mediados de 1919 hasta febrero de 1923, publicó cientos de artículos de opinión (hasta 5 ó 6 a la semana), uno de ellos dedicado a la confirmación de las teorías de Einstein ( 7 de noviembre de 1919) (Mitchell, 1937, 268). Desde marzo de 1921 hasta junio de 1924, Mitchell escribió un artículo científico semanal en la sección «Progress of Science» de The Times para popularizar la ciencia. Esta tarea le exigía un gran esfuerzo para conocer los últimos avances del mundo científico. Desde 1924 hasta 1932, apareció quincenalmente. Tales artículos le permitieron conocer a un número importante de personas.

Terminada la guerra mundial, uno de los momentos álgidos de la actividad de Mitchell llegó cuando supo que el Gobierno británico estudiaba establecer una ruta aérea entre El Cairo y la Ciudad del Cabo. Entusiasmado por el futuro de la aviación, lord Northcliffe - el propietario de The Times - se interesó por el proyecto y envió a Mitchell —otro convencidoa comprobar aquella ruta, junto con pilotos competentes. La descripción de aquel accidentado pero extraordinario «Golden Journey» dura 61 páginas de sus memorias. El 6 de enero de 1920, Mitchell comenzó aquella misión, que le llevó al punto de partida en Alejandría. El 6 de febrero despegaron de Heliópolis (cerca de El Cairo). El 24 de febrero el avión llegó a las fuentes del Nilo, las cataratas de Victoria Nyanza; pasaron por el golfo de Kavirondo, hasta llegar a Kisumu. Estaban en el este de África, en la estación de término del ferrocarril de Mombasa. Todo el trayecto realizado había requerido 31 horas y 25 minutos de vuelo (Mitchell, 1937, 345). En Kisumu no pudieron cambiar los motores del avión. El 26 de febrero despegaron de nuevo y entraron en el hemisferio sur a través del territorio de Tanganyika (sic) (antigua África oriental alemana). El 27 de febrero de 1920 sufrieron un accidente al despegar, por lo que allí terminó su aventura, sin conseguir ser los primeros en realizar el primer viaje entre El Cairo y Sudáfrica. La hazaña la llevó a cabo el «Silver Queen», con Van Rensellar como primer piloto, tras reponer las alas en El Cairo y cambiar de avión en Rhodesia (Mitchell, 1937, 357).

Entre 1920 y 1922, en artículos de opinión, el propio Mitchell insistió en que las futuras acciones defensivas y ofensivas y el transporte estaban en la aviación (Mitchell, 1937, 272). 
En 1911, Mitchell había publicado un estudio, «On the Longevity and Relative Viability in Mammals and Birds", donde afirmaba que el clima y los cambios de temperatura no eran los principales factores de supervivencia de animales en cautividad, sino el espacio y el aire fresco (Mitchell, 1937, 369). Y esto es lo que hizo al desarrollar otro importante proyecto al que dedicó muchas energías entre 1911 y 1935: la construcción del parque de Whipsnade, unas instalaciones espaciosas al aire libre. Era una extensión del zoo de Londres en el campo para la mejor preservación de la fauna, sin llegar a ser un parque natural; aunque varios de ellos ya habían sido creados en Estados Unidos, Canadá, Sudáfrica y en el Congo. El proyecto se llevó a cabo tras la primera guerra mundial, con ayuda gubernamental, y se inauguró en 1931. Mitchell y Vevers diseñaron las líneas generales de la organización y distribución de espacios. Según Mitchell, Whipsnade Park fue «The Zoological Society's most valuable achievement in a century» (Mitchell, 1937, 361).

\section{LA RELACIÓN DE SIR PETER CHALMERS MITCHELL CON ESPAÑA}

El recuerdo de su relación con España y con Málaga quedó recogido en el último capítulo de My Fill of the Days y en otra de sus obras, My House in Málaga. También aparecen referencias en los libros de Arthur Koestler, ${ }^{18}$ pues fue en la propia casa de Mitchell en Málaga donde los sublevados detuvieron a Koestler en $1937 .{ }^{19}$ En el primero de sus libros (Mitchell, 1937, 25), recordaba sus contactos iniciales con la cultura española a través de sus lecturas de adolescencia: $E l$ Cid y la obra de George Borrow The Bible in Spain. En sus años de Oxford estudió algo de español y en Londres conoció al hispanista Fitzmaurice Kelly. Pero sólo al final de su vida entró en contacto con la literatura española. En 1936 decía que, «in my recent introduction to Spanish literature» (Mitchell, 1937, 133), le había gustado el marqués de Santillana, Jorge Manrique, los romances moriscos, fray Luis de León y varios autores contemporáneos: Pérez de Ayala, ValleInclán, Ricardo León, Pío Baroja y Sender, del que escribió:

even more surprising and exhilerating was my first contact with Ramón Sender, artist and psychologist interpreter of the spirit of the revolution to the blind old civilizations. (Mitchell, 1937, 133)

Otro de sus intereses cuando vino a España fue entender el toreo, por lo que vio muchas corridas, algunas de ellas con Belmonte como primer espada. Concluía: «[...] there is a good deal to be said in defence or even in praise of the bullring...» (Mitchell, 1937, 177).

\footnotetext{
18 Arthur KoESTLER, Spanish Testament y Dialogue with Death, publicados en Inglaterra a comienzos de 1938 (cfr. José Luis AlCOFAR NAssaEs, «La aventura española de Arthur Koestler», en Arthur y Cynthia KOESTLER, Extraños en la plaza, Barcelona, Ediciones de Nuevo Arte Thor [Col. «El Laberinto», 27], 1988, pp. 312 y 316).

19 José Luis AlCOFAR NASSAES, «La aventura española de Arthur Koestler», cit.
} 
De cuanto escribió en sus memorias puede deducirse que, en los estadios iniciales de la guerra española, se relacionó y ayudó a unos y a otros, al margen de su ideología. A pesar de albergar derechistas en su casa (como sus vecinos, la familia de B.), ${ }^{20}$ desde julio hasta principios de septiembre de 1936, y de arriesgarse mucho ayudándoles a escapar de Málaga, los republicanos no le molestaron. A principios de octubre de 1936 parecía que quería huir a Inglaterra por temor a la entrada de los sublevados en Málaga:

[...] I have a very good idea of what will happen when the rebels [...] batter their way in. Certainly I do not know where or if ever I shall finish this chapter. As a shelterer of «Rights», I am compromised here; as a passionate «Red", I am in no mood to make the fascist salute. (Mitchell, 1937, 383)

Sin embargo, por las obras de Arthur Koestler se ve que Mitchell aún estaba en Málaga en febrero de 1937, cuando la ciudad cayó en manos de los sublevados. A pesar de tan arriesgada situación, el periodista Koestler también decidió quedarse allí, entre otras razones,

para no dejar solo a su recién adquirido amigo Sir Peter Chalmers-Mitchell [...] simpatizante con los republicanos, cuya actuación en esta ciudad había defendido en varias cartas enviadas al diario The Times y a cuya casa - «Villa Lucía» - acabó por irse a vivir (Koestler) a partir del 6 de febrero. (Alcofar Nassaes, 1988, 306)

En los días iniciales de la sublevación fue testigo de la detención y registro de los domicilios de filosublevados por los republicanos, donde se descubrieron arsenales de armas. Vio la quema y saqueo de algunas de sus casas y supo de asesinatos realizados en el Camino Nuevo, cerca de «Villa Lucía» - su casa-, así como de otros más en represalia por la muerte de inocentes durante bombardeos de los sublevados a Málaga. A finales de septiembre de 1936 vio una Málaga llena de refugiados de pueblos próximos mal alojados. También pudo observar la conducta habitual de los derechistas que huían de zona republicana: al llegar a zona sublevada se convertían en violentos propagandistas contra la República. Sobre la actividad anarquista en Málaga al comienzo de la guerra decía:

I am sure that the Anarchists and Syndicalists of Málaga are fighting for the soul of the human race, for a possible future against greedy savages who are fighting, with the blessing of the Church, only in defence of their own unearned and undeserved privileges. And I am equally certain that, whatever happens here, the battle will be repeated in the United Sta-

20 Tío de Luis Bolín (José Luis AlCOFar NASSAES, cit., p. 307). Bolín era el jefe del Departamento de Prensa de los sublevados, corresponsal del diario $A B C$ en Londres antes de la guerra civil y directo implicado en la sublevación al organizar en esa ciudad, junto con el ingeniero Juan de la Cierva, la adquisición y posterior vuelo del «Dragon Rapide» desde Croydon (Londres) a Canarias, para que en dicho avión viajase Franco desde las islas al norte de África y comenzase la sublevación. 
tes and in Great Britain on a more terrific scale, unless those of good intention first take things out of the hands of the existing political groups. (Mitchell, 1937, 404)

Contaba Koestler en Dialogue with Death que, según decía sir Peter, si no había observadores, los sublevados podrían llegar a fusilar a cincuenta mil personas tras la toma de Málaga, pero si había observadores sólo matarían a cuarenta mil. Por esta razón, ambos decidieron permanecer en Málaga, para ser testigos de los más que probables excesos de los sublevados (se contaba ya con el antecedente de Badajoz - agosto de 1936-, entre otros). Así podrían dar fe de ello en cartas a los periódicos o en futuros libros. Creían que podrían pasar

inadvertidos durante los primeros días hasta que se calmasen los disturbios
y volviese a Málaga el cónsul británico, lograríamos más tarde cruzar la cer-
cana frontera de Gibraltar. Hasta entonces ningún periodista extranjero había
sido testigo de lo que ocurría cuando los insurgentes tomaban una ciudad.
(Alcofar Nassaes, 1988, 306)

Al principio de la toma de Málaga llegó Luis Bolín. Tras visitar el domicilio de su tío, fue a investigar la casa de sir Peter, pues sabía que él aún estaba en Málaga y sospechaba que habría intentado proteger a alguien importante. Así fue como detuvo a Arthur Koestler, que, desde la terraza de la casa de sir Peter, espiaba la cantidad de tropas italianas que llegaban a Málaga. ${ }^{21}$ Bolín también detuvo a sir Peter y lo dejó instalado en el hotel «Hernán Cortés». Mitchell le aseguró que no huiría pero, al día siguiente, se fugó y fue a refugiarse en el «Basilisk», un destructor británico anclado en el puerto (Alcofar Nassaes, 1988, 308).

Tras la guerra española, sir Peter parece que estuvo algún tiempo en Acapulco.También volvió a ver a Koestler en el Londres de finales de la segunda guerra mundial. Koestler había publicado la novela Darkness at Noon. Mitchell le dijo que no le gustaba y le recriminó su conducta ética, con lo que rompieron su amistad (Alcofar Nassaes, 1988, 317).

\section{CONCLUSIONES}

Por cuanto nos interesa aquí, vemos que la relación entre sir Peter Chalmers Mitchell y Ramón J. Sender —siendo una más entre las muchas

\footnotetext{
21 Así lo confirman tanto Luis BoLÍn en sus memorias como Arthur KOESTLER en su libro Spanish Testament (cfr. José Luis AICOFAR NASSAES, cit., p. 308). Tras unos días de prisión en Málaga y sesenta y cuatro incomunicado en Sevilla, ambos bandos accedieron a un intercambio de prisioneros en Gibraltar, gestionado por la Cruz Roja Internacional. El Gobierno republicano rechazó la oferta de los sublevados de canjear a 21 presos republicanos por la esposa del aviador nacionalista Haya de la Torre. Finalmente prefirió canjear a Koestler por la esposa de dicho aviador. El 14 de mayo Koestler fue liberado y el 15, canjeado en La Línea de la Concepción (cfr. José Luis Alcofar NASSAES, cit., pp. 313-315).
} 
que ambos entablaron-, tuvo, si bien se mira, unas consecuencias importantes para la divulgación en Gran Bretaña de la obra del aragonés y para la vida misma de Sender. Aunque no es fácil definir el alcance e importancia de esta amistad en la vida de Sender, intuimos que las consecuencias no fueron nimias. Debemos reparar en algunos detalles de mucha relevancia: $1^{\circ}$ ) Gracias a las traducciones de Mitchell - y a las correspondientes ediciones de estas obras en Inglaterra-, Sender empezó a ser conocido en el mundo anglosajón. Tal conocimiento no debió de ser escaso, pues parece que, a principios de los años 40 , Sender podía vivir modestamente de los derechos de autor que le devengaban las traducciones al inglés, lo cual no era poco. $2^{\circ}$ ) No estamos en condiciones de afirmar si a causa de esta divulgación inicial en el mundo anglosajón Sender acabó recalando en Estados Unidos. En todo caso, vistos los hechos con posterioridad, puede pensarse que bien pudo existir una relación entre ambos hechos. De confirmarse esta hipótesis, la amistad de Sender con Mitchell en los años 30 adquiriría una dimensión mucho más importante.

En el Mitchell de los años 30 encontramos al individuo maduro, que desde 1934 pasaba lar̀gas temporadas en Málaga (Alcofar Nassaes, 1988, 306). Se había jubilado tras una extensa actividad como biólogo investigador de la anatomía animal, como secretario del zoo de Londres y como directo colaborador del periódico The Times, para el que escribió una gran cantidad de artículos sobre múltiples temas, con predominio de los de carácter científico. También elaboró múltiples reseñas de libros — suponemos que novedades editoriales; y esta actividad decía Mitchell que fue la que más satisfacciones le dio-. Colaboró asimismo en la edición de una obra señera en la cultura inglesa: la Encyclopædia Britannica.

El Sender que Mitchell recién había conocido era un escritor joven, tremendamente activo en los años 30, con dos hijos de muy corta edad en 1936 y con ciertas dudas de adscripción ideológica, pues, durante la guerra civil, desde su inicial identificación con el anarquismo, pasó a militar en el Partido Comunista. Tal "deserción ideológica» fue motivo de un fuerte ataque dialéctico de los anarquistas Eduardo de Guzmán y José García Pradas en un libro del primero escrito en 1938: Madrid, rojo y negro (Milicias Confederales).22

A pesar de estar en el estadio final de su vida, sir Peter vivió de lleno los inicios de la sublevación militar y de la subsiguiente revolución española de 1936, en la que vio de cerca una serie de importantes hechos. Ideológicamente se identificó con los anarquistas (así se ve en el capítulo XX de sus memorias, aunque desconocemos si Sender pudo tener alguna responsabilidad en la adquisición de esta nueva fe).

Quizás por la actividad de Mitchell como redactor de reseñas periodísticas de libros, realizada durante tantos años para The Times, entró en

22 Eduardo DE GUZMÁN, Madrid rojo y negro (Milicias Confederales), Barcelona, Edic. Tierra y Libertad (prologado por el periodista José GARCís PRADAS), 1938. 
contacto con la obra de Sender y, por la inicial coincidencia ideológica de ambos, se decidió a preparar las tres traducciones de sus obras para dar a conocer a Sender en Inglaterra. Indirectamente, también contribuyó con estas traducciones a la batalla propagandística que se libraba en Inglaterra entre partidarios y detractores de la República.

Sir Peter Chalmers Mitchell aún vivió una nueva experiencia de enfrentamientos bélicos con la segunda guerra mundial. Murió en 1945, atropellado por un autobús (Alcofar Nassaes, 1988, 317). 


\title{
De tal palo, tal astilla: biografía y creación literaria en los Sender
}

\author{
Anthony Trippett \\ University of Sheffield
}

Dado el carácter autobiográfico de una parte importante de la obra de Sender, es probable que cualquier investigación que se centre en su biografía sea de utilidad en un estudio del proceso de la creación literaria del autor, ya que aclarará el material a partir del cual se forjaron algunas obras. De hecho este artículo podría referirse bien al área temática de la biografía, bien a la de la creación literaria, bien a una tercera área temática a caballo entre las otras dos: la que abarca las relaciones entre vida y literatura, la que invita a la especulación de los motivos psicológicos que puedan subyacer a la creación literaria.

El punto de partida de mi aportación es A Death in Zamora (Albuquerque, University of New Mexico Press, 1989) de Ramón Sender Barayón, hijo del novelista exiliado, quien intenta descubrir las circunstancias de la muerte de su madre en 1936, a raíz de un primer viaje de regreso a España más de cuarenta y cinco años después. El relato fue escrito en inglés.

Además de ser un documento humano extraordinariamente conmovedor, ${ }^{1}$ es importantísimo este libro porque nos da acceso a material bio-

1 Como se verá, mi valoración de $A$ Death in Zamora es radicalmente diferente de la de Francisco Carrasquer LaUned (véase «Un Edipo extemporáneo», Alazet [Huesca], 4 [1992], pp. 123-132). 
gráfico antes desconocido o mal comprendido. Ante las extraordinarias expectativas que despertó entre los biógrafos de Sender, hay que afirmar que el material que ofrece no es tan obvio ni tan fácil de elucidar como cabría esperarse. Para evaluarlo adecuadamente hay que apreciar la perspectiva desde la que escribe el hijo de Sender. Esta apreciación ilumina no sólo el material sino también problemas más generales asociados con la biografía senderiana. Es más, el hecho de que el hijo presente los hechos de la historia familiar de los Sender bajo una perspectiva muy particular indica que en cierto modo - como luego explicaré- se parece a su propio padre. O sea, de tal palo, tal astilla.

Siempre se había negado Sender a hablar a sus dos hijos - hay una hija menor, Andrea- de su madre y de las circunstancias de su muerte. $Y$ a ellos les había resultado casi imposible enterarse de nada: vivían en los Estados Unidos, lejos de su patria, sus parientes y, normalmente, de su padre. Durante muchos años tuvieron que contentarse con una versión novelada de su pasado familiar, la elaborada por Julia Davis, su madre adoptiva: The Sun Climbs Slow (Nueva York, E. P. Dutton \& Co. Inc., 1942). Si los hijos intentaban descubrir más, el padre se enfadaba y les obstaculizaba las investigaciones. De su madre no sabían ni la fecha de su nacimiento ni la de su muerte. Pero tal obstruccionismo sólo consiguió aumentar el deseo de informarse y en el año 1977 la hija de Sender volvió a España para enfrentarse con «la pesadilla de nuestra infancia». En 1983 lo haría el hijo, para describirlo luego en $A$ Death in Zamora.

En gran parte el fin del viaje era terapéutico; y la terapia parece haber tenido cierto éxito: habla de "un dolor bueno" y de "heridas sanadas" ( $p$. 212). ${ }^{2}$ El punto álgido de su experiencia fue el doloroso encuentro con la tumba de su madre (pp. 176-177). Claro que no habría sido necesaria tal experiencia ni tal terapia de haber cumplido el padre sus responsabilidades emocionales para con los hijos (p. 27).

La forma de comportarse del padre acrecentó las dificultades emocionales del hijo, traumatizado ya — según varios comunicantes- antes de salir de España. Siendo persona mayor de habla inglesa, necesitaba recuperar un pasado infantil de palabras españolas, si no preverbal, que su mente consciente desconocía. Recurrió a la hipnoterapia. Llegó a escudriñar obsesivamente fotografías y diccionarios biográficos de los años 30 para vislumbrar la huella de Amparo... Por lo tanto no es de sorprender que el relato de su viaje de regreso esté salpicado de especulaciones sobre posibles recuerdos de ruidos, olores y vistas, todo lo cual indica la fuerza de las preocupaciones y la profundidad de las heridas psíquicas. La necesidad de recuperar el pasado puede explicar el motivo por el cual el hijo llega a reconstruir conversaciones de las que no habría podido tener infor-

\footnotetext{
2 Remito al lector español a la versión española, Muerte en Zamora (Barcelona, Plaza \& Janés, 1990), llevada a cabo por Mercedes EsTEBAN-MAEs KEMP.
} 
mación ni siquiera indirecta. Todo es útil, todo ayuda en lo que se refiere a la necesidad psicológica de recobrar el pasado. Se entiende por qué al hacerlo no examina el material que se le ofrece con los criterios rigurosos, digamos, de un historiador profesional. No lo es, y tampoco tiene los propósitos de un historiador profesional ni los de un biógrafo científico. Así que los lectores que buscan hechos fehacientes o datos biográficos incontrovertibles van a sufrir una decepción. Y así nos lo anuncia la traductora en un prólogo a $A$ Death in Zamora.

Otra barrera que se interpuso entre el hijo y los hechos que quería aclarar en su viaje a España fue el idioma. Él mismo reconoce el problema hasta cierto punto e incluso se burla de sus propias dificultades. Ahora bien, en $A$ Death in Zamora el autor traduce al inglés bastantes párrafos de las novelas de su padre. Es penoso, pero importante, afirmar que una y otra vez entiende mal y se equivoca en la traducción; abundan los errores (ello no es evidente para los lectores de la traducción española, ya que la traductora reproduce los textos senderianos originales). Es evidente que al hijo de Sender le habrá costado muchísimo entender bien a sus interlocutores españoles. Esto explica, en parte, por qué parecen algo artificiales y poco convincentes las conversaciones redactadas en inglés a raíz de las que escuchó en castellano. No se trata de un intelectual ni de un autor profesional. Es un ser humano que relata una experiencia entrañablemente personal y subjetiva. Como él mismo reconoce en los agradecimientos que prologan su libro, necesitaba mucha ayuda tanto en la redacción como en la estructuración del mismo. También me parece significativo el hecho de que medien seis años largos entre el viaje de regreso y la fecha de publicación. Debe de haber sido muy dolorosa la redacción del libro, cuyas cualidades extraordinarias son la naturalidad y la franqueza.

Después de señalar la perspectiva particular que organiza el material biográfico presentado por el hijo de Sender y las parcialidades que puedan haber influido en dicho material, quisiera comentar los puntos nuevos más significativos que sí parecen haber salido a la luz. Según el hijo, Sender se casó con Amparo Barayón en una ceremonia civil un poco antes del 3 de febrero de 1936, la fecha del nacimiento de Andrea (el hijo había nacido el 29 de octubre de 1934). Evidentemente llevaban mucho tiempo viviendo juntos. Según Concha, la hermana de Sender, pudieron haberse conocido en el invierno de 1931 o incluso antes. Pero nada es sencillo en este relato y que sirva el siguiente ejemplo como primera ilustración. Hablando con el hijo, la conservadora sobrina de Amparo, Magdalena, expresó la duda de que Sender y Amparo estuvieran casados (p. 195). Es tal vez un problema muy específico de la época: el mismo padre de Sender, también muy conservador, se negaba a reconocer la validez de una ceremonia civil y la misma mentalidad también puede explicar por qué está inscrita Amparo como «soltera» en el certificado oficial de defunción. 
Aparte de sus dos matrimonios generalmente reconocidos -con Amparo y Florence Hall -3 es evidente que Sender tuvo relaciones con una mujer de familia vasca llamada Elizabeth Sauzon, quien fue madre de Emmanuel (nacido en noviembre de 1937), hermanastro del autor de $A$ Death in Zamora. Según Elizabeth, aunque el mismo Sender siempre lo negaba, se casaron formalmente en Barcelona en una ceremonia civil a finales de diciembre de 1936. Ramón hijo acepta la palabra de Elizabeth Sauzon. Pero para mí de todo esto lo único incontrovertible es la existencia de Emmanuel y Elizabeth y su abandono por Sender. Al morir el novelista tenía las señas actuales de Emmanuel, nacido más de cuarenta años antes, y Ramón hijo pudo llegar a conocerle a él y a su madre. Hace gran falta comprobar la aseveración de Elizabeth porque a primera vista parece dudoso que se volviera a casar Sender inmediatamente después de enterarse de la muerte de Amparo. Pero he aquí otro problema por resolver. ¿Cuándo supo Sender que su mujer había muerto? En 1983 dos comunicantes del hijo señalan el 6 ó 7 de noviembre de 1936; pero Contraataque (Madrid-Barcelona, Nuestro Pueblo, 1938), escrito en 1936-1937, especifica «a fines del mes de diciembre» y en Conversaciones con Ramón J. Sender (M. Peñuelas, Madrid, Magisterio Español, 1970) habla de enero de 1937. A Death in Zamora no resuelve estas discrepancias. Pero son muy importantes porque facilitan la comprensión de la mentalidad de Sender en aquellos meses tan cruciales para él: ¿sería capaz de deserción del frente y cobardía ante el fuego, según la acusación de Enrique Líster en Nuestra guerra (París, Éditions de la Librairie du Globe, 1966, pp. 75 y 82-83), o se explica casi todo a raíz de las noticias trágicas que acababa de recibir? Según se combinen las fechas ofrecidas sale Sender bígamo, cínico o un desgraciado abrumado por una crisis de nervios.

A Sender le gustaba la compañía de las mujeres. Lo afirmó Marcelle, su cuñada, refiriéndose al período antes de que saliera de España. Otras fuentes apuntan a la misma observación: si el mismo Sender es de fiar, por lo que dice en Tres ejemplos de amor y una teoría (Madrid, Alianza, 1969) la destinataria del material original de Carta de Moscú sobre el amor (Madrid, Pueyo, 1934), redactada en Moscú en el verano de 1933, era una de las dos mujeres con las que compartía su cariño al mismo tiempo. Ramón hijo llegó a convencerse de que su padre tenía una aventura amorosa mientras estaba encarcelada Amparo; así lo creía también la conservadora Magdalena, sobrina de aquélla. Elizabeth Sauzon se quejó de una periodista vienesa...

El libro de Ramón hijo deja claro que el padre dedicó poco tiempo y poco dinero a los tres hijos. De hecho, el padre y Ramón hijo se llevaron muy mal. A Death in Zamora lleva implícitos una cólera y un resentimiento profundos contra el padre por parte del hijo debido a la negligencia de que - con razón- se sentía víctima. Refiere conversaciones tormentosas

\footnotetext{
3 Según Charles KinG, Ramón J. Sender (Nueva York, Twayne Publishers, 1974), se casaron el 12 de agosto de 1943; se divorciaron el 3 de septiembre de 1963.
} 
entre los dos, incluso la última --telefónica--, durante la cual el padre le colgó. Lo curioso desde el punto de vista psicológico y biográfico es que en esta forma de comportarse Sender se parece a su propio padre. Esta observación se basa no sólo en lo que se relata en Crónica del alba (Barcelona, Delos-Aymá, 1965-1966) - lo que sería muy peligroso- sino también en la documentación que aporta Charles King en Ramón J. Sender (Nueva York, Twayne Publishers, 1974, pp. 15-19). También se parecen el padre y Ramón hijo en su calidad de hijos rebeldes. Cabría preguntar si no se dan aquí dos casos de sentimientos edípicos. Sabemos poco de la infancia del padre, pero en el caso del hijo algunos de los años de más trauma familiar corresponden a los de la etapa edípica, que según el freudianismo tradicional tiene lugar de los tres a los cinco años. El complejo se resuelve gracias a un proceso largo a través del cual el niño se identifica con el padre y redescubre a la madre como persona mayor. Ninguno de los tres hijos de Sender tuvo esta oportunidad nunca.

A Death in Zamora permite perfilar mucho mejor de lo que se ha hecho hasta ahora la figura de la mujer de Sender. Aunque parece evidente el «ferviente catolicismo» que subraya José María Jover ${ }^{4}$ también lo es la independencia de Amparo, quien supo vivir con Sender sin casarse. Es verdad que enseñó el catecismo en su nativa Zamora y aceptó las presiones de su suegro, sin que lo supiera Sender, para bautizar a los dos hijos; pero también escribió artículos y críticas de obras de teatro para la prensa de Zamora y fue miembro de un "ateneo republicano», que solía reunirse en un café que pertenecía a la familia. Además, tenía su propia profesión como empleada de la Telefónica, primero en Zamora, luego en Madrid. Es muy significativo que consiguiera independizarse de su familia y que pasara a vivir en Madrid justamente en el período del advenimiento de la República. Por cierto, su madre murió cuando tenía siete años y su padre cuando tenía trece, lo que habría podido influir en su formación como persona independiente. También es cierto que había gente liberal y de izquierdas en su familia: su hermano, Antonio, y su hermanastro, Saturnino, quienes fueron fusilados en Zamora en los primeros meses de la guerra civil.

Faltan palabras adecuadas para describir la crueldad e injusticia de la que fue víctima Amparo, detenida y fusilada por las fuerzas nacionales en Zamora en 1936. Tal vez sean las más valiosas las del testimonio de Pilar Fidalgo, ${ }^{5}$ hecho en forma de declaraciones ante el cónsul español en Bayona en 1937. Lo que dice sí merece especial respeto, aunque traducido como fue al inglés y al francés sin duda desempeñaría un papel en la guerra propagandística. Lo que indigna más es el claro hecho de que estuviesen

\footnotetext{
4 Véase la introducción de su edición de Mister Witt en el cantón, Madrid, Castalia, 1987.

${ }^{5}$ A Young Mother in Franco's Prisons (Londres, United Editorial Ltd., 1939); "Nueve meses en manos de los fascistas, un testimonio personal», El Socialista [Madrid], 20, 21 y 22 de mayo de 1937.
} 
implicados en el asesinato, por omisión si no por comisión, algunos miembros de la familia inmediata de Amparo: la hermana mayor, Casimira, y su marido, Miguel Sevilla. No es del todo claro si a éstos los motivaba el miedo o la avaricia: sin duda tenía Sevilla influencia que hubiera podido emplear a favor de su cuñada; la posibilidad de quedarse los parientes con la herencia de Amparo también habría podido influir. En cuanto al comportamiento de gente de fuera de la familia, muy obvias son las ocultaciones efectuadas por las autoridades: a los dos años de la muerte de Amparo obligaron a Casimira y a otra hermanastra, Magdalena, a firmar una declaración que decía que Amparo había muerto a consecuencia de una pulmonía. En términos generales el testimonio de los testigos a los que consultó el hijo en España deja a veces mucho que desear: el mismo padre en Contraataque (ya en 1937) censuró fuertemente el comportamiento de la hermana Conchita, que sería uno de los comunicantes principales del hijo. Parece que unos familiares se sentían culpables en cierta medida y no querían hacer declaraciones claras; ${ }^{6}$ por otra parte, en la España de la posguerra muchos miembros de la familia sufrieron, bien encarcelamiento, $o$ cuando menos falta de ascenso a consecuencia de la asociación con Sender, Amparo y sus dos hermanos fusilados. En el caso de un cuñado, Emiliano, esto dio lugar a un profundo resentimiento e irritación. En cambio, Asunción, hermana de Sender, estuvo y sigue estando muy indignada por la injusticia sufrida por los fusilados y muy compadecida para con ellos. $Y$ todo esto evidentemente influye en el testimonio que puedan dar. Asimismo escasean testimonios incontrovertibles entre los testigos no familiares; lo que no quiere decir que haya que descartar lo que dicen, sino que hay que reconocer la naturaleza subjetiva de su testimonio. Me estoy refiriendo en particular a las afirmaciones de Palmira Sanjuán Misis y Maruchi Rivera, citadas por Ramón hijo. La primera, que compartió la celda de Amparo, declara haber quedado traumatizada por sus experiencias; la segunda sólo tenía siete años en el verano de 1936.

A fin de rematar y concluir esta sección de mi argumento quisiera referir al lector curioso las enormes dificultades que veía Charles King cuando se puso a intentar escribir una biografía de Sender con la colaboración del novelista (op. cit., pp. 13-14 y 24). La empresa iba a ser, si no del todo imposible, dificilísima y el período de la guerra más que ningún otro. ${ }^{7}$

Hasta ahora hemos examinado lo que podría considerarse un testimonio que, aun cuando no era objetivo, tenía pretensión de serlo. El hijo

\footnotetext{
6 Son observaciones hechas por Ramón Sender Barayón al autor de este artículo, en una carta personal del 31 de diciembre de 1992.

${ }^{7}$ No obstante, los trabajos recientes de Donatella PINI MORO (Ramón José Sender tra la guerra e l'esilio, Alessandria, Edizioni dell'Orso, 1994) y de Jesús Vived MaIRAL («La vida de Ramón J. Sender al hilo de su obra”, Alazet [Huesca], 4 [1992], pp. 231-270) sí han arrojado luz sobre muchos puntos biográficos difíciles; y es de esperar que se aclarará mucho más cuando Jesús Vived Mairal publique su ya anunciada biografía completa de Sender.
} 


\section{ANTHONY TRIPPETT}

había ido a España para ponerse en comunicación con este testimonio. Pero hay otro testimonio, consultado por el hijo antes de ir a España y que luego consultaría mucho más, animado en particular por sus dos tías Magdalena y Concha. Éste es muy poco objetivo. Me refiero a las mismas novelas autobiográficas de Sender, en particular Los cinco libros de Ariadna (Nueva York, Ibérica, 1957) y Siete domingos rojos (Barcelona, Balagué, 1932). En muchos casos - pero no en todos- la consulta es explícita:

Lo que pasó aquella noche en "Villa Frutos» puede adivinarse al leer la novela de mi padre Los cinco libros de Ariadna. Ariadna habla por Amparo, Javier por mi padre. Conchita me aseguró que los paralelos autobiográficos son inconfundibles. "Aquella noche Javier y yo estuvimos despiertos. Yo le pregunté si me quería. [...]». (Muerte en Zamora, p. 53)

Ahora bien, aunque sea Sender un autor en quien abundan los elementos autobiográficos y tal material sea de gran interés para los estudiosos de la obra y biografía del novelista, la creación literaria no constituye ninguna base para la historiografía seria. Las leyes de la vida y las del arte son diferentes, de la misma forma que es diferente una nariz real de su representación en un cuadro. Basta comparar un momento las actividades de dos creaciones de Sender, un Pepe Garcés o un Ramiro Vallemediano, respectivamente un suicida y un verdugo, con lo que sabemos de la vida de su autor, que no era ni lo uno ni lo otro, para percibir el problema. Por consiguiente, por lo que se refiere a las aportaciones conseguidas por el autor de $A$ Death in Zamora gracias a esta metodología, el libro tiene menos interés; donde tiene más es en su descubrimiento directo e indirecto de los sentimientos del padre o de hechos reales relacionados con Amparo. Antes de pasar a considerar éstos quisiera hacer un breve comentario sobre la relación entre Siete domingos rojos y la vida de Amparo, cuestión que surge de $A$ Death in Zamora.

Da la casualidad de que la protagonista de Siete domingos rojos tiene el mismo nombre de la que sería la primera mujer de Sender. Sabemos, por los parientes, que Sender ya en el verano de 1931 conocía a Amparo, quien escribió Orden público (Madrid, Cenit, 1931) a máquina para él. Lo más probable es que también pasara a máquina Siete domingos rojos. ¿Expresaba Sender un toque de humor al darle a la novia virginal y sumisa de Samar el nombre de su compañera independiente? Por cierto, distaba mucho la Amparo histórica de la Amparo García de la novela, quien más probablemente se inspiraba en Mercedinas, hija del comandante en jefe de la caballería española. Ahora bien, no es del todo inverosímil que la carta de amor tan conmovedora que dirige Samar a la Amparo de la ficción ${ }^{8}$ se basara en sentimientos que había experimentado Sender por su compañera real; pero lo que sí habría que averiguar y a primera vista me parece muy poco probable es que, igual que la Emilia de Siete domingos rojos,

8 Véase Muerte en Zamora, cit., p. 82. 
Amparo plantara una bomba en la Telefónica de Madrid en el verano de 1931. ¿Sería capaz de referirse Sender, a los pocos meses después de que ocurriera, a un acto ilegal, reconocible, cometido por su compañera? En la descripción que dio Sender de su mujer en Contraataque, a raíz de su asesinato, negó que jamás tuviera ella un cometido político; aunque es concebible que exagerara un poco su apoliticismo para destacar la barbarie de su muerte.

El desesperado afán por ocultarles a los hijos las circunstancias de la muerte de Amparo apunta a una preocupación y dolor muy profundos en Sender. El hijo llega a la conclusión de que el padre no había terminado de enfrentarse con sus propios sentimientos de culpabilidad. Es muy posible. Por cierto, la preocupación por la muerte de Amparo parece haber sido una obsesión de toda la vida. Poco después de morir Sender, una amiga colombiana del novelista hizo al hijo escuchar una grabación extraordinaria del padre borracho, quien hablaba de una Amparo de aventuras amorosas y abortos ilegales, perdonada magnánimamente por él (pp. 41-42). Sería desaconsejable aventurarse uno demasiado en la interpretación de esto sin saber más de las circunstancias en que se hizo la grabación y en las que el hijo la escuchó - ¿habría quien le ayudara a entender bien las palabras españolas?-; pero, con todo, quisiera hacer hincapié en los siguientes puntos significativos:

a) Parece que todavía a los cuarenta y cinco años de la muerte de Amparo Sender se pone a fantasear en torno al período de la guerra civil, centrándose en la culpabilidad y el adulterio de su relación con Amparo sobre un fondo de Madrid y Zamora.

b) Se asigna a sí mismo el papel del altruista, inocente.

c) Amparo no muere y se le asigna el papel de culpable.

Las mismas preocupaciones dominan Los cinco libros de Ariadna, que ya sale iluminado por la información revelada en $A$ Death in Zamora. Hace mucho que los críticos (Josefa Rivas, Marcelino Peñuelas, Nonoyama y King) reconocieron el carácter evidentemente autobiográfico de Los cinco libros de Ariadna y las revelaciones apuntan a la magnitud de ello. En particular los detalles y variantes en cuanto a la suerte de Ariadna en Los cinco libros de Ariadna son interesantísimos:

a) Dos veces se enfrenta con el pelotón. La primera vez es indultada; la segunda, disparan contra ella, queda herida, pero Javier la atiende como enfermero.

b) Hay mucha discusión sobre los sentimientos de cada uno respecto a la posible muerte del otro y sobre la motivación de Javier al abandonar a Ariadna a raíz de la ruptura de las hostilidades.

c) Está sobre el tapete la noción de que tanto ella como él pudieran tener una aventura amorosa, aceptada por el otro.

d) El discurso se presenta desde el punto de vista de ella y de él.

Los mecanismos de la creación literaria son misteriosos; seguramente desempeñan un papel importante factores insconscientes muy lejanos de 
los propósitos enunciados por un autor. También cabría argüir que no es seguro que la exploración de tales factores inconscientes arroje luz sobre el discurso narrativo. Hechas todas estas salvedades, defendería el interés de esta investigación por relacionarse con observaciones hechas por el propio novelista, que luego cito. Evidentemente Sender estaba explorando imaginativamente lo que había sido su experiencia. Pero en tal exploración cabía tanto una gama amplia de sentimientos - miedo, esperanza, culpabilidad, evasión, ilusiones - y de percepciones subjetivas como de hechos reales. Claramente era la literatura, para Sender, un campo ancho para la reelaboración de mitos personales y para afrontarse con sus demonios interiorizados. Sean cuales fueren los propósitos conscientes del autor, muy patentemente operaban factores psicológicos que parecen mostrar algunas de las características de la represión, censura y distorsión freudianas. El censor permite que afloren los sentimientos de ansiedad y culpabilidad, pero sólo de una forma disfrazada y no amenazadora, de modo que la conciencia del sujeto no se sienta abrumada. Tanto el argumento citado de Los cinco libros de Ariadna como el discurso del cassette grabado por Sender pueden interpretarse así. Esto está de acuerdo con lo que afirma Sender en sus Conversaciones con Marcelino Peñuelas respecto a la «esquizofrenia del artista»:

Todo auténtico artista lo que hace a lo largo de su vida es tratar de compensar su esquizofrenia [...] Si Gogol no hubiera escrito Las almas muertas habría sido un loco agresivo [...] Hay sólo dos maneras de librarse uno de sí mismo, que son el amor y el arte. (Conversaciones, pp. 269-274)

Se ha dicho más de una vez que la experiencia de la muerte de su hermano Manuel, alcalde de Huesca, fusilado por los nacionales, se refleja en Réquiem por un campesino español (Nueva York, Las Américas, 1960) ${ }^{9}$ y en la suerte de su protagonista, Paco. Es posible que también se reflejen allí algunos detalles de la detención y suerte de Amparo. El que se fusilara a Paco en el cementerio, igual que a Amparo, tal vez carezca de significación especial, ya que frecuentemente era el cementerio, según Ian Gibson (The Assassination of Lorca, Harmondsworth, 1971), el lugar de ejecución; pero me pregunto si aquel interrogatorio tan fascinante y sutil de Réquiem por un campesino español en el cual el cura, mosén Millán, consigue informarse del escondrijo de Paco, lo cual llevará a su detención y fusilamiento, no tiene alguna conexión con la forma de interrogatorio de que habría sido víctima la mujer de Sender. Pilar Fidalgo habla de un cura que abusaba de los condenados a muerte, presionándoles para que revelaran los nombres de sus compañeros, que luego pasaba a los falangistas; y luego de otro que "le rehusó la absolución [...] a Amparo porque ella se negó a declarar que su marido fuese un canalla» (p. 170). Es muy posible que Sender leyera

${ }^{9}$ Publicado por primera vez con el título de Mosén Millán (México, Aquelarre, 1953). 
este relato u oyera referir algo parecido a algún pariente o testigo: la escueta relación de los hechos que se da en las últimas páginas de Contraataque no menciona la crueldad del cura, pero sí la confesión. Hechos reales, asociados con Amparo, provenientes de éstas u otras fuentes pueden haber inspirado la creación de aquel cura de Los cinco libros de Ariadna (pp. 245250), tan preocupado por su pistola y su cinturón de cartucheras, que reacciona violentamente cuando Ariadna dice que se había casado civilmente.

Al lector de $A$ Death in Zamora le resulta dificilísimo saber en determinados casos si se trata de un hecho real, una pura ficción o algo entre los dos. Cito, como ejemplo, la historia del joven que monta a caballo para secarse después de nadar; el caballo se desboca, entra en el pueblo y dispersa una procesión de las Hijas de María. Según Concha, el mismo Sender relató esta historia antes de la guerra refiriéndola a sí mismo. El hijo confirma habérsela oído contar también años más tarde. Ahora bien, el mismo relato sale en Los cinco libros de Ariadna (p. 53) con Javier como protagonista. Es tan bueno el relato que no me sorprendería que tuviese una larga historia de ficción que se remontara a una época anterior al mismo novelista. También es posible que esto le pasara a Sender de joven y que lo incluyera en Los cinco libros de Ariadna por el carácter autobiográfico de aquel libro. Es igualmente probable que Concha se equivocara y que sin darse cuenta citara Los cinco libros de Ariadna como tantas veces había hecho. También puede ser que cuando Sender relató la historia años más tarde a su hijo se basara en su propia ficción.

La fecundidad del talento creador del novelista es sumamente evidente. No podía dejar de crear ni de expresarse; no concebía otra forma de vivir. Era su forma de adaptarse a la realidad en torno suyo. Me vienen a la mente las palabras de uno de los personajes de Las criaturas saturnianas (Barcelona, Destino, 1968), que fueron la inspiración de mi estudio Adjusting to Reality: Philosophical and Psychological Ideas in the Post-Civil War Novels of Ramón Sender (Londres, Tamesis, 1986): «[...] el problema de cada cual desde que nace es el de la adaptación a la realidad por sus propios medios (hechos, imágenes, sueños). Tarea laboriosa y enfadosa. Tarea ardua de veras» (p. 313). No es curioso que los hijos siguiesen su ejemplo. Para ellos también la palabra escrita ha resultado una forma importante de expresión y de adaptación. Sólo después de que su hija Andrea escribiera un relato de dos personas que se llamaban Elizabeth y Manuel consintió Sender en hablar del hermanastro y de la madrastra. Y cabría decir que $A$ Death in Zamora puede considerarse otro ejemplo más. El germen de este libro fue "una versión novelada de la historia de Amparo» que esbozó el hijo para su padre a fin de incitarle a hablar francamente de la historia familiar. $Y$ ya hemos hecho mención de The Sun Climbs Slow.

Sender aludió repetidamente a la importancia que tuvieron para él durante la guerra civil Amparo y su recuerdo. Refiriéndose a Los cinco libros de Ariadna ha dicho: «Y el nombre Ariadna [...] viene del hilo que mi mujer me tendió y que me permitió salir del laberinto en el cual yo iba a 
perderme» (Conversaciones, pp. 89-90). Él la convirtió en un mito vivificador que le ayudaría a sobrevivir frente a una realidad hostil y a peligros terribles no sólo en la guerra civil sino después también; igual que le pasaba a Javier en Los cinco libros de Ariadna (p. 550) y a Pepe Garcés (con Valentina) en la última parte de Crónica del alba. Gracias al talento creador del autor y unos procesos de compensación psicológica algo misteriosos, los hechos objetivos de la vida real de Amparo se convirtieron en un mito subjetivo que los trascendió. Como afirmaba Javier, "Para mí lo importante en la vida no es el amor ni el odio ni lo que siente un hombre o una mujer sino la vida proyectada en sus formas esenciales, es decir la idea de la vida" (Los cinco libros de Ariadna, p. 583). Pero tales mitos subjetivos, tales ideas tenían que ser protegidos de la luz fría de los análisis objetivos. Como decía Javier a Ariadna: «Si pudiera decirte quién eres mi definición te mataría. No pudieron matarte los fusiles de Pinarel pero mi definición te mataría» (ibid., p. 510). La necesidad psicológica que tenía el hijo de Sender de formular una imagen de su madre (a través de su libro) se enfrentó con la necesidad de su padre de proteger su propia imagen vivificadora de Amparo, vivificadora y no amenazadora. De ahí la furia del padre. Uno no sabe si llorar o sonreír compasivamente frente a la incompatibilidad de sus idénticas necesidades psicológicas.

Se justifica la investigación tan fascinante del proceso creativo de Sender por el interés que manifestaba por él el propio autor, aunque no estoy seguro de que estos apuntes hayan contribuido a la interpretación como tal de la obra creativa de Sender, la cual me parece de una riqueza extraordinaria y que siempre debe ser el objeto principal de nuestro cometido. Tampoco estoy seguro de que haya acabado de establecer datos biográficos incontrovertibles. Espero, sin embargo, haber contribuido a los estudios biográficos de Sender destacando la extensa gama de pespectivas parciales y sesgadas que dificultan la objetividad. Algunas de éstas eran propias del mismo Sender, quien - una y otra vez- escribía su propia autobiografía y en cierto modo legó la misma tendencia al hijo.

Por lo que se refiere a la biografía de Sender, me pregunto si jamás llegaremos a saber cómo era la cueva que el escritor pretende haber visitado a los siete años (igual que Paco en Réquiem por un campesino español) ni cómo era la Valentina histórica, llamárase como se llamara, que luego saldría idealizada en Crónica del alba. Tanta fuerza tienen las creaciones subjetivas de Sender que llegan a enterrar en el olvido sus propias fuentes históricas. Entre el viaje de regreso de Andrea y el del hijo de Sender, un equipo investigador de la revista Interviú, encabezado por Heriberto Quesada, fue a la ciudad de Zamora para intentar aclarar las circunstancias de la muerte de Amparo. Durante años se creyó en Zamora que Amparo estaba embarazada cuando la detuvieron y que las autoridades esperaban a que diera a luz para fusilarla. Uno de los logros del equipo fue mostrar la falsedad de aquel dato. Lo que no llegaron a percibir fue que es probable que aquella creencia se basara en escenas de ficción del propio novelista: 
las de los últimos capítulos de Crónica del alba, en los cuales una mujer que acaba de parir esconde al recién nacido para que las autoridades sigan aplazando su ejecución. En la misma ciudad del crimen, durante muchos años la ficción había conseguido sustituir a la realidad objetiva. Pero no deberíamos sorprendernos. Es desigual la lucha entre los escuetos hechos de la realidad objetiva y la imaginación creativa: casi siempre gana ésta, sobre todo en el caso de los Sender. 
N 


\section{Sender visto por los literatos actuales $(1932-1936)^{1}$}

C uando José-Carlos Mainer - a quien como amigo quiero y como estudioso de la literatura admiro y respeto- me invitó a participar en este acto me sentí muy halagado. Aunque no sea ésta la primera vez que en Huesca hablo públicamente del insigne escritor oscense y que en fecha tan temprana, senderianamente, como 1932 di en Zaragoza una conferencia en la que por vez primera se habló del Sender novelista y del poeta Seral y Casas, primicias que pavonean mi vanidad, mi presente halago está justificado, porque como profesor de literatura jubilado, por muy «emérito» que los papeles académicos digan, uno ya no cuenta en los aconteceres académicos. ¿Qué puede decir un viejo que quizás no haga ya más que releer los libros más amados? De la incesante marea bibliográfica no le llega más que el rumor del oleaje.

Pero en este caso concreto me quedan las memorias de cientos de horas de conversación con Ramón Sender, en una gran amistad que, para el muchacho de veinte años que yo era, fue una magnífica experiencia cordial y literaria. Licenciado en Derecho desde 1931, vivía con mi familia en Madrid, enteramente dedicado a una vocación literaria que había nacido en mi adolescencia y había echado raíces en mi vida entera. Residente en la capital desde setiembre del año 29, mi interés por Aragón, sus gentes y

\footnotetext{
${ }^{1}$ Intervención de Ildefonso-Manuel Gil con que dio comienzo la mesa redonda titulada «Sender visto por los novelistas aragoneses de hoy» (4 de abril de 1995).
} 


\section{EL LUGAR DE SENDER}

sus cosas era cada vez más acuciante y, por fortuna para mí, menos nacionalista.

Los primeros meses del año 32 los había dedicado a ir preparando una conferencia sobre jóvenes escritores aragoneses. Los estudiados iban a ser Benjamín Jarnés, Fernando Castán Palomar y Ramón J. Sender, novelistas, y Tomás Seral y Casas, poeta. Como era de prever, la inclusión de Castán Palomar facilitó la organización de la conferencia en Zaragoza; sería en la Agrupación Artística Aragonesa, en la primera quincena de julio.

Había leído, releído y analizado Imán, había ojeado El problema religioso en Méjico y América antes de Colón. Iba a leer Orden público y El Verbo se hizo sexo. Recordaba varios cuentos de Sender, leídos años antes en la revista Lecturas. Escribí al autor una carta, hablándole de mi proyectada conferencia y pidiéndole que me recibiera. Debíamos de andar por los últimos días de marzo de aquel año 32. En la primera semana de abril, nos veíamos todas, casi todas, las tardes. Estaba alojado en una pensión de muy buen aspecto, en la casa que hacía chaflán entre la plaza de Santa Bárbara y Sagasta; se entraba por esa calle y la habitación suya tenía balcón a la plaza. Yo vivía en Hortaleza, 82, moderno, así que estaban cerca nuestros domicilios. A las tres de la tarde nos juntábamos y si llovía nos quedábamos en el café que había en la planta baja de su casa. Con el buen tiempo, íbamos caminando, despacio, hasta el Ateneo y si estaba de portero un conocido suyo me colaba. Allí no se hacía otra cosa que oír charlar, pero ya era bastante. Al segundo o tercer día, Sender me dio ejemplares dedicados muy amablemente de Orden público y El Verbo se hizo sexo.

Habíamos hecho una gran amistad, en tan pocos días, de modo que no me sorprendió cuando aceptó la dirección de Mundo Obrero, lo que sí extrañó a muchos de sus amigos. Ya no tenía tiempo libre para paseos y tertulias, pero cuando un Juzgado lo reclamó por un delito de prensa volvimos a vernos todas las tardes; un camarero de un bar de la calle Infantes me daba el lugar del encuentro, que cambiaba día a día. Por entonces creo que debió de comenzar a salir con la que iba a ser su esposa. En mi memoria la entreveo como una hermosa mujer, esbelta y morena.

La antigua actitud de Sender por la literatura iba cambiando bastante y ya acostumbraba a pronunciar esa palabra sin ningún tonillo de desdén ni cachondeo. Creo que fue en el verano de 1933 cuando aceptó, después de haberlo rechazado muchas veces, mi préstamo de mis ejemplares de $L a$ montaña mágica, Santuario, Canguro y Contrapunto. Si la memoria no me engaña, de cada una de esas grandes novelas escribió en sus colaboraciones en La Libertad. Con sorpresa para mí, le pareció muy bien el plan de Ricardo Gullón y mío de sacar el año siguiente, que era ya el 1934, una revista que al titularse Literatura pretendía una revalorización de lo literario. Sería bimensual, con seis salidas, y la sexta sería definitivamente la última. El dinero lo aportaría Ricardo, pues él conocía mi apurada situación económica, aunque rechazaba resueltamente mi propuesta de figurar yo sólo como secretario: seríamos directores los dos en absoluta colabora- 
ción. Literatura sacó su primer número en el día fijado; estaba domiciliada en Hortaleza, 82, y se imprimía en la imprenta de Galo Sáez, como Revista de Occidente.

Por lo que hoy nos importa, el escaso interés de los jóvenes escritores por Sender no había cambiado. Los prejuicios y supersticiones que abundaban en muchos aspectos de la vida española eran más tajantes, por pedantería, en el mundillo literario, que había establecido que Sender no era un escritor sino un periodista. Por su parte Sender no había desaprovechado ninguna oportunidad de mostrarse, él mismo, separado, aislado, distinto y distante: «Mis novelas están por encima o por debajo de la literatura». El caso era que ni en las revistas literarias mayores ni en las juveniles había ninguna presencia senderiana. Y si tal situación era comprensible en cierto modo en 1931 y aun en los comienzos del 32, ya no lo era después de Siete domingos rojos, novela muy estimable, en la que el pulso literario, el estilo narrativo eran de indudable valía. Pero cuando en nuestras tertulias ocasionales, todavía en los primeros meses del 1933, suscitaba yo mi obsesivo «tema Sender» no me tomaban en serio, querían ver en mis elogios al para mí estimable autor aragonés un pequeño-nacionalismo que les divertía. Uno de aquellos amigos me llevó una tarde este ejemplar de la tercera publicación senderiana y utilizaban su página segunda para mostrarme que allí se ofrecía periodismo, reporterismo, y no literatura. Hablaba yo de Imán y me replicaban que èra un astuto aprovechamiento de Sin novedad en el frente y yo ponía entonces mi disco de que entre nosotros la pereza intelectual iba siempre del brazo, es decir, iba de bracete con la formación de juicios de valor, y que quien hubiera leído ambas novelas, si no era tonto o puñeteramente malintencionado, tenía que ver las radicales diferencias literarias que había, por encima y por debajo de las coincidencias temáticas.

En el segundo número de Literatura (febrero-marzo del año 34) figuraba una nota mía, «Reportajes en emoción», sobre Viaje a la aldea del crimen y Madrid-Moscú, recientemente publicados por Ramón J. Sender, y en el tercero (mayo-junio) abría la revista un inédito de Sender, "Consagración de las sombras", que era un fragmento de la próxima novela del autor, $L a$ noche de las cien cabezas, "novela del tiempo en delirio». Completaban el número textos inéditos de Max Jacob, José Antonio Maravall, Vicente Aleixandre, I. M. G., Leopoldo Panero, Louis Parrot, Francisco Valdés y Ricardo Gullón, quien dedicaba en el siguiente número de nuestra revista una elogiosa nota a la aparición de un libro de ensayos literarios de Sender. Literatura acababa su publicación con el número 5-6 (otoño de 1934), tal como desde su nacimiento había anunciado. En su Sección de Libros figuró una nota sobre $\mathrm{La}$ noche de las cien cabezas. La firmaba quien ahora tiene el honor de hablaros. Sus últimas líneas decían:

Es Ramón J. Sender uno de los pocos escritores sinceros de esta hora española. Dice lo que piensa y siente, pone sus escritos al servicio de su ideal político y social, aunque sabe que esto, literariamente, le limita. Pero 


\section{EL LUGAR DE SENDER}

sabe también que, vitalmente, le completa. Y esto significa mucho para Sender, y a ello se emplea.

En junio de ese mismo año 34, tan fecundo para Sender, volvimos mi familia y yo a Aragón; los números de Literatura correspondientes a mayojunio, julio-agosto y el 5-6, de septiembre-diciembre, estaban domiciliados en Daroca.

En esa ciudad aragonesa recibía las cartas de Sender y, oportunamente, su novela Míster Witt en el cantón, Premio Nacional de Literatura y última obra suya anterior a la guerra civil. Después de aquella vil catástrofe, todo iba a ser ya otra historia.

ILDEFONSO-MANUEL GIL 


\section{Unas palabras para ser leídas en el transcurso de la mesa redonda «Sender visto por los novelistas aragoneses de hoy» ${ }^{1}$}

Siento sinceramente no poder estar aquí y ahora, tal como estaba programado, para aportar mi granito de arena en este Primer Congreso Internacional sobre Ramón J. Sender y su obra.

Hubiera debido participar, en efecto, en esta mesa redonda: «Sender visto por los novelistas aragoneses de hoy".

Yo creo, señoras y señores, que no resulta fácil a un novelista en ejercicio juzgar objetivamente la obra de otros colegas, que son, como él, notarios más o menos fieles de unos hechos y circunstancias comunes. Por algo diría Oscar Wilde (suponiendo que los novelistas podamos incluirnos en la excelsa nómina de los artistas) que los artistas son como dioses, que reconocen a sus admiradores pero no se reconocen entre sí. Y por algo diría también Hemingway que la única disciplina a que debe someterse un escritor es no leer más libros que los suyos.

Suele ocurrir, en efecto, que aunque el paisaje descrito sea el mismo cada cual tiene su perspectiva, su particular punto de mira, que pocas veces, por no decir nunca, coincide con el de su colega.

En el caso de Ramón J. Sender, sin embargo, todas esas consideraciones no sirven porque hay novelistas, como él, que exigen ser leídos, que

\footnotetext{
${ }^{1}$ Celebrada el 4 de abril de 1995.
} 
necesitan ser leídos, que deben ser leídos. Y esto no lo digo forzado o condicionado por la naturaleza de este encuentro que se consagra al estudio de la obra del maestro de Chalamera, sino porque Sender pertenece a esa extraña y limitadísima categoría de novelistas necesarios que precisamente por eso han escrito novelas necesarias.

«Mi territorio es Aragón y a él me atengo», escribió Sender. Del mismo modo hubiera podido decir: «Mi territorio es el hombre y a él me atengo». Porque ése es, en mi opinión, el único territorio que pertenece de pleno derecho a los novelistas de raza y que nadie les puede disputar jamás. Y son, por desgracia, muy escasos los novelistas españoles de este siglo que han conseguido penetrar en ese entrañable territorio con tanta hondura y perfección como lo hace Sender.

Que Dios perdone, por lo tanto, a todos aquellos lectores que no le hayan encendido o no le encienden una luz en sus altares.

Lamento, lo digo otra vez, no estar ahora mismo aquí. Pero les doy las gracias por estar ustedes.

JAVIER TOMEO 


\section{Carta de Asunción Sender a los congresistas ${ }^{1}$}

Señoras y señores congresistas:

La abajo firmante, María Asunción Sender Garcés, excuso mi asistencia a este Primer Congreso sobre mi hermano Pepe, por imperativos médicos, pues mi corazón y mi vista se encuentran seriamente quebrantados.

No obstante, es mi deseo que se lean estas líneas en un acto del Congreso, ya que mi ausencia es sólo física, por lo cual quiero sumarme a tan grato acontecimiento, representada por mi contrapariente Enrique Chabier Compairé Angulo, con el firme convencimiento de que el nombre de Huesca sea cada vez más recordado por sus hombres célebres: Pepe Sender Garcés, Ricardo Compairé Escartín, Joaquín Costa, Ramón Acín, Antonio Durán Gudiol, mi otro hermano Manolo (alcalde que fue de Huesca), etc.

MARÍA ASUNCIÓN SENDER GARCÉS

Barcelona, 2 de abril de 1995

\footnotetext{
${ }^{1}$ Leída en el acto de clausura (7 de abril de 1995) por Antonio Turmo Arnal, Director en funciones del IEA.
} 


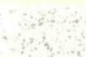

Q $2 x$

(15) is

1)

2hich

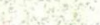




\section{Palabras de Ramón Sender Barayón en el acto de clausura ${ }^{1}$}

Primero de todo quiero expresar mi agradecimiento al Comité de Honor, a la Diputación de Huesca, a los Ayuntamientos de Huesca, Alcolea de Cinca y Chalamera y a los ponentes y responsables de este Primer Congreso, «El lugar de Sender».

Es casi imposible hallar las palabras para describir las emociones que me han inundado durante estos días. En primer lugar, porque estoy experimentando un confrontamiento profundo con mis raíces aragonesas, y segundo, porque hablo el castellano como un marciano. A veces durante las ponencias las palabras entraban en mí subconsciente como mensajes de mi niñez a larga distancia.

Una vez más, me siento conectado a esta parte de mi vida después de la cual fui trasladado a una vida norteamericana, que mi padre describió como "el paréntesis americano» y que duró cuarenta y seis años. Desgraciadamente, dentro de este periodo de tiempo fue donde mi hermana Benedicta y yo vivíamos. Digo "desgraciadamente» porque, durante este tiempo, el mundo ganó un autor de gran prestigio pero sus hijos perdieron la presencia de su padre, sin haber recibido nunca una explicación.

Revelo estos datos penosos con gran respeto a la fidelidad de algunos familiares a la persona de mi padre, pero creo que es necesario para

17 de abril de 1995. 


\section{EL LUGAR DE SENDER}

comprender mejor la profundidad de sus heridas, por la guerra y posterior exilio.

Ramón J. Sender, como escritor, era excepcional. Como hombre, amable con sus amigos... Ahora su vida es propiedad de su pueblo y por esta razón es importante comprender también que, como hombre, estuvo sufriendo bajo el peso de su conciencia.

Ahora, después de diez años de esfuerzos por parte de todos los que aparecen en el programa del Congreso, creo que es el momento de llevar a cabo la creación de la Fundación, con la posibilidad del patrocinio de la Casa Real y, por supuesto, de la Diputación de Huesca.

Hasta el próximo Congreso. Aquí, en Huesqueta, o en California.

RAMÓN SENDER BARAYÓN 
Estas Actas del I Congreso sobre Ramón J. Sender se acabaron de imprimir el día 3 de febrero de 1997, nonagésimo sexto aniversario del nacimiento del universal escritor de Chalamera. 
N 


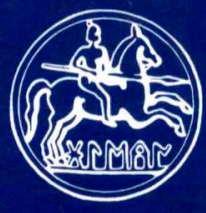

INSTITUTO DE ESTUDIOS ALTOARAGONESES (DIPUTACIÓN DE HUESCA)

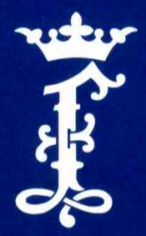

INSTITUCIÓN «FERNANDO EL CATÓLICO» (DIPUTACIÓN DE ZARAGOZA)

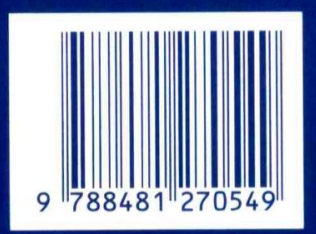

